\title{
Documentation of Caddo Funerary Objects in the Gilcrease Museum Collections
}

Timothy K. Perttula

Heritage Research Center, Stephen F. Austin State University

Bo Nelson

Heritage Research Center, Stephen F. Austin State University

Mark Walters

Heritage Research Center, Stephen F. Austin State University

Robert Cast

Bobby Gonzalez

Follow this and additional works at: https://scholarworks.sfasu.edu/ita

Part of the American Material Culture Commons, Archaeological Anthropology Commons, Environmental Studies Commons, Other American Studies Commons, Other Arts and Humanities Commons, Other History of Art, Architecture, and Archaeology Commons, and the United States History Commons

Tell us how this article helped you.

This Article is brought to you for free and open access by the Center for Regional Heritage Research at SFA ScholarWorks. It has been accepted for inclusion in Index of Texas Archaeology: Open Access Gray Literature from the Lone Star State by an authorized editor of SFA ScholarWorks. For more information, please contact cdsscholarworks@sfasu.edu. 
Documentation of Caddo Funerary Objects in the Gilcrease Museum Collections

Creative Commons License

(c) (i) (8)

This work is licensed under a Creative Commons Attribution-NonCommercial 4.0 International License 


\title{
DOCUMENTATION OF CADDO FUNERARY OBJECTS IN THE GILCREASE MUSEUM COLLECTIONS
}

Timothy K. Perttula, Bo Nelson, Mark Walters, Robert Cast, and Bobby Gonzalez

\author{
HISTORIC PRESERVATION PROGRAM \\ CADDO NATION OF OKLAHOMA \\ BINGER, OKLAHOMA
}

SPECIAL PUBLICATION NO. 12, FRIENDS OF NORTHEAST TEXAS ARCHAEOLOGY 


\section{TABLE OF CONTENTS}

List of Figures $\quad$ iv

List of Tables $\quad$ xiv

$\begin{array}{lll}\text { Acknowledgements } & \text { XV }\end{array}$

Foreword: "A Different Perspective," by Robert Cast xvi

Introduction and Purpose of the Study 1

Information on the Sites and the Collections 1

Boyd Hill Locality, Foster Site (3LA27) 2

Spirit Hill Locality Sites 3

$\begin{array}{ll}\text { Ceramic Vessel Documentation Protocol } & 7\end{array}$

$\begin{array}{ll}\text { Vessels from the Battle Site (3LA1) } & 10\end{array}$

Vessels from the William Handy Place at the Battle Site (3LA1) 17

Vessels from the Foster Site (3LA27) 22

Vessels from the Cabaness Place (3LA84) 23

Vessels from the George W. Sentell Place (3LA38) 23

Vessels from the Lester Bros. Plantation (3LA38) and Lester 24

Bros. Place (3LA48)

$\begin{array}{ll}\text { Clay Pipes } & 28\end{array}$

$\begin{array}{ll}\text { Celt } & 30\end{array}$

$\begin{array}{ll}\text { Bone Tools } & 30\end{array}$

$\begin{array}{ll}\text { Mussel Shell Tools } & 30\end{array}$

Marine Shell Ornaments 31

NAGPRA Findings and Recommendations $\quad 34$

References Cited 35 
Appendix 1, Vessels from the Battle Site or Place (3LA1) 39

Appendix 2, Vessels from the Wm. Handy Place at the Battle 155 Site (3LA1)

Appendix 3, Vessels from the Lester Bros. Plantation (3LA38) and 234 Lester Bros. Place (3LA48)

Appendix 4, Vessels from the Foster Place (3LA27) 284

Appendix 5, Vessels from the Geo. W. Sentell Place (3LA38) 291

Appendix 6, Vessels from the Cabaness Place (3LA84), Spirit Lake 300

References Cited for Appendices 306 


\section{LIST OF FIGURES}

Figure 1. The Boyd Hill and Spirit Lake localities in the Great Bend of the Red River in southwestern Arkansas, and other sites mentioned in the text.

Figure 2. The location of the Battle site, Handy Place, Joe Russell Place, Cabaness Place/Spirit Lake site, Sentell Place or Lester Bros. Plantation, and the Cedar Grove sites.

Figure 3. General map of the Battle site, the Handy Place cemetery, and Burial Plots 1-3 from the 1938 excavations.

Figure 4. Battle site, Burial 1, Plot 1.

Figure 5. Battle site, Burial 2, Plot 1.

Figure 6. Battle site, Burial No. 1, Plot 2.

Figure 7. Burial 2, Plot 2, at the Battle site.

Figure 8. Burial 3, Plot 2, at the Battle site.

Figure 9. Burial 4, Plot 2, at the Battle site.

Figure 10. Battle site, Burial 1, Plot 3.

Figure 11. Burials A-C (1940), at the William Handy Place.

Figure 12. Selected Haley phase vessels from the Battle Place (3LA1): a, Handy Engraved carinated bowl (5425-637); b, Handy Engraved carinated bowl (5425-712); c, cf. Handy-Hatchel Engraved bottle (5425-669); d, Engraved bottle (5425-666); e, Haley Engraved bottle (5425-757); f, Engraved bottle (5425-702); g, Friendship Engraved bottle (5425-753); h, Haley Complicated Incised jar (5425-656); i, Haley Complicated Incised jar (5425-747); j, Pease Brushed-Incised jar (5425-698); k, Sinner Linear Punctated jar (5425-762); 1. Moore Noded bowl (5425-721).

Figure 13. Selected Belcher phase vessels from the Battle Place: a, Belcher Engraved, var. Belcher carinated bowl (5425-674); b, Mound Tract Incised and Brushed jar (5425738); c, Mound Tract Incised and Brushed jar (5425-746); d, Foster Trailed-Incised, var. Foster (5425-661) jar; e, Foster Trailed-Incised, var. Foster jar (5425-662); f, Foster Trailed-Incised, var. Red Lake jar (5425-2431A); g, Karnack Brushed-Incised, var. Karnack jar (5425-655).

Figure 14. Selected Chakanina phase vessels from the Battle Place: a, Belcher Engraved, var. Owen carinated bowl (5425-2453); b, Natchitoches Engraved, var. unspecified carinated bowl (5425-705); c, Hodges Engraved, var. Kelly's Lake bottle (5425-725); d, 
Keno Trailed, var. unspecified jar (5425-730); e, Foster Trailed-Incised, var. Dixon jar (5425-681); f, Belcher Ridged, var. Wilson's Island jar (5425-683).

Figure 15. Selected Haley phase vessels from the Wm. Handy Place: a, Handy Engraved carinated bowl (5425-2116A-D); b, Friendship Engraved bottle (5425-2024); c, cf. Handy-Hatchel Engraved bottle (5425-2030); d, Moore Noded bowl (5425-682); e, Sinner Linear Punctated jar (5425-2125); f, Haley Complicated Incised jar (5425-701); g, Haley Complicated Incised jar (5425-2128).

Figure 16. Selected Belcher phase vessels from the Wm. Handy Place: a, Belcher Engraved, var. Belcher carinated bowl (5425-2027A); b, Hodges Engraved, var. Armour carinated bowl (5425-2034); c, Avery Engraved, cf. Bradshaw carinated bowl (54252055); d, Belcher Engraved, var. Ogden bottle (5425-2022); e, Belcher Engraved, var. Ogden bottle (5425-2059); f, cf. Mound Tract Incised and Brushed jar (5425-2119); g, Karnack Brushed-Incised, var. Karnack jar (5425-2118); h, Cowhide Stamped, var. unspecified jar (5425-2131).

Figure 17. Selected Chakanina phase vessels from the Wm. Handy Place: a, Keno Trailed, var. Scott's Lake jar (5425-7156A); b, Belcher Ridged, var. Wilson's Island jar (5425-2058); c, Foster Trailed-Incised, var. Moore jar (5425-7147).

Figure 18. Selected Belcher phase vessels from the Lester Bros. Place: a, Avery Engraved, var. Graves bowl (5425-937); b, Glassell Engraved, var. McGee carinated bowl (5425-952); c, Belcher Engraved, var. Soda Lake bottle (5425-901); d, Belcher Engraved, var. Soda Lake bottle (5425-778); e, Hodges Engraved bottle (5425-783); f, Keno Trailed, var. McClendon bottle (5425-888); g, Foster Trailed-Incised, var. Dobson jar (5425-904); h, Karnack Brushed-Incised, var. Karnack jar (5425-892).

Figure 19. Selected Chakanina phase vessels from the Lester Bros. Place: a, Natchitoches Engraved, var. Lester Bend carinated bowl (5425-895); b, Belcher Engraved, var. Owen carinated bowl (5425-925); c, Hodges Engraved, var. Sentell carinated bowl (5425-880); d, Hodges Engraved, var. Candler bottle (5425-909); e, Hodges Engraved, var. Candler bottle (5425-961); f, Keno Trailed, var. Glendora bottle (5425-1595); g, Foster TrailedIncised, var. Shaw jar (5425-889); h, Foster Trailed-Incised, var. Dixon jar (5425-911); i, Belcher Ridged, var. Wilson's Island jar (5425-1599).

Figure 20. Small elbow pipes from the Battle Place: a, P-31; P-34; c, P-54; d, P-157; e, P235; f, P-236; g, P-237; h, P-238; i, P-239.

Figure 21. Large elbow pipe from the Battle Place (P-233).

Figure 22. Pipes from the Lester Bros. Place: a, P-231; b, P-232.

Figure 23. Pebble celt from the Wm. Handy Place (6125-18848).

Figure 24. Bone tools from the Lester Bros. Place. 
Figure 25. Perforated mussel shell tool (M-138) from the Lester Bros. Place.

Figure 26. Mussel shell spoon fragments (M-85) from the Lester Bros. Place.

Figure 27. Marine columella shell beads from the Battle Place (9052-502).

Figure 28. Small marine shell disk bead from a Caddo burial in the principal mound at the Battle Place (9025-485).

Figure 29. Conch shell cup from the Battle Place: a, exterior view, note suspension holes; b, interior view of cup.

Figure 30. Marine shell ear disks from the Lester Bros. Place (accession no. 9025-272 and 273).

Figure 31. Marine shell conch ornaments from the Joe Russell Place: a, interior view; b, exterior view. Note suspension holes.

Figure 32. Marine shell ornaments from the Cabaness Place, Spirit Lake locality: a, exterior view; b, interior view; c, side view, showing suspension hole.

Figure A1-1. Engraved bowl (5425-549) from the Battle site: a, side view; b, view of the base and vessel body.

Figure A1-2. Engraved bowl (5425-549). Drawing by Bobby Gonzalez.

Figure A1-3. Zoned incised-punctated jar (5425-613).

Figure A1-4. Simms Engraved carinated bowl (5425-630).

Figure A1-5. Appliqued effigy vessel (5425-631).

Figure A1-6. Handy Engraved carinated bowl (5425-632) from the Battle site.

Figure A1-7. Friendship Engraved bowl (5425-634).

Figure A1-8. Belcher Engraved, var. Owen carinated bowl (5425-635).

Figure A1-9. Handy Engraved carinated bowl (5425-636): a, photograph; b, drawing by Bobby Gonzalez.

Figure A1-10. Handy Engraved carinated bowl (5425-637).

Figure A1-11. Cowhide Stamped jar (5425-638) from the Battle Place.

Figure A1-12. cf. Foster Trailed-Incised or Mound Tract Incised and Brushed jar (5425-

639).

Figure A1-13. Foster Trailed-Incised, var. unspecified jar (5425-640).

Figure A1-14. Engraved bottle (5425-643).

Figure A1-15. Cut-down brushed-punctated jar (5425-645).

Figure A1-16. Brushed-pinched-punctated jar (5425-649).

Figure A1-17. Handy Engraved deep bowl (5425-650) from the Battle Place.

Figure A1-18. Incised effigy vessel (5425-651).

Figure A1-19. Bowie Engraved bowl (5425-652).

Figure A1-20. Foster Trailed-Incised or Mound Tract Incised and Brushed jar (5425-

653). 
Figure A1-21. Brushed-punctated jar (5425-654).

Figure A1-22. Karnack Brushed-Incised, var. Karnack jar (5425-655).

Figure A1-23. Haley Complicated Incised jar (5425-656).

Figure A1-24. Lip notched bowl from the Battle site (5425-657).

Figure A1-25. Brushed-incised-punctated-appliqued jar (5425-658).

Figure A1-26. Engraved-appliqued bottle (5425-660).

Figure A1-27. Foster Trailed-Incised, var. Foster (5425-661) jar: a, photograph; b, drawing by Bobby Gonzalez.

Figure A1-28. Foster Trailed-Incised, var. Foster jar (5425-662).

Figure A1-29. Red-slipped bottle (5425-663).

Figure A1-30. Handy Engraved bottle (5425-664): a, circular panel; b, rectangular panel.

Figure A1-31. cf. Means Engraved bottle (5425-665).

Figure A1-32. Engraved bottle (5425-666) from the Battle Place.

Figure A1-33. Belcher Engraved, var. Soda Lake bottle (5425-668).

Figure A1-34. cf. Handy-Hatchel Engraved bottle (5425-669): a, rectangular motif; b, circular motif.

Figure A1-35. cf. Handy-Hatchel Engraved bottle (5425-669). Drawing by Bobby

Gonzalez.

Figure A1-36. Handy Engraved carinated bowl (5425-671).

Figure A1-37. Engraved carinated bowl (5425-672) from the Battle Place.

Figure A1-38. Belcher Engraved, var. Belcher carinated bowl (5425-674): a, photograph;

b, drawing by Bobby Gonzalez.

Figure A1-39. Handy Engraved carinated bowl (5425-675): a, photograph; b, drawing by Bobby Gonzalez.

Figure A1-40. Belcher Ridged, var. Wilson's Island jar (5425-677).

Figure A1-41. Foster Trailed-Incised, var. Red Lake jar (5425-679).

Figure A1-42. Foster Trailed-Incised, var. Dixon jar (5425-681).

Figure A1-43. Belcher Ridged, var. Wilson's Island jar (5425-683).

Figure A1-44. Haley Engraved bottle (5425-685).

Figure A1-45. Mound Tract Incised and Brushed jar (5425-686).

Figure A1-46. Zoned incised-punctated jar (5425-687) from the Battle site.

Figure A1-47. Zoned incised-punctated jar (5425-689).

Figure A1-48. Pease Brushed-Incised jar (5425-690).

Figure A1-49. Haley Complicated Incised jar (5425-694).

Figure A1-50. Engraved shell-tempered bottle (5425-695).

Figure A1-51. cf. Haley Engraved bottle (5425-696).

Figure A1-52. Engraved bottle (5425-697) from the Battle site.

Figure A1-53. Pease Brushed-Incised jar (5425-698).

Figure A1-54. Engraved bottle (5425-702).

Figure A1-55. Engraved bottle (5425-703).

Figure A1-56. Friendship Engraved bottle (5425-704).

Figure A1-57. Natchitoches Engraved, var. unspecified carinated bowl (5425-705).

Figure A1-58. Belcher Engraved, var. Belcher carinated bowl (5425-706).

Figure A1-59. Moore Noded bowl (5425-707).

Figure A1-60. Friendship Engraved carinated bowl (5425-709) from the Battle site. 
Figure A1-61. Handy Engraved carinated bowl (5425-712): a, photograph; b, drawing by Bobby Gonzalez.

Figure A1-62. Brushed-punctated-appliqued jar (5425-718).

Figure A1-63. cf. Sinner Linear Punctated jar (5425-720).

Figure A1-64. Moore Noded bowl (5425-721).

Figure A1-65. Belcher Engraved, var. Belcher carinated bowl (5425-722).

Figure A1-66. Hodges Engraved, var. Kelly's Lake bottle (5425-725): a, photograph; b, drawing by Bobby Gonzalez.

Figure A1-67. Incised-stamped jar (5425-728).

Figure A1-68. Keno Trailed, var. unspecified jar (5425-730): a, photograph; b, drawing by Bobby Gonzalez.

Figure A1-69. Natchitoches Engraved, var. unspecified carinated bowl (5425-731): a, photograph; b, drawing by Bobby Gonzalez.

Figure A1-70. Belcher Engraved, var. Belcher carinated bowl (5425-732) from the Battle site.

Figure A1-71. Handy Engraved carinated bowl (5425-733).

Figure A1-72. Incised effigy bowl (5425-734).

Figure A1-73. Avery Engraved, var. Bradshaw carinated bowl (5425-735).

Figure A1-74. Bowie Engraved bowl (5425-736): a, photograph; b, drawing by Bobby

Gonzalez.

Figure A1-75. cf. Hardman Engraved, var. Joan bowl (5425-737).

Figure A1-76. Mound Tract Incised and Brushed jar (5425-738).

Figure A1-77. Pease Brushed-Incised jar (5425-740).

Figure A1-78. Belcher Engraved, var. Belcher vessel (5425-741): a, photograph; b, drawing by Bobby Gonzalez.

Figure A1-79. Haley Complicated Incised jar (5425-742).

Figure A1-80. Friendship Engraved carinated bowl (5425-743) from the Battle site.

Figure A1-81. Belcher Ridged, var. Belcher Ridged jar (5425-744).

Figure A1-82. Incised jar (5425-745).

Figure A1-83. Mound Tract Incised and Brushed jar (5425-746).

Figure A1-84. Haley Complicated Incised jar (5425-747).

Figure A1-85. Pease Brushed-Incised jar (5425-748).

Figure A1-86. Friendship Engraved bottle (5425-750).

Figure A1-87. Friendship Engraved bottle (5425-751): a, photograph; b, drawing by

Bobby Gonzalez.

Figure A1-88. Friendship Engraved bottle (5425-752).

Figure A1-89. Friendship Engraved bottle (5425-753).

Figure A1-90. Haley Engraved bottle (5425-754) from the Battle site.

Figure A1-91. Haley Engraved bottle (5425-756): a, photograph; b, drawing by Bobby Gonzalez.

Figure A1-92. Haley Engraved bottle (5425-757): a, photograph; b, drawing by Bobby Gonzalez.

Figure A1-93. cf. Handy Engraved bottle (5425-759).

Figure A1-94. Friendship Engraved bottle (5425-760).

Figure A1-95. Glassell Engraved carinated bowl (5425-761): a, photograph; b, drawing by Bobby Gonzalez. 
Figure A1-96. Sinner Linear Punctated jar (5425-762).

Figure A1-97. Haley Engraved bottle (5425-1391): a, photograph; b, drawing by Bobby Gonzalez.

Figure A1-98. Foster Trailed-Incised, var. Red Lake jar (5425-2431A).

Figure A1-99. Haley Engraved bottle (5425-2438).

Figure A1-100. Brushed-appliqued-punctated jar (5425-2441).

Figure A1-101. Belcher Engraved, var. Owen carinated bowl (5425-2453).

Figure A1-102. Belcher Engraved, var. Owen carinated bowl (5425-2454) from the Battle site.

Figure A1-103. Keno Trailed, var. unspecified bottle (5425-2460/2464): a, neck and upper body; b, body sherds.

Figure A1-104. Trailed jar (5425-2461A).

Figure A1-105. Cowhide Stamped jar sherds (5425-2470).

Figure A1-106. Belcher Engraved, var. Belcher carinated bowl (5425-2646) rim sherds.

Figure A2-1. Karnack Brushed-Incised, var. Karnack jar (5425-680).

Figure A2-2. Moore Noded bowl from the Wm. Handy Place (5425-682).

Figure A2-3. Haley Complicated Incised jar (5425-692).

Figure A2-4. Haley Complicated Incised jar (5425-701).

Figure A2-5. Haley Engraved bottle (5425-749).

Figure A2-6. Handy Engraved bowl (5425-2021).

Figure A2-7. Belcher Engraved, var. Ogden bottle (5425-2022): a, photograph; b,

drawing by Bobby Gonzalez.

Figure A2-8. Means Engraved carinated bowl (5425-2023): a, photograph; b, drawing by Bobby Gonzalez.

Figure A2-9. Friendship Engraved bottle (5425-2024) from the Wm. Handy Place.

Figure A2-10. Engraved carinated bowl (5425-2025).

Figure A2-11. Engraved bottle (5425-2026).

Figure A2-12. Belcher Engraved, var. Belcher carinated bowl (5425-2027A).

Figure A2-13. Plain red-slipped bottle (5425-2028).

Figure A2-14. Foster Trailed-Incised, var. unspecified jar from the Wm. Handy Place

(5425-2029).

Figure A2-15. cf. Handy-Hatchel Engraved bottle (5425-2030): a, photograph; b, drawing by Bobby Gonzalez.

Figure A2-16. Glassell Engraved, var. Atkins carinated bowl (5425-2031A).

Figure A2-17. Hickory Engraved bottle (5425-2032).

Figure A2-18. Plain carinated bowl (5425-2033).

Figure A2-19. Hodges Engraved, var. Armour carinated bowl (5425-2034).

Figure A2-20. Engraved bottle (5425-2035) from the Wm. Handy Place.

Figure A2-21. Glassell Engraved, var. Glassell carinated bowl (5425-2036).

Figure A2-22. Plain bottle (5425-2037).

Figure A2-23. Punctated and brushed jar (5425-2038).

Figure A2-24. Belcher Engraved, var. Belcher carinated bowl (5425-2039).

Figure A2-25. Belcher Engraved, var. Owen carinated bowl (5425-2040).

Figure A2-26. Engraved bottle (5425-2041) from the Wm. Handy Place.

Figure A2-27. Plain bowl (5425-2042). 
Figure A2-28. Belcher Engraved, var. Belcher carinated bowl (5425-2043).

Figure A2-29. Hickory Engraved bottle (5425-2044).

Figure A2-30. Belcher Engraved, var. Owen carinated bowl (5425-2045).

Figure A2-31. Foster Trailed-Incised, var. unspecified jar (5425-2048) from the Wm.

Handy Place.

Figure A2-32. Plain jar with suspension holes (5425-2049).

Figure A2-33. cf. Taylor Engraved bowl (V-2044).

Figure A2-34. cf. Handy Engraved carinated bowl (5425-2051).

Figure A2-35. Engraved-punctated bowl (5425-2052): a, lower part of the vessel; b, upper part of the vessel, note rim peaks.

Figure A2-36. Taylor Engraved bottle (5425-2053) from the Wm. Handy Place.

Figure A2-37. Belcher Engraved, var. Belcher carinated bowl (5425-2054).

Figure A2-38. Avery Engraved, $c f$. Bradshaw carinated bowl (5425-2055).

Figure A2-39. Brushed-incised jar (5425-2056).

Figure A2-40. Vertical engraved bowl (5425-2057).

Figure A2-41. Belcher Ridged, var. Wilson's Island jar (5425-2058).

Figure A2-42. Belcher Engraved, var. Ogden bottle (5425-2059): a, photograph; b, drawing by Bobby Gonzalez.

Figure A2-43. Belcher Engraved, var. Belcher carinated bowl (5425-2115A-C) from the Wm. Handy Place.

Figure A2-44. Handy Engraved carinated bowl (5425-2116A-D).

Figure A2-45. Karnack Brushed-Incised, var. Karnack jar (5425-2118).

Figure A2-46. cf. Mound Tract Incised and Brushed jar (5425-2119).

Figure A2-47. Plain bottle (5425-2120).

Figure A2-48. Haley Complicated Incised jar (5425-2121) from the Wm. Handy Place.

Figure A2-49. Karnack Brushed-Incised, var. unspecified jar (5425-2122).

Figure A2-50. Belcher Engraved, var. Belcher carinated bowl (5425-2123).

Figure A2-51. Foster Trailed-Incised, var. Foster jar (5425-2124).

Figure A2-52. Sinner Linear Punctated jar (5425-2125).

Figure A2-53. Plain dugout canoe vessel (5425-2126): a, side view; b, view of the vessel interior.

Figure A2-54. Simms Engraved carinated bowl (5425-2127).

Figure A2-55. Haley Complicated Incised jar (5425-2128) from the Wm. Handy Place.

Figure A2-56. Plain effigy bowl (5425-2129).

Figure A2-57. Belcher Engraved, var. unspecified carinated bowl (5425-2130).

Figure A2-58. Cowhide Stamped, var. unspecified or De Roche Incised jar (5425-2131).

Figure A2-59. Foster Trailed-Incised, var. unspecified jar (5425-2149).

Figure A2-60. Sherds from Friendship Engraved (right side) and Hodges Engraved, var.

Candler (left side) vessels (5425-2468).

Figure A2-61. Friendship Engraved carinated bowl (5425-5978) from the Wm. Handy

Place.

Figure A2-62. Friendship Engraved carinated bowl (5425-5979).

Figure A2-63. Sherds from a Haley Engraved bottle (5425-6410), including a plain bottle neck.

Figure A2-64. Sherds from an engraved bottle (5425-6425), including a plain bottle neck. Figure A2-65. Handy Engraved carinated bowl (5425-6426). 
Figure A2-66. Friendship Engraved carinated bowl (6125-7142A).

Figure A2-67. Handy Engraved carinated bowl (5425-7143).

Figure A2-68. Foster Trailed-Incised, var. Moore jar (5425-7147) from the Wm. Handy

Place.

Figure A2-69. Keno Trailed, var. Scott's Lake jar (5425-7156A).

Figure A2-70. Hodges Engraved, var. Armour carinated bowl (5425-7158A-L).

Figure A2-71. Belcher Engraved, var. unspecified carinated bowl (5425-7180) from the Wm. Handy Place.

Figure A3-1. Belcher Engraved, var. Soda Lake bottle from the Lester Bros. Place (5425778).

Figure A3-2. Avery Engraved, var. Bradshaw jar (5425-780).

Figure A3-3. Brushed-incised jar (5425-781).

Figure A3-4. Hodges Engraved bottle (5425-783).

Figure A3-5. Belcher Engraved, var. Belcher carinated bowl from the Lester Bros. Place (5425-877).

Figure A3-6. Glassell Engraved, var. Atkins carinated bowl (5425-878).

Figure A3-7. Hodges Engraved, var. Sentell carinated bowl (5425-880).

Figure A3-8. Avery Engraved, var. Graves carinated bowl (5425-881).

Figure A3-9. Karnack Brushed-Incised, var. Karnack jar (5425-883).

Figure A3-10. Glassell Engraved, var. Atkins carinated bowl from the Lester Bros. Place (5425-886).

Figure A3-11. Plain miniature jar (5425-887).

Figure A3-12. Keno Trailed, var. McClendon bottle (5425-888).

Figure A3-13. Foster Trailed-Incised, var. Shaw jar (5425-889).

Figure A3-14. Karnack Brushed-Incised, var. Karnack jar (5425-892).

Figure A3-15. Natchitoches Engraved, var. Lester Bend carinated bowl from the Lester

Bros. Plantation (5425-895).

Figure A3-16. Base of the Natchitoches Engraved, var. Lester Bend carinated bowl (5425-895).

Figure A3-17. Hardman Engraved, var. Joan bowl from the Lester Bros. Place (5425-

897).

Figure A3-18. Belcher Engraved, var. Soda Lake bottle (5425-901).

Figure A3-19. Karnack Brushed-Incised or Foster Trailed-Incised jar (5425-903).

Figure A3-20. Foster Trailed-Incised, var. Dobson jar (5425-904) from the Lester Bros.

Place.

Figure A3-21. Keno Trailed bottle (5425-906).

Figure A3-22. Hodges Engraved, var. Candler bottle (5425-909): a, side view; b, view of the vessel base.

Figure A3-23. Foster Trailed-Incised, var. Dixon jar (5425-911).

Figure A3-24. Avery Engraved, var. Bradshaw carinated bowl (5425-920).

Figure A3-25. Effigy bowl from the Lester Bros. Place (5425-923): a, view of the notched tab tail; $b$, side view.

Figure A3-26. Belcher Engraved, var. Owen carinated bowl (5425-925).

Figure A3-27. Plain bowl (5425-926).

Figure A3-28. Appliqued effigy bowl from the Lester Bros. Place (5425-927). 
Figure A3-29. Belcher Engraved carinated bowl (5425-928).

Figure A3-30. Avery Engraved, var. Graves bowl (5425-937).

Figure A3-31. Avery Engraved, var. Graves bowl (5425-937) from the Lester Bros.

Place. Drawing by Bobby Gonzalez.

Figure A3-32. Taylor Engraved bowl (5425-945).

Figure A3-33. Plain bottle (5425-948).

Figure A3-34. Hardman Engraved, var. Joan bowl (5425-949).

Figure A3-35. Mound Tract Incised and Brushed jar (5425-951).

Figure A3-36. Glassell Engraved, var. McGee carinated bowl (5425-952).

Figure A3-37. Hardman Engraved, var. Joan deep bowl (5425-958).

Figure A3-38. Hodges Engraved, var. Candler bottle from the Lester Bros. Place (5425-

961).

Figure A3-39. Belcher Engraved, var. unspecified carinated bowl (5425-964).

Figure A3-40. Engraved and punctated bottle (5425-965): a, side view; b, drawing by

Bobby Gonzalez.

Figure A3-41. Engraved carinated bowl (5425-966).

Figure A3-42. Hardman Engraved, var. Hardman deep bowl (5425-1594).

Figure A3-43. Keno Trailed, var. Glendora bottle (5425-1595) from the Lester Bros.

Place.

Figure A3-44. Taylor Engraved bottle (5425-1597).

Figure A3-45. Belcher Ridged, var. Wilson's Island jar (5425-1599).

Figure A3-46. Haley Complicated Incised jar (5425-1601).

Figure A3-47. Hodges Engraved, var. unspecified carinated bowl (5425-2642).

Figure A4-1. Belcher Engraved, var. Soda Lake bottle from the Foster Place (5425-2133).

Figure A4-2. Brushed-incised jar (5425-2135).

Figure A4-3. Hatinu Engraved bottle (5425-2136).

Figure A4-4. Hatinu Engraved bottle from the Foster Place (5425-2136). Drawing by

Bobby Gonzalez.

Figure A4-5. Belcher Engraved carinated bowl (5425-2141).

Figure A4-6. Belcher Engraved, var. Soda Lake bottle (5425-2146).

Figure A4-7. Belcher Engraved, var. Ogden bottle from the Foster Place (5425-2148).

Figure A5-1. Engraved effigy vessel from the Geo. Sentell Place (5425-420): a, top of the vessel; $b$, back view of the vessel; $c$, view of the headless effigy from the front; $d$, side view of the vessel; e, drawing by Bobby Gonzalez.

Figure A5-2. Possible Belcher Engraved bottle (5425-482).

Figure A5-3. Hodges Engraved fine ware tripod bottle from the Geo. W. Sentell Place (5425-775).

Figure A5-4. Avery Engraved, var. Graves carinated bowl (5425-3622).

Figure A5-5. Handy Engraved carinated bowl (5425-3623).

Figure A5-6. Sinner Linear Punctated jar (5425-3625).

Figure A5-7. Engraved bottle from the Geo. W. Sentell Place (5425-3626)

Figure A5-8. Keno Trailed, var. McClendon bottle (5425-3627).

Figure A5-9. Keno Trailed, var. McClendon bottle from the Geo. Sentell Place (5425-

3627). Drawing by Bobby Gonzalez. 
Figure A6-1. Plain bowl (V-29) from the Cabaness Place (5425-156).

Figure A6-2. Natchitoches Engraved, var. unspecified from the Cabaness Place (V-37, 5425-158).

Figure A6-3. Belcher Ridged, var. unspecified jar from the Cabaness Place (V-40, 5425161).

Figure A6-4. Plain seed jar from the Cabaness Place (5425-225): a, photograph; b, drawing by Bobby Gonzalez.

Figure A6-5. Photograph of Glassell Engraved carinated bowl from the Cabaness Place (V-175, 5425-226).

Figure A6-6. Glassell Engraved carinated bowl from the Cabaness Place (5425-226).

Drawing by Bobby Gonzalez. 


\section{LIST OF TABLES}

Table 1. Vessels from the Battle site (3LA1) in the Gilcrease Museum NAGPRA collections.

Table 2. Vessels from the Handy Place at the Battle site (3LA1) in the 18 Gilcrease Museum NAGPRA collections.

Table 3. Vessels from the Lester Bros. Plantation and Lester Bros. Place in the Gilcrease Museum NAGPRA collections.

Table 4. Pipes from the Battle Place.

Table 5. Pipes from the Lester Bros. Place. 


\section{ACKNOWLEDGMENTS}

This material is based upon work assisted by a grant from the Department of the Interior, National Park Service. Any opinions, findings, and conclusions or recommendations expressed in this material are those of the authors and do not necessarily reflect the views of the Department of the Interior.

The Historic Preservation Office of the Caddo Nation would like to thank the following people at the Gilcrease Museum of the Americas for their support on this project: Mr. Randy Ramer, Collections Manager and Curator of Anthropology, Mr. Jeremy Planteen, Intern, Ms. Kelly Finnigan, NAGPRA Coordinator, and Dr. Duane King, Director. A big "thanks" goes to our archeological consultants and documentation team, Dr. Tim Perttula, who has done fantastic work for the Caddo Nation and the archeological community for over three decades. We also wish to thank Mr. Mark Walters for joining our team and his efforts on this project. We thank Mr. Bo Nelson, who took the many artifact photographs, who has always been an invaluable member of our team. We wish to thank the Director of the Caddo Nation Heritage Museum, Ms. Kim Penrod, for scanning and archiving all of the photographs and drawings. We sincerely thank Mary Botone, our administrative assistant, for managing the office in our absence. We also wish to thank Mr. Duncan McKinnon who helped part of one day with the vessel documentation effort, and also shared information and maps about the Battle site. Sandy Hannum prepared the various maps and site burial feature maps used in this report. Lastly, we would like to thank the National Park Service NAGPRA program for providing us the funding to make this project and report possible. 


\section{FOREWORD: “A DIFFERENT PERSPECTIVE”}

\section{Robert Cast}

In the gift shop of the Gilcrease Museum of the Americas in Tulsa, Oklahoma, there is a large coffee table style book entitled Treasures of the Gilcrease: Selections from the Permanent Collection. One of my favorite artists associated with Oklahoma is painter Charles Banks Wilson, so I quickly thumbed through page after page to see what paintings of his they might have selected for presentation in the book. One of the first things I noticed was that on page 93, there was indeed a beautifully detailed painting by Charles Banks Wilson of none other than Mr. William Thomas Gilcrease sitting on a small bench supposedly outside the original museum. Commissioned in 1958, the painting also had two items positioned as props sitting on the bench in front of $\mathrm{Mr}$. Gilcrease: A Caddo ceramic vessel sitting on top of what appears to be a leather-bound book entitled Plates of American Indians. I am sure that many people who have wandered around the gift shop and perhaps thumbed through this book never paid much attention to these particular items in this portrait painting.

Treasures of the Gilcrease summarizes the many contributions and efforts of Thomas Gilcrease to preserve art and history in its many forms. There is no doubt that because of his collections, the city of Tulsa has become one of the unique places holding a wondrous wealth of human heritage from the many diverse peoples of Oklahoma and from around the world.

Ironically, however, the focus of our particular report is on archeological collections at the Gilcrease Museum from the state of Arkansas. The irony, of course, is that these collections can be culturally affiliated to an Indian tribe- the Caddo Nation of Oklahoma - presently living within the state of Oklahoma, a tribe that has survived for hundreds, if not thousands of years in the states of Oklahoma, Arkansas, Louisiana, and Texas.

Gilcrease, Lemley, Agee, Hodges, Perino, and Schambach, are all names familiar to archeologists who have studied the artifacts of the Caddo Indians. From the records held at the Gilcrease Museum, one cannot help but see that the past efforts of most of these men are now a part of our present-day efforts to establish a cultural connection between the Native American Graves Protection and Repatriation Act (NAGPRA) items housed in the Gilcrease Museum and the Caddo Nation of Oklahoma.

The beautiful polished vessel in the painting of Mr. Gilcrease is what Caddo archeologists who study such things would call a Hodges Engraved vessel. A master craftswoman from the Caddo Indians surely made this vessel, probably about 400 years ago or thereabouts. The Caddo were some of the Nation's (and Oklahoma's) first and greatest artisans when it came to molding and crafting such durable, imaginative ceramic vessels. 
Art, history, and beauty aside, the Caddo people placed these vessels with their deceased as funerary offerings. These vessels have not only a special meaning to archeologists (on a scientific level) but they have a very special meaning and a direct relationship to the spiritual and cultural beliefs of the Caddo people. Each offering placed in the grave has a special purpose and special place in the Caddo world. These vessels are skillfully made from the clay of the earth. The Caddo people say they came from the earth and when they die they will return back to where they came from. These vessels are physical manifestations of the symbols and cycles of this ancestry that represent a part of their daily lives, and ultimately, a part of their final destiny.

Being somewhat familiar with Charles Banks Wilson through his daughter Carrie Wilson (past Osage and Quapaw NAGPRA Director), Bobby Gonzalez and I have had the privilege to meet Mr. Wilson on several different occasions when we were on business in the Fayetteville, Arkansas, area. Mr. Wilson always claimed Oklahoma as his home even though he was born in Springdale, Arkansas. He would joke that he was "conceived" in Oklahoma but happened to be born in Arkansas. The last time we met with him he was 90 plus years of age, still creating art and still very excited about the art he had created over the past 70 years. During our conversations, he told us proudly that it seemed everywhere he went he was always referred to as simply "Carrie's Father."

True artisans and painters may see the portrait of Thomas Gilcrease much differently than I do. Although it is a portrait of the man the museum was named after, my focus and attention locked only onto the tiny vessel sitting in front of him, as I wondered if it would be a part of our documentation effort for this collection, and wondered if Mr. Gilcrease had any idea that in 50 years from that portrait day the Caddo would be documenting and reclaiming under federal law NAGPRA objects within the museum. I can now enjoy this painting from a whole different perspective.

During the week of August $11^{\text {th }}$ through August $15^{\text {th, }}$ 2008, a small group of archeologists, preservationists, and a member of the Caddo Nation, studied a part of the Lemley Collection at the Gilcrease Museum of the Americas. The Lemley Collection alone has over 1400 complete ceramic Caddo vessels. Most of these were plowed up, dug up, removed, and then later sold to the museum. Back during those times, no one asked the Caddo what they thought about these things, and no one asked them about the importance of the places where these graves were located or the sacredness of any of the human remains and the funerary objects placed with them. Being of Creek ancestry, Mr. Gilcrease was almost obsessive about preserving and protecting Native American collections. Looking at the tiny Caddo vessel in the painting, I think I have a better understanding and much clearer picture of Mr. Gilcrease. 


\section{Introduction and Purpose of the Study}

This report is the latest in a series of reports produced and published by the Caddo Nation of Oklahoma, Historic Preservation Program, that concern the documentation of funerary objects in museum facilities that are subject to the provisions and regulations of the Native American Graves Protection and Repatriation Act (NAGPRA) (Gonzalez et al. 2005; Cast et al. 2006; Perttula et al. 2008a, 2008b). These documentation studies have been done either with grants from the National Park Service, or through funding provided by the museum facility. In the case of the present study of Caddo funerary objects in the collections at the Gilcrease Museum in Tulsa, Oklahoma, the documentation effort was supported by a NAGPRA grant provided by the National Park Service (NPS).

\section{Information on the Sites and the Collections}

During the course of the current NAGPRA grant, we completed documentation in August 2008 of 288 funerary objects at eight different Caddo sites or localities in the Gilcrease Museum collections. The principal funerary objects are ceramic vessels, and our documentation includes 241 ceramic vessels from mortuary contexts at seven different Caddo sites in the Boyd Hill and Spirit Lake localities (Figure 1) in Lafayette County, Arkansas, in the Great Bend area of the Red River: Battle Place (3LA1, n=104 vessels); the adjoining Wm. Handy Place (3LA1, n=72 vessels); Foster Place (3LA27, in the Boyd Hill Locality, $n=6$ vessels); Geo. W. Sentell Place (3LA38, $n=8$ vessels; the Sentell Place is an earlier name for the Lester Bros. Plantation); Lester Bros. Plantation (3LA38, $n=3$ vessels); Lester Bros. Place (3LA48, $n=43$ vessels); and the Cabaness Place (3LA84, $n=5$ vessels) or Spirit Lake site (Hemmings 1982) (Figure 2). The Cedar Grove site (3LA97) is a well-known protohistoric and historic Caddo site in the Spirit Lake Locality (Trubowitz 1984:Figure 1-7). include:

Other funerary objects that we have documented from these sites for this report

- $\quad$ clay pipes $(\mathrm{n}=12)$ from the Battle Place and Lester Bros. Place;

- a single stone celt from a burial at the Wm. Handy Place;

- deer antler tools $(n=4)$ from the Lester Bros. Place;

- a mussel shell tool and spoon from the Lester Bros. Place;

- 20 marine shell beads and a marine shell cup from the Battle Place, as well as two marine shell ear disks from the Lester Bros. Place;

- and seven marine shell ornaments from the Joe Russell Place (no site trinomial assigned); this site is on the Red River in the Spirit Lake Locality (see Figure 2).

Figure 1. The Boyd Hill and Spirit Lake localities in the Great Bend of the Red River in southwestern Arkansas, and other sites mentioned in the text.

Figure 2. The location of the Battle site, Handy Place, Joe Russell Place, Cabaness Place/Spirit Lake site, Sentell Place or Lester Bros. Plantation, and the Cedar Grove sites. 
The cultural context of these sites clearly indicates that they are all Caddo sites, primarily (if not exclusively) occupied after ca. A.D. 1200, and the Great Bend region of the Red River is considered one of the main heartland areas of the Caddo tradition and archeological area. In this region, the earliest known Caddo sites date from ca. A.D. 900, and include both mound centers as well as associated farmsteads in a complex and sociopolitically hierarchical society; by ca. A.D. 1200, these Caddo people were also farmers (Kelley and Guccione 2000:21; Perttula 2008).

In the Spirit Lake and Boyd Hill localities in the Great Bend region, Caddo sites dating after ca. A.D. 1200 have been divided into three phases: Haley (ca. A.D. 12001500), Belcher (ca. A.D. 1500-1670), and Chakanina (ca. A.D. 1670-1730) (Schambach 1982; Schambach and Miller 1984), primarily on the basis of the stylistically and morphologically distinctive fine ware and utility ware decorated ceramics found on them (these ceramics are best known from mortuary contexts). Haley phase sites include the following ceramic types: Haley Engraved, Handy Engraved, Hickory Engraved, Haley Complicated-Incised, Pease Brushed-Incised, and Sinner Linear Punctated (Kelley and Guccione 2000:22).

Belcher phase sites in the Great Bend region are characterized by engraved and trailed fine ware carinated bowls, bowls, and bottles (see Schambach and Miller 1984:Table 11-12): Belcher Engraved, var. Belcher, Belcher Engraved, var. Ogden, Keno Trailed, var. McClendon, Hodges Engraved, var. Armour and var. Candler, Avery Engraved, var. Graves and var. Bradshaw, and Glassell Engraved, var. Atkins and var. McGee. Belcher phase utility ware jars includes var. Foster, var. Dobson, and var. Red Lake of the Foster Trailed-Incised type, Karnack Brushed-Incised, var. Karnack and var. Fish Bayou, and Belcher Ridged, var. Wilson's Island. According to Schambach (1982:10), a small percentage of Belcher phase ceramics began to be tempered with mussel shell - principally in the utility wares (20\%). The succeeding Chakanina phase Caddo sites have these fine wares: Belcher Engraved, var. Owen, Natchitoches Engraved, var. Lester Bend, Keno Trailed, var. Phillips, var. Glendora, and var. Scott's Lake, Hodges Engraved, var. Sentell, var. Kelley's Lake, var. Armour, and var. Candler, and Cabaness Engraved (Schambach and Miller 1984:Table 11-12). Chakanina phase utility ware ceramics include Foster Trailed-Incised, var. Dixon, var. Moore, var. Finley, and var. Shaw, Karnack Brushed-Incised, var. Fish Bayou, and Belcher Ridged, var. unspecified. At Cedar Grove, the best known Chakanina phase site, shell-tempered ceramics account for about $64 \%$ of the vessels from mortuary contexts, $39 \%$ of the fine ware sherds from habitation contexts, and almost $86 \%$ of the utility ware sherds (Schambach and Miller 1984:Tables 11-4, 11-6 to 11-9).

\section{Boyd Hill Locality, Foster Site (3LA27)}

The Foster site is in the Boyd Hill locality on the Red River, about $20 \mathrm{~km}$ north of the Battle site and the cluster of contemporaneous sites in the Spirit Lake locality (see Figure 1). This mound site has been suggested by Schambach et al. (1982:91)) and Webb (1945) to have been "the major Belcher phase site in Arkansas." 
The site was first investigated by Clarence B. Moore (1912:591-619) during his wide-ranging exploration of Caddo sites on the Red River in Louisiana and Arkansas (see Weinstein et al. 2003). One of the two mounds he examined had 11 Late Caddo Belcher phase burials in it with a wide variety of funerary objects, including 246 ceramic vessels. Since that time there have been other burials excavated by amateur archeologists (including Pete Miroir) and looters, and other burials were uncovered after Red River floods (Hoffman 1970:165); the NAGPRA collections from the Foster site at the Gilcrease Museum are primarily from discoveries made after a 1938 Red River flood (see Appendix 4).

More recent investigations at the Foster site indicate that it contains extensive habitation debris and thick (up to $1 \mathrm{~m}$ in thickness) midden deposits (Kelley and Coxe 1998:93-103). Artifacts found in these areas indicate that the site was occupied in Woodland, Early Caddo, Middle Caddo, and Late Caddo period times, but the majority of the known burials date to the Late Caddo Belcher phase.

\section{Spirit Hill Locality Sites}

The Spirit Lake locality in the Great Bend region of Southwest Arkansas (Schambach 1982:10; Trubowitz 1984:5) is centered on the Battle site on Chicaninna prairie, and includes a number of sites with early historic Chakanina phase Caddo ceramics, including Natchitoches Engraved and Keno Trailed (see Figures 1 and 2). These sites probably represent a series of contemporaneous (late $17^{\text {th }}$ and early $18^{\text {th }}$ century) Caddo farmstead compounds within a large but dispersed Spirit Lake village (Schambach et al. 1982:94), as well as earlier Belcher phase farmsteads associated with the Battle site and civic-ceremonial center.

The Battle Mound is the largest known Caddo mound-205 $\mathrm{m}$ in length, $98 \mathrm{~m}$ in width, and $10.4 \mathrm{~m}$ high - and one of the largest platform mounds in the southeastern United States (Muller 1978:321), and it was built primarily in Belcher phase times over a low $(1.8 \mathrm{~m})$ Haley phase mound platform. During the Belcher phase, it was here in the Great Bend region that the Caddo cultural tradition reached its pre-European contact peak in population and socio-political complexity (Perttula 1992:24; Schambach 1989:20).

\section{Battle Site}

In addition to the large platform mound at the Battle site (Figure 3), there are at least four low mounds on the eastern side of the field east of the platform mound (Moore 1912:566-567; see also McKinnon 2008:Figure 6.1), although the location of only one of these is currently known, the others having been plowed down over the years. Moore (1912:567) located several Caddo burials in one of the low mounds.

Figure 3. General map of the Battle site, the Handy Place cemetery, and Burial Plots 1-3 from the 1938 excavations. 
The funerary objects from the Battle site in the Gilcrease Museum collections are from a number of Caddo burial features scattered across the site, including several from burials on the large earthen mound itself (see Figure 3). Arkansas Archeological Survey surface collections and recent geophysical investigations (McKinnon 2008) indicate that there are borrow pits, extensive habitation areas to the north and east of the large platform mound, as well as several Caddo cemetery areas within the bounds of the site.

The best information available on the context of the Gilcrease Museum NAGPRA collections from the Battle site is the notes and burial drawings compiled by Glenn Martin in 1939 from the various excavations done at the behest of Judge Harry J. Lemley in the spring of 1938 (Martin 1939). In that work, done in Plots 1-3 north and well northeast of the large mound platform (see Figure 3), seven Caddo burials, likely adults based on the apparent size of the burial pits, were excavated and funerary objects recovered that are now at the Gilcrease Museum. Plot 1 is in a habitation area with a 10$24 \mathrm{~cm}$ thick midden deposit covering ca. 2 acres (Martin 1939); this area appears to contain a cluster of domestic Caddo structures (McKinnon 2008:Figure 6.1). Plots 2 and 3 more than $900 \mathrm{~m}$ northeast of the platform mound, and both plots are situated on small rises; vessels from burials had previously been reported from these areas after flooding (Martin 1939).

These burials contained the bodies of one or two individuals laid on their backs in an extended position, with their heads facing either north (Figures 4, 6, and 7), south (Figures 5 and 10), east (Figures 8 and 9). Two of the burial features in Plot 2 (Figures 6 and 7) and one burial in Plot 3 (Figure 10) had two individuals placed together in the pit at death; these have a curious mix of Haley and Belcher phase ceramic vessels (see Appendix 1).

Figure 4. Battle site, Burial 1, Plot 1.

Figure 5. Battle site, Burial 2, Plot 1.

Figure 6. Battle site, Burial No. 1, Plot 2.

Figure 7. Burial 2, Plot 2, at the Battle site.

Figure 8. Burial 3, Plot 2, at the Battle site.

Figure 9. Burial 4, Plot 2, at the Battle site.

Figure 10. Battle site, Burial 1, Plot 3.

These burials contained several kinds of funerary offerings, including ceramic vessels $(n=37)$ around the head and body, pipes $(n=5)$, a celt, and red and black clay pigments. The mean number of ceramic vessels placed in the Battle site burials is 5.3, with a range of 2-8 (see Figures 4-10). Extrapolating that number with the number of ceramic vessels in the Gilcrease Museum NAGPRA collections from the Battle site 
$(n=104)$ suggests that they represent the ceramic vessel funerary offerings from approximately 20 Caddo burials.

Other important Gilcrease Museum NAGPRA contexts where Caddo burials at the Battle site have been reported include various plowed up and excavated burials (either single burials or in a cemetery) from habitation and cemetery areas in the 1920s and 1930s; a Chakanina phase burial found in 1938 at the south end of the large platform mound while digging a storm cellar; another burial found in the large platform mound with a Mound Tract Incised and Brushed shell-tempered jar; and another Chakanina phase burial on a low platform at the north end of the large platform mound, found again in 1938 while digging dirt for a chimney (see Appendix 1).

\section{Handy Place}

The Wm. Handy Place refers to a 40 acre farm owned by Wm. Handy in the 1930s and 1940s (Martin 1939) situated just north of the much larger Battle Place (see Figure 3); in the early 1910s this area was known as the Harrell Place (Moore 1912:573; Weinstein et al. 2003:Appendix A-2). There are extensive Caddo habitation deposits and cemeteries on this place (Hoffman 1970:163-164), an alluvial ridge between 125-350 m north-northeast from the Handy Place cabin, with considerable numbers (more than 100) of Caddo burials having been dug at the Handy Place by amateur archeologists and looters over the years.

Some of the recovered funerary objects (pottery vessels) from this digging are in the Gilcrease Museum NAGPRA collections, along with notes on the January and February 1940 excavation of four burials (Figure 11), one without ceramic vessels but including a ceramic ear plug and a celt, and other less well-documented amateur archeological excavations done in 1941. At the Wm. Handy Place, the NAGPRA collections are from burials excavated by Horace McLendon, Glenn Martin, W. Gamel Smith, Robert Shelton, Guy W. Stacy, and Pete Miroir in 1940 and 1941 (see Appendix 2).

Figure 11. Burials A-C (1940), at the William Handy Place.

The Caddo individuals buried at the Handy Place were placed in an extended supine position, with the head to the south, facing north. Funerary offerings, primarily ceramic vessels, were placed around the head, shoulders, and legs (see Figure 11) of the deceased. Notes in the Gilcrease Museum files on 14 documented Caddo burials excavated in 1940 and 1941 from the Wm. Handy Place had 47 ceramic vessels (0-10 per burial) and a ceramic pipe. The mean number of ceramic vessels per burial feature is 3.4 vessels. The 72 vessels in the Wm. Handy Place collections at the Gilcrease Museum are thus likely from at least 20 individual Caddo burials. 


\section{Geo. W. Sentell Place}

The eight vessels in the Gilcrease Museum collections from the Geo. W. Sentell Place on Lester Bend of the Red River (see Figure 2) came from one or more Caddo burials excavated in 1909 (see Appendix 5). These vessels include an effigy bottle, a tripod bottle, three other bottles, two carinated bowls, and a utility ware jar.

\section{Lester Bros. Plantation and Lester Bros. Place}

The Lester Bros. Plantation (3LA38) and the Lester Bros. Place (3LA48) refer to the same general area (a low rise) along the Red River floodplain in Lester Bend, where "one or more cemeteries" (Hemmings 1982:69) had been exposed and excavated in the 1920 s and 1930s, including an area known as the "Blue Hole." These cemeteries are likely part of a series of farmstead compounds dispersed along this part of the Red River (Schambach et al. 1982:94), about $3 \mathrm{~km}$ southwest of the Battle site (see Figure 2); Schambach et al. (1982:94-95) suggested that based on the number of vessels found on Lester Bend, "the vessels...must represent a parent population [of Caddo] of many hundreds and it seems clear that there was a major concentration of compounds around Lester Bend." This area had previously been owned by Geo. W. Sentell.

Funerary offerings from these burials (perhaps from 20-22 individual burial features) ended up in the Judge Lemley collection, including 118 vessels (Schambach et al. 1982:Table 6-1), mussel shell tools, clay pipes, and a perforated bear tooth. The vessels tallied by Schambach et al. (1982) included the following ceramic types: Avery Engraved ( $n=6)$, Belcher Engraved $(n=23)$, Keno Trailed $(n=9)$, Glassell Engraved $(n=4)$, Hodges Engraved $(n=8)$, Natchitoches Engraved $(n=9)$, Taylor Engraved $(n=2)$, Haley Engraved $(n=2)$, untyped engraved $(n=14)$, plain wares $(n=5)$, untyped punctated-incised $(n=3)$, Karnack Brushed $(n=2)$, Belcher Ridged $(n=5)$, Cass Appliqued $(n=3)$, Foster Trailed-Incised $(n=19)$, Cowhide Stamped $(n=2)$, and untyped coarse ware $(n=3)$. A number of these offerings eventually ended up in the Gilcrease Museum collections (see below). Specifically, the Lester Bros. Plantation and Lester Bros. Place NAGPRA collections in the Gilcrease Museum are from graves in at least one cemetery exposed after a 1915 Red River flood, burials exposed and excavated in the 1920s by various individuals, including burials exposed after dynamiting of a Red River levee in June 1929 (see Appendix 3).

\section{Cabaness Place}

The Joe Cabaness (also spelled Cabinas or Cabaniss) Place was first investigated by Clarence B. Moore (1912:573-574). The site is about $5 \mathrm{~km}$ north of the Battle site on the Red River (see Figure 2). Burials with associated ceramic vessels had been found here during the construction of a levee sometime before Moore's work, but, although Moore (1912:574) noted human remains and pottery vessel fragments on the surface, he did not locate any Caddo burials at this place despite "a considerable amount of digging," but did uncover a dog burial. 
In 1979-1980, the Arkansas Archeological Survey carried out excavations at the Spirit Lake site (3LA83) in advance of construction work associated with the Spirit Lake Revetment along the Red River (Hemmings 1982:55). Hemmings (1982:56) indicates that the "Spirit Lake site is evidently the same location investigated by Clarence B. Moore...called the Cabinas Place." During the work there, midden deposits, a dog burial, and the burial of a Caddo child were excavated at the Spirit Lake site from a Chakanina phase farmstead compound. Found as funerary offerings with the child were two Hodges Engraved vessels, a carinated bowl and a Hodges Engraved, var. Candler bottle (Hemmings 1982:78 and Figure 5-10), as well as a large vessel section from a Simms Engraved carinated bowl. Approximately $42 \%$ of the ceramic sherds from the habitation deposits are shell-tempered (Hemmings 1982:Table 5-3), consistent with a Chakanina phase Caddo occupation.

The vessels $(n=5)$ that we have documented in the Gilcrease Museum NAGPRA collections from the Cabaness Place were collected by W. P. Agee in 1915, probably from one burial (see Appendix 6). Hemmings (1982:82 and Figure 5-12) illustrates six vessels from the Cabaness Place, including one found by a collector in 1974, two of which have been documented in our study. These include a Belcher Ridged jar $(n=1)$, a Hodges Engraved, var. Candler bottle, Natchitoches Engraved bowls $(n=2)$ and Natchitoches Engraved bottles $(n=2)$, and several plain bowls.

\section{Joe Russell Place}

The Joe Russell Place is another Caddo farmstead and associated cemetery in the Spirit Lake locality. Schambach et al. (1982:94) noted that many "late vessels" (Keno Trailed and Natchitoches Engraved have been found at the Joe Russell place over the years. For this NAGPRA study, we documented only marine shell ornaments from a single Caddo burial excavated in 1915 at this habitation site on the Red River (see Figure 2).

\section{Ceramic Vessel Documentation Protocol}

Because of the number of ceramic vessels in the Gilcrease Museum NAGPRA collections that we were able to document under the NPS NAGPRA grant, we established a documentation protocol to assist in the study of each of the vessels examined in 2008 . Each of the ceramic vessels in the collections is described and illustrated utilizing a consistent set of ceramic morphological, functional, and stylistic attributes modeled after the presentations in Gonzalez et al. (2005), Cast et al. (2006), and Perttula et al. (2008a, $2008 \mathrm{~b}$ ). The purpose of the documentation is to thoroughly characterize the assemblage of ceramic vessels in the collections. Appendix 1-6 of this document are the completed vessel recordation forms from the Battle, Wm. Handy, Foster Place, Geo. W. Sentell, Lester Bros. Plantation and Lester Bros. Place, and the Cabaness Place sites. 
Vessel illustrations include a photograph of each vessel, along with an accompanying drawing by Bobby Gonzalez in several cases, that serve to better portray their decoration, shape, and surface texture. In the case of a number of ceramic vessels, engraved design motifs on bowls, compound bowls, and bottles are closely compared with Red River Caddo ceramic types and varieties defined by Schambach and Miller (1984) and Kelley (1997).

The following attributes were employed in this ceramic vessel study:

Non-plastics: Deliberate and indeterminate materials in the paste (Rice 1987:411), including a variety of tempers (grog or crushed sherds, bone, hematite/ferruginous sandstone, shell, quartz sands, etc.) and "particulate matter of some size." The grog, bone, shell, and hematite/ferruginous sandstone non-plastics appear to have been deliberately added to the paste as tempers. The bone and shell used for temper had been burned and calcined, then crushed, before it was added to the paste.

Vessel Form: Vessel form categories include open containers (bowls of several sizes, including effigy bowls, carinated bowls, and compound bowls) and restricted containers, including jars and bottles. As restricted containers, jars allow access by hand, but bottles do not (Brown 1996:335). There are several compound form vessels, one where two different vessel forms have been conjoined to create a single unique vessel form. This ceramic practice is one of the distinctive features of Great Bend ceramic vessel assemblages (cf. Bonds 2006). Other form attributes that were recorded include the rim profile (outflaring or everted, vertical or standing, and inverted), lip profile (rolled to the exterior, rounded, flat, or thinned), and base shape (flat or rounded).

Core Colors: Observations on ceramic cross-section colors permit consideration of oxidation patterns (Teltser 1993:Figure 2A-H), and thus the conditions under which the vessel was fired and then cooled after firing. Comments are included for these attributes on the presence and location of fire-clouding, sooting or smudging from cooking use (Skibo 1992), and charred organic remains.

Wall Thickness: Thickness was recorded in millimeters, using a vernier caliper, at the lip, along the rim, at several points along the body, and at the base when possible (only for the vessels that were not complete).

Interior and Exterior Surface Treatment: The primary methods of finishing the surface of the vessels includes either smoothing, burnishing, and polishing (Rice 1987:138). Brushing, while a popular method of roughening the surface (particularly the body) of large and small Middle (ca. A.D. 1200-1400) and Late Caddo (ca. A.D. 1400-1680) period cooking jars in several parts of the Caddo area, is here considered a decorative treatment rather than solely a functional surface treatment (cf. Rice 1987:138), although not all Caddo ceramic analysts treat brushing as a decorative treatment (cf. Gadus et al. 2006:31). Smoothing 
creates "a finer and more regular surface... [and] has a matte rather than a lustrous finish" (Rice 1987:138). Burnishing, on the other hand, creates an irregular lustrous finish marked by parallel facets left by the burnishing tool (perhaps a pebble or bone). A polished surface treatment is marked by a uniform and highly lustrous surface finish, done when the vessel is dry, but without "the pronounced parallel facets produced by burnishing leather-hard clay" (Rice 1987:138).

The application of a hematite-rich clay slip (Ferring and Perttula 1987), either red or black after firing in an oxidizing or reducing (i.e., low-oxygen) environment, is another form of surface treatment noted in this assemblage, although not with the frequency seen in other Caddo ceramic vessel assemblages from other parts of the Caddo archeological area (see Perttula et al. 2007, 2008a). The clay slip is more frequently applied on the vessel exterior than on the interior surface, and then was either burnished or polished after it was leather-hard or dry.

Height and Orifice Diameter: These attributes, measured in centimeters, were recorded with a ruler.

Diameter at Bottom of Rim and Base Diameter: Also recorded in millimeters using a ruler, these attributes permit characterization of the overall contour and shape of the vessel.

Volume: Vessel volume in liters was determined by filling (to within $1 \mathrm{~mm}$ of the lip) the vessel with lentil seeds, then dumping the lentil seeds in containers of known volume. In estimating the volume of vessels with holes, the vessel was first filled with a cloth that conformed to vessel contours, then the lentil seeds were poured into the depression in the cloth to within $1 \mathrm{~mm}$ of the top of the lip. Then they were dumped into containers of known volume. In cases where the vessels were not (or could not be) reconstructed, but measurements of height and orifice diameter were be obtained, volumes were estimated by comparison with known vessel volumes of specific forms (i.e., carinated bowl, jar, bottle, compound bowl, and bowl) in other documented Caddo vessel assemblages.

Decoration: Decorative techniques present in the Gilcrease Museum NAGPRA vessel collection from sites in southwestern Arkansas include engraving, incising, trailing, punctating, brushing, stamping, and appliquéing, and on certain vessels, combinations of decorative techniques (i.e., brushed-punctated) created the decorative elements and motifs. Engraving was done with a sharp tool when the vessel was either leather-hard, or after it was fired, as were the tick marks often seen on vessels in this collection, while the other decorative techniques were executed with tools (stamping, trailing, incising, and punctation), by adding strips of clay to the wet body (appliqué), using frayed sticks or grass stems (brushing) dragged across the body surface, or fingernails (certain forms of punctations), when the vessel was wet or still plastic. Excising is considered a form of engraved decoration, where the clay is deliberately and closely marked/scraped and carved 
away with a sharp tool, usually to create triangular elements, tick marks, or excised punctations.

Another form of vessel decoration is the use of red (hematite or ochre) or white (kaolin clay) clay pigments that have been smeared or rubbed into the engraved lines of certain vessels.

Type: The kinds of ceramic types and defined varieties in the Gilcrease Museum NAGPRA collections follow Webb (1959), Suhm and Jelks (1962), Schambach and Miller (1984), Early (1993), and Kelley (1997).

\section{Vessels from the Battle Site (3LA1)}

A total of 104 vessels were documented in the Gilcrease Museum NAGPRA collections from the Battle site (Table 1). This includes 13 bowls (12.5\%), among them three effigy vessels, 23 carinated bowls $(22.1 \%), 28$ bottles $(26.9 \%)$, and 40 jars $(38.5 \%)$.

Table 1. Vessels from the Battle site (3LA1) in the Gilcrease Museum NAGPRA collections. Vessels grouped together are from the same reported provenience.

Vessel No. Temper $\quad \begin{aligned} & \text { Volume } \\ & \text { (in liters) }\end{aligned} \quad$ Type/Decoration

\begin{tabular}{llll}
\hline Bowl & & & \\
V-2 & grog & 0.23 & Moore Noded \\
V-232 & grog & 0.27 & horizontal incised; effigy vessel \\
& & 0.22 & Moore Noded \\
V-316 & grog & 0.27 & Friendship Engraved \\
V-356 & grog & 0.43 & incised; effigy vessel \\
& grog & 0.64 & $\begin{array}{l}\text { Friendship Engraved } \\
\text { cf. Hardman Engraved, var. Joan } \\
\text { V-531 }\end{array}$ \\
V-1129 & grog & Bowie Engraved \\
V-1130 & grog-bone & 0.35 & lip notched \\
V-1131 & grog-hematite & 0.65 & Bowie Engraved \\
V-1740 & shell & 0.63 & appliqued ridges; effigy vessel \\
& grog-bone & 0.49 & Handy Engraved
\end{tabular}


Table 1, cont.

\begin{tabular}{|c|c|c|c|}
\hline Vessel No. & Temper & $\begin{array}{l}\text { Volume } \\
\text { (in liters) }\end{array}$ & Type/Decoration \\
\hline $\mathrm{V}-2204$ & shell & 0.15 & engraved semi-circular and scroll motifs \\
\hline \multicolumn{4}{|c|}{ Carinated Bowl } \\
\hline V-109 & grog & 0.58 & Handy Engraved \\
\hline V-1124 & grog & 0.61 & Belcher Engraved, var. Belcher \\
\hline V-1126 & grog-bone & 0.59 & cf. Avery Engraved, var. Bradshaw \\
\hline$V-1242$ & grog & 0.55 & cf. Glassell Engraved \\
\hline V-1781 & grog-bone & 0.72 & Belcher Engraved, var. Owen \\
\hline V-1782 & grog & 0.61 & Belcher Engraved, var. Owen \\
\hline V-1949 & grog-shell & 0.40 & Natchitoches Engraved, var. unspecified \\
\hline V-1950 & grog-shell & 0.38 & Natchitoches Engraved, var. unspecified \\
\hline V-1951 & grog & $\mathrm{N} / \mathrm{A}$ & Belcher Engraved, var. Belcher \\
\hline V-1967 & grog & 0.56 & vertical engraved-ticked panels \\
\hline V-1968 & grog & 0.41 & Simms Engraved \\
\hline V-1978 1/2 & grog-bone & 0.51 & Belcher Engraved, var. Belcher \\
\hline V-1983 & grog & 0.31 & Belcher Engraved, var. Belcher \\
\hline V-1986 & grog-bone & 0.31 & Belcher Engraved, var. Belcher \\
\hline V-1992 & grog & 0.35 & Belcher Engraved, var. Owen \\
\hline V-1993 & grog & 0.38 & Handy Engraved \\
\hline V-1994 & bone & 0.53 & Friendship Engraved \\
\hline V-1999 & grog-bone & 0.64 & Handy Engraved \\
\hline V-2001 & grog & 0.77 & Handy Engraved \\
\hline V-2003 & grog & 0.58 & Handy Engraved \\
\hline V-2005 & grog & 0.77 & Handy Engraved \\
\hline V-2007 & grog & 0.45 & Belcher Engraved, var. Belcher \\
\hline V-2012 & grog & 0.75 & Handy Engraved \\
\hline
\end{tabular}


Table 1, cont.

\begin{tabular}{|c|c|c|c|}
\hline Vessel No. & Temper & $\begin{array}{l}\text { Volume } \\
\text { (in liters) }\end{array}$ & Type/Decoration \\
\hline \multicolumn{4}{|l|}{ Bottle } \\
\hline $\mathrm{V}-35$ & grog & 0.46 & cf. Haley Engraved \\
\hline V-51 & grog-bone & 0.44 & Friendship Engraved \\
\hline $\mathrm{V}-54$ & grog & 0.54 & engraved panels and appliqued nodes \\
\hline V-76 & grog-bone & 0.37 & Haley Engraved \\
\hline $\mathrm{V}-180$ & grog-bone & 0.51 & Haley Engraved \\
\hline V-182 & grog-bone & 0.49 & engraved panels and semi-circles \\
\hline $\mathrm{V}-221$ & grog-bone & 0.36 & Haley Engraved \\
\hline $\mathrm{V}-225$ & shell & 0.42 & cf. Means Engraved \\
\hline V-464 & bone & 0.34 & red-slipped \\
\hline V-479 & grog & 0.13 & Hodges Engraved, var. Kelly's Lake \\
\hline V-1014 & grog & 0.50 & Haley Engraved \\
\hline V-1122 & grog & 0.37 & cf. Friendship Engraved \\
\hline $\mathrm{V}-1122+$ & grog & 0.30 & Friendship Engraved \\
\hline V-1132 & grog & 0.40 & Friendship Engraved \\
\hline V-1133 & grog & 0.50 & Friendship Engraved \\
\hline V-1741 & grog-bone & 0.52 & Friendship Engraved \\
\hline V-1952 & grog-bone & $\mathrm{N} / \mathrm{A}$ & Keno Trailed, var. unspecified \\
\hline V-1962 & grog-bone & 0.42 & Belcher Engraved, var. Soda Lake \\
\hline V-1969 & shell & 0.14 & engraved concentric circles \\
\hline V-1995 & grog & 0.72 & engraved nested diamonds \\
\hline V-1998 & grog-bone & 0.59 & Haley Engraved \\
\hline
\end{tabular}


Table 1, cont.

\begin{tabular}{|c|c|c|c|}
\hline Vessel No. & Temper & $\begin{array}{l}\text { Volume } \\
\text { (in liters) }\end{array}$ & Type/Decoration \\
\hline V-2002 & grog & 0.21 & horizontal engraved with pendant triangles \\
\hline V-2004 & grog & 0.16 & cf. Haley Engraved \\
\hline V-2006 & grog & 0.70 & engraved circles and swastika and cross \\
\hline V-2009 & grog & 0.75 & cf. Handy Engraved \\
\hline V-2010 & grog & 0.70 & cf. Haley Engraved \\
\hline V-2011 & grog & 0.54 & cf. Handy-Hatchel Engraved \\
\hline V-2013 & grog & 0.62 & cf. Handy Engraved \\
\hline \multicolumn{4}{|l|}{ Jar } \\
\hline $\mathrm{V}-70$ & grog-bone & 0.20 & brushed-punctated-appliqued \\
\hline $\mathrm{V}-103$ & grog-bone & 1.78 & Pease Brushed-Incised \\
\hline $\mathrm{V}-115$ & grog-bone & 1.14 & cf. Haley Complicated Incised \\
\hline $\mathrm{V}-117$ & grog-bone & 2.32 & Haley Complicated Incised \\
\hline$V-162$ & grog & 0.55 & brushed-pinched-punctated \\
\hline$V-165$ & $\begin{array}{l}\text { bone-grog- } \\
\text { hematite }\end{array}$ & 0.62 & cf. Sinner Linear Punctated \\
\hline$V-178$ & grog-shell & 0.53 & Mound Tract Incised and Brushed \\
\hline V-188 & grog-bone & 0.72 & $\begin{array}{l}\text { Keno Trailed, var. unspecified (cf. var. } \\
\text { Scott's Lake) }\end{array}$ \\
\hline V-197 & bone & 0.97 & Cowhide Stamped \\
\hline V-202 & shell & 0.75 & $\begin{array}{l}\text { Foster Trailed-Incised or Mound Tract } \\
\text { Incised and Brushed }\end{array}$ \\
\hline $\mathrm{V}-210$ & grog-bone & 0.88 & cf. Sinner Linear Punctated \\
\hline $\mathrm{V}-218$ & grog-bone & 0.66 & zoned incised-punctated panels \\
\hline$V-246$ & grog-bone & 0.66 & Mound Tract Incised and Brushed \\
\hline
\end{tabular}


Table 1, cont.

\begin{tabular}{|c|c|c|c|}
\hline Vessel No. & Temper & $\begin{array}{l}\text { Volume } \\
\text { (in liters) }\end{array}$ & Type/Decoration \\
\hline $\mathrm{V}-255$ & grog & 0.61 & Cowhide Stamped \\
\hline $\mathrm{V}-256^{*}$ & grog & 0.22 & brushed-punctated \\
\hline$V-268$ & grog-bone & 0.64 & cf. Sinner Linear Punctated \\
\hline$V-270$ & grog-bone & 1.71 & incised chevrons and diagonal lines \\
\hline $\mathrm{V}-281$ & grog & 0.55 & zoned incised-punctated panels \\
\hline V-331 & grog & 0.71 & Pease Brushed-Incised \\
\hline$V-348$ & grog-bone & 0.43 & Belcher Ridged, var. Wilson's Island \\
\hline$V-365$ & grog-bone & 1.78 & Belcher Ridged, var. Belcher Ridged \\
\hline V-386 & grog & 1.13 & Haley Complicated Incised \\
\hline $\mathrm{V}-1125$ & grog-bone & 0.39 & incised-stamped \\
\hline V-1127 & $\begin{array}{l}\text { grog-bone- } \\
\text { hematite }\end{array}$ & 0.86 & Mound Tract Incised and Brushed \\
\hline V-1128 & grog & 0.55 & Pease Brushed-Incised \\
\hline V-1947 & shell & 1.75 & Karnack Brushed-Incised, var. Karnack \\
\hline V-1948 & shell & 2.63 & Foster Trailed-Incised, var. Foster \\
\hline V-1966 & shell & 0.86 & $\begin{array}{l}\text { Foster Trailed-Incised or Mound Tract } \\
\text { Incised and Brushed }\end{array}$ \\
\hline V-1979 & grog & 0.44 & Foster Trailed-Incised, var. Red Lake \\
\hline V-1980 & grog & 0.46 & Foster Trailed-Incised, var. Red Lake \\
\hline V-1985 & grog & 0.54 & Foster Trailed-Incised, var. Dixon \\
\hline V-1987 & grog & 1.17 & brushed-appliqued-punctated \\
\hline V-1988 & grog-bone & 0.72 & zoned incised-punctated panels \\
\hline V-1991 & grog & 0.49 & Foster Trailed-Incised, var. unspecified \\
\hline V-1996 & grog & 0.96 & brushed-incised-punctated-appliqued \\
\hline
\end{tabular}


Table 1, cont.

\begin{tabular}{llll}
\hline Vessel No. & Temper & $\begin{array}{l}\text { Volume } \\
\text { (in liters) }\end{array}$ & Type/Decoration \\
\hline V-1997 & grog & 0.59 & Belcher Ridged, var. Wilson's Island \\
V-2000 & none & 1.39 & Foster Trailed-Incised, var. Foster \\
V-2004 1/2 & grog & 2.16 & Haley Complicated Incised \\
V-2008 & grog & 0.87 & Pease Brushed Incised \\
N/A++ & grog & N/A & Keno Trailed, var. unspecified
\end{tabular}

$+=$ although there are apparently two V-1122 vessels in the collection, they have different accession numbers (5425-750 and 5425-753); ++found together with the same accession nos. as $\mathrm{V}-1952$

*cut-down and recycled vessel

Almost $58 \%$ of the Battle Place vessels are from engraved, trailed, and redslipped fine wares. The remainder of the Battle Place collection are plain or decorated utility wares (i.e., coarse wares, cf. Schambach and Miller 1984:109), principally jars (see Table 1).

With a few exceptions, primarily in the jars and in the case of one Handy Engraved bowl, the ceramic vessels from burial contexts are relatively consistently small in height and volume (see Table 1). There is little range in mean volume in the carinated bowls (coefficient of variation $[\mathrm{CV}]=22)$ or the bottles $(\mathrm{CV}=29)$ compared to the bowls $(\mathrm{CV}=43)$ and jars $(\mathrm{CV}=48)$. The mean volume in liters of the different vessel forms is: $0.46 \pm 0.20$ (ranging from $0.15-1.20$ ) for bowls; $0.54 \pm 0.12$ (ranging from $0.31-0.77$ ) for carinated bowls; $0.45 \pm 0.13$ (ranging from $0.13-0.75$ ) for bottles; and $0.93 \pm 0.45$ (ranging from 0.20-2.63) for the jars. The largest vessels (with volumes between 1.752.63 liters, $n=6$ ) are all jars, equally divided between Haley phase and Belcher phase mortuary vessels. The bottles and jars from the Battle Place are larger in volume than those from either the Wm. Handy or Lester Bros. Place/Plantation sites, but not significantly so (see below).

Most of the Battle site vessels have been tempered with grog $(53.9 \%)$ or grog and burned bone (29.8\%). Another 7.7\% have been tempered with mussel shell, and 2.9\% have both grog and mussel shell added to the vessel clay paste. Less than $2 \%$ of the vessels are tempered with bone $(1.9 \%)$, grog-bone-hematite $(1.9 \%)$, and grog-hematite $(0.9 \%)$; one vessel did not have an obvious added temper. The shell-tempered vessels from the site (10.6\% of all the vessels) are Belcher phase and Chakanina phase styles, including examples of Foster Trailed-Incised, var. Foster, Karnack Brushed-Incised, var. Karnack, Mound Tract Incised and Brushed, and Natchitoches Engraved, var. unspecified. The Haley phase ceramic vessels are tempered with grog and/or bone. 
Based simply on the relative proportions of identifiable vessels by type, more than $42 \%$ of the NAGPRA vessels from the Battle Place are from Haley phase burials (Figure 12). This compares to $30.6 \%$ of the vessels from Wm. Handy Place burials, and a maximum of $10.9 \%$ of the mortuary vessels from the Lester Bros. Plantation/Place. Clearly there was an intensive Haley phase occupation - along with mound building and the establishment of cemeteries - at the Battle Place during the period from ca. A.D. 1200-1500.

Figure 12. Selected Haley phase vessels from the Battle Place (3LA1): a, Handy Engraved carinated bowl (5425-637); b, Handy Engraved carinated bowl (5425-712); c, cf. Handy-Hatchel Engraved bottle (5425-669); d, Engraved bottle (5425-666); e, Haley Engraved bottle (5425-757); f, Engraved bottle (5425-702); g, Friendship Engraved bottle (5425-753); h, Haley Complicated Incised jar (5425-656); i, Haley Complicated Incised jar (5425-747); j, Pease Brushed-Incised jar (5425-698); k, Sinner Linear Punctated jar (5425-762); 1. Moore Noded bowl (5425-721).

The most important Haley phase ceramic types at the Battle place are Handy Engraved bottles and carinated bowls (25\%) (see Figure 12a-c), Friendship Engraved bottles and carinated bowls (20.4\%) (see Figure 12g), Haley Engraved bottles $(9.1 \%)$ (see Figure 12 e, but probably also Figure $12 \mathrm{~d}, \mathrm{f})$, and Haley Complicated-Incised $(9.1 \%$, see Figure $12 \mathrm{~h}-\mathrm{i})$ and Pease Brushed-Incised (9.1\%, see Figure $12 \mathrm{j})$ jars. The Friendship Engraved vessels likely were made by Caddo groups living in the mid-Ouachita River region to the northeast (Early 1993:5). Unambiguous burials with Haley phase ceramic vessels at the Battle Place include Burial 3 in Plot 2 (see Figure 8), Burial 4 in Plot 2 (see Figure 9), and Burial 1 in Plot 3 (see Figure 10), in the northeastern part of the site (see Figure 3).

Belcher phase ceramic vessels identified to type and/or variety account for $19.3 \%$ of the Battle Place vessels. They include Belcher, var. Belcher carinated bowls $(30 \%$ of the identified Belcher phase ceramic vessels by type), Figure 13a), Mound Tract Incised and Brushed (15\%, Figure 13b-c) and Cowhide Stamped jars (10\%), Foster TrailedIncised, var. Foster (10\%, Figure 13d-e) and var. Red Lake (10\%, Figure 13f)) jars, and Karnack Brushed-Incised, var. Karnack (5\%, Figure 13g) jars. The one Belcher Engraved bottle from this component is a var. Soda Lake (5\%), also common at the Lester Bros. Place/Plantation Belcher phase mortuary vessels. Other ceramic vessel types from Belcher phase burials at the Battle Place include Avery Engraved, var. Bradshaw (5\%, Belcher Ridged, var. Belcher Ridged (5\%), and Simms Engraved (5\%). Other than plowed up burials in the fields at the Battle Place with Belcher phase ceramic funerary offerings (see Appendix 1), Burial 1 in Plot 1 (see Figure 4) north of the large platform mound appears to be a Belcher phase interment.

Figure 13. Selected Belcher phase vessels from the Battle Place: a, Belcher Engraved, var. Belcher carinated bowl (5425-674); b, Mound Tract Incised and Brushed jar (5425738); c, Mound Tract Incised and Brushed jar (5425-746); d, Foster Trailed-Incised, var. Foster (5425-661) jar; e, Foster Trailed-Incised, var. Foster jar (5425-662); f, Foster 
Trailed-Incised, var. Red Lake jar (5425-2431A); g, Karnack Brushed-Incised, var. Karnack jar (5425-655).

Early Historic Chakanina phase ceramic vessels, as well as ceramic types that apparently were in use in both the late Belcher phase and the Chakanina phase (including Hodges Engraved, var. Armour and var. Candler and Belcher Ridged, var. Wilson's Island, see Schambach and Miller 1984:Table 11-12), comprise 7.7\% and 1.9\%, respectively, of the NAGPRA vessels from the Battle Place. At the Battle site, the most common early Historic Caddo ceramic vessels in burials are Belcher Engraved, var. Owen (30\%, Figure 14a), Natchitoches Engraved, var. unspecified (20\%, Figure 14b), and Belcher Ridged, var. Wilson's Island (20\%, Figure 14f). Other associated vessels in Chakanina phase burials at the Battle site include Foster Trailed-Incised, var. Dixon (10\%, Figure 14e), Hodges Engraved, var. Kelly's Lake (10\%, Figure 14c), and Keno Trailed, var. unspecified (but probably var. Scott's Lake) (10\%, Figure 14d).

Figure 14. Selected Chakanina phase vessels from the Battle Place: a, Belcher Engraved, var. Owen carinated bowl (5425-2453); b, Natchitoches Engraved, var. unspecified carinated bowl (5425-705); c, Hodges Engraved, var. Kelly's Lake bottle (5425-725); d, Keno Trailed, var. unspecified jar (5425-730); e, Foster Trailed-Incised, var. Dixon jar (5425-681); f, Belcher Ridged, var. Wilson's Island jar (5425-683).

Chakanina phase Caddo burials, or burials with both late Belcher phase and Chakanina phase vessels apparently in association, occur in Plot 1 (see Figure 5), north of the large platform mound (see Figure 3). Others include a burial encountered at the north end of the large platform mound, and another burial encountered and excavated at the south end of the large platform mound in 1938, while a tenant was digging a cellar (see Appendix 1).

\section{Vessels from the William Handy Place at the Battle Site (3LA1)}

The Gilcrease Museum NAGPRA collections include a total of 72 vessels or vessel sherd sections from the Wm. Handy Place at the Battle site. These vessels include eight bowls (11.1\%), including one effigy bowl, 26 carinated bowls (36.1\%), 18 bottles $(25 \%)$, and 20 jars $(27.8 \%)$ (Table 2$)$. Approximately $64 \%$ of these vessels are engraved, trailed, and red-slipped fine wares, with the remainder comprised of plain and decorated utility wares. 
Table 2. Vessels from the Wm. Handy Place at the Battle site (3LA1) in the Gilcrease Museum NAGPRA collections. Vessels grouped together are from the same reported provenience.

$\begin{array}{lll}\text { Vessel No. Temper } & \begin{array}{l}\text { Volume } \\ \text { (in liters) }\end{array}\end{array}$

\section{Bowl}

\begin{tabular}{|c|c|c|c|}
\hline V-2001 & grog-bone & 0.10 & vertical engraved lines \\
\hline V-2039* & grog & 0.51 & Plain \\
\hline V-2041 & grog & 0.96 & Handy Engraved \\
\hline V-2044 & grog & 0.42 & cf. Taylor Engraved \\
\hline V-2099 & grog-bone & 0.19 & Plain, effigy \\
\hline V-2337 & grog & 0.16 & engraved-punctated \\
\hline V-2339 & bone & 0.26 & Plain \\
\hline V-2341 & grog & 0.46 & Moore Noded \\
\hline
\end{tabular}

\section{Carinated Bowl}

\begin{tabular}{|c|c|c|c|}
\hline V-2030 & grog & 0.96 & Belcher Engraved, var. Belcher \\
\hline V-2032 & grog & 0.83 & Hodges Engraved, var. Armour \\
\hline V-2033 & grog & 1.09 & Glassell Engraved, var. Atkins \\
\hline V-2036 & grog & 0.36 & Simms Engraved \\
\hline V-2038 & grog & 1.14 & Belcher Engraved, var. Belcher \\
\hline V-2046 & grog & 0.50 & Belcher Engraved, var. unspecified \\
\hline V-2048 & grog & 0.79 & Hodges Engraved, var. Armour \\
\hline V-2053 & grog-shell & 0.69 & Belcher Engraved, var. Owen \\
\hline V-2089 & grog & 0.53 & Means Engraved \\
\hline V-2092 & grog-bone & 0.47 & cf. Avery Engraved, var. Bradshaw \\
\hline V-2093 & grog-bone & 0.29 & Plain \\
\hline V-2096 & grog-bone & 0.23 & Belcher Engraved, var. unspecified \\
\hline V-2102 & grog-hematite & 0.32 & Belcher Engraved, var. Owen \\
\hline $\mathrm{V}-2258$ & grog & 1.11 & $\begin{array}{l}\text { engraved scroll and spurs, cf. Haley } \\
\text { Engraved }\end{array}$ \\
\hline
\end{tabular}


Table 2, cont.

\begin{tabular}{|c|c|c|c|}
\hline Vessel No. & Temper & $\begin{array}{l}\text { Volume } \\
\text { (in liters) }\end{array}$ & Type/Decoration \\
\hline $\mathrm{V}-2259$ & grog & 0.80 & Friendship Engraved, sprocket rim \\
\hline $\mathrm{V}-2260$ & grog-bone & N/A & Handy Engraved \\
\hline V-2336 & grog-bone & 0.30 & Belcher Engraved, var. Belcher \\
\hline$V-2352$ & grog & 0.57 & Belcher Engraved, var. Belcher \\
\hline $\mathrm{V}-2353$ & grog & 0.69 & Belcher Engraved, var. Belcher \\
\hline V-2354 & grog & 0.27 & Glassell Engraved, var. Glassell \\
\hline$V-2355$ & grog & 0.25 & cf. Handy Engraved \\
\hline V-2356 & grog & 0.61 & Handy Engraved \\
\hline$V-2360$ & grog & 0.42 & Handy Engraved \\
\hline V-2361 & grog & 0.43 & Friendship Engraved, sprocket rim \\
\hline V-2362 & grog & 0.67 & Friendship Engraved \\
\hline V-4043 & grog & 0.67 & Belcher Engraved, var. Belcher \\
\hline \multicolumn{4}{|l|}{ Bottle } \\
\hline V-2035+ & grog & N/A & Hodges Engraved, var. Candler \\
\hline V-2035+ & grog & N/A & Friendship Engraved \\
\hline V-2040 & grog & 0.33 & $\begin{array}{l}\text { engraved interlocking ladders and central } \\
\text { circle }\end{array}$ \\
\hline V-2047 & grog-bone & 0.39 & Plain \\
\hline V-2049 & grog & 0.48 & Belcher Engraved, var. Ogden \\
\hline V-2090 & grog & 0.18 & Plain \\
\hline V-2257 & grog & 0.61 & red-slipped \\
\hline V-2261 & grog & 0.44 & Haley Engraved \\
\hline V-2334 & grog & 0.70 & Hickory Engraved \\
\hline V-2335 & grog & 0.47 & Hickory Engraved \\
\hline V-2338 & grog & 0.35 & Taylor Engraved \\
\hline V-2342 & grog & 0.53 & cf. Handy-Hatchel Engraved \\
\hline$V-2343$ & grog & 0.57 & Friendship Engraved \\
\hline
\end{tabular}


Table 2, cont.

\begin{tabular}{|c|c|c|c|}
\hline Vessel No. & Temper & $\begin{array}{l}\text { Volume } \\
\text { (in liters) }\end{array}$ & Type/Decoration \\
\hline $\begin{array}{l}V-2344 \\
V-2345 \\
V-2346 \\
V-2364 \\
V-2365\end{array}$ & $\begin{array}{l}\text { grog } \\
\text { grog } \\
\text { grog } \\
\text { grog } \\
\text { none }\end{array}$ & $\begin{array}{l}0.59 \\
0.59 \\
0.71 \\
\mathrm{~N} / \mathrm{A} \\
0.15\end{array}$ & $\begin{array}{l}\text { Belcher Engraved, var. Ogden } \\
\text { engraved scrolls with embedded circles } \\
\text { one horizontal engraved line } \\
\text { engraved concentric circles } \\
\text { Haley Engraved }\end{array}$ \\
\hline \multicolumn{4}{|l|}{ Jar } \\
\hline V-2034 & grog & 1.09 & $\begin{array}{l}\text { Cowhide Stamped, var. unspecified or } \\
\text { De Roche Incised }\end{array}$ \\
\hline V-2037 & shell & 0.29 & Foster Trailed-Incised, var. unspecified \\
\hline V-2038 & grog & 0.71 & Foster Trailed-Incised, var. Foster \\
\hline V-2045 & shell & 1.00 & cf. Mound Tract Incised and Brushed \\
\hline V-2050 & grog & 0.71 & Foster Trailed-Incised, var. Moore \\
\hline V-2054 & grog-bone & 1.03 & horizontal brushed-cross-hatched incised \\
\hline V-2055 & shell & 0.55 & Keno Trailed, var. Scott's Lake \\
\hline V-2091 & grog & 0.68 & Belcher Ridged, var. Wilson's Island \\
\hline $\begin{array}{l}V-2095 \\
V-2097\end{array}$ & $\begin{array}{l}\text { grog } \\
\text { grog }\end{array}$ & $\begin{array}{l}0.25 \\
0.34\end{array}$ & $\begin{array}{l}\text { Foster Trailed-Incised, var. unspecified } \\
\text { punctated-brushed }\end{array}$ \\
\hline $\mathrm{V}-2100$ & grog & 0.51 & Karnack Brushed-Incised, var. Karnack \\
\hline$V-2262$ & grog-bone & 0.74 & Haley Complicated Incised \\
\hline V-2340 & grog-bone & 0.77 & Haley Complicated Incised \\
\hline $\mathrm{V}-2348$ & grog & 1.43 & Haley Complicated Incised \\
\hline V-2349 & grog & 0.87 & Foster Trailed-Incised, var. unspecified \\
\hline $\mathrm{V}-2350$ & grog & 0.60 & Haley Complicated Incised \\
\hline V-2351 & grog-bone & 0.36 & Plain \\
\hline $\mathrm{V}-2357$ & $\begin{array}{l}\text { bone-grog- } \\
\text { hematite }\end{array}$ & 0.73 & $\begin{array}{l}\text { Karnack Brushed-Incised, var. } \\
\text { unspecified }\end{array}$ \\
\hline $\mathrm{V}-2358$ & shell & 0.69 & Karnack Brushed-Incised, var. Karnack \\
\hline $\mathrm{V}-2359$ & grog & 0.83 & Sinner Linear Punctated \\
\hline
\end{tabular}


Grog-tempered ceramic vessels are predominant (70.8\%) in the Wm. Handy Place collections. Grog-bone-tempered wares are also common $(16.7 \%)$; one vessel $(1.4 \%)$ has bone temper, another has grog-bone-hematite temper $(1.4 \%)$, and a third has both grog and hematite temper additives (see Table 2). Almost 7\% of the Wm. Handy Place vessels have shell temper, either as the sole temper $(5.6 \%)$ or in combination with pieces of grog $(1.4 \%)$. Only a few Belcher phase and Chakanina phase vessels from the site have shell temper.

Wm. Handy vessels are not large in size or volume, as is generally the case in the other Great Bend region vessel assemblages examined in this NAGPRA study, and only the carinated bowl forms from the site are larger in volume here than the vessels documented from the Battle or Lester Bros. Place/Plantation. Bowls have a mean volume (in liters) of $0.36 \pm 0.18(\mathrm{CV}=50$, ranging from $0.10-0.96$ liters, the latter a Handy Engraved bowl); carinated bowl mean volume is $0.60 \pm 0.23$ (ranging from $0.23-1.11$ liters); the mean volume of the bottles is $0.39+0.16$ (ranging from $0.15-0.71$ liters); and the mean volume of the jars is only $0.71+0.22$ (ranging from $0.25-1.43$ liters). Even the largest jars at the Wm. Handy Place - with volumes ranging from 1.00-1.43 liters - are significantly smaller than the larger vessels (1.75-2.63 liters) from the Battle and Lester Bros. Place/Plantation burials.

Haley phase vessels from the Wm. Handy Place site comprise $30.6 \%$ of the typologically identified vessels in the Gilcrease Museum NAGPRA collections (see Table 2). The most common engraved fine wares include Handy Engraved carinated bowls (22.7\%, Figure 15a), Friendship Engraved bottles and carinated bowls $(22.7 \%$, Figure 15b), Haley Engraved bottles (15.6\%), and Hickory Engraved (9.1\%). Other engraved fine wares are a single Means Engraved carinated bowl and a bottle with Handy Engraved and Hatchel Engraved style engraved panels (Figure 15c). Fine wares account for more than $72 \%$ of the Haley phase vessels from mortuary contexts.

Figure 15. Selected Haley phase vessels from the Wm. Handy Place: a, Handy Engraved carinated bowl (5425-2116A-D); b, Friendship Engraved bottle (5425-2024); c, cf. Handy-Hatchel Engraved bottle (5425-2030); d, Moore Noded bowl (5425-682); e, Sinner Linear Punctated jar (5425-2125); f, Haley Complicated Incised jar (5425-701); g, Haley Complicated Incised jar (5425-2128).

The utility wares from Haley phase burials at the Wm. Handy Place are dominated by Haley Complicated Incised jars (18.2\%, see Figure 15f-g). Other utility wares include a Sinner Linear Punctated jar (see Figure 15e) and a Moore Noded bowl (see Figure 15d).

A significant proportion (26.4\%) of the Wm. Handy Place ceramic vessels are types and varieties known to date to Belcher phase times (Figure 16, see Table 2). There are several Belcher phase burials from the Wm. Handy Place cemetery in the NAGPRA collections, including Burials 1, A, and B excavated in 1940 and 1941 (see Figure 11 and Appendix 2). Among the fine wares, Belcher Engraved, var. Belcher carinated bowls (31.6\%, Figure 16a) and var. Ogden bottles (10.5\%, Figure 16d-e), as well as Taylor 
Engraved (10.5\%), and Glassell Engraved, var. Glassell (5.3\%) and var. Atkins (5.3\%) carinated bowls are the most abundant.

Figure 16. Selected Belcher phase vessels from the Wm. Handy Place: a, Belcher Engraved, var. Belcher carinated bowl (5425-2027A); b, Hodges Engraved, var. Armour carinated bowl (5425-2034); c, Avery Engraved, cf. Bradshaw carinated bowl (54252055); d, Belcher Engraved, var. Ogden bottle (5425-2022); e, Belcher Engraved, var. Ogden bottle (5425-2059); f, cf. Mound Tract Incised and Brushed jar (5425-2119); g, Karnack Brushed-Incised, var. Karnack jar (5425-2118); h, Cowhide Stamped, var. unspecified jar (5425-2131).

Utility ware vessels from Belcher phase burials at the Wm. Handy Place include Karnack Brushed-Incised, var. Karnack (10.5\%, see Figure 16g), Foster Trailed-Incised, var. Foster (5.3\%), and Mound Tract Incised and Brushed jars (5.3\%, see Figure 16f).

Chakanina phase vessels, or vessels apparently in use in both late Belcher phase and Chakanina phase times (see Schambach and Miller 1984:Table 11-12) comprise only $11.2 \%$ of the typologically identifiable vessels from the Wm. Handy Place. This compares to $9.6 \%$ at the Battle Place and $19.5 \%$ at the Lester Bros. Place/Plantation. This includes the following fine wares: Belcher Engraved, var. Owen (25\%), Hodges Engraved, var. Armour (25\%) and var. Candler (12.5\%), and Keno Trailed, var. Scott's Lake (12.5\%, Figure 17a). Utility wares include Foster Trailed-Incised, var. Moore (12.5\%, Figure 17c), and Belcher Ridged, var. Wilson's Island (12.5\%, Figure 17b). Possible late Belcher to Chakanina phase burials include two excavated in 1940 (Burials 4 and 5) in the large Wm. Handy cemetery (see Appendix 2).

Figure 17. Selected Chakanina phase vessels from the Wm. Handy Place: a, Keno Trailed, var. Scott's Lake jar (5425-7156A); b, Belcher Ridged, var. Wilson's Island jar (5425-2058); c, Foster Trailed-Incised, var. Moore jar (5425-7147).

\section{Vessels from the Foster Site (3LA27)}

The six vessels from the Foster site in the Gilcrease Museum NAGPRA collections include three grog-tempered Belcher Engraved bottles, var. Soda Lake $(\mathrm{n}=2)$ and var. Ogden $(\mathrm{n}=1)$, a well-made shell-tempered and red-slipped Hatinu Engraved bottle with negative relief designs (see Perttula et al. 2005:30 and Figure 4.5; see also Bonds [2006:Figures 83, 160, 432, 491, 523, 536, 541, 585, 629, 632] and Moore [1912:Figures 106 and 107], from the Foster site, for other examples of Hatinu Engraved vessels in the Great Bend region), a grog-shell-tempered Belcher Engraved, var. unspecified carinated bowl, and a grog-hematite-tempered brushed-incised jar.

The decorative styles of these vessels from the Foster site suggest they are from a late Belcher phase or early Chakanina phase burial context, giving weight to the proportion of shell tempering (33\%), and the occurrence of Hatinu Engraved vessels in late $17^{\text {th }}$-early $18^{\text {th }}$ century burial features at the Clements site (41CS25) (see Figure 1). 
The vessels from the Foster site are relatively small, with a mean volume of $0.48 \pm 0.09$ liters, and a range from 0.30-0.63 liters (see Appendix 4).

\section{Vessels from the Cabaness Place}

There are five vessels in the Gilcrease Museum NAGPRA collections from at least one Caddo burial excavated in 1915 at the Cabaness Place. They include a plain grog-tempered bowl with a cut-down rim, a grog-tempered plain seed jar, a Glassell Engraved, var. unspecified grog-tempered carinated bowl, a Natchitoches Engraved, var. unspecified shell-tempered bowl, and shell-tempered Belcher Ridged, var. unspecified cut-down jar (see Appendix 6). If these five burials were found together in one burialwhich is unknown if that is the case or not - the occurrence of the shell-tempered Natchitoches Engraved bowl, as well as the frequency of shell-tempering (40\%), would suggest that the burial dates from the early Historic Chakanina phase.

All of the vessels from the Cabaness Place are small in size, ranging from only 0.14-0.67 liters in volume, perhaps suggesting they were meant to accompany the burial of a child. The mean volume of the vessel is only $0.34 \pm 0.13$ liters.

\section{Vessels from the George W. Sentell Place}

The Gilcrease Museum NAGPRA collections have eight ceramic vessels from the George W. Sentell Place (see Appendix 5). These vessels are likely from two separate Caddo burials, one dating to Haley phase times (with two vessels) and the other dating to the Belcher phase (with five vessels); one straight-necked and relatively large (0.78 liters in volume) engraved and grog-tempered bottle with a unique series of engraved body panels with cross-hatched bands, half circles, and equal arm crosses probably also dates from Haley phase times. The occurrence of Haley phase vessels in this small collection is notable given that only one of the 72 vessels from the Lester Bros. Plantation/Place (see below) - the later name for the Geo. W. Sentell Place - can be identified as a Haley phase mortuary vessel.

The Haley phase grog-tempered vessels from the Sentell Place include a Handy Engraved carinated bowl and a Sinner Linear Punctated jar. These vessels range from 0.51-0.87 liters in volume (mean volume of $0.69 \pm 0.18$ liters).

The Geo. W. Sentell Place Belcher phase vessels are either grog (80\%)- or grogbone-tempered $(20 \%)$. They are also relatively small in size (mean volume of only $0.43 \pm$ 14.2 liters, ranging from 0.08-0.65 liters) (see Appendix 5). The vessels include a Keno Trailed, var. McClendon bottle, a Belcher Engraved, var. unspecified bottle, and an Avery Engraved, var. Graves carinated bowl. The other two Belcher phase vessels are relatively rare engraved forms, one being a Hodges Engraved, var. unspecified tripod bottle and the other an engraved headless turtle effigy with four feet and a small tail. 


\section{Vessels from the Lester Bros. Plantation (3LA38) and Lester Bros. Place (3LA48)}

The Gilcrease Museum NAGPRA collections documented during the present study include three vessels from the Lester Bros. Plantation and 43 vessels from the Lester Bros. Place (Table 3). Together, there are 10 bowls $(21.7 \%)$, including two effigy bowls, 13 carinated bowls $(28.3 \%), 11$ bottles $(23.9 \%)$, and 12 jars $(26.1 \%)$ from these places, both apparently part of the same Caddo habitation site and associated cemeteries. More than $65 \%$ of the vessels are engraved or trailed fine wares, with the remainder plain and/or decorated utility wares.

Table 3. Vessels from the Lester Bros. Plantation and Lester Bros. Place in the Gilcrease Museum NAGPRA collections. Vessels grouped together are from the same reported provenience.

\begin{tabular}{|c|c|c|c|}
\hline Vessel No. & Temper & $\begin{array}{l}\text { Volume } \\
\text { (in liters) }\end{array}$ & Type/Decoration \\
\hline \multicolumn{4}{|l|}{ Bowl } \\
\hline V-18 & grog & 0.64 & Hardman Engraved, var. Joan \\
\hline $\mathrm{V}-20$ & grog & 0.13 & Plain \\
\hline $\mathrm{V}-72$ & shell & 0.32 & Avery Engraved, var. Graves \\
\hline V-89 & shell & 0.25 & Plain, effigy bowl \\
\hline$V-155$ & grog & 1.22 & Hardman Engraved, var. Hardman \\
\hline V-169 & shell & 0.79 & Hardman Engraved, var. Joan \\
\hline $\mathrm{V}-228$ & grog-hematite & 0.07 & appliqued semi-circles, effigy bowl \\
\hline V-279 & grog & 0.26 & Plain \\
\hline V-364 & grog & 0.47 & cf. Taylor Engraved \\
\hline V-1754 & grog & 0.97 & Hardman Engraved, var. Joan \\
\hline
\end{tabular}

\section{Carinated bowl}

$\begin{array}{llll}\text { V-63 } & \text { grog } & 0.22 & \text { Avery Engraved, var. Bradshaw } \\ \text { V-106 } & \text { grog-bone } & 0.63 & \text { Belcher Engraved, var. Owen }\end{array}$


Table 3, cont.

\begin{tabular}{|c|c|c|c|}
\hline Vessel No. & Temper & $\begin{array}{l}\text { Volume } \\
\text { (in liters) }\end{array}$ & Type/Decoration \\
\hline $\mathrm{V}-150$ & grog & 0.51 & Belcher Engraved, var. Belcher \\
\hline V-151 & grog-hematite & 0.22 & Avery Engraved, var. Graves \\
\hline$V-216$ & grog & 0.29 & Belcher Engraved, var. unspecified \\
\hline $\mathrm{V}-260^{*}$ & grog & 0.75 & Natchitoches Engraved, var. Lester Ben \\
\hline$V-261$ & grog & 0.61 & Glassell Engraved, var. McGee \\
\hline V-291 & grog & 0.79 & Belcher Engraved, var. unspecified \\
\hline$V-358$ & grog & 0.48 & cf. Avery Engraved \\
\hline$V-465$ & grog & 0.67 & Hodges Engraved, var. unspecified \\
\hline V-478 & grog-bone & 0.15 & Hodges Engraved, var. Sentell \\
\hline V-509 & grog & 0.31 & Glassell Engraved, var. Atkins \\
\hline$V-521$ & grog & 0.35 & Glassell Engraved, var. Atkins \\
\hline \multicolumn{4}{|l|}{ Bottle } \\
\hline $\mathrm{V}-21$ & shell & 0.19 & Keno Trailed, var. McClendon \\
\hline V-62 & grog & 0.22 & cf. Hodges Engraved, var. unspecified \\
\hline$V-125$ & grog & 0.18 & Plain \\
\hline V-153 & grog & 0.29 & Hodges Engraved, var. unspecified \\
\hline$V-170$ & grog & 0.37 & Taylor Engraved \\
\hline V-173* & grog & 0.48 & Hodges Engraved, var. Candler \\
\hline V-359 & grog-shell & 0.59 & Belcher Engraved, var. Soda Lake \\
\hline$V-403$ & grog & 0.36 & Belcher Engraved, var. Soda Lake \\
\hline V-417 & grog & 0.21 & Hodges Engraved, var. Candler \\
\hline$V-445$ & grog & 0.89 & Keno Trailed, var. Glendora \\
\hline$V-499$ & grog & 0.47 & Keno Trailed, var. unspecified \\
\hline
\end{tabular}


Table 3, cont.

\begin{tabular}{llll}
\hline Vessel No. & Temper & $\begin{array}{l}\text { Volume } \\
\text { (in liters) }\end{array}$ & Type/Decoration \\
\hline Jar & grog-bone & 0.38 & Foster Trailed-Incised, var. Shaw \\
V-15 & grog & 0.72 & Avery Engraved, var. Bradshaw \\
V-41 & grog & 0.79 & Belcher Ridged, var. Wilson's Island \\
V-52 & shell & 0.53 & Karnack Brushed-Incised, var. Karnack \\
V-53* & grog & 0.49 & Mound Tract Incised and Brushed \\
V-93 & shell & 0.28 & Karnack Brushed-Incised, var. Karnack \\
V-110 & grog & 0.78 & $\begin{array}{l}\text { brushed-incised; cf. Mound Tract Incised } \\
\text { and Brushed }\end{array}$ \\
V-159 & shell & 2.32 & Foster Trailed-Incised, var. Dobson \\
V-199 & grog & 0.34 & $\begin{array}{l}\text { Plain } \\
\text { V-220 }\end{array}$ \\
V-229 & grog-bone & 0.98 & Haley Complicated Incised \\
V-371 & shell & 1.26 & $\begin{array}{l}\text { Foster Trailed-Incised, var. Dixon } \\
\text { V-372 }\end{array}$ \\
shell & 0.77 & $\begin{array}{l}\text { Karnack Brushed-Incised, var. unspecified } \\
\text { or Foster Trailed-Incised, var. unspecified }\end{array}$ \\
\hline
\end{tabular}

*vessel from Lester Bros. Plantation; all others are from Lester Bros. Place

Excepts for the jars, a large Keno Trailed, var. Glendora bottle, and one large bowl, most of the vessels from the Lester Bros. Place/Plantation are small in size and volume. By mean volume (in liters), volumes for the different vessel forms are $0.51 \pm$ 0.31 (ranging from 0.07-1.22 liters, $\mathrm{CV}=61$ ) for bowls; $0.45 \pm 0.19$ (ranging from 0.15 0.79 liters) for carinated bowls; $0.39 \pm 0.16$ (ranging from $0.18-0.89$ liters) for bottles; and $0.80 \pm 0.35$ (ranging from 0.28-2.32 liters) for the jars. The largest vessels are Belcher and Chakanina phase Foster Trailed-Incised jars (see Table 3). The bowls from the Lester Bros. Place/Plantation have a larger mean volume ( 0.51 liters) than the bowls from the Battle or Wm. Handy Places (0.36-0.46 liters), but not dramatically so.

About $65 \%$ of the Lester Bros. Place/Plantation vessels are tempered solely with grog (see Table 3). Grog-bone-tempered vessels - quite abundant in both the Battle site 
and the $\mathrm{Wm}$. Handy Place vessel assemblages (29.8\% and $16.7 \%$, respectively) - account for only $8.7 \%$ of the Lester Bros. Place/Plantation vessels. Two other vessels (4.3\%) at the site have both grog and hematite temper. Shell-tempered and grog-shell-tempered ceramic vessels, again from Belcher phase and Chakanina phase ceramic types, are more common here (21.8\%) than they are at either the Battle (10.6\%) or Wm. Handy $(7.0 \%)$ sites. Nevertheless, the use of shell temper in these ceramic vessels is considerably lower than that documented at the Belcher and Chakanina phase Cedar Grove site, where 64.2\% of the vessels $(\mathrm{n}=67)$ have either shell or grog-shell tempering (Schambach and Miller 1984). Both the Battle site and Wm. Handy Place sites have considerable numbers of non-shell-tempered Haley phase ceramics, while the Lester Bros. Place/Plantation and Cedar Grove sites have little to no evidence of pre-A.D. 1500 Caddo habitation or cemetery use.

There are five vessels (10.9\% of the vessels) from the Lester Bros. Place/Plantation that are apparently from Haley phase burials. This includes one Haley Complicated Incised jar and four Hardman Engraved bowls (see Table 3); the Hardman Engraved vessels likely originated in the Mid-Ouachita region of the Caddo archeological area and were traded/exchanged to a Haley phase Caddo group in the Great Bend region. Hardman Engraved appears to be a late Mid-Ouachita phase (ca. A.D. 1450-1500) ceramic type (cf. Early 1993:91).

Belcher phase vessels from Caddo burials are very common at the Lester Bros. Place/Plantation, more so than at either the Battle or Wm. Handy places. More than 39\% of the vessels identified to type and/or variety from the site are Belcher phase types (see Table 3). This includes Avery Engraved, var. Graves (11\%, Figure 18a) and var. Bradshaw (11\%) vessels, Glassell Engraved, var. McGee (5.6\%, Figure 18b) and var. Atkins (11\%) carinated bowls, Belcher Engraved, var. Soda Lake bottles (11\%, Figure $18 \mathrm{c}-\mathrm{d})$, Taylor Engraved (11\%), Keno Trailed, var. McClendon (5.6\%, Figure 18f), Mound Tract Incised and Brushed (11\%), Karnack Brushed-Incised (11\%, Figure 18h), and Foster Trailed-Incised, var. Dobson (5.6\%, Figure 18g).

Figure 18. Selected Belcher phase vessels from the Lester Bros. Place: a, Avery Engraved, var. Graves bowl (5425-937); b, Glassell Engraved, var. McGee carinated bowl (5425-952); c, Belcher Engraved, var. Soda Lake bottle (5425-901); d, Belcher Engraved, var. Soda Lake bottle (5425-778); e, Hodges Engraved bottle (5425-783); f, Keno Trailed, var. McClendon bottle (5425-888); g, Foster Trailed-Incised, var. Dobson jar (5425-904); h, Karnack Brushed-Incised, var. Karnack jar (5425-892).

Vessels from both late Belcher phase and Chakanina phase contexts at the Lester Bros. Place/Plantation include Hodges Engraved, var. Candler bottles ( $\mathrm{n}=2$, Figure 19de) and Belcher Ridged, var. Wilson's Island jars ( $\mathrm{n}=1$, Figure 19i). Chakanina phase vessels represent $13 \%$ of the vessels identified to type and/or variety. There are single examples from the Lester Bros. Place/Plantation in the Gilcrease Museum NAGPRA collections of Foster Trailed-Incised, var. Dixon and var. Shaw, Belcher Engraved, var. Owen, Natchitoches Engraved, var. Lester Bend (Figure 19a), Keno Trailed, var. Glendora, and Hodges Engraved, var. Sentell. 
Figure 19. Selected Chakanina phase vessels from the Lester Bros. Place: a, Natchitoches Engraved, var. Lester Bend carinated bowl (5425-895); b, Belcher Engraved, var. Owen carinated bowl (5425-925); c, Hodges Engraved, var. Sentell carinated bowl (5425-880); d, Hodges Engraved, var. Candler bottle (5425-909); e, Hodges Engraved, var. Candler bottle (5425-961); f, Keno Trailed, var. Glendora bottle (5425-1595); g, Foster TrailedIncised, var. Shaw jar (5425-889); h, Foster Trailed-Incised, var. Dixon jar (5425-911); i, Belcher Ridged, var. Wilson's Island jar (5425-1599).

\section{Clay Pipes}

\section{Battle Site}

There are 10 clay elbow pipes from the Battle site in the Gilcrease Museum NAGPRA collections (Table 4). One of the pipes (P-157) was found together in a plowed out grave along with vessels V-1242 to V-1245 (see Appendix 1), and several others came from burials excavated in 1938 in Burial Plot 2. Pipe P-34 came from a grave excavated in 1928 by Dan Jenkins, a tenant farmer living at the Battle site, while pipe P31 was from a grave excavated in 1923 at the site.

All have short thick stems with flattened lips, expanding or flaring bowls with rounded lips, and short rounded heels or distal projections (cf. Hoffman 1967:Figure 6a); the heels have not been joined to the bowl, as with the likely later form of elbow pipes from the Lester Bros. Place.

\section{Table 4. Pipes from the Battle Place.}

\begin{tabular}{lllllllll}
\hline & & & & & & & \\
Accession No. & Pipe No. & Ht.* & L & B-OD & B-Th & B-Ht. & S-OD & S-Th \\
\hline $5425-4626$ & P-31 & 38.0 & 41.0 & 32.5 & 3.9 & 18.0 & 25.5 & 6.6 \\
$5425-4628$ & P-235^ & 39.9 & 42.0 & 30.0 & 4.0 & 18.0 & 25.6 & 8.3 \\
$5425-4629$ & P-237+ & 42.2 & 56.0 & 30.9 & 5.2 & 19.0 & 27.5 & 8.6 \\
$5425-4630$ & P-236+ & 37.7 & 46.5 & 29.5 & 3.1 & 17.0 & 25.0 & 5.2 \\
$5425-4631$ & P-238** & 39.5 & 47.0 & 33.2 & 3.7 & 19.2 & 22.4 & 5.9 \\
$5425-4632$ & P-239** & 36.5 & 41.1 & 31.9 & 3.6 & 20.0 & 20.3 & 5.4 \\
$5425-4633$ & P-233 & 54.0 & 59.0 & 41.9 & 6.4 & 27.0 & 32.0 & 8.6 \\
$5425-4634$ & P-157 & 36.9 & 47.5 & 31.0 & 3.2 & 16.5 & 18.9 & 5.3 \\
$5425-4637$ & P-34 & 41.0 & 46.0 & 34.0 & 4.3 & 15.2 & 24.0 & 7.0 \\
$5425-4638$ & P-54 & $27.0+$ & 51.0 & 21.5 & 3.0 & N/A & 27.3 & 6.9
\end{tabular}

*Ht.=total height of pipe; $\mathrm{L}=$ total length of pipe; $\mathrm{B}-\mathrm{OD}=$ orifice diameter, bowl; $\mathrm{B}-\mathrm{Th}=\mathrm{bowl}$ rim thickness; $\mathrm{B}-\mathrm{Ht}$. =height of bowl; $\mathrm{S}-\mathrm{OD}=$ stem orifice diameter; $\mathrm{S}-\mathrm{Th}=$ stem rim thickness. All measurements are in mm; **Brial 4, Burial Plot 2 (see Martin 1939); + Burial 3, Burial Plot 2 (Martin 1939); ^Burial 2, Burial Plot 2 (Martin 1939).

The pipes are primarily tempered with grog $(n=8,80 \%)$; one other is tempered with grog and bone, and the last pipe has a bone temper. The pipes are smoothed or burnished on all surfaces, and none of them are decorated. Most of the pipes were fired in 
a high oxygen environment $(70 \%)$, leaving them a brown color. The other three pipes were fired in a low oxygen or reducing environment, producing pipes with a dark gray to black core and/or pipe surfaces. Stem rims and lips are direct and flat, while $90 \%$ of the bowls have direct and rounded rims and lips; the other has a flat lip.

The clay elbow pipes from the Battle site were made in two sizes: the smaller but more numerous $(\mathrm{n}=9)$ elbow pipes range between $36.5-42.2 \mathrm{~mm}$ in total pipe height and $41.0-56.0 \mathrm{~mm}$ in length, with bowl orifice diameters that range from $21.5-34.0 \mathrm{~mm}$ (Figure 20a-i). The one large elbow pipe is $54.0 \mathrm{~mm}$ in total height, $59.0 \mathrm{~mm}$ in length, and has a bowl orifice diameter of $41.9 \mathrm{~mm}$ (Figure 21); the bowl height on this pipe is $27.0 \mathrm{~mm}$, while bowl heights on the smaller pipes range only from 15.2-20.0 $\mathrm{mm}$ (see Table 4).

Figure 20. Small elbow pipes from the Battle Place: a, P-31; P-34; c, P-54; d, P-157; e, P235; f, P-236; g, P-237; h, P-238; i, P-239.

Figure 21. Large elbow pipe from the Battle Place (P-233).

\section{Lester Bros. Place}

There are two undecorated clay grog-tempered elbow pipes from the Lester Bros. Place collections. These pipes were found in 1938 in association with V-1917 to V-1923 (not documented during the present study) in a washed-out grave at the "Blue Hole" on the Lester Bros. Plantation.

The pipes have short thick stems, wide stem orifice diameters, and relatively small expanding bowls (Table 5). The stems are direct with either rounded or flattened lips, while both bowls have direct and flattened lips (Figure 22a-b). Both pipes have rounded heels that have been turned vertically and flattened somewhat against the back side of the elbow pipe bowl (cf. Moore 1912:Figure 136b, d; Hoffman 1967:Figure 6b).

Table 5. Pipes from the Lester Bros. Place.

\begin{tabular}{lllllllll} 
Accession No. & Pipe No. & Ht.* & L & B-OD & B-Th & B-Ht. & S-OD & S-Th \\
\hline $5425-4607$ & P-232 & 38.5 & 49.0 & 29.5 & 3.5 & 14.5 & 25.5 & 5.7 \\
$5425-4625$ & P-231 & 28.0 & 44.0 & 27.1 & 4.2 & 14.0 & 17.0 & 3.9 \\
\hline
\end{tabular}

*Ht.=total height of pipe; L=total length of pipe; $\mathrm{B}-\mathrm{OD}=$ orifice diameter, bowl; $\mathrm{B}-\mathrm{Th}=$ bowl rim thickness; $\mathrm{B}-\mathrm{Ht}$. =height of bowl; S-OD=stem orifice diameter; $\mathrm{S}-\mathrm{Th}=$ stem rim thickness. All measurements are in $\mathrm{mm}$.

Figure 22. Pipes from the Lester Bros. Place: a, P-231; b, P-232. 


\section{Celt}

\section{Wm. Handy Place}

A single pebble celt (see Kay 1984) from the Wm. Handy Place was reported to have been found in association with a burial (Burial D, N-748, 6125.18,848) dug there in 1940 by Robert Shelton. No vessels were apparently placed as funerary offerings with this individual.

This celt is made from a local Red River yellowish-brown claystone/siltstone pebble that has been well-polished, almost totally obliterating all flake scars on the celt, except for two on the bit, probably caused during tool use. This tool has a bifacial bit, and the bit is $33.0 \mathrm{~mm}$ in width and a maximum of $11.3 \mathrm{~mm}$ in length (Figure 23). The celt's total length is $76.0 \mathrm{~mm}$; its mid-section width is $35.5 \mathrm{~mm}$, and it has a maximum thickness of $12.7 \mathrm{~mm}$.

Figure 23. Pebble celt from the Wm. Handy Place (6125-18848).

\section{Bone Tools}

\section{Lester Bros. Place}

One of the graves found at the Lester Bros. Place in 1929 had four deer antler tool funerary objects (D-23 to D-26) (Figure 24a-d). Their rounded ends suggest they are stone knapping tools or flakers (cf. Kay 1984:192 and Figure 13-17a-d).

Figure 24. Bone tools from the Lester Bros. Place.

\section{Mussel Shell Tools}

\section{Lester Bros. Place}

One perforated mussel shell tool ( $83 \times 61 \mathrm{~mm}$ in length and width, M-138, 9025459) came from a grave found in June 1929 at the Lester Bros. Place (Figure 25). Although not well preserved, this tool is probably a mussel shell hoe. The circular perforation (17.9 $\mathrm{mm}$ in diameter) would have held a sturdy wooden stick, creating a wood-handled hoe (see Perttula et al. 2005:44). The same grave also had two pieces of scraped mussel shell (M-85), possibly from a mussel shell spoon (Figure 26).

Figure 25. Perforated mussel shell tool (M-138) from the Lester Bros. Place.

Figure 26. Mussel shell spoon fragments (M-85) from the Lester Bros. Place. 


\section{Marine Shell Ornaments}

\section{Battle Site}

A total of 19 marine columella shell disk beads (9025.502, x70-88) were recovered in 1922 around the neck of a burial in what was described in the Lemley Collection records as at the "edge of the $2^{\text {nd }}$ largest mound" at the site (Figure 27). It is unclear which of the mounds at the Battle site (see Moore 1912; McKinnon 2008) is referred to by this description, but likely this is from one of the four small mounds east of the large platform mound.

Figure 27. Marine columella shell beads from the Battle Place (9052-502).

A single small disk bead (9025.485, $\mathrm{x}-742)$ was found in a grave in the principal large mound at the Battle site. This bead is $13 \mathrm{~mm}$ in diameter and $6.3 \mathrm{~mm}$ thick, with a $6.3 \mathrm{~mm}$ perforation (Figure 28).

Figure 28. Small marine shell disk bead from a Caddo burial in the principal mound at the Battle Place (9025-485).

Also found in digging at the south end of the large mound at Battle is a small Busycon sp. or conch shell cup (9025.507, M-392); this was found in a late Belcher phase-early Chakanina phase Caddo burial association with six pottery vessels (V-1947 to V-1952), a bear's tooth (M-393, not documented during this project), and a single arrow point (M-394, not documented during this project). The cup retains the axial spire and anterior ends, with little evidence of polishing or modification, but the columella has been cut and scraped away, and the interior surface of the conch polished. There are two suspension holes on the axial spire and a third suspension hole at the anterior end. The cup is $165 \mathrm{~mm}$ in length, with a crown diameter of $110 \mathrm{~mm}$ (Figure 29a-b).

Figure 29. Conch shell cup from the Battle Place: a, exterior view, note suspension holes; b, interior view of cup.

\section{Lester Bros. Place}

There are two marine shell ear disks of the Clements style (see Perttula and Green 2006) from a burial in a Caddo cemetery at the Lester Bros. Place. They were found along with a number of skeletons in 1929 after being exposed by a Red River flood.

These marine shell ornaments have been found in late $17^{\text {th }}$ to early $18^{\text {th }}$ century contexts in several Caddo sites in northeast Texas, southwest Arkansas, and northwest Louisiana, including Clements (Perttula et al. 2005:Figure 4.24), Anglin (Perttula et al. 2009), Cedar Grove (Kay 1984:Figure 13-20a-b), Hardman (Early 1993:Figure 83a-b), and Belcher (Webb 1959:173-174). 
The marine shell ear disks from the Lester Bros. Place (G-174 and G-175) are 31$33.5 \mathrm{~mm}$ in diameter. Each has a single central perforation as well as a single engraved line encircling the disk. That engraved line inscribes a circle between $18.2-19 \mathrm{~mm}$ in diameter on the two ear disks (Figure 30).

Figure 30. Marine shell ear disks from the Lester Bros. Place (accession no. 9025-272 and 273).

\section{Joe Russell Place}

Seven distinctive marine conch shell artifacts (9025-499a-g, x-398-404) were found in a grave at the Joe Russell Place in 1915. This grave had two individuals placed in it, one of which (an adult) had the marine shell conch ornaments around its neck as a necklace. The second individual in this grave was smaller in size than the first, and was thought to be an adult female.

These ornaments are made from the axial spire and portions of the columella of a conch shell (Figure 31a-b). In cross-section they are L-shaped, with a heavily polished and virtually flat but curved axial spire section comprising the bottom of the L shape, and the remainder is made up of the upper part of the columella, also heavily polished. Six of the seven ornaments have two opposed suspension holes drilled in the axial spire; one ornament has two sets of two opposed suspension holes. These ornaments range from 53$62 \mathrm{~mm}$ in total length and $63.5-76 \mathrm{~mm}$ in total width.

Figure 31. Marine shell conch ornaments from the Joe Russell Place: a, interior view; b, exterior view. Note suspension holes.

Another such marine shell ornament in the Gilcrease Museum collection comes from what appears to be the Cabaness Place near Spirit Lake (9025.260, x-357); it is described in the Gilcrease Museum records as "found in the Red River bottom near Spirit Lake," the same description given for several vessels from the Cabaness Place. It has two suspension holes, but is only $34.8 \mathrm{~mm}$ in length and $26.0 \mathrm{~mm}$ in width (Figure 32a-c).

Figure 32. Marine shell ornaments from the Cabaness Place, Spirit Lake locality: a, exterior view; b, interior view; c, side view, showing suspension hole.

The other individual (described as a "smaller female") in this burial at the Joe Russell Place had four zoomorphic pendants (G182-185) thought to have been made of alligator teeth (these were not examined in the present NAGPRA study). These were described as laying on "her breast." Descriptions of these particular items, including the fact that they had diamond-shaped decorations with a single dot in the center, suggest these were actually marine shell zoomorphic pendants made from the curving walls of a conch shell columella, possibly representations of lizards, insects, or spiders (Perttula et al. 2005:46). Virtually identical zoomorphic pendants have been recovered in late $17^{\text {th }}$ century contexts at a number of Caddo sites, including Belcher (see Webb 1959:Figure 131) and McLelland in northwest Louisiana; the Battle, Cedar Grove, Foster, and Friday 
sites in the Great Bend region of southwest Arkansas; and the Clements, Winterbauer, and C. T. Coley sites in northeast Texas. The Lemley Collections at the Gilcrease Museum also have one of these zoomorphic pendants from a site in the Carden Bottoms in Yell County, Arkansas (9025.267B, E-5). 


\section{NAGPRA Findings and Recommendations}

In this report, we have documented funerary objects from a number of prehistoric and early historic archeological sites (dating between as early as ca. A.D. 1000 and the early $18^{\text {th }}$ century) in the Great Bend area of the Red River in Lafayette County, Arkansas. The archeological evidence that has been reviewed in this study, and the documentation of the funerary objects from the various sites, have led to the following findings under NAGPRA for the Gilcrease Museum NAGPRA collections:

- First, the funerary objects documented at the Battle site (3LA1), the Wm. Handy Place at the Battle site, the Foster site (3LA27), the Cabaness Place (3LA84), the George W. Sentell Place (3LA38), the Lester Bros. Plantation and Lester Bros. Place (3LA38/48), and the Joe Russell Place, and the information in the Gilcrease Museum files on the context of these offerings, as part of this study are from prehistoric and/or early Historic Caddo burials. It is well known from archeological, bioarcheological, historical, archival, and oral historical records that the prehistoric and early Historic Caddo peoples are ancestral to the modernday Caddo Nation of Oklahoma (Rogers and Sabo 2004: Figure 1), and the sites in question are situated within the ancestral territory of the Caddo people. Consequently, the funerary objects from these sites are culturally affiliated with the Caddo Nation of Oklahoma as defined in 25 U.S.C. 3001, Section 2 and Code of Federal Regulations, Title 43, Part 10, Section 10.2(e). These funerary objects include all whole vessels and other funerary offerings (clay pipes, a celt, bone tools, mussel shell tool, and marine shell ornaments) from the Caddo sites discussed above and documented in Appendix 1-6 of this report;

- Second, the preponderance of archeological evidence supports this finding, namely (a) the manner of burial practice when that information is available (i.e., in a pit where the body of a deceased Caddo individual was laid in the grave with a variety of funerary objects placed around the body); (b) the kinds of funerary objects placed with the deceased, including culturally diagnostic and wellrecognized Caddo pottery types; (c) the fact that whole pottery vessels on Caddo sites are, to a greater than reasonable certainty, from offerings from Caddo burial features; and (d) the occurrence of the burials from these sites in direct association with either Caddo habitation and mound features;

- and third, because there are no human remains in the Gilcrease Museum NAGPRA collections from the Lafayette County, Arkansas Caddo sites, the prehistoric and early Historic Caddo funerary objects from these sites are considered unassociated funerary objects (25 U.S.C. 3001, Section 2 (3)(b) and Code of Federal Regulations, Title 43 Section 10.2(d)(2)(ii)). 


\section{References Cited}

Bonds, J.

2006 Art of the Ancient Caddo. Grove Hill Publishing, Leonard, Texas.

Brown, J. A.

1996 The Spiro Ceremonial Center: The Archaeology of Arkansas Valley Caddoan Culture in Eastern Oklahoma. 2 Vols. Memoirs No. 29. Museum of Anthropology, The University of Michigan, Ann Arbor.

Cast, R., T. K. Perttula, B. Gonzalez, and B. Nelson

2006 Documentation of Caddo Ceramic Vessels from 41WD60, Wood County, Texas. Historic Preservation Program, Caddo Nation of Oklahoma, Binger, Oklahoma.

Early, A. M. (editor)

1993 Caddoan Saltmakers in the Ouachita Valley: The Hardman Site. Research Series No. 29. Arkansas Archeological Survey, Fayetteville.

Ferring, C. R. and T. K. Perttula

1987 Defining the Provenance of Red-Slipped Pottery from Texas and Oklahoma by Petrographic Methods. Journal of Archaeological Science 14:437-456.

Gadus, E. F., R. C. Fields, J. K. McWilliams, J. Dockall, and M. C. Wilder

2006 National Register Testing of Seven Prehistoric Sites in the Sabine Mine's Area Q, Harrison County, Texas. Reports of Investigations No. 147. Prewitt \& Associates, Inc., Austin.

Gonzalez, B., R. Cast, T. K. Perttula, and B. Nelson

2005 A Rediscovering of Caddo Heritage: The W. T. Scott Collection at the American Museum of Natural History and Other Caddo Collections from Arkansas and Louisiana. Historic Preservation Program, Caddo Nation of Oklahoma, Binger, Oklahoma.

Hemmings, E. T.

1982 Spirit Lake (3LA83): Test Excavations in a Late Caddo Site on the Red River. In Contributions to the Archeology of the Great Bend Region, edited by F. F. Schambach and F. Rackerby, pp. 55-89. Research Series No. 22. Arkansas Archeological Survey, Fayetteville.

Hoffman, M. P.

1967 Ceramic Pipe Style Chronology Along the Red River Drainage in Southwestern Arkansas. The Arkansas Archeologist 8(1):4-14.

1970 Archaeological and Historical Assessment of the Red River Basin in Arkansas. In Archeological and Historical Resources of the Red River Basin, edited by H. A. 
Davis, pp. 135-194. Research Series No. 1. Arkansas Archeological Survey, Fayetteville.

Kay, M.

1984 Late Caddo Subtractive Technology in the Red River Basin. In Cedar Grove: An Interdisciplinary Investigation of a Late Caddo Farmstead in the Red River Valley, edited by N. L. Trubowitz, pp. 174-206. Research Series No. 23. Arkansas Archeological Survey, Fayetteville.

Kelley, D. B. and M. J. Guccione

2000 Cultural Resources Survey and Evaluation of Portions of the Moore/Higginbotham Site (3MI3/30), within Item 2 of the Red River Below Denison Dam Levee Rehabilitation/Restoration Project, Miller County, Arkansas. Coastal Environments, Inc., Baton Rouge.

Kelley, D. B. (editor)

1997 Two Caddoan Farmsteads in the Red River Valley. Research Series No. 51. Arkansas Archeological Survey, Fayetteville.

Martin. G.

1939 Notes on Certain Explorations on the Battle Place, Red River Bottoms, Lafayette County, Arkansas. MS on file, Gilcrease Museum, Tulsa.

McKinnon, D. P.

2008 An Archaegeophysical Analysis of Central Caddo Settlement Patterning at Battle Mound (3LA1). Master's thesis, Department of Anthropology, University of Arkansas, Fayetteville.

Moore, C. B.

1912 Some Aboriginal Sites on Red River. Journal of the Academy of Natural Sciences of Philadelphia 14:481-644.

Muller, J. D.

1978 The Southeast. In Ancient Native Americans, edited by Jesse D. Jennings, pp. 281-325. W. H. Freeman, San Francisco.

Perttula, T. K.

1992 "The Caddo Nation": Archaeological \& Ethnohistoric Perspectives. University of Texas Press, Austin.

2008 Caddo Agriculture on the Western Frontier of the Eastern Woodlands. Plains Anthropologist 53(205):79-105.

Perttula, T. K., with contributions by E. Dowd, L. Green, G. Morgan, B. Nelson, L. Schniebs, B. Schriever, J. Todd, and M. Walters 
2009 The Archaeology of the $16^{\text {th }}$ and $17^{\text {th }}$ Century Caddo in the Post Oak Savannah of Northeast Texas: The Tuinier Farm (41HP237), R. A. Watkins (41HP238), and Anglin (41HP240) Sites in the Stouts Creek Basin, Hopkins County, Texas. Journal of Northeast Texas Archaeology 30 , in press.

Perttula, T. K. and L. Green

2006 Marine Shell Disks from Protohistoric Caddo Sites on Stouts Creek, Hopkins County, Texas. Journal of Northeast Texas Archaeology 25:19-25.

Perttula, T. K., R. Cast, B. Gonzalez, and B. Nelson

2008a Documentation of Unassociated and Culturally Unidentifiable Funerary Objects in the U.S. Army Corps of Engineers, Fort Worth District Collections Housed at the Texas Archeological Research Laboratory at The University of Texas at Austin. Historic Preservation Program, Caddo Nation of Oklahoma, Binger, Oklahoma.

Perttula, T. K., M. Walters, B. Nelson, R. Cast, and B. Gonzalez 2008b Documentation of Associated and Unassociated Funerary Objects in the Stephen F. Austin State University Collections, Nacogdoches, Texas. Historic Preservation Program, Caddo Nation of Oklahoma, Binger, Oklahoma.

Perttula, T. K., B. Nelson, R. L. Cast, and B. Gonzalez 2005 The W. T. Scott Collection at the American Museum of Natural History. In $A$ Rediscovering of Caddo Heritage: The W. T. Scott Collection at the American Museum of Natural History and Other Caddo Collections from Arkansas and Louisiana, by B. Gonzalez, R. L. Cast, T. K. Perttula, and B. Nelson, pp. 25-53. Historic Preservation Program, Caddo Nation of Oklahoma, Binger, Oklahoma.

Perttula, T. K., M. Walters, R. Cast, B. Gonzalez, and B. Nelson

2007 Documentation of Funerary Offerings from a Prehistoric Caddo Burial at Site 41WD244, Wood County, Texas. Caddo Nation of Oklahoma and Archeological \& Environmental Consultants, LLC, Binger, Oklahoma and Austin, Texas.

Rice, P. M.

1987 Pottery Analysis: A Sourcebook. University of Chicago Press, Chicago.

Rogers, J. D. and G. Sabo III

2004 Caddo. In Southeast, Volume 14 of the Handbook of North American Indians, edited by R. D. Fogelson, pp. 616-631. Smithsonian Institution, Washington, D.C.

Schambach, F. F.

1982 The Archeology of the Great Bend region in Arkansas. In Contributions to the Archeology of the Great Bend Region of the Red River Valley, Southwest Arkansas, edited by F. F. Schambach and F. Rackerby, pp. 1-11. Research Series 22. Arkansas Archeological Survey, Fayetteville. 
1989 The End of the Trail: The route of Hernando De Soto's army through southwest Arkansas and East Texas. The Arkansas Archeologist 27/28:9-33.

Schambach, F. F. and J. E. Miller

1984 A Description and Analysis of the Ceramics. In Cedar Grove: An Interdisciplinary Investigation of a Late Caddo Farmstead in the Red River Valley, edited by N. L. Trubowitz, pp. 109-170. Research Series No. 23. Arkansas Archeological Survey, Fayetteville.

Schambach, F. F., N. L. Trubowitz, F. Rackerby, E. T. Hemmings, W. F. Limp, and J. E. Miller III

1982 Test Excavations at the Cedar Grove Site (3LA97): A Late Caddo Farmstead in the Great Bend Region, Southwest Arkansas. In Contributions to the Archeology of the Great Bend Region of the Red River Valley, Southwest Arkansas, edited by F. F. Schambach and F. Rackerby, pp. 90-140. Research Series 22. Arkansas Archeological Survey, Fayetteville.

Skibo, J. M.

1992 Pottery Function: A Use-Alteration Perspective. Plenum Press, New York.

Suhm, D. A. and E. B. Jelks (editor)

1962 Handbook of Texas Archeology: Type Descriptions. Special Publication No. 1, Texas Archeological Society, and Bulletin No. 4, Texas Memorial Museum, Austin.

Teltser, P. A.

1993 An Analytic Strategy for Studying Assemblage-Scale Ceramic Variation: A Case Study from Southeast Missouri. American Antiquity 58(3):530-543.

Trubowitz, N. L. (editor)

1984 Cedar Grove: An Interdisciplinary Investigation of a Late Caddo Farmstead in the Red River Valley. Research Series No. 23. Arkansas Archeological Survey, Fayetteville.

Webb, C. H.

1945 A second historic Caddo site at Natchitoches, Louisiana. Bulletin of the Texas Archeological and Paleontological Society 16:52-83.

1959 The Belcher Mound: A Stratified Caddoan Site in Caddo Parish, Louisiana. Memoirs No. 16. Society for American Archaeology, Salt Lake City, Utah.

Weinstein, R. A., D. B. Kelley, and J. W. Saunders (editors)

2003 The Louisiana and Arkansas Expeditions of Clarence Bloomfield Moore. University of Alabama Press, Tuscaloosa. 


\section{Appendix 1,}

\section{Vessels from the Battle Site or Place (3LA1)}

SITE NAME OR SITE NUMBER: Battle Place

CONTEXT INFORMATION: Unknown; found in association with V-2201 to V-2203

(not documented as part of this study)

ACCESSION NO.: 5425-549

VESSEL NO.: V-2204

NON-PLASTICS: shell

VESSEL FORM: Bowl

RIM AND LIP FORM: Direct rim and a rounded lip

CORE COLOR: B (fired and cooled in a low oxygen environment)

INTERIOR SURFACE COLOR: black

EXTERIOR SURFACE COLOR: black

WALL THICKNESS (RIM, BODY, AND BASE IN MM): $5.1 \mathrm{~mm}$, rim

INTERIOR SURFACE TREATMENT: burnished

EXTERIOR SURFACE TREATMENT: burnished

HEIGHT (IN CM): 4.0

ORIFICE DIAMETER (IN CM): 9.1

DIAMETER AT BOTTOM OF RIM OR NECK (IN CM): N/A

BASE DIAMETER (IN CM): 4.1

ESTIMATED VOLUME (IN LITERS): 0.15 liters

DECORATION: A single horizontal engraved line encircles the rim. The remainder of the vessel body is divided into four panels with unique semi-circular and scroll engraved motifs (Figures A1-1a-b and A1-2). Each of the panels are divided by narrow vertical zones that have plain and cross-hatched fillers. One panel has opposed engraved semi- 
circles and nested cross-hatched triangles; both of the semi-circular elements have narrow embedded cross-hatched bands (Figure A1-2). The second and third panels have a short cross-hatched hooked arm scroll motif with an associated cross-hatched scroll fill background. The fourth panel has a longer cross-hatched hooked arm scroll motif, curvilinear scroll lines, one cross-hatched triangle, and a cross-hatched engraved bracket (Figures A1-1a-b and A1-2).

TYPE: Unidentified engraved fine ware

Figure A1-1. Engraved bowl (5425-549) from the Battle site: a, side view; b, view of the base and vessel body.

Figure A1-2. Engraved bowl (5425-549). Drawing by Bobby Gonzalez.

SITE NAME OR SITE NUMBER: Battle Place

CONTEXT INFORMATION: Obtained in 1927 from Dan Jenkins.

ACCESSION NO.: 5425-613

VESSEL NO.: V-281

NON-PLASTICS: grog

VESSEL FORM: Jar with a short $(11 \mathrm{~mm})$ rim

RIM AND LIP FORM: Direct rim with a rounded and exterior folded lip

CORE COLOR: B (fired and cooled in a low oxygen environment)

INTERIOR SURFACE COLOR: dark gray

EXTERIOR SURFACE COLOR: dark gray

WALL THICKNESS (RIM, BODY, AND BASE IN MM): 4.6 mm, rim

INTERIOR SURFACE TREATMENT: smoothed on the rim and upper body

EXTERIOR SURFACE TREATMENT: smoothed on the lower body and base

HEIGHT (IN CM): 9.8

ORIFICE DIAMETER (IN CM): 9.4 


\section{DIAMETER AT BOTTOM OF RIM OR NECK (IN CM): 8.7}

BASE DIAMETER (IN CM): 6.1

ESTIMATED VOLUME (IN LITERS): 0.55 liters

DECORATION: The jar rim has closely-spaced rows of tool punctations. The vessel body has alternating zoned incised-punctated motifs (Figure A1-3). There are two panels with four sets of opposed incised semi-circles; the zones between the opposed semicircles are filled with tool punctations. The other two panels have a central vertical incised divider, with two opposed sets of incised semi-circles, the innermost being filled with tool punctations (Figure A1-3). Large incised bracket dividers on either side of the incised semi-circles are also filled with tool punctations.

TYPE: Unidentified zoned incised-punctated utility ware vessel

Figure A1-3. Zoned incised-punctated jar (5425-613).

SITE NAME OR SITE NUMBER: Battle Place

CONTEXT INFORMATION: From plowed-up burial found by Dan Jenkins in February 1939. It is associated with V-1962 to V-1967 and V-1969

ACCESSION NO.: 5425-630

VESSEL NO.: V-1968

NON-PLASTICS: grog

VESSEL FORM: Carinated bowl with two rim panels

RIM AND LIP FORM: Inverted rim and a rounded lip

CORE COLOR: $\mathrm{G}$ (fired in a reducing environment and cooled in the open air)

INTERIOR SURFACE COLOR: dark grayish-brown

EXTERIOR SURFACE COLOR: strong brown, with fire clouds

WALL THICKNESS (RIM, BODY, AND BASE IN MM): $4.2 \mathrm{~mm}$, rim

INTERIOR SURFACE TREATMENT: smoothed on the rim and body

EXTERIOR SURFACE TREATMENT: burnished on the rim and body 
HEIGHT (IN CM): 5.5

ORIFICE DIAMETER (IN CM): 12.5

DIAMETER AT BOTTOM OF RIM OR NECK (IN CM): 14.0

BASE DIAMETER (IN CM): N/A, rounded base

ESTIMATED VOLUME (IN LITERS): 0.41 liters

DECORATION: The upper rim panel is plain. The lower rim panel has opposed sets of diagonal engraved lines and hatched triangles (Figure A1-4).

TYPE: Simms Engraved

Figure A1-4. Simms Engraved carinated bowl (5425-630).

SITE NAME OR SITE NUMBER: Battle Place

CONTEXT INFORMATION: From plowed-up burial found by Dan Jenkins in February 1939. It is associated with V-1962, V-1963, and V-1965 to V-1969

ACCESSION NO.: 5425-631

VESSEL NO.: V-1964

NON-PLASTICS: fine grog and bone

VESSEL FORM: Bowl with opposed effigy head and tab tail appendages; two suspension holes (Figure A1-5)

RIM AND LIP FORM: Inverted rim and rounded lip

CORE COLOR: $\mathrm{G}$ (fired in a reducing environment and cooled in the open air)

INTERIOR SURFACE COLOR: black

EXTERIOR SURFACE COLOR: strong brown; fire clouds on the rim and body

WALL THICKNESS (RIM, BODY, AND BASE IN MM): $5.6 \mathrm{~mm}$, rim

INTERIOR SURFACE TREATMENT: smoothed on the rim 
EXTERIOR SURFACE TREATMENT: smoothed on the rim and body

HEIGHT (IN CM): 7.5

ORIFICE DIAMETER (IN CM): 13.5

DIAMETER AT BOTTOM OF RIM OR NECK (IN CM): N/A

BASE DIAMETER (IN CM): N/A, rounded base

ESTIMATED VOLUME (IN LITERS): 0.41 liters

DECORATION: There are two horizontal appliqued ridges just below the rim, between the two bird head effigy attachments on the side of the vessel (not on the lip) as well as one of the suspension holes, and the flat tab tail (see Figure A1-5). The tab tail itself has a single suspension hole (in the area of the mouth) as well as two dots for eyes and a raised beak area, suggesting it also represents an effigy head, but one lying flat that is looking upwards rather than sideways (see Figure A1-5).

TYPE: Undefined effigy vessel

Figure A1-5. Appliqued effigy vessel (5425-631).

SITE NAME OR SITE NUMBER: Battle Place

CONTEXT INFORMATION: From Burial 3 in Burial Plot 2 (Martin 1939), in association with V-2000 to V-2004 1/2 and pipes P-236 and P-237.

ACCESSION NO.: 5425-632

VESSEL NO.: V-1999

NON-PLASTICS: grog and bone

VESSEL FORM: Carinated bowl

RIM AND LIP FORM: Direct rim with a rounded and exterior folded lip

CORE COLOR: I (incompletely oxidized during firing, possibly smudged/reheated)

INTERIOR SURFACE COLOR: strong brown

EXTERIOR SURFACE COLOR: very dark gray 
WALL THICKNESS (RIM, BODY, AND BASE IN MM): $6.0 \mathrm{~mm}$, rim; $7.9 \mathrm{~mm}$, body

INTERIOR SURFACE TREATMENT: burnished on the rim and body

EXTERIOR SURFACE TREATMENT: burnished on the rim and body

HEIGHT (IN CM): 5.3

ORIFICE DIAMETER (IN CM): 20.2

DIAMETER AT BOTTOM OF RIM OR NECK (IN CM): 19.4

BASE DIAMETER (IN CM): N/A, rounded base

ESTIMATED VOLUME (IN LITERS): 0.64 liters

DECORATION: The vessel has a row of small tool punctations under the lip. The rim panel has an engraved-punctated interlocking horizontal scroll motif repeated four times (Figure A1-6). The horizontal interlocking scrolls have a central horizontal engraved band filled with punctations, as well as attached punctate-filled brackets that extend towards either the rim or the vessel carination (Figure A1-6); there is a single small engraved rectangle between these brackets. Each interlocking scroll is divided by two engraved and punctate-filled brackets, and between the brackets is a single verticallyoriented engraved rectangle.

TYPE: Handy Engraved

Figure A1-6. Handy Engraved carinated bowl (5425-632) from the Battle site.

SITE NAME OR SITE NUMBER: Battle Place

CONTEXT INFORMATION: From a grave in a Caddo cemetery on the Henry Moore (Battle) place; excavated by Dan Jenkins.

ACCESSION NO.: 5425-634

VESSEL NO.: V-356

NON-PLASTICS: grog

VESSEL FORM: Bowl

RIM AND LIP FORM: Inverted rim and a rounded lip 
CORE COLOR: B (fired and cooled in a reducing environment)

INTERIOR SURFACE COLOR: dark gray

EXTERIOR SURFACE COLOR: dark gray

WALL THICKNESS (RIM, BODY, AND BASE IN MM): $4.2 \mathrm{~mm}$, rim

INTERIOR SURFACE TREATMENT: burnished on the rim

EXTERIOR SURFACE TREATMENT: burnished on the rim and body

HEIGHT (IN CM): 6.7

ORIFICE DIAMETER (IN CM): 10.2

DIAMETER AT BOTTOM OF RIM OR NECK (IN CM): 11.3

BASE DIAMETER (IN CM): N/A, rounded base

ESTIMATED VOLUME (IN LITERS): 0.27 liters

DECORATION: There are two horizontal engraved lines around the rim, above four repeating closely-spaced cross-hatched engraved bands and triangle-shaped areas (Figure A1-7). Each triangle-shaped area has two curvilinear cross-hatched engraved zones within it.

TYPE: cf. Friendship Engraved

Figure A1-7. Friendship Engraved bowl (5425-634).

SITE NAME OR SITE NUMBER: Battle Place

ACCESSION NO.: 5425-635

CONTEXT INFORMATION: Found together with V-1987-1991 and V-1993 and V1994 in Burial 1, Burial Plot 2 (Martin 1939).

VESSEL NO.: V-1992

NON-PLASTICS: grog

VESSEL FORM: Carinated bowl 
RIM AND LIP FORM: Direct rim with a rounded and exterior folded lip

CORE COLOR: B (fired and cooled in a low oxygen environment)

INTERIOR SURFACE COLOR: dark grayish-brown

EXTERIOR SURFACE COLOR: dark grayish-brown

WALL THICKNESS (RIM, BODY, AND BASE IN MM): 3.8 mm, rim

INTERIOR SURFACE TREATMENT: smoothed on the rim and body

EXTERIOR SURFACE TREATMENT: smoothed on the body and burnished on the rim

HEIGHT (IN CM): 4.5

ORIFICE DIAMETER (IN CM): 13.0

DIAMETER AT BOTTOM OF RIM OR NECK (IN CM): 11.3

BASE DIAMETER (IN CM): N/A, rounded base

ESTIMATED VOLUME (IN LITERS): 0.35 liters

DECORATION: The upper part of the rim has a horizontal engraved band filled with short diagonal lines. The remainder of the rim is divided into nine rectangular panels divided by engraved brackets; the engraved brackets have a single short vertical engraved line within it (Figure A1-8). Four of the panels have a short centrally placed horizontal engraved line within it, while the other five have a single row of excised punctations (Figure A1-8).

TYPE: Belcher Engraved, var. Owen

Figure A1-8. Belcher Engraved, var. Owen carinated bowl (5425-635).

SITE NAME OR SITE NUMBER: Battle Place

CONTEXT INFORMATION: From a grave (Burial 1) in Burial Plot 2 (Martin 1939). Associated vessels in the grave include V-1987 to V-1992 and V-1994.

ACCESSION NO.: 5425-636

VESSEL NO.: V-1993 
NON-PLASTICS: grog

VESSEL FORM: Carinated bowl

RIM AND LIP FORM: Direct rim with a rounded and exterior folded lip

CORE COLOR: $\mathrm{G}$ (fired in a reducing environment and cooled in the open air)

INTERIOR SURFACE COLOR: black

EXTERIOR SURFACE COLOR: dark brown

WALL THICKNESS (RIM, BODY, AND BASE IN MM): 5.4 mm, rim

INTERIOR SURFACE TREATMENT: burnished on the body and rim

EXTERIOR SURFACE TREATMENT: burnished on the body and rim

HEIGHT (IN CM): 4.6

ORIFICE DIAMETER (IN CM): 13.6

DIAMETER AT BOTTOM OF RIM OR NECK (IN CM): 12.4

BASE DIAMETER (IN CM): 12.3

ESTIMATED VOLUME (IN LITERS): 0.38 liters

DECORATION: The rim has a horizontal interlocking scroll motif repeated twice around the vessel (Figure A1-9a-b); the motif is delimited by upper and lower horizontal engraved lines with small triangular tick marks. The interlocking scroll consists of a single central horizontal line (also with tick marks) with two sets of upper and lower engraved brackets that reach either the upper or lower rim/carination engraved lines (Figure A1-9a-b). The interlocking scrolls are divided by a zone with two engraved brackets at either end, a central ticked curvilinear engraved line, and single vertical engraved lines on either side of the central ticked line (Figure A1-9a-b).

TYPE: Handy Engraved

Figure A1-9. Handy Engraved carinated bowl (5425-636): a, photograph; b, drawing by Bobby Gonzalez.

SITE NAME OR SITE NUMBER: Battle Place 
CONTEXT INFORMATION: From a grave (Burial 3) in Burial Plot 2 (Martin 1939). Associated funerary offerings include V-1999, V-2000, and V-2002 to V-2004 1/2.

ACCESSION NO.: 5425-637

VESSEL NO.: V-2001

NON-PLASTICS: grog

VESSEL FORM: Carinated bowl

RIM AND LIP FORM: Direct rim with a rounded and exterior folded lip

CORE COLOR: B (fired and cooled in a low oxygen environment)

INTERIOR SURFACE COLOR: very dark gray

EXTERIOR SURFACE COLOR: very dark gray

WALL THICKNESS (RIM, BODY, AND BASE IN MM): 5.6 mm, rim; 4.4 mm, body

INTERIOR SURFACE TREATMENT: burnished on the rim and body

EXTERIOR SURFACE TREATMENT: burnished on the rim and body

HEIGHT (IN CM): 6.9

ORIFICE DIAMETER (IN CM): 18.5

DIAMETER AT BOTTOM OF RIM OR NECK (IN CM): 15.0

BASE DIAMETER (IN CM): N/A, rounded base

ESTIMATED VOLUME (IN LITERS): 0.77 liters

DECORATION: The rim has two engraved-punctated horizontal interlocking scrolls (Figure A1-10) within panels defined by upper and lower rows of excised punctations. The interlocking scrolls have a central narrow horizontal engraved band filled with punctations, upper and lower encircling engraved lines, and upper and lower engraved and punctated-filled brackets (Figure A1-10). The scrolls are divided from each other by two vertical engraved and punctated-filled brackets at either end of the scroll that reach from near the rim to the vessel carination, as well as vertically-oriented engraved rectangles.

TYPE: Handy Engraved 
Figure A1-10. Handy Engraved carinated bowl (5425-637).

SITE NAME OR SITE NUMBER: Battle Place

CONTEXT INFORMATION: Found in a grave on the Henry Moore (Battle) place, 1924

ACCESSION NO.: 5425-638

VESSEL NO.: V-255

NON-PLASTICS: grog

VESSEL FORM: Jar

RIM AND LIP FORM: Direct rim with a rounded and exterior folded lip; the vessel is also lip notched (Figure A1-11)

CORE COLOR: N/A

INTERIOR SURFACE COLOR: dark grayish-brown

EXTERIOR SURFACE COLOR: light yellowish-brown

WALL THICKNESS (RIM, BODY, AND BASE IN MM): 4.4 mm, rim

INTERIOR SURFACE TREATMENT: smoothed on the rim and the body

EXTERIOR SURFACE TREATMENT: smoothed on the base

HEIGHT (IN CM): 9.7

ORIFICE DIAMETER (IN CM): 10.4

DIAMETER AT BOTTOM OF RIM OR NECK (IN CM): 8.7

BASE DIAMETER (IN CM): 7.6

ESTIMATED VOLUME (IN LITERS): 0.61 liters

DECORATION: The rim has several closely-spaced rows of stamping, and the vessel body is almost completely covered with closely-spaced fingernail impressed or stamped rows (see Figure A1-11); there is a single horizontal trailed line near the vessel base. Arcing across the vessel body and the fingernail impressed-stamped decoration is a 
trailed hooked arm scroll with adjacent upper and lower curvilinear scrolls (see Figure A1-11).

TYPE: Cowhide Stamped

Figure A1-11. Cowhide Stamped jar (5425-638) from the Battle Place.

SITE NAME OR SITE NUMBER: Battle Place

CONTEXT INFORMATION: From a grave, 1928.

ACCESSION NO.: 5425-639

VESSEL NO.: V-202

NON-PLASTICS: shell

VESSEL FORM: Jar with a dimple base

RIM AND LIP FORM: Everted rim and a rounded lip

CORE COLOR: B (fired and cooled in a reducing environment)

INTERIOR SURFACE COLOR: dark gray

EXTERIOR SURFACE COLOR: dark gray

WALL THICKNESS (RIM, BODY, AND BASE IN MM): 2.5 mm, rim

INTERIOR SURFACE TREATMENT: smoothed on the rim and upper body

EXTERIOR SURFACE TREATMENT: smoothed on the lower body

HEIGHT (IN CM): 11.9

ORIFICE DIAMETER (IN CM): 10.5

DIAMETER AT BOTTOM OF RIM OR NECK (IN CM): 12.3

BASE DIAMETER (IN CM): 3.3

ESTIMATED VOLUME (IN LITERS): 0.75 liters 
DECORATION: The vessel rim has three alternating sets of closely-spaced diagonal incised lines between horizontal incised lines (Figure A1-12). The body has a simple incised scroll with hooked arms; the hooked arms are repeated nine times around the vessel body (Figure A1-12).

TYPE: cf. Foster Trailed-Incised or Mound Tract Incised and Brushed

Figure A1-12. cf. Foster Trailed-Incised or Mound Tract Incised and Brushed jar (5425639).

SITE NAME OR SITE NUMBER: Battle Place

CONTEXT INFORMATION: From a grave (Burial 1) in Burial Plot 2 (Martin 1939). Associated vessels in this grave include V-1987 to V-1990 and V-1992 to V-1994.

ACCESSION NO.: 5425-640

VESSEL NO.: V-1991

NON-PLASTICS: grog

VESSEL FORM: Jar

RIM AND LIP FORM: Everted rim and a rounded lip

CORE COLOR: A (fired and cooled in a high oxygen environment)

INTERIOR SURFACE COLOR: brown, with dark gray fire clouds on the rim and the upper body

EXTERIOR SURFACE COLOR: brown

WALL THICKNESS (RIM, BODY, AND BASE IN MM): 4.0 mm, rim; 5.2 mm, body

INTERIOR SURFACE TREATMENT: smoothed

EXTERIOR SURFACE TREATMENT: none

HEIGHT (IN CM): 9.1

ORIFICE DIAMETER (IN CM): 8.9

DIAMETER AT BOTTOM OF RIM OR NECK (IN CM): 9.3 
BASE DIAMETER (IN CM): 6.6

ESTIMATED VOLUME (IN LITERS): 0.49 liters

DECORATION: There are single rows of punctations on this jar, one below the lip and the second immediately below the rim-body juncture. The body has four panels with incised concentric circles and hatched lines, with the central element in the body decoration being an appliqued node (Figure A1-13). Only one of the concentric incised circle panels is set apart from the others by a series of five vertical incised lines.

TYPE: Foster Trailed-Incised, var. unspecified

Figure A1-13. Foster Trailed-Incised, var. unspecified jar (5425-640).

SITE NAME OR SITE NUMBER: Battle Place

CONTEXT INFORMATION: From a grave (Burial 3) in Burial Plot 2 (Martin 1939).

Associated funerary offerings include V-1999 to V-2001 and V-2003 to V-2004 1⁄2.2.

ACCESSION NO.: 5425-643

VESSEL NO.: V-2002

NON-PLASTICS: grog; sandy paste

VESSEL FORM: Bottle

RIM AND LIP FORM: Direct rim and a rounded lip

CORE COLOR: B (fired and cooled in a low oxygen environment)

INTERIOR SURFACE COLOR: very dark gray

EXTERIOR SURFACE COLOR: very dark gray

WALL THICKNESS (RIM, BODY, AND BASE IN MM): 5.5 mm, rim

INTERIOR SURFACE TREATMENT: none

EXTERIOR SURFACE TREATMENT: smoothed on the body and neck

HEIGHT (IN CM): 11.5

ORIFICE DIAMETER (IN CM): 4.7 
DIAMETER AT BOTTOM OF RIM OR NECK (IN CM): $5.1 ; 9.8 \mathrm{~cm}$ in width at the widest part of the body

BASE DIAMETER (IN CM): 4.5

ESTIMATED VOLUME (IN LITERS): 0.21 liters

DECORATION: The upper part of the vessel body has three horizontal engraved lines with four cross-hatched engraved pendant triangles (Figure A1-14).

TYPE: unidentified engraved fine ware

Figure A1-14. Engraved bottle (5425-643).

SITE NAME OR SITE NUMBER: Battle Place

CONTEXT INFORMATION: From a grave on the Henry Moore (Battle) place, 1928.

ACCESSION NO.: 5425-645

VESSEL NO.: V-256

NON-PLASTICS: grog

VESSEL FORM: Cut-down jar, recycled as a carinated bowl (Figure A1-15).

RIM AND LIP FORM: Direct rim and a flat lip

CORE COLOR: $\mathrm{G}$ (fired in a reducing environment and cooled in the open air)

INTERIOR SURFACE COLOR: very dark gray

EXTERIOR SURFACE COLOR: brown

WALL THICKNESS (RIM, BODY, AND BASE IN MM): 6.9 mm, rim

INTERIOR SURFACE TREATMENT: none

EXTERIOR SURFACE TREATMENT: none

HEIGHT (IN CM): 4.2

ORIFICE DIAMETER (IN CM): 8.9 
DIAMETER AT BOTTOM OF RIM OR NECK (IN CM): 9.0

BASE DIAMETER (IN CM): 4.9

ESTIMATED VOLUME (IN LITERS): 0.22 liters

DECORATION: The body of the jar has been divided into eight panels by vertical rows of linear punctations (Figure A1-15); each of the panels extends to just above the vessel base. Within each panel are opposed brushed marks.

TYPE: unidentified brushed-punctated jar

Figure A1-15. Cut-down brushed-punctated jar (5425-645).

SITE NAME OR SITE NUMBER: Battle Place

CONTEXT INFORMATION: From a grave excavated by Dan Jenkins in April 1929.

ACCESSION NO.: 5425-649

VESSEL NO.: V-162

NON-PLASTICS: grog

VESSEL FORM: Bulbous jar with a pedestal base (Figure A1-16)

RIM AND LIP FORM: Everted rim with a rounded and exterior folded lip

CORE COLOR: $\mathrm{G}$ (fired in a low oxygen environment and cooled in the open air)

INTERIOR SURFACE COLOR: very dark grayish-brown

EXTERIOR SURFACE COLOR: dark yellowish-brown

WALL THICKNESS (RIM, BODY, AND BASE IN MM): 5.2 mm, rim

INTERIOR SURFACE TREATMENT: smoothed on the body and burnished on the rim EXTERIOR SURFACE TREATMENT: smoothed on the lower body or pedestal base HEIGHT (IN CM): 8.5

ORIFICE DIAMETER (IN CM): 10.7 
DIAMETER AT BOTTOM OF RIM OR NECK (IN CM): 9.5

BASE DIAMETER (IN CM): 6.8

ESTIMATED VOLUME (IN LITERS): 0.55 liters

DECORATION: The rim of this vessel has horizontal brushing above a single row of tool punctates at the rim-body juncture (see Figure A1-16). The upper part of the body has vertical pinched rows.

TYPE: unidentified brushed-pinched-punctated utility ware

Figure A1-16. Brushed-pinched-punctated jar (5425-649).

SITE NAME OR SITE NUMBER: Battle Place

CONTEXT INFORMATION: From a plowed-out grave excavated by Dan Jenkins in 1939. Associated with vessels V-1964 to 1969.

ACCESSION NO: 5425-650

VESSEL NO.: V-1965

NON-PLASTICS: fine grog

VESSEL FORM: Deep bowl with opposed suspension holes (see Suhm and Jelks 1962:Plates 31f and 32e)

RIM AND LIP FORM: Direct rim with a rounded and exterior folded lip

CORE COLOR: A (fired and cooled in an oxidizing environment)

INTERIOR SURFACE COLOR: brown

EXTERIOR SURFACE COLOR: brown; fire clouds on the body

WALL THICKNESS (RIM, BODY, AND BASE IN MM): 5.4 mm, rim

INTERIOR SURFACE TREATMENT: smoothed on the upper rim panel

EXTERIOR SURFACE TREATMENT: none

HEIGHT (IN CM): 12.0 
ORIFICE DIAMETER (IN CM): 12.6

DIAMETER AT BOTTOM OF RIM OR NECK (IN CM): 10.2

BASE DIAMETER (IN CM): 6.2

ESTIMATED VOLUME (IN LITERS): 1.20 liters

DECORATION: The lip is notched, while the tall rim has four widely-spaced horizontal engraved lines (Figure A1-17). The vessel body has an engraved motif repeated four times around the vessel. The motif consists of a near square zone outlined by four crosshatched triangles, two of which have negative ovals within them. Within this engraved zone are two circles, the innermost defined by a series of fine engraved lines (Figure A117) and four engraved spurs. Within this central spurred circle is a small engraved circle with two hooked engraved lines (Figure A1-17).

TYPE: Handy Engraved

Figure A1-17. Handy Engraved deep bowl (5425-650) from the Battle Place.

SITE NAME OR SITE NUMBER: Battle Place

CONTEXT INFORMATION: From a grave excavated by Dan Jenkins in 1929.

ACCESSION NO.: 5425-651

VESSEL NO.: V-531

NON-PLASTICS: grog

VESSEL FORM: Effigy bowl, with a bear effigy head facing inward and upward (Figure A1-18)

RIM AND LIP FORM: Direct rim and a rounded lip

CORE COLOR: B (fired and cooled in a reducing environment)

INTERIOR SURFACE COLOR: very dark gray

EXTERIOR SURFACE COLOR: very dark gray

WALL THICKNESS (RIM, BODY, AND BASE IN MM): 7.4 mm, rim; 10.0 mm, body 
INTERIOR SURFACE TREATMENT: smoothed

EXTERIOR SURFACE TREATMENT: burnished

HEIGHT (IN CM): $7.1 ; 7.7 \mathrm{~cm}$ to the top of the effigy head

ORIFICE DIAMETER (IN CM): 13.8

DIAMETER AT BOTTOM OF RIM OR NECK (IN CM): N/A

BASE DIAMETER (IN CM): N/A, rounded base

ESTIMATED VOLUME (IN LITERS): 0.43 liters

DECORATION: Six or more irregular horizontal and intersecting incised lines on the rim

TYPE: Undefined incised effigy vessel (see Figure A1-18)

Figure A1-18. Incised effigy vessel (5425-651).

SITE NAME OR SITE NUMBER: Battle Place

CONTEXT INFORMATION: Excavated from a plowed-out grave found by Dan Jenkins. This vessel is associated with V-1962.

ACCESSION NO.: 5425-652

VESSEL NO.: V-1963

NON-PLASTICS: fine grog and bone

VESSEL FORM: Bowl

RIM AND LIP FORM: Direct rim and a rounded, thickened, and flanged lip

CORE COLOR: B (fired and cooled in a low oxygen environment)

INTERIOR SURFACE COLOR: very dark gray

EXTERIOR SURFACE COLOR: very dark gray

WALL THICKNESS (RIM, BODY, AND BASE IN MM): $6.2 \mathrm{~mm}$, rim; $7.0 \mathrm{~mm}$. body INTERIOR SURFACE TREATMENT: burnished 
EXTERIOR SURFACE TREATMENT: burnished

HEIGHT (IN CM): 8.8

ORIFICE DIAMETER (IN CM): 14.0

DIAMETER AT BOTTOM OF RIM OR NECK (IN CM): N/A

BASE DIAMETER (IN CM): 10.4

ESTIMATED VOLUME (IN LITERS): 0.49 liters

DECORATION: Three horizontal engraved lines on the rim; the horizontal lines dip below the thickened and flanged part of the lip (Figure A1-19). On the lip itself are two excised teardrop-shaped areas.

TYPE: Bowie Engraved

Figure A1-19. Bowie Engraved bowl (5425-652).

SITE NAME OR SITE NUMBER: Battle Place

CONTEXT INFORMATION: From a plowed-out grave excavated by Dan Jenkins in 1939. Associated with vessels V-1964 to 1969.

ACCESSION NO.: 5425-653

VESSEL NO.: V-1966

NON-PLASTICS: shell

VESSEL FORM: Jar

RIM AND LIP FORM: Direct rim with a rounded and exterior folded lip

CORE COLOR: B (fired and cooled in a low oxygen environment)

INTERIOR SURFACE COLOR: black

EXTERIOR SURFACE COLOR: very dark gray

WALL THICKNESS (RIM, BODY, AND BASE IN MM): 3.6 mm, rim 
INTERIOR SURFACE TREATMENT: smoothed on the rim

EXTERIOR SURFACE TREATMENT: smoothed on the lower body

HEIGHT (IN CM): 12.5

ORIFICE DIAMETER (IN CM): 11.5

DIAMETER AT BOTTOM OF RIM OR NECK (IN CM): 11.0

BASE DIAMETER (IN CM): 6.2

ESTIMATED VOLUME (IN LITERS): 0.86 liters

DECORATION: The rim has two horizontal trailed lines, and five rows of alternate pitched diagonal slashed incised lines (Figure A1-20). The body has six sets of two stacked and trailed scrolls, each filled with brushing marks. The sets of trailed scrolls hook around each other (Figure A1-20).

TYPE: Foster Trailed-Incised or Mound Tract Incised and Brushed

Figure A1-20. Foster Trailed-Incised or Mound Tract Incised and Brushed jar (5425$653)$.

SITE NAME OR SITE NUMBER: Battle Place

CONTEXT INFORMATION: Obtained in 1927.

ACCESSION NO.: 5425-654

VESSEL NO.: V-210

NON-PLASTICS: grog and bone (less than $5 \%$ of the paste)

VESSEL FORM: Globular jar

RIM AND LIP FORM: Everted rim and a rounded lip

CORE COLOR: N/A

INTERIOR SURFACE COLOR: brown

EXTERIOR SURFACE COLOR: brown, with fire clouding on the body and rim 
WALL THICKNESS (RIM, BODY, AND BASE IN MM): 3.9 mm, rim

INTERIOR SURFACE TREATMENT: smoothed on the rim and the body

EXTERIOR SURFACE TREATMENT: smoothed on the lower body

HEIGHT (IN CM): 13.5

ORIFICE DIAMETER (IN CM): 10.9

DIAMETER AT BOTTOM OF RIM OR NECK (IN CM): 10.5

BASE DIAMETER (IN CM): 7.8

ESTIMATED VOLUME (IN LITERS): 0.88 liters

DECORATION: The rim has nine closely-packed rows of tool punctations. On the body there are five sets of small tool punctated rows (either two or three rows) connected by continuous rows of triangles formed by linear punctates (Figure A1-21). The tool punctated rows and linear punctated triangles are superimposed on a background of horizontal brushing marks. Below the bottom fifth set of tool punctates are two broadlyspaced horizontal engraved lines (Figure A1-21).

TYPE: unidentified brushed-punctated utility ware, cf. Sinner Linear Punctated

Figure A1-21. Brushed-punctated jar (5425-654).

SITE NAME OR SITE NUMBER: Battle Place

CONTEXT INFORMATION: This vessel was found in 1938 by Simon Cullins while digging a storm cellar at the south end of the large mound. The vessel was found in association with V-1948 to V-1952, a marine shell cup (M-392), a bear's tooth (M-393), and an arrow point of unknown type (M-394).

ACCESSION NO.: 5425-655

VESSEL NO.: V-1947

NON-PLASTICS: shell

VESSEL FORM: Jar with a short $(13 \mathrm{~mm})$ rim

RIM AND LIP FORM: Everted rim and a rounded lip 
CORE COLOR: $\mathrm{H}$ (fired in a reducing environment and cooled in the open air)

INTERIOR SURFACE COLOR: brown

EXTERIOR SURFACE COLOR: light brown

WALL THICKNESS (RIM, BODY, AND BASE IN MM): $5.2 \mathrm{~mm}$, rim; $4.8 \mathrm{~mm}$, body

INTERIOR SURFACE TREATMENT: smoothed on the rim

EXTERIOR SURFACE TREATMENT: none

HEIGHT (IN CM): 15.9

ORIFICE DIAMETER (IN CM): 12.2

DIAMETER AT BOTTOM OF RIM OR NECK (IN CM): 10.9

BASE DIAMETER (IN CM): 7.3

ESTIMATED VOLUME (IN LITERS): 1.75 liters

DECORATION: The rim is horizontally brushed, while the body has vertical brushing that extends to the base (Figure A1-22)

TYPE: Karnack Brushed-Incised, var. Karnack

Figure A1-22. Karnack Brushed-Incised, var. Karnack jar (5425-655).

SITE NAME OR SITE NUMBER: Battle Place

CONTEXT INFORMATION: From a grave in a Caddo cemetery excavated by Dan Jenkins in 1929.

ACCESSION NO.: 5425-656

VESSEL NO.: V-386

NON-PLASTICS: grog

VESSEL FORM: Jar with two plain strap handles (Figure A1-23)

RIM AND LIP FORM: Everted rim and rounded lip 
CORE COLOR: $\mathrm{G}$ (fired in a reducing environment and cooled in the open air)

INTERIOR SURFACE COLOR: dark gray

EXTERIOR SURFACE COLOR: brown

WALL THICKNESS (RIM, BODY, AND BASE IN MM): 7.7 mm, rim

INTERIOR SURFACE TREATMENT: smoothed on the rim and upper body

EXTERIOR SURFACE TREATMENT: none

HEIGHT (IN CM): 14.0

ORIFICE DIAMETER (IN CM): 13.4

DIAMETER AT BOTTOM OF RIM OR NECK (IN CM): 10.9

BASE DIAMETER (IN CM): 6.6

ESTIMATED VOLUME (IN LITERS): 1.13 liters

DECORATION: The rim has two rims of tool punctates, one at the lip and the other at the rim-body juncture; between them are eight sets of incised triangles, four between each strap handle (Figure A1-23). The vessel body has two panels defined by two stacked semi-circular sets of appliqued fillets around a large punctated appliqued node (Figure A1-23). The areas between the semi-circular appliqued fillets is filled with diagonal and cross-hatched incised lines.

TYPE: Haley Complicated Incised

Figure A1-23. Haley Complicated Incised jar (5425-656).

SITE NAME OR SITE NUMBER: Battle Place

CONTEXT INFORMATION: From a grave on the Henry Moore (Battle) place. It was plowed-out by Dan Jenkins, 1935.

ACCESSION NO.: 5425-657

VESSEL NO.: V-1740

NON-PLASTICS: shell 
VESSEL FORM: Bowl

RIM AND LIP FORM: Direct rim and a rounded lip

CORE COLOR: B (fired and cooled in a low oxygen environment)

INTERIOR SURFACE COLOR: dark gray

EXTERIOR SURFACE COLOR: dark gray

WALL THICKNESS (RIM, BODY, AND BASE IN MM): 5.7 mm, rim

INTERIOR SURFACE TREATMENT: smoothed on the rim and body

EXTERIOR SURFACE TREATMENT: burnished

HEIGHT (IN CM): 9.2

ORIFICE DIAMETER (IN CM): 17.2

DIAMETER AT BOTTOM OF RIM OR NECK (IN CM): N/A

BASE DIAMETER (IN CM): 6.0

ESTIMATED VOLUME (IN LITERS): 0.63 liters

DECORATION: Lip notched only (Figure A1-24)

TYPE: Undefined lip notched vessel

Figure A1-24. Lip notched bowl from the Battle site (5425-657).

SITE NAME OR SITE NUMBER: Battle Place

CONTEXT INFORMATION: From a grave (Burial 2) in Burial Plot 2. Associated with V-1995, V-1997, and V-1998 in the grave.

ACCESSION NO.: 5425-658

VESSEL NO.: V-1996

NON-PLASTICS: grog

VESSEL FORM: Jar with a globular body 
RIM AND LIP FORM: Everted rim and a rounded lip

CORE COLOR: A (fired and cooled in a high oxygen environment)

INTERIOR SURFACE COLOR: brown

EXTERIOR SURFACE COLOR: brown

WALL THICKNESS (RIM, BODY, AND BASE IN MM): 7.4 mm, rim

INTERIOR SURFACE TREATMENT: smoothed on the rim

EXTERIOR SURFACE TREATMENT: none

HEIGHT (IN CM): 13.4

ORIFICE DIAMETER (IN CM): 12.0

DIAMETER AT BOTTOM OF RIM OR NECK (IN CM): 11.7

BASE DIAMETER (IN CM): 7.1

ESTIMATED VOLUME (IN LITERS): 0.96 liters

DECORATION: There are single rows of tool punctations at the top of the rim and at the rim-body juncture, and the area in between has horizontal brushing marks; cross-hatched incised lines were drawn through the brushing marks (Figure A1-25). The jar body has 22 separate vertical appliqued fillets that extend from near the rim-body juncture to just above the base of the vessel.

TYPE: unidentified brushed-incised-punctated-appliqued utility ware

Figure A1-25. Brushed-incised-punctated-appliqued jar (5425-658).

SITE NAME OR SITE NUMBER: Battle Place

CONTEXT INFORMATION: Obtained in 1928.

ACCESSION NO.: 5425-660

VESSEL NO.: V-54 
NON-PLASTICS: fine grog

VESSEL FORM: Bottle with a carinated body

RIM AND LIP FORM: Direct rim and a flat lip

CORE COLOR: $\mathrm{H}$ (fired in a reducing environment and cooled in the open air)

INTERIOR SURFACE COLOR: dark grayish-brown

EXTERIOR SURFACE COLOR: dark grayish-brown

WALL THICKNESS (RIM, BODY, AND BASE IN MM): $6.1 \mathrm{~mm}$, rim; $7.7 \mathrm{~mm}$, body

INTERIOR SURFACE TREATMENT: none

EXTERIOR SURFACE TREATMENT: burnished on the neck and body

HEIGHT (IN CM): 15.8

ORIFICE DIAMETER (IN CM): 5.1

DIAMETER AT BOTTOM OF RIM OR NECK (IN CM): 6.0; $11.2 \mathrm{~mm}$ wide at the widest part of the body

BASE DIAMETER (IN CM): 8.6

ESTIMATED VOLUME (IN LITERS): 0.54 liters

DECORATION: There is a single horizontal engraved line at the neck-body juncture. On the body are five panels defined by two vertical sets of four appliqued nodes (Figure A126) that extend to the body carination. Three of the panels have three curvilinear engraved lines, a fourth panel has two semi-circular engraved lines, and the fifth panel has three curvilinear engraved lines, one of which has tick marks on it (Figure A1-26).

TYPE: unidentified engraved-appliqued fine ware

Figure A1-26. Engraved-appliqued bottle (5425-660).

SITE NAME OR SITE NUMBER: Battle Place

CONTEXT INFORMATION: Found in Burial 3, Burial Plot 2 (Martin 1939), in association with V-1999 to V-2004 1/2, as well as pipes P-236 and P-237. 
ACCESSION NO.: 5425-661

VESSEL NO.: V-2000

NON-PLASTICS: none

VESSEL FORM: Jar with a tall rim

RIM AND LIP FORM: Everted rim and a rounded lip

CORE COLOR: B (fired and cooled in a reducing environment)

INTERIOR SURFACE COLOR: very dark gray

EXTERIOR SURFACE COLOR: black

WALL THICKNESS (RIM, BODY, AND BASE IN MM): 5.0 mm, rim

INTERIOR SURFACE TREATMENT: burnished on the rim

EXTERIOR SURFACE TREATMENT: burnished on the rim and smoothed on the body

HEIGHT (IN CM): 15.3

ORIFICE DIAMETER (IN CM): 15.1

DIAMETER AT BOTTOM OF RIM OR NECK (IN CM): 11.8

BASE DIAMETER (IN CM): 4.4

ESTIMATED VOLUME (IN LITERS): 1.39 liters

DECORATION: The rim of this jar has a trailed continuous scroll with the hooked arm element, and the scroll fill background is comprised of six upper and six lower punctated circles and punctated triangles (Figure A1-27a-b). The vessel body has three repeating sets of concentric trailed circles. At the center of each of these sets is a cluster of three appliqued nodes (Figure A1-27a-b).

TYPE: cf. Foster Trailed-Incised, var. Foster, on the vessel body; the rim decoration is unique

Figure A1-27. Foster Trailed-Incised, var. Foster (5425-661) jar: a, photograph; b, drawing by Bobby Gonzalez. 
SITE NAME OR SITE NUMBER: Battle Place

CONTEXT INFORMATION: Found in a grave at the south end of the Battle mound where it was exposed by Simon Cullins in 1938 while digging a storm cellar. Associated vessels include V-1946, V-1947, and V-1949 to V-1952.

ACCESSION NO: 5425-662

VESSEL NO.: V-1948

NON-PLASTICS: shell

VESSEL FORM: Jar

RIM AND LIP FORM: Everted rim and a rounded lip

CORE COLOR: K (incompletely oxidized during firing and possibly smudged/reheated)

INTERIOR SURFACE COLOR: dark gray

EXTERIOR SURFACE COLOR: dark grayish-brown

WALL THICKNESS (RIM, BODY, AND BASE IN MM): 5.8 mm, rim

INTERIOR SURFACE TREATMENT: smoothed on the rim

EXTERIOR SURFACE TREATMENT: smoothed on the lower body

HEIGHT (IN CM): 15.8

ORIFICE DIAMETER (IN CM): 18.5

DIAMETER AT BOTTOM OF RIM OR NECK (IN CM): 12.2

BASE DIAMETER (IN CM): 5.5

ESTIMATED VOLUME (IN LITERS): 2.63 liters

DECORATION: The rim has three rows of diagonal incised lines, and there is a single horizontal trailed line at the rim-body juncture (Figure A1-28). There are three repeating sets of concentric trailed circles on the vessel body, at the center of each is a cluster of three appliqued nodes (Figure A1-28).

TYPE: Foster Trailed-Incised, var. Foster

Figure A1-28. Foster Trailed-Incised, var. Foster jar (5425-662). 
SITE NAME OR SITE NUMBER: Battle Place

CONTEXT INFORMATION: Excavated from a cemetery by Dan Jenkins, April 1929.

ACCESSION NO.: 5425-663

VESSEL NO.: V-464

NON-PLASTICS: bone

VESSEL FORM: Bottle with a long narrow neck

RIM AND LIP FORM: Direct rim and a rounded lip

CORE COLOR: $\mathrm{G}$ (fired in a reducing environment and cooled in the open air)

INTERIOR SURFACE COLOR: dark grayish-brown

EXTERIOR SURFACE COLOR: light yellowish-brown

WALL THICKNESS (RIM, BODY, AND BASE IN MM): 3.9 mm, neck; $5.8 \mathrm{~mm}$, body; $5.9 \mathrm{~mm}$, base

INTERIOR SURFACE TREATMENT: none

EXTERIOR SURFACE TREATMENT: burnished on the body

HEIGHT (IN CM): 17.0

ORIFICE DIAMETER (IN CM): 3.6

DIAMETER AT BOTTOM OF RIM OR NECK (IN CM): 5.4; $11.8 \mathrm{~cm}$ wide at its widest part of the body

BASE DIAMETER (IN CM): N/A

ESTIMATED VOLUME (IN LITERS): 0.34

DECORATION: Traces of a red slip on the exterior body and neck (Figure A1-29)

TYPE: Unidentified red-slipped bottle

Figure A1-29. Red-slipped bottle (5425-663). 
SITE NAME OR SITE NUMBER: Battle Place

CONTEXT INFORMATION: From a grave (Burial 1) in Burial Plot 3 (Martin 1939). Associated with V-2007 to V-2012 in the grave.

ACCESSION NO.: 5425-664

VESSEL NO.: V-2013

NON-PLASTICS: grog

VESSEL FORM: Bottle

RIM AND LIP FORM: Direct rim with a rounded and exterior folded lip

CORE COLOR: B (fired and cooled in a low oxygen environment)

INTERIOR SURFACE COLOR: very dark grayish-brown

EXTERIOR SURFACE COLOR: very dark grayish-brown

WALL THICKNESS (RIM, BODY, AND BASE IN MM): 6.7 mm, rim

INTERIOR SURFACE TREATMENT: none

EXTERIOR SURFACE TREATMENT: smoothed to burnished on the neck and body HEIGHT (IN CM): 19.5

ORIFICE DIAMETER (IN CM): 5.1

DIAMETER AT BOTTOM OF RIM OR NECK (IN CM): 6.4; $14.5 \mathrm{~cm}$ wide at its widest point on the vessel body

BASE DIAMETER (IN CM): 8.0

ESTIMATED VOLUME (IN LITERS): 0.62 liters

DECORATION: This bottle has a complex engraved design organized in four panels on the vessel body (Figure A1-30). Along the upper part of the body is a narrow horizontal band filled with hatched or cross-hatched brackets. 
Two of the body panels are rectangular and vertical in orientation and have the same engraved motif, while the other two body panels are circular engraved motifs and different from each other (see Figure A1-30). The rectangular panels feature bounding curvilinear engraved lines with hatched pendant triangles, followed by two vertical engraved lines, and two narrow hatched ladders. The central element in the rectangular panels is a rectangle with upper, central, and lower hatched brackets. The negative space created by the brackets has two small and vertically-oriented engraved rectangles (see Figure A1-30b).

The first of the circular panels has concentric circles bounded by two sets of two opposed semi-circular engraved lines. One of the outermost bounding lines has hatched pendant triangles facing outward away from the center of the panel. Within the bounding semi-circular lines are five concentric circles; two of the outer circles form a circular zone filled with small hatched brackets and simple semi-circles.

The second circular panel panels has concentric circles bounded by two sets of two opposed semi-circular engraved lines. The outermost lines have hatched pendant triangles that point inwards towards the center of the panel (see Figure A1-30a). Within the bounding semi-circular lines are seven concentric circles, with two of the outer circles forming a circular zone filled with small hatched brackets and seven small hatched or simple semi-circles.

TYPE: cf. Handy Engraved

Figure A1-30. Handy Engraved bottle (5425-664): a, circular panel; b, rectangular panel.

SITE NAME OR SITE NUMBER: Battle Place

CONTEXT INFORMATION: Obtained in 1928 from a grave in a Caddo cemetery.

ACCESSION NO.: 5425-665

VESSEL NO.: V-225

NON-PLASTICS: shell

VESSEL FORM: Bottle

RIM AND LIP FORM: Direct rim and a rounded lip

CORE COLOR: B (fired and cooled in a low oxygen or reducing environment)

INTERIOR SURFACE COLOR: dark grayish-brown 
EXTERIOR SURFACE COLOR: dark grayish-brown

WALL THICKNESS (RIM, BODY, AND BASE IN MM): 5.0 mm, rim

INTERIOR SURFACE TREATMENT: none

EXTERIOR SURFACE TREATMENT: smoothed on the neck and body

HEIGHT (IN CM): 16.5

ORIFICE DIAMETER (IN CM): 3.9

DIAMETER AT BOTTOM OF RIM OR NECK (IN CM): $5.2 ; 11.3 \mathrm{~cm}$ wide at the widest part of the body

BASE DIAMETER (IN CM): 6.4

ESTIMATED VOLUME (IN LITERS): 0.42 liters

DECORATION: There is a single horizontal engraved line at the neck-body juncture. Three cross-hatched engraved triangles are pendant from that engraved line (Figure A131). The main decorated motif on the body is a continuous scroll with linear tick marks and hooked arms, along with curvilinear ticked scroll lines both above and below the central hooked arm scroll.

TYPE: cf. Means Engraved

Figure A1-31. cf. Means Engraved bottle (5425-665).

SITE NAME OR SITE NUMBER: Battle Place

CONTEXT INFORMATION: From a grave on the Henry Moore (Battle) place, 1928

ACCESSION NO.: 5425-666

VESSEL NO.: V-35

NON-PLASTICS: grog

VESSEL FORM: Bottle with a straight neck

RIM AND LIP FORM: Direct rim with a flat lip

CORE COLOR: B (fired and cooled in a low oxygen environment) 
INTERIOR SURFACE COLOR: very dark gray

EXTERIOR SURFACE COLOR: very dark gray; fire cloud near vessel base

WALL THICKNESS (RIM, BODY, AND BASE IN MM): 6.4 mm, rim

INTERIOR SURFACE TREATMENT: none

EXTERIOR SURFACE TREATMENT: burnished on the neck and body

HEIGHT (IN CM): 17.0

ORIFICE DIAMETER (IN CM): 4.9

DIAMETER AT BOTTOM OF RIM OR NECK (IN CM): 5.0; $12.3 \mathrm{~cm}$ wide at its widest part of the body

BASE DIAMETER (IN CM): 6.8

ESTIMATED VOLUME (IN LITERS): 0.46 liters

DECORATION: There is a single narrow hatched engraved band at the base of the bottle neck, and a corresponding horizontal engraved line above the vessel base. The bottle body decoration consists of a continuous scroll (a narrow hatched scroll) with an embedded hatched circle (Figure A1-32). There is a smaller ticked circle within the embedded circle, and at its very center is a single excised dot; there are three embedded hatched circles along the course of the scroll. The upper and lower parts of the scroll filler background consists of curvilinear hatched areas with negative ovals; each oval has a small excised spur that cut into the oval (Figure A1-32).

TYPE: unidentified engraved fine ware, cf. Haley Engraved

Figure A1-32. Engraved bottle (5425-666) from the Battle Place.

SITE NAME OR SITE NUMBER: Battle Place

CONTEXT INFORMATION: Associated with V-1963, excavated by Dan Jenkins after plowing into some graves.

ACCESSION NO.: 5425-668

VESSEL NO.: V-1962 
NON-PLASTICS: grog and bone (less than $5 \%$ of the paste)

VESSEL FORM: Bottle with four evenly spaced body peaks (Figure A1-33)

RIM AND LIP FORM: Everted rim and a rounded lip

CORE COLOR: $\mathrm{G}$ (fired in a reducing environment and cooled in the open air)

INTERIOR SURFACE COLOR: grayish-brown

EXTERIOR SURFACE COLOR: strong brown

WALL THICKNESS (RIM, BODY, AND BASE IN MM): 4.8 mm, rim

INTERIOR SURFACE TREATMENT: smoothed on the upper neck

EXTERIOR SURFACE TREATMENT: burnished on the neck and the body

HEIGHT (IN CM): 18.0

ORIFICE DIAMETER (IN CM): 3.3

DIAMETER AT BOTTOM OF RIM OR NECK (IN CM): 4.4; $13.5 \mathrm{~cm}$ wide at the widest part of the vessel body

BASE DIAMETER (IN CM): 5.9

ESTIMATED VOLUME (IN LITERS): 0.42 liters

DECORATION: There is a single horizontal engraved line below the base of the bottle neck. On the vessel body are four repeating concentric engraved circles around body peaks and four dimpled appliqued nodes (see Figure A1-33). Each set of concentric circle motifs consist of an outer circle, a circular hatched band, a circle of dashed lines, and several closely-spaced concentric circles around the appliqued node.

The concentric circle motifs on this vessel are divided by large triangular elements that extend from near the top of the bottle body to near the base. These elements include three triangular hatched corners, separate sets of straight engraved lines, and one or two short curved engraved lines that originated along the margins of the large triangular elements (see Figure A1-33). Similar short curved lines are noted on other Belcher Engraved bottles, including one from the McClure site in Miller County, Arkansas (see Suhm and Jelks 1962:Plate 5m).

TYPE: Belcher Engraved, var. Soda Lake

Figure A1-33. Belcher Engraved, var. Soda Lake bottle (5425-668). 
SITE NAME OR SITE NUMBER: Battle Place

CONTEXT INFORMATION: From a grave (Burial 1) in Burial Plot 3 (Martin 1939). Associated with V-2007 to V-2010 and V-2012 to V-2013.

ACCESSION NO.: 5425-669

VESSEL NO.: V-2011

NON-PLASTICS: grog

VESSEL FORM: Bottle

RIM AND LIP FORM: Direct rim and a flat lip

CORE COLOR: B (fired and cooled in a reducing environment)

INTERIOR SURFACE COLOR: very dark grayish-brown

EXTERIOR SURFACE COLOR: very dark grayish-brown

WALL THICKNESS (RIM, BODY, AND BASE IN MM): 7.2 mm, rim

INTERIOR SURFACE TREATMENT: none

EXTERIOR SURFACE TREATMENT: smoothed on the neck and body

HEIGHT (IN CM): 18.0

ORIFICE DIAMETER (IN CM): 5.3

DIAMETER AT BOTTOM OF RIM OR NECK (IN CM): $5.3 ; 14.0 \mathrm{~cm}$ wide at the widest point on the bottle body

BASE DIAMETER (IN CM): 7.5

ESTIMATED VOLUME (IN LITERS): 0.54 liters

DECORATION: There are single horizontal engraved lines under the bottle neck and above the vessel base. The vessel body has two distinctive engraved motifs, each repeated twice on the body (Figures A1-34 and A1-35). 
The first engraved motif is a rectangular panel like that noted on both Handy Engraved and Haley Engraved bottles from the Battle site (see Suhm and Jelks 1962:Plates 31b and 32d) as well as at the Wm. Handy Place (see Figure A2-15, below). The panel is defined by narrow hatched borders and distinct horizontal hatched brackets that divide the rectangular panel into two areas: each of these areas has a single small vertical engraved rectangle in it (see Figures A1-34a and A1-35).

The second engraved motif is an oval or elliptical panel defined by two vertical arcing lines (see Figures A1-34b and A1-35); such panels are characteristic of Hatchel Engraved bottles (Suhm and Jelks 1962:Plate 34a, d). Within the panel itself are two large circles, the innermost of which has ticked lines that face outward as well as opposed sets of three semi-circular engraved lines; the innermost of these lines has tick marks. This inner circle is divided in half by a single horizontal engraved and ticked line that has upper and lower ticked spurs (see Figure A1-34b).

TYPE: cf. Handy-Hatchel Engraved bottle

Figure A1-34. cf. Handy-Hatchel Engraved bottle (5425-669): a, rectangular motif; b, circular motif.

Figure A1-35. cf. Handy-Hatchel Engraved bottle (5425-669). Drawing by Bobby Gonzalez.

SITE NAME OR SITE NUMBER: Battle Place

CONTEXT INFORMATION: From a grave (Burial 3) in Burial Plot 2 (Martin 1939). Associated vessels include V-1999 to V-2002 and V-2004 and V-2004 1⁄2.

ACCESSION NO.: 5425-671

VESSEL NO.: V-2003

NON-PLASTICS: grog

VESSEL FORM: Carinated bowl

RIM AND LIP FORM: Everted rim with a rounded and exterior folded lip

CORE COLOR: $\mathrm{G}$ (fired in a reducing environment and cooled in a high oxygen environment)

INTERIOR SURFACE COLOR: very dark gray; fire clouds on the rim and body

EXTERIOR SURFACE COLOR: light yellowish-brown; fire clouding 
WALL THICKNESS (RIM, BODY, AND BASE IN MM): $5.1 \mathrm{~mm}$, rim

INTERIOR SURFACE TREATMENT: burnished on the rim and body

EXTERIOR SURFACE TREATMENT: burnished on the rim and body

HEIGHT (IN CM): 5.7

ORIFICE DIAMETER (IN CM): 17.1

DIAMETER AT BOTTOM OF RIM OR NECK (IN CM): 15.2

BASE DIAMETER (IN CM): N/A, rounded base

ESTIMATED VOLUME (IN LITERS): 0.58 liters

DECORATION: The rim is divided into two panels with an horizontal interlocking engraved scroll motif; there are also small linear ticks under the lip and at the vessel carination (Figure A1-36). The scroll motif consists of a narrow horizontal and vertical engraved band filled with hatched lines, a single enclosing engraved line, and hatched brackets that end either at the rim or at the vessel carination; between the two brackets in each motif is a single small horizontally-oriented engraved rectangle (Figure A1-36).

Each motif is separated from the other by two sets of two vertical hatched brackets. Between each of the engraved brackets is a single vertically-oriented engraved rectangle (see Figure A1-36).

TYPE: Handy Engraved

Figure A1-36. Handy Engraved carinated bowl (5425-671).

SITE NAME OR SITE NUMBER: Battle Place

ACCESSION NO.: 5425-672

CONTEXT INFORMATION: Found in a plowed-up grave by Dan Jenkins in 1939, together with V-1964 to V-1966 and V-1968 and V-1969.

VESSEL NO.: V-1967

NON-PLASTICS: fine grog

VESSEL FORM: Carinated bowl with two small opposed lip nodes 
RIM AND LIP FORM: Direct rim and a rounded lip

CORE COLOR: $\mathrm{G}$ (fired in a reducing environment and cooled in the open air)

INTERIOR SURFACE COLOR: very dark gray

EXTERIOR SURFACE COLOR: light yellowish-brown; fire clouding

WALL THICKNESS (RIM, BODY, AND BASE IN MM): 5.3 mm, rim

INTERIOR SURFACE TREATMENT: smoothed on the rim

EXTERIOR SURFACE TREATMENT: burnished on the rim and smoothed on the body

HEIGHT (IN CM): 5.4

ORIFICE DIAMETER (IN CM): 17.3

DIAMETER AT BOTTOM OF RIM OR NECK (IN CM): 18.0

BASE DIAMETER (IN CM): N/A, rounded base

ESTIMATED VOLUME (IN LITERS): 0.56 liters

DECORATION: The rim has an engraved panel (i.e., defined by a horizontal engraved line under the lip and a second horizontal engraved line at the carination) filled with alternating vertical hatched panels (23 such panels) and vertical ticked engraved lines (21 such lines) (Figure A1-37). The extra vertical hatched panels begin under one of the lip nodes.

TYPE: Unidentified engraved fine ware vessel

Figure A1-37. Engraved carinated bowl (5425-672) from the Battle Place.

SITE NAME OR SITE NUMBER: Battle Place

CONTEXT INFORMATION: Found in Burial 1, Burial Plot 1, in association with V1979 to V-1983 from the same grave (Martin 1939).

ACCESSION NO.: 5425-674

VESSEL NO.: V-1978 1⁄2 
NON-PLASTICS: grog and bone (less than $5 \%$ of the paste)

VESSEL FORM: Carinated bowl with two rim panels

RIM AND LIP FORM: Everted rim with a rounded lip

CORE COLOR: N/A

INTERIOR SURFACE COLOR: brown, fire clouding

EXTERIOR SURFACE COLOR: brown, fire clouding

WALL THICKNESS (RIM, BODY, AND BASE IN MM): 4.4 mm, rim

INTERIOR SURFACE TREATMENT: burnished on the rim and body

EXTERIOR SURFACE TREATMENT: burnished on the rim and body

HEIGHT (IN CM): 5.5

ORIFICE DIAMETER (IN CM): 15.4

DIAMETER AT BOTTOM OF RIM OR NECK (IN CM): 12.6

BASE DIAMETER (IN CM): 3.7

ESTIMATED VOLUME (IN LITERS): 0.51 liters

DECORATION: The upper rim panel has a row of punctations under the lip as well as a single centrally-placed horizontal engraved line (Figure A1-38). The lower rim panel has four sets of appliqued nodes, and on either side of each node are short diagonal engraved lines pitched in opposite directions (Figure A1-38). Two sets of two longer diagonal engraved lines extend from one appliqued/engraved motif to another. Underneath these longer diagonal lines are a single row of excised punctations.

A white kaolin clay pigment had been rubbed in the engraved lines and excised punctations.

TYPE: Belcher Engraved, var. Belcher

Figure A1-38. Belcher Engraved, var. Belcher carinated bowl (5425-674): a, photograph; b, drawing by Bobby Gonzalez.

SITE NAME OR SITE NUMBER: Battle Place 
CONTEXT INFORMATION: From Burial 4 in Burial Plot 2 (Martin 1939), in association with V-2006 and pipes P-238 and P-239.

ACCESSION NO.: 5425-675

VESSEL NO.: V-2005

NON-PLASTICS: grog

VESSEL FORM: Carinated bowl

RIM AND LIP FORM: Direct rim with a rounded and exterior folded lip

CORE COLOR: B (fired and cooled in a reducing environment)

INTERIOR SURFACE COLOR: black

EXTERIOR SURFACE COLOR: very dark grayish-brown

WALL THICKNESS (RIM, BODY, AND BASE IN MM): 7.2 mm, rim

INTERIOR SURFACE TREATMENT: smoothed on the body and burnished on the rim

EXTERIOR SURFACE TREATMENT: burnished on the rim and body

HEIGHT (IN CM): 6.0

ORIFICE DIAMETER (IN CM): 21.5

DIAMETER AT BOTTOM OF RIM OR NECK (IN CM): 18.5

BASE DIAMETER (IN CM): N/A, rounded base

ESTIMATED VOLUME (IN LITERS): 0.77 liters

DECORATION: The rim panel on this vessel has two horizontal interlocking engravedpunctated scrolls; the underside of the folded lip is a row of punctations, and there is a second row of punctations at the carination point (Figure A1-39a-b).

The interlocking scroll has a central narrow engraved band filled with punctations, opposed single hooked arm engraved lines that partially encircle the central horizontal scroll band, and two attached engraved-punctated brackets that extend from the central band to the rim or the carination (see Figure A1-39a-b). Between each of these sets of brackets is a small engraved rectangle. 
The two horizontal interlocking scrolls are separated from each other by two sets of two vertical engraved and punctate-filled brackets that extend from the rim to the vessel carination. Between each of these sets is a single vertically-oriented engraved rectangle (see Figure A1-39a-b).

TYPE: Handy Engraved

Figure A1-39. Handy Engraved carinated bowl (5425-675): a, photograph; b, drawing by Bobby Gonzalez.

SITE NAME OR SITE NUMBER: Battle Place

CONTEXT INFORMATION: Found in a grave on the Henry Moore (Battle) place, 1926. Obtained from Dan Jenkins.

ACCESSION NO.: 5425-677

VESSEL NO:: V-348

NON-PLASTICS: grog and bone (less than $5 \%$ of the paste)

VESSEL FORM: Jar

RIM AND LIP FORM: Everted rim and a rounded lip

CORE COLOR: F (fired in a low oxygen environment and cooled in the open air)

INTERIOR SURFACE COLOR: strong brown

EXTERIOR SURFACE COLOR: strong brown

WALL THICKNESS (RIM, BODY, AND BASE IN MM): 4.6 mm, rim

INTERIOR SURFACE TREATMENT: smoothed on the rim and body

EXTERIOR SURFACE TREATMENT: none

HEIGHT (IN CM): 8.5

ORIFICE DIAMETER (IN CM): 8.5

DIAMETER AT BOTTOM OF RIM OR NECK (IN CM): 7.6

BASE DIAMETER (IN CM): 5.0 
ESTIMATED VOLUME (IN LITERS): 0.43 liters

DECORATION: The rim has a row of tool punctates under the lip and a second row at the rim-body juncture. The remainder of the rim has horizontal brushing marks (Figure A1-40). The vessel body is characterized by narrow vertical ridging, with vertical brushing marks between the narrow ridges.

TYPE: Belcher Ridged, var. Wilson's Island

Figure A1-40. Belcher Ridged, var. Wilson's Island jar (5425-677).

SITE NAME OR SITE NUMBER: Battle Place

CONTEXT INFORMATION: Found in Burial 1, Burial Plot 1 (Martin 1939), in association with V-1978 1/2, V-1979, and V-1981 to V-1983.

ACCESSION NO.: 5425-679

VESSEL NO.: V-1980

NON-PLASTICS: grog

VESSEL FORM: Jar

RIM AND LIP FORM: Everted rim and a rounded lip

CORE COLOR: $\mathrm{G}$ (fired in a reducing environment and cooled in the open air)

INTERIOR SURFACE COLOR: black

EXTERIOR SURFACE COLOR: grayish-brown

WALL THICKNESS (RIM, BODY, AND BASE IN MM): 4.1 mm, rim

INTERIOR SURFACE TREATMENT: smoothed on the rim

EXTERIOR SURFACE TREATMENT: none

HEIGHT (IN CM): 7.8

ORIFICE DIAMETER (IN CM): 9.8

DIAMETER AT BOTTOM OF RIM OR NECK (IN CM): 8.1 
BASE DIAMETER (IN CM): 4.7

ESTIMATED VOLUME (IN LITERS): 0.46 liters

DECORATION: The vessel rim has three horizontal incised panels, two of which are filled with short diagonal incised lines (Figure A1-41). There are three repeating sets of concentric trailed circles on the vessel body, each with a dimpled appliqued node at its center (Figure A1-41).

TYPE: Foster Trailed-Incised, var. Red Lake

Figure A1-41. Foster Trailed-Incised, var. Red Lake jar (5425-679).

SITE NAME OR SITE NUMBER: Battle Place

CONTEXT INFORMATION: Found in Burial 2, Burial Plot 1 (Martin 1939), in association with V-1984 and V-1986.

ACCESSION NO.: 5425-681

VESSEL NO.: V-1985

NON-PLASTICS: grog

VESSEL FORM: Jar with a tall rim

RIM AND LIP FORM: Direct rim with a rounded and exterior folded lip

CORE COLOR: B (fired and cooled in a low oxygen environment)

INTERIOR SURFACE COLOR: black

EXTERIOR SURFACE COLOR: black

WALL THICKNESS (RIM, BODY, AND BASE IN MM): 5.2 mm, rim

INTERIOR SURFACE TREATMENT: smoothed on the rim

EXTERIOR SURFACE TREATMENT: none

HEIGHT (IN CM): 9.5

ORIFICE DIAMETER (IN CM): 9.5 
DIAMETER AT BOTTOM OF RIM OR NECK (IN CM): 7.9

BASE DIAMETER (IN CM): 3.8

ESTIMATED VOLUME (IN LITERS): 0.54 liters

DECORATION: The tall rim has three discrete rows of short diagonal incised lines. On the vessel body are three sets of incised concentric semi-circles that extend from the rimbody juncture to the base (Figure A1-42). Each set of incised semi-circles has 13 concentric lines.

TYPE: Foster Trailed-Incised, var. Dixon

Figure A1-42. Foster Trailed-Incised, var. Dixon jar (5425-681).

SITE NAME OR SITE NUMBER: Battle Place

ACCESSION NO.: 5425-683

CONTEXT INFORMATION: Found in Burial 2, Burial Plot 2 (Martin 1939) in association with V-1995, V-1996, V-1998, a pipe (P-235) and a celt (N-730).

VESSEL NO.: V-1997

NON-PLASTICS: grog

VESSEL FORM: Jar with a short (10 mm) rim

RIM AND LIP FORM: Everted rim and a rounded lip

CORE COLOR: $\mathrm{G}$ (fired in a reducing environment and cooled in the open air)

INTERIOR SURFACE COLOR: very dark gray

EXTERIOR SURFACE COLOR: yellow

WALL THICKNESS (RIM, BODY, AND BASE IN MM): $5.5 \mathrm{~mm}$, rim

INTERIOR SURFACE TREATMENT: none

EXTERIOR SURFACE TREATMENT: none

HEIGHT (IN CM): 10.4 
ORIFICE DIAMETER (IN CM): 9.4

DIAMETER AT BOTTOM OF RIM OR NECK (IN CM): 8.7

BASE DIAMETER (IN CM): 6.3

ESTIMATED VOLUME (IN LITERS): 0.59 liters

DECORATION: The rim is horizontally brushed. The body of the vessel has closelyspaced and narrow vertical appliqued ridges that extend from the rim-body juncture to near the base (Figure A1-43).

TYPE: Belcher Ridged, var. Wilson's Island

Figure A1-43. Belcher Ridged, var. Wilson's Island jar (5425-683).

SITE NAME OR SITE NUMBER: Battle Place

CONTEXT INFORMATION: Obtained in 1927.

ACCESSION NO.: 5425-685

VESSEL NO.: V-180

NON-PLASTICS: grog and bone

VESSEL FORM: Bottle

RIM AND LIP FORM: Direct rim with a flat lip

CORE COLOR: B (fired and cooled in a reducing environment)

INTERIOR SURFACE COLOR: dark gray

EXTERIOR SURFACE COLOR: dark gray

WALL THICKNESS (RIM, BODY, AND BASE IN MM): $5.3 \mathrm{~mm}$, rim

INTERIOR SURFACE TREATMENT: smoothed on the upper neck

EXTERIOR SURFACE TREATMENT: smoothed on the body and neck

HEIGHT (IN CM): 15.7 
ORIFICE DIAMETER (IN CM): 4.8

DIAMETER AT BOTTOM OF RIM OR NECK (IN CM): $6.1 ; 12.4 \mathrm{~cm}$ wide at the widest part of the bottle body

BASE DIAMETER (IN CM): 8.2

ESTIMATED VOLUME (IN LITERS): 0.51 liters

DECORATION: There are three horizontal engraved lines under the bottle neck, and a single horizontal engraved line near the vessel base. Within the panel created by these horizontal lines are three repeated semi-circular and circular engraved motifs (Figure A144). Dividing each of the motifs are two large spurred engraved circles, one atop the other.

Each motif has two broadly spaced opposed semi-circular engraved lines that extend from the top of the vessel body to the base. There are concentric semi-circles attached to both opposed engraved lines, as well as a central engraved circle (with repeated circular lines) with spurs (see Figure A1-44); the outermost concentric semicircle has spurs or large ticks on it.

There are traces of a white kaolin clay pigment in the engraved lines.

TYPE: Haley Engraved

Figure A1-44. Haley Engraved bottle (5425-685).

SITE NAME OR SITE NUMBER: Battle Place

CONTEXT INFORMATION: From a plowed out grave, found in 1934, along with V1122 through V-1136 and V-159 to V-162.

ACCESSION NO.: 5425-686

VESSEL NO.: V-1127

NON-PLASTICS: grog-bone-hematite (ferruginous sandstone)

VESSEL FORM: Jar

RIM AND LIP FORM: Direct rim and a rounded lip 
CORE COLOR: $\mathrm{G}$ (fired in a reducing environment but cooled in an oxidizing environment)

INTERIOR SURFACE COLOR: dark grayish-brown

EXTERIOR SURFACE COLOR: brown; fire clouds on the body and base

WALL THICKNESS (RIM, BODY, AND BASE IN MM): N/A

INTERIOR SURFACE TREATMENT: smoothed on the rim and upper body; organic residue preserved on the rim and body

EXTERIOR SURFACE TREATMENT: smoothed on the lower body

HEIGHT (IN CM): 12.0

ORIFICE DIAMETER (IN CM): 11.9

DIAMETER AT BOTTOM OF RIM OR NECK (IN CM): 11.9

BASE DIAMETER (IN CM): 5.6

ESTIMATED VOLUME (IN LITERS): 0.86 liters

DECORATION: Both the tall rim and the vessel body have horizontal brushing marks. Executed through the brushing on both parts of the vessel are hooked arm trailed scrolls, each part of the hooked arm scroll being repeated four times (Figure A1-45). Above and below each hooked arm scroll are four curvilinear trailed elements that are nestled near the hooked arms.

TYPE: Mound Tract Incised and Brushed

Figure A1-45. Mound Tract Incised and Brushed jar (5425-686).

SITE NAME OR SITE NUMBER: Battle Place

CONTEXT INFORMATION: From a grave (Burial 1) in Burial Plot 2 (Martin 1939). Associated vessels in this grave are V-1987 and V-1989 to V-1994.

ACCESSION NO.: 5425-687

VESSEL NO.: V-1988

NON-PLASTICS: grog and bone (less than $5 \%$ of the paste) 
VESSEL FORM: Jar

RIM AND LIP FORM: Direct rim with a rounded and exterior folded lip

CORE COLOR: $\mathrm{G}$ (fired in a reducing environment and cooled in the open air)

INTERIOR SURFACE COLOR: very dark grayish-brown

EXTERIOR SURFACE COLOR: very dark grayish-brown

WALL THICKNESS (RIM, BODY, AND BASE IN MM): 4.6 mm, rim

INTERIOR SURFACE TREATMENT: smoothed on the rim and body

EXTERIOR SURFACE TREATMENT: smoothed on the rim and body

HEIGHT (IN CM): 12.0

ORIFICE DIAMETER (IN CM): 10.0

DIAMETER AT BOTTOM OF RIM OR NECK (IN CM): 9.1

BASE DIAMETER (IN CM): 6.7

ESTIMATED VOLUME (IN LITERS): 0.72 liters

DECORATION: The rim has five rectangular incised-punctated panels formed by narrow bands filled with tool punctates. Inside each large rectangle is a single smaller incised rectangle, four of which are filled with tool punctates; one of the incised rectangles is without the punctated fill elements (Figure A1-46).

The rim is separated from the vessel body by a single horizontal incised line. On the body are five large incised-punctated rectangular panels (see Figure A1-46). There are smaller incised-punctated panels at the center of each of the larger incised-punctated panels.

TYPE: unidentified zoned incised-punctated utility ware

Figure A1-46. Zoned incised-punctated jar (5425-687) from the Battle site.

SITE NAME OR SITE NUMBER: Battle Place

CONTEXT INFORMATION: Obtained about 1923. 
ACCESSION NO.: 5425-689

VESSEL NO.: V-218

NON-PLASTICS: grog and bone (less than $5 \%$ of the paste)

VESSEL FORM: Globular jar

RIM AND LIP FORM: Everted rim with a rounded lip

CORE COLOR: $\mathrm{G}$ (fired in a reducing environment and cooled in the open air)

INTERIOR SURFACE COLOR: black

EXTERIOR SURFACE COLOR: brown

WALL THICKNESS (RIM, BODY, AND BASE IN MM): 5.4 mm, rim

INTERIOR SURFACE TREATMENT: smoothed on the body and polished on the rim

EXTERIOR SURFACE TREATMENT: none

HEIGHT (IN CM): 10.5

ORIFICE DIAMETER (IN CM): 10.4

DIAMETER AT BOTTOM OF RIM OR NECK (IN CM): 9.6

BASE DIAMETER (IN CM): 4.8

ESTIMATED VOLUME (IN LITERS): 0.66 liters

DECORATION: There are two rows of linear punctates on the rim, one row under the lip and the other just above the rim-body juncture. A single broad incised line marks the rimbody juncture itself (Figure A1-47). On the body are 16 incised panels formed by the intersection of broad horizontal and vertical incised lines; these panels extend from the rim-body juncture to just above the base. Each panel is filled with randomly placed tool punctations. A final element are four incised triangles that are pendant from the broad incised line at the rim-body juncture and occur at the top of the incised panels. These triangles are also filled with tool punctates (Figure A1-47).

TYPE: unidentified zoned incised-punctated utility ware

Figure A1-47. Zoned incised-punctated jar (5425-689). 
SITE NAME OR SITE NUMBER: Battle Place

CONTEXT INFORMATION: Excavated in 1927 by Dan Jenkins.

ACCESSION NO.: 5425-690

VESSEL NO.: V-331

NON-PLASTICS: grog

VESSEL FORM: Jar with a short $(10 \mathrm{~mm})$ rim

RIM AND LIP FORM: Everted rim and a rounded lip

CORE COLOR: A (fired and cooled in a high oxygen environment)

INTERIOR SURFACE COLOR: very pale brown

EXTERIOR SURFACE COLOR: pale brown; fire clouds on the body

WALL THICKNESS (RIM, BODY, AND BASE IN MM): 5.5 mm, rim

INTERIOR SURFACE TREATMENT: smoothed on the rim and upper body

EXTERIOR SURFACE TREATMENT: smoothed on the base

HEIGHT (IN CM): 12.2

ORIFICE DIAMETER (IN CM): 9.7

DIAMETER AT BOTTOM OF RIM OR NECK (IN CM): 9.0

BASE DIAMETER (IN CM): 6.3

ESTIMATED VOLUME (IN LITERS): 0.71 liters

DECORATION: The rim has several rows of tool punctations. The vessel body is divided into five vertical panels by flattened vertical rows of appliqued nodes. Within each panel are triangular opposed brushed areas (Figure A1-48).

TYPE: Pease Brushed-Incised

Figure A1-48. Pease Brushed-Incised jar (5425-690). 
SITE NAME OR SITE NUMBER: Battle Place

CONTEXT INFORMATION: From a grave, 1928.

ACCESSION NO.: 5425-694

VESSEL NO.: V-115

NON-PLASTICS: grog and bone

VESSEL FORM: Jar with two strap handles

RIM AND LIP FORM: Everted rim and a rounded lip

CORE COLOR: A (fired and cooled in a high oxygen environment)

INTERIOR SURFACE COLOR: reddish-yellow

EXTERIOR SURFACE COLOR: pink

WALL THICKNESS (RIM, BODY, AND BASE IN MM): 8.4 mm, rim

INTERIOR SURFACE TREATMENT: smoothed on the rim and body

EXTERIOR SURFACE TREATMENT: none

HEIGHT (IN CM): 14.7

ORIFICE DIAMETER (IN CM): 12.9

DIAMETER AT BOTTOM OF RIM OR NECK (IN CM): 10.7

BASE DIAMETER (IN CM): 8.3

ESTIMATED VOLUME (IN LITERS): 1.14 liters

DECORATION: The rim has horizontal brushing, and the lip is notched (Figure A1-49). Both strap handles have seven or eight vertical rows of tool punctations.

The vessel body has an appliqued-brushed motif that is repeated four times around the vessel. The motif includes four increasingly larger triangular appliqued ridges, with a large appliqued circle at the apex of the smallest appliqued triangle (see Figure A1-49). The appliqued triangles alternate in orientation, with their apex either pointing 
towards the rim or towards the vessel base. The area between the appliqued triangles is filled with diagonal brushing marks.

TYPE: cf. Haley Complicated Incised

Figure A1-49. Haley Complicated Incised jar (5425-694).

SITE NAME OR SITE NUMBER: Battle Place

CONTEXT INFORMATION: From plowed-up burial found by Dan Jenkins in February 1939. It is associated with V-1962 to V-1968.

ACCESSION NO.: 5425-695

VESSEL NO.: V-1969

NON-PLASTICS: shell

VESSEL FORM: Bottle

RIM AND LIP FORM: Direct rim and a rounded lip

CORE COLOR: F (fired in a reducing environment and cooled in the open air)

INTERIOR SURFACE COLOR: yellowish-brown

EXTERIOR SURFACE COLOR: yellowish-brown

WALL THICKNESS (RIM, BODY, AND BASE IN MM): 4.6 mm, rim

INTERIOR SURFACE TREATMENT: none

EXTERIOR SURFACE TREATMENT: smoothed

HEIGHT (IN CM): $9.2 \mathrm{~cm}$ on the body

ORIFICE DIAMETER (IN CM): 3.6

DIAMETER AT BOTTOM OF RIM OR NECK (IN CM): 4.3; $13.0 \mathrm{~cm}$ wide at the widest part of the body

BASE DIAMETER (IN CM): 7.1

ESTIMATED VOLUME (IN LITERS): 0.14 
DECORATION: The vessel body is divided into four panels by a single vertical engraved line. Within each of the panels are three engraved concentric circles (Figure A1-50). The outer two concentric circles are narrow cross-hatched bands.

TYPE: unidentified engraved fine ware

Figure A1-50. Engraved shell-tempered bottle (5425-695).

SITE NAME OR SITE NUMBER: Battle Place

CONTEXT INFORMATION: From a grave (Burial 1) in Burial Plot 3 (Martin 1939). Associated with V-2007 to V-2009 and V-2011 to V-2013.

ACCESSION NO.: 5425-696

VESSEL NO.: V-2010

NON-PLASTICS: grog

VESSEL FORM: Bottle with a collar at the bottom of the neck (Figure A1-51)

RIM AND LIP FORM: Direct rim and a rounded lip

CORE COLOR: L (incompletely oxidized; possibly smudged or re-heated)

INTERIOR SURFACE COLOR: brown, fire clouds on the neck

EXTERIOR SURFACE COLOR: black, with fire clouds on the neck and body

WALL THICKNESS (RIM, BODY, AND BASE IN MM): 4.8 mm, rim

INTERIOR SURFACE TREATMENT: smoothed on the upper neck

EXTERIOR SURFACE TREATMENT: burnished on the neck and body

HEIGHT (IN CM): 17.7

ORIFICE DIAMETER (IN CM): 4.8

DIAMETER AT BOTTOM OF RIM OR NECK (IN CM): $5.3 ; 12.5 \mathrm{~cm}$ wide at the widest part of the bottle body

BASE DIAMETER (IN CM): 9.9 
ESTIMATED VOLUME (IN LITERS): 0.70 liters

DECORATION: There are three horizontal engraved lines immediately below the base of the bottle neck and an accompanying set of three horizontal lines near the vessel base. The body has three panels created by vertical engraved lines, and each panel features a complex and unique series of hatched circular, semi-circular, rectangle, and scroll elements (Figure A1-51).

The panels are divided in half by a horizontal and semi-circular hatched band with hatched spurs, with a hatched scroll and semi-circle in the upper part of the panel. The lower left part of the panel has hatched rectangles, while the lower right portion of the panel has engraved semi-circles (see Figure A1-51). The main semi-circle in each panel has three hatched bands within it.

TYPE: cf. Haley Engraved

Figure A1-51. cf. Haley Engraved bottle (5425-696).

SITE NAME OR SITE NUMBER: Battle Place

CONTEXT INFORMATION: From a grave, 1928.

ACCESSION NO.: 5425-697

VESSEL NO.: V-182

NON-PLASTICS: grog and bone

VESSEL FORM: Bottle

RIM AND LIP FORM: Everted rim and flat lip

CORE COLOR: $\mathrm{G}$ (fired in a reducing environment and cooled in the open air)

INTERIOR SURFACE COLOR: light brownish-gray

EXTERIOR SURFACE COLOR: very dark gray

WALL THICKNESS (RIM, BODY, AND BASE IN MM): 6.6 mm, rim

INTERIOR SURFACE TREATMENT: smoothed on the upper neck

EXTERIOR SURFACE TREATMENT: burnished and smudged 
HEIGHT (IN CM): 16.7

ORIFICE DIAMETER (IN CM): 5.7

DIAMETER AT BOTTOM OF RIM OR NECK (IN CM): $5.3 ; 11.6 \mathrm{~cm}$ wide at the widest part of the bottle body

BASE DIAMETER (IN CM): 7.4

ESTIMATED VOLUME (IN LITERS): 0.49 liters

DECORATION: The bottle body has a horizontal panel across the mid-point of the vessel (Figure A1-52). Within the panel are two engraved semi-circles with spurred outer lines and a single large central engraved spur.

TYPE: unidentified engraved fine ware

Figure A1-52. Engraved bottle (5425-697) from the Battle site.

SITE NAME OR SITE NUMBER: Battle Place

CONTEXT INFORMATION: Excavated by Dan Jenkins in 1927.

ACCESSION NO.: 5425-698

VESSEL NO.: V-103

NON-PLASTICS: grog and bone (less than $5 \%$ of the paste)

VESSEL FORM: Jar

RIM AND LIP FORM: Everted rim and a rounded lip

CORE COLOR: N/A

INTERIOR SURFACE COLOR: pale brown

EXTERIOR SURFACE COLOR: pale brown; fire clouding

WALL THICKNESS (RIM, BODY, AND BASE IN MM): 5.6 mm, rim

INTERIOR SURFACE TREATMENT: smoothed on the rim and the upper body 
EXTERIOR SURFACE TREATMENT: smoothed on the lower body

HEIGHT (IN CM): 16.5

ORIFICE DIAMETER (IN CM): 12.0

DIAMETER AT BOTTOM OF RIM OR NECK (IN CM): 9.7

BASE DIAMETER (IN CM): 8.9

ESTIMATED VOLUME (IN LITERS): 1.78 liters

DECORATION: On the rim there is a single row of tool punctates under the lip. The remainder of the rim has closely-spaced vertical incised lines. The vessel body is divided into five panels by vertical rows of pinching. The panels themselves are filled with triangular opposed brushed areas (Figure A1-53).

TYPE: Pease Brushed-Incised

Figure A1-53. Pease Brushed-Incised jar (5425-698).

SITE NAME OR SITE NUMBER: Battle Place

CONTEXT INFORMATION: From a grave (Burial 2) in Burial Plot 2. Found in association with V-1996 to V-1998, a celt (N-730, not documented in this study), a clay pipe (P-235), and red and black clay pigments.

ACCESSION NO.: 5425-702

VESSEL NO.: V-1995

NON-PLASTICS: fine grog

VESSEL FORM: Bottle with a straight neck

RIM AND LIP FORM: Direct rim and a flat lip

CORE COLOR: B (fired and cooled in a reducing environment)

INTERIOR SURFACE COLOR: black

EXTERIOR SURFACE COLOR: black 
WALL THICKNESS (RIM, BODY, AND BASE IN MM): 6.7 mm, rim

INTERIOR SURFACE TREATMENT: smoothed on the upper neck

EXTERIOR SURFACE TREATMENT: burnished on the neck and body

HEIGHT (IN CM): 21.8

ORIFICE DIAMETER (IN CM): 5.2

DIAMETER AT BOTTOM OF RIM OR NECK (IN CM): 5.9; $15.6 \mathrm{~cm}$ wide at the widest part of the vessel body

BASE DIAMETER (IN CM): 8.3

ESTIMATED VOLUME (IN LITERS): 0.72 liters

DECORATION: The bottle has two horizontal engraved lines at the top and bottom of the vessel body, creating a broad panel. Within the panel are a series of four repeated nested diamond motifs (Figure A1-54). The larger diamond in each motif is defined by narrow cross-hatched engraved bands, a smaller single line diamond element within it, and within that another diamond element defined by narrow cross-hatched engraved bands. Within this central diamond are two cross-hatched engraved lines (Figure A1-54). Outside each nested diamond are a repeating series of large single line engraved triangles pendant from the upper and lower parts of the body panel.

TYPE: unidentified engraved fine ware

Figure A1-54. Engraved bottle (5425-702).

SITE NAME OR SITE NUMBER: Battle Place

CONTEXT INFORMATION: From a grave (Burial 4) in Burial Plot 2 (Martin 1939). Associated with V-2005 in this grave.

ACCESSION NO.: 5425-703

VESSEL NO.: V-2006

NON-PLASTICS: grog

VESSEL FORM: Bottle with four body peaks

RIM AND LIP FORM: Direct rim and a rounded lip 
CORE COLOR: G (fired in a low oxygen environment and cooled in the open air)

INTERIOR SURFACE COLOR: very dark gray

EXTERIOR SURFACE COLOR: strong brown

WALL THICKNESS (RIM, BODY, AND BASE IN MM): 6.7 mm, rim

INTERIOR SURFACE TREATMENT: none

EXTERIOR SURFACE TREATMENT: smoothed on the neck and body

HEIGHT (IN CM): 22.0

ORIFICE DIAMETER (IN CM): 5.0

DIAMETER AT BOTTOM OF RIM OR NECK (IN CM): 6.2; $17.0 \mathrm{~cm}$ wide at the widest part of the vessel body

BASE DIAMETER (IN CM): 8.0

ESTIMATED VOLUME (IN LITERS): 0.70 liters

DECORATION: This bottle has three closely-spaced horizontal engraved lines on the bottle neck, four horizontal engraved lines below the base of the bottle neck (one of which has tick marks), and one horizontal line at the base of the engraved body panel (Figure A1-55).

The body panel has four circular engraved motifs separated by vertical engraved brackets. The circular motif consists of an outer semi-circular line and two smaller circles within it. The smaller central circle has a swastika and cross element that is centered over each body peak (see Figure A1-55). The engraved brackets have two cross-hatched bands, a central short horizontal line dividing the bracket in two, and an engraved triangle pendant from the bottom of the bracket.

TYPE: unidentified engraved fine ware

Figure A1-55. Engraved bottle (5425-703).

SITE NAME OR SITE NUMBER: Battle Place

CONTEXT INFORMATION: From a grave on the Henry Moore (Battle) place. It was plowed-out by Dan Jenkins, 1935. Associated with V-1740. 
ACCESSION NO.: 5425-704

VESSEL NO.: V-1741

NON-PLASTICS: grog and bone (less than $5 \%$ of the paste)

VESSEL FORM: Bottle with a long neck

RIM AND LIP FORM: Direct rim with a rounded lip

CORE COLOR: B (fired and cooled in a low oxygen environment)

INTERIOR SURFACE COLOR: grayish-brown

EXTERIOR SURFACE COLOR: very dark gray

WALL THICKNESS (RIM, BODY, AND BASE IN MM): 4.4 mm, rim

INTERIOR SURFACE TREATMENT: smoothed on the upper neck

EXTERIOR SURFACE TREATMENT: burnished on the neck and body

HEIGHT (IN CM): 22.5

ORIFICE DIAMETER (IN CM): 4.6

DIAMETER AT BOTTOM OF RIM OR NECK (IN CM): 5.6; $13.0 \mathrm{~cm}$ wide at the widest part of the vessel body

BASE DIAMETER (IN CM): N/A, rounded base

ESTIMATED VOLUME (IN LITERS): 0.52

DECORATION: The top of the vessel body has five horizontal engraved lines, along with four sets of six vertical rows of appliqued nodes (Figure A1-56). Below these elements are four sets of concentric engraved semi-circles in a panel that ends near the mid-point of the body; two of the semi-circles form a narrow hatched band. The central and smallest semi-circle has two small engraved dashes within it (Figure A1-56). Underneath the vertical appliqued nodes, and dividing the sets of engraved semi-circles, is a hatched engraved bracket with half of a negative S-shaped area within it.

TYPE: Friendship Engraved

Figure A1-56. Friendship Engraved bottle (5425-704). 
SITE NAME OR SITE NUMBER: Battle Place

CONTEXT INFORMATION: Found in a grave at the south end of the Battle mound in 1938 during the excavation of a storm cellar by Simon Cullins. Associated with V-1946 to V-1949 and V-1951 to V-1952.

ACCESSION NO.: 5425-705

VESSEL NO.: V-1950

NON-PLASTICS: grog; no visible evidence of shell, but shell temper has probably leached out of the paste

VESSEL FORM: Carinated bowl

RIM AND LIP FORM: Everted rim and a rounded lip

CORE COLOR: $\mathrm{G}$ (fired in a reducing environment and cooled in the open air)

INTERIOR SURFACE COLOR: very dark grayish-brown

EXTERIOR SURFACE COLOR: brown

WALL THICKNESS (RIM, BODY, AND BASE IN MM): 4.6 mm, rim; 5.1 mm, body

INTERIOR SURFACE TREATMENT: smoothed on the rim and body

EXTERIOR SURFACE TREATMENT: burnished and floated on the rim and body

HEIGHT (IN CM): 5.5

ORIFICE DIAMETER (IN CM): 11.5

DIAMETER AT BOTTOM OF RIM OR NECK (IN CM): 9.3

BASE DIAMETER (IN CM): N/A, rounded base

ESTIMATED VOLUME (IN LITERS): 0.38 liters

DECORATION: The rim panel is plain. The vessel body has four repeating sets of engraved concentric spirals (Figure A1-57).

TYPE: Natchitoches Engraved, var. unspecified 
Figure A1-57. Natchitoches Engraved, var. unspecified carinated bowl (5425-705).

SITE NAME OR SITE NUMBER: Battle Place

CONTEXT INFORMATION: From a grave (Burial 1) in Burial Plot 1 (Martin 1939). Associated vessels in the grave include V-1978 1/2 to V-1982.

ACCESSION NO.: 5425-706

VESSEL NO.: V-1983

NON-PLASTICS: grog

VESSEL FORM: Carinated bowl with two rim panels

RIM AND LIP FORM: Everted rim with a rounded lip

CORE COLOR: A (fired and cooled in a high oxygen environment)

INTERIOR SURFACE COLOR: pale brown; fire clouds on the rim

EXTERIOR SURFACE COLOR: pale brown; fire cloud on the base

WALL THICKNESS (RIM, BODY, AND BASE IN MM): 3.3 mm, rim

INTERIOR SURFACE TREATMENT: burnished on the rim and body

EXTERIOR SURFACE TREATMENT: burnished on the rim and body

HEIGHT (IN CM): 4.4

ORIFICE DIAMETER (IN CM): 11.8

DIAMETER AT BOTTOM OF RIM OR NECK (IN CM): 9.5

BASE DIAMETER (IN CM): N/A, rounded base

ESTIMATED VOLUME (IN LITERS): 0.31 liters

DECORATION: The upper rim panel has a row of excised punctations under the vessel lip, along with a single horizontal engraved line below the punctations (Figure A1-58). The lower rim panel has four appliqued nodes (that extend from the lower part of the lower panel onto the vessel body) between a repeating simple scroll motif that consists of two sets of four vertical engraved lines and two connecting diagonal lines (Figure A1- 
58). There are excised punctations underneath each of the scrolls and along the vessel carination.

TYPE: Belcher Engraved, var. Belcher

Figure A1-58. Belcher Engraved, var. Belcher carinated bowl (5425-706).

SITE NAME OR SITE NUMBER: Battle Place

CONTEXT INFORMATION: Found in a grave on the Henry Moore (Battle) place, 1926

ACCESSION NO.: 5425-707

VESSEL NO:: V-2

NON-PLASTICS: grog

VESSEL FORM: Bowl with suspension holes; there are two suspension holes $(2 \mathrm{~mm}$ in diameter) on one side, and one (2.5 $\mathrm{mm}$ in diameter) on the other side of the vessel. A second suspension hole was started from the inside of the vessel at the latter location, but the vessel was not perforated.

RIM AND LIP FORM: Direct rim and a flat lip

CORE COLOR: B (fired and cooled in a low oxygen environment)

INTERIOR SURFACE COLOR: dark grayish-brown

EXTERIOR SURFACE COLOR: very dark gray

WALL THICKNESS (RIM, BODY, AND BASE IN MM): 5.5 mm, rim

INTERIOR SURFACE TREATMENT: smoothed on the rim and the upper body

EXTERIOR SURFACE TREATMENT: smoothed only on the base

HEIGHT (IN CM): 5.1

ORIFICE DIAMETER (IN CM): 11.4

DIAMETER AT BOTTOM OF RIM OR NECK (IN CM): 10.9

BASE DIAMETER (IN CM): 8.8 
ESTIMATED VOLUME (IN LITERS): 0.23 liters

DECORATION: Six horizontal rows of closely-spaced appliqued nodes covering the rim and much of the vessel body (Figure A1-59)

TYPE: Moore Noded

Figure A1-59. Moore Noded bowl (5425-707).

SITE NAME OR SITE NUMBER: Battle Place

CONTEXT INFORMATION: From a grave (Burial 1) in Burial Plot 2 (Martin 1939).

Associated vessels in the grave are V-1987 to V-1993.

ACCESSION NO.: 5425-709

VESSEL NO.: V-1994

NON-PLASTICS: bone

VESSEL FORM: Carinated bowl with four rim peaks ( $23 \mathrm{~mm}$ wide and a maximum of 5 $\mathrm{mm}$ in height)

RIM AND LIP FORM: Direct rim and a rounded lip

CORE COLOR: $\mathrm{F}$ (fired in a reducing environment and cooled in the open air)

INTERIOR SURFACE COLOR: strong brown

EXTERIOR SURFACE COLOR: strong brown

WALL THICKNESS (RIM, BODY, AND BASE IN MM): 5.7 mm, rim

INTERIOR SURFACE TREATMENT: burnished on the rim

EXTERIOR SURFACE TREATMENT: burnished on the rim and body

HEIGHT (IN CM): 6.5

ORIFICE DIAMETER (IN CM): 13.6

DIAMETER AT BOTTOM OF RIM OR NECK (IN CM): 13.4

BASE DIAMETER (IN CM): N/A, rounded base 
ESTIMATED VOLUME (IN LITERS): 0.53 liters

DECORATION: The rim panel has a negative horizontal scroll that is repeated twice around the vessel; the scroll filler background is upper and lower horizontal crosshatched engraved bands (Figure A1-60). The two negative scrolls are divided by two vertical cross-hatched hooked arms and two cross-hatched vertical curvilinear engraved lines.

TYPE: Friendship Engraved

Figure A1-60. Friendship Engraved carinated bowl (5425-709) from the Battle site.

SITE NAME OR SITE NUMBER: Battle Place

CONTEXT INFORMATION: Obtained in 1927.

ACCESSION NO.: 5425-712

VESSEL NO.: V-109

NON-PLASTICS: grog

VESSEL FORM: Carinated bowl with two rim panels and two opposed strap handles (6.1 $\mathrm{cm}$ in width)

RIM AND LIP FORM: Everted rim and a rounded, interior beveled, lip

CORE COLOR: B (fired and cooled in a low oxygen environment)

INTERIOR SURFACE COLOR: dark gray

EXTERIOR SURFACE COLOR: dark gray

WALL THICKNESS (RIM, BODY, AND BASE IN MM): 5.8 mm, rim

INTERIOR SURFACE TREATMENT: smoothed on the body and burnished on the rim

EXTERIOR SURFACE TREATMENT: burnished on the rim and the body

HEIGHT (IN CM): 6.3

ORIFICE DIAMETER (IN CM): 15.3 


\section{DIAMETER AT BOTTOM OF RIM OR NECK (IN CM): N/A}

BASE DIAMETER (IN CM): 6.9

ESTIMATED VOLUME (IN LITERS): 0.58 liters

DECORATION: The upper rim panel has four horizontal engraved lines as well as a row of tool punctations between the upper two engraved lines (Figure A1-61a-b). The lower rim panel has a continuous engraved-punctated and spurred scroll repeated twice on the vessel around a centrally place appliqued node and a surrounding engraved-punctated semi-circle. Each scroll also has a single upper and lower engraved bracket (Figure A161a-b).

A white kaolin clay pigment had been rubbed in the engraved lines on both rim panels. Each strap handle has four opposed hatched rectangles and a central appliqued node.

TYPE: Handy Engraved

Figure A-61. Handy Engraved carinated bowl (5425-712): a, photograph; b, drawing by Bobby Gonzalez.

SITE NAME OR SITE NUMBER: Battle Place

CONTEXT INFORMATION: From a grave excavated by Danny Jenkins, 1928.

ACCESSION NO.: 5425-718

VESSEL NO.: V-70

NON-PLASTICS: grog and bone

VESSEL FORM: Miniature jar with four rim peaks and two opposed strap handles

RIM AND LIP FORM: Everted rim and a rounded lip

CORE COLOR: $\mathrm{F}$ (fired in a reducing environment and cooled in the open air)

INTERIOR SURFACE COLOR: strong brown; fire clouds on the rim

EXTERIOR SURFACE COLOR: brown; fire clouds on the body

WALL THICKNESS (RIM, BODY, AND BASE IN MM): 5.0 mm, rim; $5.2 \mathrm{~mm}$, body 
INTERIOR SURFACE TREATMENT: smoothed on the rim and body

EXTERIOR SURFACE TREATMENT: none

HEIGHT (IN CM): 5.0; 6.0 at the top of the rim peaks

ORIFICE DIAMETER (IN CM): 6.6

DIAMETER AT BOTTOM OF RIM OR NECK (IN CM): 6.2

BASE DIAMETER (IN CM): 5.5

ESTIMATED VOLUME (IN LITERS): 0.20 liters

DECORATION: Horizontal brushing on the rim, along with two rows of fingernail punctates, one under the rim and the other at the rim-body juncture (A1-62). The body has four sets of vertical appliqued fillets that extend either from the rim-body juncture or extend from the strap handles down the rim and body. Each set of appliqued fillets is composed of three closely-spaced appliqued fillets. The remainder of the vessel body has vertical brushing marks (Figure A1-62).

TYPE: Unidentified utility ware

Figure A1-62. Brushed-punctated-appliqued jar (5425-718).

SITE NAME OR SITE NUMBER: Battle Place

CONTEXT INFORMATION: Excavated by Dan Jenkins in 1927.

ACCESSION NO.: 5425-720

VESSEL NO.: V-268

NON-PLASTICS: grog and bone (less than $5 \%$ of the paste)

VESSEL FORM: Jar with a pedestal base

RIM AND LIP FORM: Everted rim and a rounded lip

CORE COLOR: B (fired and cooled in a low oxygen environment)

INTERIOR SURFACE COLOR: dark grayish-brown

EXTERIOR SURFACE COLOR: grayish-brown 
WALL THICKNESS (RIM, BODY, AND BASE IN MM): 5.6 mm, rim

INTERIOR SURFACE TREATMENT: smoothed on the rim and body

EXTERIOR SURFACE TREATMENT: smoothed on the pedestal base

HEIGHT (IN CM): 10.0

ORIFICE DIAMETER (IN CM): 10.6

DIAMETER AT BOTTOM OF RIM OR NECK (IN CM): 9.6

BASE DIAMETER (IN CM): 8.4

ESTIMATED VOLUME (IN LITERS): 0.64 liters

DECORATION: The rim has two horizontal rows of tool punctates below the lip as well as four diagonally-oriented tool punctated rows that extend to the rim-body juncture. The upper part of the body has seven horizontal rows of tool punctates above 10 tool punctated chevrons (Figure A1-63). The pedestal base is plain.

TYPE: cf. Sinner Linear Punctated

Figure A1-63. cf. Sinner Linear Punctated jar (5425-720).

SITE NAME OR SITE NUMBER: Battle Place

CONTEXT INFORMATION: Excavated by Dan Jenkins in 1928.

ACCESSION NO.: 5425-721

VESSEL NO.: V-316

NON-PLASTICS: grog

VESSEL FORM: Bowl with attachments for four missing pedestal legs; the attachments indicate the pedestal legs are $23 \mathrm{~mm}$ in diameter.

RIM AND LIP FORM: Inverted rim and a rounded lip

CORE COLOR: $\mathrm{F}$ (fired in a reducing environment and cooled in the open air)

INTERIOR SURFACE COLOR: pale brown 
EXTERIOR SURFACE COLOR: pale brown

WALL THICKNESS (RIM, BODY, AND BASE IN MM): $6.1 \mathrm{~mm}$, rim

INTERIOR SURFACE TREATMENT: smoothed on the body

EXTERIOR SURFACE TREATMENT: none

HEIGHT (IN CM): 5.5

ORIFICE DIAMETER (IN CM): 9.8

DIAMETER AT BOTTOM OF RIM OR NECK (IN CM): N/A

BASE DIAMETER (IN CM): 11.2

ESTIMATED VOLUME (IN LITERS): 0.22 liters

DECORATION: Seven rows of closely-spaced appliqued nodes covering the vessel rim and body (Figure A1-64)

TYPE: Moore Noded

Figure A1-64. Moore Noded bowl (5425-721).

SITE NAME OR SITE NUMBER: Battle Place

CONTEXT INFORMATION: Found in Burial 2, Burial Plot 1, in association with V1984 and V-1985 (Martin 1939).

ACCESSION NO.: 5425-722

VESSEL NO.: V-1986

NON-PLASTICS: grog and bone

VESSEL FORM: Carinated bowl with two rim panels

RIM AND LIP FORM: Everted rim and a rounded lip

CORE COLOR: B (fired and cooled in a reducing environment)

INTERIOR SURFACE COLOR: dark brown 
EXTERIOR SURFACE COLOR: dark brown

WALL THICKNESS (RIM, BODY, AND BASE IN MM): 3.8 mm, rim

INTERIOR SURFACE TREATMENT: burnished on the rim and body

EXTERIOR SURFACE TREATMENT: burnished on the rim and body

HEIGHT (IN CM): 4.9

ORIFICE DIAMETER (IN CM): 10.5

DIAMETER AT BOTTOM OF RIM OR NECK (IN CM): 9.3

BASE DIAMETER (IN CM): 5.0

ESTIMATED VOLUME (IN LITERS): 0.31 liters

DECORATION: The upper rim panel has a single horizontal engraved line under the lip that also has a row of engraved tick marks; there is a second engraved-ticked line at the junction of the upper and lower rim panels (Figure A1-65). The lower rim panel has four appliqued nodes with an engraved and ticked semi-circle around the node. Between each node and engraved semi-circle are six or seven regularly-spaced vertical to near vertical engraved lines (Figure A1-65). A white kaolin clay pigment had been rubbed in the engraved-ticked lines.

TYPE: Belcher Engraved, var. Belcher

Figure A1-65. Belcher Engraved, var. Belcher carinated bowl (5425-722).

SITE NAME OR SITE NUMBER: Battle Place

CONTEXT INFORMATION: Found in a grave on the Henry Moore (Battle) place. Obtained from the manager of an adjoining place about 1921.

ACCESSION NO.: 5425-725

VESSEL NO:: V-479

NON-PLASTICS: grog

VESSEL FORM: Bottle with a spool neck 
RIM AND LIP FORM: Direct to slightly everted rim and a rounded lip

CORE COLOR: B (fired and cooled in a low oxygen environment)

INTERIOR SURFACE COLOR: very dark gray

EXTERIOR SURFACE COLOR: black

WALL THICKNESS (RIM, BODY, AND BASE IN MM): 4.8 mm, rim

INTERIOR SURFACE TREATMENT: smoothed on the upper neck

EXTERIOR SURFACE TREATMENT: burnished on the neck and body

HEIGHT (IN CM): 6.6

ORIFICE DIAMETER (IN CM): 3.2

DIAMETER AT BOTTOM OF RIM OR NECK (IN CM): $6.5 \mathrm{~cm}$ wide at the widest part of the vessel body

BASE DIAMETER (IN CM): 3.5

ESTIMATED VOLUME (IN LITERS): 0.13 liters

DECORATION: The bottle body has a negative engraved meandering scroll repeated four times around the vessel (Figure A1-66a-b). There is a single engraved and ticked meandering line running down the center of the negative scroll. Upper and lower scroll fill elements include hatched triangular areas with negative circles within each of the triangles (Figure A1-66a-b).

TYPE: Hodges Engraved, var. Kelly's Lake

Figure A1-66. Hodges Engraved, var. Kelly's Lake bottle (5425-725): a, photograph; b, drawing by Bobby Gonzalez.

SITE NAME OR SITE NUMBER: Battle Place

CONTEXT INFORMATION: Found in a plowed out grave by Dan Jenkins; associated with Vessels V-1122 to V-1136 and V-159 to V-162.

ACCESSION NO.: $5425-728$

VESSEL NO.: V-1125 
NON-PLASTICS: grog and bone

VESSEL FORM: Globular jar with four body peaks

RIM AND LIP FORM: Direct rim with a rounded and exterior folded lip

CORE COLOR: B (fired and cooled in a low oxygen environment)

INTERIOR SURFACE COLOR: dark grayish-brown

EXTERIOR SURFACE COLOR: dark grayish-brown

WALL THICKNESS (RIM, BODY, AND BASE IN MM): 4.2 mm, rim

INTERIOR SURFACE TREATMENT: smoothed

EXTERIOR SURFACE TREATMENT: burnished on the rim and body

HEIGHT (IN CM): 8.0

ORIFICE DIAMETER (IN CM): 8.2

DIAMETER AT BOTTOM OF RIM OR NECK (IN CM): 7.9

BASE DIAMETER (IN CM): 5.6

ESTIMATED VOLUME (IN LITERS): 0.39 liters

DECORATION: The rim has two rectangular-shaped incised bands filled with stamping; the bands occur between two broad horizontal incised lines at the top and bottom of the rim (Figure A1-67). The vessel body has four incised circles around each of the body peaks, and the circles are filled with stamping. Between each of the stamped-incised circles are four incised hourglass-shaped elements (Figure A1-67); each of these is also filled with stamping.

TYPE: unidentified incised-stamped utility ware

Figure A1-67. Incised-stamped jar (5425-728).

SITE NAME OR SITE NUMBER: Battle Place

CONTEXT INFORMATION: From a grave, 1924. 
ACCESSION NO.: 5425-730

VESSEL NO.: V-188

NON-PLASTICS: grog and bone

VESSEL FORM: Jar with a short (10 mm) collared or raised neck (Figure A1-68a) and four body peaks

RIM AND LIP FORM: Everted rim and a rounded lip

CORE COLOR: $\mathrm{G}$ (fired in a reducing environment and cooled in the open air)

INTERIOR SURFACE COLOR: very dark gray

EXTERIOR SURFACE COLOR: strong brown; fire clouds on body

WALL THICKNESS (RIM, BODY, AND BASE IN MM): 4.3 mm, rim

INTERIOR SURFACE TREATMENT: smoothed on the rim and the upper body

EXTERIOR SURFACE TREATMENT: smoothed on the rim and body

HEIGHT (IN CM): 10.2

ORIFICE DIAMETER (IN CM): 11.8

DIAMETER AT BOTTOM OF RIM OR NECK (IN CM): 10.5

BASE DIAMETER (IN CM): N/A, rounded base

ESTIMATED VOLUME (IN LITERS): 0.72 liters

DECORATION: The short rim has a single raised or collared ridge with a row of tool punctates on it (see Figure A1-68a-b). The body has four repeating sets of trailed concentric circles, with upper and lower triangular trailed elements separating each concentric circle motif (see Figure A1-68a-b).

TYPE: Keno Trailed, var. unspecified, probably var. Scott's Lake based on the vessel form and the punctated rim (cf. Schambach and Miller 1984:Figure 11-26a).

Figure A1-68. Keno Trailed, var. unspecified jar (5425-730): a, photograph; b, drawing by Bobby Gonzalez. 
SITE NAME OR SITE NUMBER: Battle Place

CONTEXT INFORMATION: From a grave found in 1938 at the south end of the Battle mound by Simon Cullins while digging a storm cellar. Associated vessels are V-1946 to V-1948 and V-1950 to V-1952.

ACCESSION NO.: 5425-731

VESSEL NO.: V-1949

NON-PLASTICS: grog and leached shell

VESSEL FORM: Carinated bowl

RIM AND LIP FORM: Everted rim and a rounded lip

CORE COLOR: $\mathrm{G}$ (fired in a reducing environment and cooled in the open air)

INTERIOR SURFACE COLOR: very dark grayish-brown

EXTERIOR SURFACE COLOR: yellowish-brown

WALL THICKNESS (RIM, BODY, AND BASE IN MM): 5.6 mm, rim

INTERIOR SURFACE TREATMENT: smoothed on the rim and body

EXTERIOR SURFACE TREATMENT: smoothed on the rim and body

HEIGHT (IN CM): 5.8

ORIFICE DIAMETER (IN CM): 11.5

DIAMETER AT BOTTOM OF RIM OR NECK (IN CM): 9.4

BASE DIAMETER (IN CM): N/A, rounded base

ESTIMATED VOLUME (IN LITERS): 0.40 liters

DECORATION: The rim is plain. The vessel body has four engraved concentric spirals (Figure A1-69a-b).

TYPE: Natchitoches Engraved, var. unspecified. Vessel V-1950 is a very similar Natchitoches Engraved vessel from the same context (see Figure A1-57).

Figure A1-69. Natchitoches Engraved, var. unspecified carinated bowl (5425-731): a, photograph; b, drawing by Bobby Gonzalez. 
SITE NAME OR SITE NUMBER: Battle Place

CONTEXT INFORMATION: From a grave (Burial 1) in Burial Plot 3 (Martin 1939). Associated with V-2008 to V-2013.

ACCESSION NO.: 5425-732

VESSEL NO.: V-2007

NON-PLASTICS: grog

VESSEL FORM: Carinated bowl with two rim panels

RIM AND LIP FORM: Everted rim and a rounded, exterior folded, lip

CORE COLOR: B (fired and cooled in a low oxygen environment)

INTERIOR SURFACE COLOR: dark grayish-brown

EXTERIOR SURFACE COLOR: dark grayish-brown

WALL THICKNESS (RIM, BODY, AND BASE IN MM): 5.1 mm, rim

INTERIOR SURFACE TREATMENT: smoothed on the rim and body

EXTERIOR SURFACE TREATMENT: burnished on the rim and body

HEIGHT (IN CM): 6.0

ORIFICE DIAMETER (IN CM): 12.5

DIAMETER AT BOTTOM OF RIM OR NECK (IN CM): 12.0

BASE DIAMETER (IN CM): 7.5

ESTIMATED VOLUME (IN LITERS): 0.45 liters

DECORATION: The upper rim panel is plain, while the lower rim panel is delimited by upper and lower horizontal engraved lines (Figure A1-70). The lower rim panel has four appliqued nodes, in sets of two on opposing sides of the vessel and just above the vessel carination. There are a series of engraved pendant triangles on the upper part of the lower panel, one of which separates the sets of two appliqued nodes, as well as engraved semicircles (Figure A1-70). 
TYPE: Belcher Engraved, var. Belcher

Figure A1-70. Belcher Engraved, var. Belcher carinated bowl (5425-732) from the Battle site.

SITE NAME OR SITE NUMBER: Battle Place

CONTEXT INFORMATION: From a grave (Burial 1) in Burial Plot 3 (Martin 1939). Associated with V-2007 to V-2011 and V-2013 in the grave.

ACCESSION NO.: 5425-733

VESSEL NO.: V-2012

NON-PLASTICS: grog

VESSEL FORM: Carinated bowl

RIM AND LIP FORM: Direct rim with a rounded and exterior folded lip

CORE COLOR: B (fired and cooled in a low oxygen environment)

INTERIOR SURFACE COLOR: dark gray to dark grayish-brown; fire clouds on the rim and body

EXTERIOR SURFACE COLOR: dark gray to dark grayish-brown; fire cloud on the base WALL THICKNESS (RIM, BODY, AND BASE IN MM): $5.1 \mathrm{~mm}$, rim

INTERIOR SURFACE TREATMENT: burnished on the rim and body

EXTERIOR SURFACE TREATMENT: burnished on the rim and body

HEIGHT (IN CM): 6.8

ORIFICE DIAMETER (IN CM): 18.4

DIAMETER AT BOTTOM OF RIM OR NECK (IN CM): 17.4

BASE DIAMETER (IN CM): N/A, rounded base

ESTIMATED VOLUME (IN LITERS): 0.75 liters 
DECORATION: The rim has a horizontal interlocking engraved scroll that is repeated twice around the vessel (Figure A1-71). There are also single rows of tool punctates along the rim and at the vessel carination.

The horizontal interlocking scroll has a central hatched band with two upper and lower hatched brackets that extend either to the rim or the vessel carination (see Figure A1-71). Between the upper and lower set of brackets are single horizontally-oriented engraved rectangles. The remainder of the scroll motif consists of upper and lower single hooked arm engraved lines.

The two scrolls are divided by two sets of vertical engraved and hatched brackets that extend from the rim to the vessel carination. Between them is a single verticallyoriented engraved rectangle (see Figure A1-71).

TYPE: Handy Engraved

Figure A1-71. Handy Engraved carinated bowl (5425-733).

SITE NAME OR SITE NUMBER: Battle Place

CONTEXT INFORMATION: Found in 1927.

ACCESSION NO.: 5425-734

VESSEL NO.: V-232

NON-PLASTICS: fine grog

VESSEL FORM: Effigy bowl; opposed bird effigies attached to the lip, both looking outward away from the rim (Figure A1-72)

RIM AND LIP FORM: Direct rim and a rounded lip

CORE COLOR: A (fired and cooled in a high oxygen environment)

INTERIOR SURFACE COLOR: yellowish-brown

EXTERIOR SURFACE COLOR: yellowish-brown

WALL THICKNESS (RIM, BODY, AND BASE IN MM): 6.6 mm, rim

INTERIOR SURFACE TREATMENT: smoothed on the rim and body

EXTERIOR SURFACE TREATMENT: smoothed on the rim and body 
HEIGHT (IN CM): 5.9

ORIFICE DIAMETER (IN CM): 11.6

DIAMETER AT BOTTOM OF RIM OR NECK (IN CM): 10.8

BASE DIAMETER (IN CM): N/A, rounded base

ESTIMATED VOLUME (IN LITERS): 0.27 liters

DECORATION: There are three broad horizontal incised lines encircling the rim and upper body (see Figure A1-72)

TYPE: Unidentified incised effigy vessel

Figure A1-72. Incised effigy bowl (5425-734).

SITE NAME OR SITE NUMBER: Battle Place

CONTEXT INFORMATION: From a plowed out grave, 1934, along with V-1122 through V-1136 and V-159 to V-162.

ACCESSION NO.: 5425-735

VESSEL NO.: V-1126

NON-PLASTICS: grog and bone

VESSEL FORM: Carinated bowl or high rimmed shouldered bowl with two rim panels and with two opposed strap handles

RIM AND LIP FORM: Everted rim with a rounded lip

CORE COLOR: $\mathrm{G}$ (fired in a reducing environment and cooled in the open air)

INTERIOR SURFACE COLOR: dark grayish-brown

EXTERIOR SURFACE COLOR: brown

WALL THICKNESS (RIM, BODY, AND BASE IN MM): 5.9 mm, rim

INTERIOR SURFACE TREATMENT: smoothed on the rim and body 
EXTERIOR SURFACE TREATMENT: smoothed on the rim and body

HEIGHT (IN CM): 7.1

ORIFICE DIAMETER (IN CM): 10.4

DIAMETER AT BOTTOM OF RIM OR NECK (IN CM): 9.2

BASE DIAMETER (IN CM): 6.5

ESTIMATED VOLUME (IN LITERS): 0.59 liters

DECORATION: The lip has regular notching, and the upper rim panel has three horizontal engraved lines; there is a single row of tool punctates between two of the engraved lines (Figure A1-73). The bottom panel has a series of 10 concentric semicircles (as seen on Avery Engraved, var. Bradshaw vessels at the Cedar Grove site, see Schambach and Miller 1984:119 and Figure 11-42a), only one of which has a hatched fill element (Figure A1-73). There is also a row of tool punctations at the vessel carination.

The strap handles have rows of tool punctations around a central appliqued node.

TYPE: cf. Avery Engraved, var. Bradshaw

Figure A1-73. Avery Engraved, var. Bradshaw carinated bowl (5425-735).

SITE NAME OR SITE NUMBER: Battle Place

CONTEXT INFORMATION: From a plowed out grave, 1934, along with V-1122 through V-1136 and V-159 to V-162.

ACCESSION NO.: 5425-736

VESSEL NO.: V-1131

NON-PLASTICS: grog and hematite/ferruginous sandstone

VESSEL FORM: Bowl

RIM AND LIP FORM: Direct rim and a flattened lip with two thickened flanges

CORE COLOR: $\mathrm{F}$ (fired in a reducing environment and cooled in the open air)

INTERIOR SURFACE COLOR: red 
EXTERIOR SURFACE COLOR: red

WALL THICKNESS (RIM, BODY, AND BASE IN MM): $5.6 \mathrm{~mm}$, rim; $5.5 \mathrm{~mm}$, body

INTERIOR SURFACE TREATMENT: smoothed; red slip

EXTERIOR SURFACE TREATMENT: burnished; red slip

HEIGHT (IN CM): 9.5

ORIFICE DIAMETER (IN CM): 17.0

DIAMETER AT BOTTOM OF RIM OR NECK (IN CM): N/A

BASE DIAMETER (IN CM): N/A, rounded base

ESTIMATED VOLUME (IN LITERS): 0.65 liters

DECORATION: The thickened lip flanges have excised teardrop-shaped elements. The rim itself has three horizontal engraved lines that dip below the thickened flange portions of the lip (Figure A1-74).

TYPE: Bowie Engraved

Figure A1-74. Bowie Engraved bowl (5425-736): a, photograph; b, drawing by Bobby Gonzalez.

SITE NAME OR SITE NUMBER: Battle Place

CONTEXT INFORMATION: Found in 1934 a plowed out grave by Dan Jenkins. Associated vessels include V-1122 to V-1136 and V-159 to V-162.

ACCESSION NO.: 5425-737

VESSEL NO.: V-1130

NON-PLASTICS: fine grog and fine bone

VESSEL FORM: Bowl

RIM AND LIP FORM: Direct rim and a flat lip

CORE COLOR: B (fired and cooled in a low oxygen environment) 
INTERIOR SURFACE COLOR: dark gray

EXTERIOR SURFACE COLOR: dark gray

WALL THICKNESS (RIM, BODY, AND BASE IN MM): 5.7 mm, rim

INTERIOR SURFACE TREATMENT: burnished on the rim and upper body

EXTERIOR SURFACE TREATMENT: burnished on the rim and body

HEIGHT (IN CM): 8.0

ORIFICE DIAMETER (IN CM): 11.0

DIAMETER AT BOTTOM OF RIM OR NECK (IN CM): N/A

BASE DIAMETER (IN CM): N/A, rounded base

ESTIMATED VOLUME (IN LITERS): 0.35 liters

DECORATION: There are three horizontal engraved lines that encircle the upper part of the vessel (Figure A1-75)

TYPE: cf. Hardman Engraved, var. Joan (Early 1993:91)

Figure A1-75. cf. Hardman Engraved, var. Joan bowl (5425-737).

SITE NAME OR SITE NUMBER: Battle Place

CONTEXT INFORMATION: From a grave, 1928.

ACCESSION NO.: 5425-738

VESSEL NO.: V-246

NON-PLASTICS: grog and bone (less than 5\% of the paste)

VESSEL FORM: Globular jar

RIM AND LIP FORM: Everted rim with a rounded lip

CORE COLOR: B (fired and cooled in a reducing environment)

INTERIOR SURFACE COLOR: very dark grayish-brown 
EXTERIOR SURFACE COLOR: very dark grayish-brown

WALL THICKNESS (RIM, BODY, AND BASE IN MM): 4.2 mm, rim

INTERIOR SURFACE TREATMENT: smoothed on the rim and body

EXTERIOR SURFACE TREATMENT: burnished on the body outside of the decorative panel

HEIGHT (IN CM): 11.5

ORIFICE DIAMETER (IN CM): 9.5

DIAMETER AT BOTTOM OF RIM OR NECK (IN CM): 10.0

BASE DIAMETER (IN CM): 4.3

ESTIMATED VOLUME (IN LITERS): 0.66 liters

DECORATION: The rim has two broad horizontal incised lines filled with two opposed rows of diagonal incised lines pitched in different directions (Figure A1-76). The midsection of the vessel body has a series of gracefully meandering incised S-shaped scrolls (nine in all) around nine negative circles (Figure A1-76).

TYPE: Mound Tract Incised and Brushed

Figure A1-76. Mound Tract Incised and Brushed jar (5425-738).

SITE NAME OR SITE NUMBER: Battle Place

CONTEXT INFORMATION: From a plowed out grave, 1934, along with V-1122 through V-1136 and V-159 to V-162.

ACCESSION NO.: 5425-740

VESSEL NO:: V-1128

NON-PLASTICS: grog

VESSEL FORM: Jar

RIM AND LIP FORM: Everted rim with a rounded and exterior folded lip 
CORE COLOR: B

INTERIOR SURFACE COLOR: black

EXTERIOR SURFACE COLOR: dark grayish-brown

WALL THICKNESS (RIM, BODY, AND BASE IN MM): 5.8 mm, rim

INTERIOR SURFACE TREATMENT: smoothed on the rim and body

EXTERIOR SURFACE TREATMENT: smoothed on the lower body

HEIGHT (IN CM): 11.0

ORIFICE DIAMETER (IN CM): 8.3

DIAMETER AT BOTTOM OF RIM OR NECK (IN CM): 7.4

BASE DIAMETER (IN CM): 6.1

ESTIMATED VOLUME (IN LITERS): 0.55 liters

DECORATION: The rim is horizontally brushed, with two rows of tool punctations at the rim-body juncture (Figure A1-77). The vessel body has four vertical sets of appliqued fillets, two with three fillets and two with two fillets, that reach nearly to the vessel base. There are a series of vertical incised lines between each set of appliqued fillets (Figure A1-77).

TYPE: Pease Brushed-Incised

Figure A1-77. Pease Brushed-Incised jar (5425-740).

SITE NAME OR SITE NUMBER: Battle Place

CONTEXT INFORMATION: Found in a plowed-up grave with V-1122 to V-1136 and $\mathrm{V}-159$ to $\mathrm{V}-162$.

ACCESSION NO.: 5425-741

VESSEL NO.: V-1124

NON-PLASTICS: grog

VESSEL FORM: Carinated bowl with upper and lower rim panels 
RIM AND LIP FORM: Direct rim with a rounded, exterior folded lip

CORE COLOR: G (fired in a reduced environment, but cooled in the open air)

INTERIOR SURFACE COLOR: very dark gray

EXTERIOR SURFACE COLOR: dark gray

WALL THICKNESS (RIM, BODY, AND BASE IN MM): $6.2 \mathrm{~mm}$, rim; 8.7 mm, body

INTERIOR SURFACE TREATMENT: burnished on the rim and smoothed on the body

EXTERIOR SURFACE TREATMENT: burnished on the rim and body

HEIGHT (IN CM): 7.8

ORIFICE DIAMETER (IN CM): 13.1

DIAMETER AT BOTTOM OF RIM OR NECK (IN CM): 10.5

BASE DIAMETER (IN CM): 5.9

ESTIMATED VOLUME (IN LITERS): 0.61 liters

DECORATION: The upper rim panel has a single row of small excised punctations under the rim as well as three horizontal engraved lines (Figure A1-78a-b). The lower rim panel has two centrally-placed appliqued nodes above the carination, with a hatched engraved half circle around it. Completing the engraved-appliqued motif are opposed vertical cross-hatched and vertical engraved lines (in sets of three) on either side of the engraved half circle and node (Figure A1-78a-b). elements.

There is a white kaolin clay pigment in the engraved and excised punctation

TYPE: Belcher Engraved, var. Belcher

Figure A1-78. Belcher Engraved, var. Belcher vessel (5425-741): a, photograph; b, drawing by Bobby Gonzalez.

SITE NAME OR SITE NUMBER: Battle Place

CONTEXT INFORMATION: From a grave, 1928. 
ACCESSION NO.: 5425-742

VESSEL NO.: V-117

NON-PLASTICS: grog and bone

VESSEL FORM: Jar

RIM AND LIP FORM: Everted rim and a rounded lip

CORE COLOR: $\mathrm{G}$ (fired in a reducing environment and cooled in the open air)

INTERIOR SURFACE COLOR: black

EXTERIOR SURFACE COLOR: yellowish-brown

WALL THICKNESS (RIM, BODY, AND BASE IN MM): 10.2 mm, rim

INTERIOR SURFACE TREATMENT: smoothed on the rim and upper body

EXTERIOR SURFACE TREATMENT: none

HEIGHT (IN CM): 16.0

ORIFICE DIAMETER (IN CM): 16.1

DIAMETER AT BOTTOM OF RIM OR NECK (IN CM): 12.2

BASE DIAMETER (IN CM): 8.6

ESTIMATED VOLUME (IN LITERS): 2.32 liters

DECORATION: The rim is divided into four rectangular panels by vertical appliqued fillets; each panel is filled with opposed incised lines (Figure A1-79). The vessel body is divided into four semi-circular zones by appliqued fillets; at the center of each zone is a appliqued node covered with small punctations (Figure A1-79). Each zone also has circular and curvilinear brushing marks.

TYPE: Haley Complicated Incised

Figure A1-79. Haley Complicated Incised jar (5425-742). 
CONTEXT INFORMATION: From a plowed out grave, 1934, along with V-1122 through V-1136 and V-159 to V-162.

ACCESSION NO.: 5425-743

VESSEL NO.: V-1129

NON-PLASTICS: grog

VESSEL FORM: Carinated bowl

RIM AND LIP FORM: Direct rim with a rounded and exterior folded lip; the lip has a sprocket mode (cf. Miller 1986) and is also notched (Figure A1-80)

CORE COLOR: $\mathrm{G}$ (fired in a reducing environment and cooled in the open air)

INTERIOR SURFACE COLOR: very dark gray

EXTERIOR SURFACE COLOR: brown

WALL THICKNESS (RIM, BODY, AND BASE IN MM): 4.8 mm, rim; 4.8 mm, body; $4.3 \mathrm{~mm}$, base

INTERIOR SURFACE TREATMENT: smoothed on the rim and body; burnished on the lip itself

EXTERIOR SURFACE TREATMENT: smoothed on the body and burnished on the rim HEIGHT (IN CM): 6.0

ORIFICE DIAMETER (IN CM): 17.8

DIAMETER AT BOTTOM OF RIM OR NECK (IN CM): 18.4

BASE DIAMETER (IN CM): 5.8

ESTIMATED VOLUME (IN LITERS): 0.64 liters

DECORATION: The lower part of the rim has an engraved panel filled with a negative scroll repeated four times around the vessel (see Figure A1-80). The negative scrolls are outlined by upper and lower cross-hatched engraved fill or background. Each scroll is divided from the other by sets of vertical excised brackets (see Figure A1-80).

TYPE: Friendship Engraved

Figure A1-80. Friendship Engraved carinated bowl (5425-743) from the Battle site. 
SITE NAME OR SITE NUMBER: Battle Place

CONTEXT INFORMATION: From a grave excavated by Dan Jenkins in April 1929.

ACCESSION NO.: 5425-744

VESSEL NO.: V-365

NON-PLASTICS: bone and grog

VESSEL FORM: Jar with a short $(8.0 \mathrm{~mm})$ rim

RIM AND LIP FORM: Everted rim with a rounded and exterior folded lip

CORE COLOR: B (fired and cooled in a low oxygen environment)

INTERIOR SURFACE COLOR: very dark grayish-brown

EXTERIOR SURFACE COLOR: brown; fire clouds on the body and rim

WALL THICKNESS (RIM, BODY, AND BASE IN MM): $7.0 \mathrm{~mm}$, rim

INTERIOR SURFACE TREATMENT: smoothed on the rim and upper body

EXTERIOR SURFACE TREATMENT: none

HEIGHT (IN CM): 18.7

ORIFICE DIAMETER (IN CM): 10.6

DIAMETER AT BOTTOM OF RIM OR NECK (IN CM): 9.9

BASE DIAMETER (IN CM): 8.1

ESTIMATED VOLUME (IN LITERS): 1.78 liters

DECORATION: The rim has horizontal brushed-incised lines. On the body are a series of very narrow and diagonal appliqued ridges, with diagonal brushing marks between the ridges (Figure A1-81).

TYPE: Belcher Ridged, var. Belcher Ridged

Figure A1-81. Belcher Ridged, var. Belcher Ridged jar (5425-744). 
SITE NAME OR SITE NUMBER: Battle Place

CONTEXT INFORMATION: From a grave excavated in 1927 by Dan Jenkins on the Henry Moore (Battle) place

ACCESSION NO.: 5425-745

VESSEL NO.: V-270

NON-PLASTICS: grog and bone

VESSEL FORM: Jar with a short $(15 \mathrm{~mm})$ rim

RIM AND LIP FORM: Everted rim and a rounded lip

CORE COLOR: B (fired and cooled in a low oxygen environment)

INTERIOR SURFACE COLOR: dark grayish-brown

EXTERIOR SURFACE COLOR: grayish-brown; fire clouds on the body and base

WALL THICKNESS (RIM, BODY, AND BASE IN MM): $5.8 \mathrm{~mm}$, rim

INTERIOR SURFACE TREATMENT: smoothed on the rim and body

EXTERIOR SURFACE TREATMENT: smoothed on the lower body

HEIGHT (IN CM): 16.5

ORIFICE DIAMETER (IN CM): 11.5

DIAMETER AT BOTTOM OF RIM OR NECK (IN CM): 10.0

BASE DIAMETER (IN CM): 8.5

ESTIMATED VOLUME (IN LITERS): 1.71 liters

DECORATION: The short rim has a single row of incised chevrons (Figure A1-82), as well as a single horizontal incised line at the rim-body juncture. The vessel body has 11 closely-packed horizontal rows of diagonal incised lines that are pitched in different directions (Figure A1-82). These rows end a short distance above the vessel base.

TYPE: unidentified incised utility ware 
Figure A1-82. Incised jar (5425-745).

SITE NAME OR SITE NUMBER: Battle Place

CONTEXT INFORMATION: Found in the mound, 1928.

ACCESSION NO.: 5425-746

VESSEL NO.: V-178

NON-PLASTICS: grog and shell

VESSEL FORM: Globular jar with a short (12 mm) rim

RIM AND LIP FORM: Direct rim with a rounded and exterior folded lip

CORE COLOR: $\mathrm{G}$ (fired in a reducing environment and cooled in the open air)

INTERIOR SURFACE COLOR: dark brown to black

EXTERIOR SURFACE COLOR: brown

WALL THICKNESS (RIM, BODY, AND BASE IN MM): 5.0 mm, rim

INTERIOR SURFACE TREATMENT: none

EXTERIOR SURFACE TREATMENT: smoothed on the lower body

HEIGHT (IN CM): 9.5

ORIFICE DIAMETER (IN CM): 9.3

DIAMETER AT BOTTOM OF RIM OR NECK (IN CM): 8.7

BASE DIAMETER (IN CM): 4.5

ESTIMATED VOLUME (IN LITERS): 0.53 liters

DECORATION: The vessel rim has horizontal brushing marks, above a single broad horizontal incised line at the rim-body juncture (Figure A1-83). The body has three stacked sets of connected incised semi-circles, and the area between the top and bottom set is filled with horizontal brushing (Figure A1-83).

TYPE: Mound Tract Incised and Brushed 
Figure A1-83. Mound Tract Incised and Brushed jar (5425-746).

SITE NAME OR SITE NUMBER: Battle Place

CONTEXT INFORMATION: From a grave (Burial 3) in Burial Plot 2 (Martin 1939).

Associated vessels in the grave include V-1999 to V-2004.

ACCESSION NO.: 5425-747

VESSEL NO.: V-2004 1/2

NON-PLASTICS: grog

VESSEL FORM: Jar with two opposed strap handles

RIM AND LIP FORM: Everted rim and a rounded and exterior folded lip

CORE COLOR: B (fired and cooled in a reducing environment)

INTERIOR SURFACE COLOR: very dark grayish-brown

EXTERIOR SURFACE COLOR: very dark grayish-brown

WALL THICKNESS (RIM, BODY, AND BASE IN MM): $4.7 \mathrm{~mm}$, rim

INTERIOR SURFACE TREATMENT: smoothed on the body and rim

EXTERIOR SURFACE TREATMENT: smoothed on the lower body

HEIGHT (IN CM): 18.5

ORIFICE DIAMETER (IN CM): 13.0

DIAMETER AT BOTTOM OF RIM OR NECK (IN CM): 13.0

BASE DIAMETER (IN CM): 8.0

ESTIMATED VOLUME (IN LITERS): 2.16 liters

DECORATION: There are single rows of tool punctates under the vessel lip and at the rim-body juncture. Between these punctated rows are two sets of opposed incised lines divided by a single horizontal incised line (Figure A1-84). The vessel body has four sets of incised concentric circles, with an appliqued node at the center of the concentric 
circles. Furthermore, the concentric incised circles are outlined by half circles of appliqued fillets (Figure A1-84).

The two strap handles both have five vertical rows of appliqued fillets (see Figure A1-84).

TYPE: Haley Complicated Incised

Figure A1-84. Haley Complicated Incised jar (5425-747).

SITE NAME OR SITE NUMBER: Battle Place

CONTEXT INFORMATION: From a grave (Burial 1) in Burial Plot 3 (Martin 1939).

Associated with vessels V-2007 and V-2009 to V-2013.

ACCESSION NO.: 5425-748

VESSEL NO.: V-2008

NON-PLASTICS: grog

VESSEL FORM: Jar

RIM AND LIP FORM: Everted rim and a rounded lip

CORE COLOR: A (fired and cooled in a high oxygen environment)

INTERIOR SURFACE COLOR: light yellowish-brown

EXTERIOR SURFACE COLOR: light yellowish-brown

WALL THICKNESS (RIM, BODY, AND BASE IN MM): 6.5 mm, rim

INTERIOR SURFACE TREATMENT: smoothed on the rim

EXTERIOR SURFACE TREATMENT: none

HEIGHT (IN CM): 13.5

ORIFICE DIAMETER (IN CM): 10.8

DIAMETER AT BOTTOM OF RIM OR NECK (IN CM): 9.3

BASE DIAMETER (IN CM): 5.9 
ESTIMATED VOLUME (IN LITERS): 0.87 liters

DECORATION: The rim has horizontal brushing marks. The body is divided into five panels by vertical rows of appliqued nodes; two rows have four nodes and three rows have three nodes. The panels are filled with opposed brushed zones (Figure A1-85).

TYPE: cf. Pease Brushed-Incised

Figure A1-85. Pease Brushed-Incised jar (5425-748).

SITE NAME OR SITE NUMBER: Battle Place

CONTEXT INFORMATION: Found in a plowed-out grave that was excavated by Dan Jenkins in 1934. The vessel is associated with V-1122 to V-1136 and V-159 to V-162.

ACCESSION NO.: 5425-750

VESSEL NO.: V-1122

NON-PLASTICS: grog; sandy paste

VESSEL FORM: Bottle

RIM AND LIP FORM: Direct rim and a rounded lip

CORE COLOR: $\mathrm{H}$ (fired in a reducing environment and cooled in the open air)

INTERIOR SURFACE COLOR: pale brown

EXTERIOR SURFACE COLOR: very dark gray

WALL THICKNESS (RIM, BODY, AND BASE IN MM): 3.9 mm, rim; 5.3 mm, midneck

INTERIOR SURFACE TREATMENT: smoothed on the upper neck

EXTERIOR SURFACE TREATMENT: burnished on the neck and body

HEIGHT (IN CM): 16.5

ORIFICE DIAMETER (IN CM): 4.0 
DIAMETER AT BOTTOM OF RIM OR NECK (IN CM): 5.0; $11.8 \mathrm{~cm}$ wide at the widest part of the vessel body

BASE DIAMETER (IN CM): 5.6

ESTIMATED VOLUME (IN LITERS): 0.37 liters

DECORATION: There are three horizontal engraved lines on the bottle neck near the rim; the lowermost engraved line has small attached tick marks (Figure A1-86). Near the top of the vessel body is a horizontal engraved band filled with five rectangular zones of cross-hatched engraved lines. Below this is a series of five alternating and connected large and small engraved semi-circles; the large semi-circles are also connected by narrow curvilinear cross-hatched bands (Figure A1-86).

TYPE: cf. Friendship Engraved

Figure A1-86. cf. Friendship Engraved bottle (5425-750).

SITE NAME OR SITE NUMBER: Battle Place

ACCESSION NO.: 5425-751

CONTEXT INFORMTION: Found in a plowed-up grave by Dan Jenkins in 1934, together with V-1122 to V-1136 and V-159 to V-162.

VESSEL NO.: V-1132

NON-PLASTICS: grog

VESSEL FORM: Bottle

RIM AND LIP FORM: Direct rim with a rounded and exterior folded lip

CORE COLOR: $\mathrm{G}$ (fired in a reducing environment and cooled in the open air)

INTERIOR SURFACE COLOR: dark grayish-brown

EXTERIOR SURFACE COLOR: brown

WALL THICKNESS (RIM, BODY, AND BASE IN MM): 4.7 mm, rim

INTERIOR SURFACE TREATMENT: smoothed on the rim

EXTERIOR SURFACE TREATMENT: burnished on the neck and body 
HEIGHT (IN CM): 19.0; neck height, $6.5 \mathrm{~cm}$

ORIFICE DIAMETER (IN CM): 3.9

DIAMETER AT BOTTOM OF RIM OR NECK (IN CM): $4.5 ; 15.5 \mathrm{~cm}$ wide at the widest point on the vessel body

BASE DIAMETER (IN CM): N/A, rounded base

ESTIMATED VOLUME (IN LITERS): 0.40 liters

DECORATION: The top of the bottle body has six horizontal engraved lines that are bisected by three sets of three vertical appliqued ridges (cf. Suhm and Jelks 1962:Plate 23o-p). A white kaolin clay pigment had been rubbed in the engraved lines (Figure A187a-b). A similar Friendship Engraved bottle has been documented from a burial at the Wm. Handy Place (see Figure A2-9, below).

The lower part of the body has three sets of narrow concentric engraved zones, each partially filled with hatched or cross-hatched areas; one of the two concentric engraved zones in each set has a cross-hatched element that closely resembles the decoration seen on the bodies of engraved canebrake rattlesnake Caddo bottles (Walters 2006). The lower concentric element encircles three short vertical appliqued ridges (see Figure A1-87a-b). On either side of the central engraved-appliqued motifs on the lower body are three rectilinear cross-hatched engraved zones with negative ovals and triangles.

TYPE: Friendship Engraved

Figure A1-87. Friendship Engraved bottle (5425-751): a, photograph; b, drawing by Bobby Gonzalez.

SITE NAME OR SITE NUMBER: Battle Place

CONTEXT INFORMATION: This vessel, along with 18 other vessels, came from a grave exposed in June 1934 during plowing by Dan Jenkins from his potato patch. The other vessels found include V-1123 to V-1136 as well as sherds from four vessels (V-159 to $\mathrm{V}-162$ ). According to Mr. Jenkins, some of the vessels were found around the head of the individual, with the remainder at the feet.

ACCESSION NO.: 5425-752

VESSEL NO.: V-1133

NON-PLASTICS: grog 
VESSEL FORM: Bottle with a narrow neck

RIM AND LIP FORM: Direct rim and a rounded lip

CORE COLOR: B (fired and cooled in a low oxygen environment)

INTERIOR SURFACE COLOR: dark grayish-brown

EXTERIOR SURFACE COLOR: dark grayish-brown

WALL THICKNESS (RIM, BODY, AND BASE IN MM): 4.9 mm, rim

INTERIOR SURFACE TREATMENT: smoothed on the upper neck

EXTERIOR SURFACE TREATMENT: burnished on the neck and body

HEIGHT (IN CM): 21.0

ORIFICE DIAMETER (IN CM): 4.3

DIAMETER AT BOTTOM OF RIM OR NECK (IN CM): 4.2; $15.5 \mathrm{~cm}$ wide at the widest point on the vessel body

BASE DIAMETER (IN CM): N/A, rounded base

ESTIMATED VOLUME (IN LITERS): 0.50 liters

DECORATION: The top of the bottle body has six horizontal engraved lines that are bisected by three sets of three vertical appliqued ridges (Figure A1-88); one set is not as long as the others. A similar Friendship Engraved bottle has been documented from a burial at the Wm. Handy Place (see Figure A2-9, below).

The lower part of the body has three sets of narrow concentric engraved zones underneath the upper body appliqued ridges, each partially filled with hatched or crosshatched areas; one of the two concentric engraved zones in each set has a cross-hatched element that closely resembles the decoration seen on the bodies of engraved canebrake rattlesnake Caddo bottles (Walters 2006). The lower concentric element encircles three short vertical appliqued ridges (see Figure A1-88). On either side of the central engravedappliqued motifs on the lower body are three rectilinear cross-hatched engraved zones with either negative ovals or negative S-shaped areas.

TYPE: Friendship Engraved

Figure A1-88. Friendship Engraved bottle (5425-752). 
SITE NAME OR SITE NUMBER: Battle Place

CONTEXT INFORMATION: This vessel, along with 18 other vessels, came from a grave exposed in June 1934 during plowing by Dan Jenkins from his potato patch. The other vessels found include V-1123 to V-1136 as well as sherds from four vessels (V-159 to $\mathrm{V}-162)$. According to Mr. Jenkins, some of the vessels were found around the head of the individual, with the remainder at the feet.

ACCESSION NO.: 5425-753

VESSEL NO.: V-1122

NON-PLASTICS: grog

VESSEL FORM: Bottle

RIM AND LIP FORM: Direct rim and a flat lip

CORE COLOR: B (fired and cooled in a low oxygen environment)

INTERIOR SURFACE COLOR: very dark gray

EXTERIOR SURFACE COLOR: very dark gray

WALL THICKNESS (RIM, BODY, AND BASE IN MM): 5.4 mm, rim

INTERIOR SURFACE TREATMENT: none

EXTERIOR SURFACE TREATMENT: burnished on the neck and body

HEIGHT (IN CM): 14.5

ORIFICE DIAMETER (IN CM): 3.9

DIAMETER AT BOTTOM OF RIM OR NECK (IN CM): $4.1 ; 10.3 \mathrm{~cm}$ wide at the widest part of the vessel body

BASE DIAMETER (IN CM): N/A, rounded base

ESTIMATED VOLUME (IN LITERS): 0.30 liters

DECORATION: There are two horizontal engraved lines at the top of the bottle neck; the lower line has small downward-pointing triangular tick marks (Figure A1-89). The upper part of the vessel body is divided into three panels by three sets of vertical appliqued ridges. The panels contain three horizontal cross-hatched bands. On the lower body, there 
are also three panels defined by sets of vertical appliqued ridges, but in the latter case, the appliqued ridges lie at the center of the panel, and the outside edges of the panel (immediately below the vertical appliqued ridges on the upper body) are defined by engraved brackets with four triangular hatched corners (Figure A1-89). Inside each bracket is another smaller bracket, turned horizontal, also with four triangular hatched corners. Between the central appliqued ridges and the engraved brackets are two opposed sets of two curvilinear cross-hatched engraved bands (Figure A1-89).

TYPE: Friendship Engraved

Figure A1-89. Friendship Engraved bottle (5425-753).

SITE NAME OR SITE NUMBER: Battle Place

CONTEXT INFORMATION: Obtained in 1928.

ACCESSION NO.: 5425-754

VESSEL NO.: V-221

NON-PLASTICS: grog and bone

VESSEL FORM: Bottle

RIM AND LIP FORM: Direct rim with a flat lip

CORE COLOR: B (fired and cooled in a low oxygen environment)

INTERIOR SURFACE COLOR: very dark gray

EXTERIOR SURFACE COLOR: very dark gray

WALL THICKNESS (RIM, BODY, AND BASE IN MM): 4.5 mm, rim

INTERIOR SURFACE TREATMENT: none

EXTERIOR SURFACE TREATMENT: smoothed on the neck and body; fire clouds on the body

HEIGHT (IN CM): 13.0; $4.0 \mathrm{~cm}$ bottle neck height

ORIFICE DIAMETER (IN CM): 3.7 
DIAMETER AT BOTTOM OF RIM OR NECK (IN CM): 4.5; $9.4 \mathrm{~cm}$ wide at the widest part of the vessel body

BASE DIAMETER (IN CM): 6.9

ESTIMATED VOLUME (IN LITERS): 0.36 liters

DECORATION: This bottle has three horizontal engraved lines below the base of the bottle neck. On the body is a vertical engraved scroll motif with an embedded concentric circle; this motif is repeated three times on the vessel (Figure A1-90). There are also single curvilinear and ticked engraved lines on either side of the embedded concentric circles as well as hatched triangle elements.

TYPE: Haley Engraved

Figure A1-90. Haley Engraved bottle (5425-754) from the Battle site.

SITE NAME OR SITE NUMBER: Battle Place

CONTEXT INFORMATION: From a grave (Burial 2) in Burial Plot 2 (Martin 1939). Associated vessels in the grave are V-1995 to V-1997.

ACCESSION NO.: 5425-756

VESSEL NO.: V-1998

NON-PLASTICS: grog and bone (less than 5\% in the paste)

VESSEL FORM: Bottle

RIM AND LIP FORM: Direct rim with a rounded and exterior folded lip

CORE COLOR: $\mathrm{G}$ (fired in a reducing environment and cooled in the open air)

INTERIOR SURFACE COLOR: dark grayish-brown

EXTERIOR SURFACE COLOR: strong brown

WALL THICKNESS (RIM, BODY, AND BASE IN MM): 6.4 mm, rim

INTERIOR SURFACE TREATMENT: smoothed on the upper neck

EXTERIOR SURFACE TREATMENT: smoothed in patches on the neck and vessel body 
HEIGHT (IN CM): 19.5

ORIFICE DIAMETER (IN CM): 5.4

DIAMETER AT BOTTOM OF RIM OR NECK (IN CM): $5.8 ; 13.5 \mathrm{~cm}$ wide at the widest part of the vessel body

BASE DIAMETER (IN CM): 7.5

ESTIMATED VOLUME (IN LITERS): 0.59 liters

DECORATION: At the top of the vessel body is a narrow engraved panel with eight hatched brackets. The remainder of the vessel body has an elaborate vertical hooked arm scroll motif enclosed in rectangular panels delimited by vertical engraved lines on the sides, and negative ovals (between 3-5 negative ovals per panel) on the side of the panel opposite the hooked scroll (Figure A1-91a-b). These negative ovals are outlined by punctate-filled brackets.

The hooked arm scroll includes a central engraved line with a hook at one end as well as a second hooked arm that is comprised of several fine engraved lines and hatched spurs or small pendant triangles (see Figure A1-91a-b). At the center of the hooked arm scroll is a small hourglass-shaped element with hatched corners; this element is attached to a vertical excised band that is joined to a second cross-hatched and excised curvilinear zone that parallels the second hooked arm (see Figure A1-91a-b). At its base is an open area with a single engraved half circle.

TYPE: Haley Engraved

Figure A1-91. Haley Engraved bottle (5425-756): a, photograph; b, drawing by Bobby Gonzalez.

SITE NAME OR SITE NUMBER: Battle Place

CONTEXT INFORMATION: Plowed up by Danny Jenkins in 1922.

ACCESSION NO.: 5425-757

VESSEL NO.: V-76

NON-PLASTICS: grog-bone

VESSEL FORM: Bottle with a short neck 
RIM AND LIP FORM: Direct rim and a flat lip

CORE COLOR: B (fired and cooled in a reducing environment)

INTERIOR SURFACE COLOR: very dark gray

EXTERIOR SURFACE COLOR: very dark gray

WALL THICKNESS (RIM, BODY, AND BASE IN MM): 6.3 mm, rim

INTERIOR SURFACE TREATMENT: smoothed on the neck

EXTERIOR SURFACE TREATMENT: burnished on the rim and body

HEIGHT (IN CM): 13.5; $3.2 \mathrm{~cm}$ bottle neck height

ORIFICE DIAMETER (IN CM): 4.7

DIAMETER AT BOTTOM OF RIM OR NECK (IN CM): $4.8 ; 8.8 \mathrm{~cm}$ wide at the widest point on the vessel body

BASE DIAMETER (IN CM): 6.8

ESTIMATED VOLUME (IN LITERS): 0.37 liters

DECORATION: The bottle neck has three horizontal engraved lines below the lip, and there are two horizontal engraved lines near the vessel base. The vessel body has two rectangular engraved panels filled with a hooked arm scroll motif (Figure A1-92a-b). The sides of each panel are defined by five fine and closely-spaced vertical engraved lines, with spurs on the two outside lines (Figure A1-92a-b).

The hooked arm scroll motif in each panel includes two opposed hooked arms (consisting of multiple fine engraved lines) connected by two free-flowing curvilinear lines (see Figure A1-92a-b). At the top of each panel are a cross-hatched pendant triangle and a curvilinear zone with a single centrally-placed cross-hatched bracket. A companion element is also noted at the bottom of each panel, along with two small half circles.

TYPE: Haley Engraved

Figure A1-92. Haley Engraved bottle (5425-757): a, photograph; b, drawing by Bobby Gonzalez. 
CONTEXT INFORMATION: From a grave (Burial 1) in Burial Plot 3 (Martin 1939).

Associated in the grave with V-2007, V-2008, and V-2010 to V-2013.

ACCESSION NO.: 5425-759

VESSEL NO.: V-2009

NON-PLASTICS: grog

VESSEL FORM: Bottle with a globular body

RIM AND LIP FORM: Direct rim and a rounded lip

CORE COLOR: $\mathrm{F}$ (fired in a reducing environment and cooled in the open air)

INTERIOR SURFACE COLOR: strong brown

EXTERIOR SURFACE COLOR: strong brown

WALL THICKNESS (RIM, BODY, AND BASE IN MM): 5.4 mm, rim

INTERIOR SURFACE TREATMENT: smoothed on the upper neck

EXTERIOR SURFACE TREATMENT: smoothed on the body and neck

HEIGHT (IN CM): 19.8

ORIFICE DIAMETER (IN CM): 4.9

DIAMETER AT BOTTOM OF RIM OR NECK (IN CM): 4.8; $11.3 \mathrm{~cm}$ wide at its widest point on the vessel body

BASE DIAMETER (IN CM): 9.5

ESTIMATED VOLUME (IN LITERS): 0.75 liters

DECORATION: The top and bottom of the vessel body have either two or three horizontal engraved lines. The remainder of the body has a series of three engraved concentric circles and hatched vertical panels (Figure A1-93). Each concentric circle is different: the first has four concentric circles, the outer two forming a narrow hatched band and the inner two having small pendant half circles; the second has two concentric circles, the outer engraved circle having small pendant half circles; and the third has three concentric circles, with the inner two circles having small pendant circles (Figure A1-93).

TYPE: cf. Handy Engraved 
Figure A1-93. cf. Handy Engraved bottle (5425-759).

SITE NAME OR SITE NUMBER: Battle Place

CONTEXT INFORMATION: From a grave, 1928.

ACCESSION NO.: 5425-760

VESSEL NO.: V-51

NON-PLASTICS: grog and bone (less than 5\% of the paste)

VESSEL FORM: Bottle

RIM AND LIP FORM: Direct rim and a flat lip

CORE COLOR: B (fired and cooled in a low oxygen environment)

INTERIOR SURFACE COLOR: grayish-brown

EXTERIOR SURFACE COLOR: grayish-brown and very dark gray

WALL THICKNESS (RIM, BODY, AND BASE IN MM): 4.8 mm, rim

INTERIOR SURFACE TREATMENT: smoothed on the upper neck

EXTERIOR SURFACE TREATMENT: smoothed on the neck and body

HEIGHT (IN CM): 16.9

ORIFICE DIAMETER (IN CM): 4.5

DIAMETER AT BOTTOM OF RIM OR NECK (IN CM): 5.1

BASE DIAMETER (IN CM): N/A, rounded base

ESTIMATED VOLUME (IN LITERS): 0.44 liters

DECORATION: The top of the bottle body has four horizontal engraved lines that are bisected by three sets of two vertical appliqued ridges (Figure A1-94).

The lower part of the body has three sets of narrow concentric engraved half circles underneath the upper body appliqued ridges, one of which is partially filled with hatched or cross-hatched areas. The inner concentric element encircles two short vertical 
appliqued ridges (see Figure A1-94). On either side of the central engraved-appliqued motifs on the lower body are curvilinear excised zones with upward-pointing excised spurs.

TYPE: Friendship Engraved

Figure A1-94. Friendship Engraved bottle (5425-760).

SITE NAME OR SITE NUMBER: Battle Place

CONTEXT INFORMATION: Plowed into and excavated by Dan Jenkins in June 1935, along with V-1243 to V-1245 and pipe P-157. They came from a hill behind Mr. Jenkin's house.

ACCESSION NO.: 5425-761

VESSEL NO.: V-1242

NON-PLASTICS: fine grog

VESSEL FORM: Carinated bowl with two rim panels

RIM AND LIP FORM: Direct rim with a rounded and exterior folded lip

CORE COLOR: $\mathrm{G}$ (fired in a reducing environment and cooled in the open air)

INTERIOR SURFACE COLOR: very dark gray

EXTERIOR SURFACE COLOR: light brown

WALL THICKNESS (RIM, BODY, AND BASE IN MM): 3.8 mm, rim

INTERIOR SURFACE TREATMENT: burnished on the rim

EXTERIOR SURFACE TREATMENT: burnished on the rim

HEIGHT (IN CM): 8.2

ORIFICE DIAMETER (IN CM): 11.2

DIAMETER AT BOTTOM OF RIM OR NECK (IN CM): 11.0

BASE DIAMETER (IN CM): 4.8 
ESTIMATED VOLUME (IN LITERS): 0.55 liters

DECORATION: The decoration on this vessel appears to be a stacked combination of Means Engraved and Glassell motifs; similar vessel/design stacking has been noted on other Caddo vessels (cf. Suhm and Jelks 1962:105 and Plate 53h). The upper rim panel (the Means Engraved design) has three horizontal rows of ticked engraved lines (Figure A1-95a-b). The lower panel (the Glassell Engraved design) has four negative scrolls outlined by upper and lower hatched fill elements and broad excised brackets; there are small punctations on either side of the vertical brackets (Figure A1-95a-b).

TYPE: cf. Glassell Engraved

Figure A1-95. Glassell Engraved carinated bowl (5425-761): a, photograph; b, drawing by Bobby Gonzalez.

SITE NAME OR SITE NUMBER: Battle Place

CONTEXT INFORMATION: Obtained in 1923.

ACCESSION NO.: 5425-762

VESSEL NO.: V-165

NON-PLASTICS: bone, grog, and hematite/ferruginous sandstone (less than $1 \%$ of the paste)

VESSEL FORM: Jar

RIM AND LIP FORM: Direct rim and a rounded lip

CORE COLOR: $\mathrm{G}$ (fired in a reducing environment and cooled in the open air)

INTERIOR SURFACE COLOR: gray

EXTERIOR SURFACE COLOR: very pale brown; fire clouds on the rim, body, and base

WALL THICKNESS (RIM, BODY, AND BASE IN MM): $5.1 \mathrm{~mm}$, rim

INTERIOR SURFACE TREATMENT: smoothed on the rim and upper body

EXTERIOR SURFACE TREATMENT: none

HEIGHT (IN CM): 10.1 
ORIFICE DIAMETER (IN CM): 10.2

DIAMETER AT BOTTOM OF RIM OR NECK (IN CM): 9.4

BASE DIAMETER (IN CM): 6.3

ESTIMATED VOLUME (IN LITERS): 0.62 liters

DECORATION: The rim has two closely-spaced horizontal incised lines under the lip, followed by a panel filled with diagonal incised lines, and below that, three rows of linear tool punctates (Figure A1-96). The body is divided into four panels by vertical rows (five lines within each row) of tool punctates. The panels are each filled with tool-punctated chevrons.

TYPE: cf. Sinner Linear Punctated

Figure A1-96. Sinner Linear Punctated jar (5425-762).

SITE NAME OR SITE NUMBER: Battle Place

CONTEXT INFORMATION: This vessel was found in one of the mounds at the Battle site, sometime before 1932; which mound is not known, although apparently it was not the large primary Battle mound.

ACCESSION NO.: 5425-1391

VESSEL NO.: V-1014

NON-PLASTICS: grog

VESSEL FORM: Bottle with a long neck

RIM AND LIP FORM: Direct rim and a rounded lip

CORE COLOR: $\mathrm{H}$ (fired in a reducing environment and cooled in the open air)

INTERIOR SURFACE COLOR: strong brown

EXTERIOR SURFACE COLOR: dark grayish-brown

WALL THICKNESS (RIM, BODY, AND BASE IN MM): 6.2 mm, rim

INTERIOR SURFACE TREATMENT: smoothed on the rim 
EXTERIOR SURFACE TREATMENT: smoothed on the rim and body

HEIGHT (IN CM): 19.0

ORIFICE DIAMETER (IN CM): 3.9

DIAMETER AT BOTTOM OF RIM OR NECK (IN CM): $4.8 ; 12.0 \mathrm{~cm}$ wide at the widest point on the vessel body

BASE DIAMETER (IN CM): 6.6

ESTIMATED VOLUME (IN LITERS): 0.50 liters

DECORATION: This bottle has an unusual design of two panels set off by diagonal grooves that begin at the top of the vessel body and extend almost to the base (Figure A197a-b). There are also a series of horizontal engraved lines at the top of the vessel body.

The first engraved body panel has two parts divided by a central diagonal engraved band and an intersecting central horizontal engraved band. Each part has half circles with spurs, ovals, and hatched brackets (see Figure A1-97a-b). The second panel is divided by a scroll with spurs with an embedded, spurred, circle. On the upper left hand side of the panel is a small rectangular area (with spurs along the outside of the rectangle) filled with hooked engraved lines, cross-hatched bands, excised brackets, and hatched half circles. The lower right hand side of the panel has a corresponding small rectangular area, but it has half circles, small circles, and cross-hatched brackets (see Figure A1-97a-b).

TYPE: Haley Engraved

Figure A1-97. Haley Engraved bottle (5425-1391): a, photograph; b, drawing by Bobby Gonzalez.

SITE NAME OR SITE NUMBER: Battle Place

ACCESSION NO.: 5425-2431A

CONTEXT INFORMATION: Found in Burial 1, Burial Plot 1, in 1938, along with V1978 1/2 and V-1980 to V-1983.

VESSEL NO.: V-1979

NON-PLASTICS: grog 
VESSEL FORM: Jar

RIM AND LIP FORM: Everted rim and a rounded lip

CORE COLOR: B (fired and cooled in a low oxygen environment)

INTERIOR SURFACE COLOR: grayish-brown

EXTERIOR SURFACE COLOR: grayish-brown

WALL THICKNESS (RIM, BODY, AND BASE IN MM): 5.4 mm, rim; 4.8 mm, body

INTERIOR SURFACE TREATMENT: smoothed on the rim

EXTERIOR SURFACE TREATMENT: smoothed on the base

HEIGHT (IN CM): 7.9

ORIFICE DIAMETER (IN CM): 9.2

DIAMETER AT BOTTOM OF RIM OR NECK (IN CM): 7.1

BASE DIAMETER (IN CM): 4.6

ESTIMATED VOLUME (IN LITERS): 0.44 liters

DECORATION: The rim has four horizontal incised lines that separate three rows of short diagonal incised lines (Figure A1-98); there is a row of tool punctates under the vessel lip. The vessel body has three sets of concentric trailed circles, each with a cluster of three appliqued nodes at the center of the concentric circles (Figure A1-98).

TYPE: Foster Trailed-Incised, var. Red Lake

Figure A1-98. Foster Trailed-Incised, var. Red Lake jar (5425-2431A).

SITE NAME OR SITE NUMBER: Battle Place

CONTEXT INFORMATION: From a grave (Burial 3) in Burial Plot 2 (Martin 1939). Associated vessels include V-1999 to V-2003 and V-2004 1/2.

ACCESSION NO.: 5425-2438

VESSEL NO.: V-2004 
NON-PLASTICS: grog

VESSEL FORM: Bottle

RIM AND LIP FORM: N/A (95\% of neck is missing)

CORE COLOR: B (fired and cooled in a reducing environment)

INTERIOR SURFACE COLOR: black

EXTERIOR SURFACE COLOR: black

WALL THICKNESS (RIM, BODY, AND BASE IN MM): $5.3 \mathrm{~mm}$, neck; $4.7 \mathrm{~mm}$, body

INTERIOR SURFACE TREATMENT: none

EXTERIOR SURFACE TREATMENT: burnished on the body

HEIGHT (IN CM): 7.8 (bottle body height)

ORIFICE DIAMETER (IN CM): 4.8

DIAMETER AT BOTTOM OF RIM OR NECK (IN CM): 4.8; $9.5 \mathrm{~cm}$ wide at the widest part of the vessel body

BASE DIAMETER (IN CM): 7.3

ESTIMATED VOLUME (IN LITERS): 0.16 liters

DECORATION: The body is divided into three rectangular engraved panels by fine vertical engraved lines with spurs (Figure A1-99). Within the panel is a single set of engraved and ticked concentric circles, and the outer concentric circle is attached to horizontal and diagonal engraved lines and narrow hatched bands. There is a similar set of vertical engraved lines and narrow hatched bands on the bottom half of each panel (Figure A1-99).

TYPE: cf. Haley Engraved

Figure A1-99. Haley Engraved bottle (5425-2438).

SITE NAME OR SITE NUMBER: Battle Place 
CONTEXT INFORMATION: This vessel was found in Burial 1, Burial Plot 2 (Martin 1939), in association with V-1988 to V-1994.

ACCESSION NO.: 5425-2441

VESSEL NO.: V-1987

NON-PLASTICS: grog

VESSEL FORM: Jar

RIM AND LIP FORM: Direct rim with a rounded and exterior folded lip

CORE COLOR: A (fired and cooled in an oxidizing environment)

INTERIOR SURFACE COLOR: brown

EXTERIOR SURFACE COLOR: brown

WALL THICKNESS (RIM, BODY, AND BASE IN MM): 6.6 mm, rim

INTERIOR SURFACE TREATMENT: smoothed on the rim and upper body

EXTERIOR SURFACE TREATMENT: smoothed on the lower body

HEIGHT (IN CM): 14.5

ORIFICE DIAMETER (IN CM): 13.4

DIAMETER AT BOTTOM OF RIM OR NECK (IN CM): 12.2

BASE DIAMETER (IN CM): 9.5

ESTIMATED VOLUME (IN LITERS): 1.17 liters

DECORATION: There are single rows of tool punctates under the lip and at the rim-body juncture. Between these punctated rows are horizontal and diagonal brushing marks and appliqued nodes: three sets of two nodes (one above the other) and one set with one lower node (Figure A1-100). The vessel body is covered with opposed brushing marks.

TYPE: unidentified brushed-appliqued-punctated utility ware

Figure A1-100. Brushed-appliqued-punctated jar (5425-2441). 
SITE NAME OR SITE NUMBER: Battle Place

ACCESSION NO.: 5425-2453

CONTEXT INFORMATION: Found in a grave, in association with V-1781, on the west side of a low platform at the north end of the Battle Mound in 1938, by Perry Marshall. This grave was encountered when Mr. Marshall was digging in the mound to obtain dirt for a chimney.

VESSEL NO.: V-1782

NON-PLASTICS: grog; sandy paste

VESSEL FORM: Carinated bowl with two rim panels

RIM AND LIP FORM: Everted rim and a rounded lip

CORE COLOR: B (fired and cooled in a low oxygen environment)

INTERIOR SURFACE COLOR: black

EXTERIOR SURFACE COLOR: black

WALL THICKNESS (RIM, BODY, AND BASE IN MM): 4.5 mm, rim; $5.3 \mathrm{~mm}$, body

INTERIOR SURFACE TREATMENT: smoothed on the body and burnished on the rim

EXTERIOR SURFACE TREATMENT: burnished on the rim and body

HEIGHT (IN CM): 6.5

ORIFICE DIAMETER (IN CM): 15.6

DIAMETER AT BOTTOM OF RIM OR NECK (IN CM): 13.1

BASE DIAMETER (IN CM): 5.4

ESTIMATED VOLUME (IN LITERS): 0.61 liters

DECORATION: The upper rim panel has a row of excised punctations under the lip as well as a single central horizontal engraved line. The lower panel has two distinctive engraved motifs. The first, delimited by two sets of three diagonal engraved lines and an upper horizontal engraved line, has a ticked curvilinear scroll, with a row of tick marks along the upper horizontal line (Figure A1-101). The second motif has the same sets of three diagonal engraved lines at either end, with the featured elements including four 
diagonal dashed lines and four diagonal lines with upper and lower hatched triangles (Figure A1-101).

A white kaolin clay pigment had been rubbed in the engraved lines.

TYPE: Belcher Engraved, var. Owen

Figure A1-101. Belcher Engraved, var. Owen carinated bowl (5425-2453).

SITE NAME OR SITE NUMBER: Battle Place

CONTEXT INFORMATION: Found in a grave, in association with V-1782, on the west side of a low platform at the north end of the Battle Mound in 1938, by Perry Marshall. This grave was encountered when Mr. Marshall was digging in the mound to obtain dirt for a chimney.

ACCESSION NO.: 5425-2454

VESSEL NO.: V-1781

NON-PLASTICS: grog and bone

VESSEL FORM: Carinated bowl with two rim panels

RIM AND LIP FORM: Direct rim and a rounded lip

CORE COLOR: B (fired and cooled in a reducing environment)

INTERIOR SURFACE COLOR: black

EXTERIOR SURFACE COLOR: black

WALL THICKNESS (RIM, BODY, AND BASE IN MM): 5.1 mm, rim; $5.1 \mathrm{~mm}$, body; $6.2 \mathrm{~mm}$, base

INTERIOR SURFACE TREATMENT: burnished on the rim and body

EXTERIOR SURFACE TREATMENT: burnished on the rim and body

HEIGHT (IN CM): 7.1

ORIFICE DIAMETER (IN CM): 17.0

DIAMETER AT BOTTOM OF RIM OR NECK (IN CM): 13.8 
BASE DIAMETER (IN CM): N/A, rounded base

ESTIMATED VOLUME (IN LITERS): 0.72 liters

DECORATION: The upper rim panel has a row of excised punctations under the lip as well as a single central horizontal engraved line. The lower panel has an engraved motif that is repeated four times (Figure A1-102). It includes two sets of four vertical engraved lines that separates the repeated motif, followed by two diagonal engraved lines, tick marks along the carination under these diagonal lines, and a central element of opposed sets of four short diagonal engraved lines (Figure A1-102).

A white kaolin clay pigment had been rubbed in the engraved lines.

TYPE: Belcher Engraved, var. Owen

Figure A1-102. Belcher Engraved, var. Owen carinated bowl (5425-2454) from the Battle site.

SITE NAME OR SITE NUMBER: Battle Place

CONTEXT INFORMATION: From a grave found at the south end of the Battle mound by Simon Cullins in 1938 during digging of a storm cellar. Associated vessels are V-1946 to $\mathrm{V}-1951$.

ACCESSION NO.: 5425-2460, 2461B, 2461C, and 2464

VESSEL NO.: V-1952

NON-PLASTICS: grog and bone

VESSEL FORM: Bottle, with a possible spool neck

RIM AND LIP FORM: Direct rim with a flat lip

CORE COLOR: B (fired and cooled in a low oxygen environment)

INTERIOR SURFACE COLOR: black

EXTERIOR SURFACE COLOR: black

WALL THICKNESS (RIM, BODY, AND BASE IN MM): 5.6 mm, rim; 5.0 mm, body 
INTERIOR SURFACE TREATMENT: none

EXTERIOR SURFACE TREATMENT: smoothed on the body and neck

HEIGHT (IN CM): N/A

ORIFICE DIAMETER (IN CM): N/A

DIAMETER AT BOTTOM OF RIM OR NECK (IN CM): N/A

BASE DIAMETER (IN CM): N/A

ESTIMATED VOLUME (IN LITERS): N/A

DECORATION: The body of this vessel has four sets of trailed concentric half circles below a series of four trailed triangular elements whose apex intersects the central concentric half circle (Figure A1-103a-b). The uppermost trailed triangular element is filled with tool punctates.

TYPE: Keno Trailed, var. unspecified

Figure A1-103. Keno Trailed, var. unspecified bottle (5425-2460/2464): a, neck and upper body; b, body sherds.

SITE NAME OR SITE NUMBER: Battle Place

CONTEXT INFORMATION: From a grave found at the south end of the Battle mound by Simon Cullins in 1938 during digging of a storm cellar. Associated vessels are V-1946 to $\mathrm{V}-1951$.

ACCESSION NO.: 5425-2461A

VESSEL NO.: N/A (found together in the Gilcrease Museum collections with the Keno Trailed bottle, 5425-2460/2464)

NON-PLASTICS: grog

VESSEL FORM: Jar

RIM AND LIP FORM: Everted rim and a rounded lip

CORE COLOR: B (fired and cooled in a low oxygen environment)

INTERIOR SURFACE COLOR: very dark gray 
EXTERIOR SURFACE COLOR: very dark gray

WALL THICKNESS (RIM, BODY, AND BASE IN MM): 4.7 mm, rim; 5.2 mm, body

INTERIOR SURFACE TREATMENT: smoothed on the rim and body

EXTERIOR SURFACE TREATMENT: none

HEIGHT (IN CM): N/A

ORIFICE DIAMETER (IN CM): 17.0

DIAMETER AT BOTTOM OF RIM OR NECK (IN CM): N/A

BASE DIAMETER (IN CM): N/A

ESTIMATED VOLUME (IN LITERS): N/A

DECORATION: This vessel is lip notched (Figure A1-104). It also has opposing sets of trailed triangles on the rim and vertical trailed lines on the upper part of the body. The complete motif is not known on this vessel because it is only represented by a few sherds.

TYPE: Keno Trailed vessel, possibly related to Keno Trailed, var. Phillips (Schambach and Miller 1984:123).

Figure A1-104. Keno Trailed jar (5425-2461A).

SITE NAME OR SITE NUMBER: Battle Place

CONTEXT INFORMATION: From a grave excavated by Dan Jenkins in 1928.

ACCESSION NO :: 5425-2470

VESSEL NO.: V-197

NON-PLASTICS: bone

VESSEL FORM: Jar

RIM AND LIP FORM: Direct rim with a rounded and exterior folded lip

CORE COLOR: B (fired and cooled in a low oxygen environment) 
INTERIOR SURFACE COLOR: very dark gray

EXTERIOR SURFACE COLOR: very dark gray

WALL THICKNESS (RIM, BODY, AND BASE IN MM): $5.1 \mathrm{~mm}$, rim; $4.8 \mathrm{~mm}$, body; $7.0 \mathrm{~mm}$, base

INTERIOR SURFACE TREATMENT: burnished on the rim and body

EXTERIOR SURFACE TREATMENT: smoothed on the body

HEIGHT (IN CM): 13.3

ORIFICE DIAMETER (IN CM): 12.1

DIAMETER AT BOTTOM OF RIM OR NECK (IN CM): 9.3

BASE DIAMETER (IN CM): 5.7

ESTIMATED VOLUME (IN LITERS): 0.97 liters

DECORATION: The rim has two narrow panels of opposed incised lines, as well as a broad incised line at the rim-body juncture (Figure A1-105, right). The vessel body has broad incised scrolls filled with stamping (Figure A1-105, left).

TYPE: Cowhide Stamped

Figure A1-105. Cowhide Stamped jar sherds (5425-2470).

SITE NAME OR SITE NUMBER: Battle Place

CONTEXT INFORMATION: From a grave found at the south end of the Battle mound in 1938 by Simon Cullins during digging of a storm cellar. Associated vessels are V-1946 to V-1950 and V-1952.

ACCESSION NO.: 5425-2646

VESSEL NO.: V-1951

NON-PLASTICS: grog

VESSEL FORM: Carinated bowl with a flanged rim and two small strap handles RIM AND LIP FORM: Direct rim and a rounded lip 
CORE COLOR: B (fired and cooled in a reducing environment)

INTERIOR SURFACE COLOR: very dark gray

EXTERIOR SURFACE COLOR: very dark gray

WALL THICKNESS (RIM, BODY, AND BASE IN MM): $5.1 \mathrm{~mm}$, rim; $4.8 \mathrm{~mm}$, body

INTERIOR SURFACE TREATMENT: burnished on the rim and smoothed on the body

EXTERIOR SURFACE TREATMENT: burnished on the rim and body

HEIGHT (IN CM): N/A

ORIFICE DIAMETER (IN CM): 19.0

DIAMETER AT BOTTOM OF RIM OR NECK (IN CM): 19.3

BASE DIAMETER (IN CM): N/A

ESTIMATED VOLUME (IN LITERS): N/A

DECORATION: There is a row of punctations under the lip as well as two horizontal engraved lines on the rim panel (Figure A1-106); there is also a row of tick marks at the vessel carination. There are a series of widely-spaced diagonal engraved lines in groups of three on the lower part of the rim panel; the two outer diagonals have small tick marks. Each of the series of diagonal engraved lines on the lower rim are either separated by the two strap handles or by two sets of four closely-spaced engraved lines on either side of two appliqued nodes (Figure A1-106).

The two strap handles both have a large central appliqued node with surrounding tick marks, as well as nine vertical engraved lines with small tick marks.

TYPE: Belcher Engraved, var. Belcher

Figure A1-106. Belcher Engraved, var. Belcher carinated bowl (5425-2646) rim sherds. 


\section{Appendix 2,}

\section{Vessels from the Wm. Handy Place at the Battle Site (3LA1)}

SITE NAME OR SITE NUMBER: Wm. Handy Place

CONTEXT INFORMATION: From a grave (Burial C) in a cemetery excavated in 1940

by Glenn Martin. Associated vessels in the grave are V-2098, V-2099, and V-2101.

ACCESSION NO.: 5425-680

VESSEL NO.: V-2100

NON-PLASTICS: grog

VESSEL FORM: Jar with a short (10 mm) rim

RIM AND LIP FORM: Everted rim with a rounded lip

CORE COLOR: A (fired and cooled in a high oxygen environment)

INTERIOR SURFACE COLOR: strong brown

EXTERIOR SURFACE COLOR: strong brown, with fire clouding

WALL THICKNESS (RIM, BODY, AND BASE IN MM): 4.3 mm, rim

INTERIOR SURFACE TREATMENT: smoothed on the rim and body

EXTERIOR SURFACE TREATMENT: none

HEIGHT (IN CM): 9.0

ORIFICE DIAMETER (IN CM): 9.5

DIAMETER AT BOTTOM OF RIM OR NECK (IN CM): 8.7

BASE DIAMETER (IN CM): 5.8

ESTIMATED VOLUME (IN LITERS): 0.51 liters

DECORATION: The rim is plain, except for a horizontal row of tool punctates at the rim-body juncture. The body has vertical brushed-incised lines that end well above the vessel base (Figure A2-1).

TYPE: Karnack Brushed-Incised, var. Karnack 
Figure A2-1. Karnack Brushed-Incised, var. Karnack jar (5425-680).

SITE NAME OR SITE NUMBER: Wm. Handy Place

CONTEXT INFORMATION: From a grave (Burial E) in a cemetery excavated by W. Gamel Smith in the fall of 1941. Associated funerary objects include V-2338 to V-2340 and a jasper arrow point of unknown form and type.

ACCESSION NO.: 5425-682

VESSEL NO.: V-2341

NON-PLASTICS: grog

VESSEL FORM: Bowl

RIM AND LIP FORM: Inverted rim with a rounded lip

CORE COLOR: $\mathrm{G}$ (fired in a reducing environment and cooled in the open air)

INTERIOR SURFACE COLOR: black

EXTERIOR SURFACE COLOR: brown

WALL THICKNESS (RIM, BODY, AND BASE IN MM): $5.5 \mathrm{~mm}$, rim

INTERIOR SURFACE TREATMENT: smoothed

EXTERIOR SURFACE TREATMENT: none

HEIGHT (IN CM): 8.8

ORIFICE DIAMETER (IN CM): 13.1

DIAMETER AT BOTTOM OF RIM OR NECK (IN CM): N/A

BASE DIAMETER (IN CM): 7.4

ESTIMATED VOLUME (IN LITERS): 0.46 liters

DECORATION: There are six rows of large appliqued nodes that completely cover the rim and much of the vessel body (Figure A2-2); the lower body is plain. 
TYPE: Moore Noded

Figure A2-2. Moore Noded bowl from the Wm. Handy Place (5425-682)

SITE NAME OR SITE NUMBER: Wm. Handy Place

CONTEXT INFORMATION: From a grave (Burial E) in a cemetery excavated by W. Gamel Smith in the fall of 1941. Associated funerary objects include V-2338, 2339, and 2341 and a jasper arrow point.

ACCESSION NO.: 5425-692

VESSEL NO.: V-2340

NON-PLASTICS: grog-bone

VESSEL FORM: Jar with two opposed strap handles (30 mm in width)

RIM AND LIP FORM: Everted with a rounded lip

CORE COLOR: $\mathrm{G}$ (fired in a reducing environment and cooled in the open air)

INTERIOR SURFACE COLOR: very dark gray

EXTERIOR SURFACE COLOR: light yellowish-brown

WALL THICKNESS (RIM, BODY, AND BASE IN MM): 5.2 mm, rim

INTERIOR SURFACE TREATMENT: smoothed on the rim and body

EXTERIOR SURFACE TREATMENT: none

HEIGHT (IN CM): 10.5

ORIFICE DIAMETER (IN CM): 12.3

DIAMETER AT BOTTOM OF RIM OR NECK (IN CM): 9.7

BASE DIAMETER (IN CM): 7.8

ESTIMATED VOLUME (IN LITERS): 0.77 liters

DECORATION: The rim has single rows of tool punctations, one row under the lip and the other at the rim-body juncture. Horizontal brushing fills the area between the tool 
punctated rows, along with two opposed appliqued nodes in the central part of the rim (Figure A2-3). The strap handles have opposed and overlapping brushed marks on them.

The vessel body has a series of nine appliqued chevrons that extend from the rimbody juncture to near the base. The area defined by each of the appliqued chevrons is filled with opposed brushing; eight of the appliqued chevron areas also has a small centrally placed appliqued node (see Figure A2-3).

TYPE: Haley Complicated Incised

Figure A2-3. Haley Complicated Incised jar (5425-692).

SITE NAME OR SITE NUMBER: Wm. Handy Place

CONTEXT INFORMATION: From a grave (or graves) in a cemetery excavated by Horace McLendon in the fall of 1941. Associated vessels (from several graves dug at that time) include V-2342 to V-2365.

ACCESSION NO.: 5425-701

VESSEL NO.: V-2348

NON-PLASTICS: grog

VESSEL FORM: Jar with opposed strap handles

RIM AND LIP FORM: Everted rim with a flat and exterior folded lip

CORE COLOR: $\mathrm{G}$ (fired in a reducing environment and cooled in the open air)

INTERIOR SURFACE COLOR: dark gray with patches of pinkish gray

EXTERIOR SURFACE COLOR: pinkish gray with patches of dark gray

WALL THICKNESS (RIM, BODY, AND BASE IN MM): 5.0 mm, rim

INTERIOR SURFACE TREATMENT: smoothed

EXTERIOR SURFACE TREATMENT: none

HEIGHT (IN CM): 15.7

ORIFICE DIAMETER (IN CM): 15.2 


\section{DIAMETER AT BOTTOM OF RIM OR NECK (IN CM): 11.5}

BASE DIAMETER (IN CM): 8.6

ESTIMATED VOLUME (IN LITERS): 1.43 liters

DECORATION: The rim has horizontal brushed-incised lines, and the lip is notched. The strap handles have seven closely-spaced and vertical appliqued ridges on them (Figure A2-4).

The body of this jar has four chevrons defined by appliqued fillets; the apex of two of the appliqued chevrons is underneath the strap handles. At the center of each chevron is a large appliqued node. The remainder of the vessel body, including the area within each of the chevrons, has opposed brushed-incised marks (see Figure A2-4).

TYPE: Haley Complicated Incised

Figure A2-4. Haley Complicated Incised jar (5425-701).

SITE NAME OR SITE NUMBER: Wm. Handy Place

CONTEXT INFORMATION: From a burial (an adult) in a cemetery, excavated by Guy W. Stacy in 1941. This vessel was found in association with V-2258 to V-2263.

ACCESSION NO.: 5425-749

VESSEL NO.: V-2261

NON-PLASTICS: grog; sandy paste

VESSEL FORM: Bottle

RIM AND LIP FORM: Direct rim with a rounded but exterior folded lip

CORE COLOR: A (fired and cooled in a high oxygen environment)

INTERIOR SURFACE COLOR: strong brown

EXTERIOR SURFACE COLOR: strong brown, with fire clouds on the body

WALL THICKNESS (RIM, BODY, AND BASE IN MM): 5.2 mm, rim

INTERIOR SURFACE TREATMENT: smoothed on the upper neck 
EXTERIOR SURFACE TREATMENT: smoothed on the neck and body

HEIGHT (IN CM): 17.0

ORIFICE DIAMETER (IN CM): 3.9

DIAMETER AT BOTTOM OF RIM OR NECK (IN CM): $4.7 ; 10.3 \mathrm{~cm}$ in width at its widest point on the body

BASE DIAMETER (IN CM): 6.4

ESTIMATED VOLUME (IN LITERS): 0.44 liters

DECORATION: Set between upper and lower sets of horizontal and curvilinear engraved lines (below the base of the bottle neck and just above the vessel base), the bottle body has an engraved continuous scroll with three circle elements along the scroll (Figure A25). Both the scroll and circle elements have the characteristic spurred lines of the Haley Engraved type. There are also upper and lower sets (three each) of excised pendant triangles on upper and lower horizontal engraved lines that encircle the vessel.

TYPE: Haley Engraved

Figure A2-5. Haley Engraved bottle (5425-749).

SITE NAME OR SITE NUMBER: Wm. Handy Place

CONTEXT INFORMATION: From a grave (Burial 2) in a cemetery excavated by

Robert Shelton or Pete Miroir in 1940. Associated vessels include V-2040 and V-2042 to V-2044.

ACCESSION NO.: 5425-2021

VESSEL NO.: V-2041

NON-PLASTICS: grog

VESSEL FORM: Bowl with a small globular body; vessel has a cut-down rim

RIM AND LIP FORM: Direct rim with a flat cut-down lip

CORE COLOR: B (fired and cooled in a low oxygen environment)

INTERIOR SURFACE COLOR: very dark gray, with fire clouds 
EXTERIOR SURFACE COLOR: very dark gray, with fire clouds

WALL THICKNESS (RIM, BODY, AND BASE IN MM): 3.4 mm, rim

INTERIOR SURFACE TREATMENT: burnished on the rim and body

EXTERIOR SURFACE TREATMENT: burnished on the rim and body

HEIGHT (IN CM): 10.5

ORIFICE DIAMETER (IN CM): 11.4

DIAMETER AT BOTTOM OF RIM OR NECK (IN CM): 11.0

BASE DIAMETER (IN CM): N/A, rounded base

ESTIMATED VOLUME (IN LITERS): 0.96 liters

DECORATION: The vessel has four vertical engraved panels filled with narrow sets of curvilinear and vertical engraved zones that have small punctates within each of the zones (Figure A2-6). The panels are separated from each other by one or two vertical engraved lines. At the bottom of each vertical panel is a continuous series of negative ovals defined by excising: the number of negative ovals ranges from six to eight in the four panels

TYPE: Handy Engraved

Figure A2-6. Handy Engraved bowl (5425-2021).

SITE NAME OR SITE NUMBER: Wm. Handy Place

CONTEXT INFORMATION: From a grave in a cemetery excavated by Horace McLendon in the fall of 1941. Associated vessels (from several graves dug at that time) include V-2342 to V-2365.

ACCESSION NO.: 5425-2022

VESSEL NO.: V-2344

NON-PLASTICS: fine grog

VESSEL FORM: Bottle with a flaring neck

RIM AND LIP FORM: Direct rim with a flaring neck 
CORE COLOR: B (fired and cooled in a reducing environment)

INTERIOR SURFACE COLOR: very dark gray

EXTERIOR SURFACE COLOR: very dark gray

WALL THICKNESS (RIM, BODY, AND BASE IN MM): 5.4 mm, neck

INTERIOR SURFACE TREATMENT: smoothed on the upper neck

EXTERIOR SURFACE TREATMENT: burnished

HEIGHT (IN CM): 22.0

ORIFICE DIAMETER (IN CM): 4.8

DIAMETER AT BOTTOM OF RIM OR NECK (IN CM): $4.1 ; 18.0 \mathrm{~cm}$ in width at the widest part of the body

BASE DIAMETER (IN CM): 6.7

ESTIMATED VOLUME (IN LITERS): 0.59 liters

DECORATION: The vessel body has a circular engraved motif that is repeated four times. The motif consists of alternating circular engraved lines (three lines) or circular dashed lines (two lines), and each motif shares part of one of the circular dashed lines (Figure A2-7a-b). Suspended from the top of the bottle body are four repeating triangular elements with hatched lines in each corner of the triangle; these elements are set above the area where the larger circular motifs merge and help to divide the circular engraved motifs.

TYPE: Belcher Engraved, var. Ogden

Figure A2-7. Belcher Engraved, var. Ogden bottle (5425-2022): a, photograph; b, drawing by Bobby Gonzalez.

SITE NAME OR SITE NUMBER: Wm. Handy Place

CONTEXT INFORMATION: From a grave (Burial A) in a cemetery excavated in 1940 by Glenn Martin or Robert Shelton. Associated vessels in the grave are V-2090 and V2091.

ACCESSION NO.: 5425-2023 
VESSEL NO.: V-2089

NON-PLASTICS: grog

VESSEL FORM: Carinated bowl

RIM AND LIP FORM: Inverted rim with a rounded and exterior folded lip

CORE COLOR: B (fired and cooled in a low oxygen environment)

INTERIOR SURFACE COLOR: black

EXTERIOR SURFACE COLOR: black

WALL THICKNESS (RIM, BODY, AND BASE IN MM): $5.5 \mathrm{~mm}$, rim

INTERIOR SURFACE TREATMENT: smoothed on the rim and body

EXTERIOR SURFACE TREATMENT: burnished on the rim and body

HEIGHT (IN CM): 8.9

ORIFICE DIAMETER (IN CM): 10.0

DIAMETER AT BOTTOM OF RIM OR NECK (IN CM): 13.2

BASE DIAMETER (IN CM): 7.8

ESTIMATED VOLUME (IN LITERS): 0.53 liters

DECORATION: The rim has four engraved panels defined by upper and lower horizontal engraved lines (both have fine tick marks) and sets of three vertical engraved lines, the last of which also has fine tick marks. Within the panels themselves are seven semicircular lines that have fine tick marks on them (Figure A2-8a-b).

TYPE: Means Engraved

Figure A2-8. Means Engraved carinated bowl (5425-2023): a, photograph; b, drawing by Bobby Gonzalez.

SITE NAME OR SITE NUMBER: Wm. Handy Place 
CONTEXT INFORMATION: From a grave in a cemetery excavated by Horace McLendon in the fall of 1941. Associated vessels (from several graves dug at that time) include V-2342 to V-2365.

ACCESSION NO:: 5425-2024

VESSEL NO.: V-2343

NON-PLASTICS: grog

VESSEL FORM: Bottle with a straight neck

RIM AND LIP FORM: Direct rim and a rounded lip

CORE COLOR: B (fired and cooled in a low oxygen environment)

INTERIOR SURFACE COLOR: dark grayish-brown

EXTERIOR SURFACE COLOR: very dark grayish-brown

WALL THICKNESS (RIM, BODY, AND BASE IN MM): 4.8 mm, rim

INTERIOR SURFACE TREATMENT: smoothed on the upper neck

EXTERIOR SURFACE TREATMENT: burnished on the neck and body

HEIGHT (IN CM): 18.0

ORIFICE DIAMETER (IN CM): 4.2

DIAMETER AT BOTTOM OF RIM OR NECK (IN CM): $4.9 ; 14.0 \mathrm{~cm}$ in width at the widest part of the vessel body

BASE DIAMETER (IN CM): N/A, rounded base

ESTIMATED VOLUME (IN LITERS): est. 0.57 liters

DECORATION: The top of the bottle body has six horizontal engraved lines that are bisected by three sets of three vertical appliqued ridges (cf. Suhm and Jelks 1962:Plate 23o-p). A white kaolin clay pigment had been rubbed in the engraved lines (Figure A29).

The lower part of the body has three sets of narrow concentric engraved zones, each partially filled with hatched or cross-hatched areas; one of the two concentric engraved zones in each set has a cross-hatched element that closely resembles the decoration seen on the bodies of engraved canebrake rattlesnake Caddo bottles (Walters 
2006). The lower concentric element encircles three short vertical appliqued ridges (see Figure A2-9). On either side of the central engraved-appliqued motifs on the lower body are three rectilinear cross-hatched engraved zones with negative ovals and triangles.

TYPE: Friendship Engraved

Figure A2-9. Friendship Engraved bottle (5425-2024) from the Wm. Handy Place.

SITE NAME OR SITE NUMBER: Wm. Handy Place

CONTEXT INFORMATION: From a burial (an adult) in a cemetery, excavated by Guy W. Stacy in 1941. This vessel was found in association with V-2258 to V-2263.

ACCESSION NO.: 5425-2025

VESSEL NO.: V-2258

NON-PLASTICS: grog

VESSEL FORM: Carinated bowl with two rim panels

RIM AND LIP FORM: Everted rim with a rounded and exterior folded lip

CORE COLOR: B (fired and cooled in a low oxygen environment)

INTERIOR SURFACE COLOR: black

EXTERIOR SURFACE COLOR: black

WALL THICKNESS (RIM, BODY, AND BASE IN MM): $5.1 \mathrm{~mm}$, rim

INTERIOR SURFACE TREATMENT: burnished on the rim and smoothed on the body

EXTERIOR SURFACE TREATMENT: burnished on the rim and the body

HEIGHT (IN CM): 9.2

ORIFICE DIAMETER (IN CM): 20.1

DIAMETER AT BOTTOM OF RIM OR NECK (IN CM): 17.8

BASE DIAMETER (IN CM): 8.8

ESTIMATED VOLUME (IN LITERS): 1.11 liters 
DECORATION: The upper rim panel has two horizontal engraved lines (Figure A2-10). The lower rim panel has an engraved scroll motif repeated four times on the vessel. The elements of the motif include central semi-circular lines and narrow hatched semicircular zones connected with each other by a narrow hatched diagonal scroll line with alternating excised spurs on it.

TYPE: Unidentified engraved fine ware vessel, cf. Haley Engraved

Figure A2-10. Engraved carinated bowl (5425-2025).

SITE NAME OR SITE NUMBER: Wm. Handy Place

CONTEXT INFORMATION: From a grave in a cemetery excavated by Horace McLendon in the fall of 1941. Associated vessels (from several graves dug at that time) include V-2342 to V-2365.

ACCESSION NO:: 5425-2026

VESSEL NO.: V-2346

NON-PLASTICS: grog

VESSEL FORM: Bottle with a straight neck

RIM AND LIP FORM: Direct rim and a rounded, exterior folded lip

CORE COLOR: A (fired and cooled in a high oxygen environment)

INTERIOR SURFACE COLOR: light brown

EXTERIOR SURFACE COLOR: light brown, with very dark gray fire clouds on the neck

WALL THICKNESS (RIM, BODY, AND BASE IN MM): 3.9 mm, rim

INTERIOR SURFACE TREATMENT: smoothed on the upper neck

EXTERIOR SURFACE TREATMENT: burnished on the neck and body

HEIGHT (IN CM): 22.0

ORIFICE DIAMETER (IN CM): 4.9 
DIAMETER AT BOTTOM OF RIM OR NECK (IN CM): 4.9; $14.8 \mathrm{~cm}$ in width at the widest part of the body

BASE DIAMETER (IN CM): 8.1

ESTIMATED VOLUME (IN LITERS): 0.71 liters

DECORATION: The bottle has a single horizontal engraved line on the body (Figure A2$11)$.

TYPE: Unidentified engraved fine ware bottle

Figure A2-11. Engraved bottle (5425-2026).

SITE NAME OR SITE NUMBER: Wm. Handy Place

CONTEXT INFORMATION: From a grave (Burial 1) excavated in 1940 by Robert Shelton on the Handy Place, a 40 acre tract of land owned by Wm. Handy. The grave, and others, was situated on a ridge a short distance from the Handy cabin. This vessel is associated with V-2031 to V-2039. Burial 1 is an adult, extended on its back, with its head to the south.

ACCESSION NO.: 5425-2027A

VESSEL NO.: V-2030

NON-PLASTICS: grog

VESSEL FORM: Carinated bowl with a dimpled base and two rim panels

RIM AND LIP FORM: Everted rim with a rounded lip

CORE COLOR: B (fired and cooled in a low oxygen environment)

INTERIOR SURFACE COLOR: dark gray; fire clouds on the rim and body

EXTERIOR SURFACE COLOR: dark gray; fire clouds on the rim and body

WALL THICKNESS (RIM, BODY, AND BASE IN MM): 4.8 mm, rim; $4.4 \mathrm{~mm}$, body; $4.1 \mathrm{~mm}$, base

INTERIOR SURFACE TREATMENT: burnished on the rim and body

EXTERIOR SURFACE TREATMENT: burnished on the rim and body 
HEIGHT (IN CM): 7.4

ORIFICE DIAMETER (IN CM): 21.6

DIAMETER AT BOTTOM OF RIM OR NECK (IN CM): 20.8

BASE DIAMETER (IN CM): 4.0

ESTIMATED VOLUME (IN LITERS): 0.96 liters

DECORATION: The upper rim panel has a line of excised punctations below the lip and above a single horizontal engraved line (Figure A2-12). The lower rim panel-defined by an upper horizontal engraved line and a lower line of excised punctations-includes a central appliqued node, two sets of four opposed diagonal engraved lines on either side of the appliqued node, and two scroll lines on either side of the diagonal engraved lines element (Figure A2-12). These two scroll lines are repeated four times on the lower panel, once for each of the four central appliqued nodes

TYPE: Belcher Engraved, var. Belcher

Figure A2-12. Belcher Engraved, var. Belcher carinated bowl (5425-2027A).

SITE NAME OR SITE NUMBER: Wm. Handy Place

CONTEXT INFORMATION: From a burial (an adult) in a cemetery, excavated by Guy W. Stacy in 1941. This vessel was found in association with V-2258 to V-2263.

ACCESSION NO.: 5425-2028

VESSEL NO.: V-2257

NON-PLASTICS: grog

VESSEL FORM: Bottle with a straight to slightly flared neck (Figure A2-13)

RIM AND LIP FORM: Direct rim with a rounded lip

CORE COLOR: N/D

INTERIOR SURFACE COLOR: red

EXTERIOR SURFACE COLOR: red 
WALL THICKNESS (RIM, BODY, AND BASE IN MM): 3.7 mm, rim

INTERIOR SURFACE TREATMENT: none

EXTERIOR SURFACE TREATMENT: smoothed on the body; eroded red slip

HEIGHT (IN CM): 18.5

ORIFICE DIAMETER (IN CM): 4.3

DIAMETER AT BOTTOM OF RIM OR NECK (IN CM): 4.4; $13.0 \mathrm{~cm}$ at the widest point at the body

BASE DIAMETER (IN CM): 8.2

ESTIMATED VOLUME (IN LITERS): 0.61 liters

DECORATION: The exterior surface has a red slip

TYPE: Unidentified fine ware bottle, cf. Smithport Plain (Webb 1959:139)

Figure A2-13. Plain red-slipped bottle (5425-2028).

SITE NAME OR SITE NUMBER: Wm. Handy Place

CONTEXT INFORMATION: From a grave (Burial B) in a cemetery excavated by Glenn Martin in 1940. Associated vessels in the grave are V-2092 to V-2094 and V-2096 to V2097.

ACCESSION NO.: 5425-2029

VESSEL NO.: V-2095

NON-PLASTICS: grog

VESSEL FORM: Jar with a tall rim

RIM AND LIP FORM: Everted rim and a rounded lip

CORE COLOR: A (fired and cooled in a high oxygen environment)

INTERIOR SURFACE COLOR: strong brown

EXTERIOR SURFACE COLOR: strong brown 
WALL THICKNESS (RIM, BODY, AND BASE IN MM): 4.4 mm, rim

INTERIOR SURFACE TREATMENT: smoothed on the rim and body

EXTERIOR SURFACE TREATMENT: smoothed on the rim and body

HEIGHT (IN CM): 6.2

ORIFICE DIAMETER (IN CM): 6.6

DIAMETER AT BOTTOM OF RIM OR NECK (IN CM): 5.4

BASE DIAMETER (IN CM): 4.0

ESTIMATED VOLUME (IN LITERS): 0.25 liters

DECORATION: The rim has three rows of diagonal incised lines, with horizontal brushing marks between the incised rows (Figure A2-14). The body has a central broad trailed circle, repeated four times around the vessel, that encloses a cluster of three appliqued nodes. Each trailed circle and appliqued node cluster is separated from the other by large trailed triangle elements pendant from the rim-body juncture; each of the triangles is filled with circular punctations (Figure A2-14).

TYPE: Foster Trailed-Incised, var. unspecified

Figure A2-14. Foster Trailed-Incised, var. unspecified jar from the Wm. Handy Place (5425-2029).

SITE NAME OR SITE NUMBER: Wm. Handy Place

CONTEXT INFORMATION: From a grave in a cemetery excavated by Horace McLendon in the fall of 1941. Associated vessels (from several graves dug at that time) include V-2343 to V-2365.

ACCESSION NO.: 5425-2030

VESSEL NO.: V-2342

NON-PLASTICS: fine grog

VESSEL FORM: Bottle with a straight to slightly tapered neck

RIM AND LIP FORM: Direct rim with a rounded lip 
CORE COLOR: B (fired and cooled in a low oxygen environment)

INTERIOR SURFACE COLOR: dark grayish-brown

EXTERIOR SURFACE COLOR: dark grayish-brown

WALL THICKNESS (RIM, BODY, AND BASE IN MM): 4.4 mm, rim

INTERIOR SURFACE TREATMENT: smoothed on the upper neck

EXTERIOR SURFACE TREATMENT: burnished on the body and neck

HEIGHT (IN CM): 19.1

ORIFICE DIAMETER (IN CM): 3.9

DIAMETER AT BOTTOM OF RIM OR NECK (IN CM): $4.8 ; 13.6 \mathrm{~cm}$ wide at the widest part of the body

BASE DIAMETER (IN CM): 7.0

ESTIMATED VOLUME (IN LITERS): 0.53 liters

DECORATION: The engraved motifs on the vessel body are delimited by four horizontal engraved lines at the top and bottom of the body; a red pigment had been rubbed in the engraved lines. The main motif on the body is repeated twice, and consists of a large engraved semi-circle or large ellipse with three distinct elements: a vertical hatched panel with two excised parabolas (and with two central small excised punctations) and one narrow oval (with a single short vertical engraved line within it); two sets of two vertical engraved lines; and two opposed hooked arm scroll lines attached to vertical engraved lines with short spurs or tick marks (Figure A2-15). The large semi-circles or ellipses are divided by two vertical hatched panels; these panels are nearly the same as the vertical hatched panels within the semi-circles or ellipses, except that they have two excised parabolas (with two excised punctations) and two narrow ovals with short vertical engraved lines within them (Figure A2-15).

TYPE: the bottle has elements of both Handy Engraved and Hatchel Engraved bottles (see Suhm and Jelks 1962:Plates 32 and 34)

Figure A2-15. cf. Handy-Hatchel Engraved bottle (5425-2030): a, photograph; b, drawing by Bobby Gonzalez.

SITE NAME OR SITE NUMBER: Wm. Handy Place 
CONTEXT INFORMATION: From a grave (Burial 1) excavated by Robert Shelton in 1940. Associated vessels include V-2030 to V-2032 and V-2034 to V-2039.

ACCESSION NO.: 5425-2031A

VESSEL NO.: V-2033

NON-PLASTICS: grog

VESSEL FORM: Carinated bowl

RIM AND LIP FORM: Inverted rim with a rounded, exterior folded lip

CORE COLOR: $\mathrm{G}$ (fired in a reducing environment, but cooled in the open air)

INTERIOR SURFACE COLOR: very dark gray

EXTERIOR SURFACE COLOR: very dark gray

WALL THICKNESS (RIM, BODY, AND BASE IN MM): 5.5 mm, rim; 4.9 mm, body

INTERIOR SURFACE TREATMENT: smoothed on the body and burnished on the rim

EXTERIOR SURFACE TREATMENT: burnished on the rim and body

HEIGHT (IN CM): 9.9

ORIFICE DIAMETER (IN CM): 18.3

DIAMETER AT BOTTOM OF RIM OR NECK (IN CM): 19.5

BASE DIAMETER (IN CM): 7.4, rounded base

ESTIMATED VOLUME (IN LITERS): 1.09 liters

DECORATION: The rim panel has a continuous scroll motif repeated four times, ending in excised brackets and a series of curvilinear engraved lines or negative $S$-shaped dividers (Figure A2-16). The scroll filler background consists of a series of small excised brackets and small excised triangles.

TYPE: Glassell Engraved, var. Atkins

Figure A2-16. Glassell Engraved, var. Atkins carinated bowl (5425-2031A). 
SITE NAME OR SITE NUMBER: Wm. Handy Place

CONTEXT INFORMATION: From a grave (Burial A) in a cemetery excavated in the fall of 1941. A clay pipe (P-257) was also found in the grave (this pipe was not documented in the present study)

ACCESSION NO:: 5425-2032

VESSEL NO.: V-2334

NON-PLASTICS: grog

VESSEL FORM: Bottle with a globular body and a straight neck

RIM AND LIP FORM: Direct rim with a flat lip

CORE COLOR: A (fired and cooled in an oxidizing environment)

INTERIOR SURFACE COLOR: pinkish gray

EXTERIOR SURFACE COLOR: pinkish gray

WALL THICKNESS (RIM, BODY, AND BASE IN MM): 6.3 mm, rim

INTERIOR SURFACE TREATMENT: none

EXTERIOR SURFACE TREATMENT: burnished on the neck and the body

HEIGHT (IN CM): 22.0

ORIFICE DIAMETER (IN CM): 5.2

DIAMETER AT BOTTOM OF RIM OR NECK (IN CM): 6.6; $13.5 \mathrm{~cm}$ at the widest part of the body

BASE DIAMETER (IN CM): 8.0

ESTIMATED VOLUME (IN LITERS): 0.70 liters

DECORATION: Three very closely-spaced horizontal engraved lines encircling the top of the vessel body (Figure A2-17).

TYPE: Hickory Engraved

Figure A2-17. Hickory Engraved bottle (5425-2032). 
SITE NAME OR SITE NUMBER: Wm. Handy Place

CONTEXT INFORMATION: From a grave (Burial B) in a cemetery excavated by Glenn Martin in 1940. Associated vessels in the grave are V-2092 and V-2094 to V-2097.

ACCESSION NO.: 5425-2033

VESSEL NO.: V-2093

NON-PLASTICS: grog and bone

VESSEL FORM: Carinated bowl with two rim panels (Figure A2-18)

RIM AND LIP FORM: Everted rim with a rounded lip

CORE COLOR: A (fired and cooled in an oxidizing environment)

INTERIOR SURFACE COLOR: strong brown with dark brown fire clouds on the rim

EXTERIOR SURFACE COLOR: strong brown with dark brown fire clouds on the body

WALL THICKNESS (RIM, BODY, AND BASE IN MM): 4.8 mm, rim

INTERIOR SURFACE TREATMENT: burnished on the rim and body

EXTERIOR SURFACE TREATMENT: burnished on the rim and body

HEIGHT (IN CM): 6.0

ORIFICE DIAMETER (IN CM): 8.1

DIAMETER AT BOTTOM OF RIM OR NECK (IN CM): 7.8, upper rim panel; $8.8 \mathrm{~cm}$ at the lower panel carination

BASE DIAMETER (IN CM): 3.6

ESTIMATED VOLUME (IN LITERS): 0.29 liters

DECORATION: Plain

TYPE: Undefined plain ware vessel 
Figure A2-18. Plain carinated bowl (5425-2033).

SITE NAME OR SITE NUMBER: Wm. Handy Place

CONTEXT INFORMATION: From a grave (Burial 3) in a cemetery excavated by Robert Shelton in 1940. Associated vessels in the grave are V-2045 to V-2047.

ACCESSION NO.: 5425-2034

VESSEL NO.: V-2048

NON-PLASTICS: grog

VESSEL FORM: Carinated bowl

RIM AND LIP FORM: Inverted rim and a rounded lip

CORE COLOR: B (fired and cooled in a reducing environment)

INTERIOR SURFACE COLOR: dark grayish-brown

EXTERIOR SURFACE COLOR: very dark grayish-brown

WALL THICKNESS (RIM, BODY, AND BASE IN MM): 4.5 mm, rim

INTERIOR SURFACE TREATMENT: smoothed on the rim and body

EXTERIOR SURFACE TREATMENT: smoothed on the rim and body

HEIGHT (IN CM): 8.0

ORIFICE DIAMETER (IN CM): 16.5

DIAMETER AT BOTTOM OF RIM OR NECK (IN CM): 18.5

BASE DIAMETER (IN CM): N/A, rounded base

ESTIMATED VOLUME (IN LITERS): 0.79 liters

DECORATION: The rim panel has concentric hatched diagonal scrolls repeated four times (Figure A2-19); there is a single negative oval within each hatched diagonal scroll zone. Between each scroll zone is a single diagonal engraved line; one of these four diagonal lines has small tick marks. 
TYPE: Hodges Engraved, var. Armour

Figure A2-19. Hodges Engraved, var. Armour carinated bowl (5425-2034).

SITE NAME OR SITE NUMBER: Wm. Handy Place

CONTEXT INFORMATION: From a grave in a cemetery excavated by Horace McClendon in the fall of 1941. Associated vessels (from several graves dug at that time) include V-2342 to V-2365.

ACCESSION NO.: 5425-2035

VESSEL NO.: V-2345

NON-PLASTICS: grog

VESSEL FORM: Bottle

RIM AND LIP FORM: Direct rim; the lip is missing

CORE COLOR: $\mathrm{F}$ (fired in a reducing environment, and cooled in the open air)

INTERIOR SURFACE COLOR: very dark brown

EXTERIOR SURFACE COLOR: very dark brown

WALL THICKNESS (RIM, BODY, AND BASE IN MM): 4.7 mm, neck

INTERIOR SURFACE TREATMENT: none

EXTERIOR SURFACE TREATMENT: burnished on the neck and body

HEIGHT (IN CM): 19.5+ (lip is missing)

ORIFICE DIAMETER (IN CM): 4.4

DIAMETER AT BOTTOM OF RIM OR NECK (IN CM): 4.5; $13.0 \mathrm{~cm}$ at the widest part of the body

BASE DIAMETER (IN CM): 7.5

ESTIMATED VOLUME (IN LITERS): est. 0.59 liters 
DECORATION: There are three horizontal engraved lines at the top of the vessel body, and another near the vessel base. Pendant from the lowermost horizontal line near the top of the body are three cross-hatched engraved triangles, each with two small negative ovals. There are four large engraved triangles pendant from the one horizontal engraved line near the vessel base (Figure A2-20).

The main engraved element on the vessel body is a central scroll with embedded circles (four in number). Each of the embedded circles has a small central excised dot (see Figure A2-20). There are two unadorned scroll lines above and below the central scroll.

TYPE: Unidentified engraved fine ware

Figure A2-20. Engraved bottle (5425-2035) from the Wm. Handy Place.

SITE NAME OR SITE NUMBER: Wm. Handy Place

CONTEXT INFORMATION: From a grave in a cemetery excavated by Horace McClendon in the fall of 1941. Associated vessels (from several graves dug at that time) include V-2342 to V-2365.

ACCESSION NO.: 5425-2036

VESSEL NO.: V-2354

NON-PLASTICS: grog

VESSEL FORM: Carinated bowl

RIM AND LIP FORM: Direct rim and a rounded, exterior folded, lip

CORE COLOR: A (fired and cooled in a high oxygen environment)

INTERIOR SURFACE COLOR: dark yellowish-brown

EXTERIOR SURFACE COLOR: dark yellowish-brown with very dark grayish-brown fire clouds

WALL THICKNESS (RIM, BODY, AND BASE IN MM): 5.0 mm, rim; 7.0 mm, base

INTERIOR SURFACE TREATMENT: smoothed on the rim and body

EXTERIOR SURFACE TREATMENT: burnished on the rim and body 
HEIGHT (IN CM): 4.0

ORIFICE DIAMETER (IN CM): 11.4

DIAMETER AT BOTTOM OF RIM OR NECK (IN CM): 10.8

BASE DIAMETER (IN CM): N/A (base is missing)

ESTIMATED VOLUME (IN LITERS): 0.27 liters

DECORATION: The rim has two rectilinear engraved panels defined by two sets of either vertical excised or cross-hatched zones (Figure A2-21). Within each of the panels are horizontal interlocking lines and a single horizontal ticked line, as well as two excised brackets that extend from the rim and carination to the central horizontal ticked line. The top and bottom of the rectilinear panel also has small triangular tick marks (Figure A220).

TYPE: Glassell Engraved, var. Glassell (Kelley 1997:50)

Figure A2-21. Glassell Engraved, var. Glassell carinated bowl (5425-2036).

SITE NAME OR SITE NUMBER: Wm. Handy Place

CONTEXT INFORMATION: From a grave (Burial 3) in a cemetery excavated by Robert Shelton in 1940. Associated vessels in the grave include V-2045, V-2046, and V2048.

ACCESSION NO.: 5425-2037

VESSEL NO.: V-2047

NON-PLASTICS: grog and bone

VESSEL FORM: Bottle with a straight to slightly flaring neck (Figure A2-22)

RIM AND LIP FORM: Direct rim with a rounded and exterior folded lip

CORE COLOR: $\mathrm{G}$ (fired in a reducing environment but cooled in the open air)

INTERIOR SURFACE COLOR: very dark gray

EXTERIOR SURFACE COLOR: pale brown with very dark gray fire clouds 
WALL THICKNESS (RIM, BODY, AND BASE IN MM): 5.1 mm, neck

INTERIOR SURFACE TREATMENT: smoothed on the upper neck

EXTERIOR SURFACE TREATMENT: burnished on the neck and body

HEIGHT (IN CM): 16.9

ORIFICE DIAMETER (IN CM): 5.5

DIAMETER AT BOTTOM OF RIM OR NECK (IN CM): 4.2; $11.7 \mathrm{~cm}$ at the widest point on the body

BASE DIAMETER (IN CM): 5.7

ESTIMATED VOLUME (IN LITERS): 0.39 liters

DECORATION: Plain

TYPE: Unidentified plain ware bottle

Figure A2-22. Plain bottle (5425-2037).

SITE NAME OR SITE NUMBER: Wm. Handy Place

CONTEXT INFORMATION: From a grave (Burial B) in a cemetery excavated by Glenn Martin in 1940. Associated vessels in the grave are V-2092 to V-2096.

ACCESSION: 5425-2038

VESSEL NO.: V-2097

NON-PLASTICS: grog

VESSEL FORM: Jar

RIM AND LIP FORM: Everted rim and a rounded lip

CORE COLOR: A (fired and cooled in a high oxygen environment)

INTERIOR SURFACE COLOR: grayish-brown

EXTERIOR SURFACE COLOR: strong brown; fire clouds on the base 
WALL THICKNESS (RIM, BODY, AND BASE IN MM): 4.4 mm, rim; 5.6 mm, body

INTERIOR SURFACE TREATMENT: smoothed on the rim

EXTERIOR SURFACE TREATMENT: poorly smoothed on the rim and lower body

HEIGHT (IN CM): 7.5

ORIFICE DIAMETER (IN CM): 7.5

DIAMETER AT BOTTOM OF RIM OR NECK (IN CM): 5.8

BASE DIAMETER (IN CM): 4.5

ESTIMATED VOLUME (IN LITERS): 0.34 liters

DECORATION: There is a single row of diagonal punctates at the rim-body juncture of the vessel as well as a row underneath the vessel lip (Figure A2-23). These punctated rows cut through faint diagonal brushing on the rim.

TYPE: Unidentified punctated and brushed utility ware vessel

Figure A2-23. Punctated and brushed jar (5425-2038).

SITE NAME OR SITE NUMBER: Wm. Handy Place

ACCESSION NO.: 5425-2039

VESSEL NO.: V-4043

NON-PLASTICS: fine grog

VESSEL FORM: Carinated bowl with two rim panels

RIM AND LIP FORM: Inverted rim and a rounded lip

CORE COLOR: $\mathrm{G}$ (fired in a reducing environment and cooled in the open air)

INTERIOR SURFACE COLOR: very dark gray

EXTERIOR SURFACE COLOR: brown

WALL THICKNESS (RIM, BODY, AND BASE IN MM): $5.1 \mathrm{~mm}$, rim; $5.4 \mathrm{~mm}$, body 
INTERIOR SURFACE TREATMENT: burnished on the rim and smoothed on the body

EXTERIOR SURFACE TREATMENT: burnished on the rim and body

HEIGHT (IN CM): 7.8+ (missing the base)

ORIFICE DIAMETER (IN CM): 14.0

DIAMETER AT BOTTOM OF RIM OR NECK (IN CM): 12.0

BASE DIAMETER (IN CM): N/D

ESTIMATED VOLUME (IN LITERS): est. 0.67 liters

DECORATION: The upper rim panel has a line of excised punctations below the lip, followed by a single horizontal engraved line and a second row of punctations (Figure A2-24). The lower panel has four appliqued nodes evenly spaced around the vessel, and placed just above the carination; there are triangular tick marks along the carination. On either side of each appliqued node are two sets of four diagonal engraved lines pitched in opposite directions (Figure A2-24). The area of the lower rim panel between each set of node and associated diagonal engraved lines has two diagonal engraved lines with triangular tick marks.

TYPE: Belcher Engraved, var. Belcher

Figure A2-24. Belcher Engraved, var. Belcher carinated bowl (5425-2039).

SITE NAME OR SITE NUMBER: Wm. Handy Place

CONTEXT INFORMATION: From a grave (Burial 4) in a cemetery excavated by Robert Shelton in 1940. Associated vessels in the grave are V-2049 to V-2052.

ACCESSION NO.: 5425-2040

VESSEL NO.: V-2053

NON-PLASTICS: shell and fine grog

VESSEL FORM: Carinated bowl with two rim panels

RIM AND LIP FORM: Everted rim with a rounded lip

CORE COLOR: $\mathrm{G}$ (fired in a reducing environment and cooled in the open air) 
INTERIOR SURFACE COLOR: dark grayish-brown

EXTERIOR SURFACE COLOR: strong brown to very dark grayish-brown

WALL THICKNESS (RIM, BODY, AND BASE IN MM): 4.9 mm, rim

INTERIOR SURFACE TREATMENT: burnished on the rim and body

EXTERIOR SURFACE TREATMENT: burnished on the rim and body, but badly eroded

HEIGHT (IN CM): 7.0

ORIFICE DIAMETER (IN CM): 16.5

DIAMETER AT BOTTOM OF RIM OR NECK (IN CM): 14.0

BASE DIAMETER (IN CM): 5.5

ESTIMATED VOLUME (IN LITERS): 0.69 liters

DECORATION: The upper rim panel has a single row of punctations below the lip, and above a single horizontal engraved line (Figure A2-25). The lower rim panel has a second row of punctations just above the vessel carination, and these are divided into distinct areas by sets of two diagonal engraved lines (Figure A2-25).

TYPE: Belcher Engraved, var. Owen

Figure A2-25. Belcher Engraved, var. Owen carinated bowl (5425-2040).

SITE NAME OR SITE NUMBER: Wm. Handy Place

CONTEXT INFORMATION: From a grave (Burial 2) in a cemetery excavated in 1940 by Robert Shelton on the Handy Place, a 40 acre tract of land owned by Wm. Handy. The grave, and others, was situated on a ridge a short distance northeast from the Handy cabin. This vessel is associated with V-2041 to V-2044. Burial 2 is an adolescent, extended on its back, with its head to the south.

ACCESSION NO.: 5425-2041

VESSEL NO.: V-2040

NON-PLASTICS: grog

VESSEL FORM: Bottle 
RIM AND LIP FORM: Direct rim and a flat, exterior-thickened lip

CORE COLOR: A (fired and cooled in a high oxygen environment)

INTERIOR SURFACE COLOR: light brown

EXTERIOR SURFACE COLOR: light brown; fire clouds on the neck and body

WALL THICKNESS (RIM, BODY, AND BASE IN MM): 4.8 mm, rim

INTERIOR SURFACE TREATMENT: smoothed on the upper neck

EXTERIOR SURFACE TREATMENT: burnished on the neck and body

HEIGHT (IN CM): 15.3

ORIFICE DIAMETER (IN CM): 5.4

DIAMETER AT BOTTOM OF RIM OR NECK (IN CM): 4.4; $11.6 \mathrm{~cm}$ at the widest part of the body

BASE DIAMETER (IN CM): 5.4

ESTIMATED VOLUME (IN LITERS): 0.33 liters

DECORATION: The engraved motif on this vessel consists of three knotted and interlocking and circular hatched ladders and a central engraved circle (Figure A2-26). The central circle is different in each knotted/interlocking engraved motif, with a single diagonal or horizontal hatched ladder bisecting the circle (Figure A2-26).

TYPE: Unidentified engraved bottle

Figure A2-26. Engraved bottle (5425-2041) from the Wm. Handy Place.

SITE NAME OR SITE NUMBER: Wm. Handy Place

CONTEXT INFORMATION: From a burial (Burial E) in a cemetery excavated by W. Gamel Smith in the fall of 1941. Associated funerary objects include V-2338, V-2340, and V-2341 and a jasper arrow point of unknown form and type.

ACCESSION NO.: 5425-2042

VESSEL NO.: V-2339 
NON-PLASTICS: bone

VESSEL FORM: Bowl (Figure A2-27)

RIM AND LIP FORM: Direct rim and a rounded lip

CORE COLOR: $\mathrm{G}$ (fired in a reducing environment and cooled in the open air)

INTERIOR SURFACE COLOR: very dark gray

EXTERIOR SURFACE COLOR: brown with very dark gray fire clouds

WALL THICKNESS (RIM, BODY, AND BASE IN MM): 7.7 mm, rim

INTERIOR SURFACE TREATMENT: smoothed on the rim and body

EXTERIOR SURFACE TREATMENT: smoothed on the rim and body

HEIGHT (IN CM): 6.8

ORIFICE DIAMETER (IN CM): 9.5

DIAMETER AT BOTTOM OF RIM OR NECK (IN CM): N/A

BASE DIAMETER (IN CM): 5.0

ESTIMATED VOLUME (IN LITERS): 0.26 liters

DECORATION: Plain

TYPE: Undefined plain ware vessel

Figure A2-27. Plain bowl (5425-2042).

SITE NAME OR SITE NUMBER: Wm. Handy Place

CONTEXT INFORMATION: From a grave in a cemetery excavated by Horace McLendon in the fall of 1941. Associated vessels (from several graves dug at that time) include V-2342 to V-2365.

ACCESSION NO.: 5425-2043

VESSEL NO.: V-2353 
NON-PLASTICS: grog

VESSEL FORM: Carinated bowl with two rim panels and two opposed strap handles

RIM AND LIP FORM: Everted rim with a flat and exterior folded lip

CORE COLOR: B (fired and cooled in a low oxygen environment)

INTERIOR SURFACE COLOR: dark brown

EXTERIOR SURFACE COLOR: dark brown

WALL THICKNESS (RIM, BODY, AND BASE IN MM): 6.3 mm, rim

INTERIOR SURFACE TREATMENT: burnished on the rim and body

EXTERIOR SURFACE TREATMENT: burnished on the rim and body

HEIGHT (IN CM): 7.0

ORIFICE DIAMETER (IN CM): 16.5

DIAMETER AT BOTTOM OF RIM OR NECK (IN CM): 15.0

BASE DIAMETER (IN CM): 6.9

ESTIMATED VOLUME (IN LITERS): 0.69 liters

DECORATION: The upper rim panel has a row of tool punctations under the lip as well as a single centrally placed horizontal engraved line (Figure A2-28). On the lower rim panel are engraved and excised semi-circle motifs, repeated twice between the strap handles, surrounding a central appliqued node (Figure A2-28). There are two sets of diagonal engraved and diagonal punctated lines on either side of the central motif, and two rows of punctates at the upper and lower margins of the lower rim panel; in some instances, the lower row of punctates are placed not on the carination, but below it.

The two strap handles have upper and lower rows of tool punctates, two short rows of punctates along each side of the handle, as well as a single central punctate (see Figure A2-28).

TYPE: Belcher Engraved, var. Belcher

Figure A2-28. Belcher Engraved, var. Belcher carinated bowl (5425-2043). 
SITE NAME OR SITE NUMBER: Wm. Handy Place

CONTEXT INFORMATION: From a grave (Burial B) in a cemetery excavated by W. Gamel Smith in the fall of 1941. This vessel was found in association with V-2336 and V-2337.

ACCESSION NO.: 5425-2044

VESSEL NO.: V-2335

NON-PLASTICS: grog

VESSEL FORM: Bottle with a tapered neck and a globular body

RIM AND LIP FORM: Direct rim and a rounded lip

CORE COLOR: A (fired and cooled in a high oxygen environment)

INTERIOR SURFACE COLOR: brown

EXTERIOR SURFACE COLOR: brown, with dark grayish-brown fire clouds

WALL THICKNESS (RIM, BODY, AND BASE IN MM): 6.6 mm, neck

INTERIOR SURFACE TREATMENT: none

EXTERIOR SURFACE TREATMENT: smoothed on the neck and body

HEIGHT (IN CM): 18.0

ORIFICE DIAMETER (IN CM): 3.9

DIAMETER AT BOTTOM OF RIM OR NECK (IN CM): $5.1 ; 11.0 \mathrm{~cm}$ at the widest part of the body

BASE DIAMETER (IN CM): 6.5

ESTIMATED VOLUME (IN LITERS): 0.47 liters

DECORATION: Four horizontal engraved lines on the upper body of the bottle (Figure A2-29)

TYPE: Hickory Engraved

Figure A2-29. Hickory Engraved bottle (5425-2044). 
SITE NAME OR SITE NUMBER: Wm. Handy Place

CONTEXT INFORMATION: From a grave in a cemetery; V-2030 and V-2089 came from the same Caddo burial feature.

ACCESSION NO.: 5425-2045

VESSEL NO.: V-2102

NON-PLASTICS: grog and hematite/ferruginous sandstone

VESSEL FORM: Carinated bowl with two rim panels and two strap handles

RIM AND LIP FORM: Everted rim and a rounded lip

CORE COLOR: A (fired and cooled in a high oxygen environment)

INTERIOR SURFACE COLOR: strong brown

EXTERIOR SURFACE COLOR: strong brown

WALL THICKNESS (RIM, BODY, AND BASE IN MM): $5.2 \mathrm{~mm}$, rim; $5.7 \mathrm{~mm}$, body

INTERIOR SURFACE TREATMENT: smoothed on the body and burnished on the rim

EXTERIOR SURFACE TREATMENT: burnished on the rim and body

HEIGHT (IN CM): 4.9

ORIFICE DIAMETER (IN CM): 11.0

DIAMETER AT BOTTOM OF RIM OR NECK (IN CM): 9.0 on the upper panel; $9.7 \mathrm{~cm}$ at the carination

BASE DIAMETER (IN CM): 6.1

ESTIMATED VOLUME (IN LITERS): 0.32 liters

DECORATION: The upper rim panel has a single row of triangular punctates under the lip as well as a single centrally placed horizontal engraved line (Figure A2-30). The lower rim panel has a motif of engraved and punctated semi-circles between the strap handles, and there are sets of three diagonal engraved and excised lines on either side of 
the semi-circles (Figure A2-30). There is a row of oval-shaped punctations at the lower panel carination.

The strap handles are decorated with two opposed curvilinear appliqued ridges and a central appliqued node; the handle also has a rectangular engraved element around the appliqued node (see Figure A2-30).

TYPE: Belcher Engraved, var. Owen

Figure A2-30. Belcher Engraved, var. Owen carinated bowl (5425-2045).

SITE NAME OR SITE NUMBER: Wm. Handy Place

CONTEXT INFORMATION: From a grave (Burial 1) in a cemetery excavated by Robert Shelton in 1940. Associated vessels include V-2030 to V-2036 and V-2038 to V2039.

ACCESSION NO.: 5425-2048

VESSEL NO.: V-2037

NON-PLASTICS: shell

VESSEL FORM: Miniature jar with a tall rim

RIM AND LIP FORM: Direct rim with a rounded and exterior folded lip

CORE COLOR: A (fired and cooled in a high oxygen environment)

INTERIOR SURFACE COLOR: brown

EXTERIOR SURFACE COLOR: brown

WALL THICKNESS (RIM, BODY, AND BASE IN MM): $4.1 \mathrm{~mm}$, rim

INTERIOR SURFACE TREATMENT: smoothed on the rim

EXTERIOR SURFACE TREATMENT: none

HEIGHT (IN CM): 6.5

ORIFICE DIAMETER (IN CM): 7.5 
DIAMETER AT BOTTOM OF RIM OR NECK (IN CM): 6.4

BASE DIAMETER (IN CM): 4.1

ESTIMATED VOLUME (IN LITERS): 0.29 liters

DECORATION: The rim has two rows of short diagonal incised lines (Figure A2-31). The body has sets of incised semi-circles repeated three times around the vessel.

TYPE: Foster Trailed-Incised, var. unspecified

Figure A2-31. Foster Trailed-Incised, var. unspecified jar (5425-2048) from the Wm. Handy Place.

SITE NAME OR SITE NUMBER: Wm. Handy Place

CONTEXT INFORMATION: From a grave in a cemetery excavated by Horace McLendon in the fall of 1941. Associated vessels (from several graves dug at that time) include V-2342 to V-2365.

ACCESSION NO.: 5425-2049

VESSEL NO.: V-2351

NON-PLASTICS: grog and bone

VESSEL FORM: Jar with two suspension holes (2.5 mm in diameter) (Figure A2-32)

RIM AND LIP FORM: Direct rim with a rounded lip

CORE COLOR: $\mathrm{G}$ (fired in a reducing environment and cooled in the open air)

INTERIOR SURFACE COLOR: very dark gray

EXTERIOR SURFACE COLOR: brown, with very dark gray fire clouds

WALL THICKNESS (RIM, BODY, AND BASE IN MM): 4.6 mm, rim

INTERIOR SURFACE TREATMENT: smoothed on the rim

EXTERIOR SURFACE TREATMENT: smoothed on the rim and body

HEIGHT (IN CM): 9.5 
ORIFICE DIAMETER (IN CM): 6.4

DIAMETER AT BOTTOM OF RIM OR NECK (IN CM): 6.3

BASE DIAMETER (IN CM): 5.2

ESTIMATED VOLUME (IN LITERS): 0.36 liters

DECORATION: Plain

TYPE: Undefined plain ware vessel

Figure A2-32. Plain jar with suspension holes (5425-2049).

SITE NAME OR SITE NUMBER: Wm. Handy Place

CONTEXT INFORMATION: From a grave (Burial 2) in a cemetery excavated by

Robert Shelton in 1940. Associated vessels in the grave include V-2040 to V-2043.

ACCESSION NO.: 5425-2050A-H

VESSEL NO.: V-2044

NON-PLASTICS: fine grog

VESSEL FORM: Bowl

RIM AND LIP FORM: Direct rim with a rounded and exterior folded lip

CORE COLOR: $\mathrm{H}$ (fired in a reducing environment and cooled in the open air)

INTERIOR SURFACE COLOR: brown

EXTERIOR SURFACE COLOR: very dark gray

WALL THICKNESS (RIM, BODY, AND BASE IN MM): $5.3 \mathrm{~mm}$, rim; $5.7 \mathrm{~mm}$, body;

$5.4 \mathrm{~mm}$, base

INTERIOR SURFACE TREATMENT: smoothed on the rim

EXTERIOR SURFACE TREATMENT: burnished on the rim and body

HEIGHT (IN CM): 9.6 
ORIFICE DIAMETER (IN CM): 11.0

DIAMETER AT BOTTOM OF RIM OR NECK (IN CM): 10.9

BASE DIAMETER (IN CM): 5.2

ESTIMATED VOLUME (IN LITERS): 0.42 liters

DECORATION: The upper part of the vessel has four horizontal engraved lines, two with small tick marks (Figure A2-33). The lower part of the vessel has an interlocking scroll with hooked arm elements, the motif repeated four times around the vessel.

TYPE: cf. Taylor Engraved

Figure A2-33. cf. Taylor Engraved bowl (V-2044).

SITE NAME OR SITE NUMBER: Wm. Handy Place

CONTEXT INFORMATION: From a grave in a cemetery excavated by Horace McLendon in the fall of 1941. Associated vessels (from several graves dug at that time) include V-2342 to V-2365.

ACCESSION NO.: 5425-2051

VESSEL NO.: V-2355

NON-PLASTICS: grog

VESSEL FORM: Carinated bowl

RIM AND LIP FORM: Direct rim with a flat and exterior folded lip

CORE COLOR: B (fired and cooled in a low oxygen environment)

INTERIOR SURFACE COLOR: very dark gray

EXTERIOR SURFACE COLOR: very dark gray

WALL THICKNESS (RIM, BODY, AND BASE IN MM): 7.8 mm, rim; 7.6 mm, base

INTERIOR SURFACE TREATMENT: smoothed on the body and burnished on the rim 
EXTERIOR SURFACE TREATMENT: burnished on the rim and body

HEIGHT (IN CM): 3.4

ORIFICE DIAMETER (IN CM): 12.1

DIAMETER AT BOTTOM OF RIM OR NECK (IN CM): 10.7

BASE DIAMETER (IN CM): N/A, rounded base

ESTIMATED VOLUME (IN LITERS): 0.25 liters

DECORATION: The rim has a single horizontal engraved line underneath the lip. There are 10 engraved brackets or vertical dividers attached to that engraved line that form 10 ovals on the rim panel (Figure A2-34); these brackets/dividers extend to the rim carination. Each bracket/divider is comprised of two sets of two opposed vertical curvilinear lines, with the area between each arc of engraved lines filled with a single vertical row of tool punctates (Figure A2-34).

TYPE: cf. Handy Engraved

Figure A2-34. cf. Handy Engraved carinated bowl (5425-2051).

SITE NAME OR SITE NUMBER: Wm. Handy Place

CONTEXT INFORMATION: From a grave (Burial B) in a cemetery excavated by W. Gamel Smith in 1941. Associates vessels include V-2335 and V-2336.

ACCESSION NO: 5425-2052

VESSEL NO.: V-2337

NON-PLASTICS: grog

VESSEL FORM: Bowl, possibly a stacked vessel, with a peaked rim

RIM AND LIP FORM: Direct rim and a rounded lip

CORE COLOR: $\mathrm{F}$ (fired in a reducing environment and cooled in the open air)

INTERIOR SURFACE COLOR: brown

EXTERIOR SURFACE COLOR: brown 
WALL THICKNESS (RIM, BODY, AND BASE IN MM): $11.8 \mathrm{~mm}$, rim; $7.0 \mathrm{~mm}$, body; $8.8 \mathrm{~mm}$, base

INTERIOR SURFACE TREATMENT: smoothed

EXTERIOR SURFACE TREATMENT: smoothed

HEIGHT (IN CM): 4.4

ORIFICE DIAMETER (IN CM): 9.0

DIAMETER AT BOTTOM OF RIM OR NECK (IN CM): N/A

BASE DIAMETER (IN CM): 5.7

ESTIMATED VOLUME (IN LITERS): 0.16 liters

DECORATION: The lower of the two stacked vessels has horizontal engraved lines at the top and bottom of the bowl, with two sets of two diagonal engraved zones filled with tool punctations (Figure A2-35a). The broad and flat rim (Figure A2-35a) has an attachment for the second stacked vessel, which consists of the rim of a bowl with four rim peaks (Figure A2-35b). This part of the conjoined vessels has two sets of five opposed diagonal engraved lines below each rim peak (Figure A2-35b).

TYPE: Unidentified engraved-punctated vessel

Figure A2-35. Engraved-punctated bowl (5425-2052): a, lower part of the vessel; b, upper part of the vessel, note rim peaks.

SITE NAME OR SITE NUMBER: Wm. Handy Place

CONTEXT INFORMATION: From an adult grave (Burial E) in a cemetery excavated in the fall of 1941. Associated vessels include V-2339 to V-2341, as well as a jasper arrow point (H-509, not documented during this project)

ACCESSION NO.: 5425-2053

VESSEL NO.: V-2338

NON-PLASTICS: grog

VESSEL FORM: Bottle 
RIM AND LIP FORM: Everted/flared rim with a rounded lip

CORE COLOR: $\mathrm{G}$ (fired in a reducing environment and cooled in the open air)

INTERIOR SURFACE COLOR: dark grayish-brown

EXTERIOR SURFACE COLOR: brown to dark grayish-brown

WALL THICKNESS (RIM, BODY, AND BASE IN MM): 5.9 mm, rim

INTERIOR SURFACE TREATMENT: smoothed on the upper neck

EXTERIOR SURFACE TREATMENT: burnished on the body and the neck; the burnished is vertically oriented on the neck and horizontally burnished on the body

HEIGHT (IN CM): 16.5

ORIFICE DIAMETER (IN CM): 4.6

DIAMETER AT BOTTOM OF RIM OR NECK (IN CM): $5.4 ; 12.5 \mathrm{~cm}$ at its widest point on the body

BASE DIAMETER (IN CM): 5.3

ESTIMATED VOLUME (IN LITERS): 0.35 liters

DECORATION: There are two horizontal engraved lines on the vessel body below the bottle neck, and a continuous scroll motif on the body itself (Figure A2-36). This scroll motif, with hooked arms, is repeated five times on the vessel. There are also four sets of curvilinear engraved lines (scroll background fill elements) on the vessel, two above and two below the central hooked arm continuous scroll.

TYPE: Taylor Engraved

Figure A2-36. Taylor Engraved bottle (5425-2053) from the Wm. Handy Place.

SITE NAME OR SITE NUMBER: Wm. Handy Place

CONTEXT INFORMATION: From a burial excavated in the fall of 1941 by W. Gamel Smith. Associated funerary offerings include V-2335 and V-2337.

ACCESSION NO.: 5425-2054 
VESSEL NO.: V-2336

NON-PLASTICS: grog and bone

VESSEL FORM: Carinated bowl with two rim panels and two opposed strap handles (26.5 mm wide)

RIM AND LIP FORM: Everted rim with a rounded lip

CORE COLOR: B (fired and cooled in a reducing environment)

INTERIOR SURFACE COLOR: gray; fire clouds on the rim and body

EXTERIOR SURFACE COLOR: very dark gray; fire clouds on the lower body and base

WALL THICKNESS (RIM, BODY, AND BASE IN MM): $5.2 \mathrm{~mm}$, rim

INTERIOR SURFACE TREATMENT: smoothed on the rim and body

EXTERIOR SURFACE TREATMENT: smoothed on the rim and burnished on the body

HEIGHT (IN CM): 5.2

ORIFICE DIAMETER (IN CM): 9.6

DIAMETER AT BOTTOM OF RIM OR NECK (IN CM): 9.3

BASE DIAMETER (IN CM): 6.9

ESTIMATED VOLUME (IN LITERS): 0.30 liters

DECORATION: The vessel's upper rim panel has a row of punctations under the lip as well as a central horizontal engraved line (Figure A2-37). The lower rim panel has two appliqued nodes that are set between the strap handles. The appliqued nodes are the central element with engraved scrolls on either side of the nodes themselves (Figure A237), and with concentric semi-circles around each node. The central engraved line of each of the scrolls has tick marks; there is also a row of triangular punctations along the lower panel carination. The two strap handles each have a central appliqued node.

TYPE: Belcher Engraved, var. Belcher

Figure A2-37. Belcher Engraved, var. Belcher carinated bowl (5425-2054). 
CONTEXT INFORMATION: From a grave (Burial B) in a cemetery excavated by Glenn Martin in 1940. Associated vessels in the grave are V-2093 to V-2097.

ACCESSION NO.: 5425-2055

VESSEL NO.: V-2092

NON-PLASTICS: grog and bone (less than $5 \%$ of the paste)

VESSEL FORM: Carinated bowl with two rim panels

RIM AND LIP FORM: Direct rim with a rounded lip

CORE COLOR: A (fired and cooled in a high oxygen environment)

INTERIOR SURFACE COLOR: strong brown

EXTERIOR SURFACE COLOR: strong brown

WALL THICKNESS (RIM, BODY, AND BASE IN MM): $6.0 \mathrm{~mm}$, rim

INTERIOR SURFACE TREATMENT: smoothed on the rim and body

EXTERIOR SURFACE TREATMENT: smoothed on the rim and body

HEIGHT (IN CM): 7.5

ORIFICE DIAMETER (IN CM): 10.5

DIAMETER AT BOTTOM OF RIM OR NECK (IN CM): 12.5

BASE DIAMETER (IN CM): 5.5

ESTIMATED VOLUME (IN LITERS): 0.47 liters

DECORATION: The upper rim panel is plain, but the lower rim panel has concentric engraved semi-circles; each set is repeated four times around the rim panel (Figure A238). The concentric engraved semi-circles are divided by excised brackets.

TYPE: cf. Avery Engraved, var. Bradshaw

Figure A2-38. Avery Engraved, var. Bradshaw carinated bowl (5425-2055). 
SITE NAME OR SITE NUMBER: Wm. Handy Place

CONTEXT INFORMATION: From a grave (Burial 5) in a cemetery excavated in 1940 by Robert Shelton on the Handy Place, a 40 acre tract of land owned by Wm. Handy. The grave, and others, was situated on a ridge a short distance from the Handy cabin. This vessel is associated with V-2055. Burial 5 is a child, extended on its back, with its head to the south.

ACCESSION NO.: 5425-2056

VESSEL NO.: V-2054

NON-PLASTICS: grog and bone (less than $5 \%$ of the paste)

VESSEL FORM: Globular jar

RIM AND LIP FORM: Direct rim with a rounded but flaring lip

CORE COLOR: B (fired and cooled in a low oxygen environment)

INTERIOR SURFACE COLOR: black

EXTERIOR SURFACE COLOR: very dark grayish-brown

WALL THICKNESS (RIM, BODY, AND BASE IN MM): 5.4 mm, rim

INTERIOR SURFACE TREATMENT: smoothed on the rim

EXTERIOR SURFACE TREATMENT: smoothed on the lower body

HEIGHT (IN CM): 15.0

ORIFICE DIAMETER (IN CM): 11.5

DIAMETER AT BOTTOM OF RIM OR NECK (IN CM): 9.3

BASE DIAMETER (IN CM): 4.0

ESTIMATED VOLUME (IN LITERS): 1.03 liters

DECORATION: The rim has broad cross-hatched incised lines, beginning under a narrow swath of horizontal brushing under the lip (Figure A2-39). The vessel body has horizontal brushing, but this ends well above the base.

TYPE: Unidentified utility ware vessel 
Figure A2-39. Brushed-incised jar (5425-2056).

SITE NAME OR SITE NUMBER: Wm. Handy Place; other records indicate this vessel is from the Battle Place (see Figure 8)

CONTEXT INFORMATION: From a grave (Burial 3) in Burial Plot 2 (Martin 1939). Associated with V-1999, V-2000, and V-2002 to V-2004 1/2.

ACCESSION NO.: 5425-2057

VESSEL NO.: V-2001

NON-PLASTICS: grog-bone

VESSEL FORM: Bowl with a possible appendage/attachment (Figure A2-40)

RIM AND LIP FORM: Direct rim and a rounded lip

CORE COLOR: B (fired and cooled in a reducing environment)

INTERIOR SURFACE COLOR: dark grayish-brown

EXTERIOR SURFACE COLOR: dark grayish-brown

WALL THICKNESS (RIM, BODY, AND BASE IN MM): 3.7 mm, rim

INTERIOR SURFACE TREATMENT: smoothed

EXTERIOR SURFACE TREATMENT: burnished

HEIGHT (IN CM): 4.0

ORIFICE DIAMETER (IN CM): 6.2

DIAMETER AT BOTTOM OF RIM OR NECK (IN CM): N/A

BASE DIAMETER (IN CM): 3.4

ESTIMATED VOLUME (IN LITERS): 0.1 liters

DECORATION: There is a single horizontal engraved line below the vessel rim. From this line are a series of widely-spaced vertical engraved lines that extend to near the vessel base (Figure A2-40). 
TYPE: unidentified engraved fine ware vessel

Figure A2-40. Vertical engraved bowl (5425-2057).

SITE NAME OR SITE NUMBER: Wm. Handy Place

CONTEXT INFORMATION: From a grave (Burial A) in a cemetery excavated by Glenn Martin in 1940. Associated vessels in the grave are V-2089 and V-2090.

ACCESSION NO.: 5425-2058

VESSEL NO.: V-2091

NON-PLASTICS: grog

VESSEL FORM: Jar with a short $(11 \mathrm{~mm})$ rim

RIM AND LIP FORM: Everted rim and a rounded lip

CORE COLOR: $\mathrm{G}$ (fired in a reducing environment and cooled in the open air)

INTERIOR SURFACE COLOR: brown

EXTERIOR SURFACE COLOR: brown

WALL THICKNESS (RIM, BODY, AND BASE IN MM): 5.4 mm, rim

INTERIOR SURFACE TREATMENT: smoothed on the rim and body

EXTERIOR SURFACE TREATMENT: smoothed on the body

HEIGHT (IN CM): 12.0

ORIFICE DIAMETER (IN CM): 9.5

DIAMETER AT BOTTOM OF RIM OR NECK (IN CM): 8.7

BASE DIAMETER (IN CM): 6.0

ESTIMATED VOLUME (IN LITERS): 0.68 liters 
DECORATION: There are closely-spaced vertical incised lines on the short rim. The body of the vessel has nine pairs of narrow ridges and five single narrow ridges (Figure A2-41).

TYPE: Belcher Ridged, var. Wilson's Island (Schambach and Miller 1984:120)

Figure A2-41. Belcher Ridged, var. Wilson's Island jar (5425-2058).

SITE NAME OR SITE NUMBER: Wm. Handy Place

CONTEXT INFORMATION: From a grave (Burial 4) in a cemetery excavated in 1940 by Robert Shelton on the Handy Place, a 40 acre tract of land owned by Wm. Handy. The grave, and others, was situated on a ridge a short distance from the Handy cabin. This vessel is associated with V-2050 to V-2053 in the grave. Burial 4 is an adult, extended on its back, with its head to the south.

ACCESSION NO.: 5425-2059

VESSEL NO.: V-2049

NON-PLASTICS: grog

VESSEL FORM: Bottle with a straight neck

RIM AND LIP FORM: Everted rim and a rounded lip

CORE COLOR: $\mathrm{H}$ (fired in a low oxygen environment and cooled in the open air)

INTERIOR SURFACE COLOR: brown

EXTERIOR SURFACE COLOR: dark grayish-brown

WALL THICKNESS (RIM, BODY, AND BASE IN MM): 4.2 mm, rim

INTERIOR SURFACE TREATMENT: smoothed on the upper neck

EXTERIOR SURFACE TREATMENT: burnished on the neck and body

HEIGHT (IN CM): 22.5

ORIFICE DIAMETER (IN CM): 5.4

DIAMETER AT BOTTOM OF RIM OR NECK (IN CM): $5.5 ; 18.5 \mathrm{~cm}$ wide at the widest point on the body 
BASE DIAMETER (IN CM): 7.5

ESTIMATED VOLUME (IN LITERS): 0.48 liters

DECORATION: The top of the vessel body has a single horizontal engraved line with four engraved pendant triangles (Figure A2-42a-b). Each pendant triangle has hatched corners, forming a central negative circle within the triangles. The bottle body has four concentric circles formed of alternating engraved and dashed lines. The central element within each of the concentric circles is a hatched square with a negative oval (Figure A242a-b).

TYPE: Belcher Engraved, var. Ogden

Figure A2-42. Belcher Engraved, var. Ogden bottle (5425-2059): a, photograph; b, drawing by Bobby Gonzalez.

SITE NAME OR SITE NUMBER: Wm. Handy Place

CONTEXT INFORMATION: From a grave (Burial 1) in a cemetery excavated by Robert Shelton in 1940. Associated vessels in the grave include V-2030 to V-2037 and V-2039.

ACCESSION NO.: 5425-2115A-C

VESSEL NO.: V-2038

NON-PLASTICS: grog

VESSEL FORM: Carinated bowl with two rim panels and a dimpled base

RIM AND LIP FORM: Everted rim and a rounded lip

CORE COLOR: $F$ (fired in a reducing environment and cooled in the open air)

INTERIOR SURFACE COLOR: very dark grayish-brown and brown; fire clouds on the rim and body

EXTERIOR SURFACE COLOR: very dark grayish-brown and brown; fire clouds on the rim and body

WALL THICKNESS (RIM, BODY, AND BASE IN MM): $2.5 \mathrm{~mm}$, rim; $3.7 \mathrm{~mm}$, body; $6.0 \mathrm{~mm}$, base 
INTERIOR SURFACE TREATMENT: burnished on the rim and body

EXTERIOR SURFACE TREATMENT: burnished on the rim and body

HEIGHT (IN CM): 7.9

ORIFICE DIAMETER (IN CM): 24.0

DIAMETER AT BOTTOM OF RIM OR NECK (IN CM): 20.0

BASE DIAMETER (IN CM): 4.4

ESTIMATED VOLUME (IN LITERS): 1.14 liters

DECORATION: The upper rim panel has a row of punctations below the lip as well as two horizontal engraved lines; the lower of the two lines has downward-pointing triangular tick marks (Figure A2-43). The lower rim panel of this vessel has four appliqued nodes equally spaced along the carination, with opposed sets (four lines each) of diagonal engraved lines on either side of each node. There are also three diagonal engraved lines with triangular tick marks that are pitched in an opposite direction from the opposed sets of diagonal engraved lines around the appliqued nodes (Figure A2-43).

TYPE: Belcher Engraved, var. Belcher

Figure A2-43. Belcher Engraved, var. Belcher carinated bowl (5425-2115A-C) from the Wm. Handy Place.

SITE NAME OR SITE NUMBER: Wm. Handy Place

CONTEXT INFORMATION: From a grave in a cemetery excavated by Horace McLendon in the fall of 1941. Associated vessels (from several graves dug at that time) include V-2342 to V-2365.

ACCESSION NO.: 5425-2116A-D

VESSEL NO.: V-2356

NON-PLASTICS: grog

VESSEL FORM: Carinated bowl

RIM AND LIP FORM: Direct rim with a rounded but exterior folded lip 
CORE COLOR: E (incompletely oxidized during firing)

INTERIOR SURFACE COLOR: very dark gray to dark gray, with dark yellowish-brown fire clouds on the rim

EXTERIOR SURFACE COLOR: very dark gray and brown fire clouds on the base

WALL THICKNESS (RIM, BODY, AND BASE IN MM): $5.2 \mathrm{~mm}$, rim; $6.2 \mathrm{~mm}$, body

INTERIOR SURFACE TREATMENT: burnished on the rim and body

EXTERIOR SURFACE TREATMENT: burnished on the rim and body

HEIGHT (IN CM): 5.5

ORIFICE DIAMETER (IN CM): 18.5

DIAMETER AT BOTTOM OF RIM OR NECK (IN CM): 14.0

BASE DIAMETER (IN CM): N/A, rounded base

ESTIMATED VOLUME (IN LITERS): 0.61 liters

DECORATION: There are two rows of engraved dashed or tick marks underneath the vessel lip, and a third row along the carination (Figure A2-44). On the rim itself are two panels of horizontal interlocking scrolls and vertical engraved brackets/dividers.

The central part of each interlocking scroll is a narrow engraved band filled with punctations; on either side of this punctated band are two short interlocking scrolls (see Figure A2-44). Four sets of hatched brackets extend from near the top and bottom of the rim to the central engraved-punctated band. There are small horizontally-oriented engraved rectangles between the two sets of brackets.

The engraved brackets/dividers that set off each panel include two horizontal hatched brackets at each end of the panel (see Figure A2-44). Between each of the hatched brackets are vertically-oriented engraved rectangles.

TYPE: Handy Engraved

Figure A2-44. Handy Engraved carinated bowl (5425-2116A-D).

SITE NAME OR SITE NUMBER: Wm. Handy Place 
CONTEXT INFORMATION: From a grave in a cemetery excavated by Horace McLendon in the fall of 1941. Associated vessels (from several graves dug at that time) include V-2342 to V-2365.

ACCESSION NO.: 5425-2118

VESSEL NO.: V-2358

NON-PLASTICS: shell

VESSEL FORM: Jar with short $(9 \mathrm{~mm})$ rim

RIM AND LIP FORM: Everted rim and a rounded lip

CORE COLOR: $\mathrm{G}$ (fired in a reducing environment and cooled in the open air)

INTERIOR SURFACE COLOR: very dark gray

EXTERIOR SURFACE COLOR: very dark gray and dark yellowish-brown

WALL THICKNESS (RIM, BODY, AND BASE IN MM): $4.1 \mathrm{~mm}$, rim; $3.1 \mathrm{~mm}$, body

INTERIOR SURFACE TREATMENT: smoothed on the rim

EXTERIOR SURFACE TREATMENT: none

HEIGHT (IN CM): 11.3

ORIFICE DIAMETER (IN CM): 10.2

DIAMETER AT BOTTOM OF RIM OR NECK (IN CM): 9.2

BASE DIAMETER (IN CM): 7.2

ESTIMATED VOLUME (IN LITERS): 0.69 liters

DECORATION: The short rim has horizontal brushing on, and there is a single horizontal incised line at the rim-body juncture. Vertical brushed-incised lines cover the vessel body, extending to the base of the vessel (Figure A2-45).

TYPE: Karnack Brushed-Incised, var. Karnack

Figure A2-45. Karnack Brushed-Incised, var. Karnack jar (5425-2118). 
SITE NAME OR SITE NUMBER: Wm. Handy Place

CONTEXT INFORMATION: From a grave (Burial 3) in a cemetery excavated in 1940 by Robert Shelton on the Handy Place, a 40 acre tract of land owned by Wm. Handy. The grave, and others, was situated on a ridge a short distance from the Handy cabin. This vessel is associated with V-2046 to V-2048. Burial 3 is an adolescent, extended on its back, with its head to the south.

ACCESSION NO.: 5425-2119

VESSEL NO.: V-2045

NON-PLASTICS: shell

VESSEL FORM: Jar

RIM AND LIP FORM: Everted rim with a rounded and exterior folded lip

CORE COLOR: B (fired and cooled in a reducing environment)

INTERIOR SURFACE COLOR: black

EXTERIOR SURFACE COLOR: black

WALL THICKNESS (RIM, BODY, AND BASE IN MM): 4.0 mm, rim

INTERIOR SURFACE TREATMENT: smoothed on the rim

EXTERIOR SURFACE TREATMENT: smoothed on the body and base

HEIGHT (IN CM): 13.8

ORIFICE DIAMETER (IN CM): 12.0

DIAMETER AT BOTTOM OF RIM OR NECK (IN CM): 11.4

BASE DIAMETER (IN CM): N/A, rounded base

ESTIMATED VOLUME (IN LITERS): 1.0 liter

DECORATION: The rim has a single row of tool punctations under the lip, as well as rows of vertical stamping (Figure A2-46). There are incised continuous scrolls on the vessel body, and these are filled with light brushing marks (Figure A2-46). 
TYPE: Cowhide Stamped (see Suhm and Jelks 1962:Plate 15b, m) or Mound Tract Incised and Brushed (see Kelley 1997:52; Kidder 1988; Webb 1959:Figure 109a, f-g, i-j, n).

Figure A2-46. cf. Mound Tract Incised and Brushed jar (5425-2119).

SITE NAME OR SITE NUMBER: Wm. Handy Place

CONTEXT INFORMATION: From a grave (Burial A) in a cemetery excavated by Glenn Martin in 1940. Associated vessels in the grave are V-2089 and V-2091.

ACCESSION NO.: 5425-2120

VESSEL NO.: V-2090

NON-PLASTICS: grog

VESSEL FORM: Bottle

RIM AND LIP FORM: N/A, missing

CORE COLOR: $\mathrm{F}$ (fired in a reducing environment and cooled in the open air)

INTERIOR SURFACE COLOR: brown

EXTERIOR SURFACE COLOR: dark brown

WALL THICKNESS (RIM, BODY, AND BASE IN MM): 5.8 mm, neck

INTERIOR SURFACE TREATMENT: none

EXTERIOR SURFACE TREATMENT: burnished on the neck (vertically) and body (horizontally)

HEIGHT (IN CM): 9.5+

ORIFICE DIAMETER (IN CM): N/A

DIAMETER AT BOTTOM OF RIM OR NECK (IN CM): $3.1 ; 9.0 \mathrm{~cm}$ at the widest part of the vessel body

BASE DIAMETER (IN CM): 4.6

ESTIMATED VOLUME (IN LITERS): est. 0.18 liters 
DECORATION: Plain

TYPE: Undefined plain ware bottle (Figure A2-47)

Figure A2-47. Plain bottle (5425-2120).

SITE NAME OR SITE NUMBER: Wm. Handy Place

CONTEXT INFORMATION: From a grave in a cemetery excavated by Horace McLendon in the fall of 1941. Associated vessels (from several graves dug at that time) include V-2342 to V-2365.

ACCESSION NO.: 5425-2121

VESSEL NO.: V-2350

NON-PLASTICS: grog

VESSEL FORM: Jar with four rim peaks and two opposed strap handles under two of the rim peaks

RIM AND LIP FORM: Everted rim with a rounded and exterior folded lip

CORE COLOR: F (fired in a reducing environment and cooled in the open air)

INTERIOR SURFACE COLOR: strong brown

EXTERIOR SURFACE COLOR: strong brown

WALL THICKNESS (RIM, BODY, AND BASE IN MM): $5.1 \mathrm{~mm}$, rim

INTERIOR SURFACE TREATMENT: smoothed on the rim and body

EXTERIOR SURFACE TREATMENT: smoothed on the lower body

HEIGHT (IN CM): $9.5 ; 10.5 \mathrm{~cm}$ at the top of the rim peaks

ORIFICE DIAMETER (IN CM): 10.5

DIAMETER AT BOTTOM OF RIM OR NECK (IN CM): 9.2

BASE DIAMETER (IN CM): 5.5 


\section{ESTIMATED VOLUME (IN LITERS): 0.60 liters}

DECORATION: The rim has a row of tool punctates under the lip and along the rim peaks, as well as a second row of tool punctates at the rim-body juncture (Figure A2-48). Between these punctated rows are four broad horizontal incised lines.

The vessel body has four sets of concentric incised circles and semi-circles around a central appliqued node (see Figure A2-48). Each set of incised circles and semi-circles is outlined by a single broad semi-circular appliqued fillet; on the opposite side of the appliqued fillets are four repeating sets of four curvilinear incised lines that extend to near the vessel base. The ends of the broad appliqued fillets on the vessel body lie under the rim peaks.

The strap handles have two vertical rows of tool punctates along the outside edge of the handles and two sets of four diagonal opposed incised lines (see Figure A2-48).

TYPE: Haley Complicated Incised

Figure A2-48. Haley Complicated Incised jar (5425-2121) from the Wm. Handy Place.

SITE NAME OR SITE NUMBER: Wm. Handy Place

CONTEXT INFORMATION: From a grave in a cemetery excavated by Horace McLendon in the fall of 1941. Associated vessels (from several graves dug at that time) include V-2342 to V-2365.

ACCESSION NO.: 5425-2122

VESSEL NO.: V-2357

NON-PLASTICS: bone, grog, and crushed hematite/ferruginous sandstone

VESSEL FORM: Jar with a short (12 mm) rim

RIM AND LIP FORM: Everted rim and a rounded lip

CORE COLOR: $\mathrm{G}$ (fired in a reducing environment and cooled in the open air)

INTERIOR SURFACE COLOR: black

EXTERIOR SURFACE COLOR: light yellowish-brown; fire clouds on body

WALL THICKNESS (RIM, BODY, AND BASE IN MM): $5.9 \mathrm{~mm}$, rim 
INTERIOR SURFACE TREATMENT: smoothed on the rim and body

EXTERIOR SURFACE TREATMENT: smoothed on the lower body

HEIGHT (IN CM): 12.7

ORIFICE DIAMETER (IN CM): 9.6

DIAMETER AT BOTTOM OF RIM OR NECK (IN CM): 8.6

BASE DIAMETER (IN CM): 5.2

ESTIMATED VOLUME (IN LITERS): 0.73 liters

DECORATION: The short rim has horizontal brushing (Figure A2-49). The body is divided into eight panels by vertical incised lines; the panels extend to the base of the vessel. The panels are filled with triangular zones of opposed brushing (Figure A2-49).

TYPE: Karnack Brushed-Incised, var. unspecified

Figure A2-49. Karnack Brushed-Incised, var. unspecified jar (5425-2122).

SITE NAME OR SITE NUMBER: Wm. Handy Place

CONTEXT INFORMATION: From a grave in a cemetery excavated by Horace McLendon in the fall of 1941. Associated vessels (from several graves dug at that time) include V-2342 to V-2365.

ACCESSION NO.: 5425-2123

VESSEL NO.: V-2352

NON-PLASTICS: grog

VESSEL FORM: Carinated bowl with two rim panels

RIM AND LIP FORM: Everted rim and a rounded lip

CORE COLOR: $\mathrm{F}$ (fired in a reducing environment and cooled in the open air)

INTERIOR SURFACE COLOR: dark brown

EXTERIOR SURFACE COLOR: dark brown to strong brown 
WALL THICKNESS (RIM, BODY, AND BASE IN MM): 5.8 mm, rim

INTERIOR SURFACE TREATMENT: smoothed on the body and burnished on the rim

EXTERIOR SURFACE TREATMENT: burnished on the rim and body

HEIGHT (IN CM): 7.0

ORIFICE DIAMETER (IN CM): 13.5

DIAMETER AT BOTTOM OF RIM OR NECK (IN CM): 13.0

BASE DIAMETER (IN CM): 6.3

ESTIMATED VOLUME (IN LITERS): 0.57 liters

DECORATION: The upper rim panel has a row of tool punctates under the lip, along with a single central horizontal engraved line (Figure A2-50). The lower rim panel is delimited by upper and lower (at the carination) rows of tool punctations. The central element in the scroll motif, repeated four times, is an appliqued node with one surrounding semi-circular engraved line and two opposed sets of four arcing engraved lines (Figure A2-50). The remainder of the motif includes two engraved triangles at the top and bottom of the rim panel as well as two diagonal engraved bands filled with a diagonal row of punctations (Figure A2-50).

TYPE: Belcher Engraved, var. Belcher

Figure A2-50. Belcher Engraved, var. Belcher carinated bowl (5425-2123).

SITE NAME OR SITE NUMBER: Wm. Handy Place

CONTEXT INFORMATION: A funerary offering in Burial 1 excavated by Robert Shelton in 1940. Associated funerary vessels include V-2030 to V-2037 and V-2039.

ACCESSION NO.: 5425-2124

VESSEL NO.: V-2038

NON-PLASTICS: grog

VESSEL FORM: Jar; three deer antler pieces still remain in a matrix of sediment resting on the interior vessel base

RIM AND LIP FORM: Direct rim and a rounded lip 
CORE COLOR: $\mathrm{G}$ (fired in a reducing environment but cooled in the open air)

INTERIOR SURFACE COLOR: gray

EXTERIOR SURFACE COLOR: light yellowish-brown

WALL THICKNESS (RIM, BODY, AND BASE IN MM): 5.4 mm, rim; 4.8 mm, body

INTERIOR SURFACE TREATMENT: smoothed on the rim

EXTERIOR SURFACE TREATMENT: none

HEIGHT (IN CM): 9.8

ORIFICE DIAMETER (IN CM): 12.1

DIAMETER AT BOTTOM OF RIM OR NECK (IN CM): 11.3

BASE DIAMETER (IN CM): 5.9

ESTIMATED VOLUME (IN LITERS): 0.71 liters

DECORATION: There are two diagonally incised rows of incised lines on the rim, each pitched in different directions (Figure A2-51). The vessel body has four sets of incised circles around a dimpled appliqued node, as well as surrounding sets (four incised lines each) of curvilinear incised lines that extend from the rim-body juncture to the base (Figure A2-51).

TYPE: Foster Trailed-Incised, var. Foster

Figure A2-51. Foster Trailed-Incised, var. Foster jar (5425-2124).

SITE NAME OR SITE NUMBER: Wm. Handy Place

CONTEXT INFORMATION: From a grave in a cemetery excavated by Horace McLendon in the fall of 1941. Associated vessels (from several graves dug at that time) include V-2342 to V-2365.

ACCESSION NO.: 5425-2125

VESSEL NO.: V-2359 
NON-PLASTICS: grog

VESSEL FORM: Jar with a short $(9 \mathrm{~mm})$ rim

RIM AND LIP FORM: Everted rim with a rounded and exterior folded lip

CORE COLOR: $\mathrm{G}$ (fired in a reducing environment and cooled in the open air)

INTERIOR SURFACE COLOR: black

EXTERIOR SURFACE COLOR: yellowish-brown with very dark gray fire clouds on the rim and body

WALL THICKNESS (RIM, BODY, AND BASE IN MM): 4.4 mm, rim

INTERIOR SURFACE TREATMENT: smoothed on the rim and body

EXTERIOR SURFACE TREATMENT: smoothed on the lower body

HEIGHT (IN CM): 14.0

ORIFICE DIAMETER (IN CM): 9.9

DIAMETER AT BOTTOM OF RIM OR NECK (IN CM): 9.1

BASE DIAMETER (IN CM): 7.3

ESTIMATED VOLUME (IN LITERS): 0.83 liters

DECORATION: There are five closely-spaced rows of tool punctations on the rim (Figure A2-52). On the body there are horizontal and vertical rows of closely-spaced tool punctations covering almost the entirety of the body, except in a small band above the base.

TYPE: Sinner Linear Punctated

Figure A2-52. Sinner Linear Punctated jar (5425-2125).

SITE NAME OR SITE NUMBER: Wm. Handy Place

CONTEXT INFORMATION: From a grave (Burial 1) in a cemetery excavated by Robert Shelton in 1940. Associated vessels include V-2030 to V-2038.

ACCESSION NO.: 5425-2126 
VESSEL NO.: V-2039

NON-PLASTICS: grog

VESSEL FORM: Dugout canoe form (Figure A2-53a-b)

RIM AND LIP FORM: Direct rim and a flat lip

CORE COLOR: A (fired and cooled in an oxidizing environment)

INTERIOR SURFACE COLOR: brown

EXTERIOR SURFACE COLOR: brown

WALL THICKNESS (RIM, BODY, AND BASE IN MM): 4.4 mm, rim

INTERIOR SURFACE TREATMENT: smoothed

EXTERIOR SURFACE TREATMENT: smoothed

HEIGHT (IN CM): 4.8

ORIFICE DIAMETER (IN CM): $26.5 \mathrm{~cm}$ in length and $8.4 \mathrm{~cm}$ in width

DIAMETER AT BOTTOM OF RIM OR NECK (IN CM): N/A

BASE DIAMETER (IN CM): N/A

ESTIMATED VOLUME (IN LITERS): 0.51 liters

DECORATION: Plain

TYPE: Undefined plain ware vessel of an unique form (see Figure A2-53a-b)

Figure A2-53. Plain dugout canoe vessel (5425-2126): a, side view; b, view of the vessel interior.

SITE NAME OR SITE NUMBER: Wm. Handy Place

CONTEXT INFORMATION: From a grave (Burial 1) in a cemetery excavated by Robert Shelton in 1940. Associated vessels include V-2030 to V-2035 and V-2037 to V2039. 
ACCESSION NO.: 5425-2127

VESSEL NO.: V-2036

NON-PLASTICS: fine grog

VESSEL FORM: Carinated bowl with two rim panels

RIM AND LIP FORM: Everted rim with a rounded lip

CORE COLOR: A (fired and cooled in an oxidizing environment)

INTERIOR SURFACE COLOR: light yellowish-brown

EXTERIOR SURFACE COLOR: light yellowish-brown

WALL THICKNESS (RIM, BODY, AND BASE IN MM): 4.9 mm, rim

INTERIOR SURFACE TREATMENT: smoothed on the rim panels

EXTERIOR SURFACE TREATMENT: burnished on the rim and body

HEIGHT (IN CM): 5.0

ORIFICE DIAMETER (IN CM): 11.9

DIAMETER AT BOTTOM OF RIM OR NECK (IN CM): 8.8

BASE DIAMETER (IN CM): 3.4

ESTIMATED VOLUME (IN LITERS): 0.36 liters

DECORATION: There is a single horizontal engraved line on the upper rim panel, underneath the lip. The lower rim panel has a motif repeated 11 times around the vessel, defined by horizontal engraved lines at the top and bottom of the panel: the motif consists of sets of three closely-spaced vertical engraved lines between hatched triangles pendant from the upper horizontal engraved line (Figure A2-54).

TYPE: Simms Engraved

Figure A2-54. Simms Engraved carinated bowl (5425-2127). 
CONTEXT INFORMATION: From a burial (an adult) in a cemetery, excavated by Guy W. Stacy in 1941. This vessel was found in association with V-2258 to V-2263.

ACCESSION NO.: 5425-2128

VESSEL NO.: V-2262

NON-PLASTICS: grog and finely crushed bone

VESSEL FORM: Jar with a short rim and two brushed strap handles (Figure A2-55)

RIM AND LIP FORM: Everted rim and a rounded lip

CORE COLOR: $\mathrm{G}$ (fired in a reducing environment and cooled in the open air)

INTERIOR SURFACE COLOR: very dark gray

EXTERIOR SURFACE COLOR: dark yellowish-brown

WALL THICKNESS (RIM, BODY, AND BASE IN MM): 6.0 mm, rim

INTERIOR SURFACE TREATMENT: smoothed on the rim and upper body

EXTERIOR SURFACE TREATMENT: none

HEIGHT (IN CM): 10.7

ORIFICE DIAMETER (IN CM): 11.5

DIAMETER AT BOTTOM OF RIM OR NECK (IN CM): 10.2

BASE DIAMETER (IN CM): 6.3

ESTIMATED VOLUME (IN LITERS): 0.74 liters

DECORATION: The rim of this vessel has horizontal brushing marks, and there is a row of large tool punctates at the rim-body juncture (see Figure A2-55). The vessel body is divided into two panels by vertical appliqued fillets. One panel has two V-shaped appliqued fillets and two diagonal appliqued fillets that extend nearly to the vessel base, with diagonal brushing marks between the fillets (see Figure A2-55). The second panel has both V-shaped appliqued fillets and diagonal and V-shaped rows of tool punctates, but again with diagonal brushing marks between those elements (see Figure A2-55).

TYPE: Haley Complicated Incised

Figure A2-55. Haley Complicated Incised jar (5425-2128) from the Wm. Handy Place. 
SITE NAME OR SITE NUMBER: Wm. Handy Place

CONTEXT INFORMATION: From a grave (Burial C) in a cemetery excavated by Glenn Martin in 1940. Associated vessels are V-2098, V-2100, and V-2101.

ACCESSION NO.: 5425-2129

VESSEL NO.: V-2099

NON-PLASTICS: grog and bone

VESSEL FORM: Bowl with opposed attachments/appendages, including tab tail $(18 \mathrm{~mm}$ in length, $16 \mathrm{~mm}$ in width at the rim, and $10 \mathrm{~mm}$ thick) and an attachment for an effigy head (Figure A2-56)

RIM AND LIP FORM: Everted rim and a rounded lip

CORE COLOR: A (fired and cooled in a high oxygen environment)

INTERIOR SURFACE COLOR: strong brown

EXTERIOR SURFACE COLOR: strong brown; fire clouding on the base

WALL THICKNESS (RIM, BODY, AND BASE IN MM): 5.7 mm, rim

INTERIOR SURFACE TREATMENT: smoothed on the rim and the body

EXTERIOR SURFACE TREATMENT: smoothed on the rim and the body

HEIGHT (IN CM): 4.5

ORIFICE DIAMETER (IN CM): 10.5

DIAMETER AT BOTTOM OF RIM OR NECK (IN CM): N/A

BASE DIAMETER (IN CM): 4.3

ESTIMATED VOLUME (IN LITERS): 0.19 liters

DECORATION: The bowl itself is plain; there is a single incised line at the flattened end of the tab tail (see Figure A2-56)

TYPE: Undefined effigy bowl type 
Figure A2-56. Plain effigy bowl (5425-2129).

SITE NAME OR SITE NUMBER: Wm. Handy Place

CONTEXT INFORMATION: From a burial (Burial 3) in a cemetery excavated by Robert Shelton in 1940. Associated vessels in the grave are V-2045, V-2047, and V2048.

ACCESSION NO.: 5425-2130

VESSEL NO.: V-2046

NON-PLASTICS: grog

VESSEL FORM: Carinated bowl with two rim panels and four rim peaks (each $15 \mathrm{~mm}$ wide)

RIM AND LIP FORM: Direct rim with a rounded lip

CORE COLOR: $\mathrm{G}$ (fired in a reducing environment and cooled in the open air)

INTERIOR SURFACE COLOR: very dark grayish-brown

EXTERIOR SURFACE COLOR: strong brown

WALL THICKNESS (RIM, BODY, AND BASE IN MM): 6.7 mm, rim

INTERIOR SURFACE TREATMENT: smoothed on the rim and body

EXTERIOR SURFACE TREATMENT: burnished on the rim and the body

HEIGHT (IN CM): 7.0

ORIFICE DIAMETER (IN CM): 12.0

DIAMETER AT BOTTOM OF RIM OR NECK (IN CM): 13.5

BASE DIAMETER (IN CM): N/A, rounded base

ESTIMATED VOLUME (IN LITERS): 0.50 liters

DECORATION: The upper rim panel is plain. The lower rim panel is divided into four rectangular panels by four sets of eight or nine closely-spaced vertical engraved lines 
(Figure A2-57); these vertical engraved lines are set underneath each of the rim peaks. Each rectangular panel has a single horizontal engraved line in it, with rows of excised punctations (two panels have two sets of seven excised punctations and the other two panels have sets of six excised punctations) both above and below the horizontal line (Figure A2-57).

TYPE: Belcher Engraved, var. unspecified

Figure A2-57. Belcher Engraved, var. unspecified carinated bowl (5425-2130).

SITE NAME OR SITE NUMBER: Wm. Handy Place

CONTEXT INFORMATION: From a grave (Burial 1) excavated by Robert Shelton in 1940. Associated vessels include V-2030 to V-2033 and V-2035 to V-2039.

ACCESSION NO.: 5425-2131

VESSEL NO.: V-2034

NON-PLASTICS: grog

VESSEL FORM: Globular jar with a short $(15 \mathrm{~mm})$ rim

RIM AND LIP FORM: Inverted rim with a rounded and exterior folded lip

CORE COLOR: $\mathrm{G}$ (fired in a reducing environment and cooled in the open air)

INTERIOR SURFACE COLOR: very dark grayish-brown

EXTERIOR SURFACE COLOR: strong brown with very dark grayish-brown fire clouds

WALL THICKNESS (RIM, BODY, AND BASE IN MM): 4.4 mm, rim; 5.1 mm, body

INTERIOR SURFACE TREATMENT: smoothed on the rim and body

EXTERIOR SURFACE TREATMENT: smoothed on the body

HEIGHT (IN CM): 14.0

ORIFICE DIAMETER (IN CM): 13.0

DIAMETER AT BOTTOM OF RIM OR NECK (IN CM): 12.5

BASE DIAMETER (IN CM): N/A, rounded base 
ESTIMATED VOLUME (IN LITERS): 1.09 liters

DECORATION: The jar rim has five rows of vertical stamping (Figure A2-58). The vessel body has trailed nested diamonds repeated four times around the body.

TYPE: Cowhide Stamped, var. unspecified (see Webb 1959:Figure 109p) or De Roche Incised (Early 1993:87, 2000:96 and Figure 43), because of the nested diamond motif. Early (1993:87-88) notes that De Roche Incised vessels in the Ouachita River valley are both grog-tempered and shell-tempered.

Figure A2-58. Cowhide Stamped, var. unspecified or De Roche Incised jar (5425-2131).

SITE NAME OR SITE NUMBER: Wm. Handy Place

CONTEXT INFORMATION: From a grave in a cemetery excavated by Horace McLendon in the fall of 1941. Associated vessels (from several graves dug at that time) include V-2342 to V-2365.

ACCESSION NO.: 5425-2149

VESSEL NO.: V-2349

NON-PLASTICS: grog

VESSEL FORM: Jar with two small (14 mm in diameter) and opposed lug handles

RIM AND LIP FORM: Everted rim and rounded lip

CORE COLOR: $\mathrm{G}$ (fired in a reducing environment and cooled in the open air)

INTERIOR SURFACE COLOR: black

EXTERIOR SURFACE COLOR: strong brown, with fire clouds on body and rim

WALL THICKNESS (RIM, BODY, AND BASE IN MM): 5.6 mm, rim

INTERIOR SURFACE TREATMENT: smoothed on the rim and body; burnished patches on the rim

EXTERIOR SURFACE TREATMENT: smoothed on the lower body

HEIGHT (IN CM): 13.2 
ORIFICE DIAMETER (IN CM): 11.0

DIAMETER AT BOTTOM OF RIM OR NECK (IN CM): 9.8

BASE DIAMETER (IN CM): 5.8

ESTIMATED VOLUME (IN LITERS): 0.87 liters

DECORATION: The jar rim has three opposed rows of diagonal incised lines, and there is a single broad incised line at the rim-body juncture (Figure A2-59). The vessel body has light diagonal opposed brushed-incised lines extending part way towards the base of the vessel.

TYPE: cf. Foster Trailed-Incised, var. unspecified

Figure A2-59. Foster Trailed-Incised, var. unspecified jar (5425-2149).

SITE NAME OR SITE NUMBER: Wm. Handy Place

CONTEXT INFORMATION: From a grave (Burial 1) excavated in 1940 by Robert Shelton. Associated vessels include V-2030 to V-2034 and V-2036 to V-2039.

ACCESSION NO.: 5425-2468

VESSEL NO.: V-2035

NON-PLASTICS: grog

VESSEL FORM: Bottle with a spool neck (Hodges Engraved, var. Candler)

RIM AND LIP FORM: Direct rim with a rounded and exterior folded lip

CORE COLOR: $\mathrm{G}$ (fired in a reducing environment and cooled in the open air)

INTERIOR SURFACE COLOR: very dark gray

EXTERIOR SURFACE COLOR: very dark gray

WALL THICKNESS (RIM, BODY, AND BASE IN MM): $6.0 \mathrm{~mm}$, rim

INTERIOR SURFACE TREATMENT: none

EXTERIOR SURFACE TREATMENT: burnished on the neck and body 
HEIGHT (IN CM): 4.1+ (bottle body height)

ORIFICE DIAMETER (IN CM): 5.3

DIAMETER AT BOTTOM OF RIM OR NECK (IN CM): 4.75

\section{BASE DIAMETER (IN CM): N/A}

\section{ESTIMATED VOLUME (IN LITERS): N/A}

DECORATION: The Friendship Engraved bottle sherds represent part of the vessel body. Decorative elements apparent include four horizontal engraved lines near the base, each with tick marks, that are bisected by a single vertical appliqued ridge (Figure A2-60), as well as engraved semi-circles, one of which is filled with tool punctates. Adjacent to the engraved semi-circles are at least two vertical cross-hatched bands-one with tick marks along one edge-and a curving arc of three engraved lines.

The Hodges Engraved, var. Candler sherds are from the upper part of the bottle body (see Figure A2-60, left) as well as the undecorated spool neck. The decoration on the vessel body includes rectilinear cross-hatched engraved zones with a series of large and small negative ovals separated by an area bisected by three closely-spaced diagonal engraved lines. One of the rectilinear cross-hatched engraved zones has a row of small tick marks along one outside edge (see Figure A2-60, left).

TYPE: Friendship Engraved and Hodges Engraved, var. Candler vessels are represented in the few sherds in this accession no., possibly as part of a stacked vessel

Figure A2-60. Sherds from Friendship Engraved (right side) and Hodges Engraved, var. Candler (left side) vessels (5425-2468).

SITE NAME OR SITE NUMBER: Wm. Handy Place

CONTEXT INFORMATION: From a grave in a cemetery excavated by Horace McLendon in the fall of 1941. Associated vessels (from several graves dug at that time) include V-2342 to V-2365.

ACCESSION NO.: 5425-5978

VESSEL NO.: V-2361

NON-PLASTICS: fine grog

VESSEL FORM: Carinated bowl with a sprocket rim (cf. Miller 1986) 
RIM AND LIP FORM: Direct rim with a rounded and exterior folded lip

CORE COLOR: L (incompletely oxidized, and possibly smudged)

INTERIOR SURFACE COLOR: brown

EXTERIOR SURFACE COLOR: very dark gray

WALL THICKNESS (RIM, BODY, AND BASE IN MM): 3.8 mm, rim; $4.1 \mathrm{~mm}$, body

INTERIOR SURFACE TREATMENT: burnished on the rim and smoothed on the body

EXTERIOR SURFACE TREATMENT: burnished on the rim and body

HEIGHT (IN CM): ca. 4.0 (estimated)

ORIFICE DIAMETER (IN CM): 18.0

DIAMETER AT BOTTOM OF RIM OR NECK (IN CM): 18.5

BASE DIAMETER (IN CM): N/A

ESTIMATED VOLUME (IN LITERS): est. 0.43 liters

DECORATION: The rim has a negative engraved scroll motif, repeated four times around the vessel (Figure A2-61). The negative scroll is defined by closely-spaced vertical engraved line dividers and an upper and lower scroll fill background of either horizontal engraved lines or small triangular or rectangular hatched zones. The panel between each of the negative scrolls (defined by the vertical engraved line dividers) also has small opposed arcs of engraved lines pendant from the upper and lower part of the rim panel (Figure A2-61). These panels sit under each of the rim sprockets.

TYPE: Friendship Engraved

Figure A2-61. Friendship Engraved carinated bowl (5425-5978) from the Wm. Handy Place.

SITE NAME OR SITE NUMBER: Wm. Handy Place

CONTEXT INFORMATION: From a grave in a cemetery excavated by Horace McLendon in the fall of 1941. Associated vessels (from several graves dug at that time) include V-2342 to V-2365.

ACCESSION NO.: 5425-5979 
VESSEL NO.: V-2362

NON-PLASTICS: grog

VESSEL FORM: Carinated bowl

RIM AND LIP FORM: Direct rim with a rounded and exterior folded lip

CORE COLOR: B (fired and cooled in a low oxygen environment)

INTERIOR SURFACE COLOR: very dark gray with brown fire clouds on the rim and the body

EXTERIOR SURFACE COLOR: very dark gray, with brown fire clouds on the rim and body

WALL THICKNESS (RIM, BODY, AND BASE IN MM): $3.4 \mathrm{~mm}$, rim; $4.0 \mathrm{~mm}$, body; $5.6 \mathrm{~mm}$, base

INTERIOR SURFACE TREATMENT: burnished on the rim and the body

EXTERIOR SURFACE TREATMENT: burnished on the rim and body

HEIGHT (IN CM): 6.3

ORIFICE DIAMETER (IN CM): 17.7

DIAMETER AT BOTTOM OF RIM OR NECK (IN CM): 16.0

BASE DIAMETER (IN CM): N/A, rounded base

ESTIMATED VOLUME (IN LITERS): 0.67 liters

DECORATION: The upper part of the rim has two horizontal engraved lines. Below that is a negative engraved scroll motif repeated four times around the vessel (Figure A2-62). The scroll fill background consists of upper and lower zones filled with closely-spaced vertical engraved lines. The negative scrolls end at a punctate-filled engraved circle surrounded by concentric semi-circles (Figure A2-62). The punctate-filled engraved circle element is repeated four times around the rim.

TYPE: Friendship Engraved

Figure A2-62. Friendship Engraved carinated bowl (5425-5979). 
SITE NAME OR SITE NUMBER: Wm. Handy Place

CONTEXT INFORMATION: From a grave in a cemetery excavated by Horace McLendon in the fall of 1941. Associated vessels (from several graves dug at that time) include V-2342 to V-2365.

ACCESSION NO.: 5425-6410

VESSEL NO.: V-2365

NON-PLASTICS: none; sandy paste

VESSEL FORM: Bottle with a tapered neck

RIM AND LIP FORM: Direct rim with a rounded and exterior folded lip

CORE COLOR: $\mathrm{H}$ (fired in a reducing environment and cooled in the open air)

INTERIOR SURFACE COLOR: yellowish-brown

EXTERIOR SURFACE COLOR: dark grayish-brown

WALL THICKNESS (RIM, BODY, AND BASE IN MM): 5.6 mm, neck; 5.0 mm, body; $7.1 \mathrm{~mm}$, base

INTERIOR SURFACE TREATMENT: none

EXTERIOR SURFACE TREATMENT: burnished on the neck and body

HEIGHT (IN CM): 7.3 (neck height)

ORIFICE DIAMETER (IN CM): 4.1

DIAMETER AT BOTTOM OF RIM OR NECK (IN CM): 5.2

BASE DIAMETER (IN CM): 7.1

ESTIMATED VOLUME (IN LITERS): est. 0.15 liters

DECORATION: The body of the bottle has engraved scrolls, with fine lines in parallel sets, and vertical panels (Figure A2-63). Several of the outside engraved lines in a set of fine engraved lines also have small spurs, a common decorative element on Haley Engraved bottles (Suhm and Jelks 1962:61).

TYPE: Haley Engraved 
Figure A2-63. Sherds from a Haley Engraved bottle (5425-6410), including a plain bottle neck.

SITE NAME OR SITE NUMBER: Wm. Handy Place

CONTEXT INFORMATION: From a grave in a cemetery excavated by Horace McLendon in the fall of 1941. Associated vessels (from several graves dug at that time) include V-2342 to V-2365.

ACCESSION NO:: 5425-6425

VESSEL NO.: V-2364

NON-PLASTICS: grog

VESSEL FORM: Bottle with a tapered neck

RIM AND LIP FORM: Direct rim and a rounded, exterior folded, lip

CORE COLOR: $\mathrm{H}$ (fired in a reducing environment but cooled in the open air)

INTERIOR SURFACE COLOR: dark gray

EXTERIOR SURFACE COLOR: black

WALL THICKNESS (RIM, BODY, AND BASE IN MM): $11.1 \mathrm{~mm}$, base

INTERIOR SURFACE TREATMENT: none

EXTERIOR SURFACE TREATMENT: burnished

HEIGHT (IN CM): 7.3 (bottle neck height)

ORIFICE DIAMETER (IN CM): 3.9

DIAMETER AT BOTTOM OF RIM OR NECK (IN CM): 4.5

BASE DIAMETER (IN CM): N/A

ESTIMATED VOLUME (IN LITERS): N/A 
DECORATION: The bottle body has a series of engraved concentric circles repeated four times around the vessel. The central circle is a swastika in circle engraved element (Figure A2-64) (see Reilly 2004:Figure 7c). There is a cross-hatched and ticked engraved bracket divider between each of the sets of concentric circles.

TYPE: unidentified engraved bottle

Figure A2-64. Sherds from an engraved bottle (5425-6425), including a plain bottle neck.

SITE NAME OR SITE NUMBER: Wm. Handy Place

CONTEXT INFORMATION: From a grave in a cemetery excavated by Horace McLendon in the fall of 1941. Associated vessels (from several graves dug at that time) include V-2342 to V-2365.

ACCESSION NO.: 5425-6426

VESSEL NO.: V-2360

NON-PLASTICS: grog

VESSEL FORM: Carinated bowl

RIM AND LIP FORM: Direct rim with a flat and exterior folded lip

CORE COLOR: A (fired and cooled in a high oxygen environment)

INTERIOR SURFACE COLOR: dark brown

EXTERIOR SURFACE COLOR: dark brown

WALL THICKNESS (RIM, BODY, AND BASE IN MM): 5.7 mm, rim; 5.5 mm, body

INTERIOR SURFACE TREATMENT: smoothed on the body and burnished on the rim

EXTERIOR SURFACE TREATMENT: burnished

HEIGHT (IN CM): $5.0+$ (rim height is $3.0 \mathrm{~cm}$ )

ORIFICE DIAMETER (IN CM): 14.0

DIAMETER AT BOTTOM OF RIM OR NECK (IN CM): N/A

BASE DIAMETER (IN CM): N/A 
ESTIMATED VOLUME (IN LITERS): est. 0.42 liters

DECORATION: There are triangular tick marks underneath the vessel lip and at the carination (Figure A2-65). Between them are four panels with horizontal interlocking scrolls. The ends of each panel are comprised of a hatched bracket divider and a pendant rectangle (Figure A2-65). The interlocking scroll itself includes a narrow central hatched band and two small rectangular hatched attachments that extend to the top or bottom of the panel. On either side of the central hatched band is a single engraved horizontal interlocking scroll line.

TYPE: Handy Engraved

Figure A2-65. Handy Engraved carinated bowl (5425-6426).

SITE NAME OR SITE NUMBER: Wm. Handy Place

CONTEXT INFORMATION: From a burial (an adult) in a cemetery, excavated by Guy W. Stacy in 1941. This vessel was found in association with V-2258 to V-2263.

ACCESSION NO.: 6125-7142A

VESSEL NO.: V-2259

NON-PLASTICS: grog

VESSEL FORM: Carinated bowl with a sprocket rim (cf. Miller 1986)

RIM AND LIP FORM: Direct rim with a flat lip

CORE COLOR: B (fired and cooled in a reducing environment)

INTERIOR SURFACE COLOR: very dark grayish-brown

EXTERIOR SURFACE COLOR: very dark grayish-brown

WALL THICKNESS (RIM, BODY, AND BASE IN MM): $4.5 \mathrm{~mm}$, rim; $4.1 \mathrm{~mm}$, body; the sprocket rim is $8.0 \mathrm{~mm}$ in width

INTERIOR SURFACE TREATMENT: smoothed on the body and burnished on the rim EXTERIOR SURFACE TREATMENT: burnished on the rim and the body 
HEIGHT (IN CM): 6.5

ORIFICE DIAMETER (IN CM): 20.5

DIAMETER AT BOTTOM OF RIM OR NECK (IN CM): 19.5

BASE DIAMETER (IN CM): N/A, rounded base

ESTIMATED VOLUME (IN LITERS): 0.80 liters

DECORATION: The rim has negative engraved scrolls outlined by alternating crosshatched and hatched scroll fill zones (Figure A2-66) at the top and bottom of the scroll; there are dashed lines separating the hatched scroll fill zone areas. The negative scroll repeats four times around the vessel. Each of the negative scrolls ends in a negative Sshaped element defined by excised areas and spurs (Figure A2-66).

TYPE: Friendship Engraved

Figure A2-66. Friendship Engraved carinated bowl (6125-7142A).

SITE NAME OR SITE NUMBER: Wm. Handy Place

CONTEXT INFORMATION: From a burial (an adult) in a cemetery, excavated by Guy W. Stacy in 1941. This vessel was found in association with V-2258 to V-2263.

ACCESSION NO.: 5425-7143

VESSEL NO.: V-2260

NON-PLASTICS: grog-bone

VESSEL FORM: Carinated bowl

RIM AND LIP FORM: Direct rim with a rounded and exterior folded lip

CORE COLOR: K (incompletely oxidized and possibly smudged)

INTERIOR SURFACE COLOR: black

EXTERIOR SURFACE COLOR: strong brown

WALL THICKNESS (RIM, BODY, AND BASE IN MM): $6.6 \mathrm{~mm}$, rim; $6.7 \mathrm{~mm}$, body 
INTERIOR SURFACE TREATMENT: burnished on the rim and body

EXTERIOR SURFACE TREATMENT: burnished on the rim and body

HEIGHT (IN CM): N/A

ORIFICE DIAMETER (IN CM): 19.0

DIAMETER AT BOTTOM OF RIM OR NECK (IN CM): 20.1

BASE DIAMETER (IN CM): N/A

ESTIMATED VOLUME (IN LITERS): N/A

DECORATION: The rim has a horizontal interlocking engraved scroll motif that is repeated four times around the vessel (Figure A2-67). Each panel is defined by two hatched vertical bracket dividers that extend from the top to the bottom of the panel; there is also a single isolated hatched bracket within the panel. The interlocking scroll consists of a single centrally-placed horizontal engraved line, two connecting hatched brackets that extend to either the top or bottom of the panel, and a short curvilinear engraved line that wraps around one end of the central horizontal line (Figure A2-67). There are short triangular and linear tick marks on the central horizontal engraved line and the upper engraved panel line. A white kaolin clay pigment has also been rubbed in the engraved lines.

TYPE: Handy Engraved

Figure A2-67. Handy Engraved carinated bowl (5425-7143).

SITE NAME OR SITE NUMBER: Wm. Handy Place

CONTEXT INFORMATION: From a grave (Burial 4) in a cemetery excavated by Robert Shelton in 1940. Associated vessels in the grave are V-2049 and V-2051 to V2053.

ACCESSION NO.: 5425-7147

VESSEL NO.: V-2050

NON-PLASTICS: grog

VESSEL FORM: Jar 
RIM AND LIP FORM: Direct rim and a rounded, exterior folded, lip

CORE COLOR: B (fired and cooled in a low oxygen environment)

INTERIOR SURFACE COLOR: very dark gray

EXTERIOR SURFACE COLOR: very dark gray

WALL THICKNESS (RIM, BODY, AND BASE IN MM): $6.6 \mathrm{~mm}$, rim

INTERIOR SURFACE TREATMENT: smoothed on the rim

EXTERIOR SURFACE TREATMENT: none

HEIGHT (IN CM): 11.4

ORIFICE DIAMETER (IN CM): 10.4

DIAMETER AT BOTTOM OF RIM OR NECK (IN CM): 9.7

BASE DIAMETER (IN CM): N/A, rounded base

ESTIMATED VOLUME (IN LITERS): 0.71 liters

DECORATION: The rim has 10 closely-spaced rows of vertical stamping. The vessel body has four sets of incised concentric circles with a central dimpled appliqued node (Figure A2-68).

TYPE: Foster Trailed-Incised, var. Moore (Schambach and Miller 1984:121 and Figure 11-10)

Figure A2-68. Foster Trailed-Incised, var. Moore jar (5425-7147) from the Wm. Handy Place.

SITE NAME OR SITE NUMBER: Wm. Handy Place

CONTEXT INFORMATION: From a grave (Burial 5) in a cemetery excavated by Robert Shelton in 1940. It is associated with V-2054.

ACCESSION NO.: 5425-7156A

VESSEL NO.: V-2055 
NON-PLASTICS: shell

VESSEL FORM: Jar

RIM AND LIP FORM: Direct rim with a rounded and exterior folded lip

CORE COLOR: B (fired and cooled in a low oxygen environment)

INTERIOR SURFACE COLOR: dark grayish-brown

EXTERIOR SURFACE COLOR: dark grayish-brown

WALL THICKNESS (RIM, BODY, AND BASE IN MM): $5.6 \mathrm{~mm}$, rim; $5.0 \mathrm{~mm}$, body

INTERIOR SURFACE TREATMENT: smoothed on the rim

EXTERIOR SURFACE TREATMENT: none

HEIGHT (IN CM): 9.0

ORIFICE DIAMETER (IN CM): 10.1

DIAMETER AT BOTTOM OF RIM OR NECK (IN CM): 8.6

BASE DIAMETER (IN CM): 7.0

ESTIMATED VOLUME (IN LITERS): 0.55 liters

DECORATION: There are four closely-spaced rows of tool punctations on the rim. The vessel body has three repeating sets of concentric trailed circles (Figure A2-69).

TYPE: Keno Trailed, var. Scott's Lake (Schambach and Miller 1984:123 and Figure 1126a)

Figure A2-69. Keno Trailed, var. Scott's Lake jar (5425-7156A).

SITE NAME OR SITE NUMBER: Wm. Handy Place

CONTEXT INFORMATION: From a grave (Burial 1) excavated by Robert Shelton in 1940. Associated vessels include V-2030, V-2031, and V-2033 to V-2039.

ACCESSION NO.: 5425-7158A-L 
VESSEL NO.: V-2032

NON-PLASTICS: grog

VESSEL FORM: Carinated bowl

RIM AND LIP FORM: Direct rim with a rounded and exterior folded lip

CORE COLOR: $\mathrm{H}$ (fired in a reducing environment and cooled in the open air)

INTERIOR SURFACE COLOR: brown

EXTERIOR SURFACE COLOR: very dark gray

WALL THICKNESS (RIM, BODY, AND BASE IN MM): 3.9 mm, rim; $4.0 \mathrm{~mm}$, body

INTERIOR SURFACE TREATMENT: smoothed on the body and rim

EXTERIOR SURFACE TREATMENT: burnished on the body and rim

HEIGHT (IN CM): 8.1

ORIFICE DIAMETER (IN CM): 17.0

DIAMETER AT BOTTOM OF RIM OR NECK (IN CM): 17.2

BASE DIAMETER (IN CM): N/A

ESTIMATED VOLUME (IN LITERS): 0.83 liters

DECORATION: The rim panel has negative scrolls that are repeated four times around the vessel (Figure A2-70). The upper and lower scroll fill elements each include three excised brackets and negative ovals, and the ends of the fill elements are hooked arms with tick marks. The central element of the motif is a large negative oval defined by cross-hatched brackets that extend from the rim to the vessel carination (Figure A2-70).

TYPE: Hodges Engraved, var. Armour (Schambach and Miller 1984:Figure 11-34a)

Figure A2-70. Hodges Engraved, var. Armour carinated bowl (5425-7158A-L).

SITE NAME OR SITE NUMBER: Wm. Handy Place

CONTEXT INFORMATION: From a grave (Burial B) in a cemetery excavated by Glenn Martin in 1940. Associated vessels in the grave include V-2092 to V-2095 and V-2097. 
ACCESSION NO.: 5425-7180

VESSEL NO.: V-2096

NON-PLASTICS: grog and bone (less than $5 \%$ of the paste)

VESSEL FORM: Carinated bowl with two rim panels and four rim peaks (Figure A2-71)

RIM AND LIP FORM: Direct rim and a rounded lip

CORE COLOR: $F$ (fired in a reducing environment but cooled in the open air)

INTERIOR SURFACE COLOR: strong brown and dark grayish-brown

EXTERIOR SURFACE COLOR: strong brown

WALL THICKNESS (RIM, BODY, AND BASE IN MM): $5.7 \mathrm{~mm}$, rim; $4.3 \mathrm{~mm}$, body

INTERIOR SURFACE TREATMENT: smoothed on the rim and body

EXTERIOR SURFACE TREATMENT: smoothed on the rim and body

HEIGHT (IN CM): 5.5

ORIFICE DIAMETER (IN CM): 7.0

DIAMETER AT BOTTOM OF RIM OR NECK (IN CM): 8.2

BASE DIAMETER (IN CM): 3.2

ESTIMATED VOLUME (IN LITERS): 0.23 liters

DECORATION: The upper rim panel is plain. The lower rim panel is divided into four roughly rectangular areas defined by two sets (of three lines each) of vertical arcing engraved lines (Figure A2-71) on either side of the rectangular-shaped area; the vertical arcing lines occur under each of the rim peaks. Within these rectangular areas is a single central horizontal engraved line with single rows of excised punctations both above and below the horizontal line; each of the rows of punctations have either six or seven excised punctations (Figure A2-71).

TYPE: Belcher Engraved, var. unspecified

Figure A2-71. Belcher Engraved, var. unspecified carinated bowl (5425-7180) from the Wm. Handy Place. 


\section{Appendix 3,}

\section{Vessels from the Lester Bros. Plantation (3LA38) and Lester Bros. Place (3LA48)}

SITE NAME OR SITE NUMBER: Lester Bros. Place

CONTEXT INFORMATION: From a grave in a Caddo cemetery, 1928.

ACCESSION NO.: 5425-495

VESSEL NO.: V-279

NON-PLASTICS: fine grog

VESSEL FORM: Bowl with opposed attachments

RIM AND LIP FORM: Direct rim with a rounded lip

CORE COLOR: $\mathrm{F}$ (reducing environment, but cooled in the open air)

INTERIOR SURFACE COLOR: strong brown with fire clouds on the base

EXTERIOR SURFACE COLOR: strong brown with fire clouds on the body and the base WALL THICKNESS (RIM, BODY, AND BASE IN MM): 6.3 mm, rim

INTERIOR SURFACE TREATMENT: smoothed

EXTERIOR SURFACE TREATMENT: burnished

HEIGHT (IN CM): 6.5

ORIFICE DIAMETER (IN CM): 10.0

DIAMETER AT BOTTOM OF RIM OR NECK (IN CM): N/A

BASE DIAMETER (IN CM): 4.2

ESTIMATED VOLUME (IN LITERS): 0.26 liters

DECORATION: Plain 
TYPE: Undefined plain bowl with one rim peak and an opposed tab tail (31 $\mathrm{mm}$ in width and $12 \mathrm{~mm}$ in height)

SITE NAME OR SITE NUMBER: Lester Bros. Place

CONTEXT INFORMATION: From a grave in a Caddo cemetery exposed during dynamiting of a levee, 1929.

ACCESSION NO.: 5425-778

VESSEL NO.: V-359

NON-PLASTICS: grog and fine shell

VESSEL FORM: Bottle with a straight neck

RIM AND LIP FORM: Direct but flared rim, with a rounded lip

CORE COLOR: B (fired and cooled in a reducing environment)

INTERIOR SURFACE COLOR: very dark grayish-brown

EXTERIOR SURFACE COLOR: very dark grayish-brown

WALL THICKNESS (RIM, BODY, AND BASE IN MM): 4.1 mm, neck

INTERIOR SURFACE TREATMENT: smoothed only on the upper bottle neck

EXTERIOR SURFACE TREATMENT: neck and body are burnished

HEIGHT (IN CM): 21.0

ORIFICE DIAMETER (IN CM): 5.0

DIAMETER AT BOTTOM OF RIM OR NECK (IN CM): $4.8 ; 16.0 \mathrm{~cm}$ in width at the widest part of the body

BASE DIAMETER (IN CM): N/D, rounded base

ESTIMATED VOLUME (IN LITERS): 0.59 liters

DECORATION: The main engraved element on this bottle consists of four panels of engraved concentric circles alternating with engraved dashes or slot-like circular lines (Figure A3-1). At the center of each of these panels is a circle or sun symbol with five 
spurs or excised triangles along its margins, and with a small circle at its center. Each of the panels are divided from each other by engraved dashes as well as an upper zone of cross-hatched pendant triangles and four negative ovals (Figure A3-1).

TYPE: Belcher Engraved, var. Soda Lake

Figure A3-1. Belcher Engraved, var. Soda Lake bottle from the Lester Bros. Place (5425778).

SITE NAME OR SITE NUMBER: Lester Bros. Place

CONTEXT INFORMATION: Exposed after a Red River flood, 1915

ACCESSION NO.: 5425-780

VESSEL NO.: V-41

NON-PLASTICS: grog

VESSEL FORM: Jar with four strap handles and four rim peaks above the handles

RIM AND LIP FORM: Direct rim, with a rounded but exterior folded lip

CORE COLOR: B (fired and cooled in a reducing environment)

INTERIOR SURFACE COLOR: black

EXTERIOR SURFACE COLOR: very dark grayish-brown

WALL THICKNESS (RIM, BODY, AND BASE IN MM): 4.9 mm, rim

INTERIOR SURFACE TREATMENT: burnished on the rim and smoothed on the body

EXTERIOR SURFACE TREATMENT: burnished on the rim and body

HEIGHT (IN CM): 11.5

ORIFICE DIAMETER (IN CM): 10.4

DIAMETER AT BOTTOM OF RIM OR NECK (IN CM): 8.9

BASE DIAMETER (IN CM): 6.2

ESTIMATED VOLUME (IN LITERS): 0.72 liters 
DECORATION: The rim of this jar is plain. The body has four repeating sets of engraved semi-circles with either four or five lines in each set of semi-circles (Figure A3-2). The uppermost semi-circular engraved line is connected to sets of small hatched pendant triangles that extend downward from the top of the vessel body.

TYPE: Avery Engraved, var. Bradshaw

Figure A3-2. Avery Engraved, var. Bradshaw jar (5425-780).

SITE NAME OR SITE NUMBER: Lester Bros. Place

CONTEXT INFORMATION: From a grave in a Caddo cemetery, 1928.

ACCESSION NO.: 5425-781

VESSEL NO.: V-159

NON-PLASTICS: grog

VESSEL FORM: Jar

RIM AND LIP FORM: Everted rim with a rounded and exterior folded lip

CORE COLOR: B (fired and cooled in a reducing environment)

INTERIOR SURFACE COLOR: very dark grayish-brown

EXTERIOR SURFACE COLOR: strong brown with fire clouds on the rim and body

WALL THICKNESS (RIM, BODY, AND BASE IN MM): $5.2 \mathrm{~mm}$, rim

INTERIOR SURFACE TREATMENT: smoothed on the rim and body

EXTERIOR SURFACE TREATMENT: lower undecorated portion of the body is burnished

HEIGHT (IN CM): 11.8

ORIFICE DIAMETER (IN CM): 11.0

DIAMETER AT BOTTOM OF RIM OR NECK (IN CM): 9.2

BASE DIAMETER (IN CM): 5.5 
ESTIMATED VOLUME (IN LITERS): 0.78 liters

DECORATION: Vertical brushing on the rim and body, and there is a single horizontal incised line at the rim-body juncture (Figure A3-3). There are eight horizontal sets of stacked incised semi-circles (four lines per semi-circle on the rim and five lines per semicircle on the body) on the rim and body, and the incised lines have cut through the brushing.

TYPE: unidentified brushed-incised jar. If the brushing had been confined to the incised semi-circles, it could be included as an undefined variety of Mound Tract Incised and Brushed (see Kelley 1997:52).

Figure A3-3. Brushed-incised jar (5425-781).

SITE NAME OR SITE NUMBER: Lester Bros. Place

CONTEXT INFORMATION: From a grave in a Caddo cemetery, 1927.

ACCESSION NO.: 5425-783

VESSEL NO.: V-153

NON-PLASTICS: fine grog

VESSEL FORM: Bottle with flared neck

RIM AND LIP FORM: The neck is direct, but the rim is everted/flared, with a flat lip

CORE COLOR: $\mathrm{G}$ (fired in a reducing environment, but cooled in the open air)

INTERIOR SURFACE COLOR: very dark gray

EXTERIOR SURFACE COLOR: strong brown, with fire clouds on the body and neck

WALL THICKNESS (RIM, BODY, AND BASE IN MM): $4.8 \mathrm{~mm}$, rim

INTERIOR SURFACE TREATMENT: smoothed on the upper bottle neck

EXTERIOR SURFACE TREATMENT: burnished on the body and neck

HEIGHT (IN CM): 15.3

ORIFICE DIAMETER (IN CM): 4.9 
DIAMETER AT BOTTOM OF RIM OR NECK (IN CM): 4.7; $13.4 \mathrm{~cm}$ at the widest part of the body

\section{BASE DIAMETER (IN CM): 4.7}

\section{ESTIMATED VOLUME (IN LITERS): 0.29 liters}

DECORATION: There are two horizontal engraved lines at the top of the bottle body. The main engraved element is a continuous meandering scroll line with small triangular tick marks on it (Figure A3-4). Controlling the pattern of the meandering scroll are four upper and lower engraved elements that are pendant from the upper and lower horizontal engraved lines on the body. These elements begin with four simple pendant triangles, and each have long curving sets of closely-spaced engraved lines that end near the ticked meandering scroll (Figure A3-4).

TYPE: Hodges Engraved, var. unspecified

Figure A3-4. Hodges Engraved bottle (5425-783).

SITE NAME OR SITE NUMBER: Lester Bros. Place

CONTEXT INFORMATION: From a grave in a Caddo cemetery exposed during the dynamiting of a Red River levee, June 1929.

ACCESSION NO.: 5425-877

VESSEL NO.: V-150

NON-PLASTICS: grog

VESSEL FORM: Carinated bowl with two rim panels

RIM AND LIP FORM: Everted with a rounded lip

CORE COLOR: B (fired and cooled in a reducing environment)

INTERIOR SURFACE COLOR: grayish-brown

EXTERIOR SURFACE COLOR: strong brown; fire clouding on the rim and body

WALL THICKNESS (RIM, BODY, AND BASE IN MM): 4.3 mm, rim

INTERIOR SURFACE TREATMENT: smoothed on the rim and body 
EXTERIOR SURFACE TREATMENT: burnished on the rim and body

HEIGHT (IN CM): 5.4

ORIFICE DIAMETER (IN CM): 15.7

DIAMETER AT BOTTOM OF RIM OR NECK (IN CM): 13.5

BASE DIAMETER (IN CM): N/A, rounded base

ESTIMATED VOLUME (IN LITERS): 0.51 liters

DECORATION: The upper rim panel has a single horizontal row of punctations below the lip, followed by a single central horizontal engraved line (Figure A3-5). The lower rim panel has four evenly spaced small nodes $(8 \mathrm{~mm}$ in width) just above the rim carination. Bisecting each of these nodes are sets of six closely-spaced vertical engraved lines that extend from the top of the lower rim panel to (and in some cases, beyond) the rim carination. Between each of these nodes and vertical engraved line sets are four diagonal sets of engraved lines with small triangular tick marks (Figure A3-5). Finally, there are small tool punctates along the lower panel carination point.

TYPE: Belcher Engraved, var. Belcher

Figure A3-5. Belcher Engraved, var. Belcher carinated bowl from the Lester Bros. Place (5425-877).

SITE NAME OR SITE NUMBER: Lester Bros. Place

CONTEXT INFORMATION: From a grave in a Caddo cemetery exposed during the dynamiting of a Red River levee, June 1929.

ACCESSION NO.: 5425-878

VESSEL NO.: V-521

NON-PLASTICS: grog

VESSEL FORM: Carinated bowl with a cut-down rim

RIM AND LIP FORM: Inverted rim with a rounded lip

CORE COLOR: B (fired and cooled in a reducing environment) 
INTERIOR SURFACE COLOR: black

EXTERIOR SURFACE COLOR: black

WALL THICKNESS (RIM, BODY, AND BASE IN MM): 5.2 mm, rim

INTERIOR SURFACE TREATMENT: smoothed

EXTERIOR SURFACE TREATMENT: burnished

HEIGHT (IN CM): 4.9

ORIFICE DIAMETER (IN CM): 11.8

DIAMETER AT BOTTOM OF RIM OR NECK (IN CM): 11.9

BASE DIAMETER (IN CM): N/A, rounded base

ESTIMATED VOLUME (IN LITERS): 0.35 liters

DECORATION: Only a portion of an interlocking scroll motif is preserved on the cutdown rim by four sets of gracefully curved lines (Figure A3-6) that extend from the rim carination point (the Evans 1 rim pattern, Schambach and Miller 1984:122 and Figure 11$6)$.

TYPE: cf. Glassell Engraved, var. Atkins

Figure A3-6. Glassell Engraved, var. Atkins carinated bowl (5425-878).

SITE NAME OR SITE NUMBER: Lester Bros. Place, 1927

CONTEXT INFORMATION: From a grave in a Caddo cemetery, 1927.

ACCESSION NO.: 5425-880

VESSEL NO.: V-478

NON-PLASTICS: fine grog and bone

VESSEL FORM: Small carinated bowl

RIM AND LIP FORM: Inverted rim and a rounded lip

CORE COLOR: B (fired and cooled in a reducing environment) 
INTERIOR SURFACE COLOR: black

EXTERIOR SURFACE COLOR: black

WALL THICKNESS (RIM, BODY, AND BASE IN MM): 3.6 mm, rim

INTERIOR SURFACE TREATMENT: smoothed on the body and burnished on the rim

EXTERIOR SURFACE TREATMENT: burnished

HEIGHT (IN CM): 3.7

ORIFICE DIAMETER (IN CM): 6.8

DIAMETER AT BOTTOM OF RIM OR NECK (IN CM): 7.5

BASE DIAMETER (IN CM): N/A, rounded base

ESTIMATED VOLUME (IN LITERS): 0.15 liters

DECORATION: This vessel is decorated on the rim with two engraved panels separated by a single diagonal engraved line with small tick marks (Figure A3-7). The panels themselves have short meandering ticked scroll lines between upper and lower crosshatched engraved background zones with large and small negative ovals.

TYPE: Hodges Engraved, var. Sentell

Figure A3-7. Hodges Engraved, var. Sentell carinated bowl (5425-880).

SITE NAME OR SITE NUMBER: Lester Bros. Place, 1929

CONTEXT INFORMATION: From a grave in a Caddo cemetery exposed along a levee that had been dynamited, 1929.

ACCESSION NO.: 5425-881

VESSEL NO.: V-151

NON-PLASTICS: bone and hematite/ferruginous sandstone

VESSEL FORM: Carinated bowl

RIM AND LIP FORM: Everted rim and a rounded lip 
CORE COLOR: $\mathrm{F}$ (fired in a reducing environment and cooled in the open air)

INTERIOR SURFACE COLOR: light brown

EXTERIOR SURFACE COLOR: light brown

WALL THICKNESS (RIM, BODY, AND BASE IN MM): $5.5 \mathrm{~mm}$, rim

INTERIOR SURFACE TREATMENT: smoothed on the rim

EXTERIOR SURFACE TREATMENT: burnished on the rim and body

HEIGHT (IN CM): 4.6

ORIFICE DIAMETER (IN CM): 7.9

DIAMETER AT BOTTOM OF RIM OR NECK (IN CM): 7.5

BASE DIAMETER (IN CM): 4.5

ESTIMATED VOLUME (IN LITERS): 0.22 liters

DECORATION: The rim is plain on this carinated bowl. The body has four sets of nested engraved semi-circles that begin with a central hooked arm element (Figure A3-8). The sets of engraved semi-circles are divided by large excised/hatched upper and lower pendant triangles (El Dorado 2 pattern, Schambach and Miller 1984:Figure 11-6).

TYPE: Avery Engraved, var. Graves

Figure A3-8. Avery Engraved, var. Graves carinated bowl (5425-881).

SITE NAME OR SITE NUMBER: Lester Bros. Place, 1929

CONTEXT INFORMATION: From a grave in a Caddo cemetery, 1929.

ACCESSION NO.: 5425-883

VESSEL NO.: V-110

NON-PLASTICS: shell

VESSEL FORM: Jar with a short (6.6 $\mathrm{mm}$ in height) rim 
RIM AND LIP FORM: Everted rim with a rounded lip

CORE COLOR: B (fired and cooled in a reducing environment)

INTERIOR SURFACE COLOR: black

EXTERIOR SURFACE COLOR: black

WALL THICKNESS (RIM, BODY, AND BASE IN MM): 3.7 mm, rim

INTERIOR SURFACE TREATMENT: smoothed on rim

EXTERIOR SURFACE TREATMENT: none

HEIGHT (IN CM): 7.3

ORIFICE DIAMETER (IN CM): 6.3

DIAMETER AT BOTTOM OF RIM OR NECK (IN CM): 6.0

BASE DIAMETER (IN CM): N/A, rounded base

ESTIMATED VOLUME (IN LITERS): 0.28 liters

DECORATION: The rim of this vessel is plain. The vessel body has vertical brushedincised lines that extend on the vessel to just above the base (Figure A3-9).

TYPE: Karnack Brushed-Incised, var. Karnack

Figure A3-9. Karnack Brushed-Incised, var. Karnack jar (5425-883).

SITE NAME OR SITE NUMBER: Lester Bros. Place

CONTEXT INFORMATION: From a grave in a Caddo cemetery exposed in the dynamiting of a Red River levee, June 1929.

ACCESSION NO.: 5425-886

VESSEL NO.: V-509

NON-PLASTICS: fine grog

VESSEL FORM: Carinated bowl 
RIM AND LIP FORM: Inverted rim with a rounded lip

CORE COLOR: A (fired and cooled in an oxidizing environment)

INTERIOR SURFACE COLOR: brown

EXTERIOR SURFACE COLOR: brown

WALL THICKNESS (RIM, BODY, AND BASE IN MM): $4.1 \mathrm{~mm}$, rim

INTERIOR SURFACE TREATMENT: burnished on the rim

EXTERIOR SURFACE TREATMENT: burnished on the rim and the body

HEIGHT (IN CM): 5.5

ORIFICE DIAMETER (IN CM): 9.5

DIAMETER AT BOTTOM OF RIM OR NECK (IN CM): 10.2

BASE DIAMETER (IN CM): N/A, rounded base

ESTIMATED VOLUME (IN LITERS): 0.31 liters

DECORATION: The rim panel has an interlocking scroll motif repeated five times around the vessel. The upper and lower parts of the scroll have zones filled with gracefully curved engraved lines (Figure A3-10).

TYPE: Glassell Engraved, var. Atkins

Figure A3-10. Glassell Engraved, var. Atkins carinated bowl from the Lester Bros. Place (5425-886).

SITE NAME OR SITE NUMBER: Lester Bros. Place, 1927

CONTEXT INFORMATION: From a grave in a Caddo cemetery

ACCESSION NO.: 5425-887

VESSEL NO.: V-220

NON-PLASTICS: grog

VESSEL FORM: Miniature jar (Figure A3-11) 
RIM AND LIP FORM: Everted rim with a rounded lip

CORE COLOR: B (fired and cooled in a reducing environment)

INTERIOR SURFACE COLOR: black

EXTERIOR SURFACE COLOR: black

WALL THICKNESS (RIM, BODY, AND BASE IN MM): 4.3 mm, rim

INTERIOR SURFACE TREATMENT: smoothed on the rim

EXTERIOR SURFACE TREATMENT: smoothed on the rim and body

HEIGHT (IN CM): 7.2

ORIFICE DIAMETER (IN CM): 7.8

DIAMETER AT BOTTOM OF RIM OR NECK (IN CM): 6.3

BASE DIAMETER (IN CM): 4.5

ESTIMATED VOLUME (IN LITERS): 0.34 liters

DECORATION: Plain

TYPE: Undefined plain ware vessel

Figure A3-11. Plain miniature jar (5425-887).

SITE NAME OR SITE NUMBER: Lester Bros. Place

CONTEXT INFORMATION: From a Caddo cemetery, June 1929. The cemetery was disturbed by the dynamiting of a levee, and the vessel was found in the cut bank of the hole caused by the explosion.

ACCESSION NO.: 5425-888

VESSEL NO.: V-21

NON-PLASTICS: shell 
VESSEL FORM: Bottle with a bulbous and flanged neck and a low pedestal base (Figure A3-12)

RIM AND LIP FORM: Everted rim and a rounded lip

CORE COLOR: B (fired and cooled in a reducing environment)

INTERIOR SURFACE COLOR: black

EXTERIOR SURFACE COLOR: very dark gray

WALL THICKNESS (RIM, BODY, AND BASE IN MM): $4.0 \mathrm{~mm}$, rim

INTERIOR SURFACE TREATMENT: smoothed on the upper neck

EXTERIOR SURFACE TREATMENT: smoothed on the body and burnished on the neck and the lower body

HEIGHT (IN CM): 10.0

ORIFICE DIAMETER (IN CM): 3.4

DIAMETER AT BOTTOM OF RIM OR NECK (IN CM): $3.1 ; 7.8 \mathrm{~cm}$ at the widest part of the body

BASE DIAMETER (IN CM): 4.8

ESTIMATED VOLUME (IN LITERS): 0.19 liters

DECORATION: There are two horizontal trailed lines under the bottle neck, on the vessel body, and a single horizontal trailed line on the upper part of the pedestal base (see Figure A3-12). Between them are four sets of interlocking curvilinear trailed lines (Belhaven 14 pattern, Schambach and Miller 1984:123) that completely cover the vessel body (see Figure A3-12).

TYPE: Keno Trailed, var. McClendon

Figure A3-12. Keno Trailed, var. McClendon bottle (5425-888).

SITE NAME OR SITE NUMBER: Lester Bros. Place

CONTEXT INFORMATION: From a grave in a Caddo cemetery, 1927.

ACCESSION NO.: 5425-889 
VESSEL NO.: V-15

NON-PLASTICS: grog and bone

VESSEL FORM: Jar

RIM AND LIP FORM: Direct rim with a rounded and exterior folded lip

CORE COLOR: $\mathrm{G}$ (fired in an reducing environment, but cooled in the open air)

INTERIOR SURFACE COLOR: very dark gray

EXTERIOR SURFACE COLOR: light brown with fire clouds

WALL THICKNESS (RIM, BODY, AND BASE IN MM): 3.2 mm, rim

INTERIOR SURFACE TREATMENT: smoothed on the body and rim

EXTERIOR SURFACE TREATMENT: smoothed on the body

HEIGHT (IN CM): 8.0

ORIFICE DIAMETER (IN CM): 7.9

DIAMETER AT BOTTOM OF RIM OR NECK (IN CM): 7.0

BASE DIAMETER (IN CM): N/A, rounded base

ESTIMATED VOLUME (IN LITERS): 0.38 liters

DECORATION: The rim has closely-spaced vertical rows of tool punctates, and the body has four panels each filled with six broad incised or trailed concentric circles (Figure A313). Each set of concentric circles is divided from another by upper and lower sets of diagonal trailed lines that begin at the rim or just above the vessel base.

TYPE: Foster Trailed-Incised, var. Shaw

Figure A3-13. Foster Trailed-Incised, var. Shaw jar (5425-889).

SITE NAME OR SITE NUMBER: Lester Bros. Plantation

CONTEXT INFORMATION: From a grave in a Caddo cemetery exposed during dynamiting of a levee, June 1929. 
ACCESSION NO.: 5425-892

VESSEL NO.: V-53

NON-PLASTICS: shell

VESSEL FORM: Jar with a short (13 $\mathrm{mm}$ in height) rim

RIM AND LIP FORM: Everted rim with a rounded lip

CORE COLOR: $\mathrm{G}$ (fired in a reducing environment, but cooled in the open air)

INTERIOR SURFACE COLOR: very dark gray

EXTERIOR SURFACE COLOR: strong brown

WALL THICKNESS (RIM, BODY, AND BASE IN MM): 5.4 mm, rim

INTERIOR SURFACE TREATMENT: smoothed on the rim

EXTERIOR SURFACE TREATMENT: none

HEIGHT (IN CM): 8.8

ORIFICE DIAMETER (IN CM): 10.0

DIAMETER AT BOTTOM OF RIM OR NECK (IN CM): 7.8

BASE DIAMETER (IN CM): 4.2

ESTIMATED VOLUME (IN LITERS): 0.53 liters

DECORATION: The short rim has horizontal brushing marks, and the lip is carefully notched. The body has vertical brushing marks that end well above the vessel base (Figure A3-14).

TYPE: Karnack Brushed-Incised, var. Karnack

Figure A3-14. Karnack Brushed-Incised, var. Karnack jar (5425-892).

SITE NAME OR SITE NUMBER: Lester Bros. Plantation, 1929 
CONTEXT INFORMATION: From a grave in a Caddo cemetery exposed during

dynamiting of a levee, June 1929.

ACCESSION NO.: 5425-895

VESSEL NO.: V-260

NON-PLASTICS: grog

VESSEL FORM: Carinated bowl with two rim panels (Figure A3-15)

RIM AND LIP FORM: Direct rim with a rounded lip

CORE COLOR: $\mathrm{G}$ (fired in a reducing environment and cooled in the open air)

INTERIOR SURFACE COLOR: black

EXTERIOR SURFACE COLOR: very dark gray

WALL THICKNESS (RIM, BODY, AND BASE IN MM): $4.4 \mathrm{~mm}$, rim

INTERIOR SURFACE TREATMENT: burnished on the rim and smoothed on the body

EXTERIOR SURFACE TREATMENT: burnished on the rim and body

HEIGHT (IN CM): 6.8

ORIFICE DIAMETER (IN CM): 18.3

DIAMETER AT BOTTOM OF RIM OR NECK (IN CM): 14.9

BASE DIAMETER (IN CM): 7.3

ESTIMATED VOLUME (IN LITERS): 0.75 liters

DECORATION: The upper rim panel has a set of engraved dashes immediately below the lip as well as a single horizontal engraved line with small tick marks (see Figure A315). The lower rim panel has a complicated engraved design repeated four times, with a meandering and ticked scroll line, with hatched curvilinear background zones above and below the meandering scroll line (Figure A3-16). There are large and small negative ovals within these background engraved zones. There is also an interior engraved line at the carination point of the lower rim panel.

TYPE: Natchitoches Engraved, var. Lester Bend 
Figure A3-15. Natchitoches Engraved, var. Lester Bend carinated bowl from the Lester Bros. Plantation (5425-895).

Figure A3-16. Base of the Natchitoches Engraved, var. Lester Bend carinated bowl (5425-895).

SITE NAME OR SITE NUMBER: Lester Bros. Place

CONTEXT INFORMATION: From a grave in a Caddo cemetery, 1929

ACCESSION NO.: 5425-897

VESSEL NO.: V-169

NON-PLASTICS: shell

VESSEL FORM: Deep bowl

RIM AND LIP FORM: Direct rim and a rounded lip

CORE COLOR: A (fired and cooled in an oxidizing environment)

INTERIOR SURFACE COLOR: brown, with fire clouds on the rim and body

EXTERIOR SURFACE COLOR: yellowish-red, with fire clouds on the rim and body

WALL THICKNESS (RIM, BODY, AND BASE IN MM): 3.8 mm, rim

INTERIOR SURFACE TREATMENT: smoothed on the rim and body

EXTERIOR SURFACE TREATMENT: burnished on the rim and body

HEIGHT (IN CM): 9.0

ORIFICE DIAMETER (IN CM): 11.0

DIAMETER AT BOTTOM OF RIM OR NECK (IN CM): 9.5

BASE DIAMETER (IN CM): 4.5

ESTIMATED VOLUME (IN LITERS): 0.79 liters

DECORATION: There are three carelessly executed horizontal engraved lines that encircle the vessel rim (Figure A3-17). The lip has fine diagonal lip notching. 
TYPE: Hardman Engraved, var. Joan

Figure A3-17. Hardman Engraved, var. Joan bowl from the Lester Bros. Place (5425897).

SITE NAME OR SITE NUMBER: Lester Bros. Place

CONTEXT INFORMATION: From a grave in a Caddo cemetery, 1927

ACCESSION NO.: 5425-901

VESSEL NO.: V-403

NON-PLASTICS: grog

VESSEL FORM: Bottle with a straight neck and a flaring lip

RIM AND LIP FORM: Everted/flared rim with a rounded lip

CORE COLOR: B (fired and cooled in a reducing environment)

INTERIOR SURFACE COLOR: very dark gray

EXTERIOR SURFACE COLOR: very dark gray

WALL THICKNESS (RIM, BODY, AND BASE IN MM): 3.5 mm, rim

INTERIOR SURFACE TREATMENT: smoothed on the upper neck

EXTERIOR SURFACE TREATMENT: burnished on the rim and body

HEIGHT (IN CM): 17.5

ORIFICE DIAMETER (IN CM): 5.0

DIAMETER AT BOTTOM OF RIM OR NECK (IN CM): 4.6; $12.8 \mathrm{~cm}$ at the widest point on the body

BASE DIAMETER (IN CM): 5.2

ESTIMATED VOLUME (IN LITERS): 0.36 liters 
DECORATION: The body of the bottle has four panels filled with concentric circles and alternating concentric dashes (Figure A3-18). The smallest and central circle has short spurs around its radius, suggesting a sun symbol (cf. Webb 1959:122), as well as a central circular punctated/excised element. The four panels are divided by four large hatched pendant triangles at the top of the bottle body; each of these pendant triangles has 4-5 hatched lines at its three corners, and there is a single triangular punctate or tick mark at its center.

TYPE: Belcher Engraved, var. Soda Lake

Figure A3-18. Belcher Engraved, var. Soda Lake bottle (5425-901).

SITE NAME OR SITE NUMBER: Lester Bros. Place

CONTEXT INFORMATION: From a grave in a Caddo cemetery, 1927.

ACCESSION NO.: 5425-903

VESSEL NO.: V-372

NON-PLASTICS: shell

VESSEL FORM: Jar

RIM AND LIP FORM: Everted rim with a rounded lip

CORE COLOR: A (fired and cooled in a high oxygen environment)

INTERIOR SURFACE COLOR: brown

EXTERIOR SURFACE COLOR: reddish-yellow

WALL THICKNESS (RIM, BODY, AND BASE IN MM): 5.4 mm, rim

INTERIOR SURFACE TREATMENT: smoothed on the rim

EXTERIOR SURFACE TREATMENT: smoothed on the lower body

HEIGHT (IN CM): 10.6

ORIFICE DIAMETER (IN CM): 12.1

DIAMETER AT BOTTOM OF RIM OR NECK (IN CM): 9.8 


\section{BASE DIAMETER (IN CM): 5.1}

ESTIMATED VOLUME (IN LITERS): 0.77 liters

DECORATION: The rim has two panels of alternating and short diagonal incised lines, and a third (and middle panel) with concentric incised semi-circles (each with three lines) repeated eight times across the panel; above every two incised semi-circles is a hatched incised triangle pendant from the upper incised panel (Figure A3-19). The body of the vessel has vertical brushed-incised lines.

TYPE: Karnack Brushed-Incised, var. unspecified or Foster Trailed-Incised, var. unspecified

Figure A3-19. Karnack Brushed-Incised or Foster Trailed-Incised jar (5425-903).

SITE NAME OR SITE NUMBER: Lester Bros. Place

CONTEXT INFORMATION: From a grave in a Caddo cemetery, 1927.

ACCESSION NO.: 5425-904

VESSEL NO.: V-199

NON-PLASTICS: shell

VESSEL FORM: Jar with a tall rim (Figure A3-20)

RIM AND LIP FORM: Direct rim with a rounded and exterior folded lip

CORE COLOR: $\mathrm{G}$ (fired in a reducing environment, and cooled in the open air)

INTERIOR SURFACE COLOR: black

EXTERIOR SURFACE COLOR: strong brown and black

WALL THICKNESS (RIM, BODY, AND BASE IN MM): 4.8 mm, rim

INTERIOR SURFACE TREATMENT: smoothed on the rim

EXTERIOR SURFACE TREATMENT: none

HEIGHT (IN CM): 17.0

ORIFICE DIAMETER (IN CM): 15.2 
DIAMETER AT BOTTOM OF RIM OR NECK (IN CM): 12.6

BASE DIAMETER (IN CM): 5.1

ESTIMATED VOLUME (IN LITERS): 2.32 liters

DECORATION: The tall rim has four stacked sets of diagonal and horizontal incised lines (see Figure A3-20). The body has a trailed motif repeated five times: opposed concentric semi-circles arced around a small dimpled appliqued node. The concentric semi-circles each have between 5-8 trailed lines (see Figure A3-20).

TYPE: Foster Trailed-Incised, var. Dobson

Figure A3-20. Foster Trailed-Incised, var. Dobson jar (5425-904) from the Lester Bros. Place.

SITE NAME OR SITE NUMBER: Lester Bros. Place

CONTEXT INFORMATION: From a grave in a Caddo cemetery, damaged by the dynamiting of a levee in 1929 .

ACCESSION NO.: 5425-906

VESSEL NO.: V-499

NON-PLASTICS: grog

VESSEL FORM: Short-necked bottle with a "pulley-shaped neck" (Webb 1959:Figure 111a) (Figure A3-21).

RIM AND LIP FORM: Direct rim with a rounded lip

CORE COLOR: B (fired and cooled in a low oxygen environment)

INTERIOR SURFACE COLOR: dark brown

EXTERIOR SURFACE COLOR: very dark grayish-brown

WALL THICKNESS (RIM, BODY, AND BASE IN MM): 3.7 mm, neck; 4.7 mm, body

INTERIOR SURFACE TREATMENT: smoothed on the upper neck

EXTERIOR SURFACE TREATMENT: smoothed on the rim and body 
HEIGHT (IN CM): 18.5

ORIFICE DIAMETER (IN CM): 6.5

DIAMETER AT BOTTOM OF RIM OR NECK (IN CM): 6.1; $19.4 \mathrm{~cm}$ in width at the widest part of the vessel body

BASE DIAMETER (IN CM): 6.3

ESTIMATED VOLUME (IN LITERS): 0.47 liters

DECORATION: There is a single row of small tool punctates on a raised ridge in the central part of the short bottle neck (see Figure A3-21); the bottle lip is also notched. A single curvilinear row of tool punctates was also placed at the very top of the vessel body, above four concentric circles of broad trailed lines. The concentric circles are divided by triangular sets of trailed lines at the upper and lower parts of the body, nearly meeting in the center of the vessel body (see Figure A3-21). These dividers are formed of either three or four trailed lines.

TYPE: Keno Trailed, var. unspecified

Figure A3-21. Keno Trailed bottle (5425-906).

SITE NAME OR SITE NUMBER: Lester Bros. Plantation, 1929

CONTEXT INFORMATION: From a grave in a Caddo cemetery.

ACCESSION NO.: 5425-909

VESSEL NO.: V-173

NON-PLASTICS: fine grog

VESSEL FORM: Bottle with a bulbous or spool-shaped neck (Figure A3-22a)

RIM AND LIP FORM: Flaring or everted rim with a rounded lip

CORE COLOR: B (fired and cooled in a low oxygen environment)

INTERIOR SURFACE COLOR: black

EXTERIOR SURFACE COLOR: black; brown fire clouds on the body 
WALL THICKNESS (RIM, BODY, AND BASE IN MM): $5.2 \mathrm{~mm}$, rim

INTERIOR SURFACE TREATMENT: burnished on the neck

EXTERIOR SURFACE TREATMENT: burnished

HEIGHT (IN CM): 19.2

ORIFICE DIAMETER (IN CM): 6.3

DIAMETER AT BOTTOM OF RIM OR NECK (IN CM): $4.8 ; 16.0 \mathrm{~cm}$ at the widest part of the body

BASE DIAMETER (IN CM): 6.25

ESTIMATED VOLUME (IN LITERS): 0.48 liters

DECORATION: Immediately below the bottle neck is a narrow zone of closely-spaced opposed hatched engraved lines. Below that are three stacked tiers of cross-hatched engraved fill zones and negative meandering scrolls that are repeated four times around the vessel (see Figure A3-22a). Each of the cross-hatched engraved zones has eight negative ovals within it. Radiating from a single engraved line that encircles the base are four triangles with cross-hatched engraved corners and a single central negative oval (see Figure A3-22b); each triangle has a single graceful curved line that hooks towards the bottom of the cross-hatched fill zones.

TYPE: Hodges Engraved, var. Candler

Figure A3-22. Hodges Engraved, var. Candler bottle (5425-909): a, side view; b, view of the vessel base.

SITE NAME OR SITE NUMBER: Lester Bros. Place

CONTEXT INFORMATION: From a grave in a Caddo cemetery, 1927.

ACCESSION NO.: 5425-911

VESSEL NO.: V-371

NON-PLASTICS: shell

VESSEL FORM: Jar with a tall rim

RIM AND LIP FORM: Everted rim with a rounded lip 
CORE COLOR: B (fired and cooled in a reducing environment)

INTERIOR SURFACE COLOR: very dark gray

EXTERIOR SURFACE COLOR: very dark gray

WALL THICKNESS (RIM, BODY, AND BASE IN MM): 5.4 mm, rim

INTERIOR SURFACE TREATMENT: smoothed on the rim

EXTERIOR SURFACE TREATMENT: none

HEIGHT (IN CM): 13.0

ORIFICE DIAMETER (IN CM): 16.2

DIAMETER AT BOTTOM OF RIM OR NECK (IN CM): 11.3

BASE DIAMETER (IN CM): 5.0

ESTIMATED VOLUME (IN LITERS): 1.26 liters

DECORATION: The tall rim of this jar has five rows of short diagonal incised lines (Figure A3-23). The body has four repeating sets of interlocking curvilinear trailed lines that encircle dimpled appliqued nodes (Figure A3-23).

TYPE: Foster Trailed-Incised, var. Dixon

Figure A3-23. Foster Trailed-Incised, var. Dixon jar (5425-911).

SITE NAME OR SITE NUMBER: Lester Bros. Place

CONTEXT INFORMATION: From a grave in a Caddo cemetery exposed after the dynamiting of a Red River levee, June 1929.

ACCESSION NO.: 5425-920

VESSEL NO.: V-63

NON-PLASTICS: grog

VESSEL FORM: Carinated bowl with two rim panels 
RIM AND LIP FORM: Everted rim with a rounded lip

CORE COLOR: B (fired and cooled in a reducing environment)

INTERIOR SURFACE COLOR: very dark gray

EXTERIOR SURFACE COLOR: very dark gray

WALL THICKNESS (RIM, BODY, AND BASE IN MM): $3.7 \mathrm{~mm}$, rim

INTERIOR SURFACE TREATMENT: burnished on the rim and body

EXTERIOR SURFACE TREATMENT: burnished on the rim and body

HEIGHT (IN CM): 4.4

ORIFICE DIAMETER (IN CM): 8.3

DIAMETER AT BOTTOM OF RIM OR NECK (IN CM): 7.6

BASE DIAMETER (IN CM): N/A, rounded base

ESTIMATED VOLUME (IN LITERS): 0.22 liters

DECORATION: The upper rim panel of this carinated bowl is plain. The lower rim panel has six sets of engraved semi-circles (each with three semi-circular lines) that begin at the carination (Figure A3-24). The engraved semi-circles are divided by six large triangles, with a long, narrow, spur at its tip, that are pendant from the top of the lower rim panel; five of these have hatched corners, forming a central oval, while the sixth has only three hatched lines.

TYPE: Avery Engraved, var. Bradshaw

Figure A3-24. Avery Engraved, var. Bradshaw carinated bowl (5425-920).

SITE NAME OR SITE NUMBER: Lester Bros. Place

CONTEXT INFORMATION: From a grave in a Caddo cemetery, 1927

ACCESSION NO.: 5425-923

VESSEL NO.: V-89

NON-PLASTICS: shell 
VESSEL FORM: Bowl with opposing attachments or appendages

RIM AND LIP FORM: Direct rim with a rounded lip

CORE COLOR: $\mathrm{F}$ (fired in a reducing environment, but cooled in the open air)

INTERIOR SURFACE COLOR: red

EXTERIOR SURFACE COLOR: dark red; fire clouds on the base

WALL THICKNESS (RIM, BODY, AND BASE IN MM): 3.9 mm, body

INTERIOR SURFACE TREATMENT: smoothed on the body

EXTERIOR SURFACE TREATMENT: burnished on the body

HEIGHT (IN CM): 5.9

ORIFICE DIAMETER (IN CM): 10.8

DIAMETER AT BOTTOM OF RIM OR NECK (IN CM): N/A

BASE DIAMETER (IN CM): N/A, rounded base

ESTIMATED VOLUME (IN LITERS): 0.25 liters

DECORATION: Plain

TYPE: Unidentified plain effigy vessel with a notched tab tail (Figure A3-25a) and an opposing bird head effigy. The effigy head is facing inward towards the vessel orifice (Figure A3-25b).

Figure A3-25. Effigy bowl from the Lester Bros. Place (5425-923): a, view of the notched tab tail; $b$, side view.

SITE NAME OR SITE NUMBER: Lester Bros. Place

CONTEXT INFORMATION: From a grave in a Caddo cemetery, 1929

ACCESSION: 5425-925

VESSEL NO.: V-106 
NON-PLASTICS: grog and bone

VESSEL FORM: Carinated bowl with two rim panels

RIM AND LIP FORM: Everted rim with a rounded lip

CORE COLOR: B (fired and cooled in a reducing environment)

INTERIOR SURFACE COLOR: dark brown

EXTERIOR SURFACE COLOR: very dark brown

WALL THICKNESS (RIM, BODY, AND BASE IN MM): 4.2 mm, rim

INTERIOR SURFACE TREATMENT: burnished on the rim and body

EXTERIOR SURFACE TREATMENT: burnished on the rim and body

HEIGHT (IN CM): 5.8

ORIFICE DIAMETER (IN CM): 18.0

DIAMETER AT BOTTOM OF RIM OR NECK (IN CM): 15.0

BASE DIAMETER (IN CM): 4.5

ESTIMATED VOLUME (IN LITERS): 0.63 liters

DECORATION: The upper rim panel has a single row of tool punctates below the vessel lip, followed by a single horizontal engraved line with small triangular tick marks (Figure A3-26). The lower rim panel is defined by a single horizontal engraved line at the top, and by a single row of triangular tool punctations at the lower carination point. The motif in the lower rim panel, repeated four times, consists of four sets of diagonally pitched engraved lines (each set with four lines) on either side of a single centrally placed horizontal engraved line (Figure A3-26); this line does not touch any of the diagonally pitched set of engraved lines.

TYPE: Belcher Engraved, var. Owen

Figure A3-26. Belcher Engraved, var. Owen carinated bowl (5425-925).

SITE NAME OR SITE NUMBER: Lester Bros. Place

CONTEXT INFORMATION: From a grave 
ACCESSION NO.: 5425-926

VESSEL NO.: V-20

NON-PLASTICS: fine grog

VESSEL FORM: Bowl (Figure A3-27)

RIM AND LIP FORM: Direct rim and a rounded lip

CORE COLOR: B (fired and cooled in a reducing environment)

INTERIOR SURFACE COLOR: very dark brown

EXTERIOR SURFACE COLOR: very dark brown

WALL THICKNESS (RIM, BODY, AND BASE IN MM): $4.0 \mathrm{~mm}$, rim; $5.0 \mathrm{~mm}$, body

INTERIOR SURFACE TREATMENT: burnished

EXTERIOR SURFACE TREATMENT: burnished

HEIGHT (IN CM): 5.0

ORIFICE DIAMETER (IN CM): 6.6

DIAMETER AT BOTTOM OF RIM OR NECK (IN CM): 6.5

BASE DIAMETER (IN CM): 3.8

ESTIMATED VOLUME (IN LITERS): 0.13 liters

DECORATION: Plain

TYPE: Unidentified plain ware vessel

Figure A3-27. Plain bowl (5425-926).

SITE NAME OR SITE NUMBER: Lester Bros. Place

CONTEXT INFORMATION: From a grave

ACCESSION NO.: 5425-927 
VESSEL NO.: V-228

NON-PLASTICS: grog and hematite/ferruginous sandstone

VESSEL FORM: Bowl with opposed attachments or appendages (the effigy head itself is missing or broken off); the tab tail appendage has a single suspension hole (Figure A328).

RIM AND LIP FORM: Inverted rim with a rounded lip

CORE COLOR: $\mathrm{F}$ (fired in a reducing environment but cooled in the open air)

INTERIOR SURFACE COLOR: light yellowish-brown

EXTERIOR SURFACE COLOR: light yellowish-brown

WALL THICKNESS (RIM, BODY, AND BASE IN MM): 4.3 mm, rim

INTERIOR SURFACE TREATMENT: none

EXTERIOR SURFACE TREATMENT: none

HEIGHT (IN CM): 3.5

ORIFICE DIAMETER (IN CM): 5.1

DIAMETER AT BOTTOM OF RIM OR NECK (IN CM): N/A

BASE DIAMETER (IN CM): N/A, rounded base

ESTIMATED VOLUME (IN LITERS): 0.07 liters

DECORATION: The sides of the bowl have a motif of semi-circular appliqued ridges that are repeated twice (see Figure A3-28) on either side of the vessel. There are a series of short and parallel incised lines on the top of the tab tail attachment.

TYPE: Unidentified effigy vessel

Figure A3-28. Appliqued effigy bowl from the Lester Bros. Place (5425-927).

SITE NAME OR SITE NUMBER: Lester Bros. Place 
CONTEXT INFORMATION: From a grave in a Caddo cemetery exposed during the dynamiting of a Red River levee, June 1929.

ACCESSION NO.: 5425-928

VESSEL NO.: V-216

NON-PLASTICS: grog

VESSEL FORM: Carinated bowl with two rim panels

RIM AND LIP FORM: Direct rim and a rounded lip

CORE COLOR: B (fired and cooled in a low oxygen environment)

INTERIOR SURFACE COLOR: very dark gray with reddish-brown fire clouds on the lip

EXTERIOR SURFACE COLOR: very dark gray with reddish-brown fire clouds on the rim and base

WALL THICKNESS (RIM, BODY, AND BASE IN MM): 4.2 mm, rim

INTERIOR SURFACE TREATMENT: smoothed on the body and burnished on the rim

EXTERIOR SURFACE TREATMENT: smoothed on the body and burnished on the rim HEIGHT (IN CM): 5.4

ORIFICE DIAMETER (IN CM): 9.0

DIAMETER AT BOTTOM OF RIM OR NECK (IN CM): 9.9

BASE DIAMETER (IN CM): N/A, rounded base

ESTIMATED VOLUME (IN LITERS): 0.29 liters

DECORATION: The upper rim panel is plain. The lower rim panel has four repeating sets of four short horizontal dashed lines set between four vertical bands filled with diagonal engraved lines (Figure A3-29). The outer two vertical bands in each set of four vertical bands have upward or downward-pointing spurred lines on them.

TYPE: Belcher Engraved, var. unspecified

Figure A3-29. Belcher Engraved carinated bowl (5425-928). 
SITE NAME OR SITE NUMBER: Lester Bros. Place

CONTEXT INFORMATION: From a grave excavated by Joe and W. G. Smith, 1927.

ACCESSION NO.: 5425-937

VESSEL NO.: V-72

NON-PLASTICS: shell

VESSEL FORM: Bowl with tall rim

RIM AND LIP FORM: Everted rim with a rounded lip

CORE COLOR: B (fired and cooled in a reducing environment)

INTERIOR SURFACE COLOR: black

EXTERIOR SURFACE COLOR: very dark gray

WALL THICKNESS (RIM, BODY, AND BASE IN MM): $4.1 \mathrm{~mm}$, rim

INTERIOR SURFACE TREATMENT: smoothed on the body and burnished on the rim EXTERIOR SURFACE TREATMENT: burnished on the rim and body

HEIGHT (IN CM): 6.8

ORIFICE DIAMETER (IN CM): 11.8

DIAMETER AT BOTTOM OF RIM OR NECK (IN CM): 8.6

BASE DIAMETER (IN CM): N/A, rounded base

ESTIMATED VOLUME (IN LITERS): 0.32 liters

DECORATION: The rim panel has four sets of semi-circular engraved lines, each set with four lines; alternating lines have triangular tick marks (Figures A3-30 and A3-31). The vessel body has a concentric circle motif repeated four times around the vessel; the innermost circle in the motif has two small hatched bands within it. The second circle has triangular tick marks. Every other circle motif on the body is divided from another by a large cross-hatched engraved pendant triangle that originates at the rim-body juncture.

TYPE: Avery Engraved, var. Graves 
Figure A3-30. Avery Engraved, var. Graves bowl (5425-937).

Figure A3-31. Avery Engraved, var. Graves bowl (5425-937) from the Lester Bros. Place. Drawing by Bobby Gonzalez.

SITE NAME OR SITE NUMBER: Lester Bros. Place

CONTEXT INFORMATION: From a burial in a cemetery, 1929.

ACCESSION NO.: 5425-945

VESSEL NO.: V-364

NON-PLASTICS: grog

VESSEL FORM: Bowl

RIM AND LIP FORM: Everted rim and a rounded lip

CORE COLOR: B (fired and cooled in a reducing environment)

INTERIOR SURFACE COLOR: very dark grayish-brown

EXTERIOR SURFACE COLOR: very dark grayish-brown

WALL THICKNESS (RIM, BODY, AND BASE IN MM): $4.3 \mathrm{~mm}$, rim

INTERIOR SURFACE TREATMENT: smoothed on the body and burnished on the rim EXTERIOR SURFACE TREATMENT: burnished on the rim and body

HEIGHT (IN CM): 9.0

ORIFICE DIAMETER (IN CM): 13.0

DIAMETER AT BOTTOM OF RIM OR NECK (IN CM): 9.8

BASE DIAMETER (IN CM): 4.3

ESTIMATED VOLUME (IN LITERS): 0.47 liters

DECORATION: The rim has four horizontal but opposed rows of hatched engraved pendant triangles (Figure A3-32); the lowermost horizontal engraved line has triangular- 
shaped tick marks. The vessel body has engraved scrolls with four separate hooked arm elements; four large hatched pendant triangles serve as fill background for the hooked arm scrolls (Figure A3-32). A white pigment had been rubbed into the engraved lines, and the lip is carefully notched.

TYPE: cf. Taylor Engraved

Figure A3-32. Taylor Engraved bowl (5425-945).

SITE NAME OR SITE NUMBER: Lester Bros. Place

CONTEXT INFORMATION: From a grave in a Caddo cemetery, 1929.

ACCESSION NO.: 5425-948

VESSEL NO.: V-125

NON-PLASTICS: fine grog

VESSEL FORM: Bottle with a flared neck (Figure A3-33)

RIM AND LIP FORM: Everted rim with a flat lip

CORE COLOR: B (fired and cooled in a low oxygen environment)

INTERIOR SURFACE COLOR: black

EXTERIOR SURFACE COLOR: black

WALL THICKNESS (RIM, BODY, AND BASE IN MM): 4.5 mm, neck

INTERIOR SURFACE TREATMENT: smoothed

EXTERIOR SURFACE TREATMENT: burnished

HEIGHT (IN CM): 11.0

ORIFICE DIAMETER (IN CM): 3.8

DIAMETER AT BOTTOM OF RIM OR NECK (IN CM): $3.3 ; 8.1 \mathrm{~cm}$ at the widest part of the body

BASE DIAMETER (IN CM): 4.1 
ESTIMATED VOLUME (IN LITERS): 0.18 liters

DECORATION: Plain

TYPE: Unidentified plain bottle

Figure A3-33. Plain bottle (5425-948).

SITE NAME OR SITE NUMBER: Lester Bros. Place

CONTEXT INFORMATION: From a grave in a Caddo cemetery, 1927

ACCESSION NO.: 5425-949

VESSEL NO.: V-18

NON-PLASTICS: grog

VESSEL FORM: Miniature deep bowl

RIM AND LIP FORM: Everted rim with a rounded lip

CORE COLOR: B (fired and cooled in a reducing environment)

INTERIOR SURFACE COLOR: very dark gray

EXTERIOR SURFACE COLOR: very dark gray

WALL THICKNESS (RIM, BODY, AND BASE IN MM): 2.4 mm, rim

INTERIOR SURFACE TREATMENT: burnished on the rim and body

EXTERIOR SURFACE TREATMENT: burnished on the rim and body

HEIGHT (IN CM): 7.7

ORIFICE DIAMETER (IN CM): 10.4

DIAMETER AT BOTTOM OF RIM OR NECK (IN CM): 7.8

BASE DIAMETER (IN CM): 5.1

ESTIMATED VOLUME (IN LITERS): 0.64 liters 
DECORATION: There are three horizontal engraved lines encircling the vessel rim, and each of these lines has tick marks on it (Figure A3-34). The lip is also notched.

TYPE: Hardman Engraved, var. Joan

Figure A3-34. Hardman Engraved, var. Joan bowl (5425-949).

SITE NAME OR SITE NUMBER: Lester Bros. Place

CONTEXT INFORMATION: From a grave in a Caddo cemetery exposed on the north or east bank of the Red River, 1927.

ACCESSION NO.: 5425-951

VESSEL NO.: V-93

NON-PLASTICS: grog

VESSEL FORM: Jar

RIM AND LIP FORM: Everted rim with a rounded lip

CORE COLOR: $\mathrm{G}$ (fired in a reducing environment, but cooled in the open air)

INTERIOR SURFACE COLOR: black

EXTERIOR SURFACE COLOR: brown

WALL THICKNESS (RIM, BODY, AND BASE IN MM): $6.1 \mathrm{~mm}$, rim

INTERIOR SURFACE TREATMENT: smoothed on the rim

EXTERIOR SURFACE TREATMENT: smoothed on the lower body

HEIGHT (IN CM): 9.5

ORIFICE DIAMETER (IN CM): 8.6

DIAMETER AT BOTTOM OF RIM OR NECK (IN CM): 8.5

BASE DIAMETER (IN CM): 4.7

ESTIMATED VOLUME (IN LITERS): 0.49 liters 
DECORATION: The jar rim has three sets of horizontal and opposed diagonal incised lines (Figure A3-35). The mid-point of the vessel body has seven connected curvilinear trailed scroll zones filled with curvilinear brushing; six of these zones have plain negative ovals, but in the seventh zone, the brushing entirely fills the zones (Figure A3-35).

TYPE: cf. Mound Tract Incised and Brushed

Figure A3-35. Mound Tract Incised and Brushed jar (5425-951).

SITE NAME OR SITE NUMBER: Lester Bros. Place

CONTEXT INFORMATION: From a grave in a Caddo cemetery exposed after dynamiting of a Red River levee, June 1929.

ACCESSION NO.: 5425-952

VESSEL NO.: V-261

NON-PLASTICS: fine grog

VESSEL FORM: Carinated bowl with two rim panels

RIM AND LIP FORM: Inverted rim with a flat lip

CORE COLOR: G (fired in a reducing environment but cooled in the open air)

INTERIOR SURFACE COLOR: very dark gray

EXTERIOR SURFACE COLOR: brown

WALL THICKNESS (RIM, BODY, AND BASE IN MM): 3.7 mm, rim

INTERIOR SURFACE TREATMENT: smoothed on the body and burnished on the rim

EXTERIOR SURFACE TREATMENT: burnished on the rim and the body

HEIGHT (IN CM): 8.7

ORIFICE DIAMETER (IN CM): 11.7

DIAMETER AT BOTTOM OF RIM OR NECK (IN CM): 13.8

BASE DIAMETER (IN CM): N/A, rounded base 
ESTIMATED VOLUME (IN LITERS): 0.61 liters

DECORATION: The upper rim panel has an interlocking or hooked arm scroll motif repeated four times (Figure A3-36). A diagonal engraved and ticked line divides each of the scrolls. The lower panel has four sets of four hatched engraved brackets. The vessel body has four sets of trailed hooked arm scrolls; four sets of trailed semi-circles serve as anchoring elements that connect each of the hooked arm scrolls to one another.

TYPE: Glassell Engraved, var. McGee

Figure A3-36. Glassell Engraved, var. McGee carinated bowl (5425-952).

SITE NAME OR SITE NUMBER: Lester Bros. Place

CONTEXT INFORMATION: Unknown; Gilcrease Museum records indicate it is associated with V-1751

ACCESSION NO.: 5425-958

VESSEL NO.: V-1754

NON-PLASTICS: grog

VESSEL FORM: Deep bowl

RIM AND LIP FORM: Everted rim and a rounded lip

CORE COLOR: B (fired and cooled in a reducing environment)

INTERIOR SURFACE COLOR: very dark gray

EXTERIOR SURFACE COLOR: very dark gray

WALL THICKNESS (RIM, BODY, AND BASE IN MM): 3.9 mm, rim

INTERIOR SURFACE TREATMENT: smoothed on the rim and upper body

EXTERIOR SURFACE TREATMENT: smoothed on the body

HEIGHT (IN CM): 10.5

ORIFICE DIAMETER (IN CM): 11.5 
DIAMETER AT BOTTOM OF RIM OR NECK (IN CM): 8.4

BASE DIAMETER (IN CM): 5.3

ESTIMATED VOLUME (IN LITERS): 0.97 liters

DECORATION: Three closely spaced horizontal engraved lines on the rim, each with very small tick marks (Figure A3-37). Except for the absence of lip notching, the engraved decoration is the same as that seen on V-18 from the Lester Bros. Place (see Figure A3-34).

TYPE: Hardman Engraved, var. Joan

Figure A3-37. Hardman Engraved, var. Joan deep bowl (5425-958).

SITE NAME OR SITE NUMBER: Lester Bros. Place

CONTEXT INFORMATION: From a grave in a Caddo cemetery, 1927

ACCESSION NO.: 5425-961

VESSEL NO.: V-417

NON-PLASTICS: fine grog

VESSEL FORM: Bottle with a spool neck

RIM AND LIP FORM: Everted rim with a rounded lip

CORE COLOR: $\mathrm{H}$ (fired in a reducing environment, but cooled in the open air)

INTERIOR SURFACE COLOR: dark brown

EXTERIOR SURFACE COLOR: dark brown

WALL THICKNESS (RIM, BODY, AND BASE IN MM): $3.0 \mathrm{~mm}$, rim

INTERIOR SURFACE TREATMENT: smoothed on the upper neck

EXTERIOR SURFACE TREATMENT: burnished

HEIGHT (IN CM): 11.2

ORIFICE DIAMETER (IN CM): 4.3 
DIAMETER AT BOTTOM OF RIM OR NECK (IN CM): 3.4; $9.4 \mathrm{~cm}$ at the widest part of the bottle body

BASE DIAMETER (IN CM): 4.6

ESTIMATED VOLUME (IN LITERS): 0.21 liters

DECORATION: The bottle body has four stacked negative meander scrolls outlines by finely-executed cross-hatched engraved fill zones (Figure A3-38). There are negative ovals within the cross-hatched engraved fill zones, and each negative oval has a single small excised circle in its center (Figure A3-38).

TYPE: Hodges Engraved, var. Candler

Figure A3-38. Hodges Engraved, var. Candler bottle from the Lester Bros. Place (5425961).

SITE NAME OR SITE NUMBER: Lester Bros. Place

CONTEXT INFORMATION: From a Caddo cemetery, 1928.

ACCESSION NO.: 5425-964

VESSEL NO.: V-291

NON-PLASTICS: fine grog

VESSEL FORM: Carinated bowl with two rim panels

RIM AND LIP FORM: Direct rim and a rounded lip

CORE COLOR: B (fired and cooled in a reducing environment)

INTERIOR SURFACE COLOR: black

EXTERIOR SURFACE COLOR: black

WALL THICKNESS (RIM, BODY, AND BASE IN MM): 5.9 mm, rim

INTERIOR SURFACE TREATMENT: smoothed on the body and burnished on the rim EXTERIOR SURFACE TREATMENT: burnished on the rim and body 
HEIGHT (IN CM): 8.5

ORIFICE DIAMETER (IN CM): 15.4

DIAMETER AT BOTTOM OF RIM OR NECK (IN CM): 17.8

BASE DIAMETER (IN CM): N/A, rounded base

ESTIMATED VOLUME (IN LITERS): 0.79 liters

DECORATION: The upper rim panel is undecorated. The lower panel has a motif repeated four times that consists of a single short horizontal engraved line with single rows of excised punctations (six or seven per row) above and below the engraved line (Figure A3-39), as well as small upper and lower triangular hatched zones pendant from the top and bottom of the rim panel. The four sets of the motif are divided by broad crosshatched engraved brackets with triangular tick marks (Figure A3-39).

TYPE: Belcher Engraved, var. unspecified

Figure A3-39. Belcher Engraved, var. unspecified carinated bowl (5425-964).

SITE NAME OR SITE NUMBER: Lester Bros. Place

CONTEXT INFORMATION: From a Caddo cemetery, June 1929.

ACCESSION NO.: 5425-965

VESSEL NO.: V-62

NON-PLASTICS: grog

VESSEL FORM: Carinated bottle with a short neck and a pedestal base (Figure A3-40a)

RIM AND LIP FORM: Direct rim with a rounded but flared lip

CORE COLOR: B (fired and cooled in a reducing environment)

INTERIOR SURFACE COLOR: very dark gray

EXTERIOR SURFACE COLOR: very dark gray; fire clouds at the carination

WALL THICKNESS (RIM, BODY, AND BASE IN MM): 4.0 mm, rim

INTERIOR SURFACE TREATMENT: smoothed on the upper neck 
EXTERIOR SURFACE TREATMENT: burnished on the body

HEIGHT (IN CM): 11.4

ORIFICE DIAMETER (IN CM): 4.5

DIAMETER AT BOTTOM OF RIM OR NECK (IN CM): $4.1 ; 11.9 \mathrm{~cm}$ at the carination

BASE DIAMETER (IN CM): 4.9

ESTIMATED VOLUME (IN LITERS): 0.22 liters

DECORATION: The bottle neck has four rows of tool punctates (Figures A3-40a-b) made before the vessel was fired. The vessel body has a negative meandering scroll repeated five times; the background engraved fill zones are filled with engraved punctations. The pedestal base has two horizontal engraved lines on it (Figures A3-40ab).

TYPE: Unidentified fine ware bottle, cf. Hodges Engraved

Figure A3-40. Engraved and punctated bottle (5425-965): a, side view; b, drawing by Bobby Gonzalez.

SITE NAME OR SITE NUMBER: Lester Bros. Place, 1927

CONTEXT INFORMATION: From a grave in a Caddo cemetery

ACCESSION NO.: 5425-966

VESSEL NO.: V-358

NON-PLASTICS: grog

VESSEL FORM: Carinated bowl with two rim panels

RIM AND LIP FORM: Direct rim with a flat lip

CORE COLOR: B (fired and cooled in a reducing environment)

INTERIOR SURFACE COLOR: very dark grayish-brown

EXTERIOR SURFACE COLOR: dark grayish-brown 
WALL THICKNESS (RIM, BODY, AND BASE IN MM): 4.8 mm, rim

INTERIOR SURFACE TREATMENT: burnished on the rim

EXTERIOR SURFACE TREATMENT: body and rim are burnished

HEIGHT (IN CM): 8.0

ORIFICE DIAMETER (IN CM): 10.0

DIAMETER AT BOTTOM OF RIM OR NECK (IN CM): 10.5

BASE DIAMETER (IN CM): N/A, rounded base

ESTIMATED VOLUME (IN LITERS): 0.48 liters

DECORATION: The upper rim panel is plain. The lower rim panel has four sets of engraved concentric semi-circles divided by large cross-hatched engraved pendant triangles whose apex extends to the carination point (Figure A3-41). In two of the sets of engraved semi-circles, the outermost engraved lines have triangular ticks, and the other engraved semi-circles form two curvilinear bands filled with excised punctations (Figure A3-41). The other two sets of engraved semi-circles have only one line with tick marks and three curvilinear bands filled with excised punctations.

TYPE: Unidentified engraved fine ware vessel, cf. Avery Engraved

Figure A3-41. Engraved carinated bowl (5425-966).

SITE NAME OR SITE NUMBER: Lester Bros. Place

CONTEXT INFORMATION: From a grave in a Caddo cemetery, 1929.

ACCESSION NO.: 5425-1594

VESSEL NO.: V-155

NON-PLASTICS: grog

VESSEL FORM: Deep bowl

RIM AND LIP FORM: Direct rim and a rounded lip

CORE COLOR: B (fired and cooled in a reducing environment) 
INTERIOR SURFACE COLOR: very dark gray

EXTERIOR SURFACE COLOR: very dark gray

WALL THICKNESS (RIM, BODY, AND BASE IN MM): 6.9 mm, rim

INTERIOR SURFACE TREATMENT: smoothed on the rim and upper body

EXTERIOR SURFACE TREATMENT: smoothed, with patches of burnishing

HEIGHT (IN CM): 13.3

ORIFICE DIAMETER (IN CM): 11.5

DIAMETER AT BOTTOM OF RIM OR NECK (IN CM): 10.1

BASE DIAMETER (IN CM): 6.1

ESTIMATED VOLUME (IN LITERS): 1.22 liters

DECORATION: There are three closely spaced horizontal engraved lines encircling the rim; the lip is notched (Figure A3-42). Pendant from the lowest horizontal engraved line are eight large engraved triangles with a single spur at the triangle's apex (Figure A3-42). Seven of these pendant triangles have cross-hatched engraved oval areas at the three corners of the triangle; the other has one cross-hatched oval in a corner, while the other two corners have hatched oval areas.

TYPE: Hardman Engraved, var. Hardman (Early 1993:91) vessel

Figure A3-42. Hardman Engraved, var. Hardman deep bowl (5425-1594).

SITE NAME OR SITE NUMBER: Lester Bros. Place

CONTEXT INFORMATION: From a grave in a Caddo cemetery, 1928.

ACCESSION NO.: 5425-1595

VESSEL NO.: V-445

NON-PLASTICS: fine grog

VESSEL FORM: Bottle with a spool neck

RIM AND LIP FORM: Flared rim with an exterior folded lip 
CORE COLOR: B (fired and cooled in a low oxygen environment)

INTERIOR SURFACE COLOR: very dark gray

EXTERIOR SURFACE COLOR: very dark gray

WALL THICKNESS (RIM, BODY, AND BASE IN MM): 5.3 mm, rim

INTERIOR SURFACE TREATMENT: none

EXTERIOR SURFACE TREATMENT: burnished

HEIGHT (IN CM): 19.4

ORIFICE DIAMETER (IN CM): 6.3

DIAMETER AT BOTTOM OF RIM OR NECK (IN CM): $5.0 ; 18.5 \mathrm{~cm}$ at the widest place on the vessel body

BASE DIAMETER (IN CM): 11.5

ESTIMATED VOLUME (IN LITERS): 0.89 liters

DECORATION: The uppermost part of the vessel body has three horizontal trailed lines. On the remainder of the vessel are two stacked sets of four repeated continuous trailed scrolls and scrolls with hooked arm elements (Figure A3-43). The continuous scrolls extend from the top to the bottom of the vessel body, while the hooked arm scroll motif in each stacked set originate from a discrete series of four horizontal trailed lines at different places on the body itself.

TYPE: Keno Trailed, var. Glendora

Figure A3-43. Keno Trailed, var. Glendora bottle (5425-1595) from the Lester Bros. Place.

SITE NAME OR SITE NUMBER: Lester Bros. Place

CONTEXT INFORMATION: From a grave in a cemetery, 1929

ACCESSION NO.: 5425-1597

VESSEL NO.: V-170 
NON-PLASTICS: fine grog

VESSEL FORM: Carinated bottle with a straight neck

RIM AND LIP FORM: Direct rim with a flared but flat lip

CORE COLOR: B (fired and cooled in a low oxygen environment)

INTERIOR SURFACE COLOR: black

EXTERIOR SURFACE COLOR: dark brown

WALL THICKNESS (RIM, BODY, AND BASE IN MM): 3.9 mm, neck

INTERIOR SURFACE TREATMENT: smoothed on the upper neck

EXTERIOR SURFACE TREATMENT: burnished on the body and bottle neck

HEIGHT (IN CM): 15.5

ORIFICE DIAMETER (IN CM): 4.5

DIAMETER AT BOTTOM OF RIM OR NECK (IN CM): 4.3; $13.0 \mathrm{~cm}$ at its widest point

BASE DIAMETER (IN CM): 6.0

ESTIMATED VOLUME (IN LITERS): 0.37 liters

DECORATION: There is a single horizontal engraved line under the bottle lip. The vessel body has engraved scrolls that begin with hooked arms; the scroll motif is repeated five times around the vessel (Figure A3-44).

TYPE: Taylor Engraved

Figure A3-44. Taylor Engraved bottle (5425-1597).

SITE NAME OR SITE NUMBER: Lester Bros. Place

CONTEXT INFORMATION: From a grave in a Caddo cemetery exposed during dynamiting of a Red River levee, June 1929.

ACCESSION NO.: 5425-1599 
VESSEL NO.: V-52

NON-PLASTICS: grog

VESSEL FORM: Jar with a short $(1.2 \mathrm{~cm})$ rim

RIM AND LIP FORM: Everted rim with a rounded but exterior folded lip

CORE COLOR: $\mathrm{G}$ (fired in a reducing environment but cooled in the open air)

INTERIOR SURFACE COLOR: black

EXTERIOR SURFACE COLOR: dark grayish-brown

WALL THICKNESS (RIM, BODY, AND BASE IN MM): 3.9 mm, rim

INTERIOR SURFACE TREATMENT: smoothed on the rim and upper body

EXTERIOR SURFACE TREATMENT: smoothed on the lower body

HEIGHT (IN CM): 13.1

ORIFICE DIAMETER (IN CM): 10.0

DIAMETER AT BOTTOM OF RIM OR NECK (IN CM): 8.8

BASE DIAMETER (IN CM): 7.0

ESTIMATED VOLUME (IN LITERS): 0.79 liters

DECORATION: The short rim has closely-spaced vertical incised lines (Figure A3-45). The decoration on the body consists of thin vertical ridges separated by narrow vertical brushed areas. These decorative elements end well above the vessel base (Figure A3-45).

TYPE: Belcher Ridged, var. Wilson's Island

Figure A3-45. Belcher Ridged, var. Wilson's Island jar (5425-1599).

SITE NAME OR SITE NUMBER: Lester Bros. Place

CONTEXT INFORMATION: From a grave in a Caddo cemetery, 1927 
ACCESSION NO.: 5425-1601

VESSEL NO.: V-229

NON-PLASTICS: grog and bone

VESSEL FORM: Jar with two opposed strap handles

RIM AND LIP FORM: Direct rim with a rounded and exterior folded lip

CORE COLOR: B (fired and cooled in a low oxygen environment)

INTERIOR SURFACE COLOR: very dark grayish-brown

EXTERIOR SURFACE COLOR: dark grayish-brown

WALL THICKNESS (RIM, BODY, AND BASE IN MM): 7.6 mm, rim

INTERIOR SURFACE TREATMENT: smoothed on the rim and body

EXTERIOR SURFACE TREATMENT: none

HEIGHT (IN CM): 13.0

ORIFICE DIAMETER (IN CM): 12.5

DIAMETER AT BOTTOM OF RIM OR NECK (IN CM): 11.8

BASE DIAMETER (IN CM): 8.5

ESTIMATED VOLUME (IN LITERS): 0.98 liters

DECORATION: The rim has single rows of tool punctates at the top and bottom of the rim. The remainder of the rim has horizontal brushing with two opposed appliqued nodes (Figure A3-46).

The decoration on the vessel body consists of four diamond-shaped areas outlined with appliqued fillets; the diamond-shaped areas are filled with opposed brushing marks and centrally-placed nodes (see Figure A3-46). There are eight (four upper and four lower) triangular-shaped areas between the diamond-shaped areas; these are filled with horizontal brushing marks and centrally-placed appliqued nodes.

The strap handles are decorated with five vertical rows of appliqued fillets with areas of vertical brushing between the fillets (see Figure A3-46).

TYPE: Haley Complicated Incised 
Figure A3-46. Haley Complicated Incised jar (5425-1601).

SITE NAME OR SITE NUMBER: Lester Bros. Place

CONTEXT INFORMATION: From a grave in a Caddo cemetery exposed along a levee after it had been dynamited, June 1929.

ACCESSION NO.: 5425-2642

VESSEL NO.: V-465

NON-PLASTICS: grog

VESSEL FORM: Carinated bowl

RIM AND LIP FORM: Inverted rim with a rounded and slightly exterior folded lip

CORE COLOR: F (fired in a reducing environment, but cooled in the open air)

INTERIOR SURFACE COLOR: brown, with fire clouding

EXTERIOR SURFACE COLOR: brown, with fire clouding

WALL THICKNESS (RIM, BODY, AND BASE IN MM): rim, $2.8 \mathrm{~mm}$; body, $3.7 \mathrm{~mm}$

INTERIOR SURFACE TREATMENT: burnished on the rim and body

EXTERIOR SURFACE TREATMENT: burnished on the rim and body

HEIGHT (IN CM): 8.0

ORIFICE DIAMETER (IN CM): 14.0

DIAMETER AT BOTTOM OF RIM OR NECK (IN CM): 15.0

BASE DIAMETER (IN CM): 4.5

ESTIMATED VOLUME (IN LITERS):

DECORATION: The rim has a simple scroll motif repeated four times, with a row of punctations on the underside of the carination (Figure A3-47). The body of the vessel has a negative meandering scroll outlined by four repeating sets of cross-hatched hooked arm fill elements; two of the hooked arms have negative circles. 
TYPE: Hodges Engraved, var. unspecified

Figure A3-47. Hodges Engraved, var. unspecified carinated bowl (5425-2642). 


\section{Appendix 4,}

\section{Vessels from the Foster Place (3LA27)}

SITE NAME OR SITE NUMBER: Foster Place (3LA27)

CONTEXT INFORMATION: From a grave exposed during a 1938 Red River flood.

Associated vessels include V-1960 (another Belcher Engraved, var. Soda Lake bottle).

ACCESSION NO.: 5425-2133

VESSEL NO.: V-1961

NON-PLASTICS: grog

VESSEL FORM: Bottle with a straight neck

RIM AND LIP FORM: Missing

CORE COLOR: B (fired and cooled in a reducing environment)

INTERIOR SURFACE COLOR: black

EXTERIOR SURFACE COLOR: dark brown, with fire clouds

WALL THICKNESS (RIM, BODY, AND BASE IN MM): 3.5 mm, neck

INTERIOR SURFACE TREATMENT: none

EXTERIOR SURFACE TREATMENT: smoothed on the body

HEIGHT (IN CM): 15.0+

ORIFICE DIAMETER (IN CM): 3.6

DIAMETER AT BOTTOM OF RIM OR NECK (IN CM): 4.4, neck; 12.0 at the widest part of the body

BASE DIAMETER (IN CM): 5.0

ESTIMATED VOLUME (IN LITERS): 0.30 liters

DECORATION: There are four engraved panels on the bottle body, divided by a row of dashes or slot-like lines and four triangular excised areas under the bottle neck; these excised areas also have small negative circles (Figure A4-1). 
On the body of the bottle itself, the decoration consists of four sets of concentric circles that alternate with rows of dashes and slot-like lines. At the center of these concentric circles is a circle with nine attached excised triangles (Elizabeth 1 body design, Schambach and Miller 1984:Figure 11-8).

TYPE: Belcher Engraved, var. Soda Lake (Schambach and Miller 1984:120)

Figure A4-1. Belcher Engraved, var. Soda Lake bottle from the Foster Place (5425-2133).

SITE NAME OR SITE NUMBER: Foster Place (3LA27)

CONTEXT INFORMATION: Found on the outside of the Red River levee by Will Lacy in 1941

ACCESSION NO.: 5425-2135

VESSEL NO.: V-2264

NON-PLASTICS: grog and hematite/ferruginous sandstone

VESSEL FORM: Jar

RIM AND LIP FORM: Direct rim and a rounded lip

CORE COLOR: $\mathrm{G}$ (fired in a reduced oxygen environment, but cooled in the open air)

INTERIOR SURFACE COLOR: black

EXTERIOR SURFACE COLOR: black and light yellowish-brown

WALL THICKNESS (RIM, BODY, AND BASE IN MM): $5.0 \mathrm{~mm}$, rim; $4.9 \mathrm{~mm}$, body

INTERIOR SURFACE TREATMENT: smoothed

EXTERIOR SURFACE TREATMENT: none

HEIGHT (IN CM): 11.6

ORIFICE DIAMETER (IN CM): 8.5

DIAMETER AT BOTTOM OF RIM OR NECK (IN CM): 8.4

BASE DIAMETER (IN CM): 4.9 
ESTIMATED VOLUME (IN LITERS): 0.59 liters

DECORATION: The vessel has two stacked panels of brushed-incised marks, one on the tall rim and the other on the vessel body, separating by a single horizontal incised line midway on the vessel body (Figure A4-2). The stacked panels have opposed sets of brushed-incised marks that form alternating triangles with their apex either pointing up towards the rim or pointing downwards towards the vessel base.

TYPE: Unidentified utility ware

Figure A4-2. Brushed-incised jar (5425-2135).

SITE NAME OR SITE NUMBER: Foster Place (3LA27)

CONTEXT INFORMATION: From a grave exposed from a Red River flood in 1938. Associated vessels include V-1956, V-1958, and V-1959.

ACCESSION NO.: 5425-2136

VESSEL NO.: V-1957

NON-PLASTICS: shell

VESSEL FORM: Bottle with a straight to slightly bulging neck

RIM AND LIP FORM: Direct rim with a rounded, exterior folded lip

CORE COLOR: A (fired in a high oxygen or oxidizing environment)

INTERIOR SURFACE COLOR: reddish-yellow

EXTERIOR SURFACE COLOR: reddish-yellow on scraped areas; red on slipped areas

WALL THICKNESS (RIM, BODY, AND BASE IN MM): 5.5 mm, neck

INTERIOR SURFACE TREATMENT: none

EXTERIOR SURFACE TREATMENT: slipped and burnished

HEIGHT (IN CM): 18.5

ORIFICE DIAMETER (IN CM): 3.9

DIAMETER AT BOTTOM OF RIM OR NECK (IN CM): 4.3 


\section{BASE DIAMETER (IN CM): 6.6}

\section{ESTIMATED VOLUME (IN LITERS): 0.49 liters}

DECORATION: This vessel was first covered with a red-slip, and then after it was fired, the slip was scraped away (to show the original color of the vessel before it was slipped) in certain distinctive ways to create decorative areas marked either by a slipped or scraped surface (Figures A4-3 and A4-4). In this case, the slip was scraped away in a narrow horizontal panel under the neck, followed by a slipped area with three horizontal lines cut throw the slipping, and then by a continuous series of connected ovals created by scraping away the slip.

The principal decorative motif on this bottle, repeated four times, consists of a large circle made with alternating areas of slipped and non-slipped areas, with a central five-sided element; three of these large circles have a small slipped circle or dot at its very center, surrounded by a scraped area, but the fourth circle has the five-sided element and central dot or small circle outlined as scraped areas and by engraved lines (Figures A4-3 and A4-4). Above the vessel base is a series of four curvilinear zones outlined by the scraping slipped areas away. The base has no slipping on it.

TYPE: Hatinu Engraved (Perttula et al. 2005:30 and Figure 4.5)

Figure A4-3. Hatinu Engraved bottle (5425-2136).

Figure A4-4. Hatinu Engraved bottle from the Foster Place (5425-2136). Drawing by Bobby Gonzalez.

SITE NAME OR SITE NUMBER: Foster Place (3LA27)

CONTEXT INFORMATION: From a grave exposed from a Red River flood in 1938. Associated vessels include V-1956 to V-1958.

ACCESSION NO.: 5425-2141

VESSEL NO.: V-1959

NON-PLASTICS: shell and grog

VESSEL FORM: Carinated bowl with two rim panels

RIM AND LIP FORM: Direct rim with a rounded lip

CORE COLOR: B (fired and cooled in a reducing environment) 
INTERIOR SURFACE COLOR: very dark gray

EXTERIOR SURFACE COLOR: very dark gray

WALL THICKNESS (RIM, BODY, AND BASE IN MM): $3.3 \mathrm{~mm}$, rim; $3.2 \mathrm{~mm}$, body

INTERIOR SURFACE TREATMENT: burnished on the rim and body

EXTERIOR SURFACE TREATMENT: burnished on the rim and body

HEIGHT (IN CM): 6.3

ORIFICE DIAMETER (IN CM): 12.5

DIAMETER AT BOTTOM OF RIM OR NECK (IN CM): 11.3 on the upper panel; 13.6 at the carination

BASE DIAMETER (IN CM): N/A, rounded base

ESTIMATED VOLUME (IN LITERS): 0.47 liters

DECORATION: The upper panel is undecorated. The lower panel is divided by sets of closely-spaced vertical curvilinear lines that extend from the bottom of the upper panel to the carination, between which is a single horizontal line (Figure A4-5). Above and below that horizontal engraved line is a series of dashes or slot-like marks. There are no nodes visible on this vessel, although it has been heavily reconstructed.

TYPE: Belcher Engraved, var. unspecified

Figure A4-5. Belcher Engraved carinated bowl (5425-2141).

SITE NAME OR SITE NUMBER: Foster Place (3LA27)

CONTEXT INFORMATION: From a grave exposed from a Red River flood in 1938. Associated with V-1961 and V-1962 and two clay ear plugs

ACCESSION NO: 5425-2146

VESSEL NO.: V-1960

NON-PLASTICS: grog, with a sandy paste

VESSEL FORM: Bottle with four body peaks and a straight neck 
RIM AND LIP FORM: Direct rim with a rounded and exterior folded lip

CORE COLOR: B (fired and cooled in a reducing environment)

INTERIOR SURFACE COLOR: dark grayish-brown

EXTERIOR SURFACE COLOR: strong brown with fire clouding

WALL THICKNESS (RIM, BODY, AND BASE IN MM): 4.6 mm, neck

INTERIOR SURFACE TREATMENT: smoothed on the upper neck

EXTERIOR SURFACE TREATMENT: smoothed on the neck and body

HEIGHT (IN CM): 18.5

ORIFICE DIAMETER (IN CM): 3.9

DIAMETER AT BOTTOM OF RIM OR NECK (IN CM): 4.8; 15.5 at the widest part of the body

BASE DIAMETER (IN CM): 8.5

ESTIMATED VOLUME (IN LITERS): 0.63 liters

DECORATION: The top of the body is encircled with a single horizontal engraved line. the remainder of the body has four panels defined by four sets of large engraved pendant triangles with negative ovals, three hatched corners, and a fourth hatched triangle next to a thin engraved spur that extends into the negative ovals (Figure A4-6). Within each of these panels is a large circle that has a five-sided element at its center. The five-sided element is hatched along its margins, forming five negative ovals, and at the center is a smaller circle or disc with a small dimple at its center, and with three lines radiating from it.

TYPE: cf. Belcher Engraved, var. Soda Lake

Figure A4-6. Belcher Engraved, var. Soda Lake bottle (5425-2146).

SITE NAME OR SITE NUMBER: Foster Place (3LA27)

CONTEXT INFORMATION: From a grave exposed from a Red River flood in 1938. Associated vessels include V-1956 to V-1958. 
ACCESSION NO.: 5425-2148

VESSEL NO.: V-1956

NON-PLASTICS: grog

VESSEL FORM: Bottle with a tapered neck

RIM AND LIP FORM: Everted rim with a rounded lip

CORE COLOR: B (fired and cooled in a reducing environment)

INTERIOR SURFACE COLOR: very dark gray

EXTERIOR SURFACE COLOR: very dark gray

WALL THICKNESS (RIM, BODY, AND BASE IN MM): 5.1 mm, neck

INTERIOR SURFACE TREATMENT: smoothed on the upper neck

EXTERIOR SURFACE TREATMENT: burnished on the neck and body

HEIGHT (IN CM): 22.8

ORIFICE DIAMETER (IN CM): 4.3

DIAMETER AT BOTTOM OF RIM OR NECK (IN CM): $6.4 ; 23.0 \mathrm{~cm}$ wide at the widest point on the body

BASE DIAMETER (IN CM): N/A, rounded base

ESTIMATED VOLUME (IN LITERS): 0.39 liters

DECORATION: The bottle body has four panels with engraved concentric circles $(n=4)$. At the center of these concentric circles is a small circle with a narrow hatched band running horizontally across it (Figure A4-7). Marking the boundaries of each of these four panels of concentric circles are large pendant triangles at the top of the vessel body; these pendant triangles have hatched corners, forming a negative oval within the larger triangular element.

TYPE: Belcher Engraved, var. Ogden

Figure A4-7. Belcher Engraved, var. Ogden bottle from the Foster Place (5425-2148). 


\section{Appendix 5,}

\section{Vessels from the Geo. W. Sentell Place (3LA38)}

SITE NAME OR SITE NUMBER: Geo. W. Sentell Place

CONTEXT INFORMATION: From a grave excavated in 1909 by W. L. Conevy. Associated with V-55.

ACCESSION NO.: 5425-420

VESSEL NO:: V-402

NON-PLASTICS: fine grog

VESSEL FORM: Bottle; headless turtle effigy with four feet and short tail (Figure A51a-d)

RIM AND LIP FORM: Direct rim and rounded lip

CORE COLOR: $\mathrm{H}$ (fired in a reducing environment, but cooled in the open air)

INTERIOR SURFACE COLOR: brown (on the neck)

EXTERIOR SURFACE COLOR: black

WALL THICKNESS (RIM, BODY, AND BASE IN MM): 4.5 mm, rim

INTERIOR SURFACE TREATMENT: none

EXTERIOR SURFACE TREATMENT: burnished

HEIGHT (IN CM): 5.8 on the body; 6.0 at the bottle neck

ORIFICE DIAMETER (IN CM): 3.2

DIAMETER AT BOTTOM OF RIM OR NECK (IN CM): 2.8

BASE DIAMETER (IN CM): N/A

ESTIMATED VOLUME (IN LITERS): 0.08 liters

DECORATION: The upper body of the effigy is decorated with a scroll motif (beginning with a hooked arm element at either end of the scroll) that is repeated twice on the body 
(Figure A5-1a,d-e). The scroll motif is enclosed within a single engraved line that encircles the outer margins of the body, the neck, and the tail.

TYPE: Unidentified engraved fine ware effigy vessel

Figure A5-1. Engraved effigy vessel from the Geo. Sentell Place (5425-420): a, top of the vessel; $b$, back view of the vessel; $c$, view of the headless effigy from the front; $d$, side view of the vessel; e, drawing by Bobby Gonzalez.

SITE NAME OR SITE NUMBER: Geo. W. Sentell Place, 1909

CONTEXT INFORMATION: From a grave, 1909

ACCESSION NO.: 5425-482

VESSEL NO.: V-55

NON-PLASTICS: grog

VESSEL FORM: Bottle with four body peaks and a straight neck

RIM AND LIP FORM: Direct rim and a flat lip

CORE COLOR: B (fired and cooled in a low oxygen environment)

INTERIOR SURFACE COLOR: brown

EXTERIOR SURFACE COLOR: dark gray

WALL THICKNESS (RIM, BODY, AND BASE IN MM): 5.0 mm, rim

INTERIOR SURFACE TREATMENT: smoothed on the upper neck

EXTERIOR SURFACE TREATMENT: burnished on the neck and body

HEIGHT (IN CM): 18.1

ORIFICE DIAMETER (IN CM): 4.6

DIAMETER AT BOTTOM OF RIM OR NECK (IN CM): $6.8 ; 10.8 \mathrm{~cm}$ wide at its widest point on the body

BASE DIAMETER (IN CM): 6.5 
ESTIMATED VOLUME (IN LITERS): 0.47 liters

DECORATION: The top and base of the bottle neck are decorated with horizontal engraved bands filled with vertical engraved lines (Figure A5-2). Each of the four body peaks on this bottle have sets of engraved circles: three have crossed lines at the center, while the fourth has engraved spurs along one side of the central or inner engraved circle. The engraved peaks are divided by sets of vertical and curvilinear engraved lines that extend from the top of the body to near the base, and the central lines have excised spur elements

TYPE: possible Belcher Engraved, var. unspecified

Figure A5-2. Possible Belcher Engraved bottle (5425-482).

SITE NAME OR SITE NUMBER: Geo. W. Sentell Place

CONTEXT INFORMATION: From a grave in a Caddo cemetery, excavated by W. L. Conevy in 1909.

ACCESSION NO.: 5425-775

VESSEL NO.: V-294

NON-PLASTICS: grog

VESSEL FORM: Tripod bottle with hollow legs; the bottle has a straight neck

RIM AND LIP FORM: Direct rim and a rounded lip

CORE COLOR: B (fired and cooled in a low oxygen environment)

INTERIOR SURFACE COLOR: brown

EXTERIOR SURFACE COLOR: dark grayish-brown

WALL THICKNESS (RIM, BODY, AND BASE IN MM): 5.5 mm, neck

INTERIOR SURFACE TREATMENT: smoothed on the upper neck

EXTERIOR SURFACE TREATMENT: burnished on the neck, body, and legs

HEIGHT (IN CM): 19.6 
ORIFICE DIAMETER (IN CM): 5.2

DIAMETER AT BOTTOM OF RIM OR NECK (IN CM): 5.2

BASE DIAMETER (IN CM): N/A, rounded base

ESTIMATED VOLUME (IN LITERS): est. 0.5 liters

DECORATION: Each of the legs of the tripod bottle has been engraved with vertical bands of nearly horizontal hatching (Figure A5-3). On one of the legs there are two vertical bands of engraved lines filled with sets (of three lines) of horizontal hatched lines; on the two other legs, there is a single hatched line next to a hatched vertical band; this hatched line joins with a triangular set of hatched bands and a small excised triangle between them. Each of the legs are connected by a vertical to curvilinear engraved band filled with hatched lines.

TYPE: Hodges Engraved fine ware tripod bottle (see Webb 1959:Figure 107n)

Figure A5-3. Hodges Engraved fine ware tripod bottle from the Geo. W. Sentell Place (5425-775).

SITE NAME OR SITE NUMBER: Geo. W. Sentell Place

CONTEXT INFORMATION: From a grave in a Caddo cemetery, 1909

ACCESSION NO.: 5425-3622

VESSEL NO.: V-299

NON-PLASTICS: fine grog

VESSEL FORM: Carinated bowl with two rim panels

RIM AND LIP FORM: direct rim with a rounded lip

CORE COLOR: B (fired and cooled in a reducing environment)

INTERIOR SURFACE COLOR: very dark gray

EXTERIOR SURFACE COLOR: very dark gray

WALL THICKNESS (RIM, BODY, AND BASE IN MM): 4.6 mm, rim

INTERIOR SURFACE TREATMENT: burnished on rim 
EXTERIOR SURFACE TREATMENT: burnished on rim and body

HEIGHT (IN CM): 8.5

ORIFICE DIAMETER (IN CM): 12.8

DIAMETER AT BOTTOM OF RIM OR NECK (IN CM): 14.3 at the carination

BASE DIAMETER (IN CM): N/A, rounded base

ESTIMATED VOLUME (IN LITERS): 0.65

DECORATION: The upper panel of the vessel is undecorated. The lower panel has 12 sets of concentric semi-circles (defined by three semi-circles) (Figure A5-4) set off from one another by a cross-hatched engraved background (El Dorado 2 pattern, except on the lower rim) (see Schambach and Miller 1984:Figure 11-6).

TYPE: cf. Avery Engraved, var. Graves

Figure A5-4. Avery Engraved, var. Graves carinated bowl (5425-3622).

SITE NAME OR SITE NUMBER: Geo. W. Sentell

CONTEXT INFORMATION: From a grave, 1909

ACCESSION NO.: 5425-3623

VESSEL NO.: V-179

NON-PLASTICS: grog

VESSEL FORM: Carinated bowl

RIM AND LIP FORM: direct rim with a rounded and exterior folded lip

CORE COLOR: B (fired and cooled in a reducing environment)

INTERIOR SURFACE COLOR: black

EXTERIOR SURFACE COLOR: very dark gray

WALL THICKNESS (RIM, BODY, AND BASE IN MM): 6.7 mm, rim 
INTERIOR SURFACE TREATMENT: smoothed on rim and body

EXTERIOR SURFACE TREATMENT: smoothed on rim and body; fire clouds on body

HEIGHT (IN CM): 7.0

ORIFICE DIAMETER (IN CM): 20.8

DIAMETER AT BOTTOM OF RIM OR NECK (IN CM): 19.4

BASE DIAMETER (IN CM): N/A, rounded base

ESTIMATED VOLUME (IN LITERS): 0.87 liters

DECORATION: Interlocking horizontal engraved scroll motif repeated twice on the vessel rim; the motifs are separated by two curved cross-hatched engraved brackets, and the space between the bracket dividers is filled with punctations (Figure A5-5). The interlocking scroll is set in an oval surrounded by a punctated zone. Within the oval is a broad horizontal scroll of cross-hatched engraved lines, with two attached sets of curved brackets that either extend to the carination or the upper part of the rim.

TYPE: Handy Engraved

Figure A5-5. Handy Engraved carinated bowl (5425-3623).

SITE NAME OR SITE NUMBER: Geo. W. Sentell Place

CONTEXT INFORMATION: From a grave, 1909

ACCESSION NO.: 5425-3625

VESSEL NO.: V-43

NON-PLASTICS: grog

VESSEL FORM: Jar

RIM AND LIP FORM: direct rim with a rounded and exterior folded lip

CORE COLOR: B (fired and cooled in a reducing environment)

INTERIOR SURFACE COLOR: brown

EXTERIOR SURFACE COLOR: brown 
WALL THICKNESS (RIM, BODY, AND BASE IN MM): $5.3 \mathrm{~mm}$, rim

INTERIOR SURFACE TREATMENT: smoothed on the rim

EXTERIOR SURFACE TREATMENT: none

HEIGHT (IN CM): 10.4

ORIFICE DIAMETER (IN CM): 8.2

DIAMETER AT BOTTOM OF RIM OR NECK (IN CM): 7.9

BASE DIAMETER (IN CM): 6.9

ESTIMATED VOLUME (IN LITERS): 0.51 liters

DECORATION: The rim has opposed triangular sets of very closely-spaced tool punctations that are separated by five single vertical rows of punctations (Figure A5-6). The body is divided into 17 narrow panels by 17 vertical appliqued fillets that extend from the rim-body juncture to near the vessel base. Between each set of appliqued fillets are vertical brushing marks.

TYPE: Sinner Linear Punctated

Figure A5-6. Sinner Linear Punctated jar (5425-3625).

SITE NAME OR SITE NUMBER: Geo. W. Sentell Place

CONTEXT INFORMATION: From a grave, 1909

ACCESSION NO.: 5425-3626

VESSEL NO.: V-56

NON-PLASTICS: grog, with a sandy paste

VESSEL FORM: Bottle with a straight neck

RIM AND LIP FORM: Direct rim with a rounded and exterior folded lip

CORE COLOR: B (fired and cooled in a low oxygen environment)

INTERIOR SURFACE COLOR: black 
EXTERIOR SURFACE COLOR: black; fire clouds on the body and neck

WALL THICKNESS (RIM, BODY, AND BASE IN MM): 6.0 mm, neck

INTERIOR SURFACE TREATMENT: none

EXTERIOR SURFACE TREATMENT: smoothed on the body and neck

HEIGHT (IN CM): 20.8

ORIFICE DIAMETER (IN CM): 4.9

DIAMETER AT BOTTOM OF RIM OR NECK (IN CM): 5.8; $13.7 \mathrm{~cm}$ wide at the widest point on the body

BASE DIAMETER (IN CM): 9.4

ESTIMATED VOLUME (IN LITERS): 0.78 liters

DECORATION: The bottle body has five distinct engraved rectangular panels that extend from the base of the bottle neck to just above the base; there is a single horizontal engraved line encircling the lower part of the bottle body (Figure A5-7). All five panels feature narrow curvilinear and semi-circular zones or bands that are interconnected, some of which are filled with cross-hatched engraved lines while others are left undecorated. One of the panels also has a large cross-hatched pendant triangle from the top of the panel, while another has a small cross-hatched triangle pendant from the side of a panel. These same panels also have single equal-arm cross elements.

TYPE: Unidentified engraved bottle

Figure A5-7. Engraved bottle from the Geo. W. Sentell Place (5425-3626)

SITE NAME OR SITE NUMBER: Geo. W. Sentell

CONTEXT INFORMATION: From a grave excavated by W. L. Conevy in 1909.

ACCESSION NO.: 5425-3627

VESSEL NO.: V-1121

NON-PLASTICS: grog and bone

VESSEL FORM: Bottle with straight to slightly bulging neck 
RIM AND LIP FORM: direct rim with a rounded and exterior folded lip

CORE COLOR: B (fired and cooled in a reducing or low oxygen environment)

INTERIOR SURFACE COLOR: very dark gray

EXTERIOR SURFACE COLOR: black

WALL THICKNESS (RIM, BODY, AND BASE IN MM): $4.1 \mathrm{~mm}$, rim

INTERIOR SURFACE TREATMENT: none

EXTERIOR SURFACE TREATMENT: burnished

HEIGHT (IN CM): 20.7

ORIFICE DIAMETER (IN CM): 4.8

DIAMETER AT BOTTOM OF RIM OR NECK (IN CM): 5.2 at the neck; 13.1 at the widest part of the body

BASE DIAMETER (IN CM): 5.6

ESTIMATED VOLUME (IN LITERS): 0.46 liters

DECORATION: The body has vertical interlocking trailed scrolls repeated four times. Encircling the upper part of the bottle body, directly under the neck, are four sets of horizontal trailed lines, each with eight trailed lines (Figures A5-8 and A5-9).

TYPE: cf. Keno Trailed, var. McClendon (see Schambach and Miller 1984:Figure 1141a).

Figure A5-8. Keno Trailed, var. McClendon bottle (5425-3627).

Figure A5-9. Keno Trailed, var. McClendon bottle from the Geo. Sentell Place (54253627). Drawing by Bobby Gonzalez. 


\section{Appendix 6,}

\section{Vessels from the Cabaness Place (3LA84), Spirit Lake}

SITE NAME OR SITE NUMBER: Cabaness Place, Spirit Lake, found in 1915

CONTEXT INFORMATION: From a grave, 1915; obtained by W. P. Agee. Associated with V-37.

ACCESSION NO.: 5425-156

VESSEL NO.: V-29

NON-PLASTICS: grog

VESSEL FORM: Bowl with a cut down rim (Figure A6-1)

RIM AND LIP FORM: Direct with a flat lip on the cut-down rim

CORE COLOR: B (fired and cooled in a reducing environment)

INTERIOR SURFACE COLOR: grayish-brown

EXTERIOR SURFACE COLOR: dark grayish-brown

WALL THICKNESS (RIM, BODY, AND BASE IN MM): 4.4 mm, body

INTERIOR SURFACE TREATMENT: smoothed on the body

EXTERIOR SURFACE TREATMENT: burnished on the body

HEIGHT (IN CM): 5.0

ORIFICE DIAMETER (IN CM): 6.9

DIAMETER AT BOTTOM OF RIM OR NECK (IN CM): N/D

BASE DIAMETER (IN CM): 3.8

ESTIMATED VOLUME (IN LITERS): 0.14 liters

DECORATION: Undecorated

TYPE: Unidentified plain ware 
Figure A6-1. Plain bowl (V-29) from the Cabaness Place (5425-156).

SITE NAME OR SITE NUMBER: Cabaness Place, Spirit Lake, found in 1915

CONTEXT INFORMATION: From a grave, 1915. Associated with V-29.

ACCESSION NO.: 5425-158

VESSEL NO.: V-37

NON-PLASTICS: shell

VESSEL FORM: Bowl

RIM AND LIP FORM: Everted rim with a rounded and exterior folded lip

CORE COLOR: B (fired and cooled in a reducing environment)

INTERIOR SURFACE COLOR: black

EXTERIOR SURFACE COLOR: very dark grayish-brown

WALL THICKNESS (RIM, BODY, AND BASE IN MM): 2.9 mm, rim

INTERIOR SURFACE TREATMENT: burnished on the rim; smoothed on the body

EXTERIOR SURFACE TREATMENT: burnished on the rim and body

HEIGHT (IN CM): 6.2

ORIFICE DIAMETER (IN CM): 13.6

DIAMETER AT BOTTOM OF RIM OR NECK (IN CM): 10.3

BASE DIAMETER (IN CM): $6.5 \mathrm{~cm}$

ESTIMATED VOLUME (IN LITERS): 0.34 liters

DECORATION: The rim has engraved concentric semi-circles (El Dorado 2 design) repeated four times around the rim; each set of engraved semi-circles is divided by crosshatched engraved brackets (Figure A6-2).

The body has a continuous meandering negative scroll with tick marks that are defined or delimited by four equally-spaced curvilinear zones, two originating at the base 
of the vessel and two at the top of the meandering scroll. These zones have hatched lines at their tips, and the remainder of the fills of these zones are filled with small semicircular "fish-scale" elements (see Figure A6-2; see also Hemmings 1982:Figure 5-12b). There are traces of a white kaolin clay pigment in the engraved lines of this vessel.

TYPE: Natchitoches Engraved, var. unspecified

Figure A6-2. Natchitoches Engraved, var. unspecified from the Cabaness Place (V-37, 5425-158).

SITE NAME OR SITE NUMBER: Cabaness Place, Spirit Lake, found in 1915

CONTEXT INFORMATION: From a grave; the vessel was obtained from W. P. Agee

ACCESSION NO.: 5425-161

VESSEL NO.: V-40

NON-PLASTICS: shell

VESSEL FORM: Jar

RIM AND LIP FORM: Cut-down rim is inverted (Figure A6-3), with a rounded lip

CORE COLOR: A (fired and cooled in an oxidizing or high oxygen environment)

INTERIOR SURFACE COLOR: brown

EXTERIOR SURFACE COLOR: strong brown with evidence of fire clouding

WALL THICKNESS (RIM, BODY, AND BASE IN MM): 4.4 mm, rim; 4.7 mm, body

INTERIOR SURFACE TREATMENT: smoothed on the body

EXTERIOR SURFACE TREATMENT: none

HEIGHT (IN CM): $8.5 \mathrm{~cm}$

ORIFICE DIAMETER (IN CM): 9.5

DIAMETER AT BOTTOM OF RIM OR NECK (IN CM): 9.5

BASE DIAMETER (IN CM): 6.5 
ESTIMATED VOLUME (IN LITERS): 0.32 liters

DECORATION: Vertical and narrow appliqued ridges on the rim and body; the ridges extend from the rim to just above the base of the vessel (Figure A6-3; see also Hemmings 1982:Figure 5-12a). The cut down rim has lip notching.

TYPE: Belcher Ridged, var. unspecified

Figure A6-3. Belcher Ridged, var. unspecified jar from the Cabaness Place (V-40, 5425$161)$.

SITE NAME OR SITE NUMBER: Cabaness Place, near Spirit Lake

CONTEXT INFORMATION: From a grave; the vessel was obtained from W. P. Agee

ACCESSION NO.: 5425-225

VESSEL NO.: V-242

NON-PLASTICS: grog, bone, and hematite/ferruginous sandstone

VESSEL FORM: Seed jar with two opposed suspension holes (7.4 $\mathrm{mm}$ in diameter) near the lip (Figure A6-4a-b)

RIM AND LIP FORM: Inverted rim with a flat lip

CORE COLOR: B (fired and cooled in a reducing environment)

INTERIOR SURFACE COLOR: strong brown

EXTERIOR SURFACE COLOR: strong brown with gray and brown fire-clouds

WALL THICKNESS (RIM, BODY, AND BASE IN MM): 7.6 mm, rim

INTERIOR SURFACE TREATMENT: none

EXTERIOR SURFACE TREATMENT: smoothed on body

HEIGHT (IN CM): 9.0

ORIFICE DIAMETER (IN CM): 4.3

DIAMETER AT BOTTOM OF RIM OR NECK (IN CM): $10.0 \mathrm{~cm}$ at the widest part of the body 
BASE DIAMETER (IN CM): 9.0

ESTIMATED VOLUME (IN LITERS): 0.23 liters

DECORATION: Plain

TYPE: Unidentified plain seed jar

Figure A6-4. Plain seed jar from the Cabaness Place (5425-225): a, photograph; b, drawing by Bobby Gonzalez.

SITE NAME OR SITE NUMBER: Cabaness Place, near Spirit Lake CONTEXT INFORMATION: From a grave; obtained from W. P. Agee

ACCESSION NO.: 5425-226

VESSEL NO.: V-175

NON-PLASTICS: grog

VESSEL FORM: Carinated bowl

RIM AND LIP FORM: Inverted rim with a rounded and exterior folded lip

CORE COLOR: B (fired and cooled in a reducing environment)

INTERIOR SURFACE COLOR: grayish-brown

EXTERIOR SURFACE COLOR: dark grayish-brown

WALL THICKNESS (RIM, BODY, AND BASE IN MM): $4.6 \mathrm{~mm}$, rim

INTERIOR SURFACE TREATMENT: smoothed on the rim and body

EXTERIOR SURFACE TREATMENT: smoothed on the rim and body

HEIGHT (IN CM): 7.4

ORIFICE DIAMETER (IN CM): 15.0

DIAMETER AT BOTTOM OF RIM OR NECK (IN CM): 16.0 
BASE DIAMETER (IN CM): N/D, rounded base

ESTIMATED VOLUME (IN LITERS): 0.67 liters

DECORATION: Two stacked and alternating sets of engraved elements, each repeated twice across the rim panel. The engraved elements include two horizontal lines with excised pendant triangles (either pointing downward as in the case of the upper stacked design or pointing upward in the case of the lower stacked design) separated by vertically curvilinear engraved lines (Figures A6-5 and A6-6). With the stacking of the design elements, the pendant triangles on the upper stack are stacked above the vertical curvilinear lines on the lower stack, just as the pendant triangles on the lower stack are directly below the vertical curvilinear engraved lines element on the upper stack.

TYPE: Glassell Engraved

Figure A6-5. Photograph of Glassell Engraved carinated bowl from the Cabaness Place (V-175, 5425-226).

Figure A6-6. Glassell Engraved carinated bowl from the Cabaness Place (5425-226). Drawing by Bobby Gonzalez. 


\section{References Cited for Appendices}

Early, A. M.

2000 Ceramics. In Data Recovery at the Helm Site, 3HS449, Hot Spring County, Arkansas, by R. H. Lafferty III, A. Early, M. C. Sierzchula, M. C. Hill, G. S. Powell, N. H. Lopinot, L. S. Cummings, S. L. Scott, S. K. Nash, and T. K. Perttula, pp. 69-121. MCRA Report 2000-1. Mid-Continental Research Associates, Inc., Lowell, Arkansas.

Early, A. M. (editor)

1993 Caddoan Saltmakers in the Ouachita Valley: The Hardman Site. Research Series No. 43. Arkansas Archeological Survey, Fayetteville.

Hemmings, E. T.

1982 Spirit Lake (3LA83): Test Excavations in a Late Caddo Site on the Red River. In Contributions to the Archeology of the Great Bend Region, edited by F. F. Schambach and F. Rackerby, pp. 55-89. Research Series No. 22. Arkansas Archeological Survey, Fayetteville.

Kelley, D. B. (editor)

1997 Two Caddoan Farmsteads in the Red River Valley. Research Series No. 51. Arkansas Archeological Survey, Fayetteville.

Kidder, T. R.

1988 Prehistoric and Early Historic Culture Dynamics in Southeast Arkansas and Northeast Louisiana, A.D. 1500-1700. Ph.D. dissertation, Department of Anthropology, Harvard University, Cambridge.

Martin, G.

1939 Notes on Certain Explorations on the Battle Place, Red River Bottoms, Lafayette County, Arkansas. MS on file, Gilcrease Museum, Tulsa.

Miller, J. E., III

1986 The Myers Mound: Salvage Excavations at a Caddo II Site in Southwest Arkansas. The Arkansas Archeologist 23/24:67-127.

Perttula, T. K., B. Nelson, R. L. Cast, and B. Gonzalez

2005 The W. T. Scott Collection at the American Museum of Natural History. In $A$ Rediscovering of Caddo Heritage: The W. T. Scott Collection at the American Museum of Natural History and Other Caddo Collections from Arkansas and Louisiana, by B. Gonzalez, R. L. Cast, T. K. Perttula, and B. Nelson, pp. 25-53. Historic Preservation Program, Caddo Nation of Oklahoma, Binger, Oklahoma. 
Reilly, F. K., III

2004 People of Earth, People of Sky: Visualizing the Sacred in Native American Art of the Mississippian Period. In Hero, Hawk, and Open Hand: American Indian Art of the Ancient Midwest and South, edited by R. F. Townsend and R. V. Sharp, pp. 124-137. The Art Institute of Chicago and Yale University Press, New Haven and London.

Schambach, F. F. and J. E. Miller

1984 A Description and Analysis of the Ceramics. In Cedar Grove: An Interdisciplinary Investigation of a Late Caddo Farmstead in the Red River Valley, edited by N. L. Trubowitz, pp. 109-170. Research Series No. 23. Arkansas Archeological Survey, Fayetteville.

Suhm, D. A. and E. B. Jelks (editors)

1962 Handbook of Texas Archeology: Type Descriptions. Special Publication No. 1, Texas Archeological Society, and Bulletin No. 4, Texas Memorial Museum, Austin.

Walters, $M$.

2006 The Lake Clear (41SM243) Site and Crotalus horridus atricaudatus. Caddo Archeology Journal 15:5-39.

Webb, C. H.

1959 The Belcher Mound: A Stratified Caddoan Site in Caddo Parish, Louisiana. Memoirs No. 16. Society for American Archaeology, Salt Lake City, Utah. 
Figure Gilcrease-1

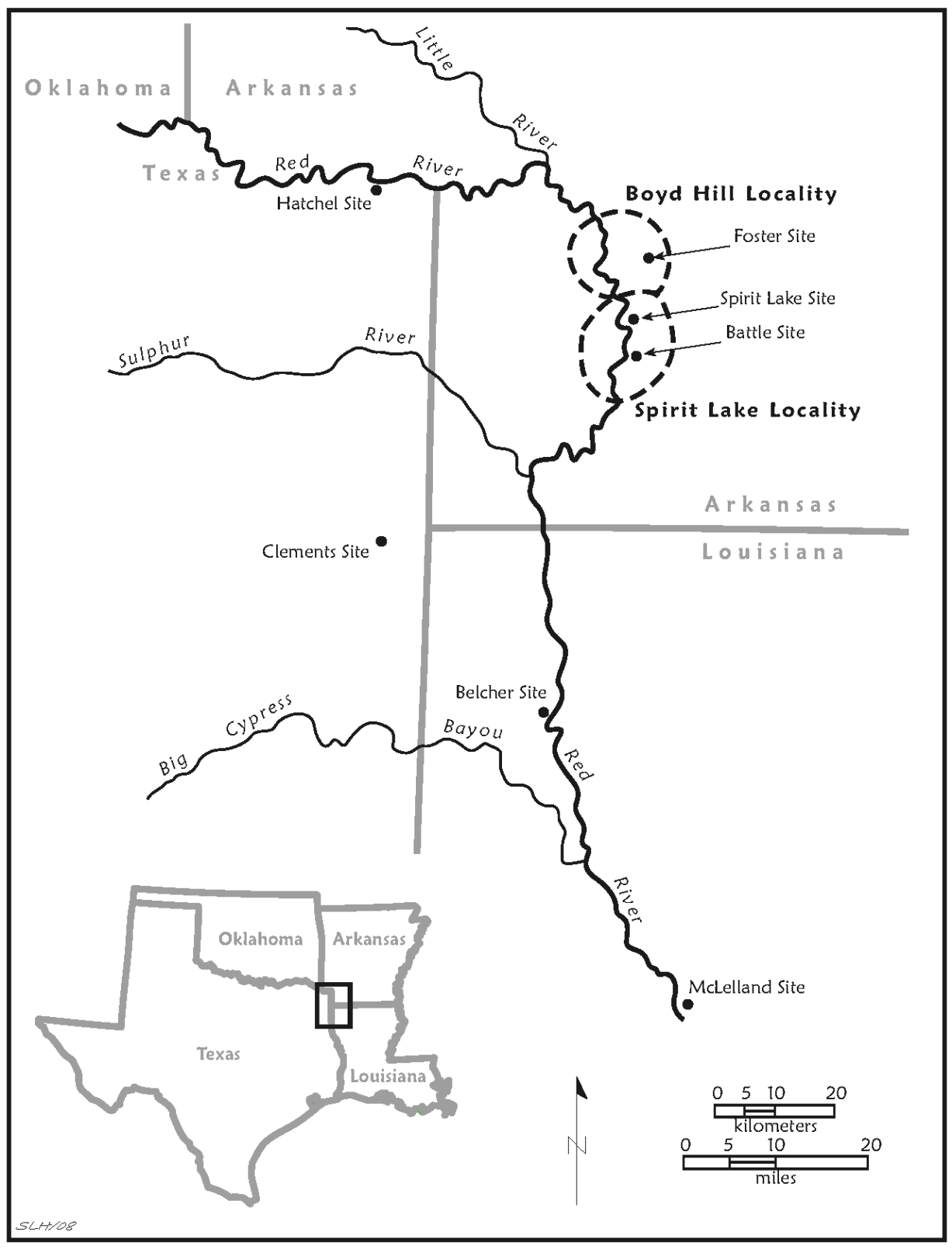

Figure 1 
Figure Gilcrease-2

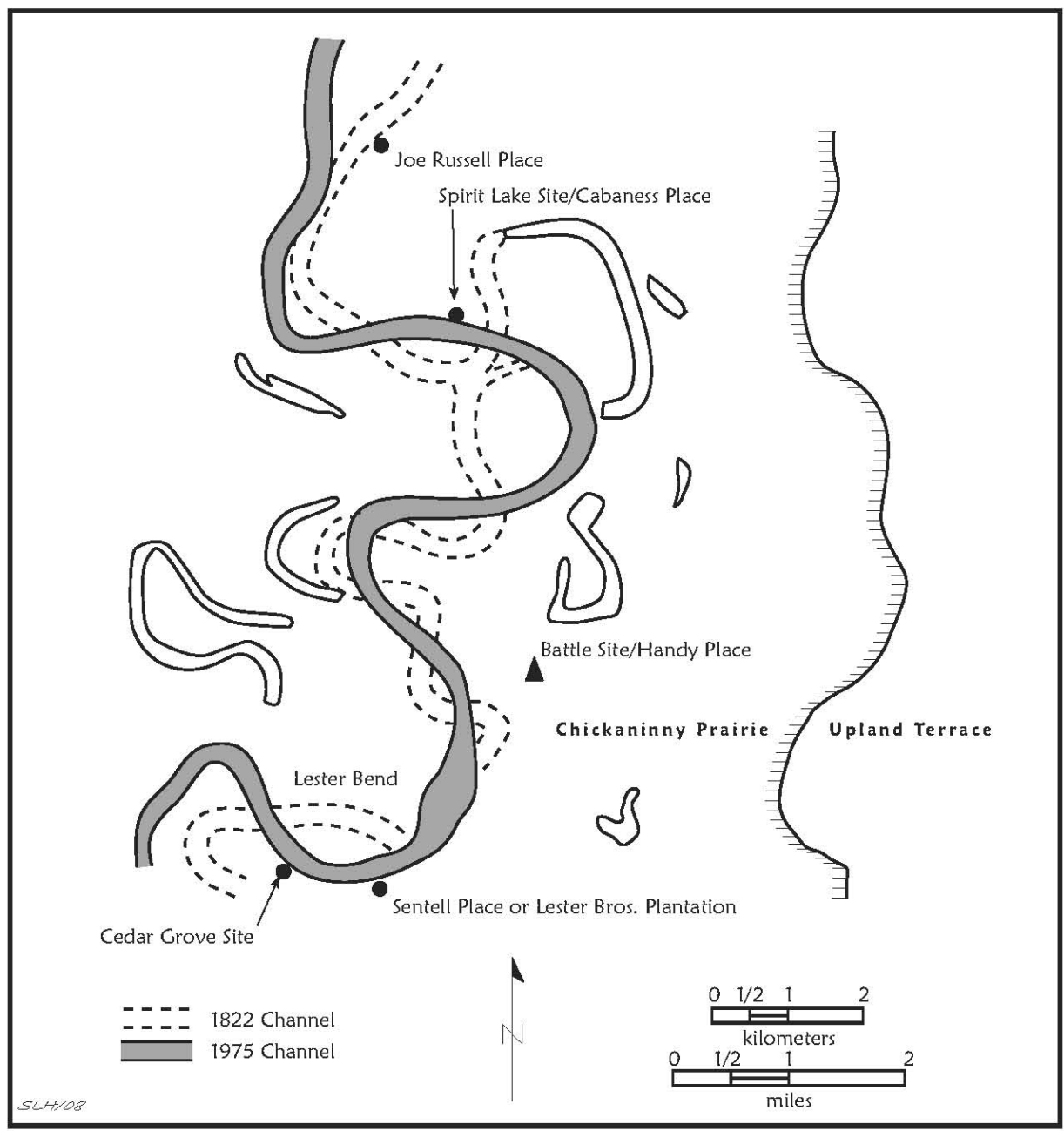

Figure 2 
Figure Gilcrease-3

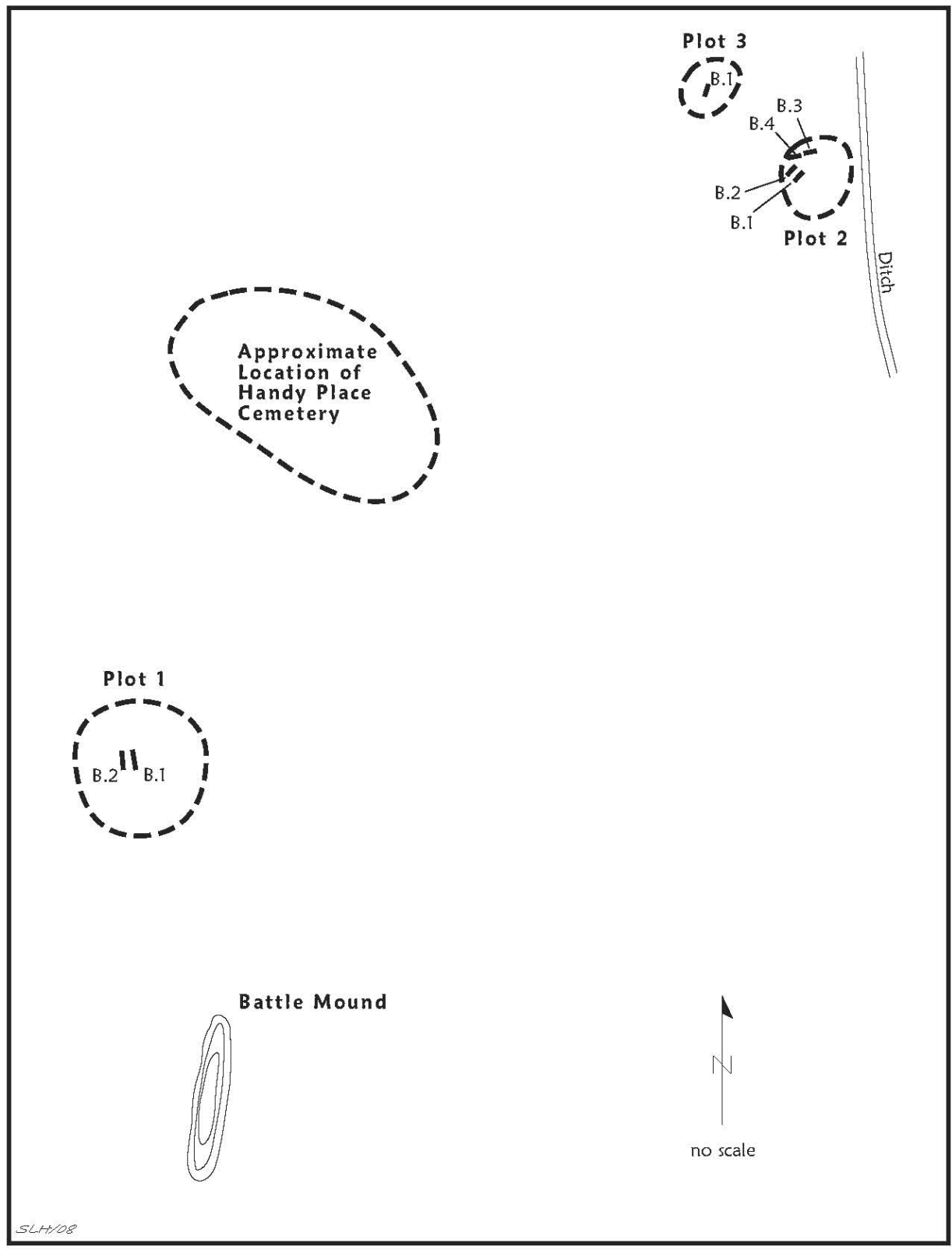

Figure 3 
Figure Gilcrease-4

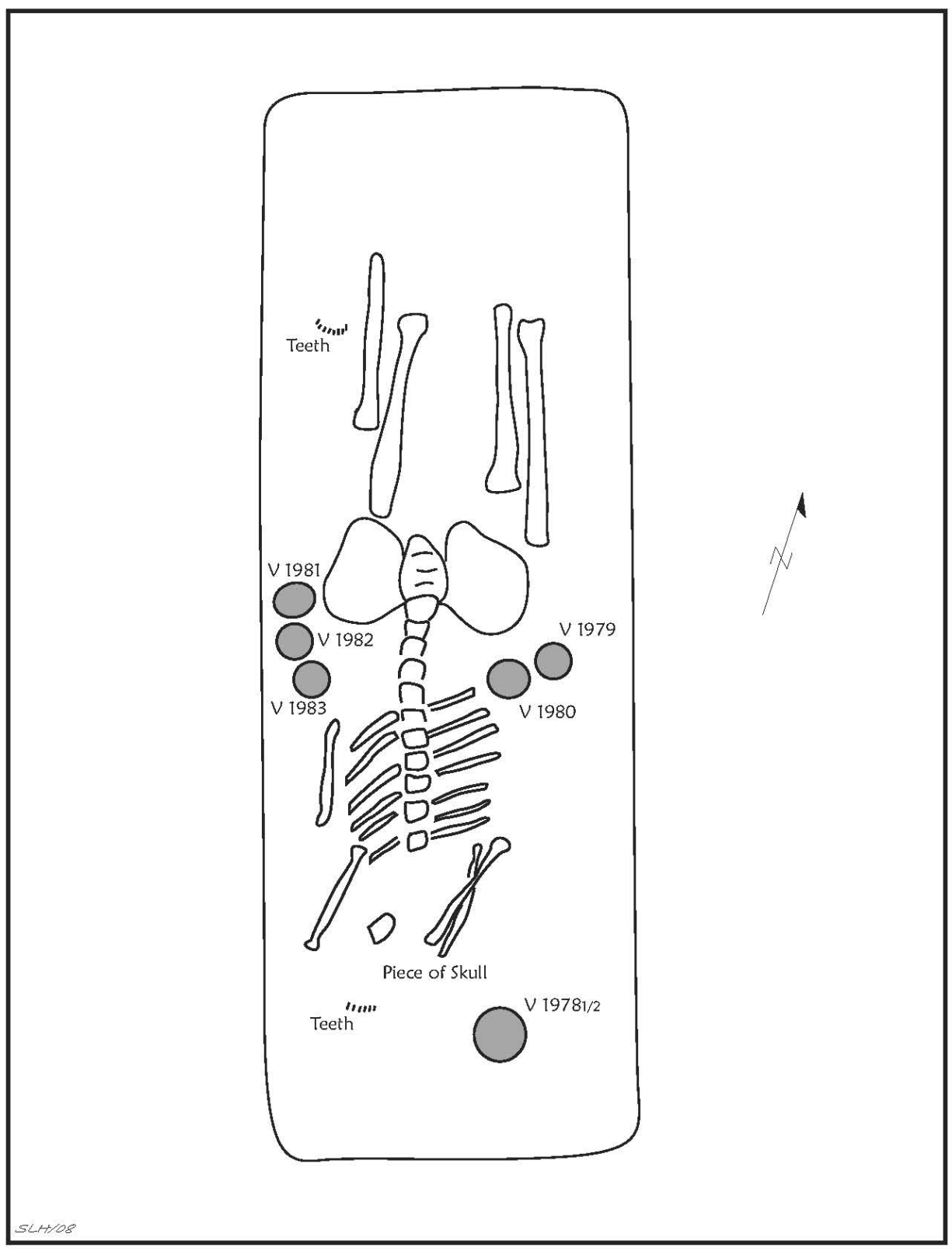

Figure 4 
Figure Gilcrease-5

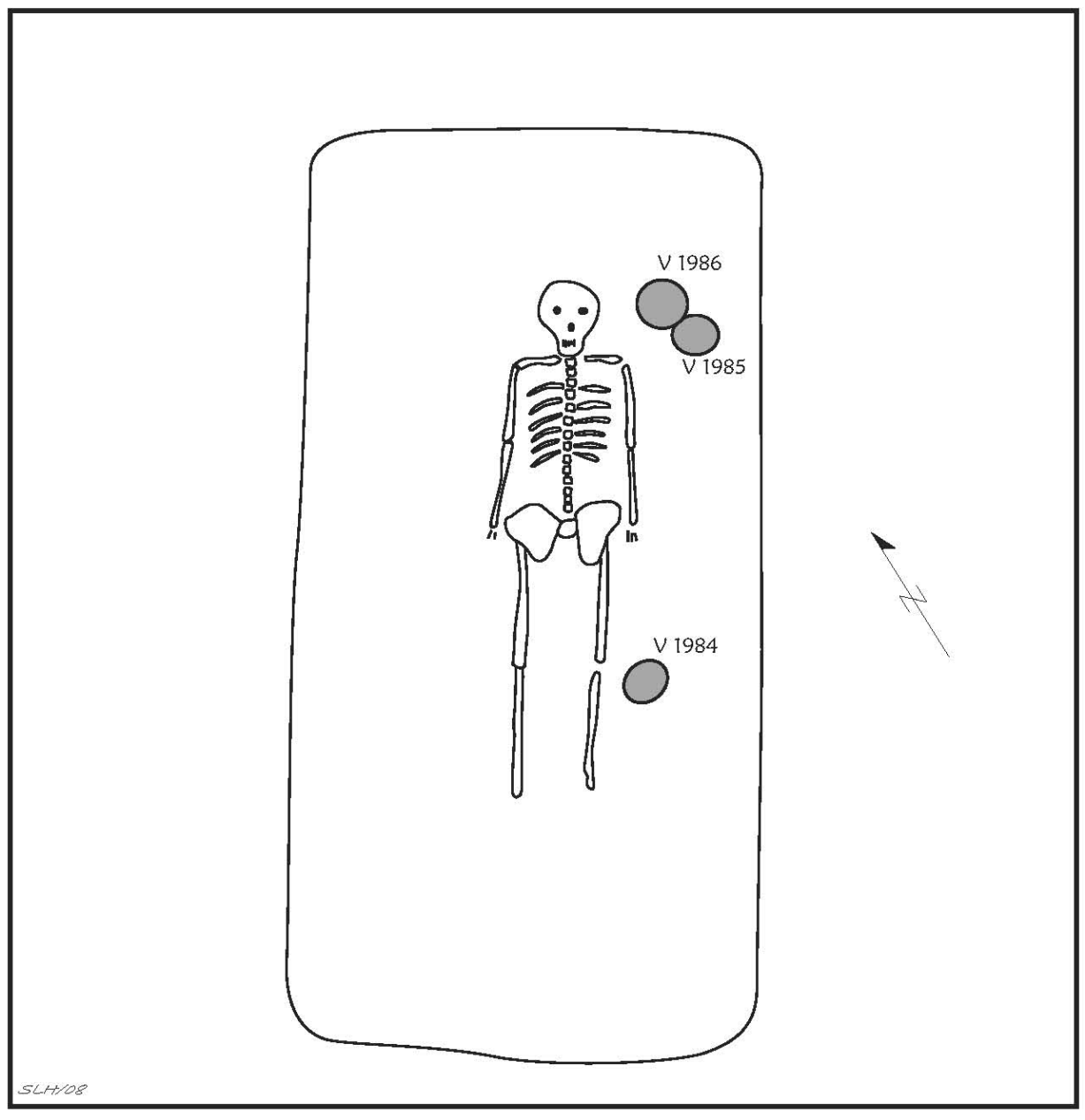

Figure 5 
Figure Gilcrease-6

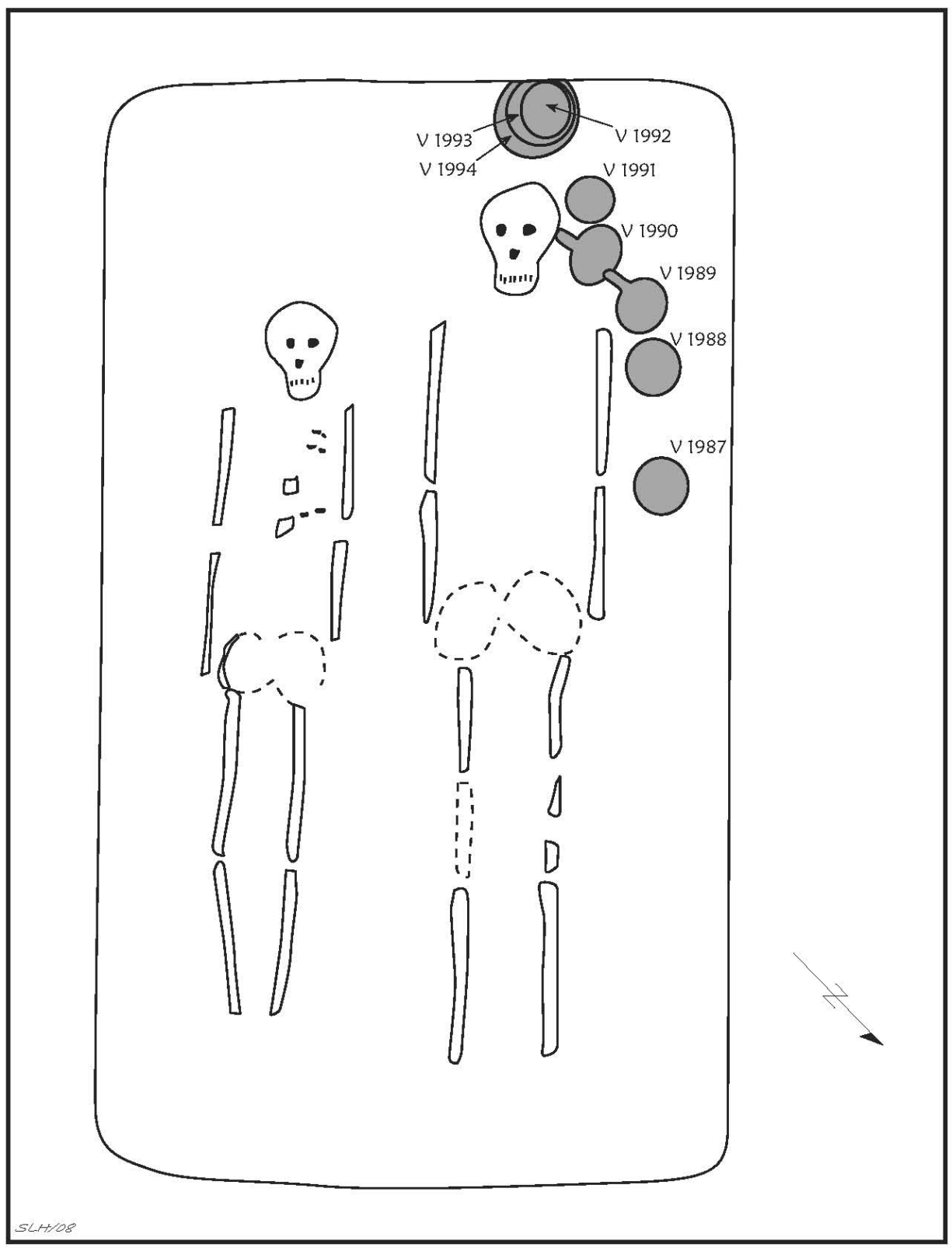

Figure 6 
Figure Gilcrease-7

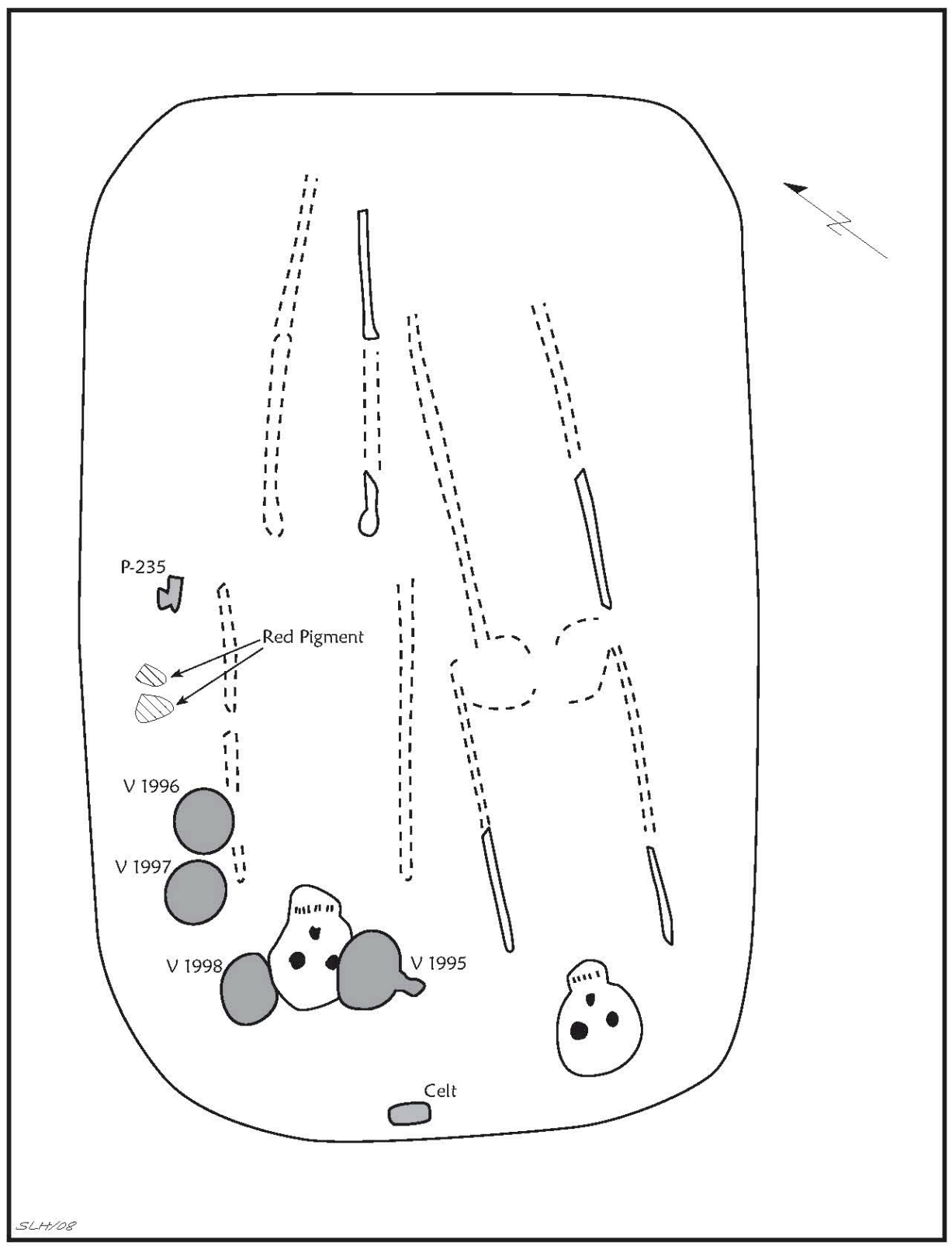

Figure 7 
Figure Gilcrease-8

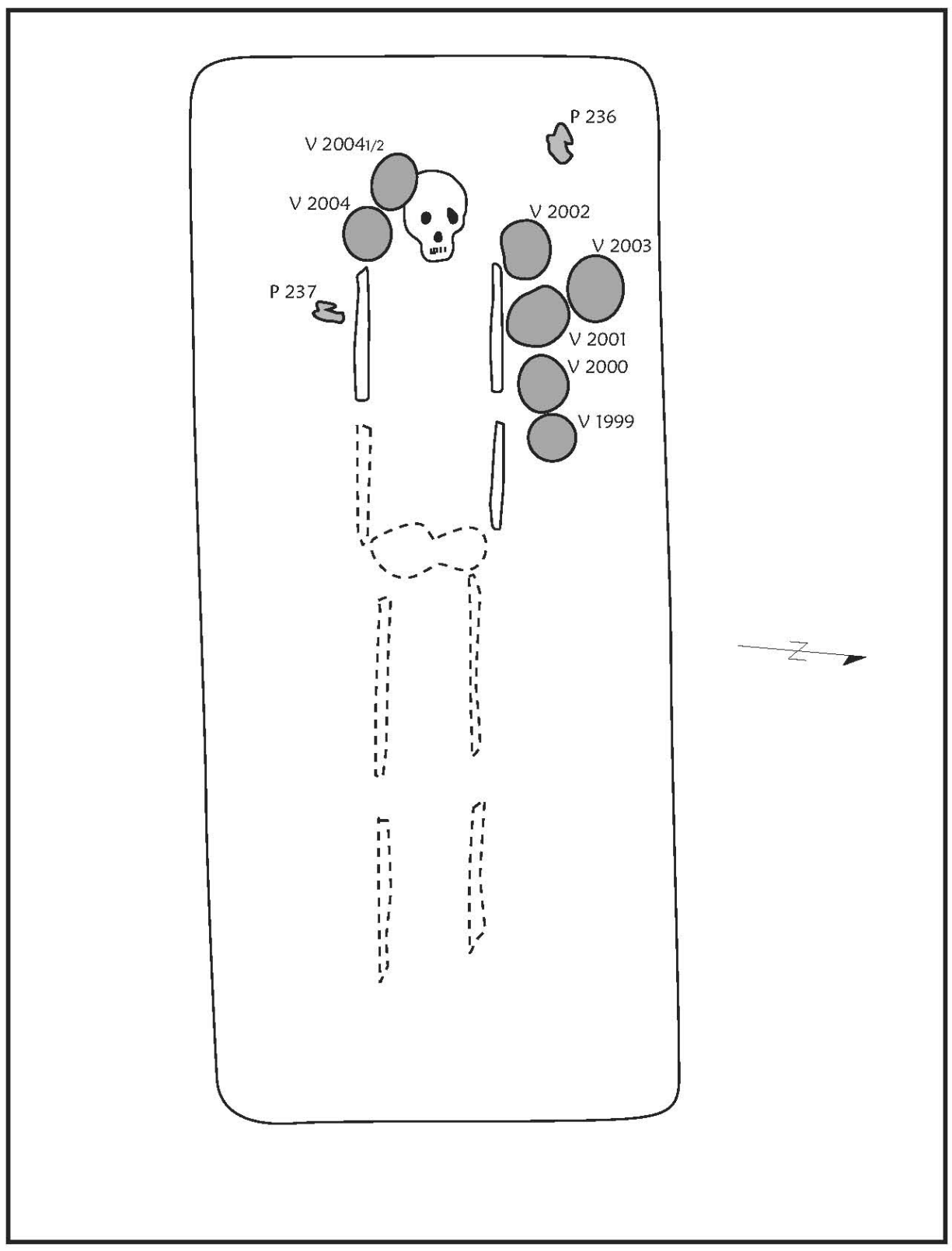

Figure 8 
Figure Gilcrease-9

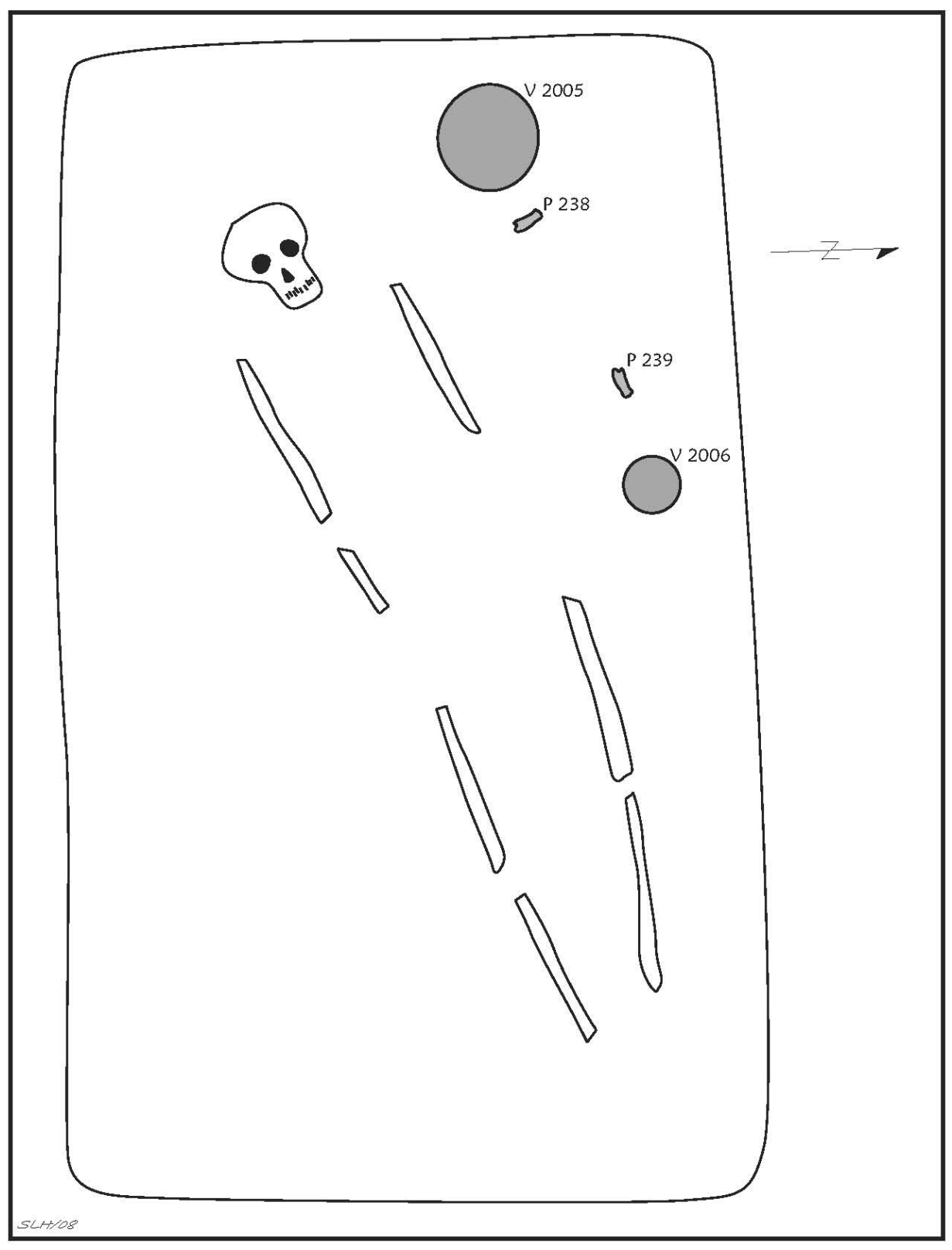

Figure 9 
Figure Gilcrease-10

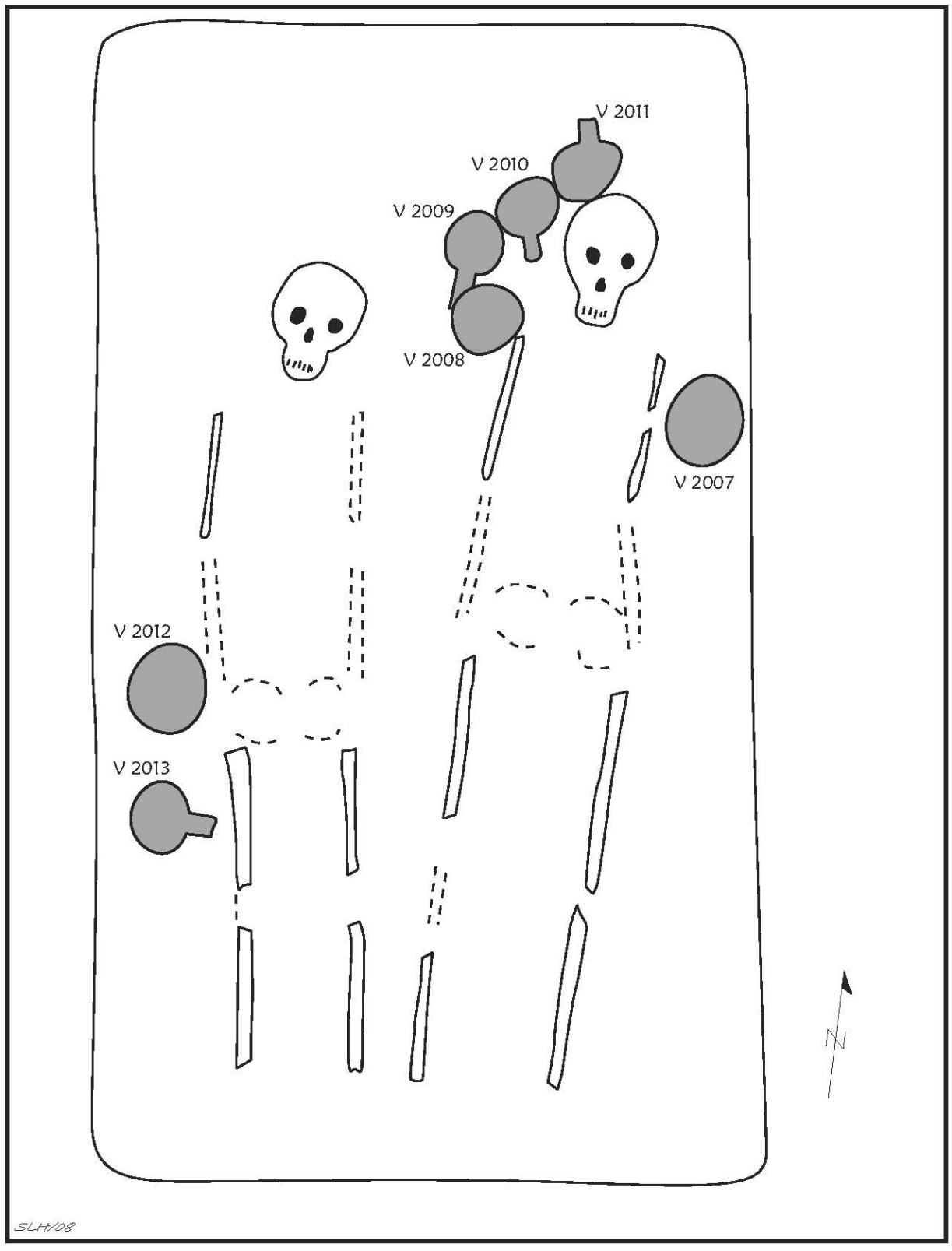

Figure 10 
Figure Gilcrease-11

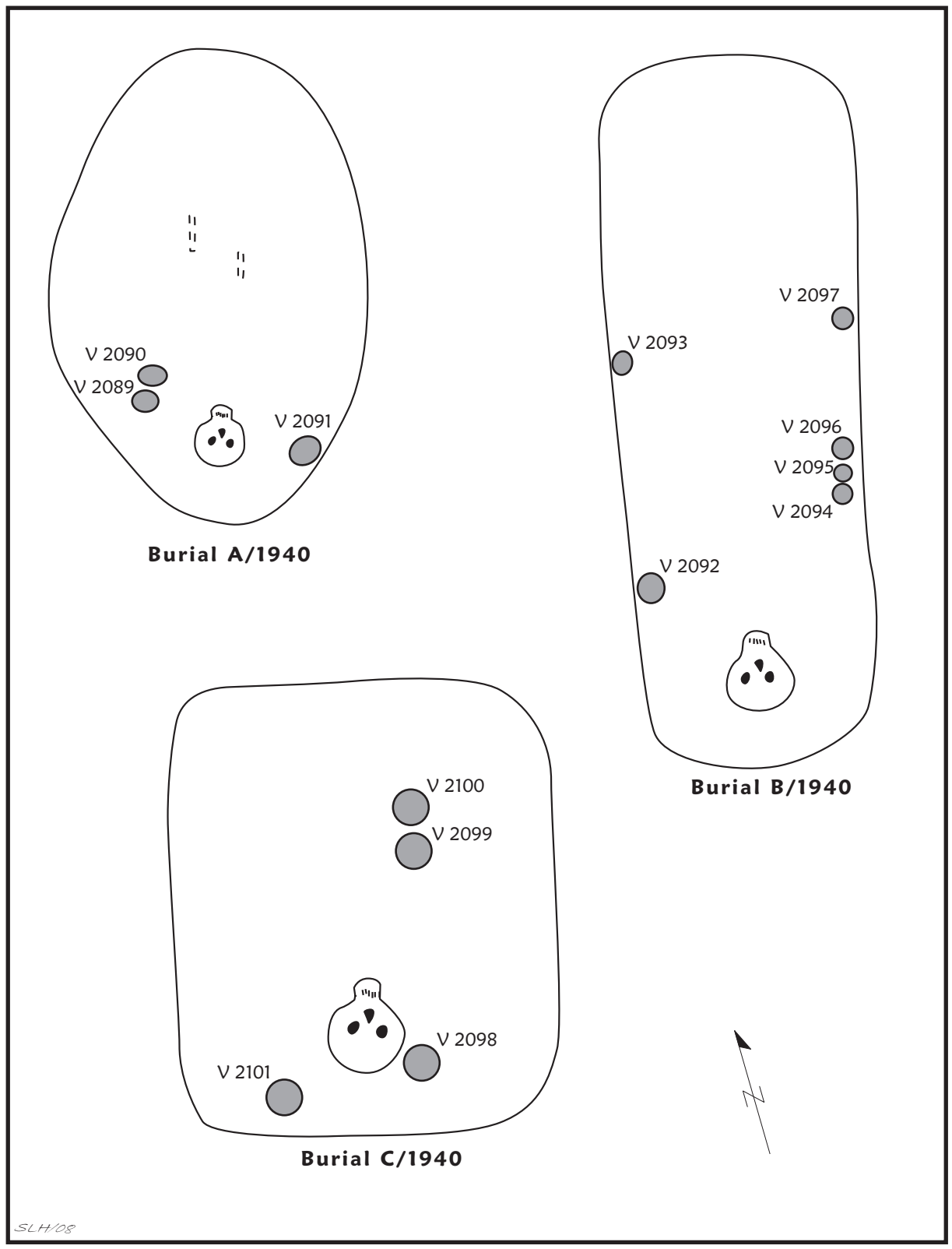

Figure 11 


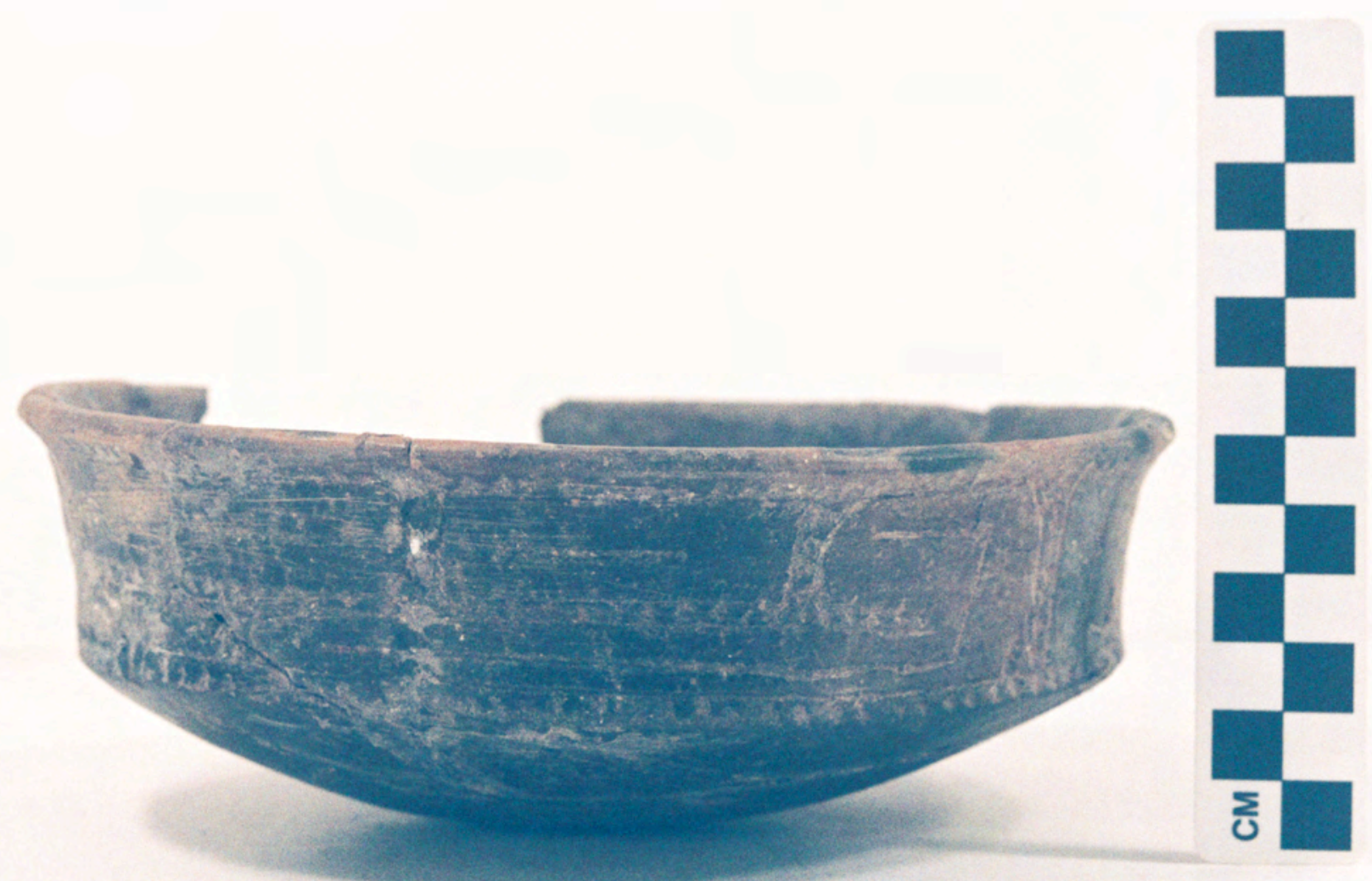

Figure $12 \mathrm{a}$

Figure A1-10 


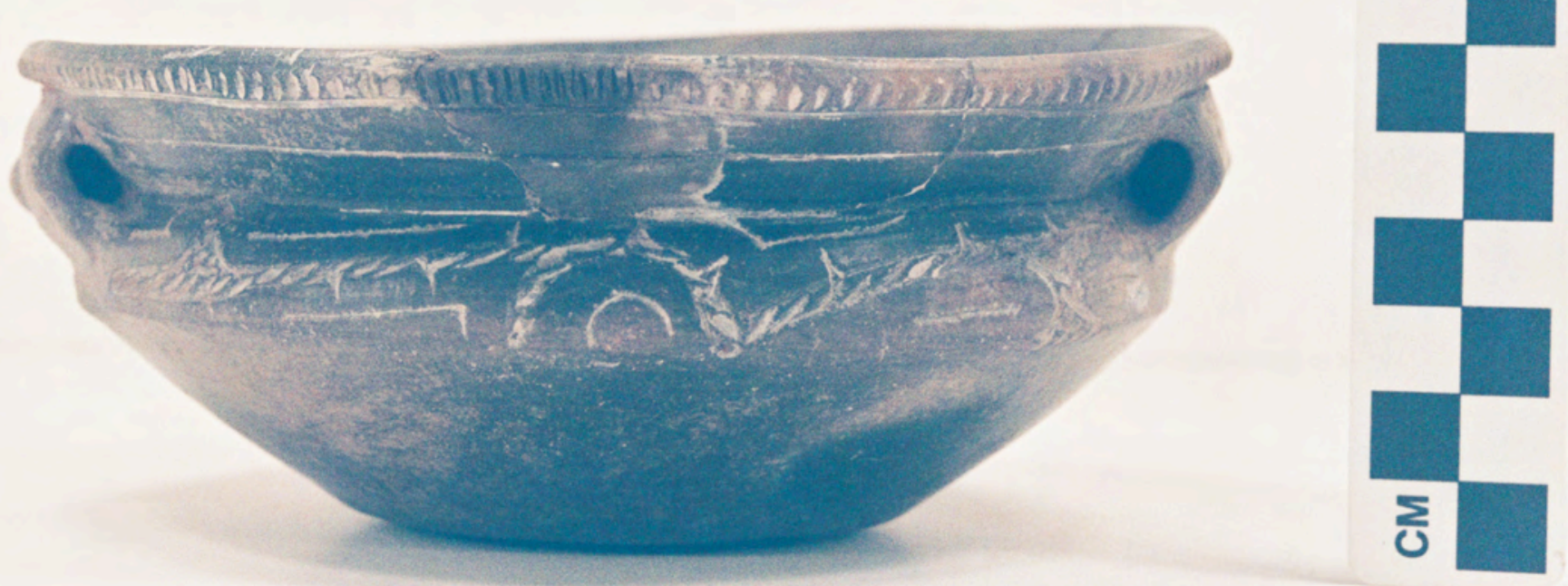

Figure $12 \mathrm{~b}$

Figure A1-61a 


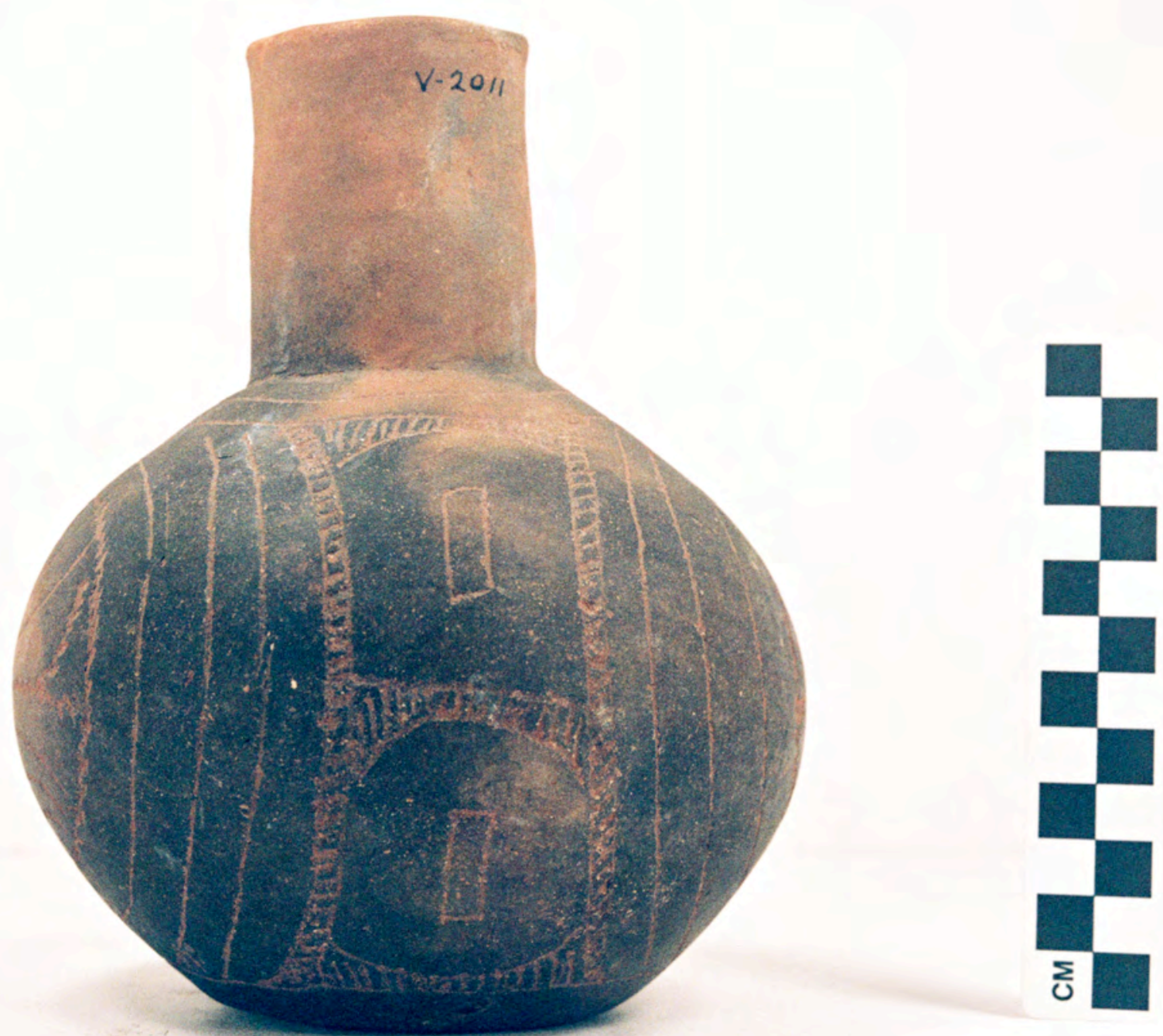

Figure 12c

Figure A1-34a 


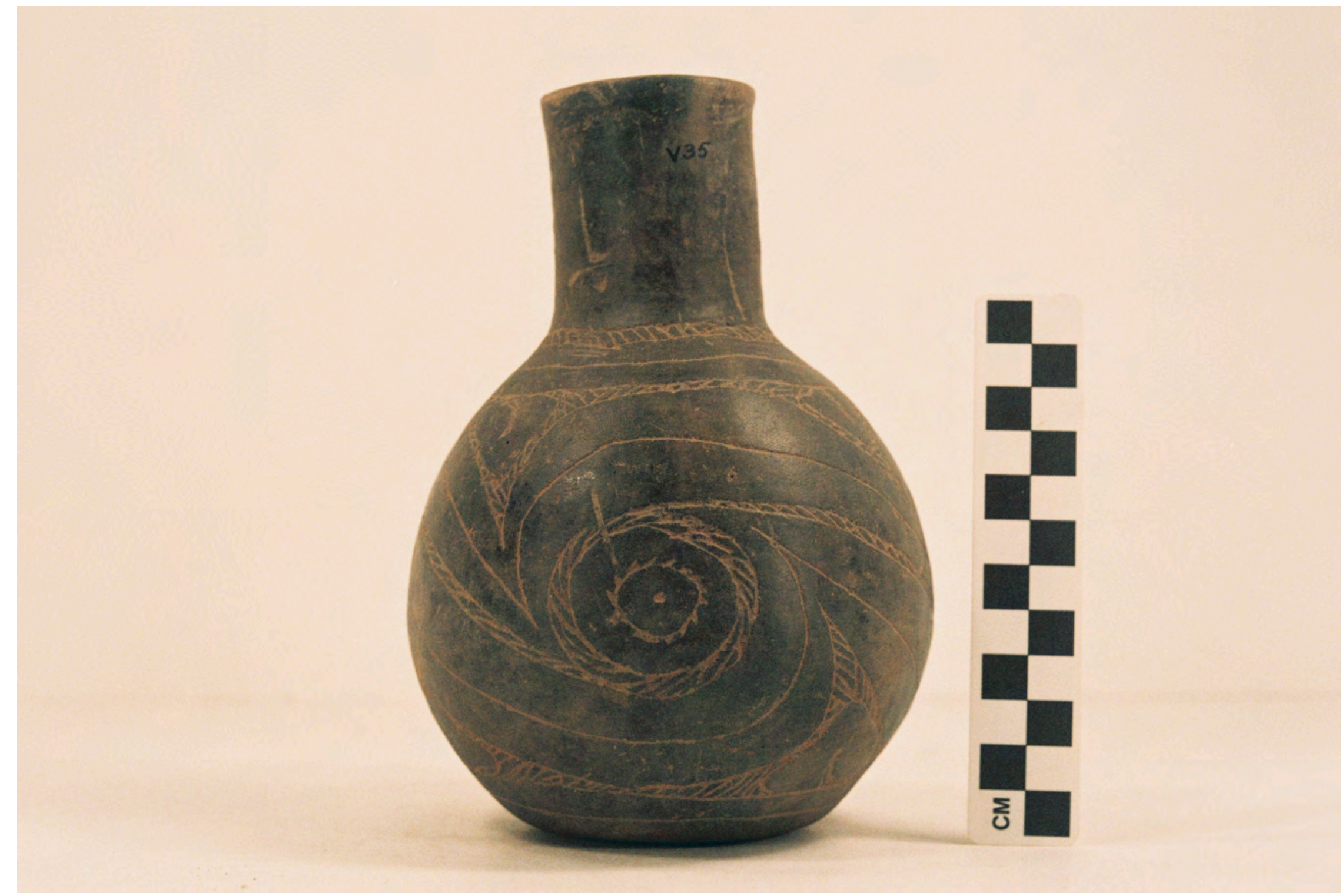

Figure 12d

Figure A1-32 


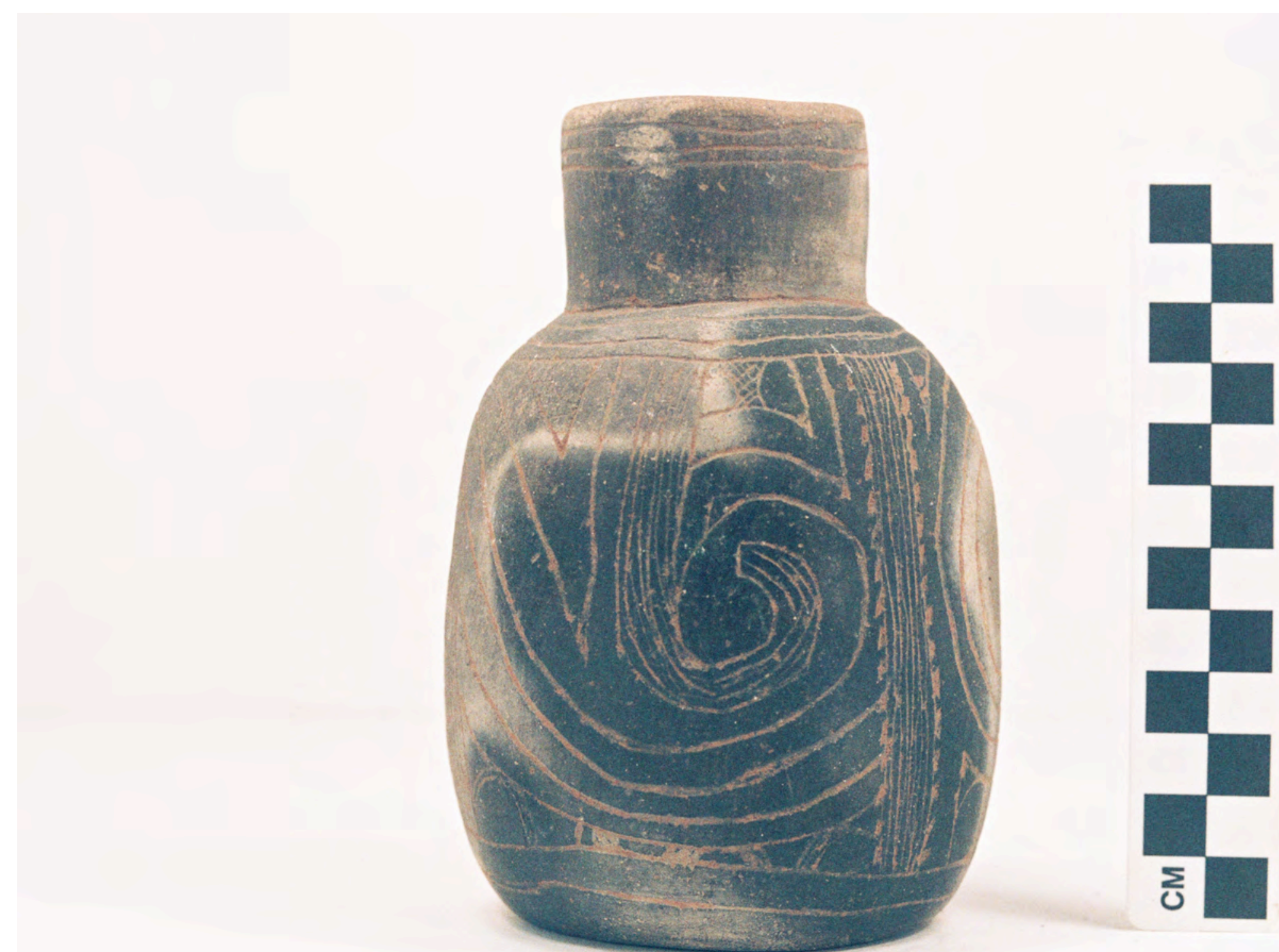

Figure $12 \mathrm{e}$

Figure A-92a 


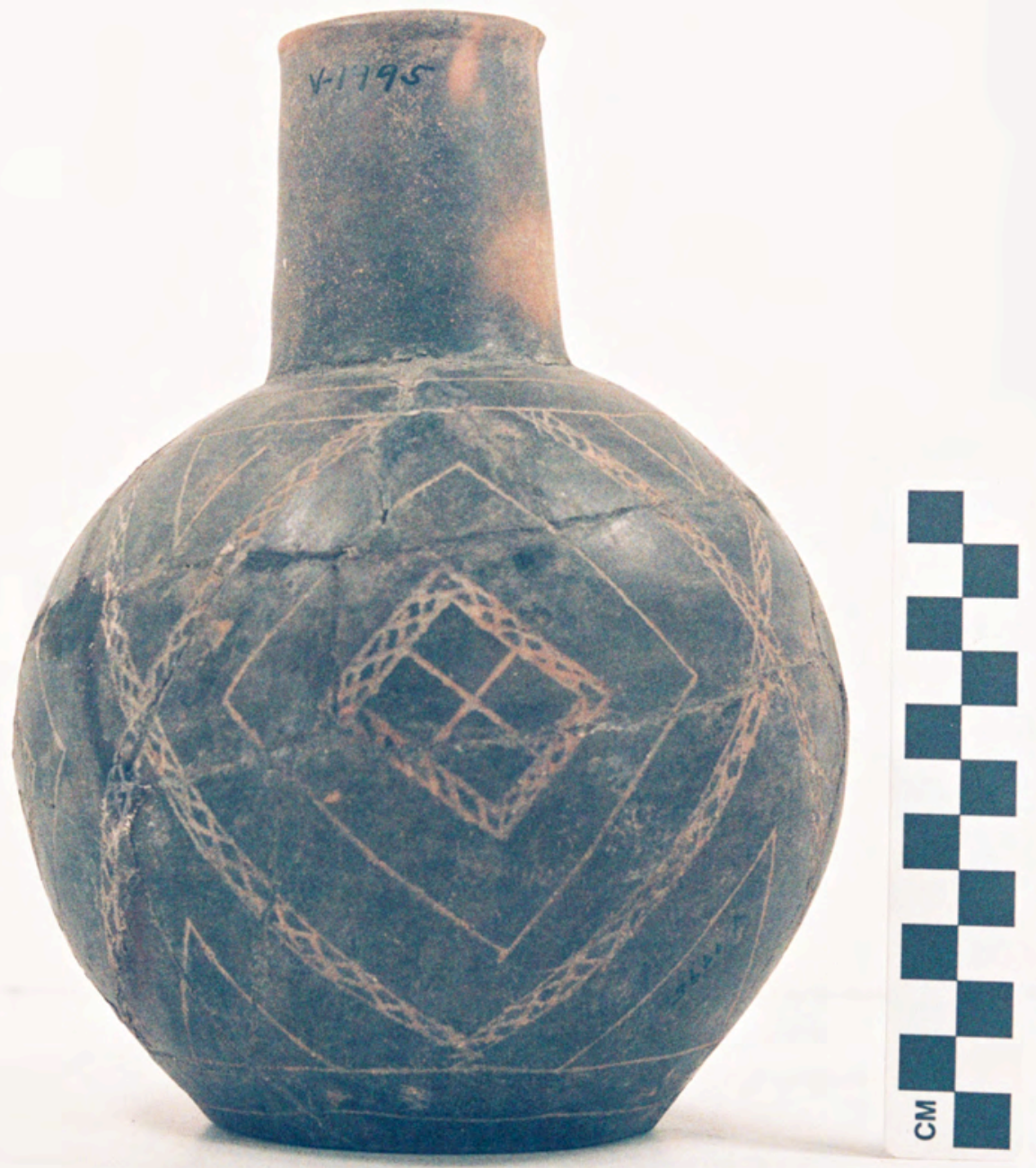

Figure 12f

Figure A1-54 


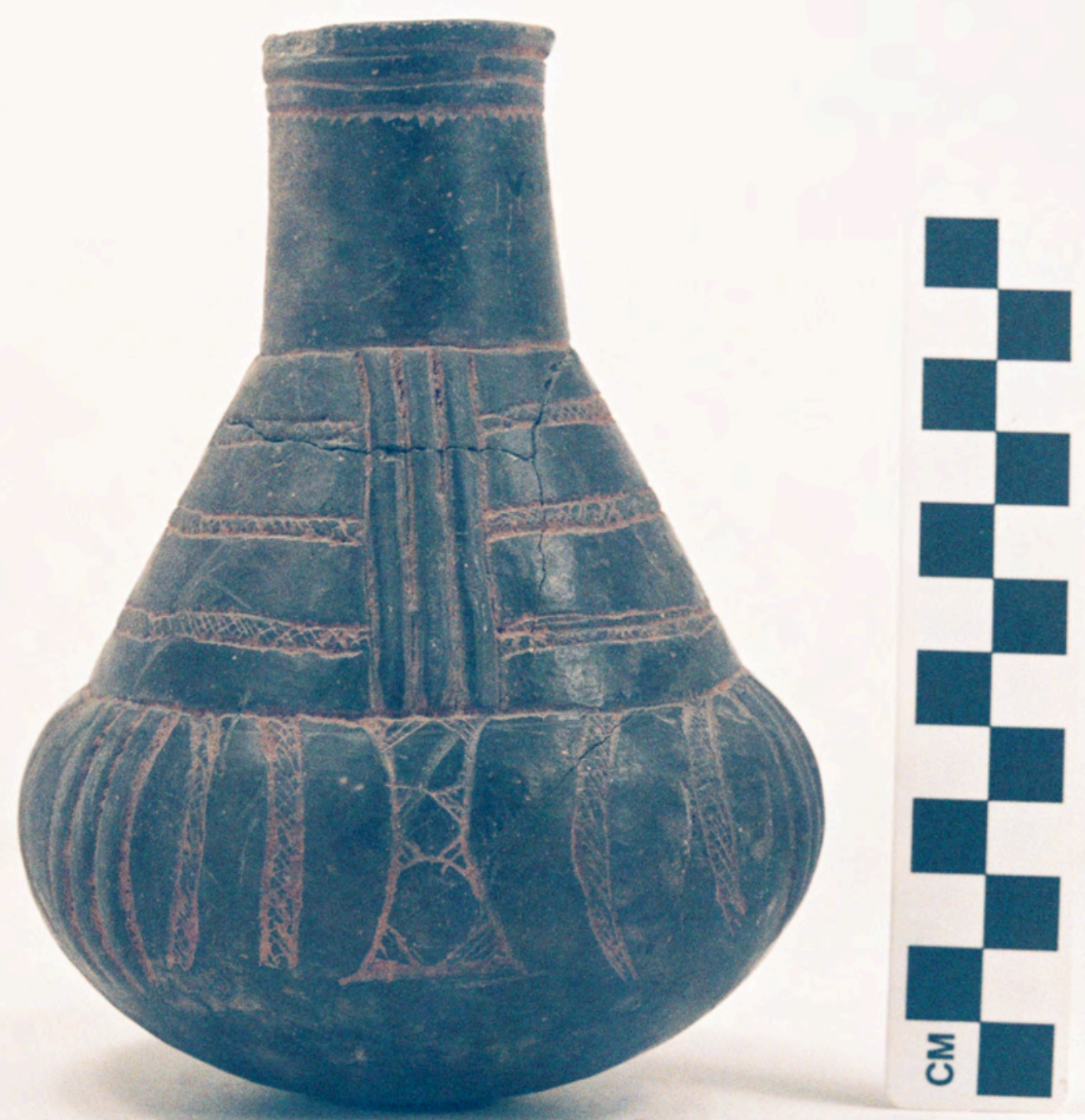

Figure $12 \mathrm{~g}$

Figure A1-89 


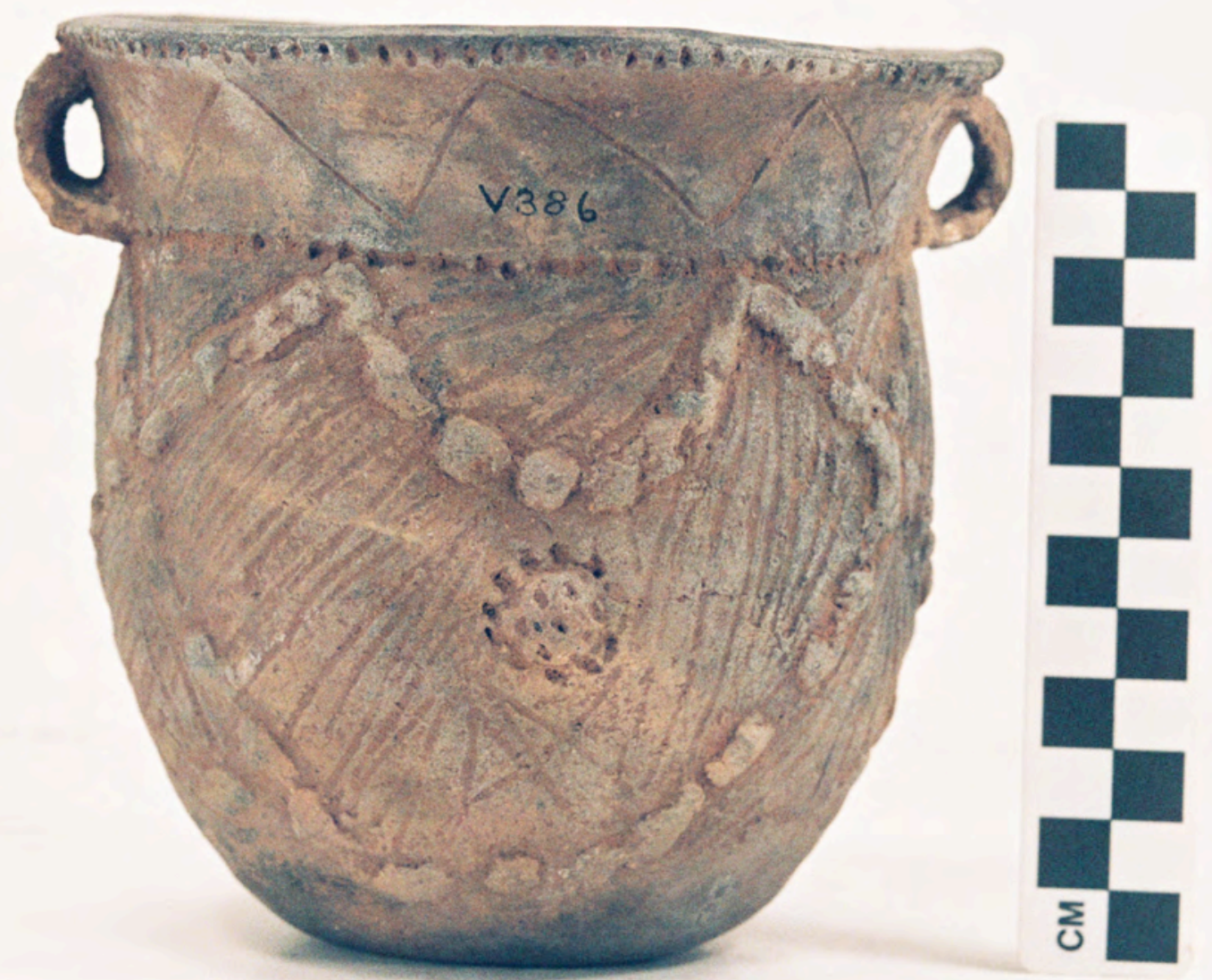

Figure $12 \mathrm{~h}$

Figure A1-23 


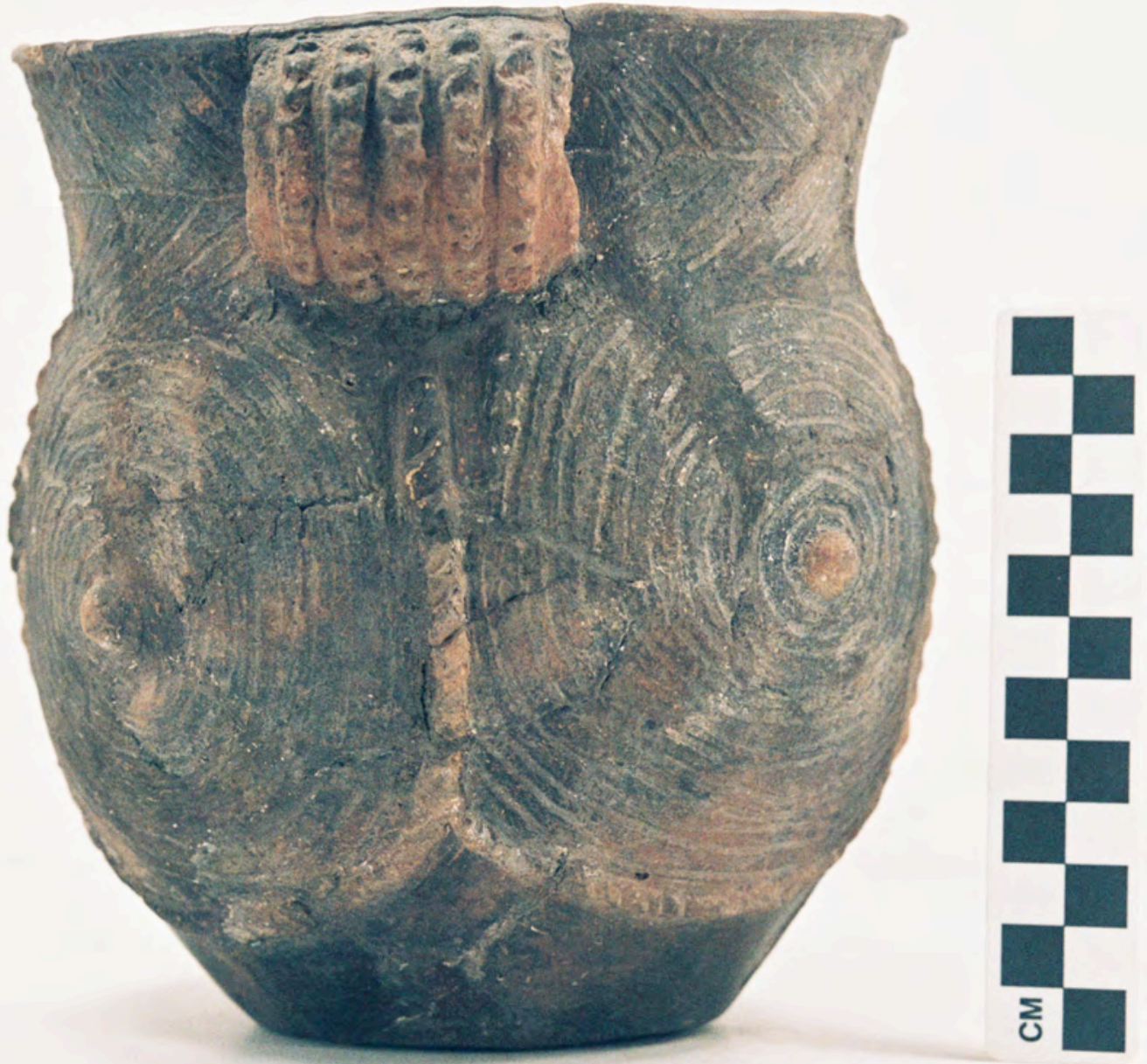

Figure $12 i$

Figure A1-84 


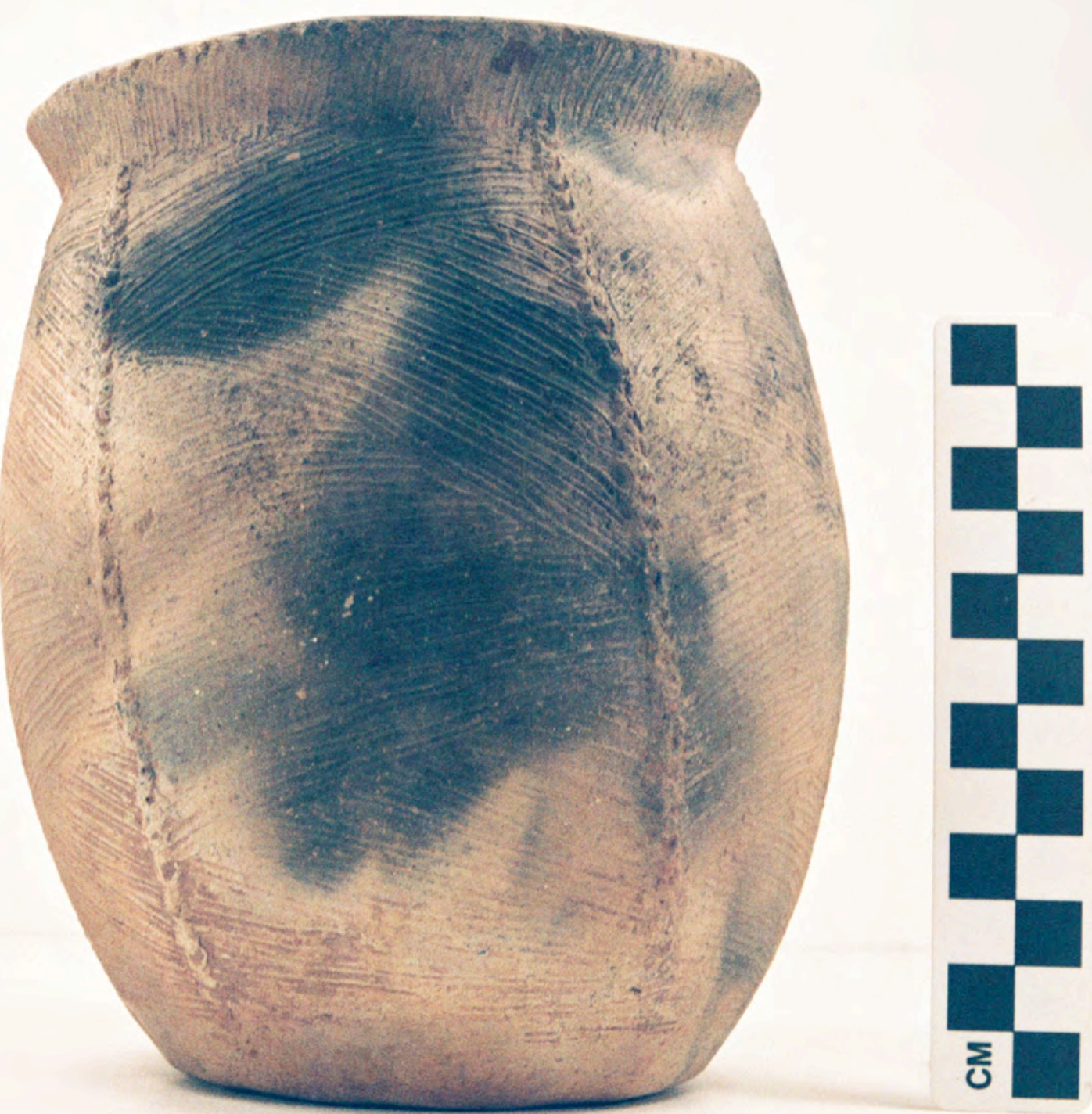

Figure $12 \mathrm{j}$

Figure A1-53 

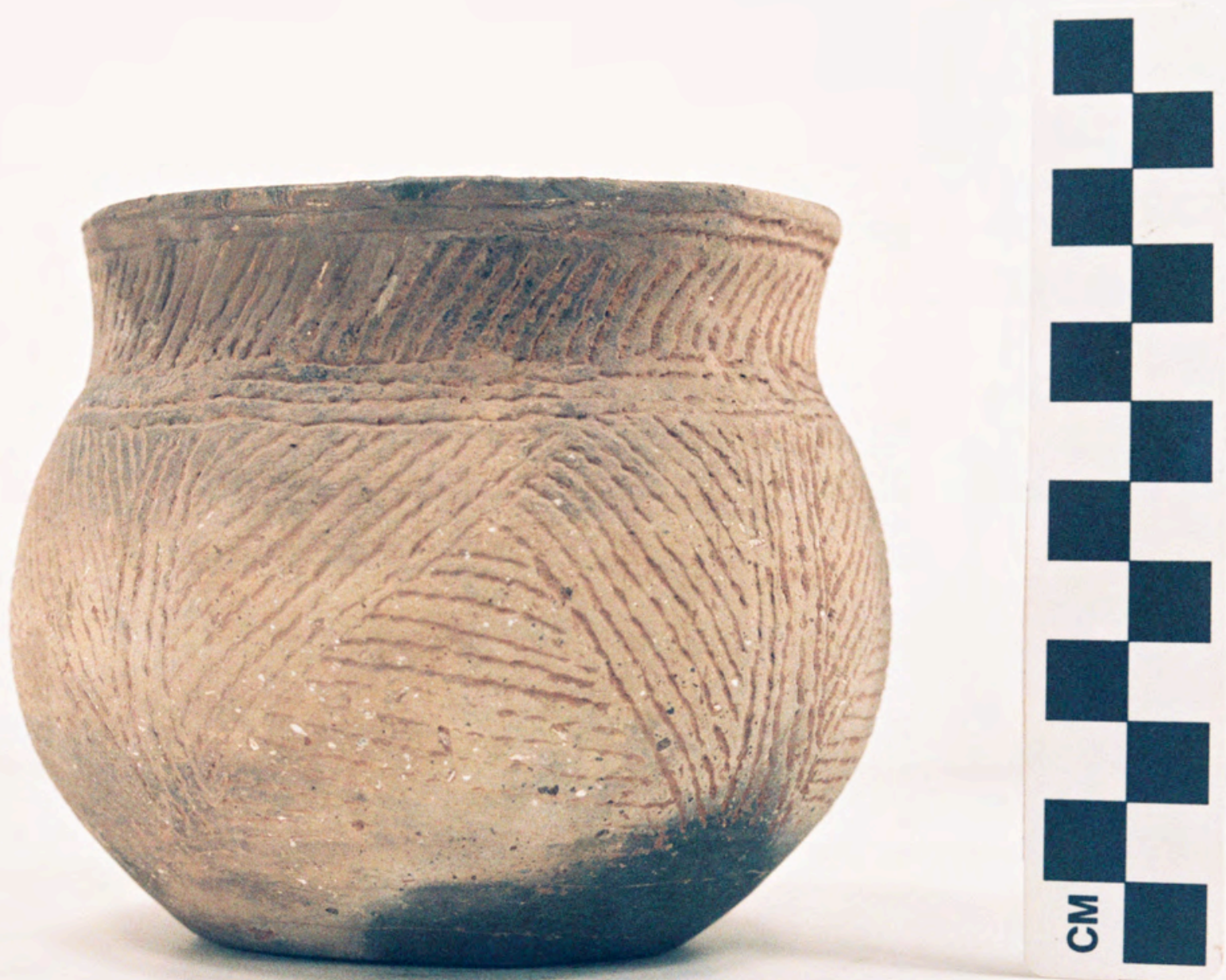

Figure 12k

Figure A1-96 


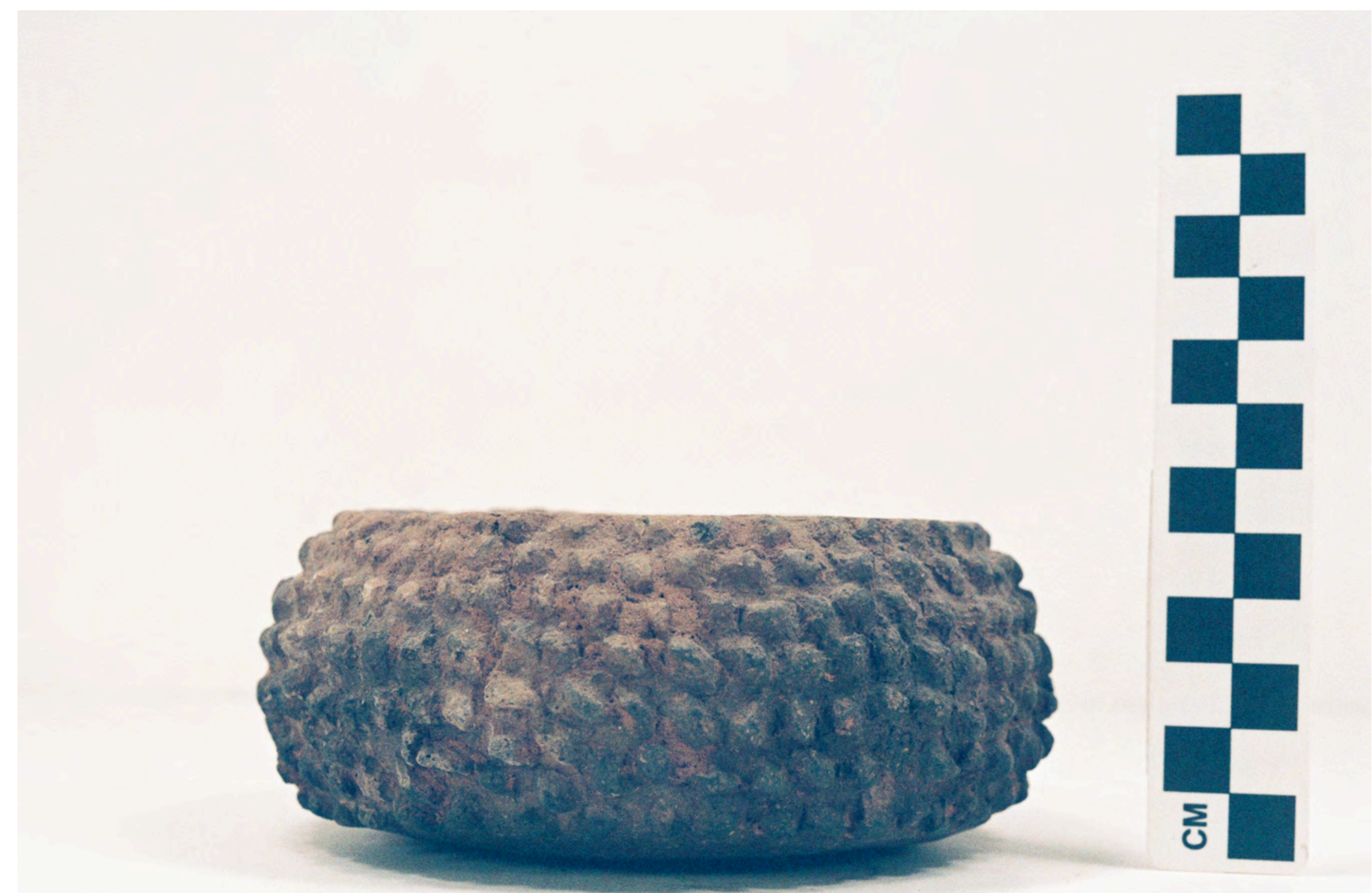

Figure 121

Figure A1-64 


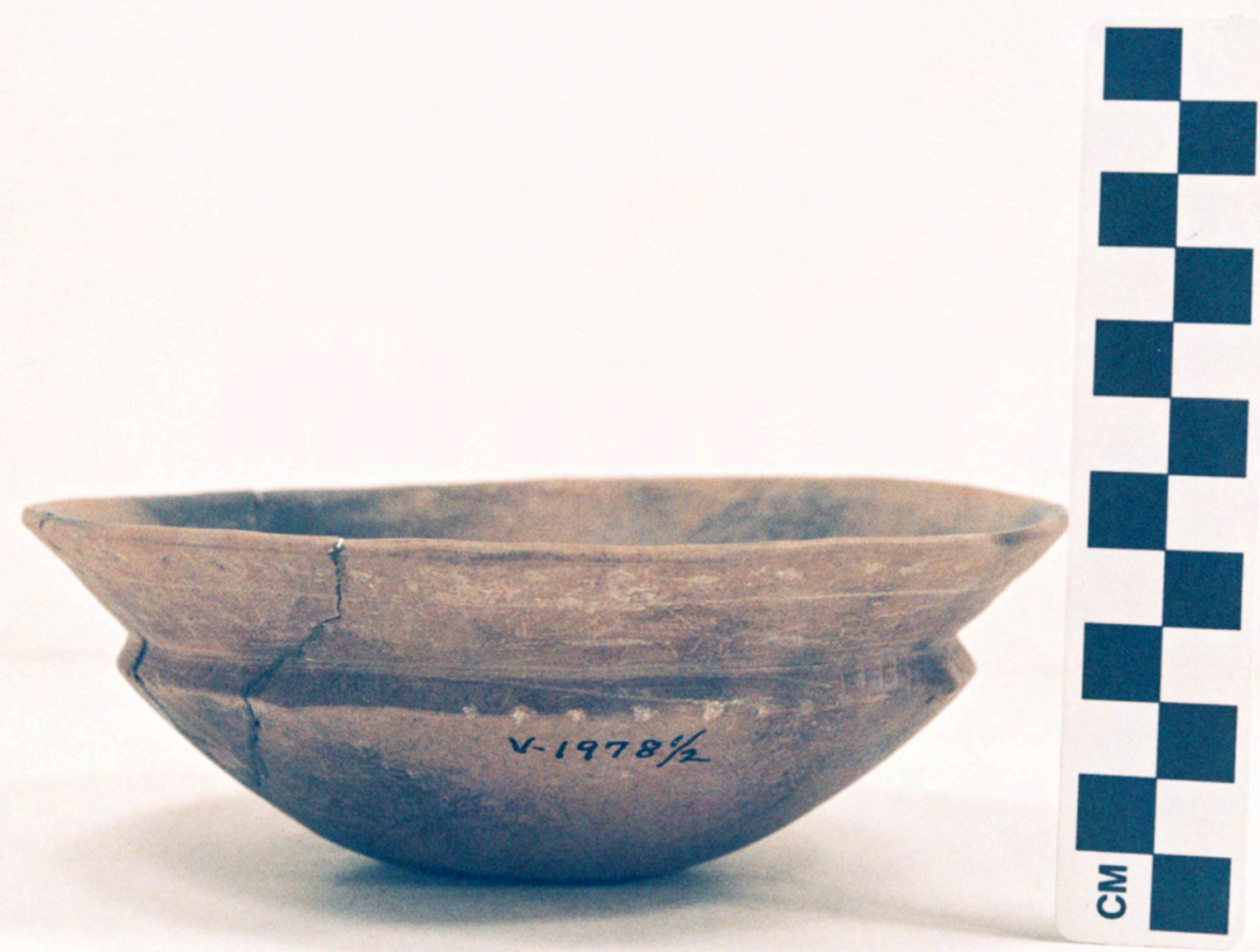

Figure 13a

Figure A1-38a 


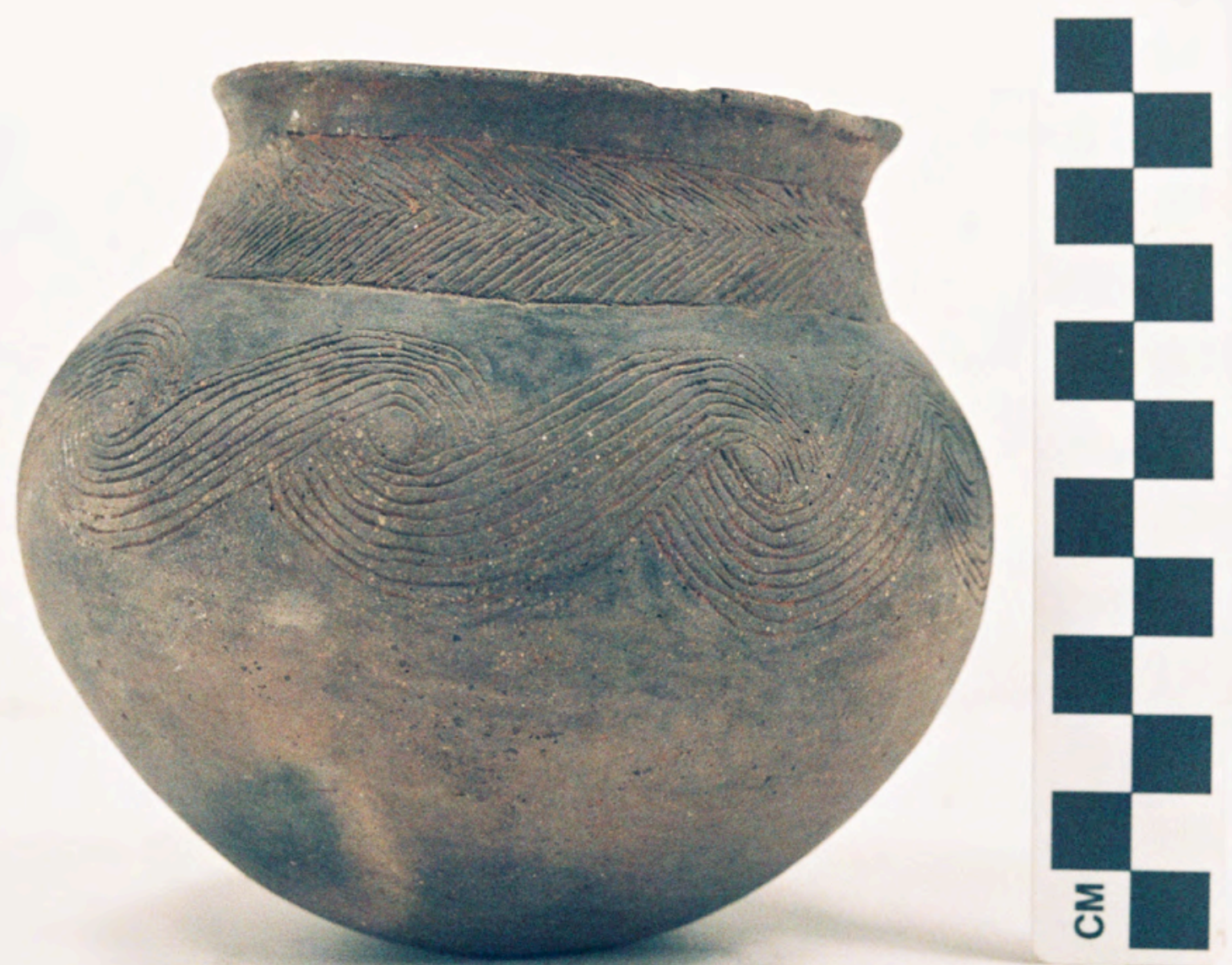

Figure 13b

Figure A1-76 


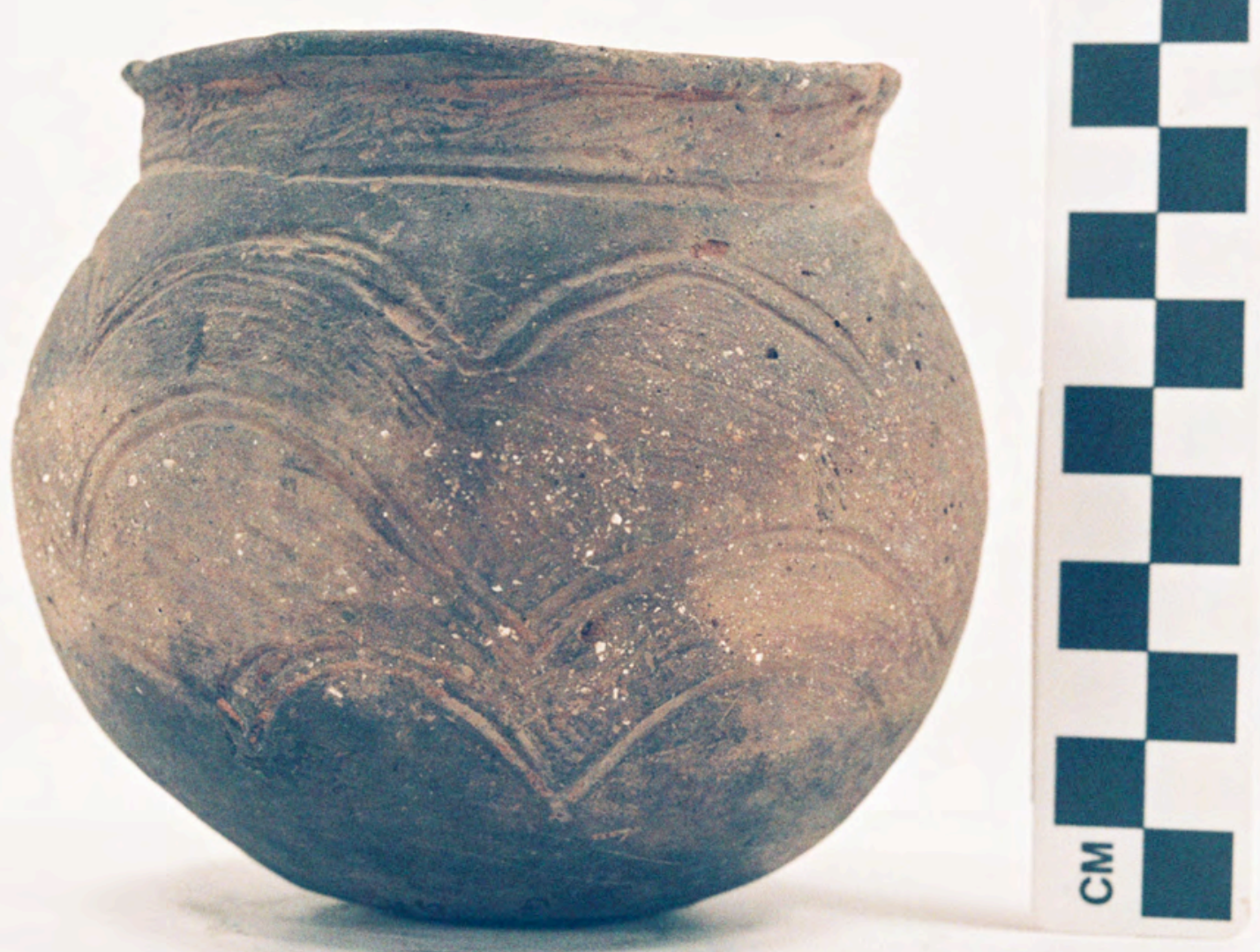

Figure 13c

Figure A1-83 


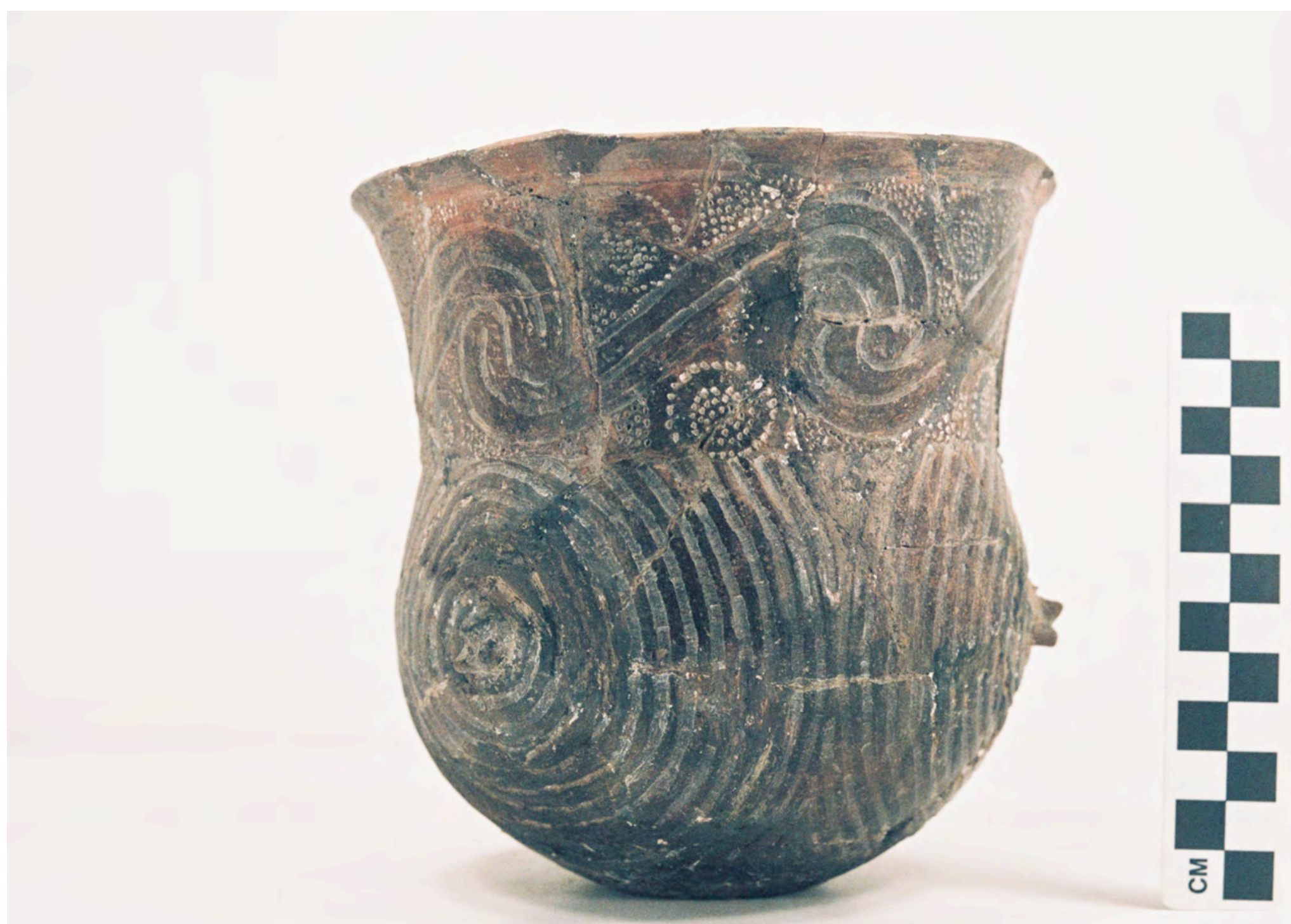

Figure 13d

Figure A1-27a 


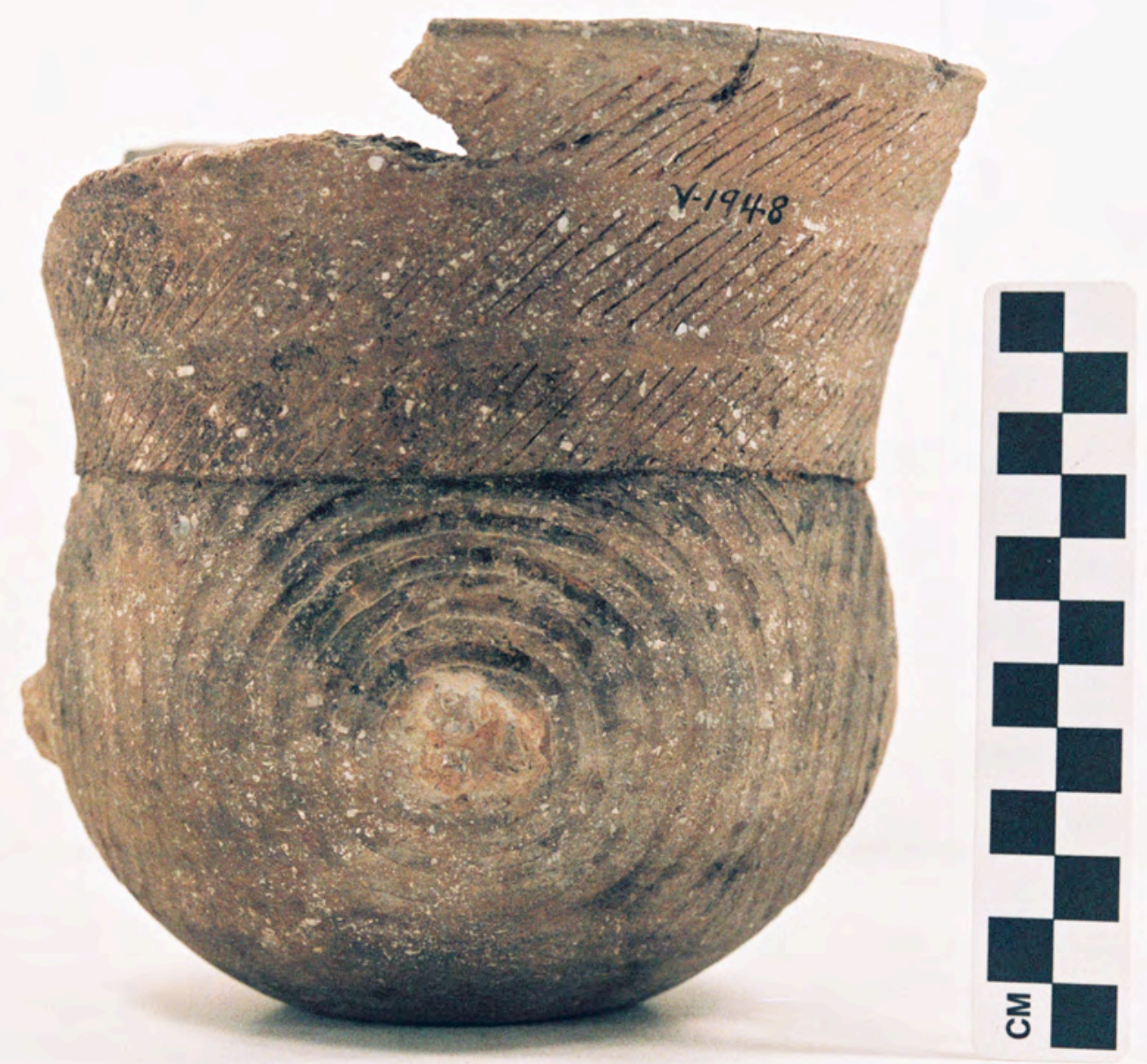

Figure $13 \mathrm{e}$

Figure A1-28 

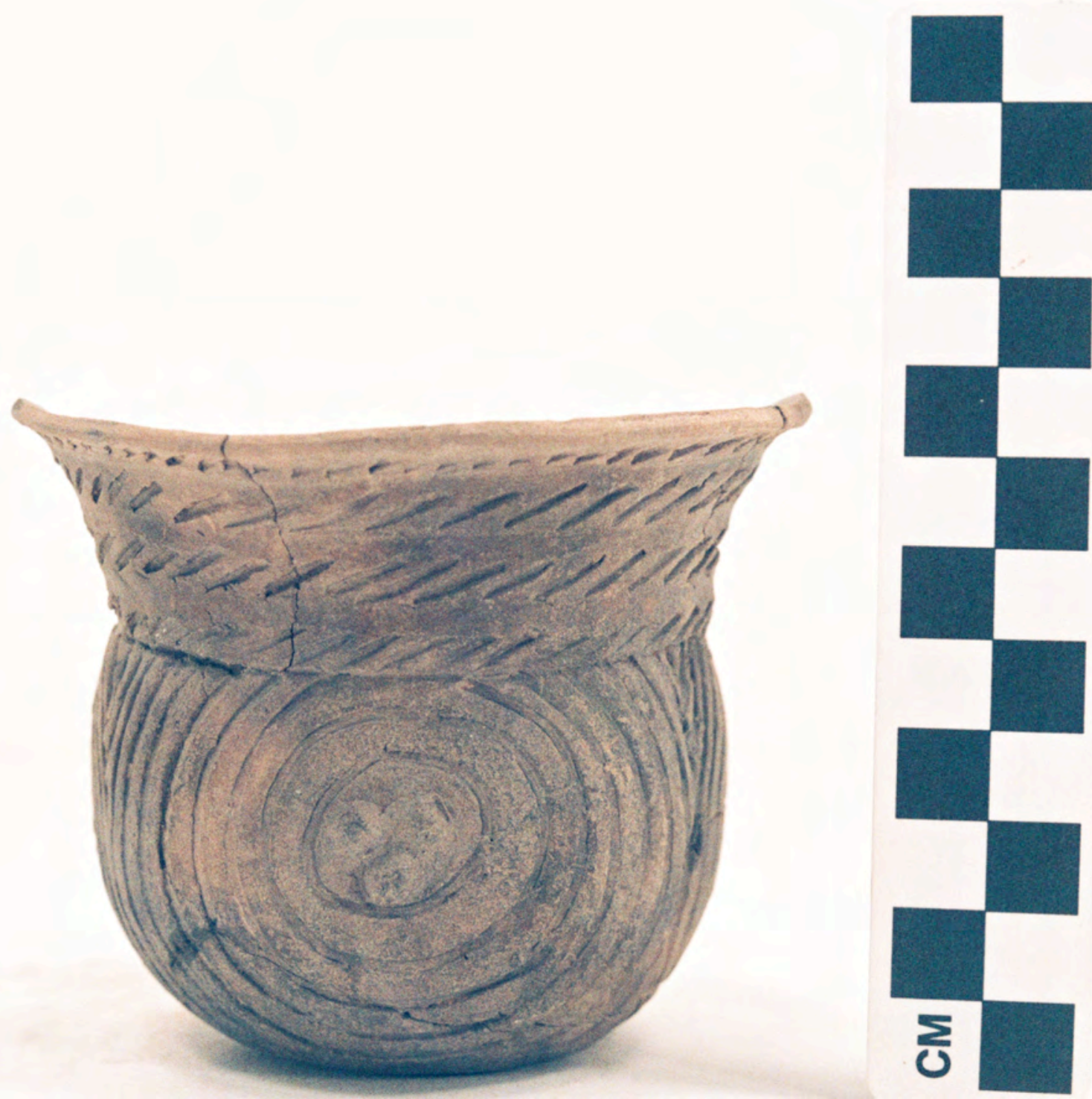

Figure 13f

Figure A1-98 


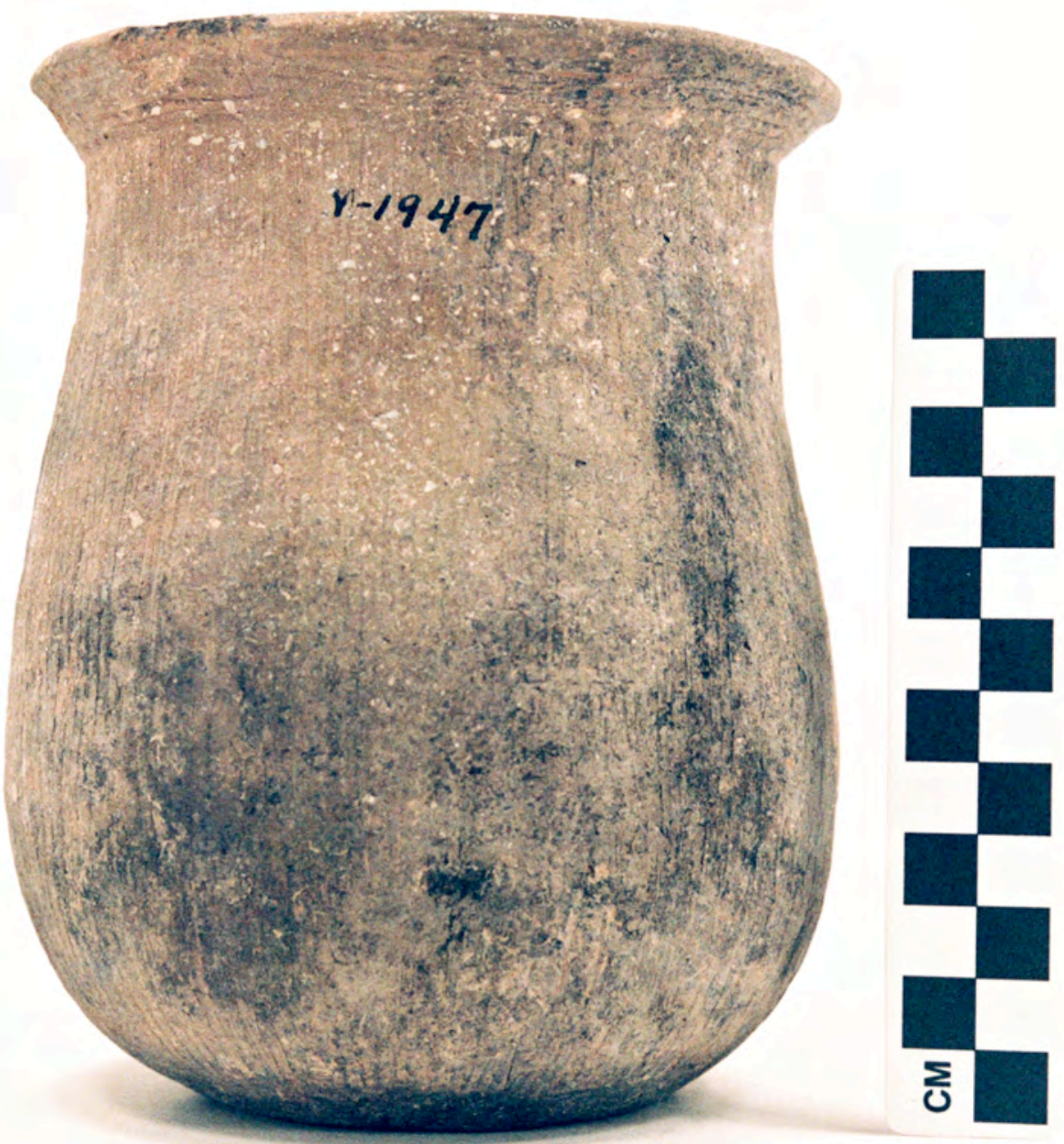

Figure 13g

Figure A1-22 


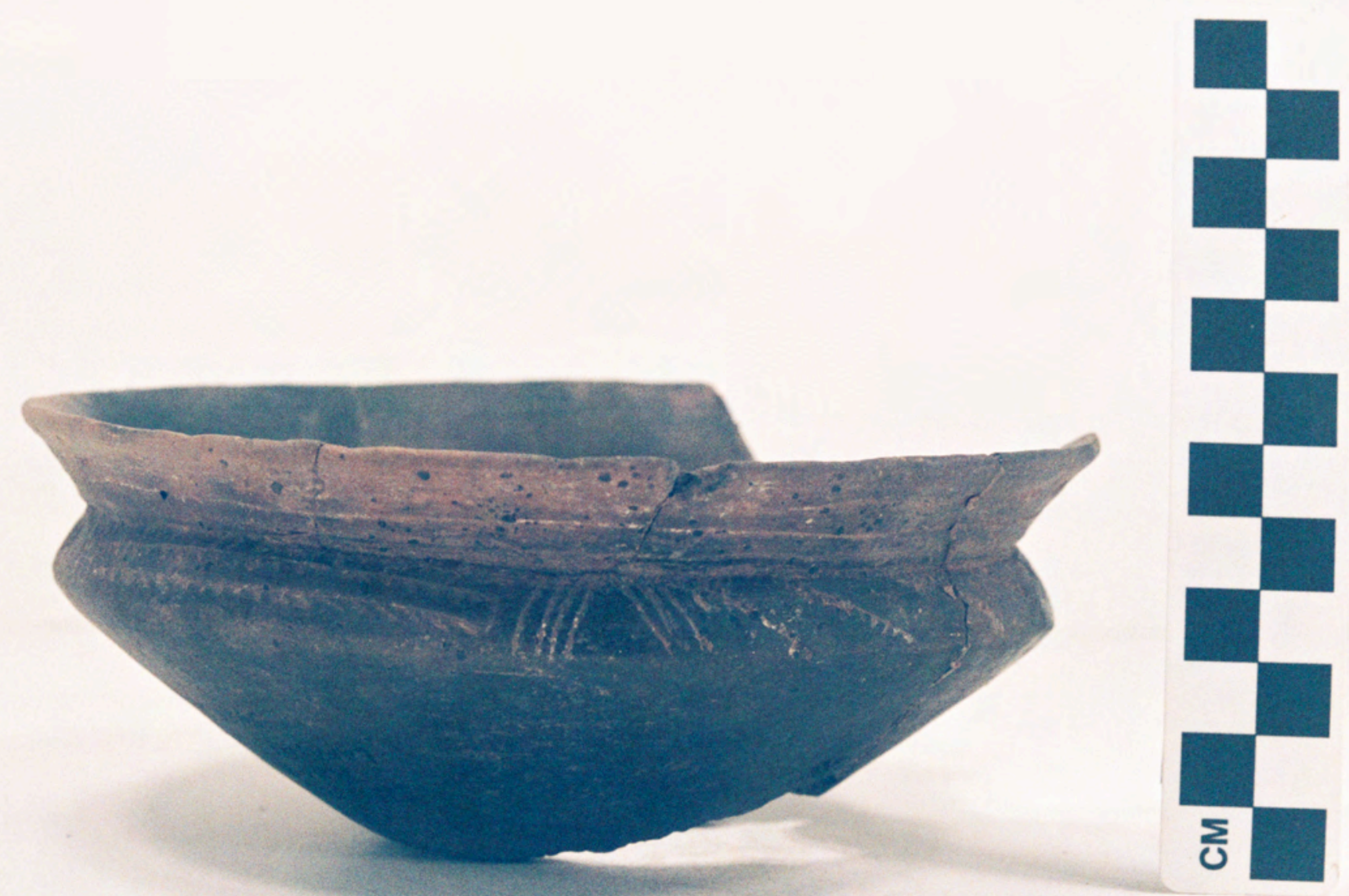

Figure 14a

Figure A1-101 


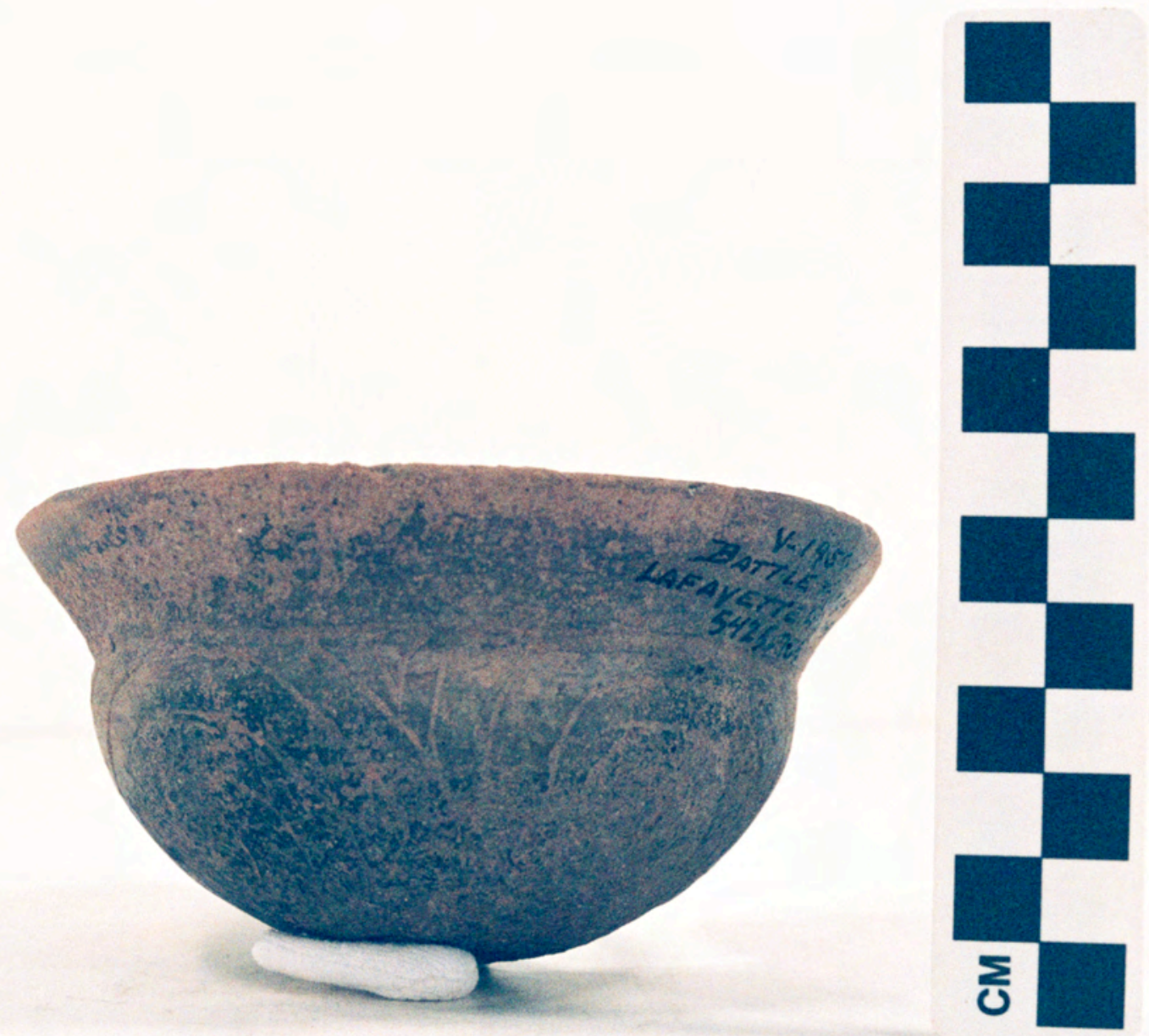

Figure $14 b$

Figure A1-57 


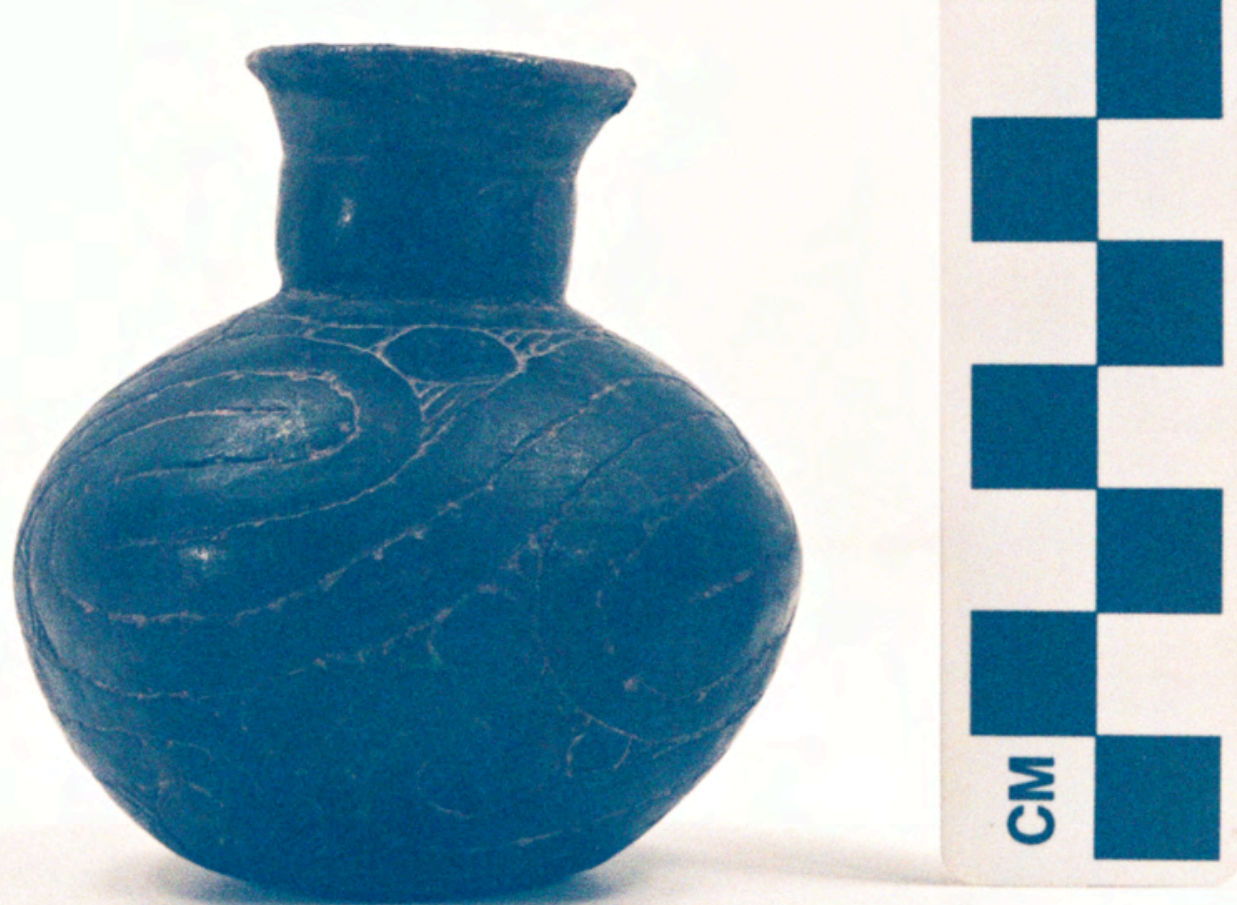

Figure 14c

Figure A1-66a 


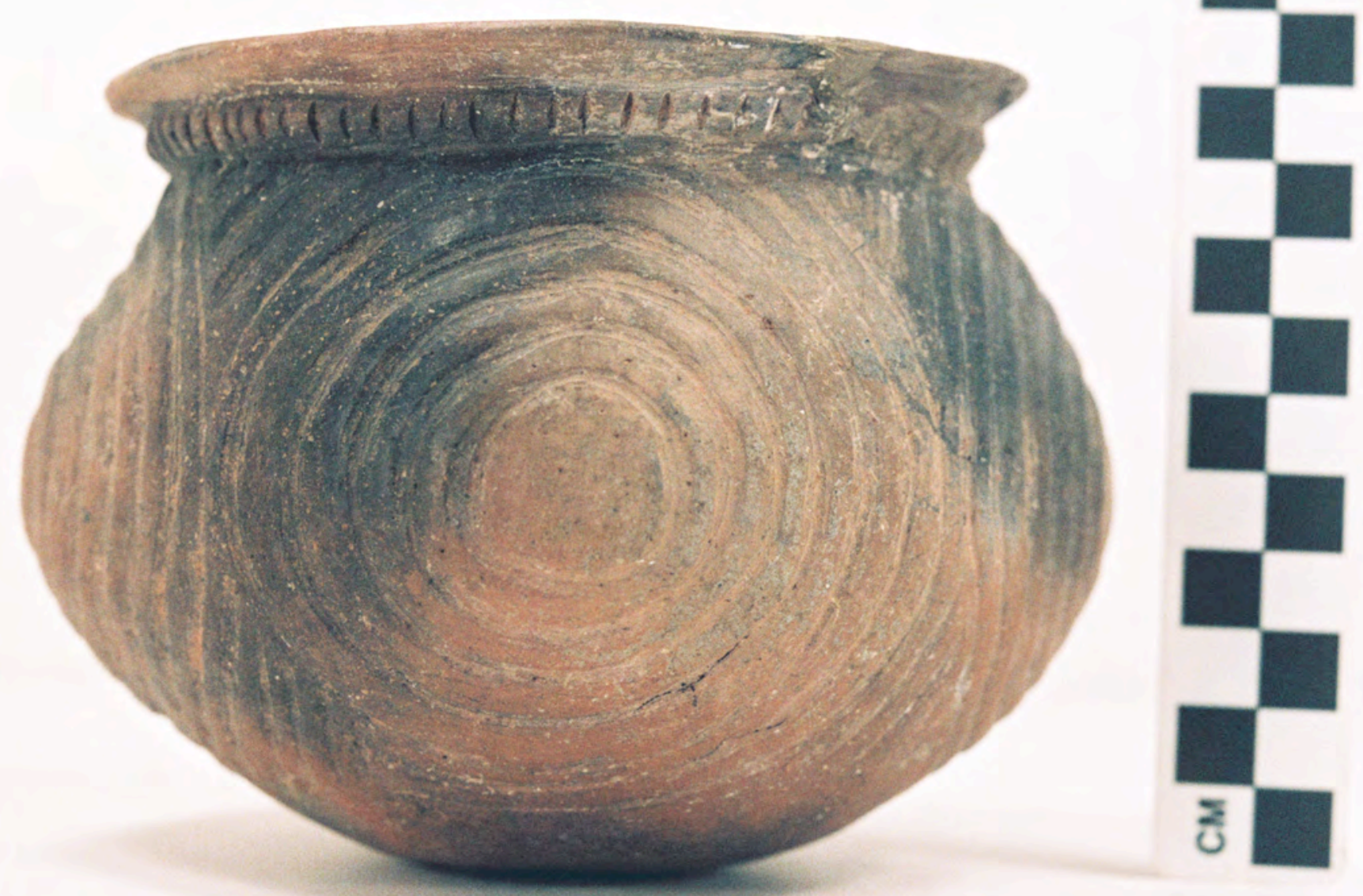

Figure 14d

Figure A1-68a 

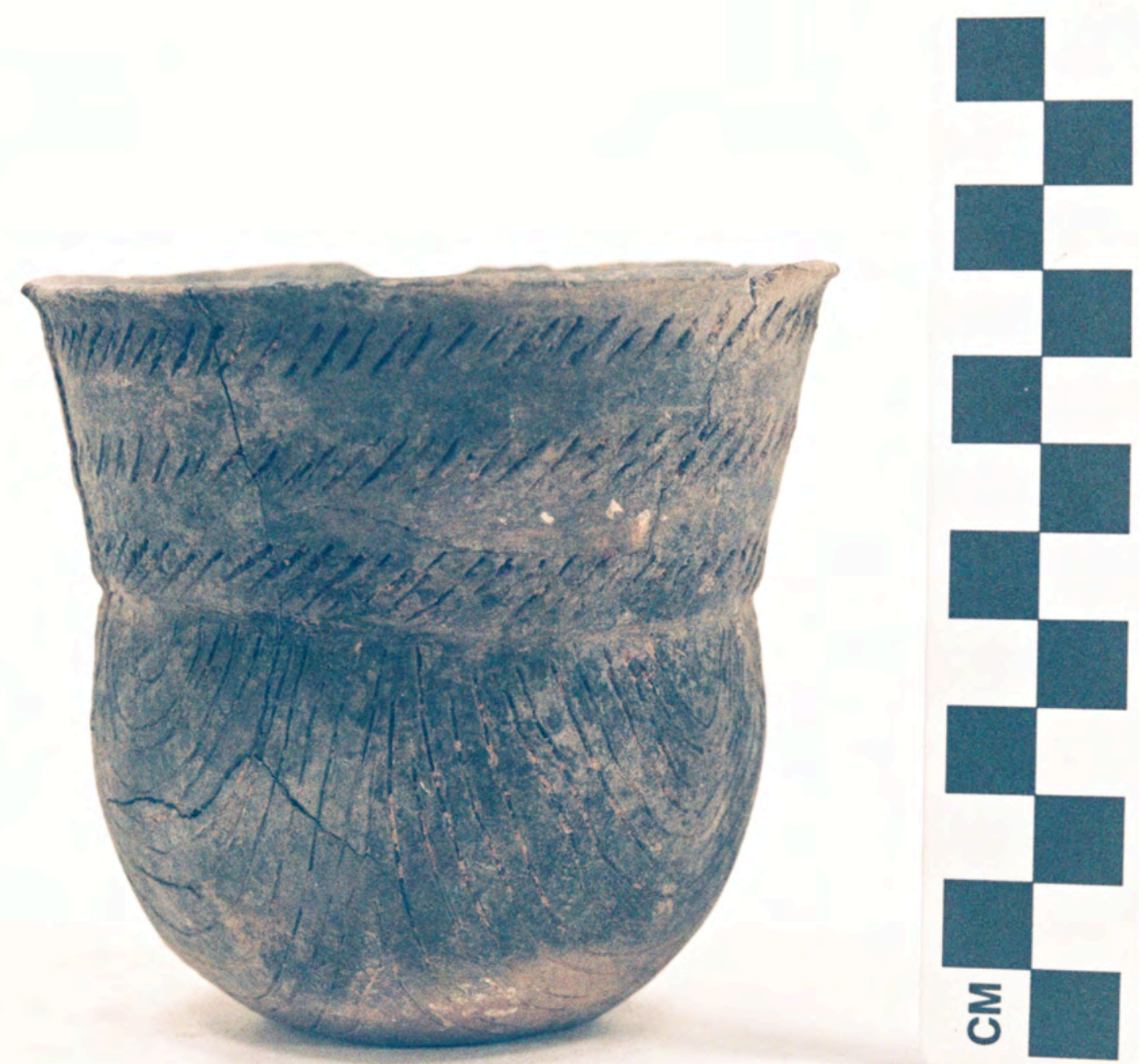

Figure $14 \mathrm{e}$

Figure A1-42 


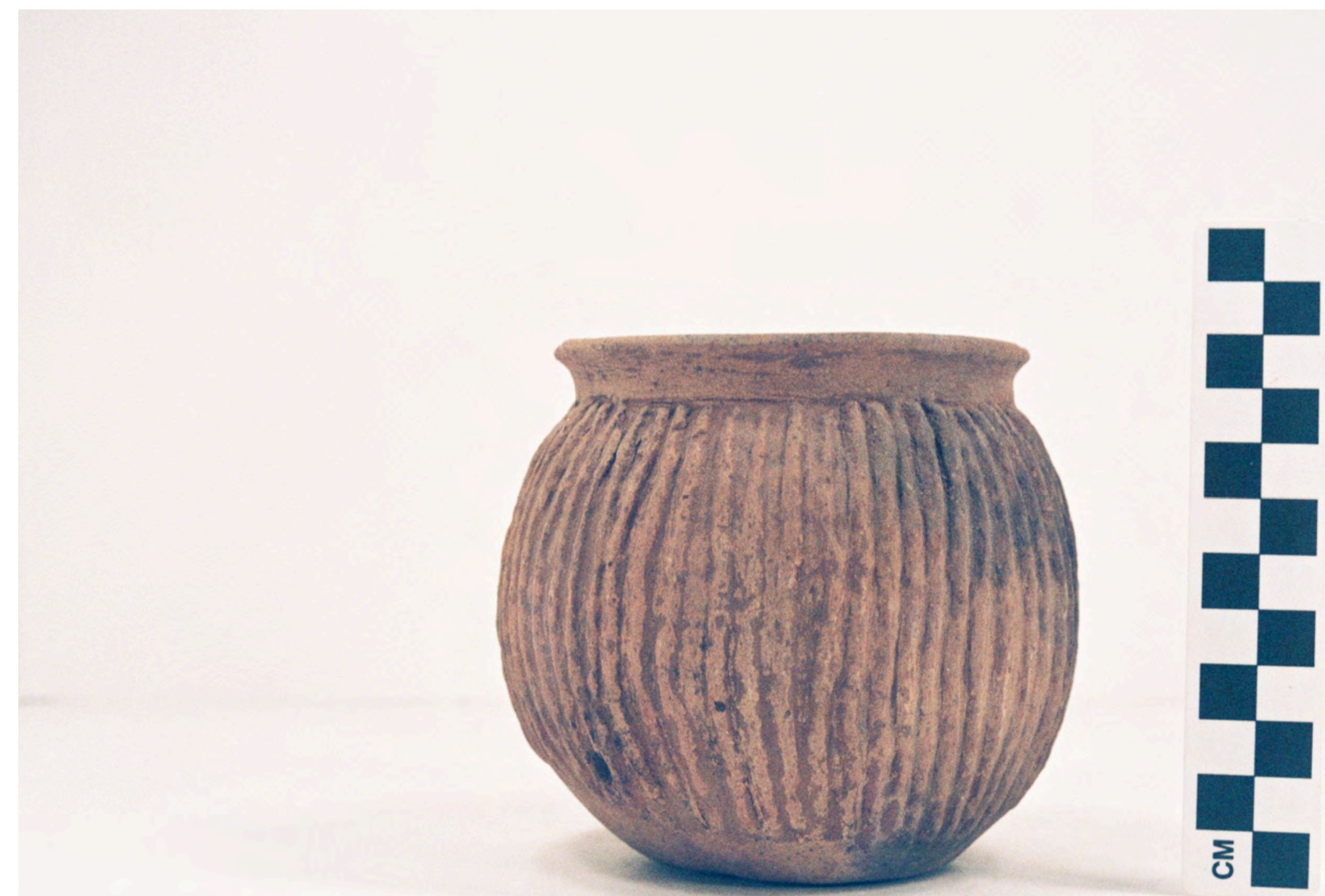

Figure 14f

Figure A1-43 


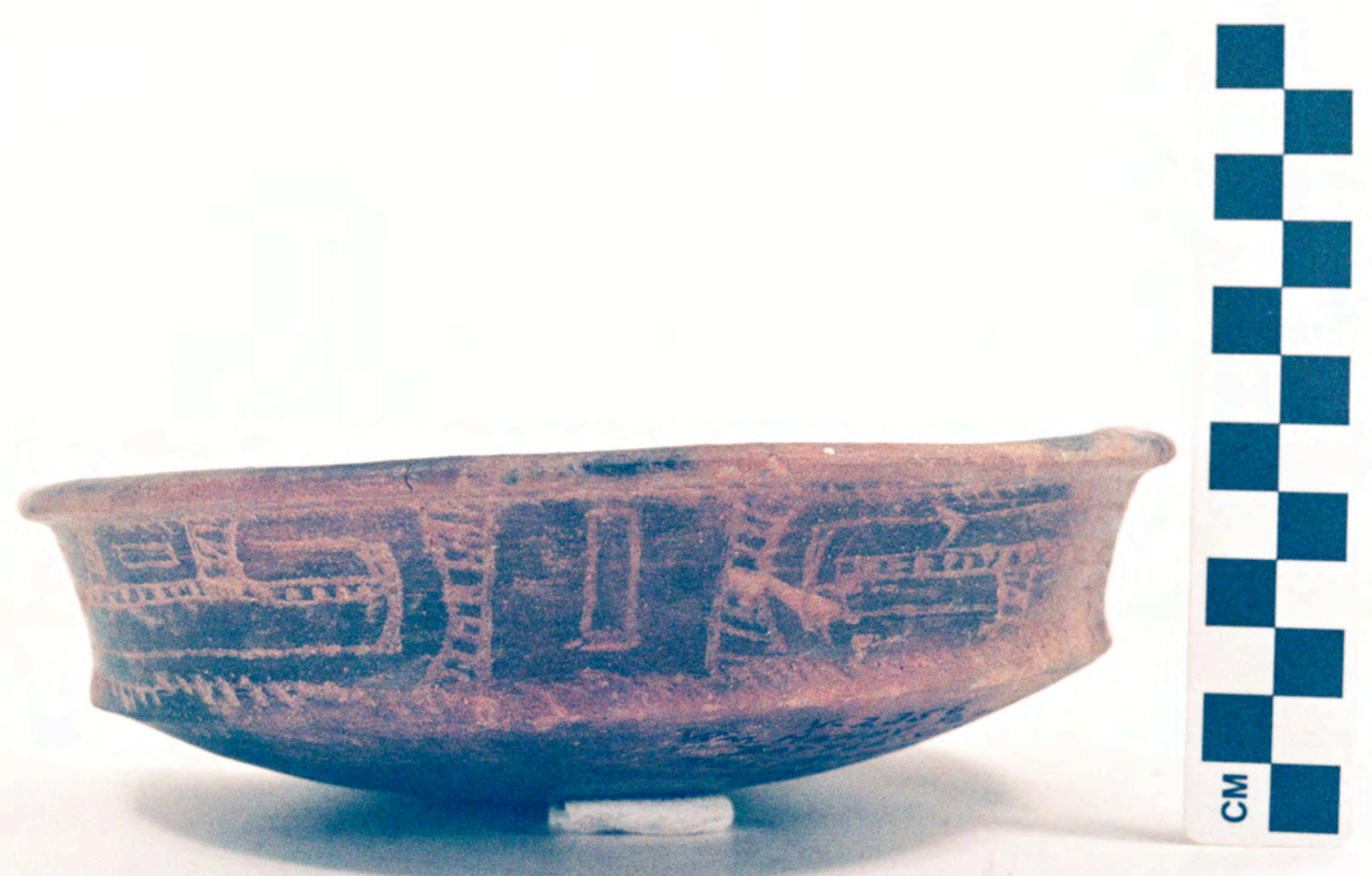

Figure $15 \mathrm{a}$

Figure A2-44 


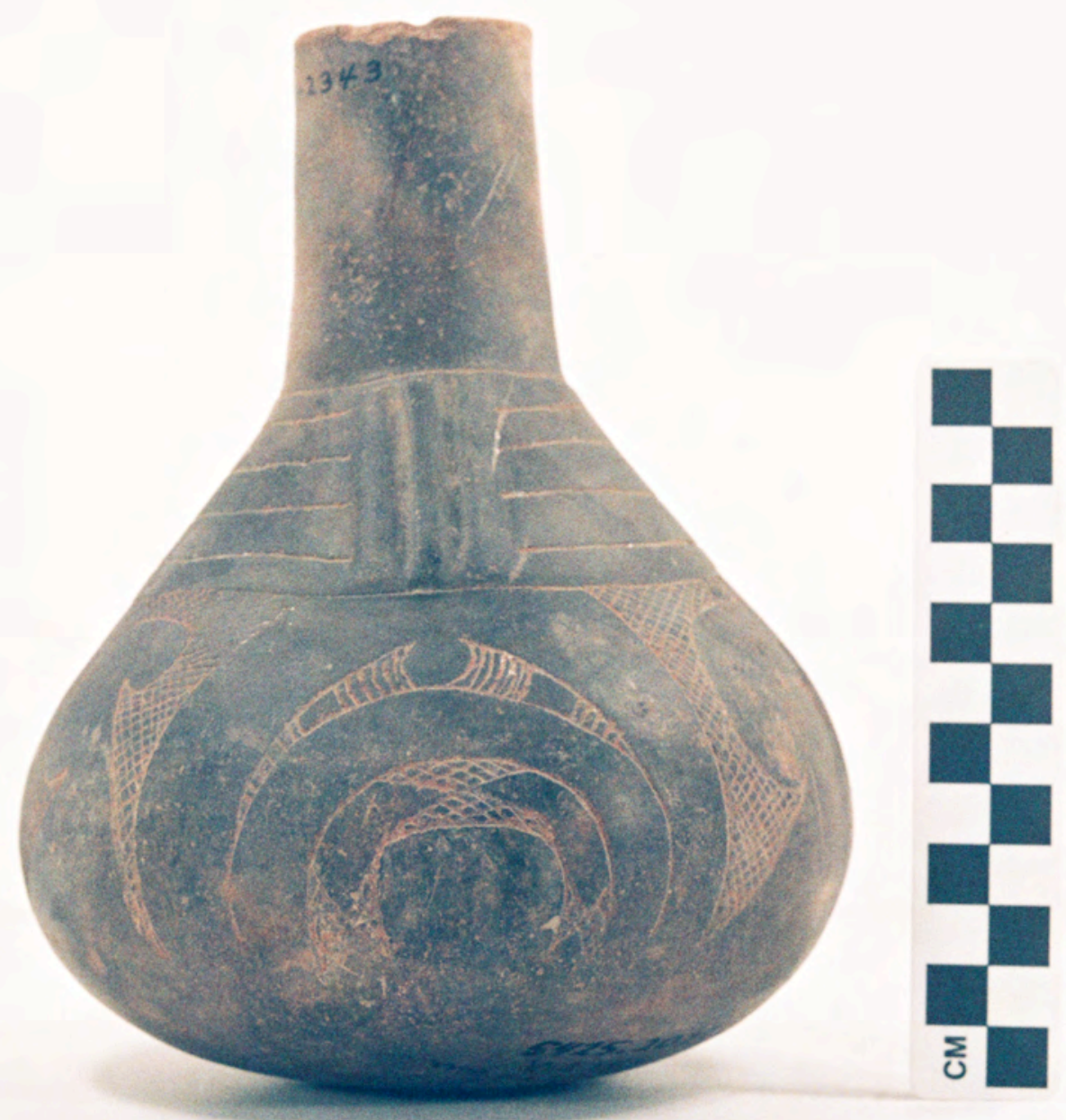

Figure $15 b$

Figure A2-9 


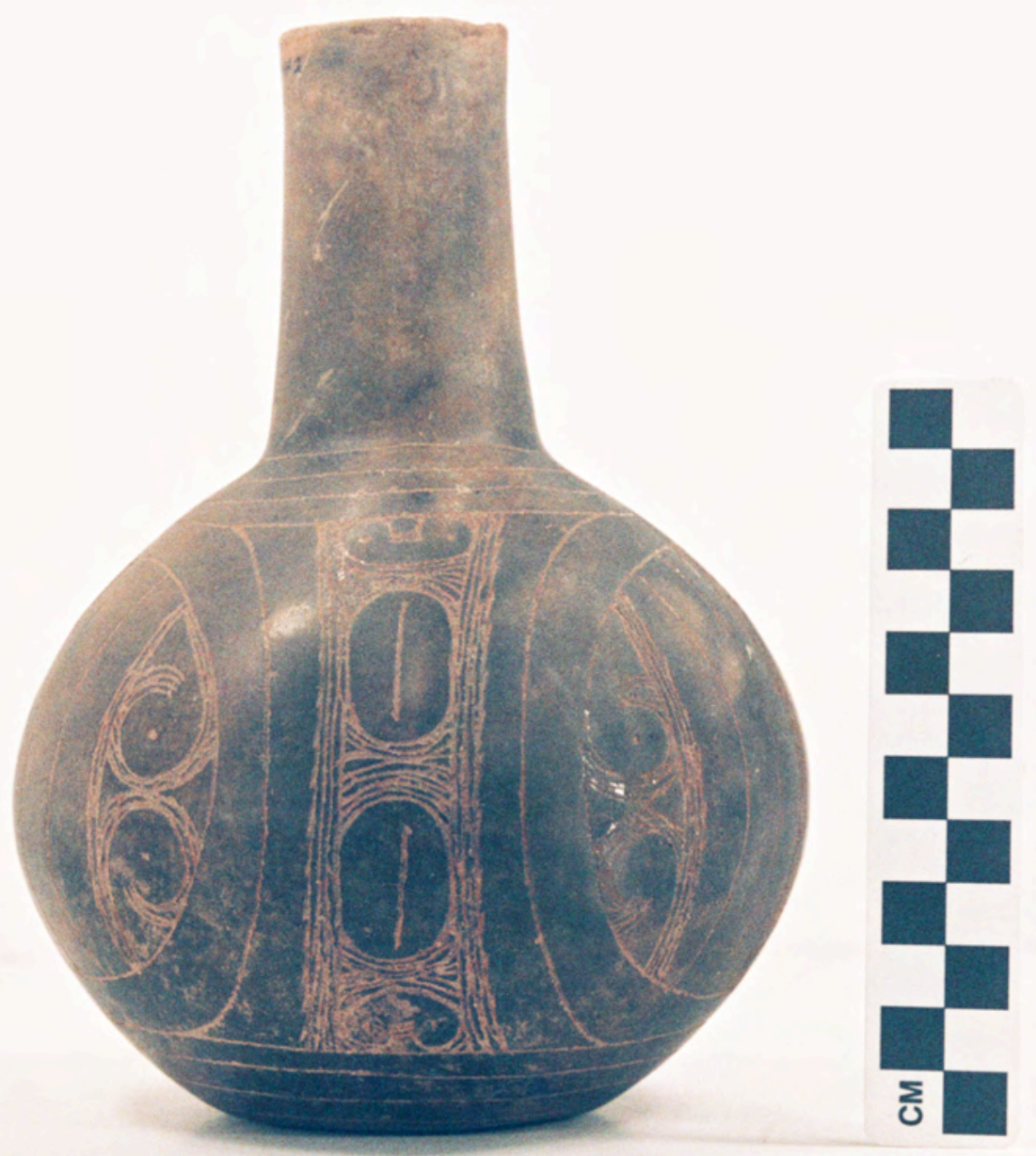

Figure 15c

Figure A2-15 


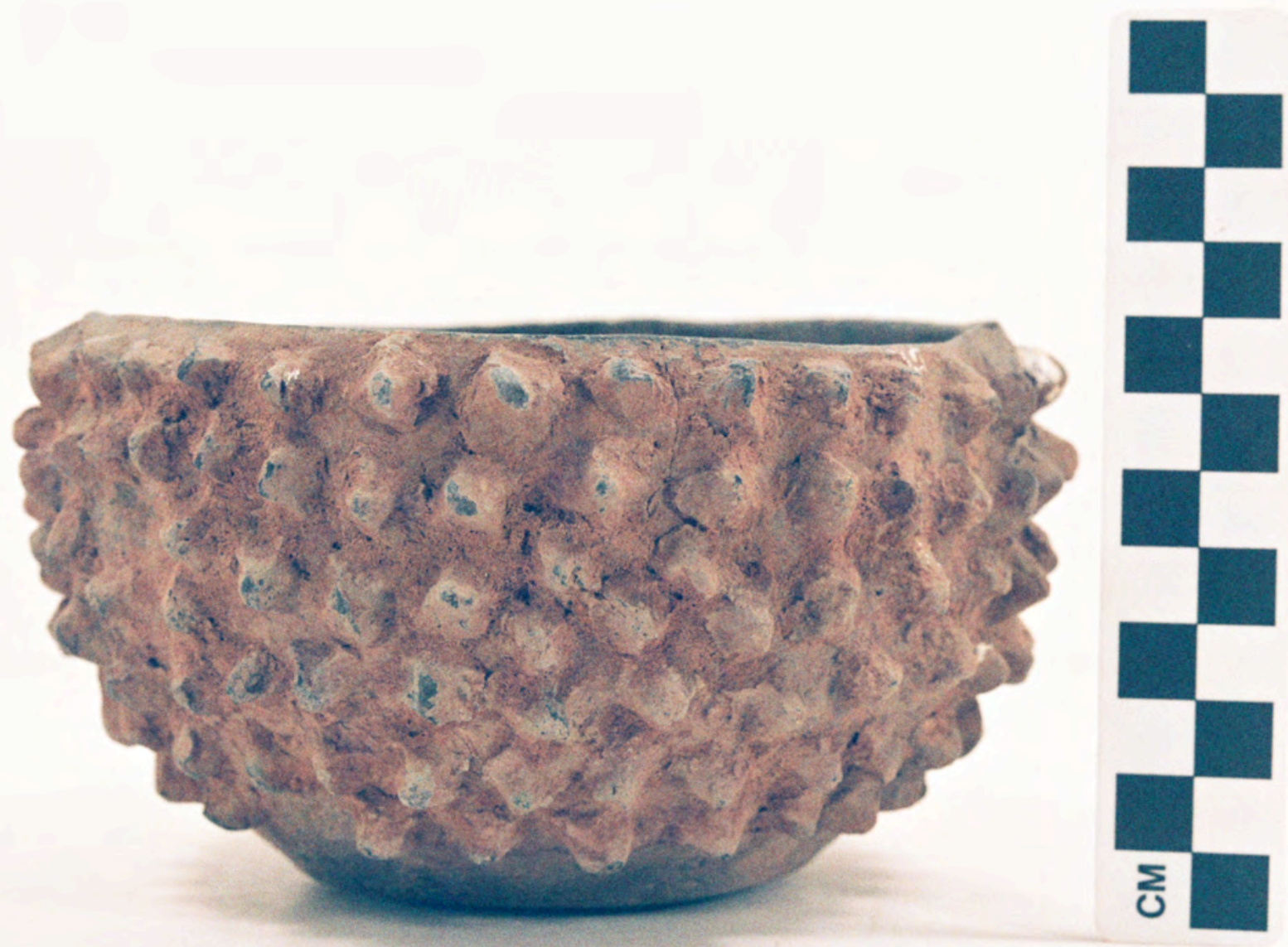

Figure 15d

Figure A2-2 


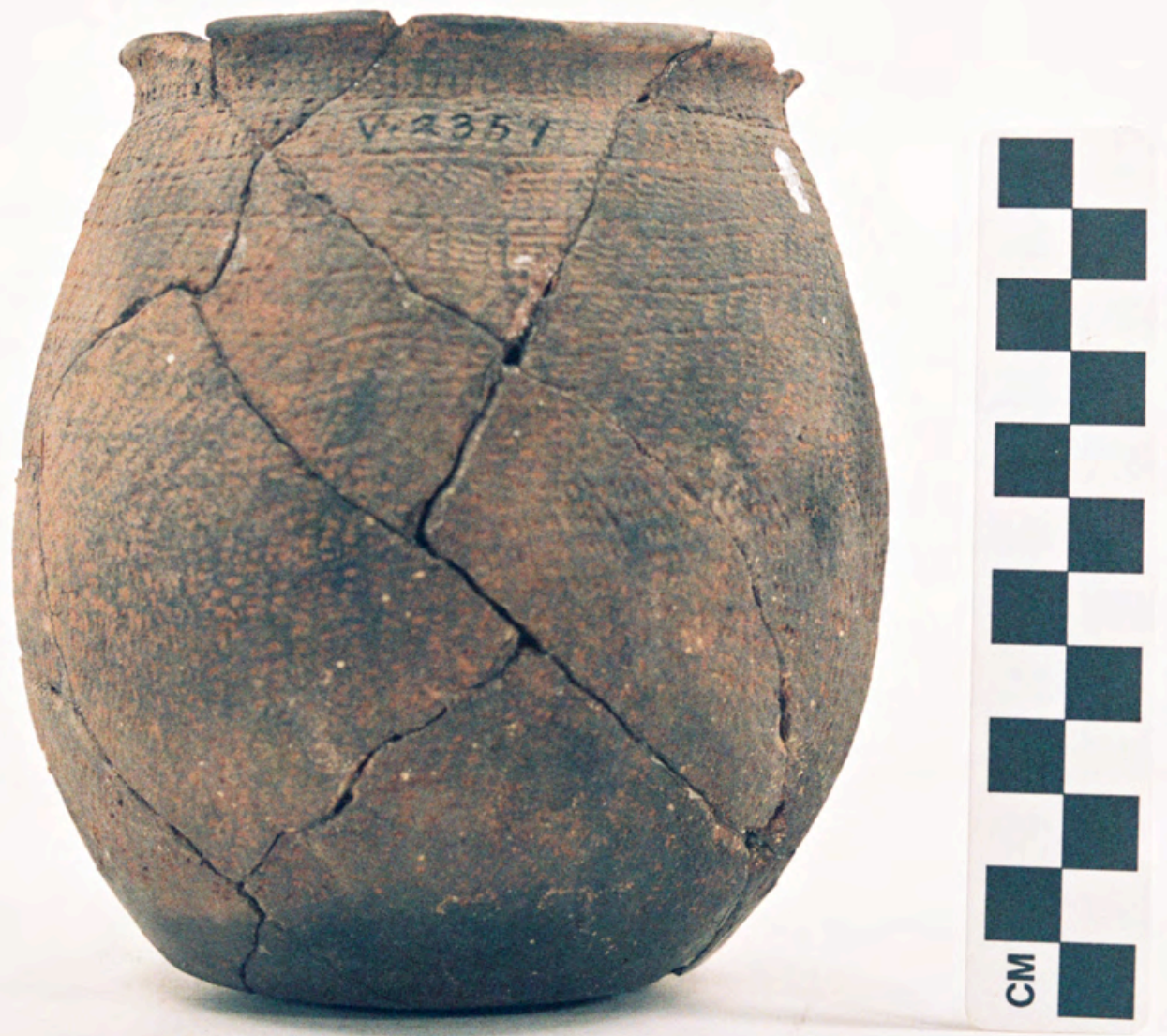

Figure 15e

Figure A2-52 


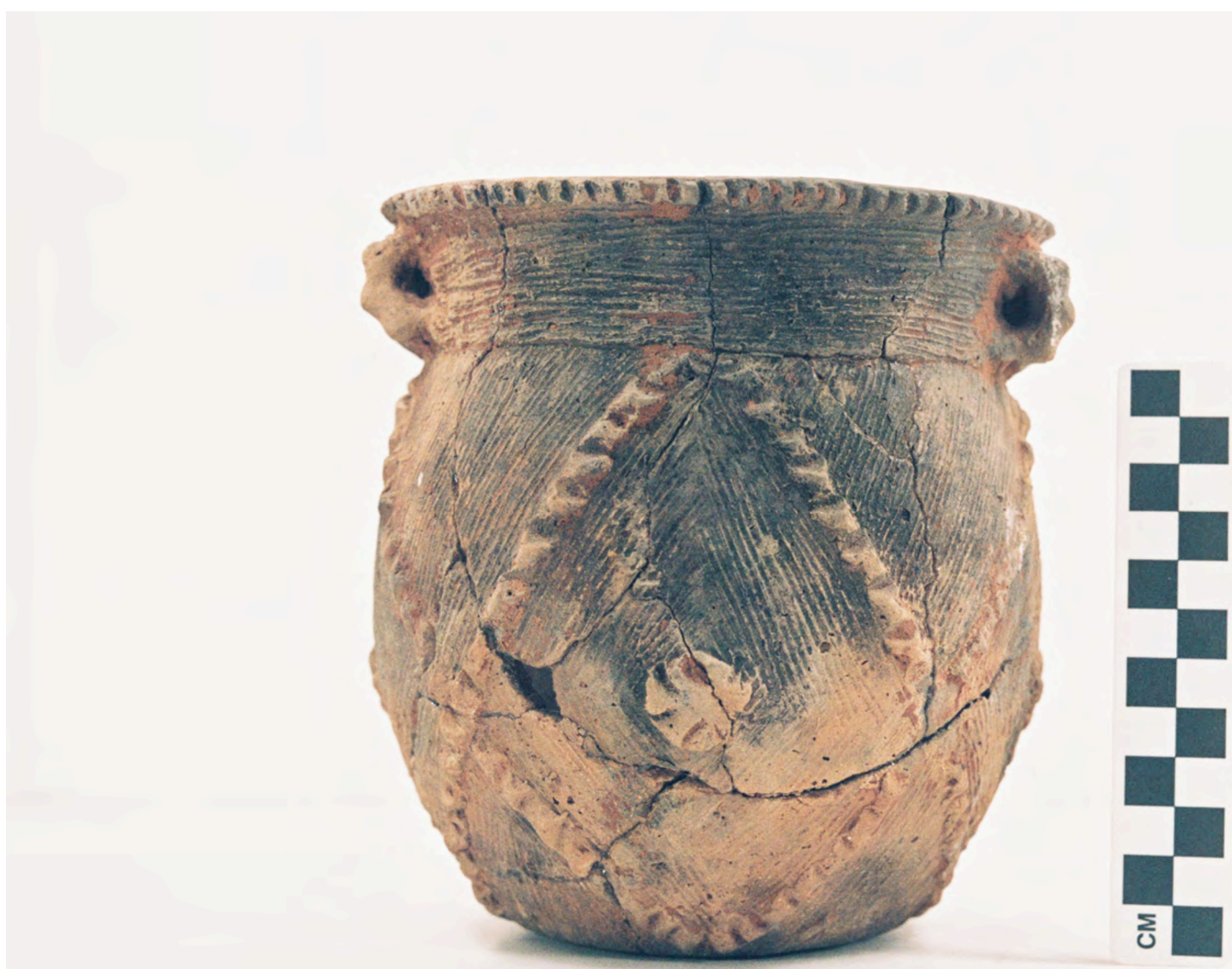

Figure 15f

Figure A2-4 


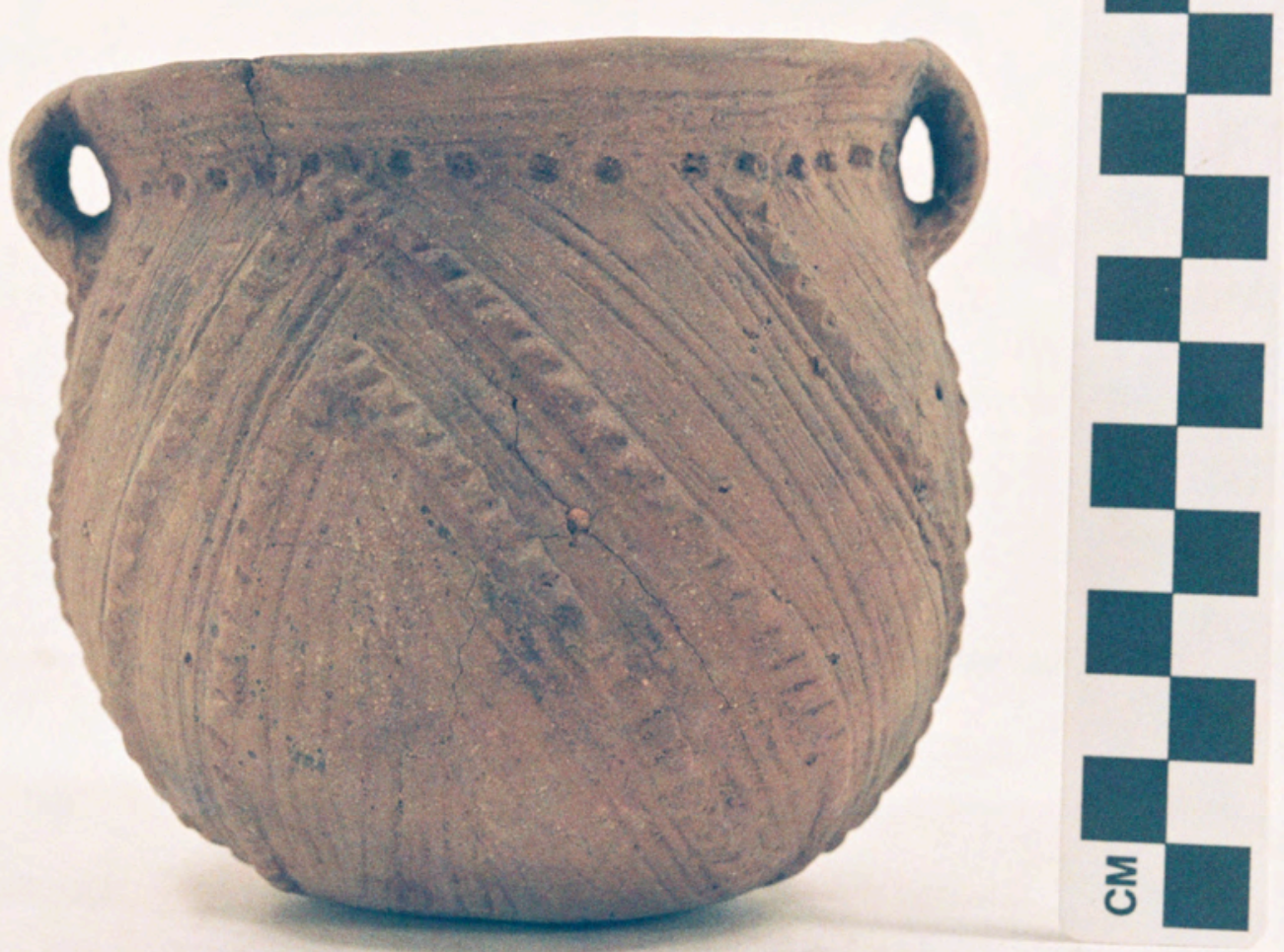

Figure $15 \mathrm{~g}$

Figure A2-55 


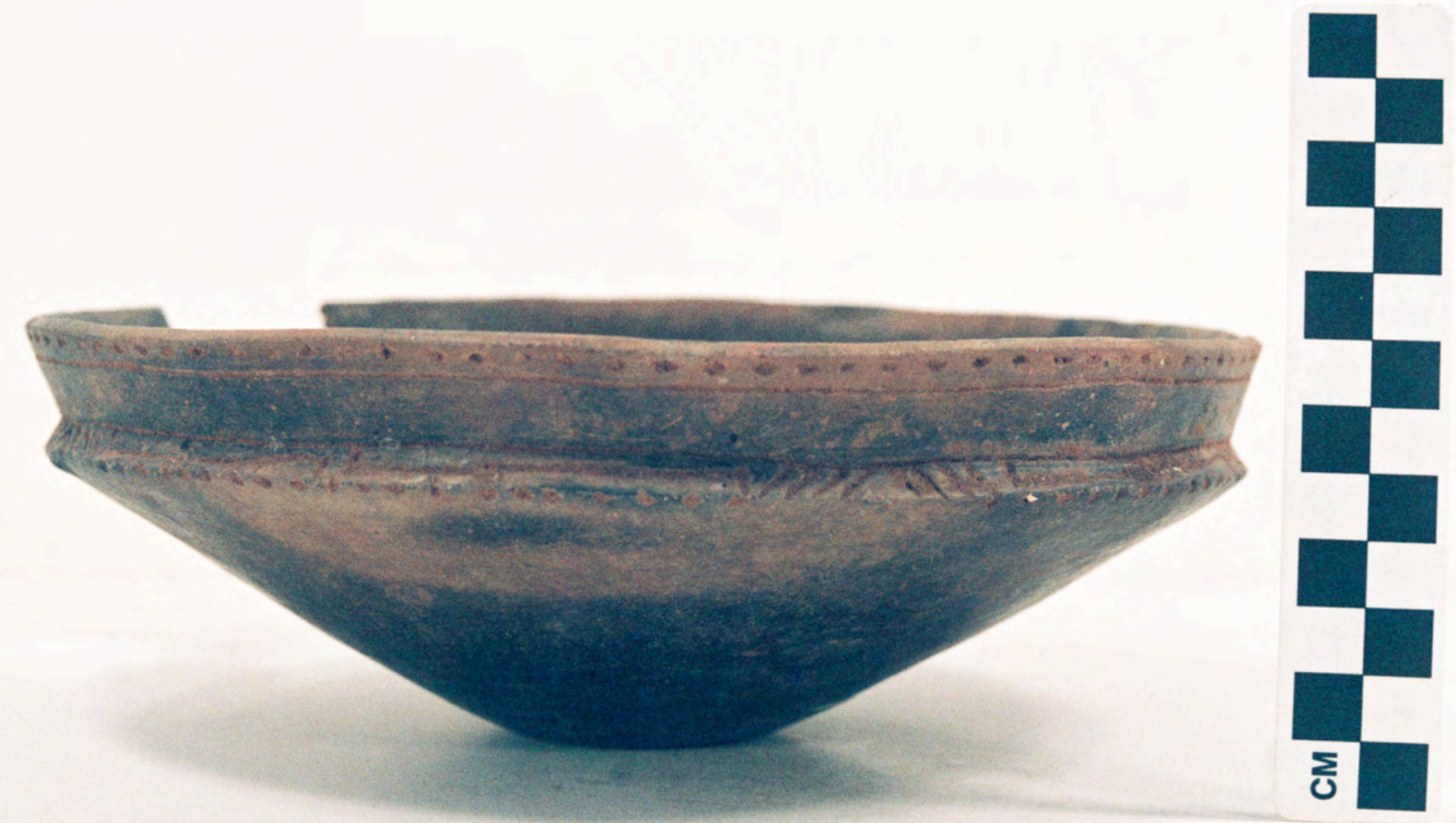

Figure 16a

Figure A2-12 


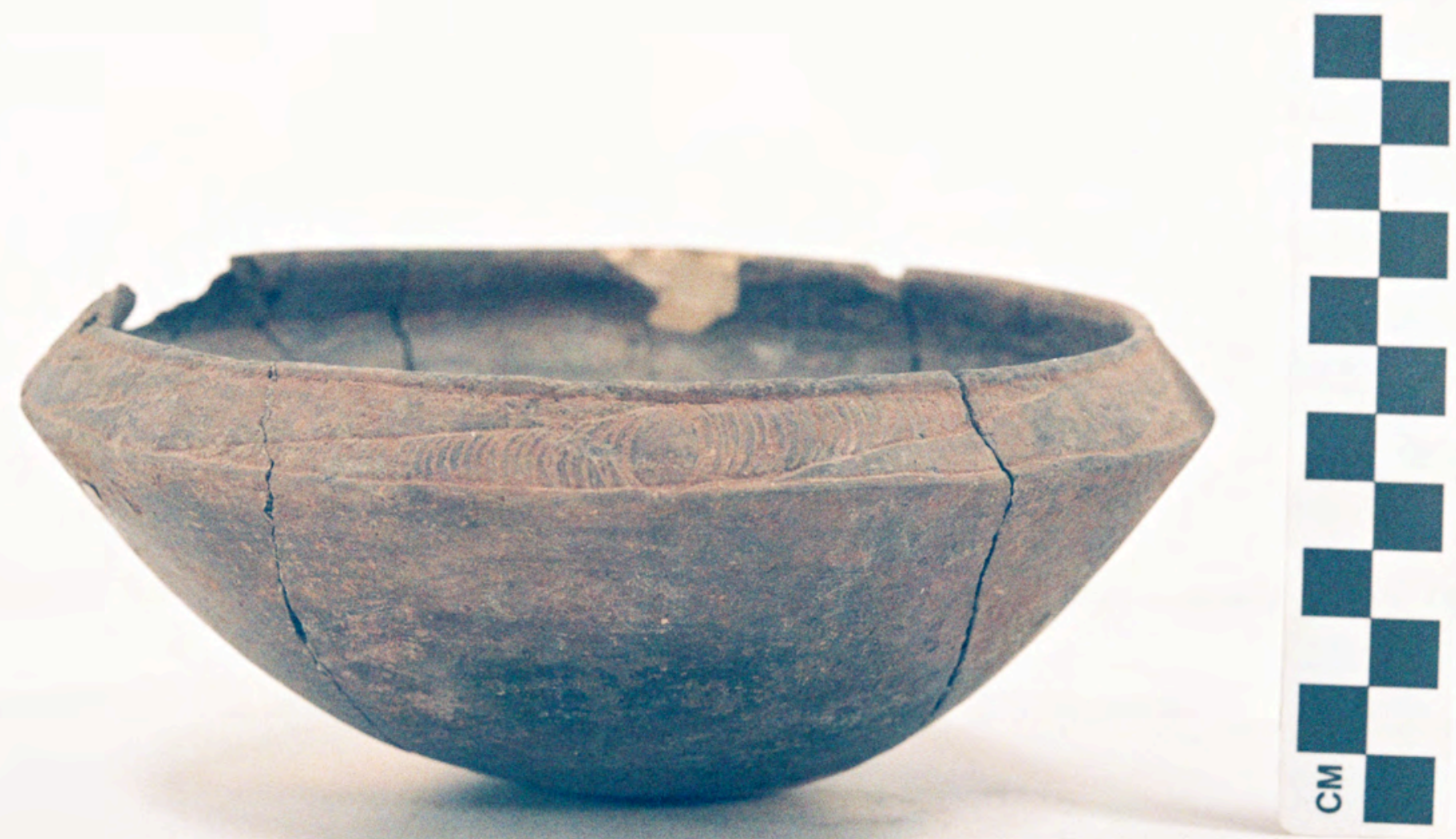

Figure 16b

Figure A2-19 


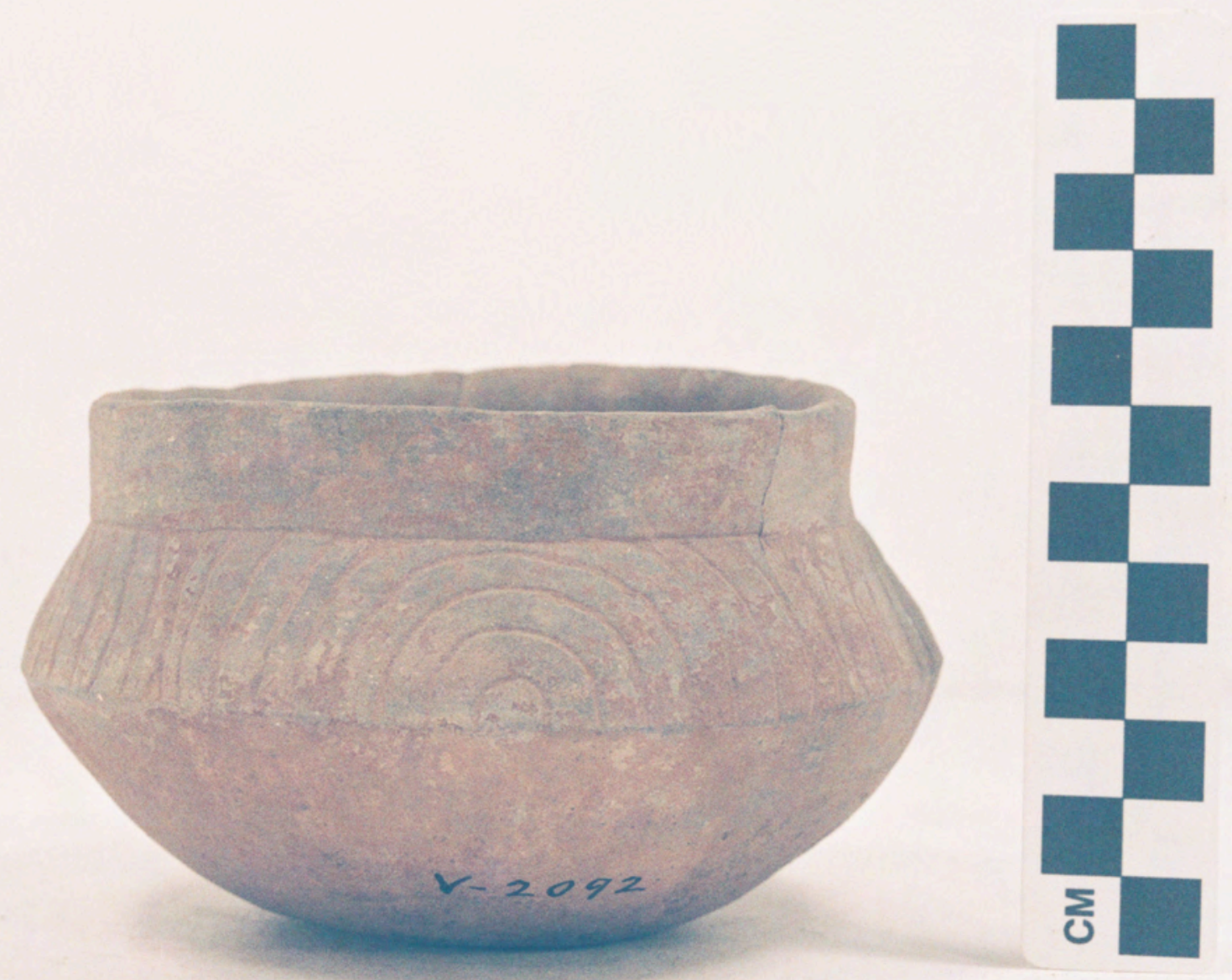

Figure 16c

Figure A2-38 


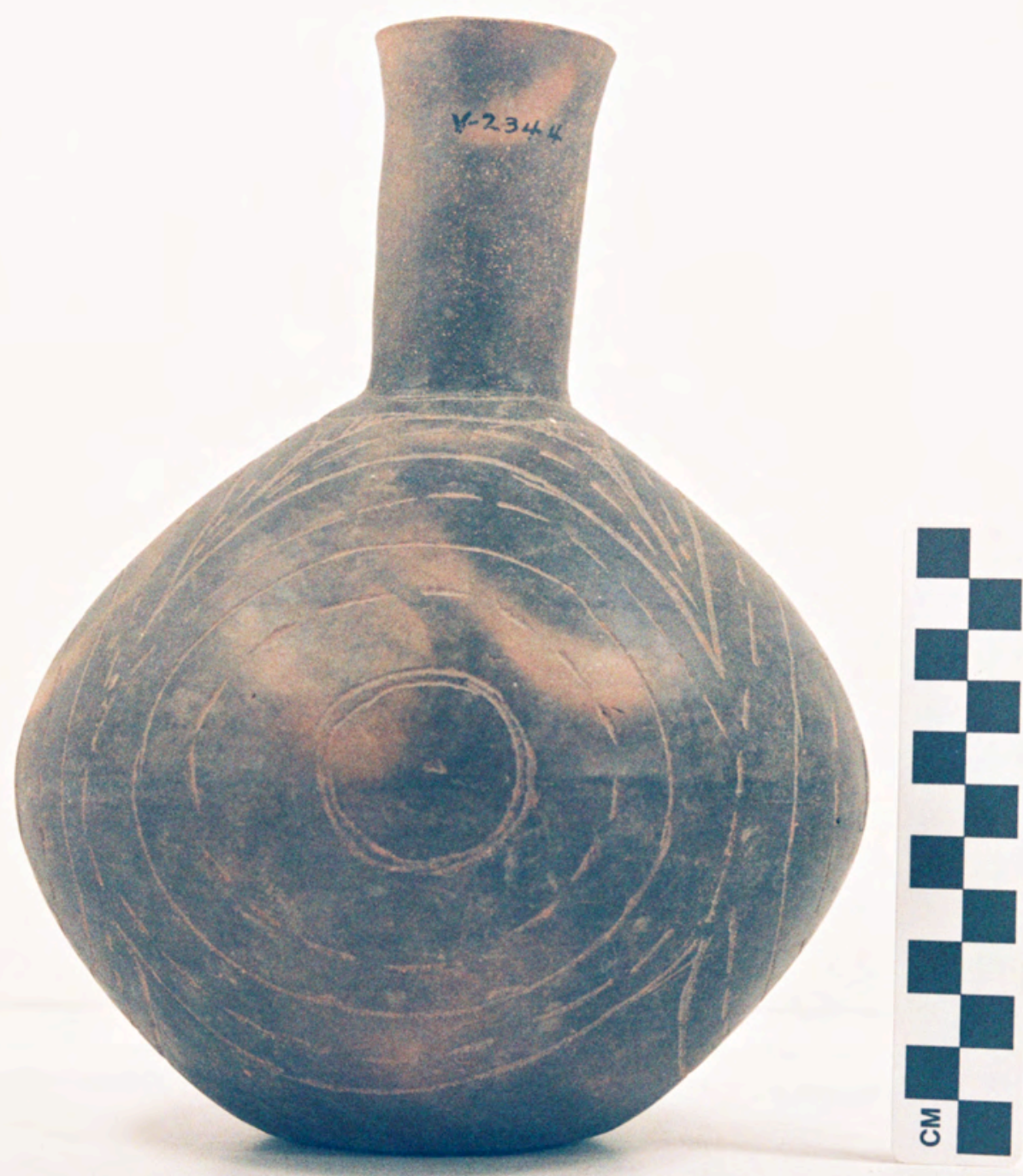

Figure 16d

Figure A2-7a 


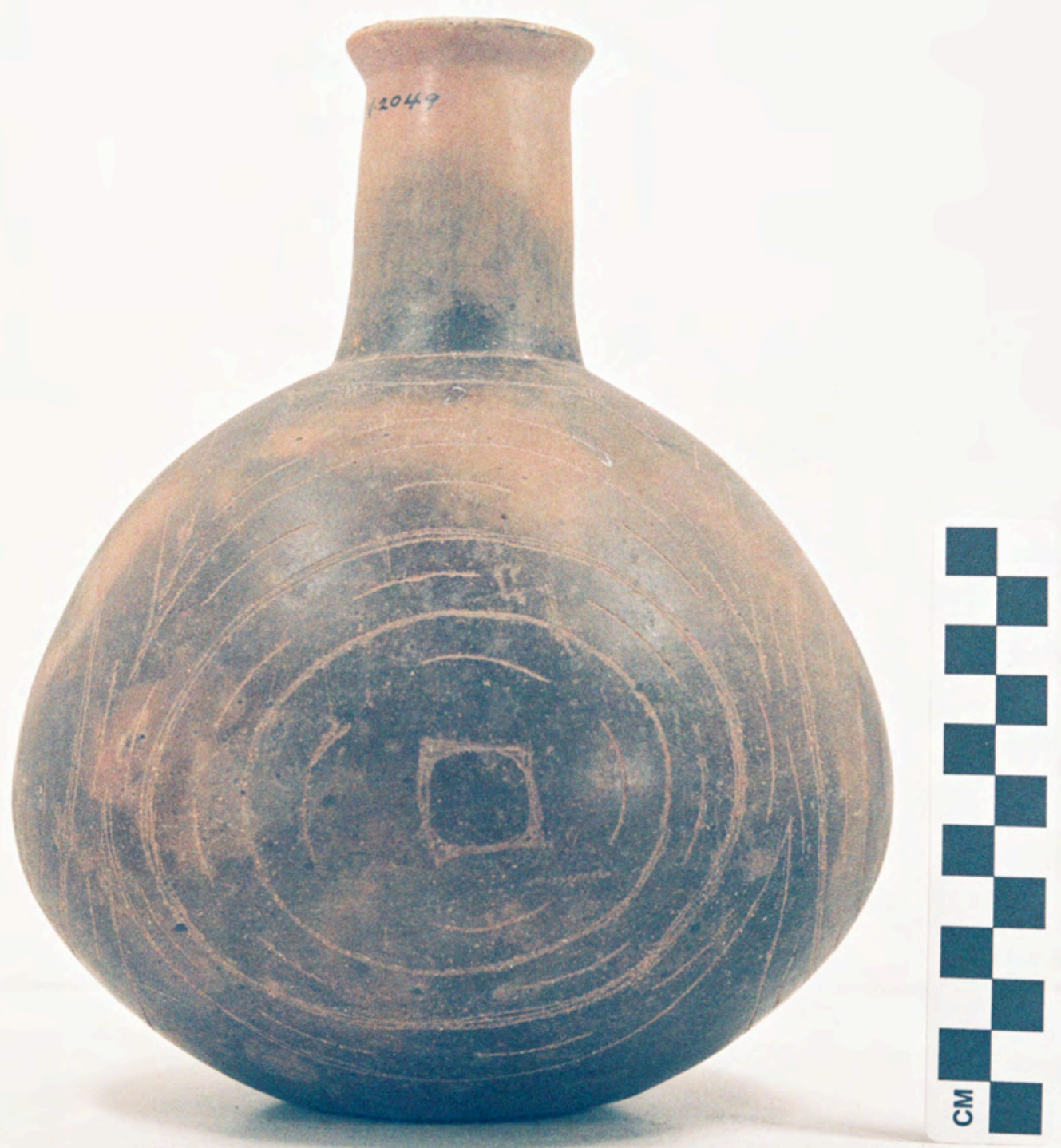

Figure $16 \mathrm{e}$

Figure A2-42a 


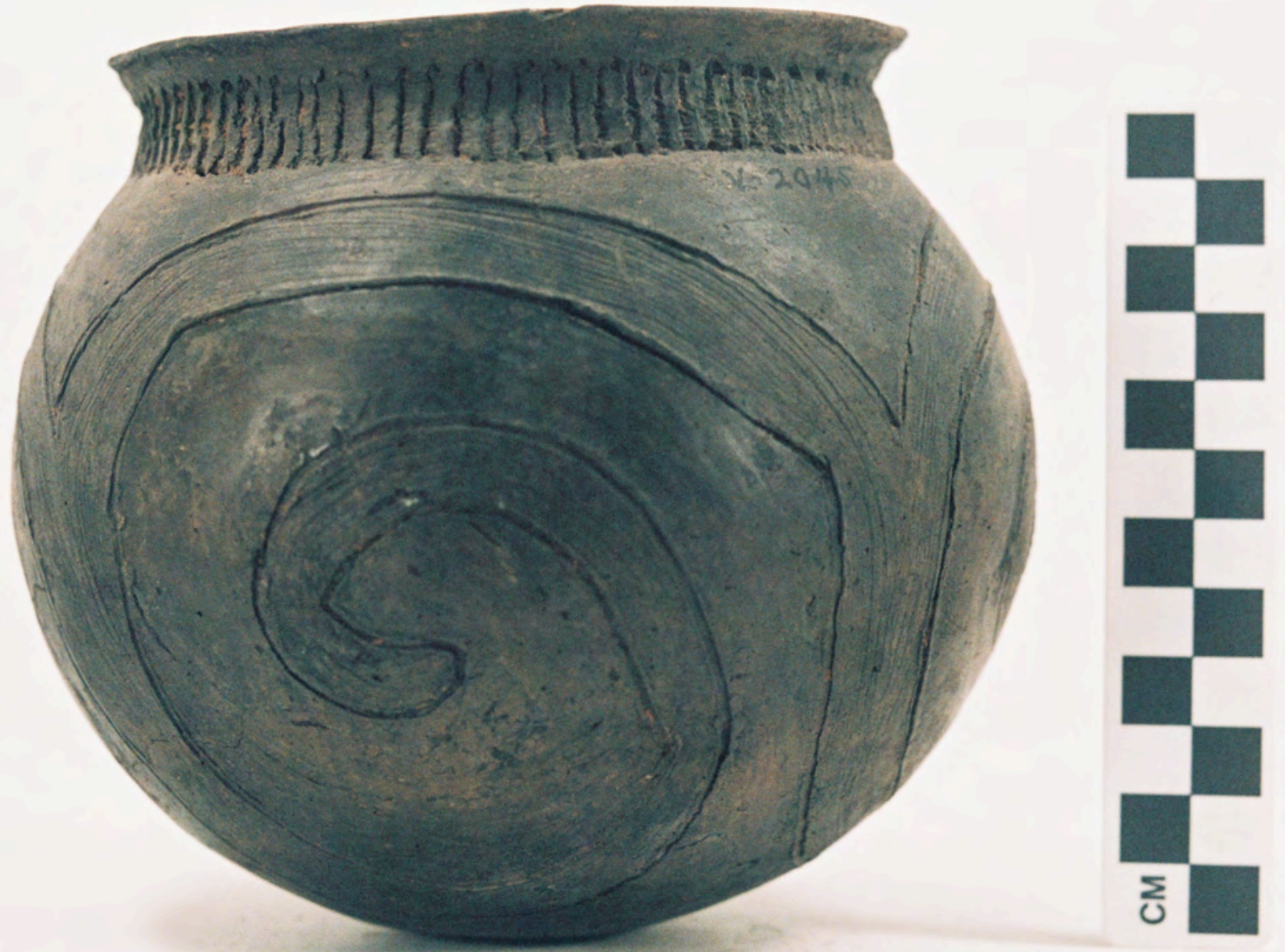

Figure 16f

Figure A2-46 


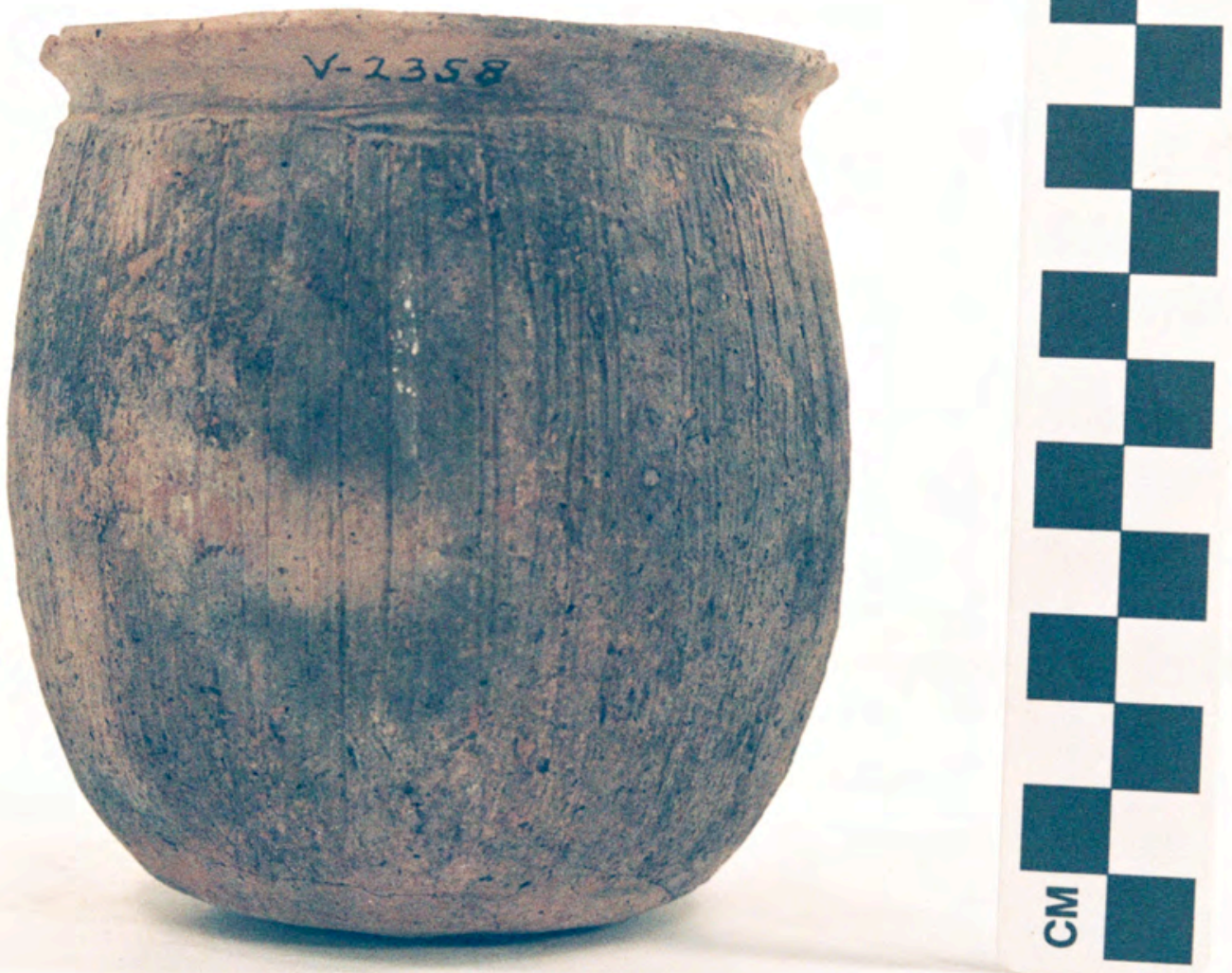

Figure $16 \mathrm{~g}$

Figure A2-45 


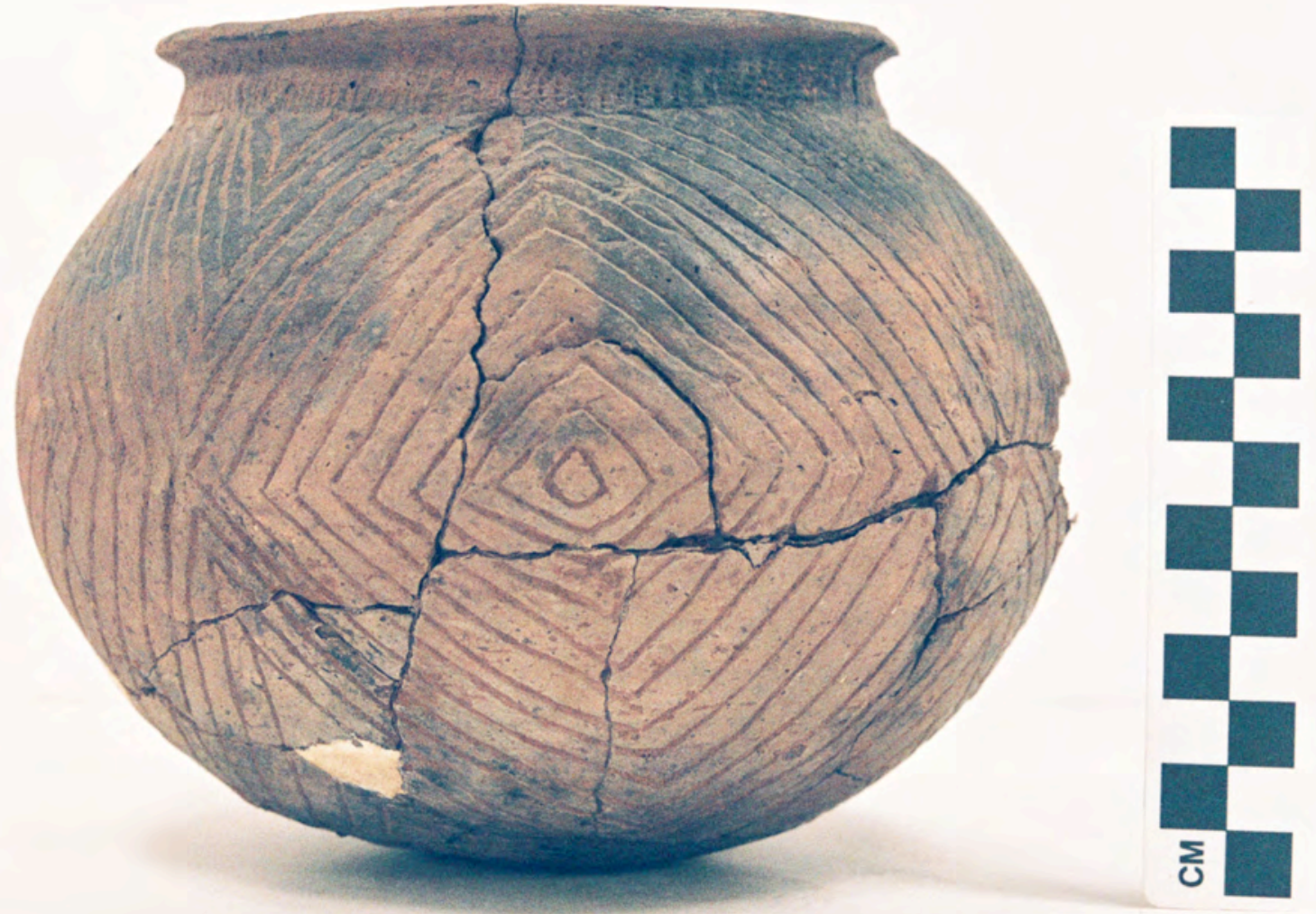

Figure $16 \mathrm{~h}$

Figure A2-58 


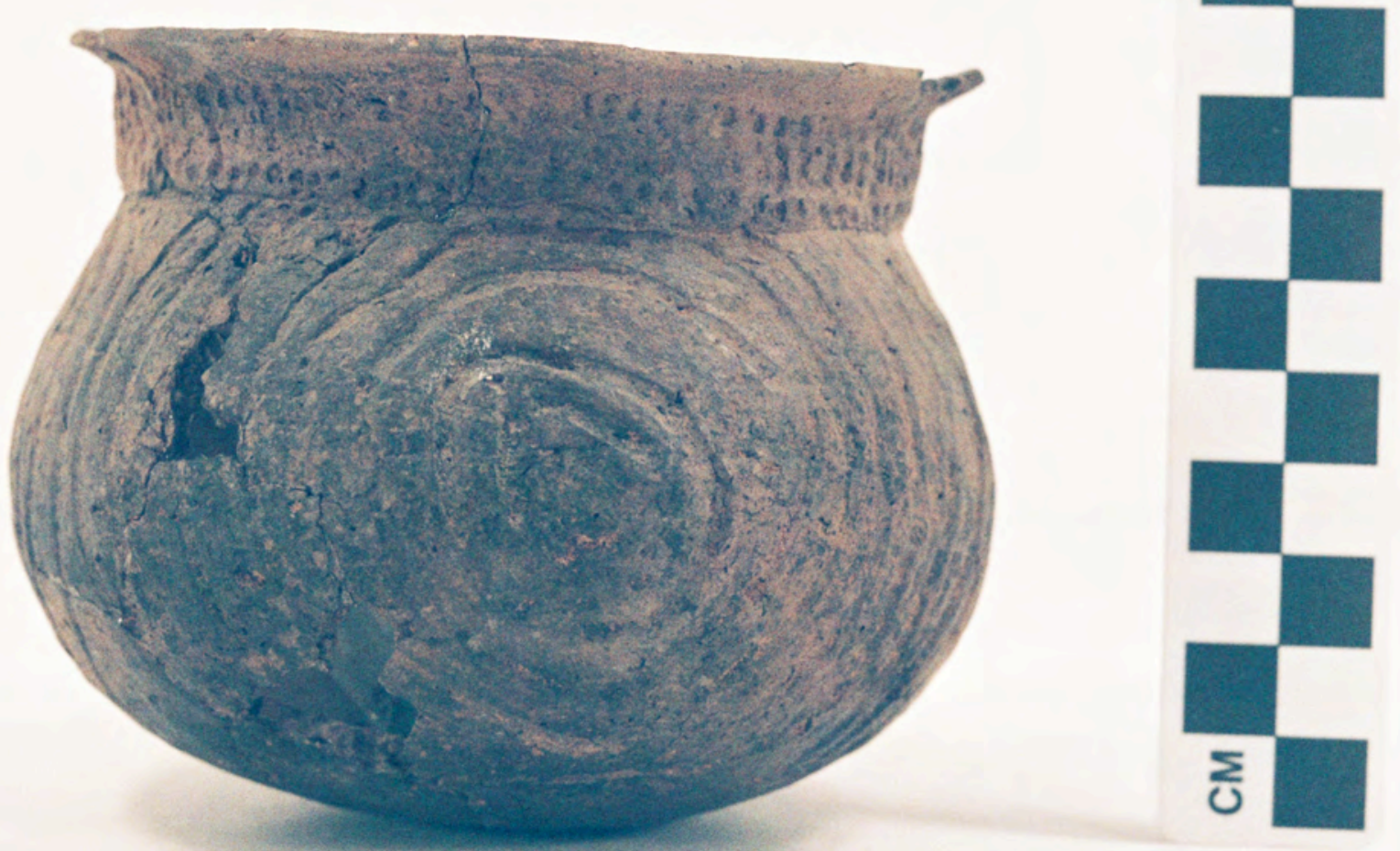

Figure 17a

Figure A2-69 


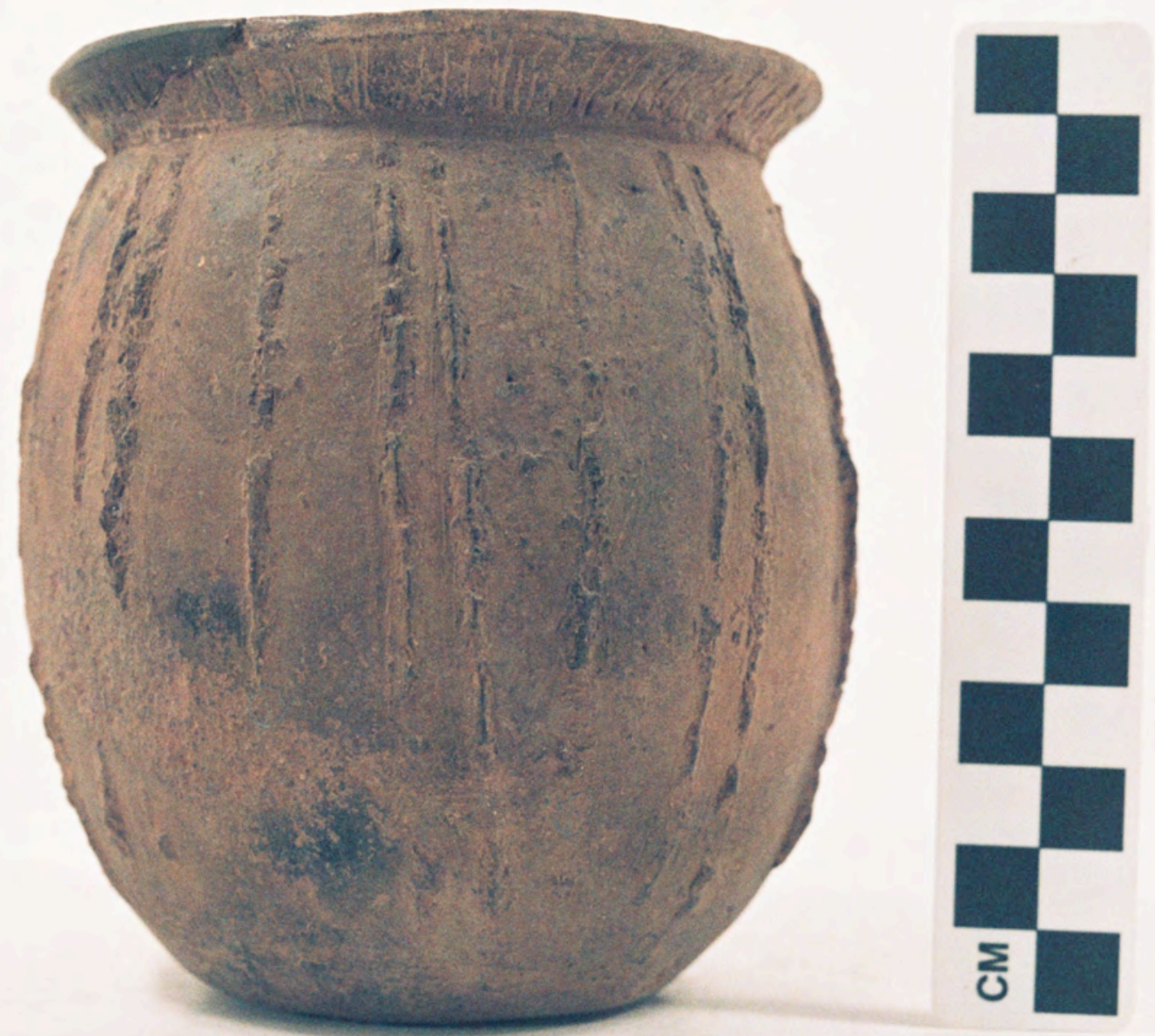

Figure $17 \mathrm{~b}$

Figure A2-41 

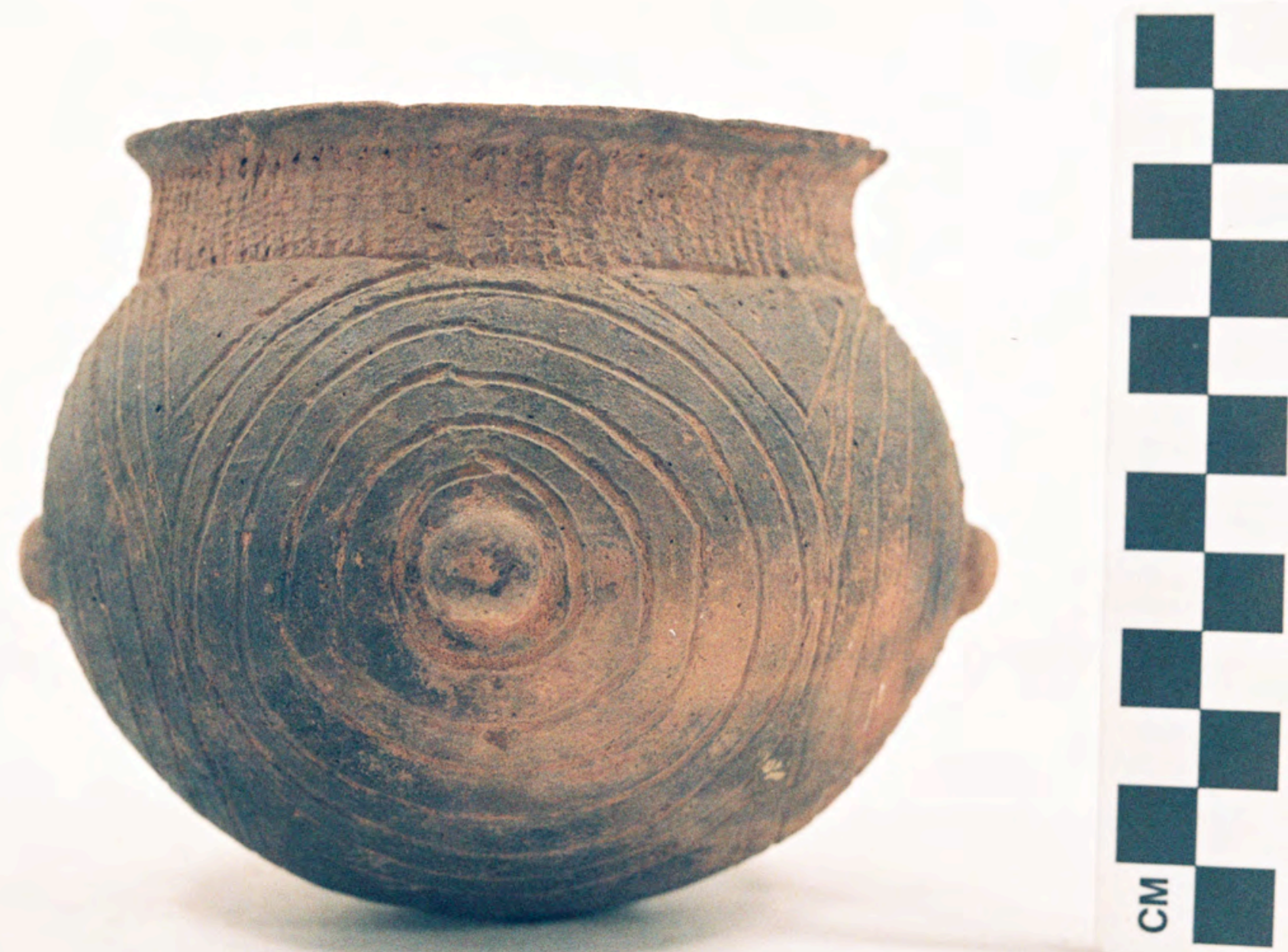

Figure 17c

Figure A2-68 


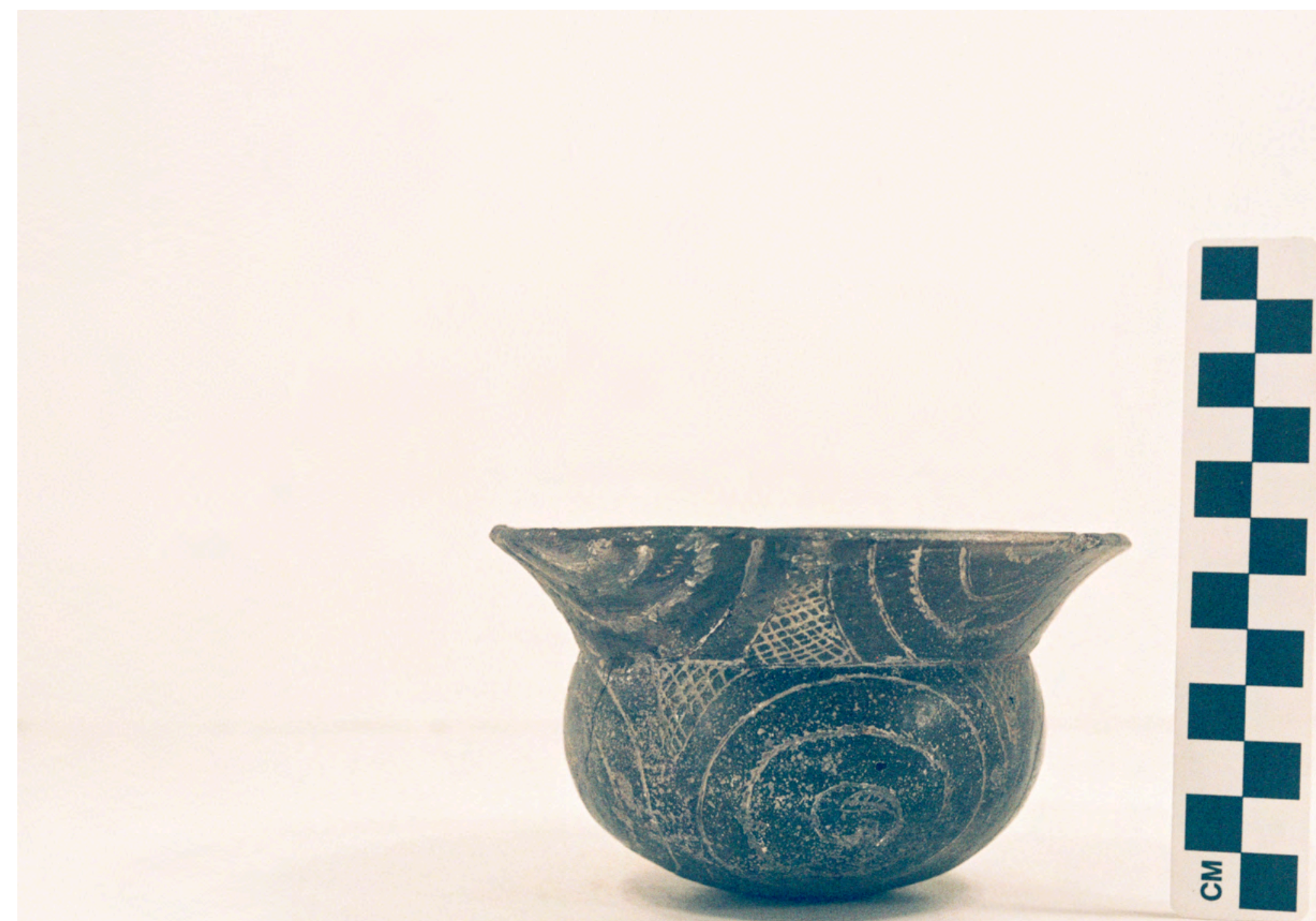

Figure 18a

Figure A3-30 


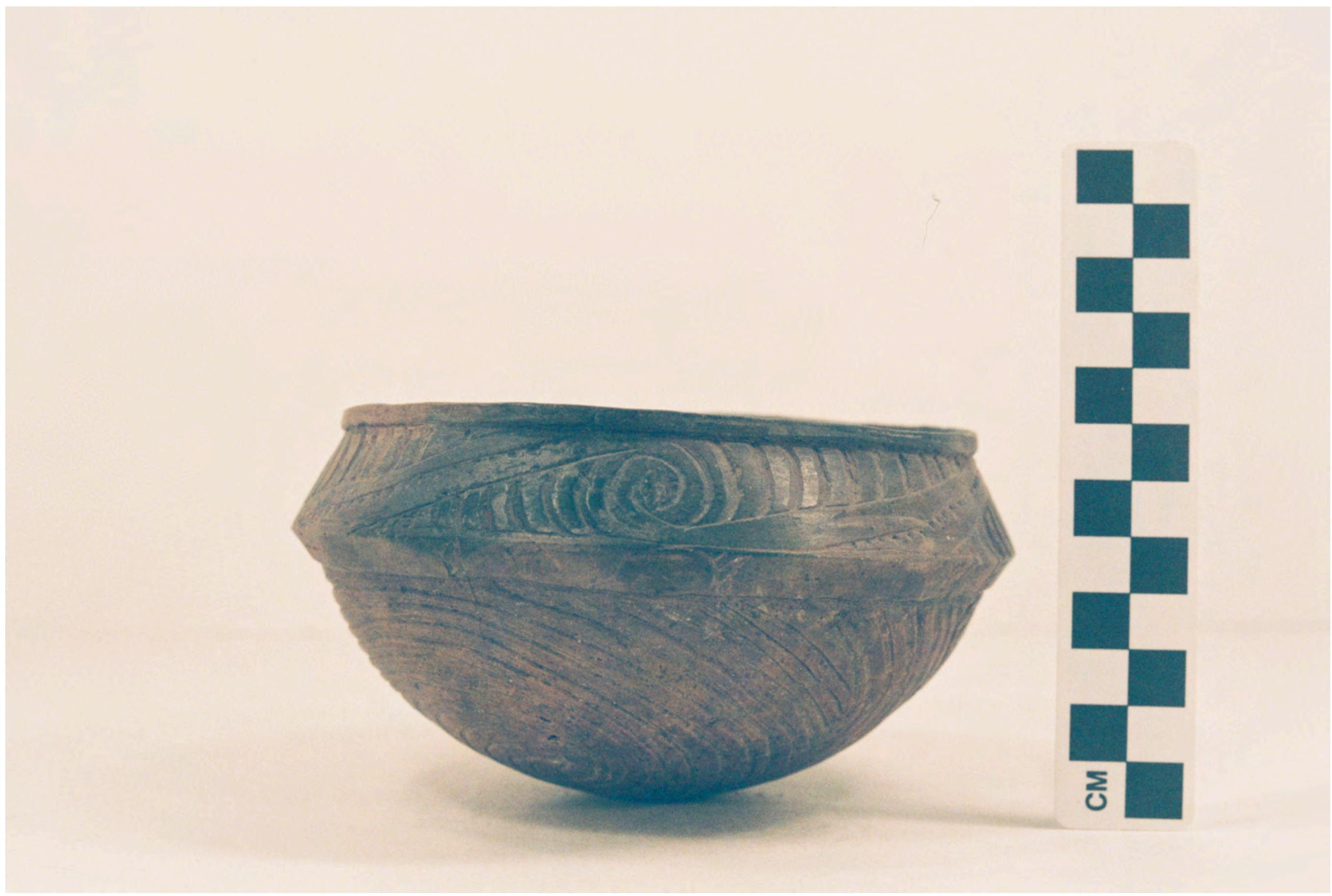

Figure $18 b$

Figure A3-36 


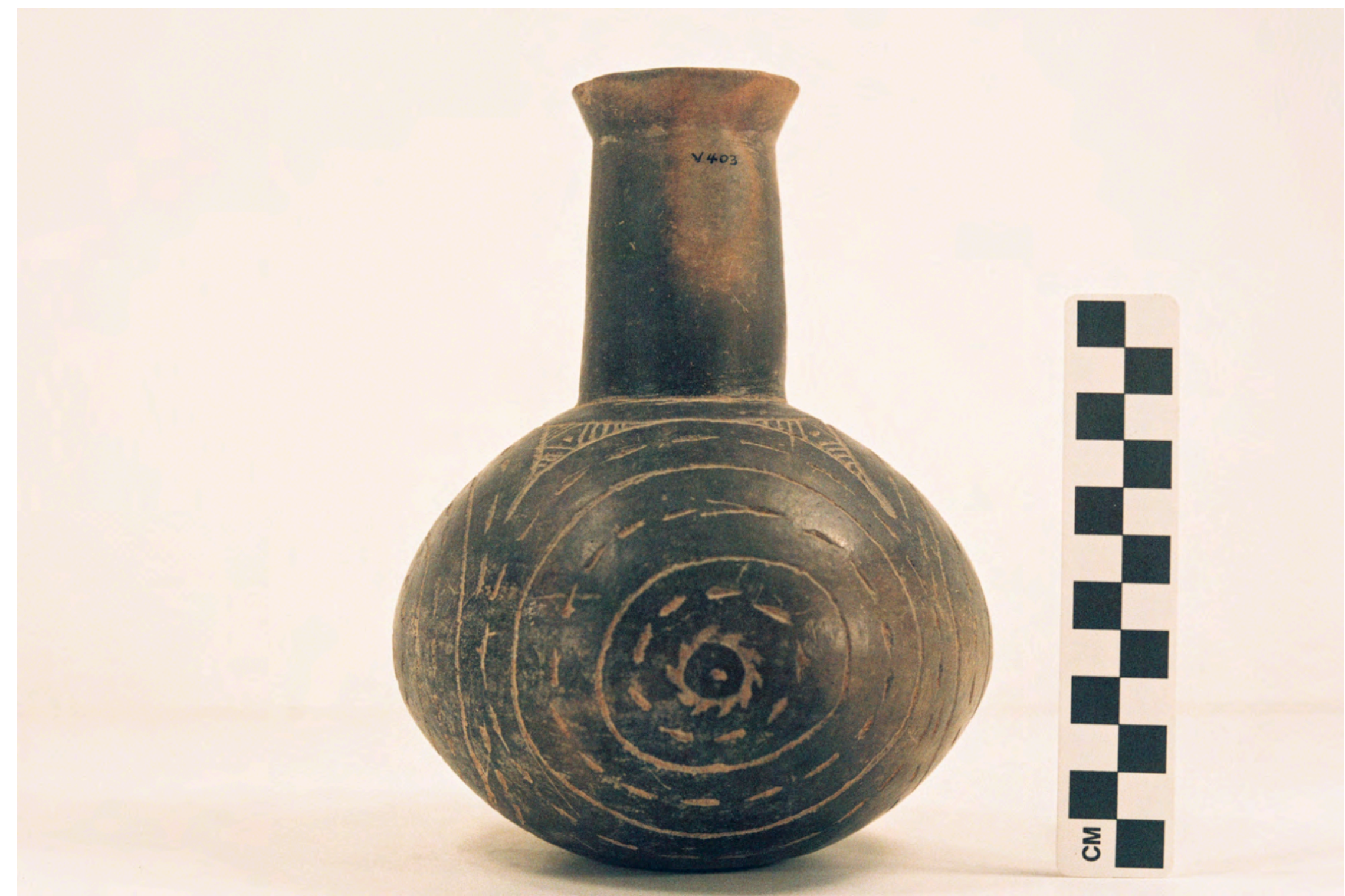

Figure 18c

Figure A3-18 


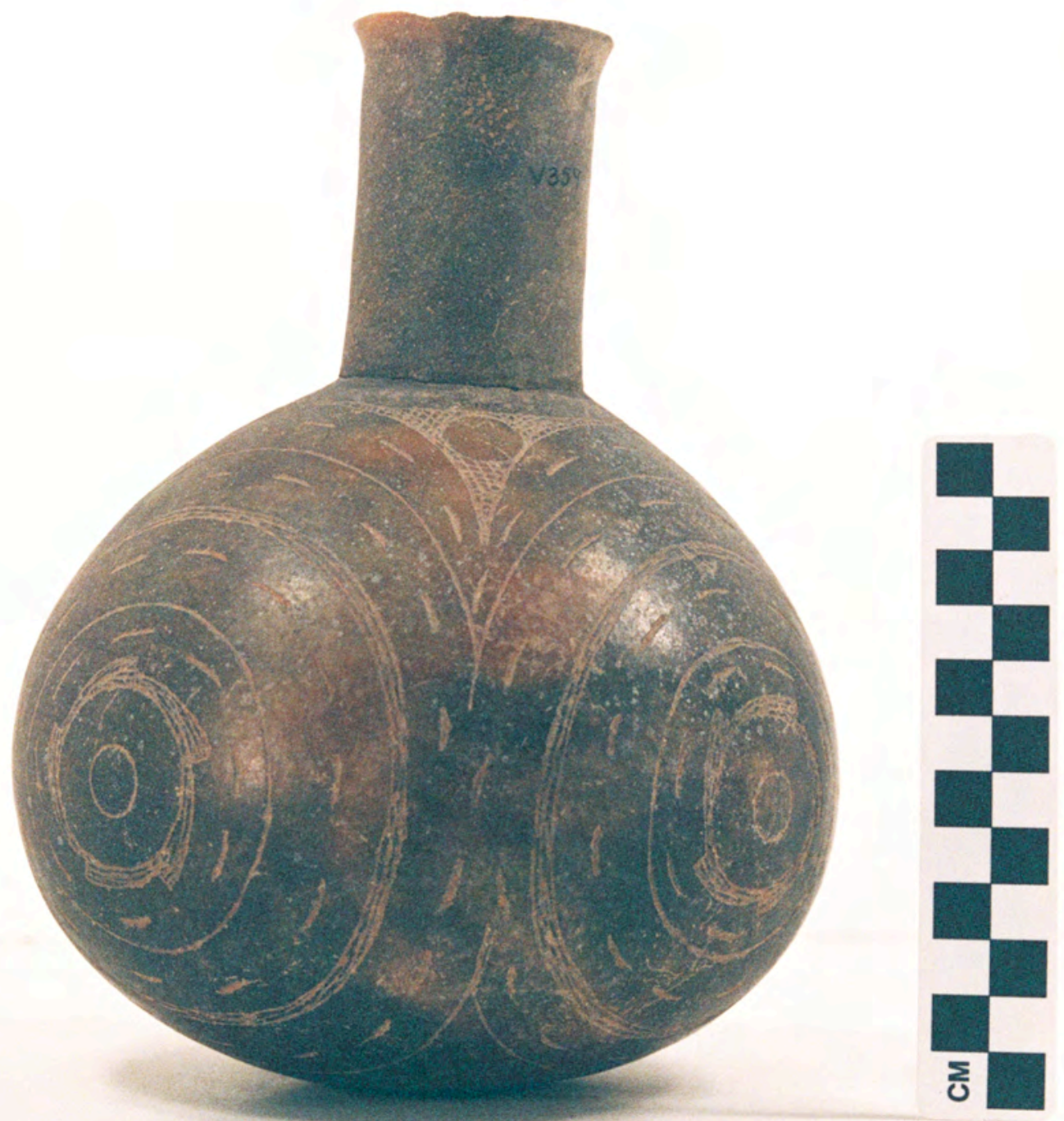

Figure 18d

Figure A3-1 


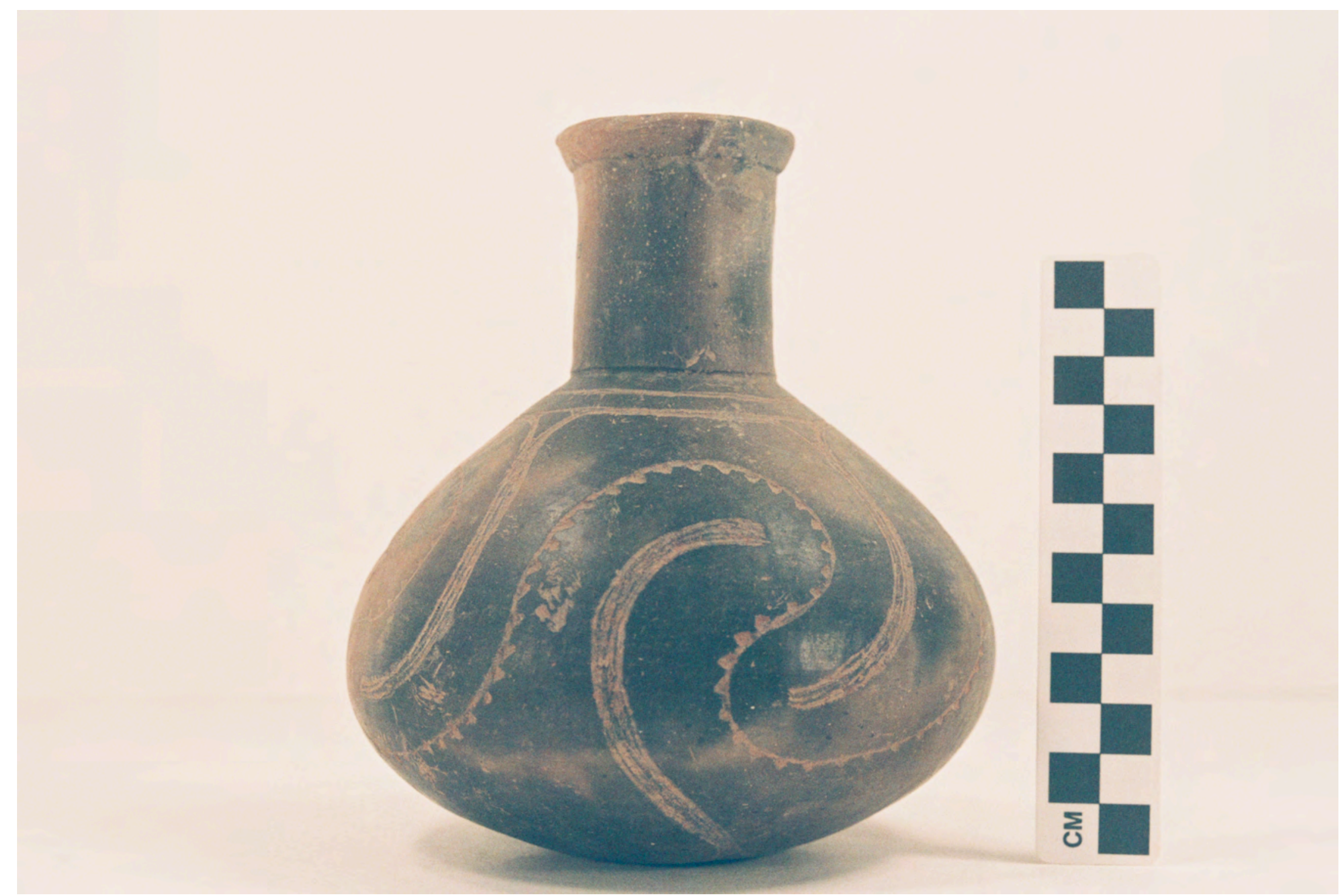

Figure $18 \mathrm{e}$

Figure A3-4 


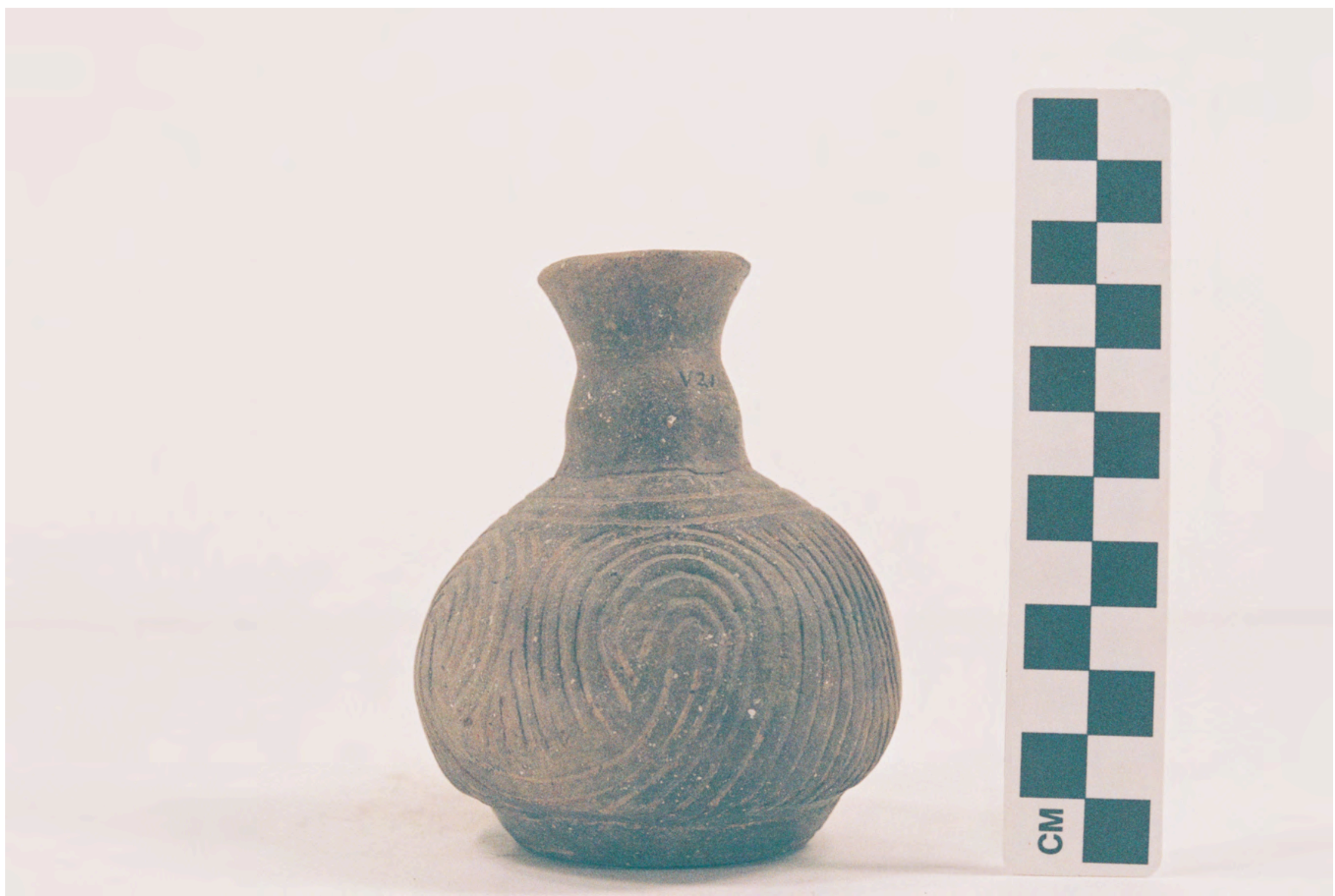

Figure $18 \mathrm{f}$

Figure A3-12 


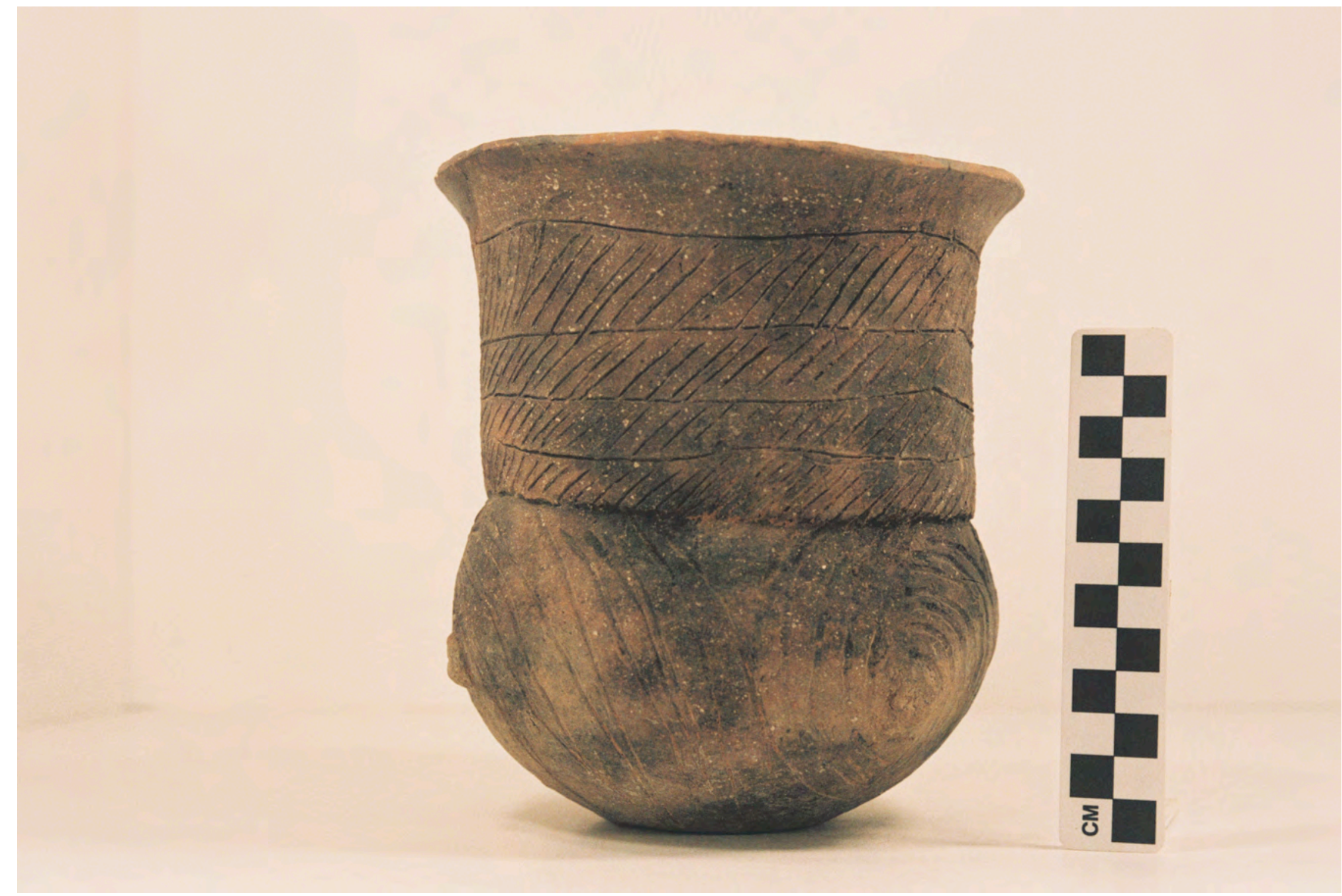

Figure $18 \mathrm{~g}$

Figure A3-20 


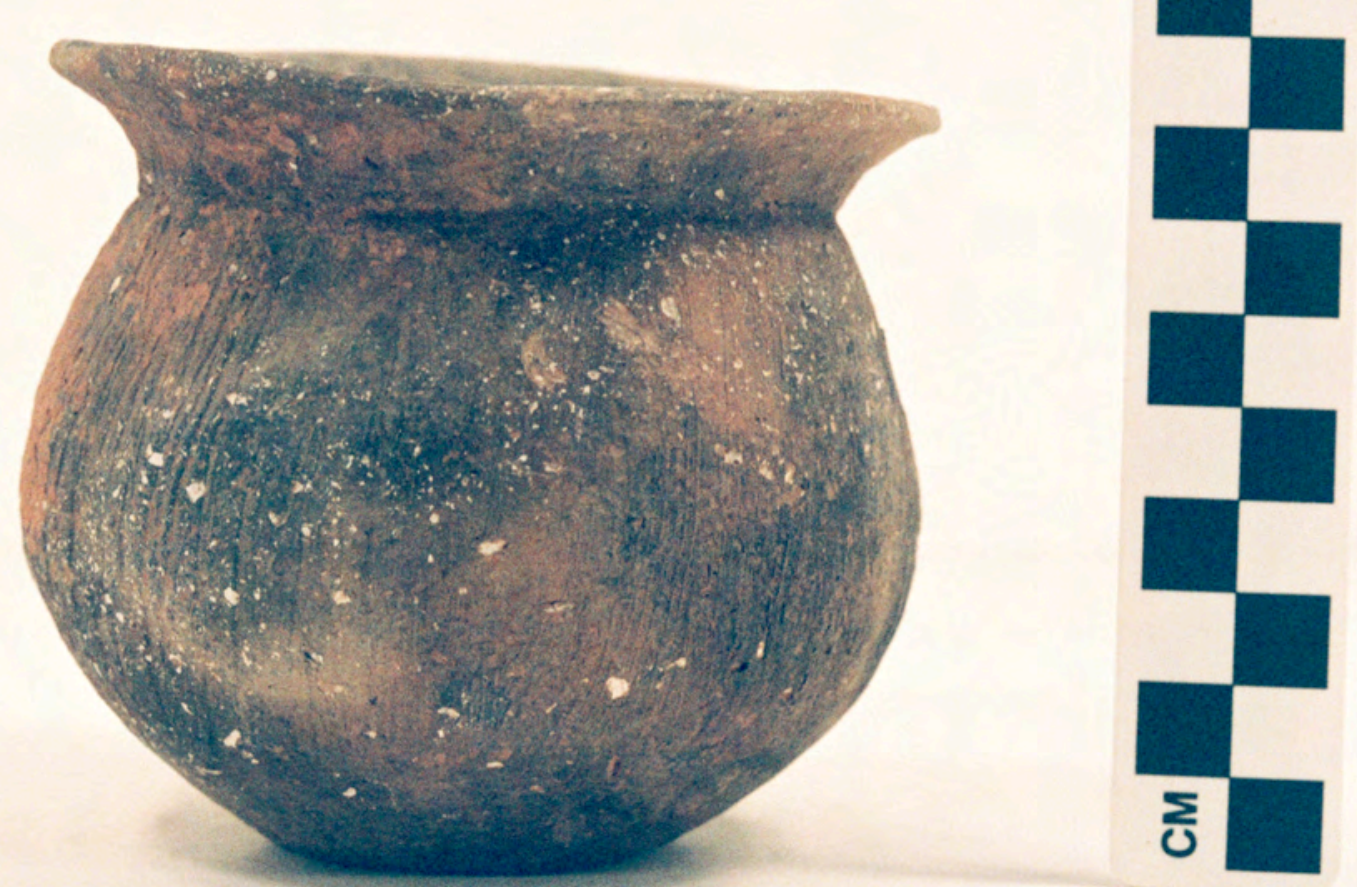

Figure $18 \mathrm{~h}$

Figure A3-14 


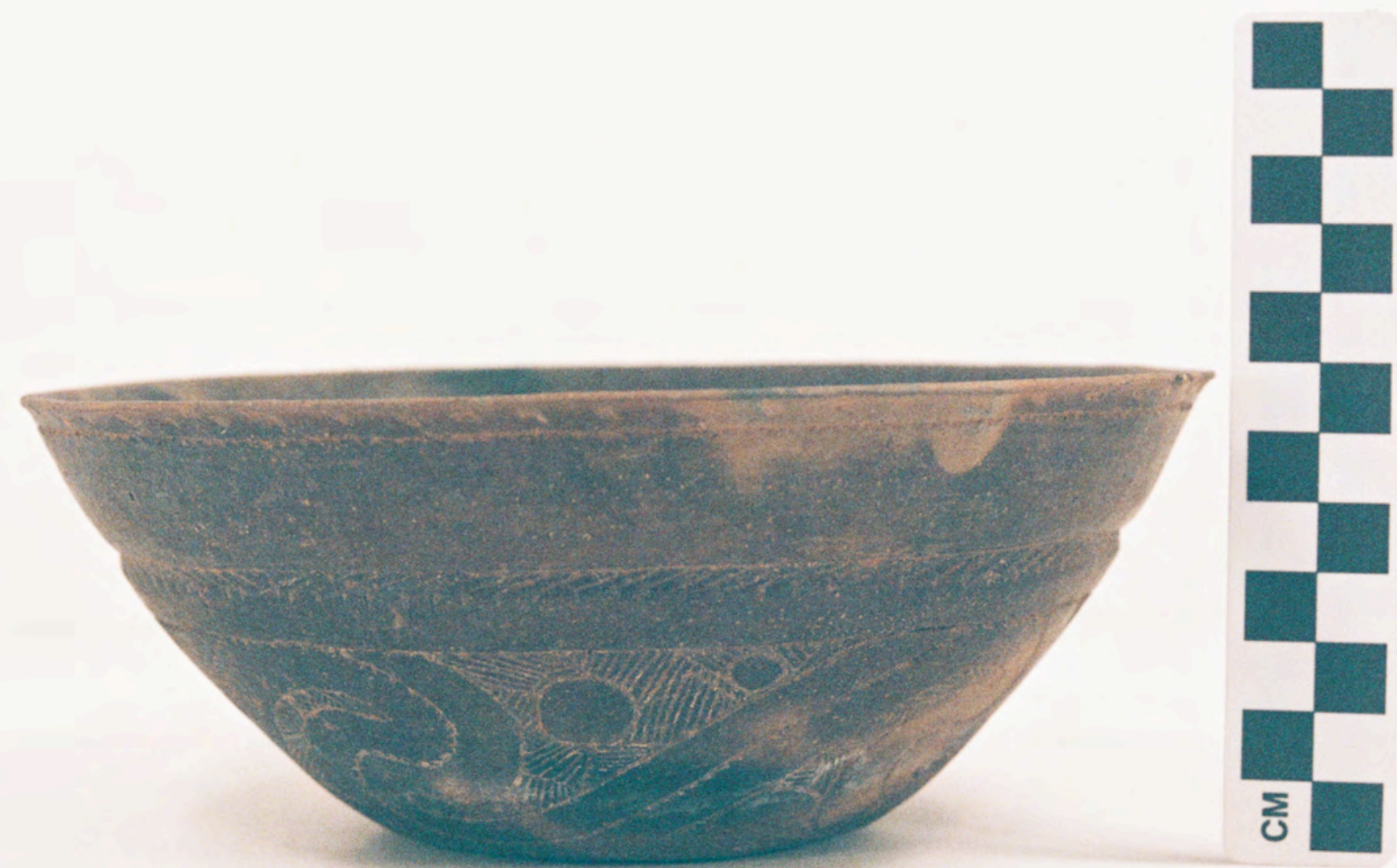

Figure 19a

Figure A3-15 


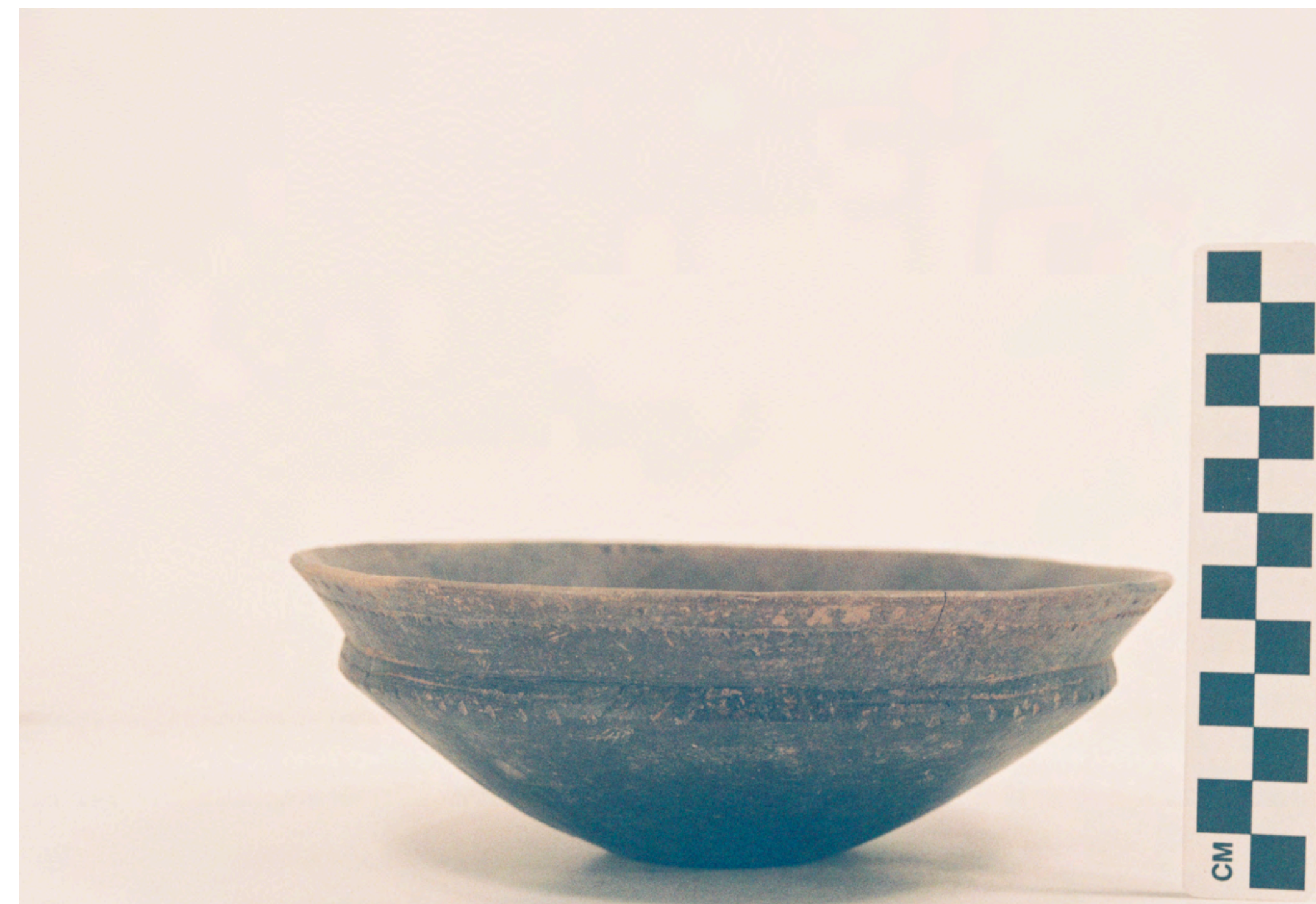

Figure 19b

Figure A3-26 


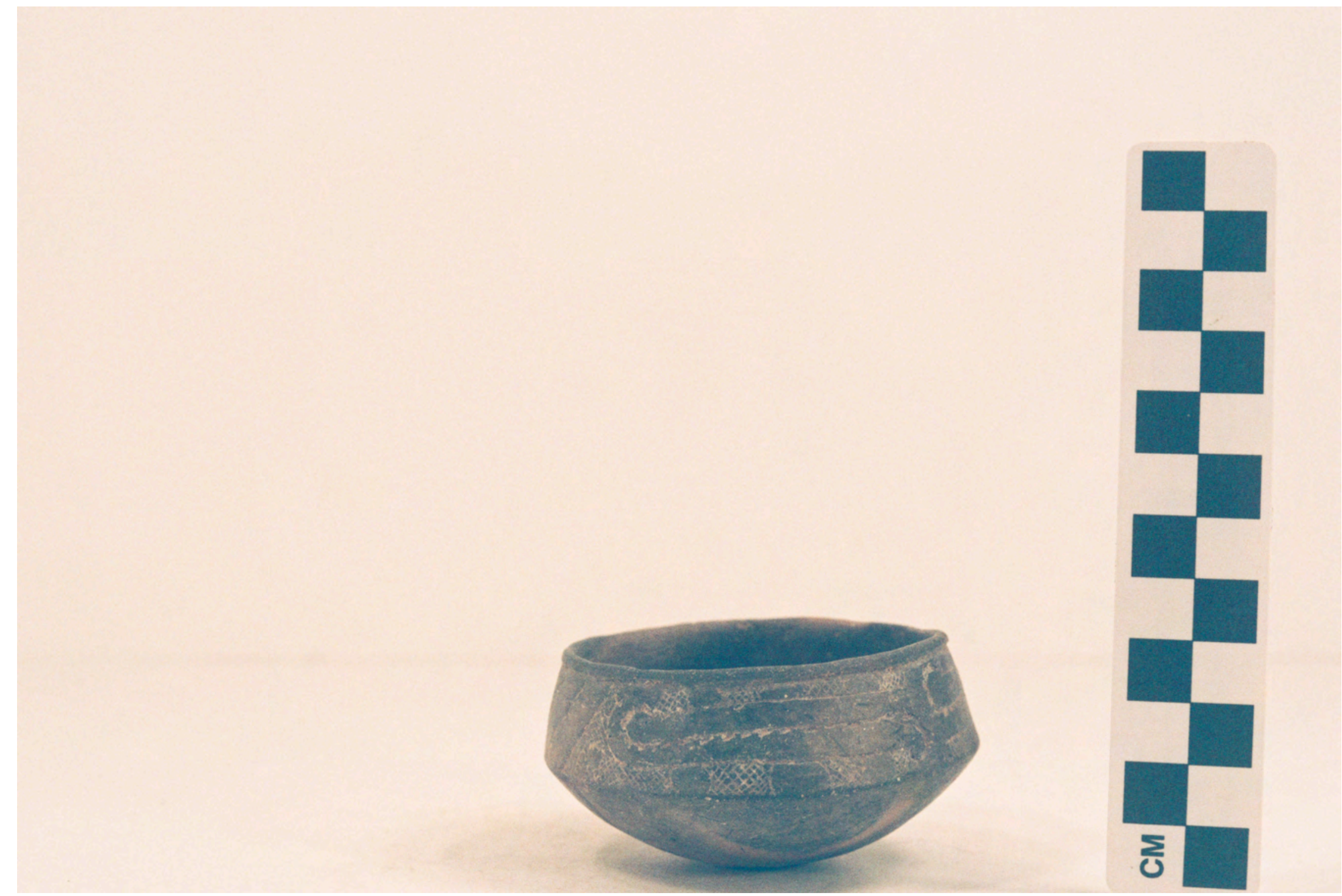

Figure 19c

Figure A3-7 


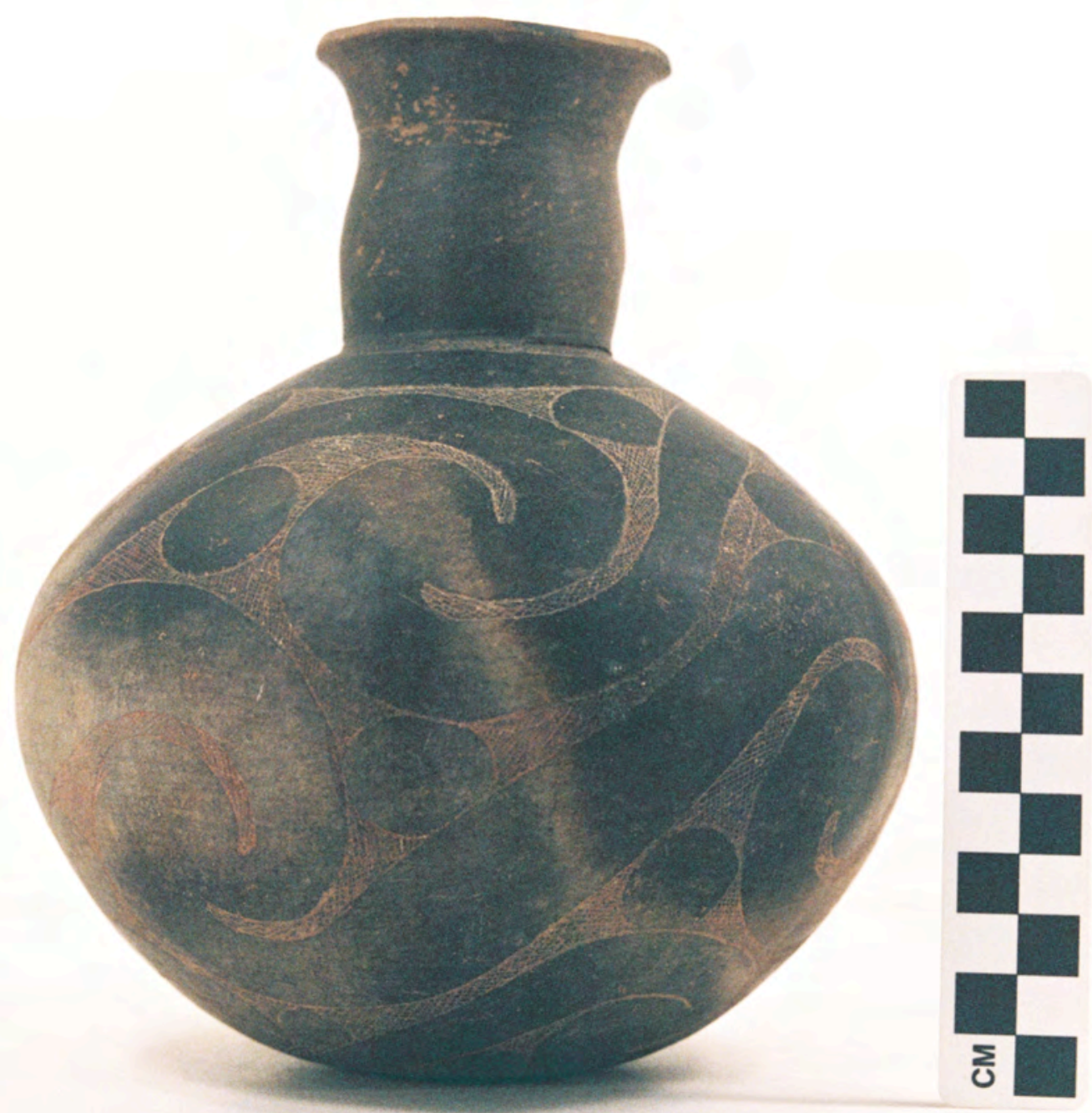

Figure 19d

Figure A3-22a 


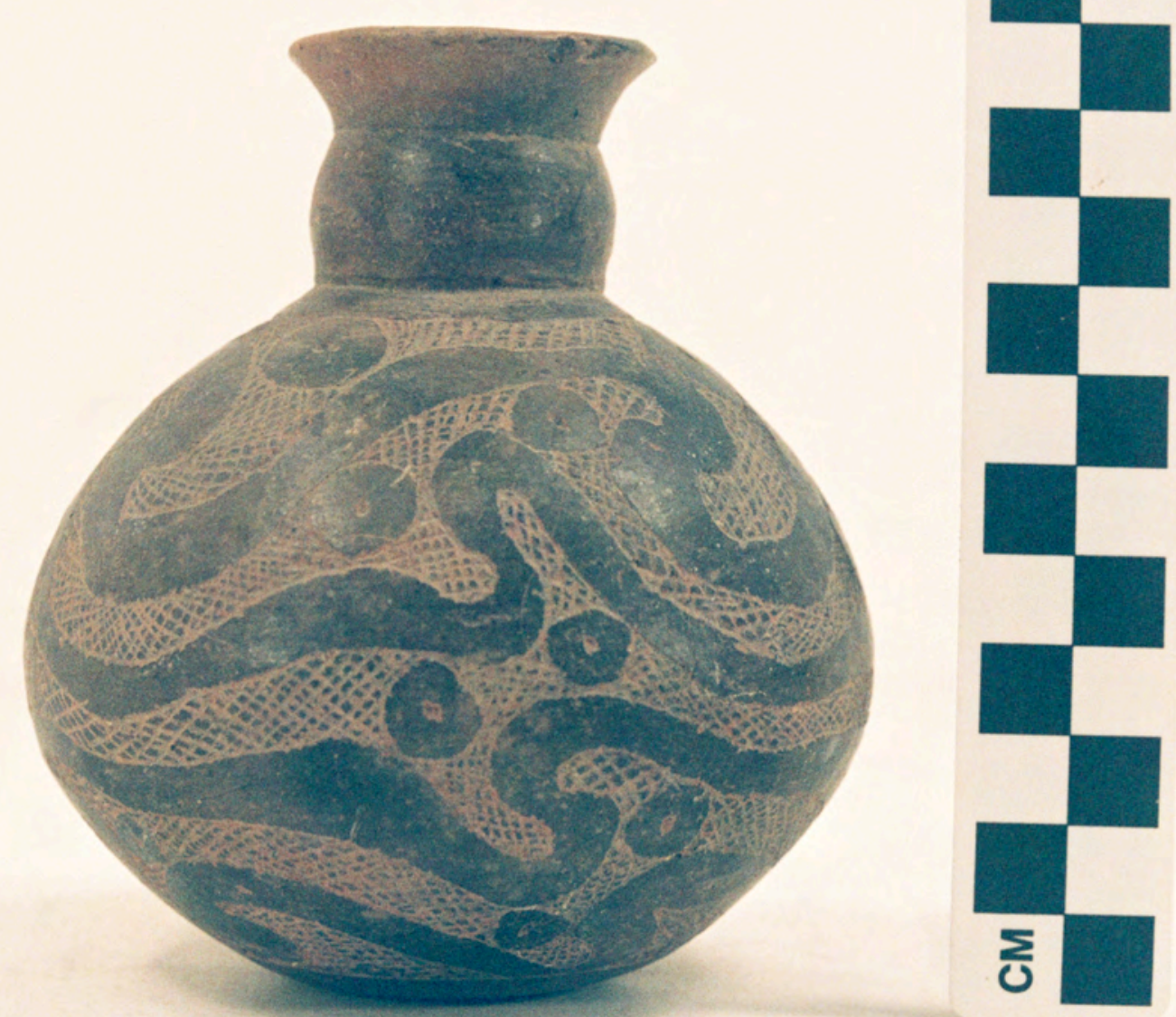

Figure $19 \mathrm{e}$

Figure A3-38 


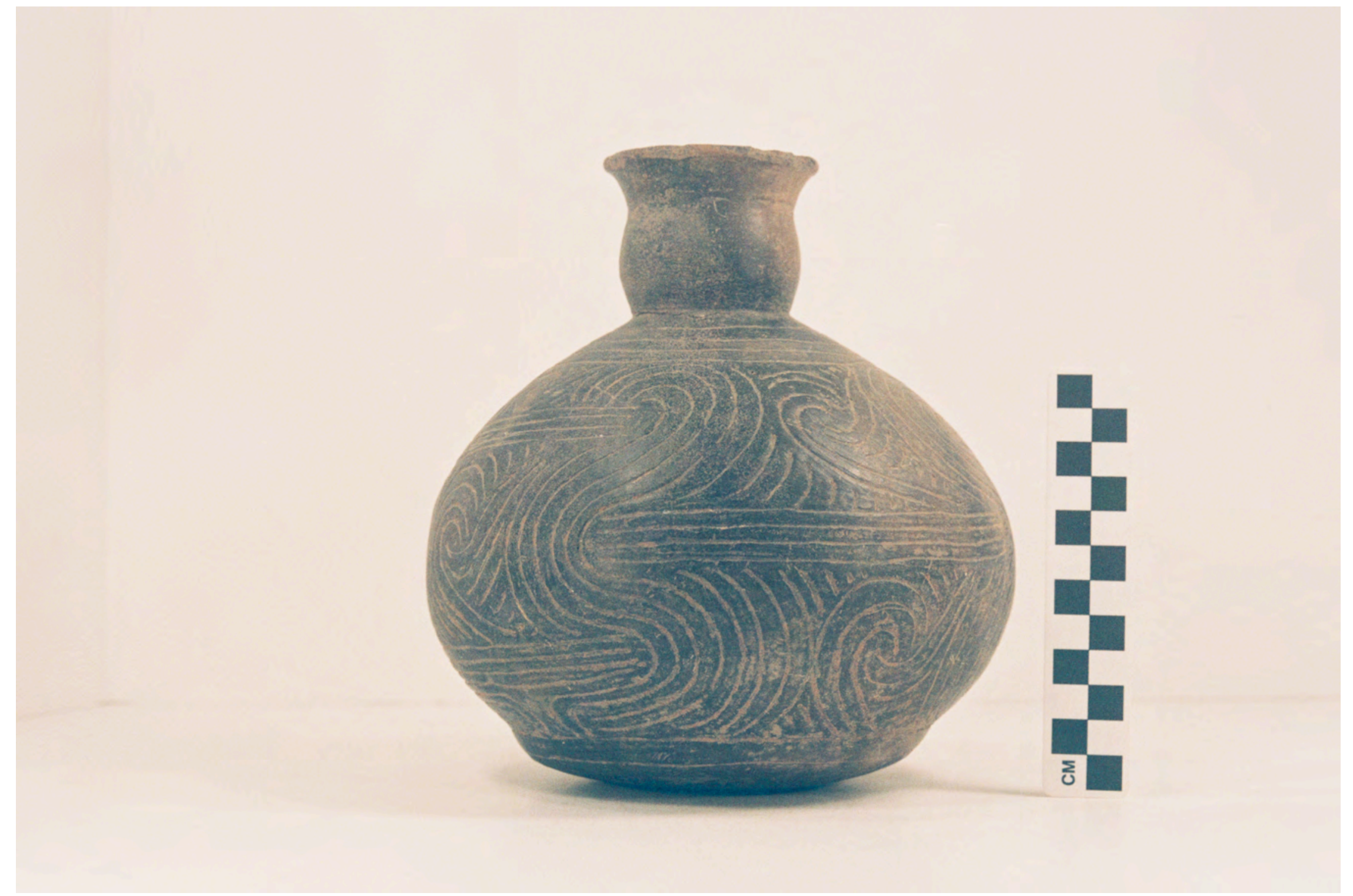

Figure 19f

Figure A3-43 


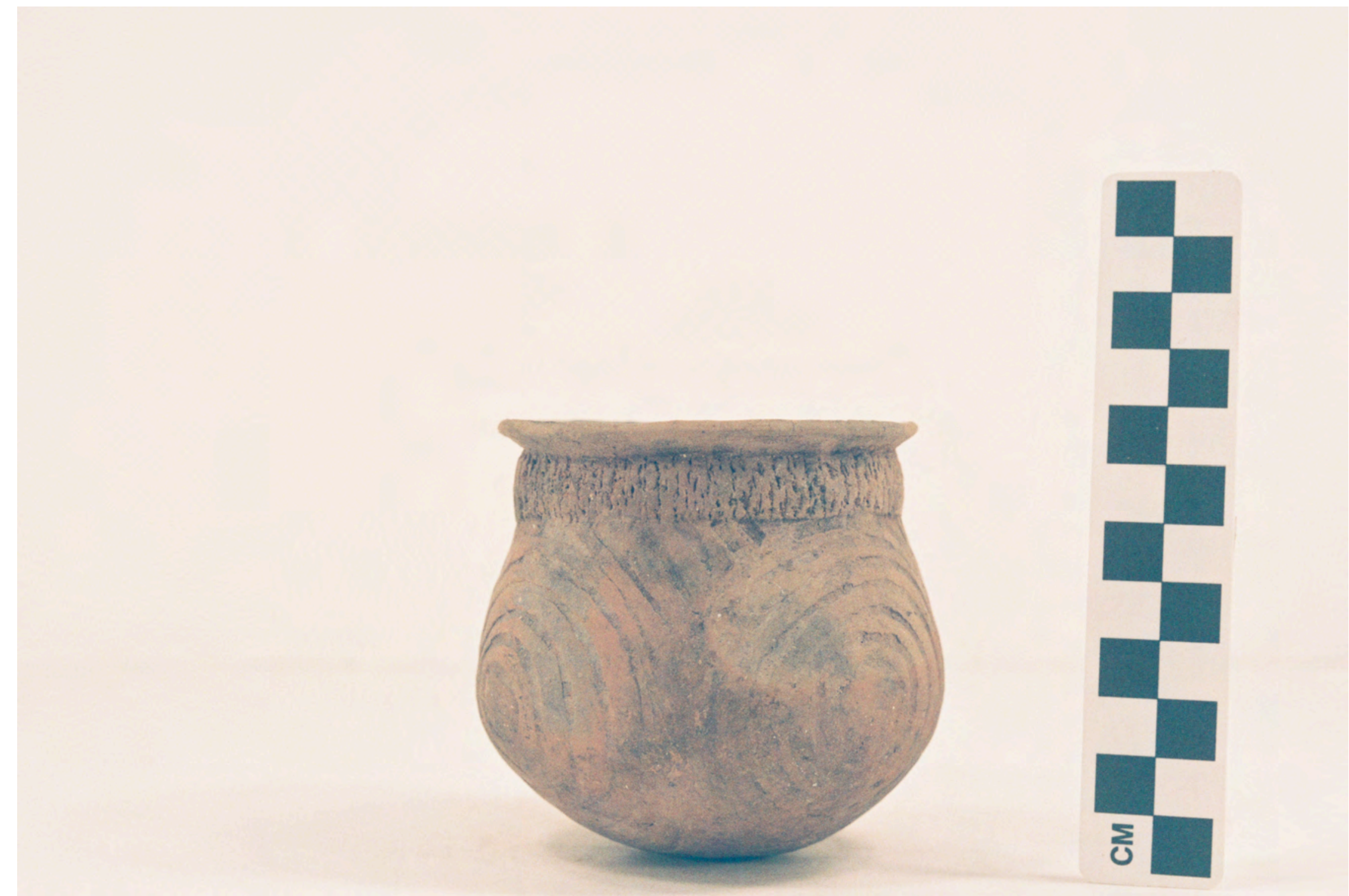

Figure $19 \mathrm{~g}$

Figure A3-13 


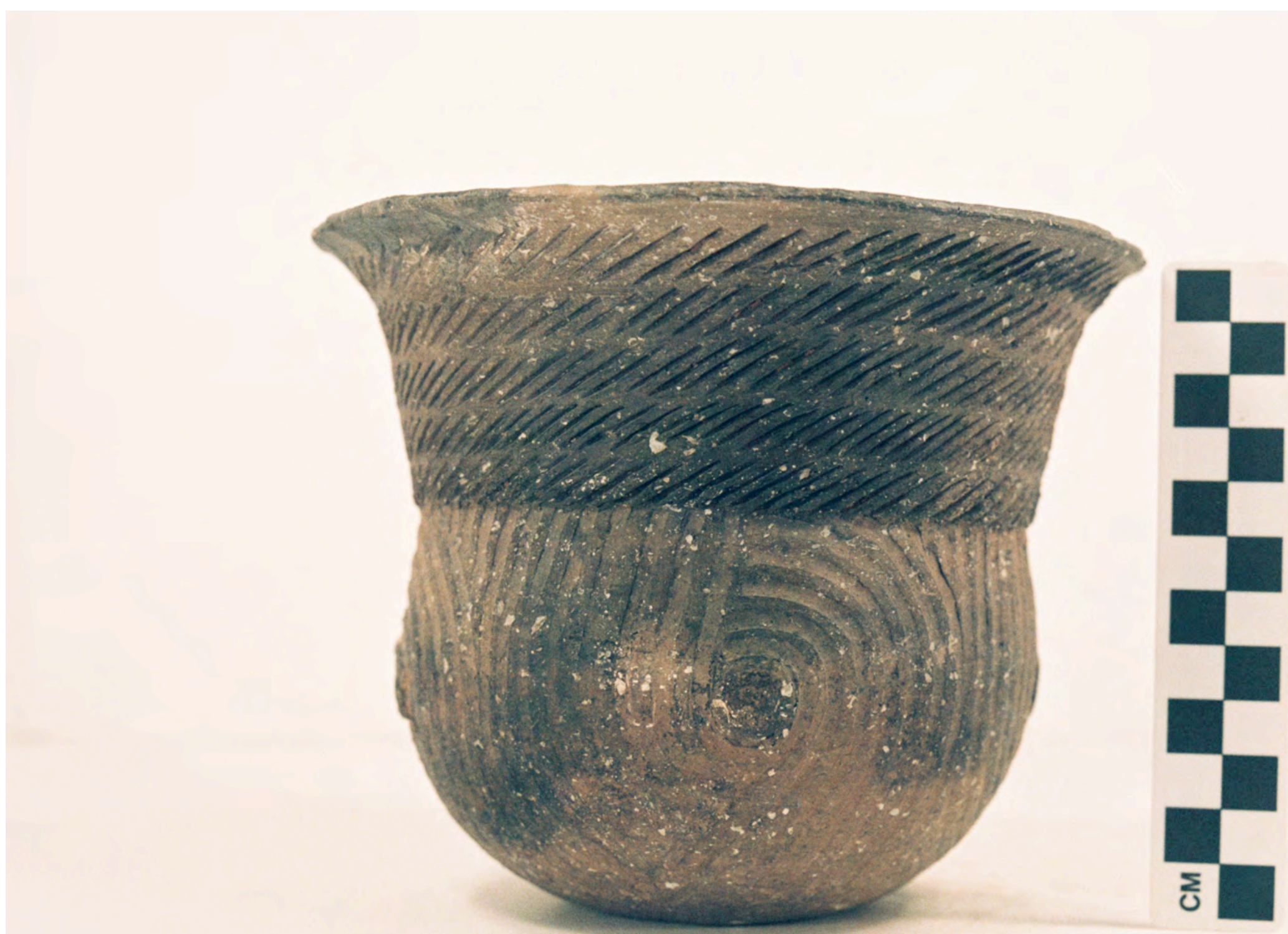

Figure $19 \mathrm{~h}$

Figure A3-23 


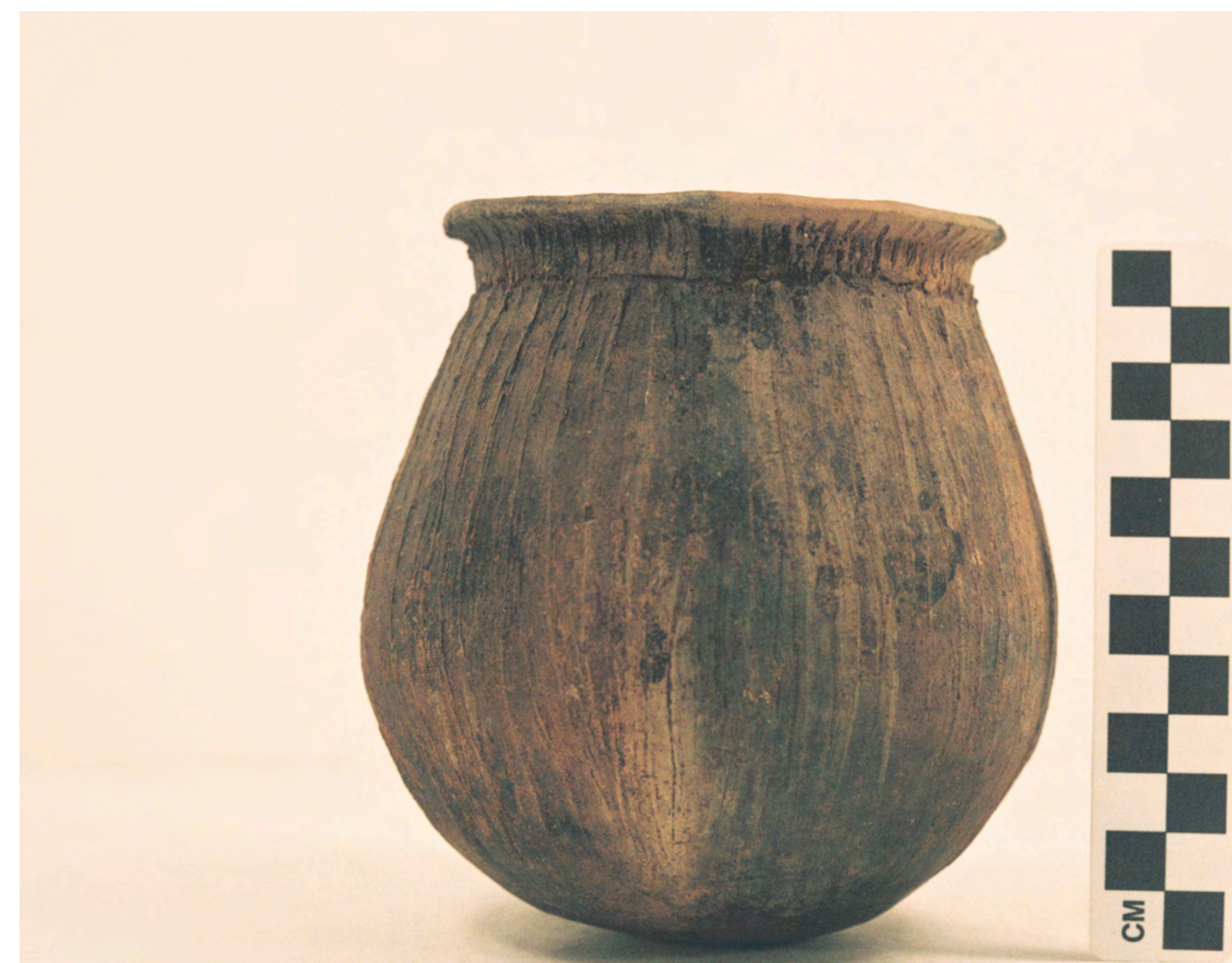

Figure 19i

Figure A3-45 


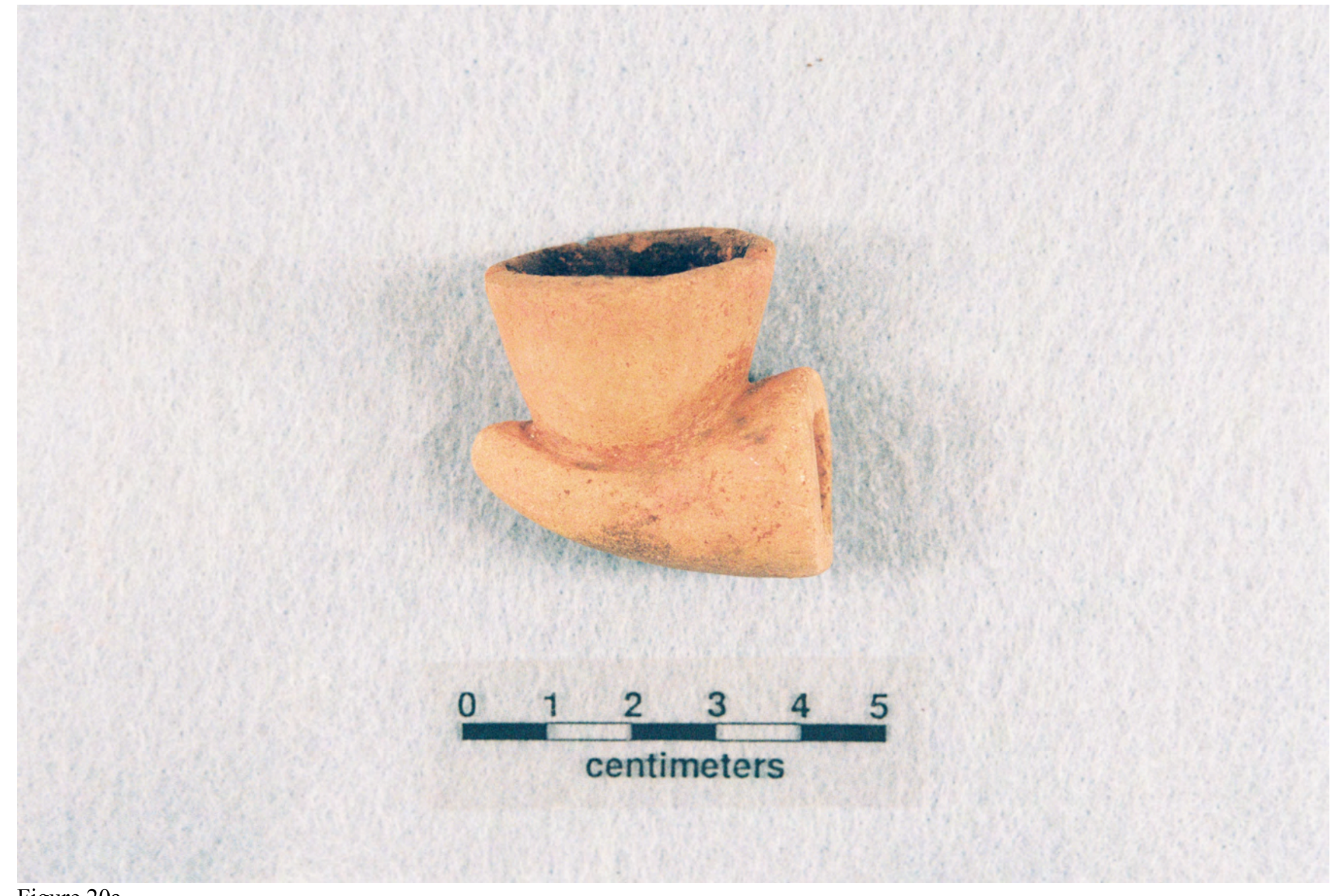

Figure 20a 


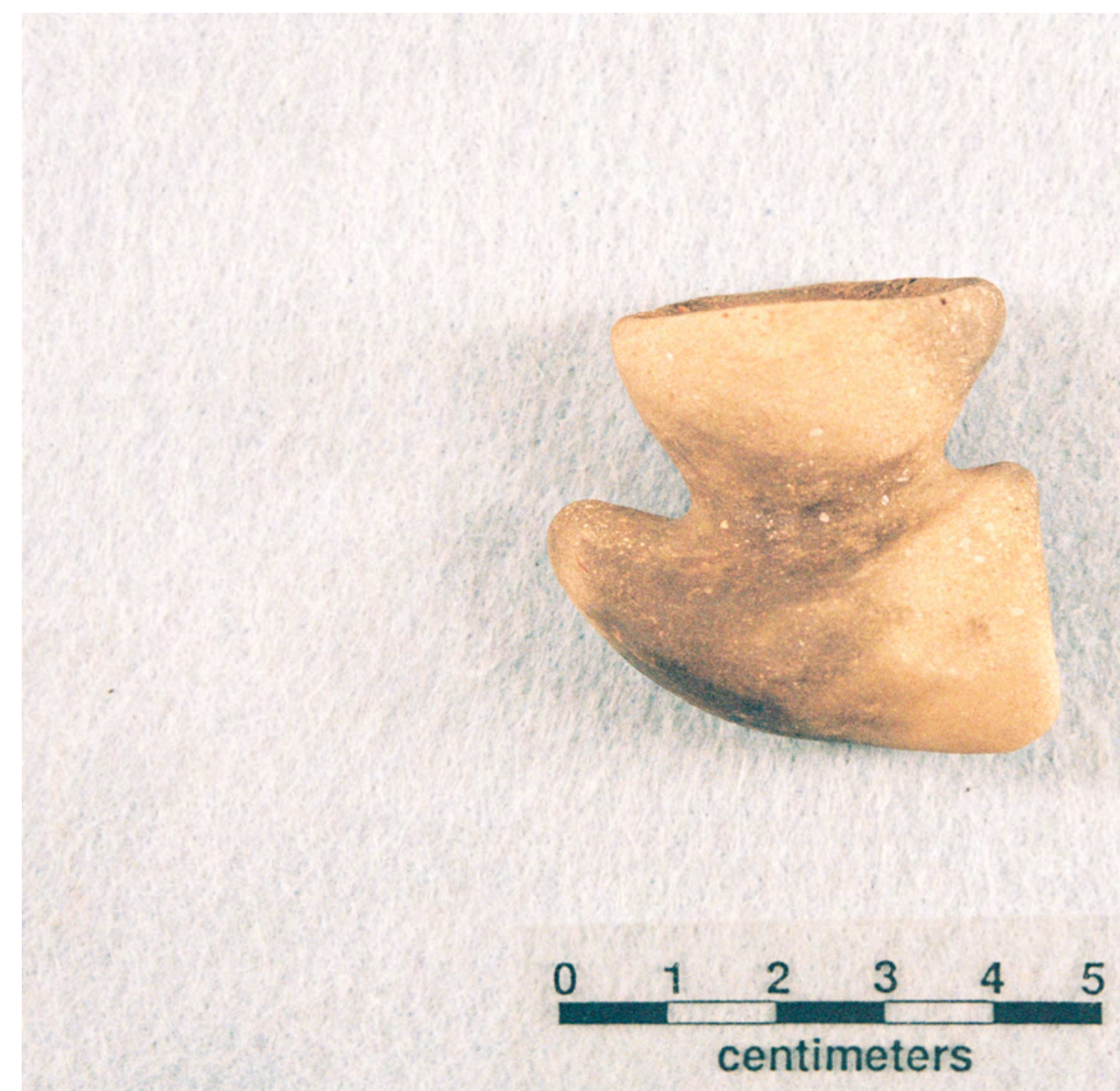

Figure $20 \mathrm{~b}$ 


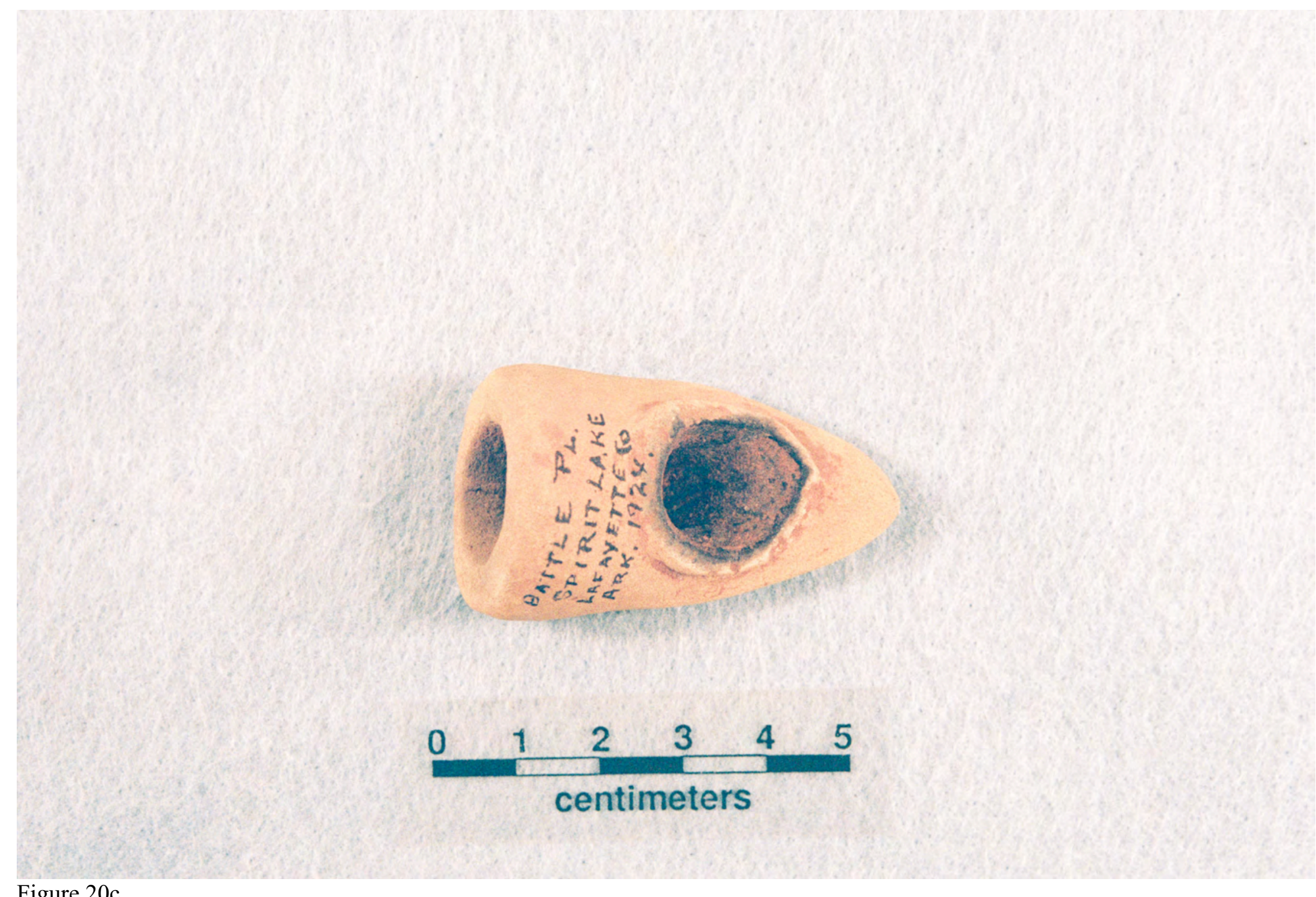

Figure 20c 


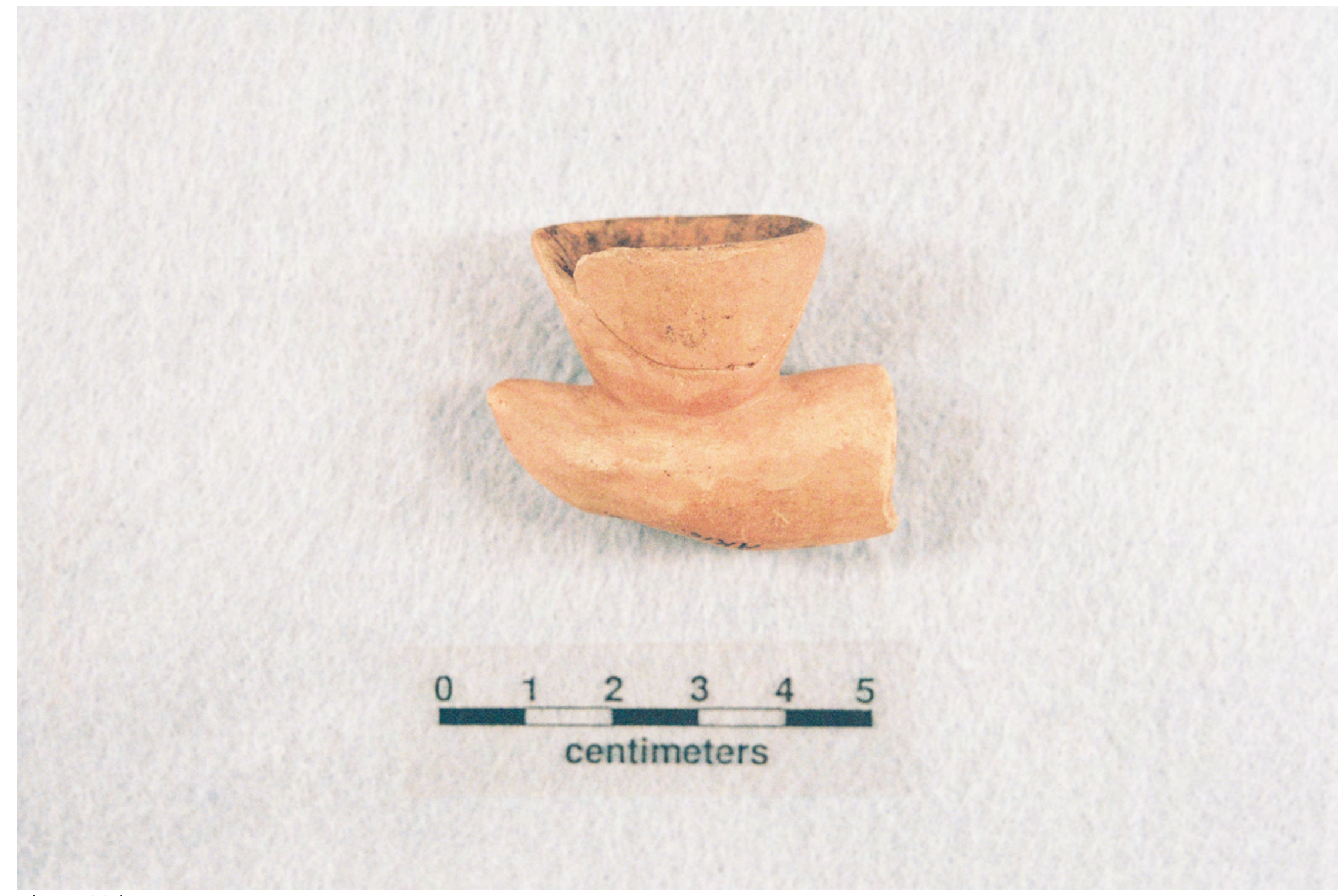

Figure 20d 


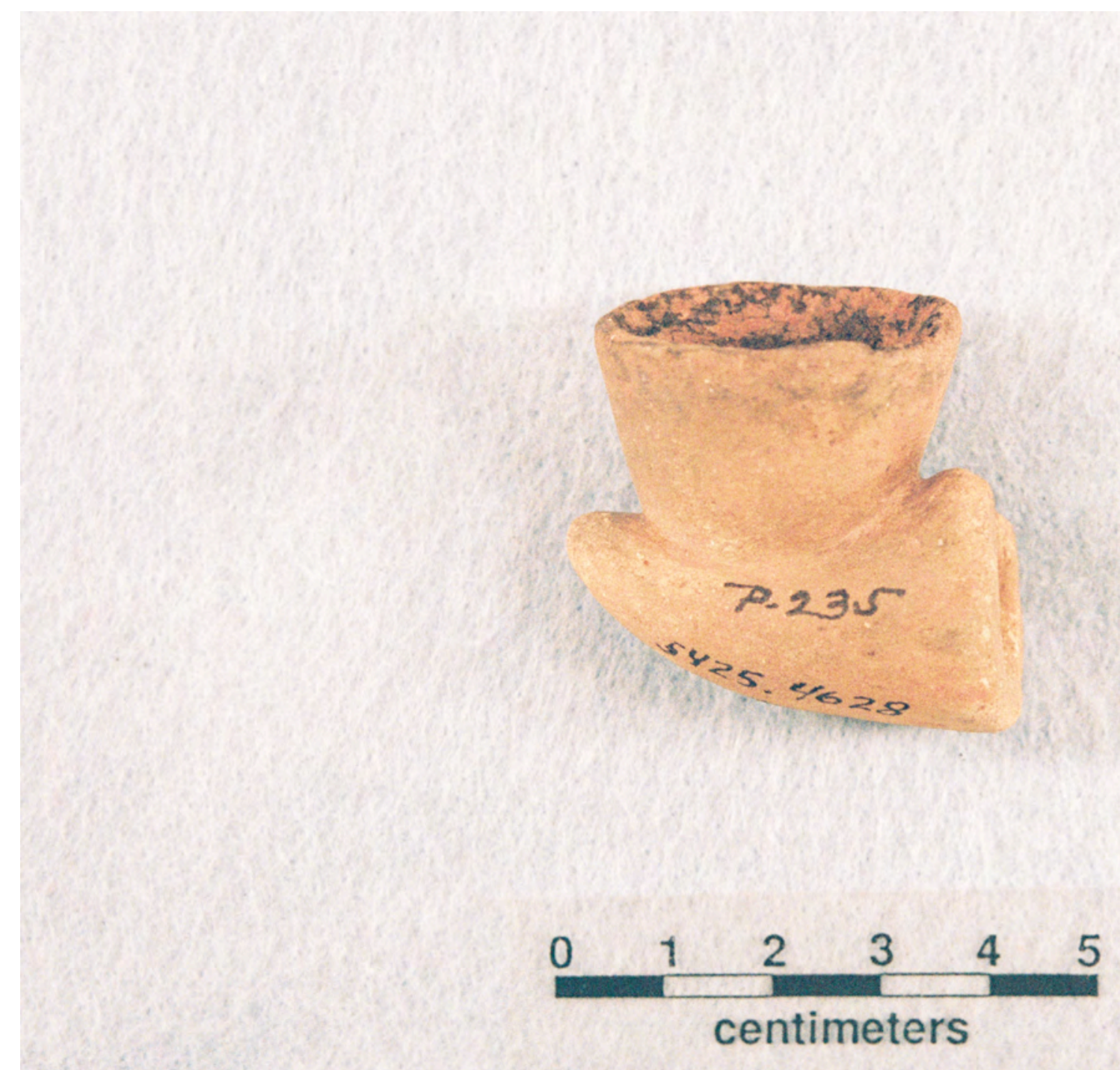

Figure 20e 


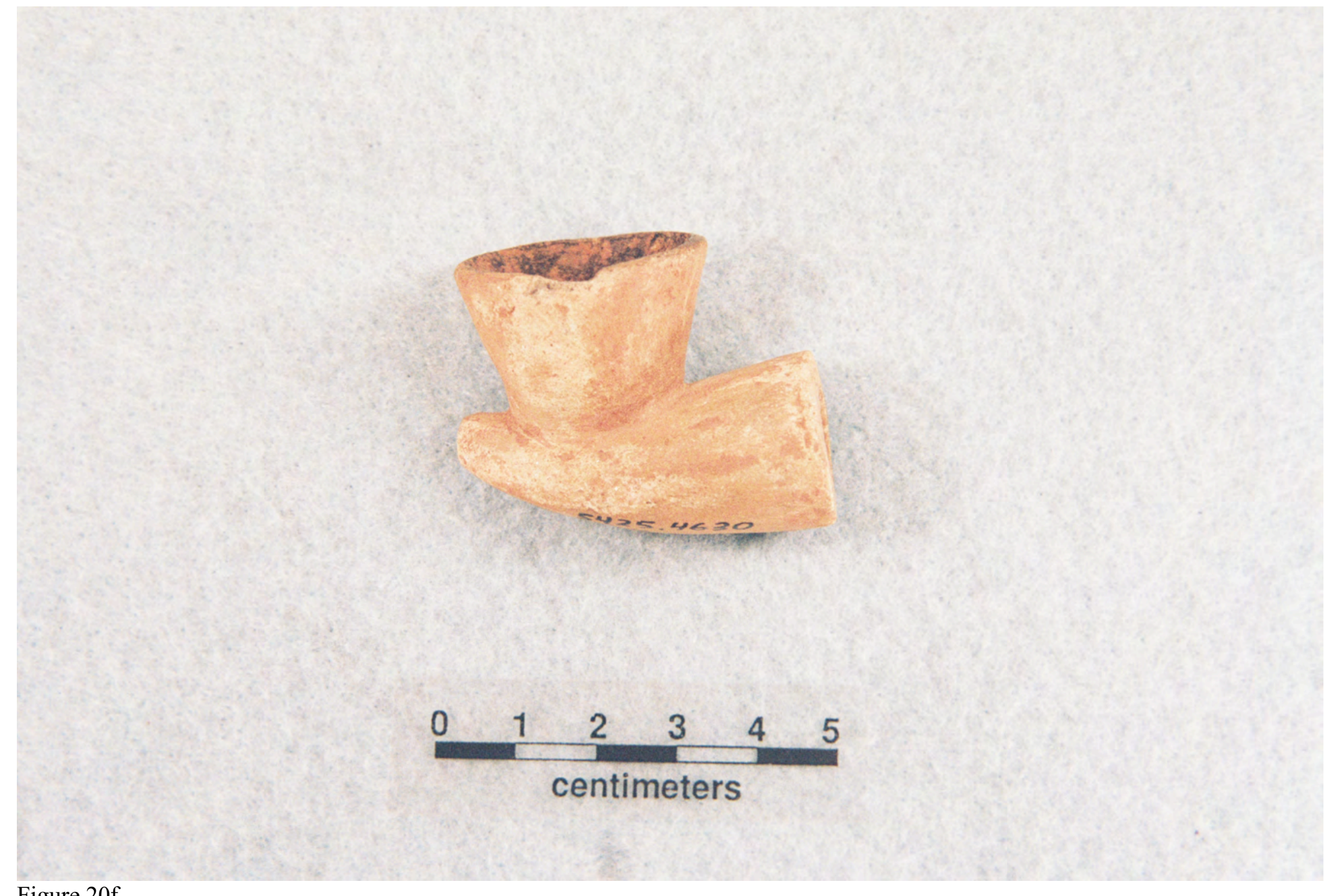

Figure 20f 


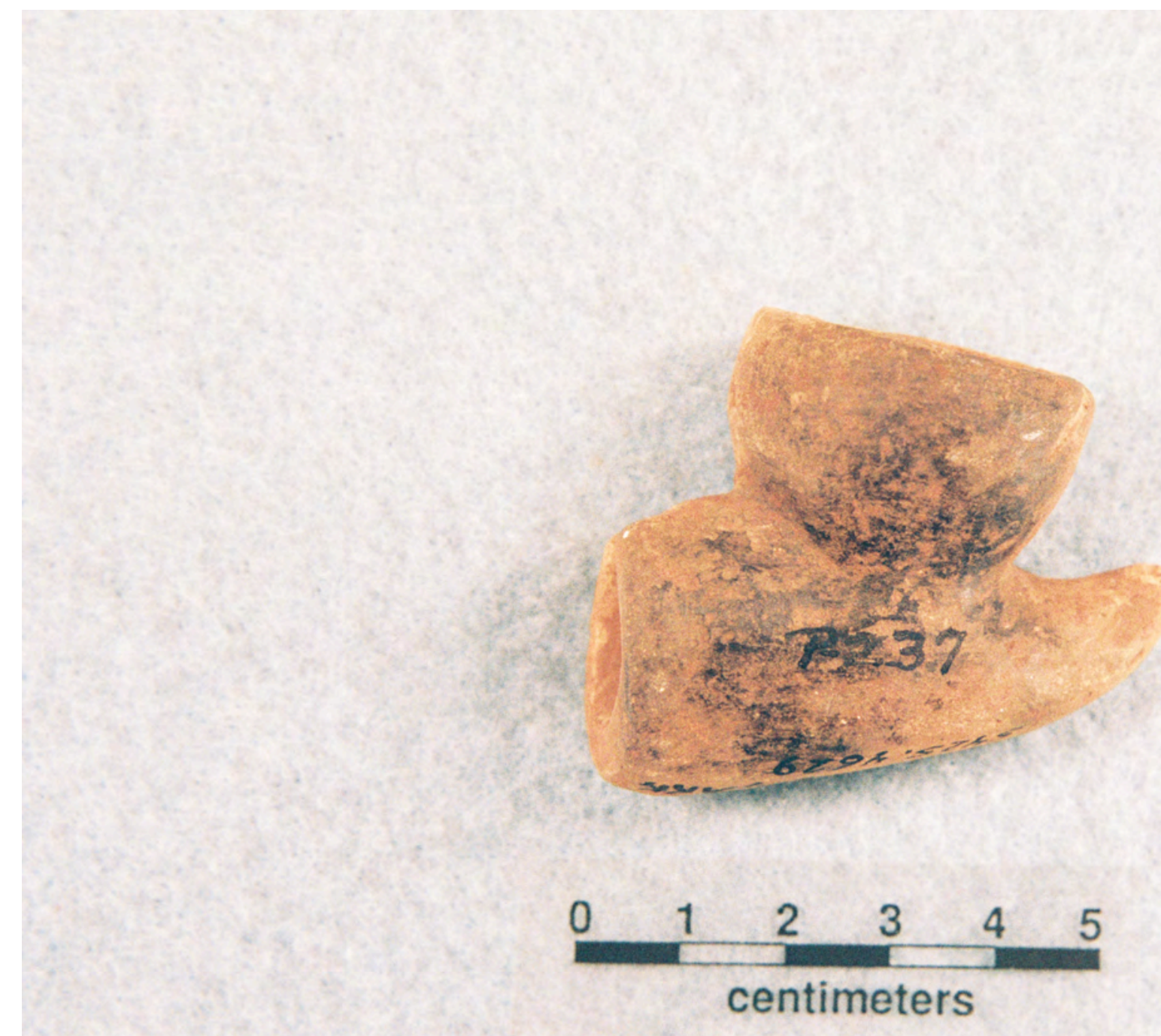

Figure $20 \mathrm{~g}$ 


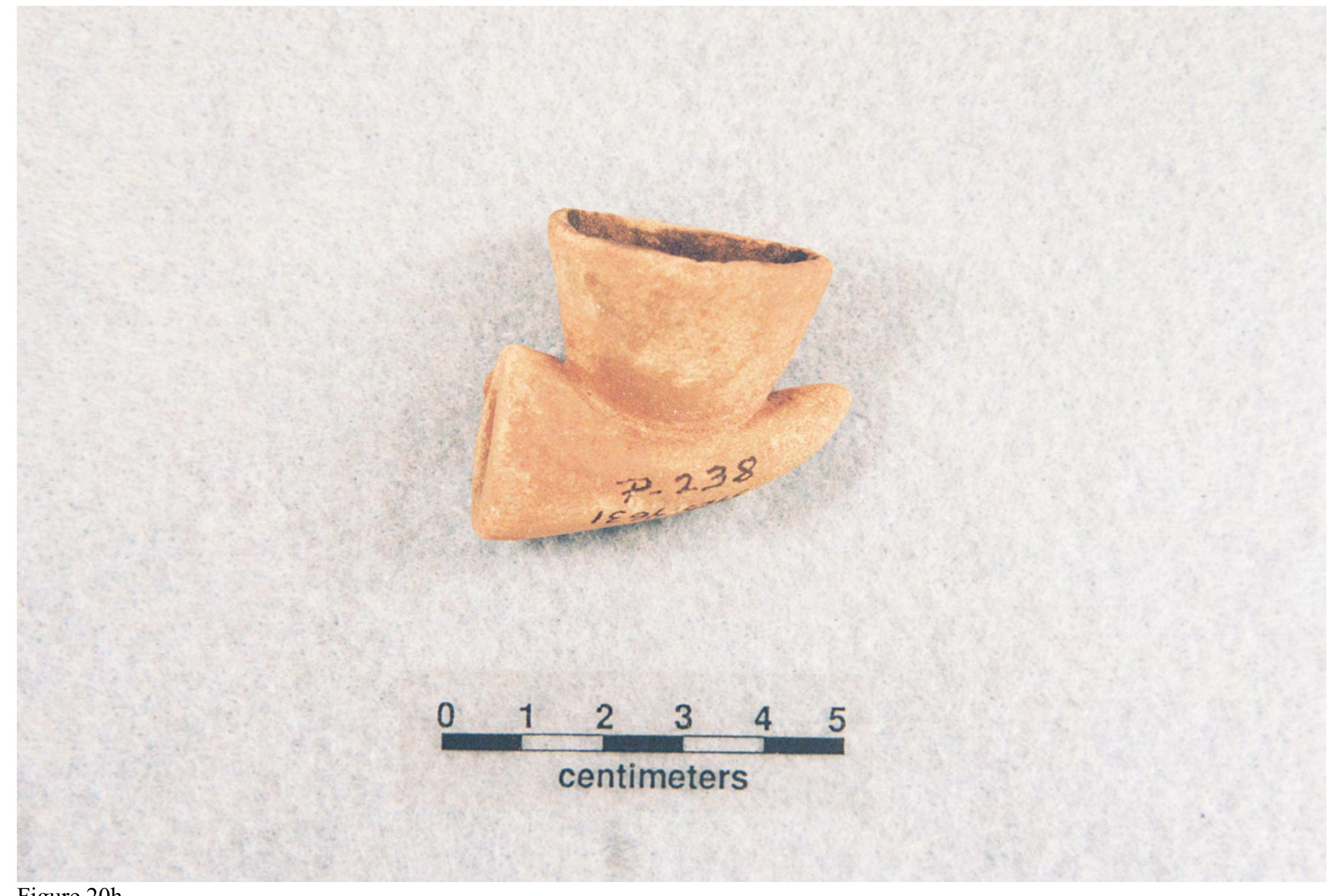

Figure 20h 


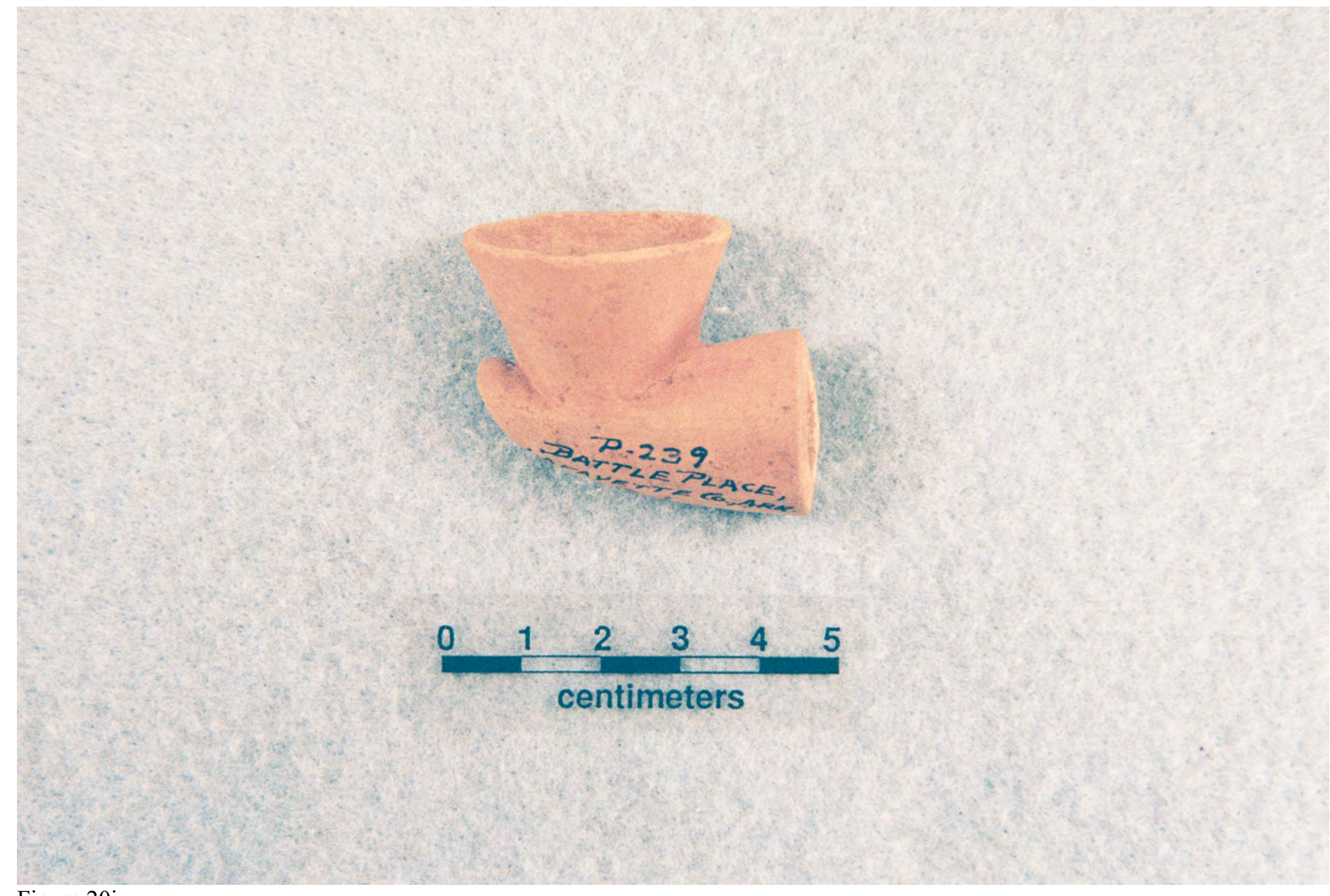

Figure 20i 


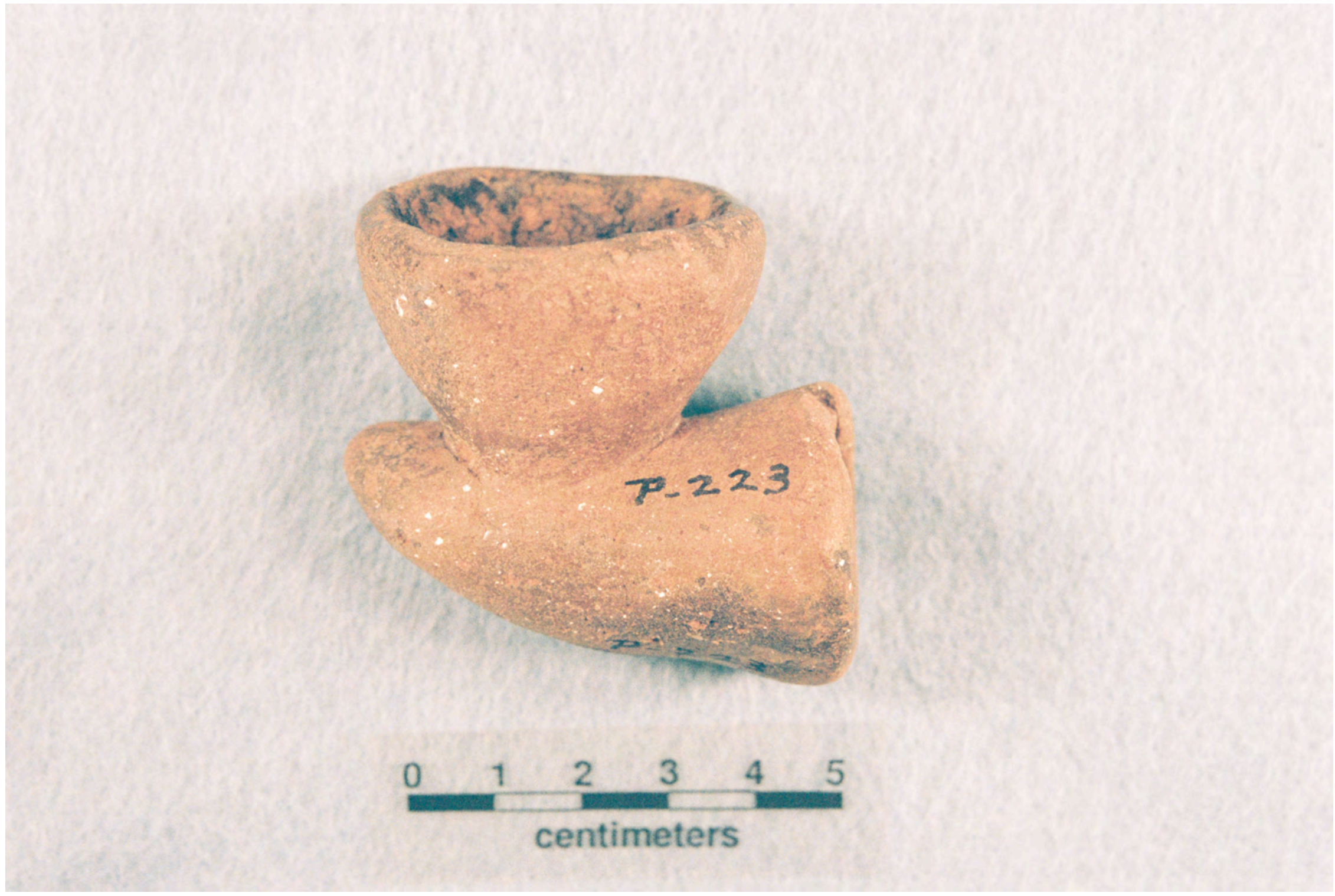

Figure 21 


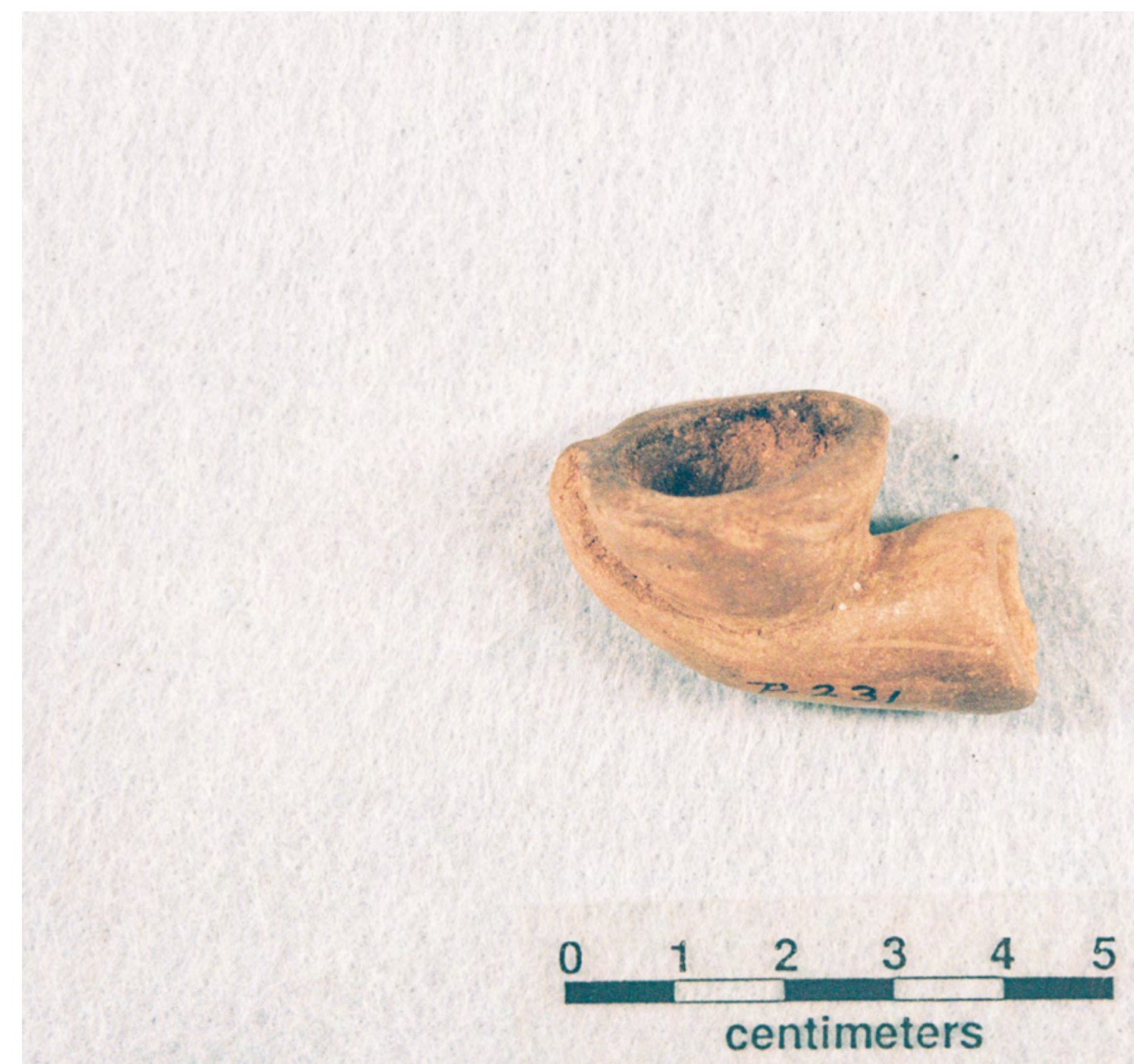

Figure 22a 


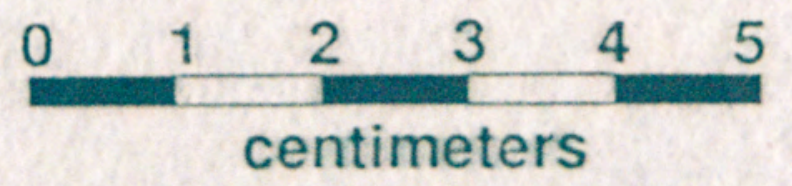

Figure 22b 


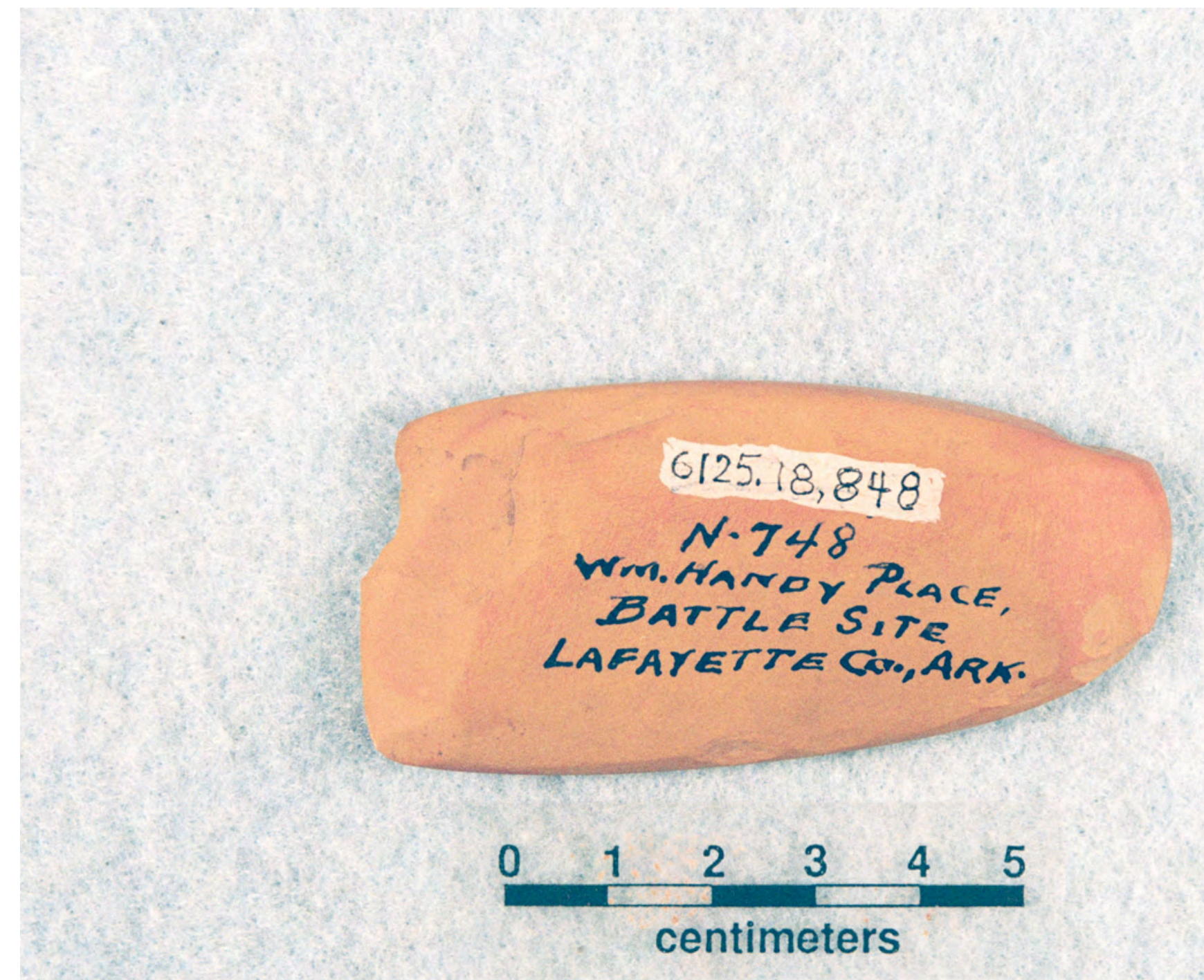

Figure 23 


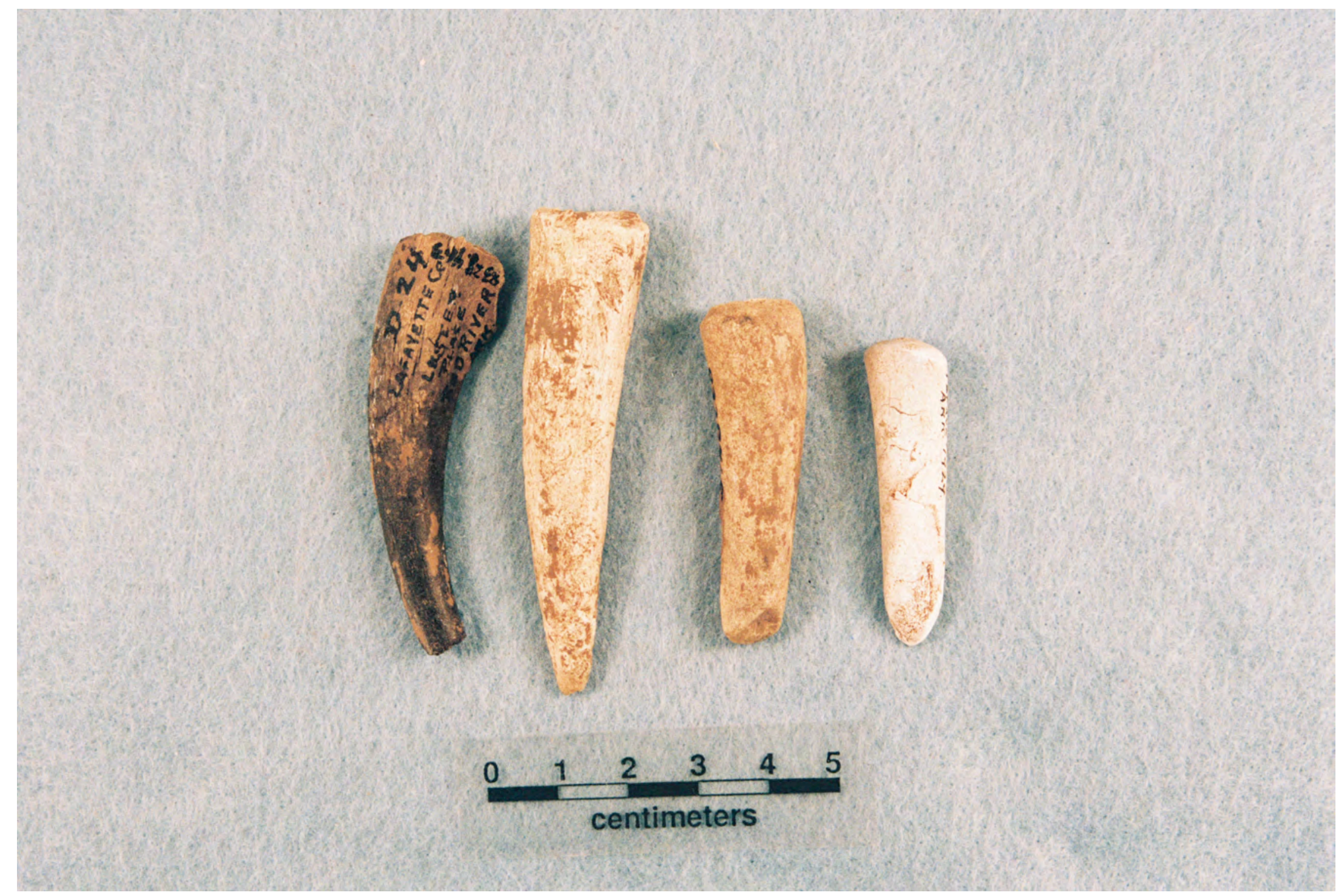

Figure 24 


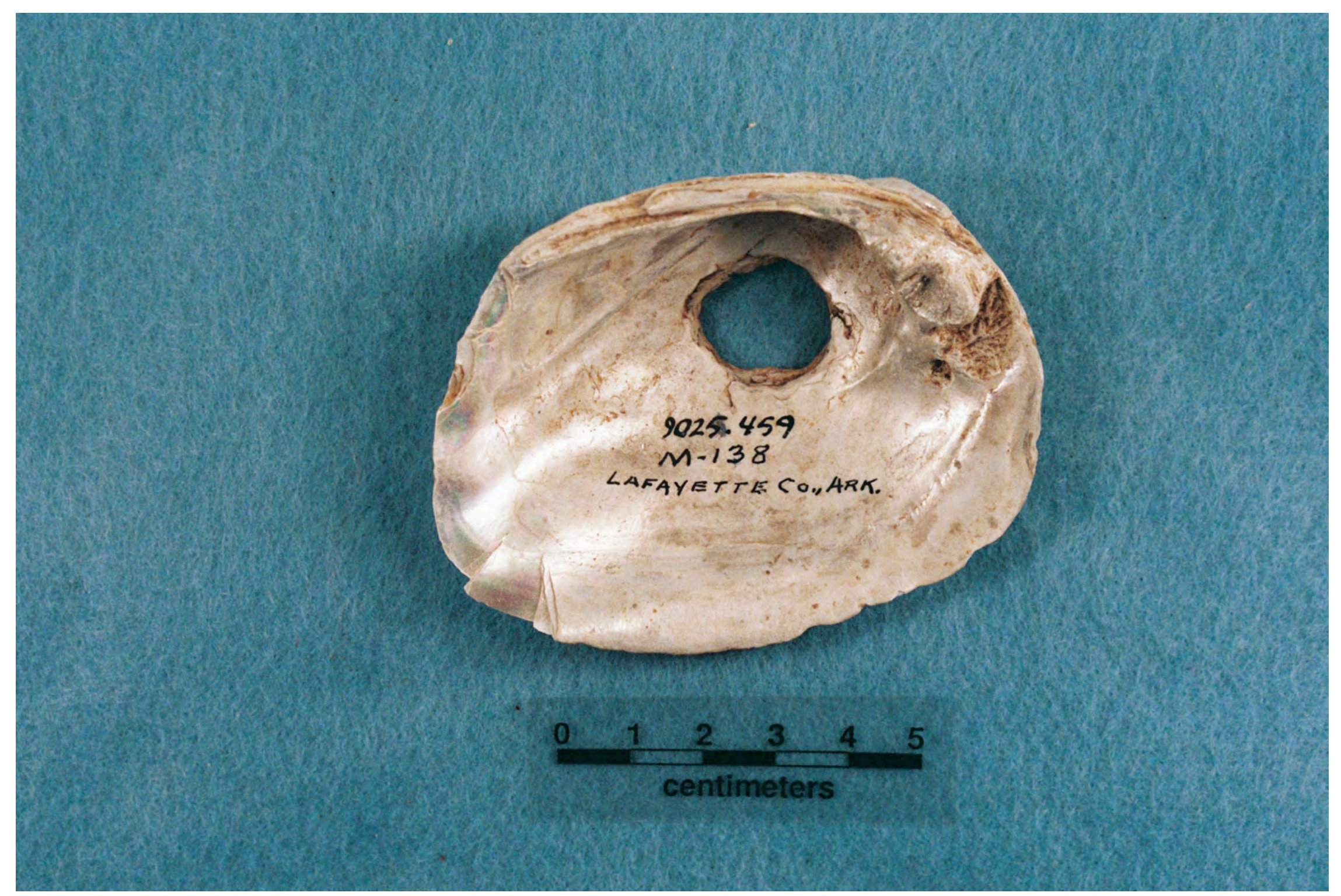

Figure 25 


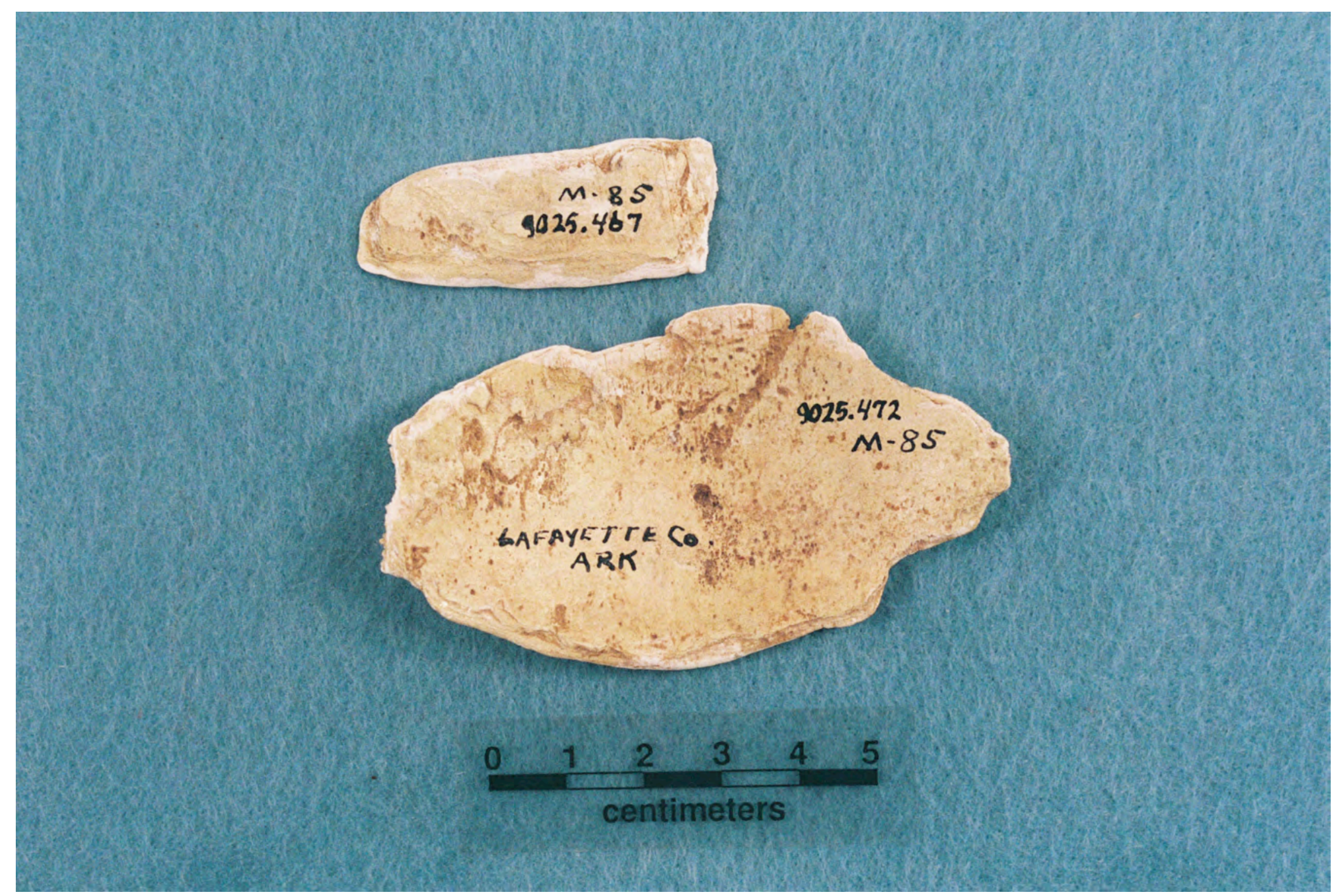

Figure 26 


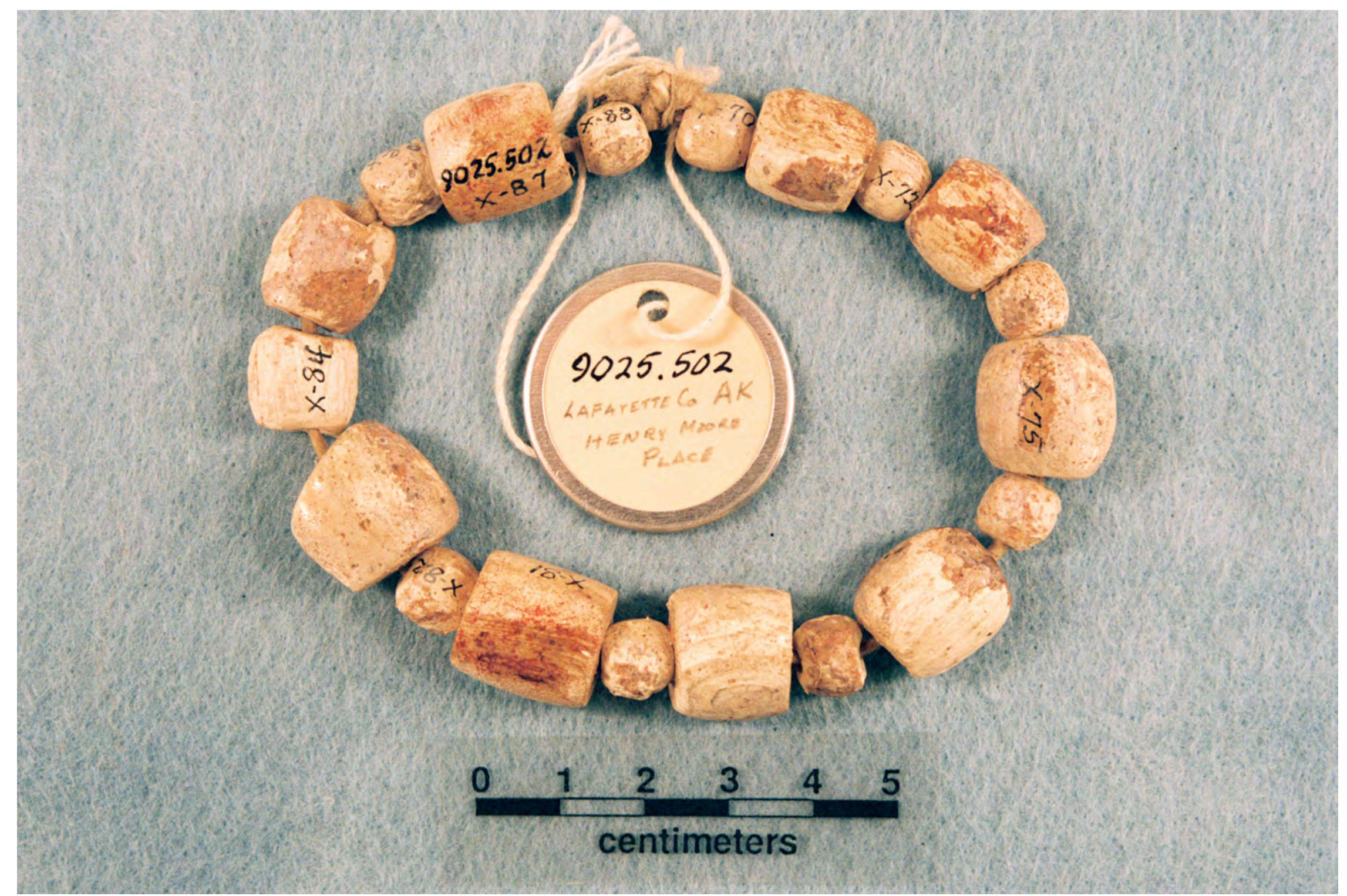

Figure 27 


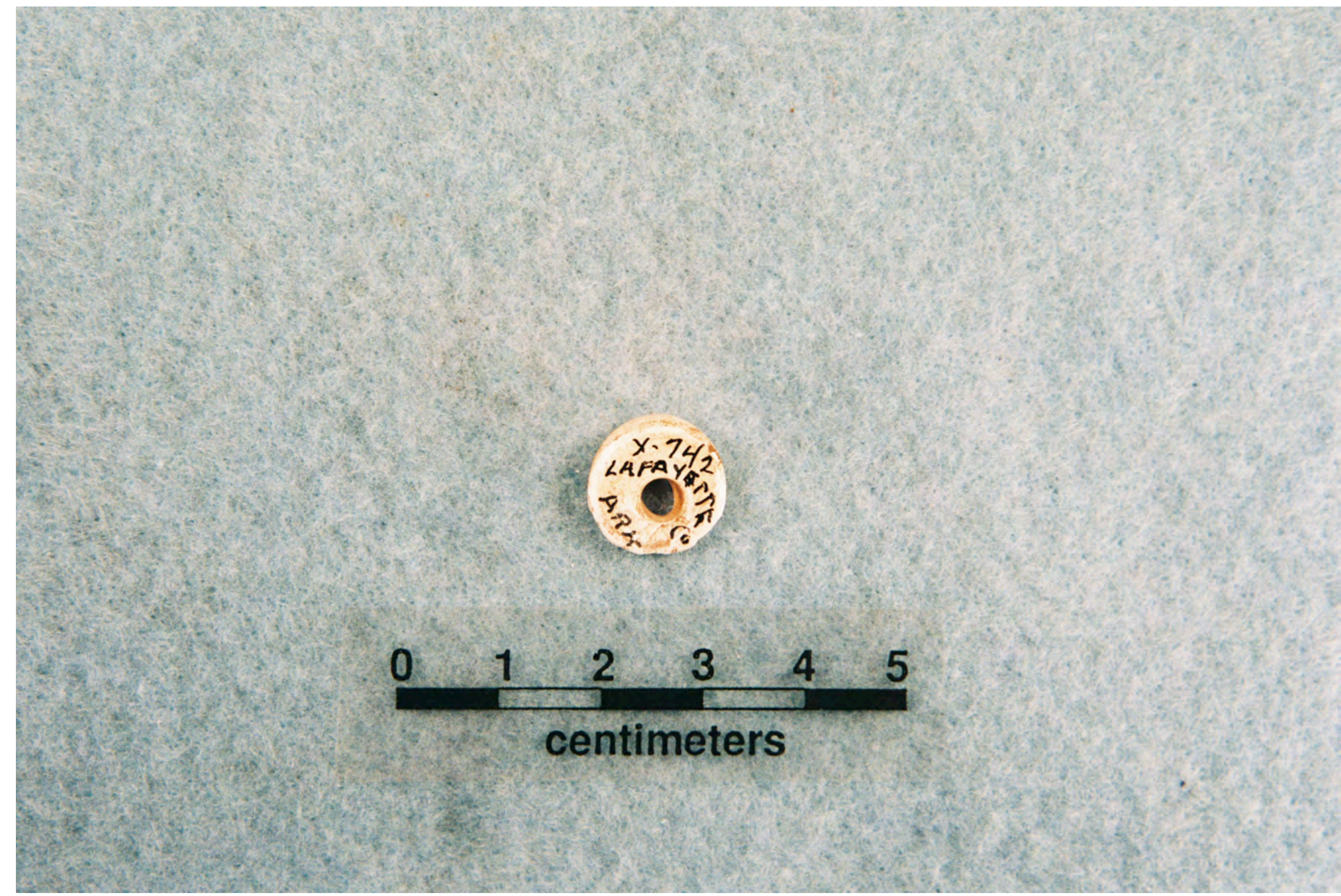

Figure 28 


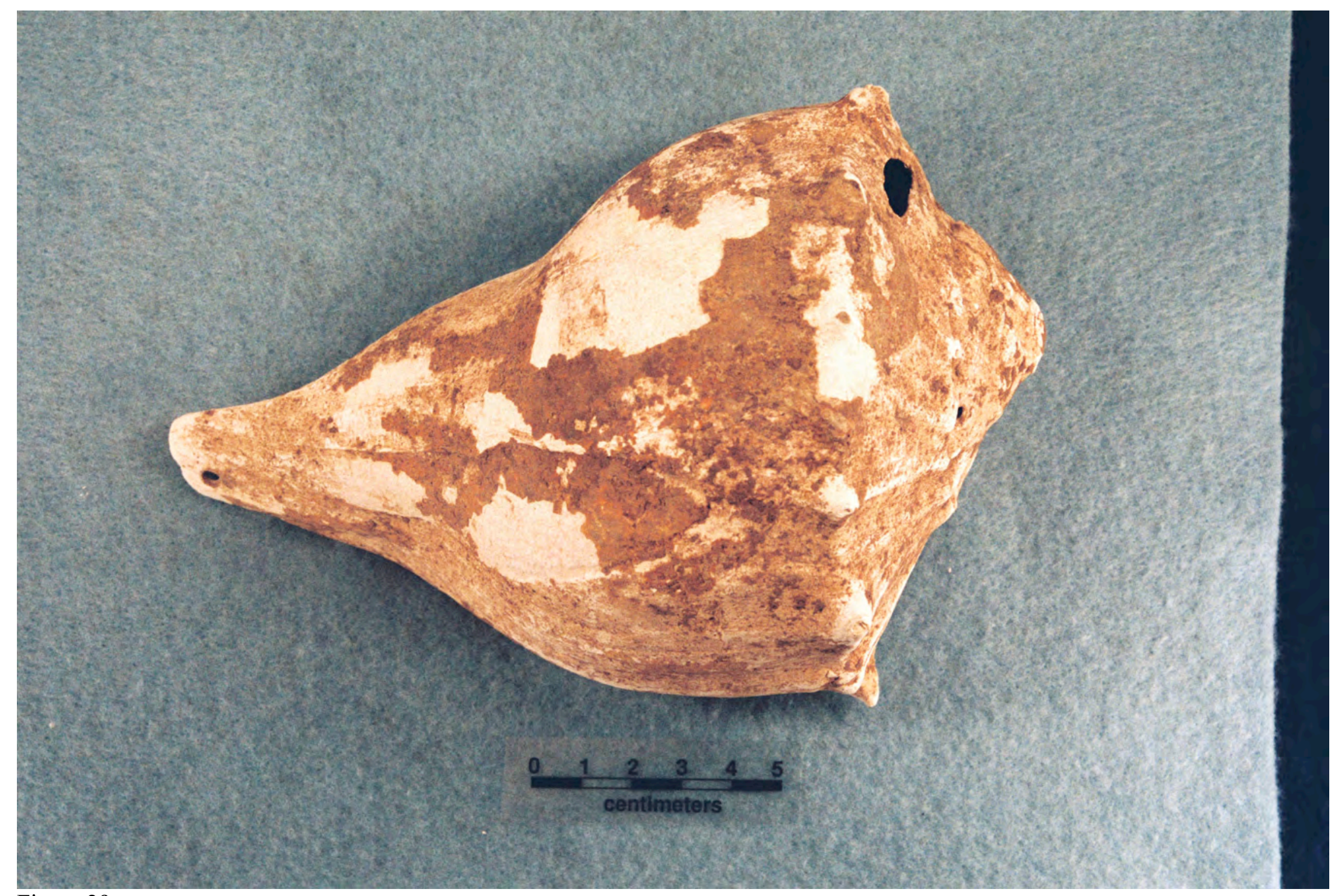

Figure 29a 


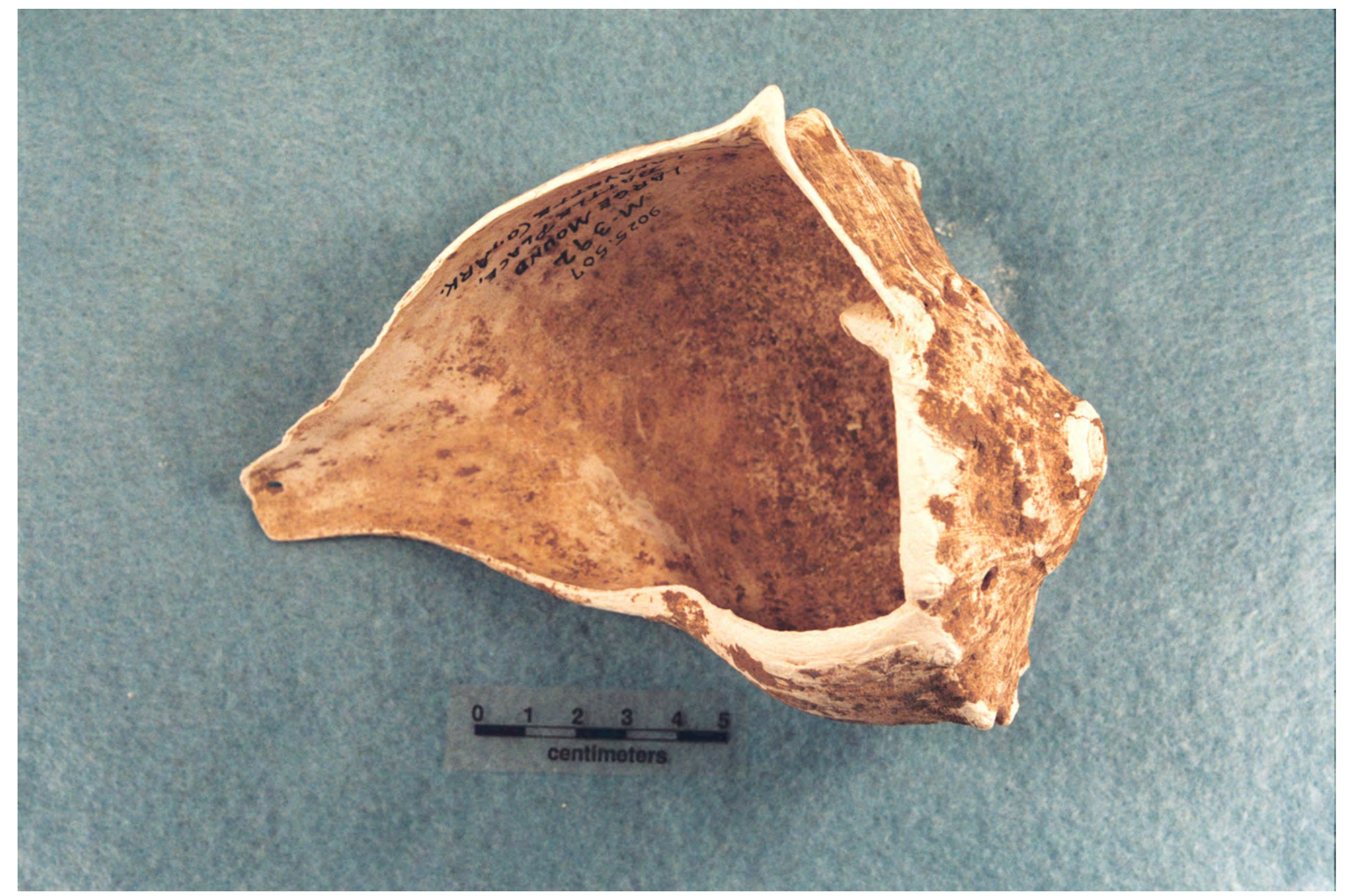

Figure 29b 


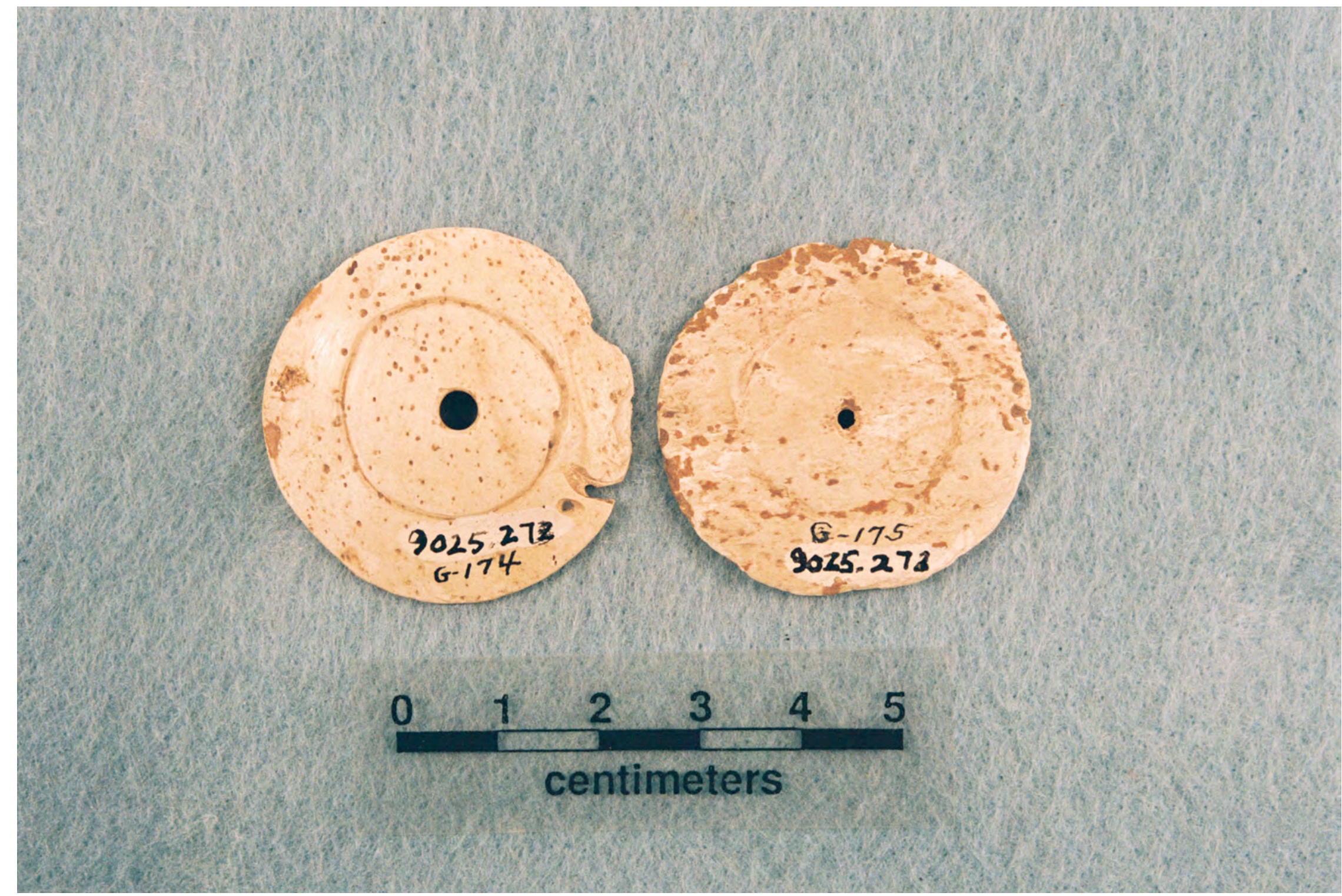

Figure 30 


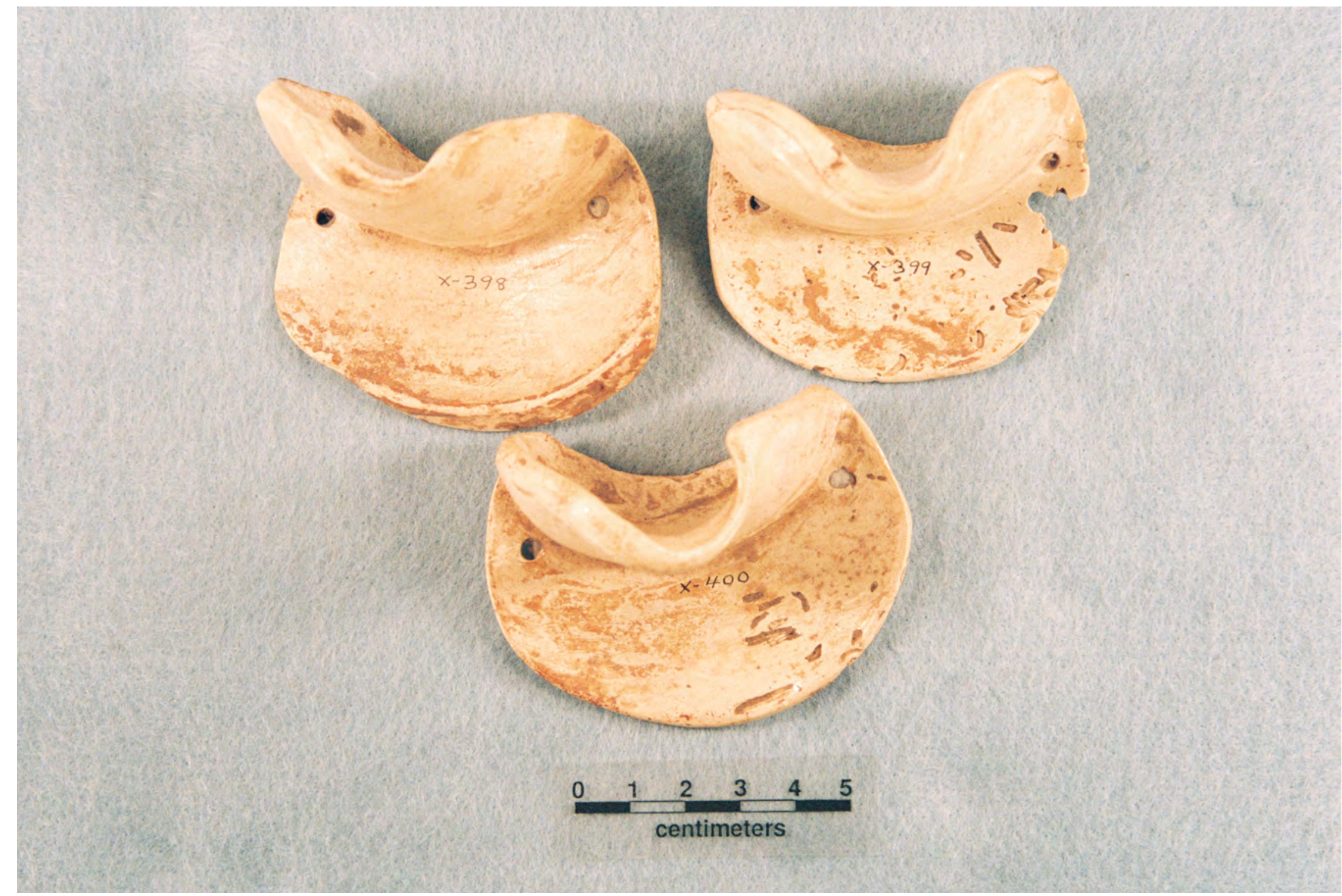

Figure $31 \mathrm{a}$ 


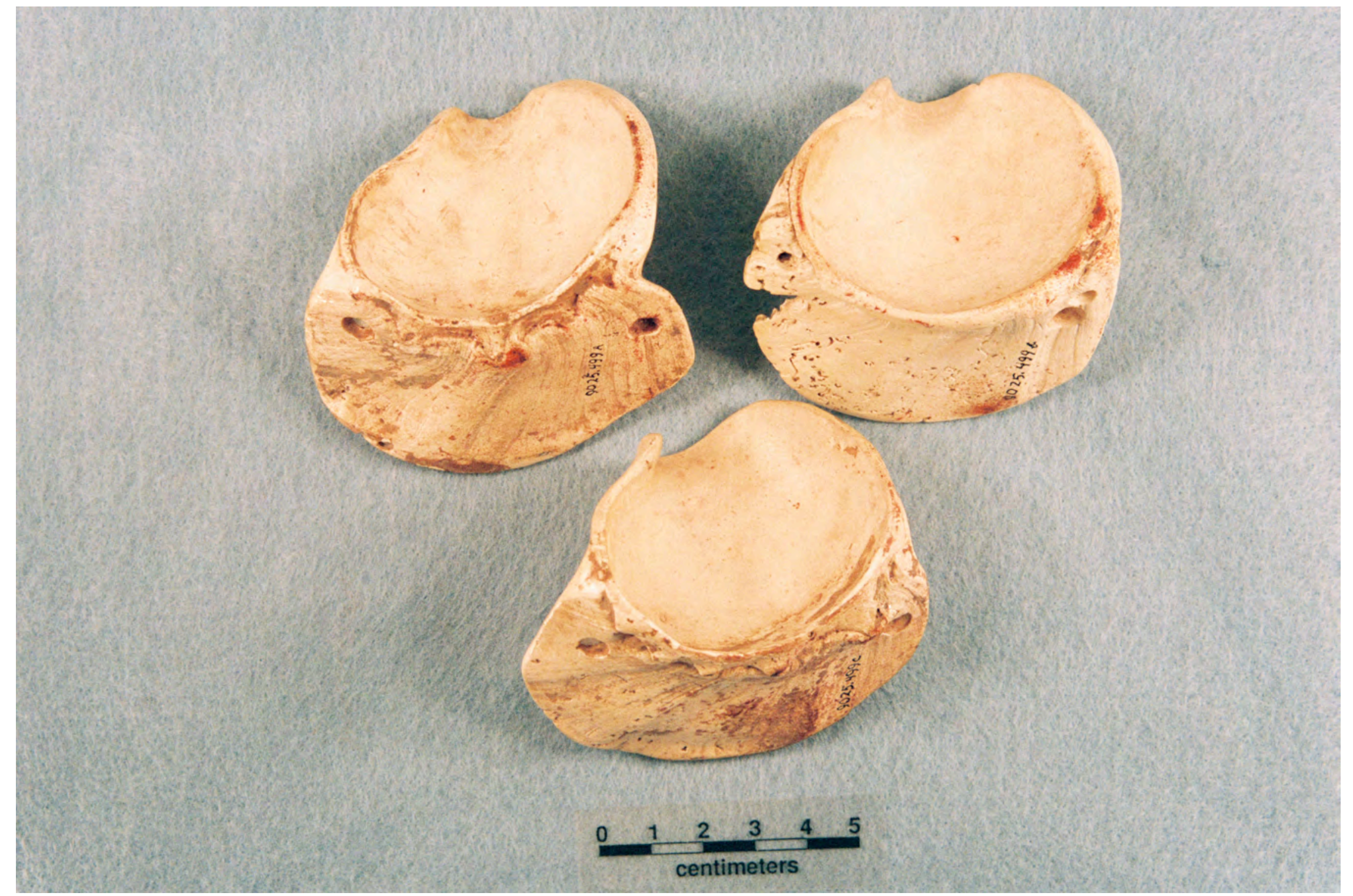

Figure $31 \mathrm{~b}$ 


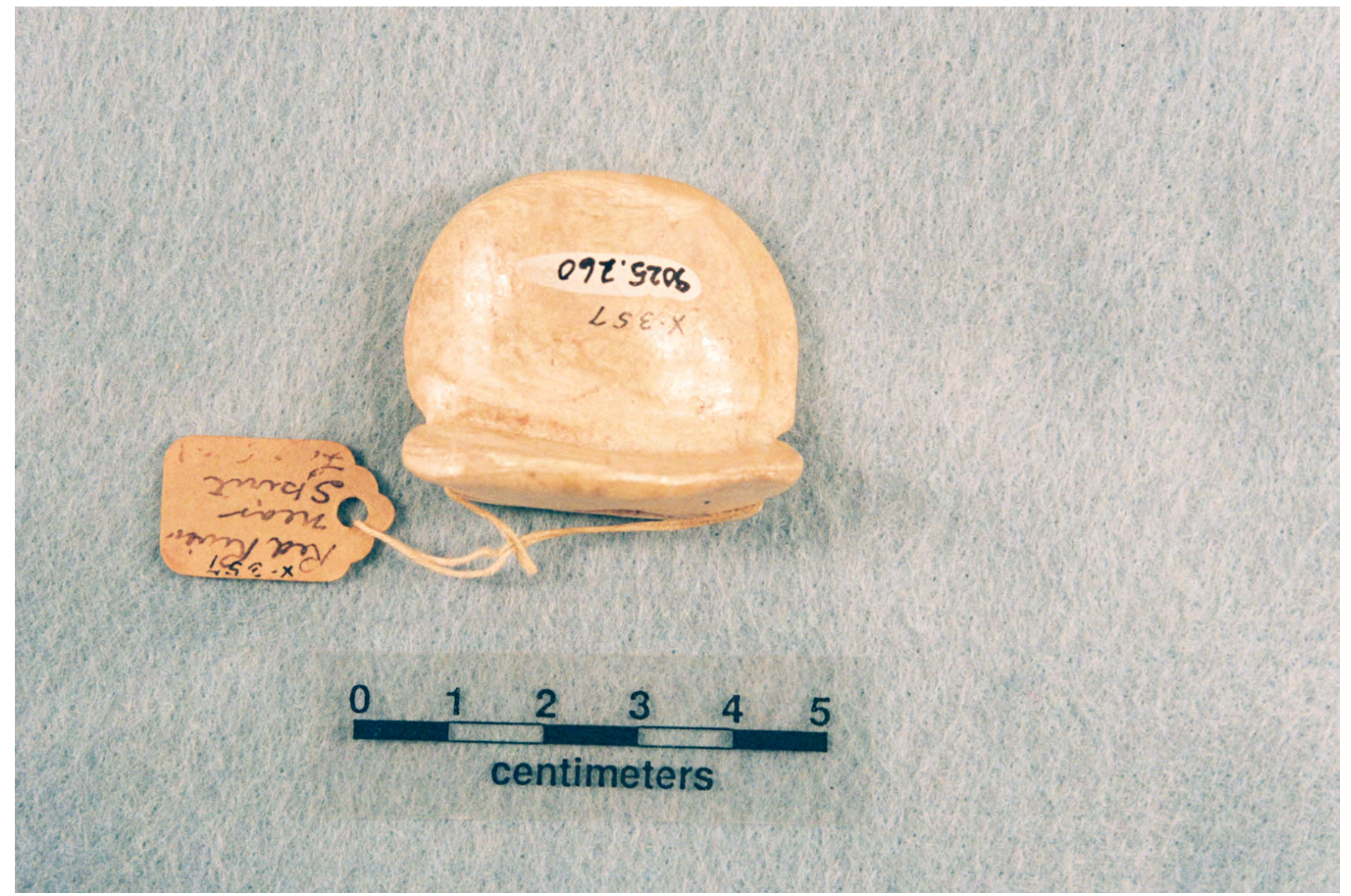

Figure $32 \mathrm{a}$ 


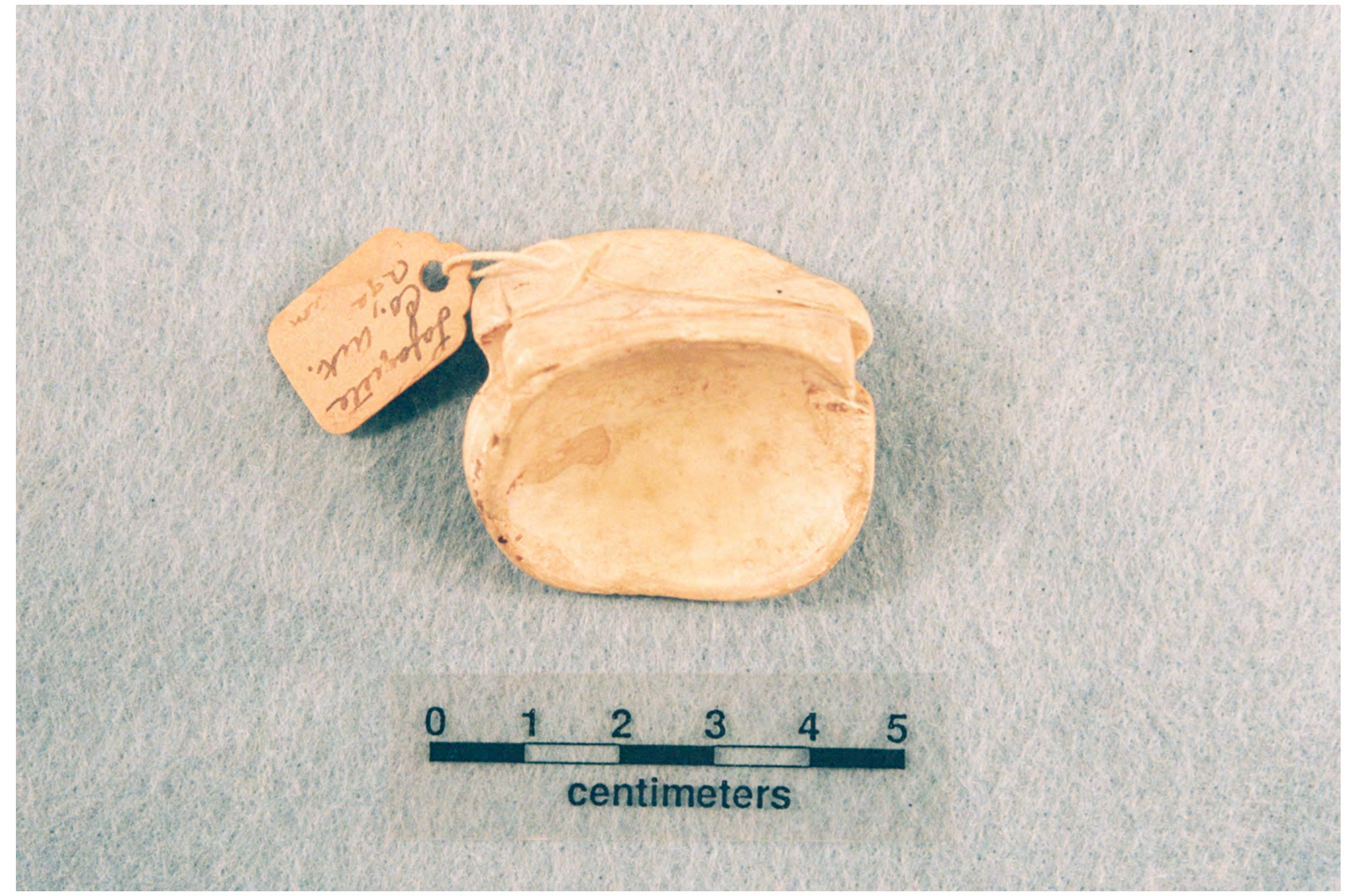

Figure $32 b$ 


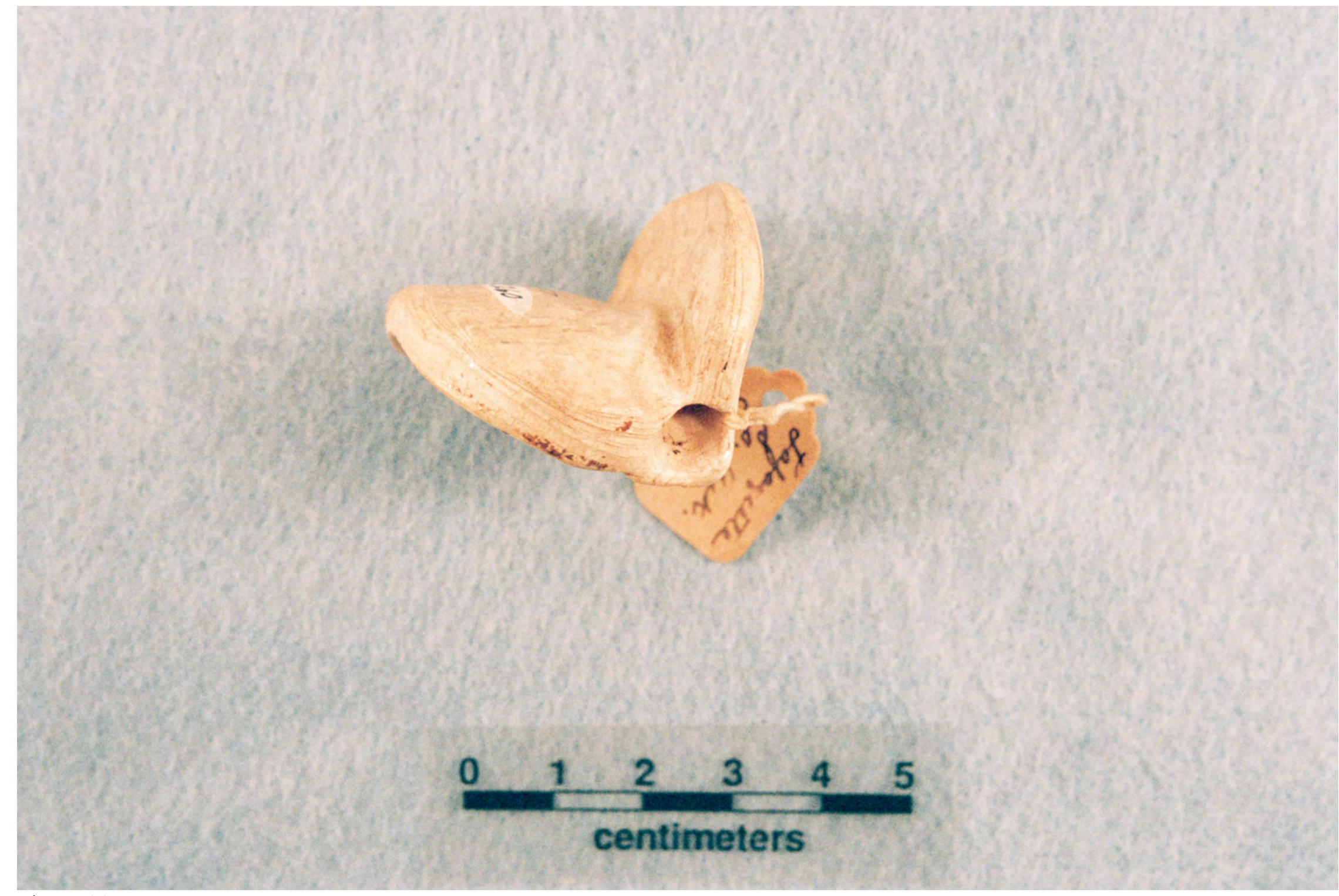

Figure 32c 


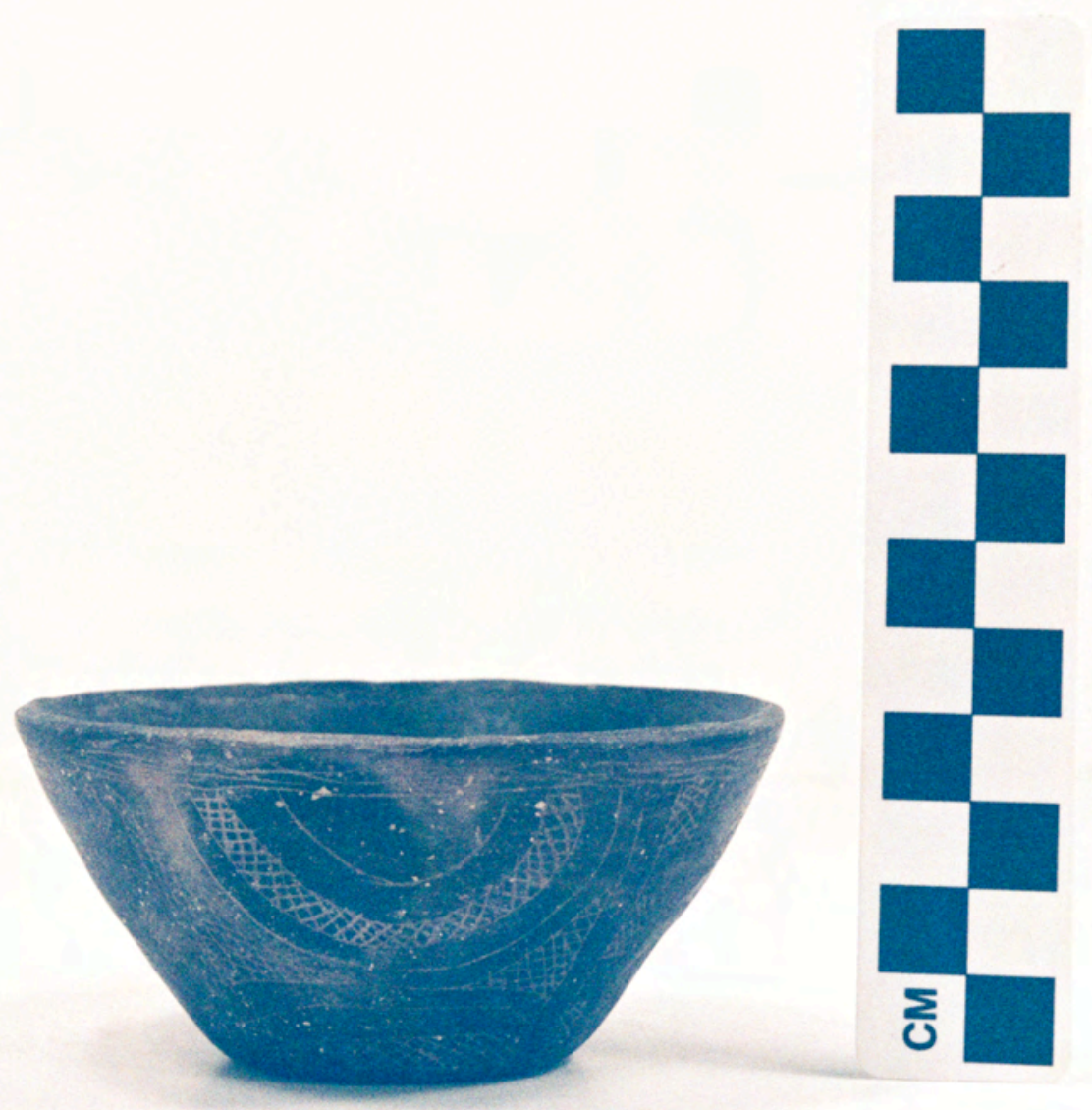

Figure A1-1a 


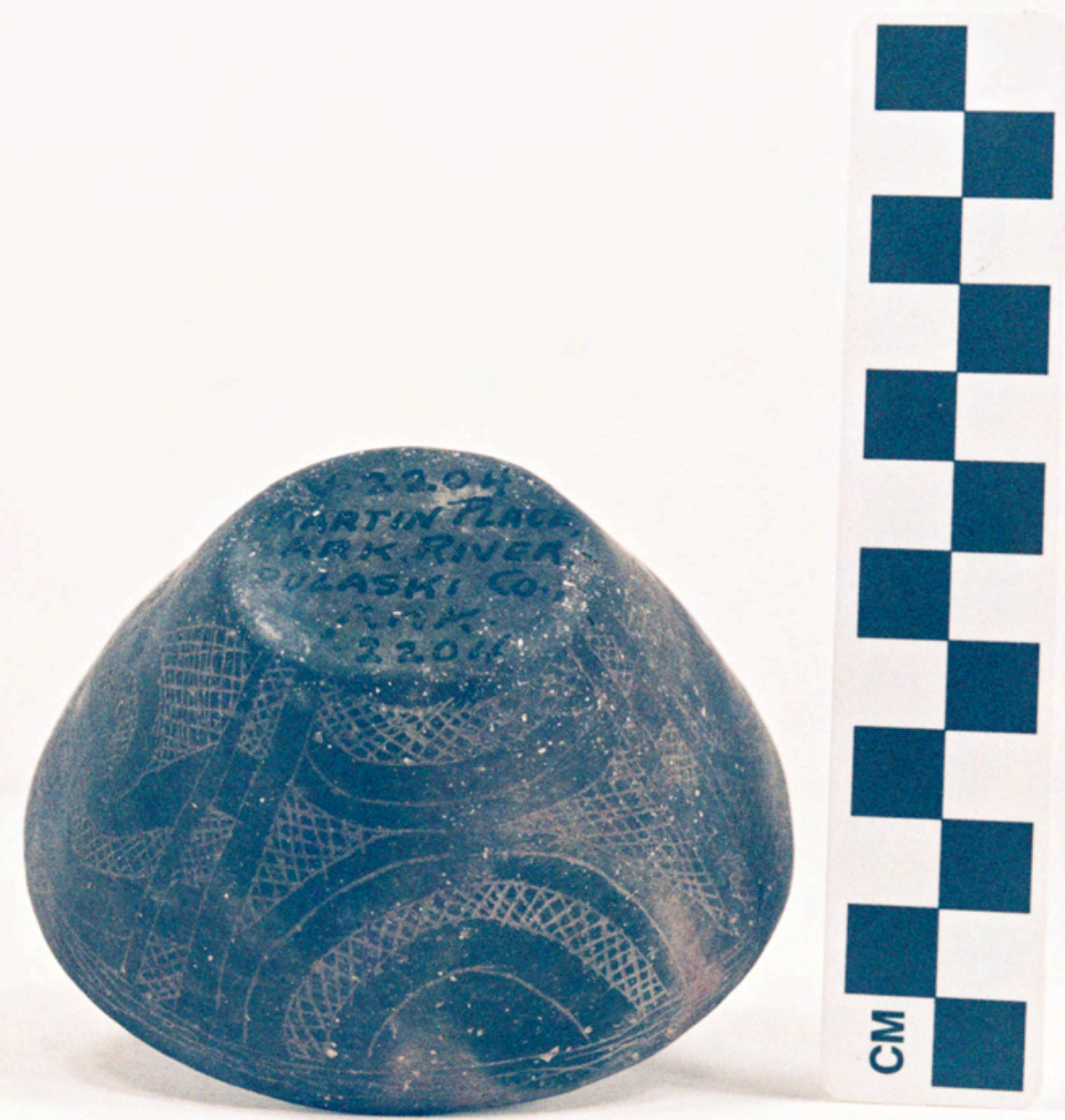

Figure A1-1b 


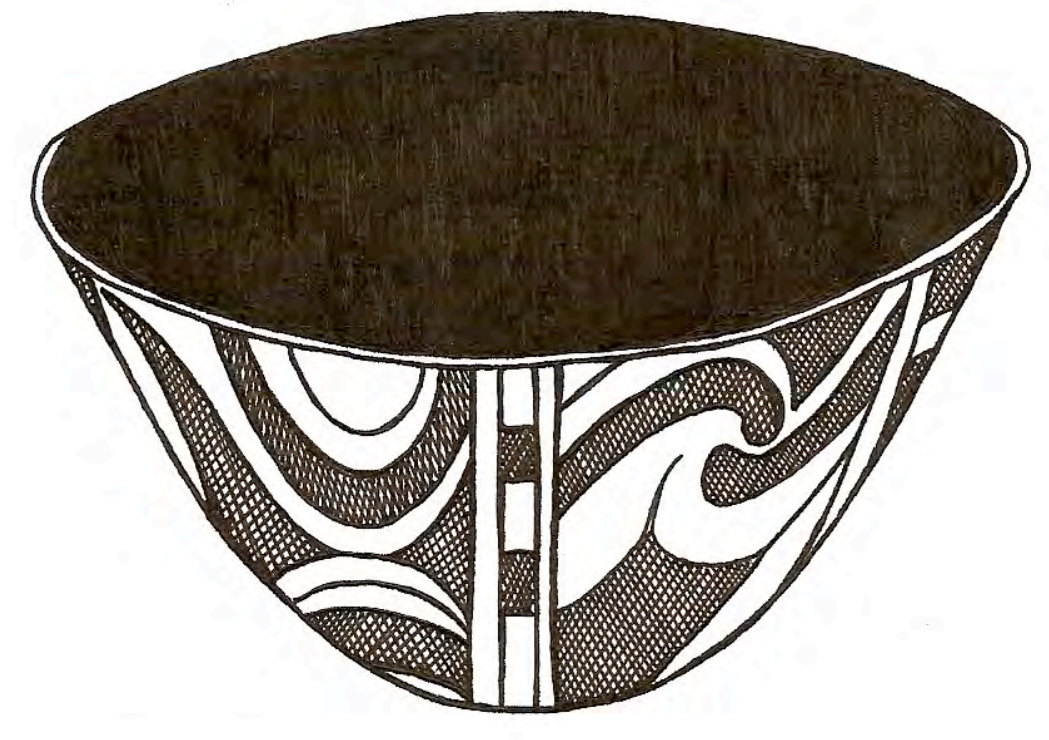

Figure A1-2. Engraved bowl (5425-549).

Drawing by Bobby Gonzalez.

Figure A1-2 


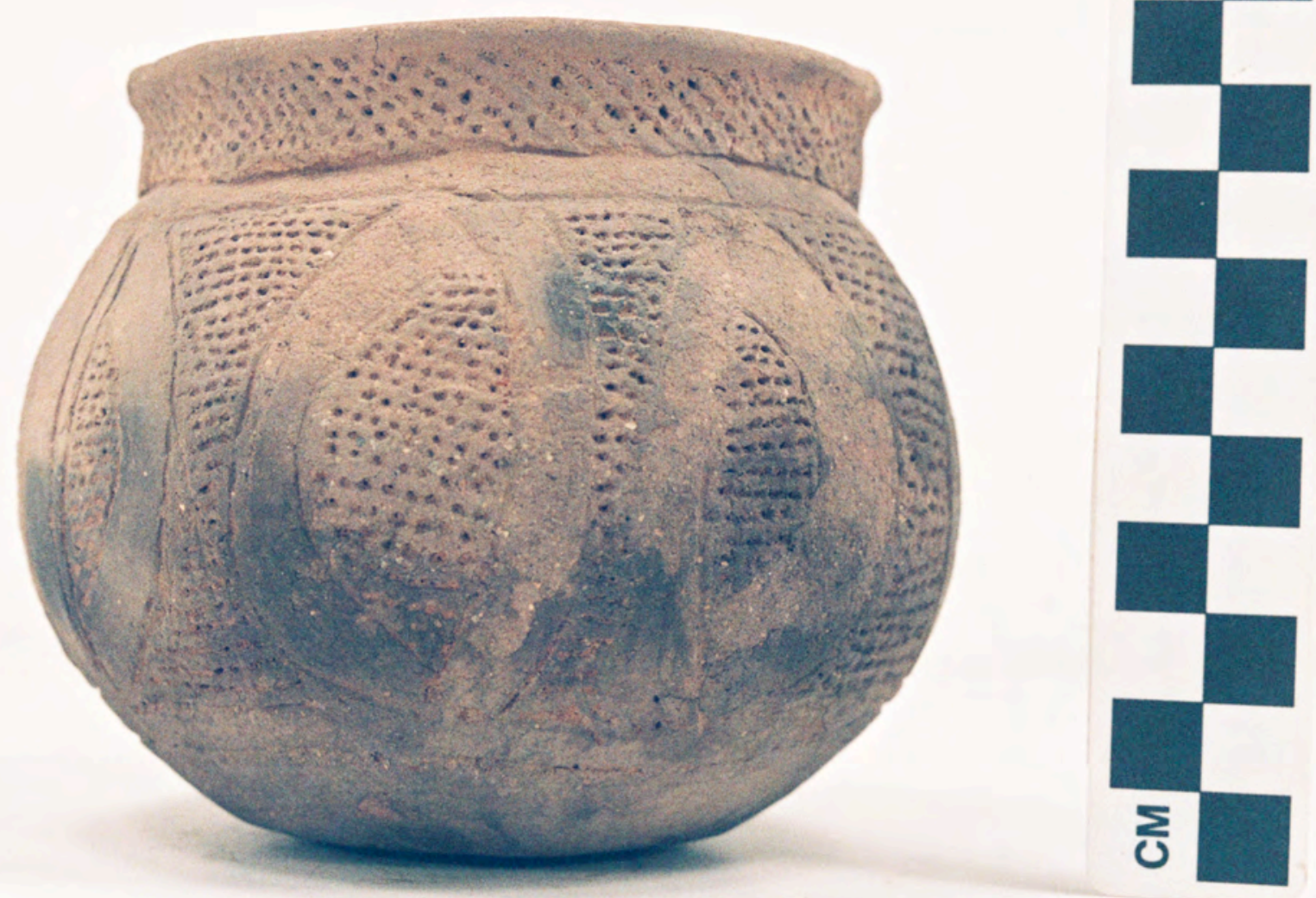

Figure A1-3 


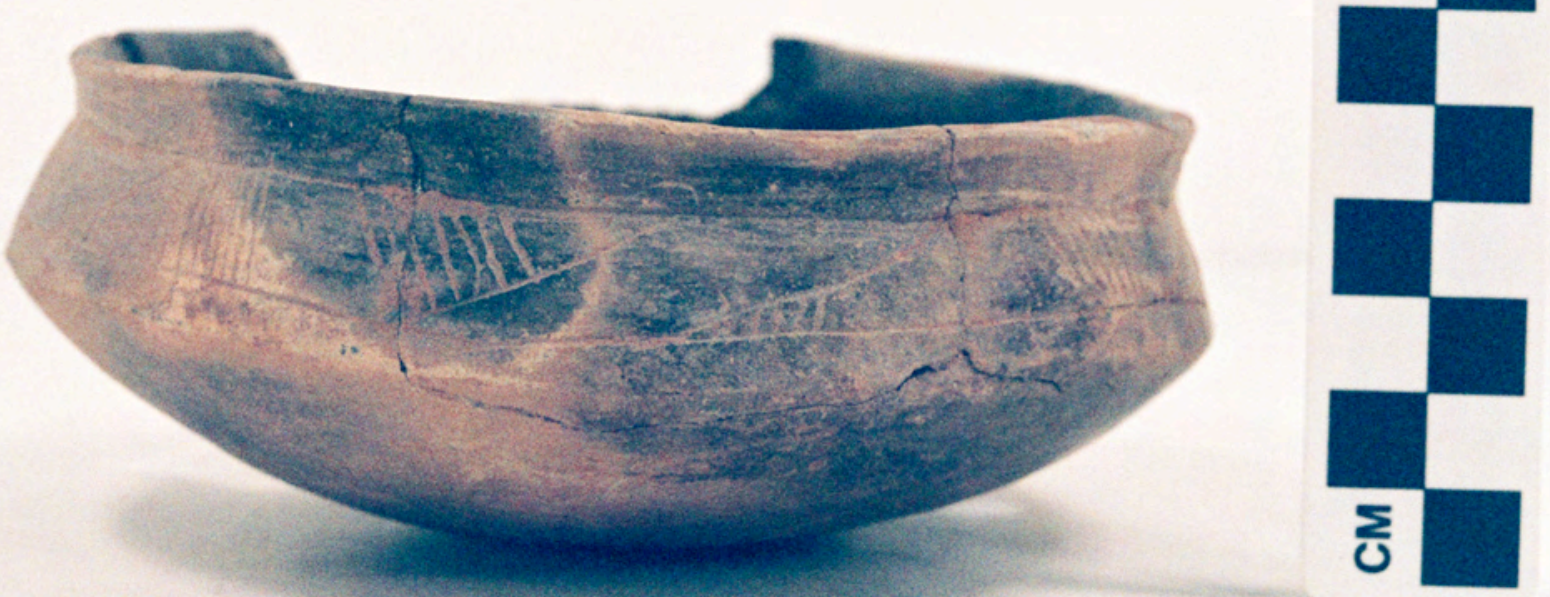

Figure A1-4 


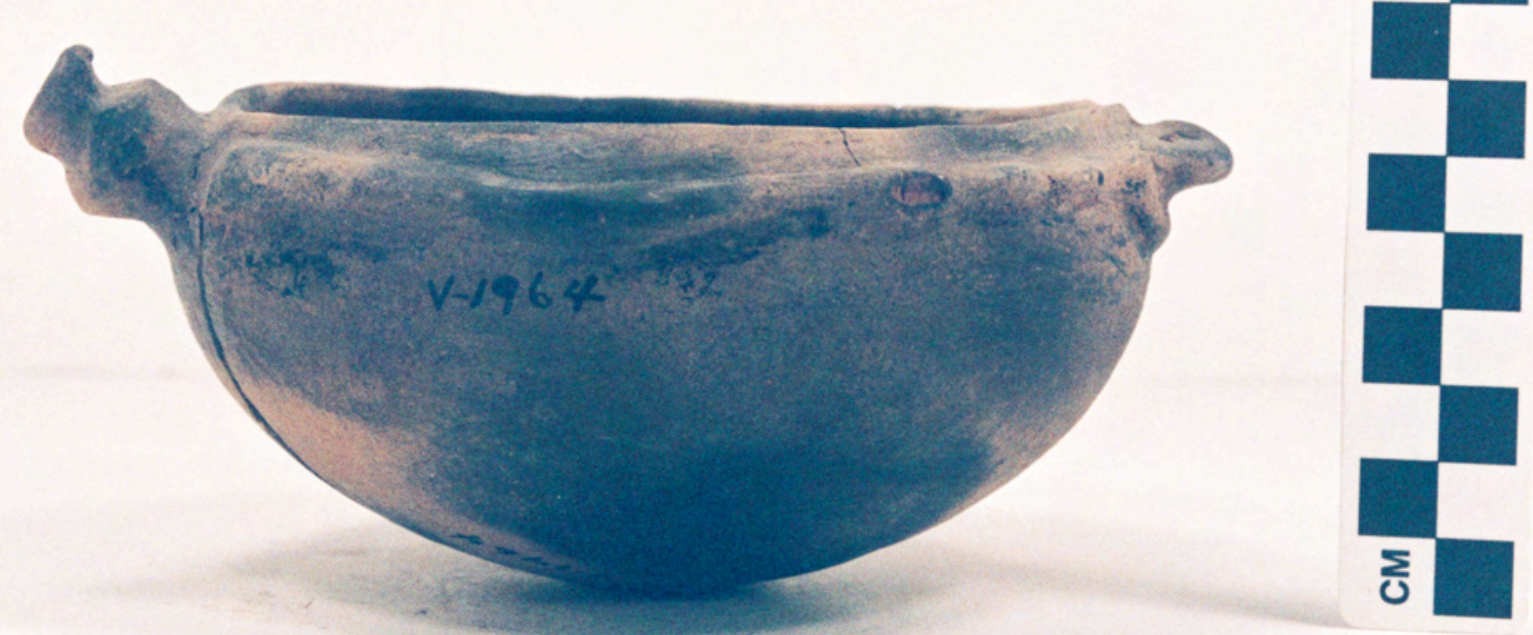

Figure A1-5 


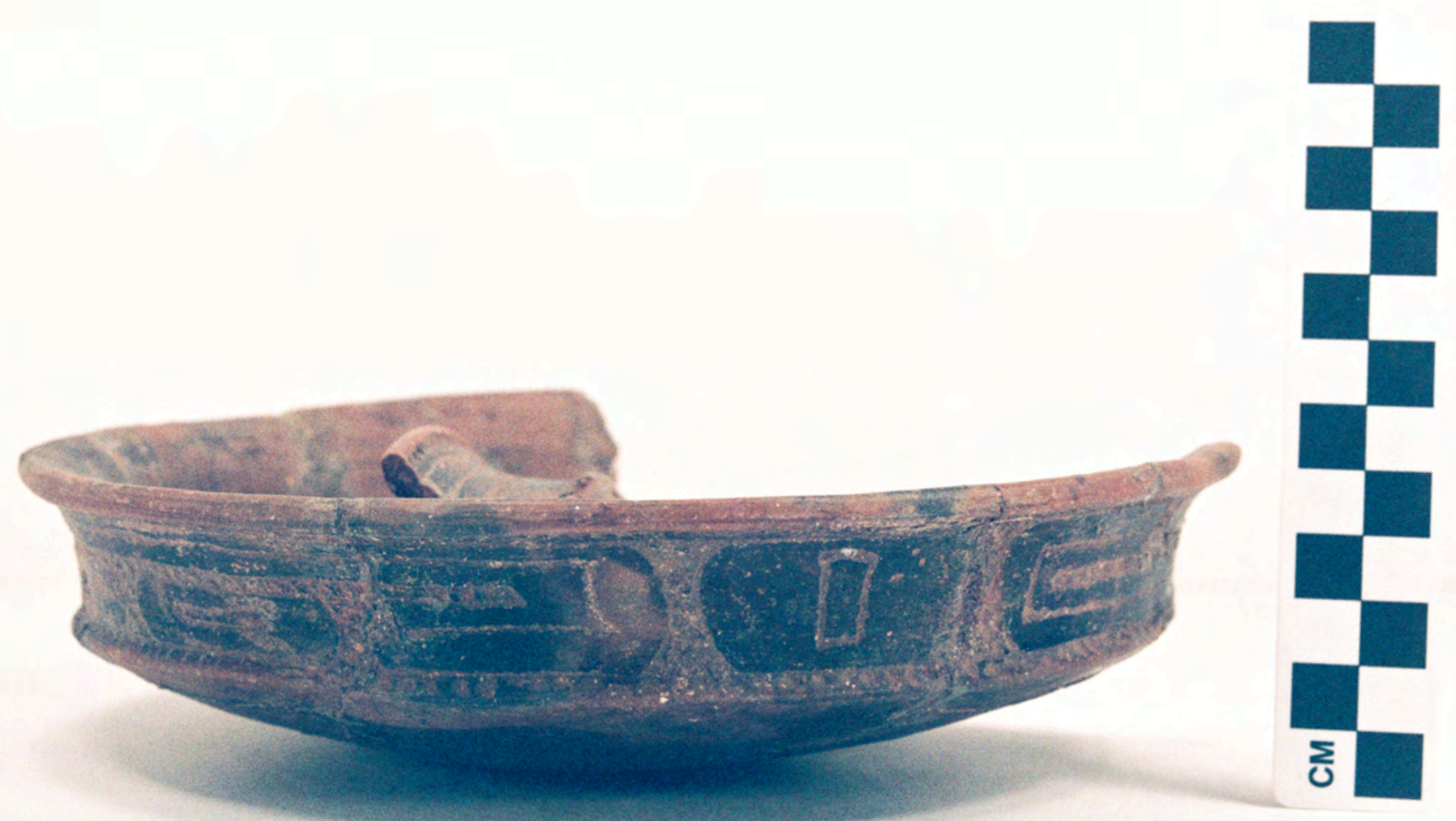

Figure A1-6 


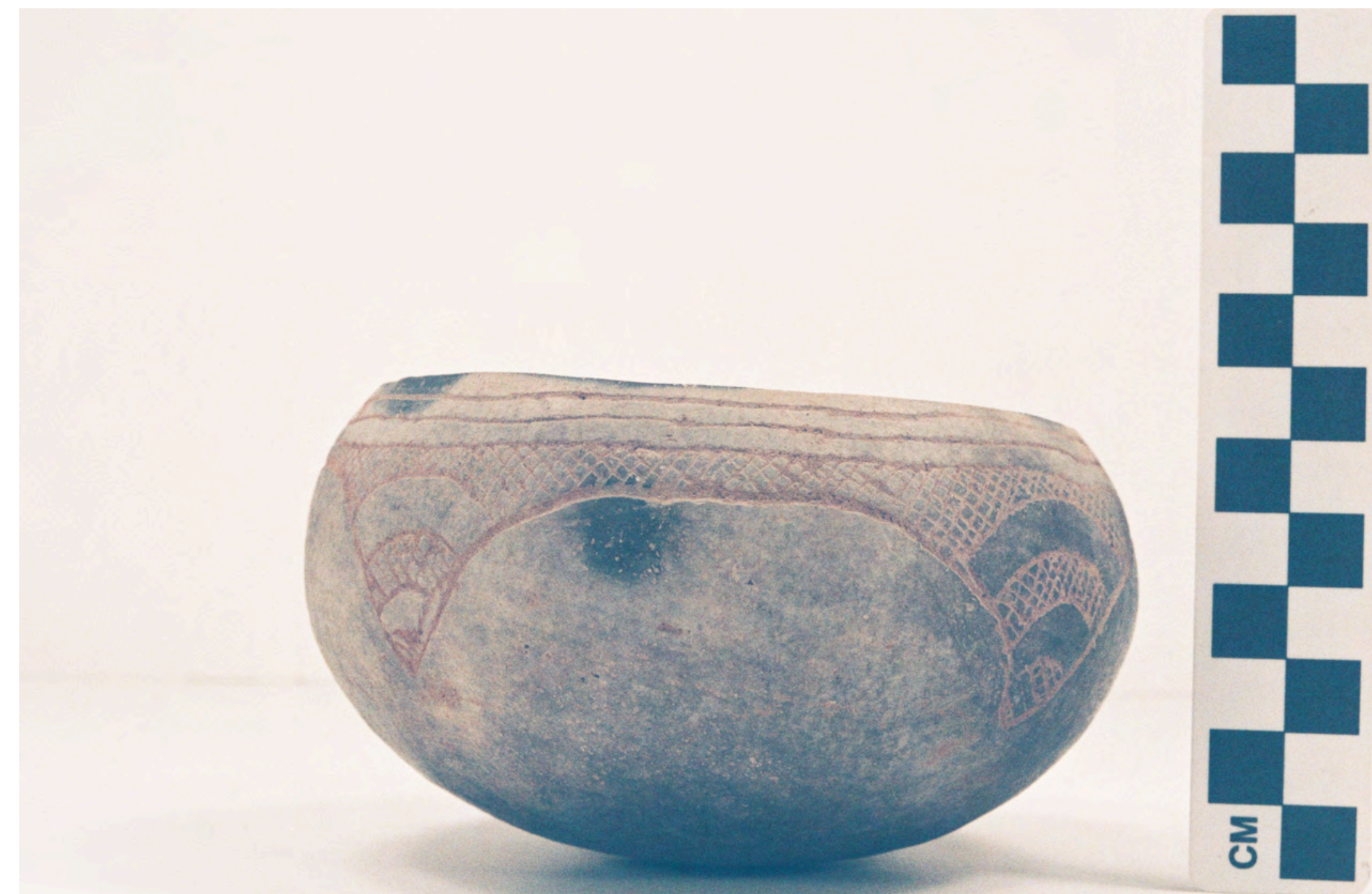

Figure A1-7 


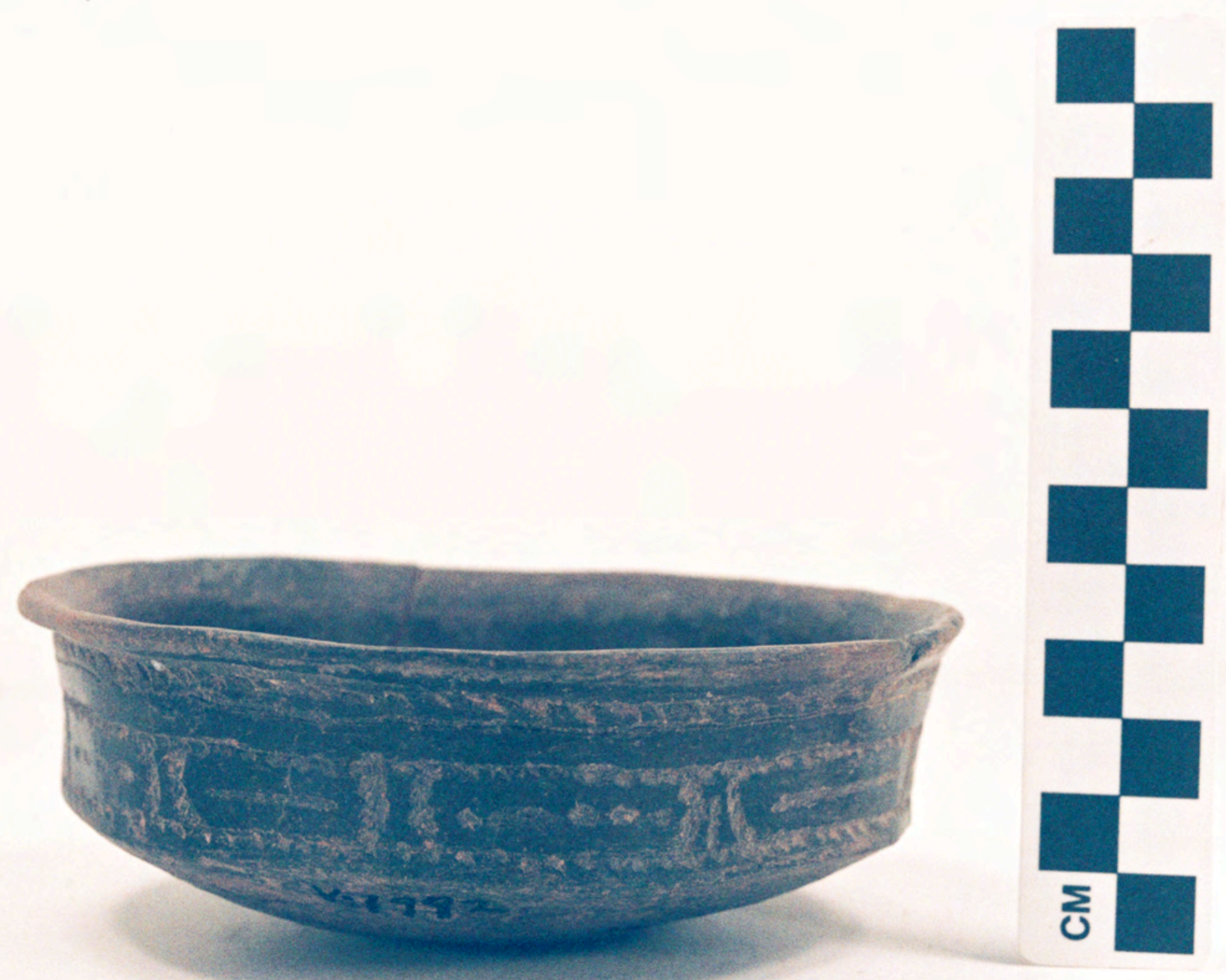

Figure A1-8 


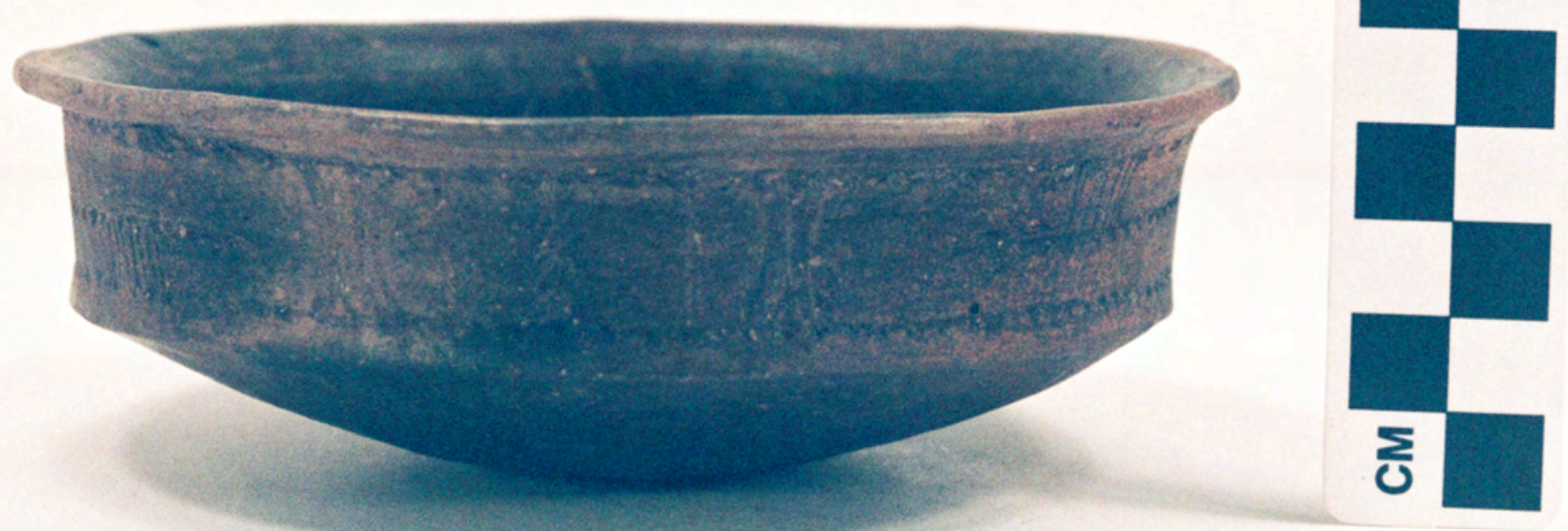

Figure A1-9a 


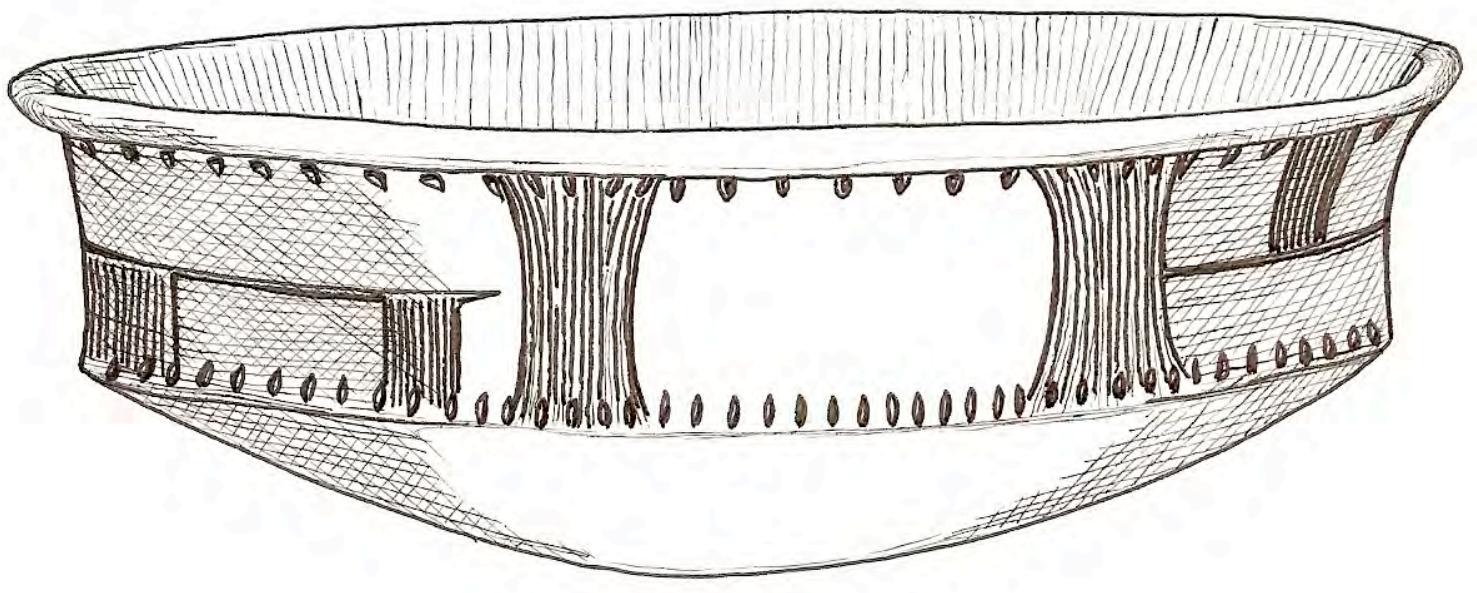

Figure A1-9. Handy Engraved carinated bowl (5425-636) b, drawing by Bobby Gonzalez.

Figure A1-9b 


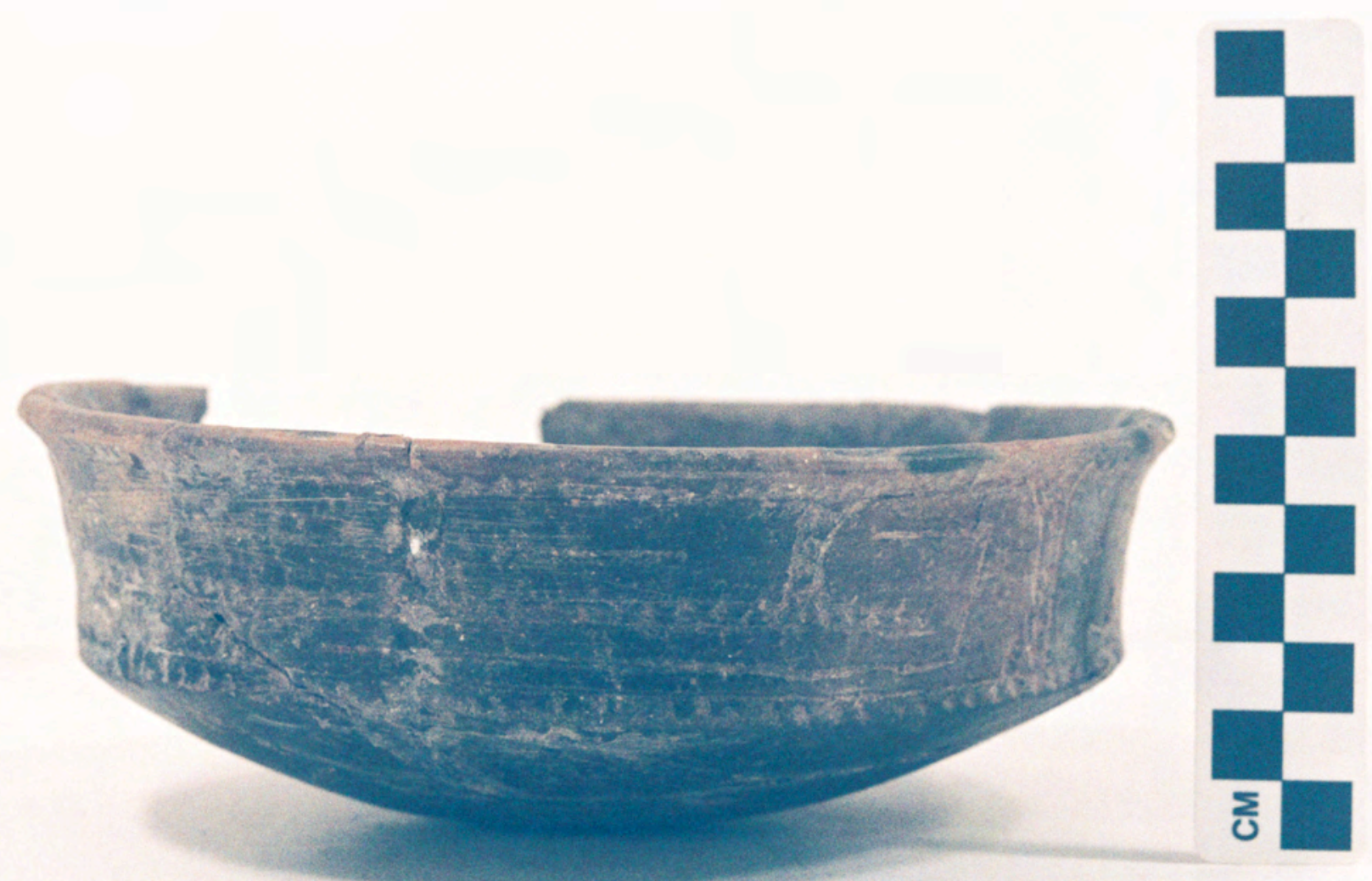

Figure A1-10 


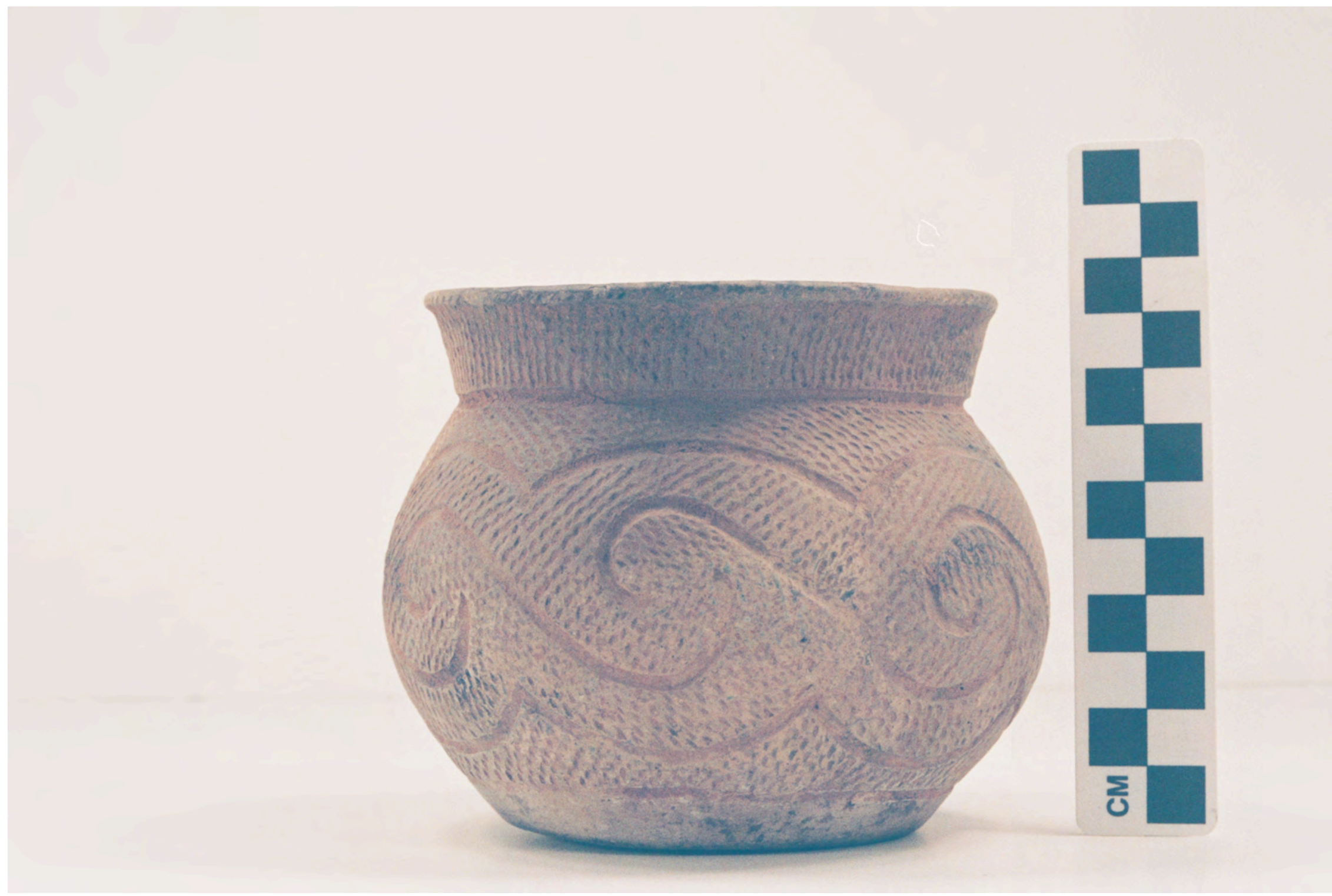

Figure A1-11 


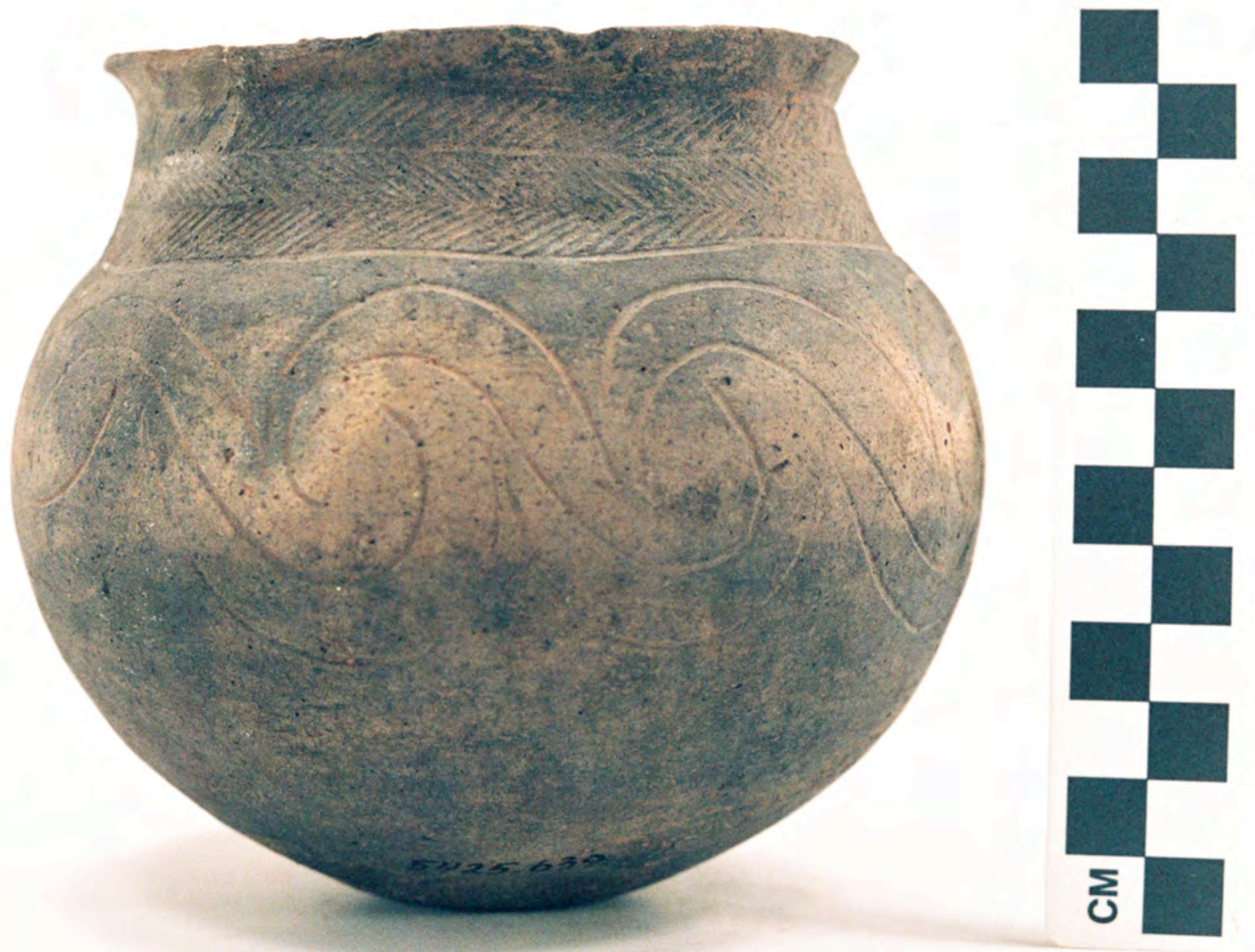

Figure A1-12 


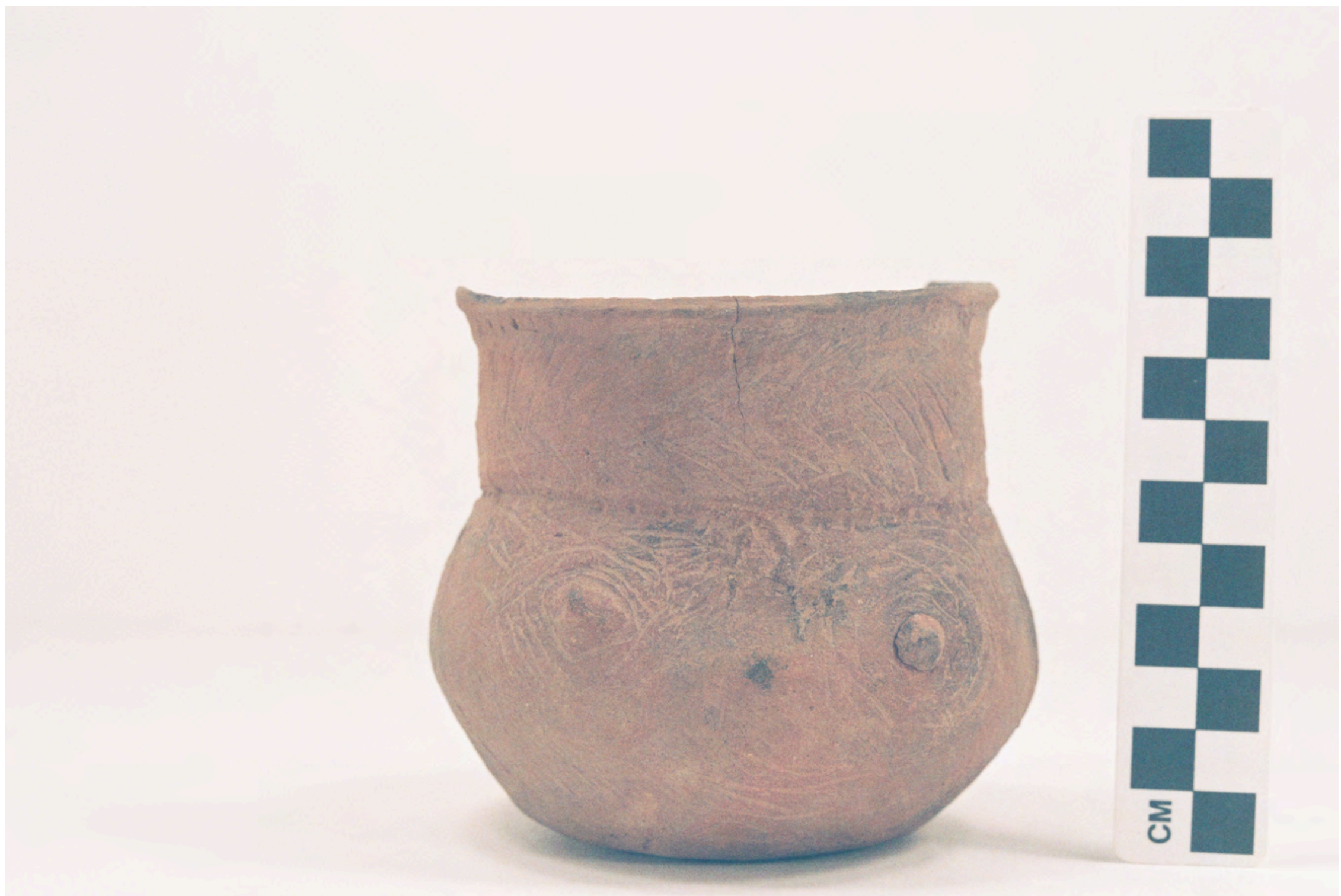

Figure A1-13 


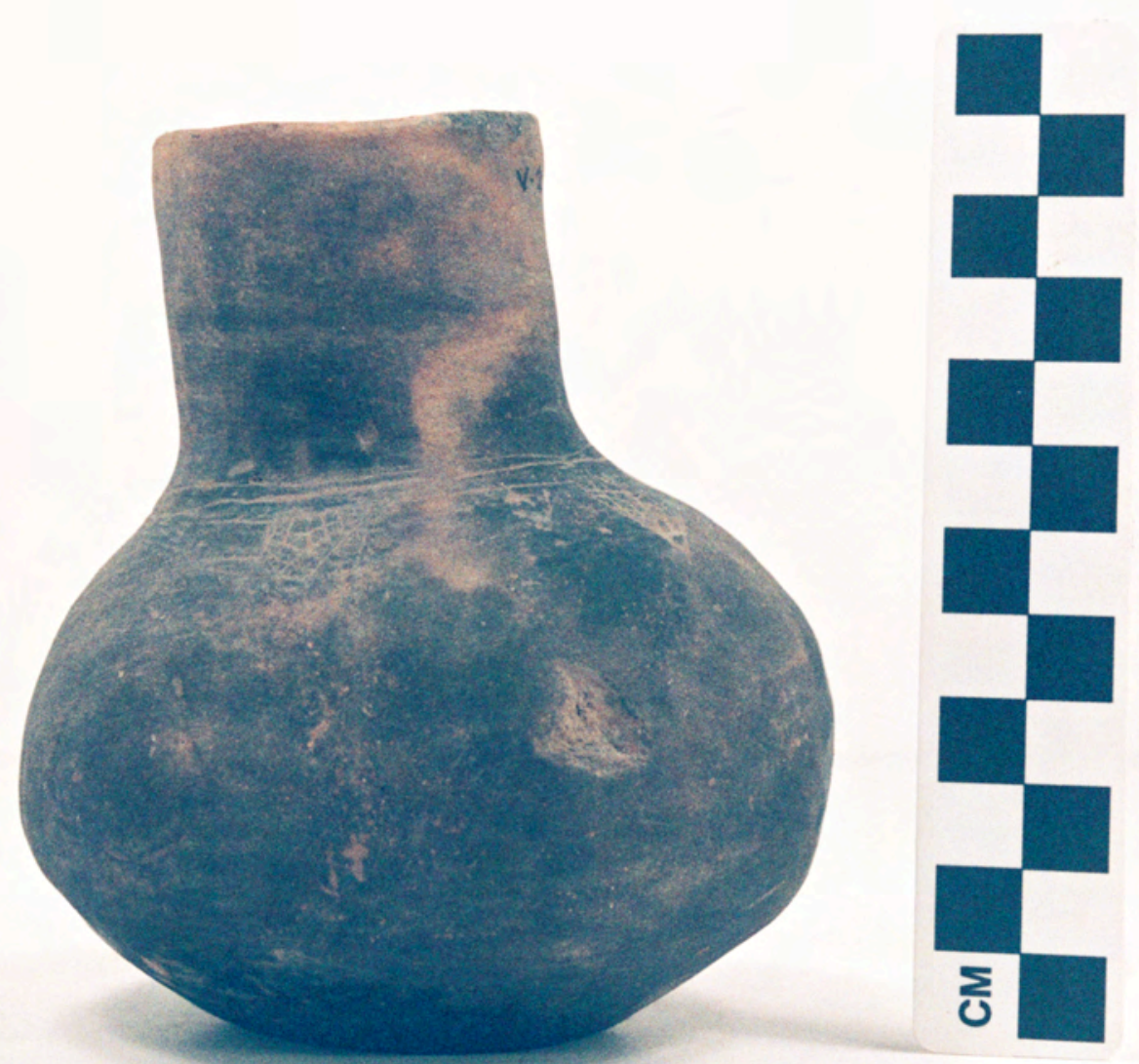

Figure A1-14 


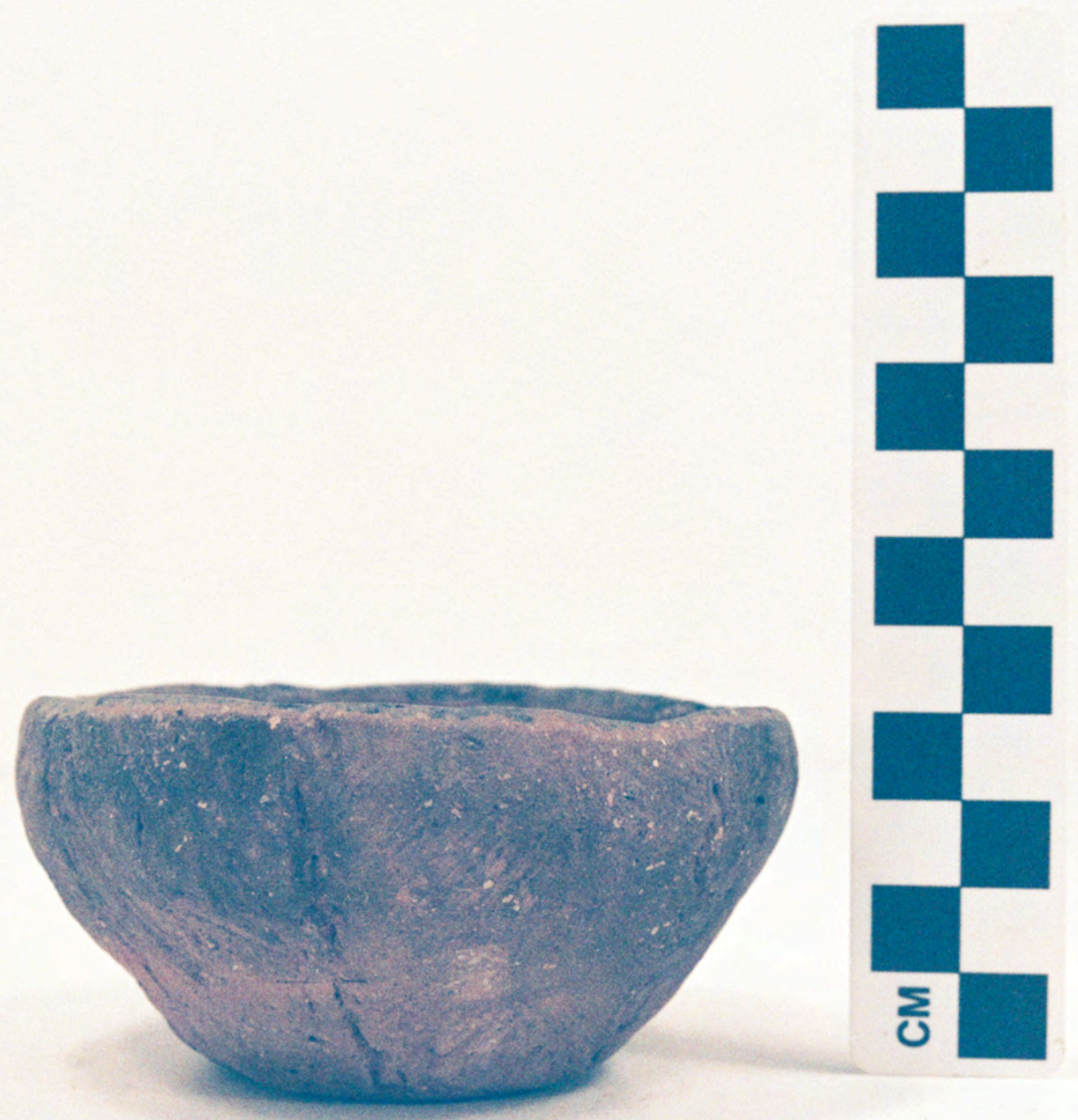

Figure A1-15 


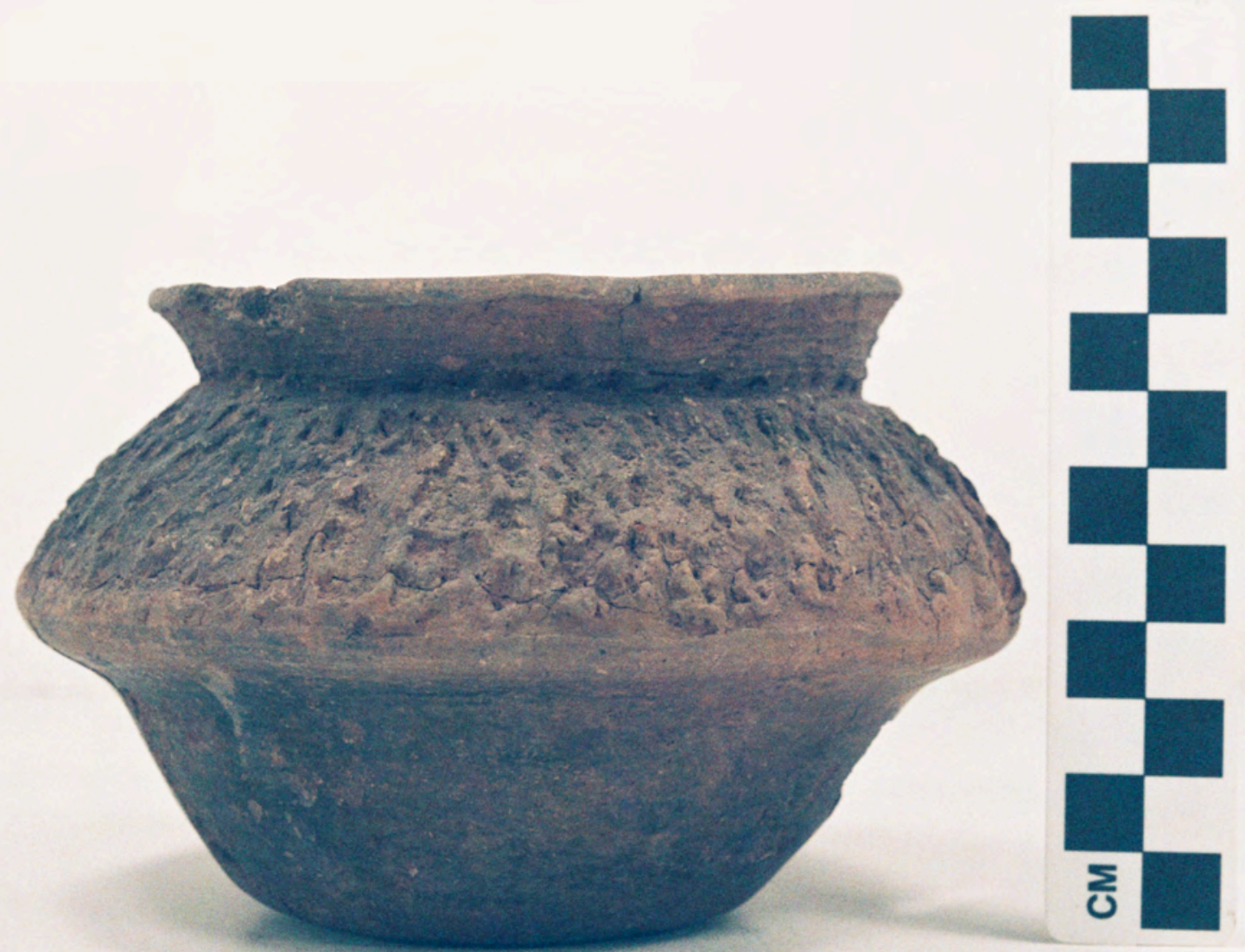

Figure A1-16 


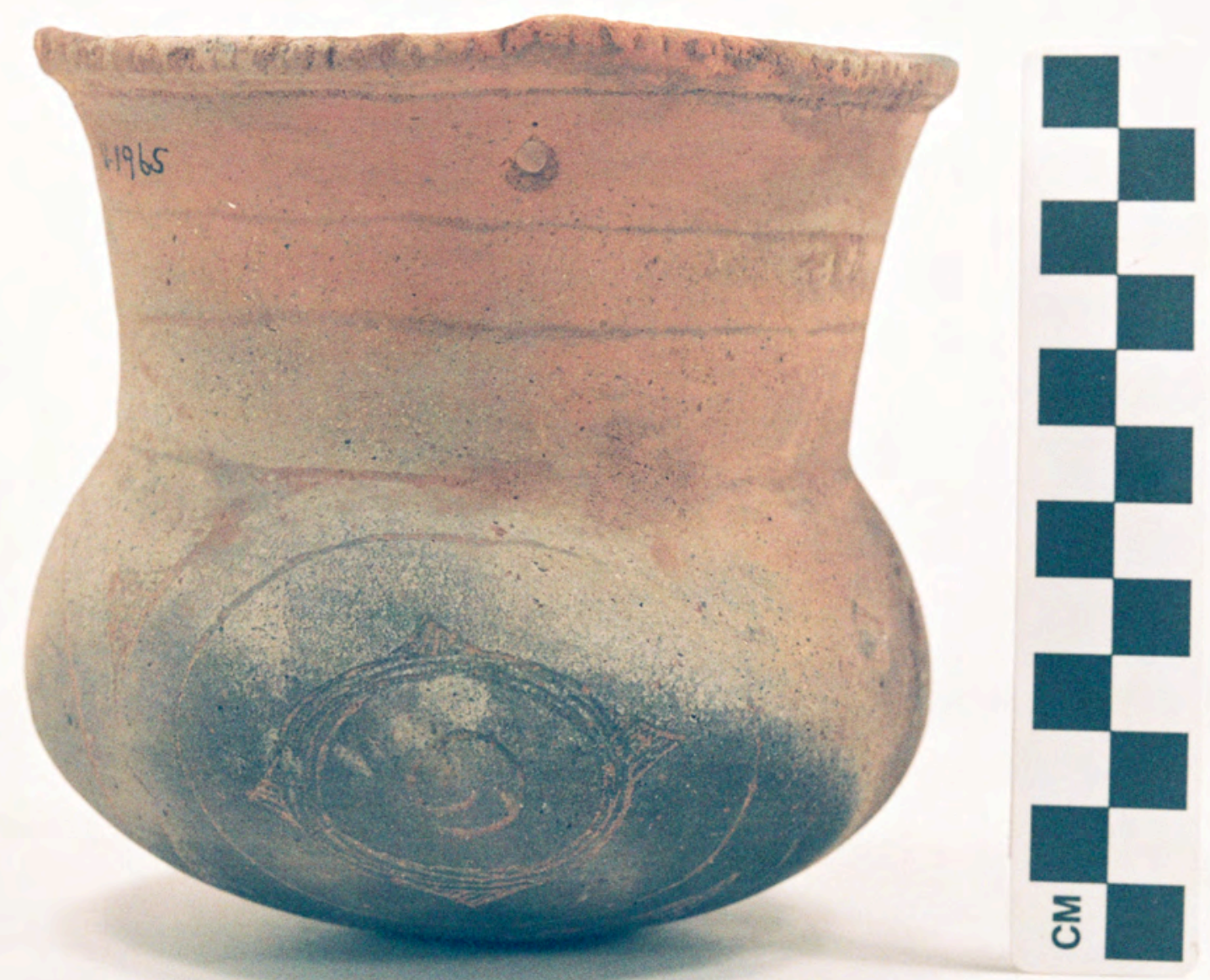

Figure A1-17 


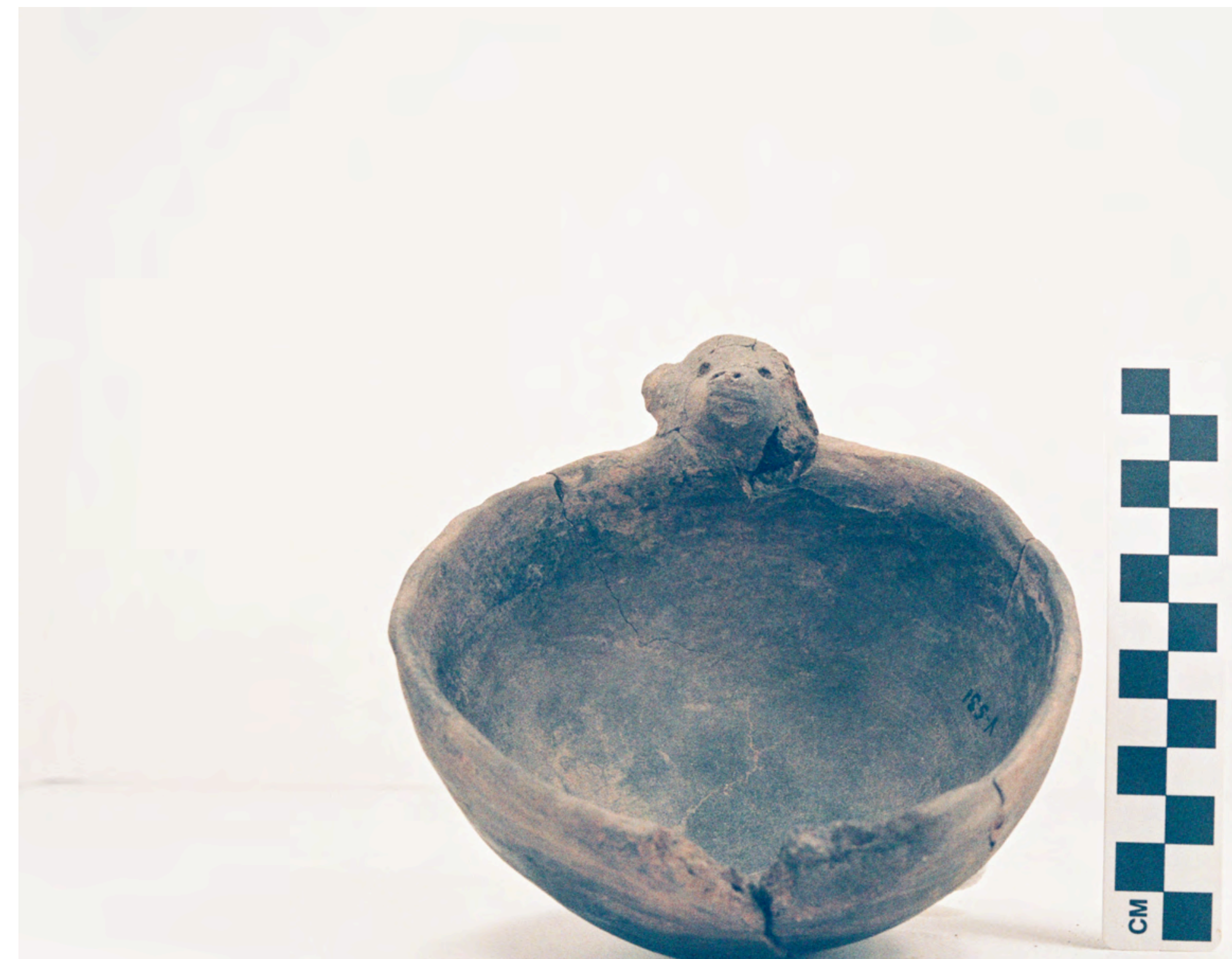

Figure A1-18 


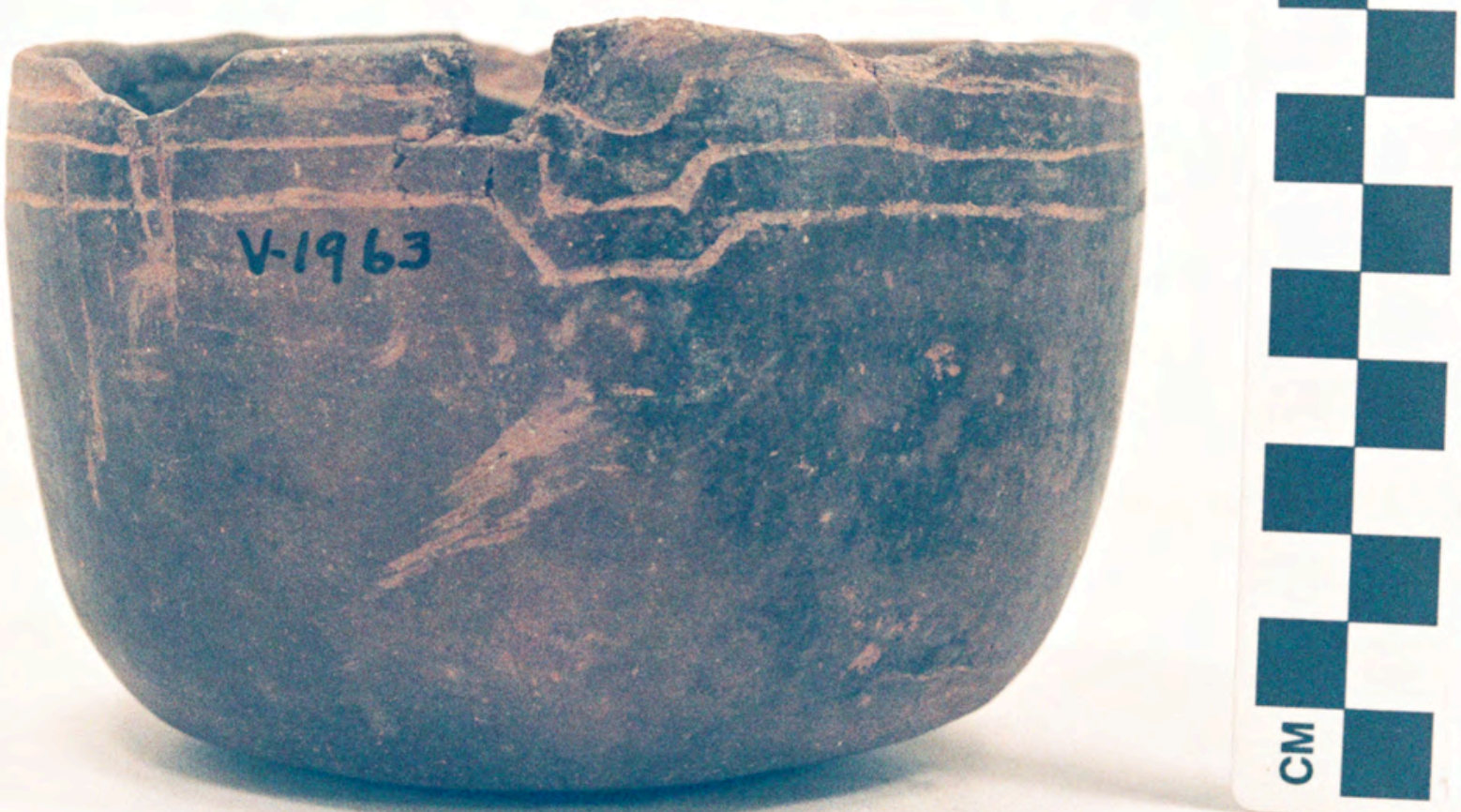

Figure A1-19 


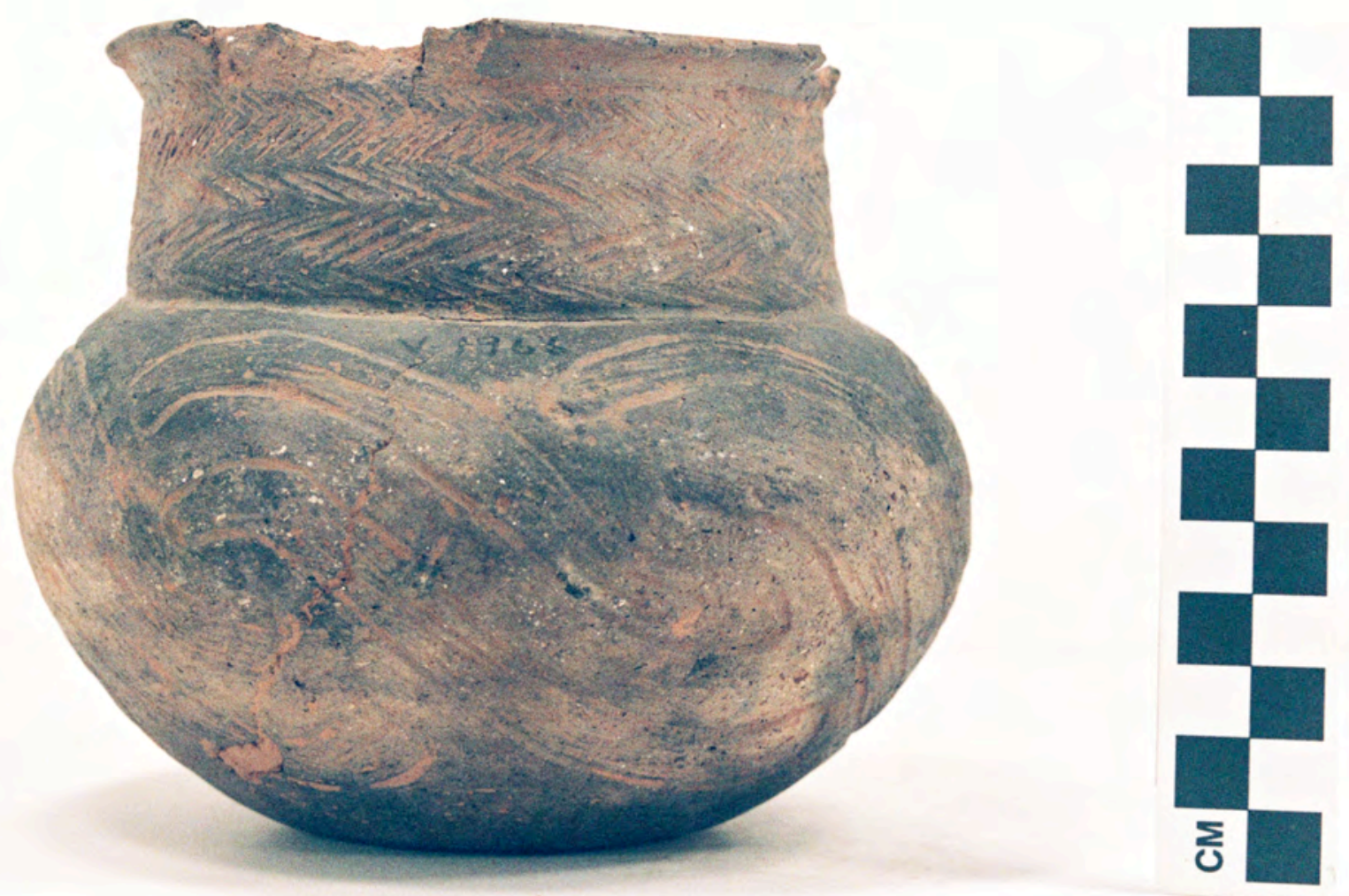

Figure A1-20 


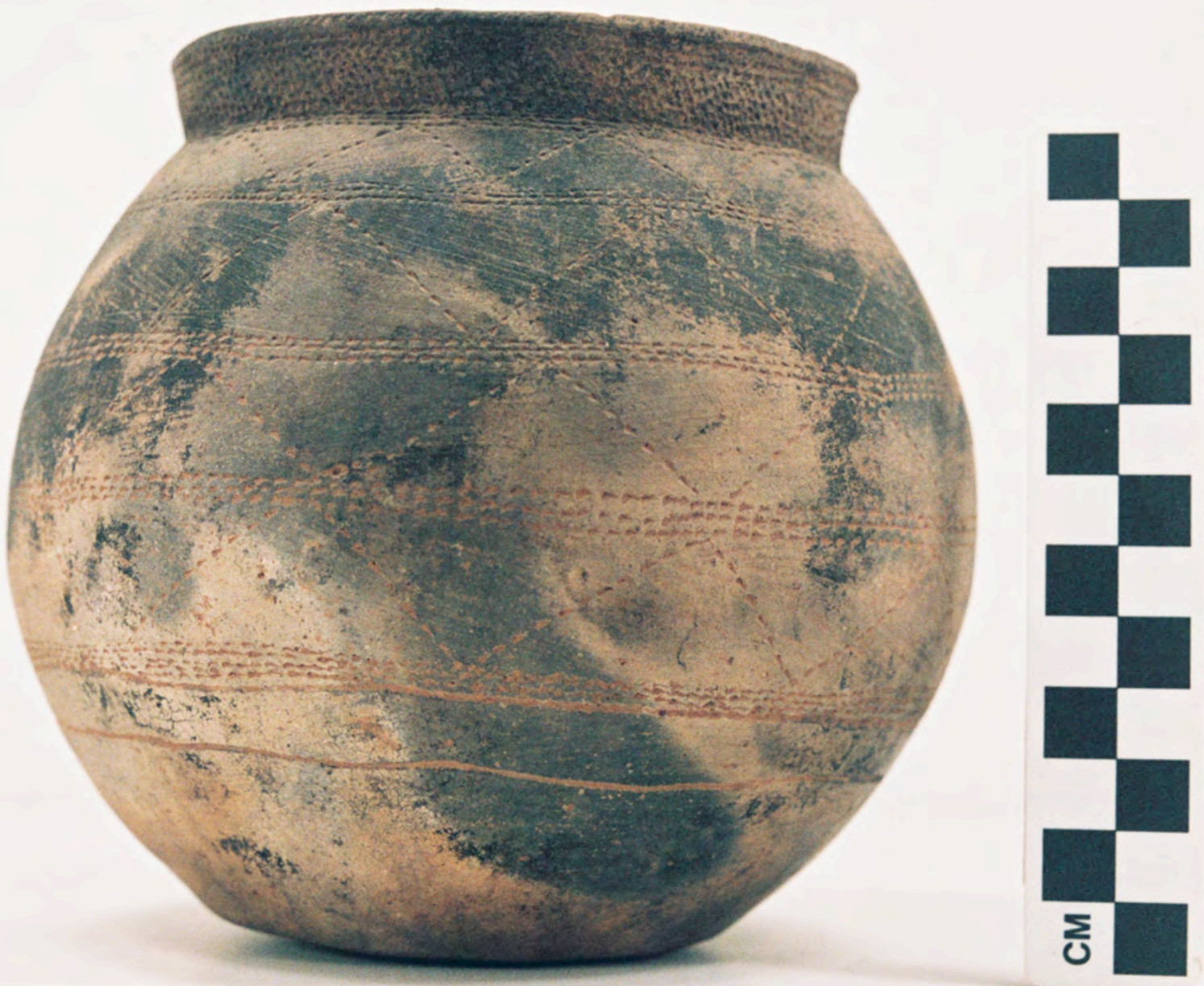

Figure A1-21 


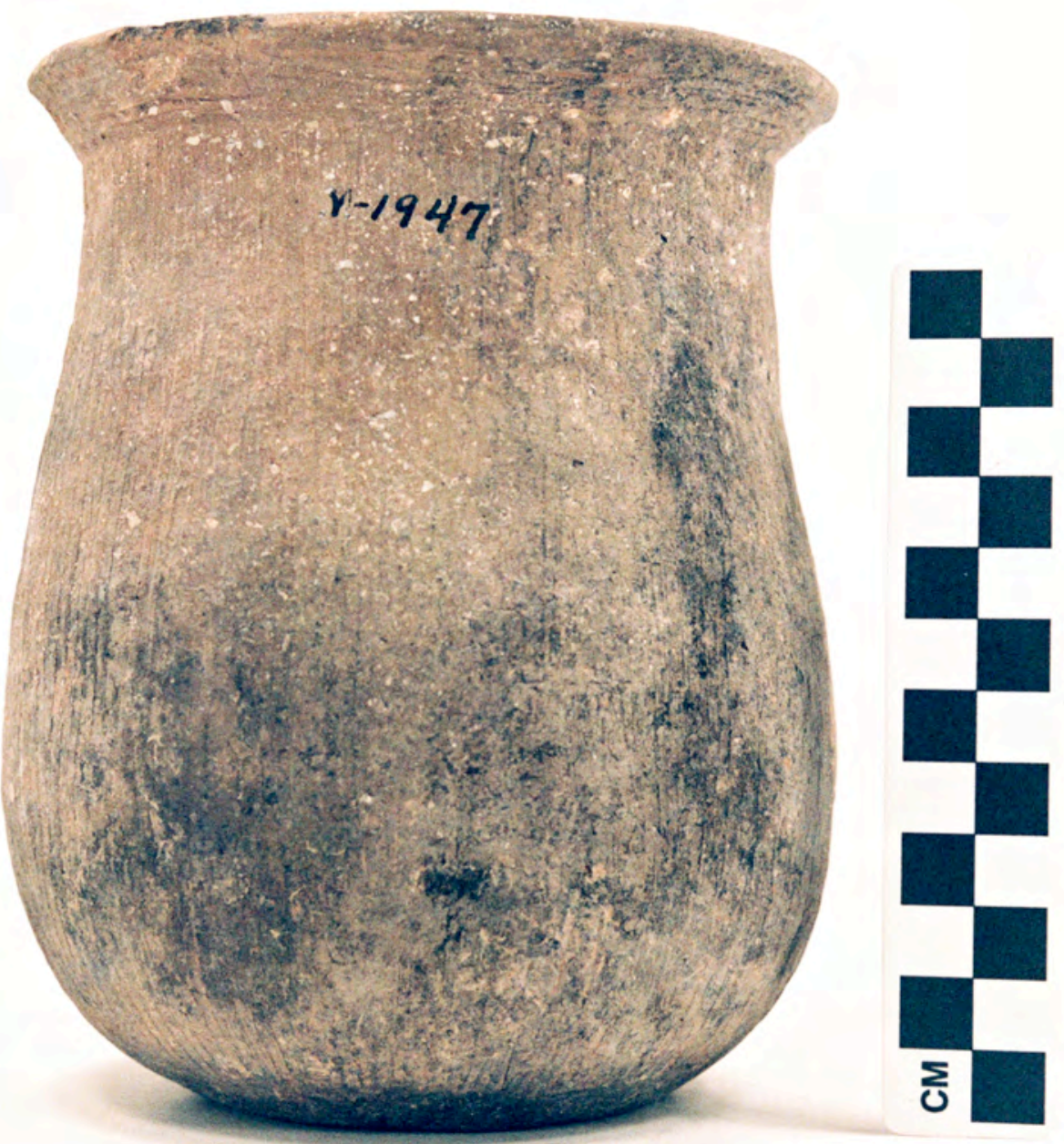

Figure A1-22 


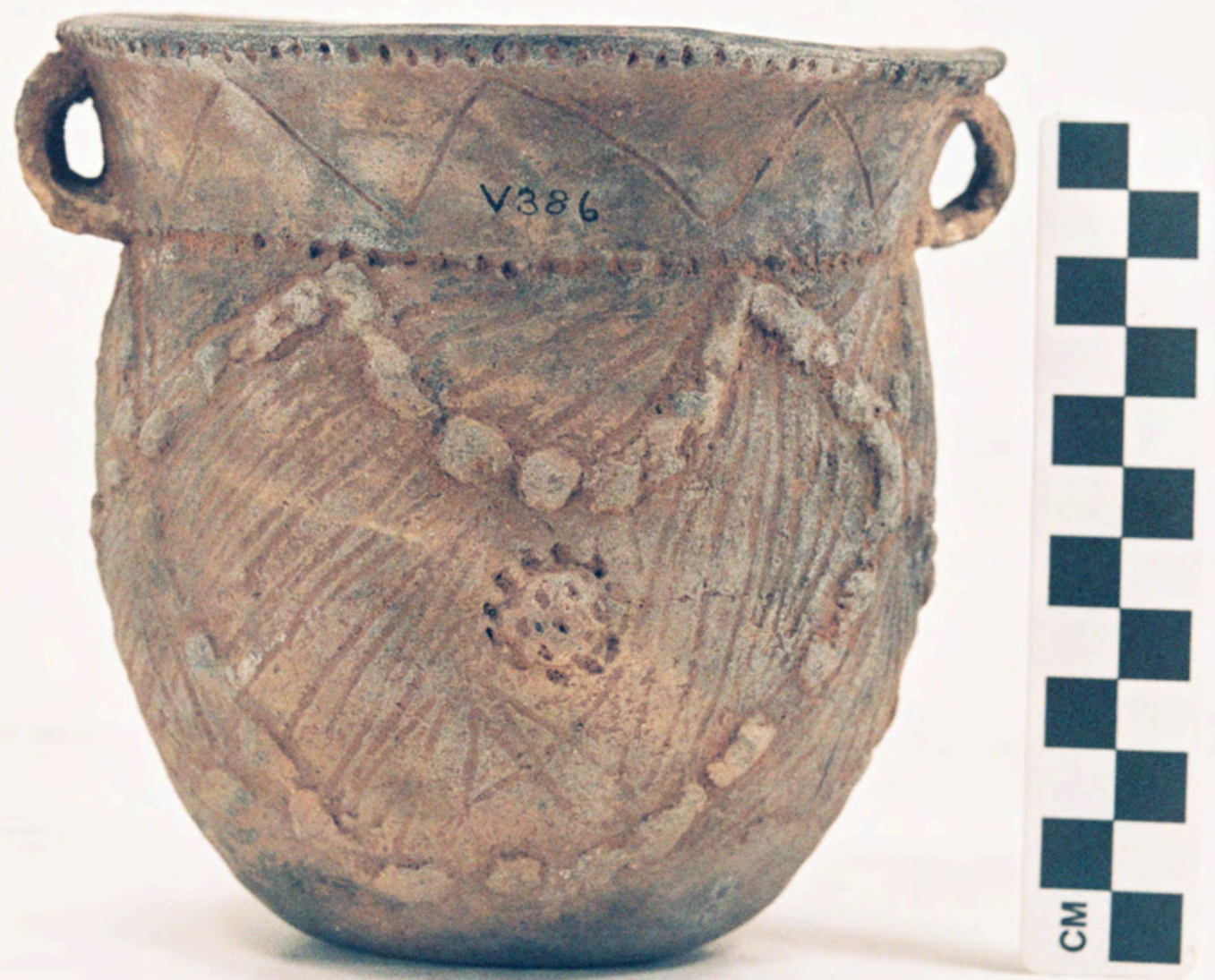

Figure A1-23 


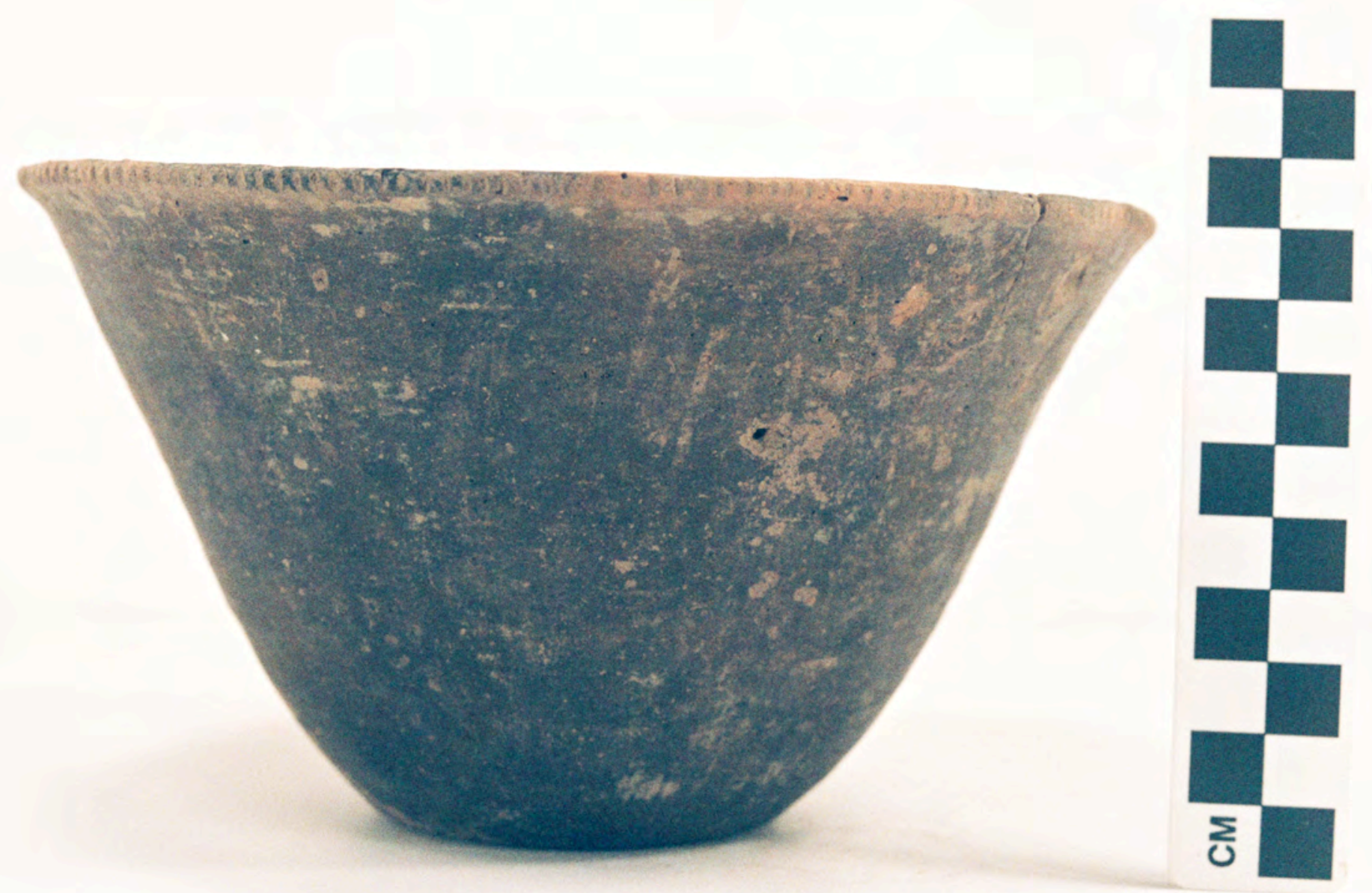

Figure A1-24 


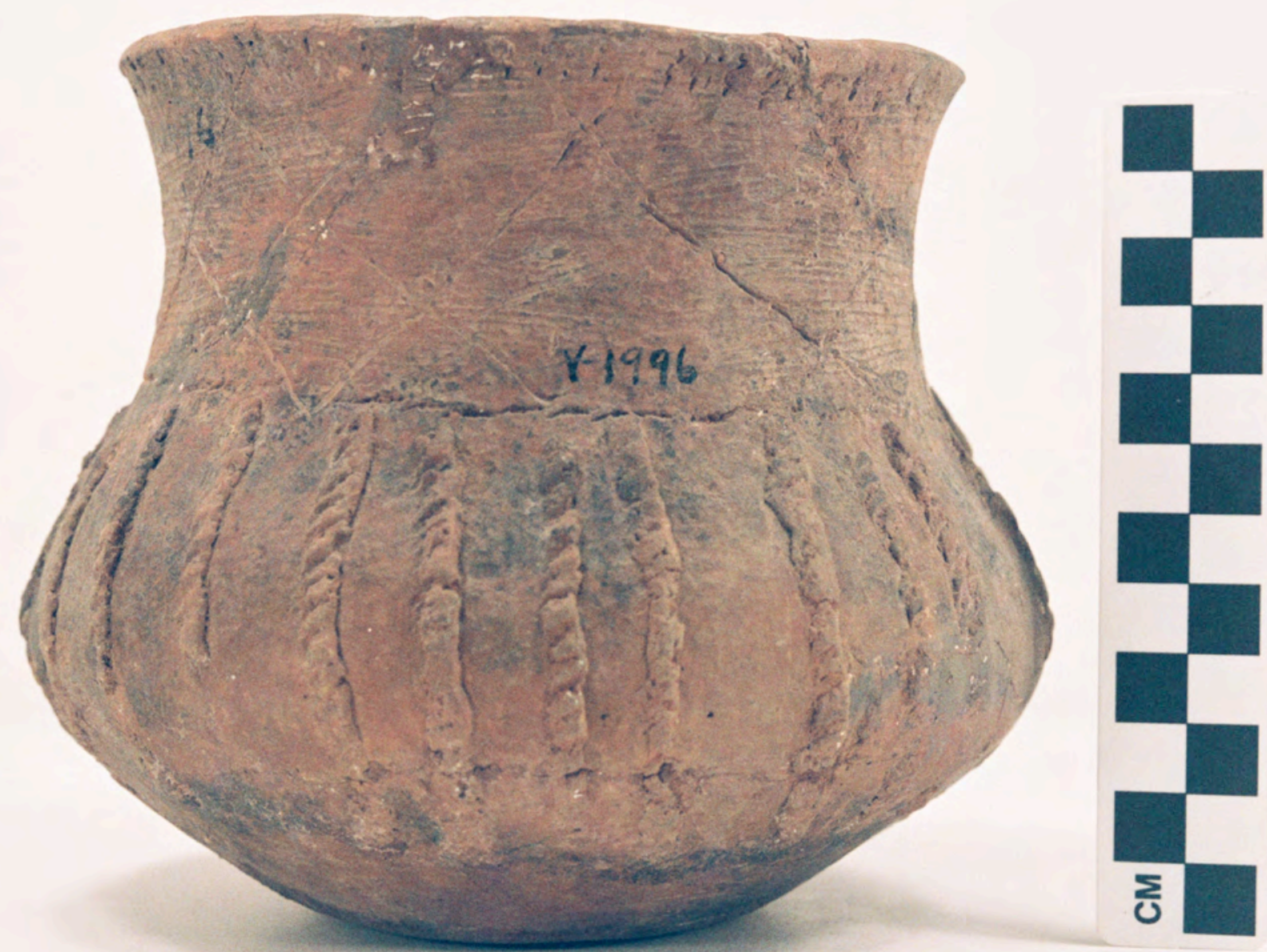

Figure A1-25 


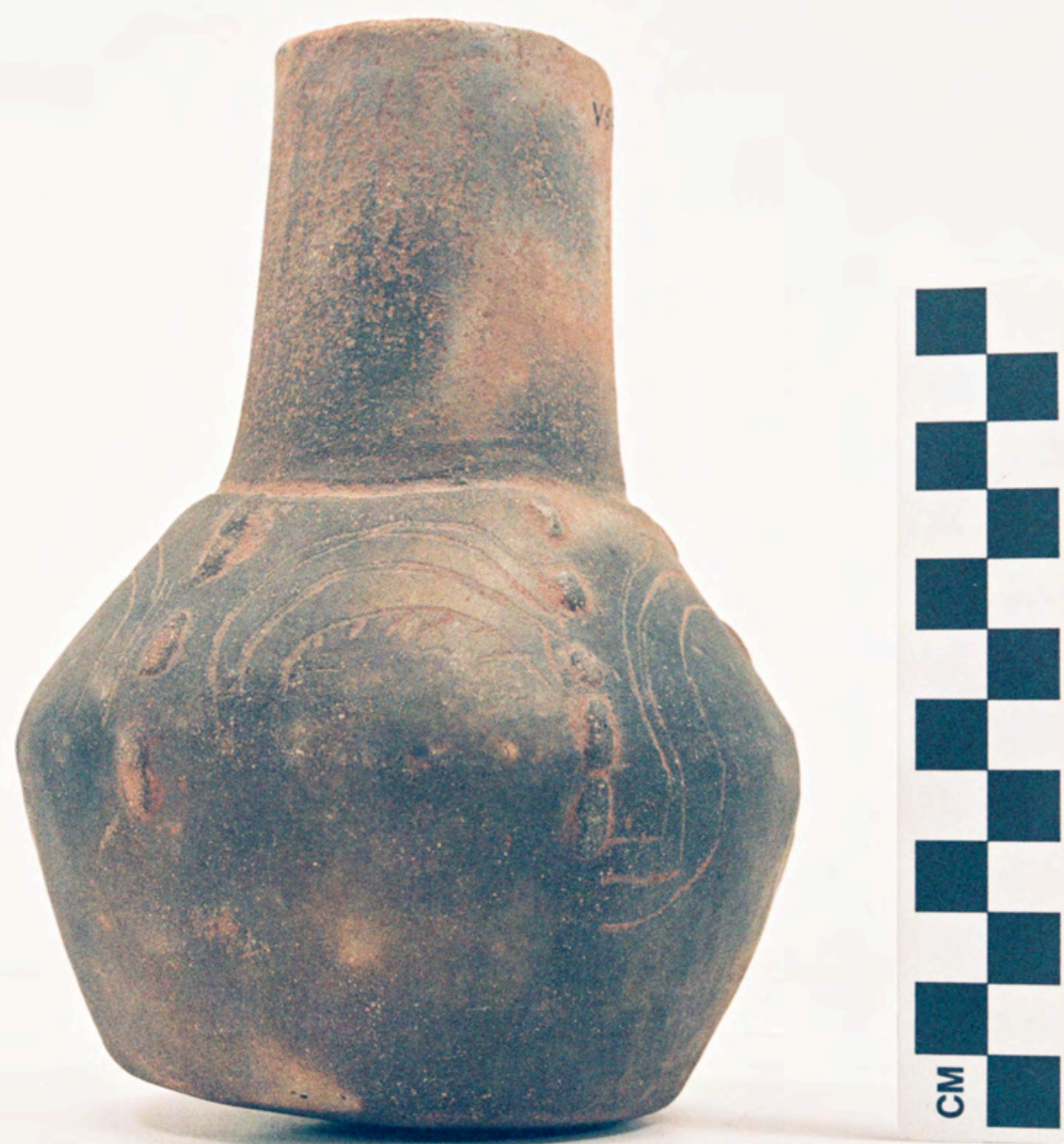

Figure A1-26 


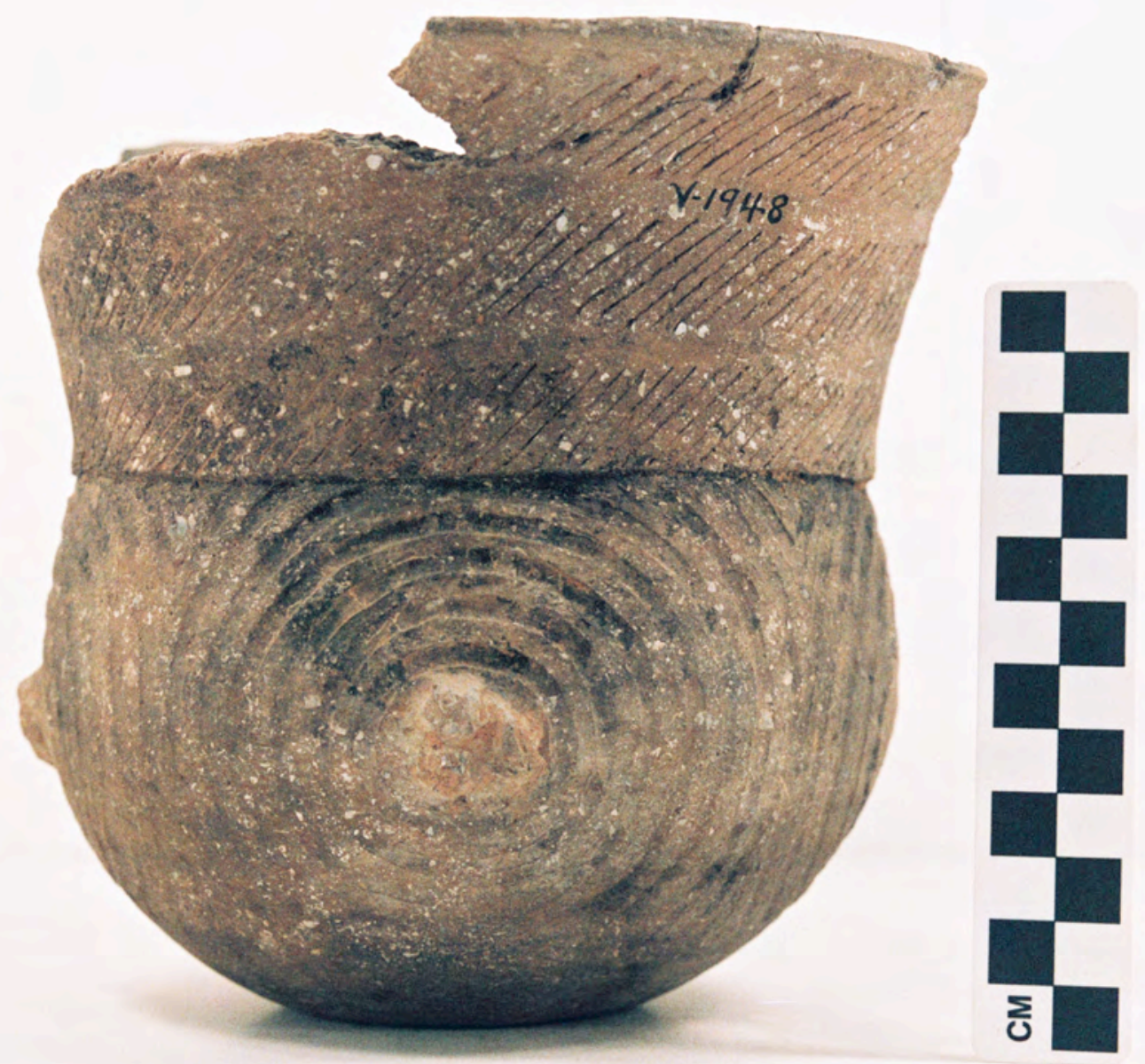

Figure A1-28 


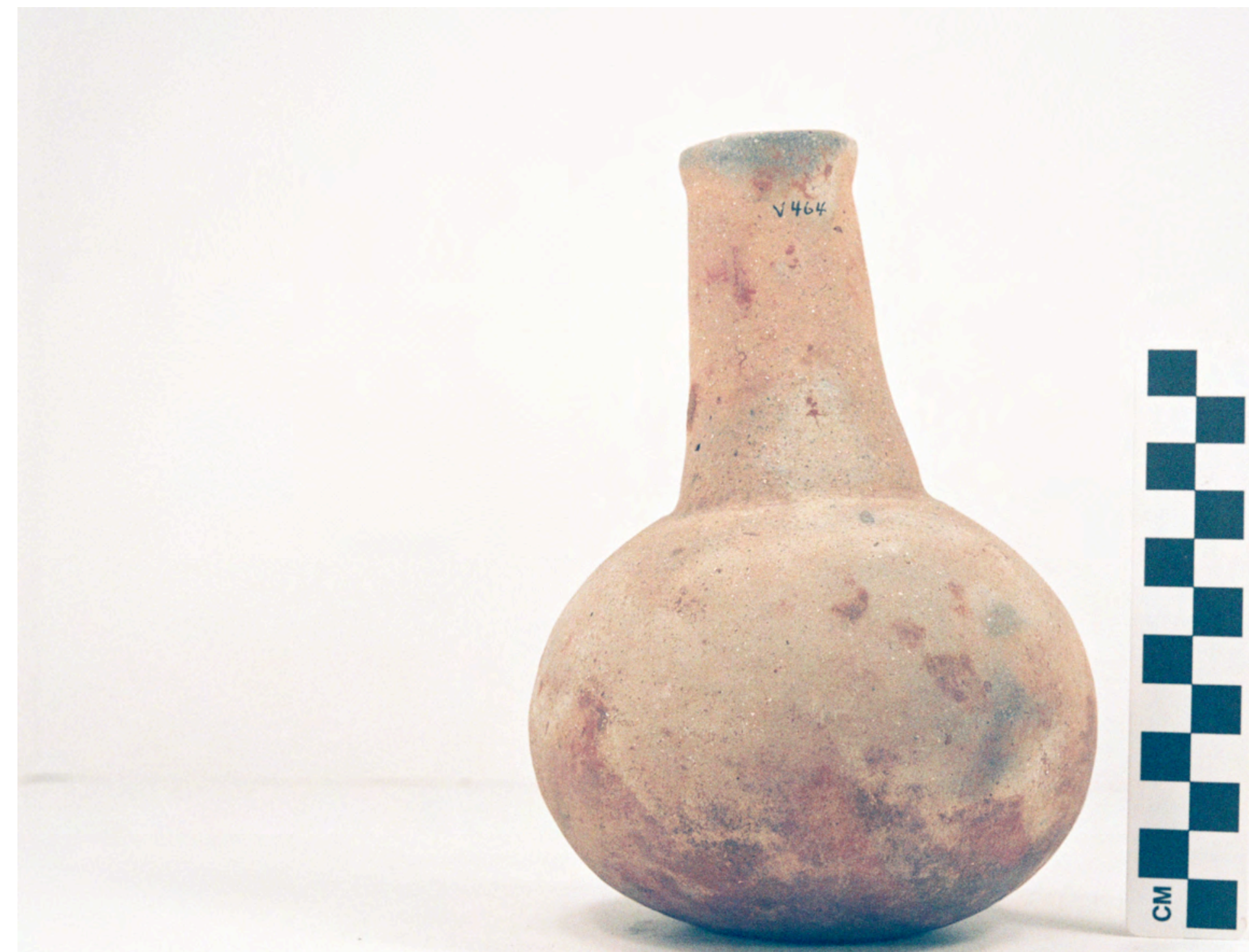

Figure A1-29 


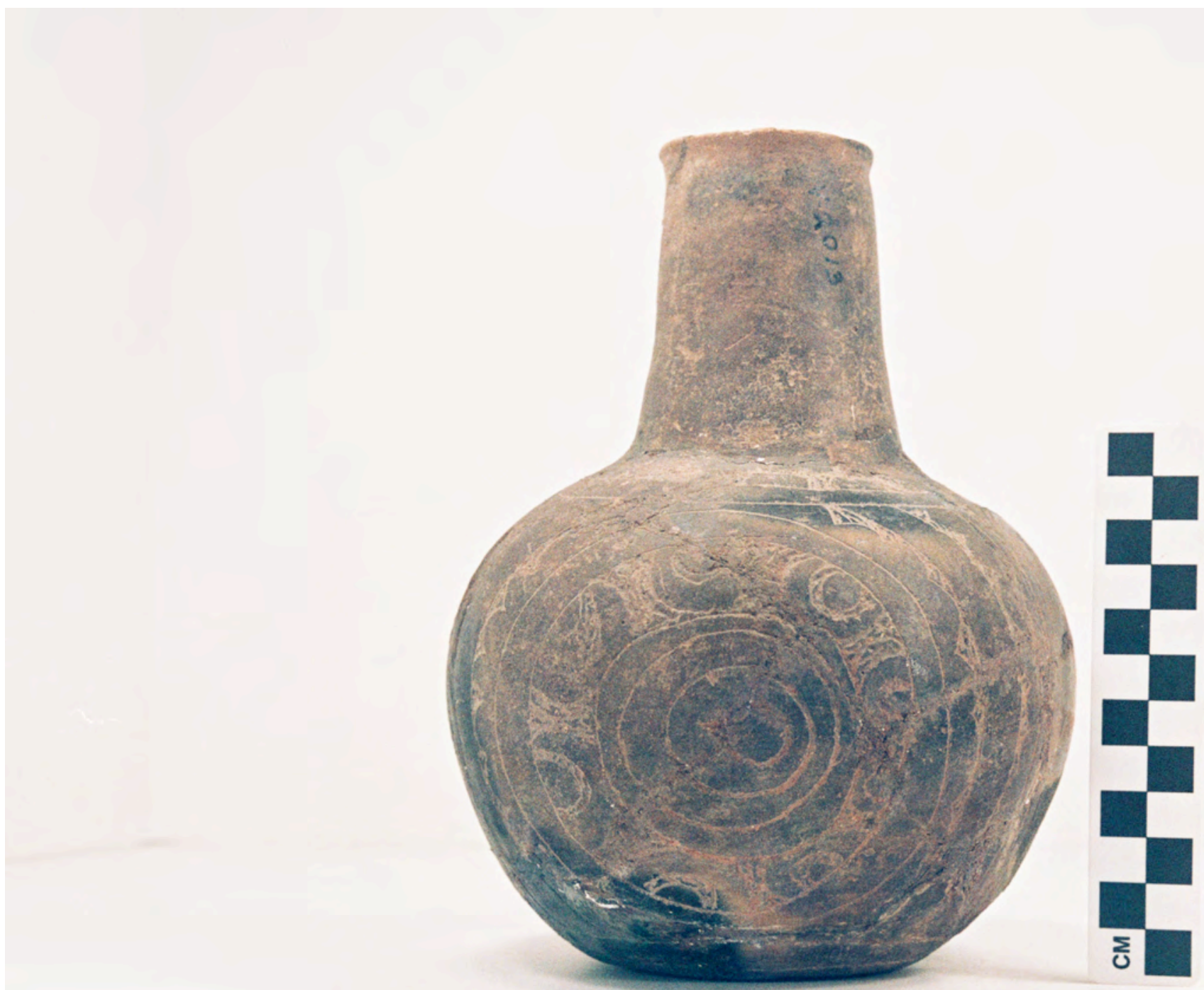

Figure A1-30a 


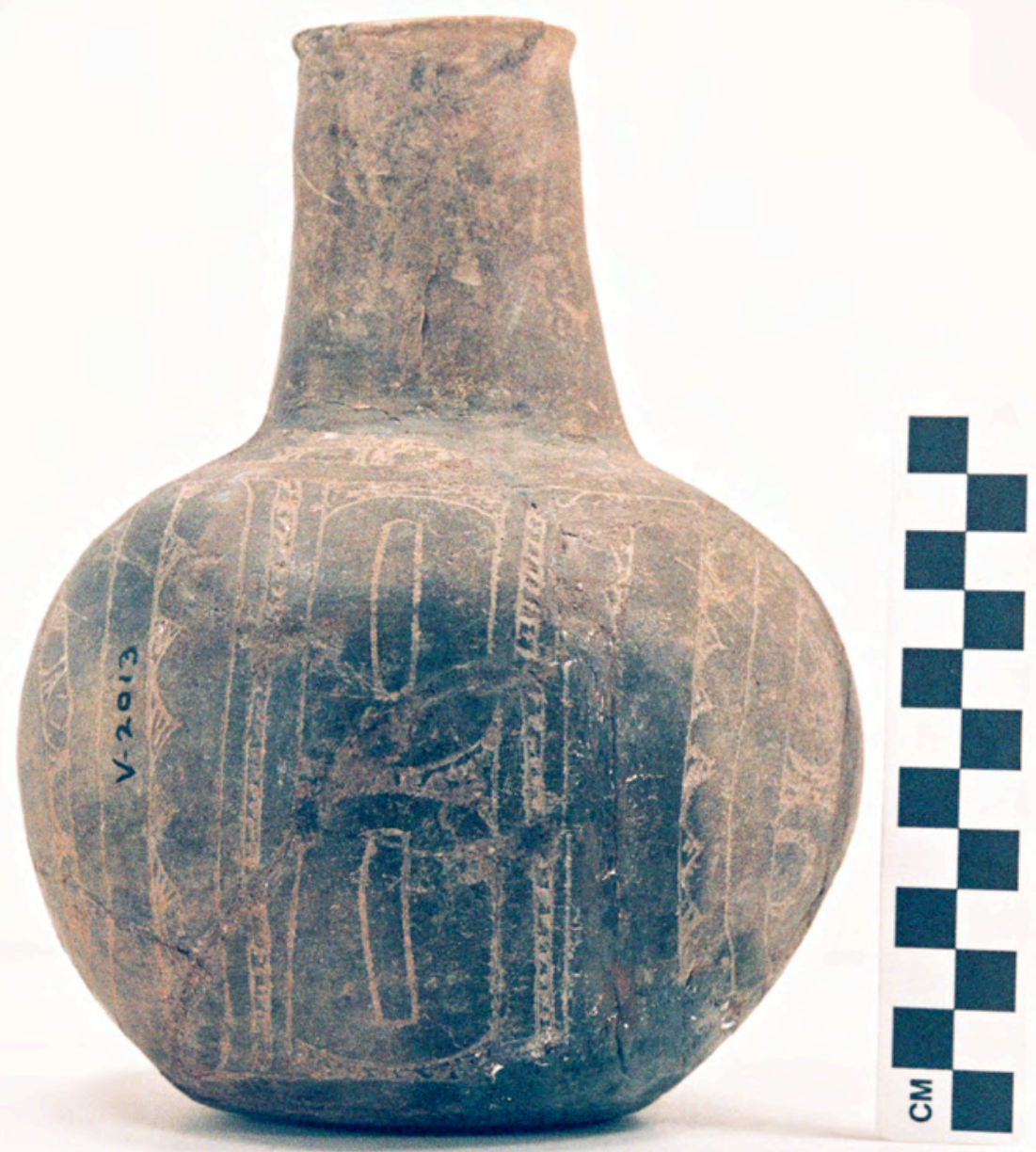

Figure A1-30b 


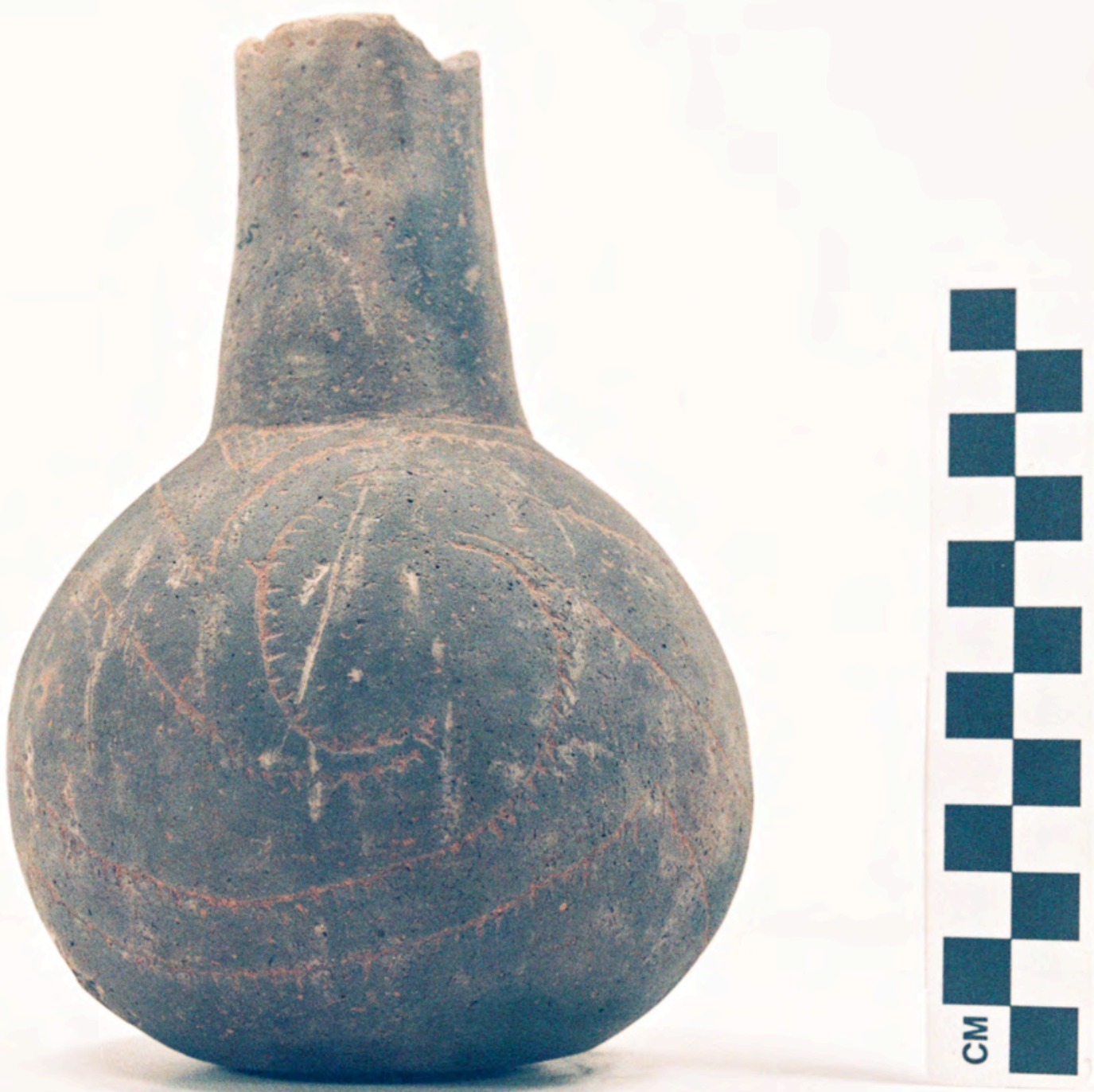

Figure A1-31 


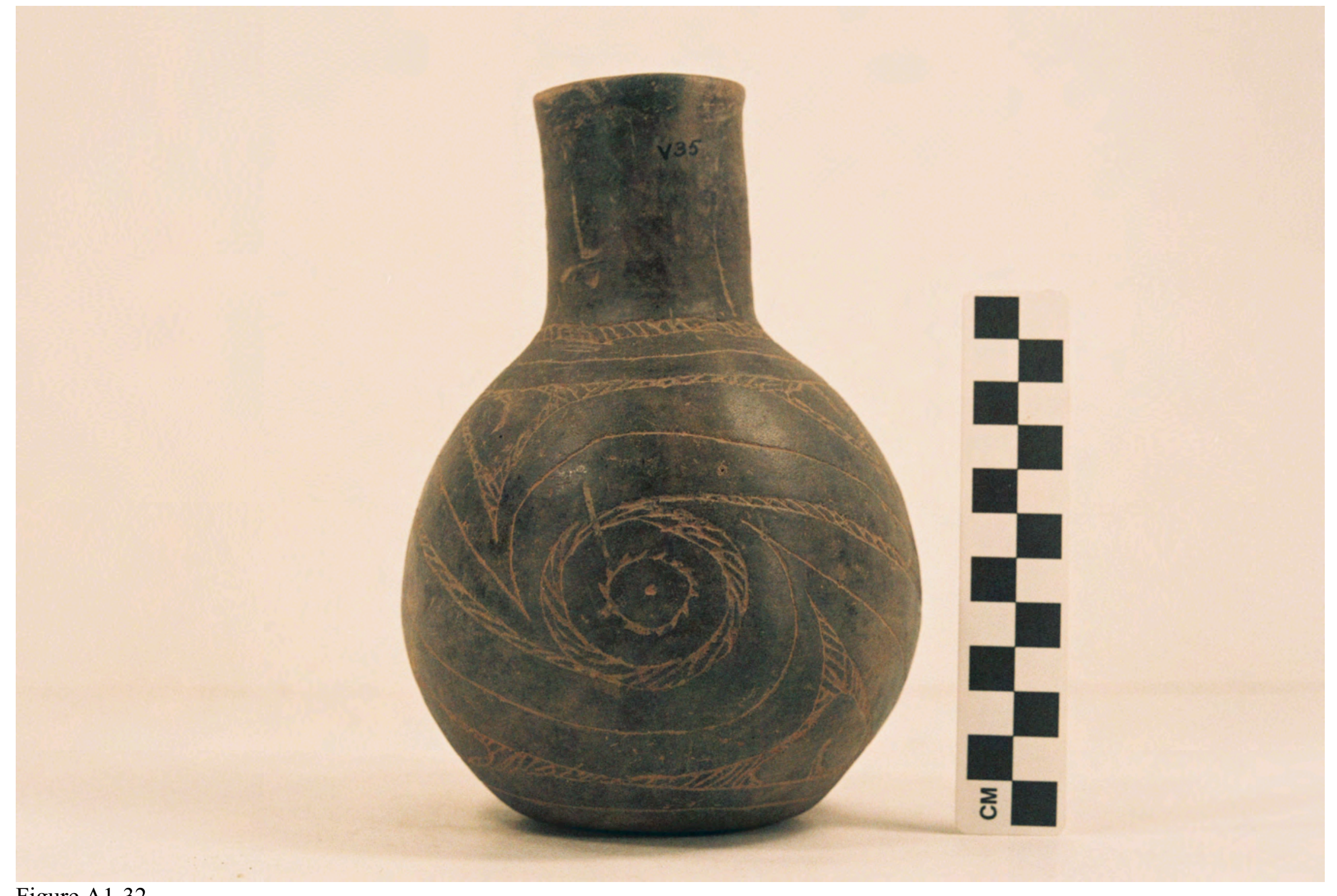

Figure A1-32 


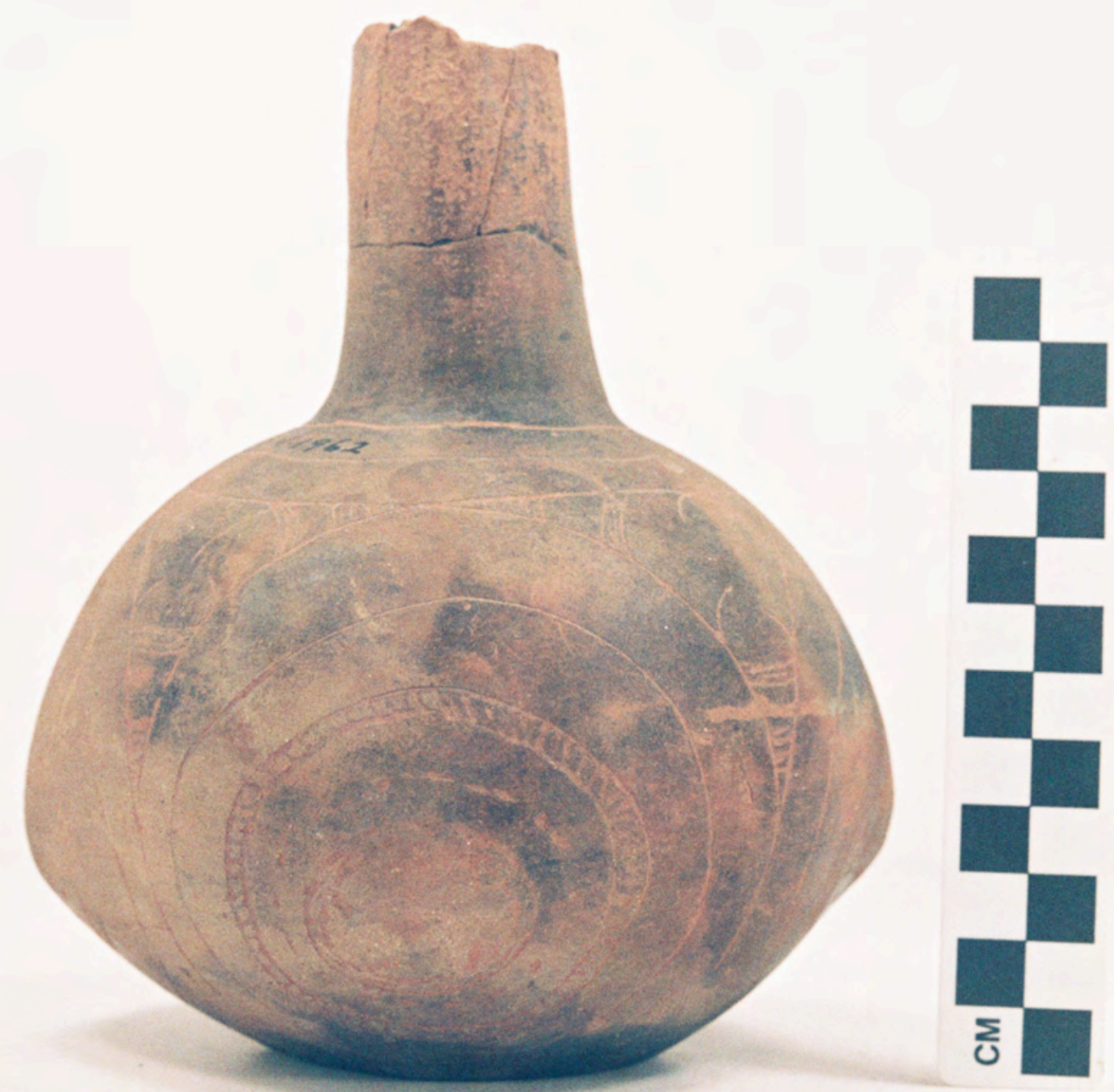

Figure A1-33 


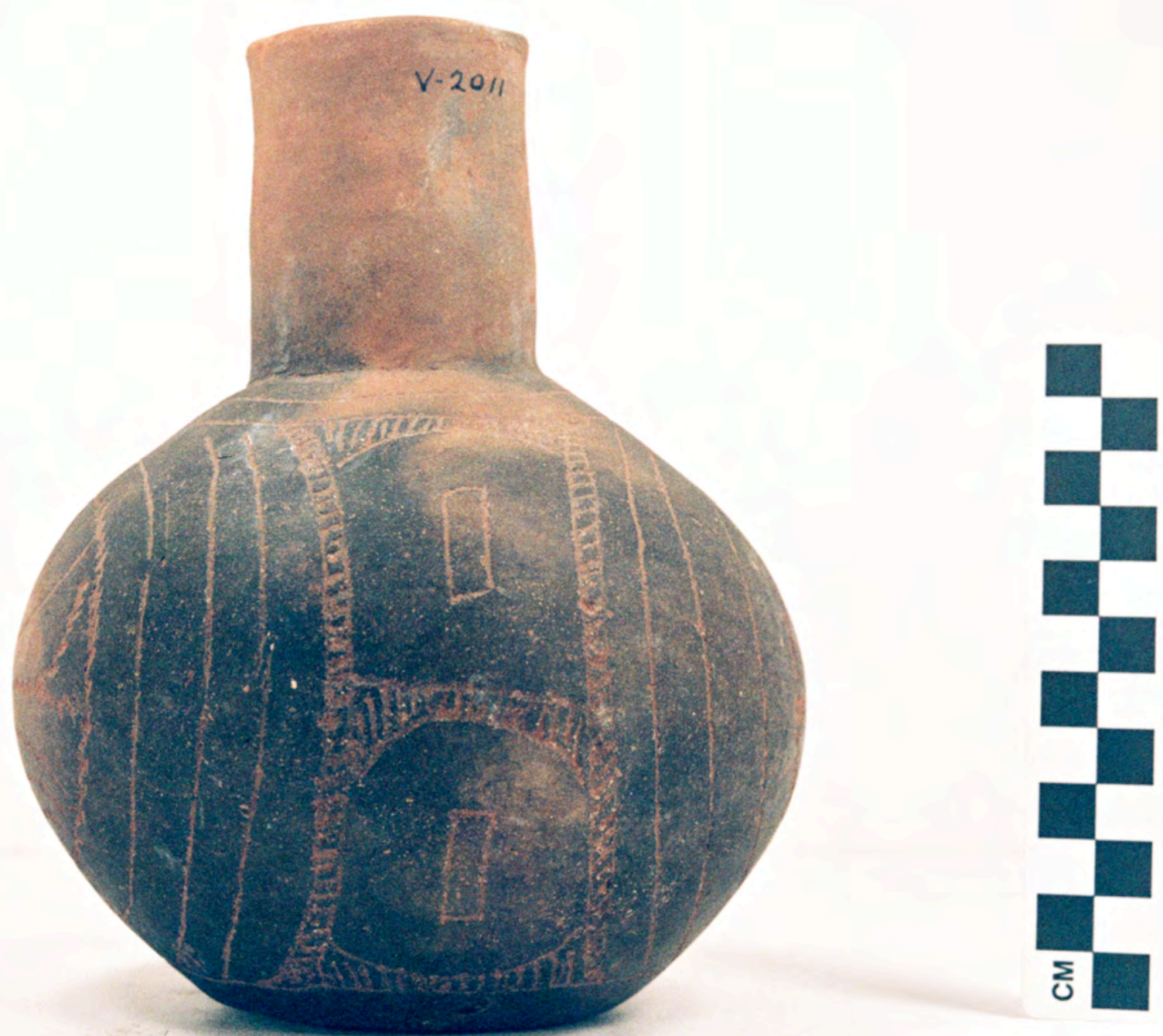

Figure A1-34a 


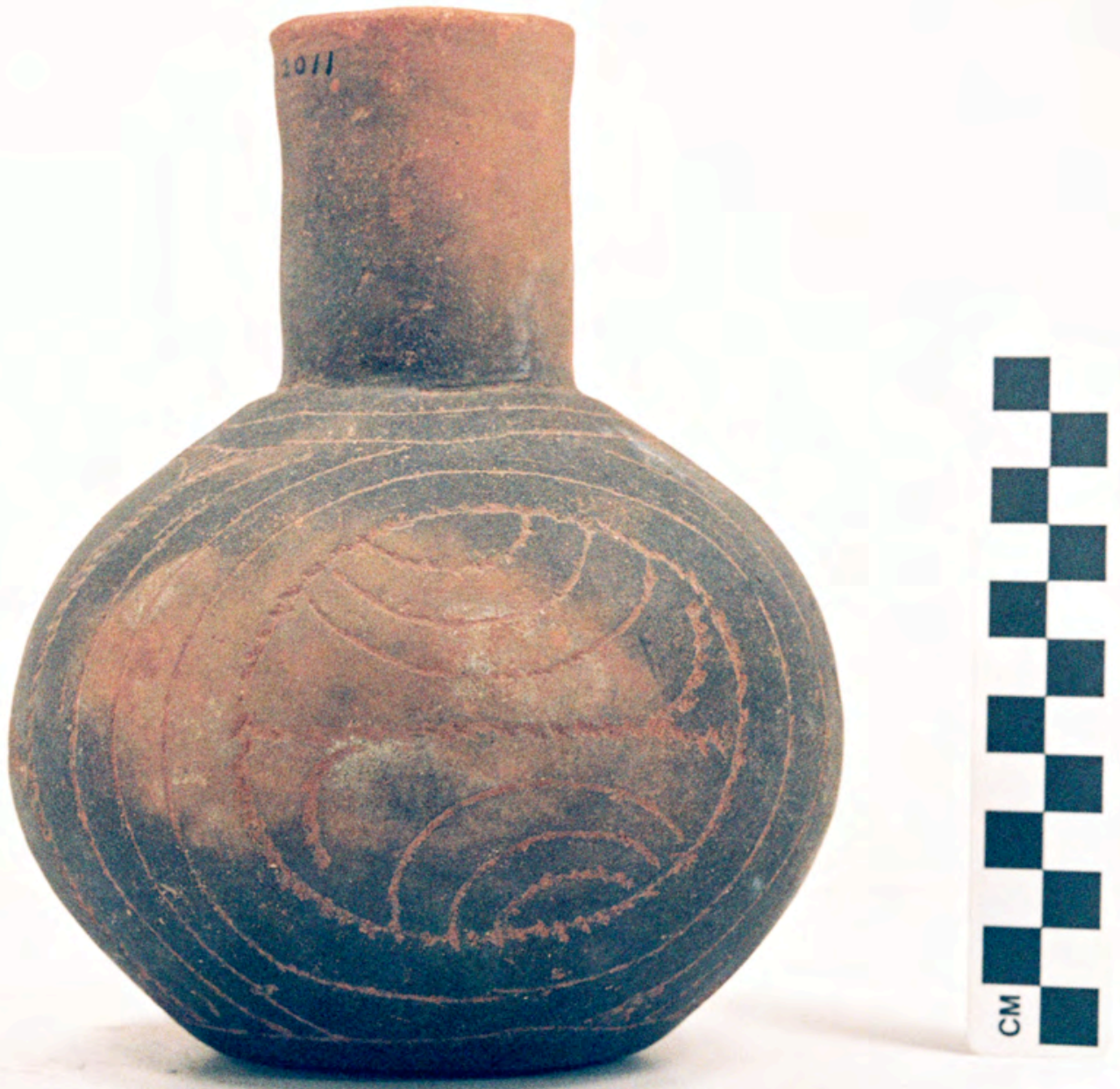

Figure A1-34b 


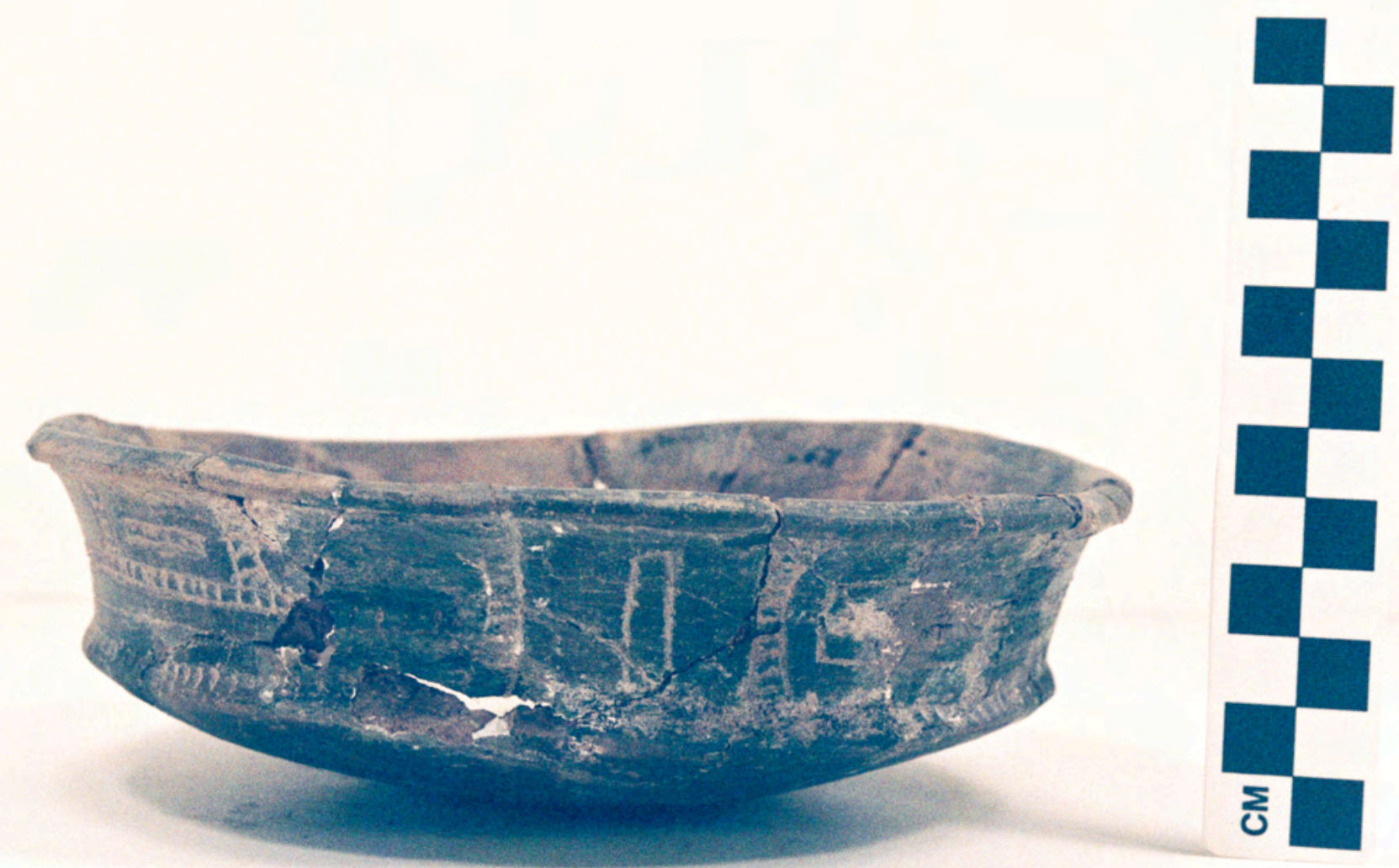

Figure A1-36 


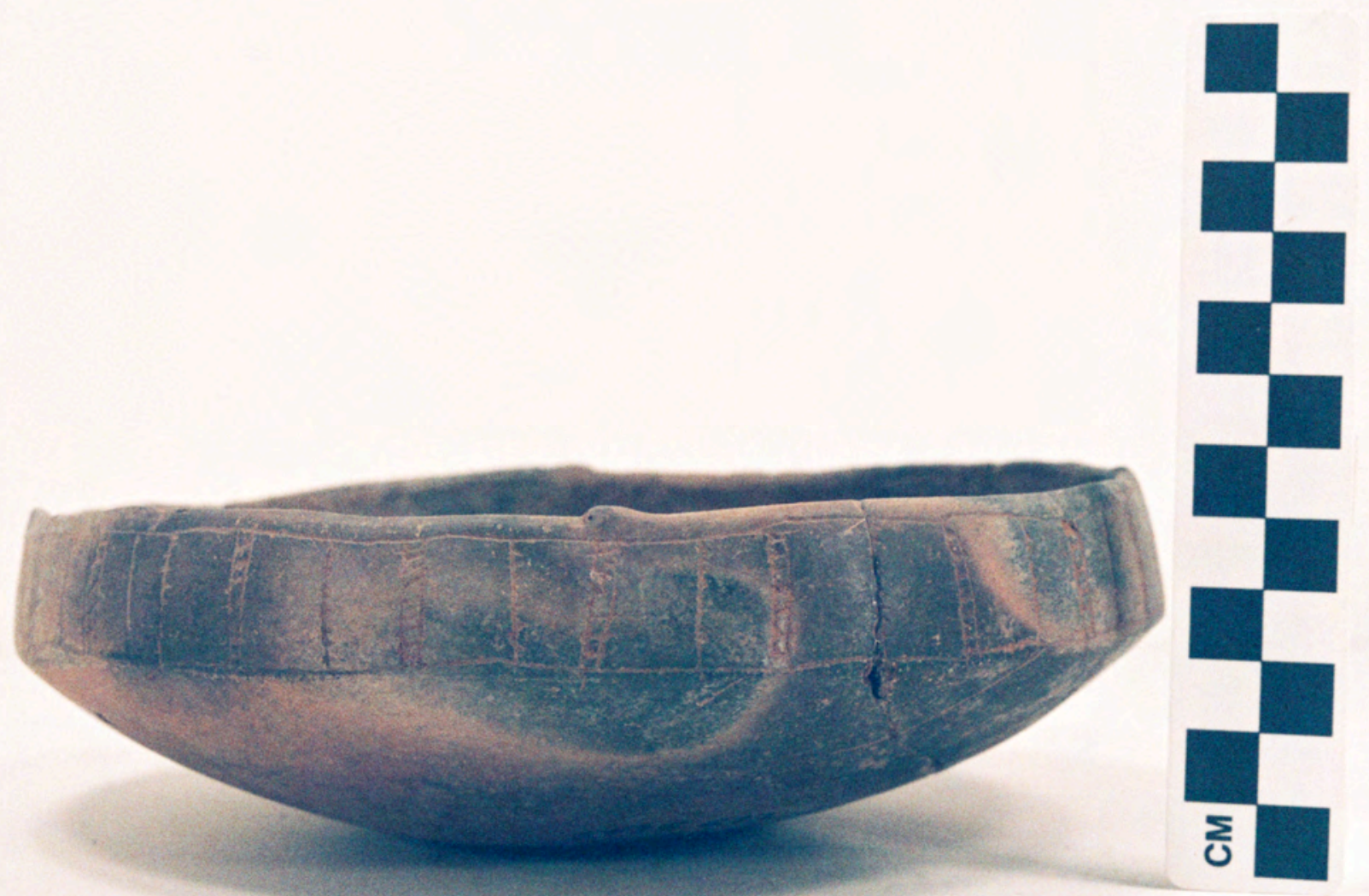

Figure A1-37 


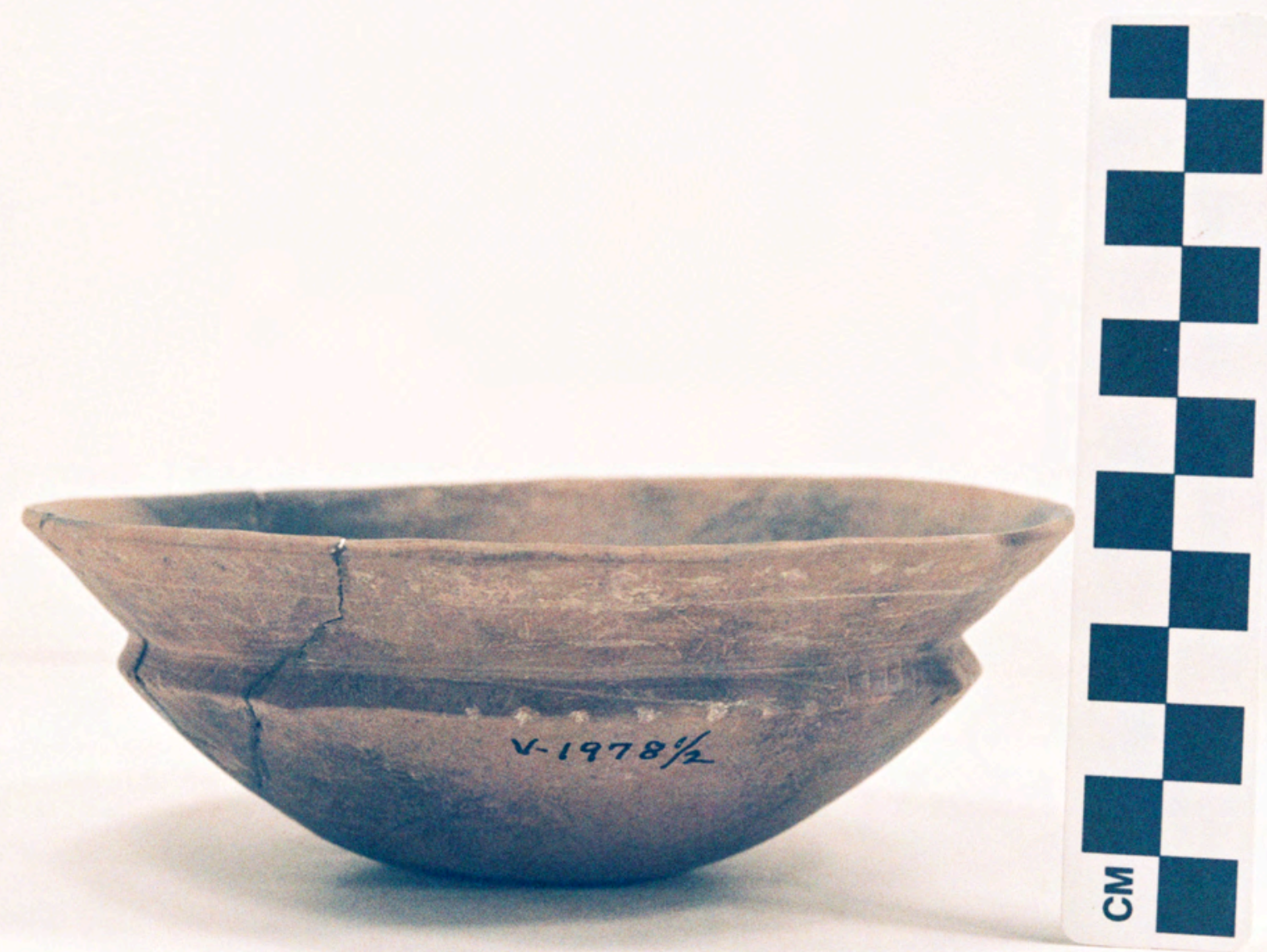

Figure A1-38a 


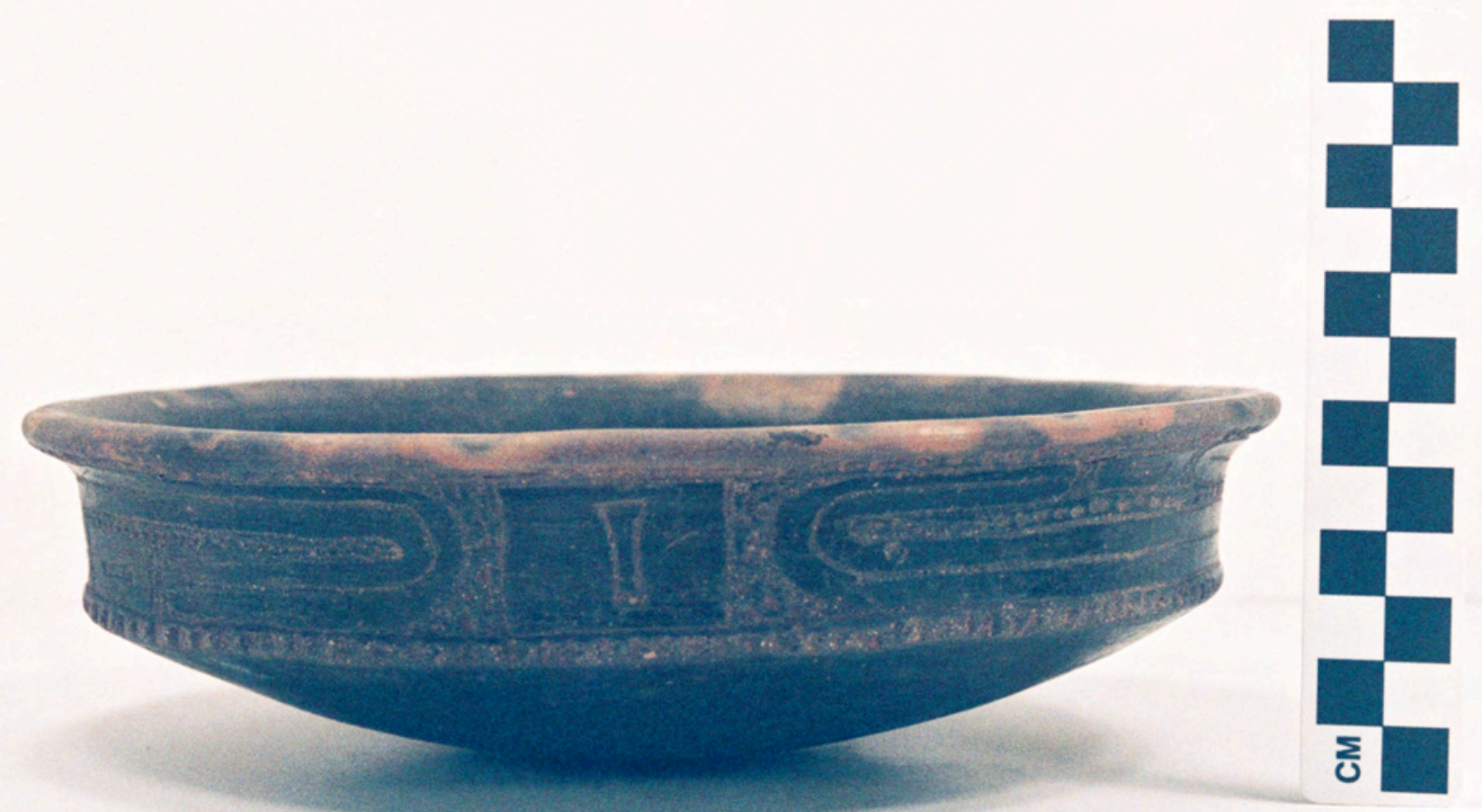

Figure A1-39a 


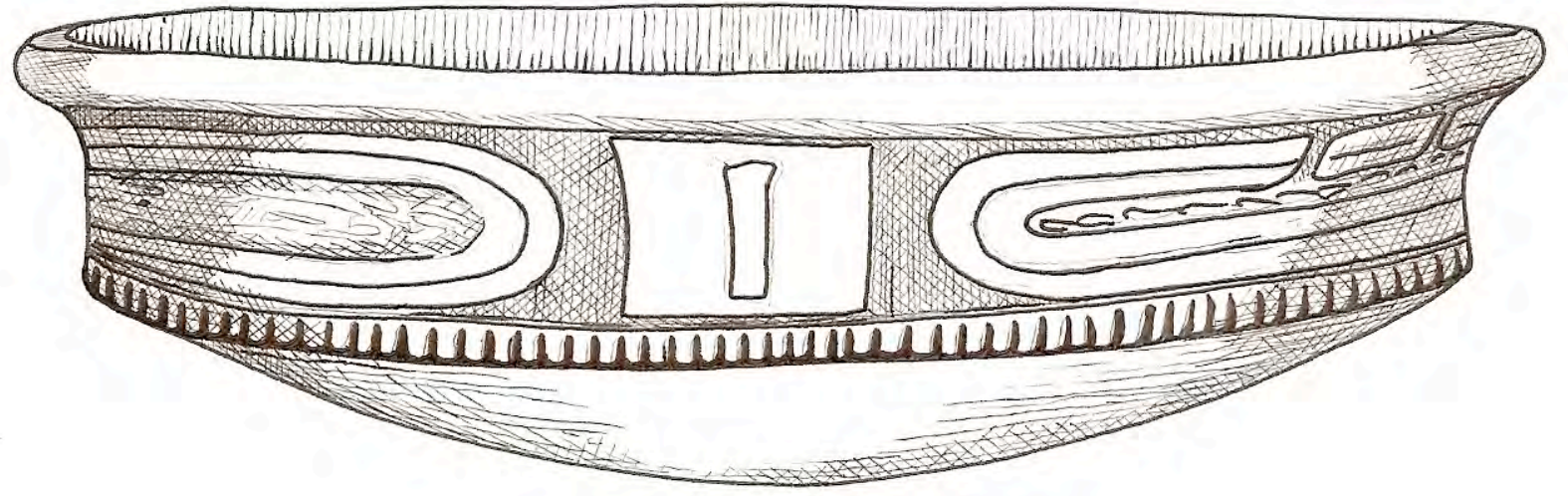

Figure A1-39. Handy Engraved carinated bowl (5425-675): b, drawing by Bobby Gonzalez.

Figure A1-39b 


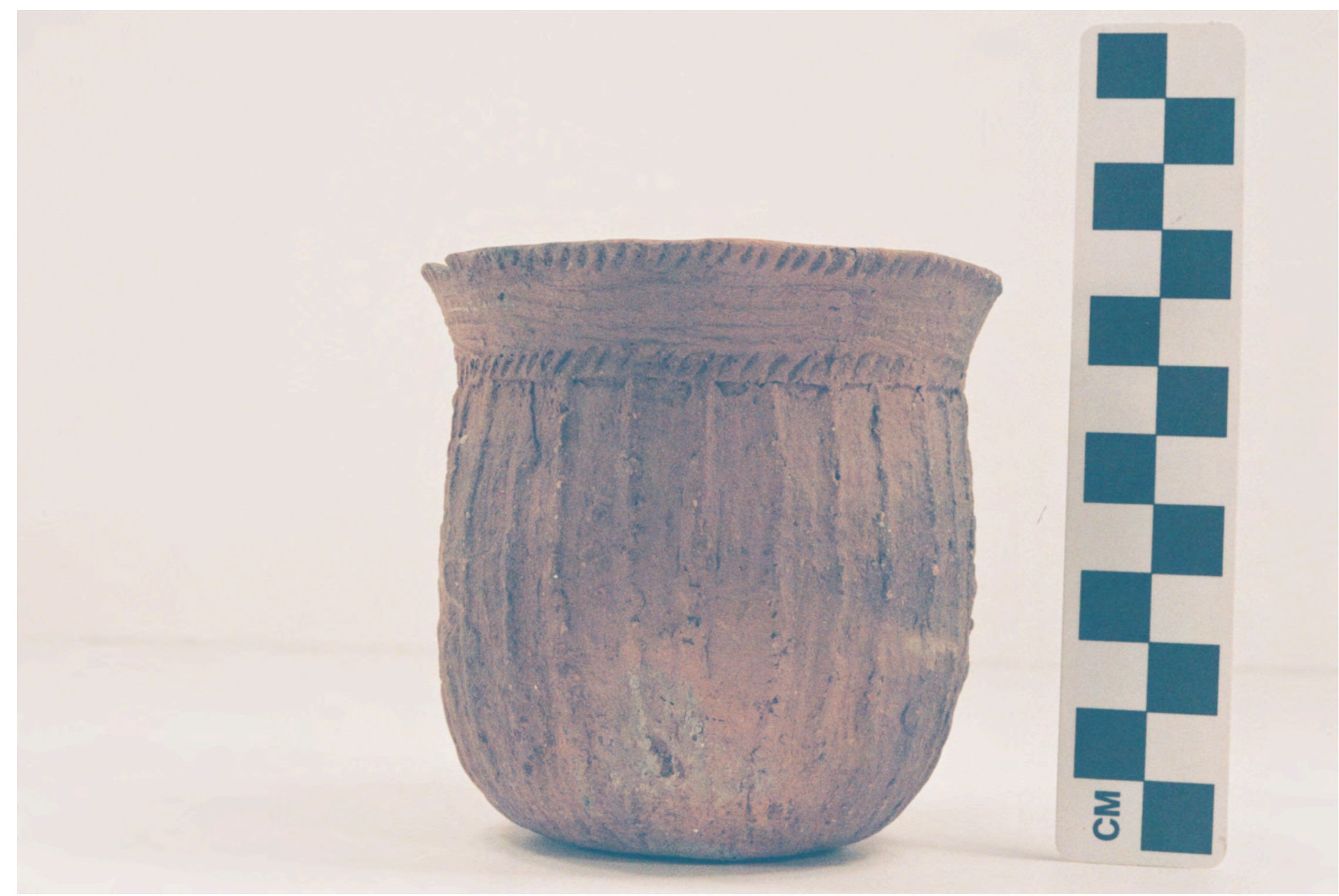

Figure A1-40 


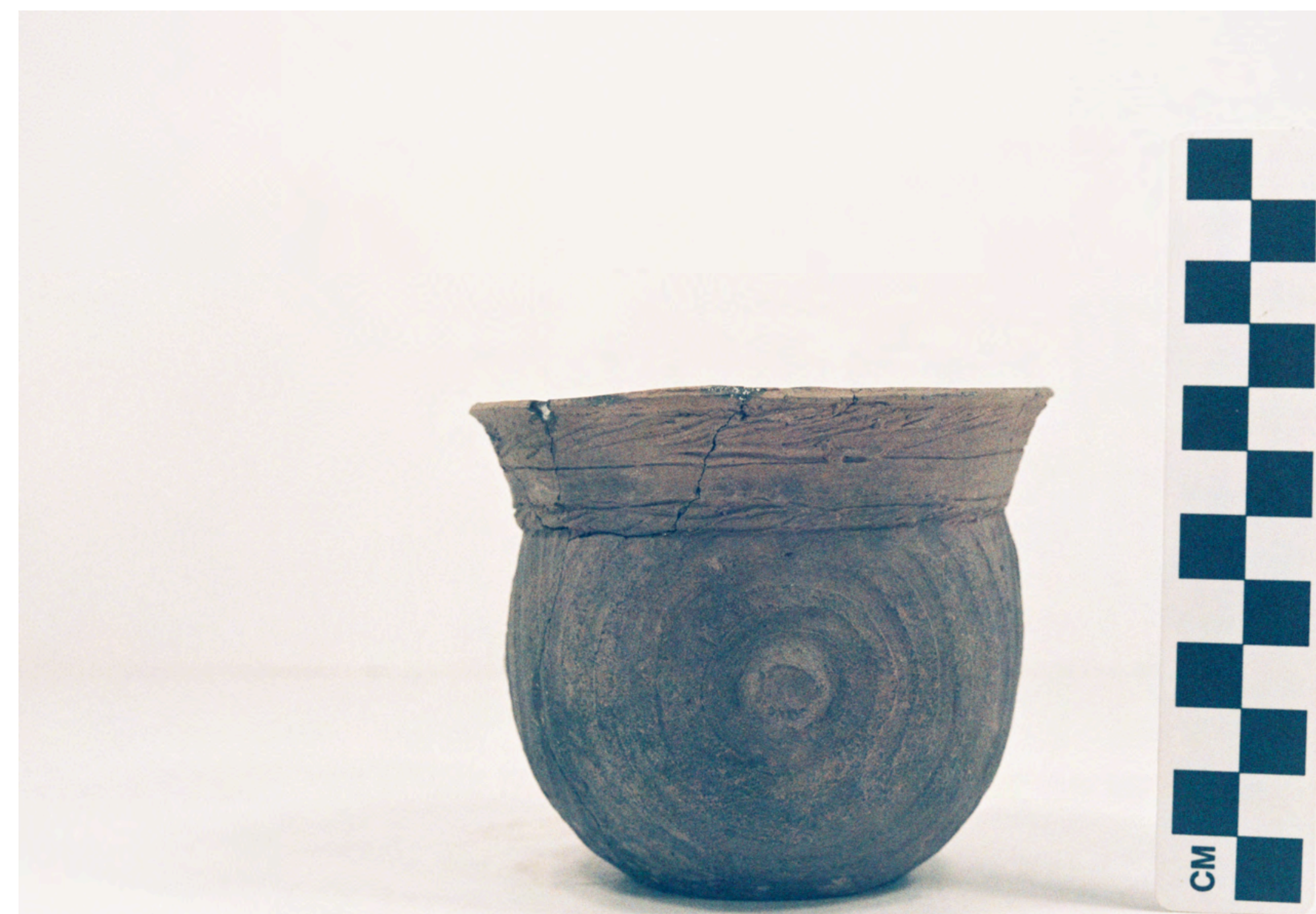

Figure A1-41 

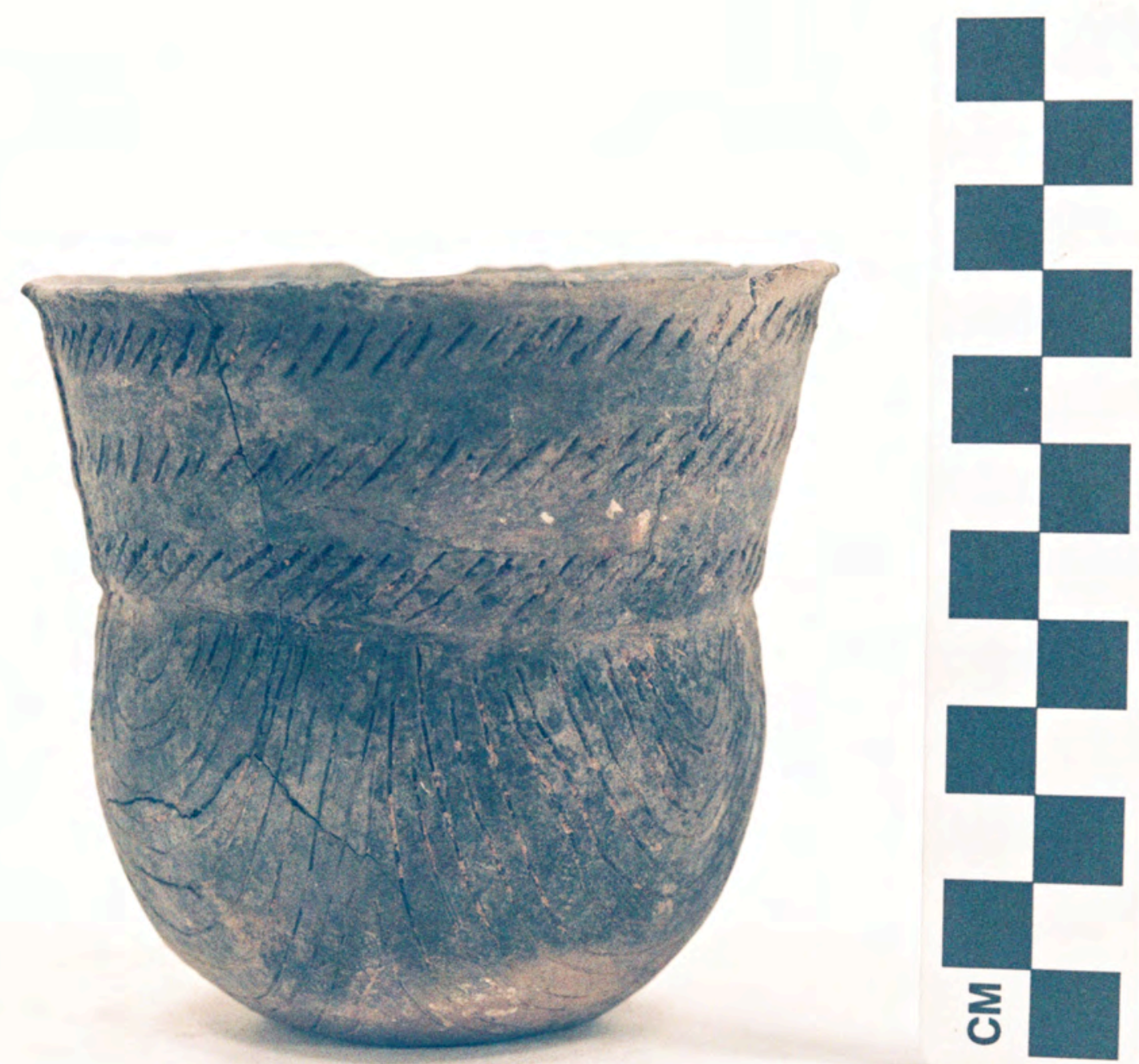

Figure A1-42 


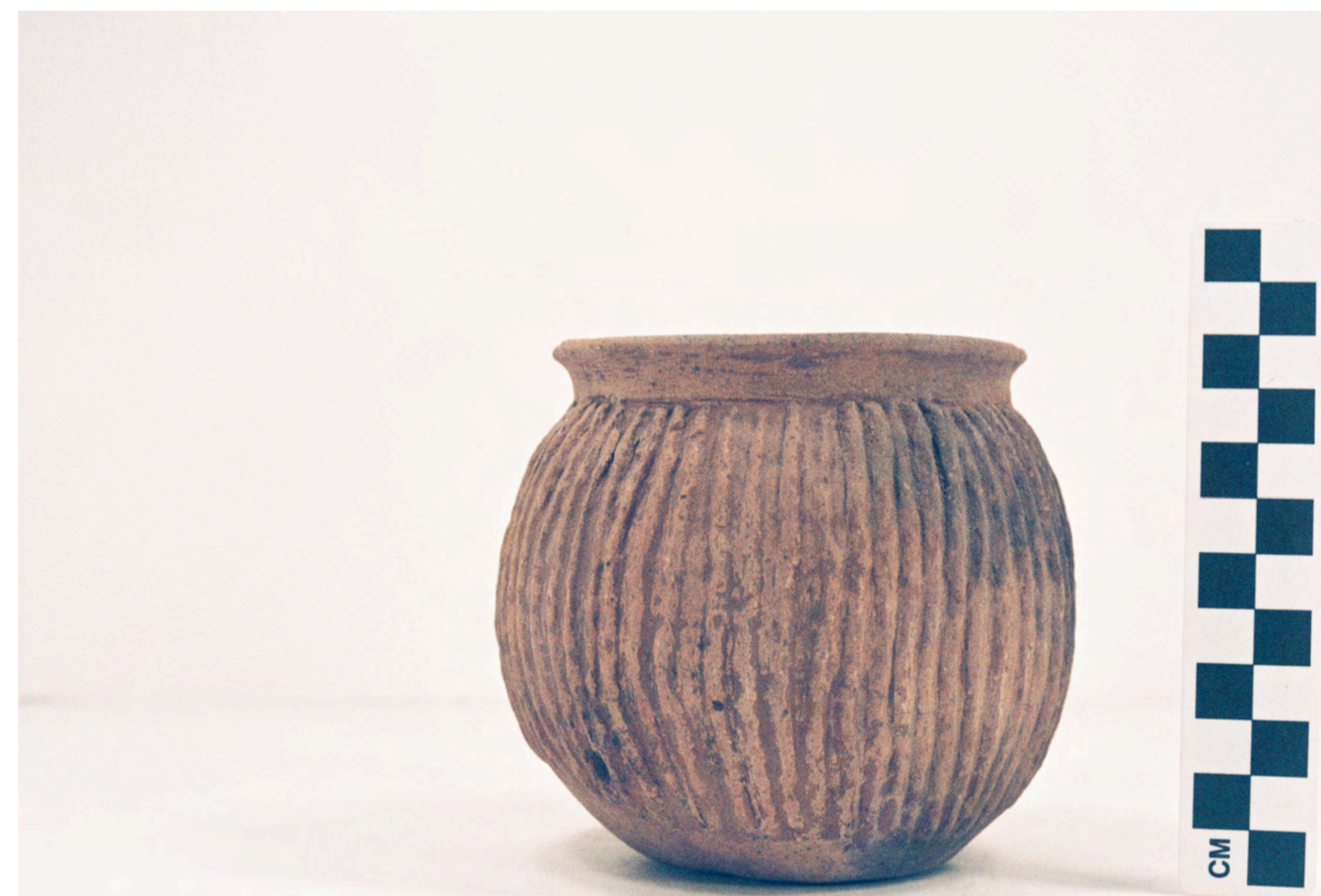

Figure A1-43 


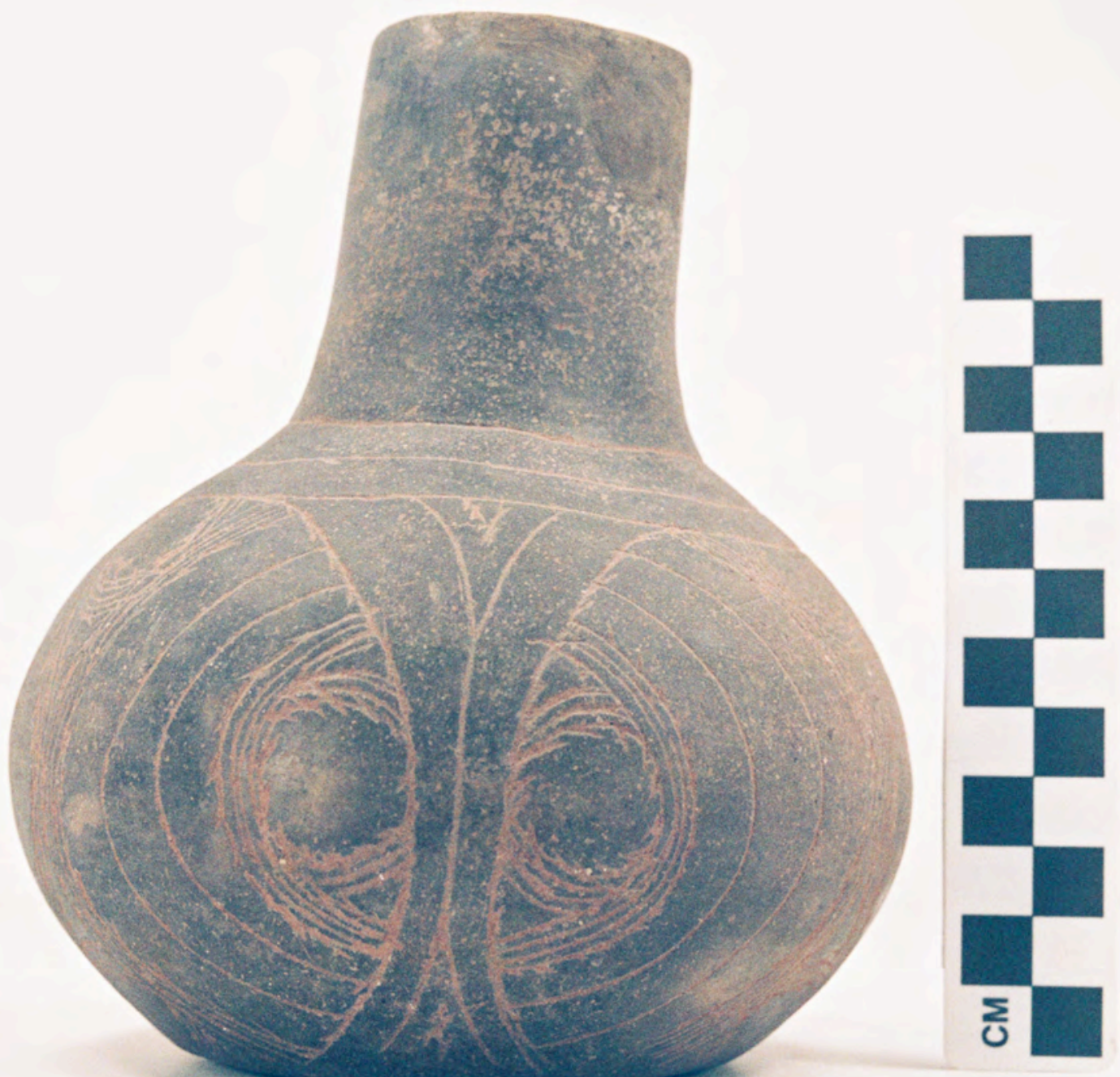

Figure A1-44 


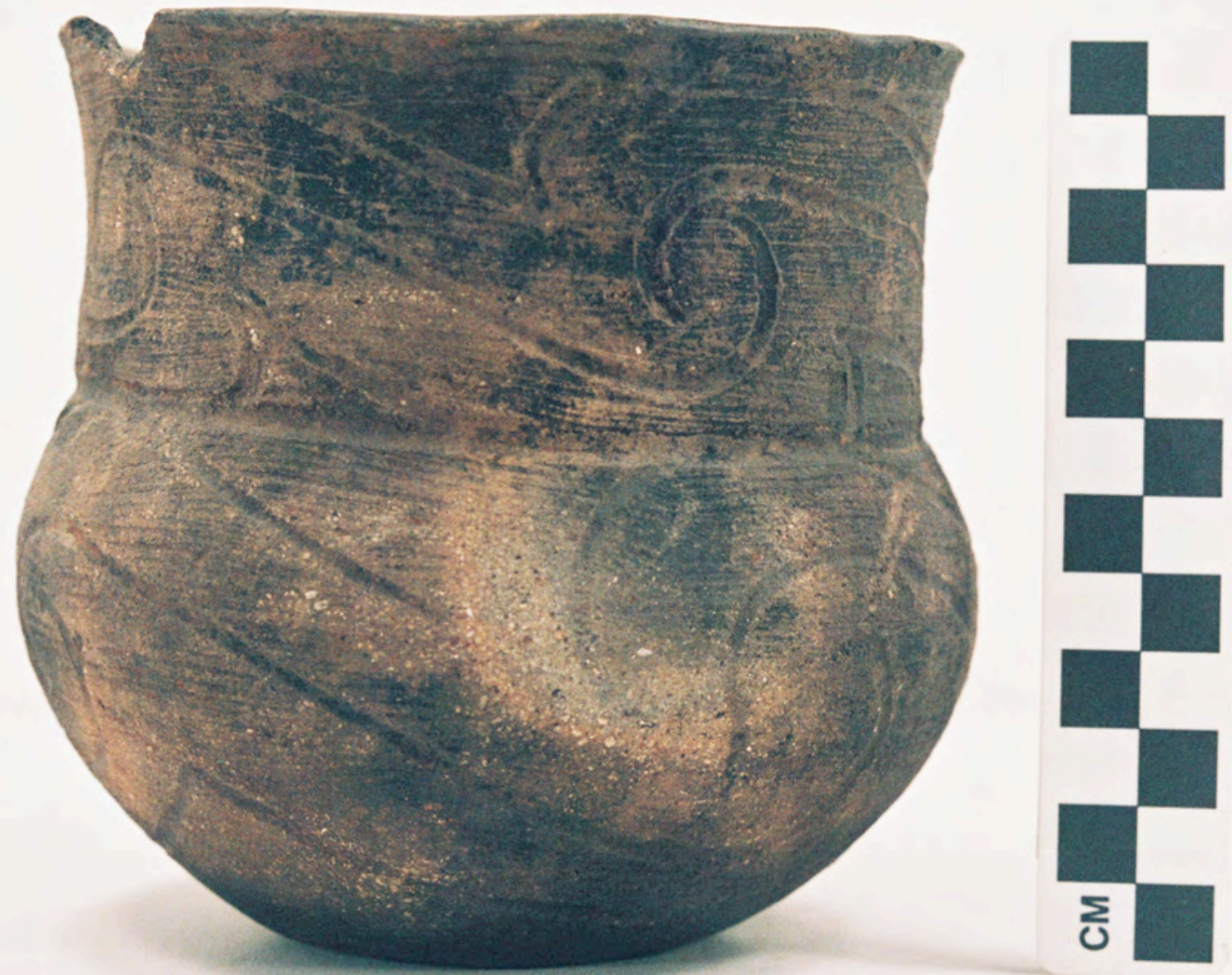

Figure A1-45 


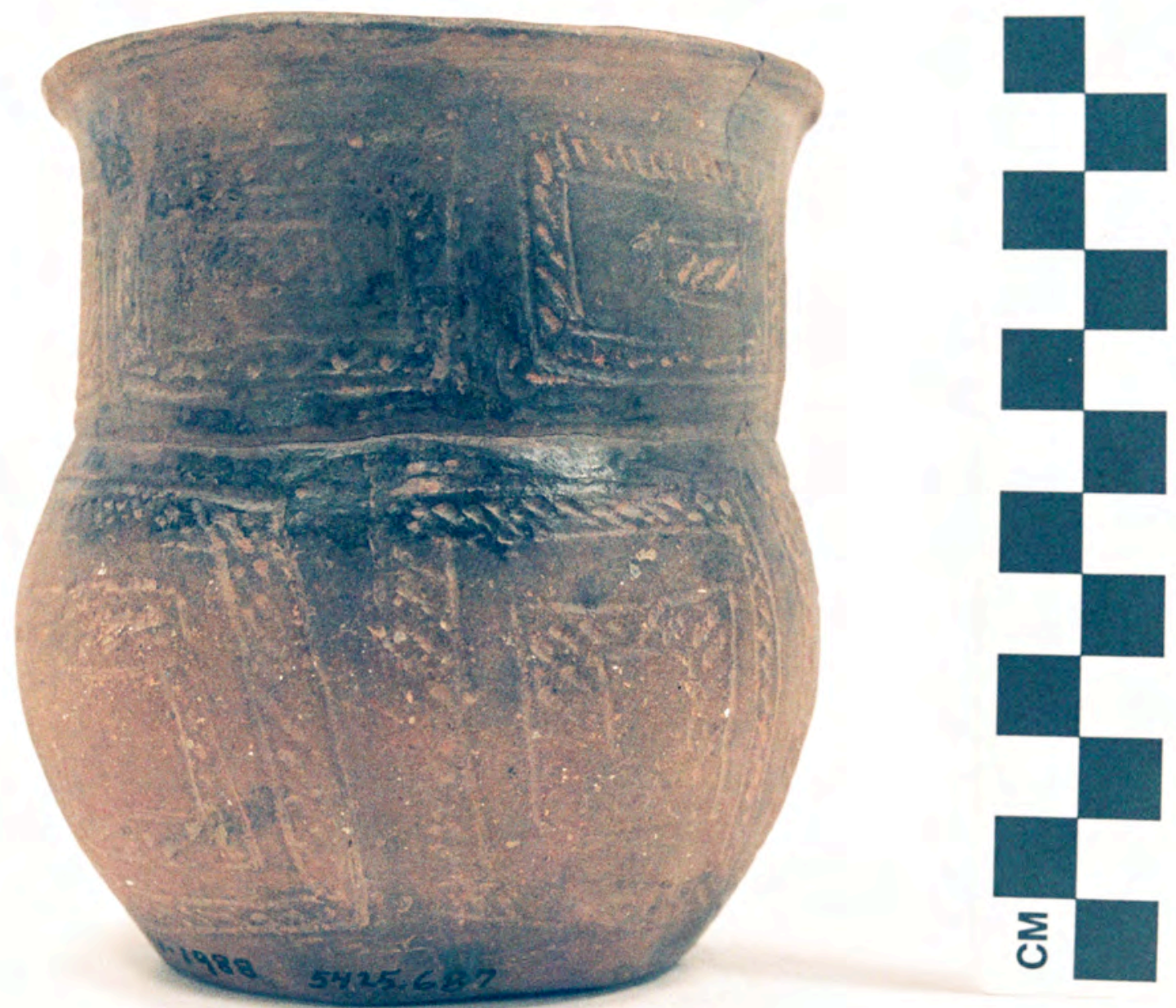

Figure A1-46 


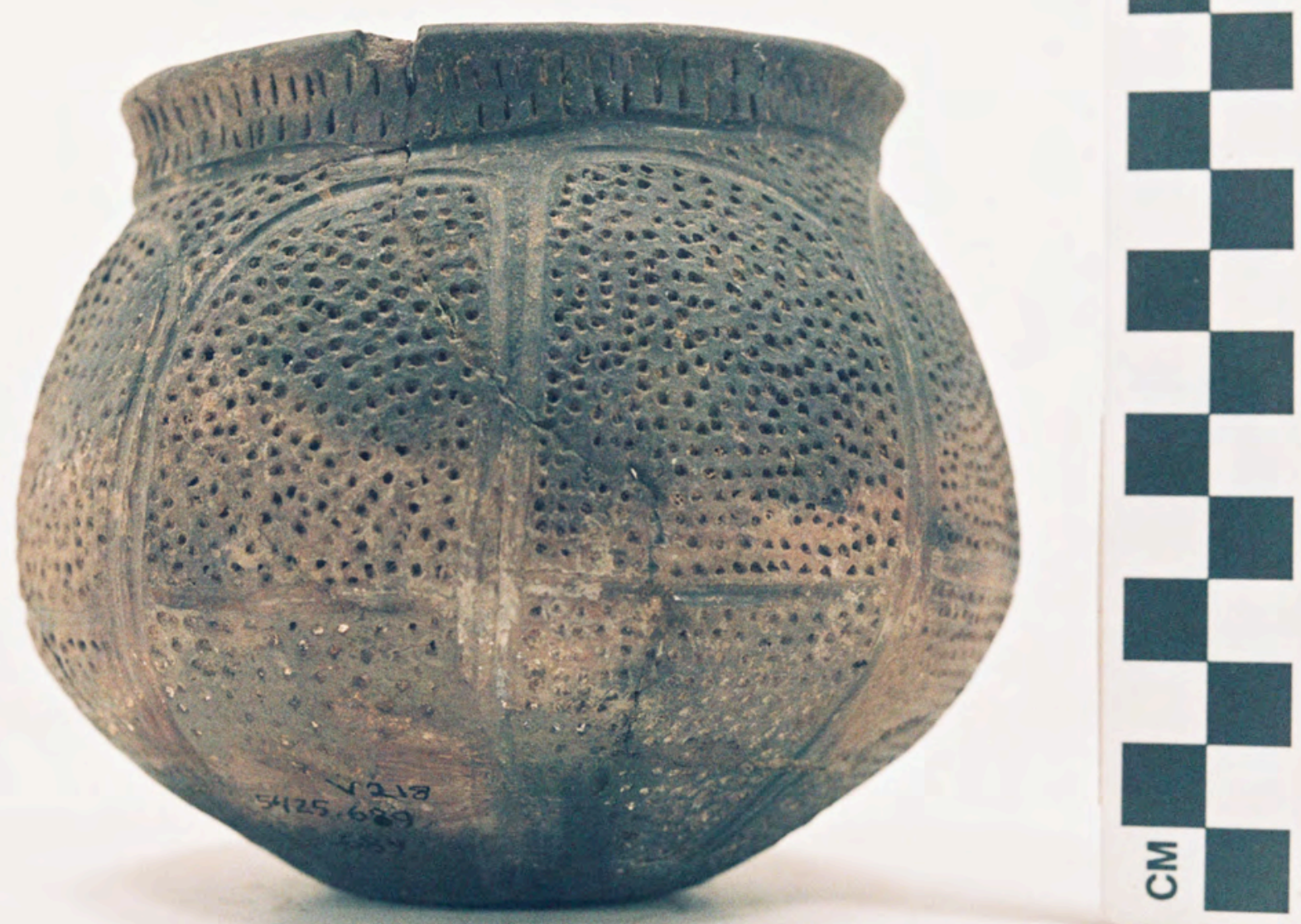

Figure A1-47 


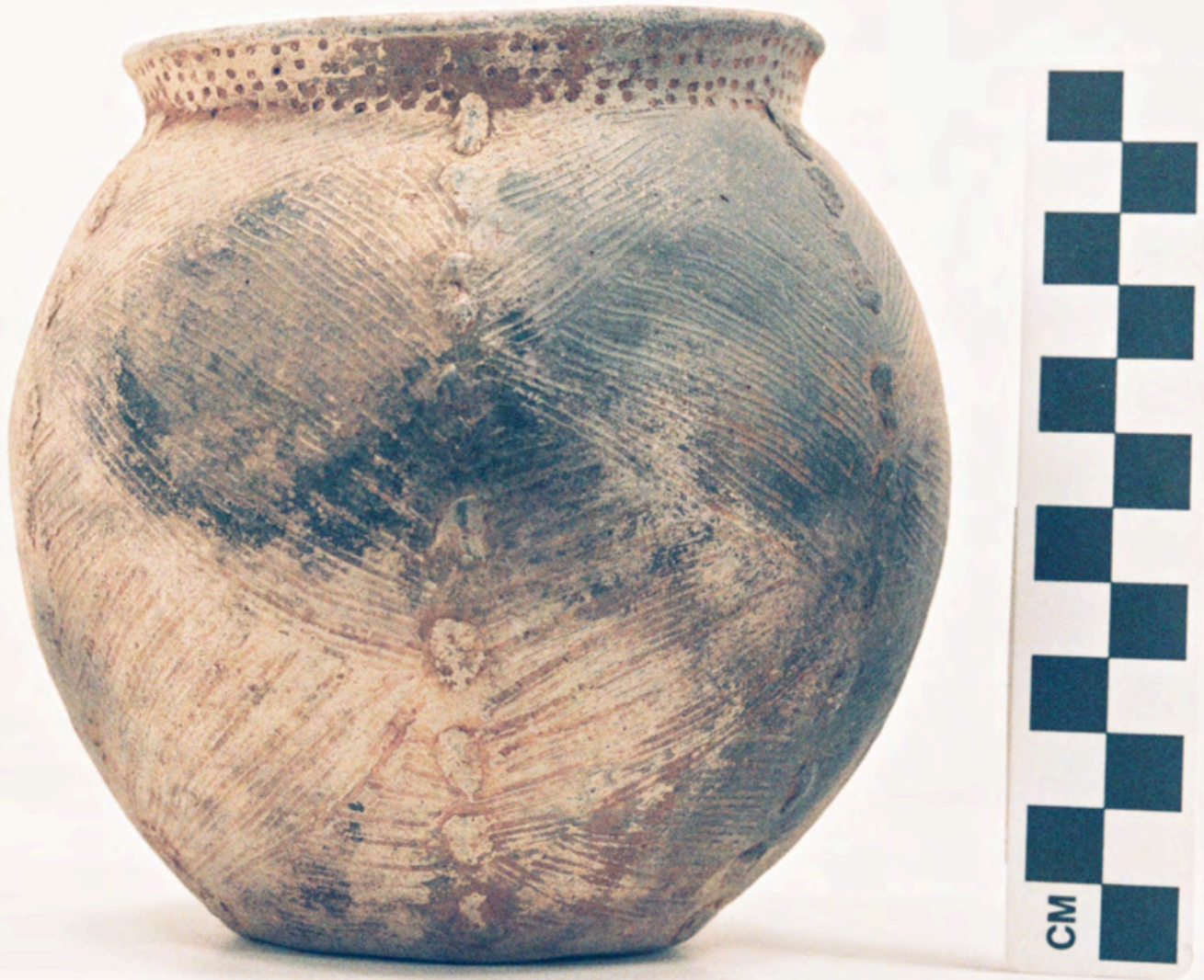

Figure A1-48 


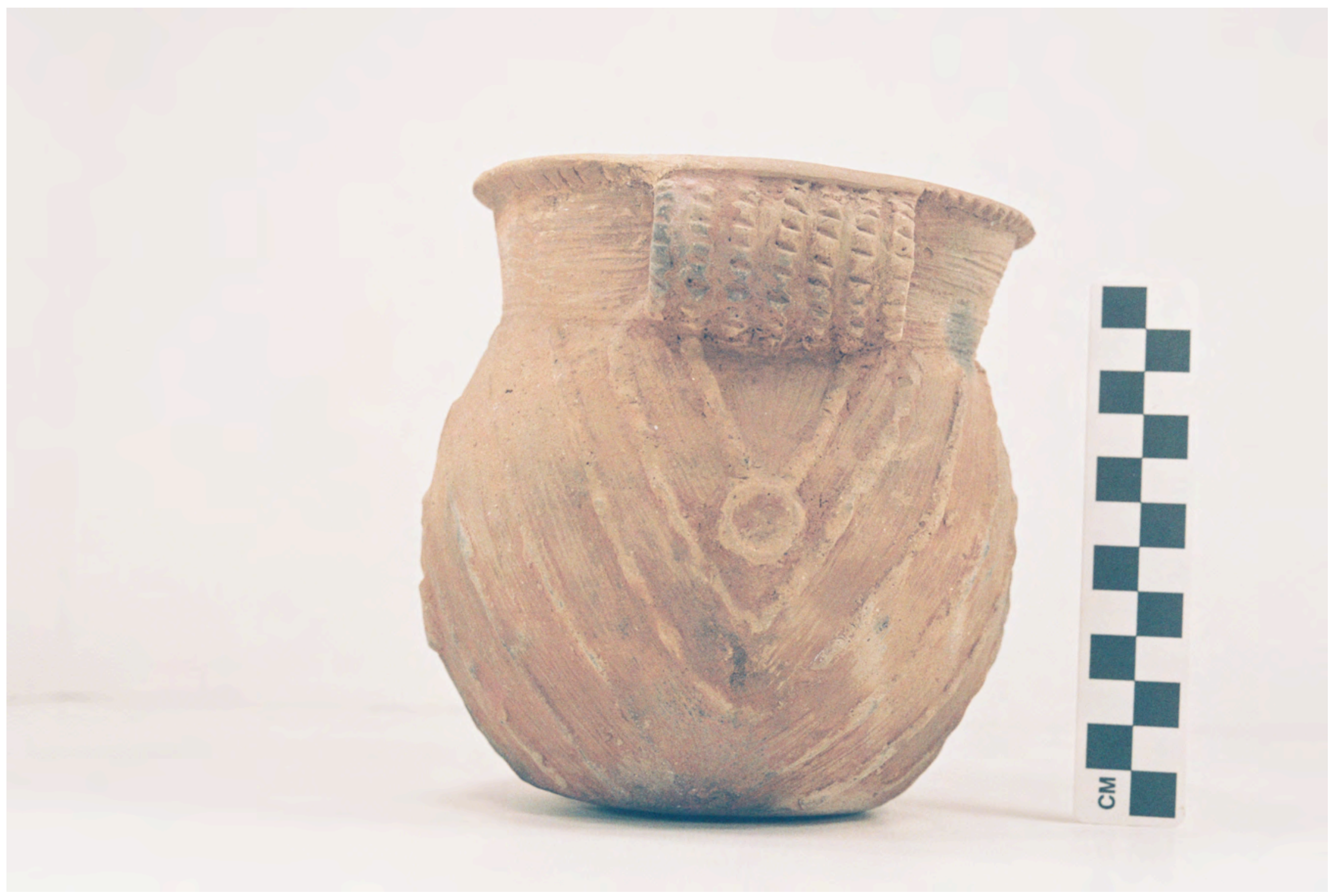

Figure A1-49 


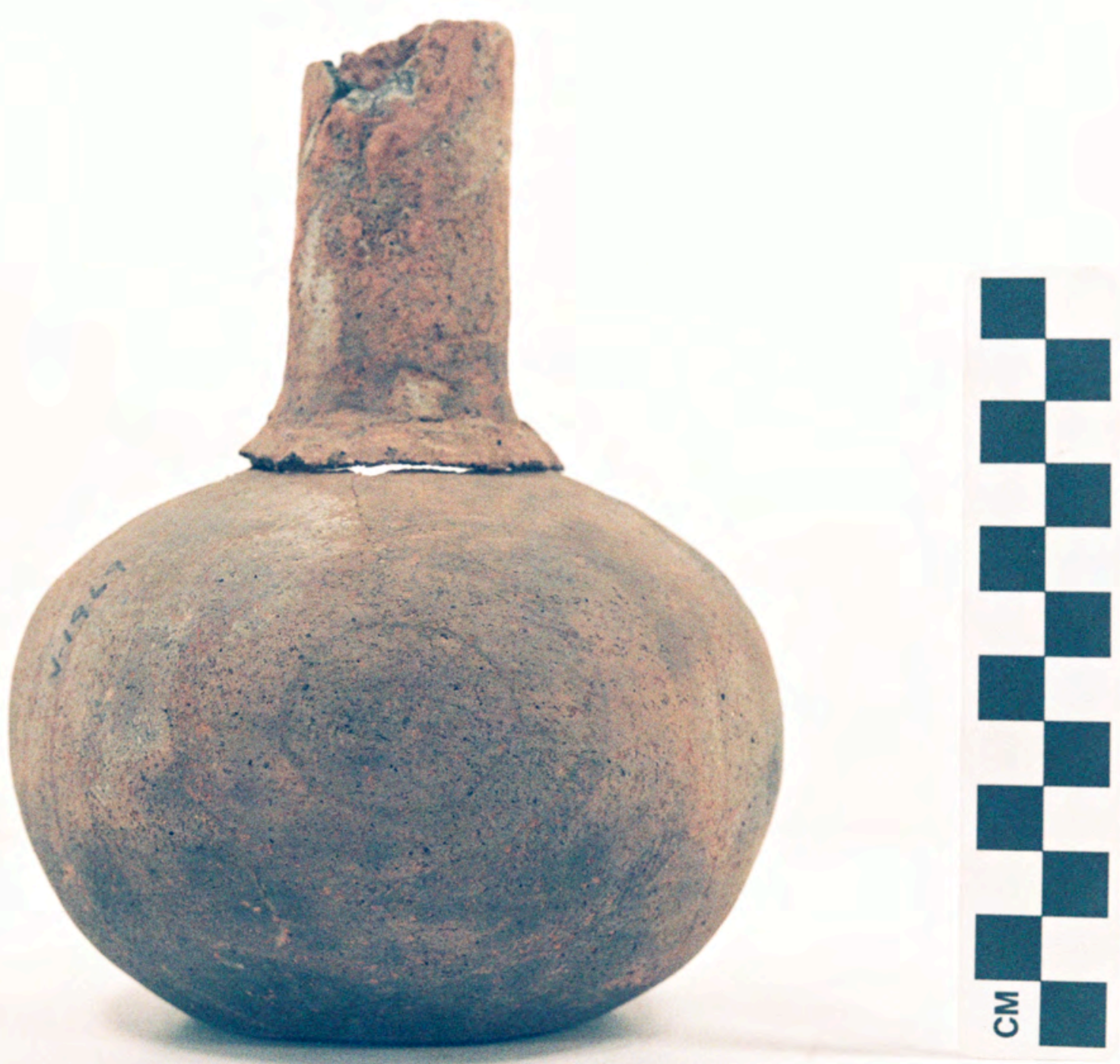

Figure A1-50 


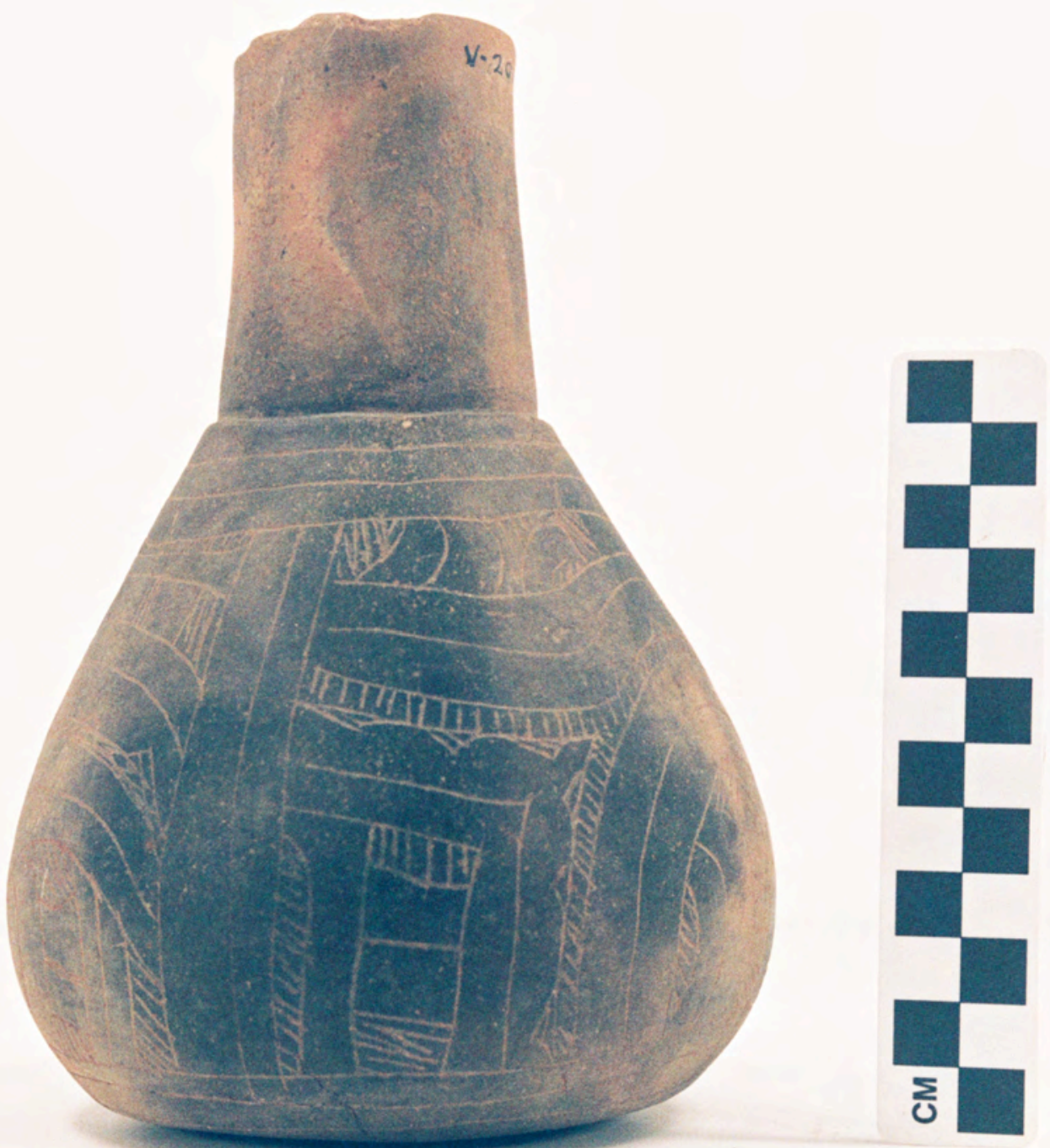

Figure A1-51 


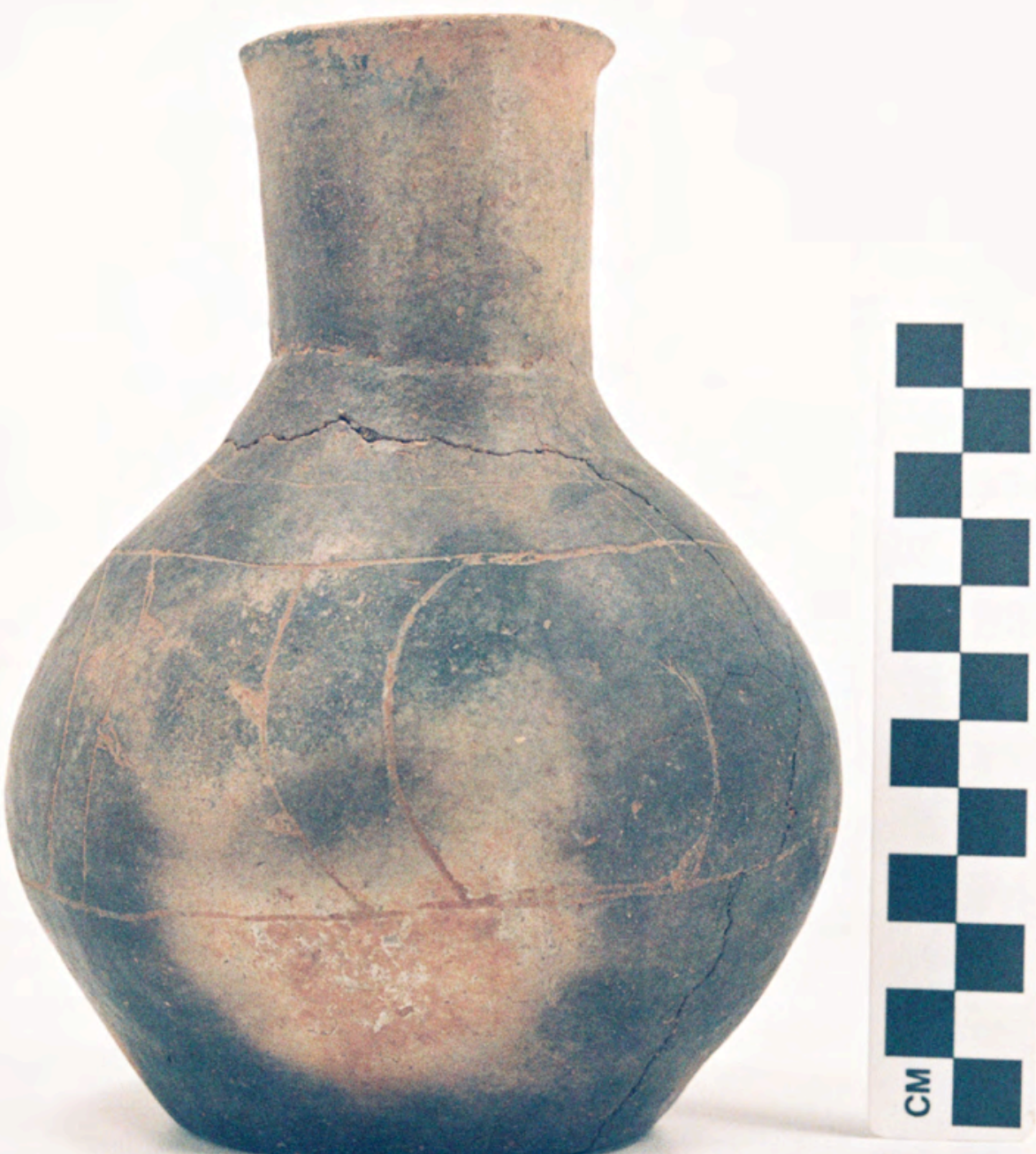

Figure A1-52 


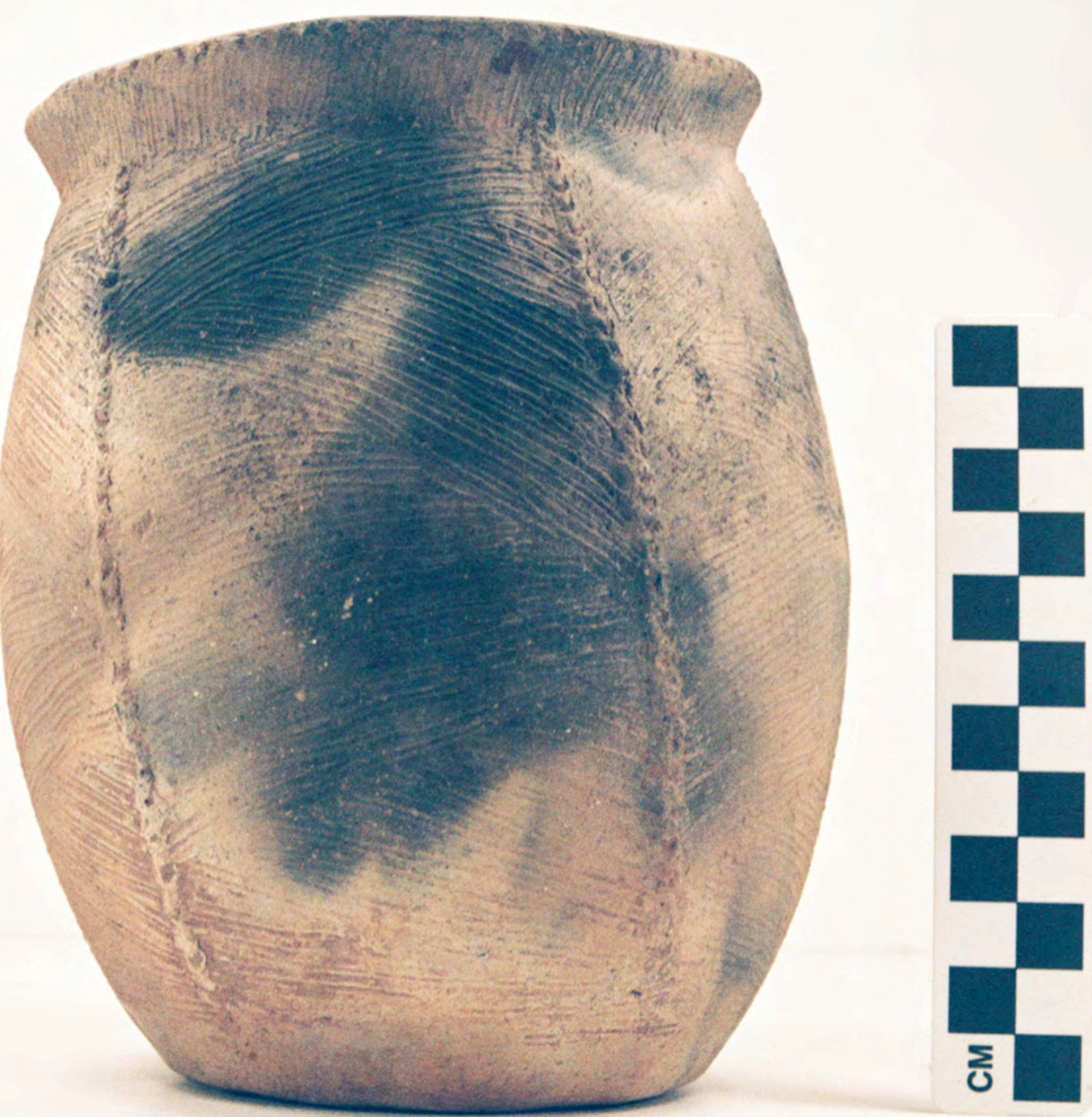

Figure A1-53 


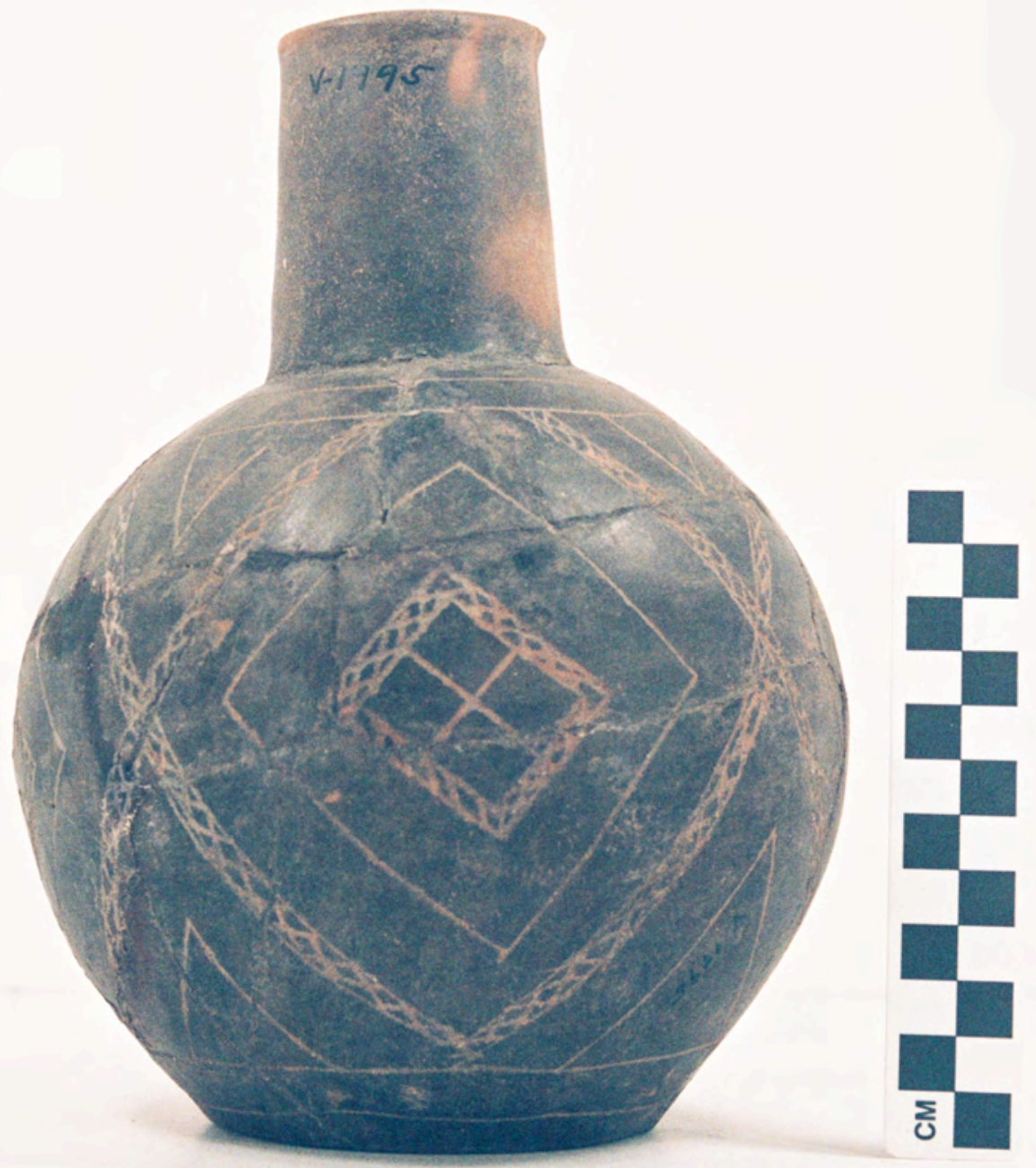

Figure A1-54 


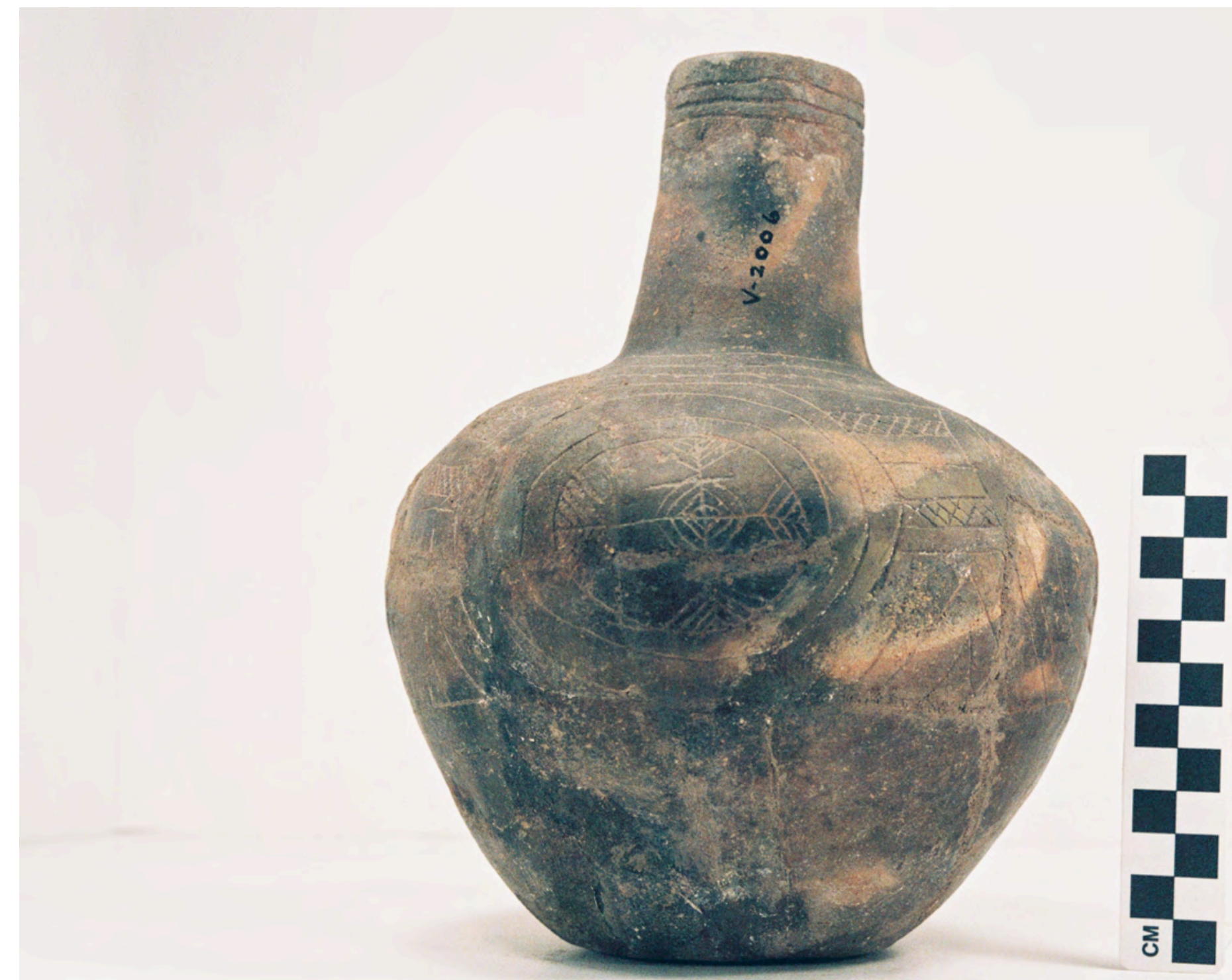

Figure A1-55 


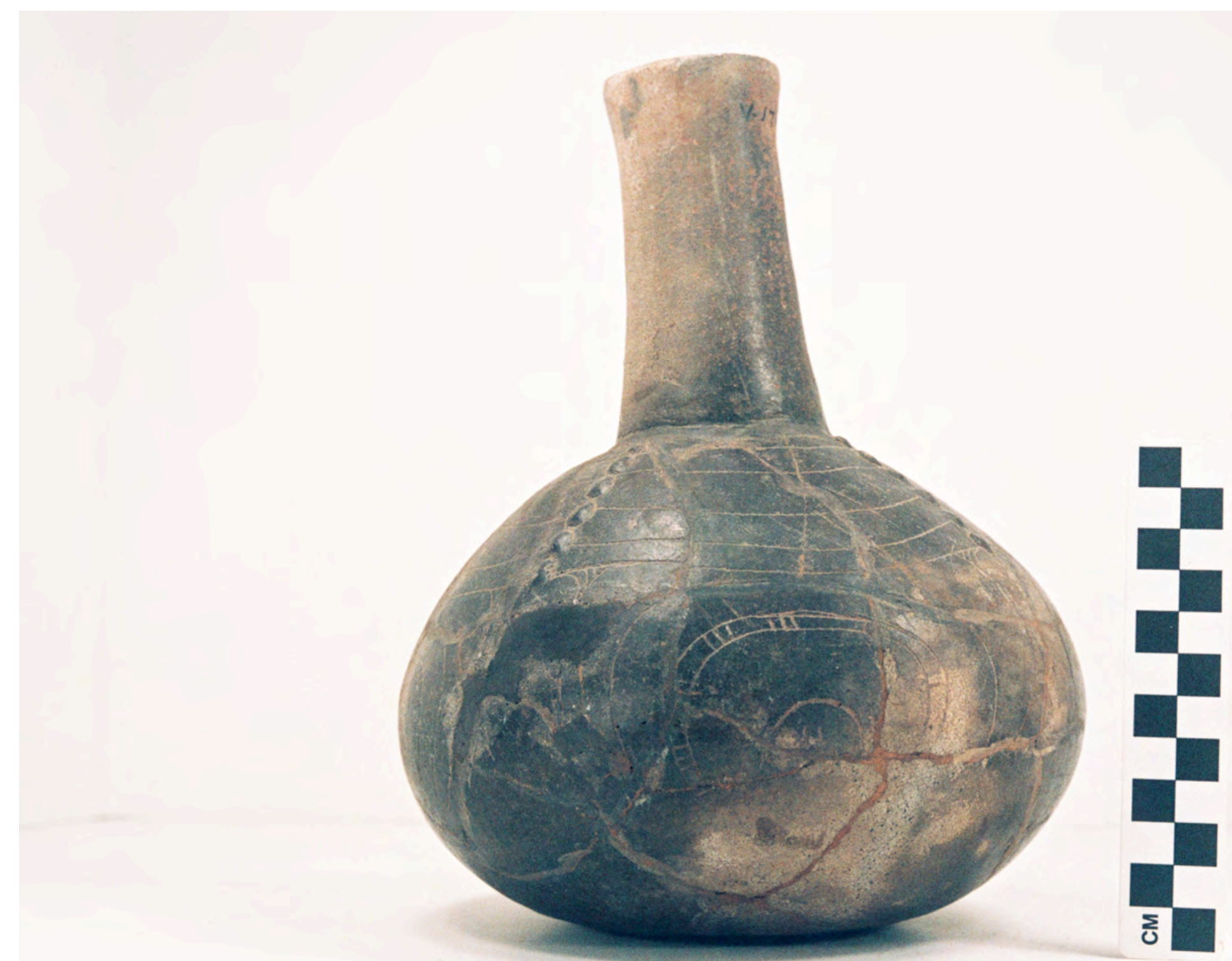

Figure A1-56 


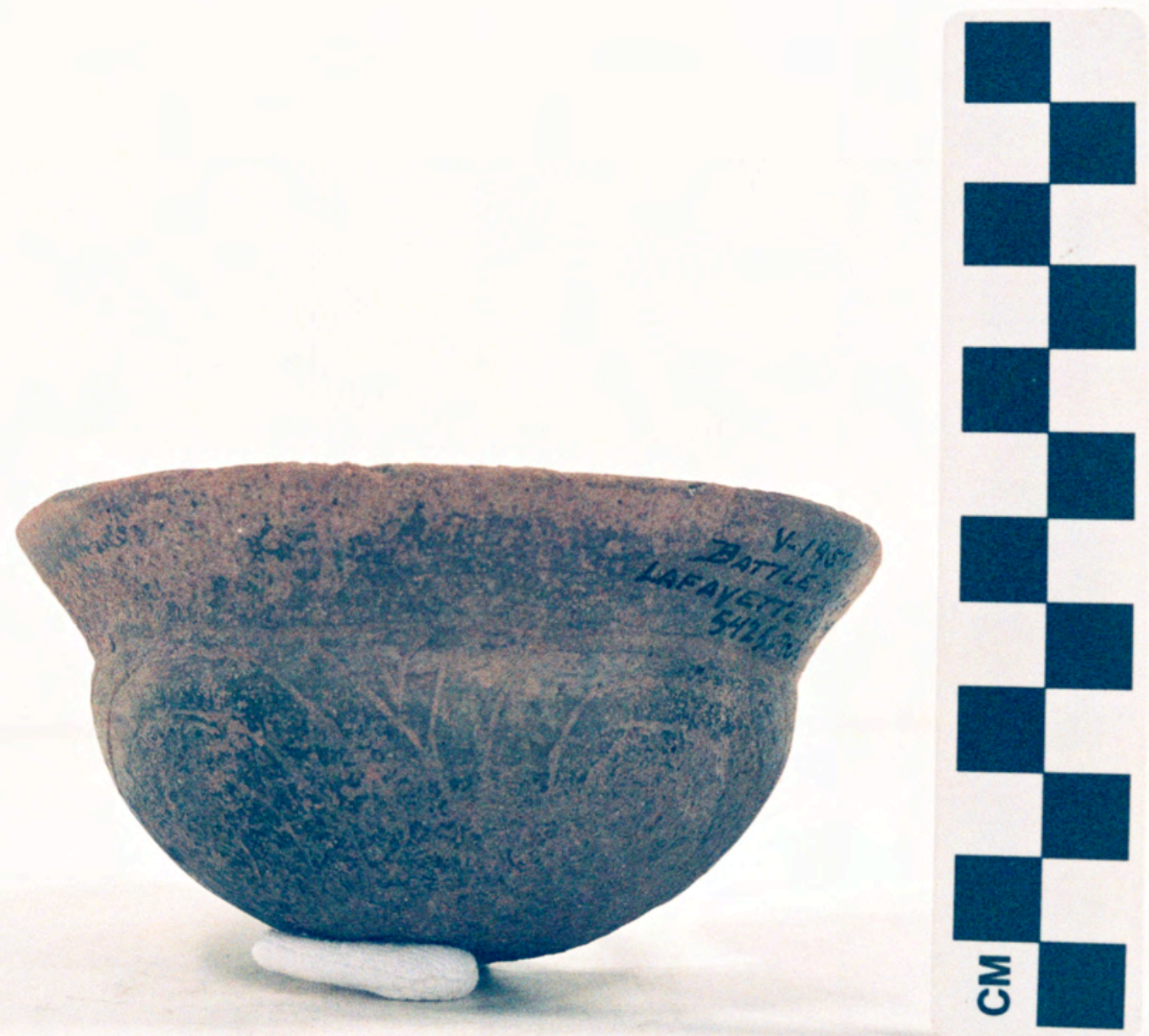

Figure A1-57 


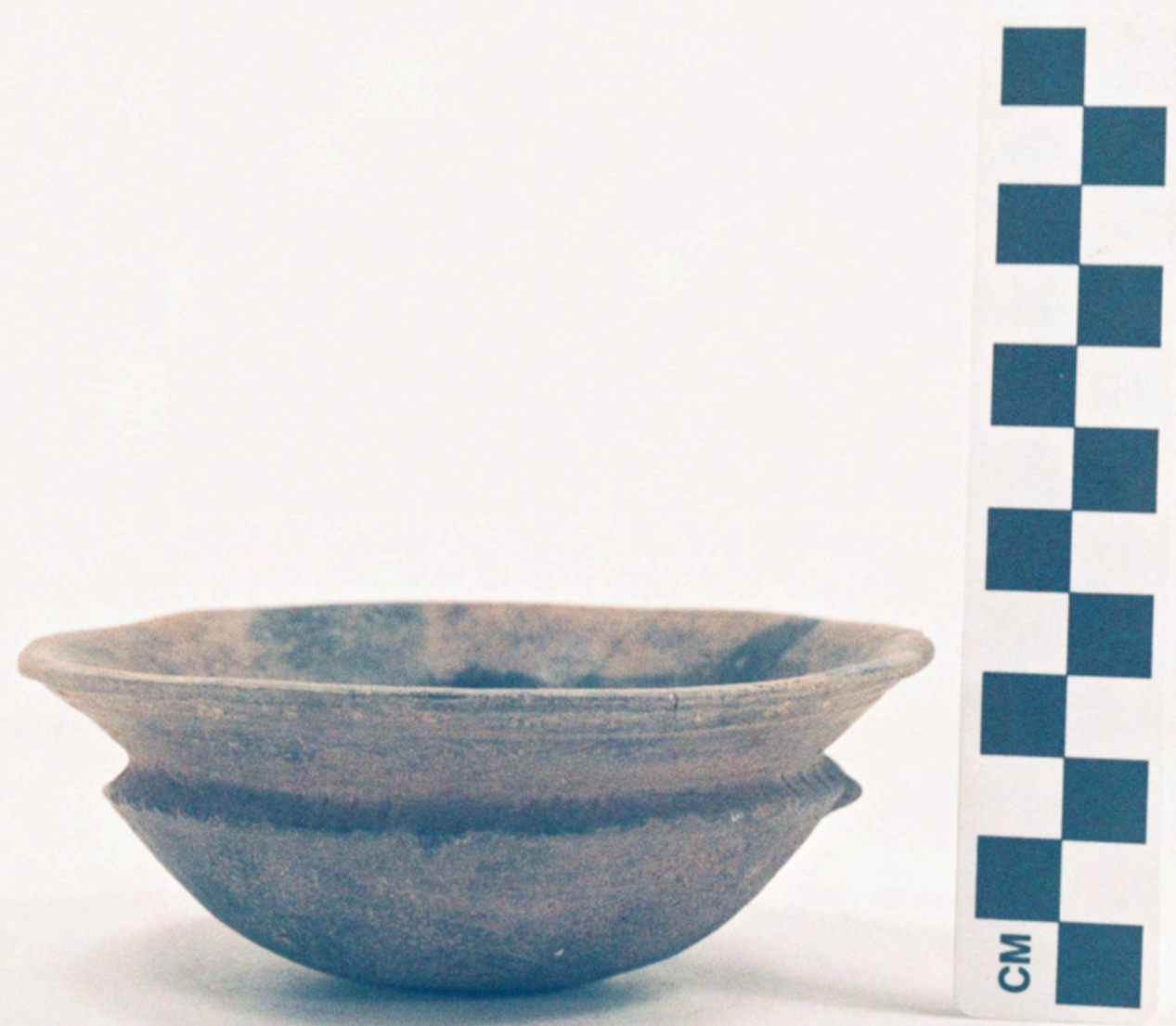

Figure A1-58 


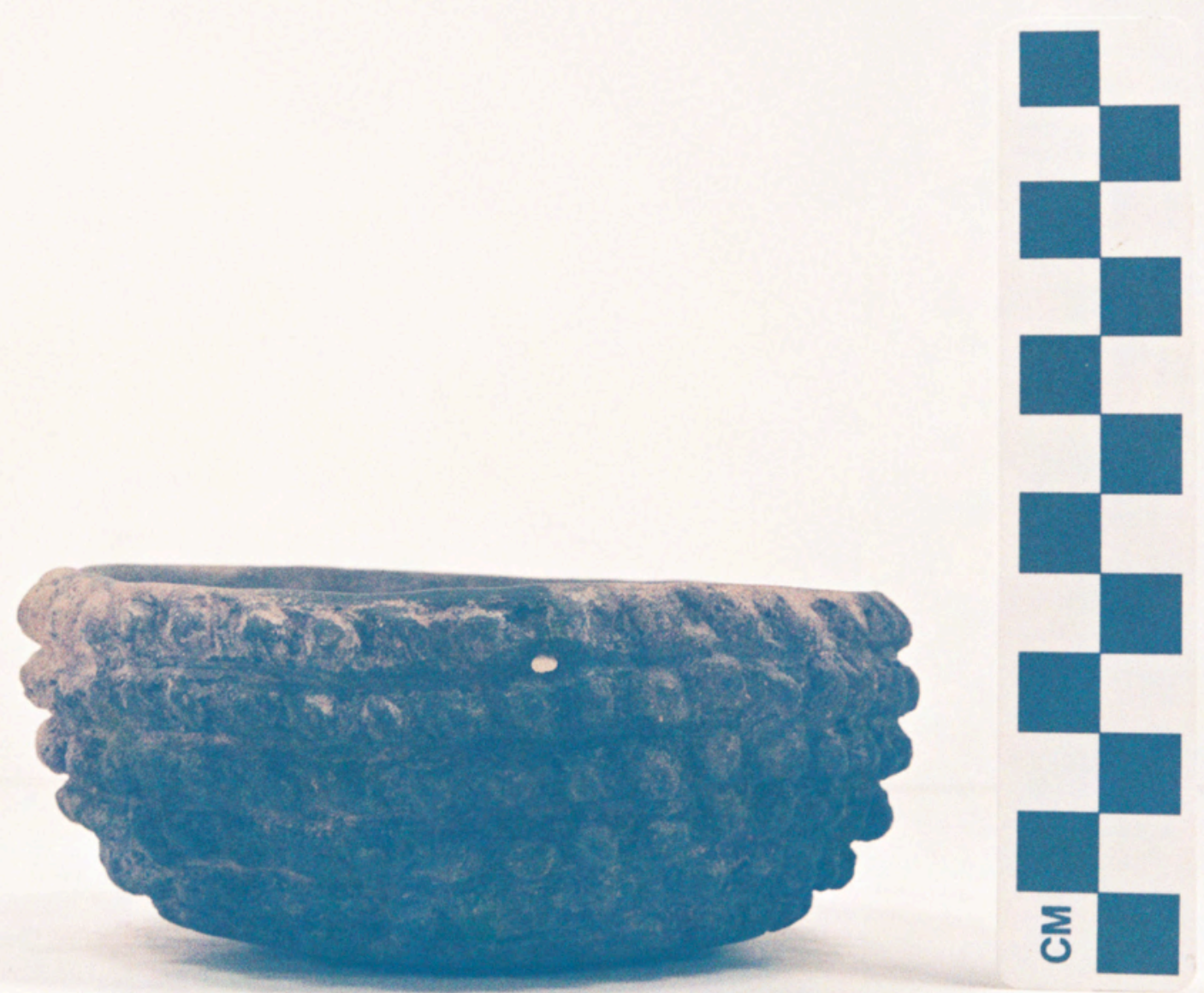

Figure A1-59 


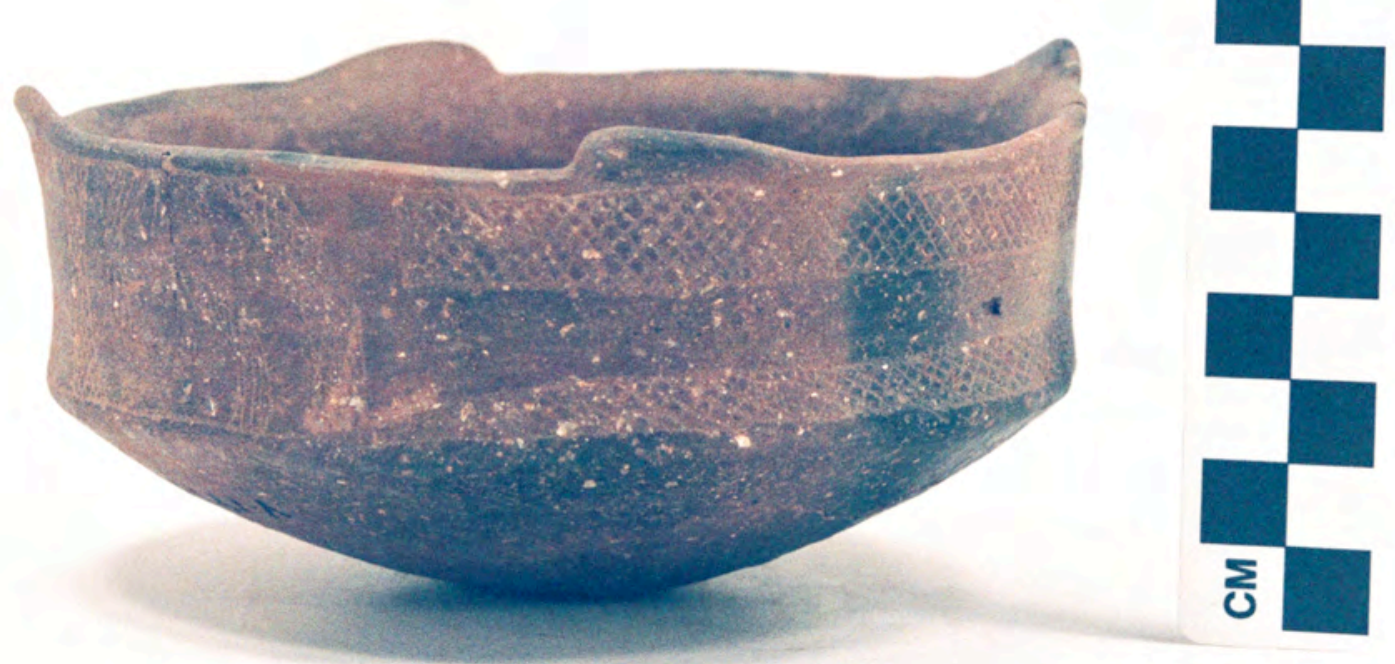

Figure A1-60 


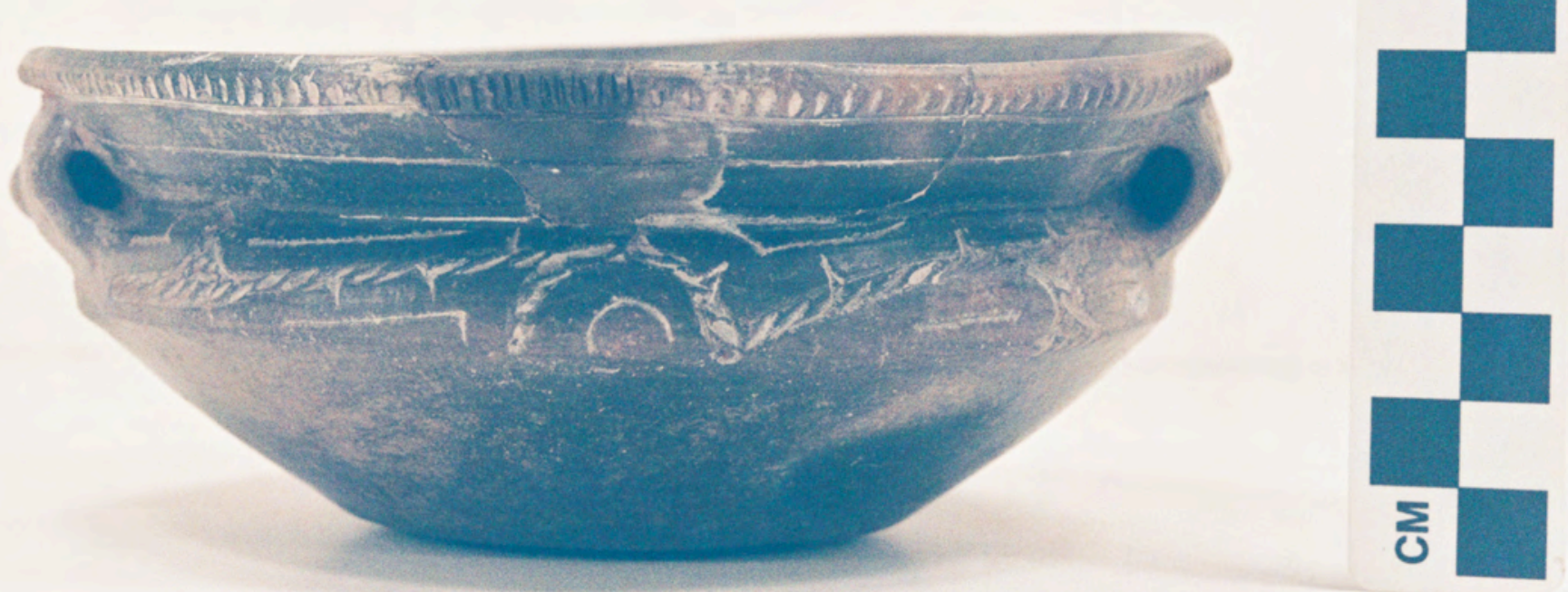

Figure A1-61a 


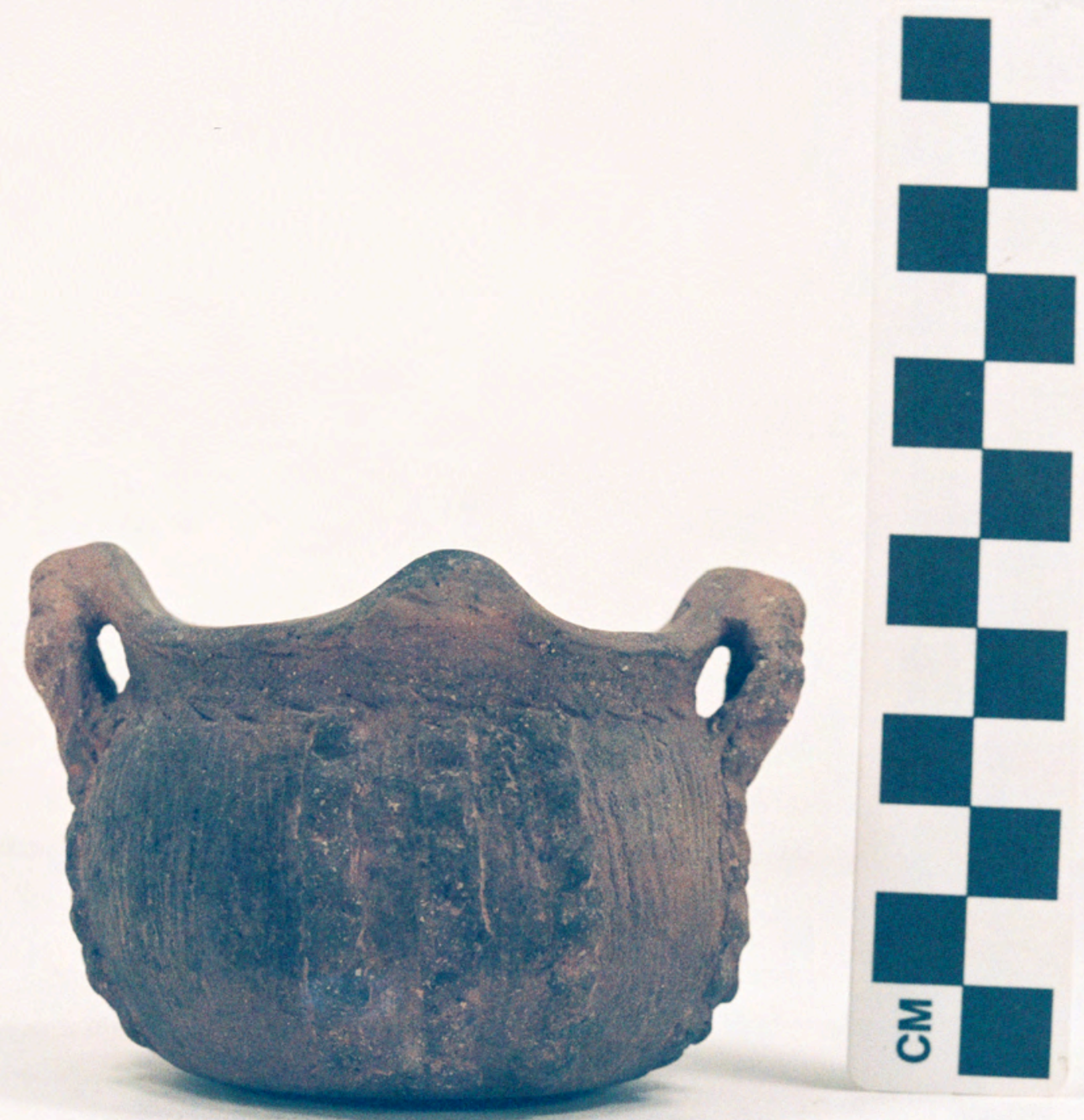

Figure A1-62 

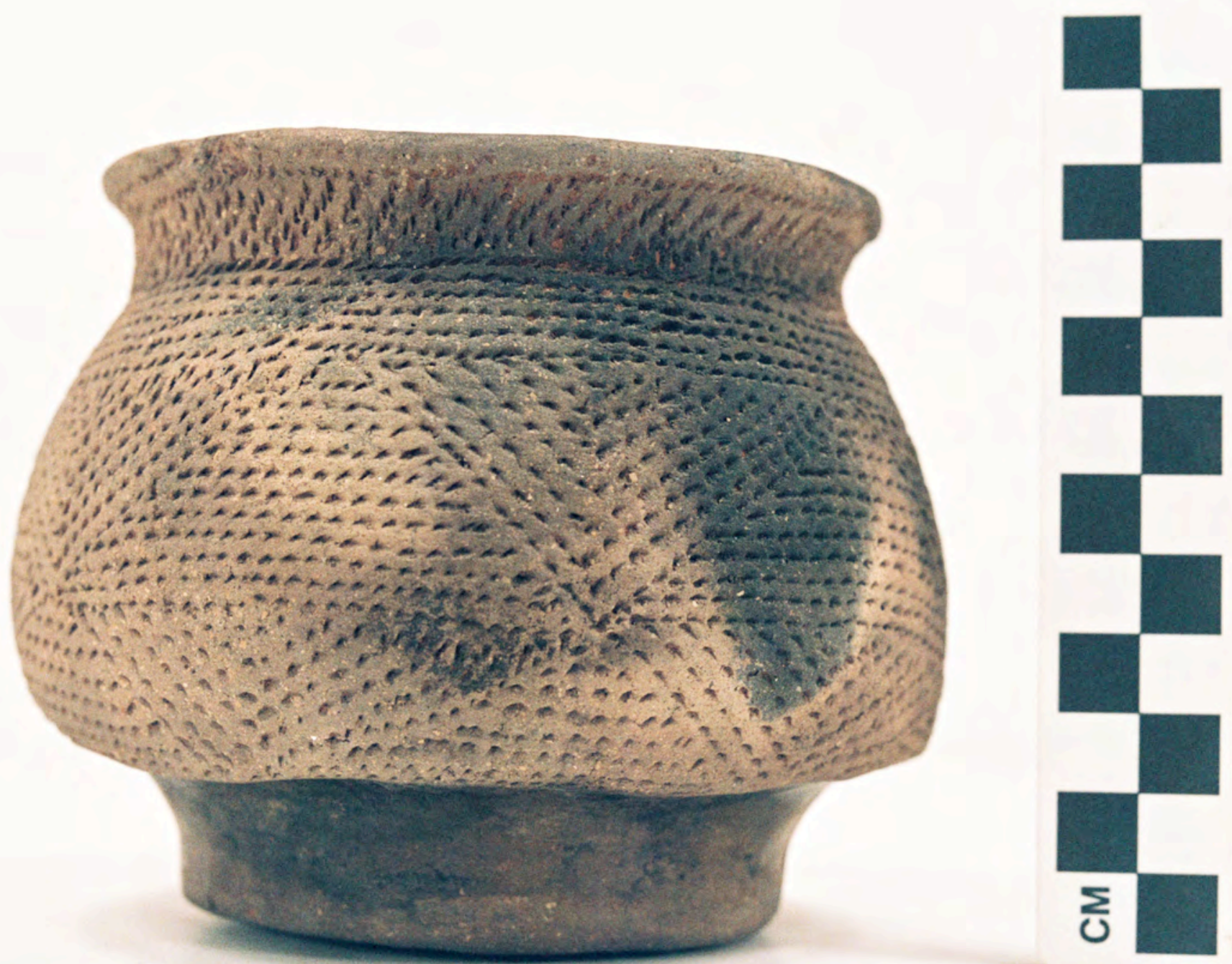

Figure A1-63 


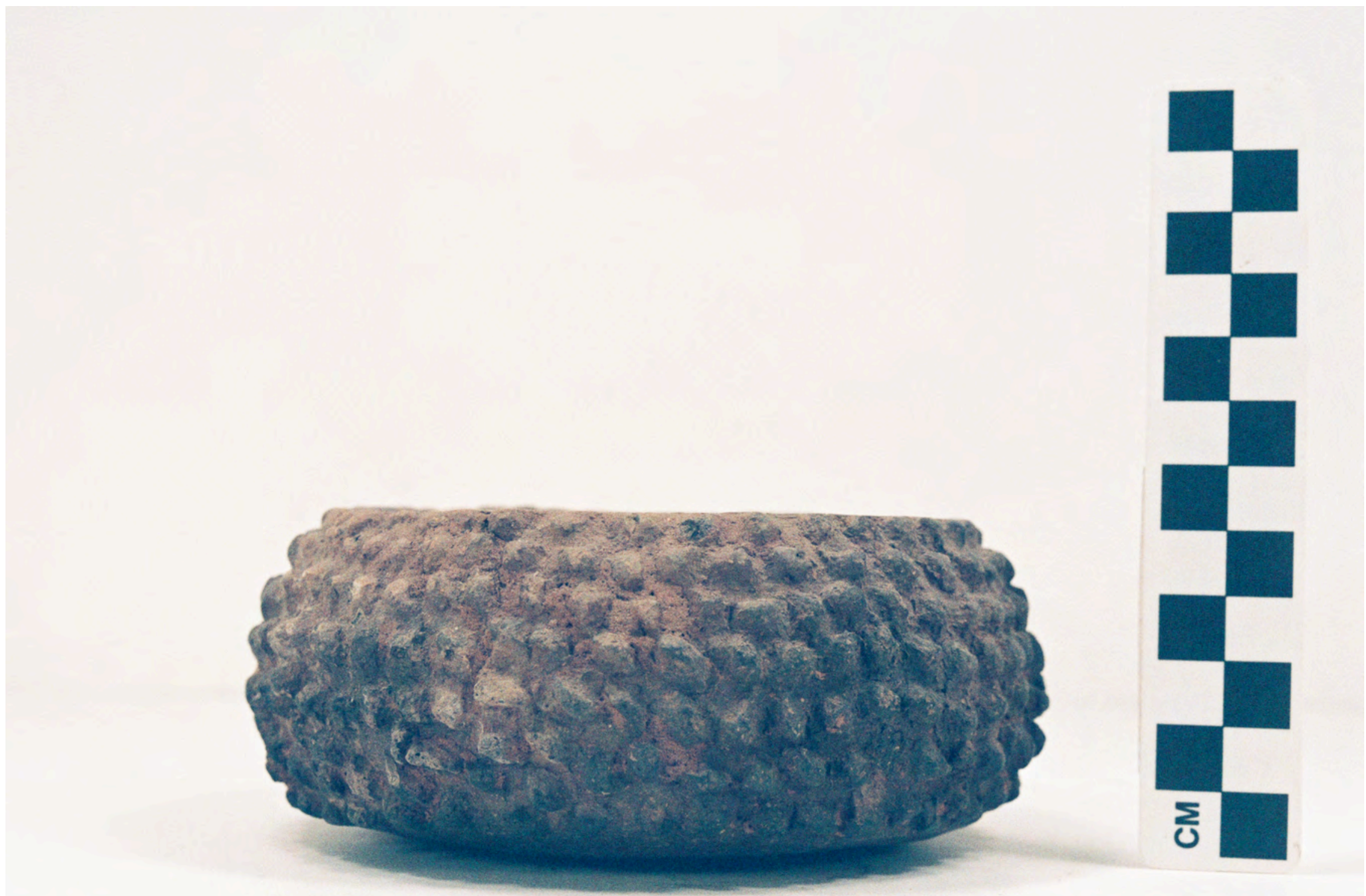

Figure A1-64 


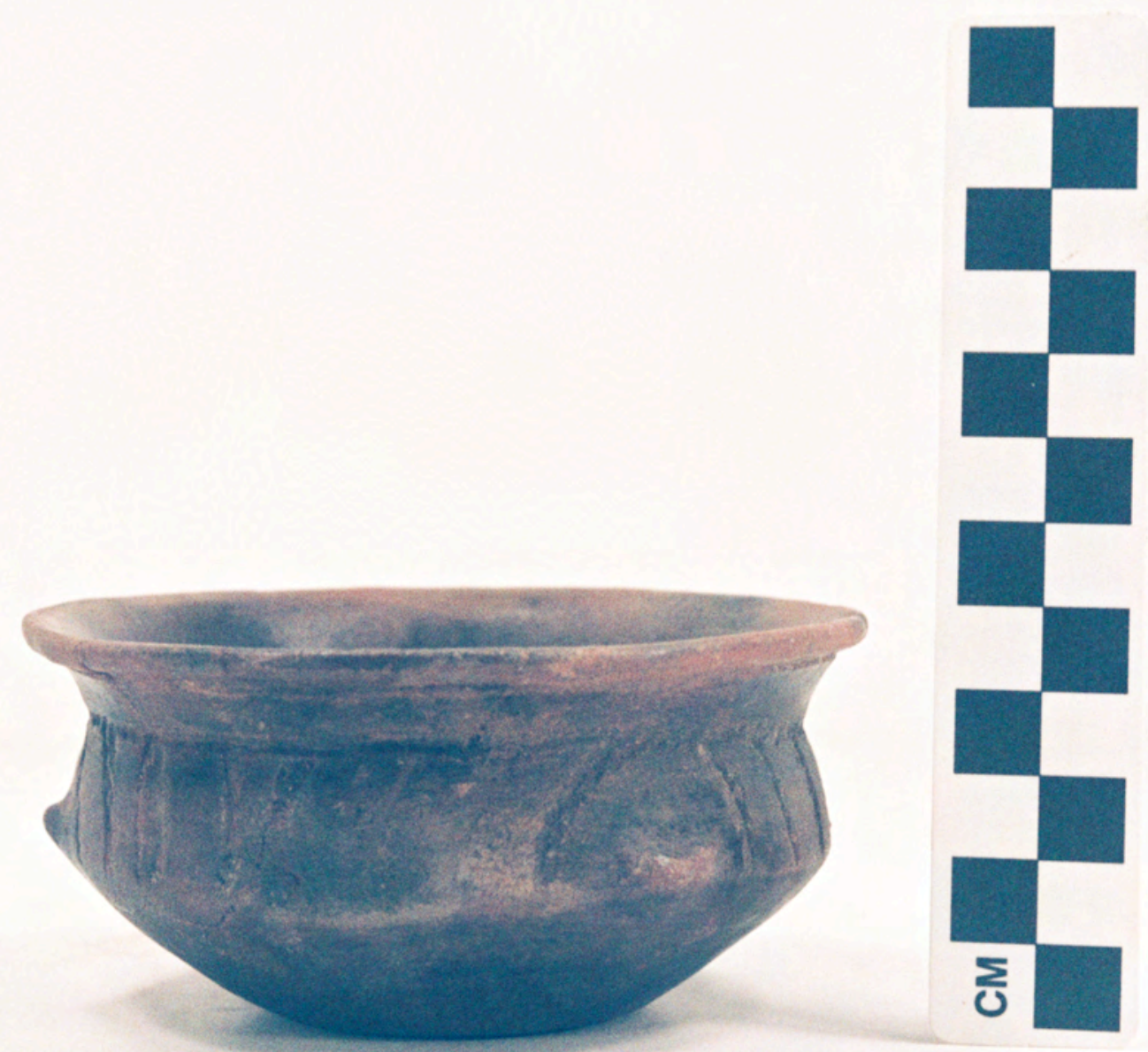

Figure A1-65 


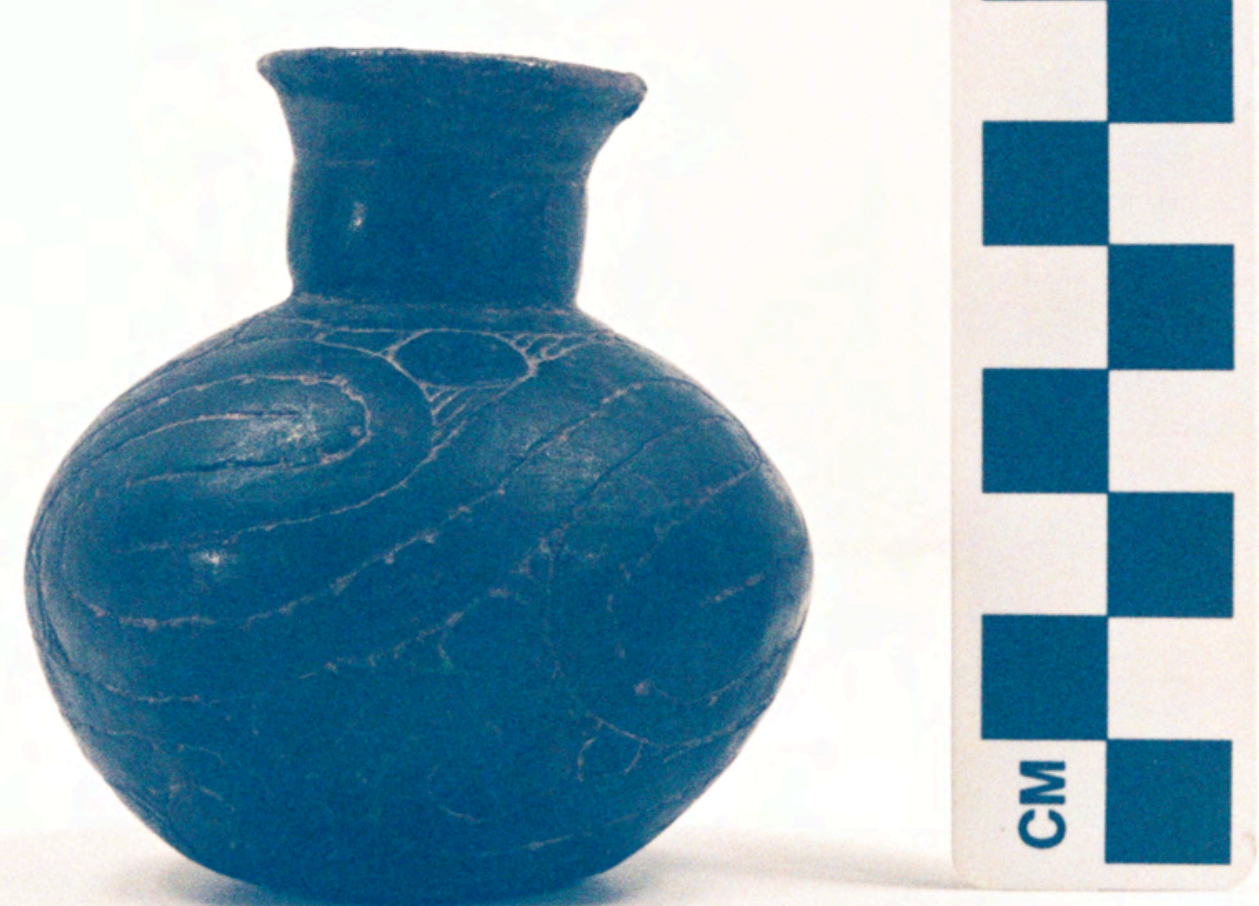

Figure A1-66a 


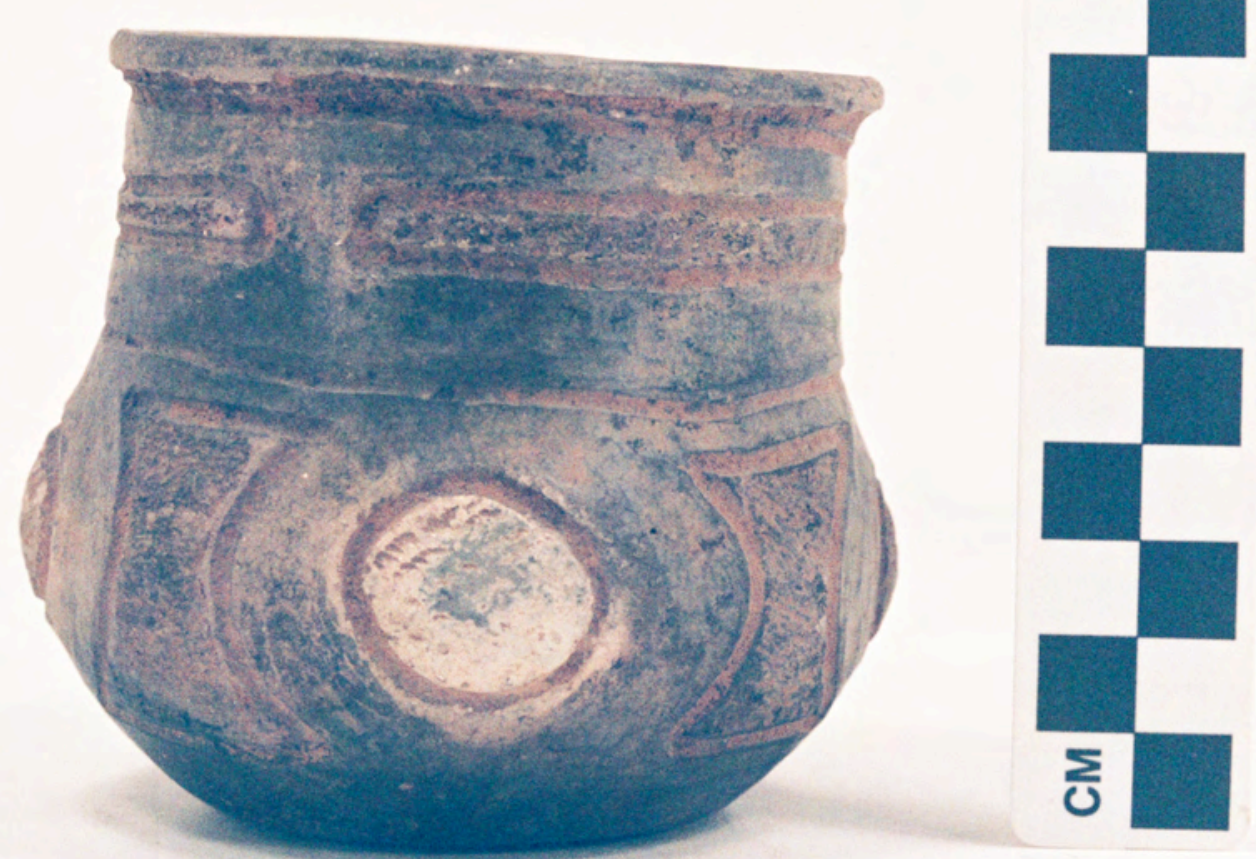

Figure A1-67 


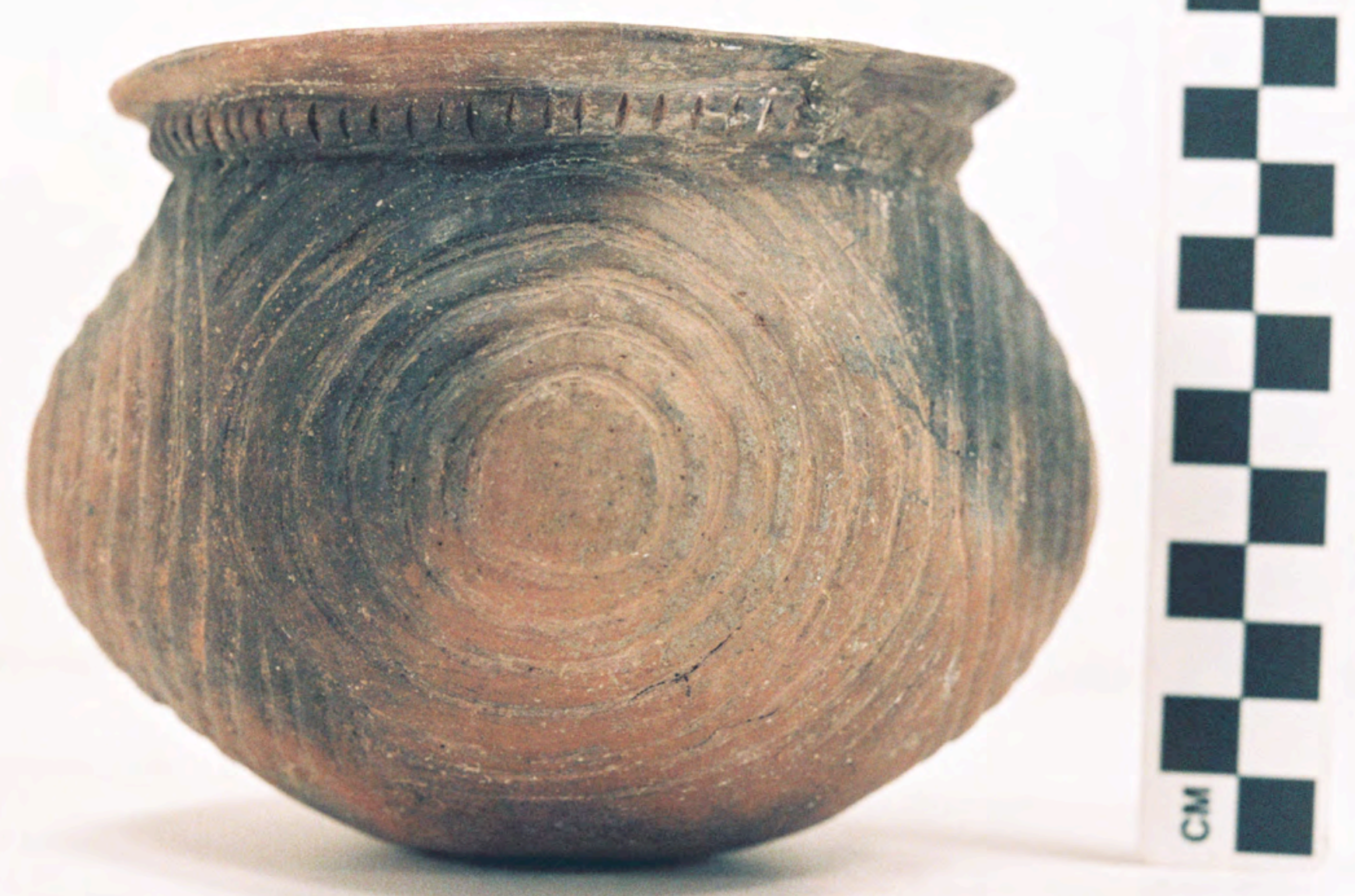

Figure A1-68a 


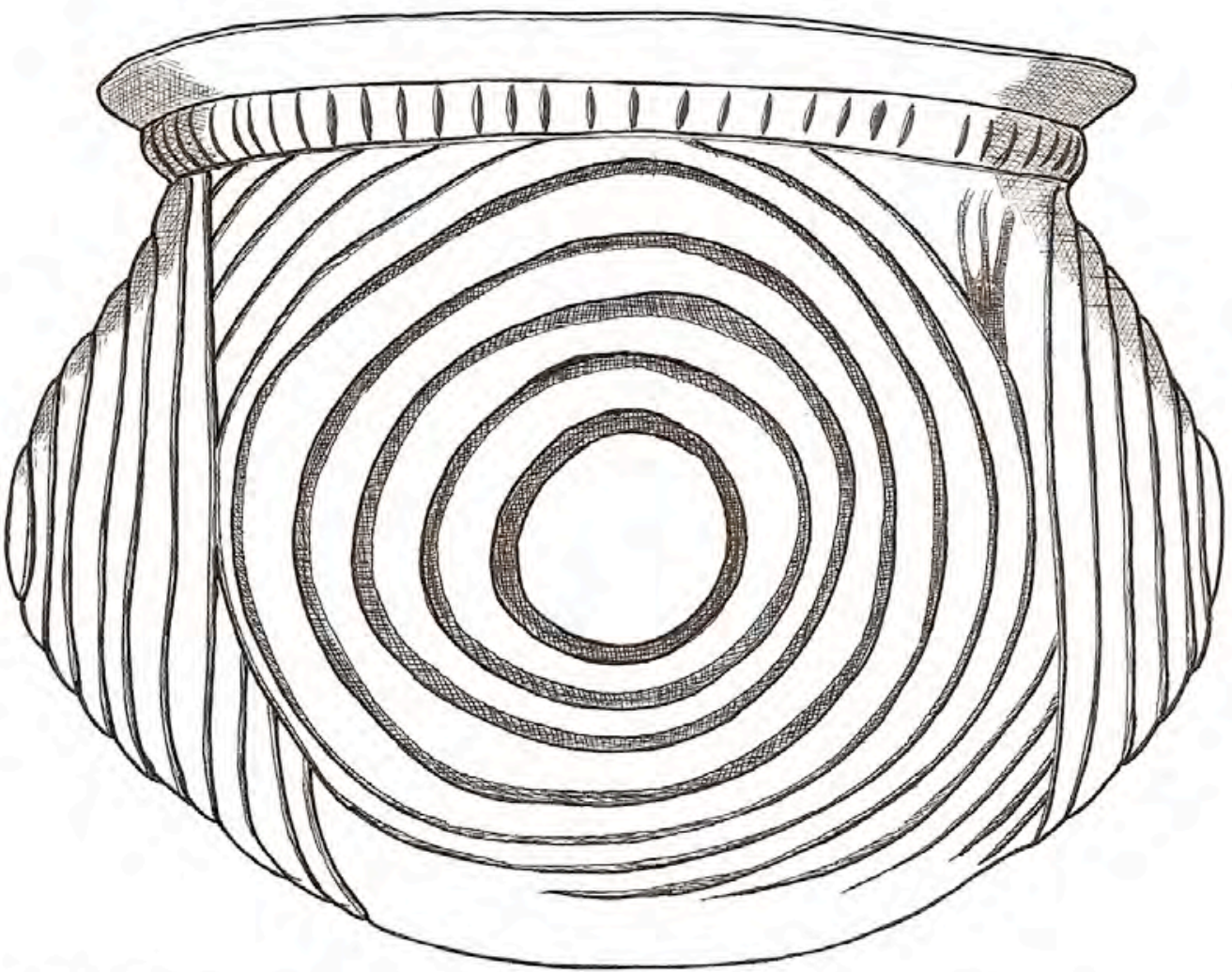

Figure A1-68. Keno Trailed, var. unspecified jar (5425-730): b, drawing by Bobby Gonzalez.

Figure A1-68b 


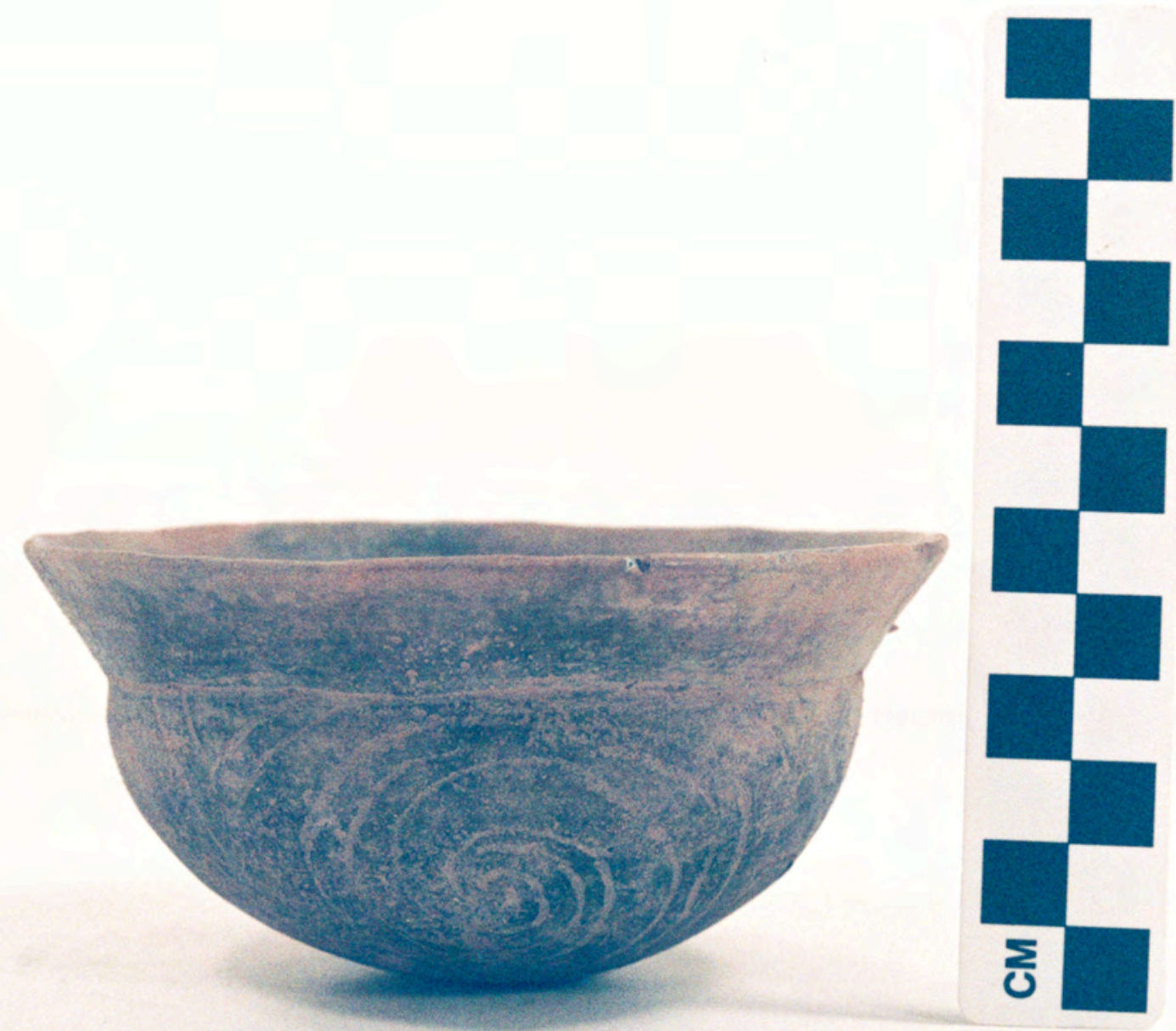

Figure A1-69a 


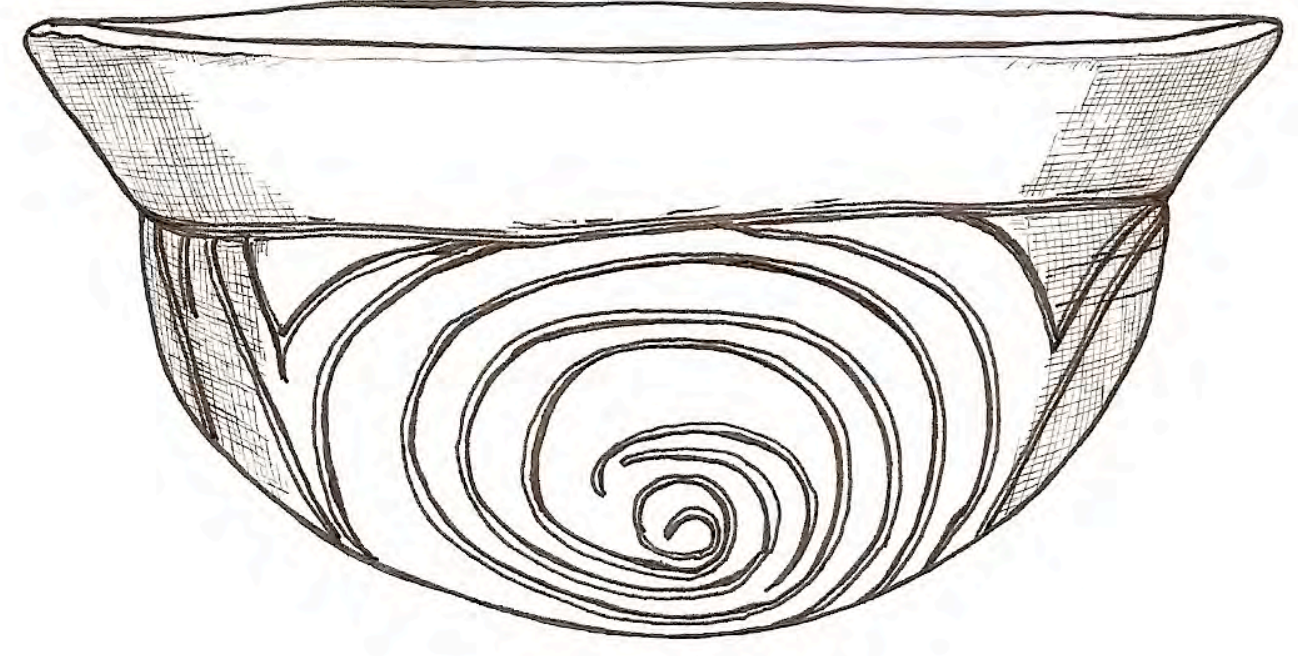

Figure A1-69. Natchitoches Engraved, var. unspecified carinated bowl (5425-731): b, drawing by Bobby Gonzalez.

Figure A1-69b 


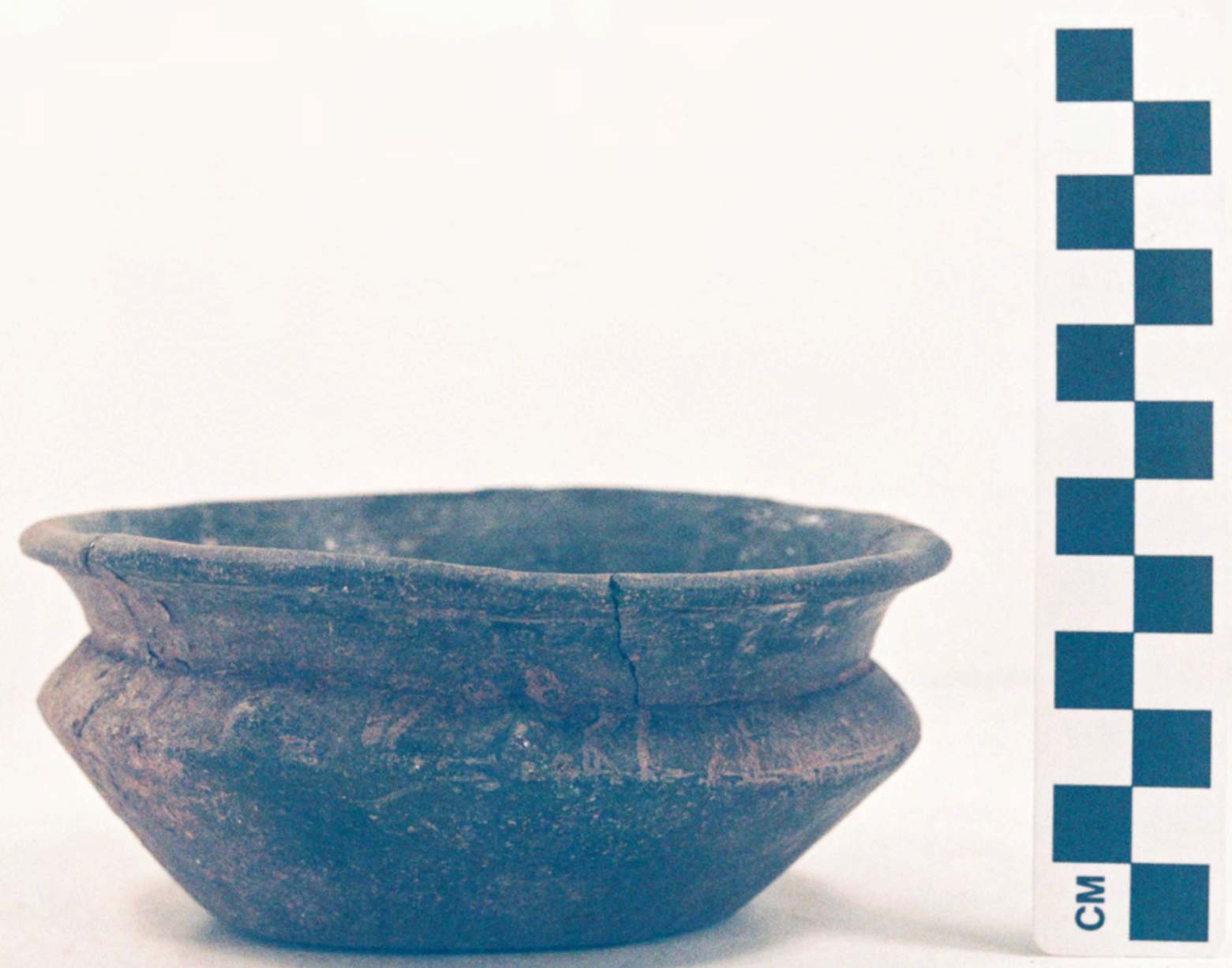

Figure A1-70 


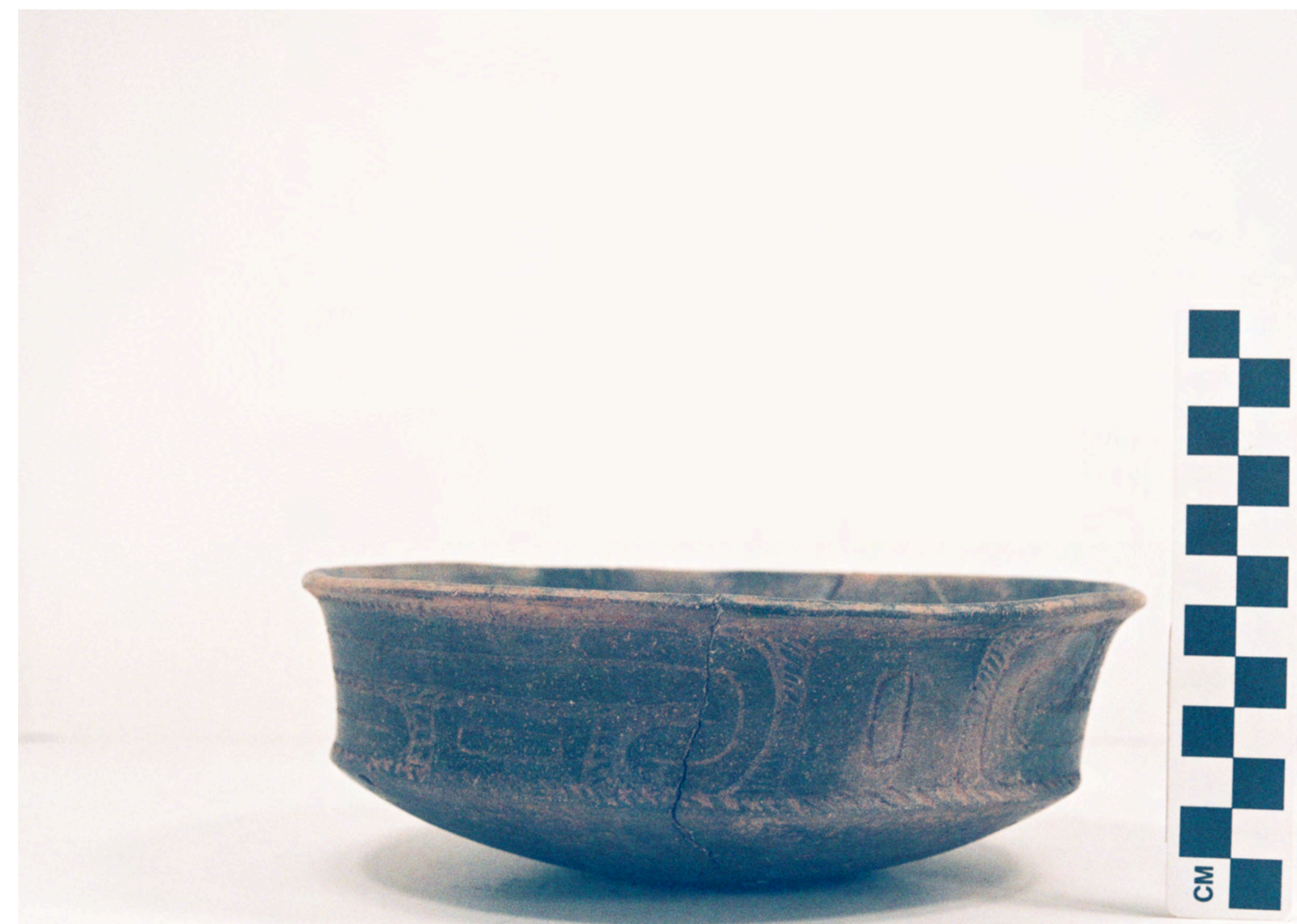

Figure A1-71 

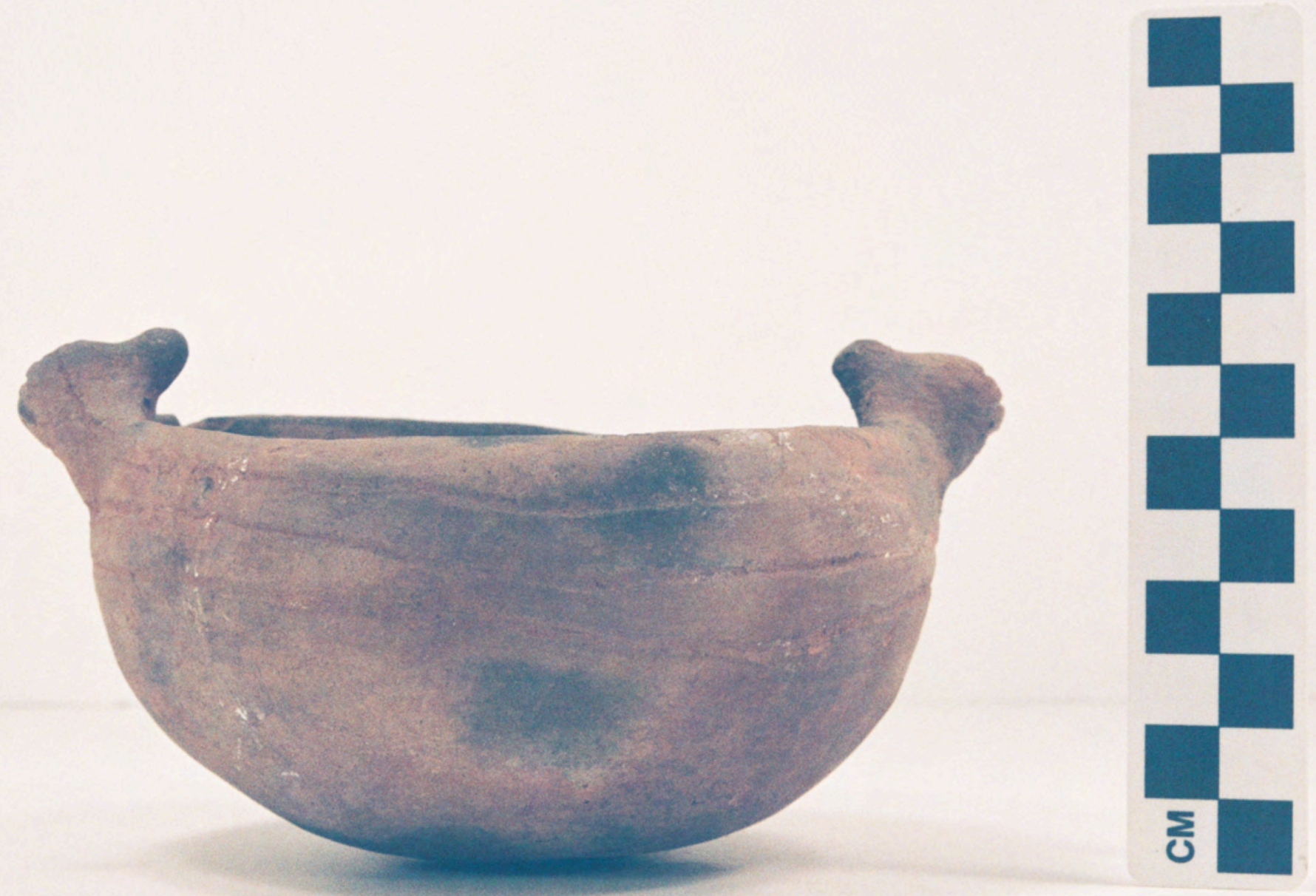

Figure A1-72 


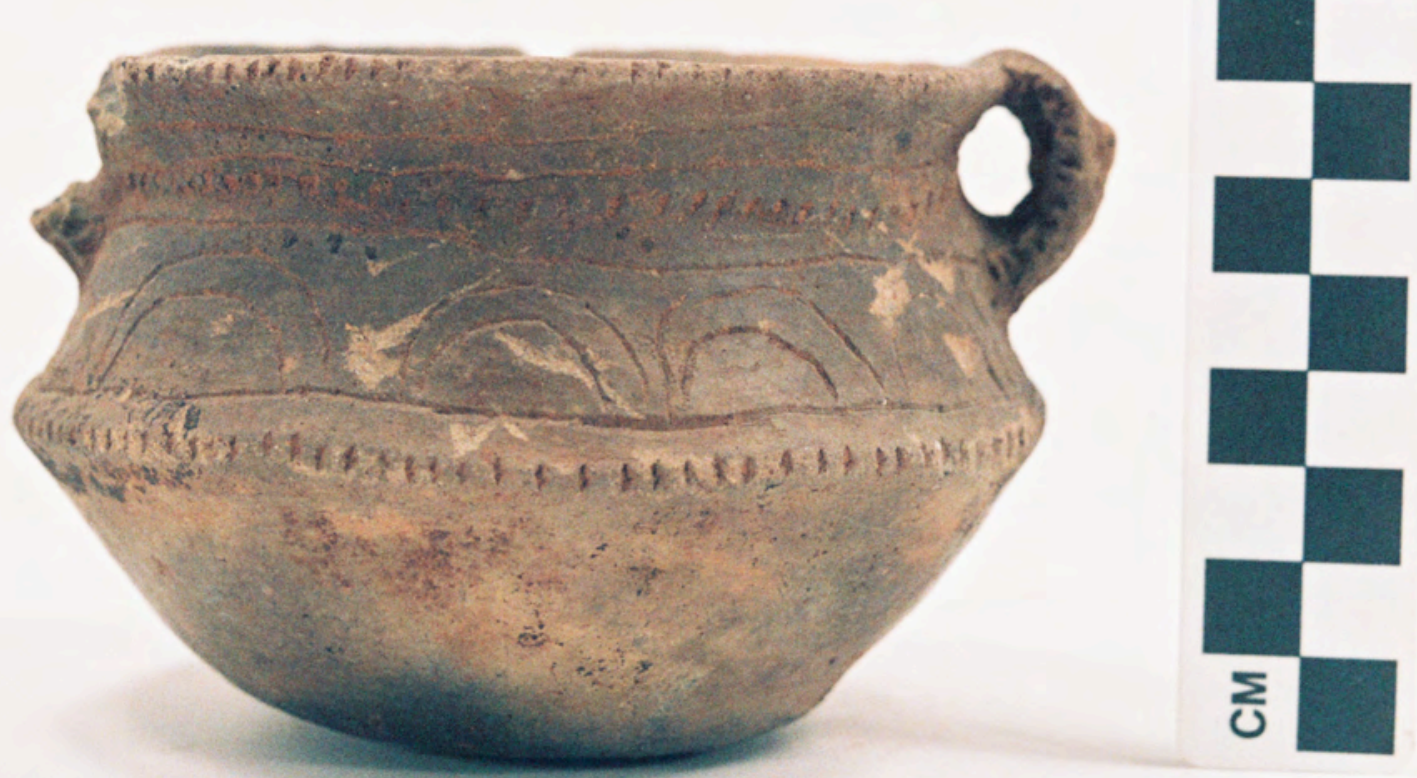

Figure A1-73 


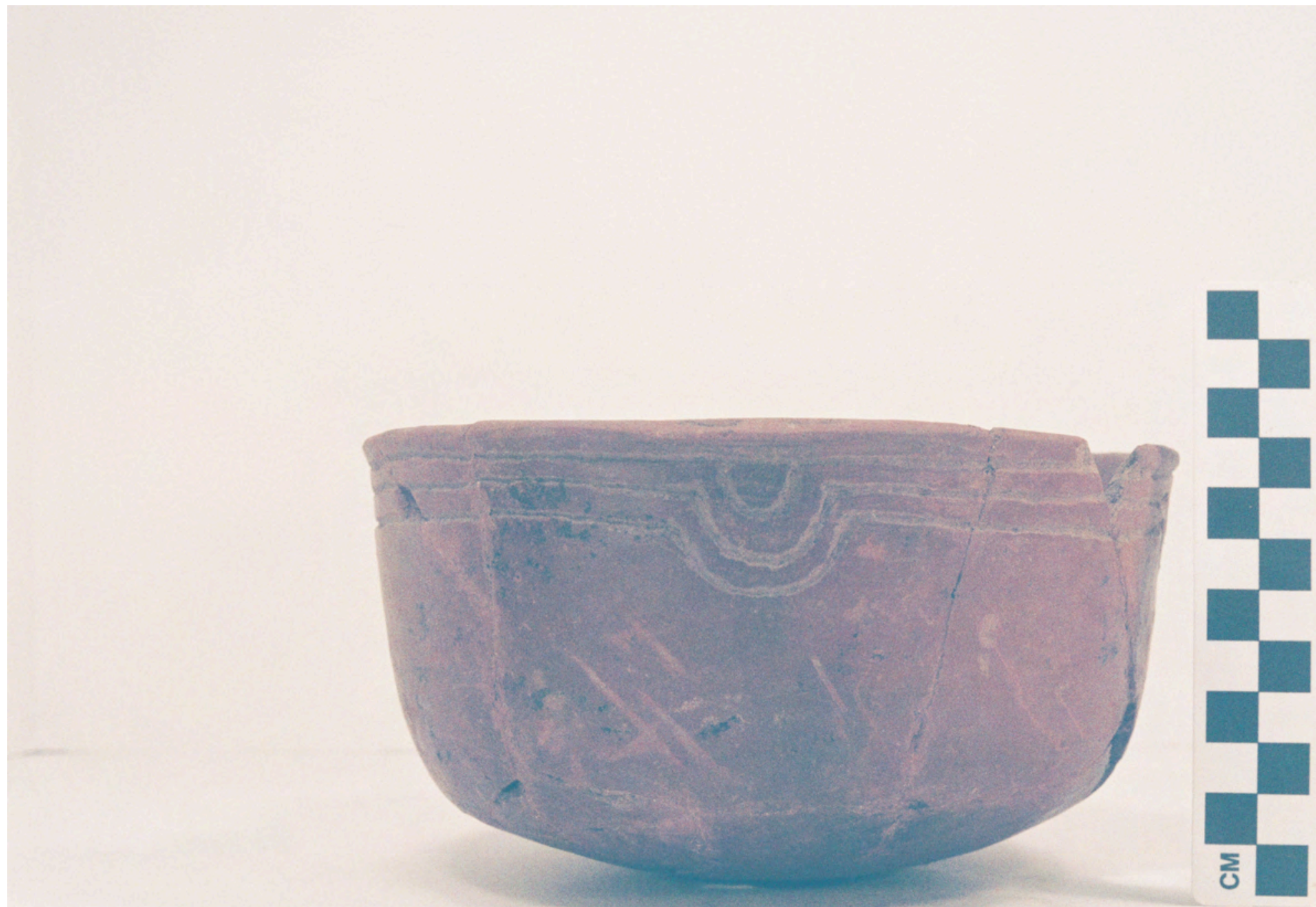

Figure A1-74 


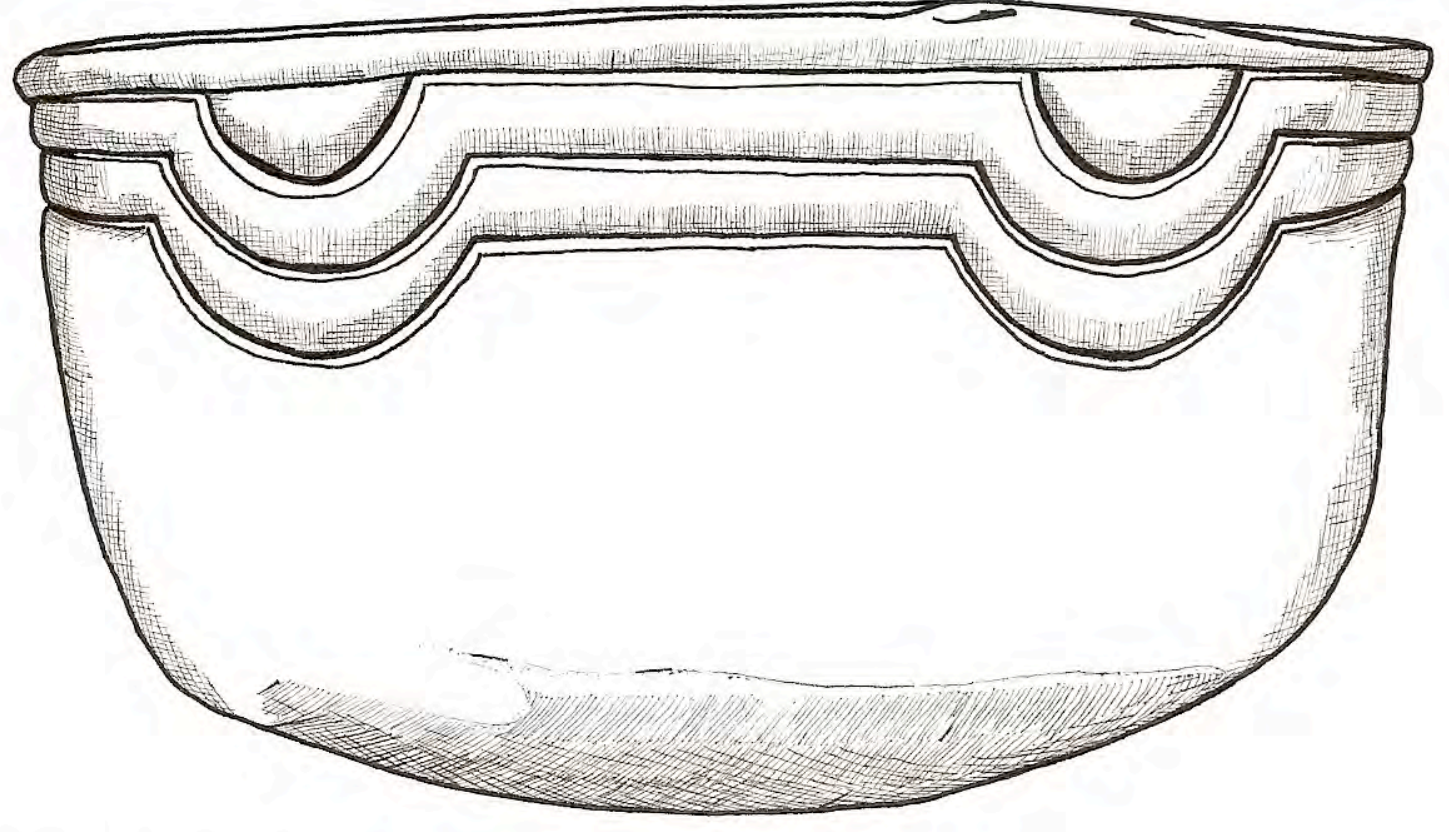

Figure A1-74. Bowie Engraved bowl (5425-736): b, drawing by Bobby Gonzalez.

Figure A1-74b 


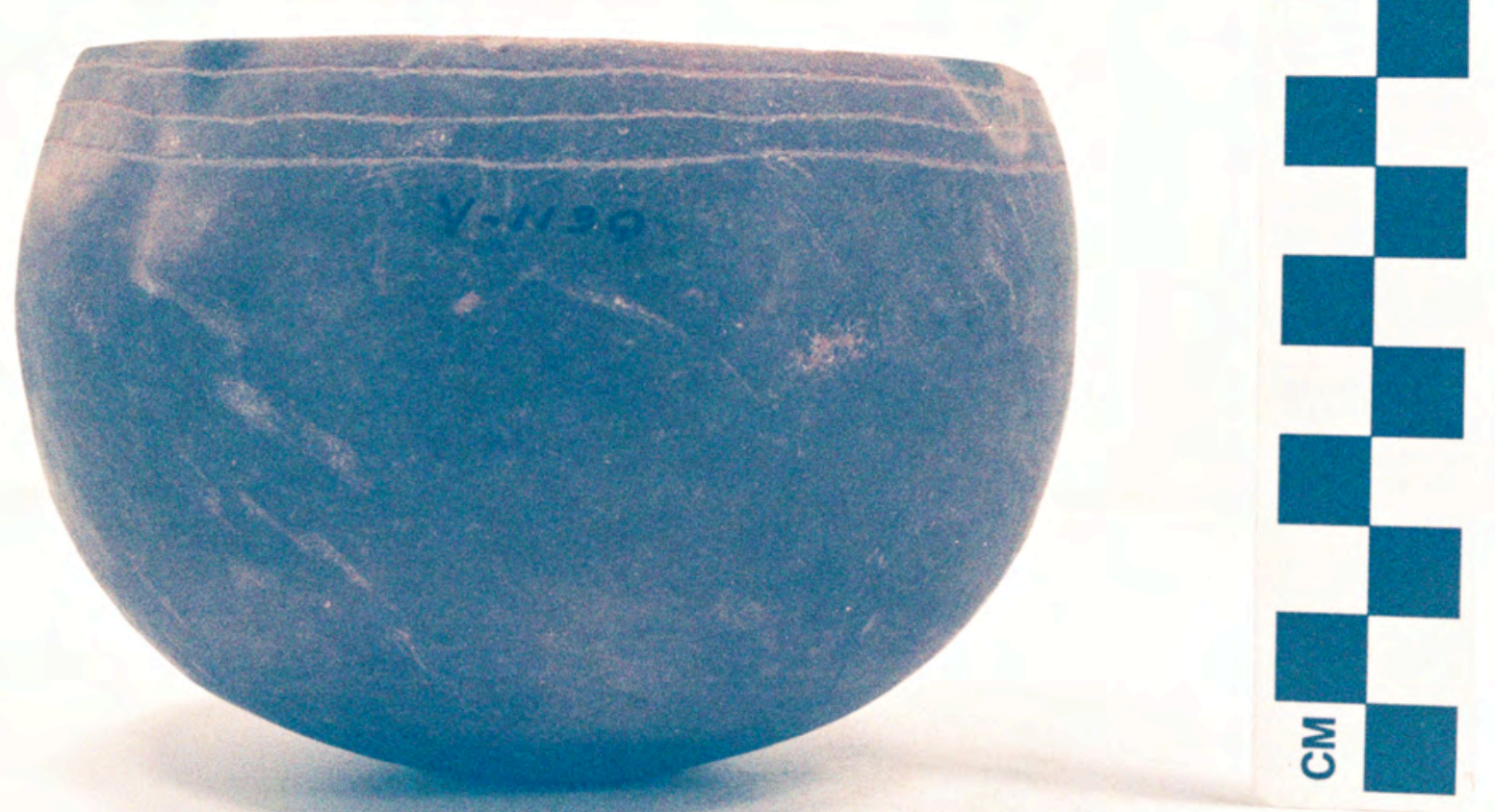

Figure A1-75 


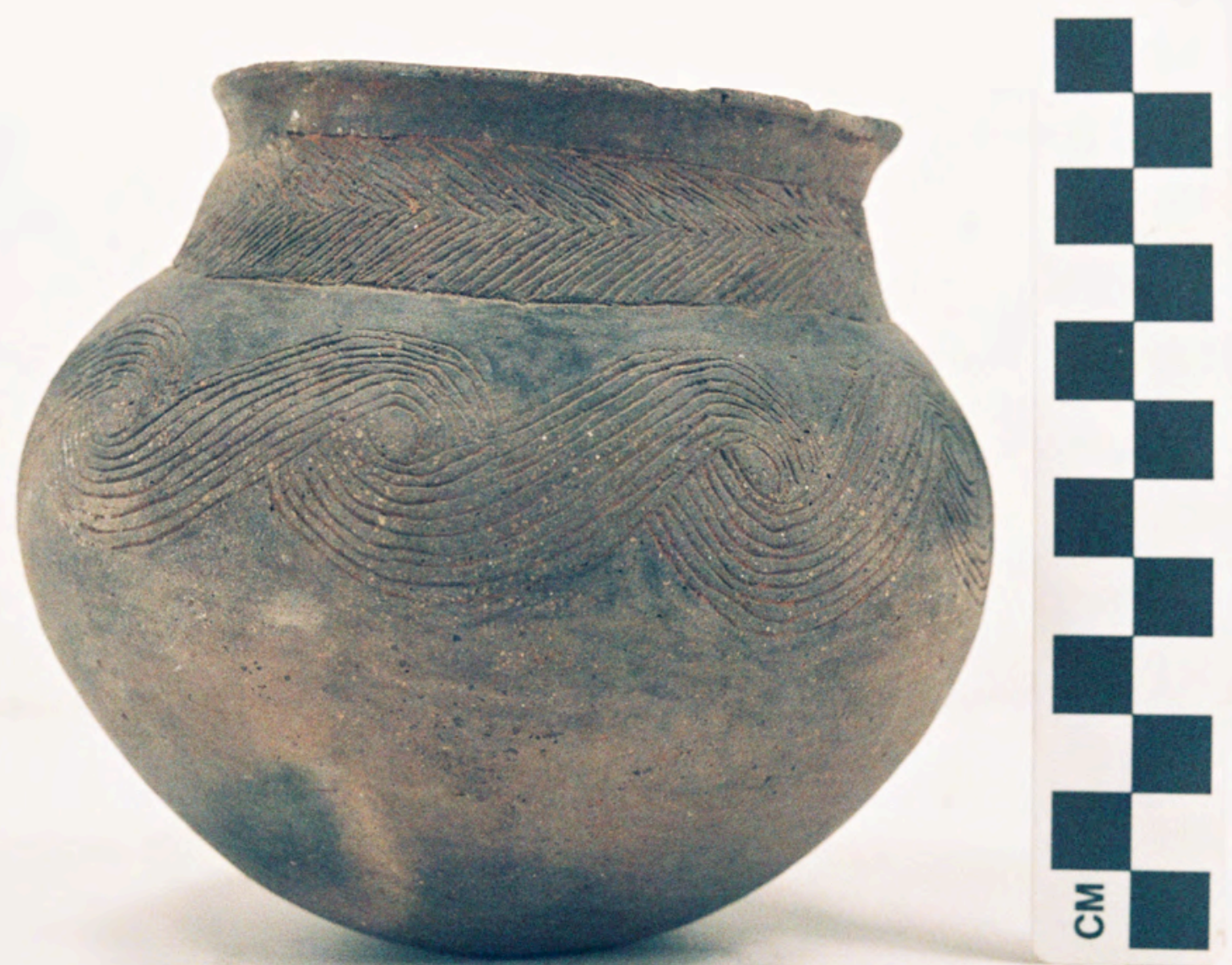

Figure A1-76 


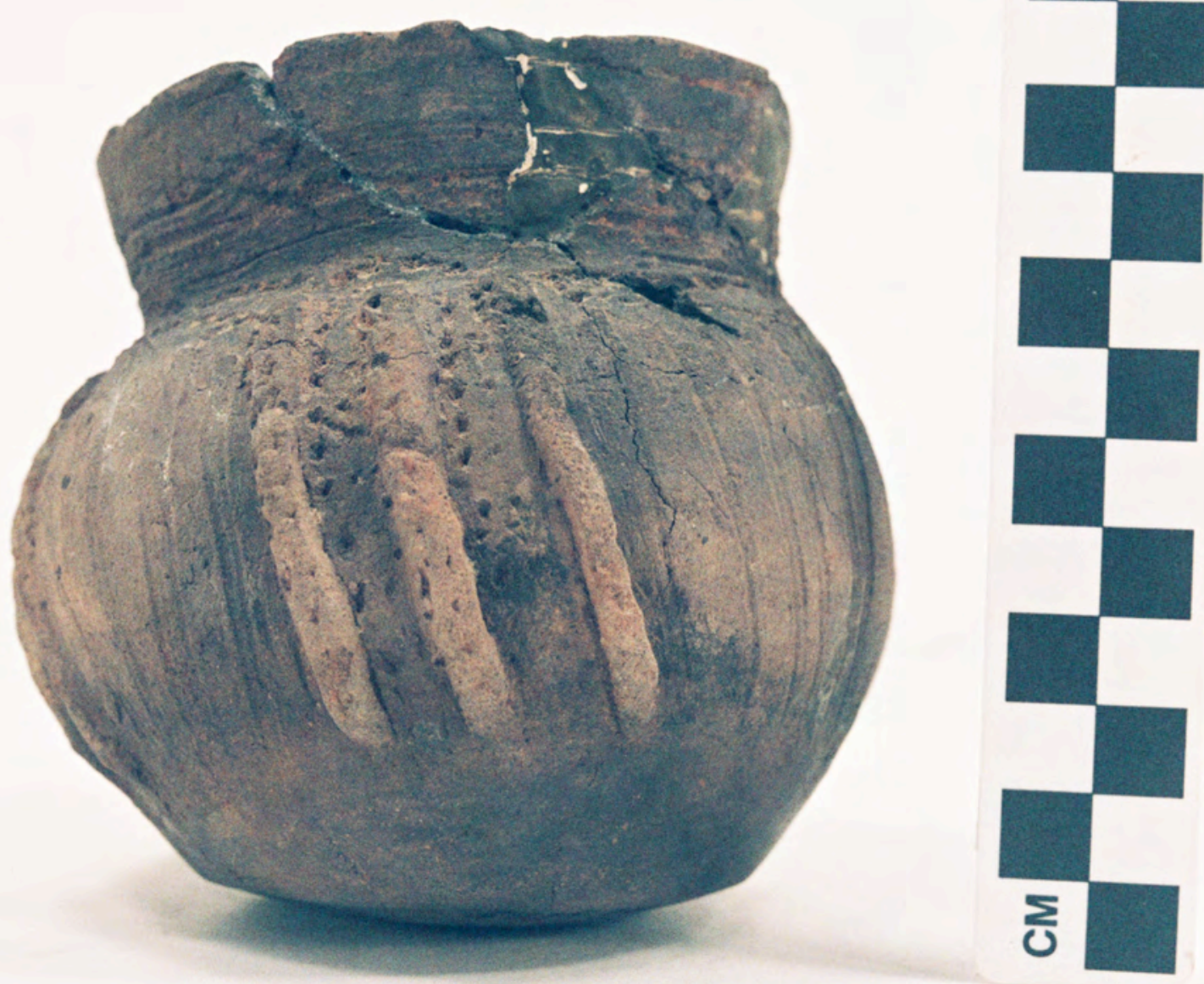

Figure A1-77 


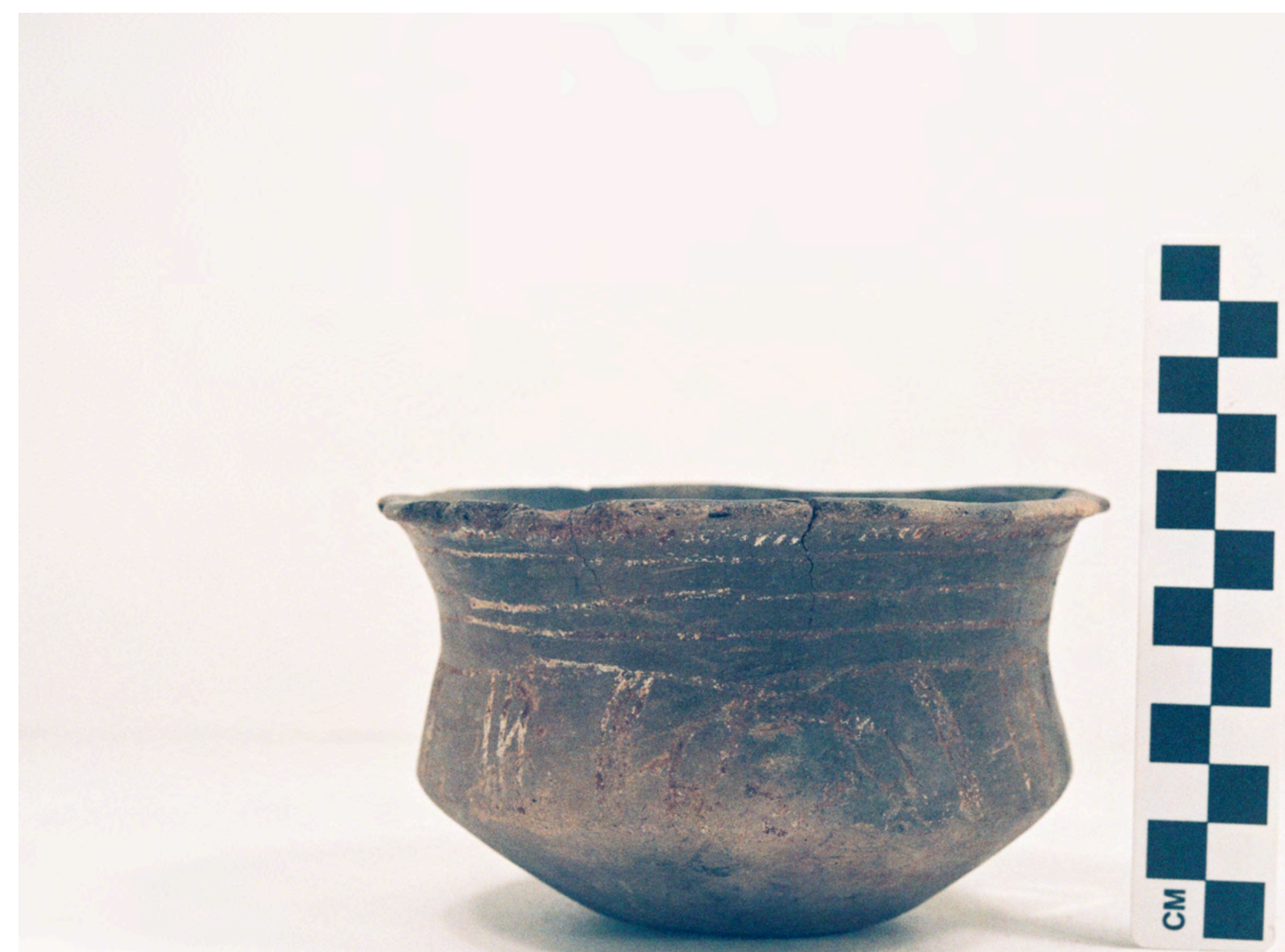

Figure A1-78a 


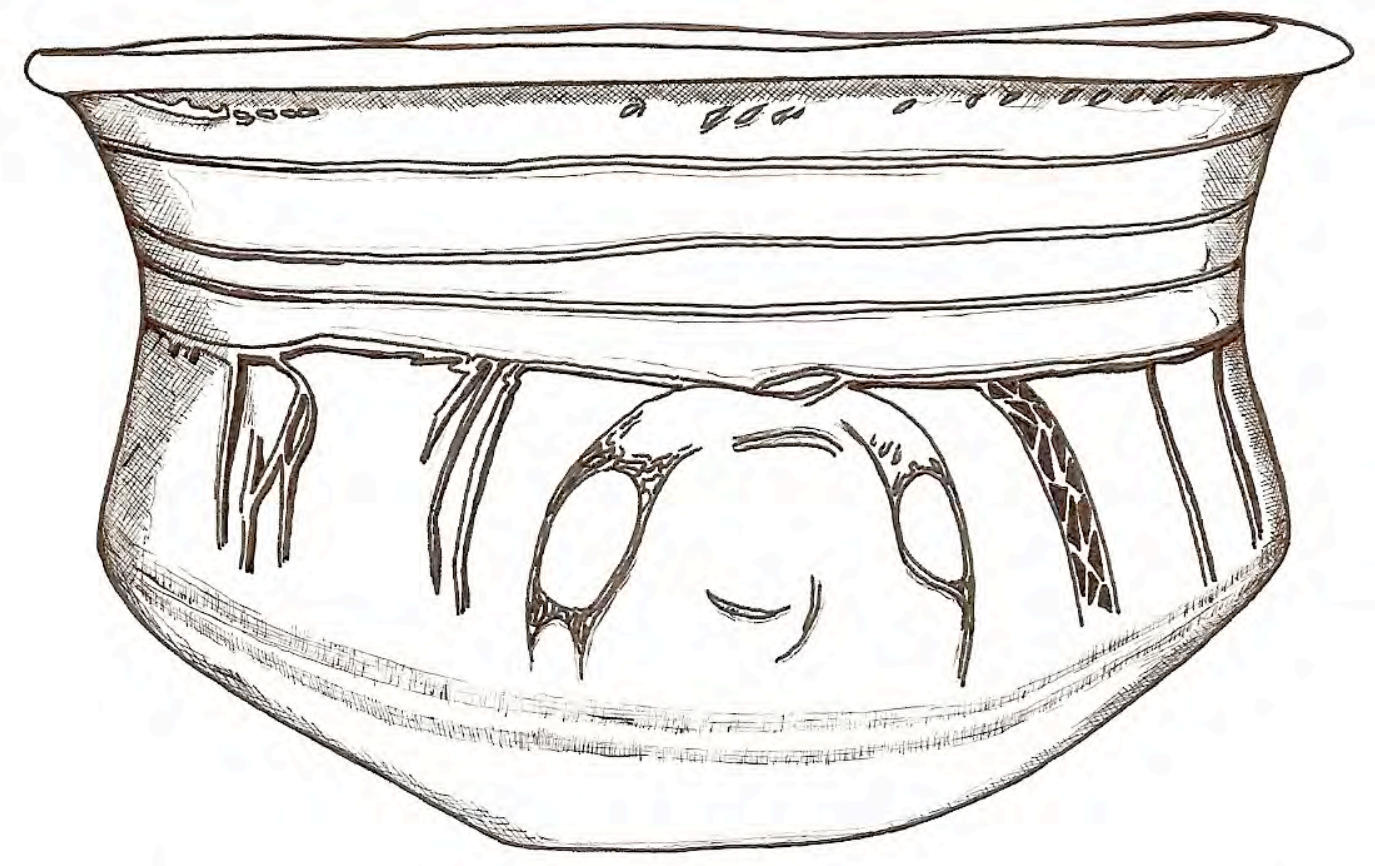

Figure A1-78. Belcher Engraved, var. Belcher vessel (5425-741): b, drawing by Bobby Gonzalez.

Figure A1-78b 


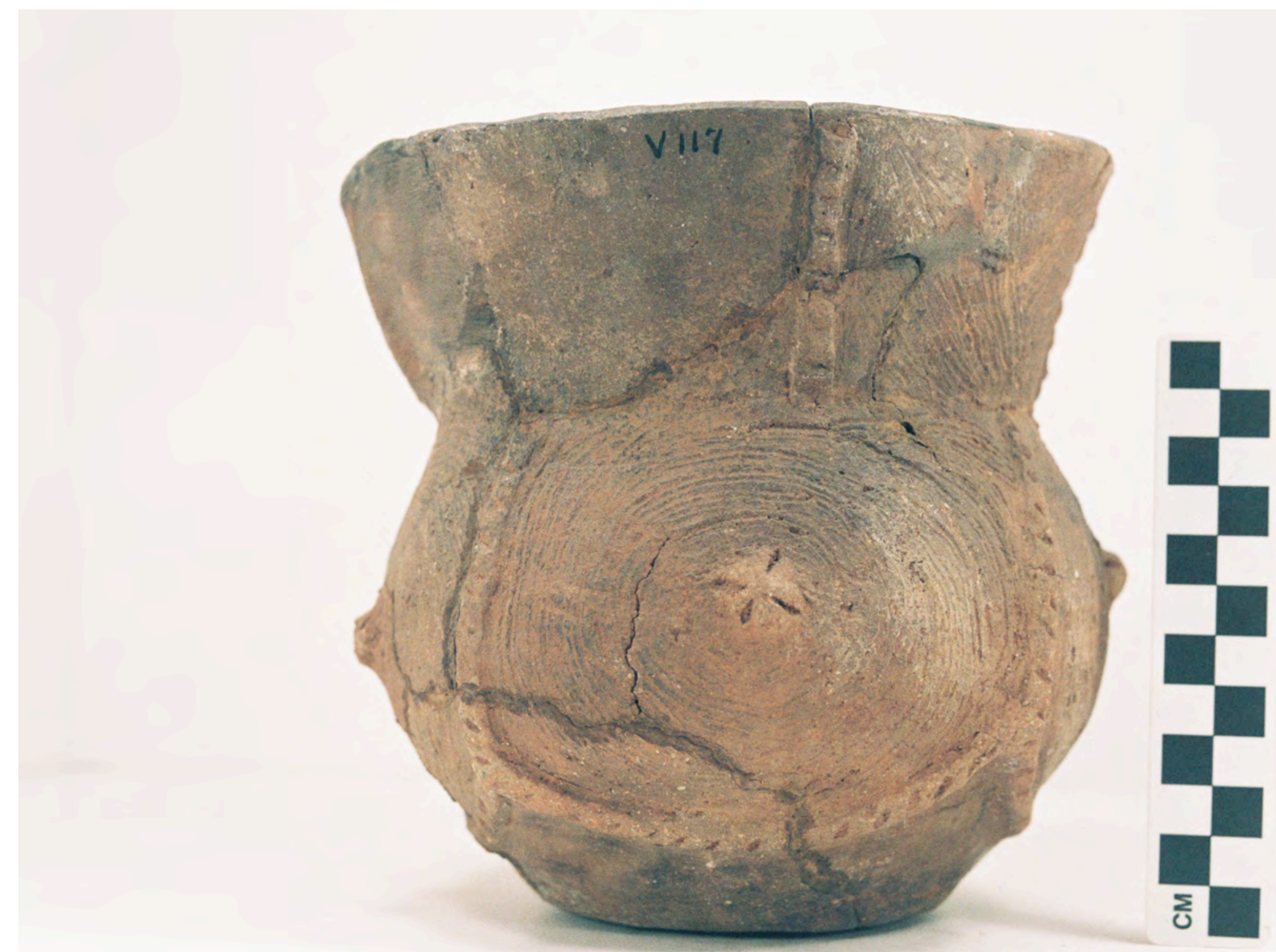

Figure A1-79 


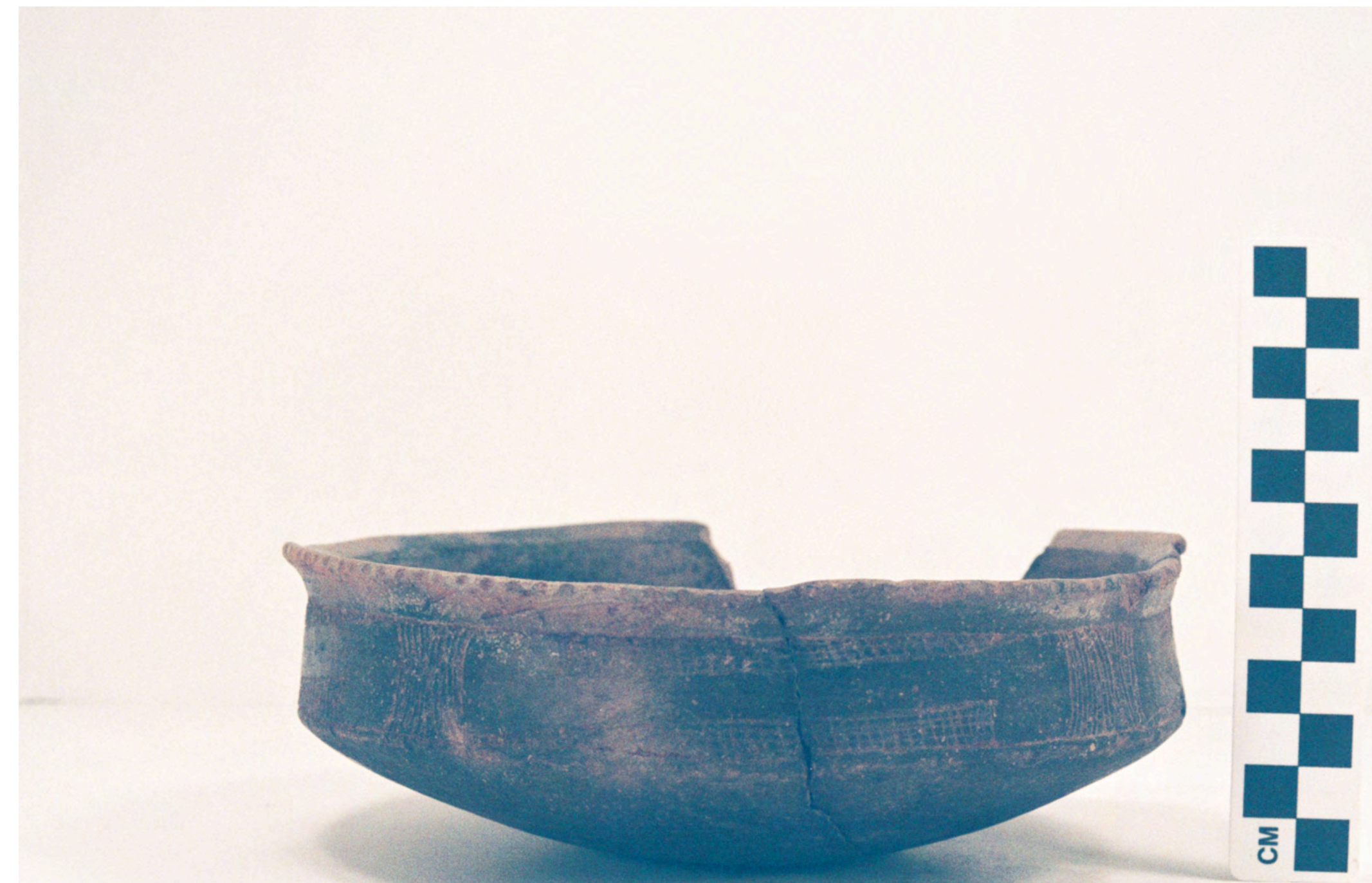

Figure A1-80 


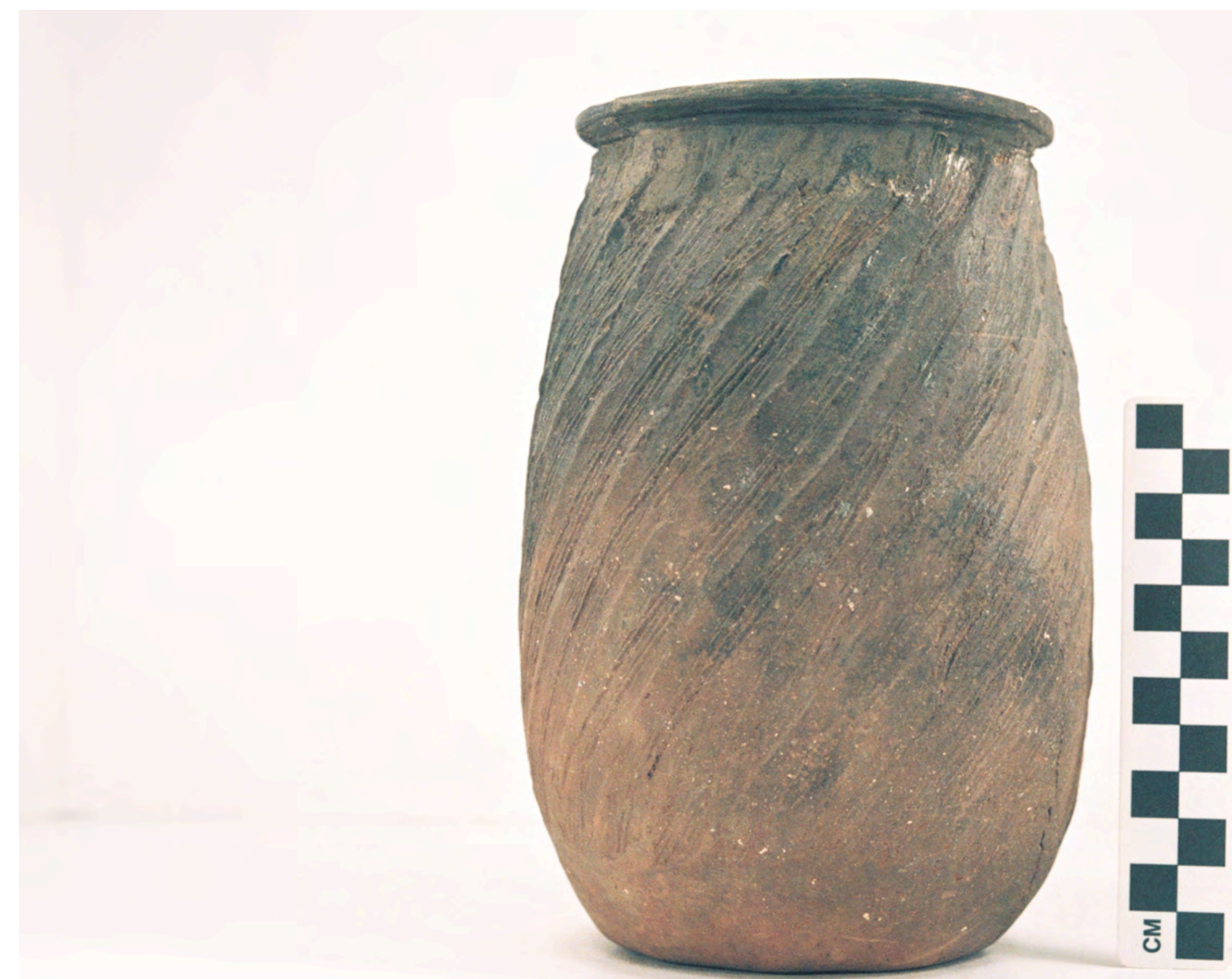

Figure A1-81 


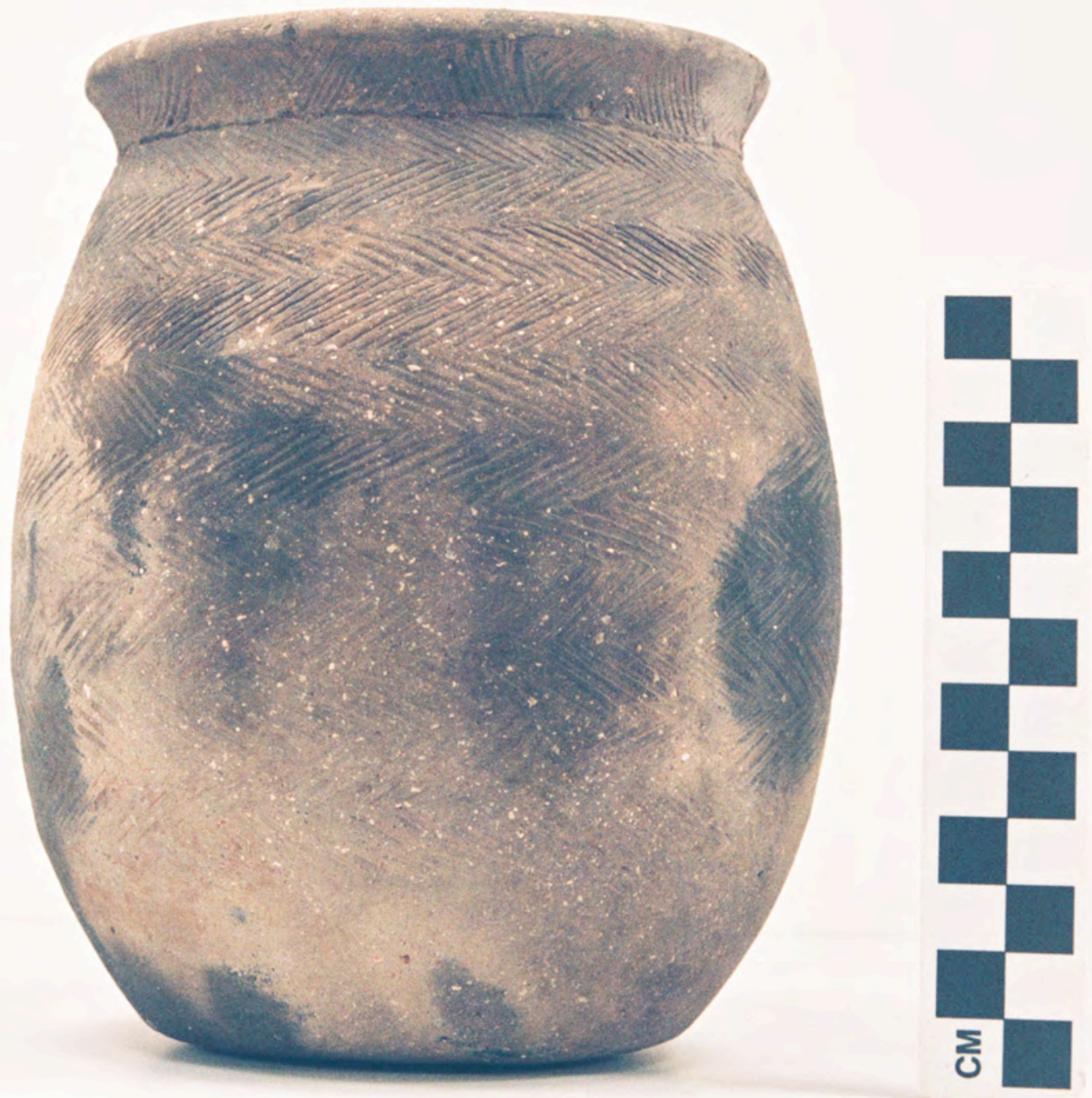

Figure A1-82 


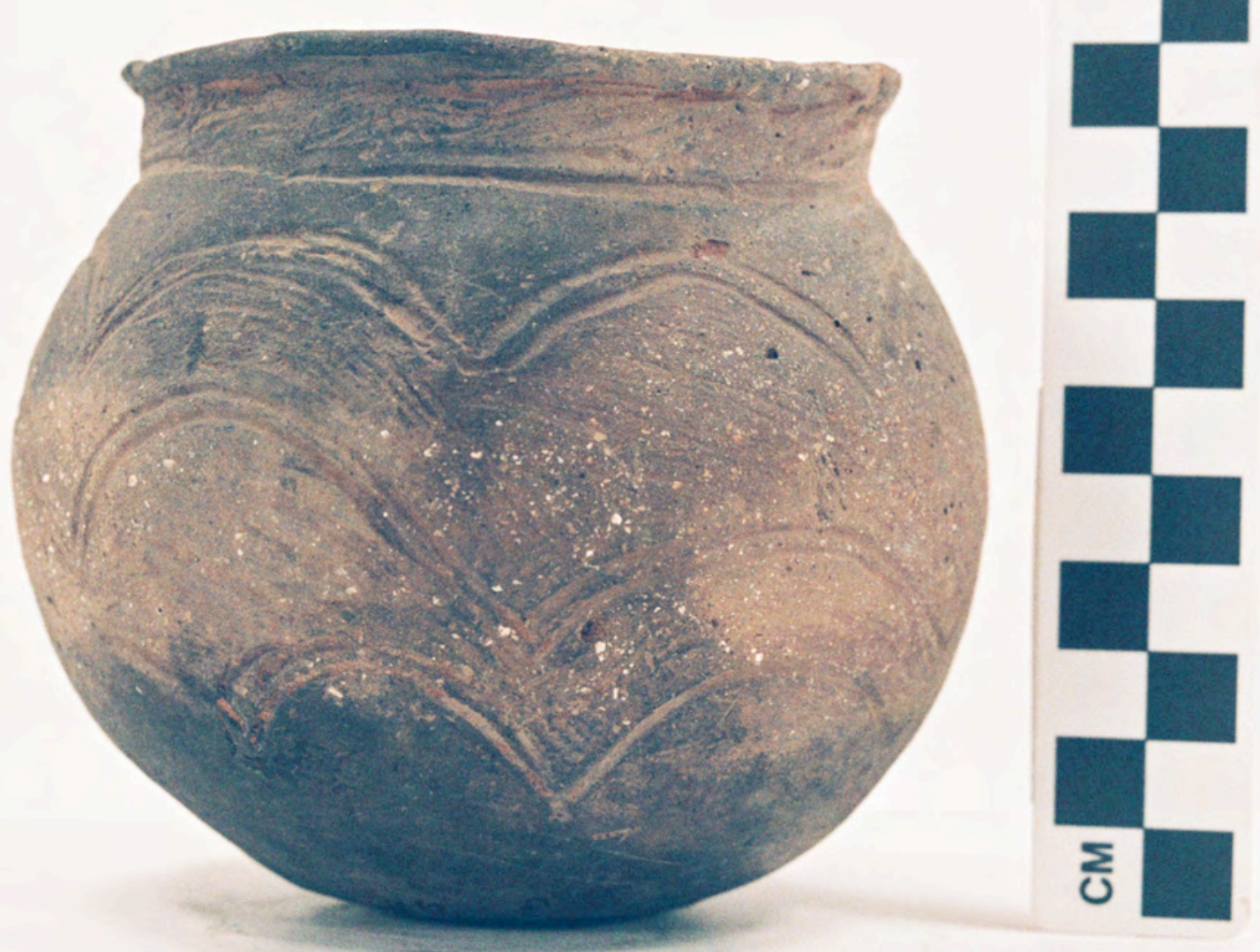

Figure A1-83 


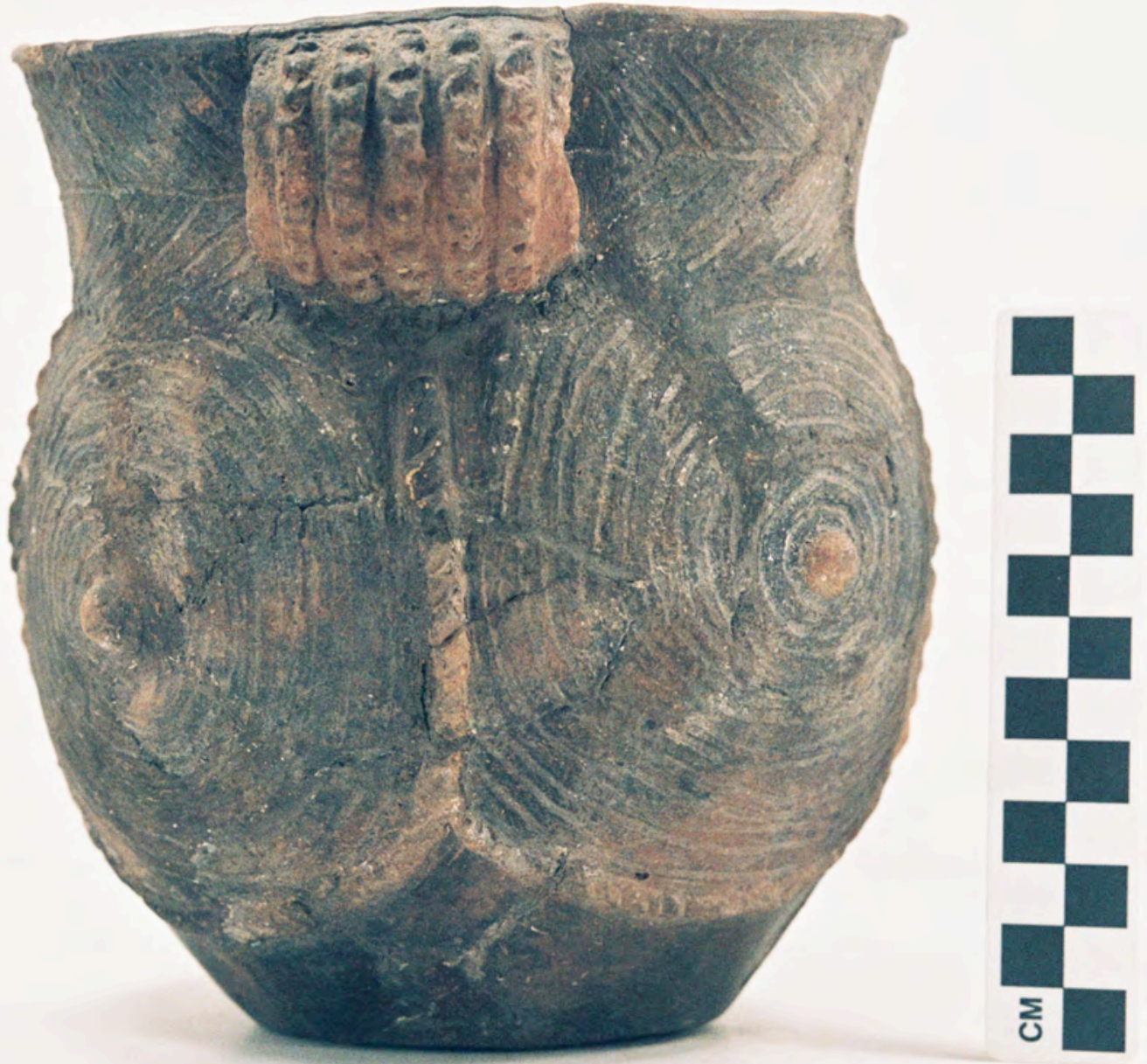

Figure A1-84 


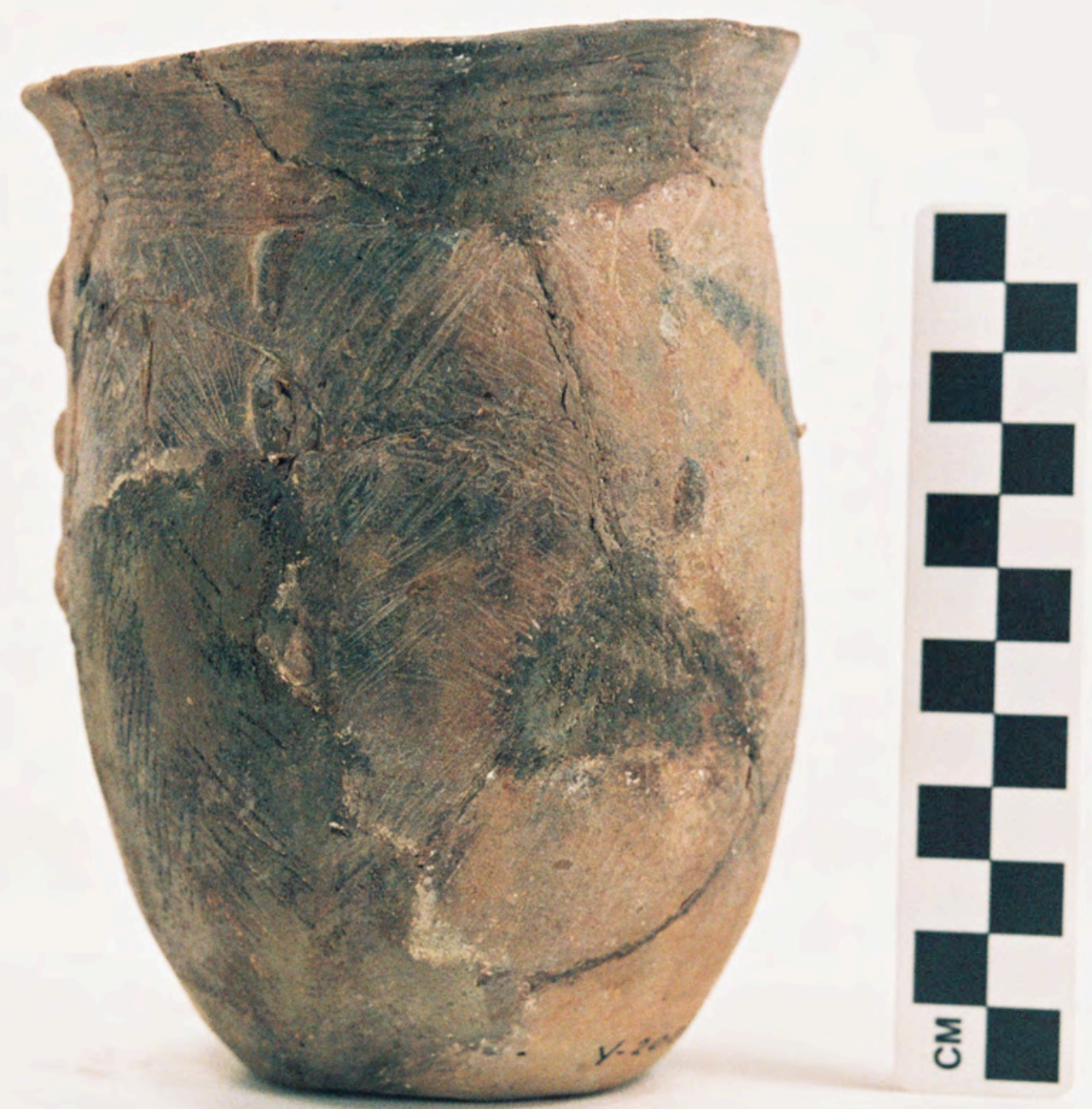

Figure A1-85 


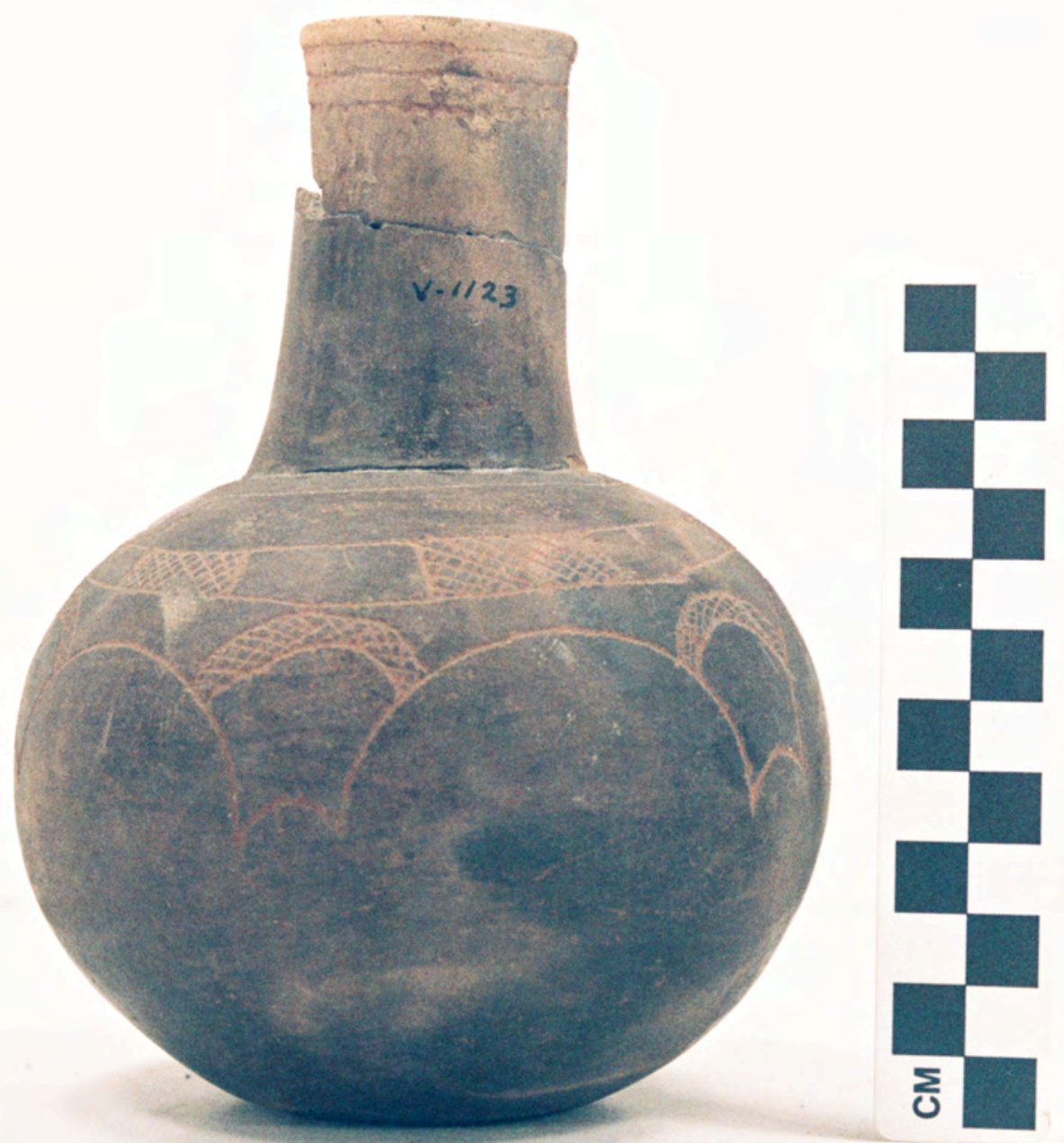

Figure A1-86 


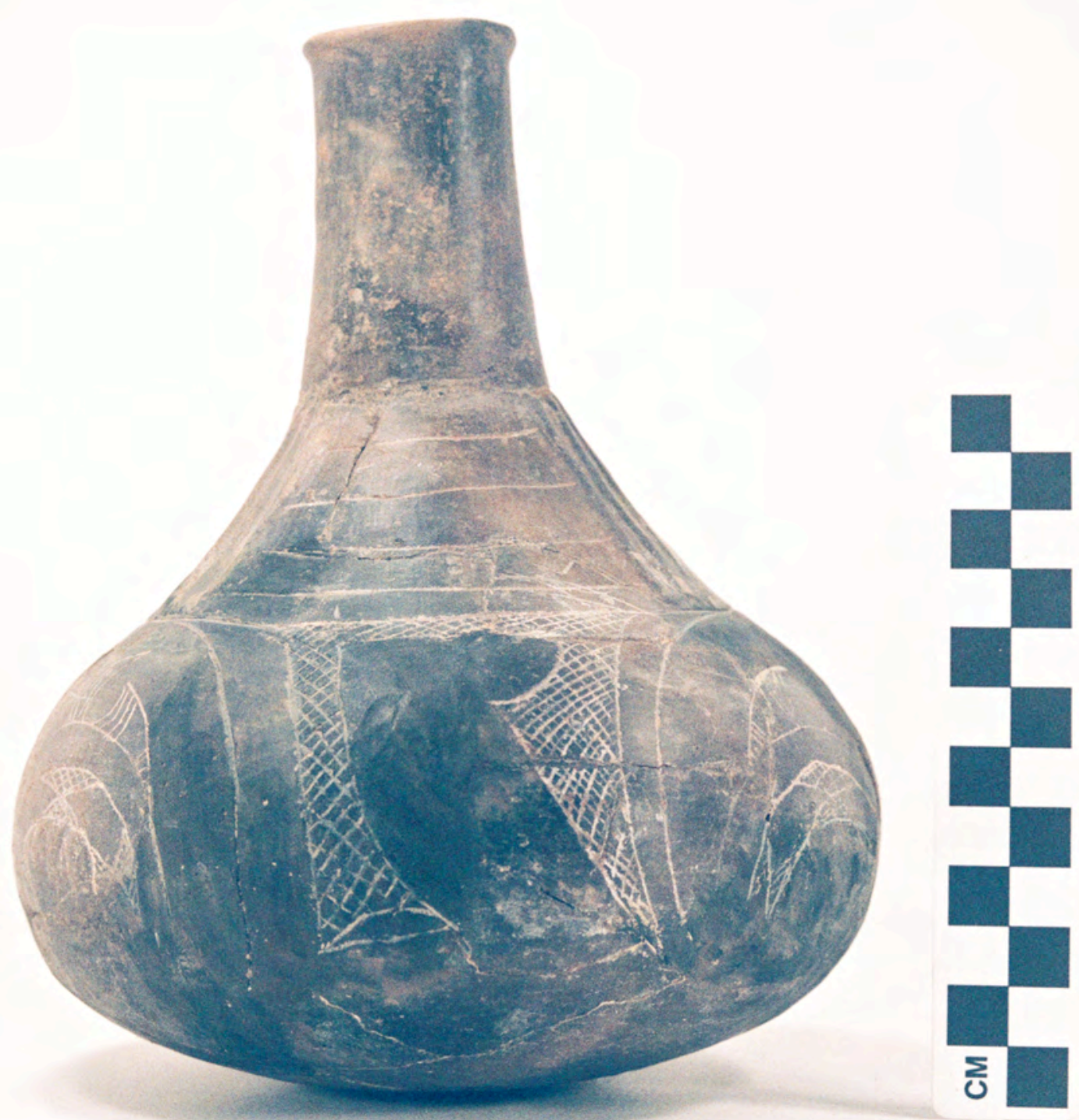

Figure A1-87a 


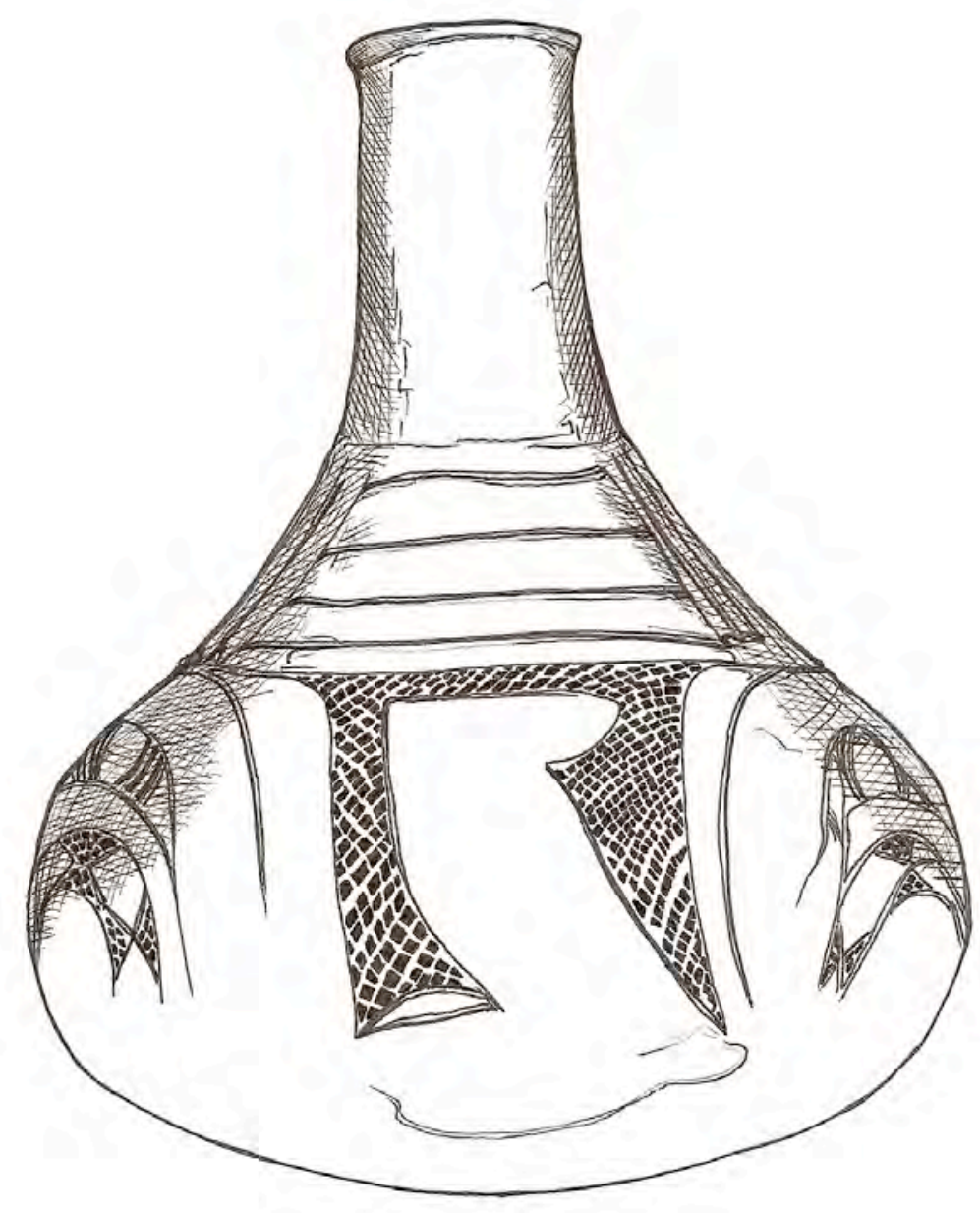

Figure A1-87. Friendship Engraved bottle (5425-751): b, drawing by Bobby Gonzalez.

Figure A1-87b 


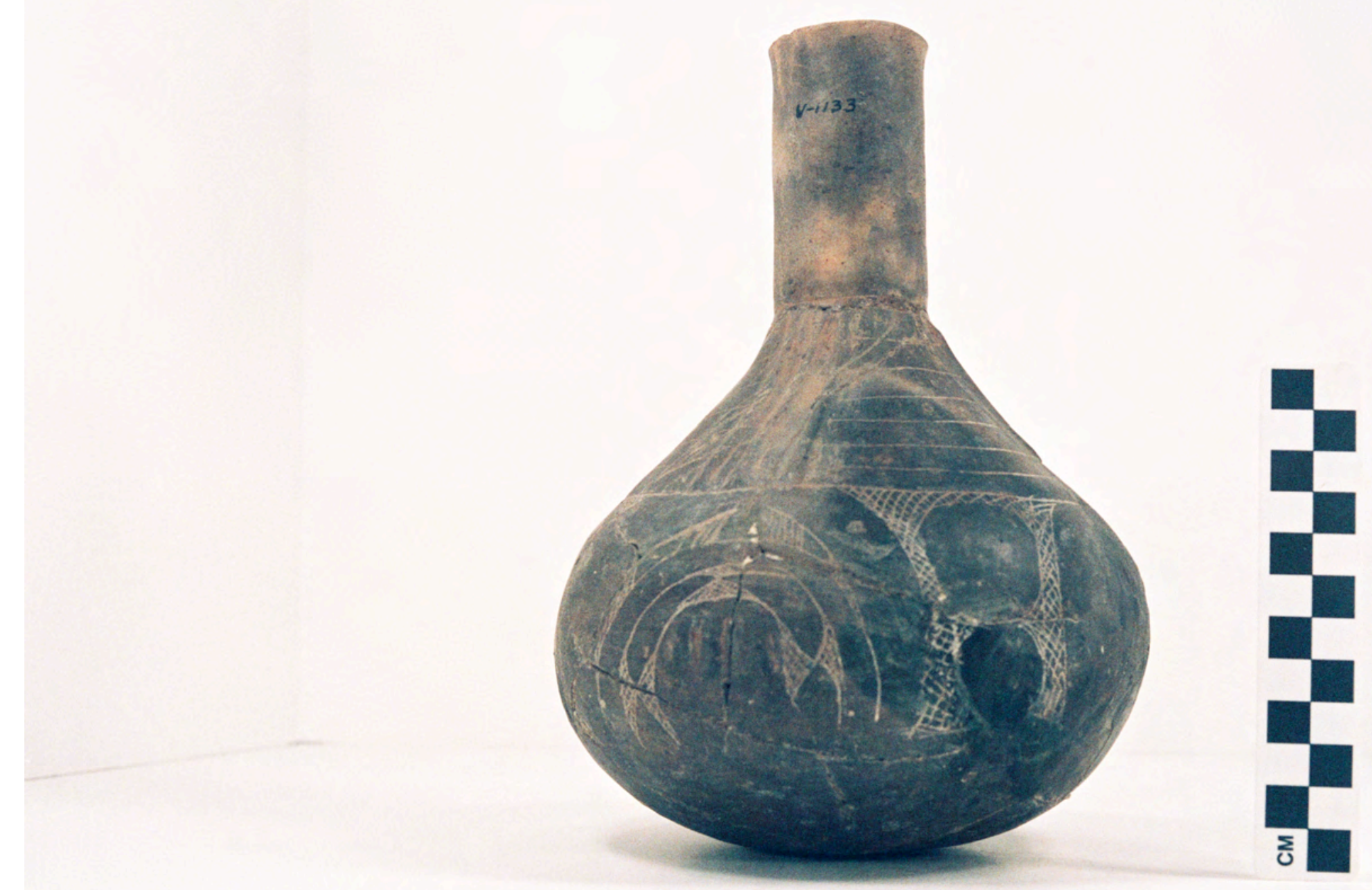

Figure A1-88 


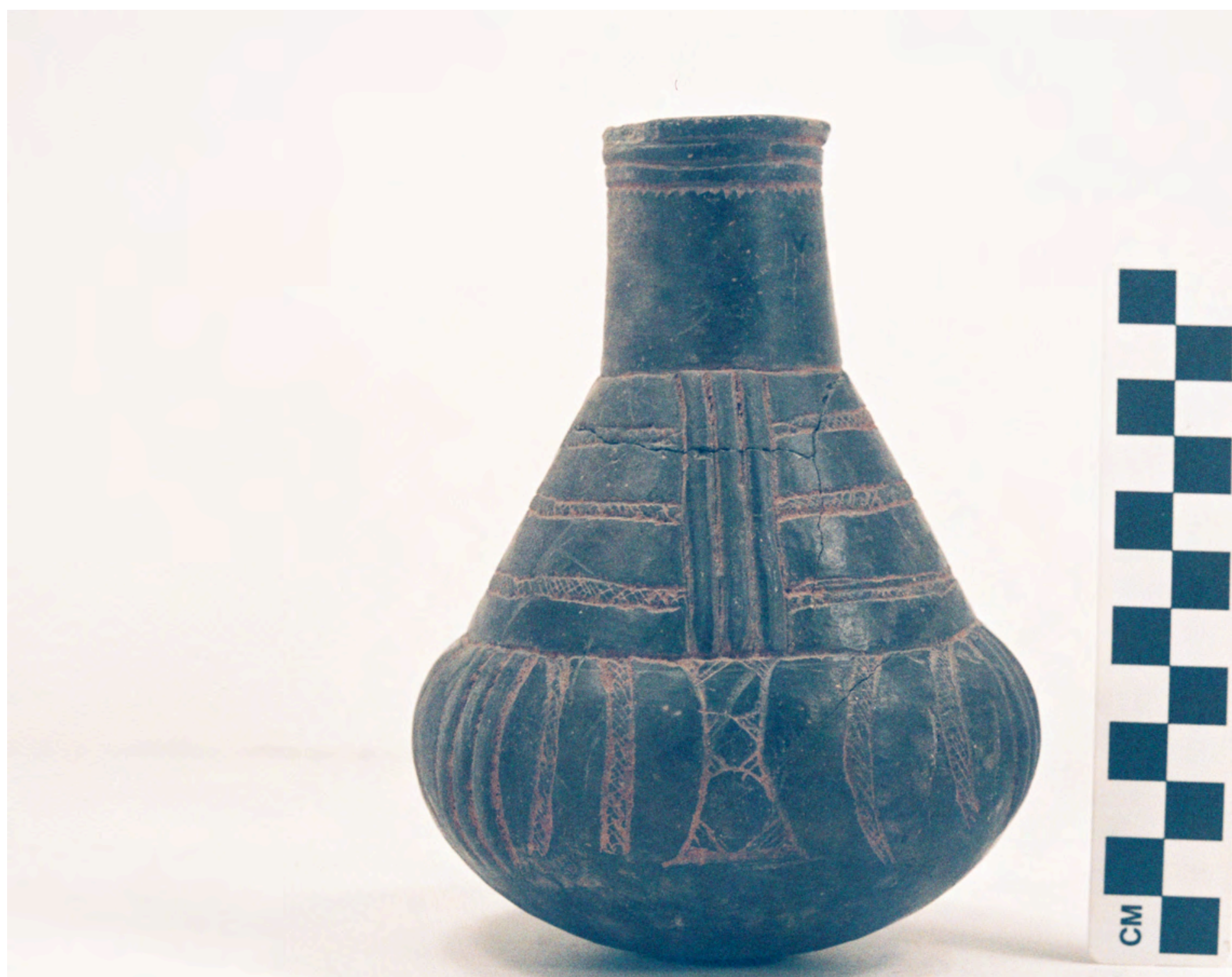

Figure A1-89 


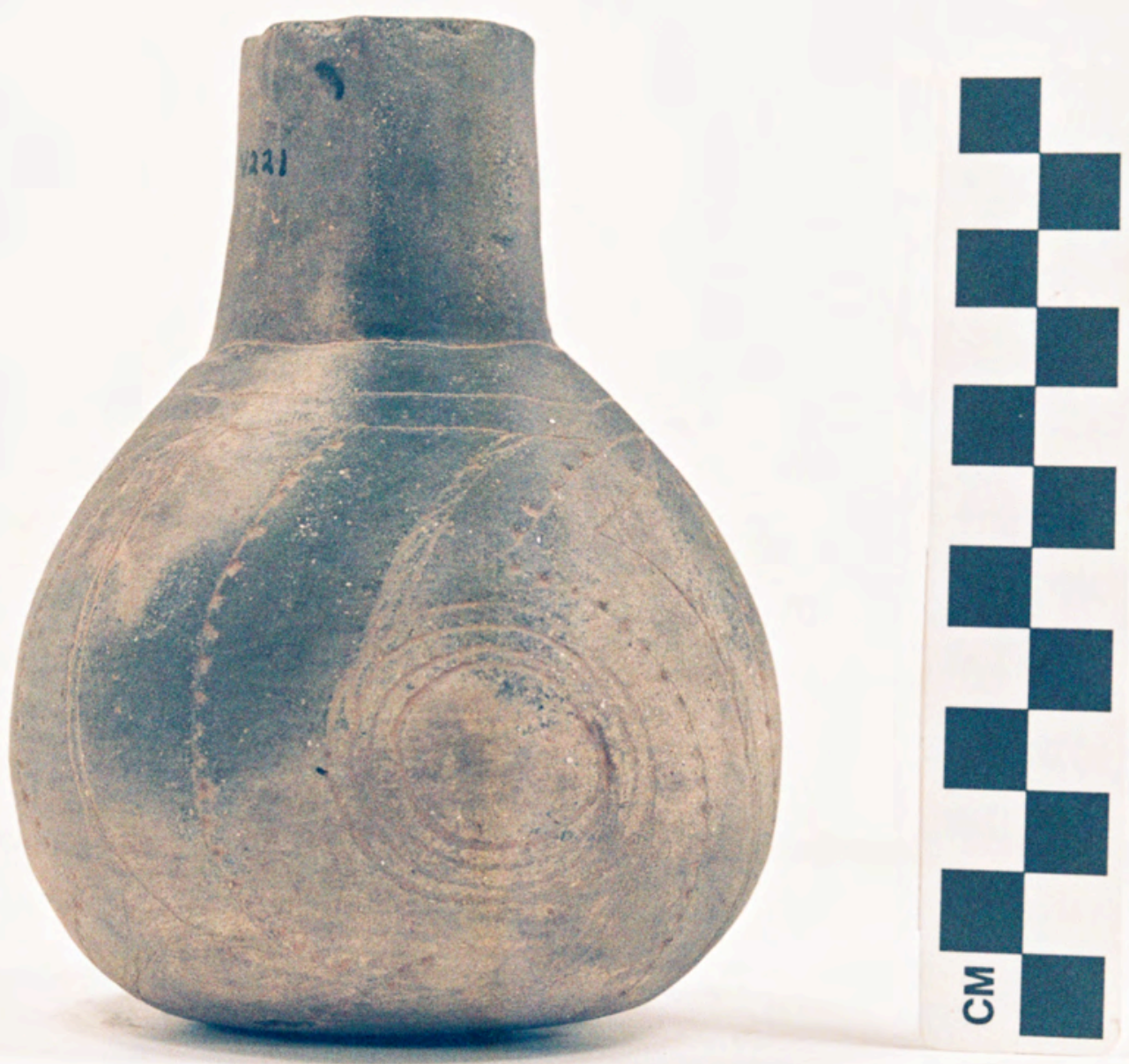

Figure A1-90 


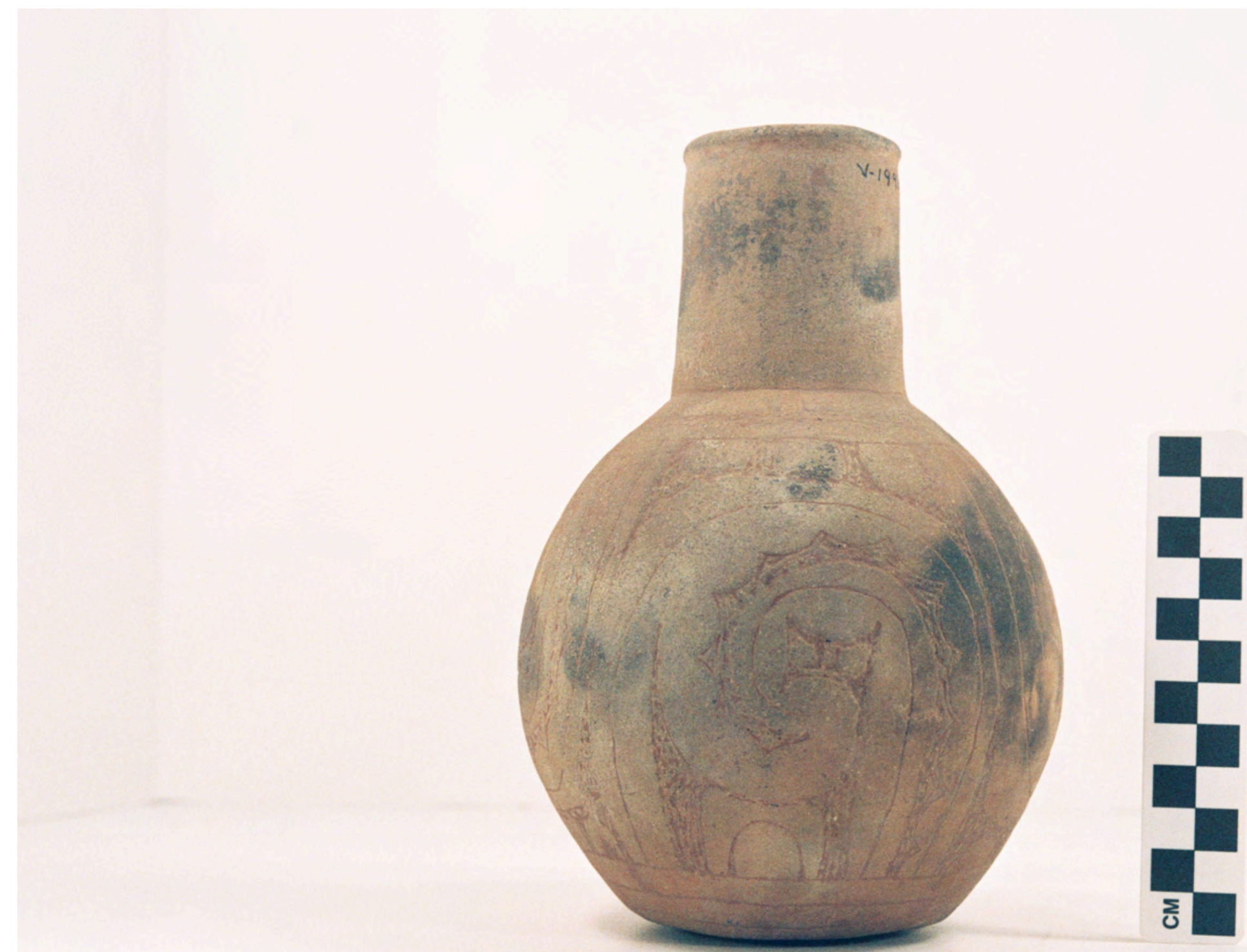

Figure A1-91a 


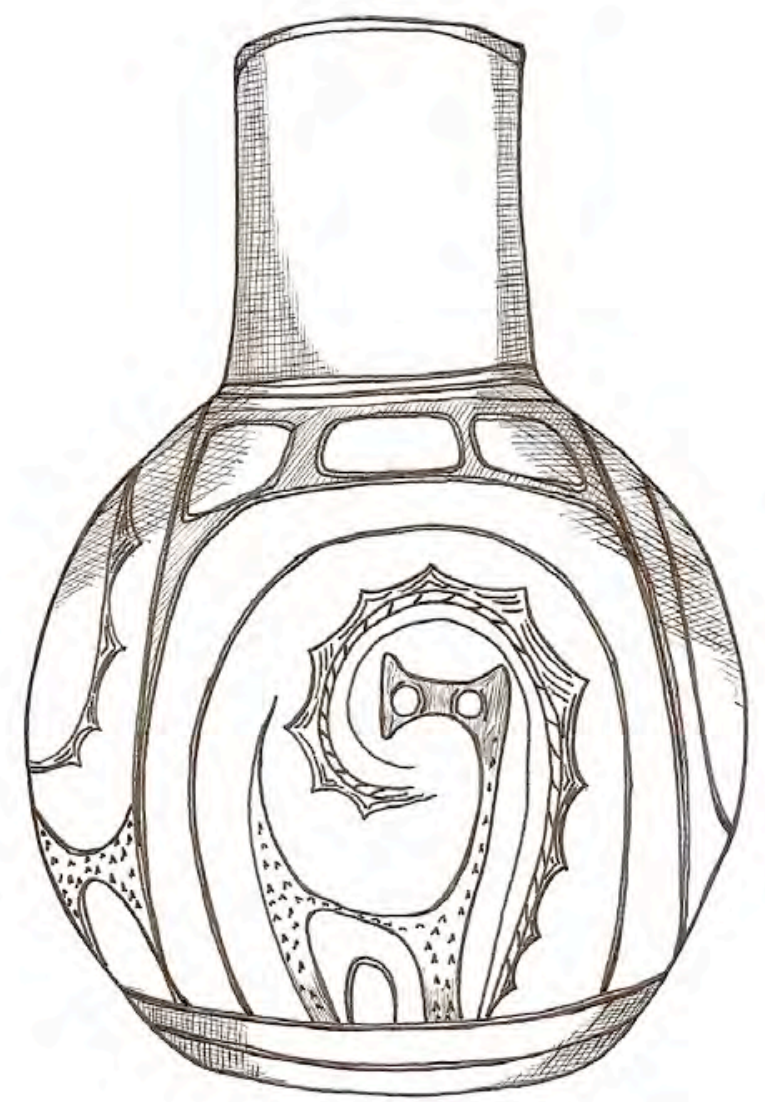

Figure A1-91. Haley Engraved bottle (5425-756): b, drawing by Bobby Gonzalez.

Figure A1-91b 


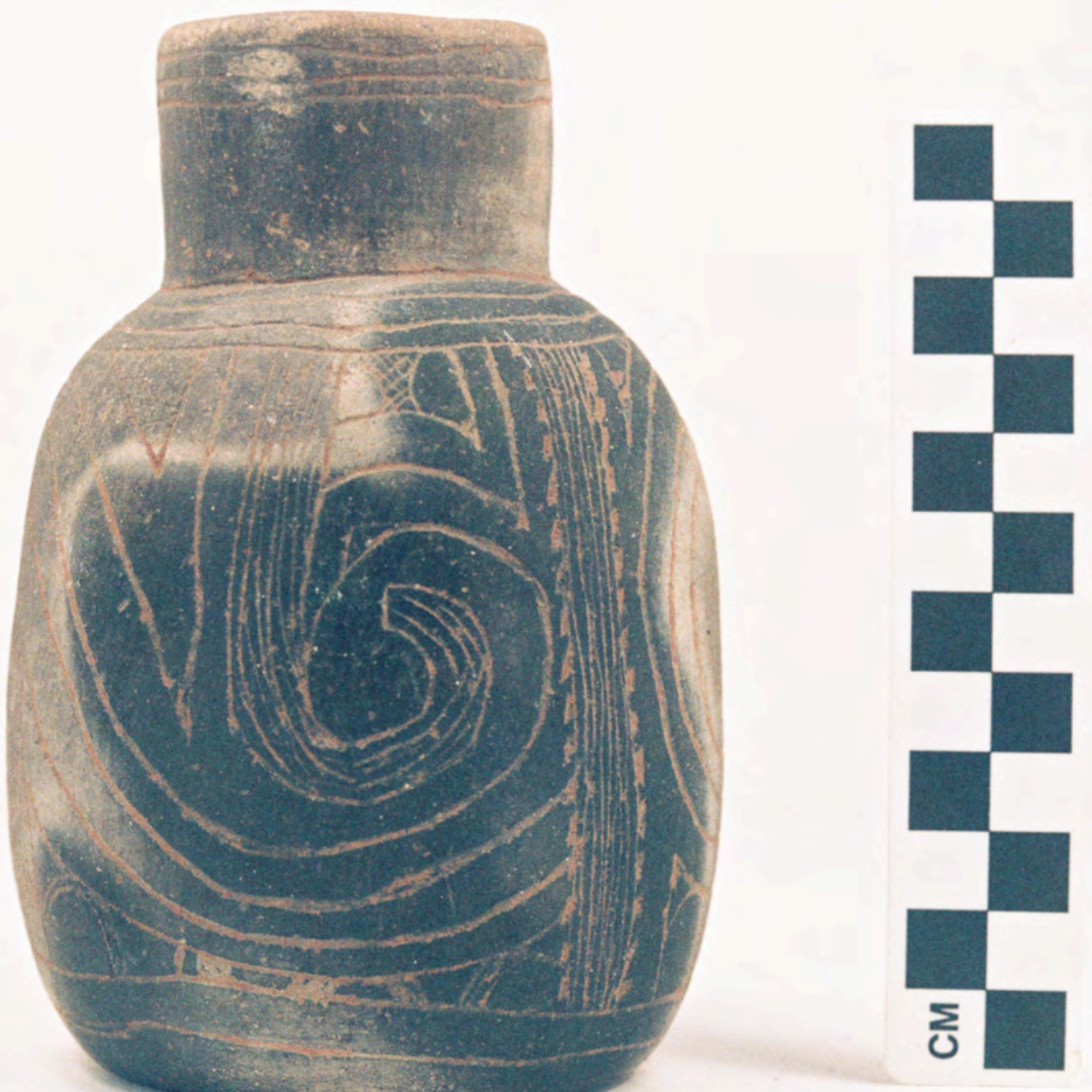

Figure A1-92a 


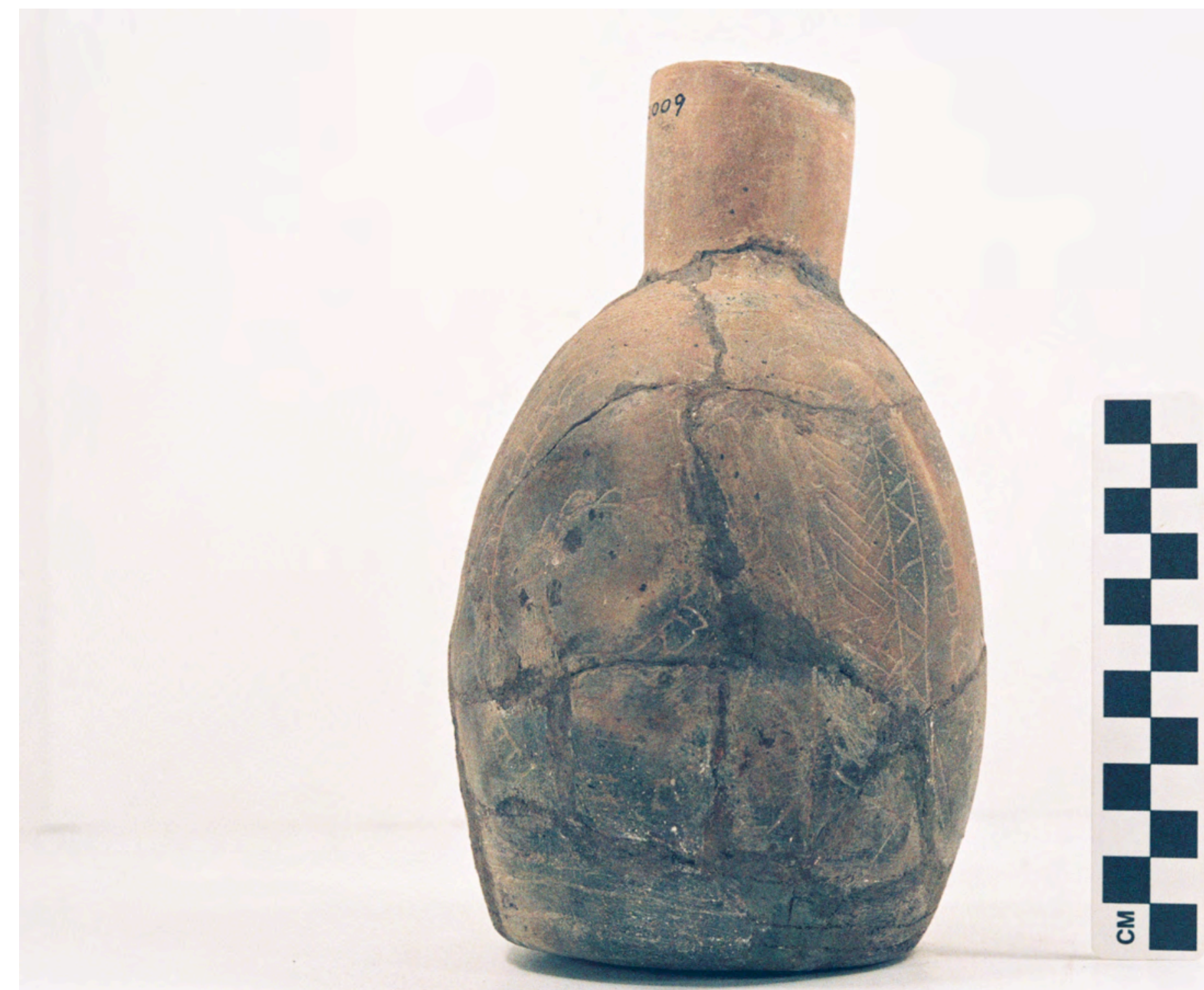

Figure A1-93 


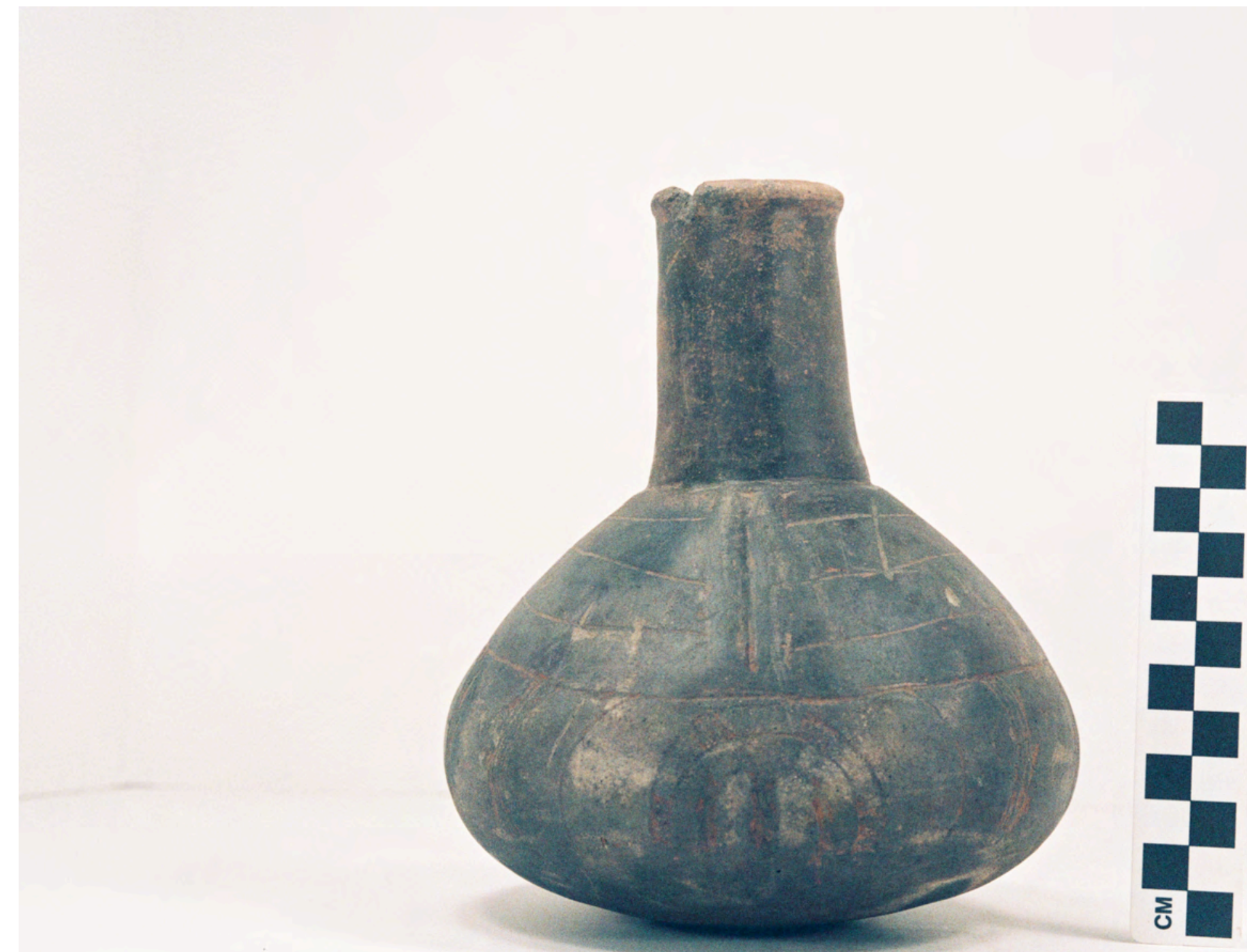

Figure A1-94 


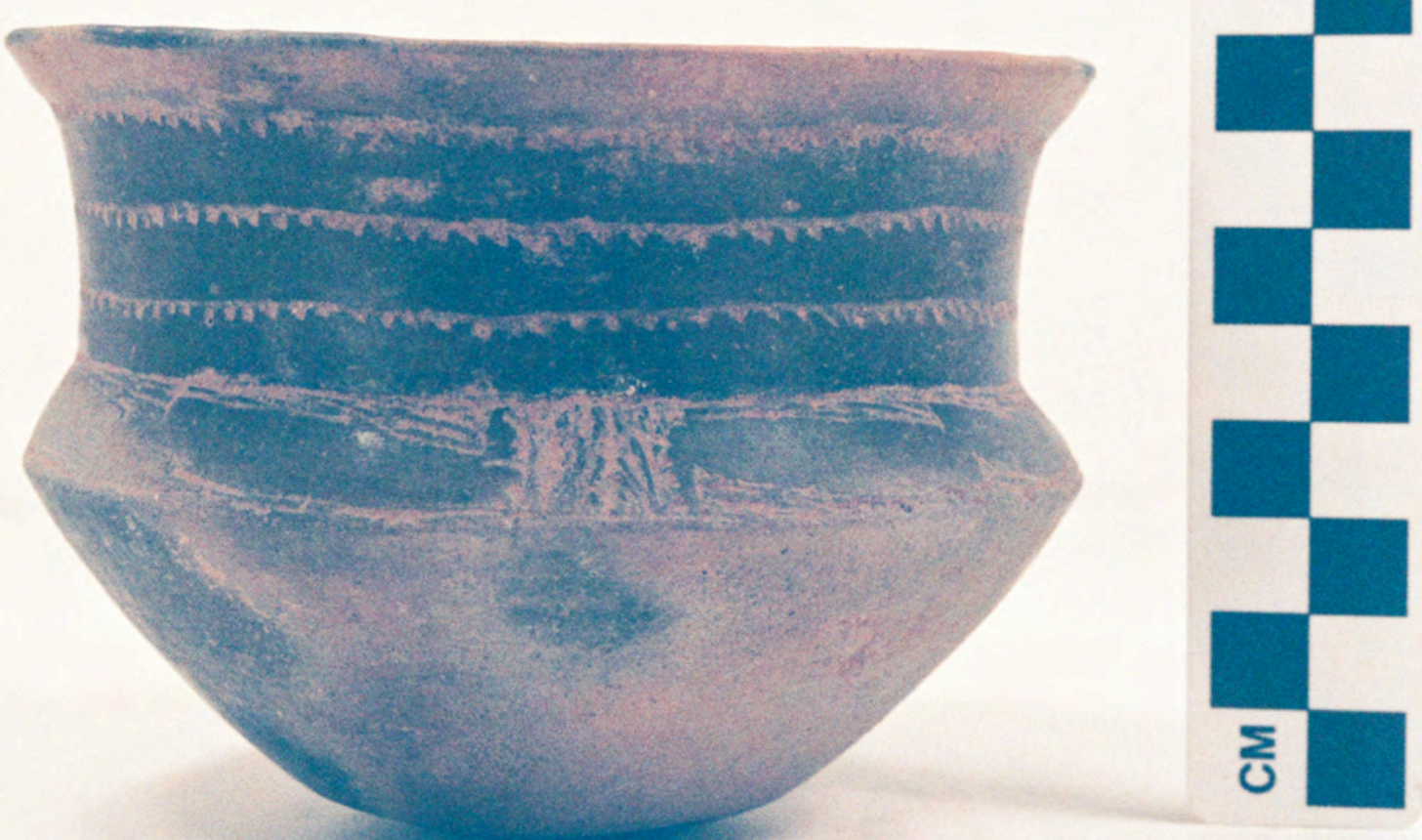

Figure A1-95a 


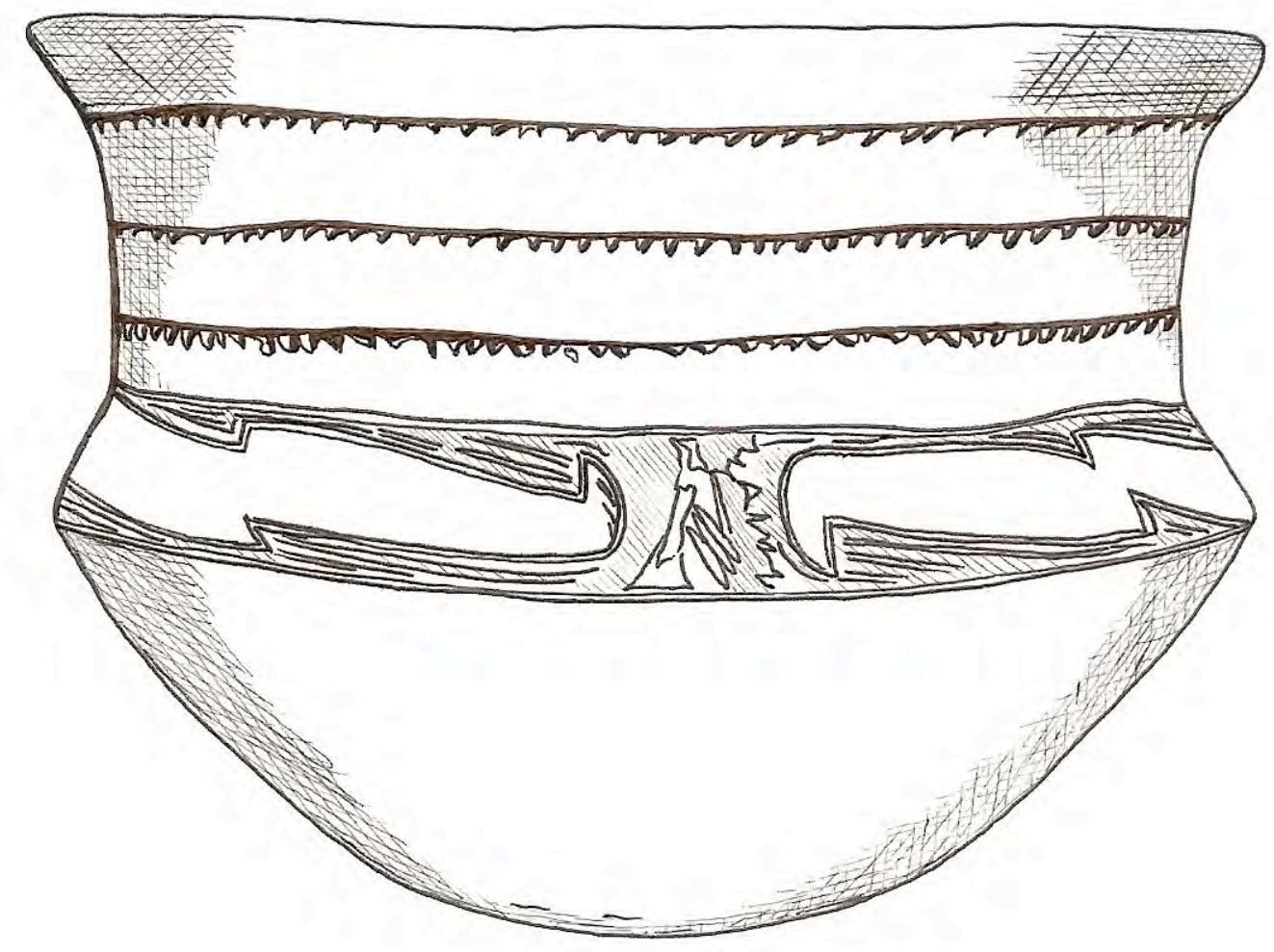

Figure A1-95. Glassell Engraved carinated bowl (5425-761): b, drawing by Bobby Gonzalez.

Figure A1-95b 

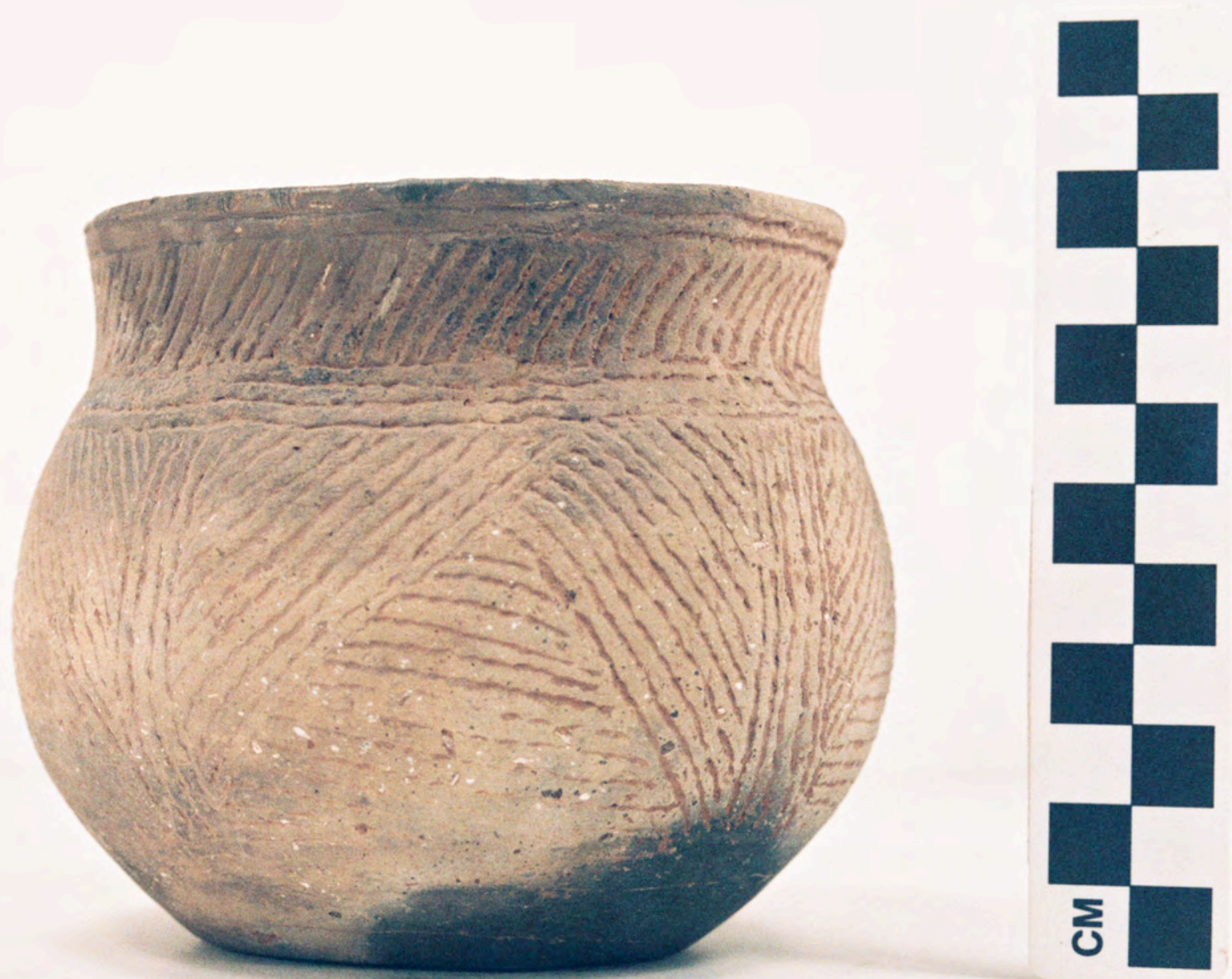

Figure A1-96 


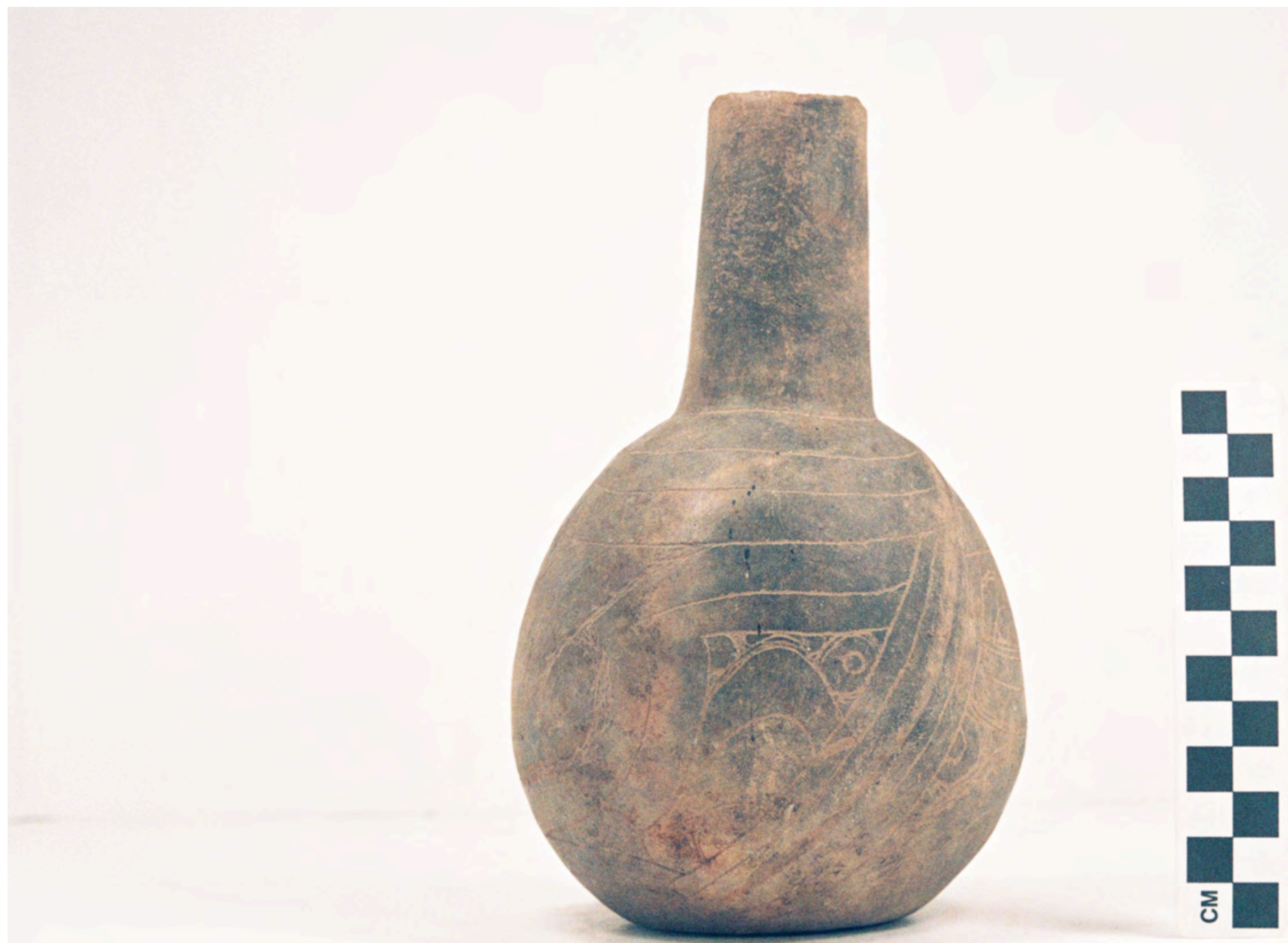

Figure A1-97a 


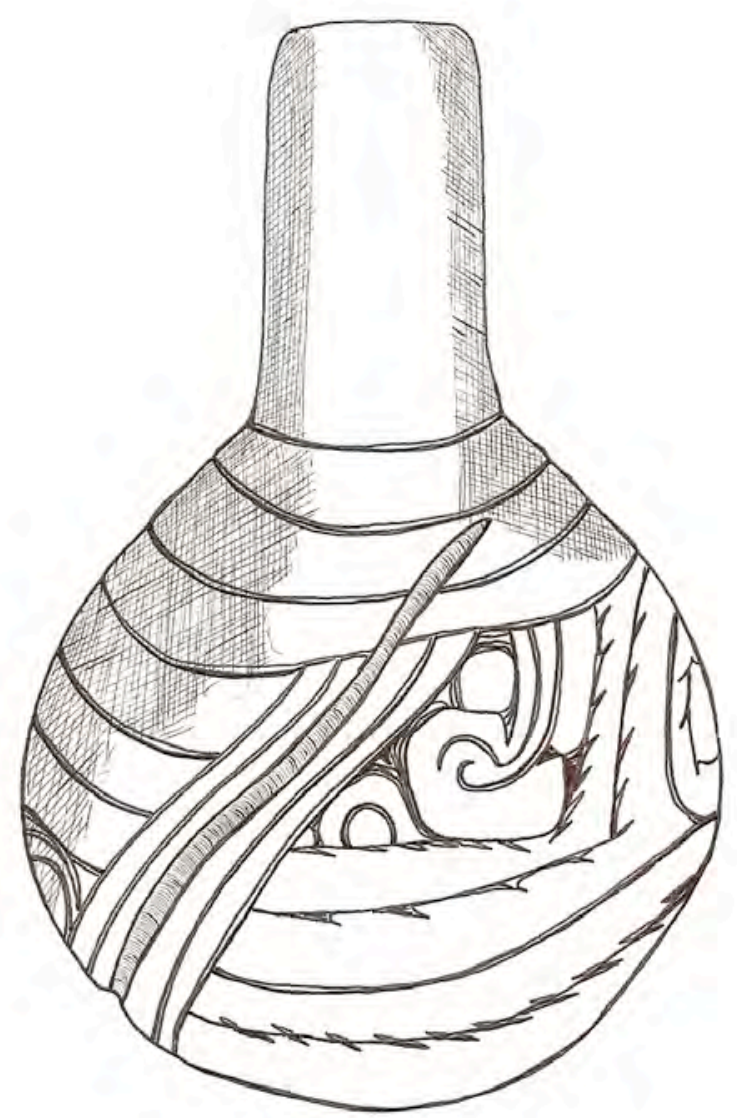

Figure A1-97. Haley Engraved bottle (5425-1391): b, drawing by Bobby Gonzalez.

Figure A1-97b 

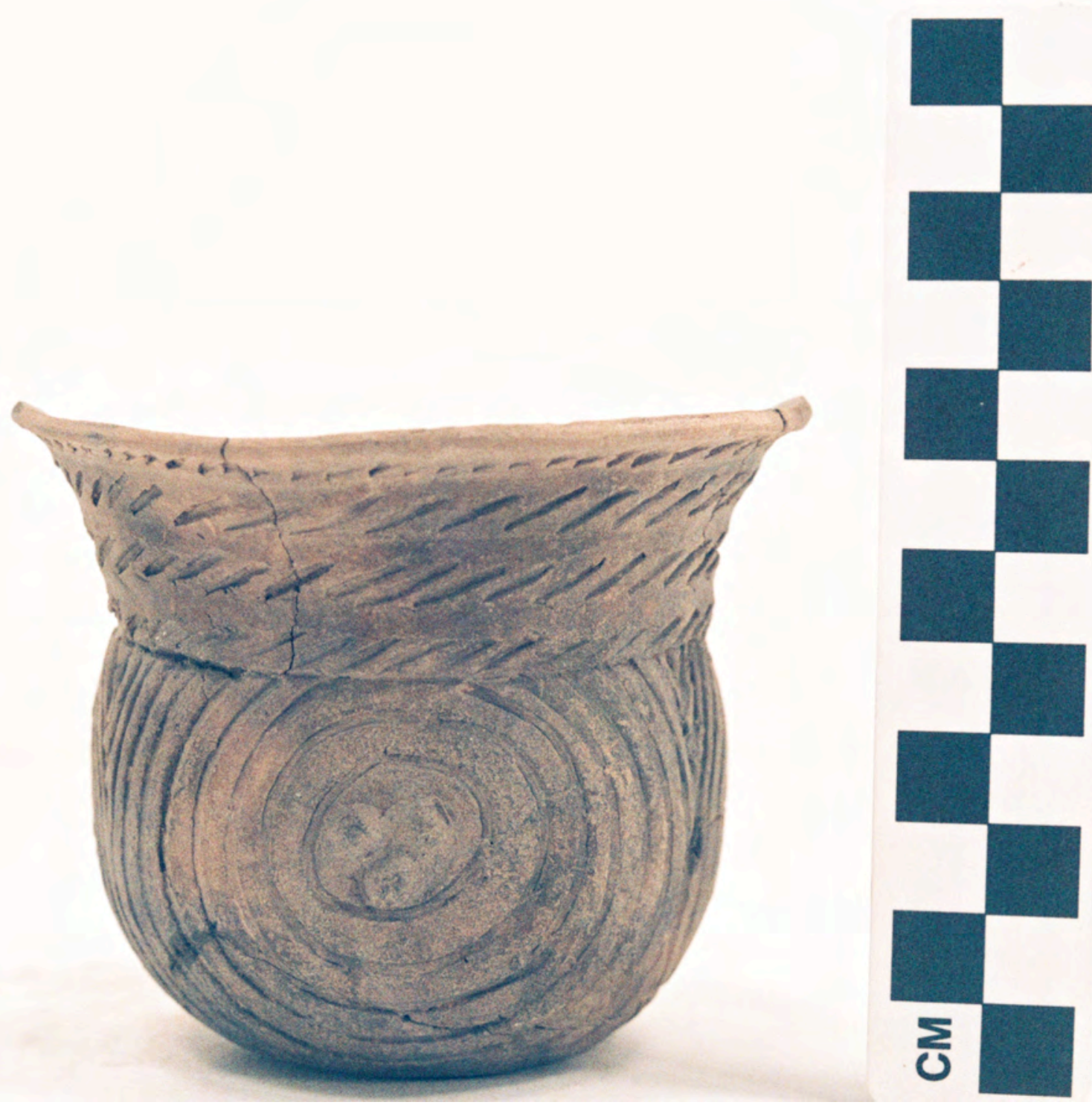

Figure A1-98 


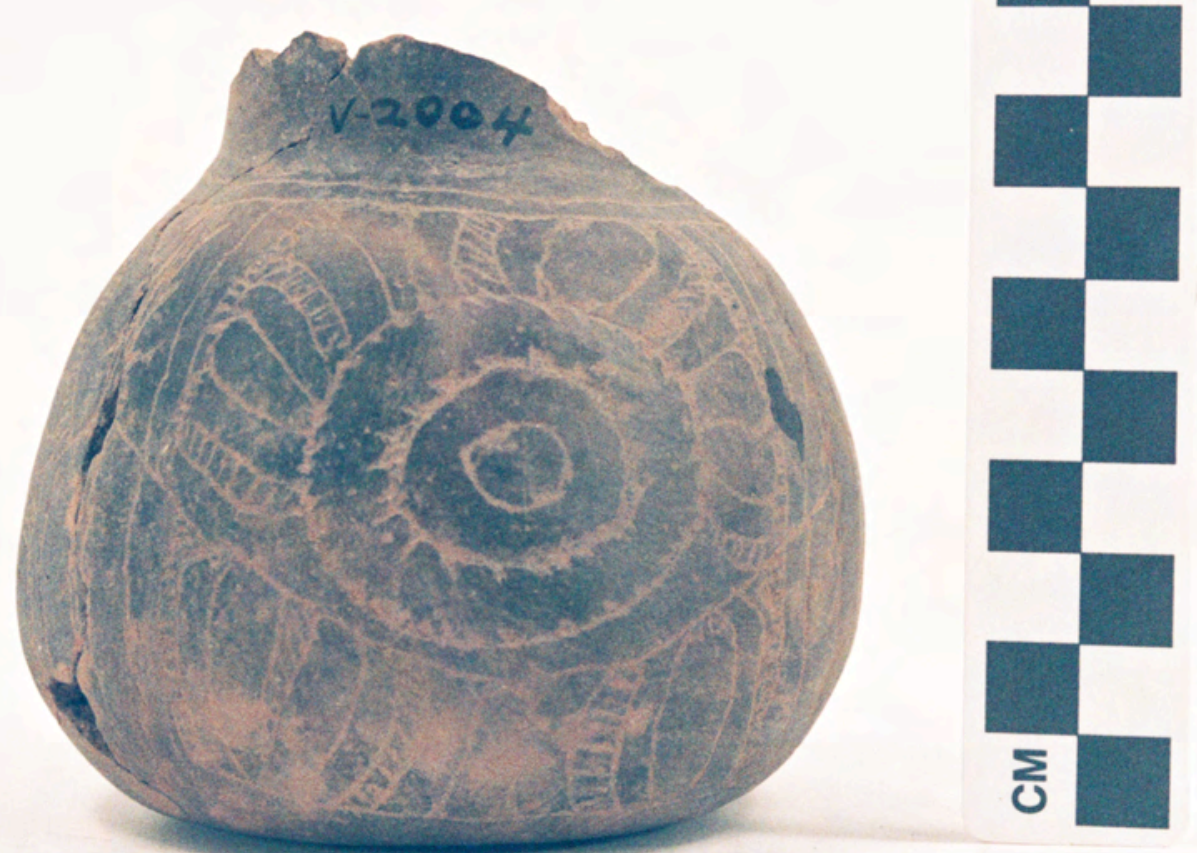

Figure A1-99 


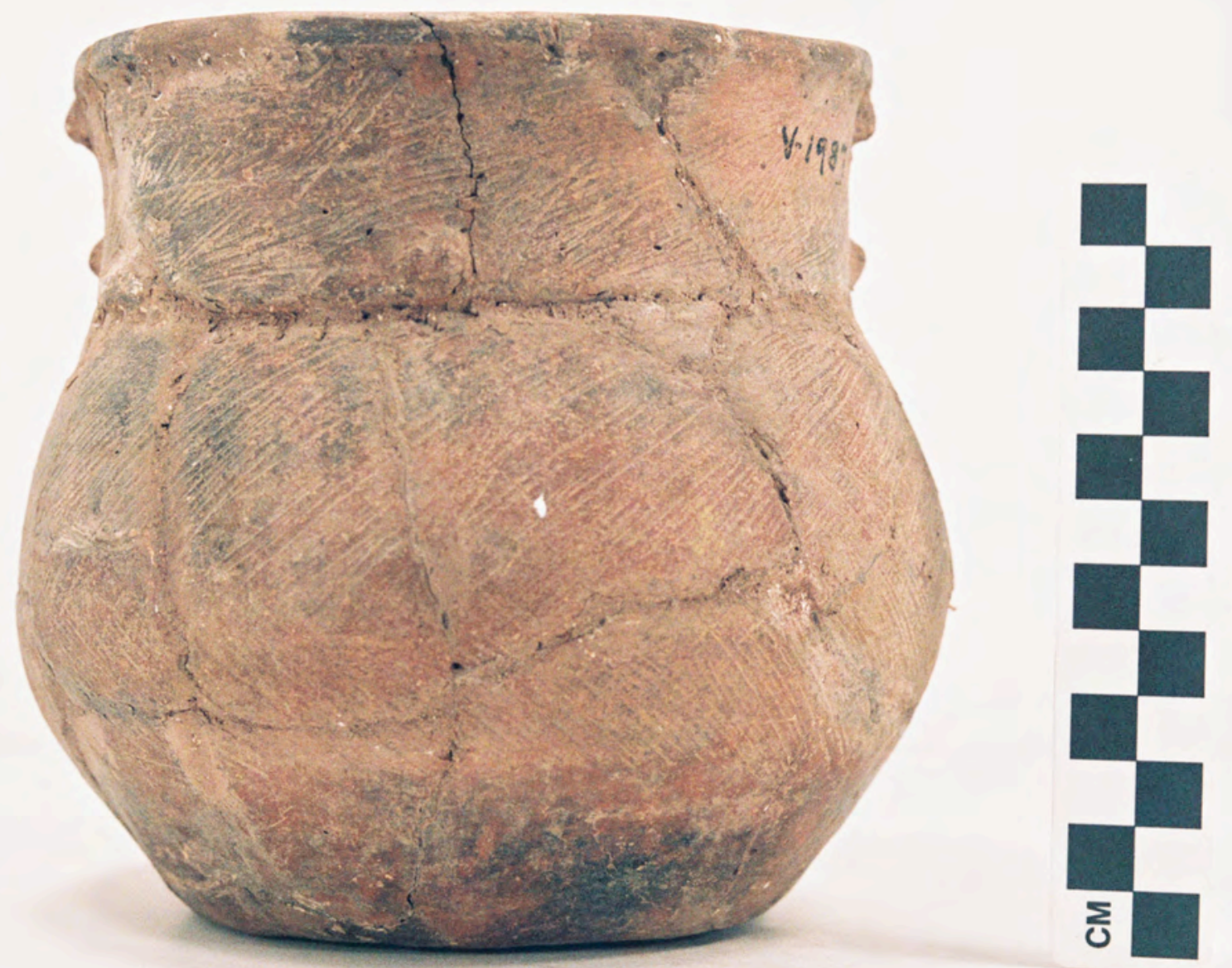

Figure A1-100 


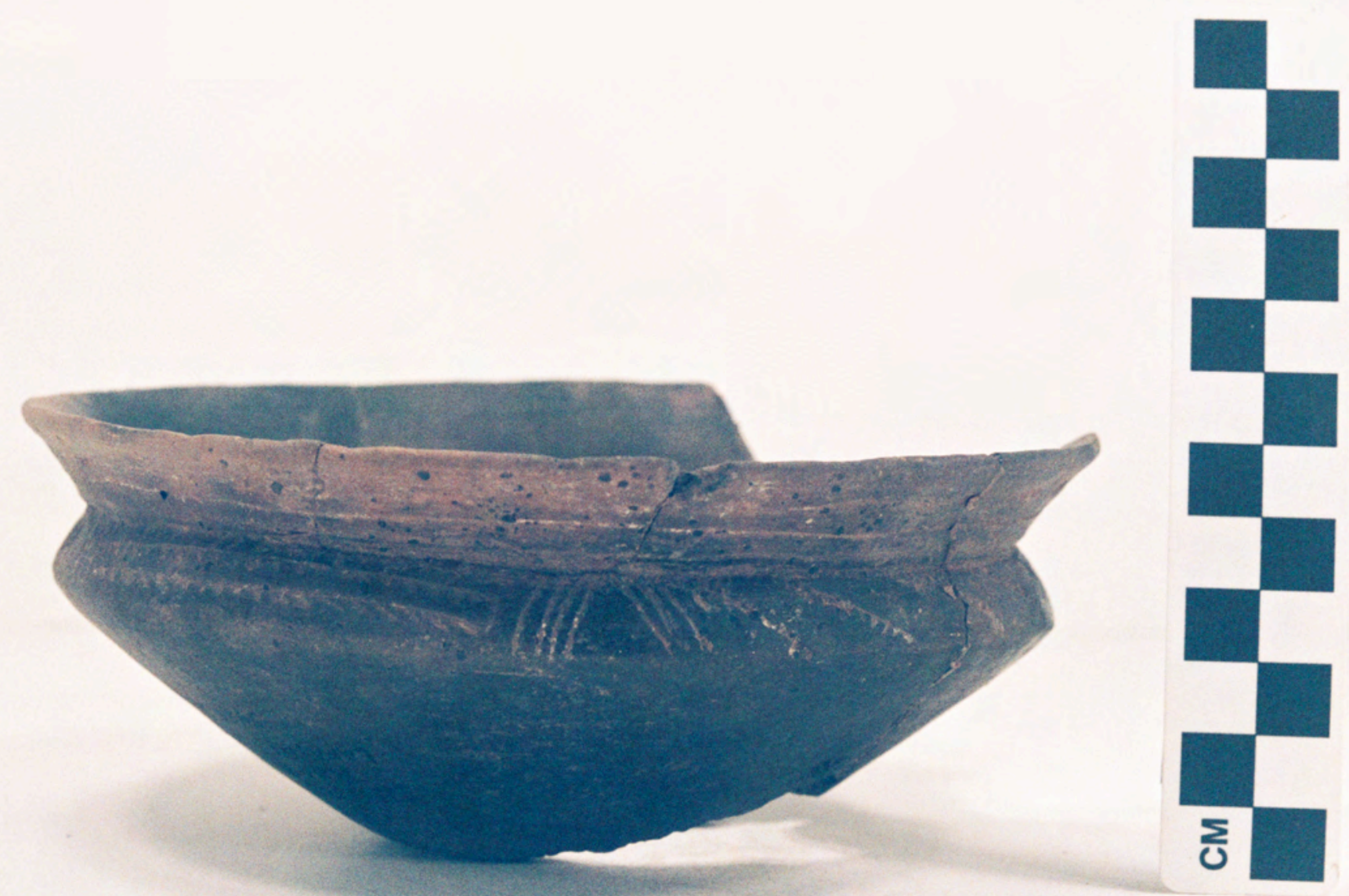

Figure A1-101 


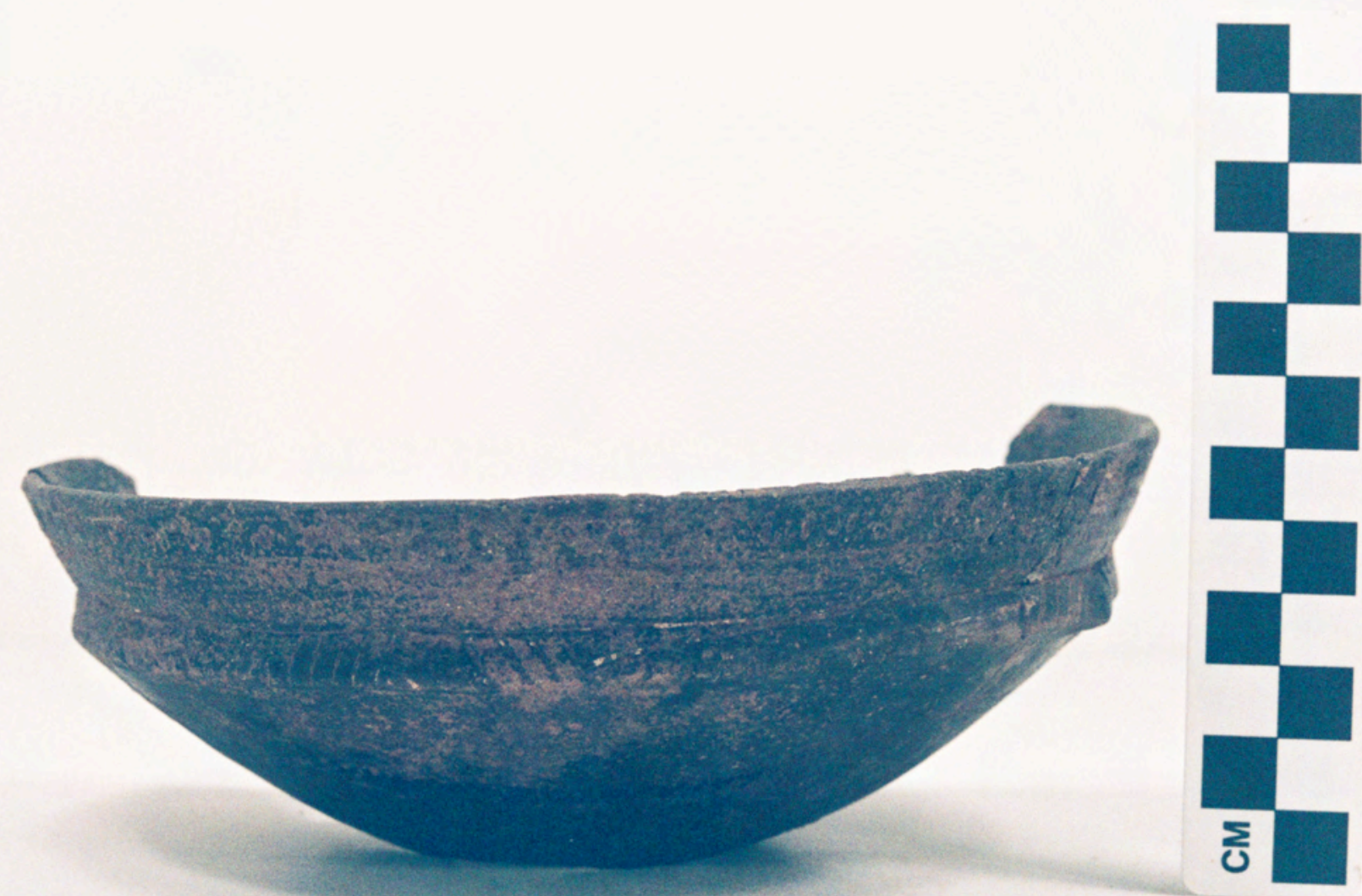

Figure A1-102 


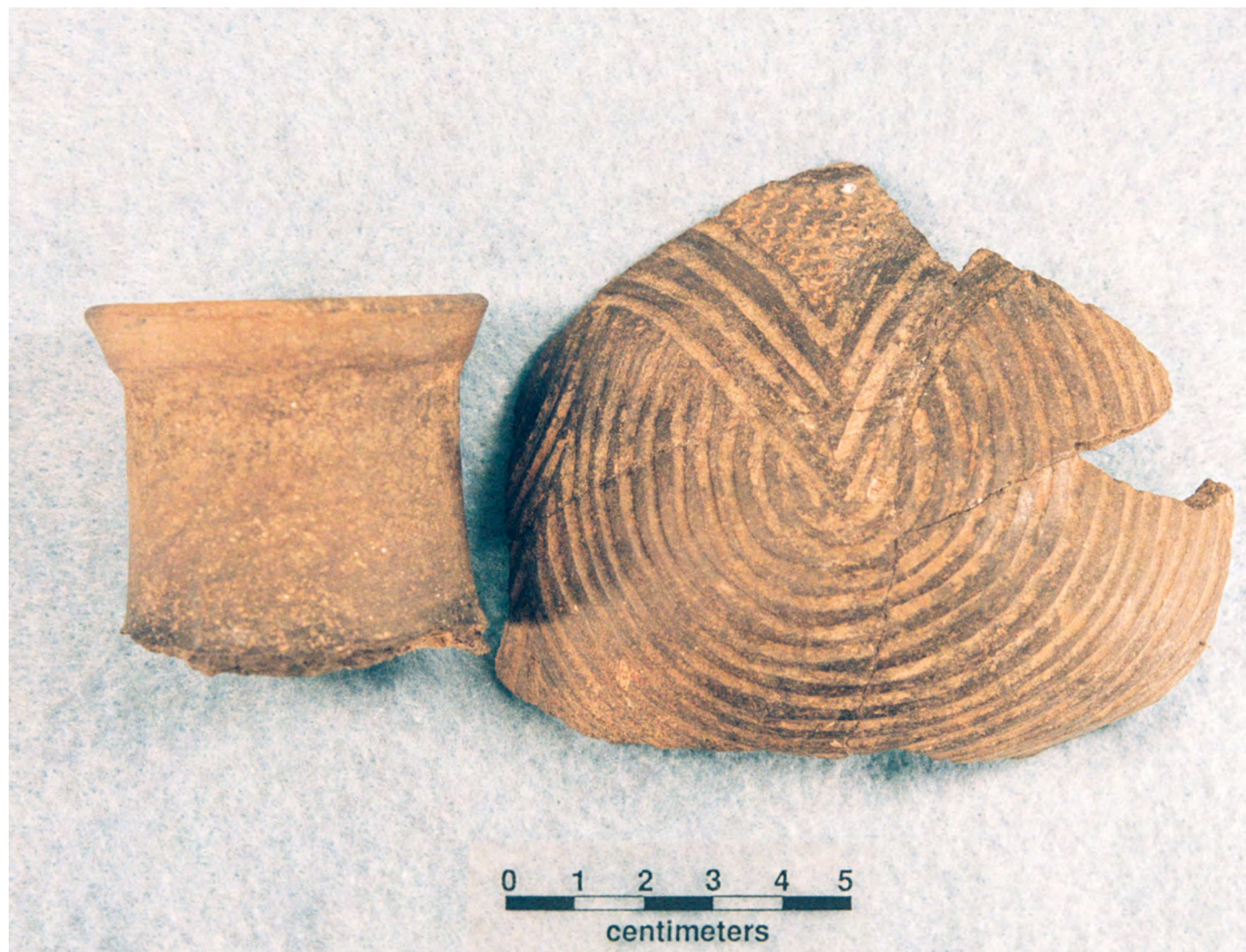

Figure A1-103a 


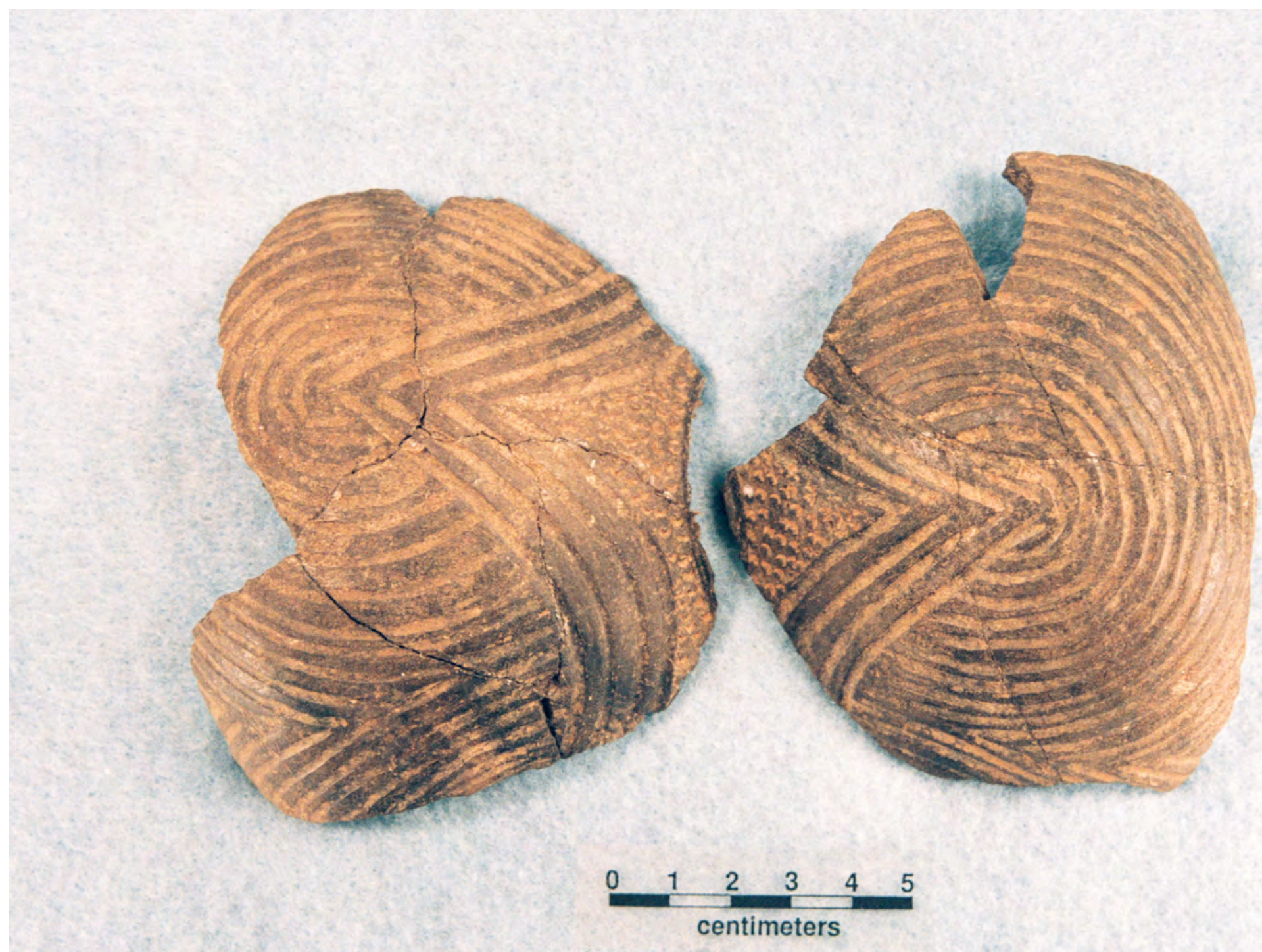

Figure A1-103b 


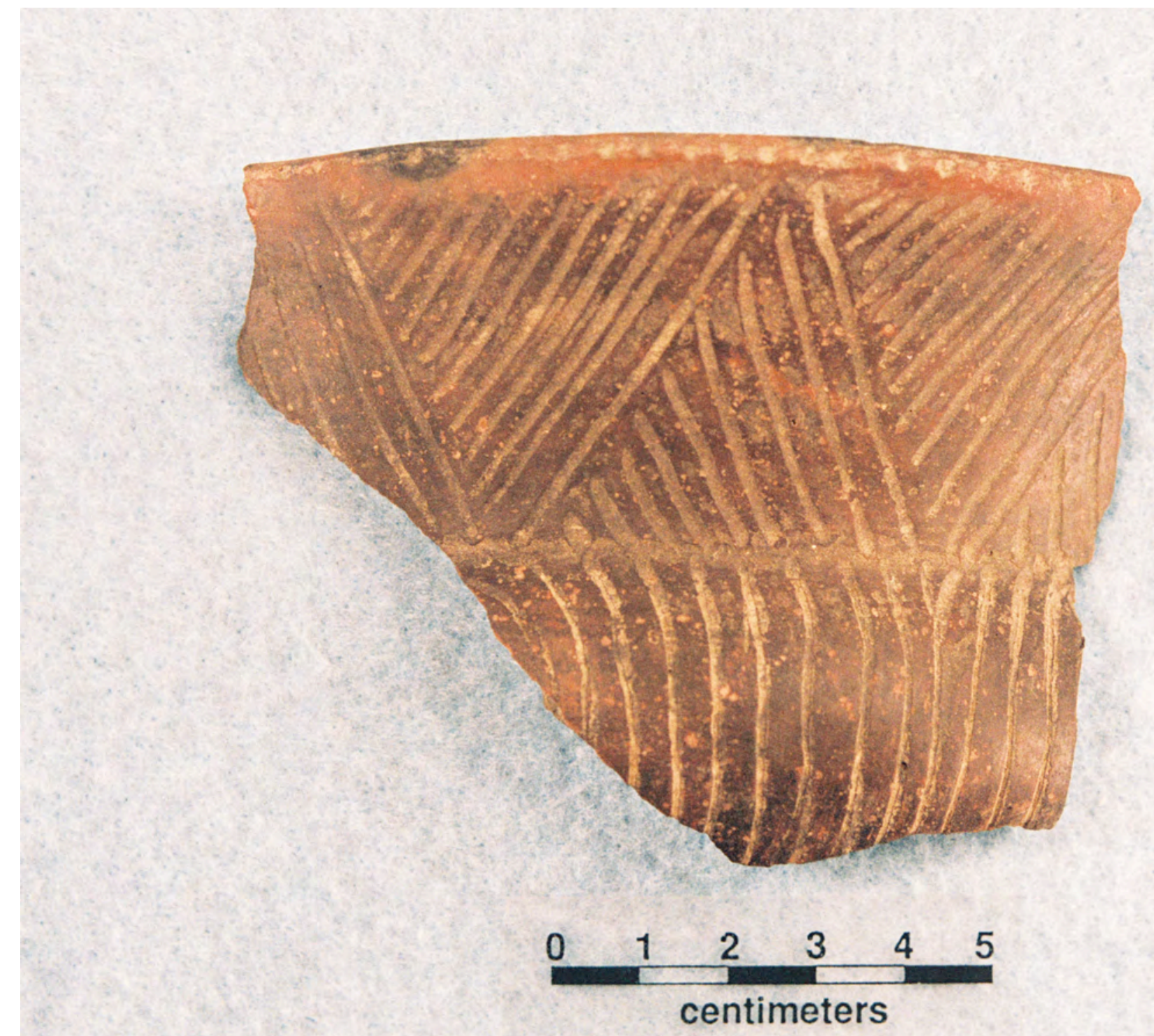

Figure A1-104 


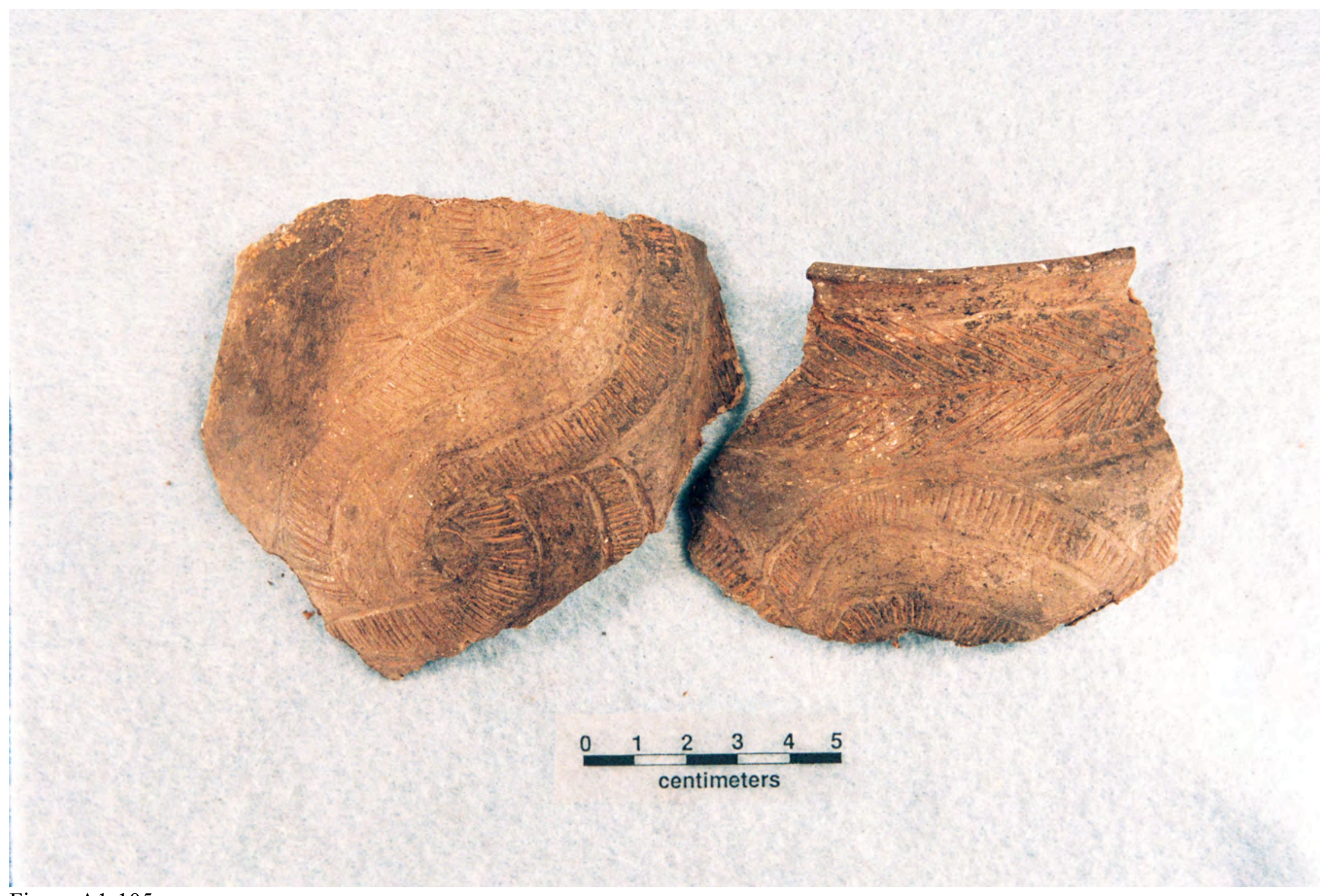

Figure A1-105 


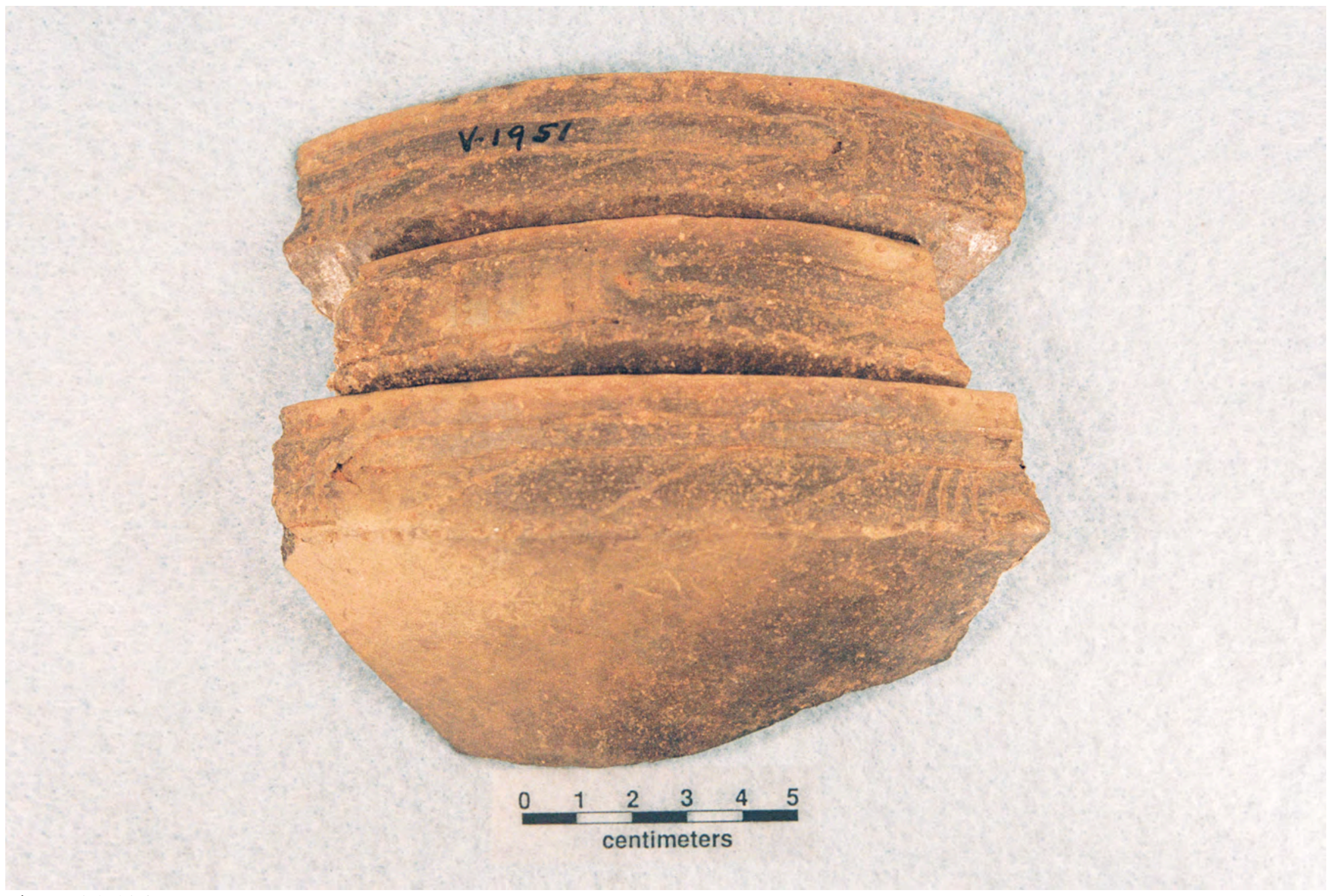

Figure A1-106 


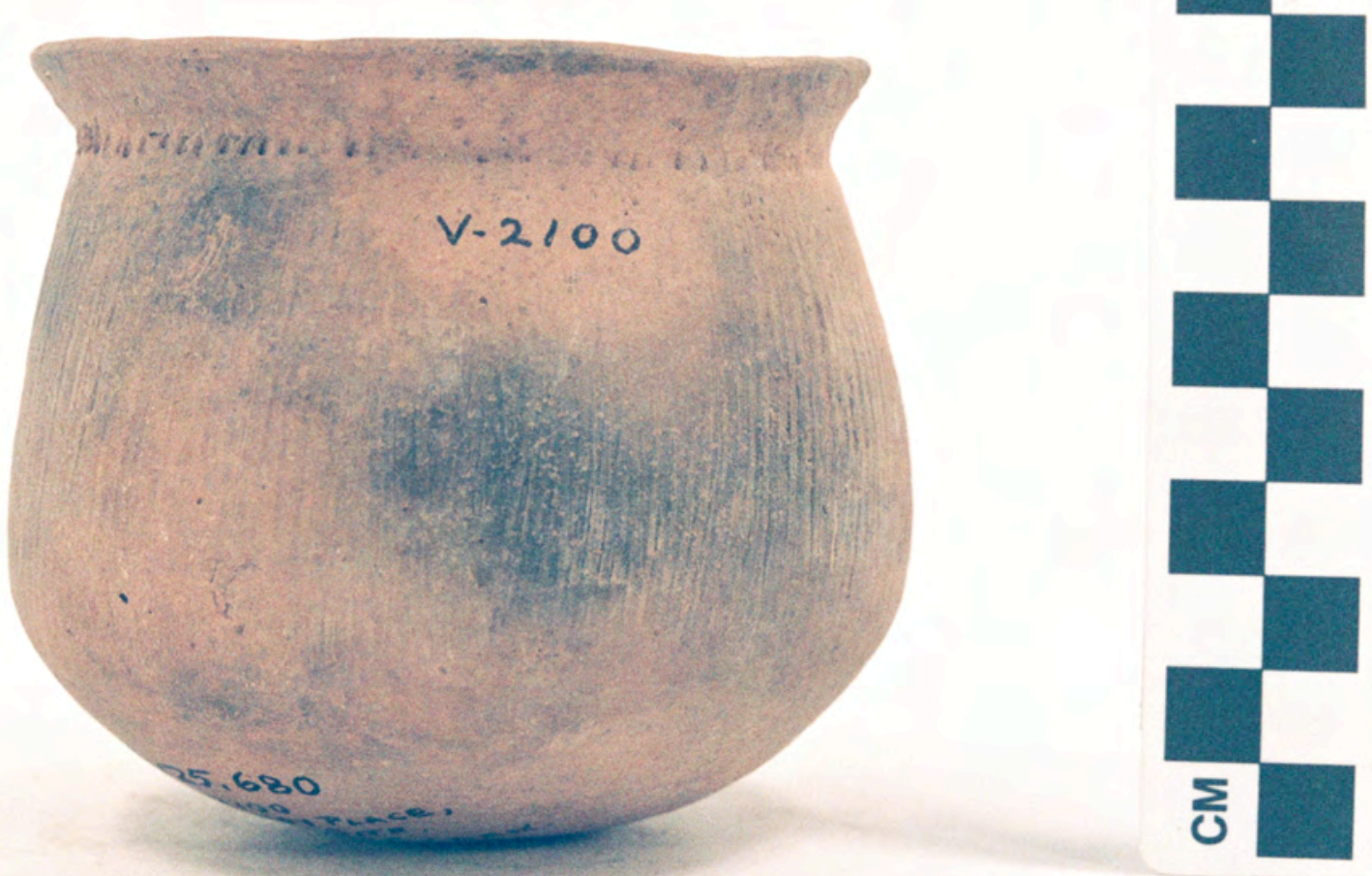

Figure A2-1 


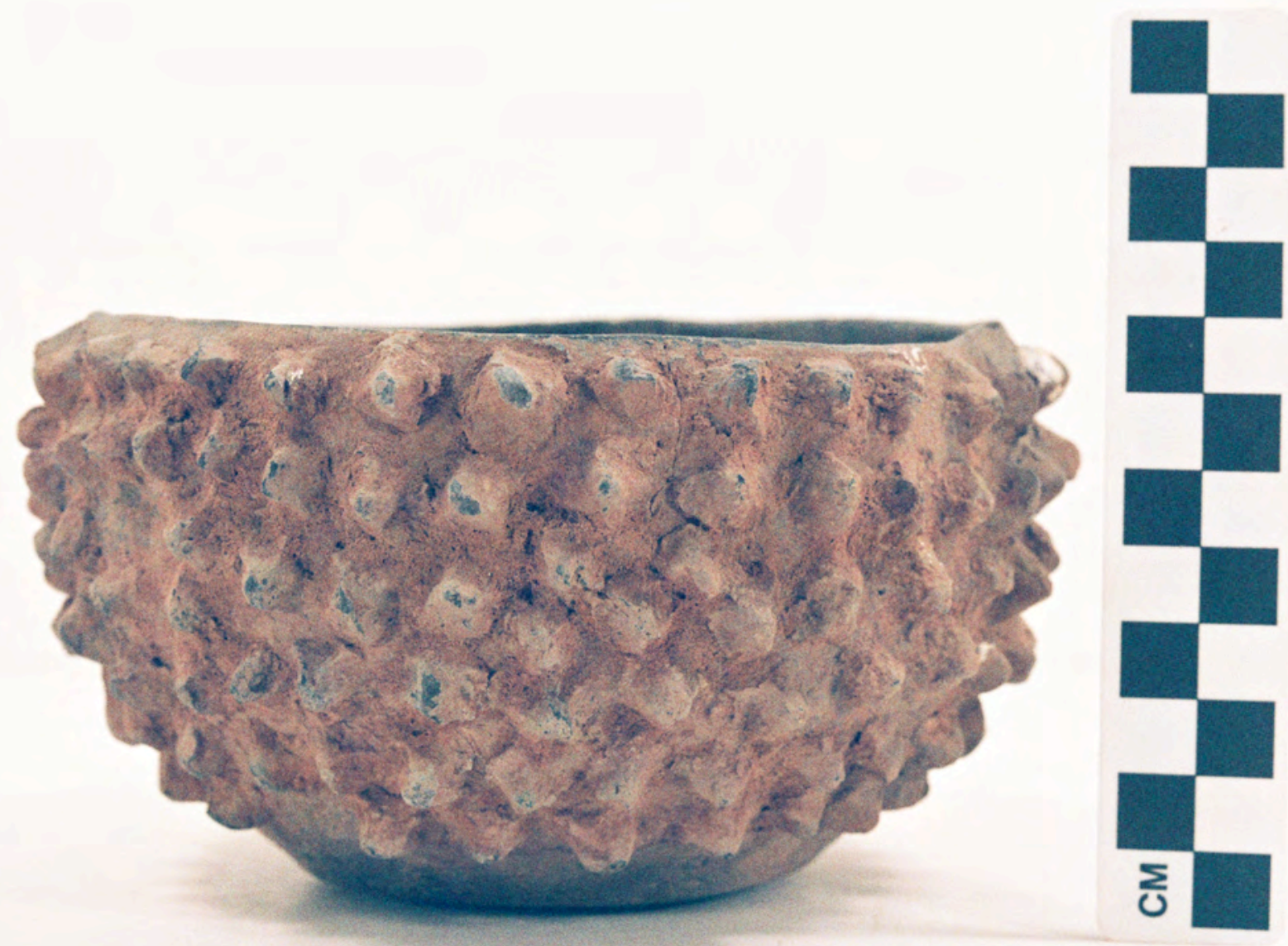

Figure A2-2 


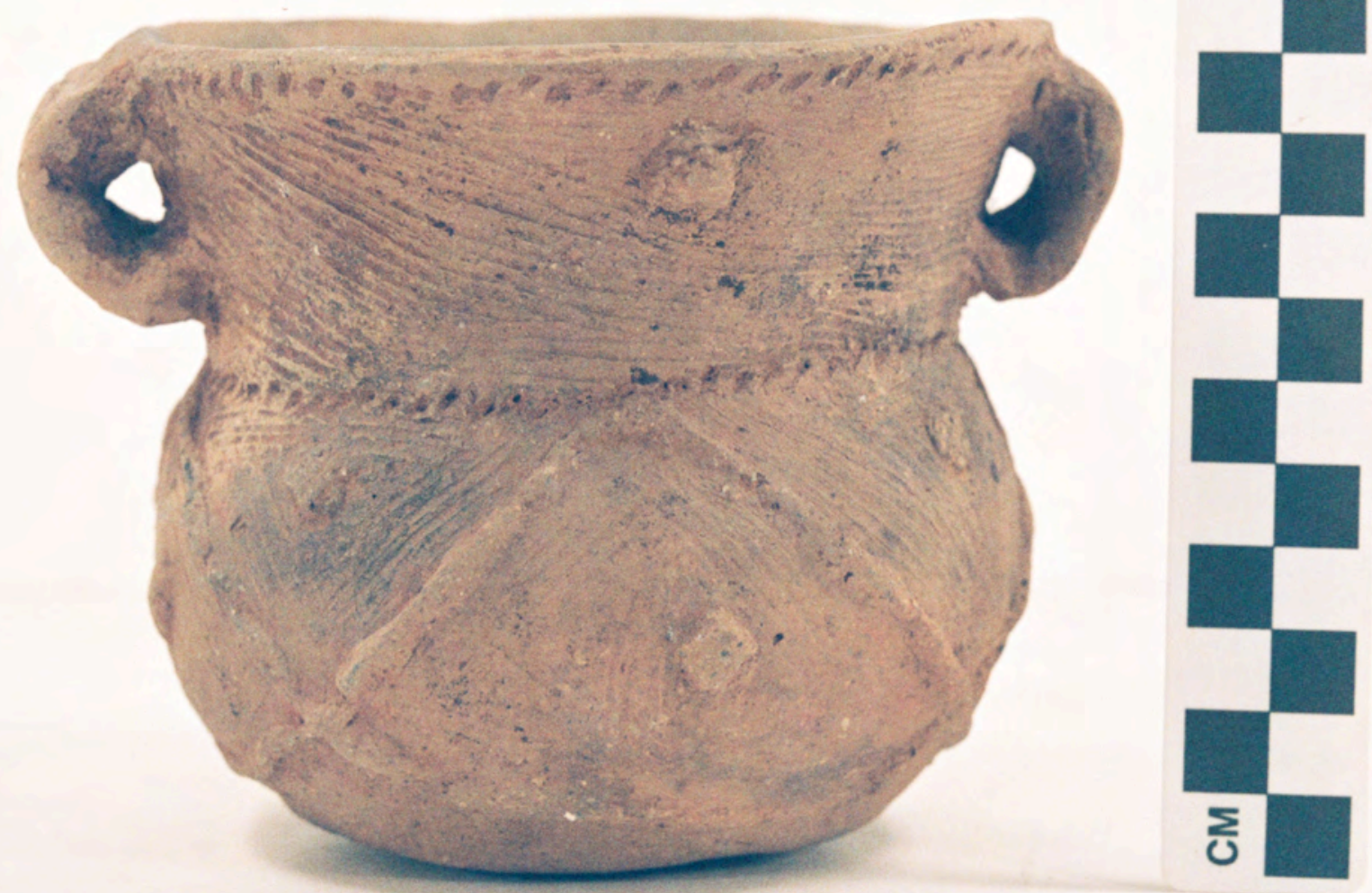

Figure A2-3 


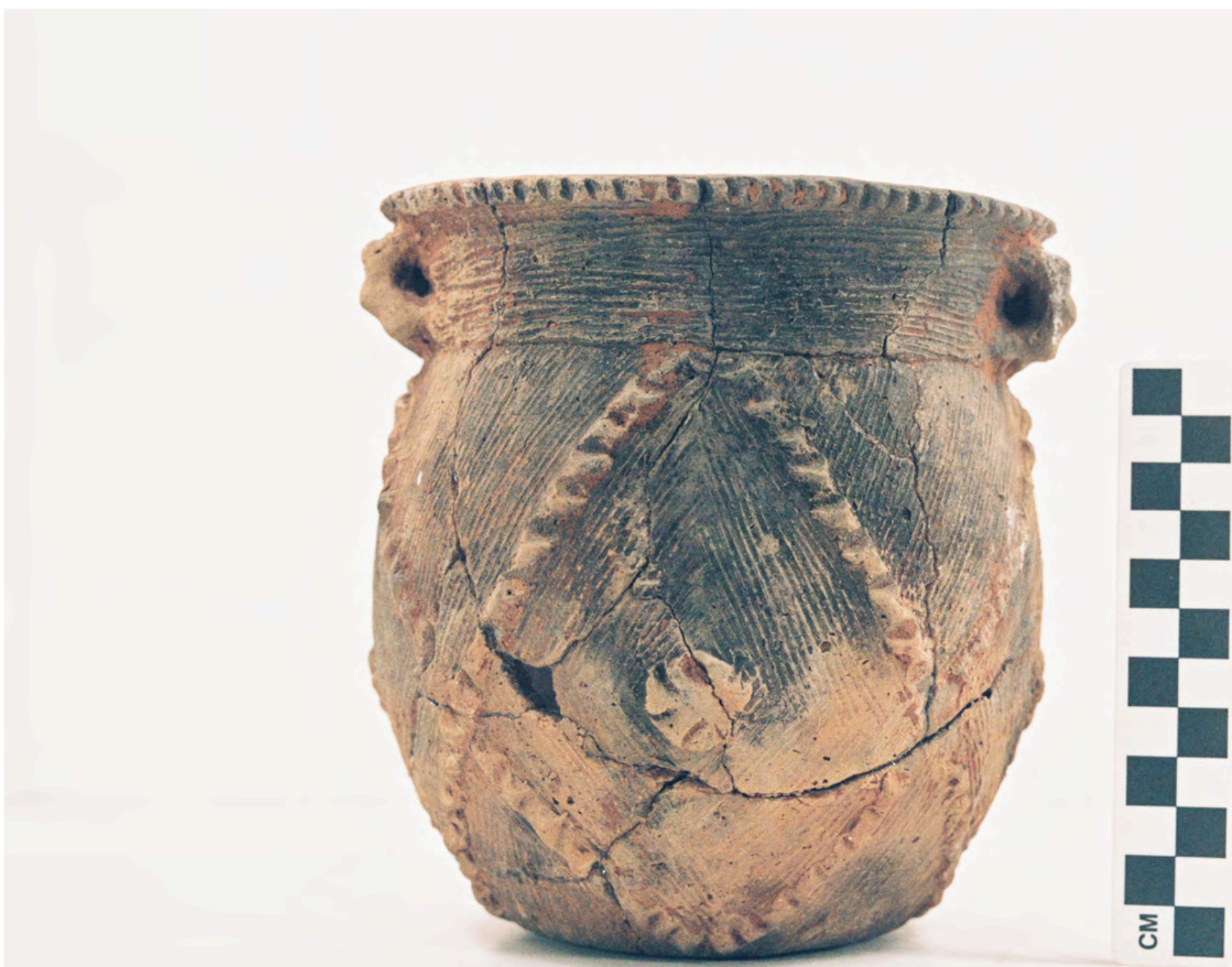

Figure A2-4 


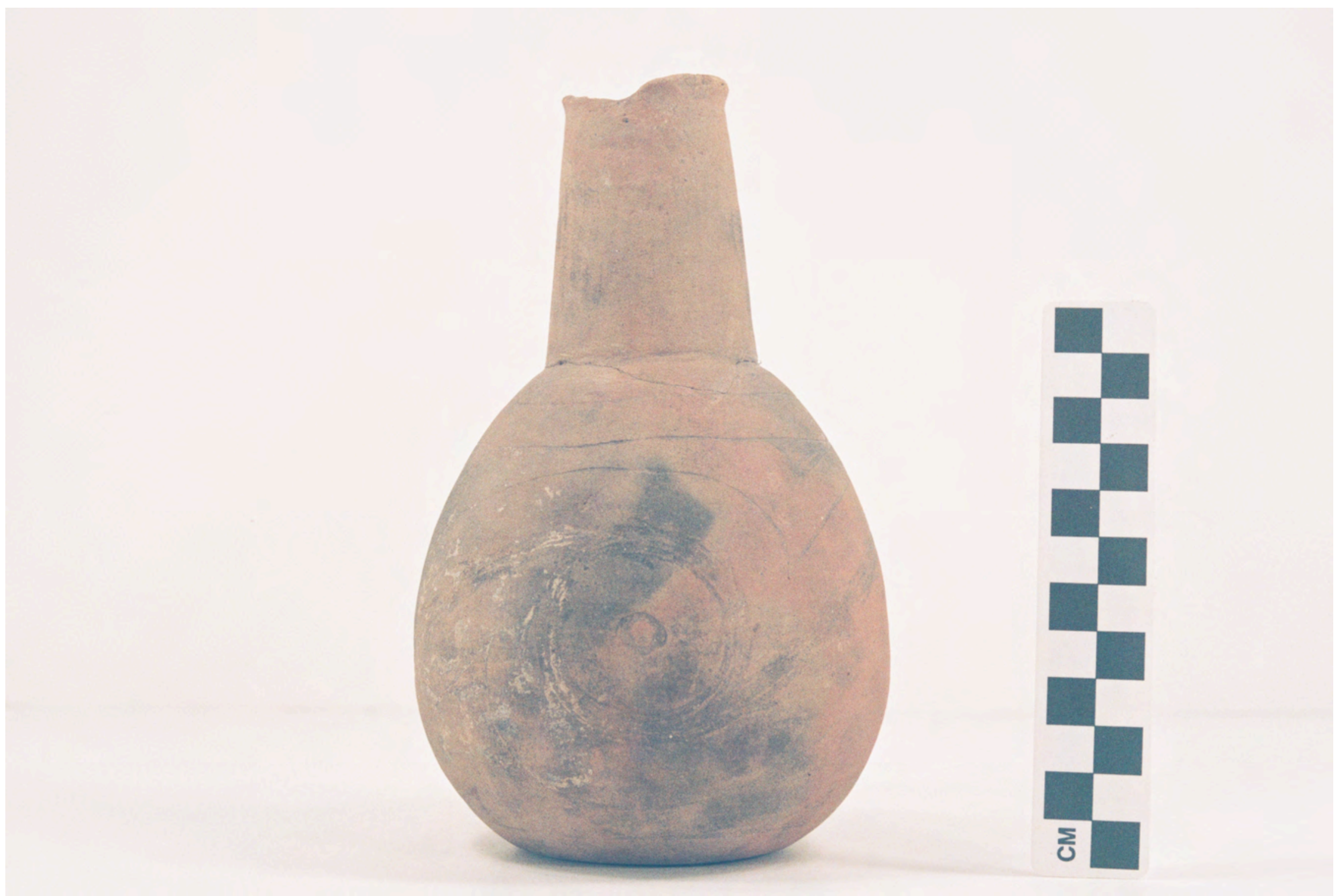

Figure A2-5 


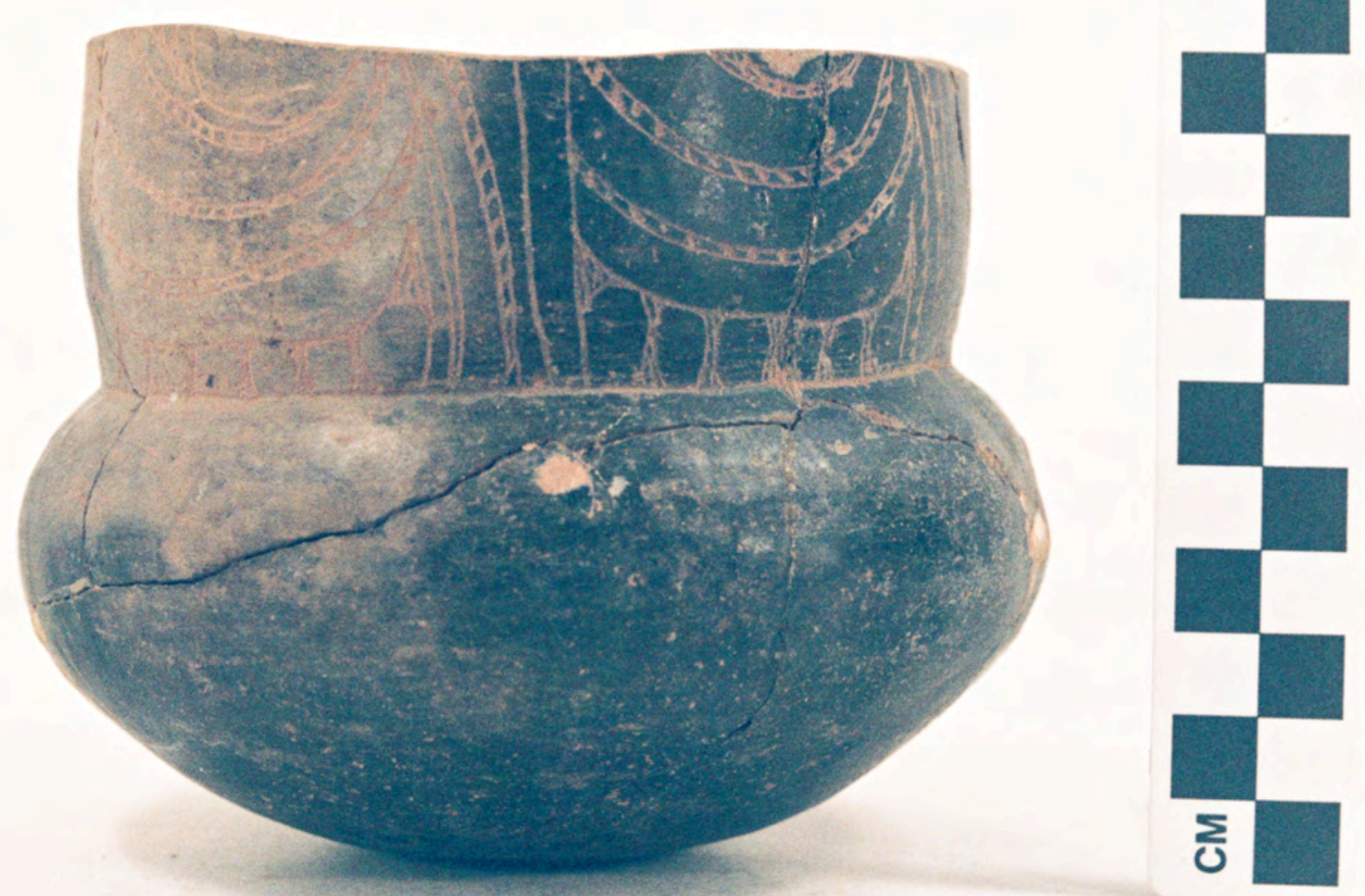

Figure A2-6 


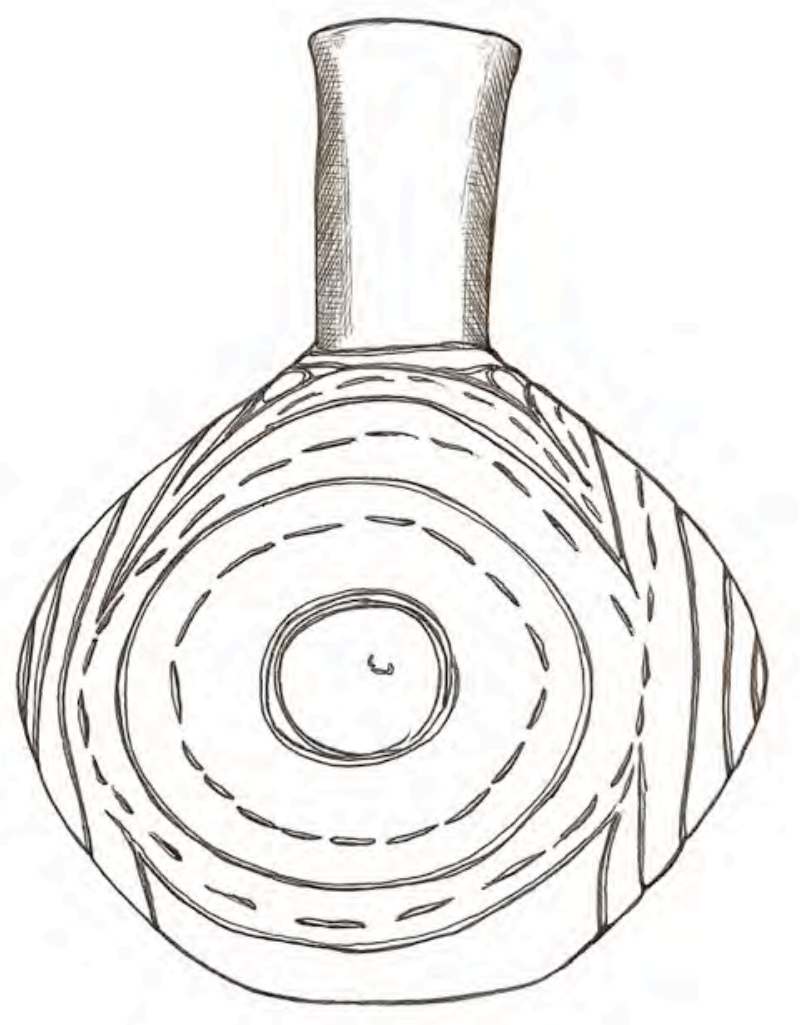

Figure A2-7. Belcher Engraved, var.Ogden bottle (5425-2022); b. drawing by Bobby Gonzalez.

Figure A2-7 


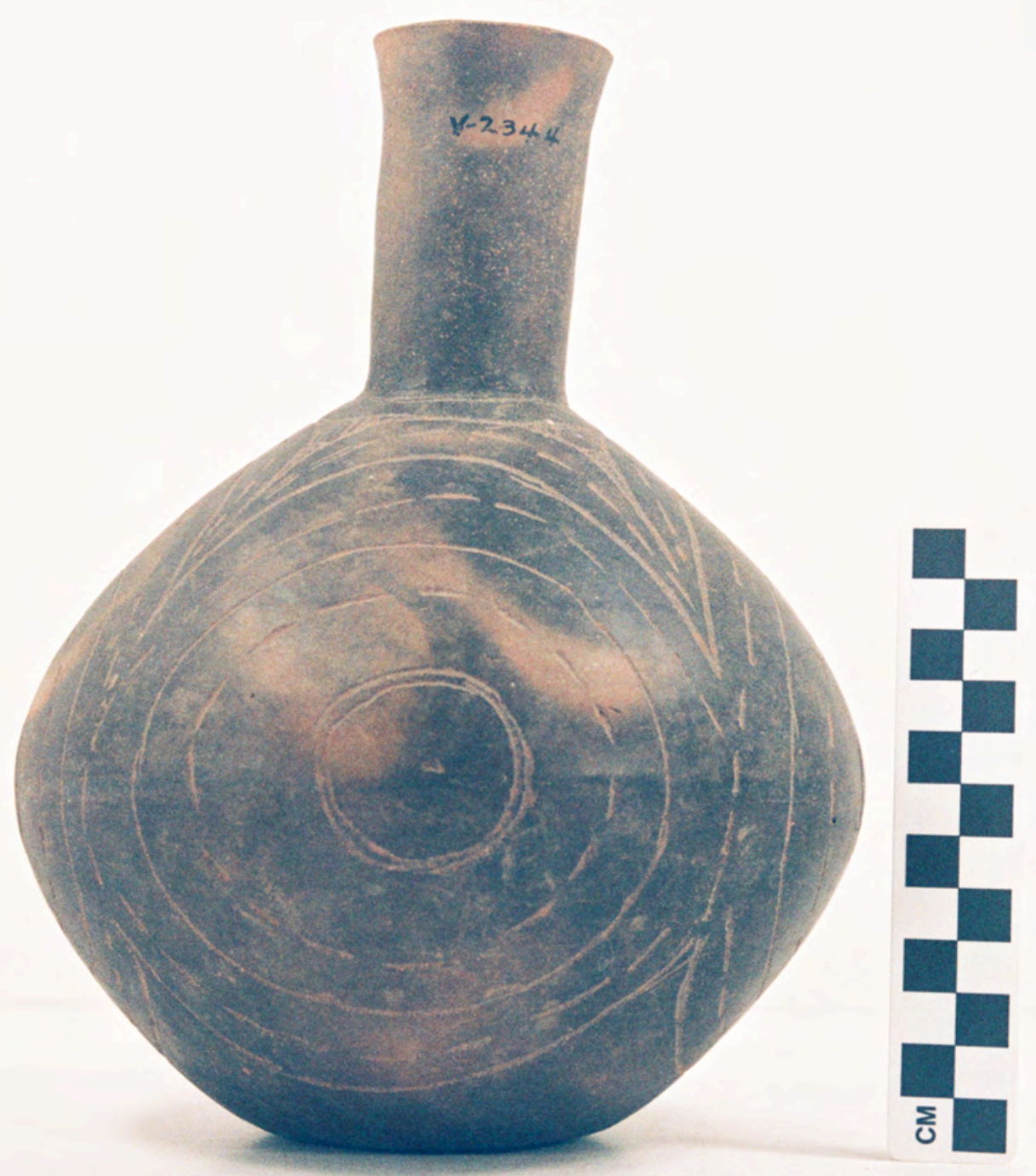

Figure A2-7a 


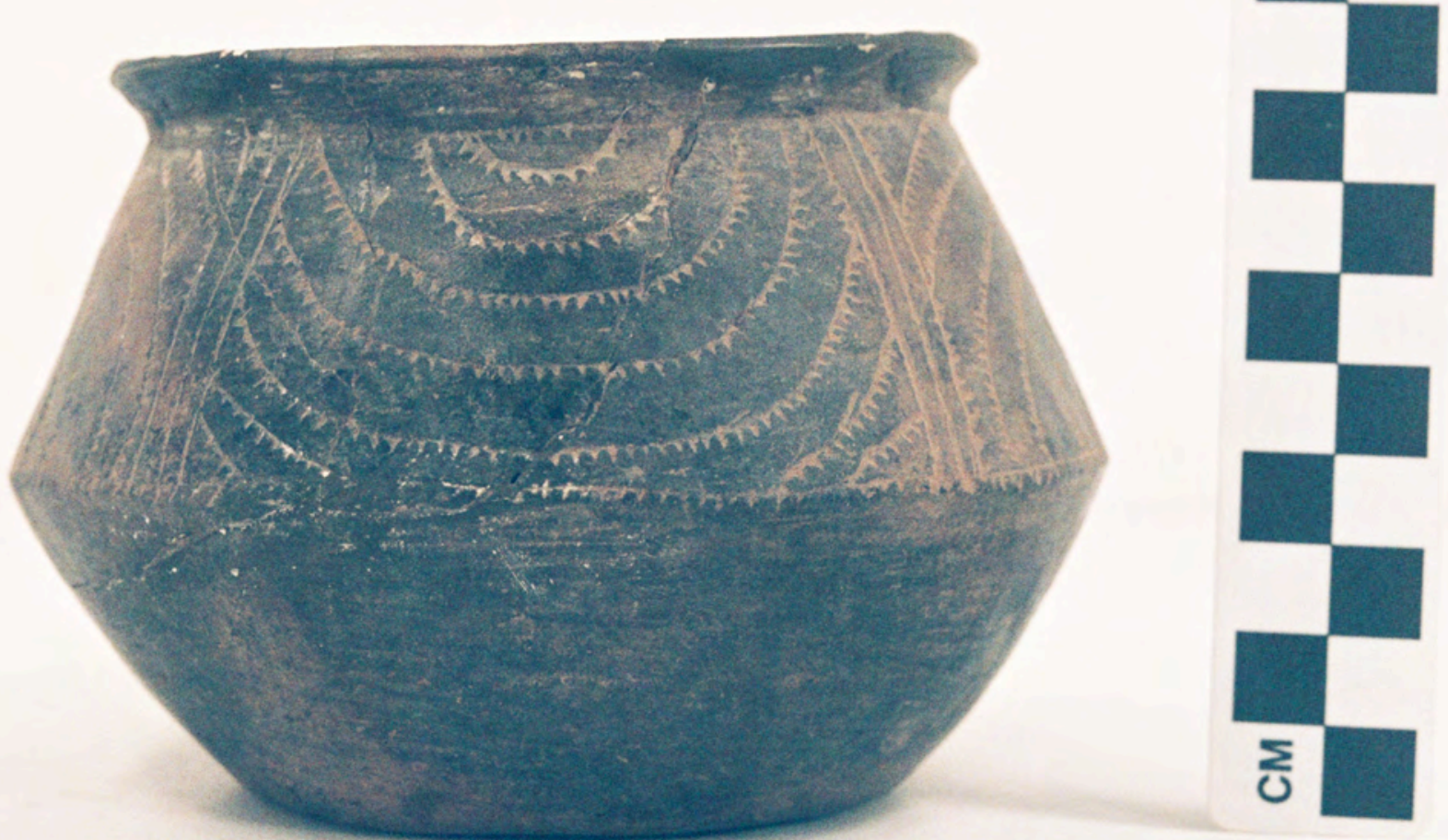

Figure A2-8a 


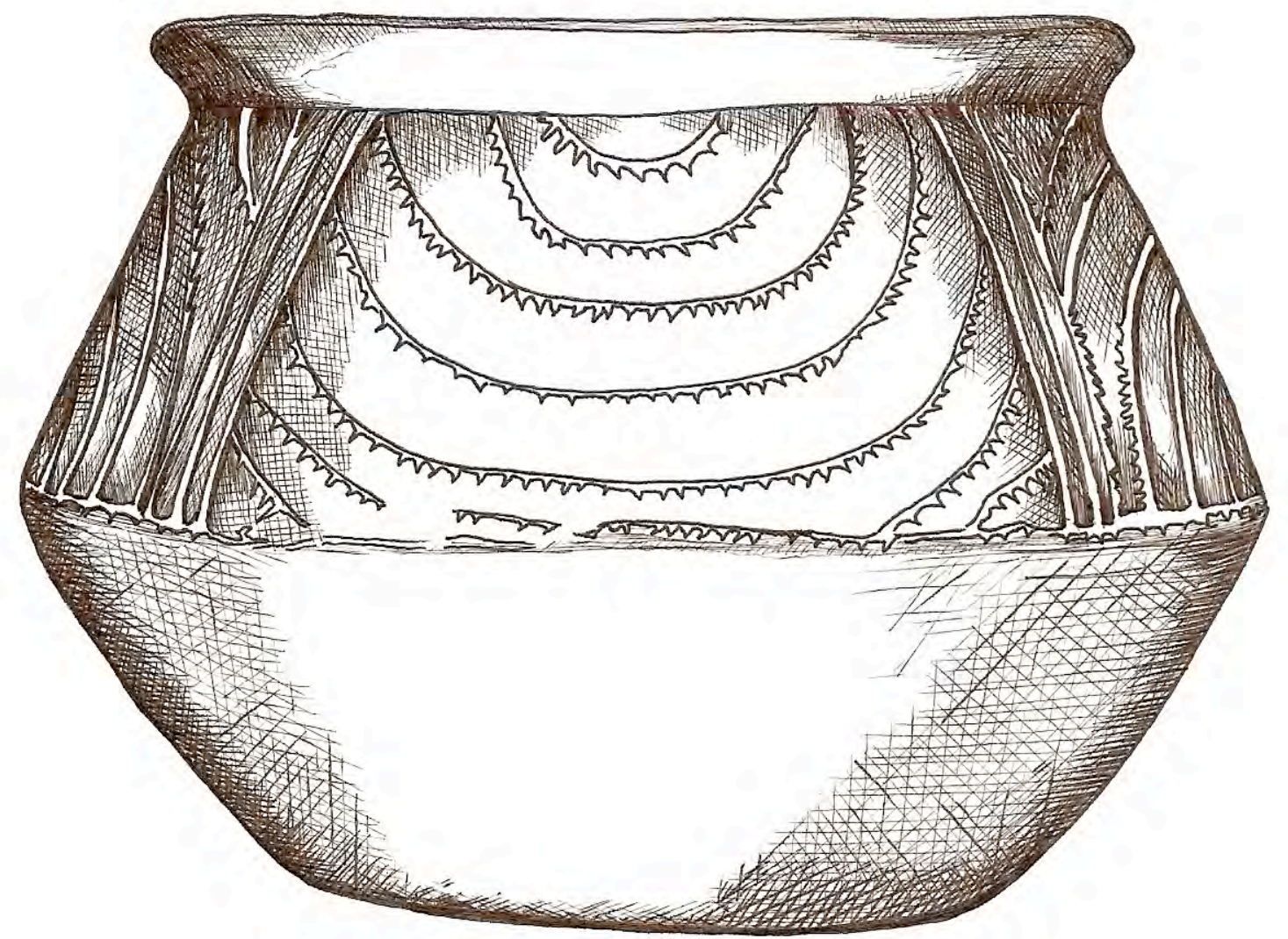

Figure A2-8. Means Engraved carinated bowl (5425-2023): b, drawing by Bobby Gonzalez.

Figure A2-8b 


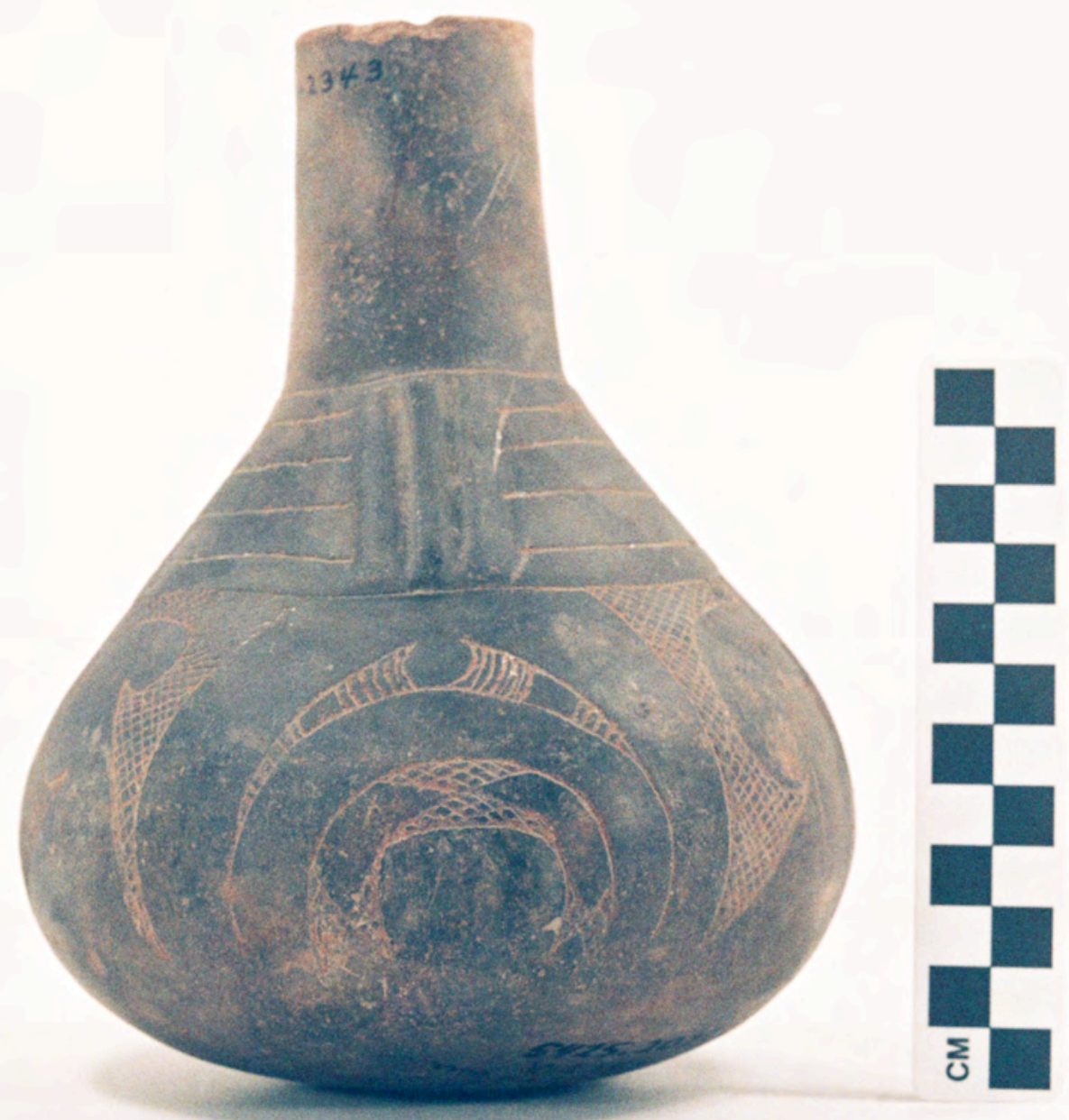

Figure A2-9 


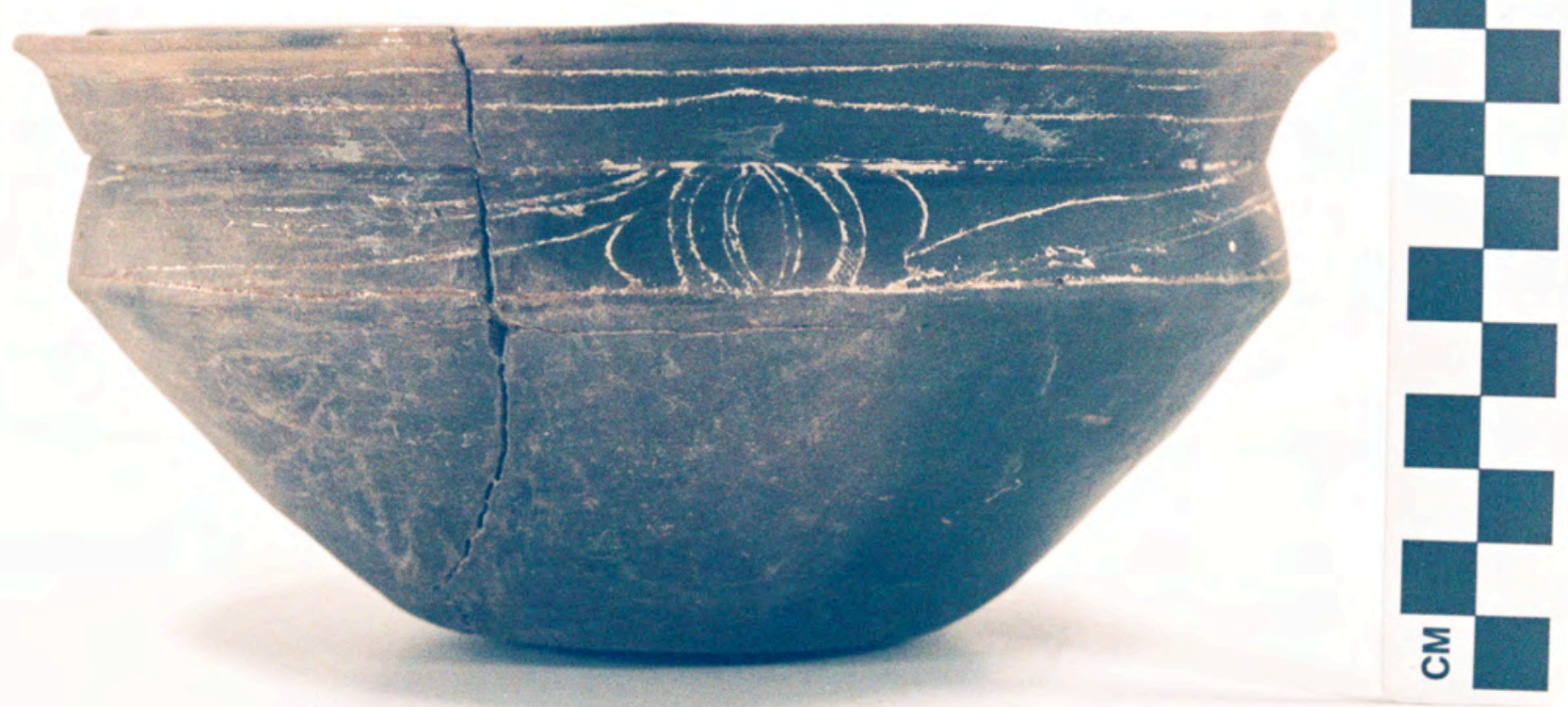

Figure A2-10 


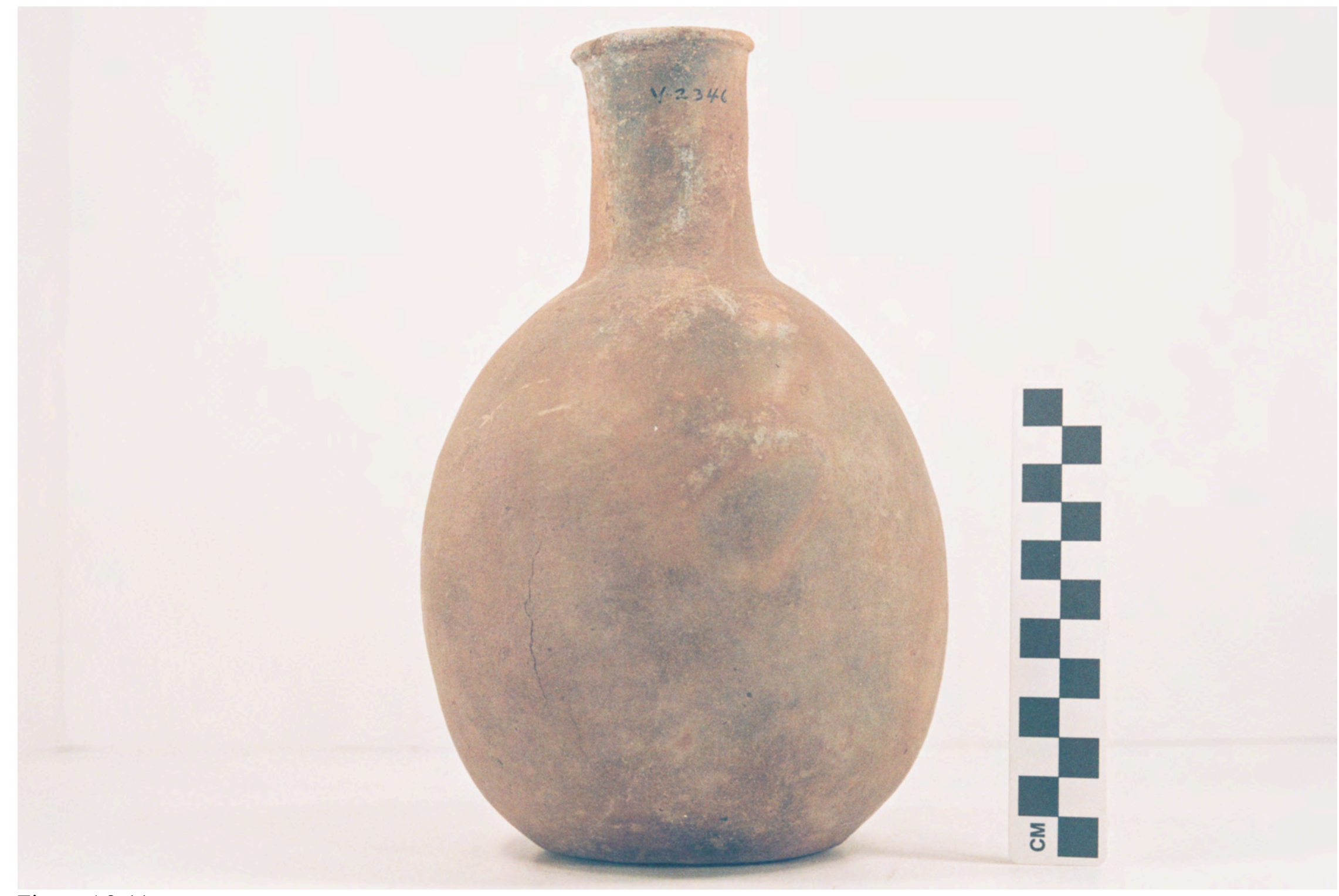

Figure A2-11 


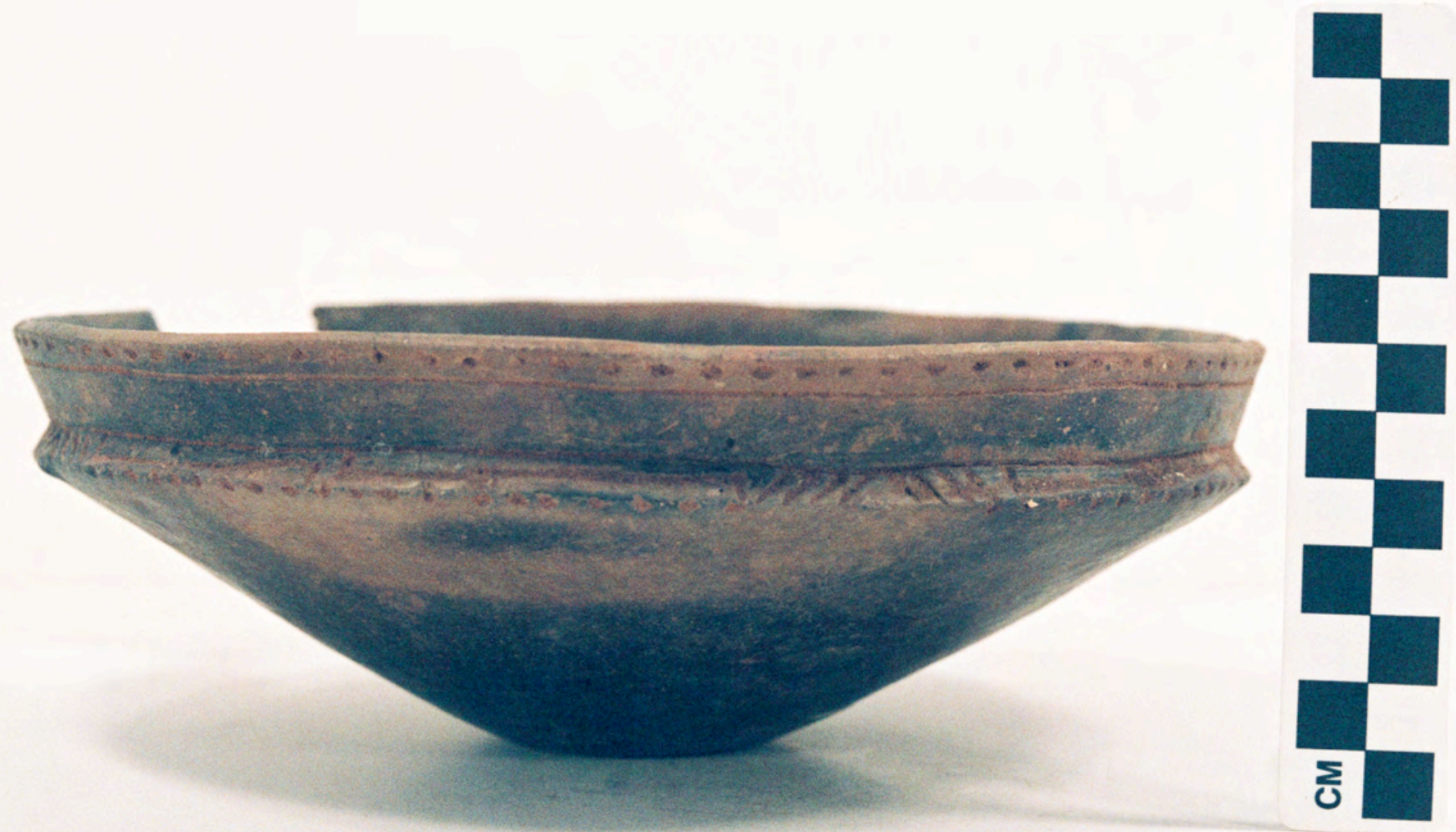

Figure A2-12 


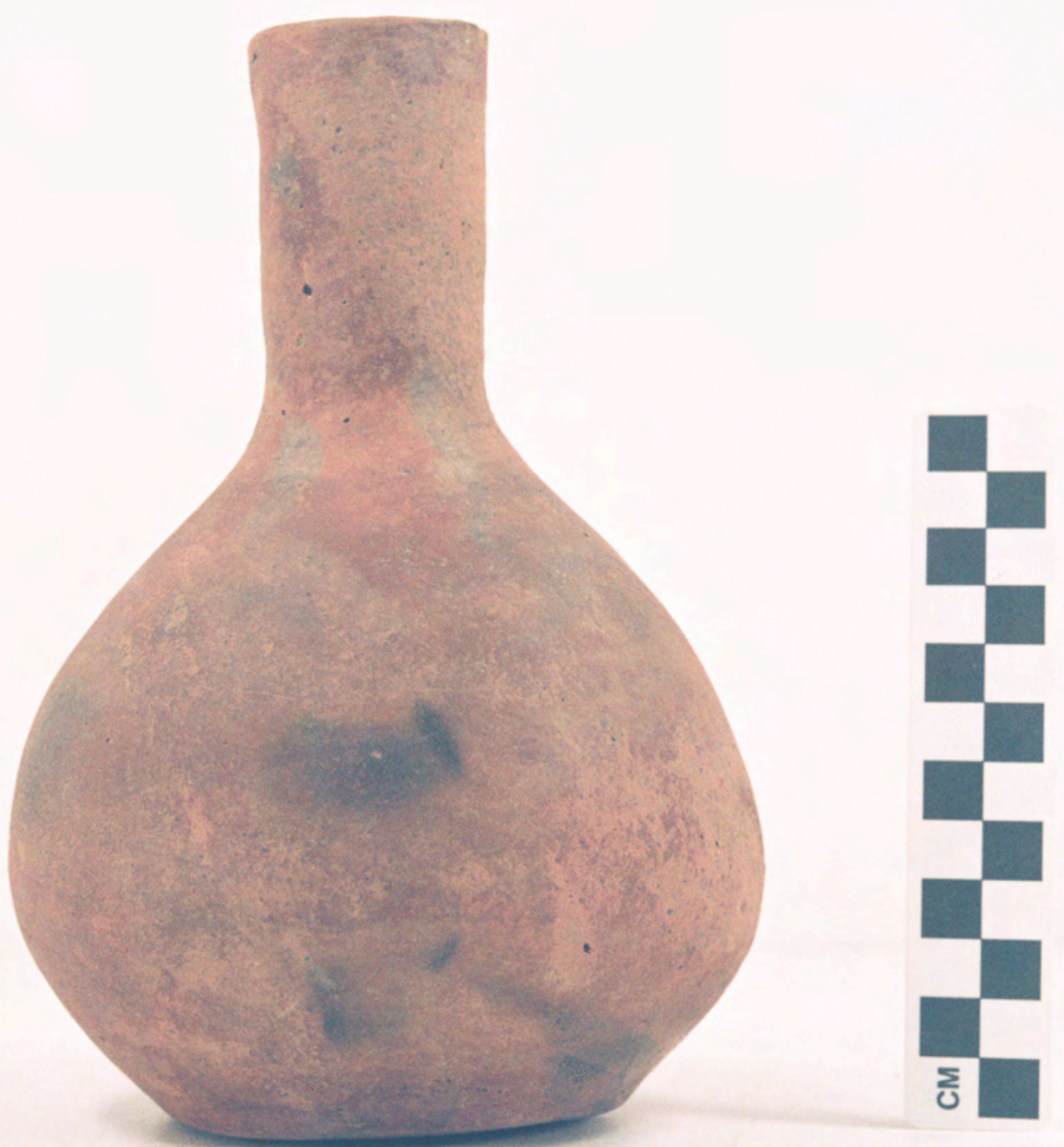

Figure A2-13 


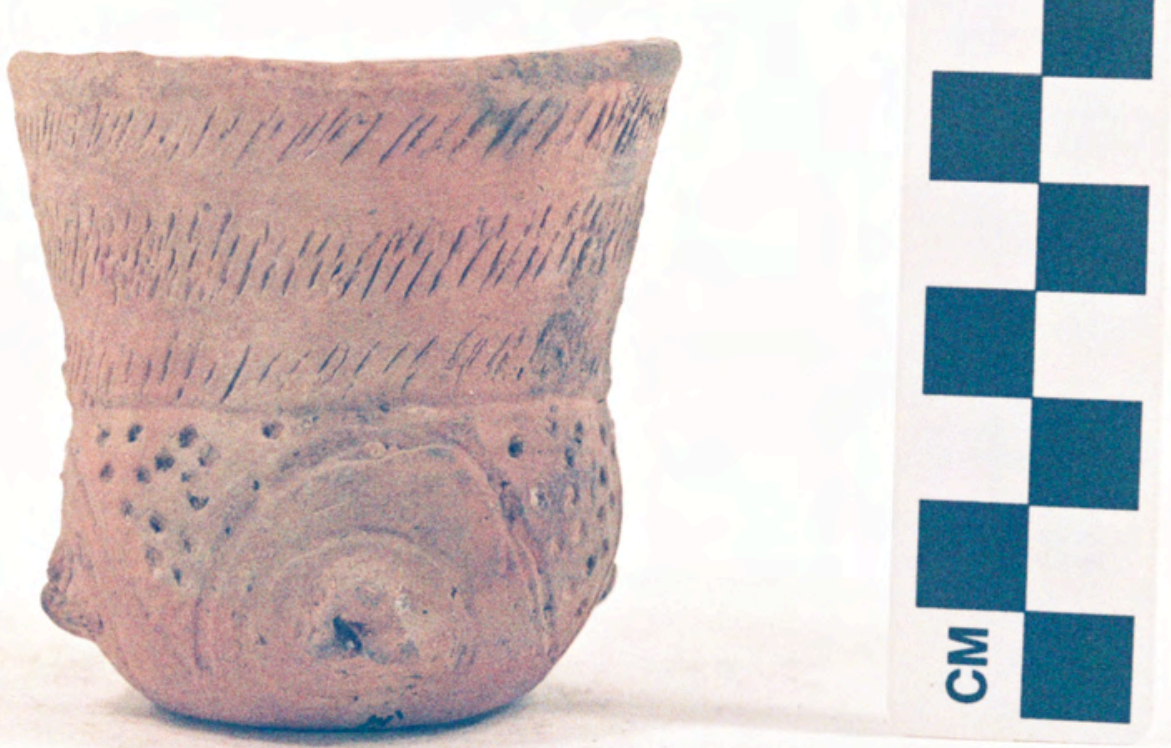

Figure A2-14 


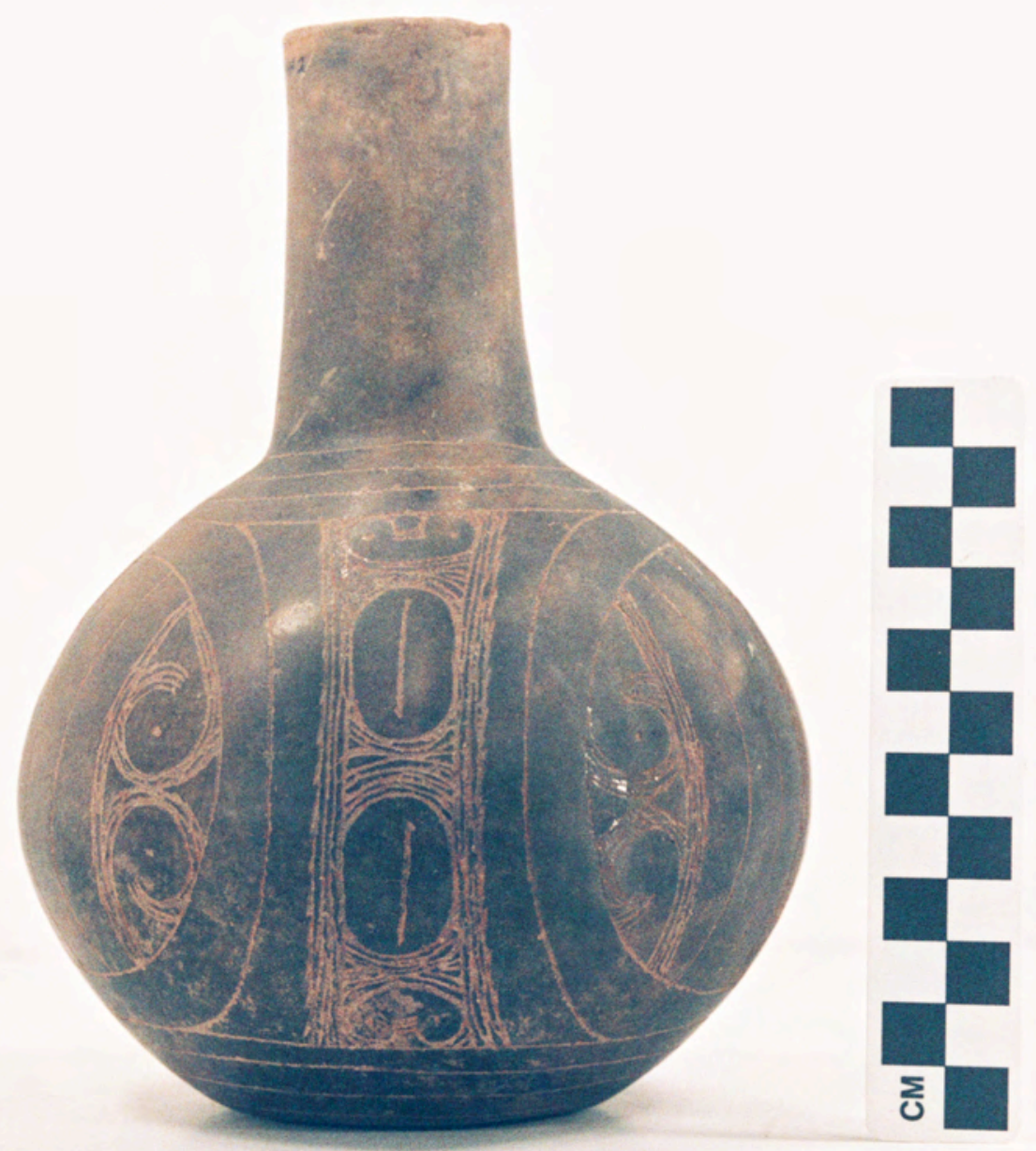

Figure A2-15 


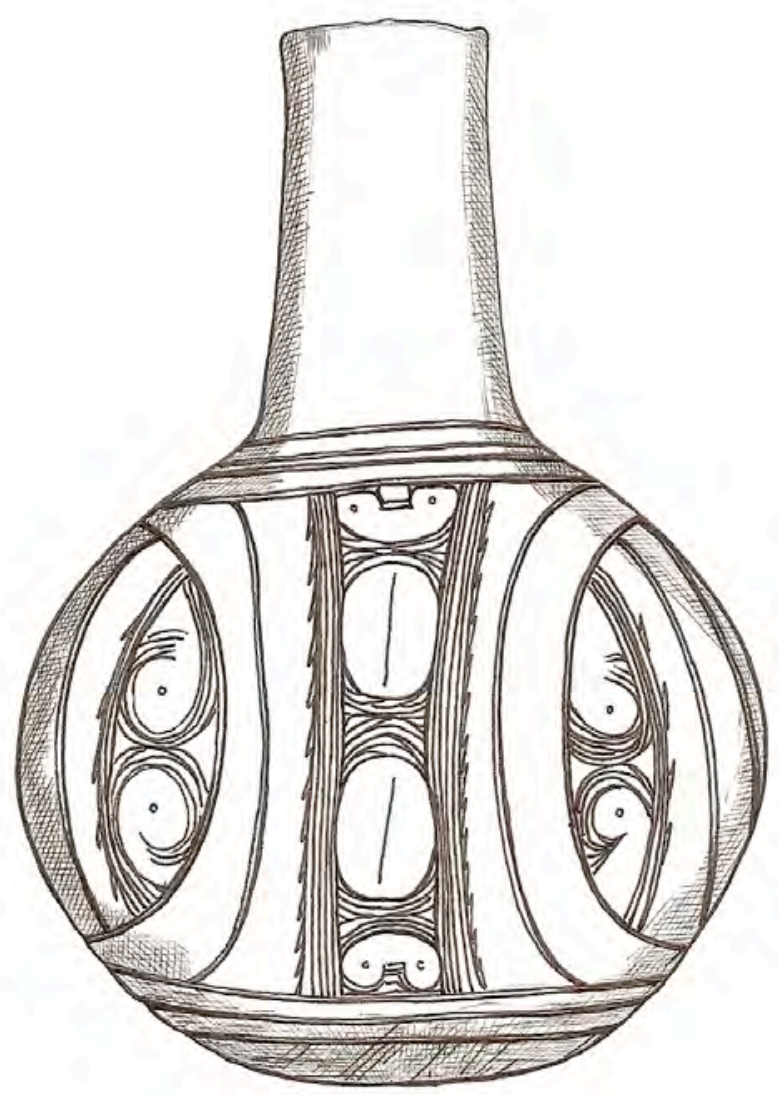

Figure A2-15. cf. Handy-Hatchel Engraved bottle (5425-2030) b, drawing by Bobby Gonzalez.

Figure A2-15b 


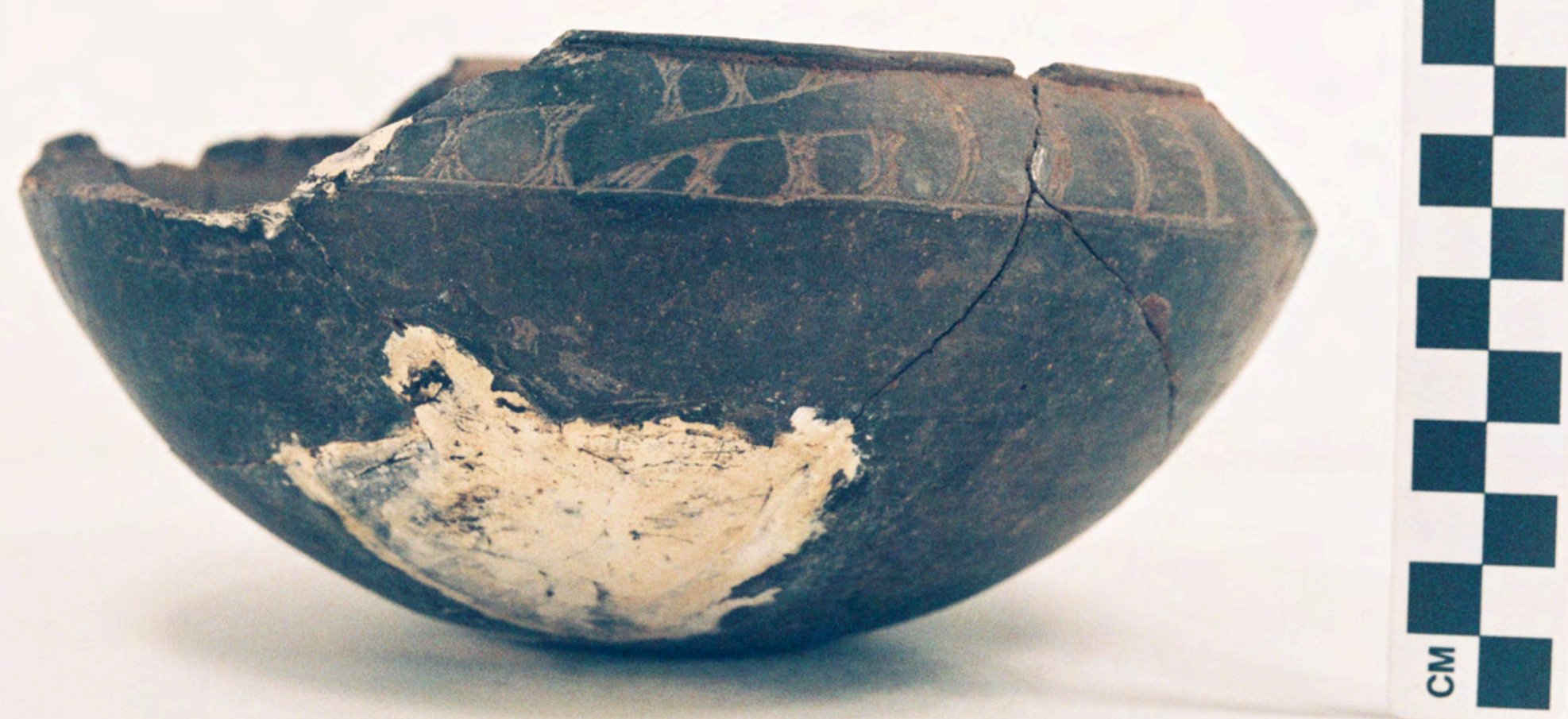

Figure A2-16 


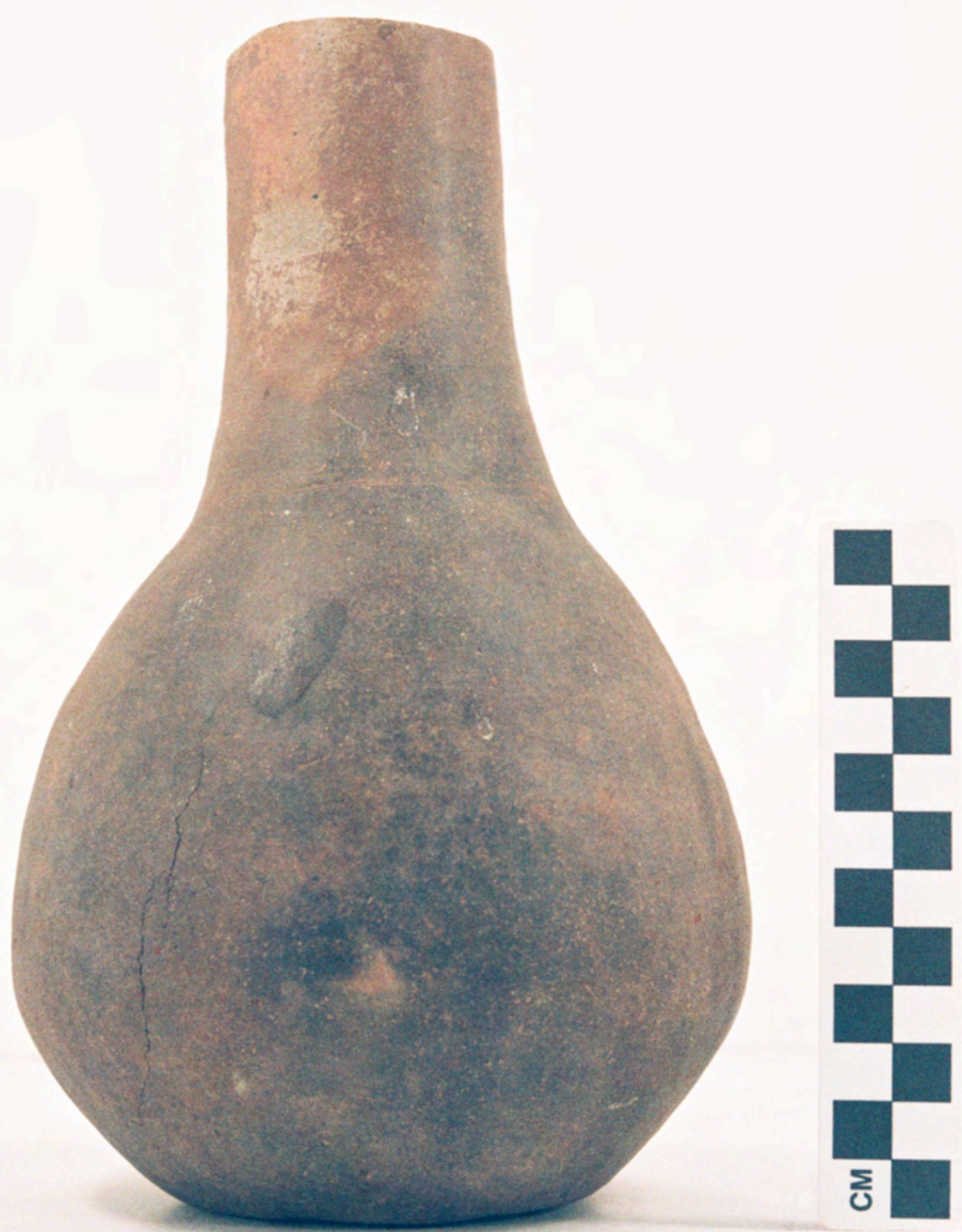

Figure A2-17 


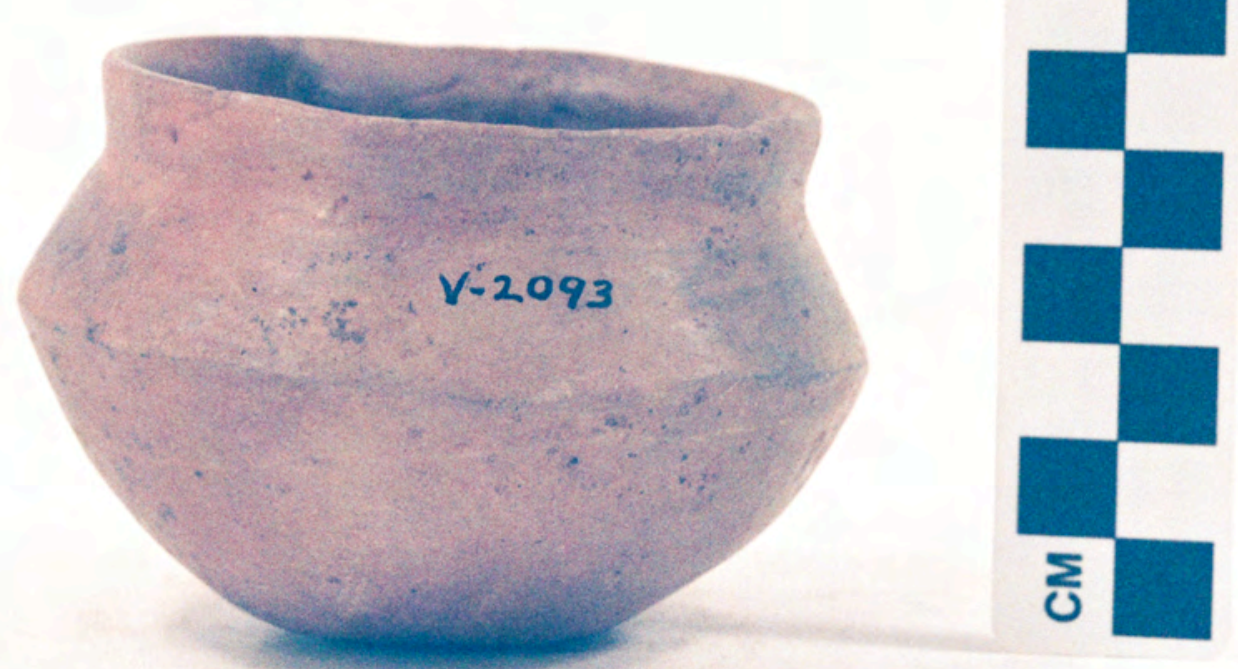

Figure A2-18 


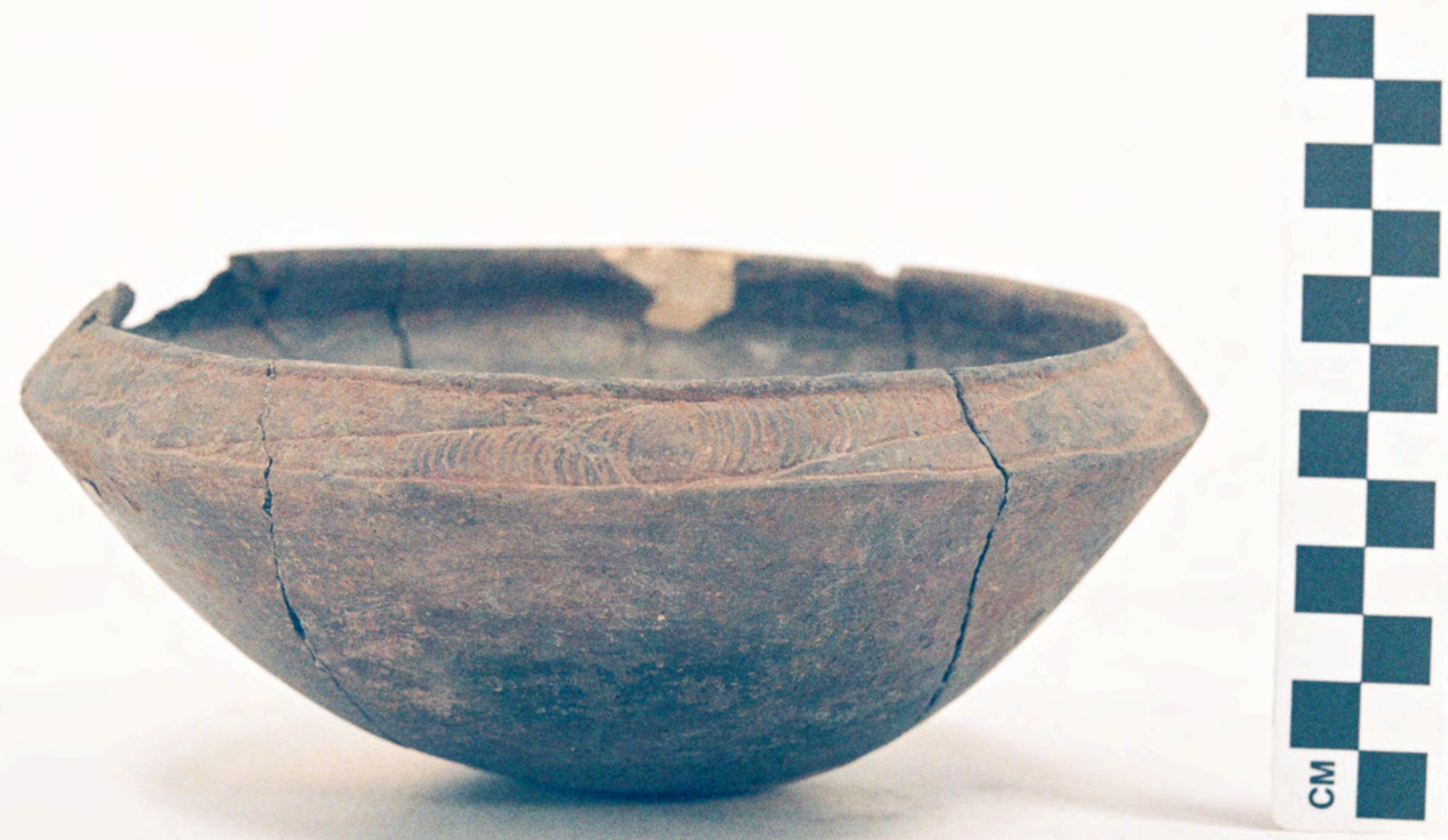

Figure A2-19 


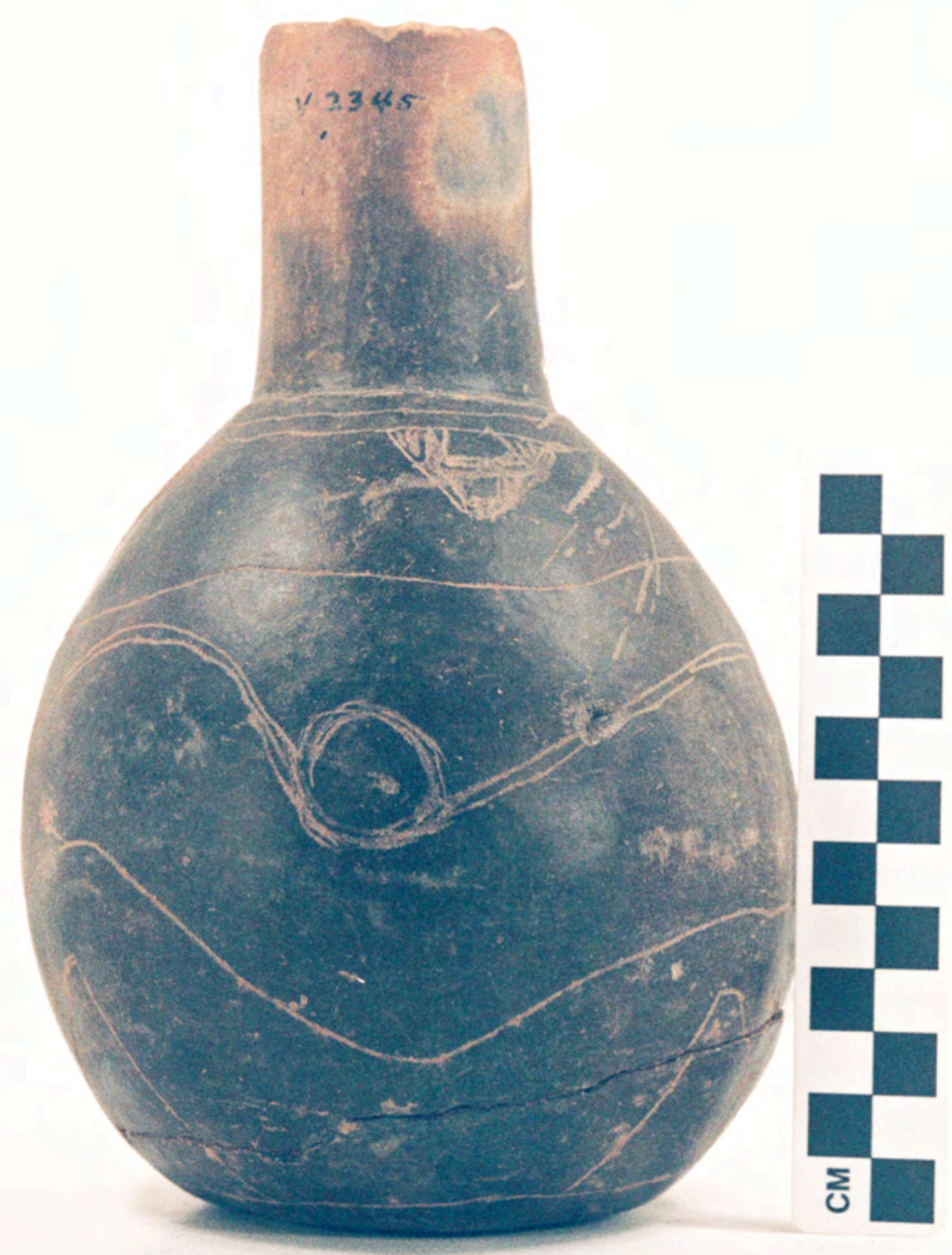

Figure A2-20 
Figure A2-21

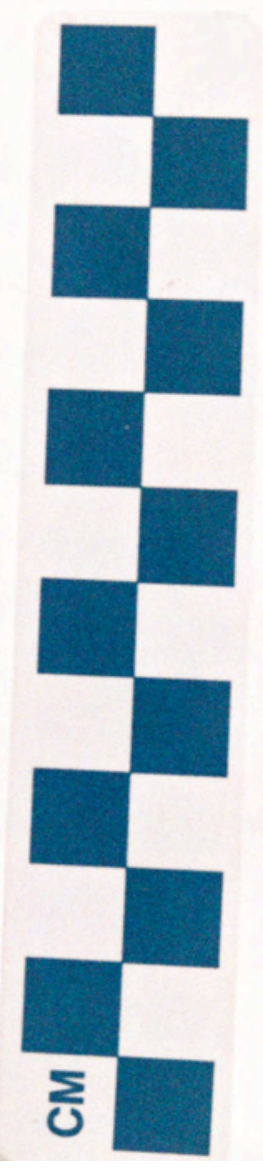




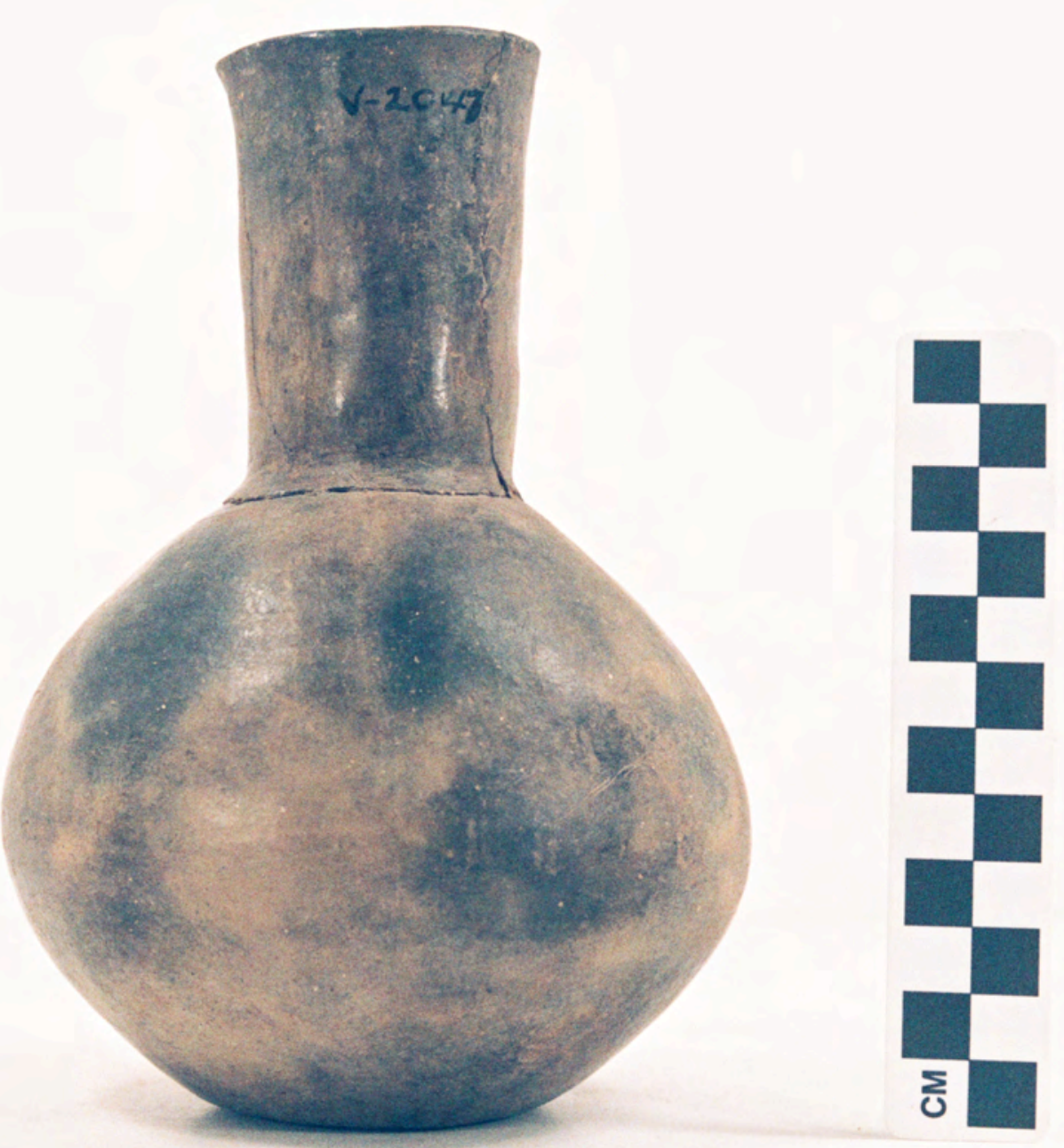

Figure A2-22 


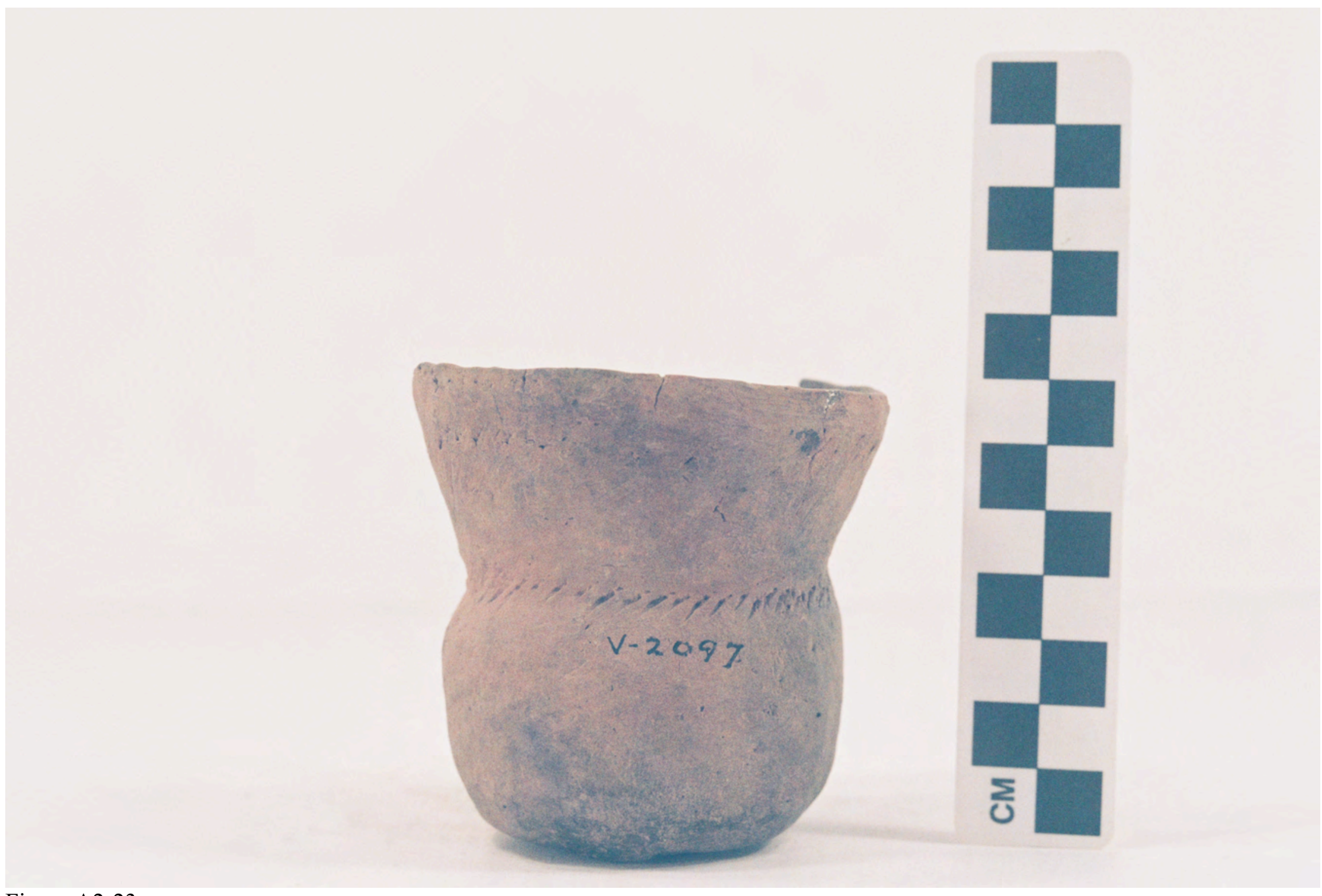

Figure A2-23 


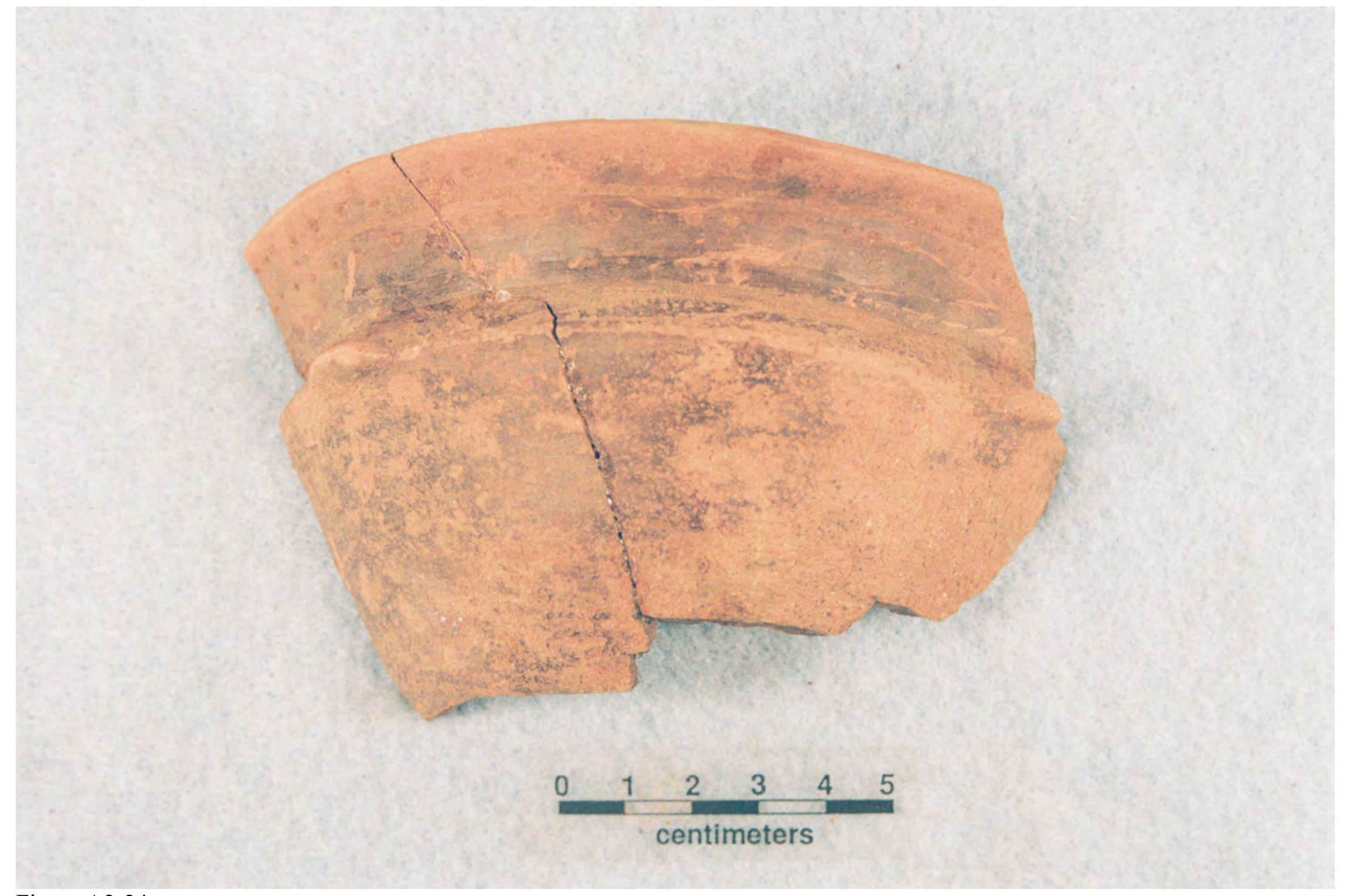

Figure A2-24 


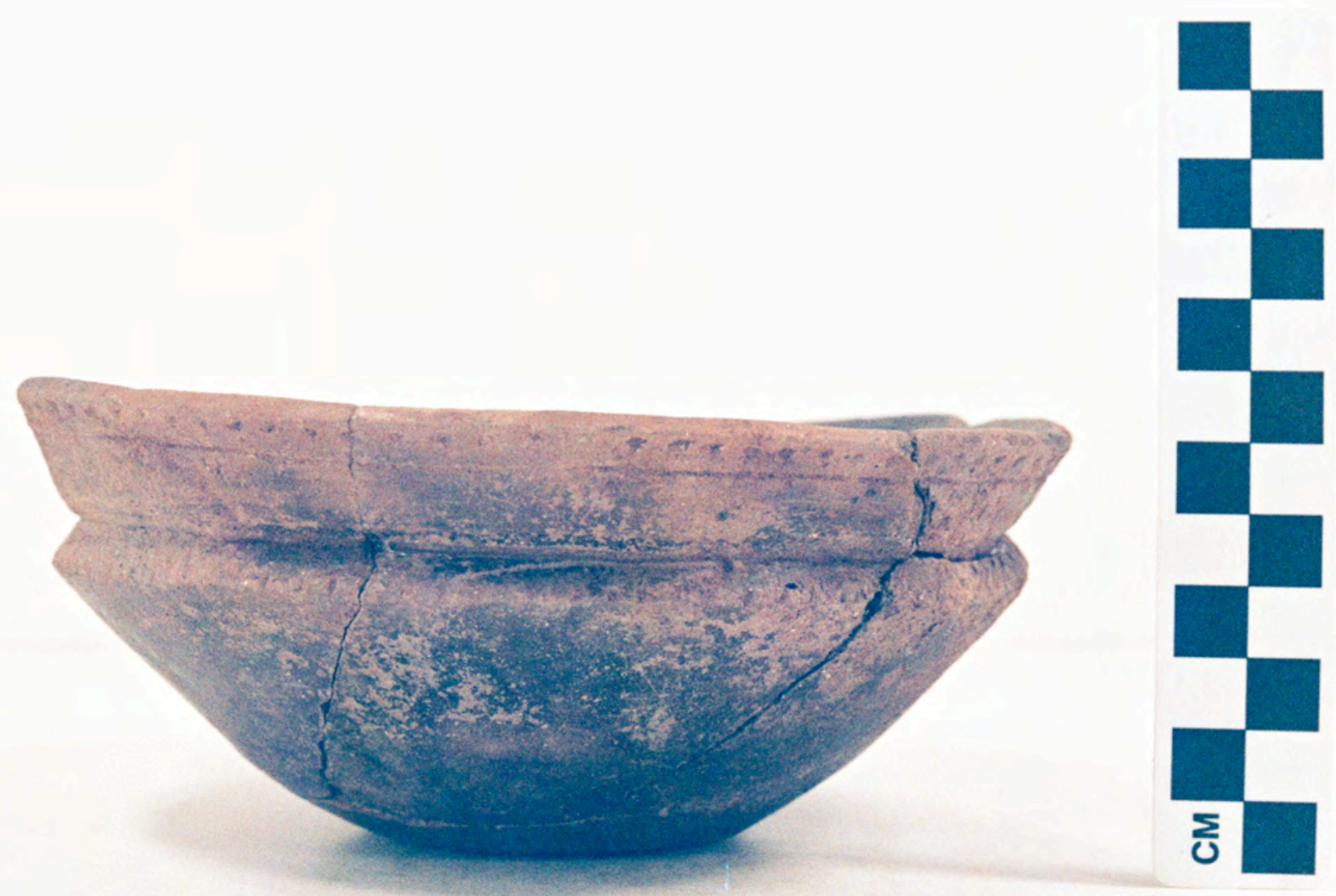

Figure A2-25 
Figure A2-26
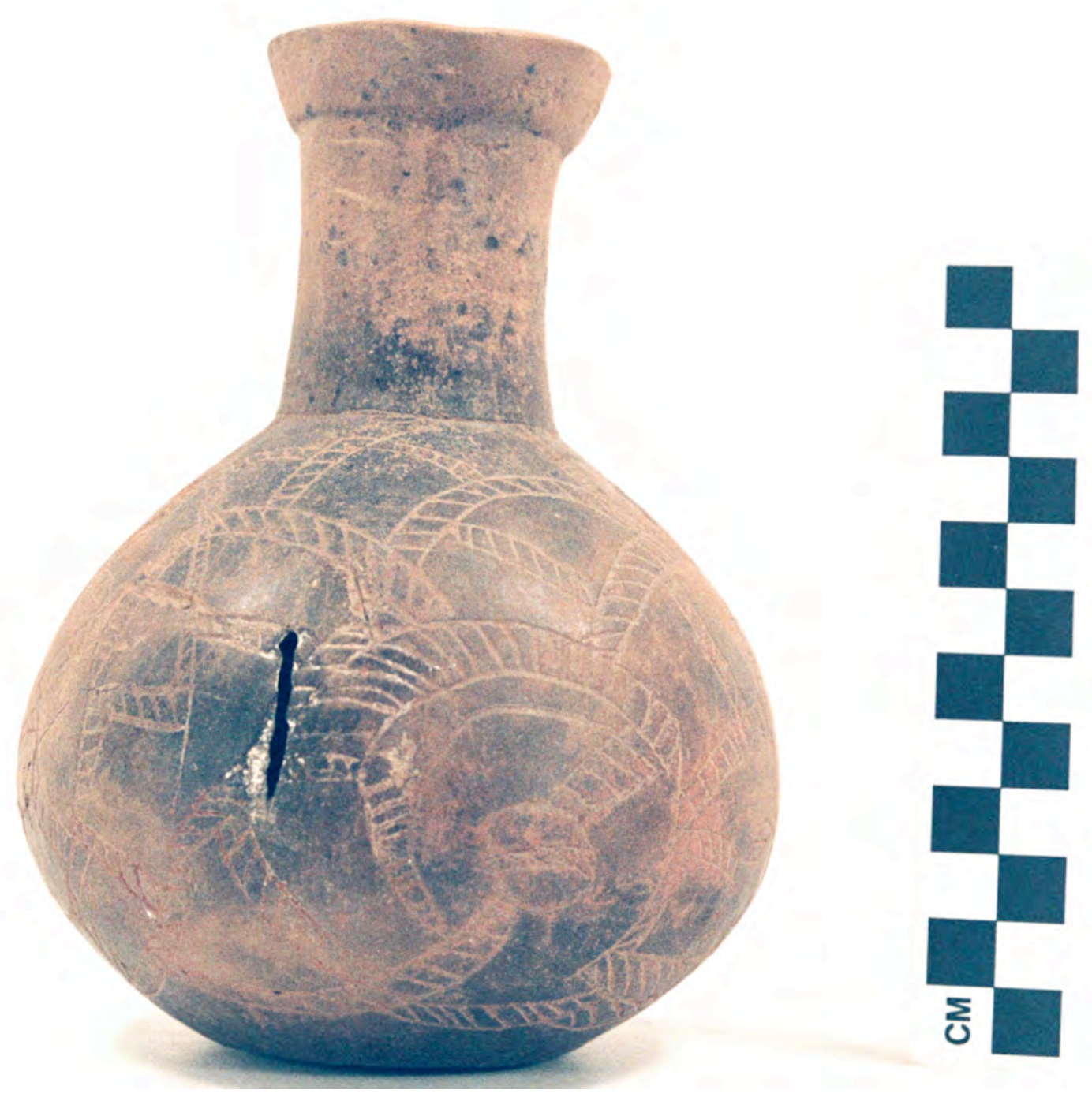


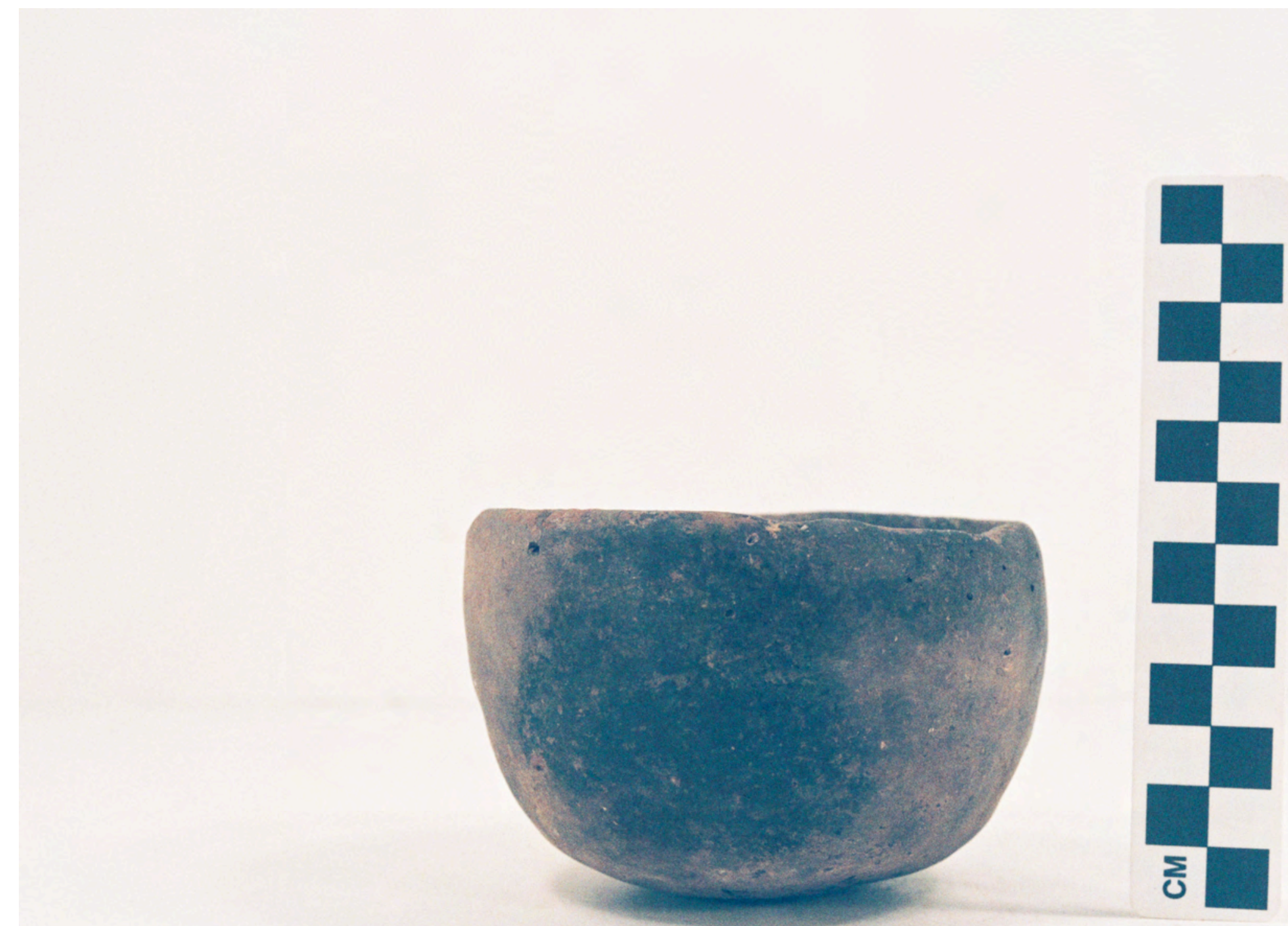

Figure A2-27 


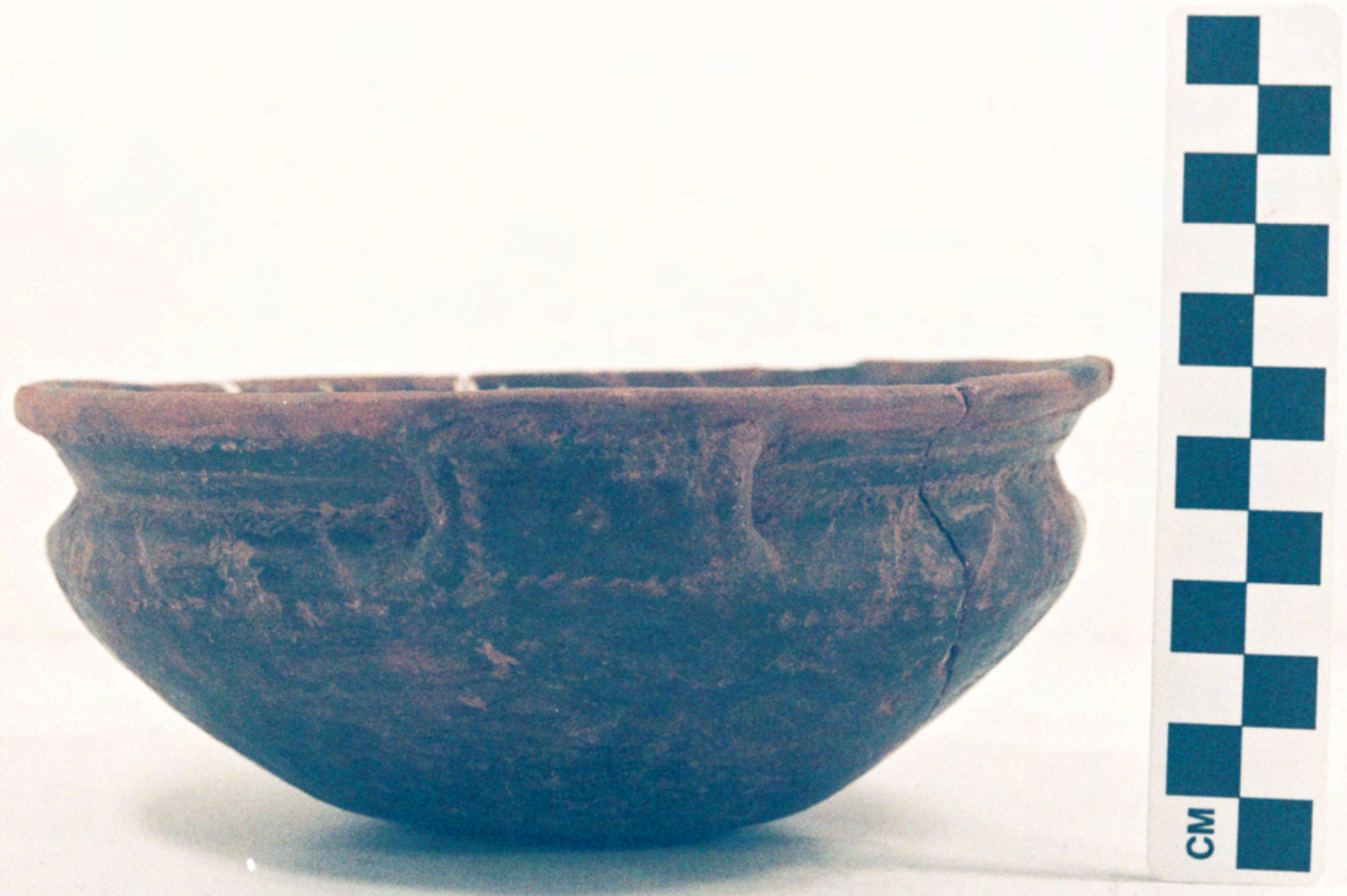

Figure A2-28 


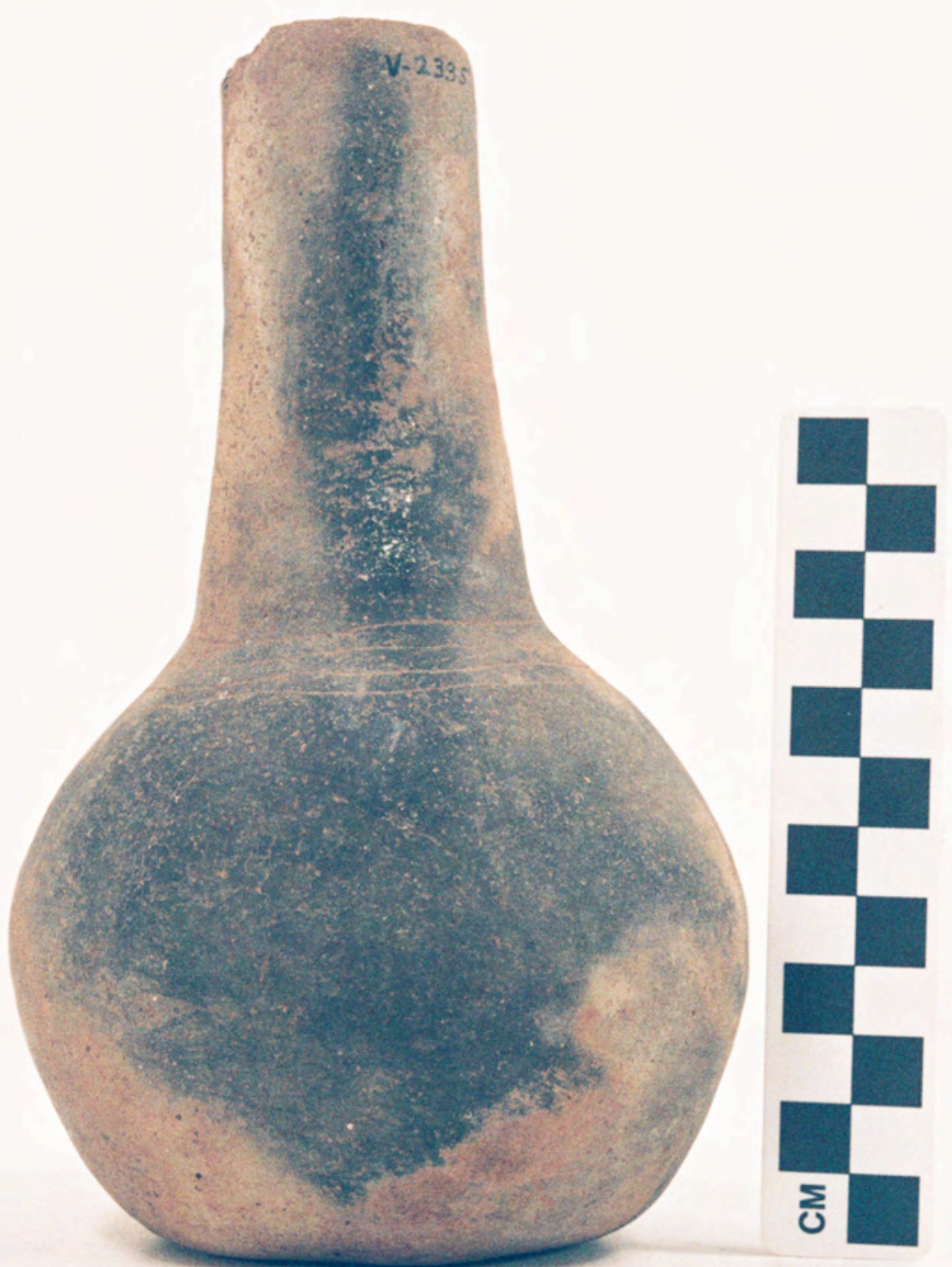

Figure A2-29 


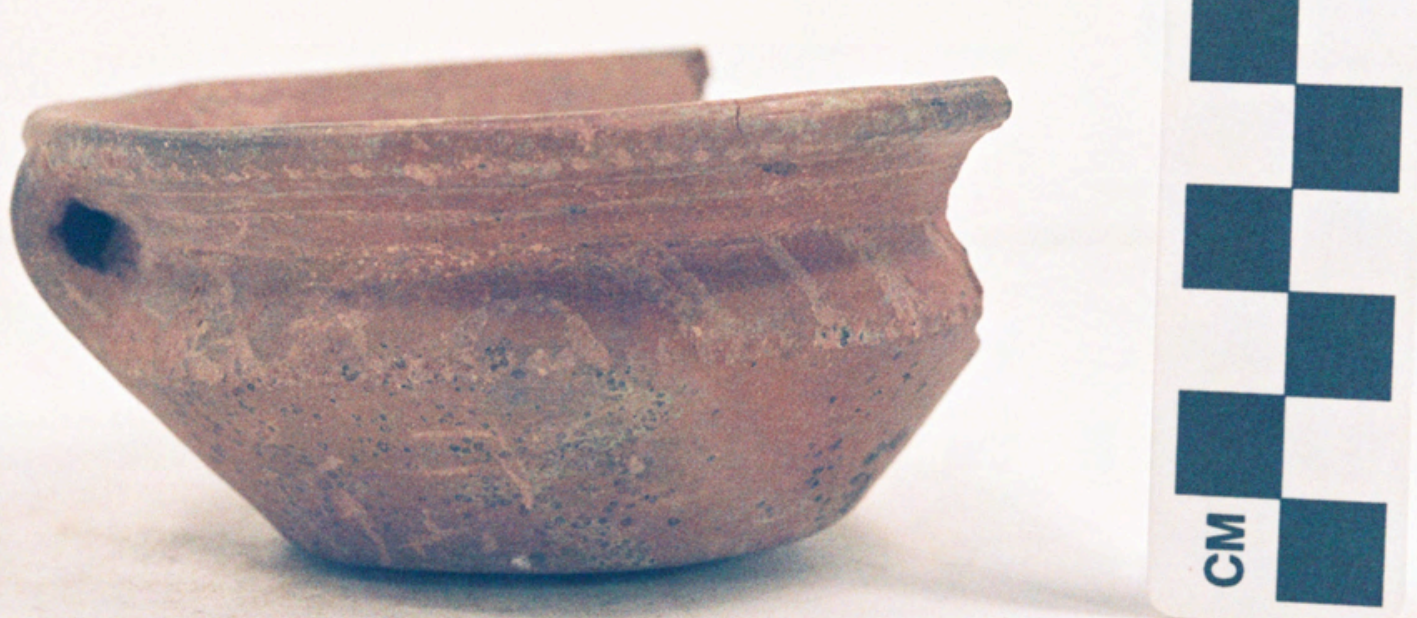

Figure A2-30 


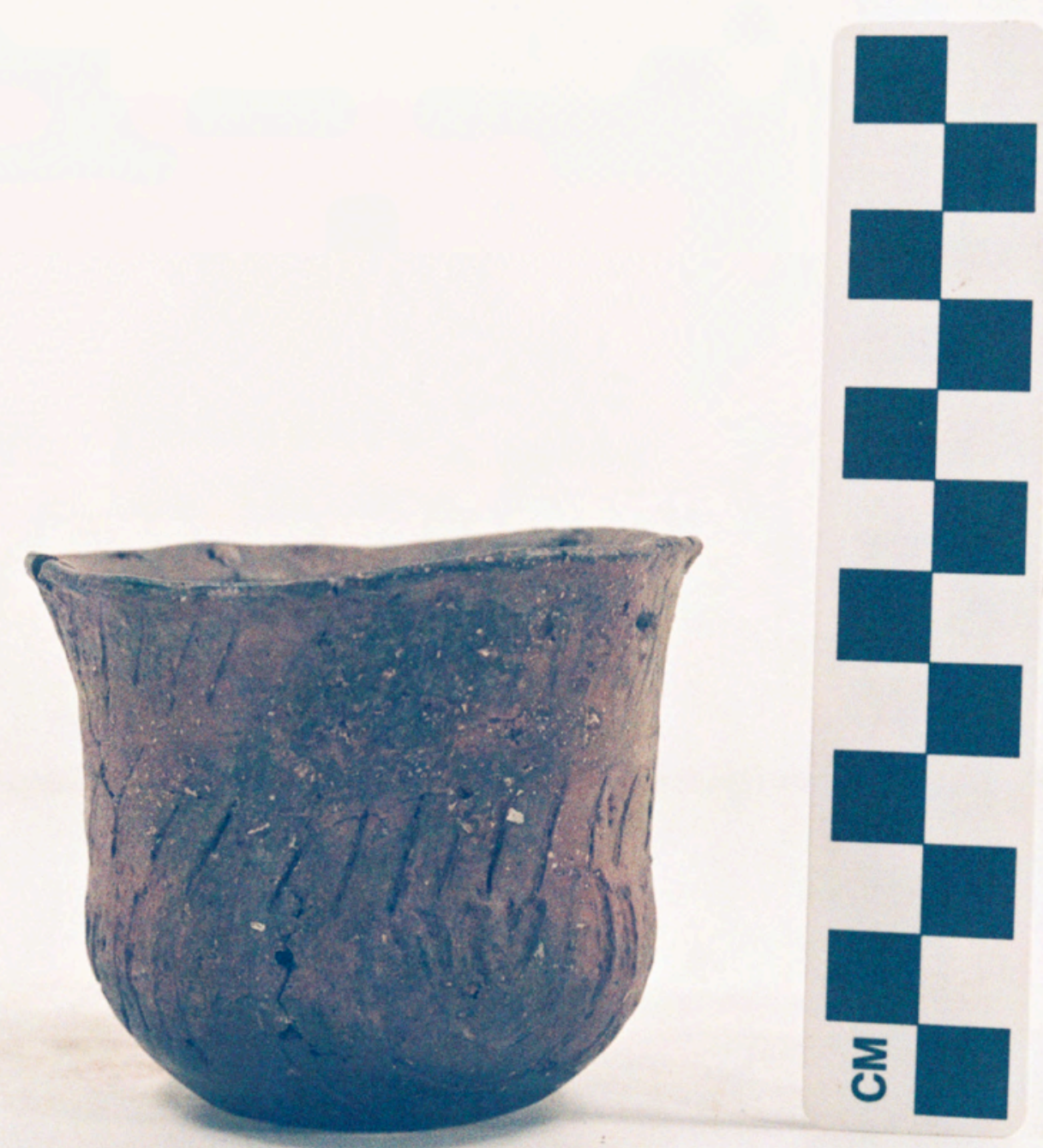

Figure A2-31 

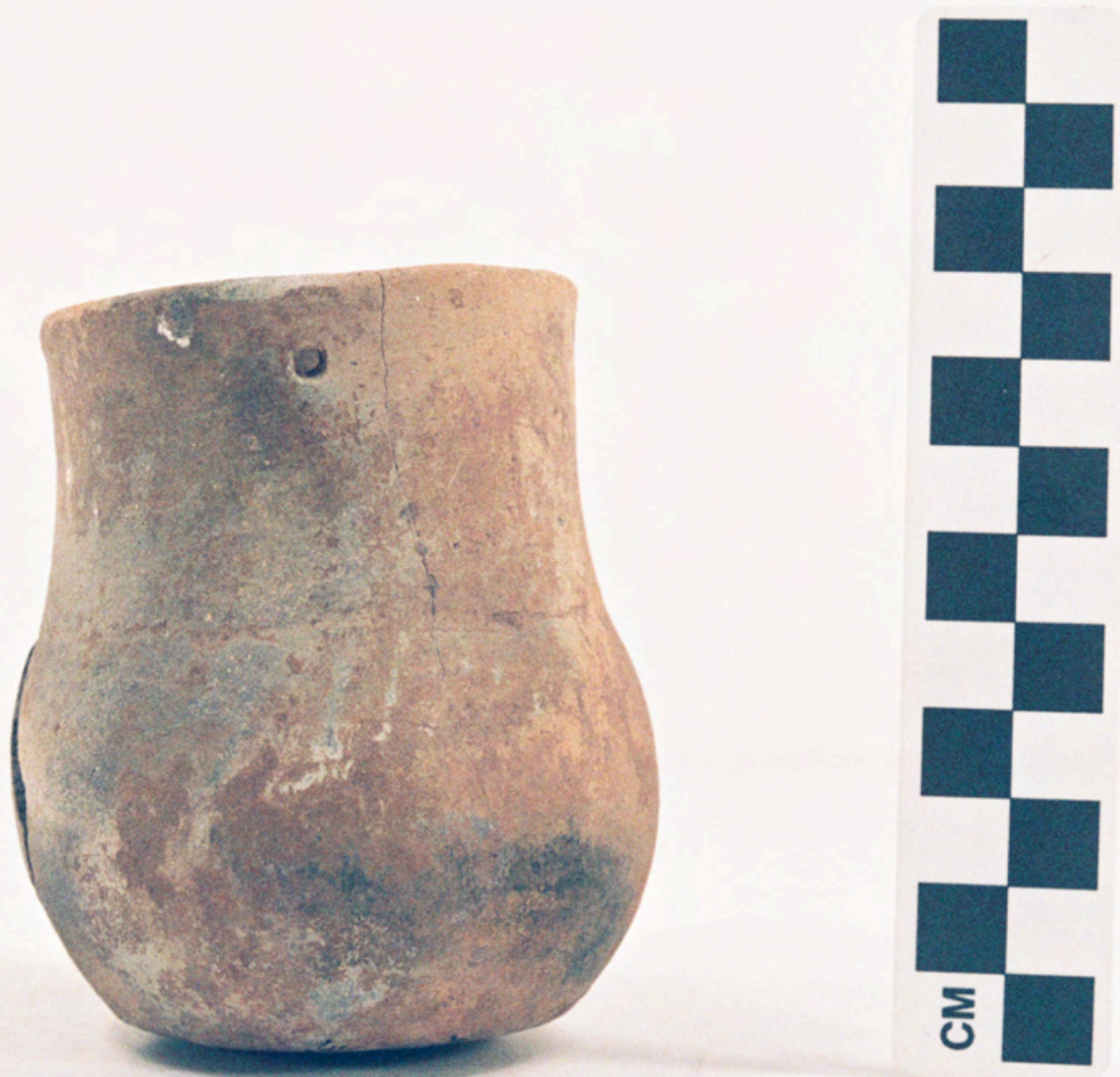

Figure A2-32 


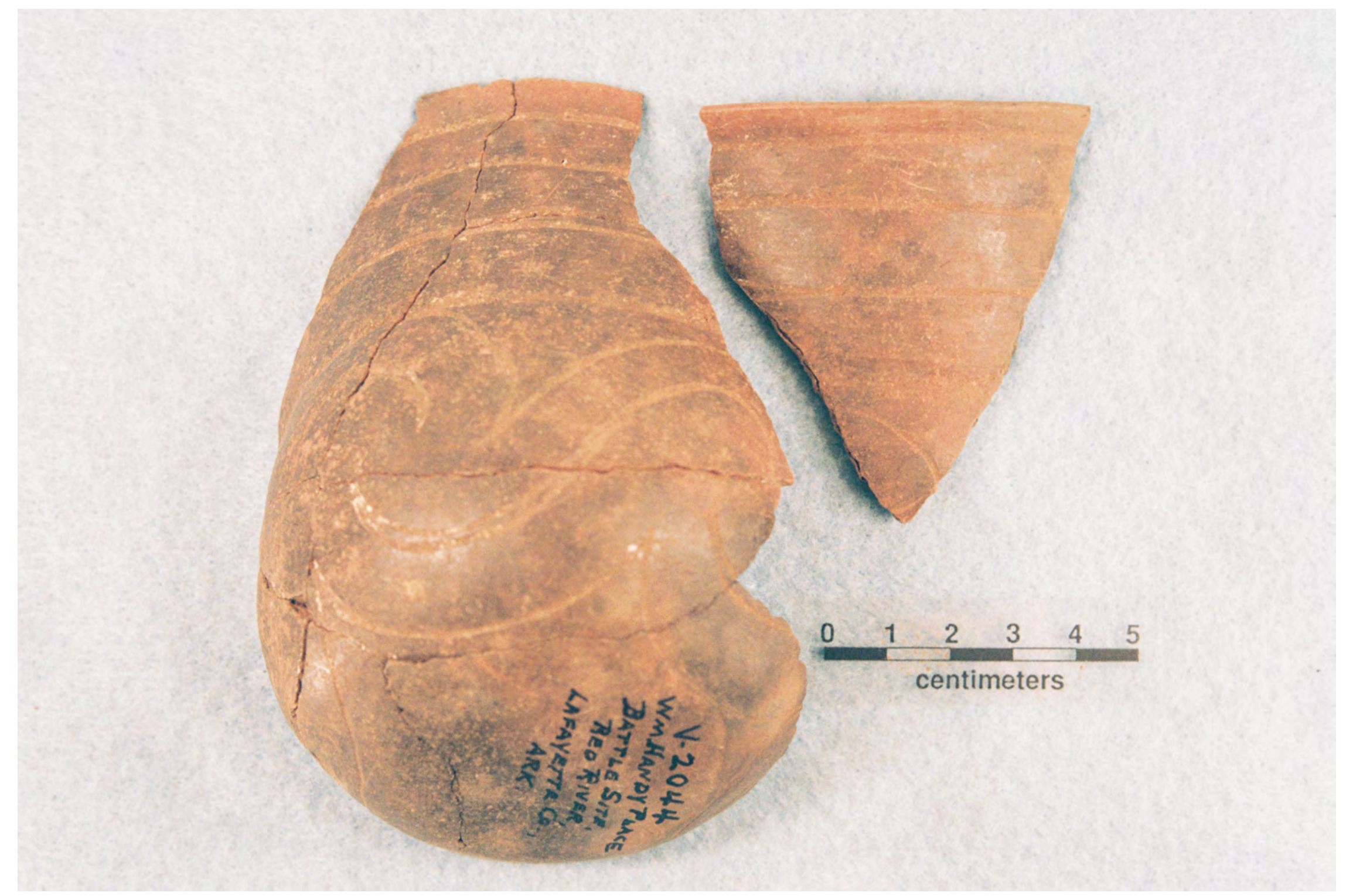

Figure A2-33 

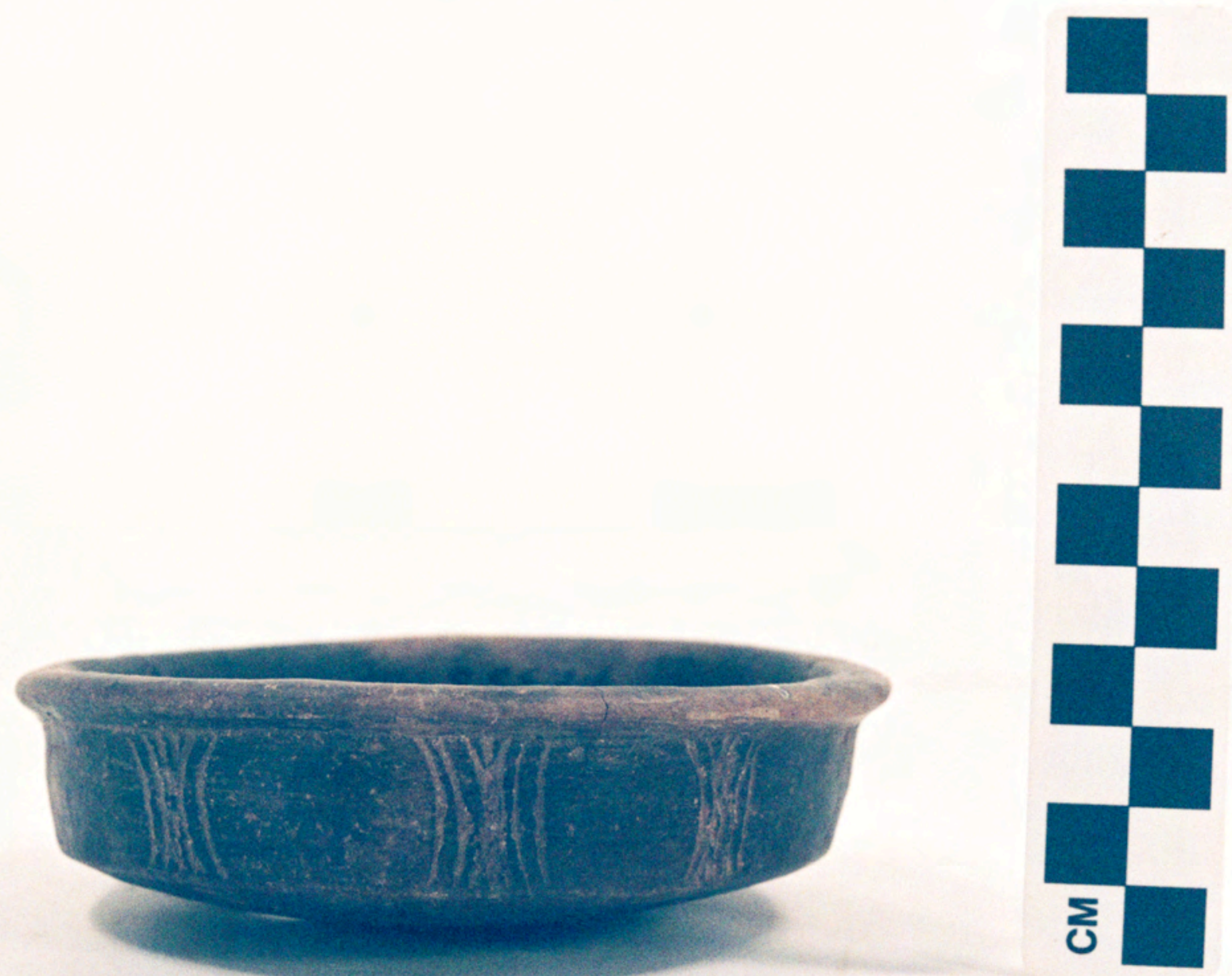

Figure A2-34 


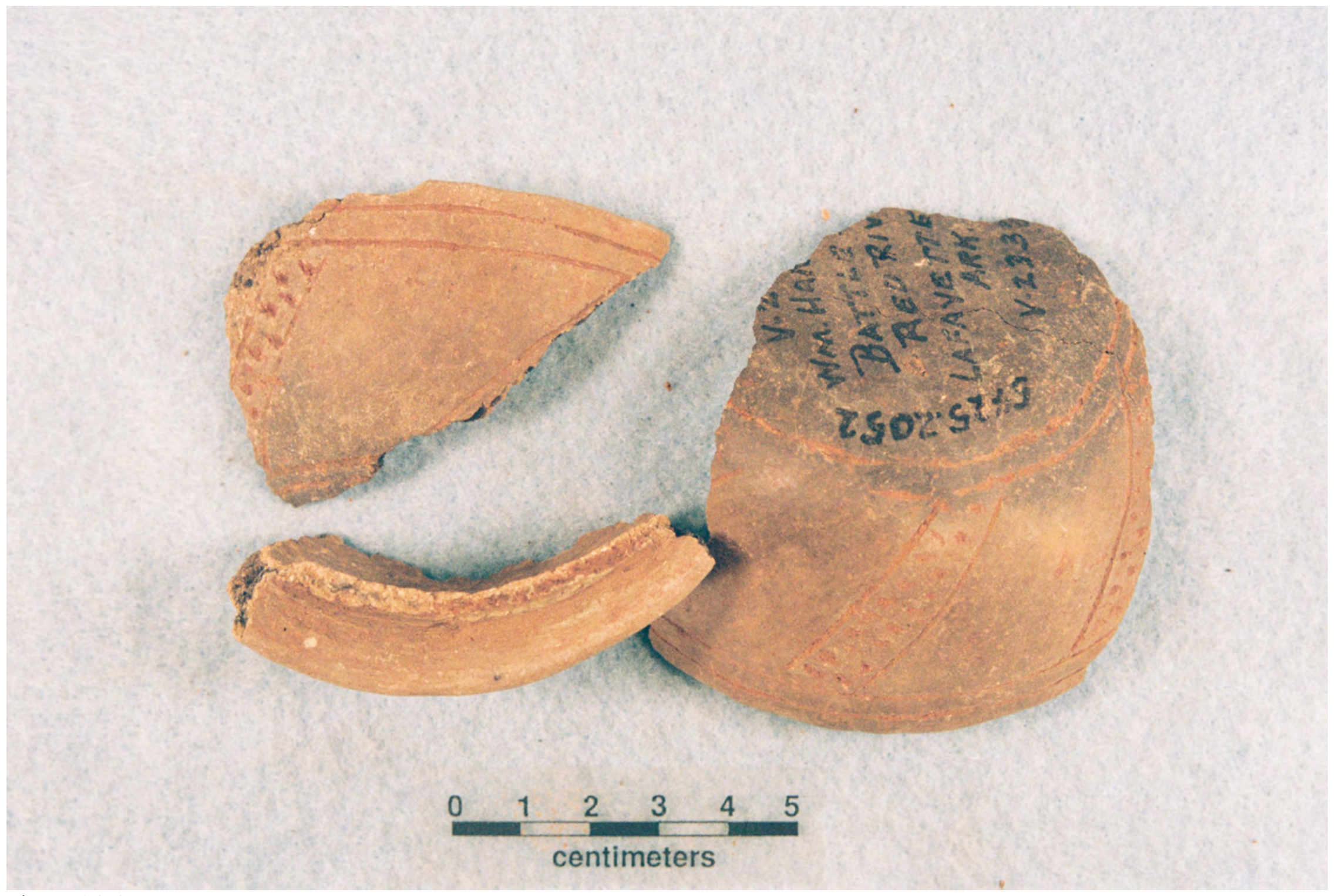

Figure A2-35a 


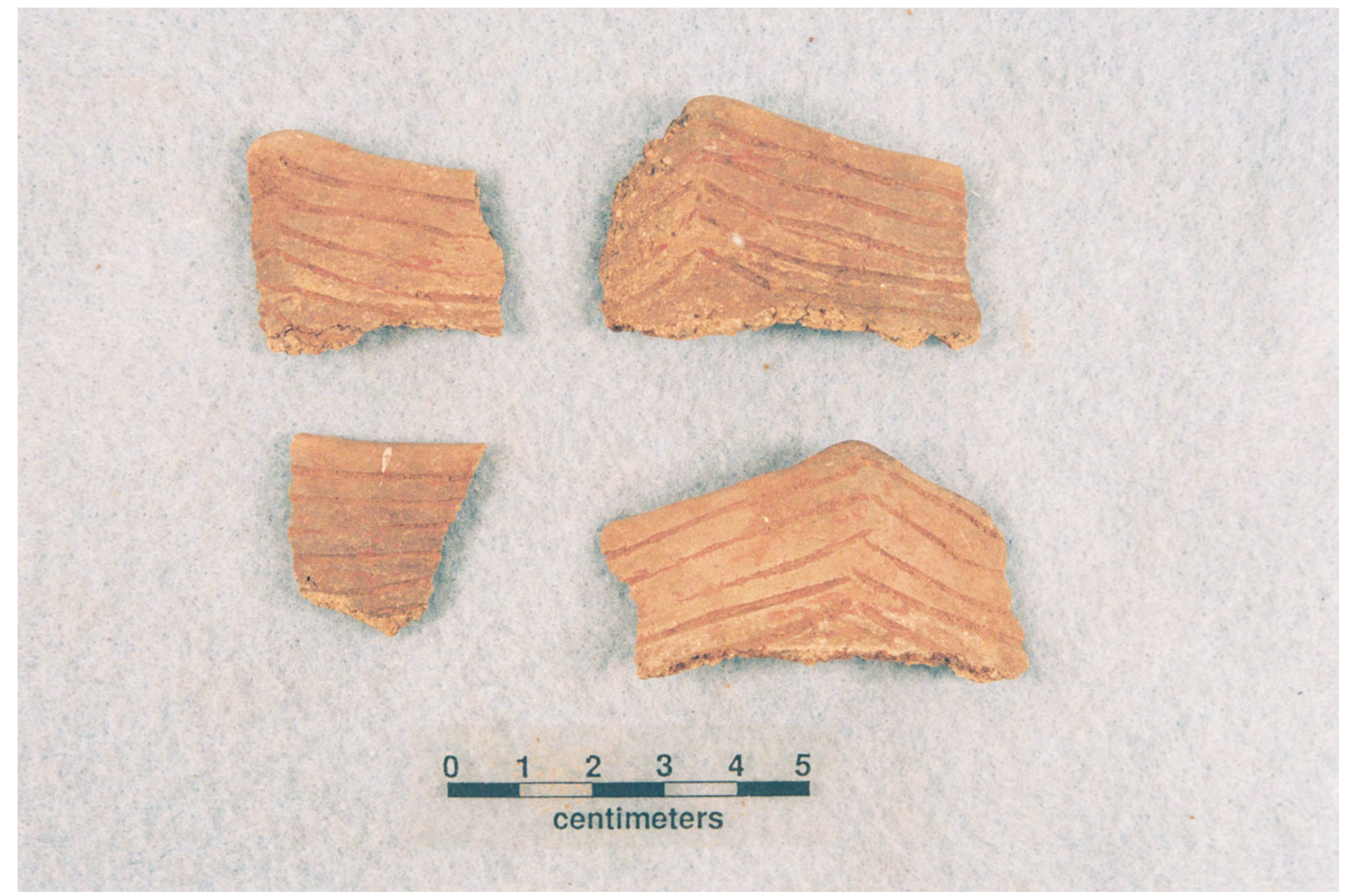

Figure A2-35b 


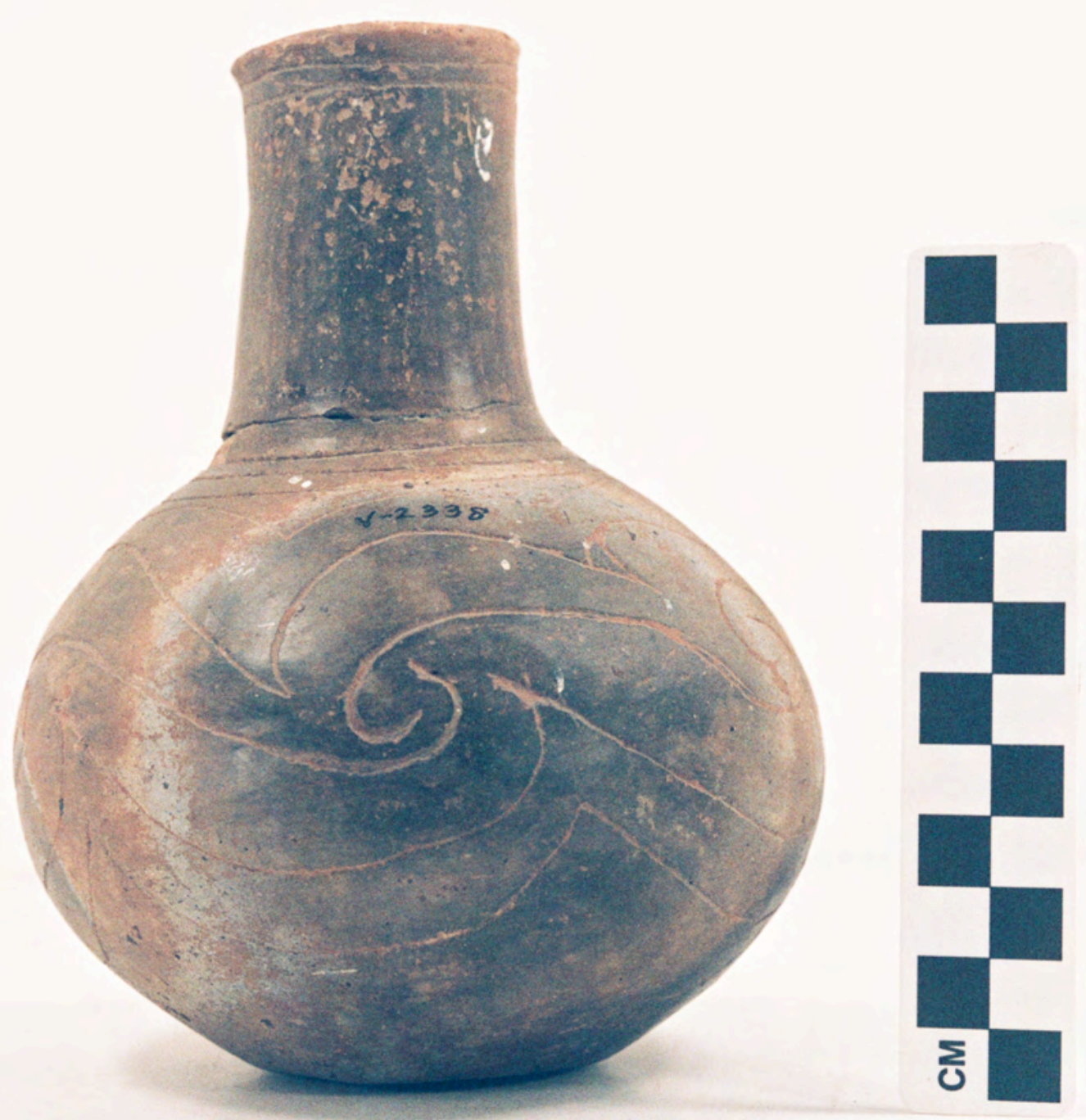

Figure A2-36 


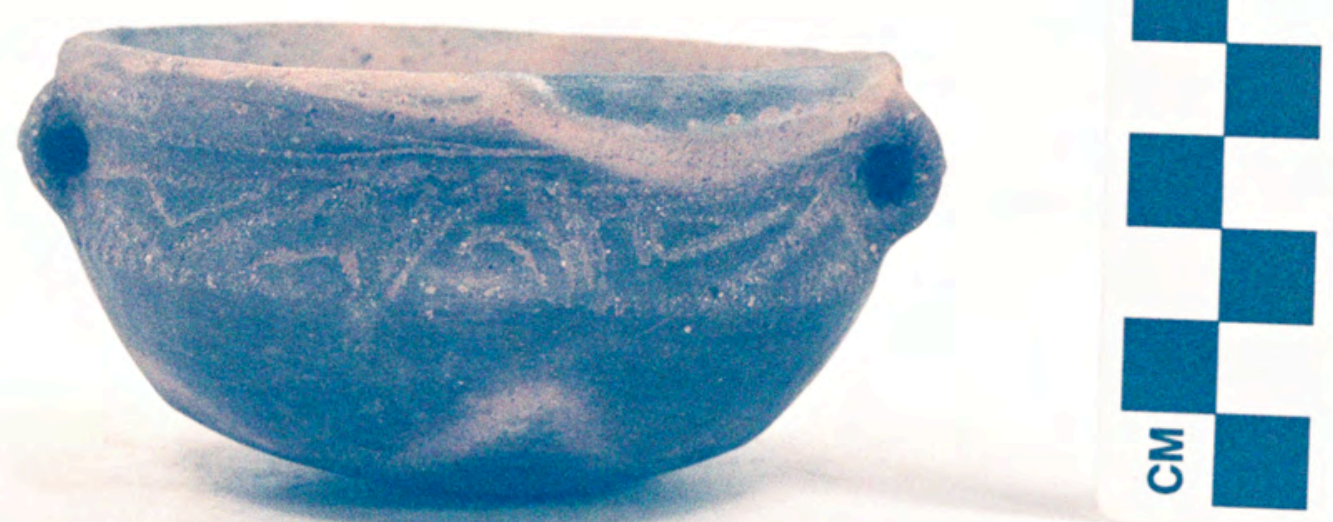

Figure A2-37 


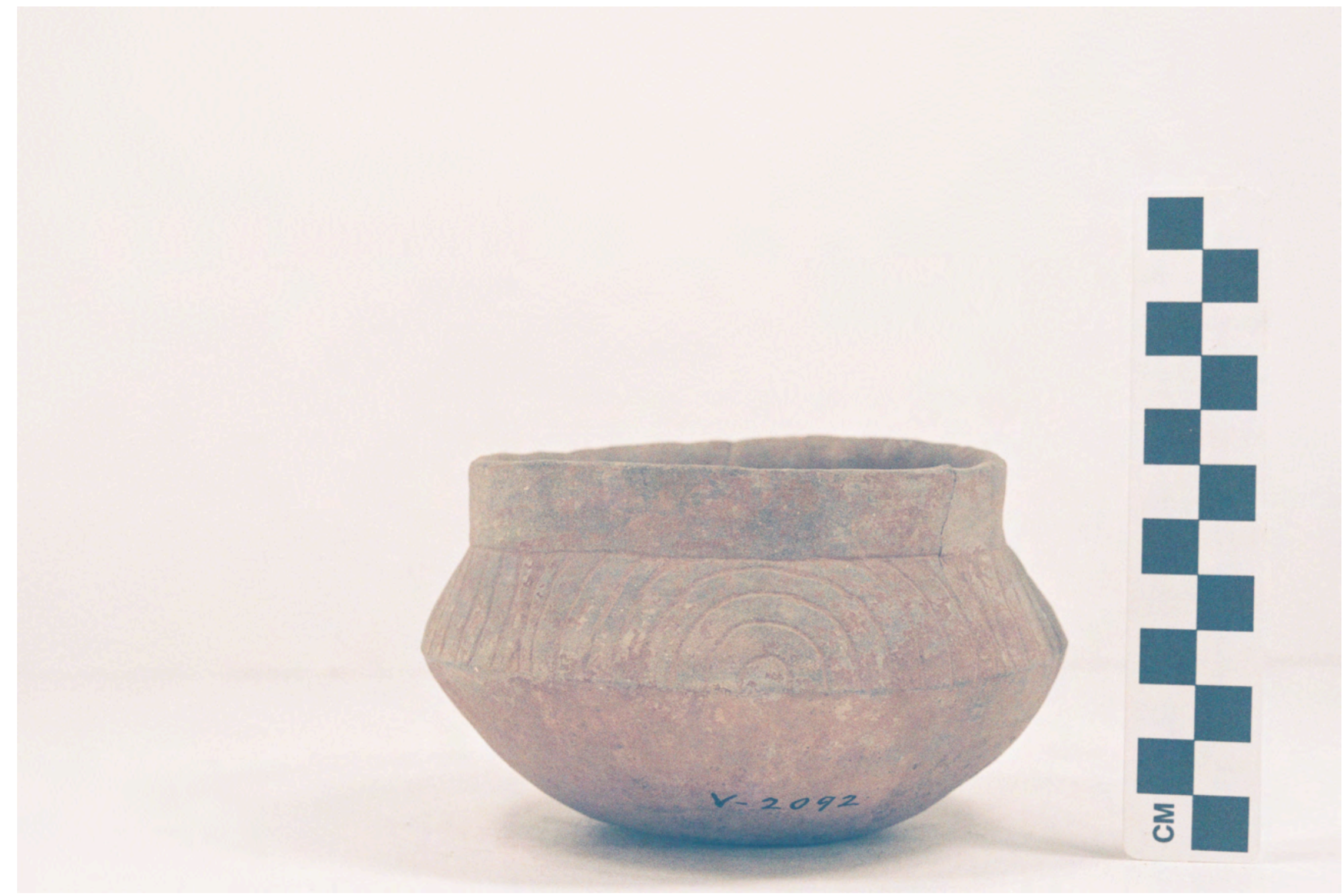

Figure A2-38 


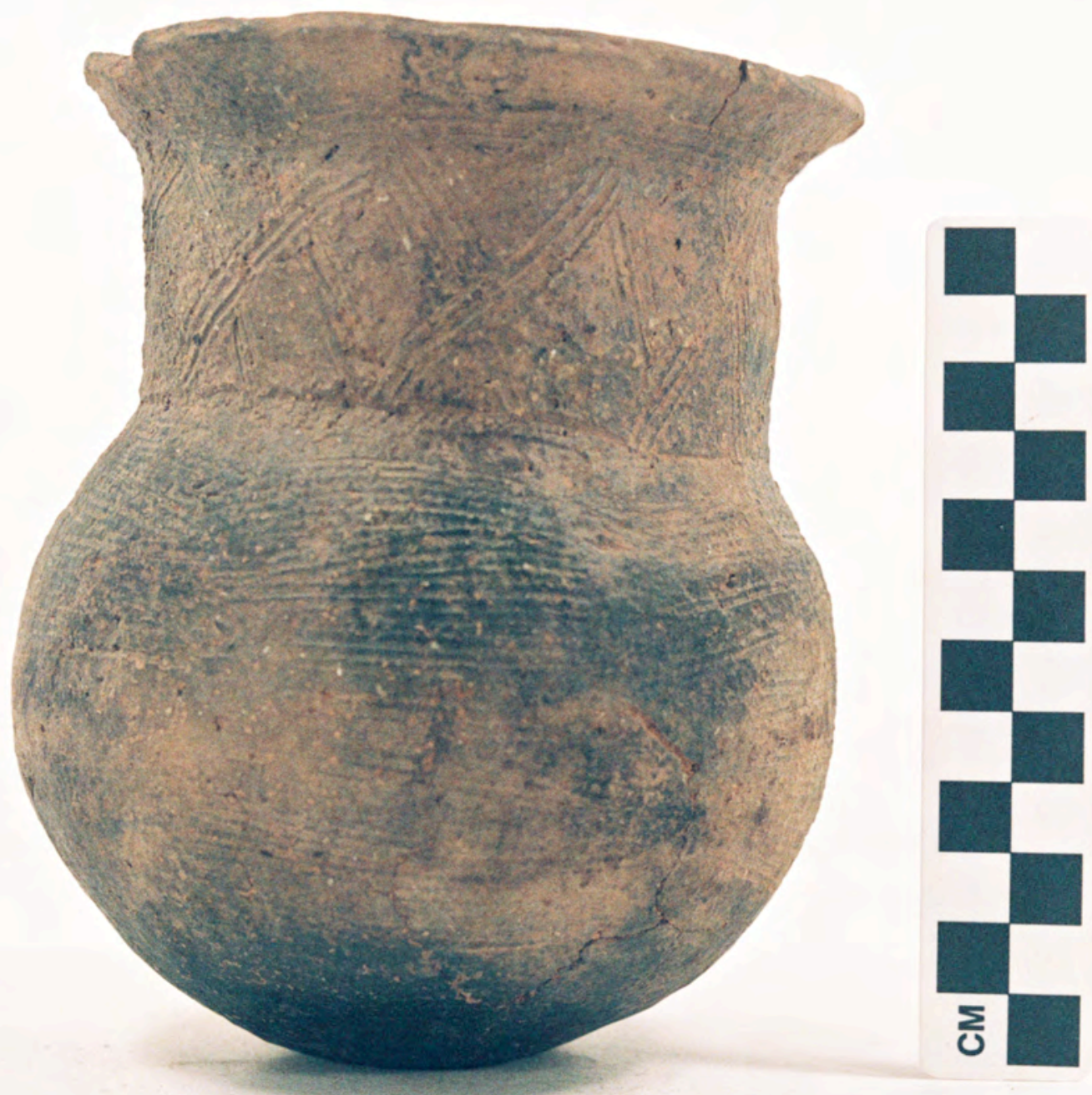

Figure A2-39 


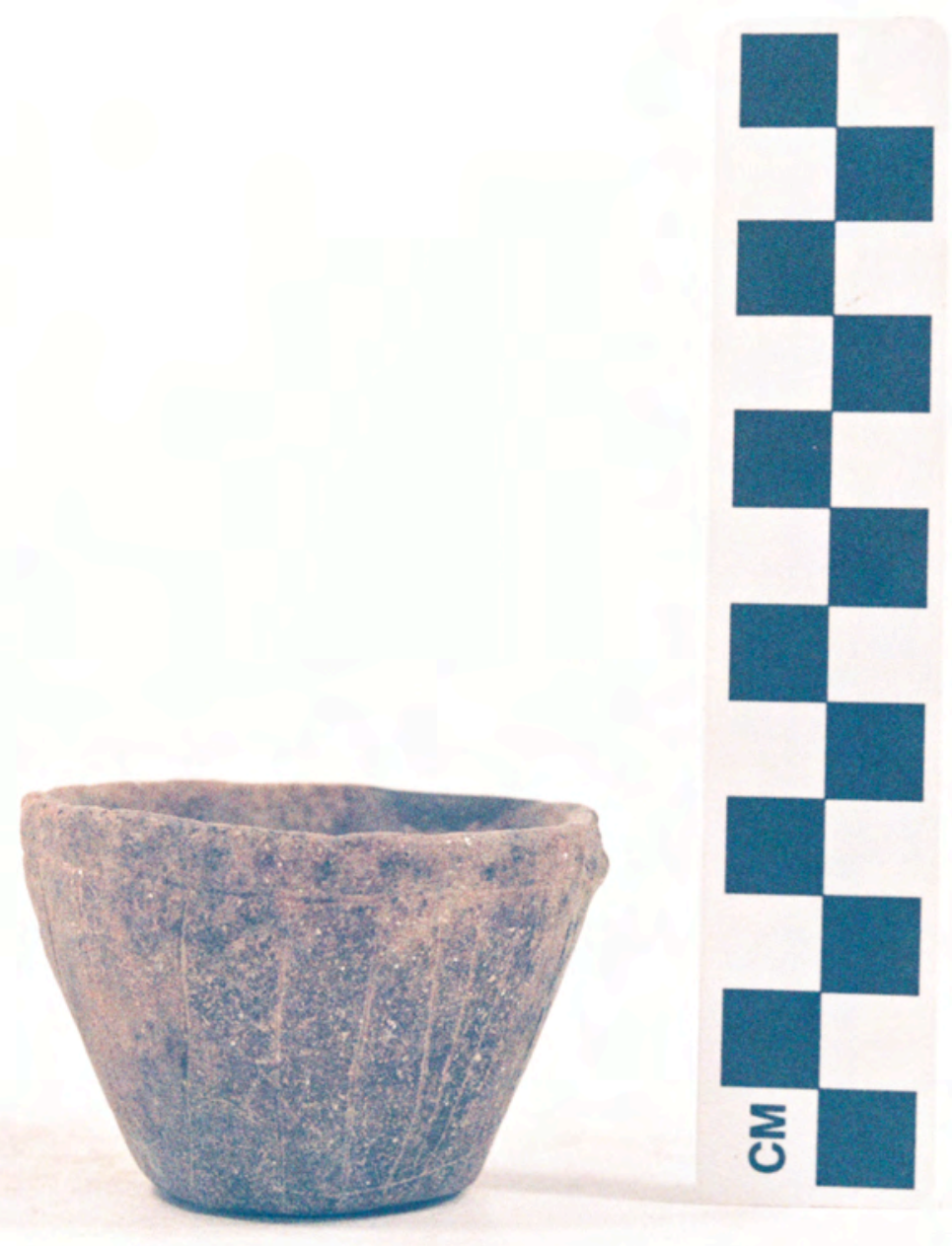

Figure A2-40 


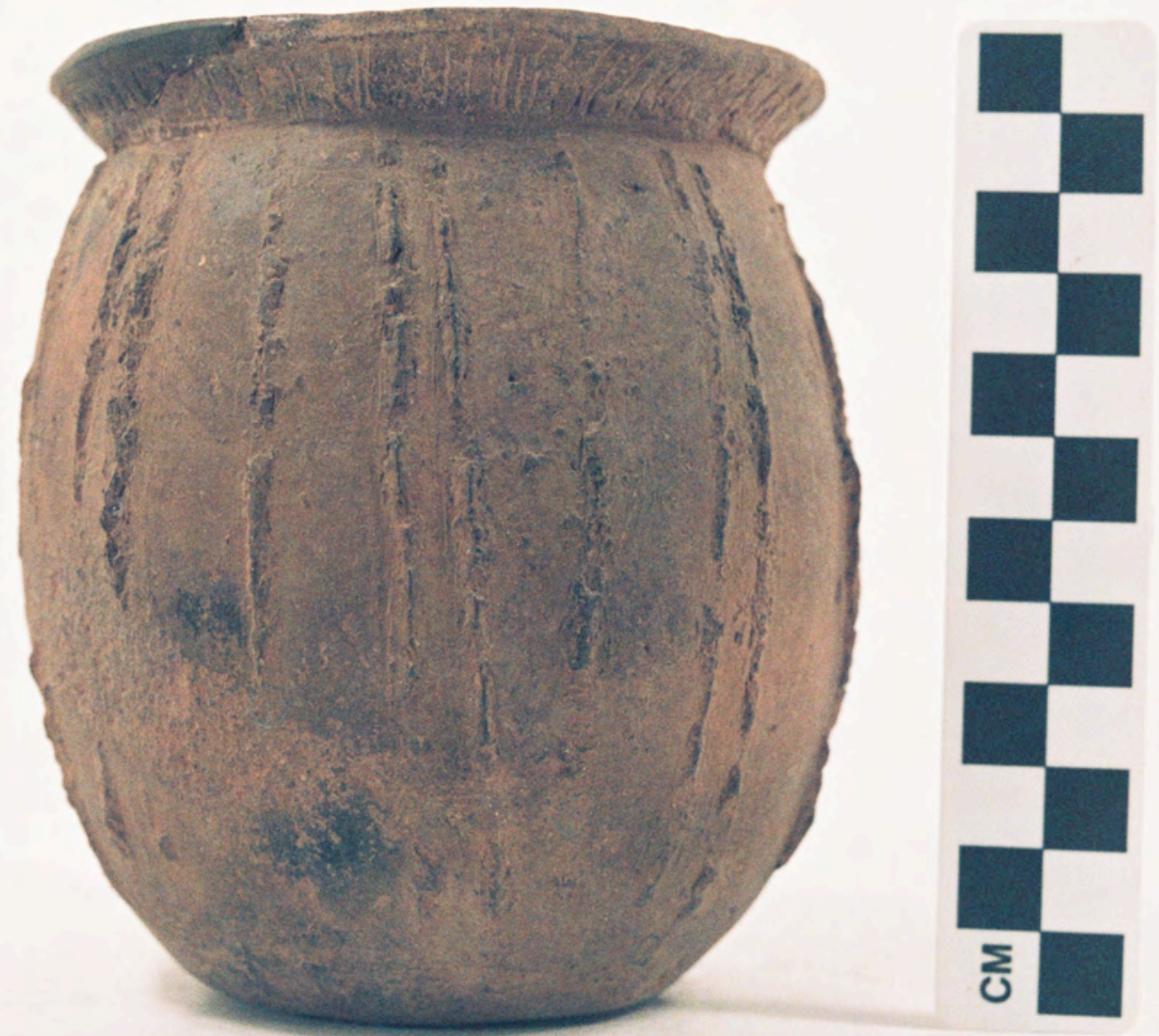

Figure A2-41 


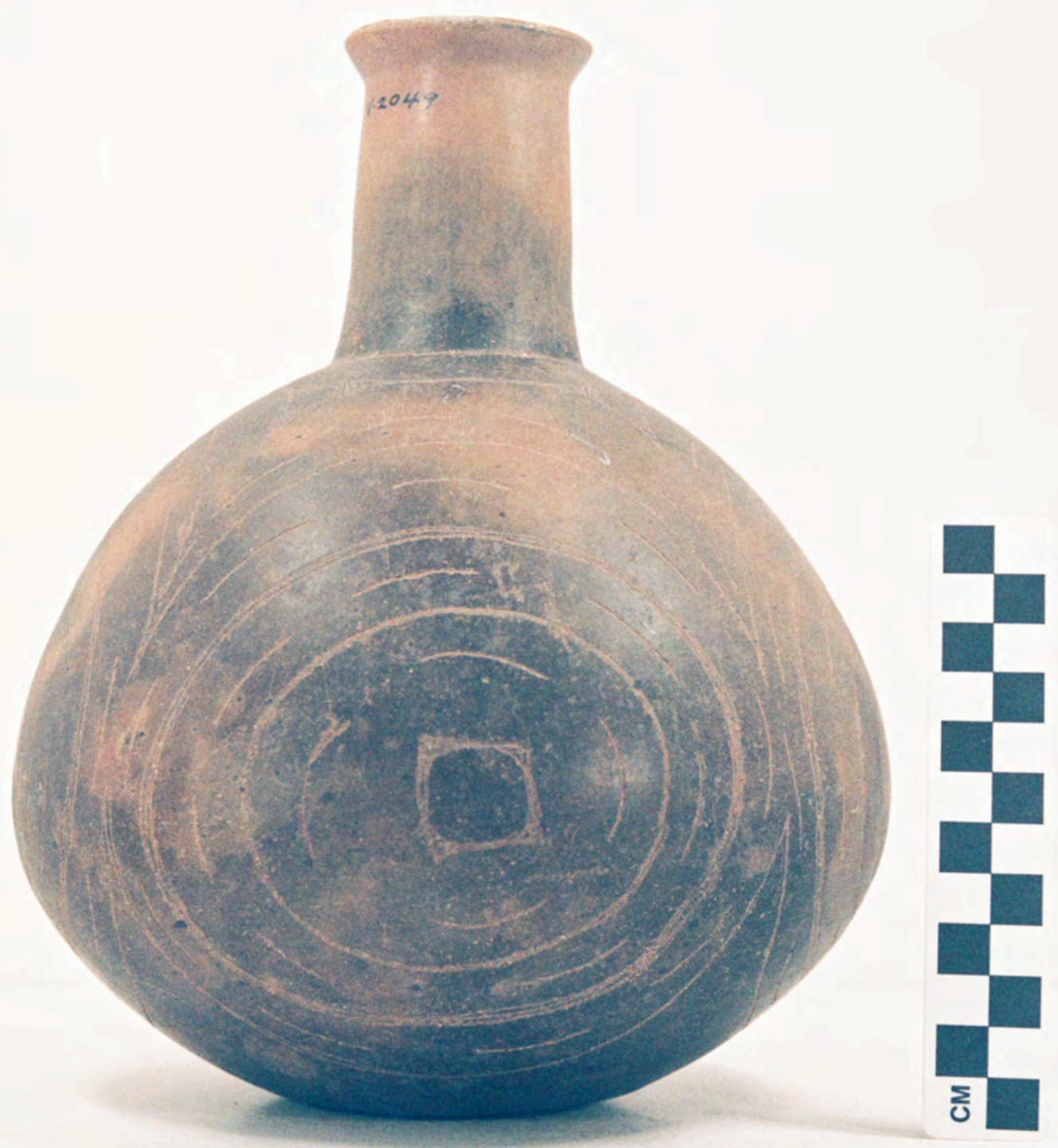

Figure A2-42a 


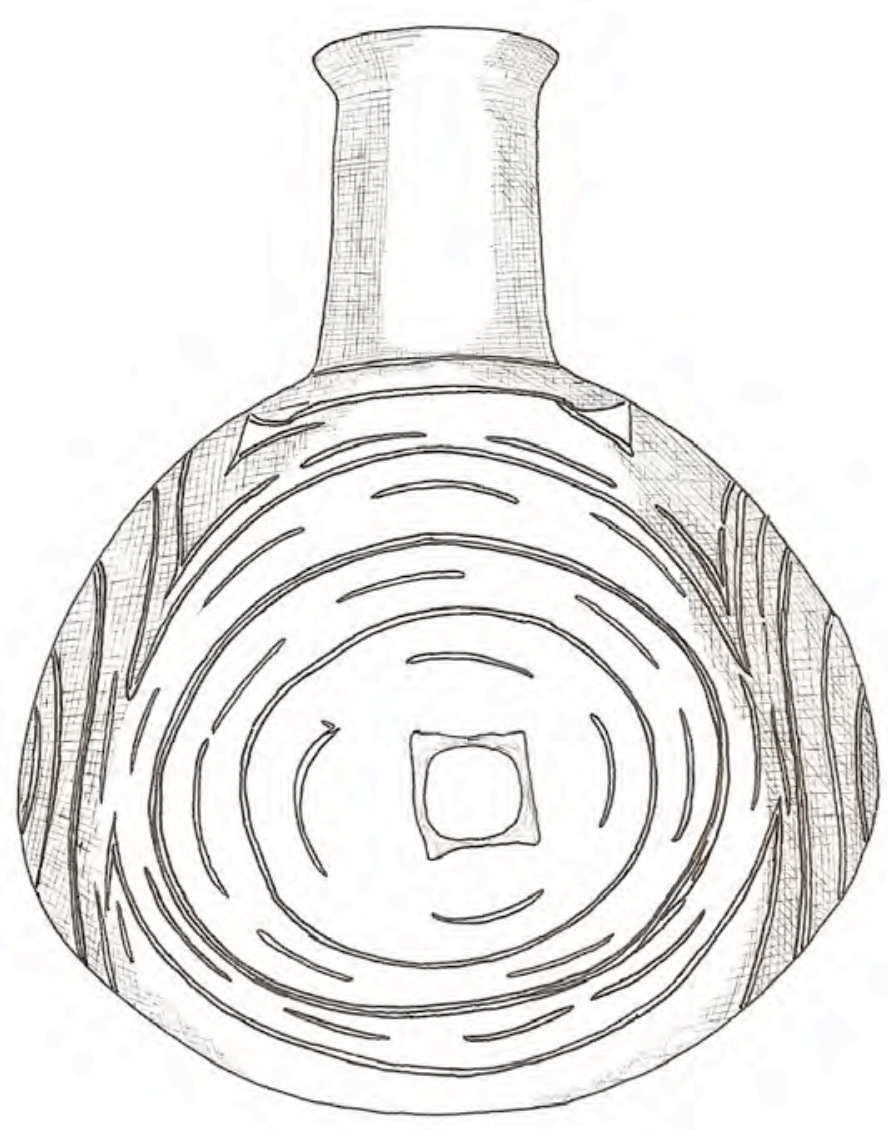

Figure A2-42. Belcher Engraved, var. Ogden bottle (5425-2059); b. drawing by Bobby Gonzalez.

Figure A2-42b 


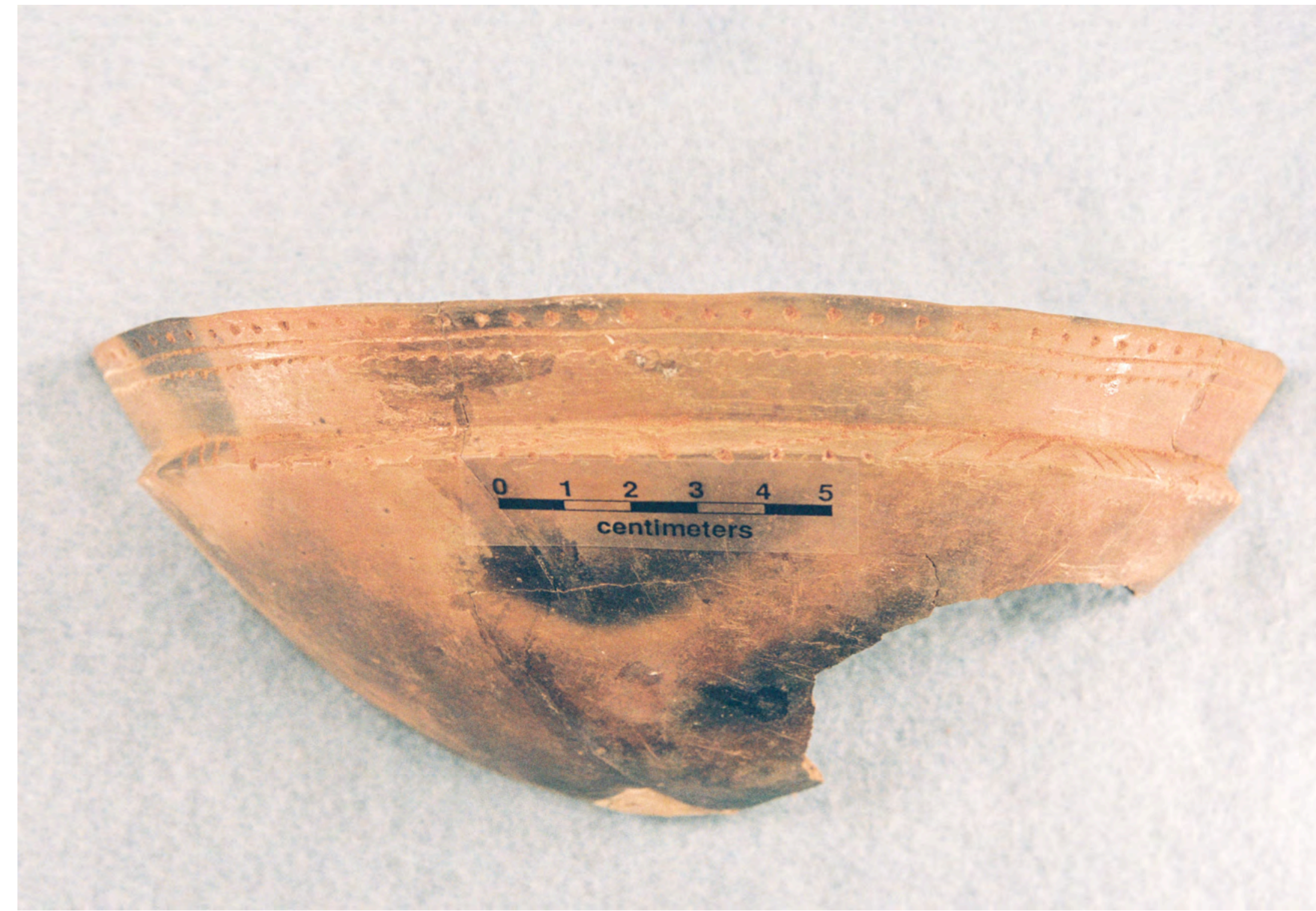

Figure A2-43 


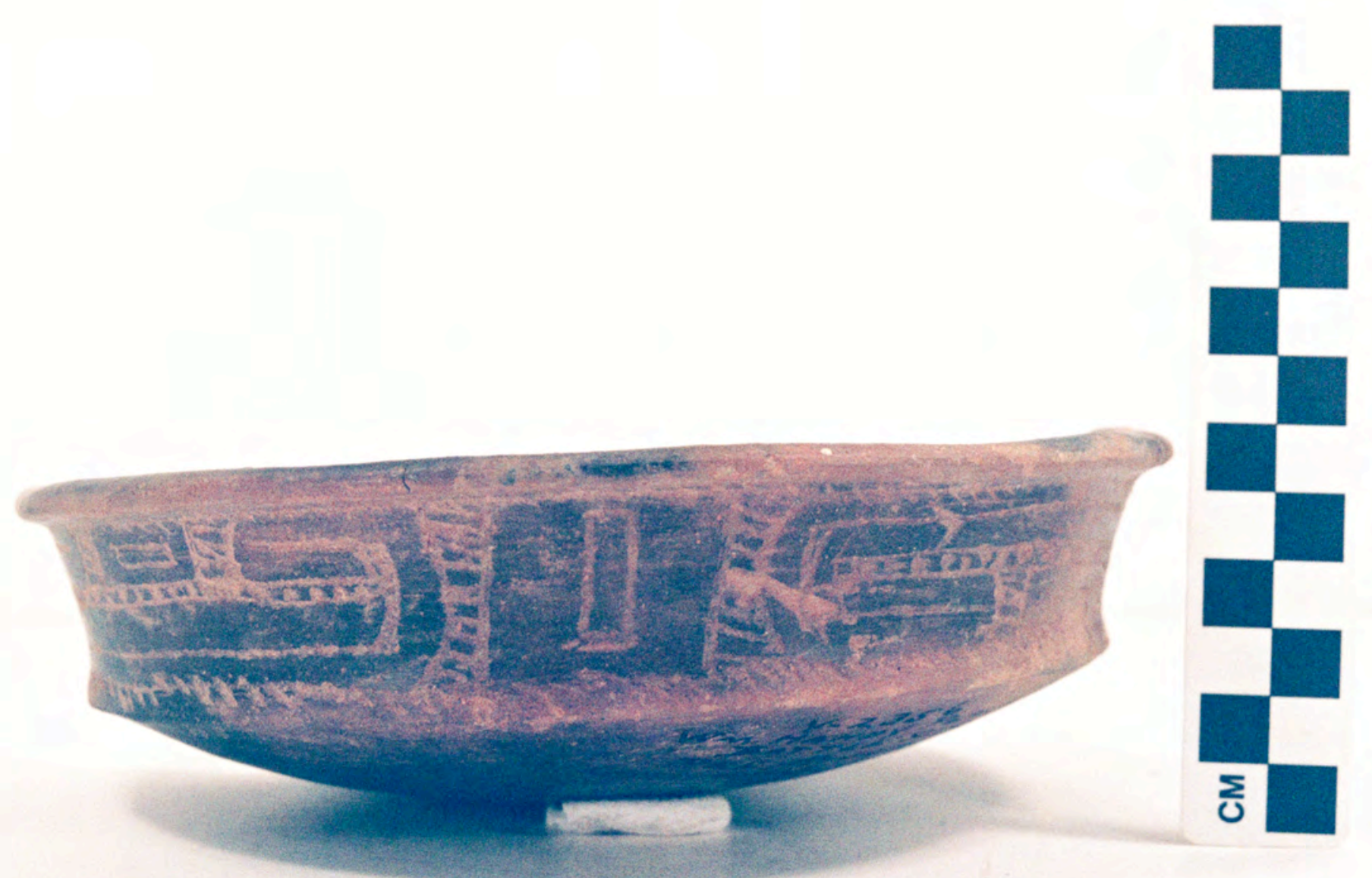

Figure A2-44 


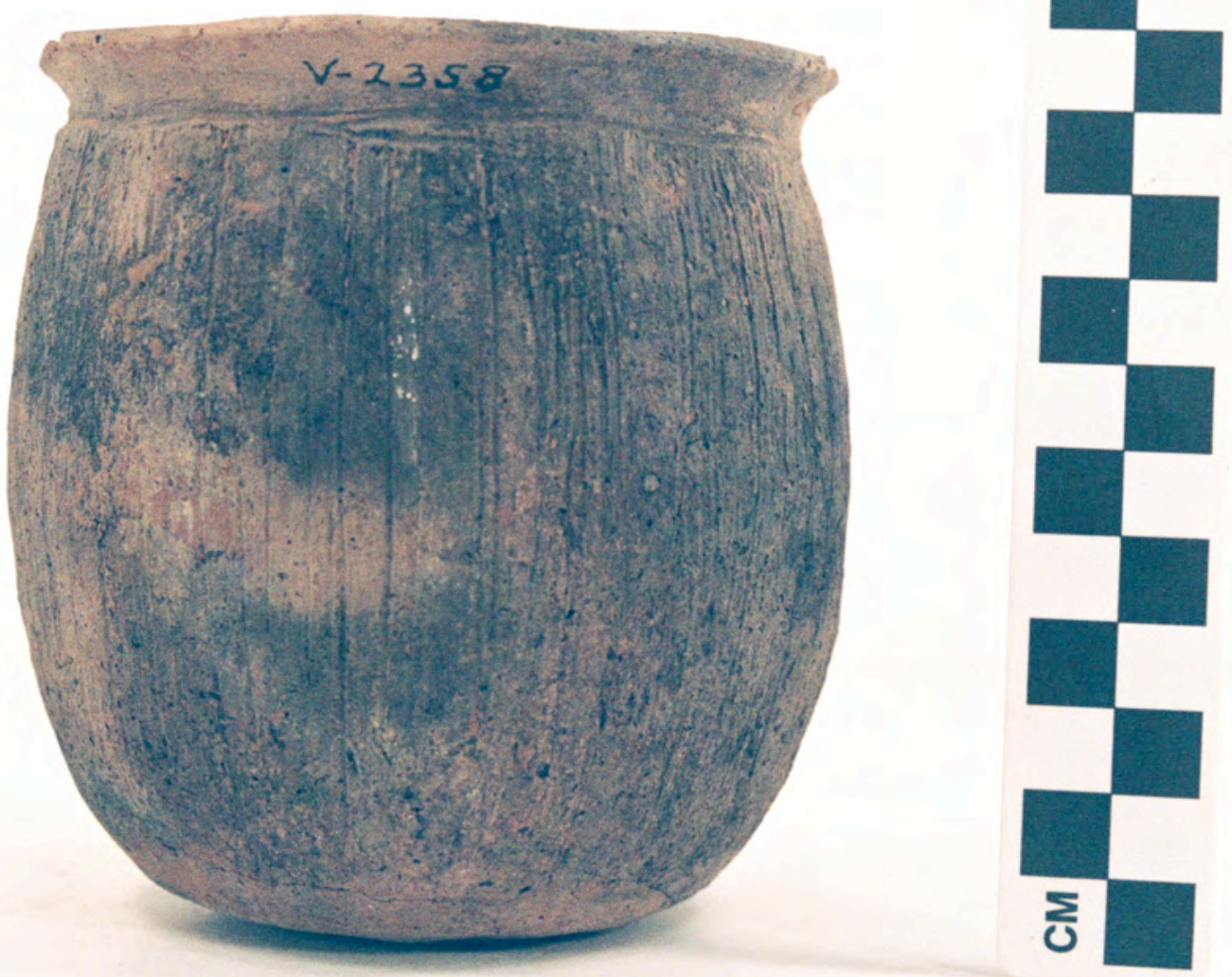

Figure A2-45 


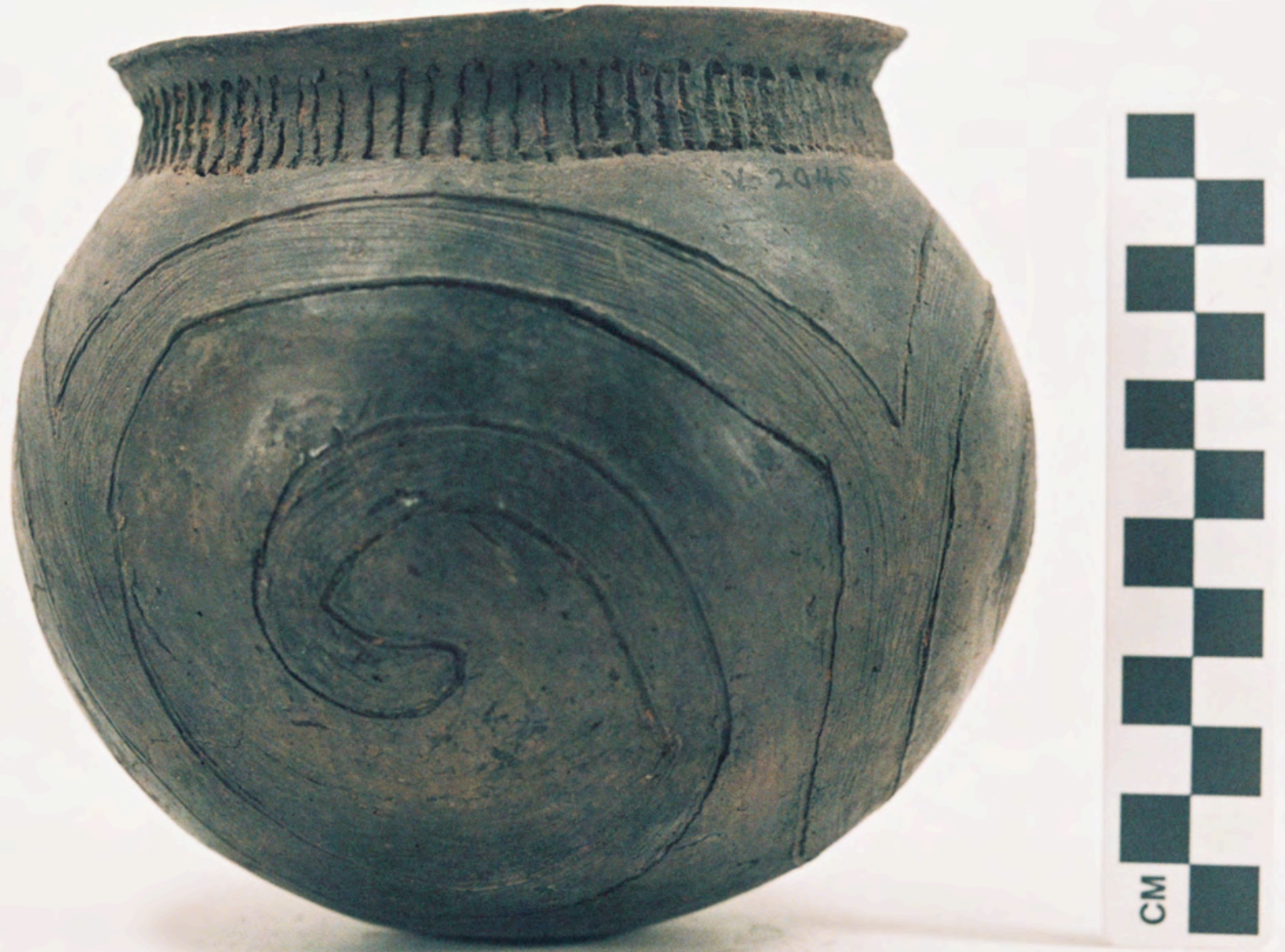

Figure A2-46 


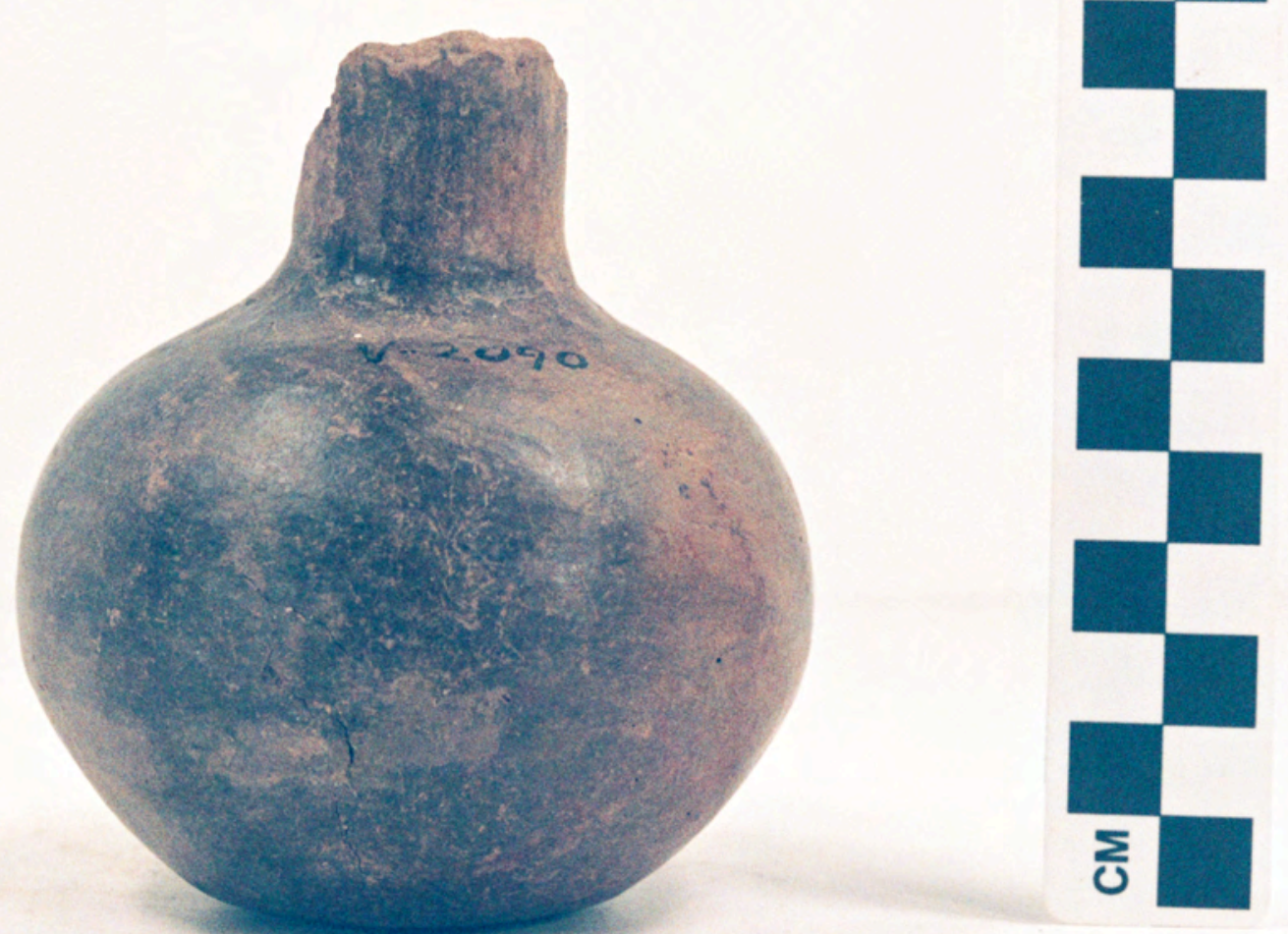

Figure A2-47 


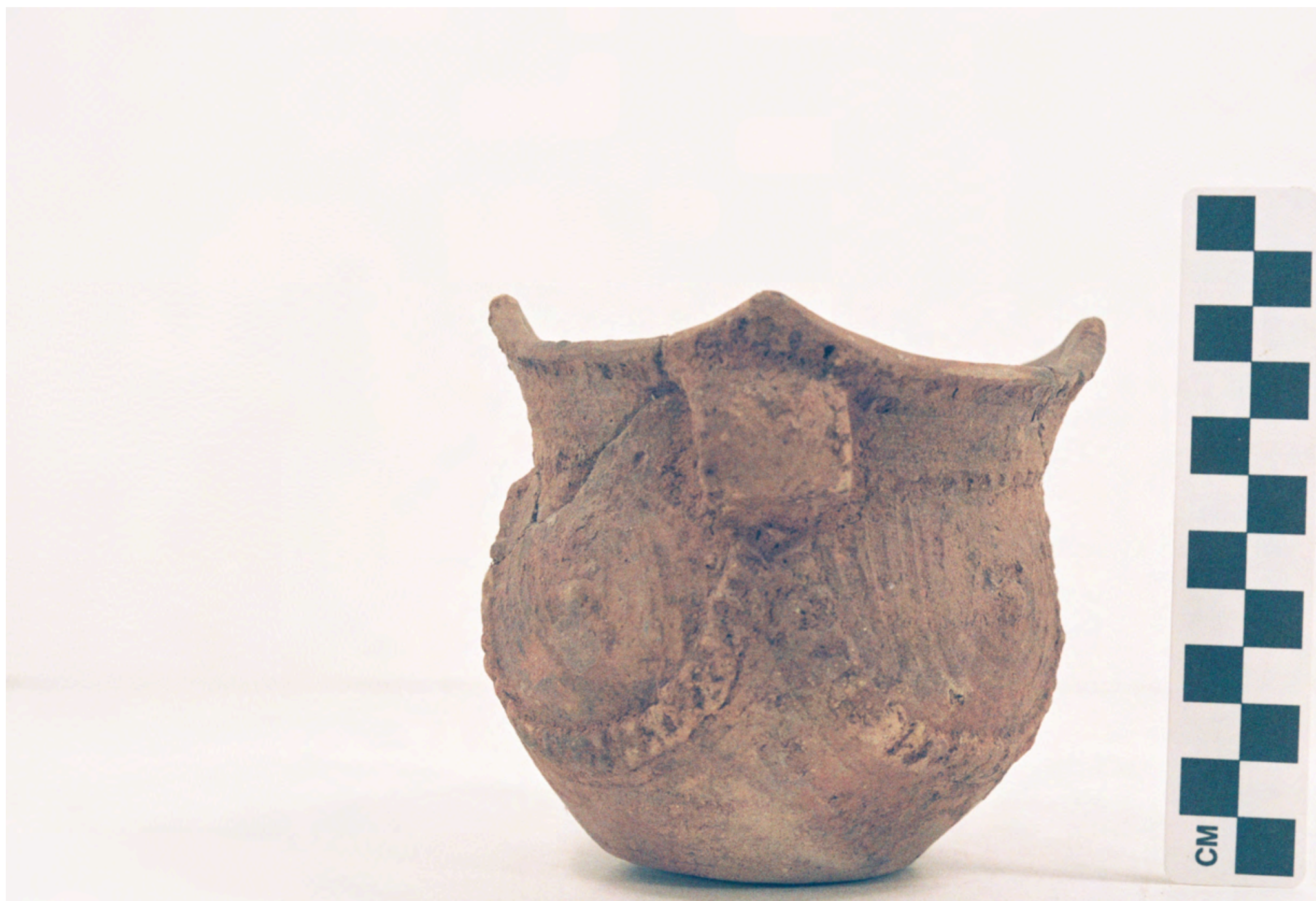

Figure A2-48 


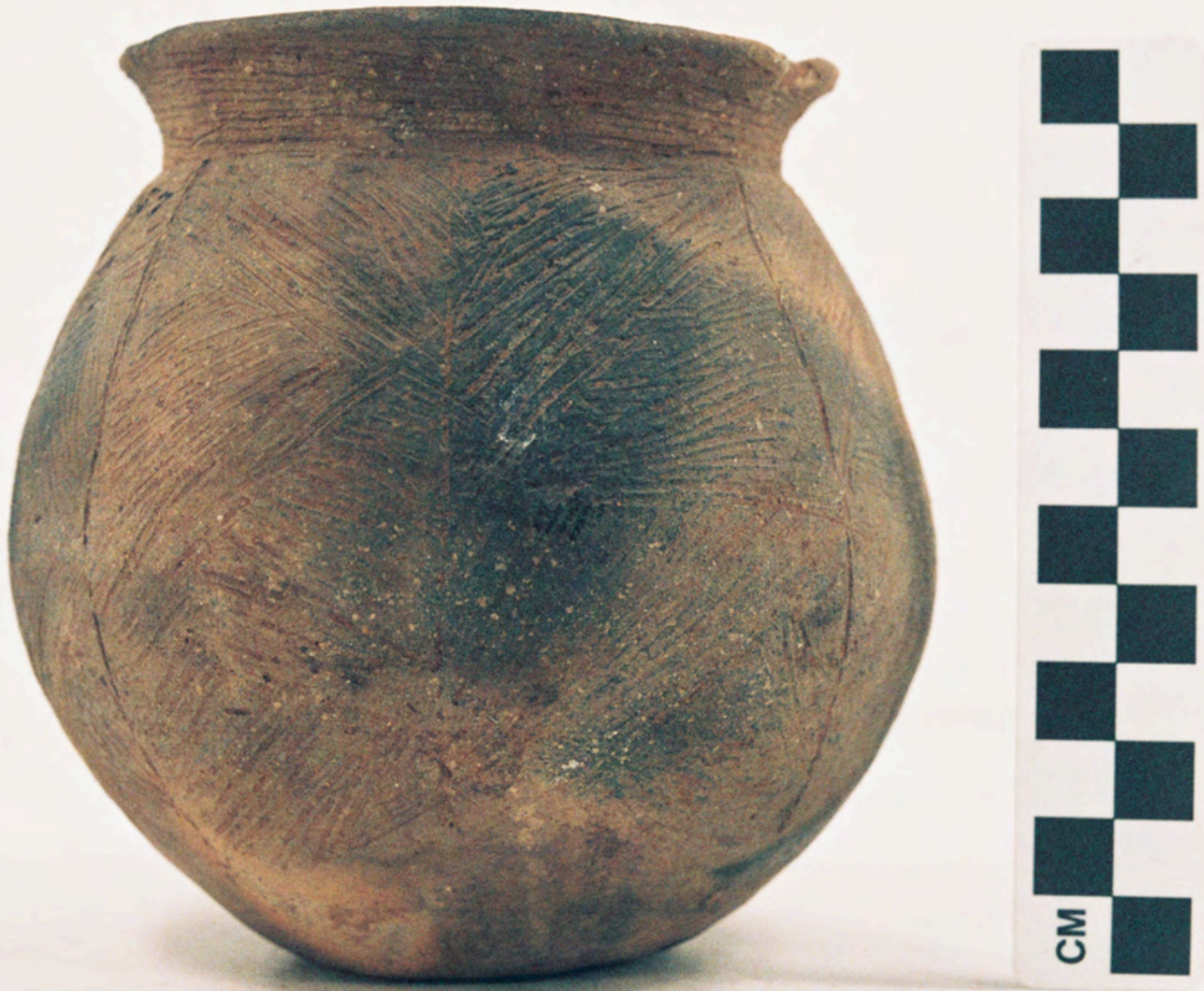

Figure A2-49 


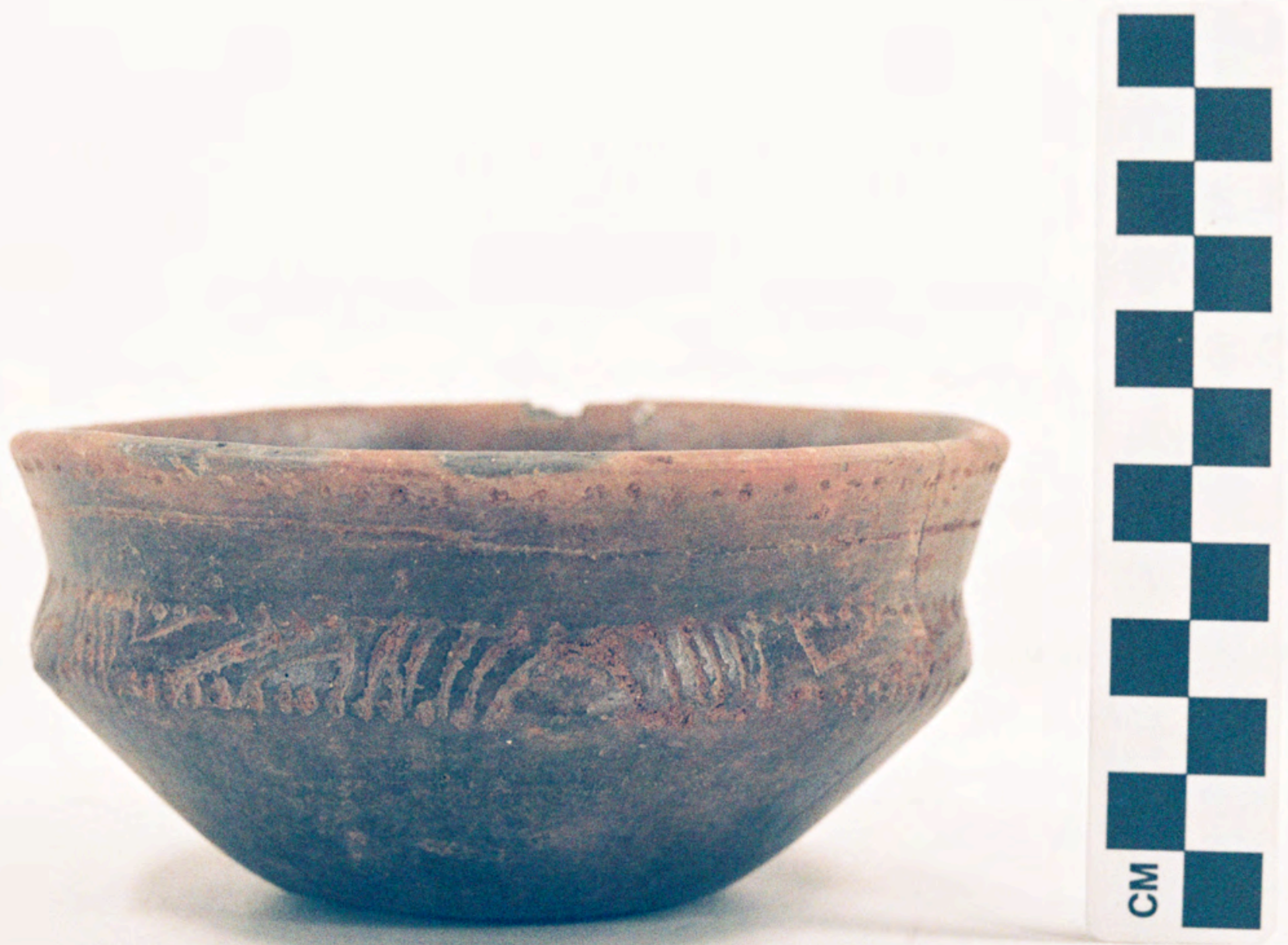

Figure A2-50 


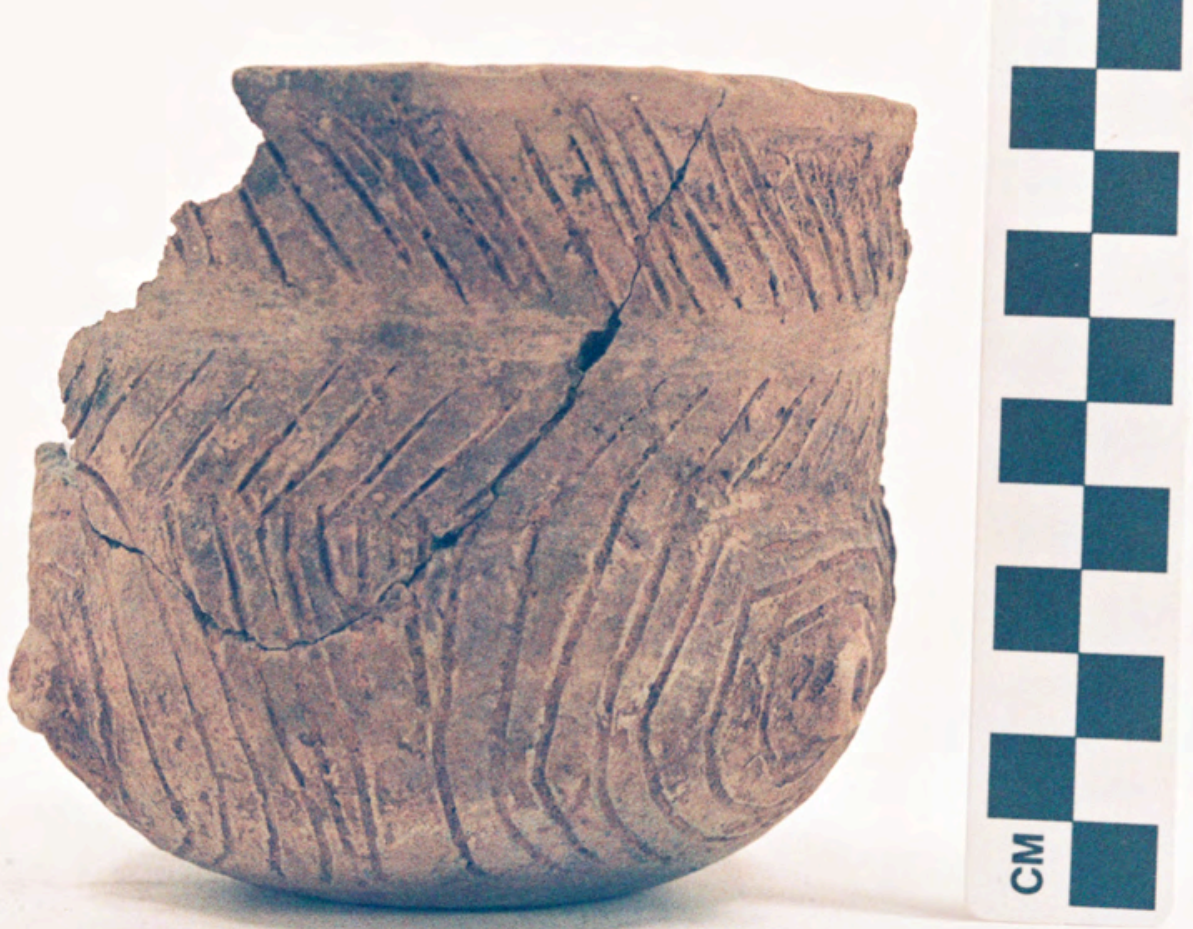

Figure A2-51 


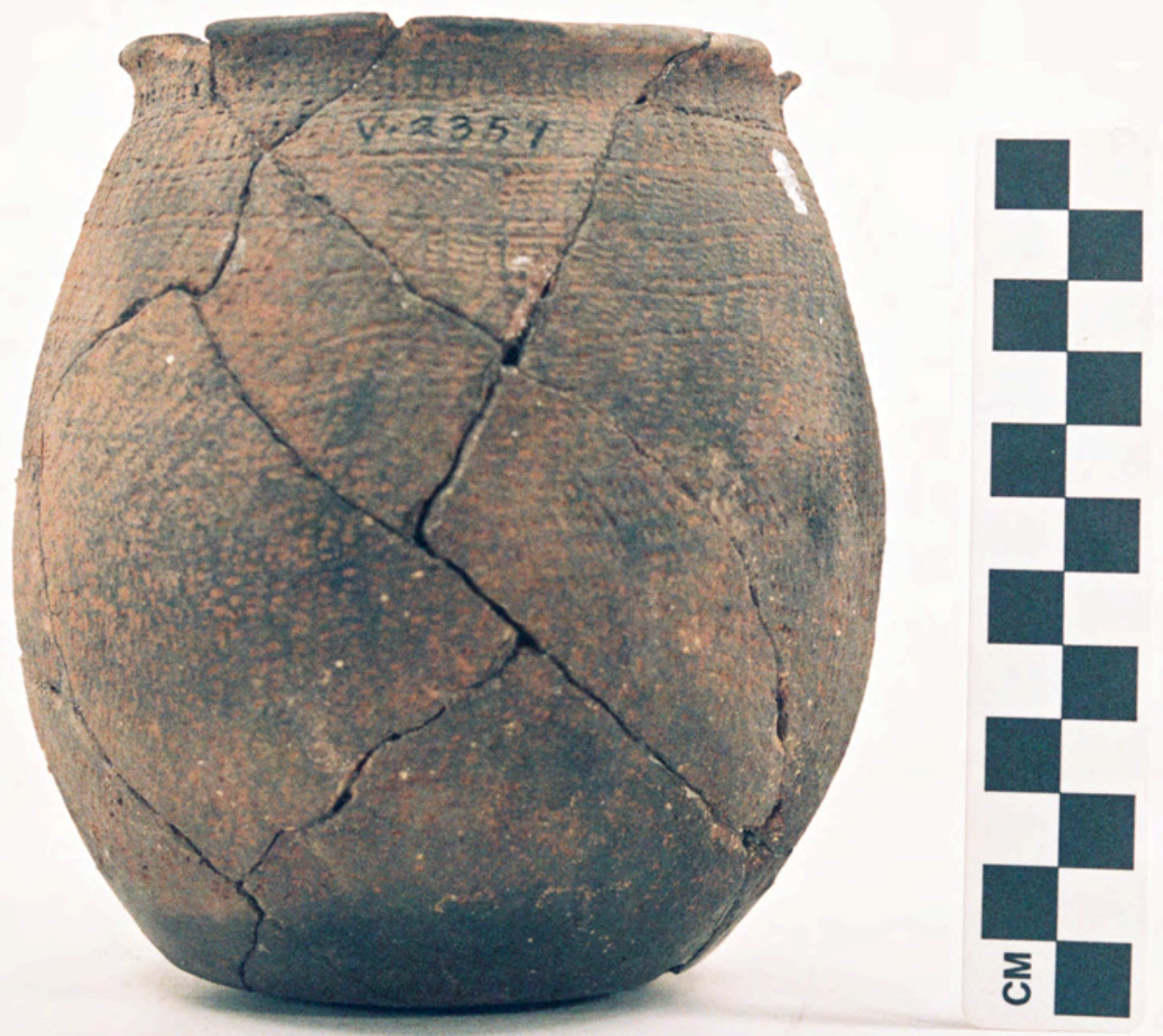

Figure A2-52 


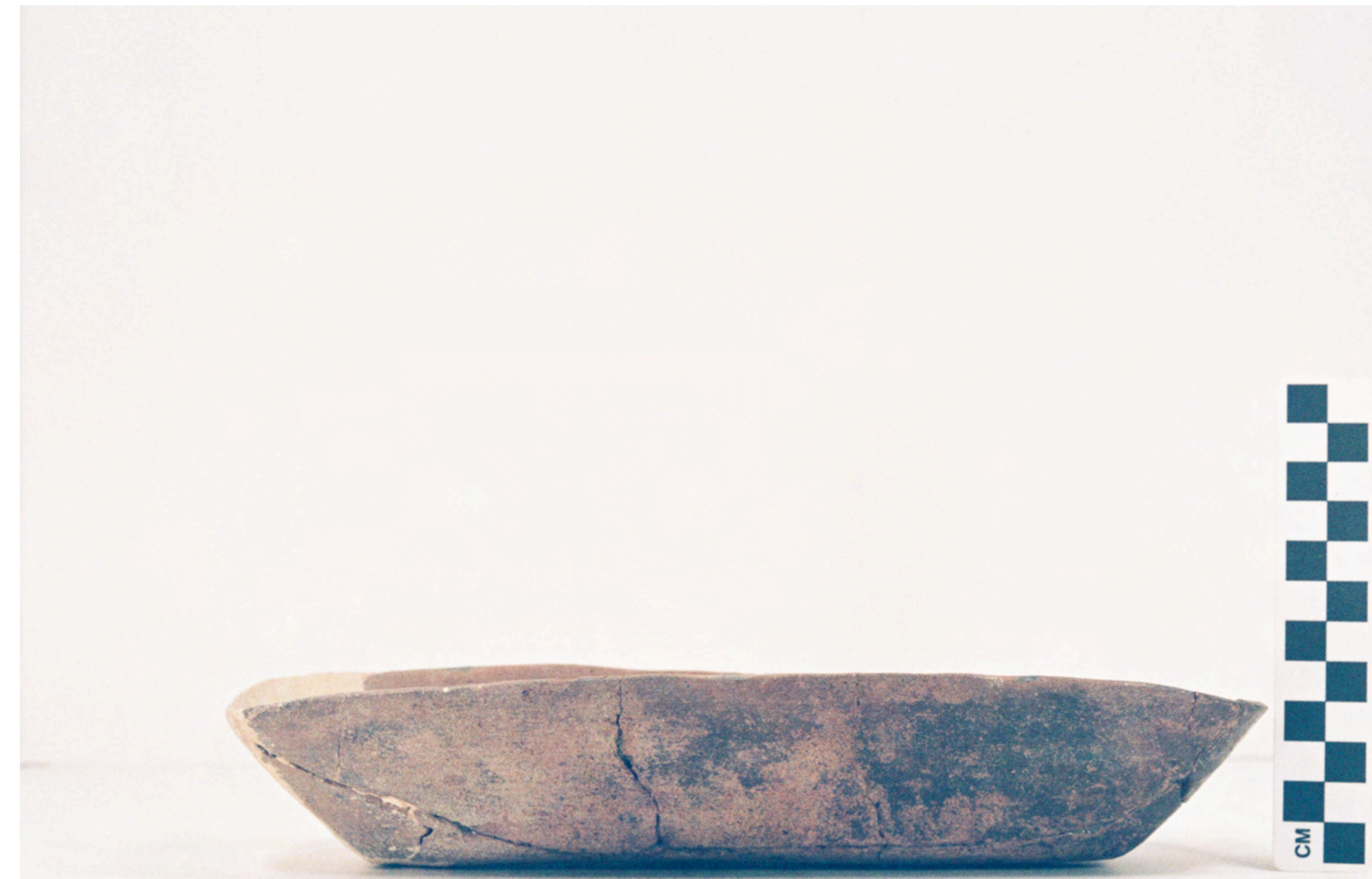

Figure A2-53a 


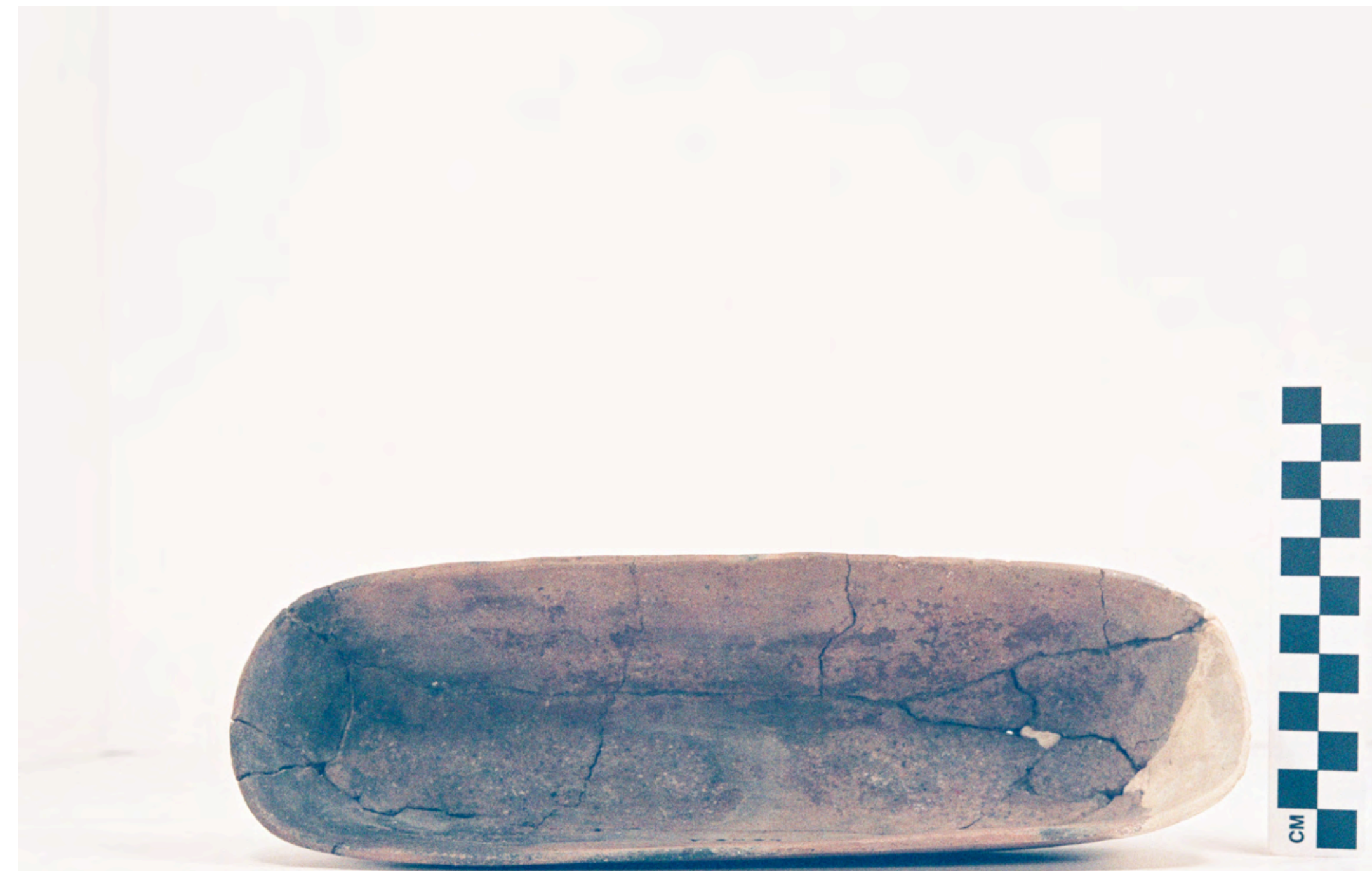

Figure A2-53b 

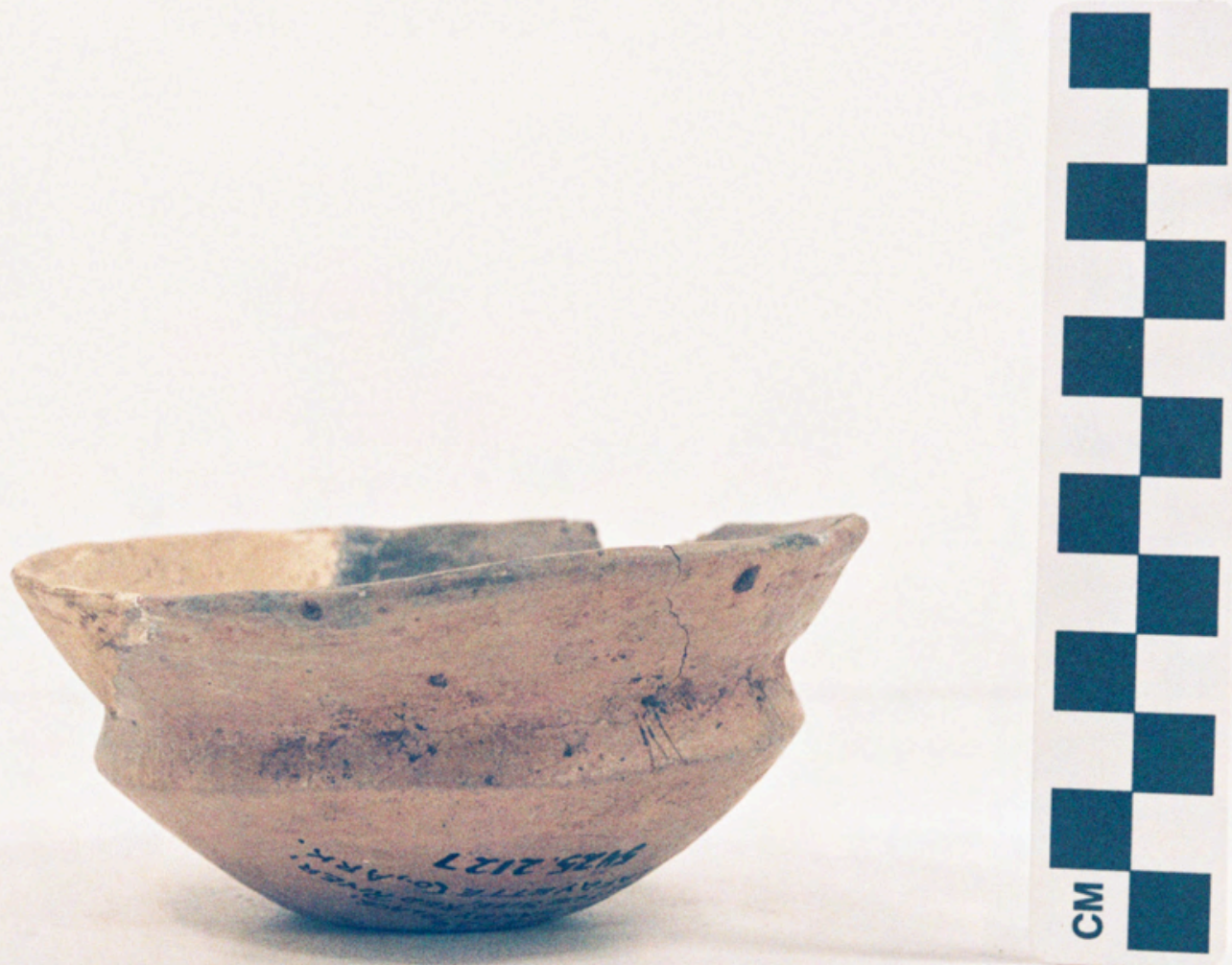

Figure A2-54 


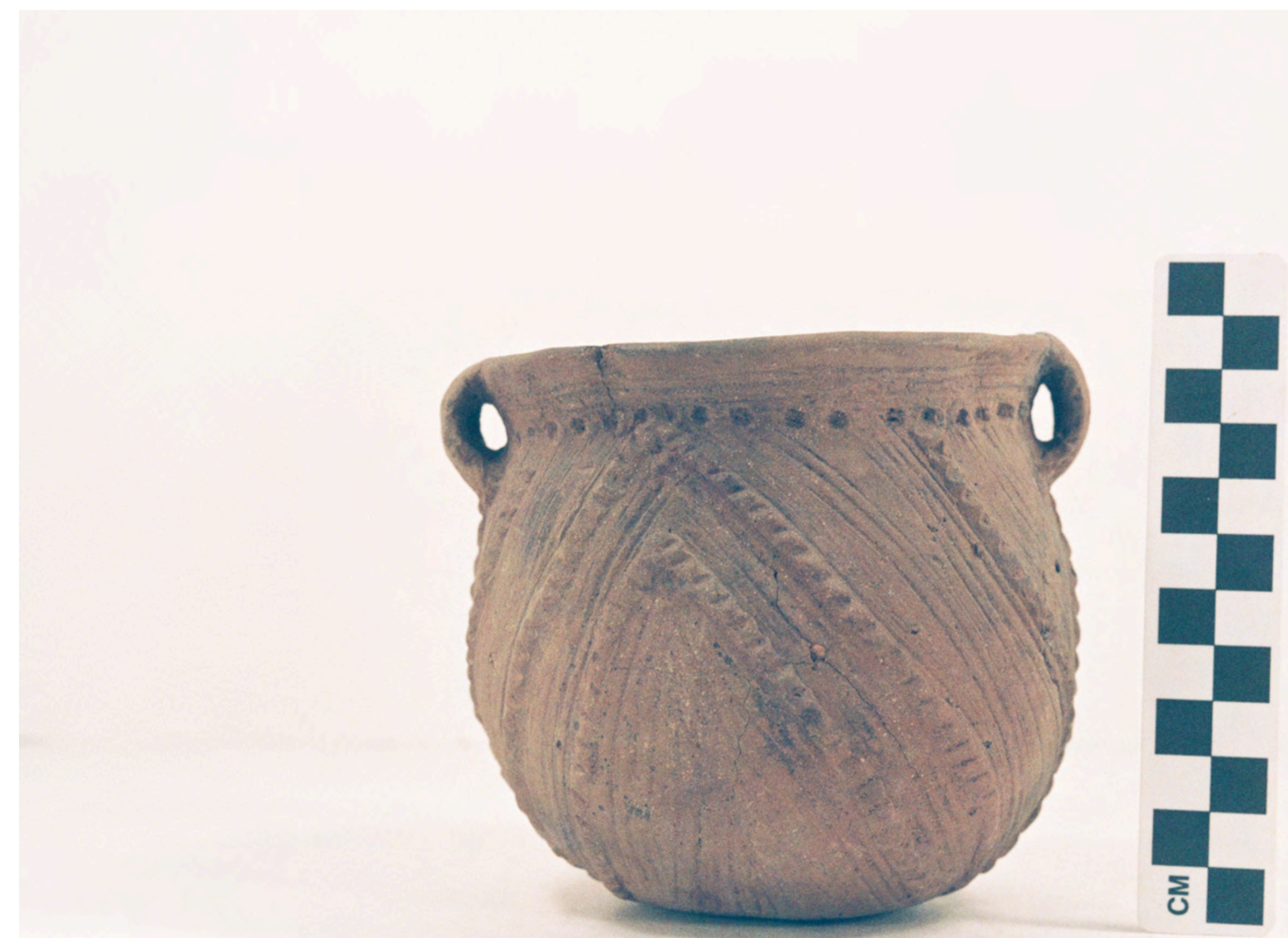

Figure A2-55 


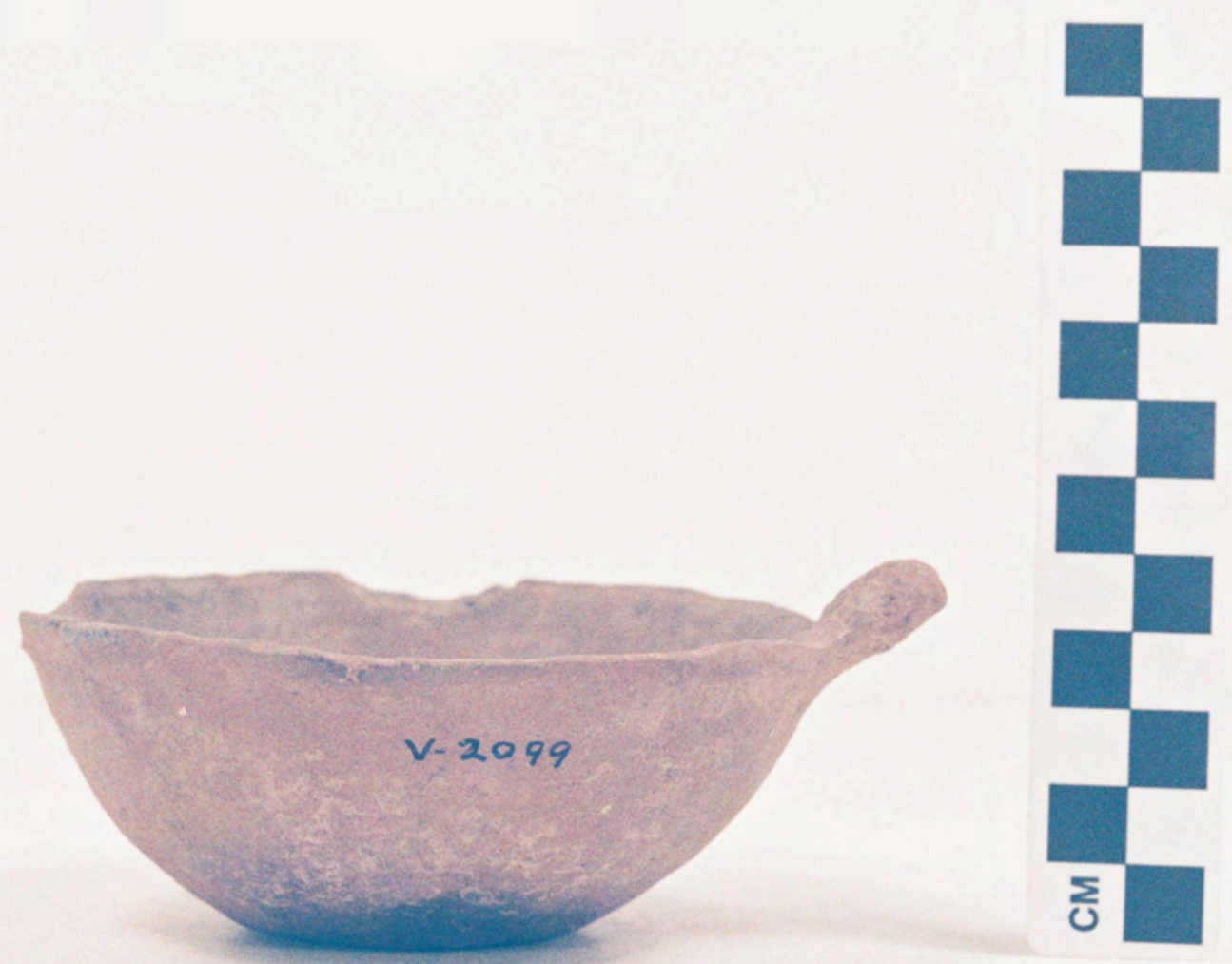

Figure A2-56 


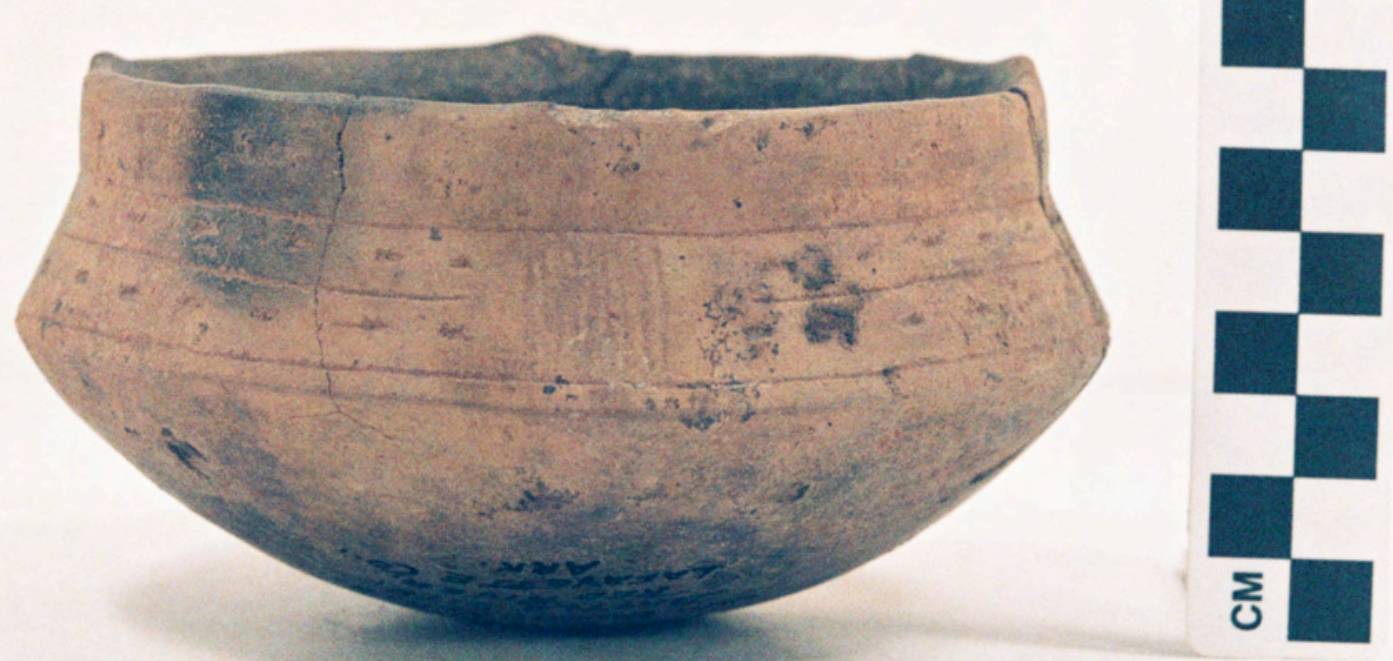

Figure A2-57 


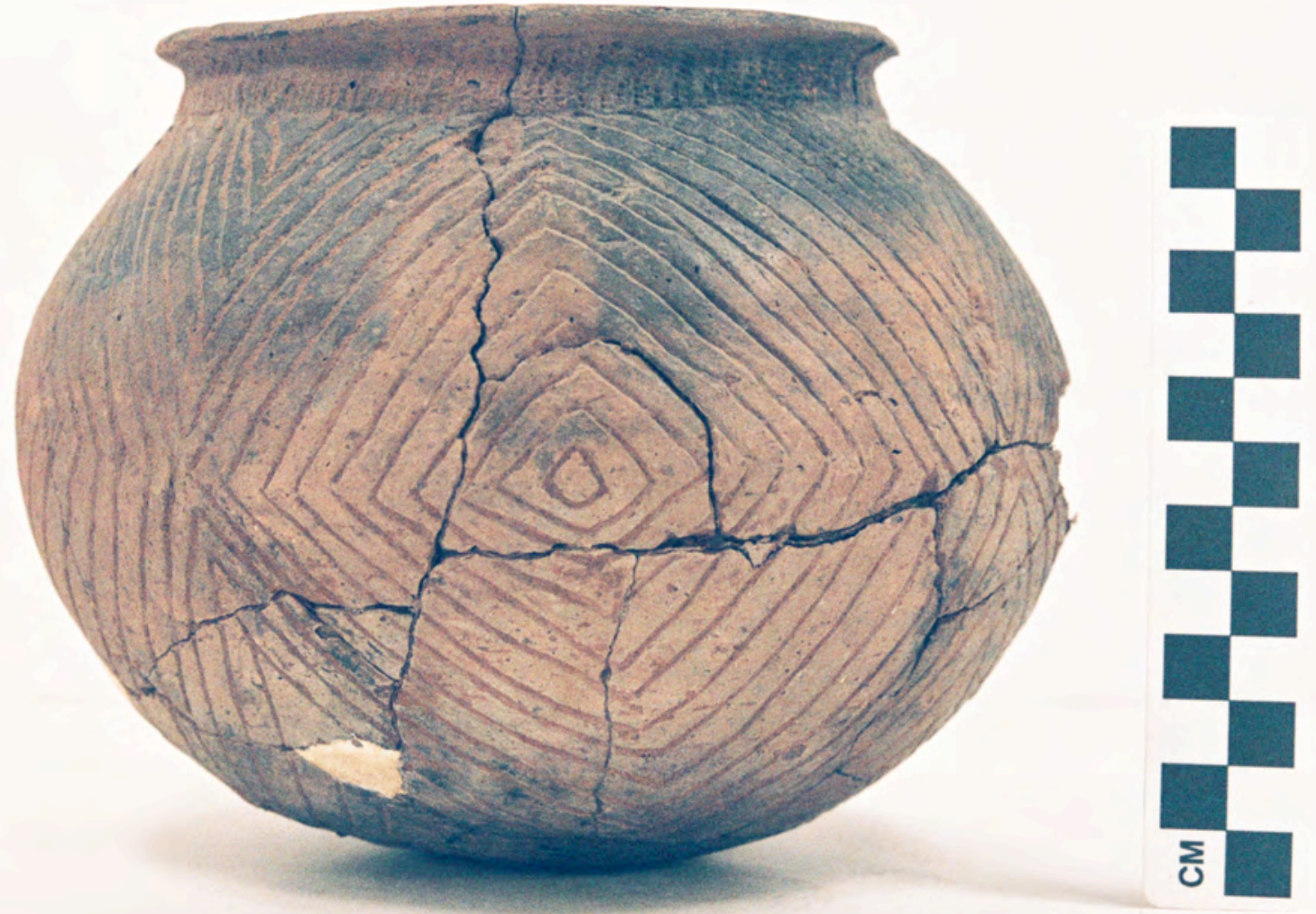

Figure A2-58 


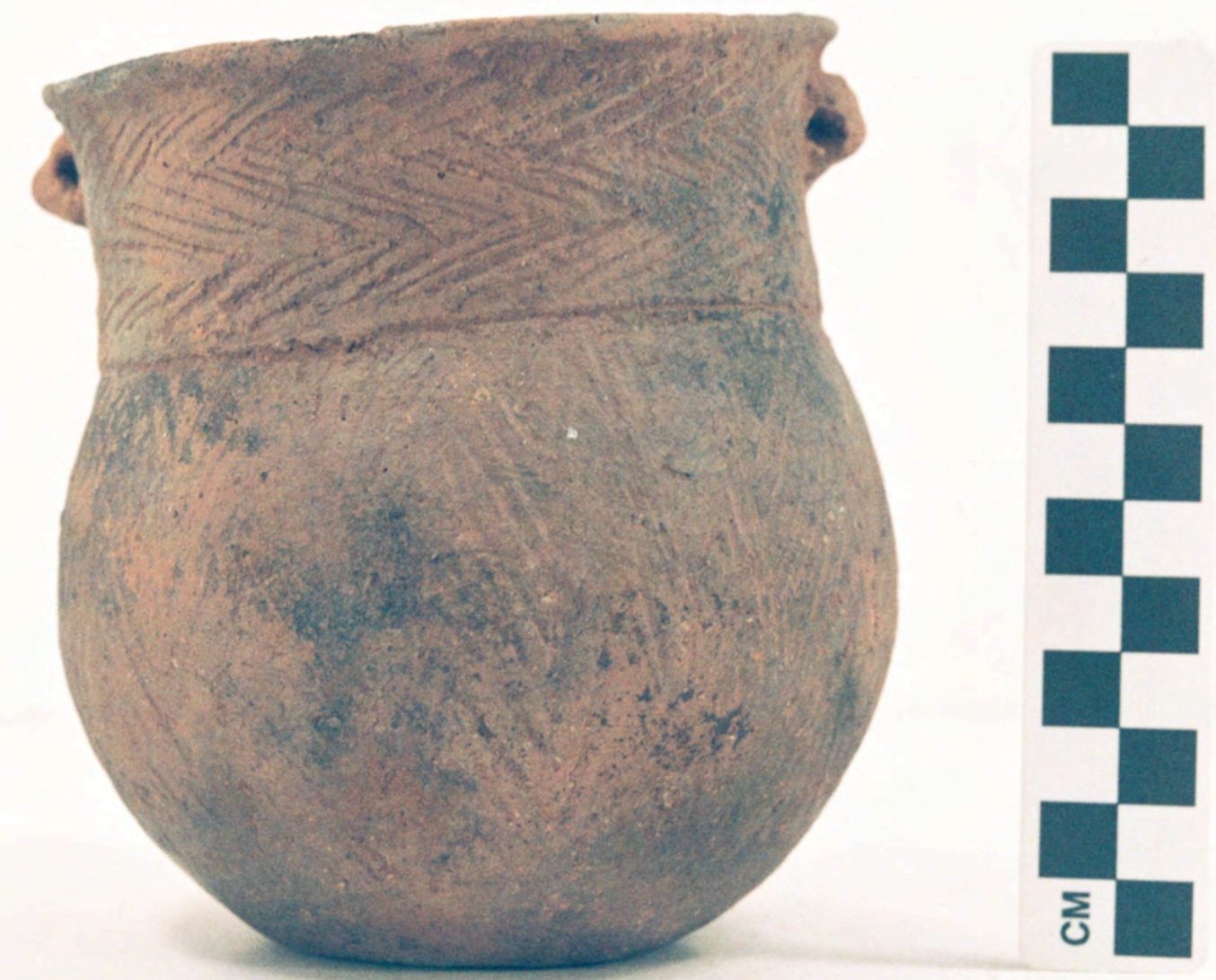

Figure A2-59 


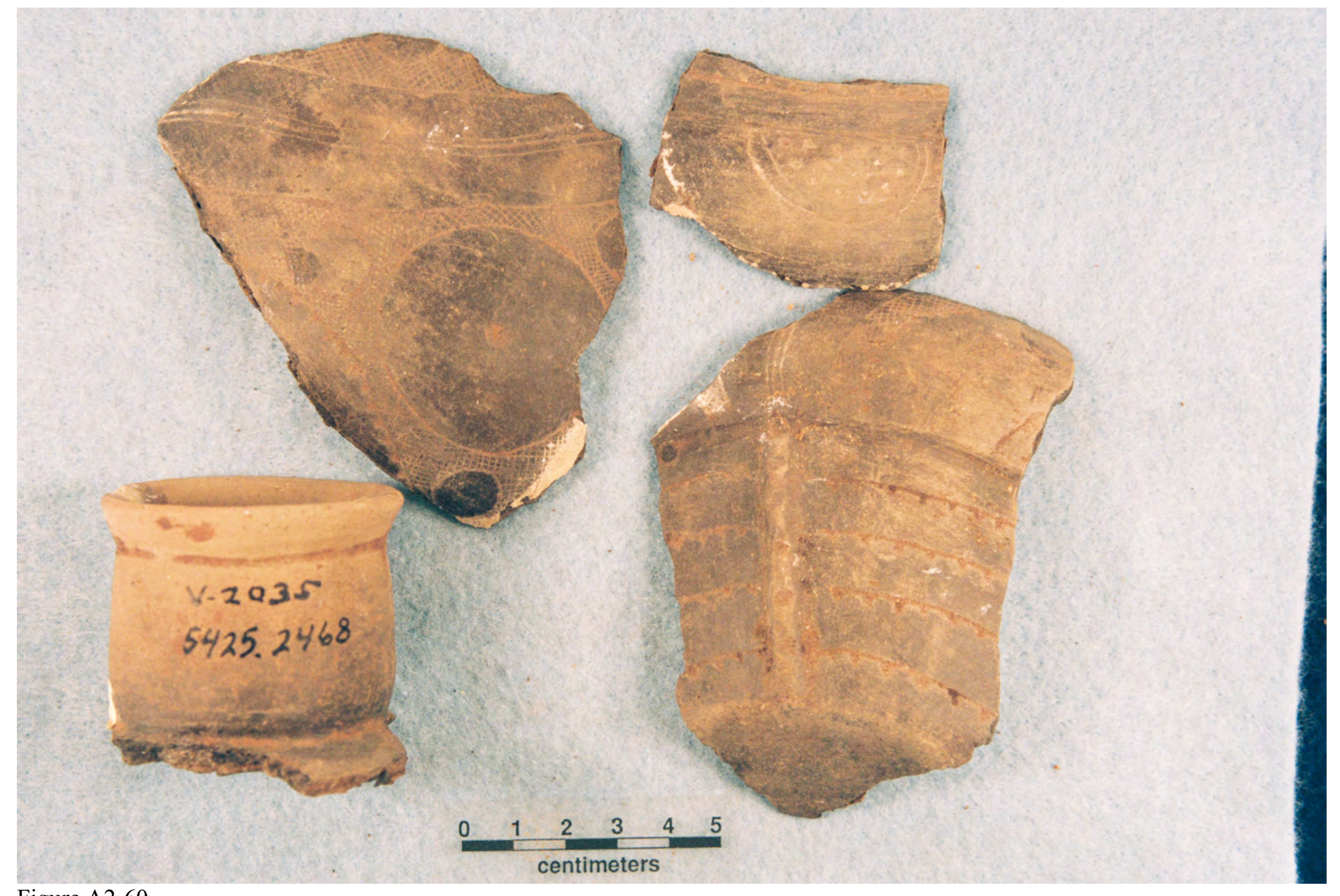

Figure A2-60 


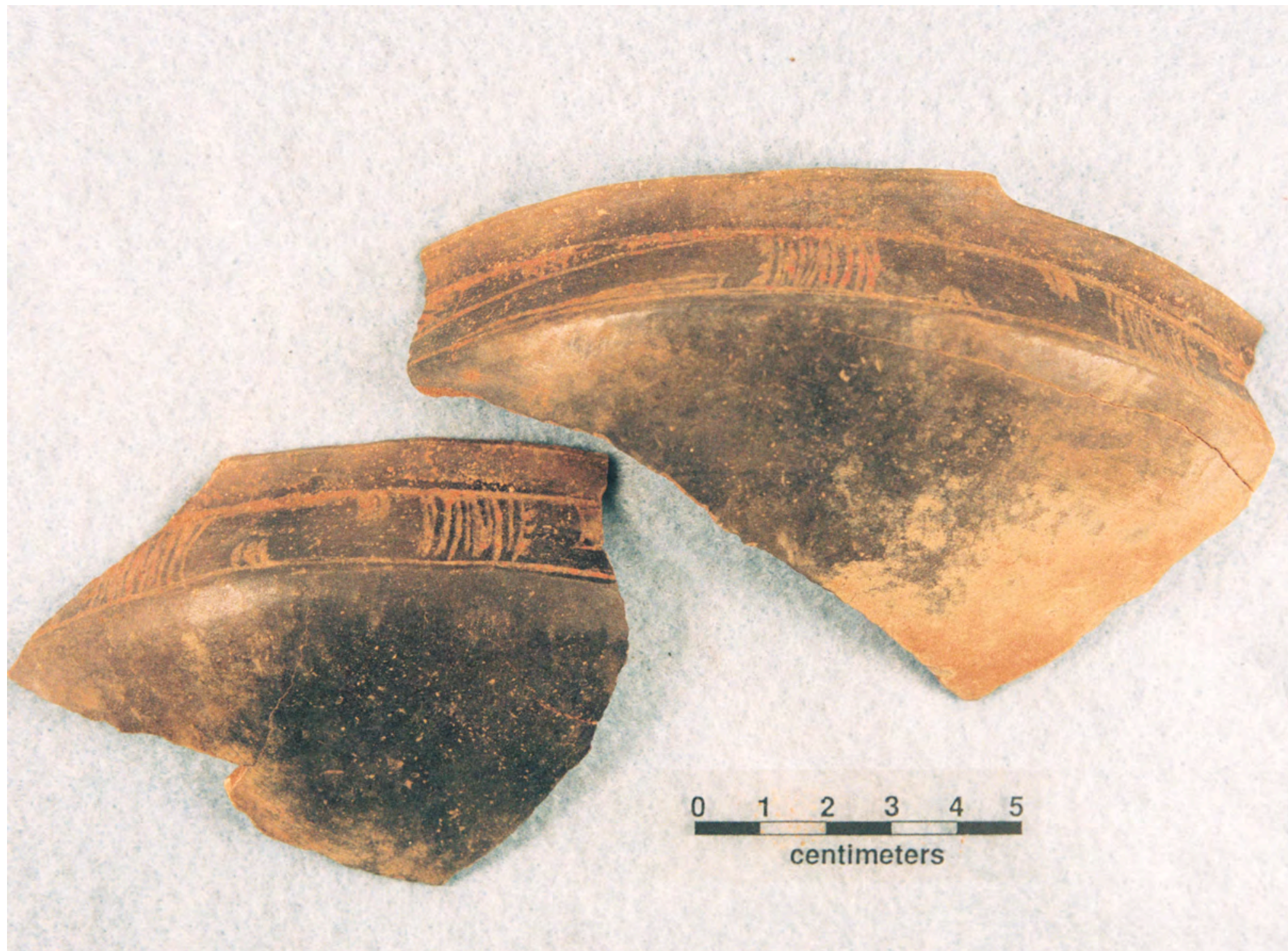

Figure A2-61 


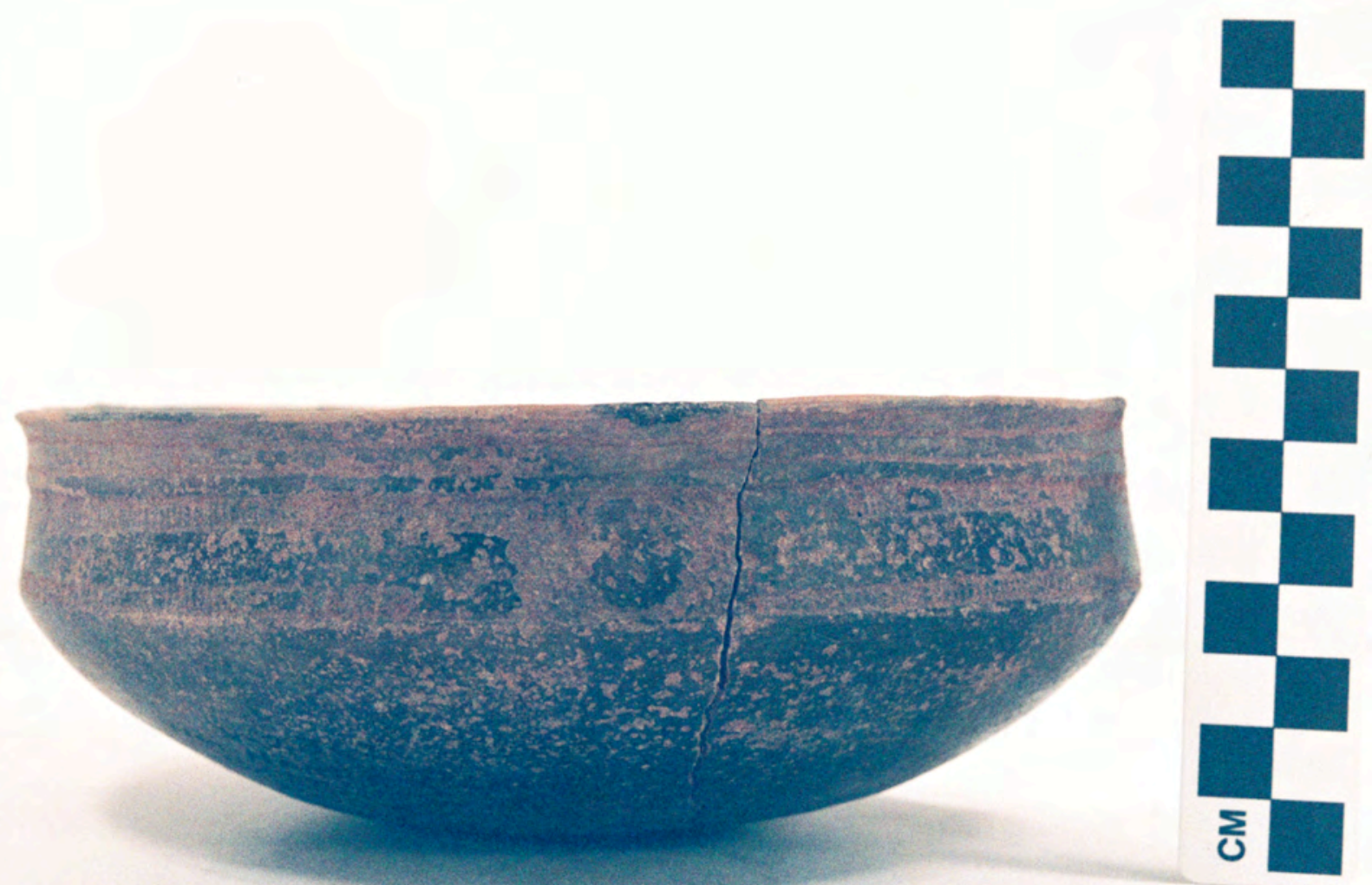

Figure A2-62 


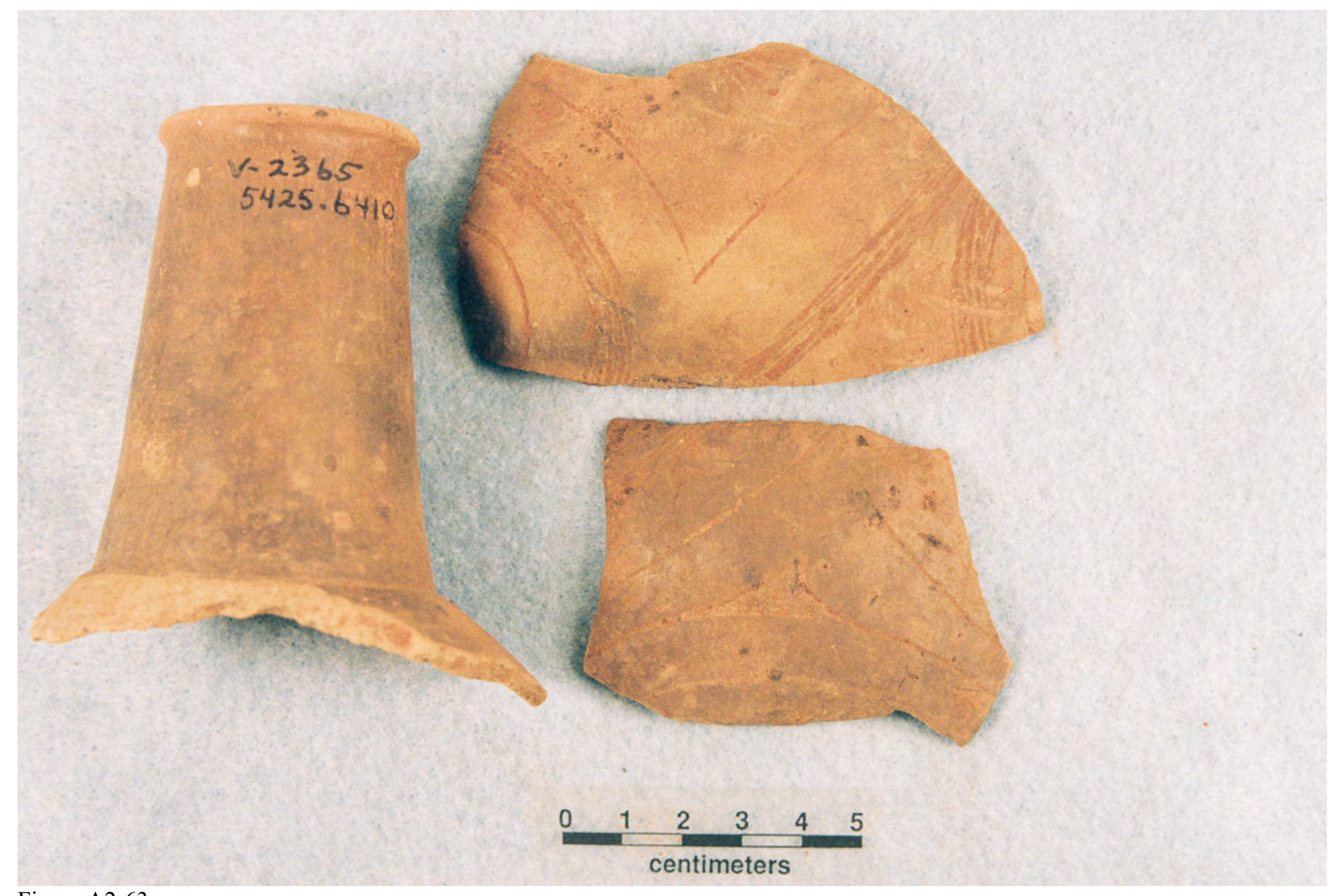

Figure A2-63 


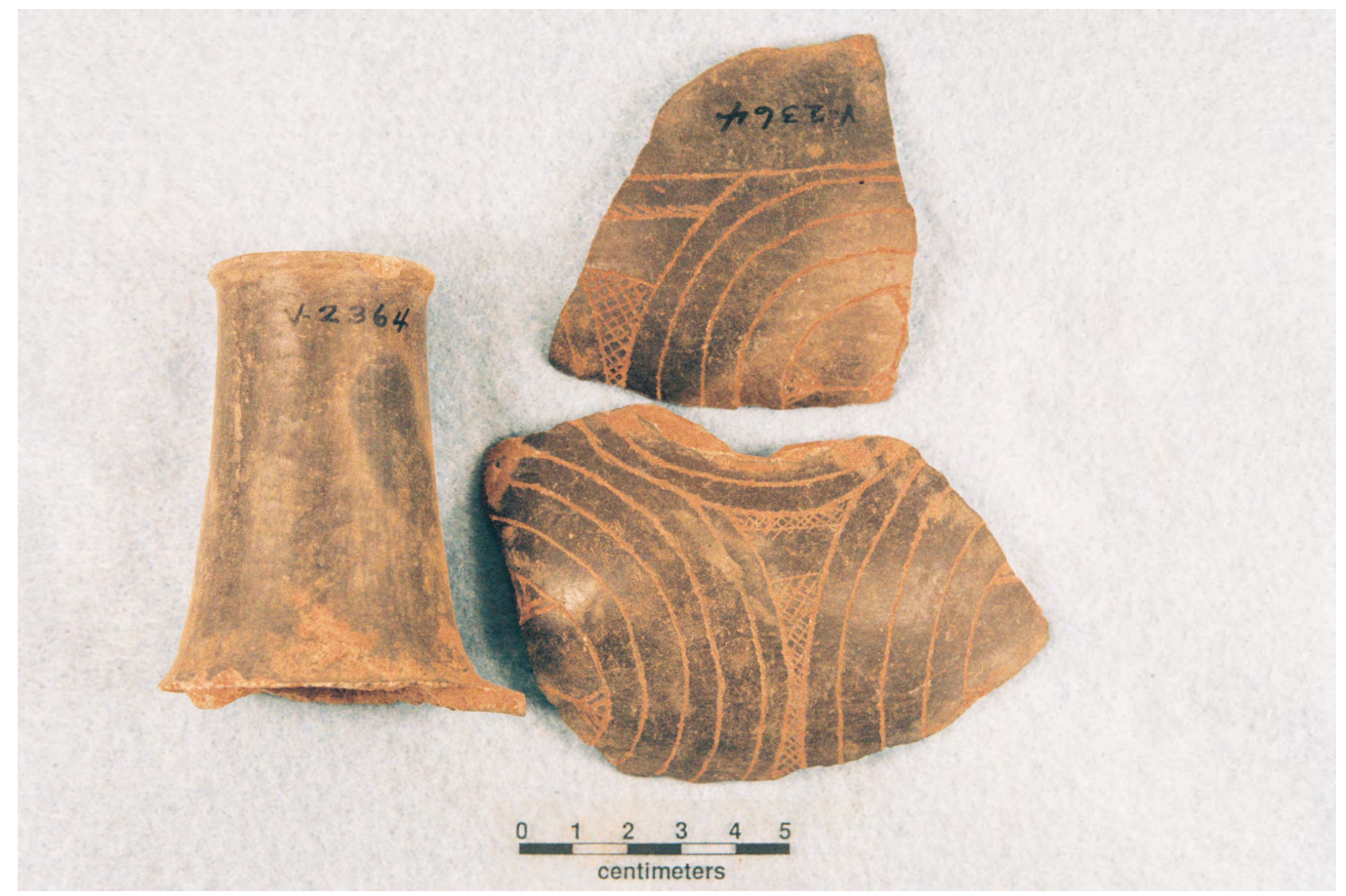

Figure A2-64 


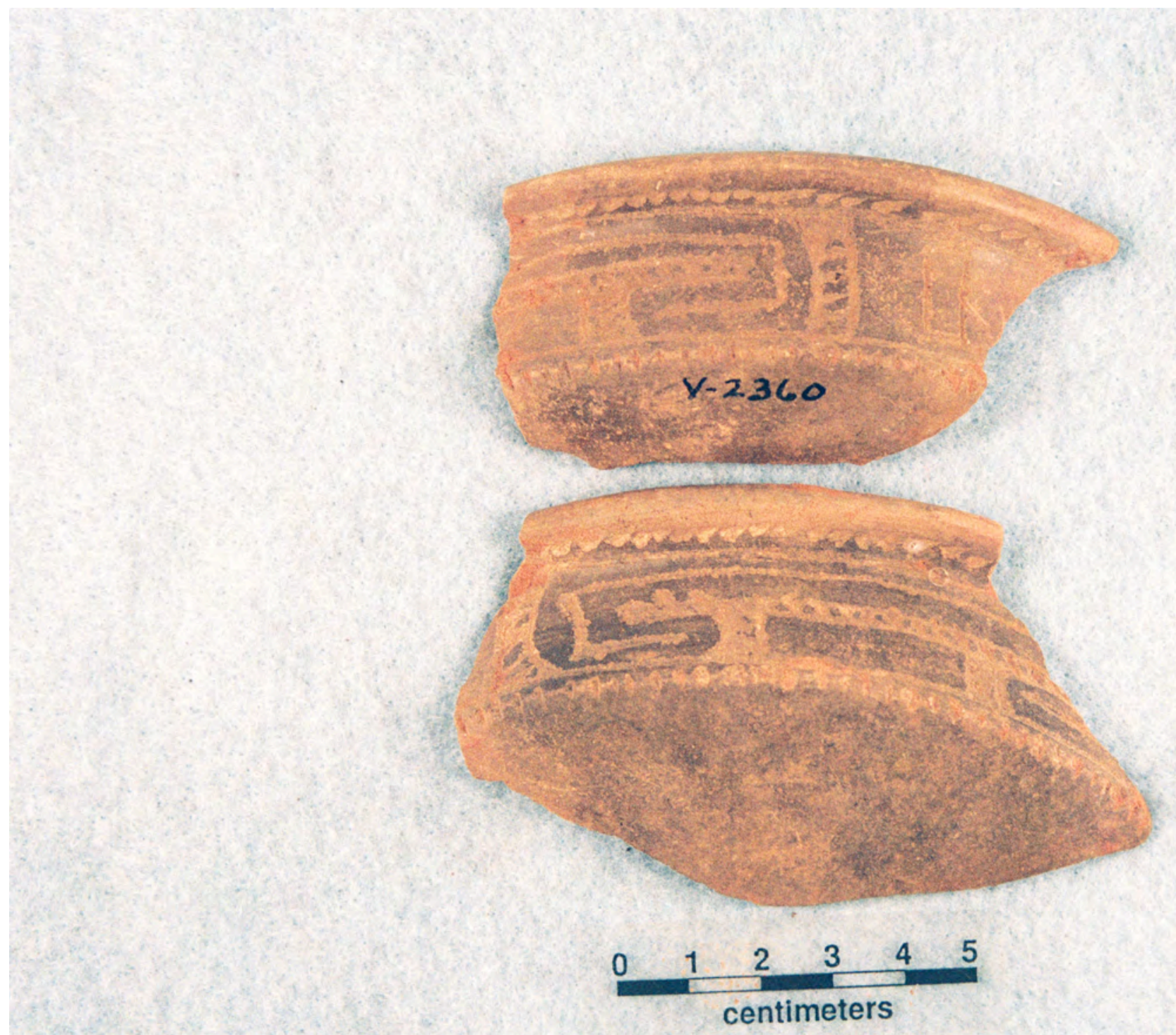

Figure A2-65 


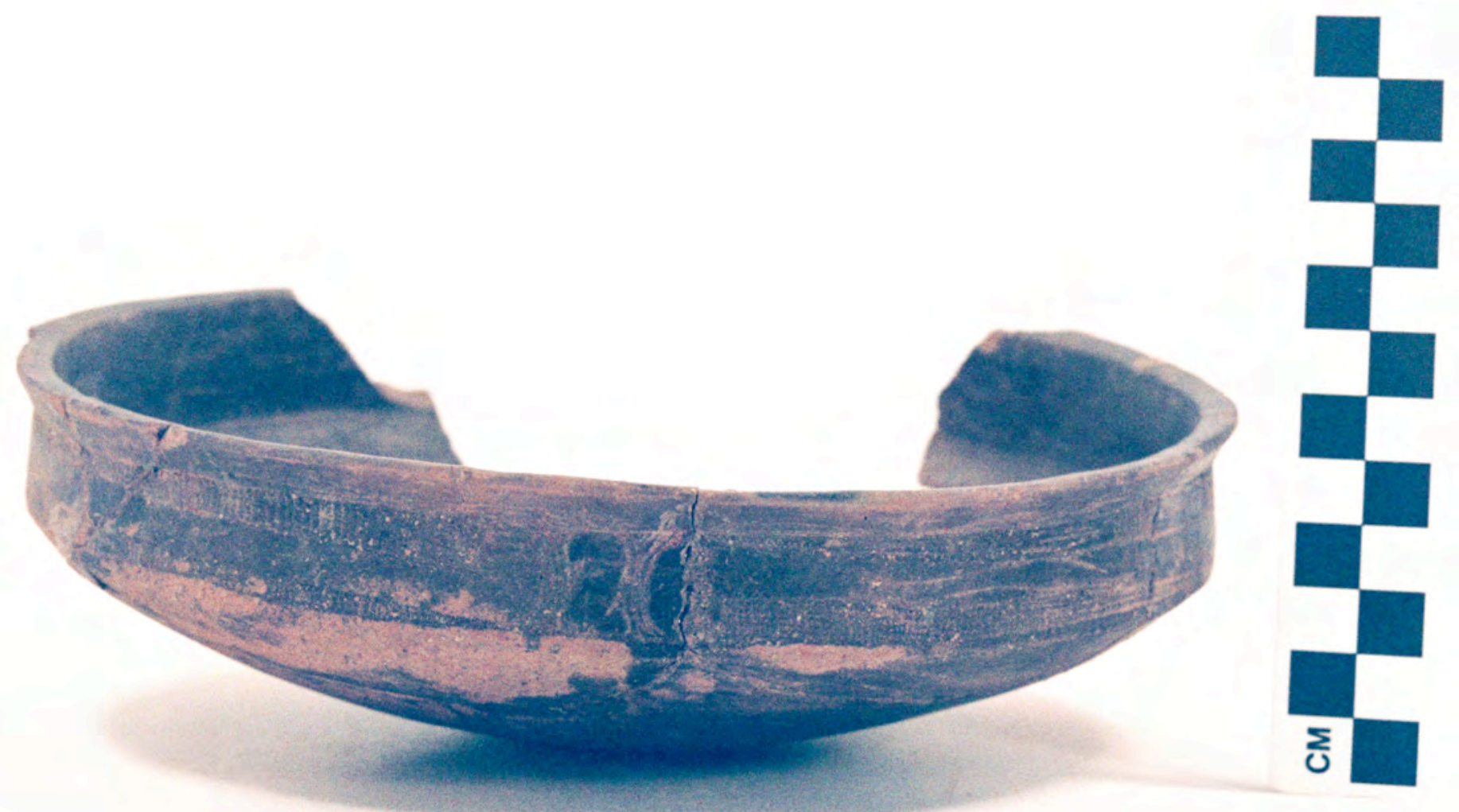

Figure A2-66 


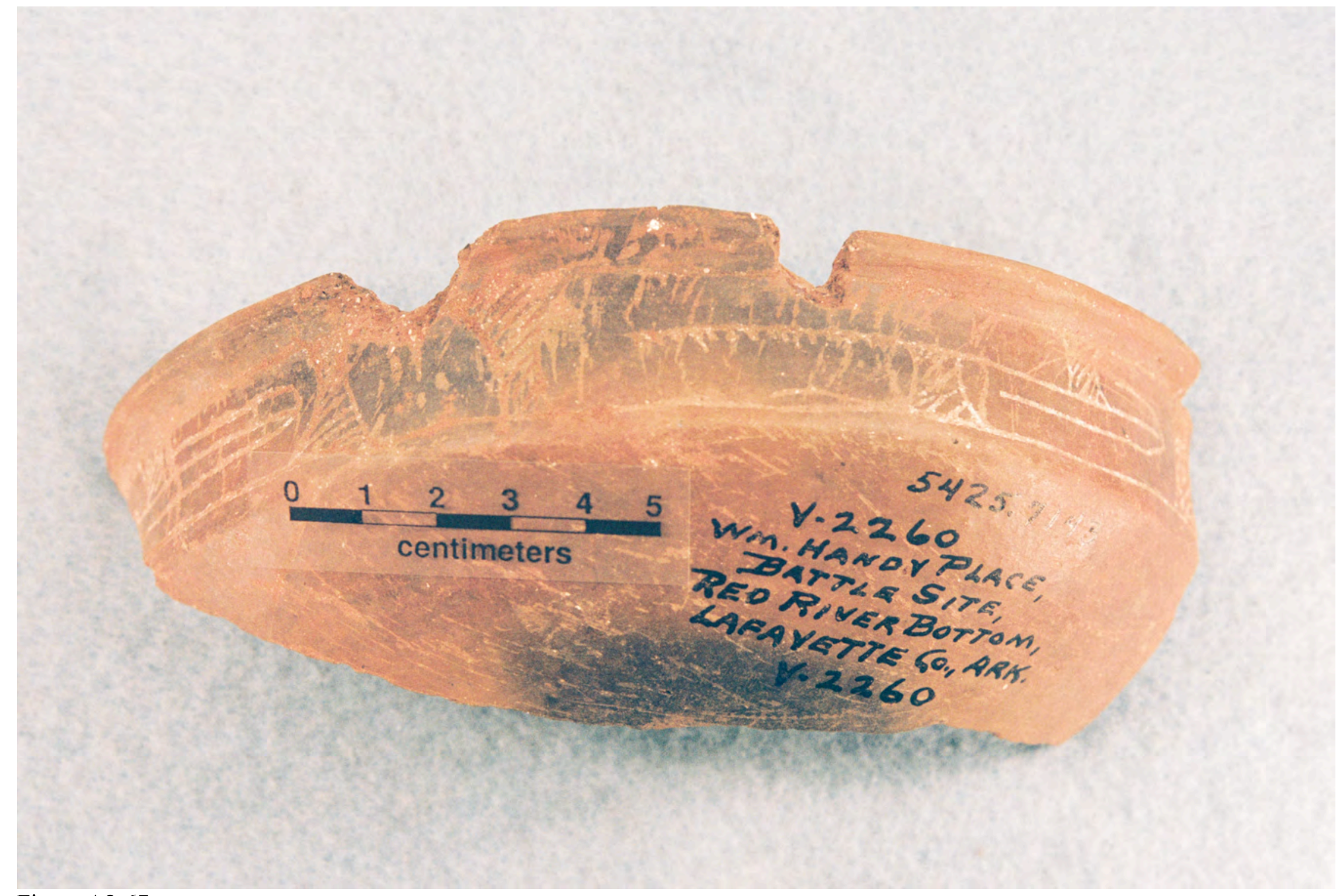



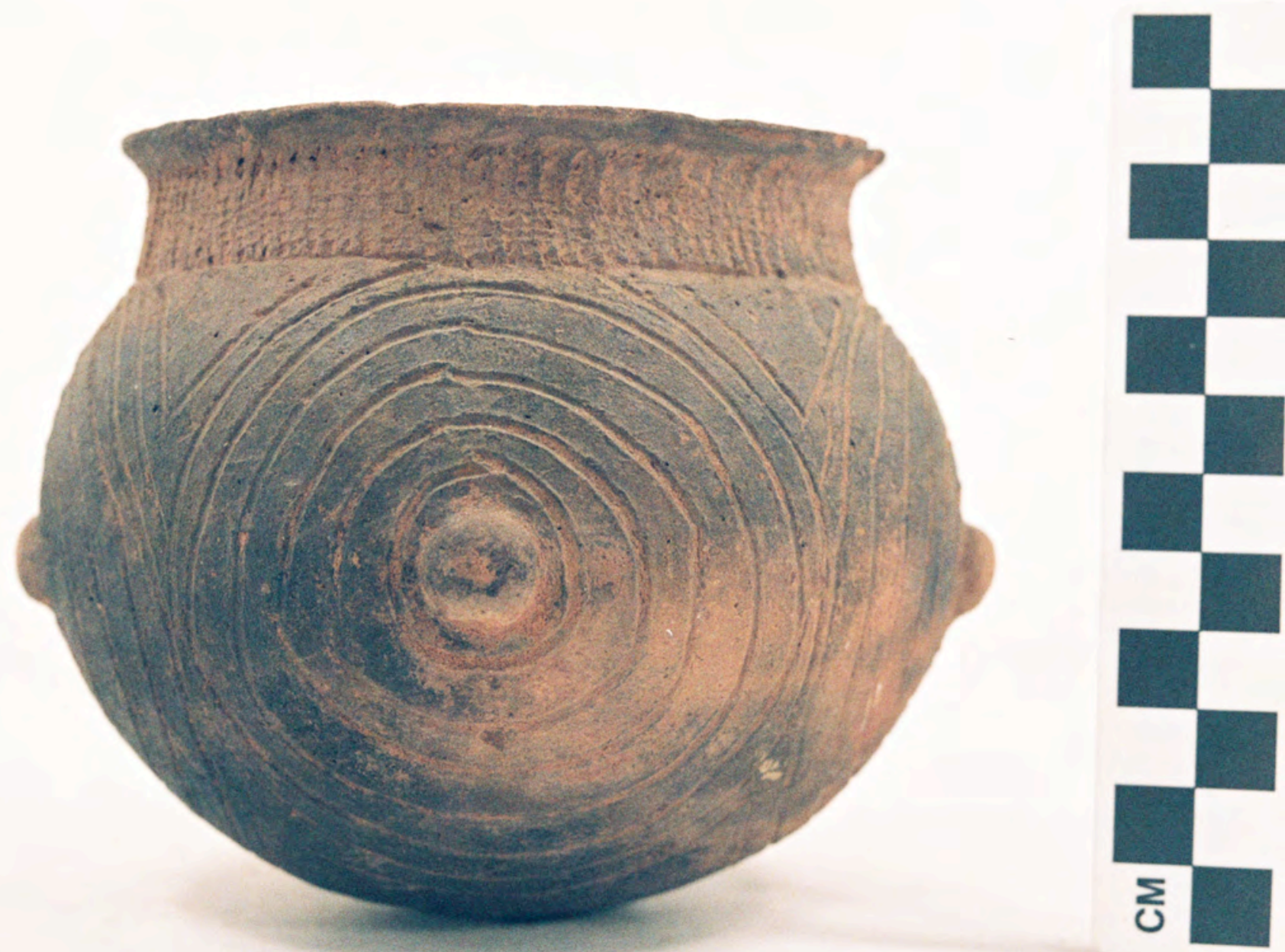

Figure A2-68 


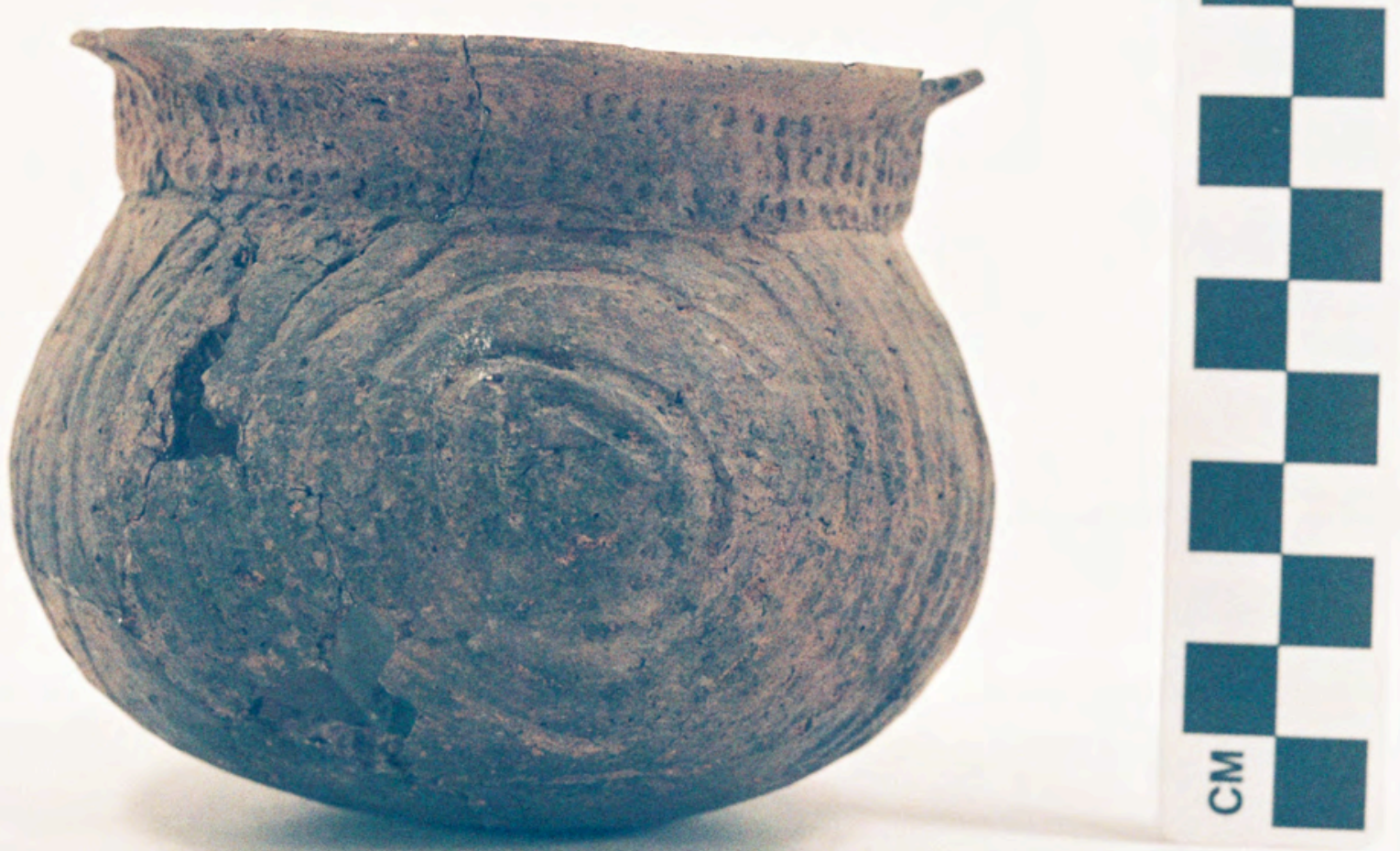

Figure A2-69 


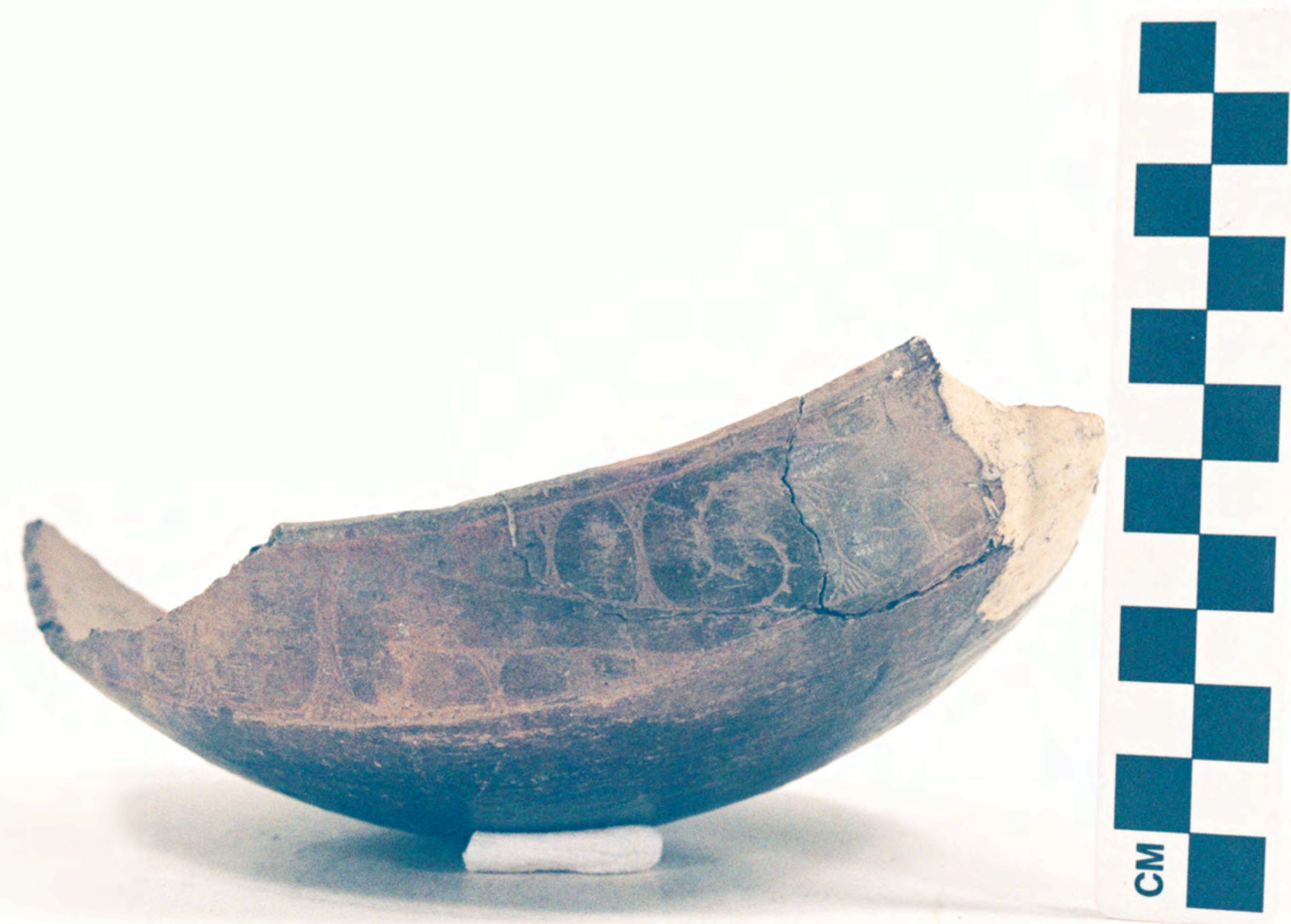

Figure A2-70 


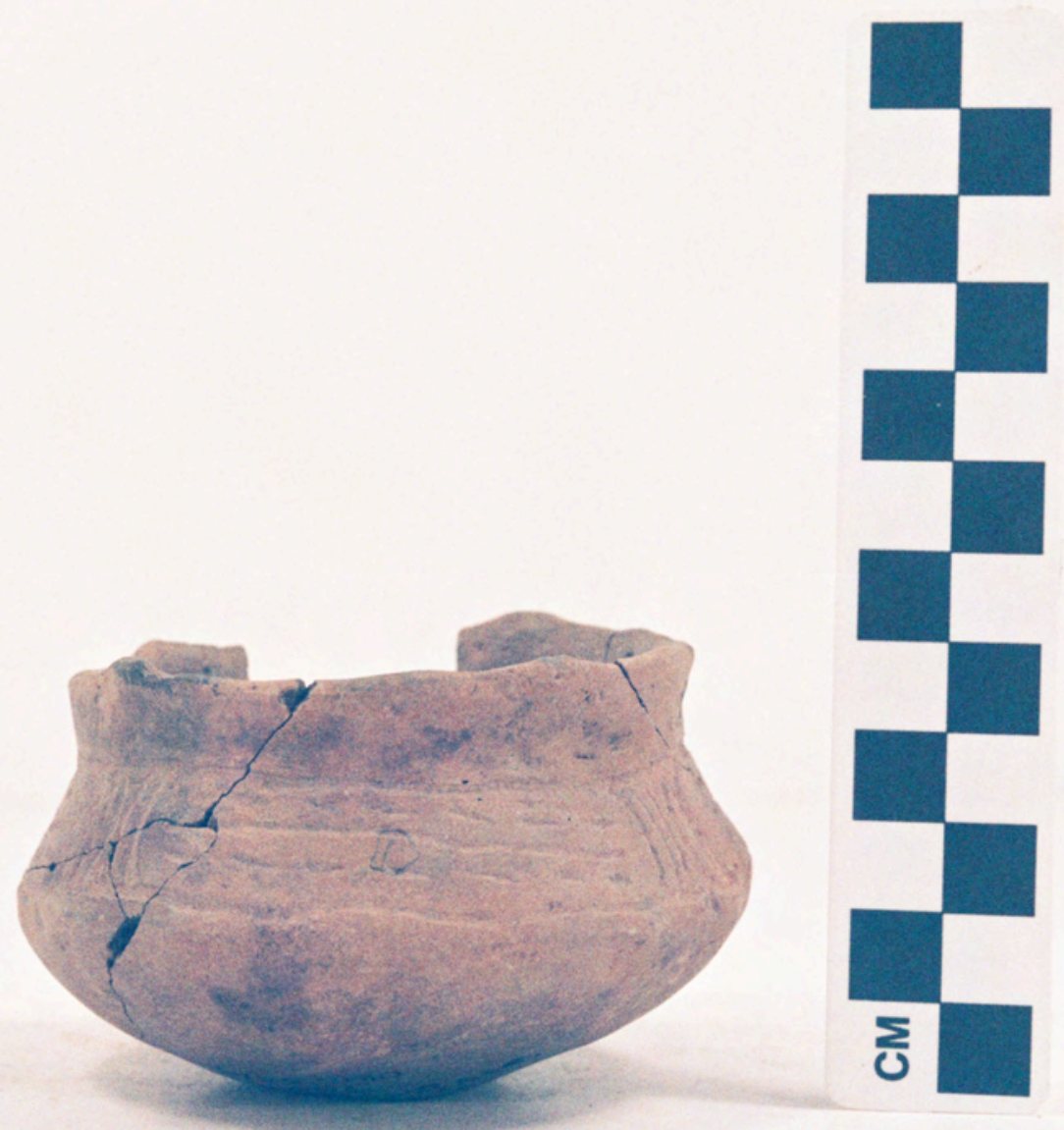

Figure A2-71 


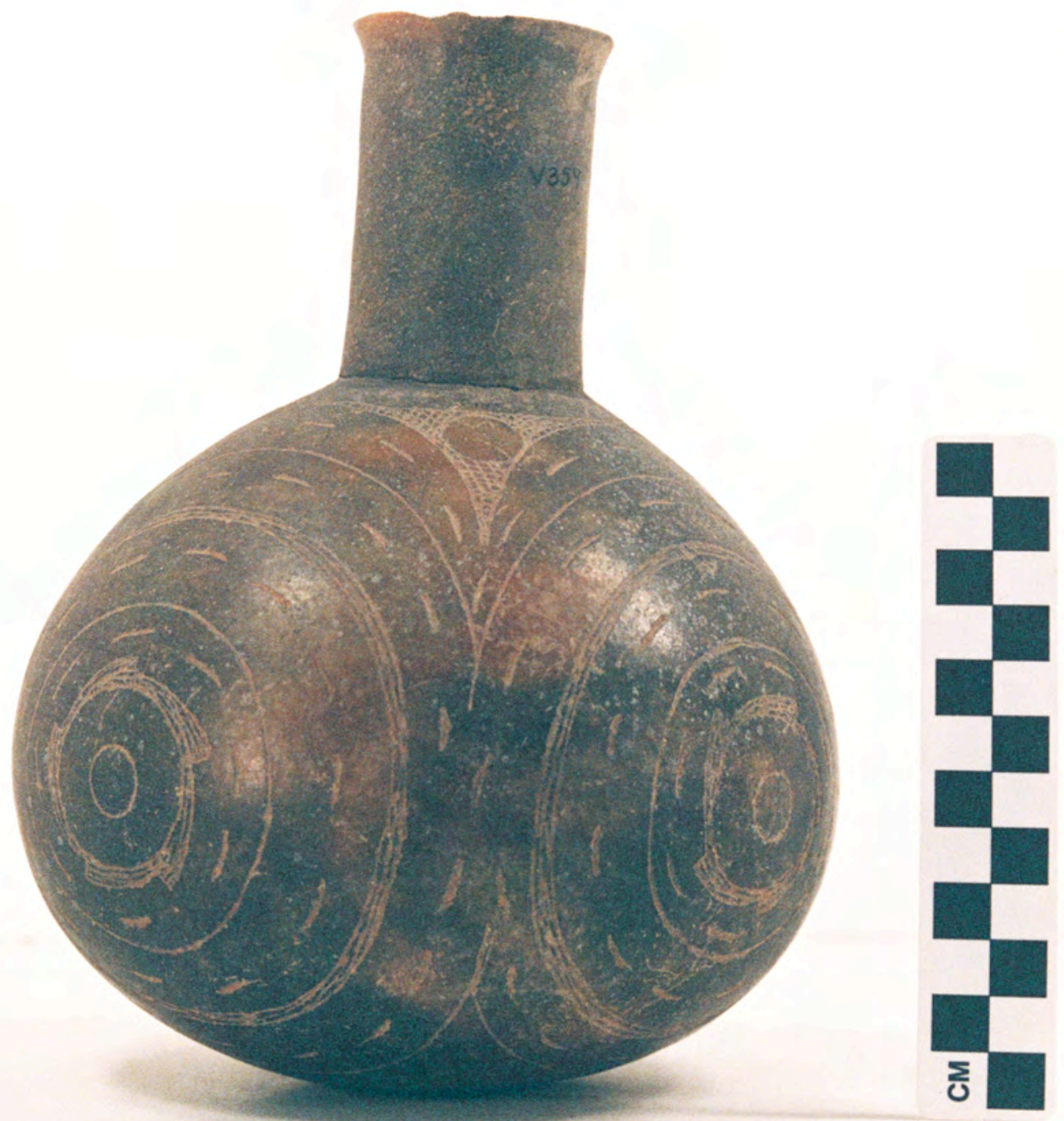

Figure A3-1 


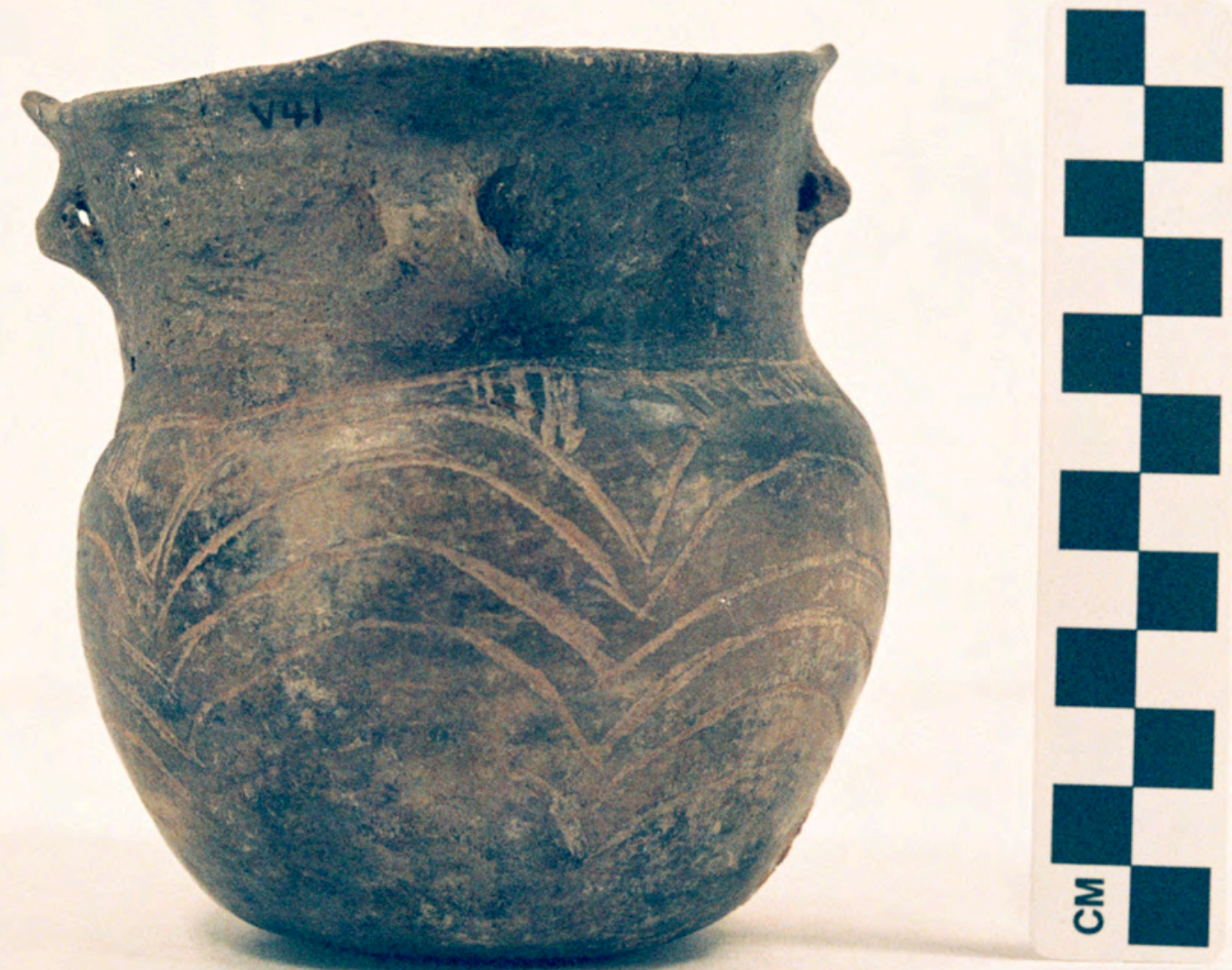

Figure A3-2 


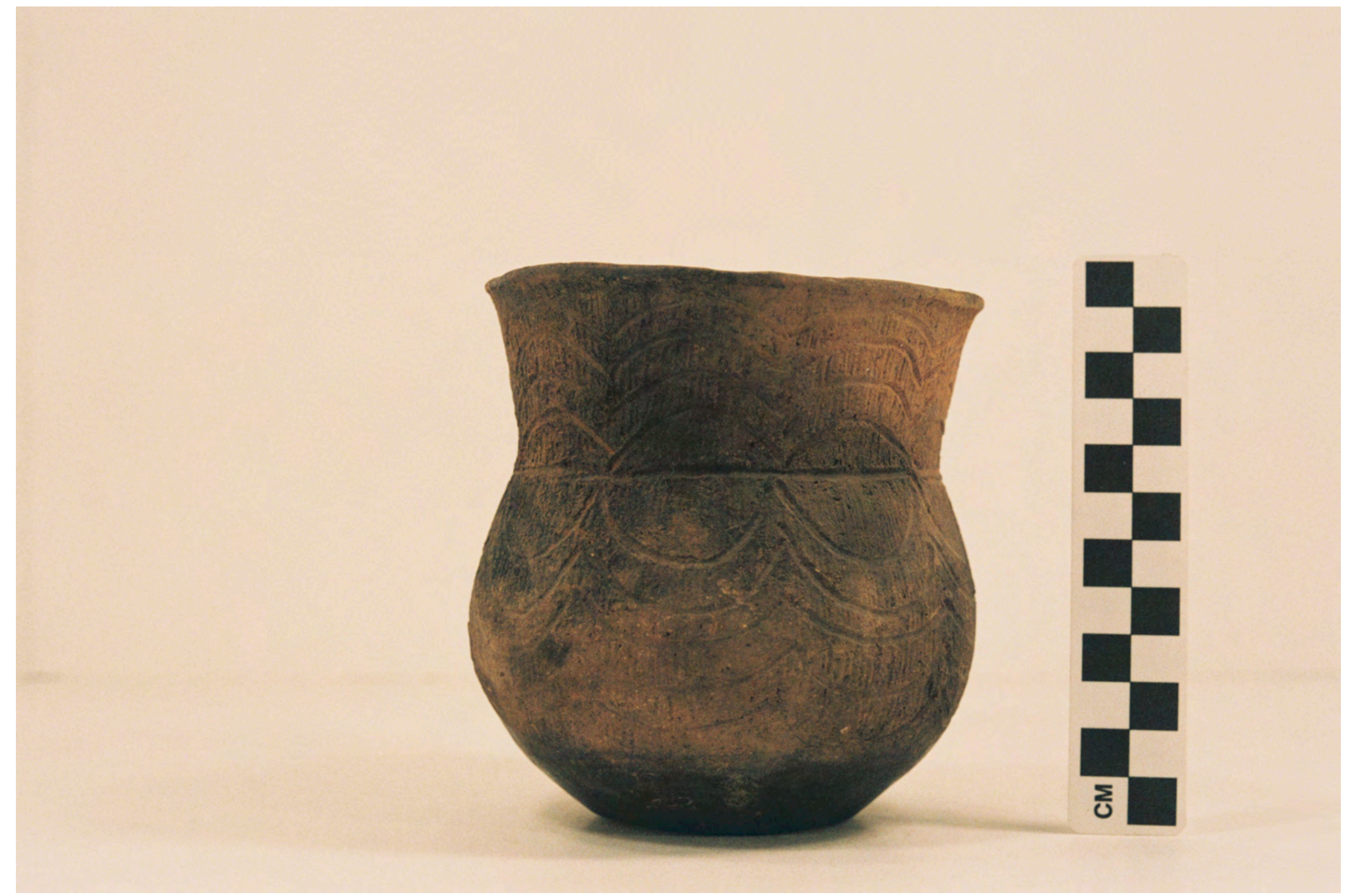

Figure A3-3 


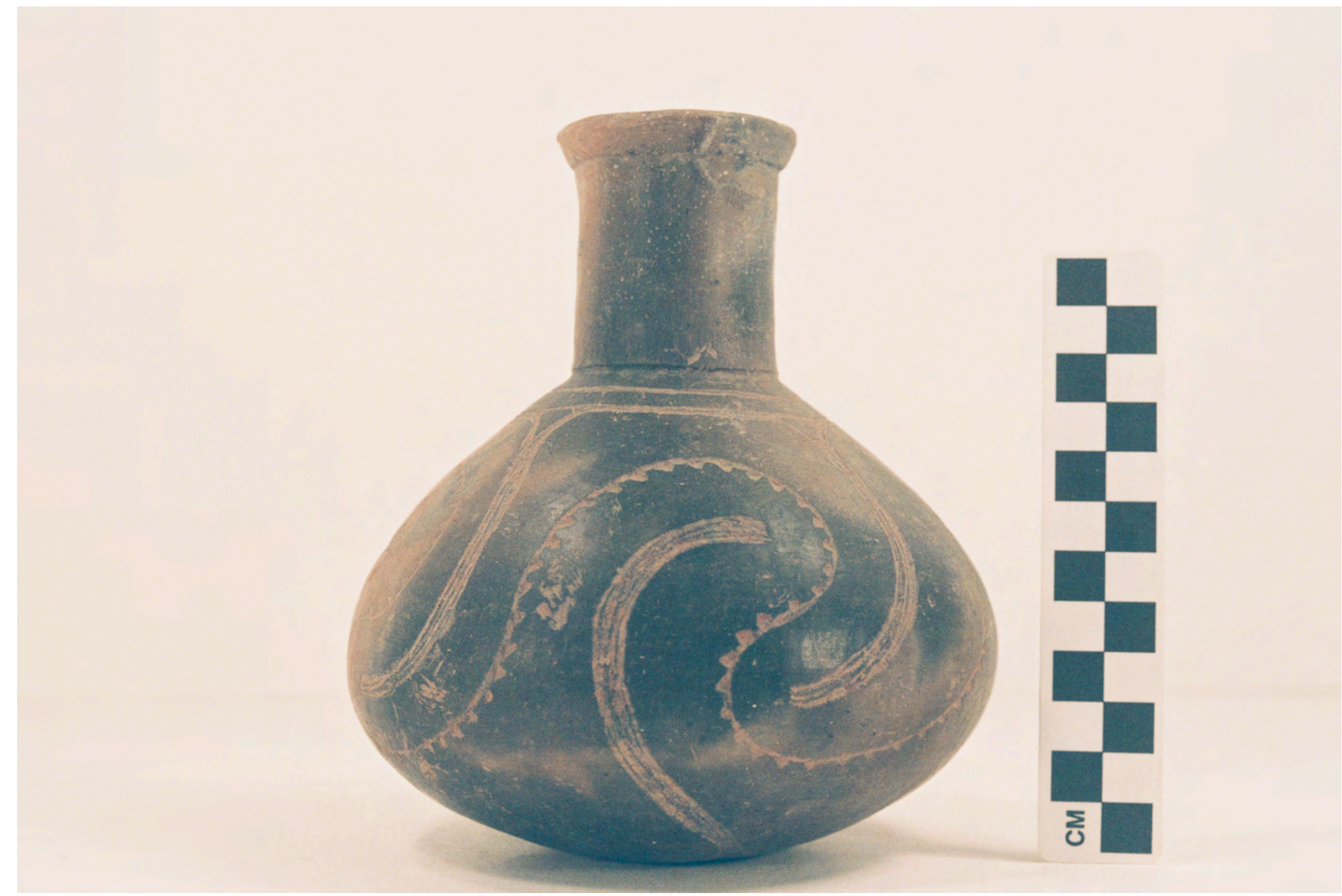

Figure A3-4 


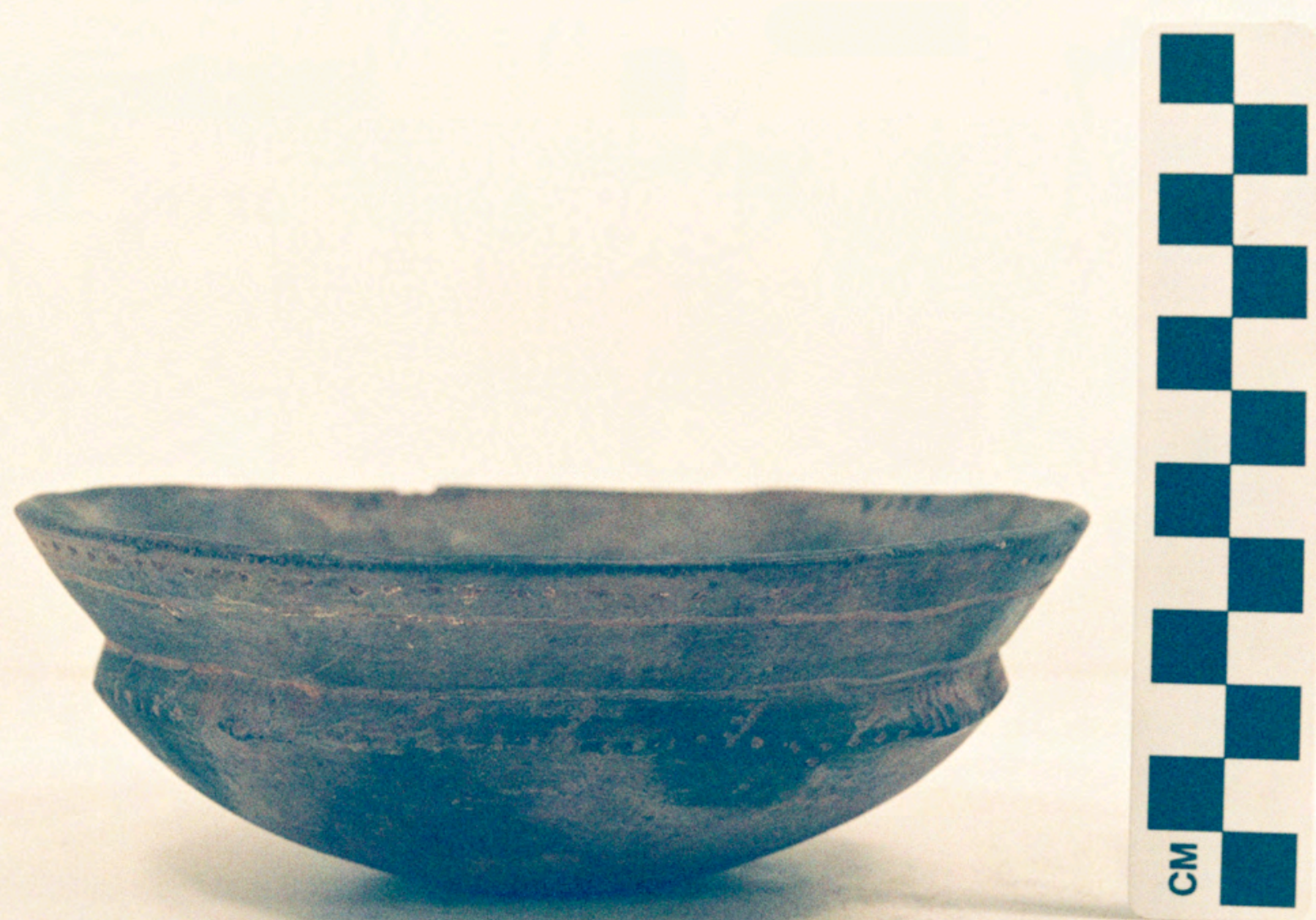

Figure A3-5 


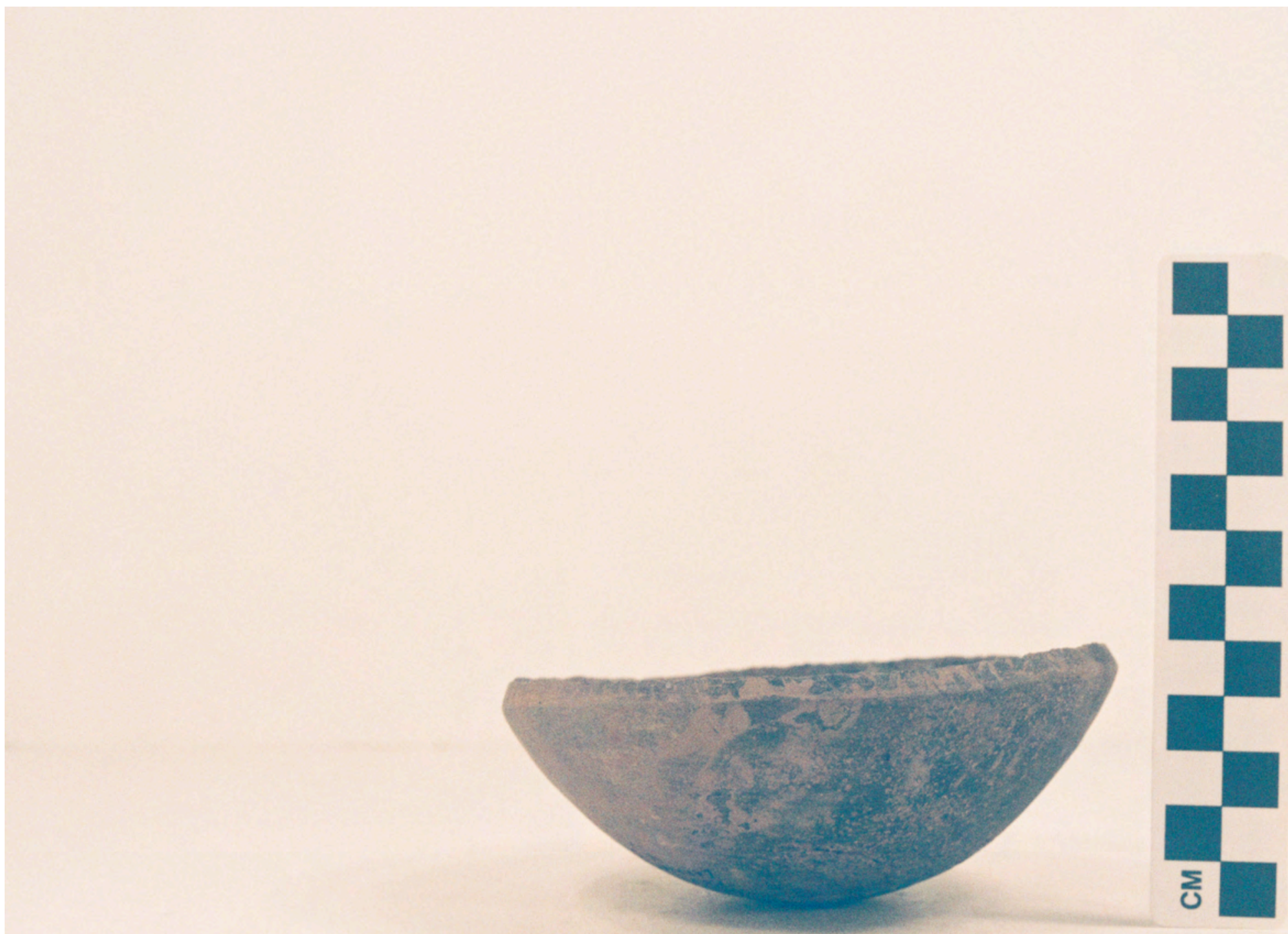

Figure A3-6 


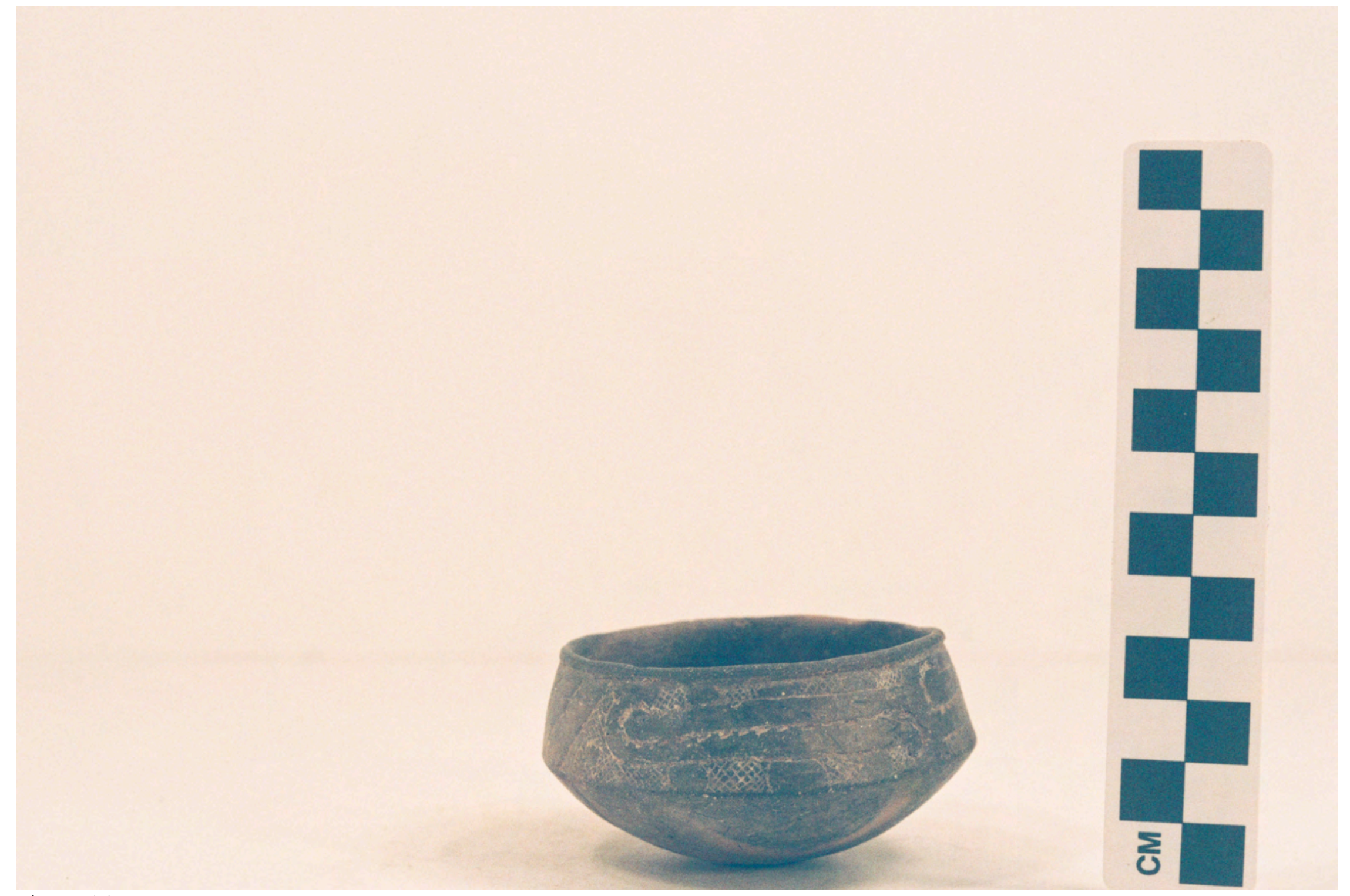

Figure A3-7 


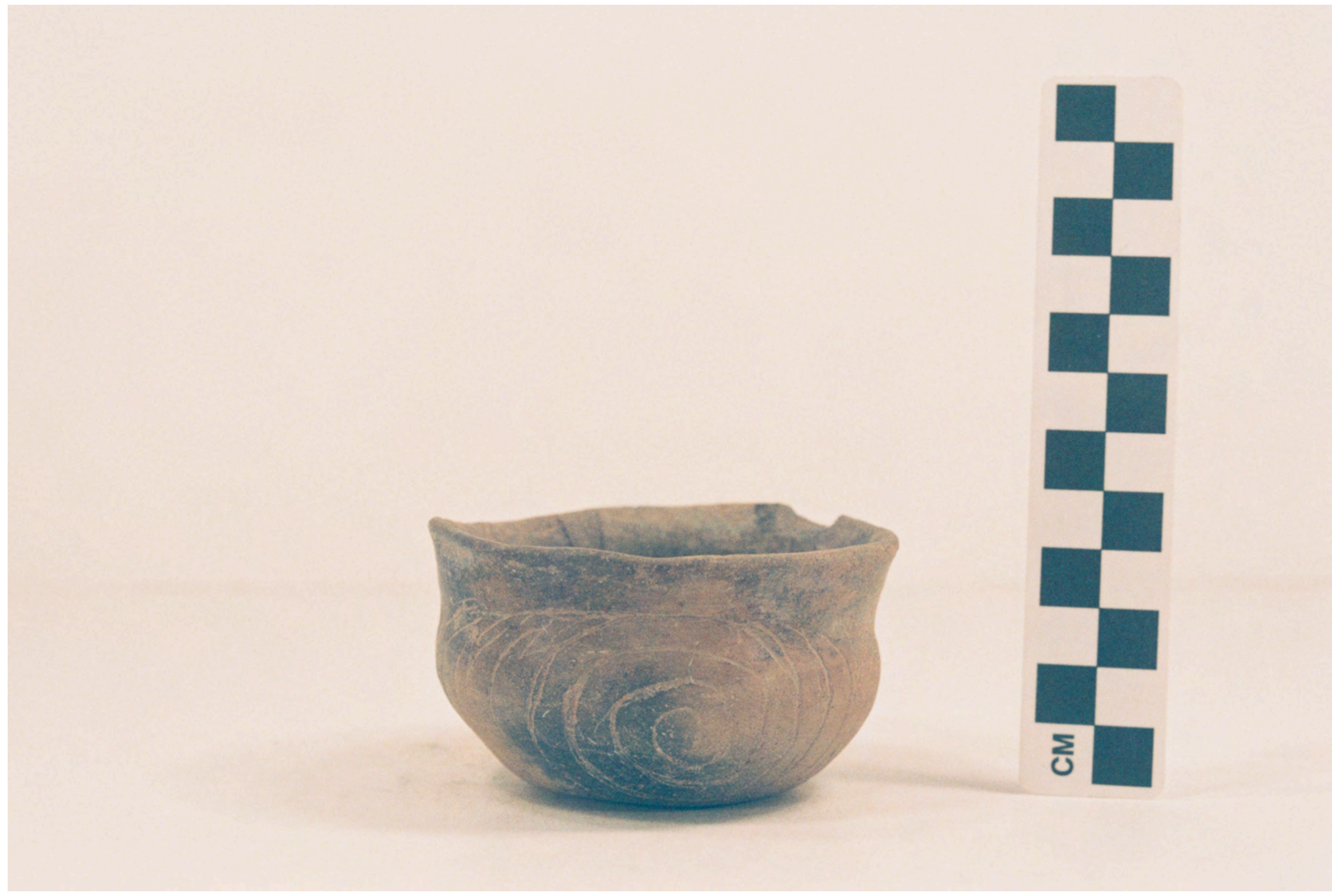

Figure A3-8 


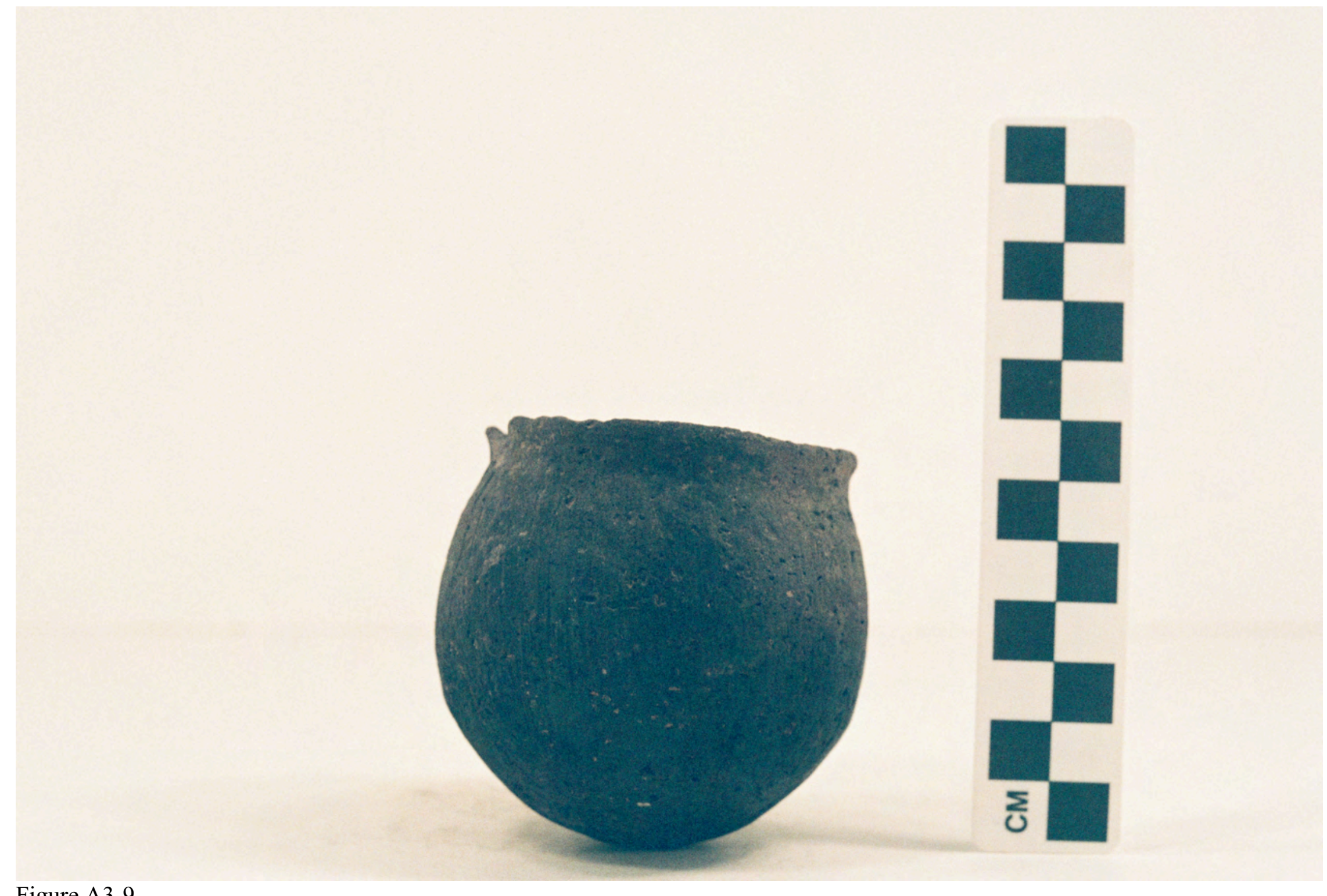

Figure A3-9 


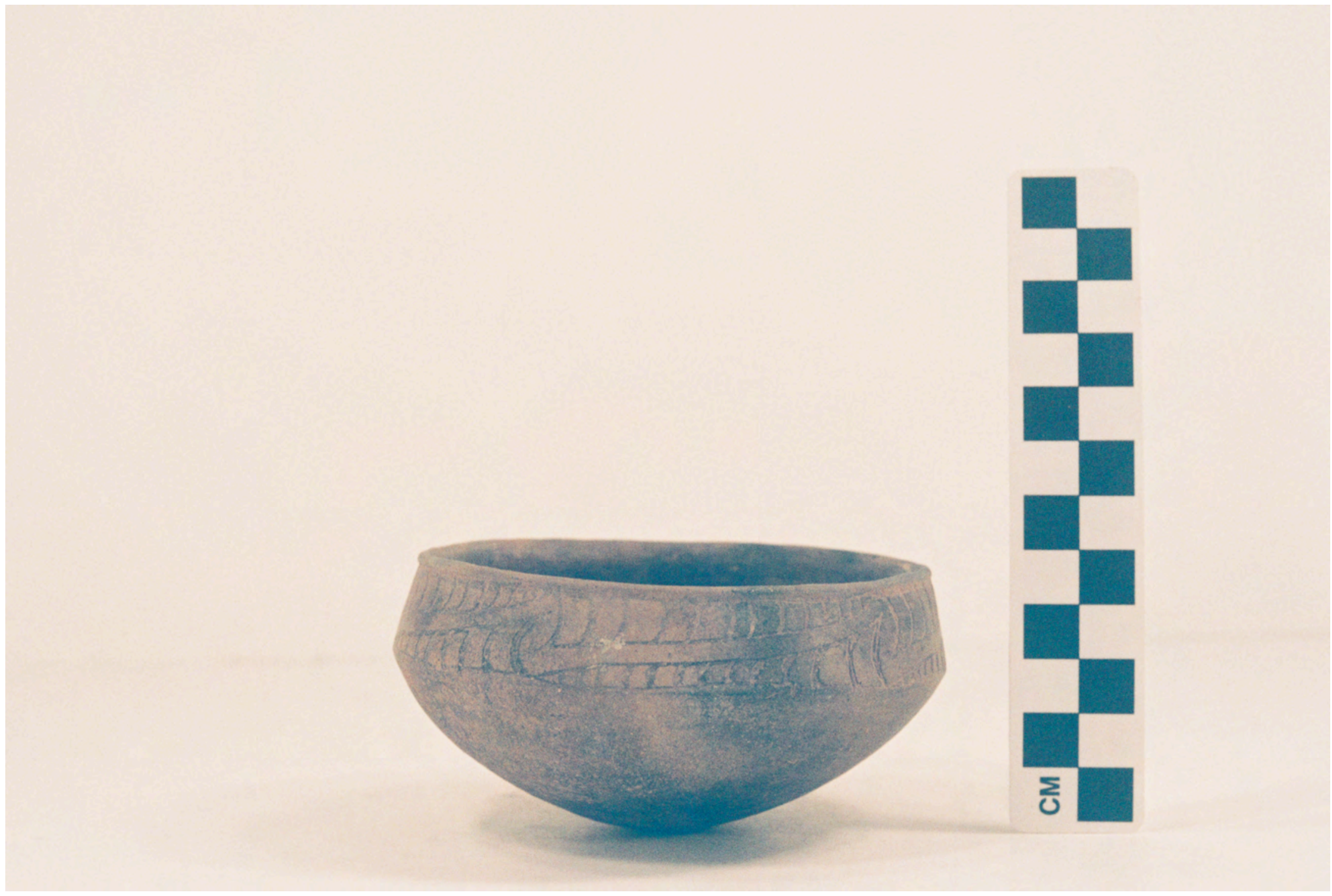

Figure A3-10 


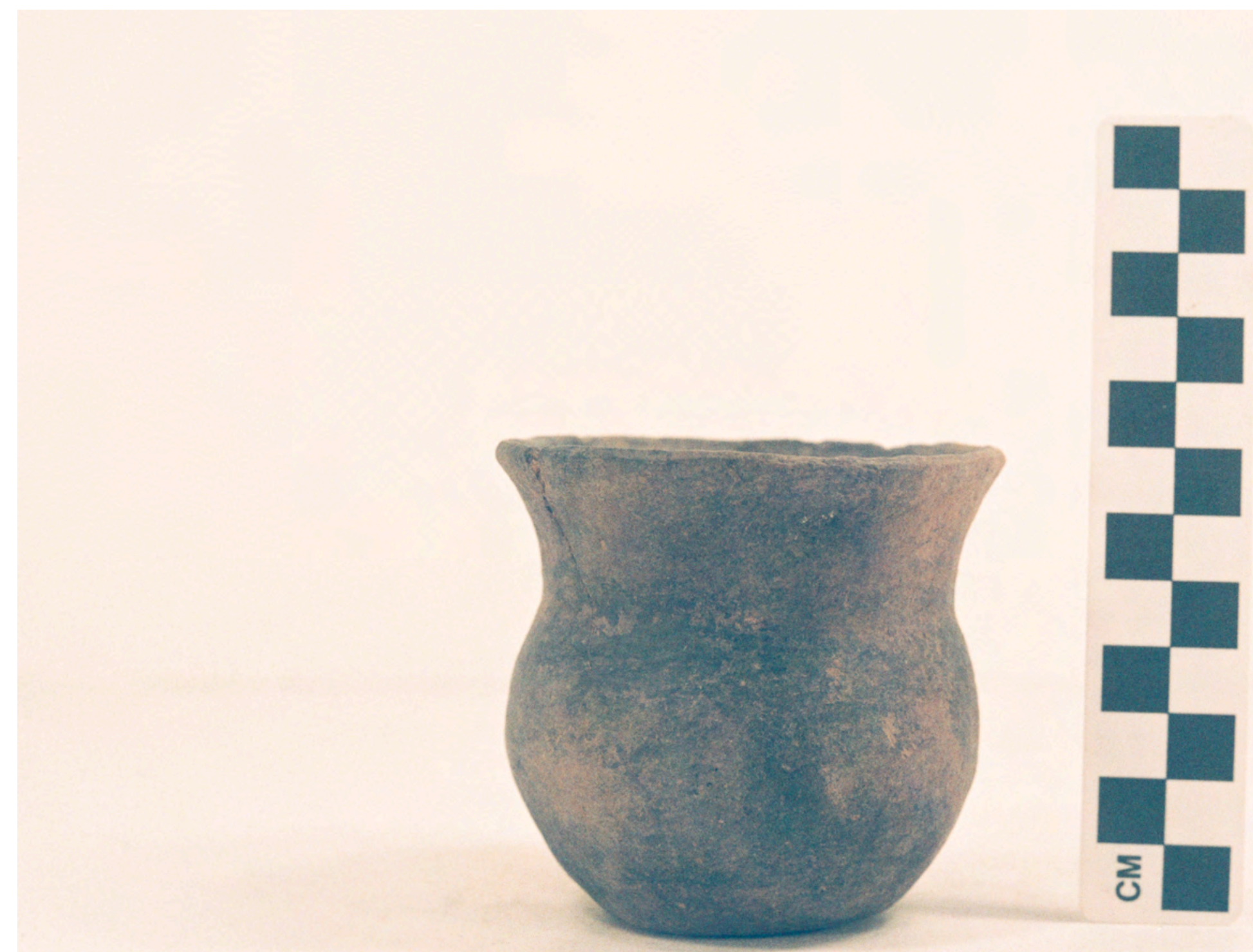

Figure A3-11 


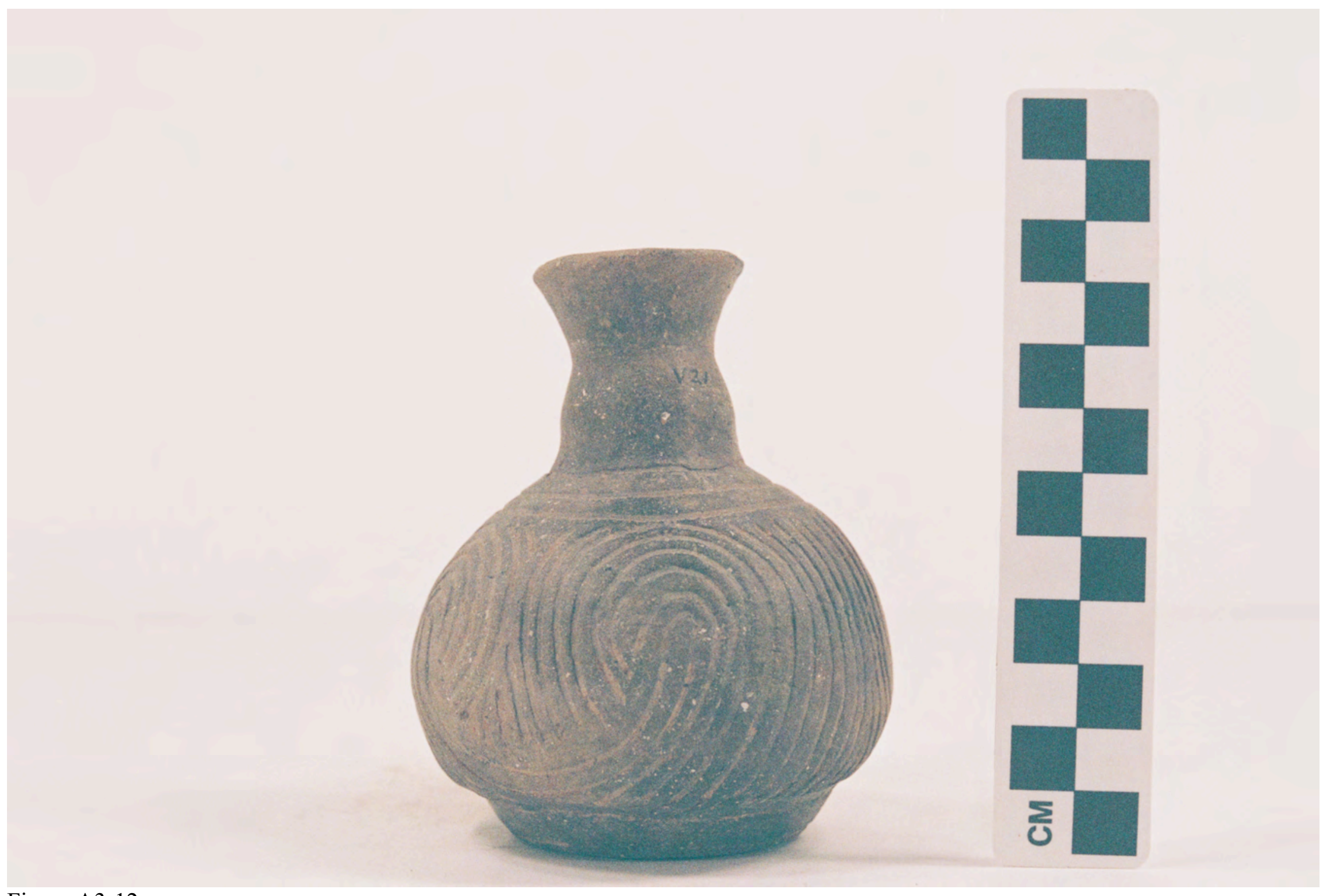

Figure A3-12 


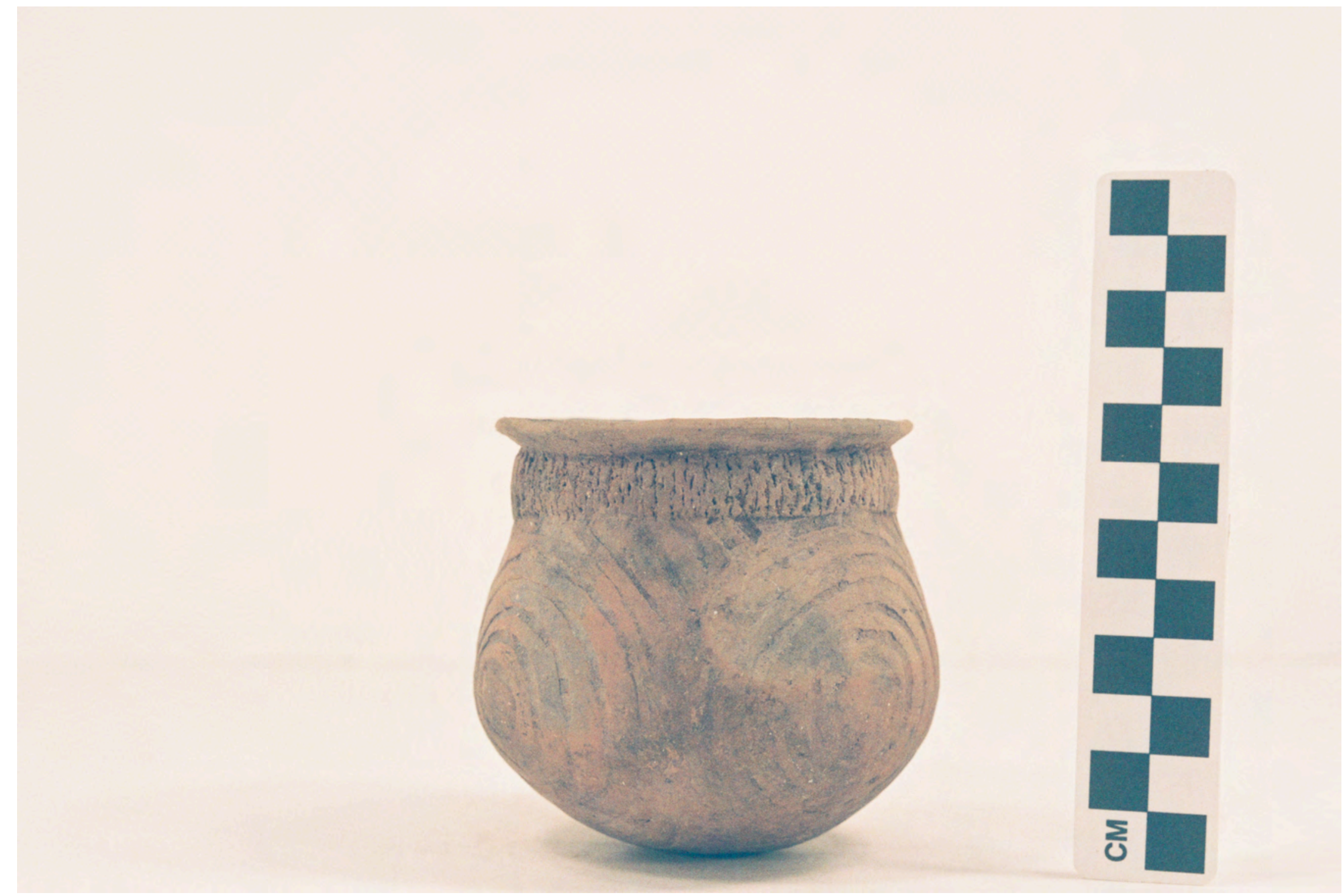

Figure A3-13 


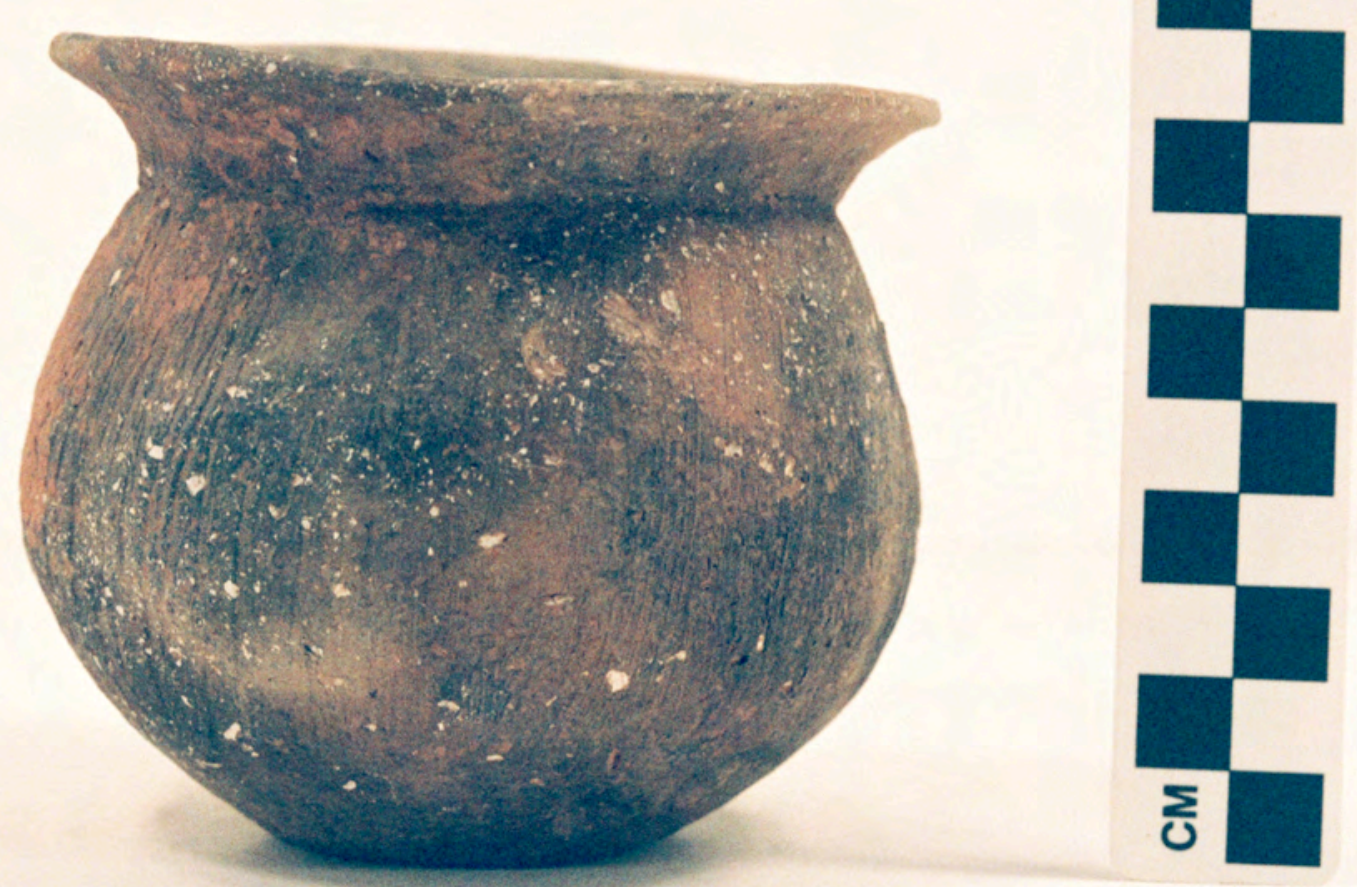

Figure A3-14 


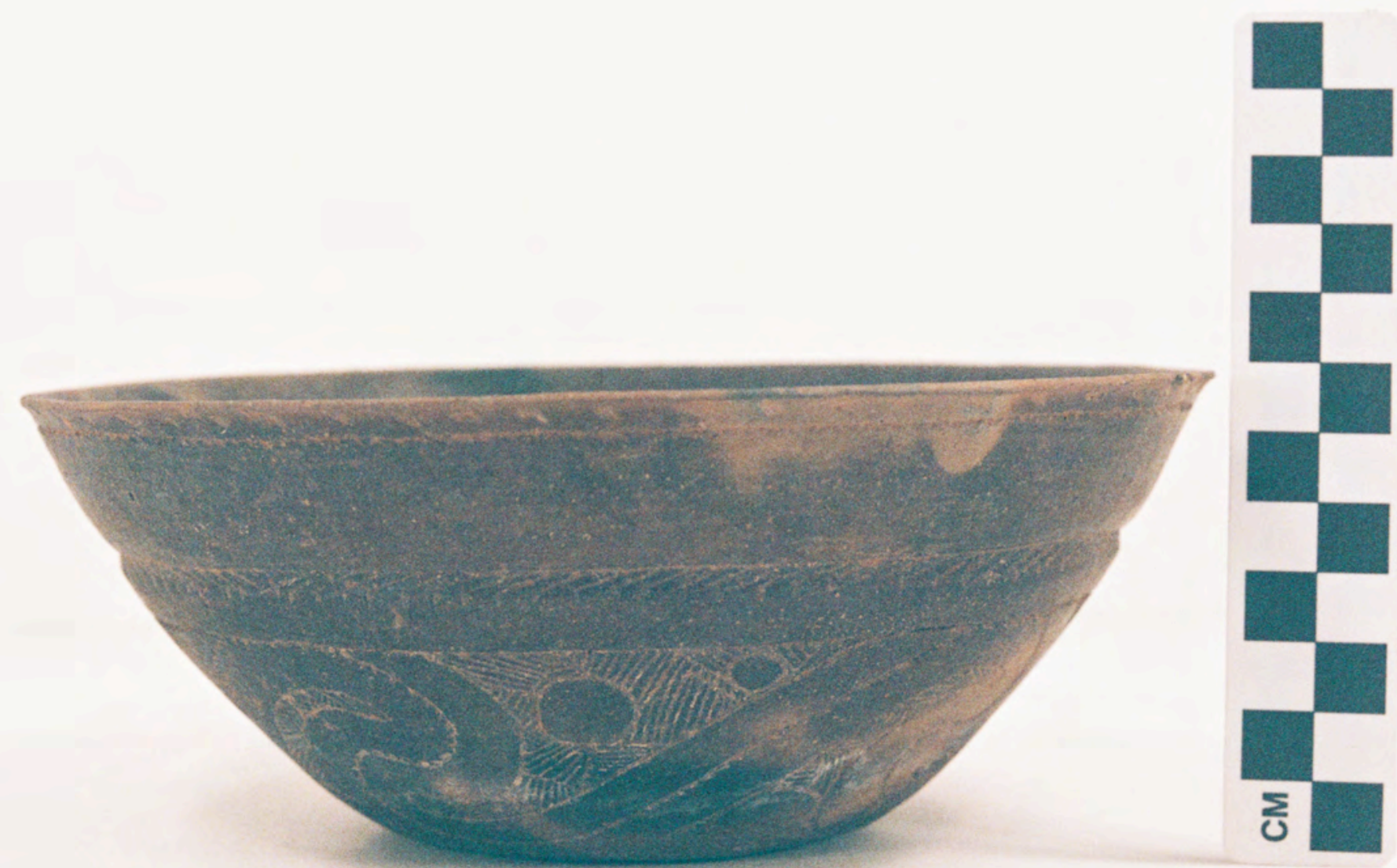

Figure A3-15 


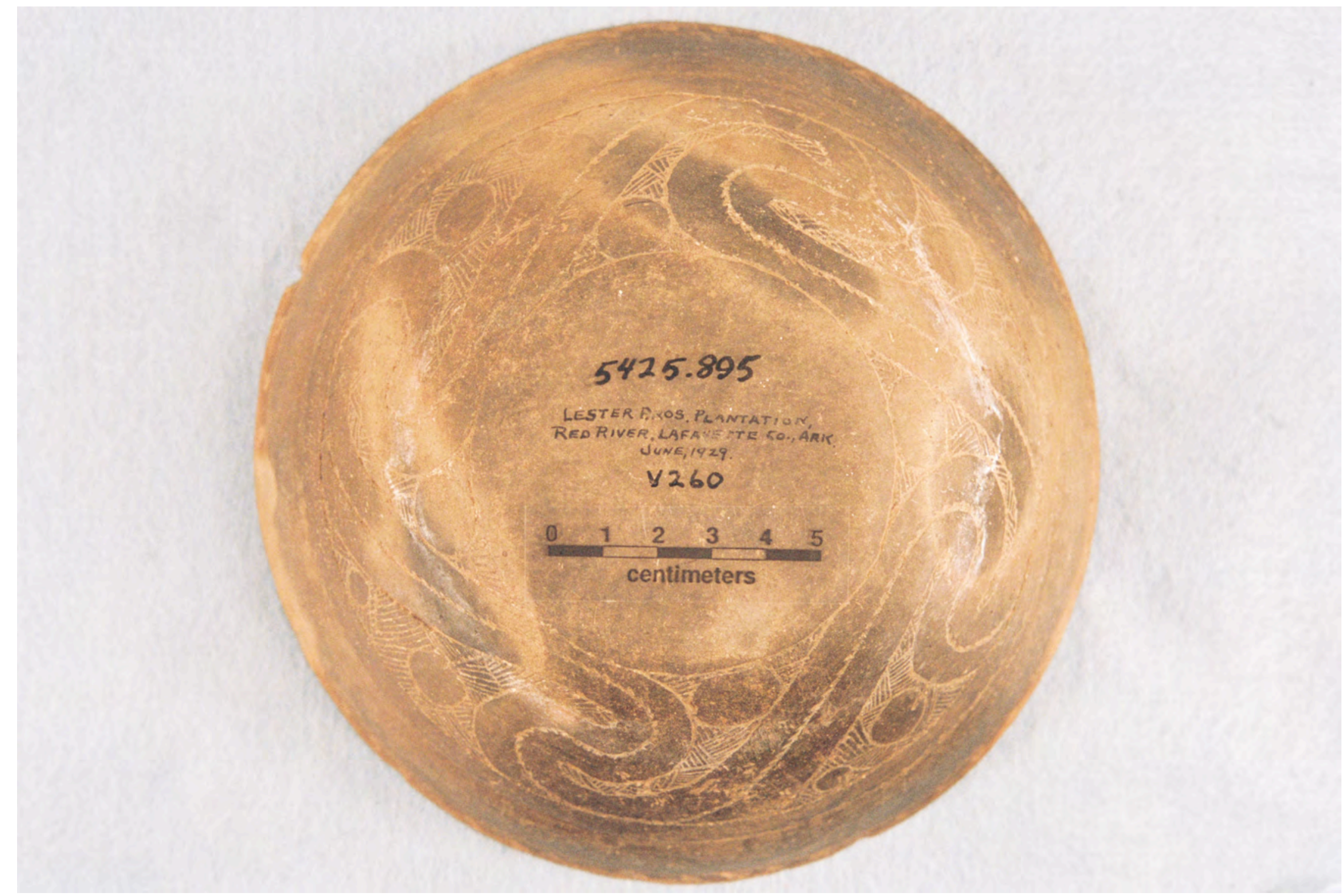

Figure A3-16 


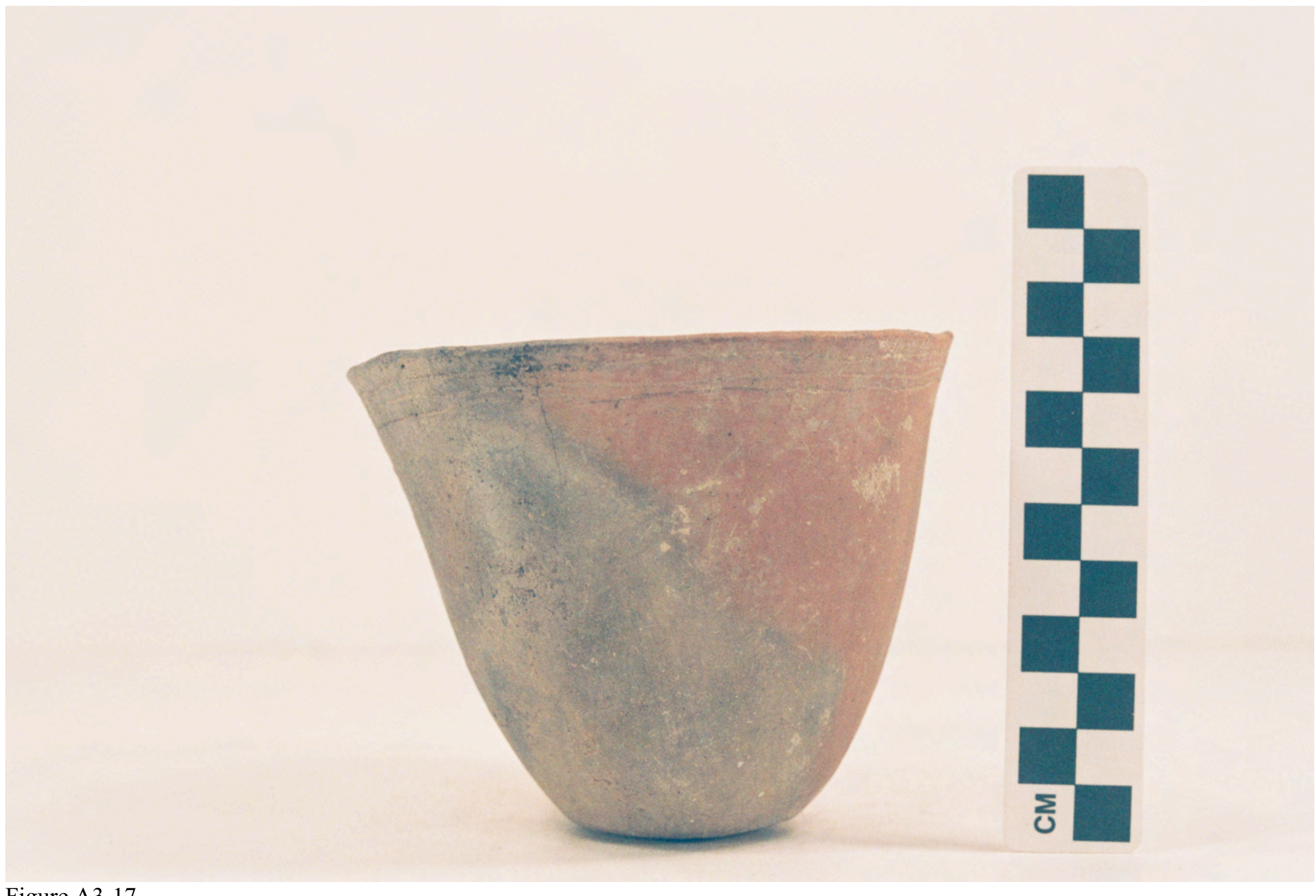

Figure A3-17 


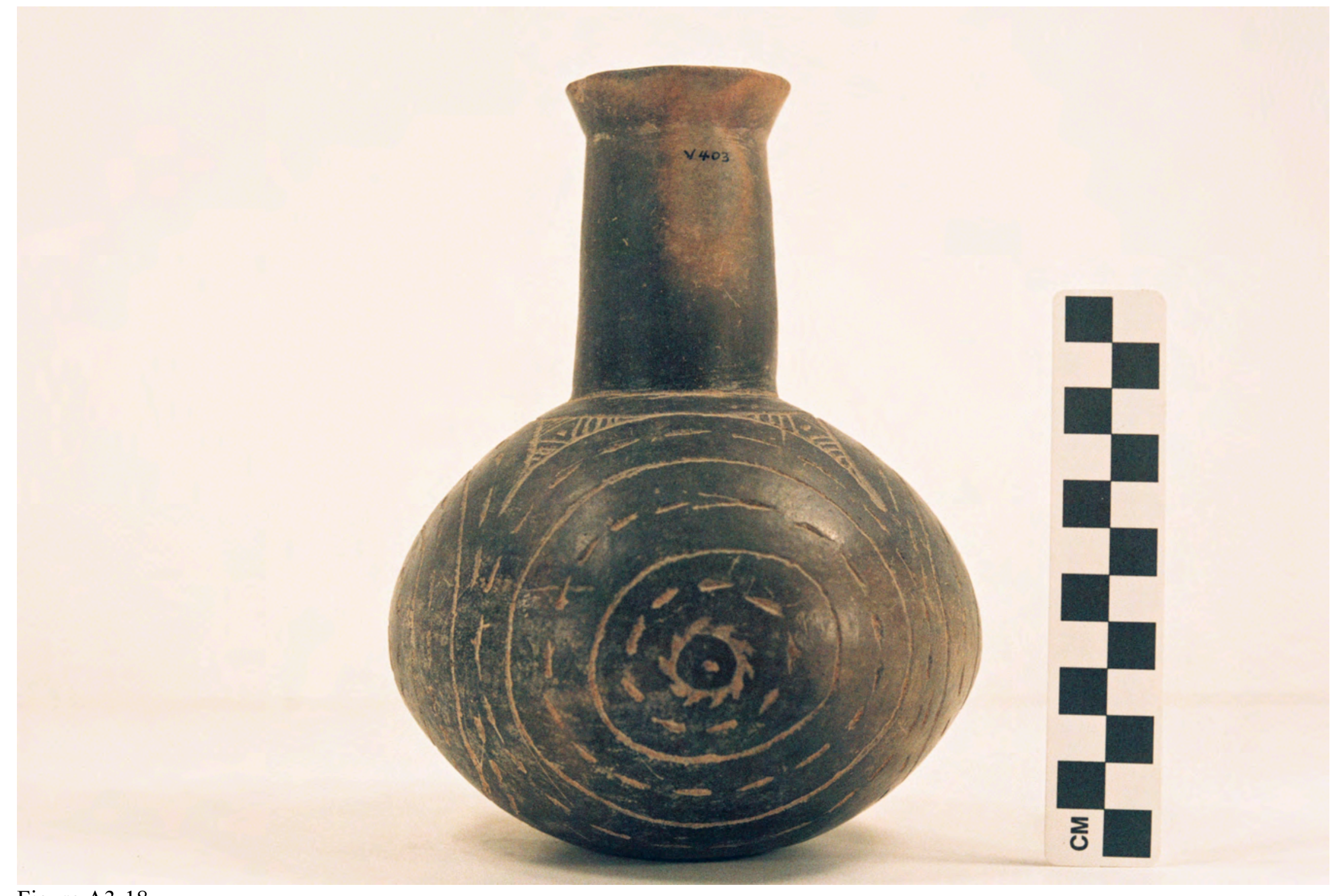

Figure A3-18 


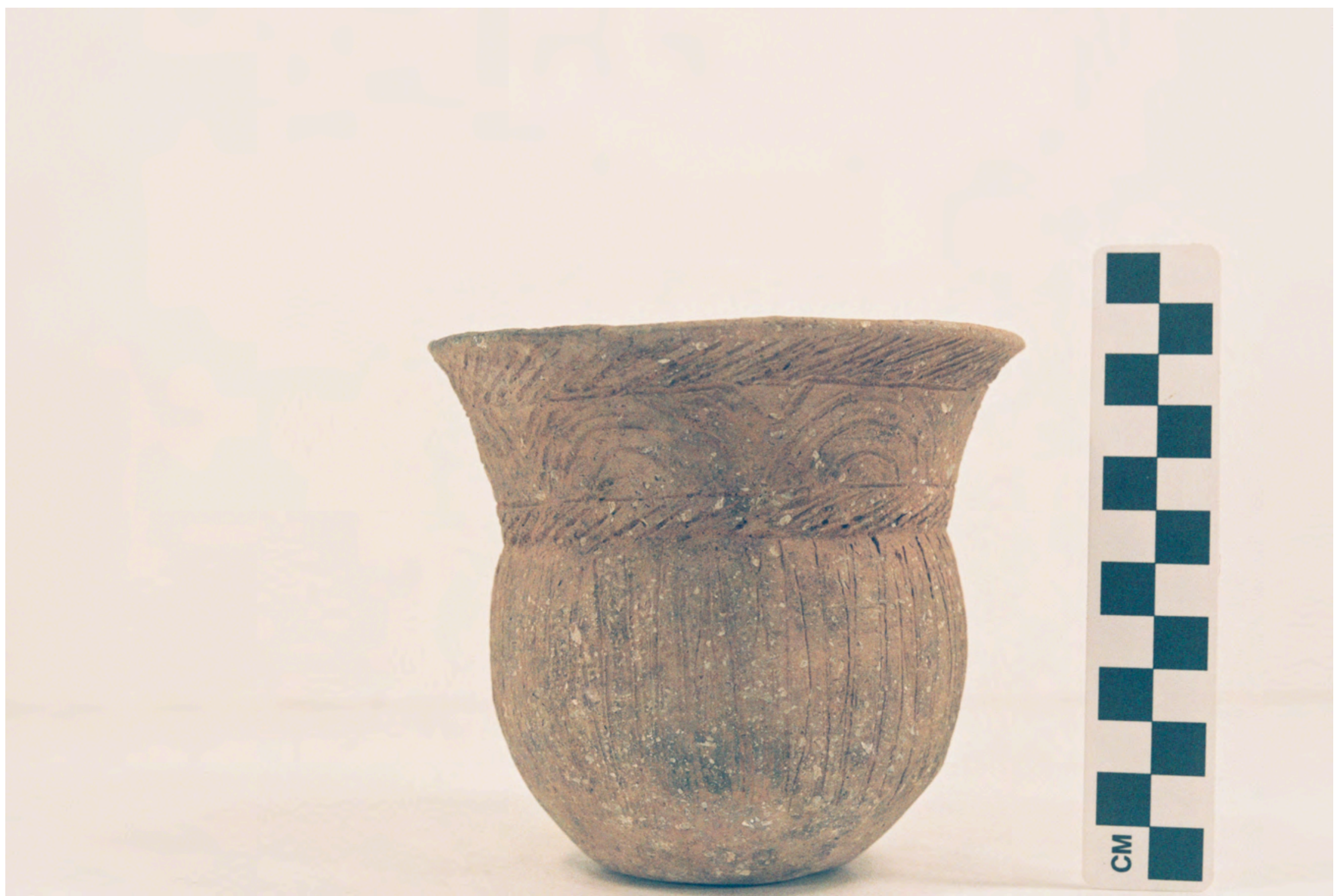

Figure A3-19 


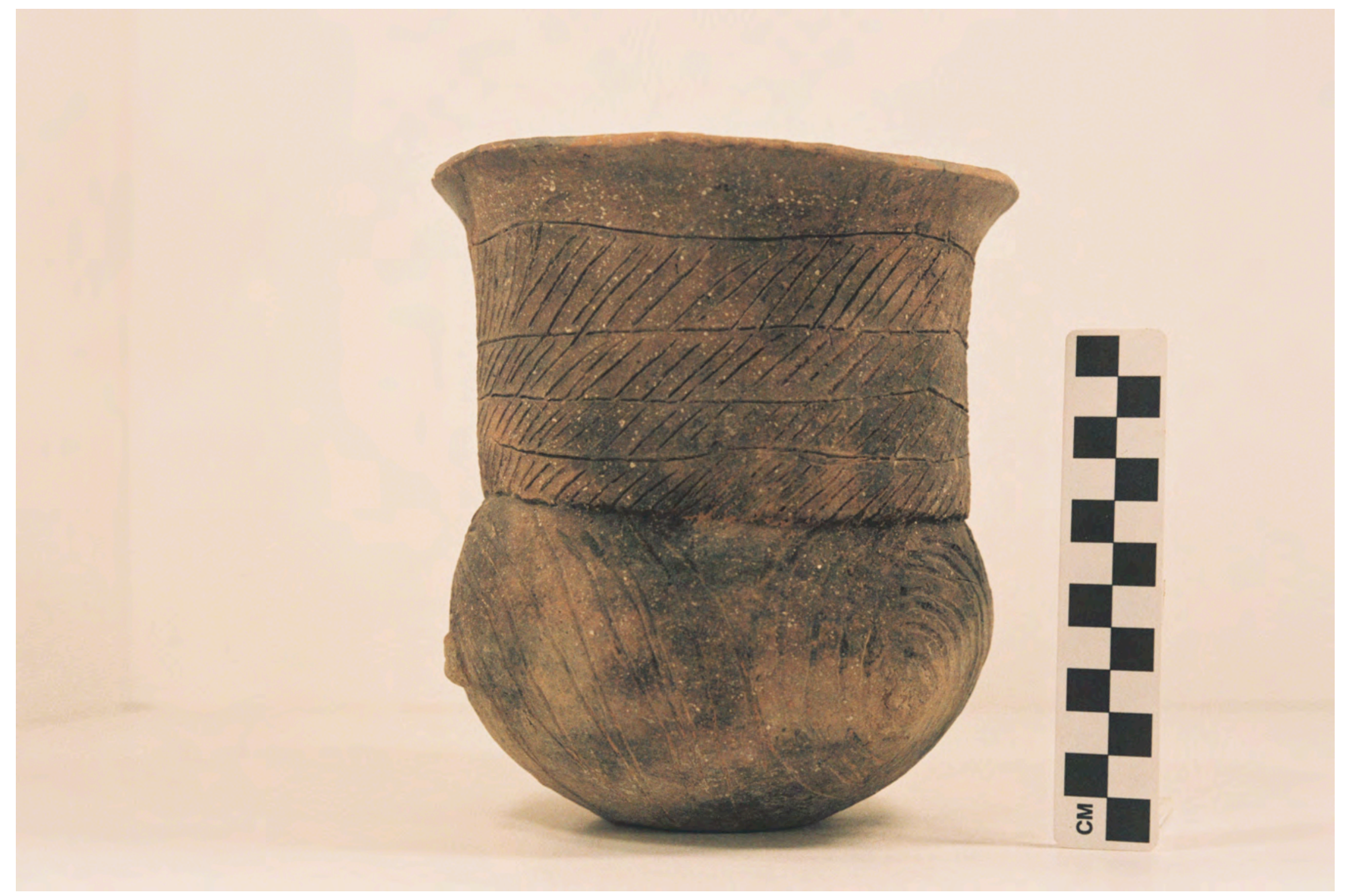

Figure A3-20 


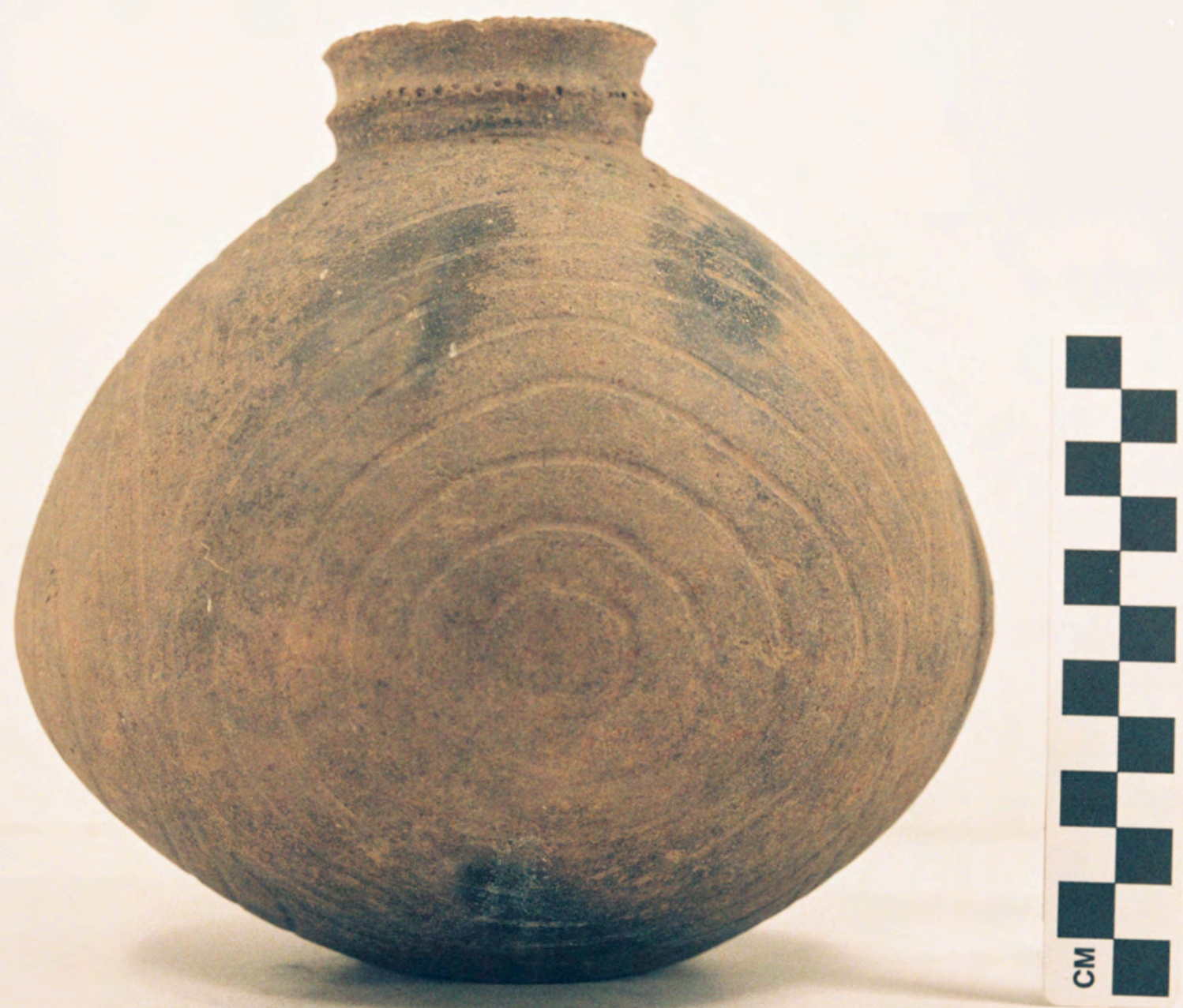

Figure A3-21 


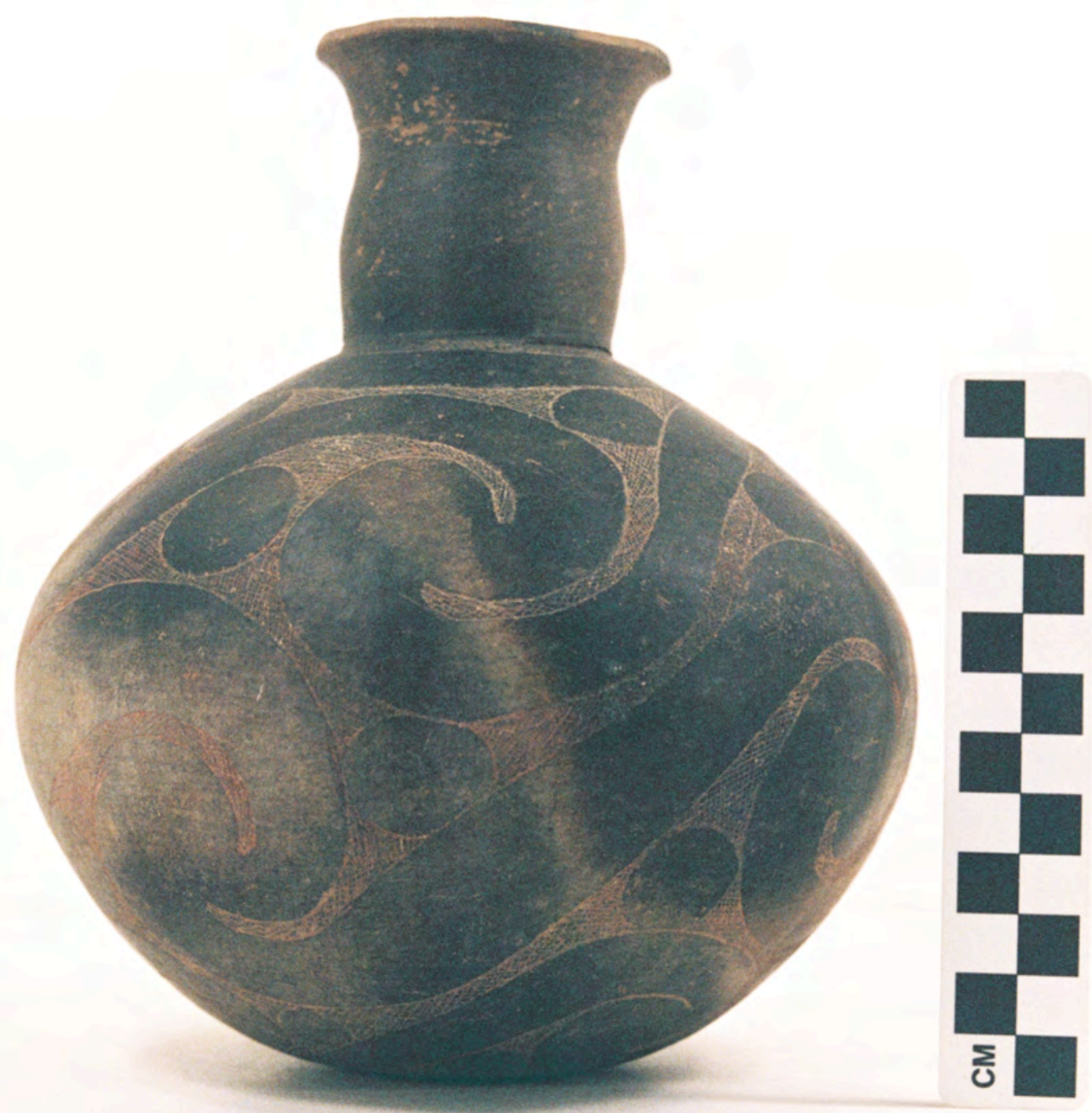

Figure A3-22 


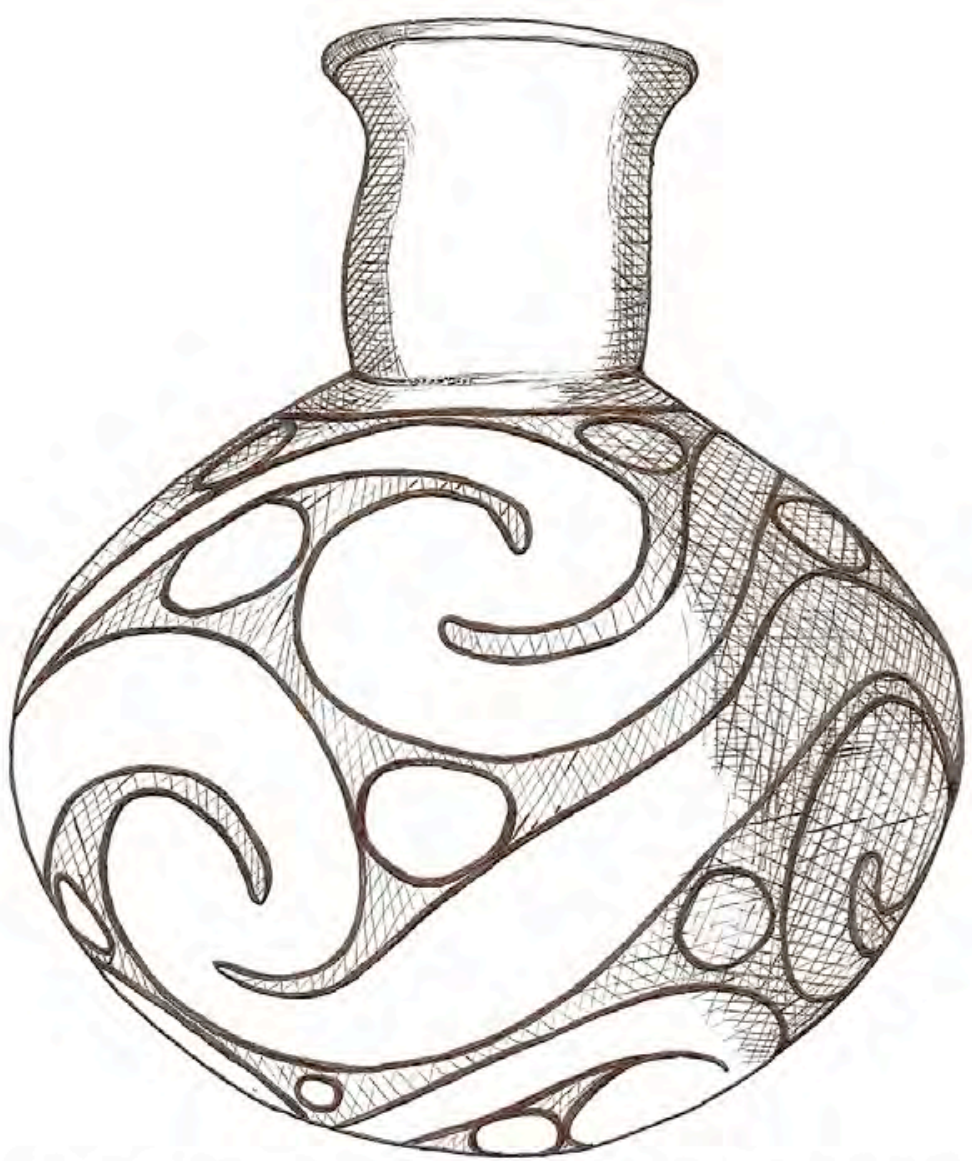

Figure A3-22. Hodges Engraved, var. Candler bottle (5425-909):a, side view. Drawing by Bobby Gonzalez.

Figure A3-22a 


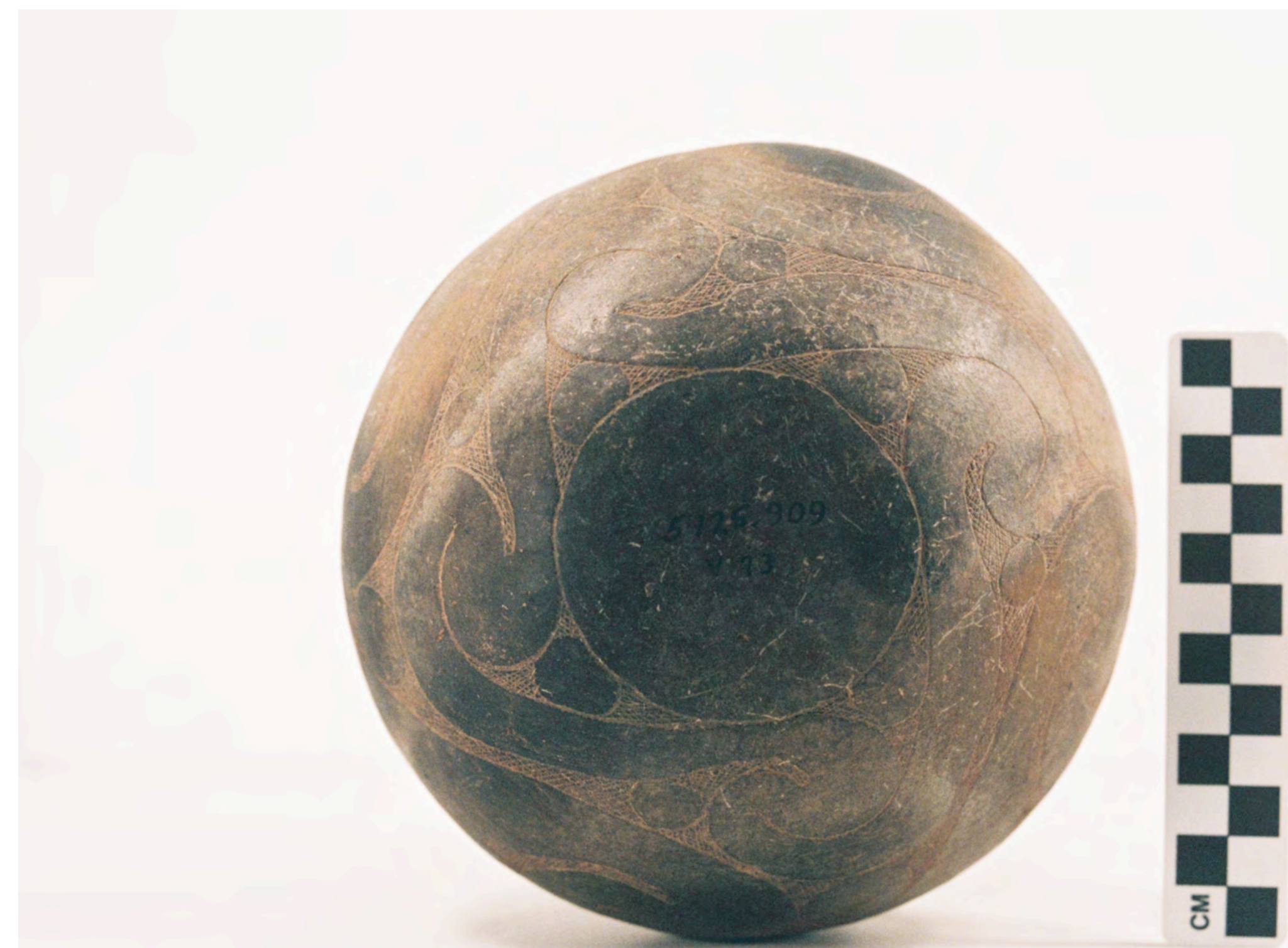

Figure A3-22b 


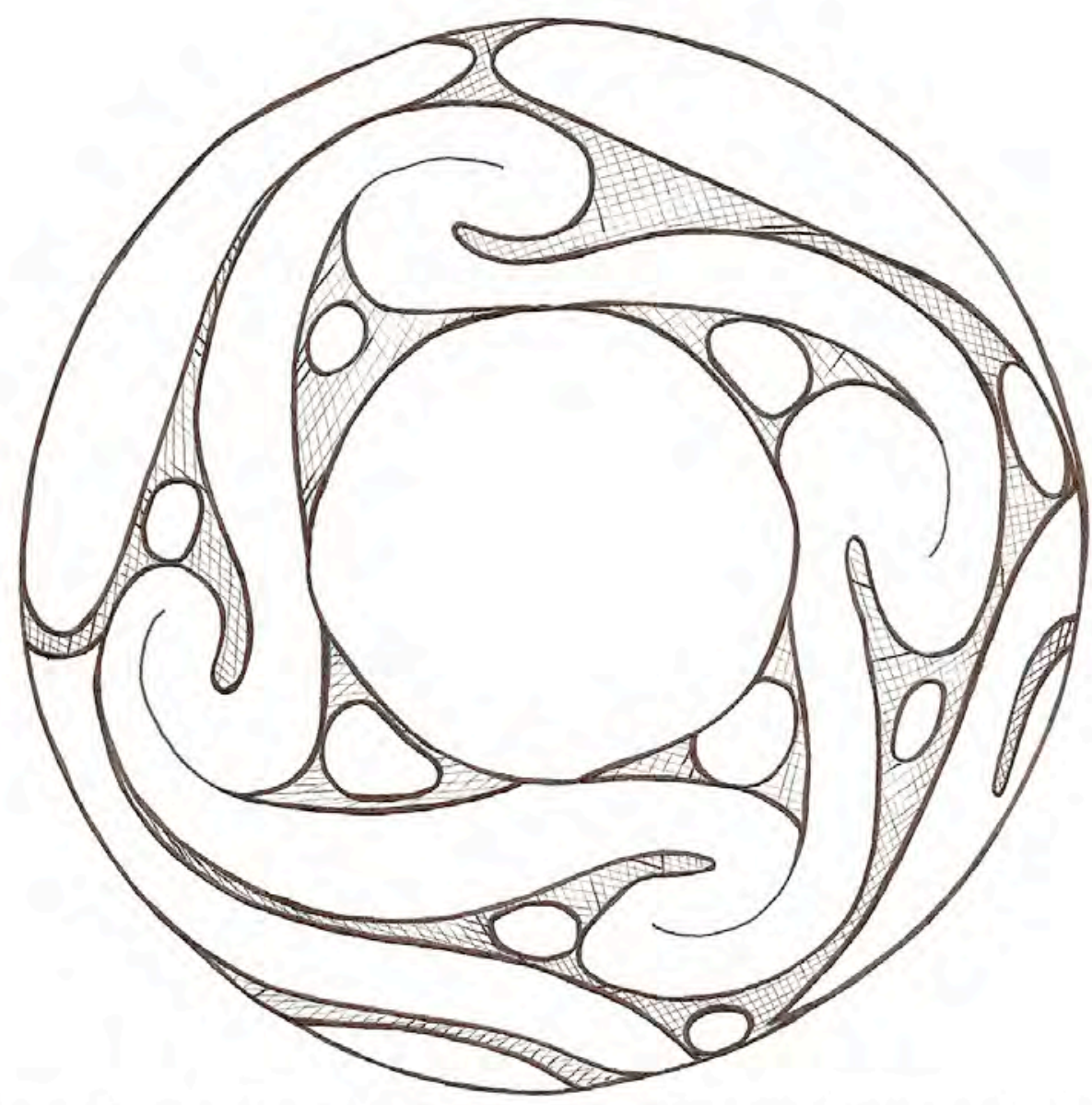

Figure A3-22. Hodges Engraved, var. Candler bottle (5425-909): b, view of vessel base. Drawing by Bobby Gonzalez.

Figure A3-22c 


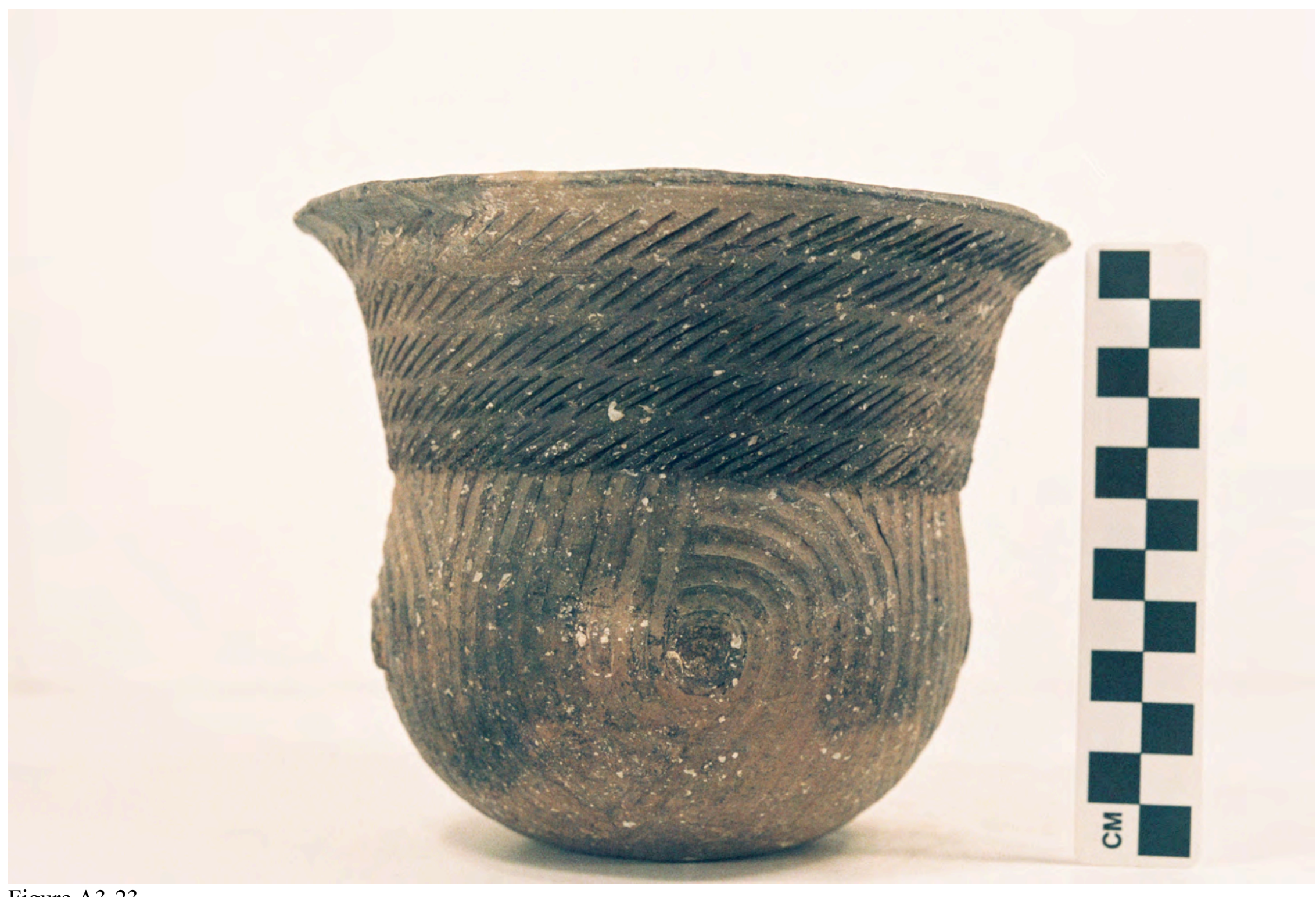

Figure A3-23 


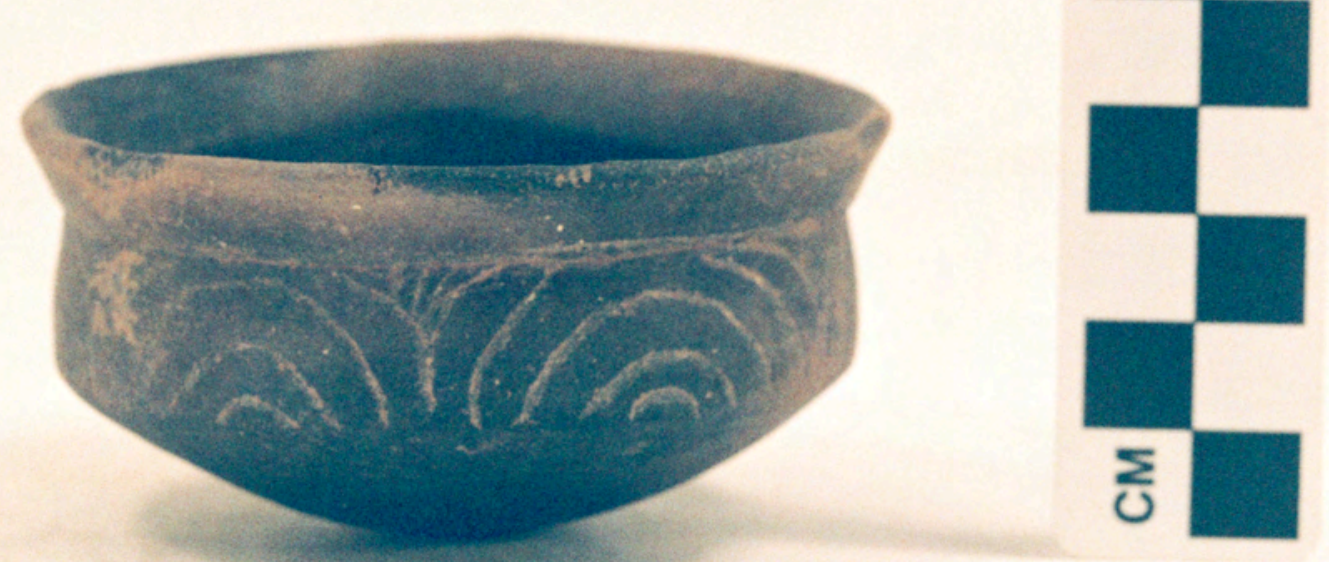

Figure A3-24 


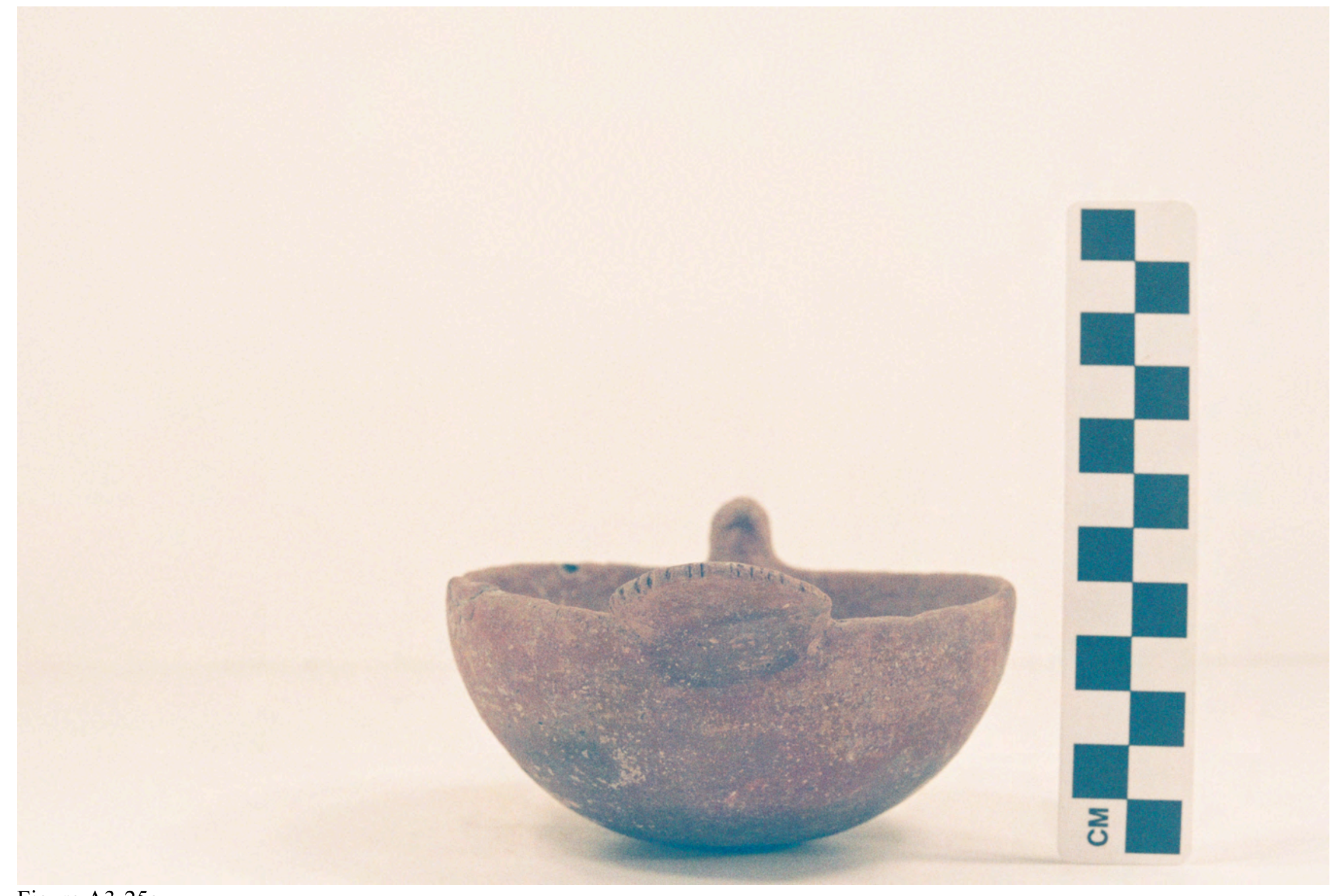

Figure A3-25a 


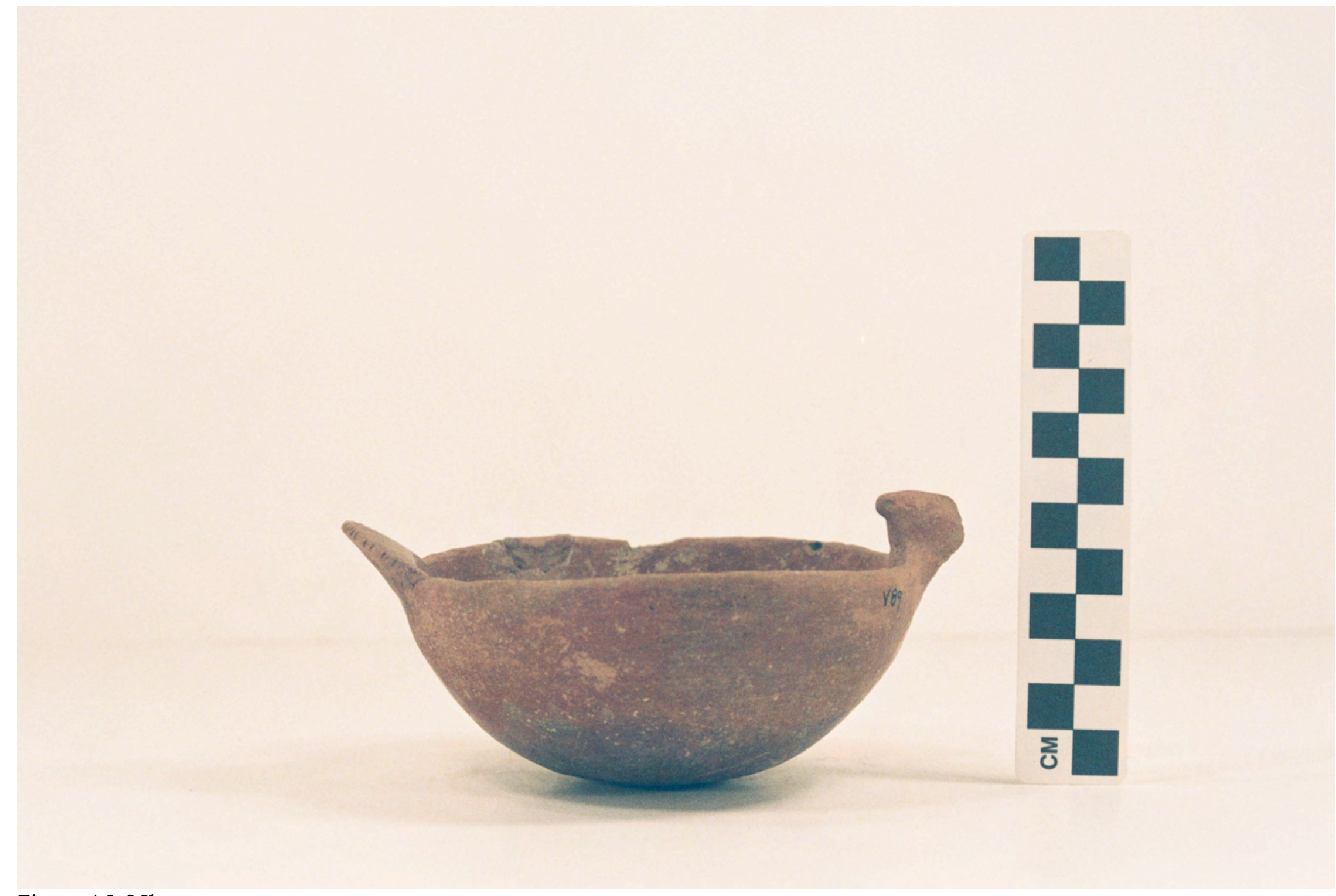

Figure A3-25b 


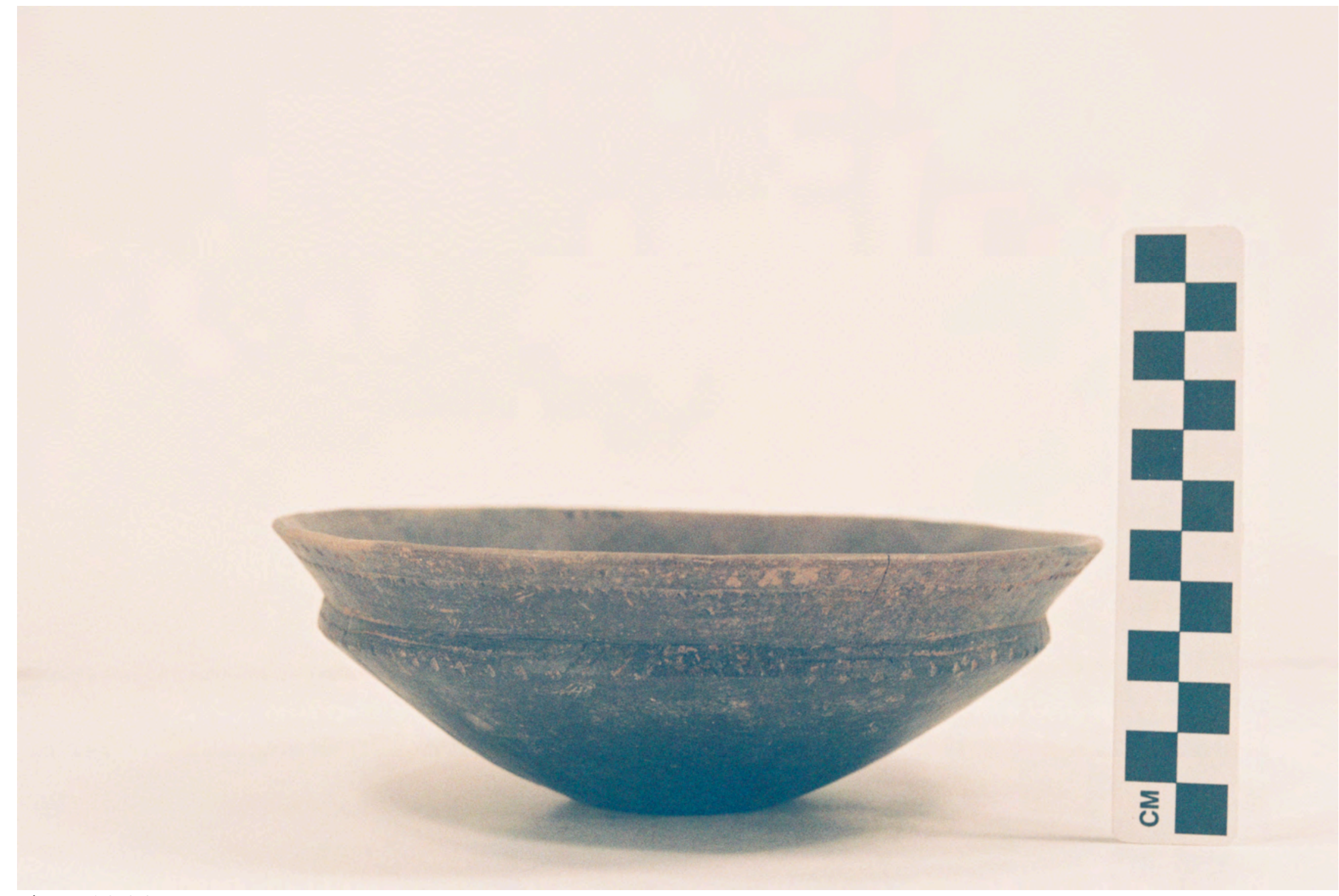

Figure A3-26 


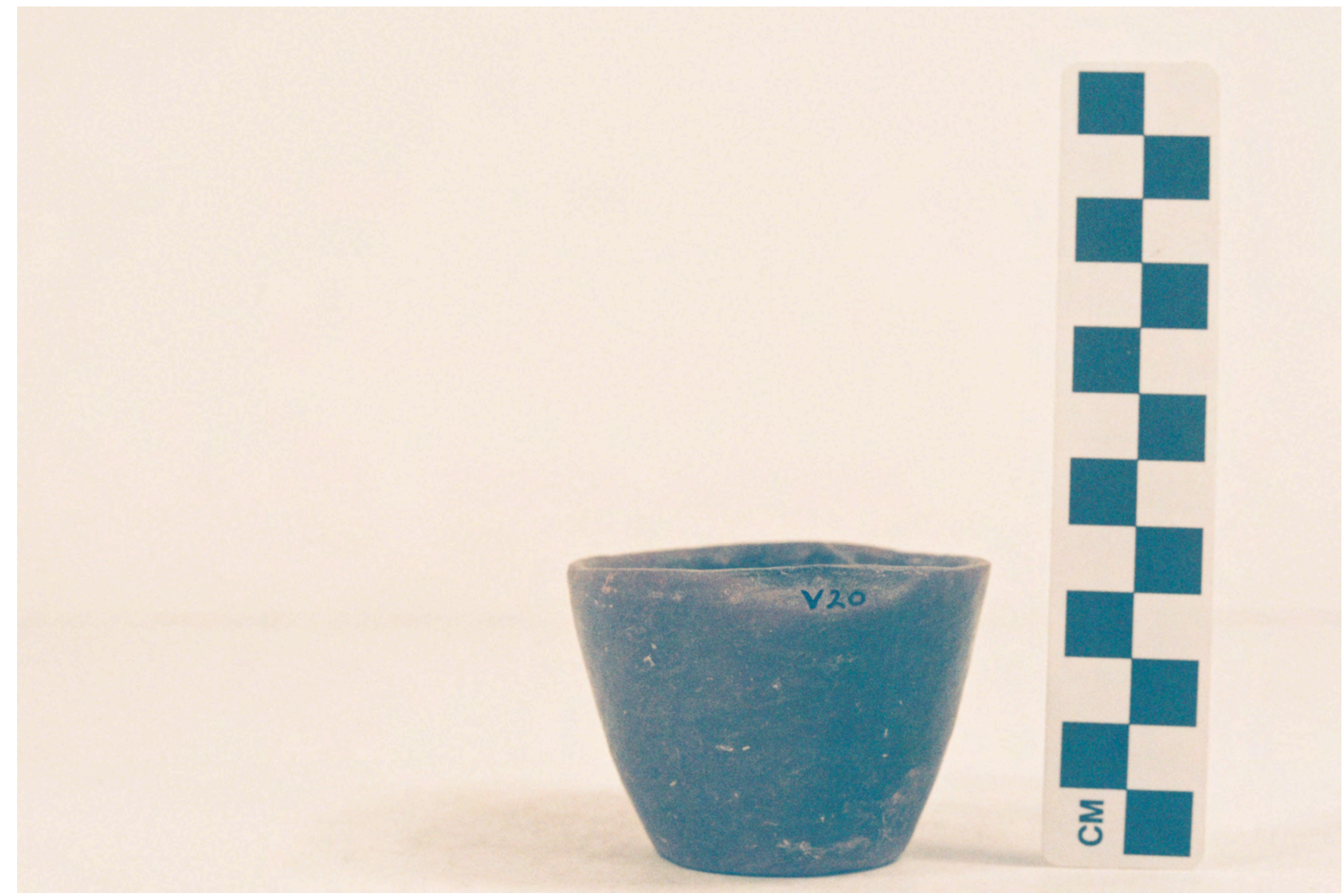

Figure A3-27 

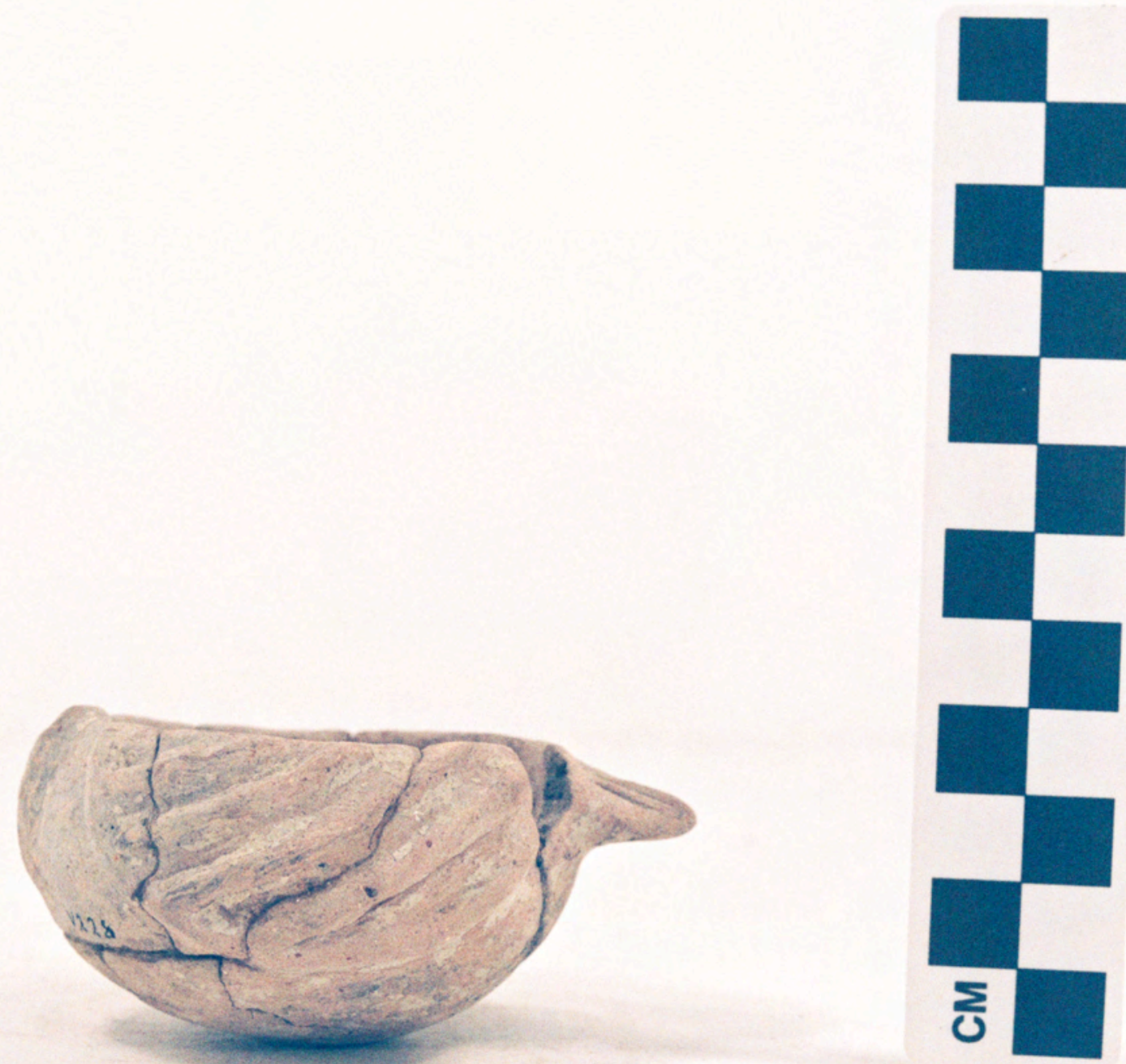

Figure A3-28 


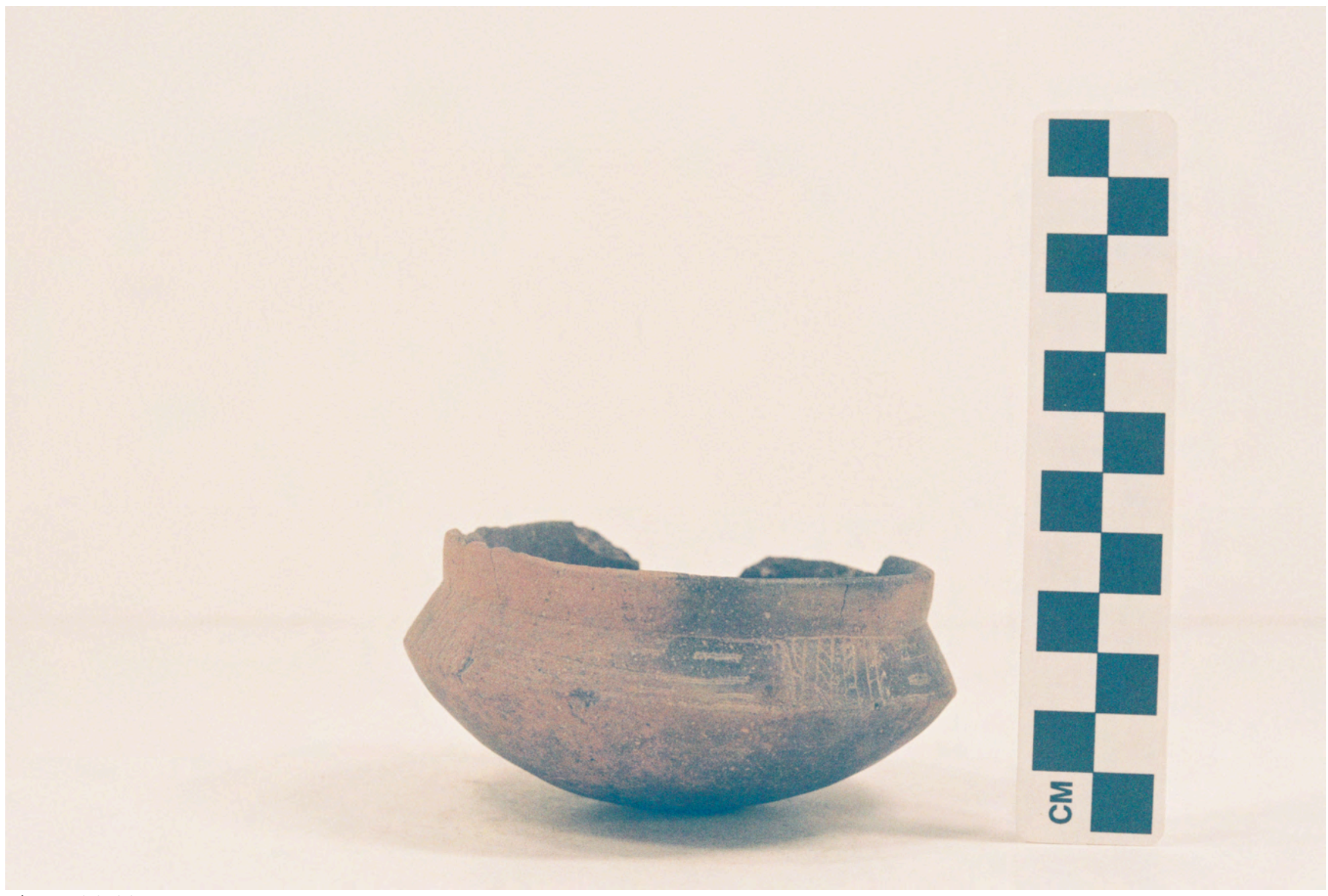

Figure A3-29 


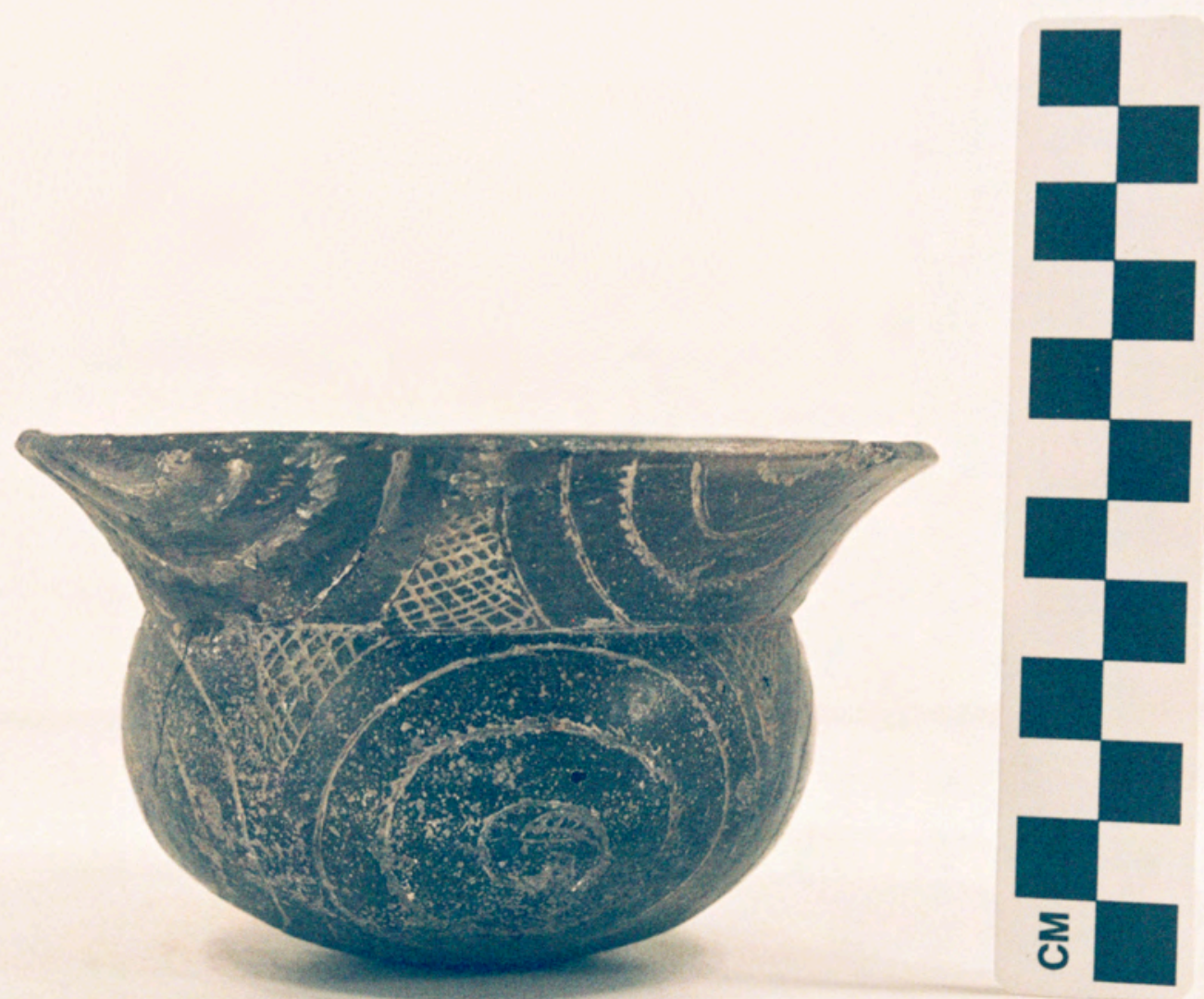

Figure A3-30 


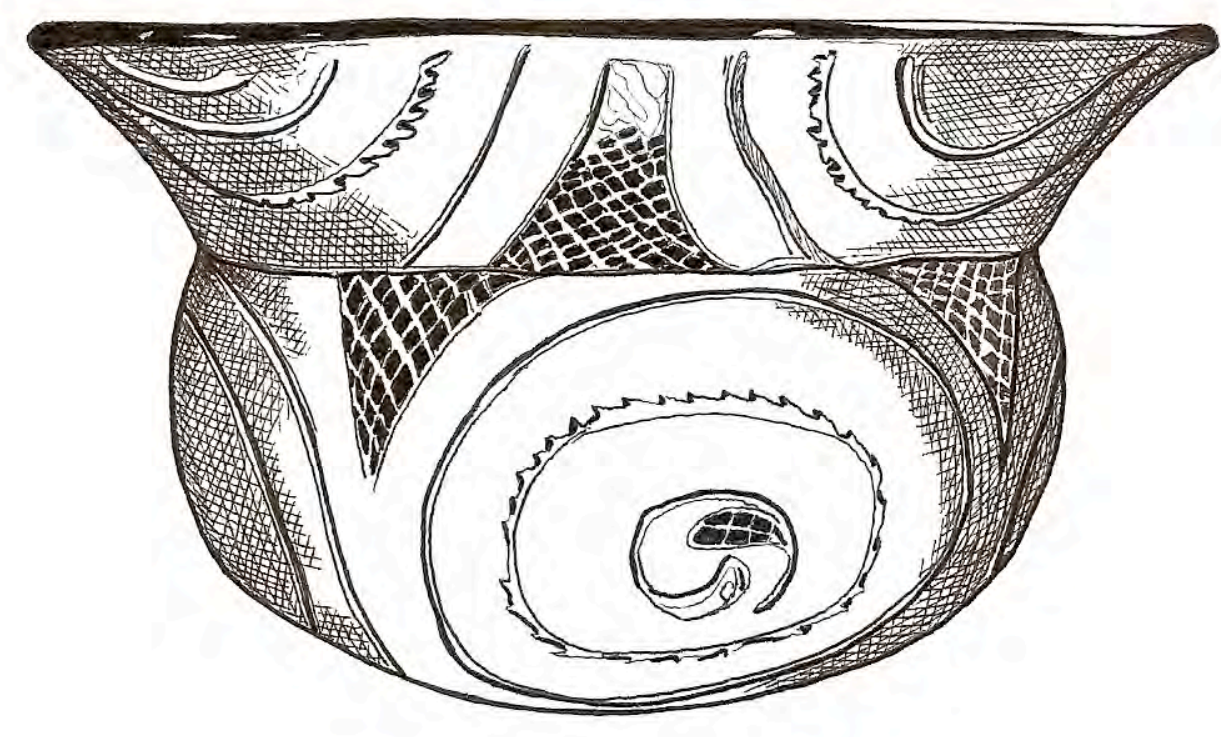

Figure A3-31. Avery Engraved, var. Graves bowl (5425-937). From the Lester Bros. Place. Drawing by Bobby Gonzalez.

Figure A3-31 

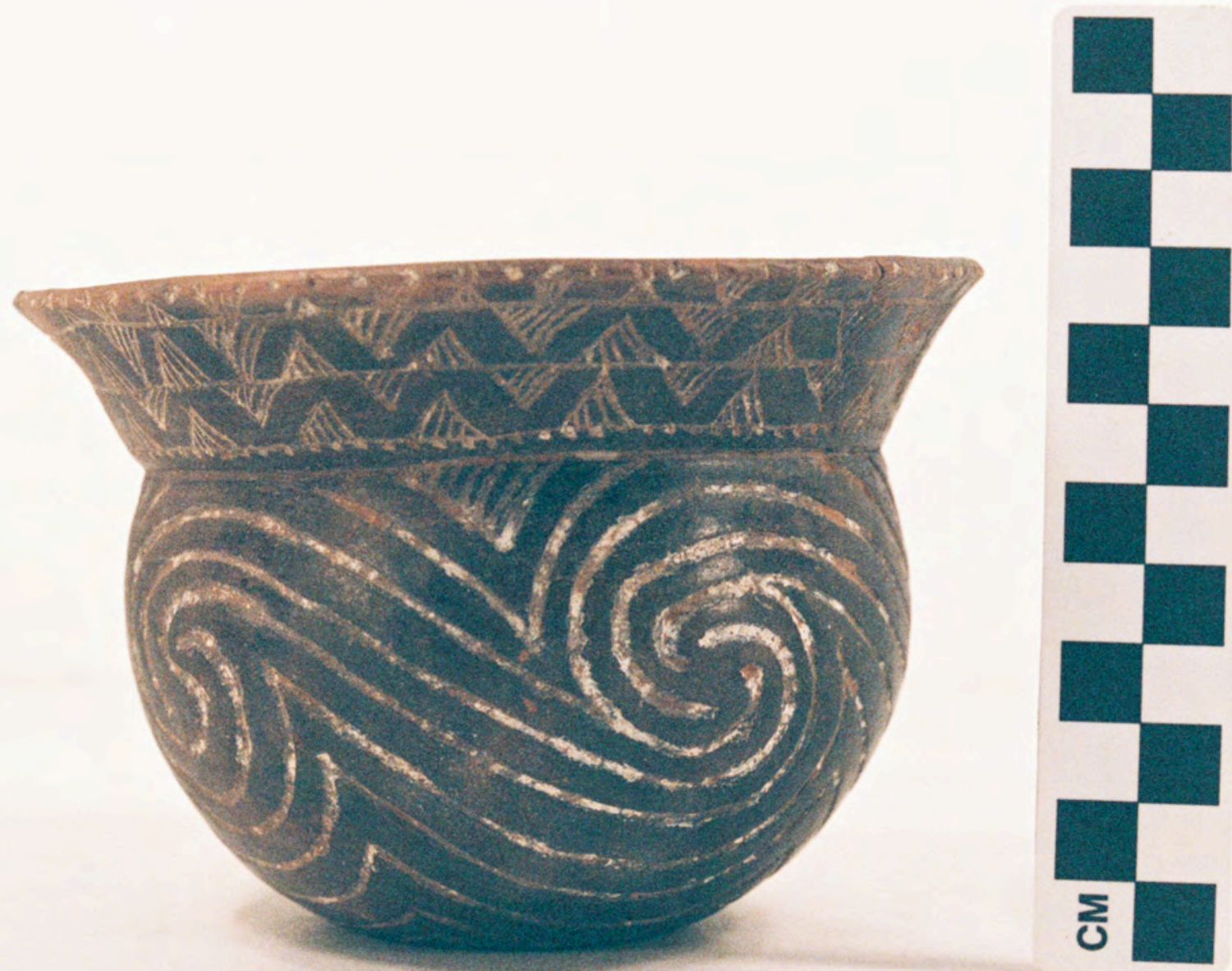

Figure A3-32 


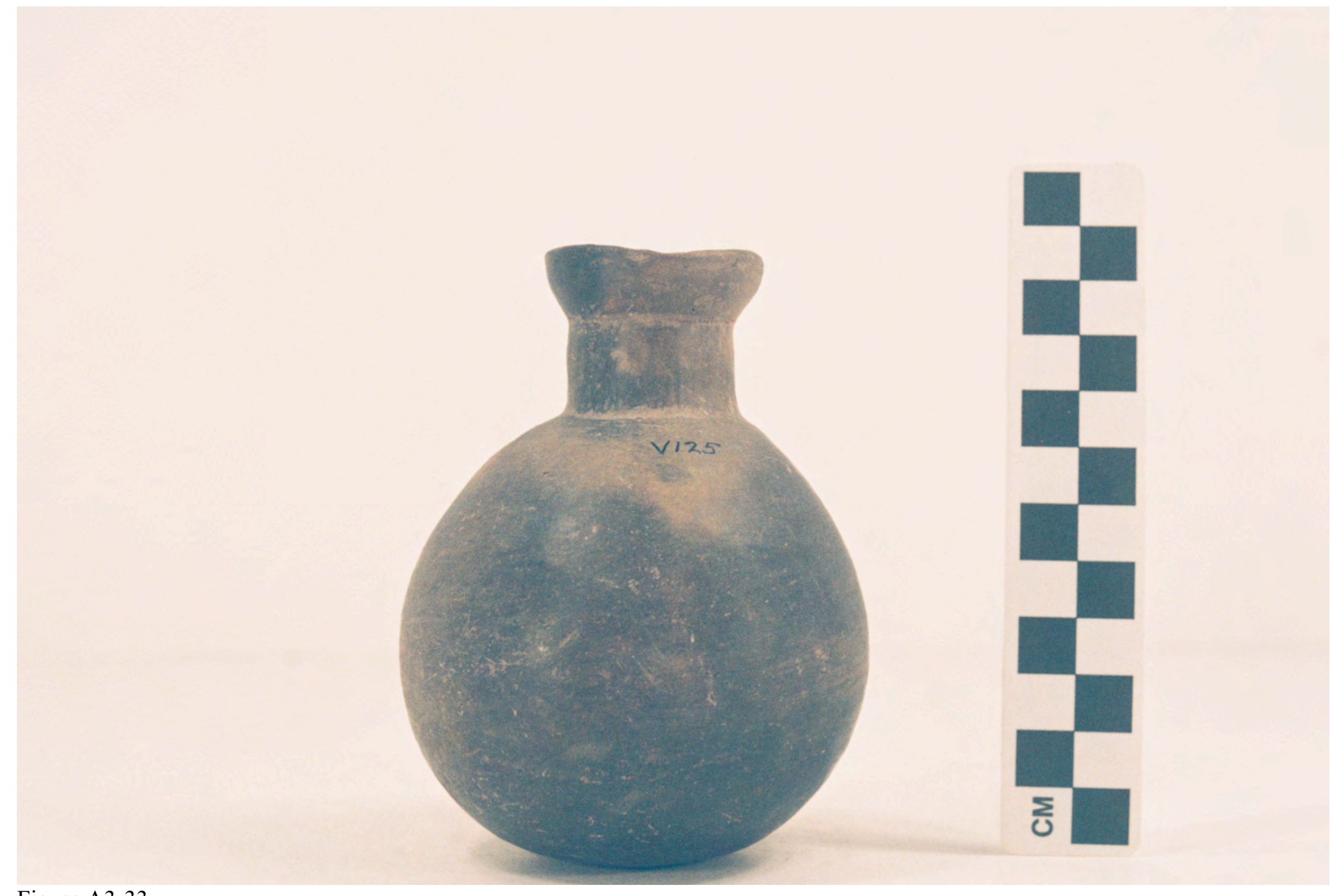

Figure A3-33 


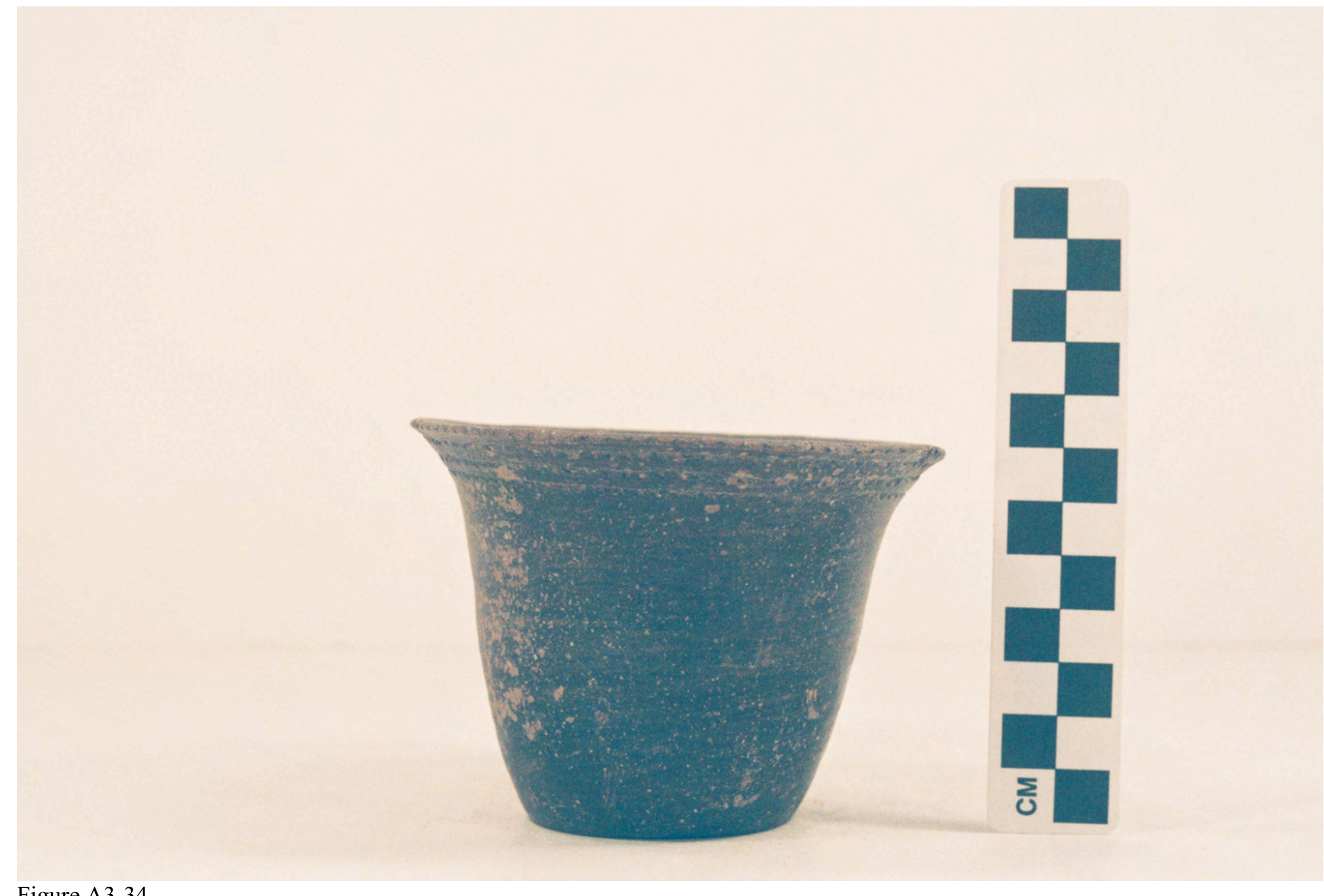

Figure A3-34 


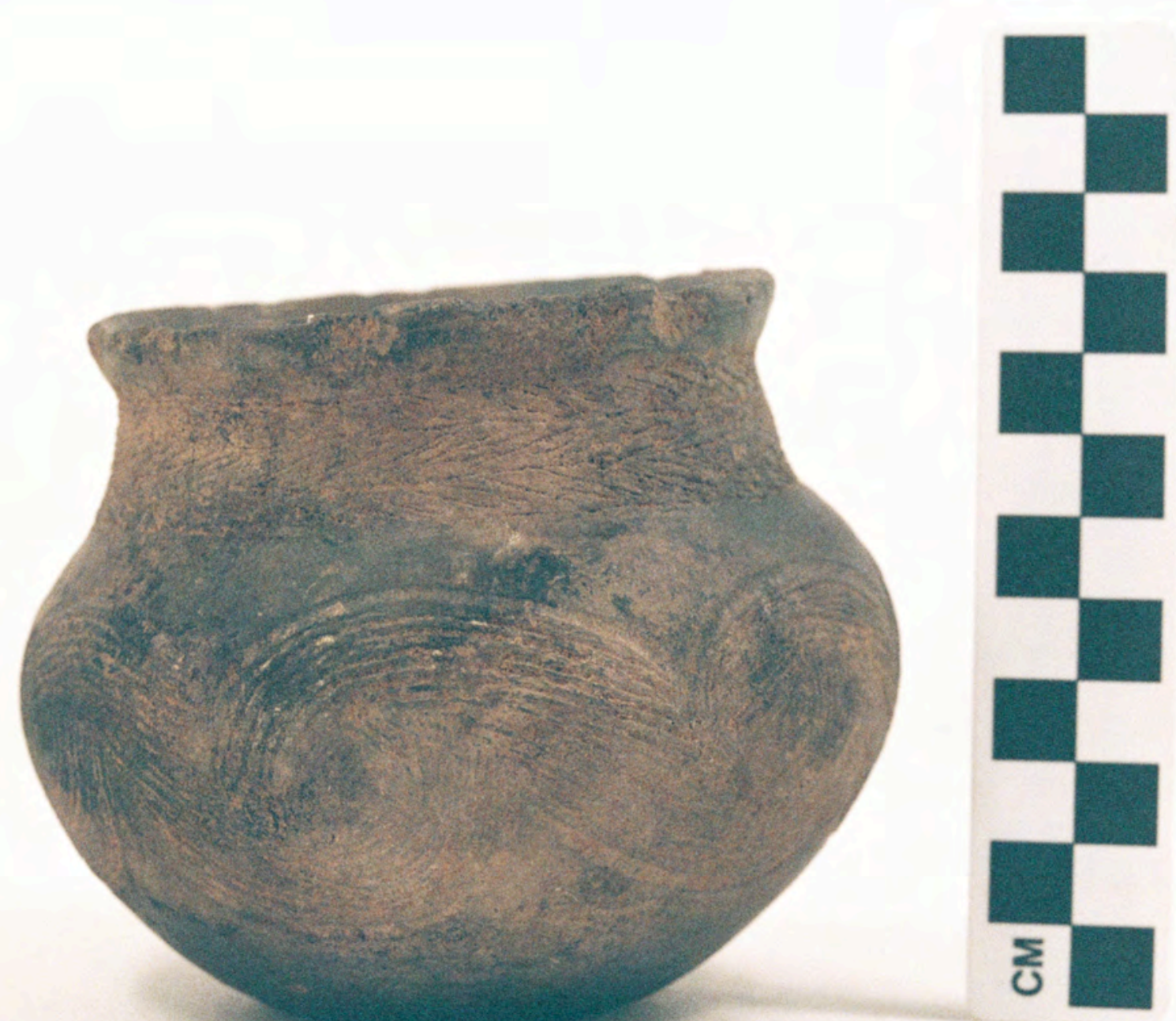

Figure A3-35 


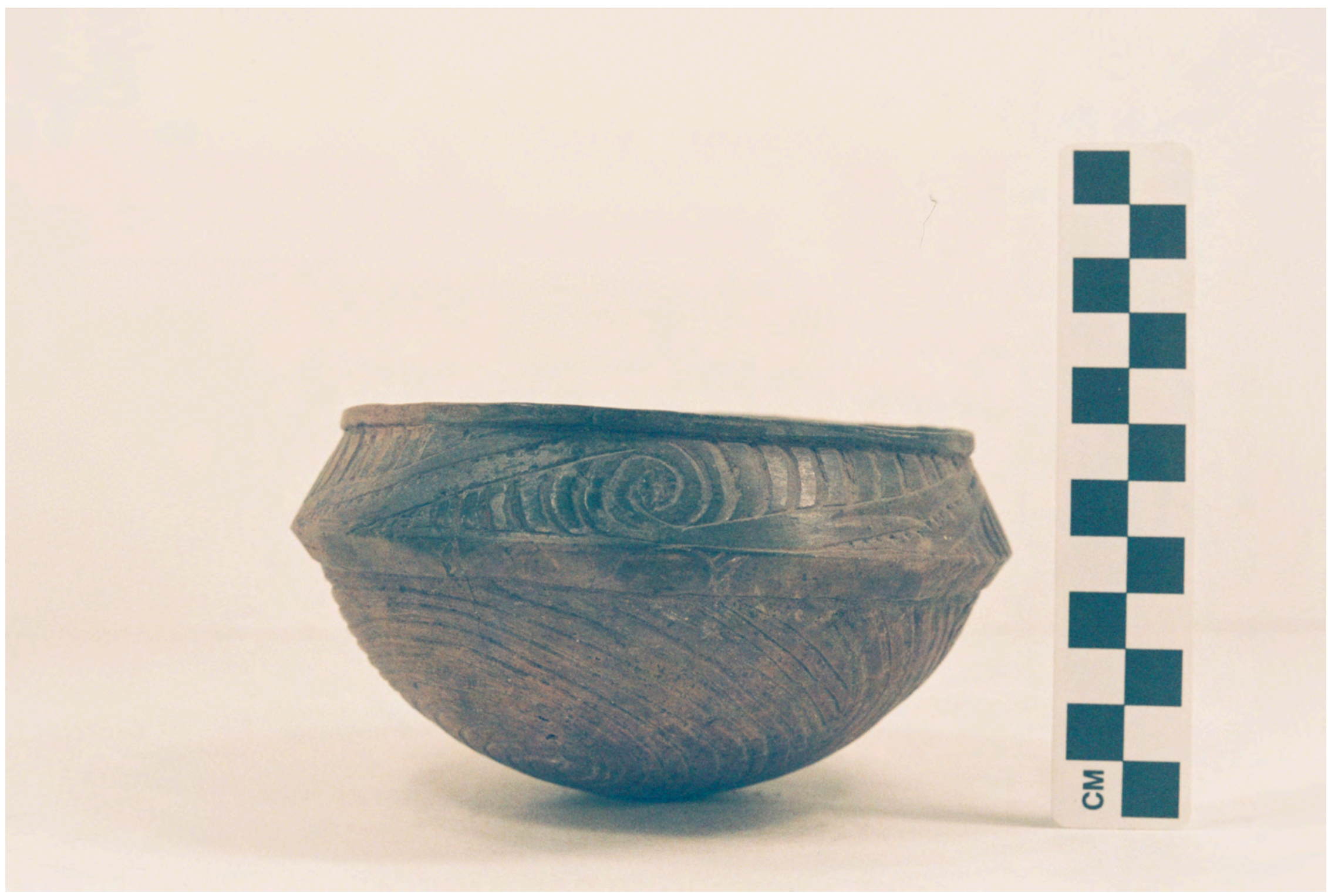

Figure A3-36 


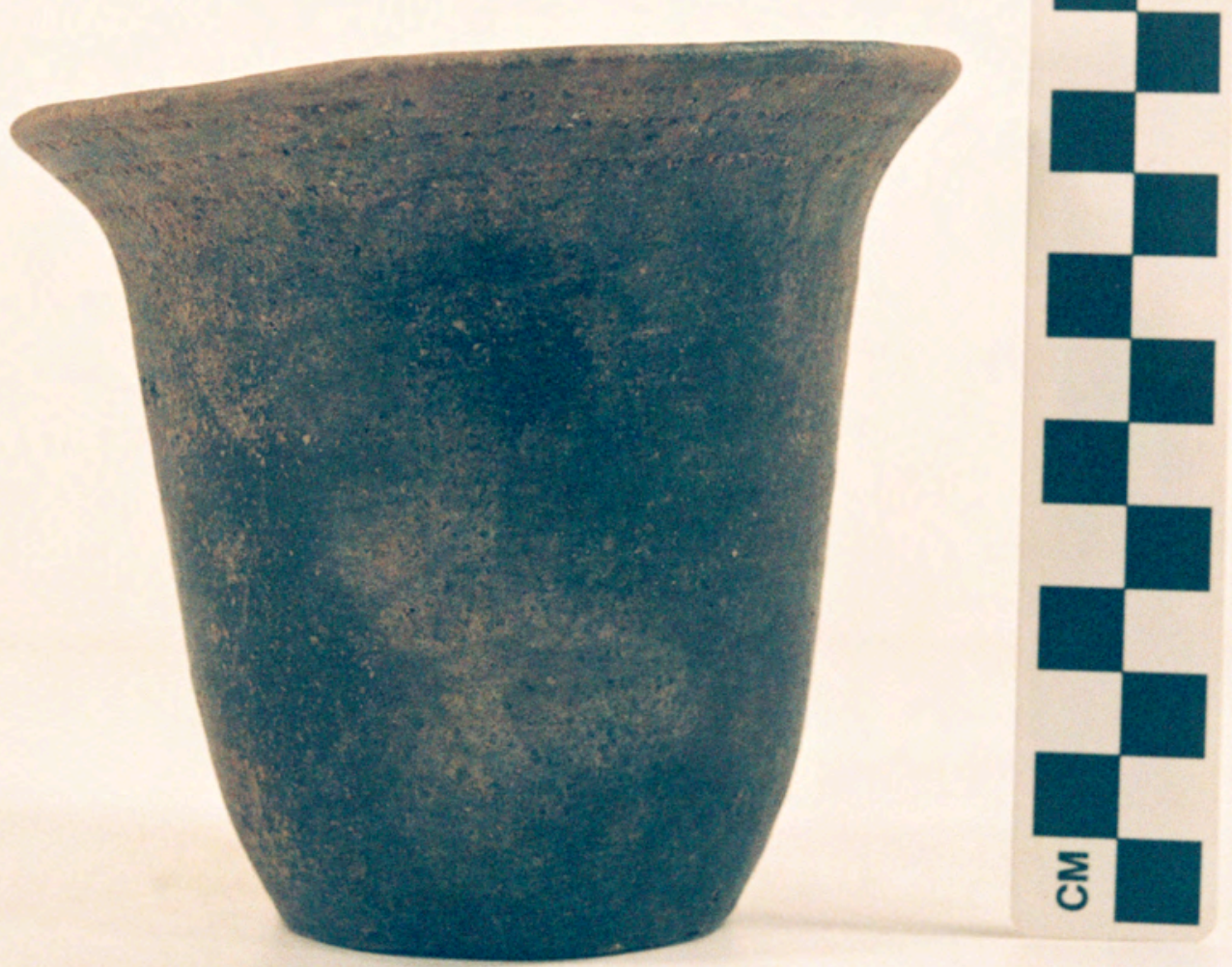

Figure A3-37 


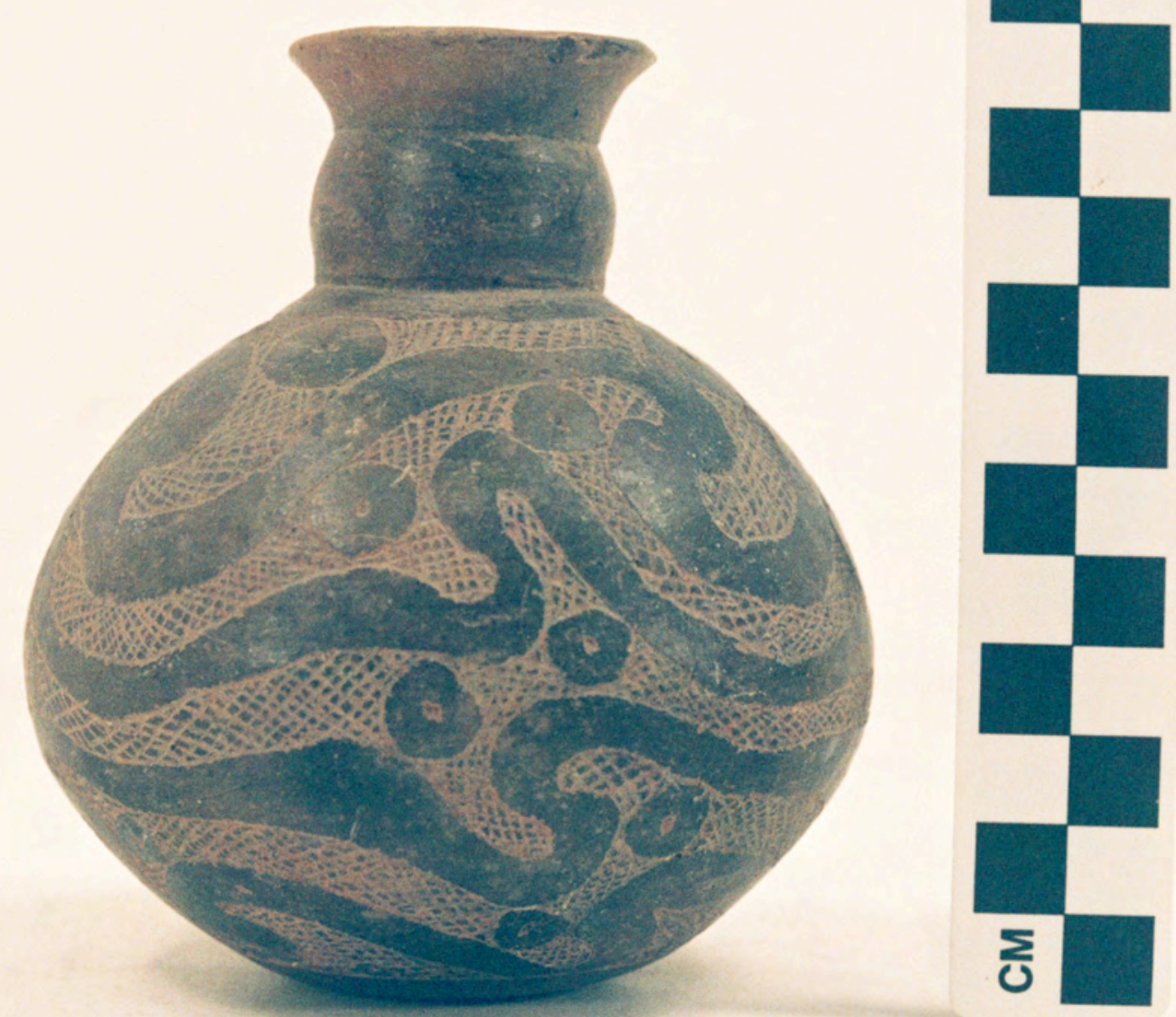

Figure A3-38 


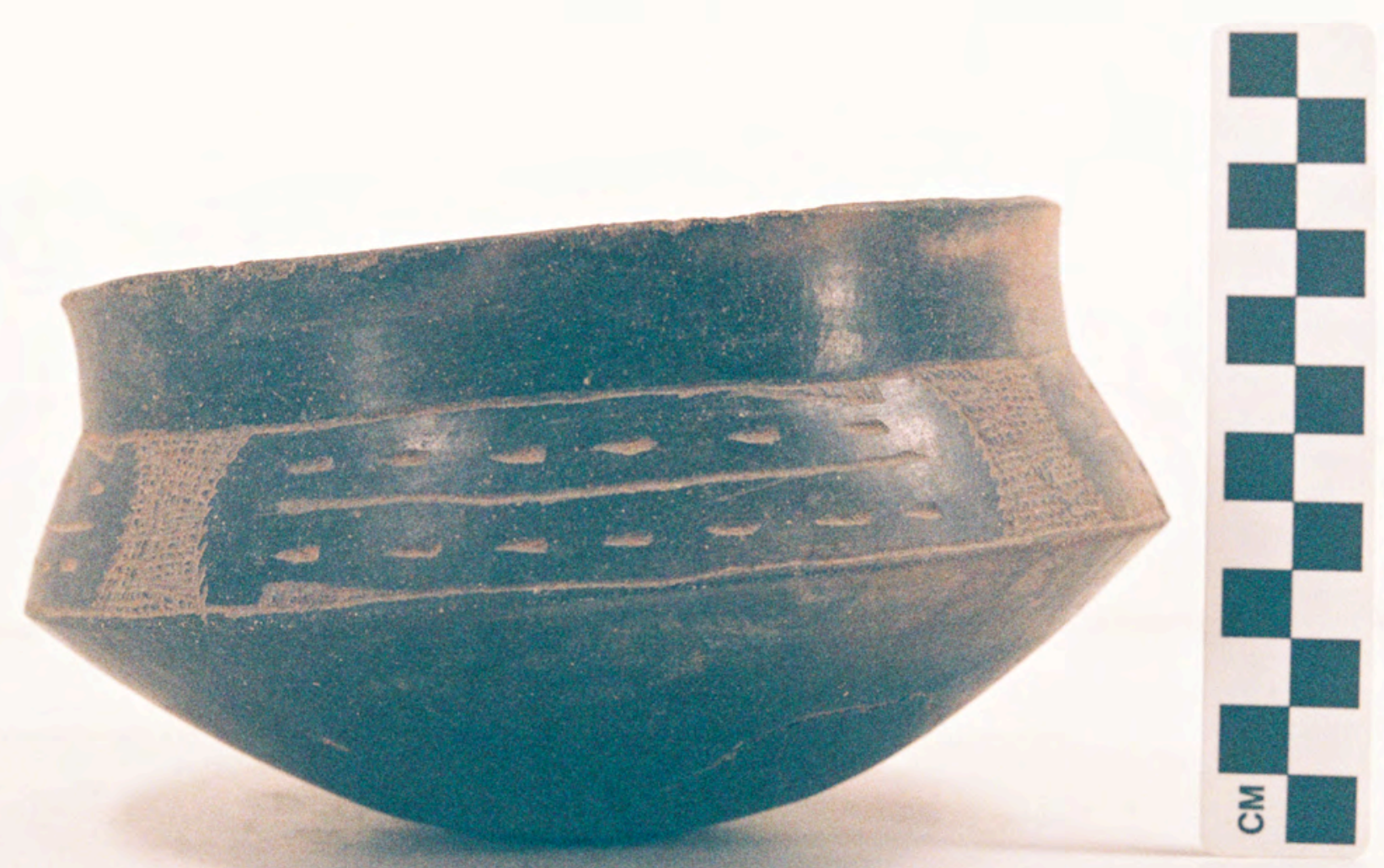

Figure A3-39 

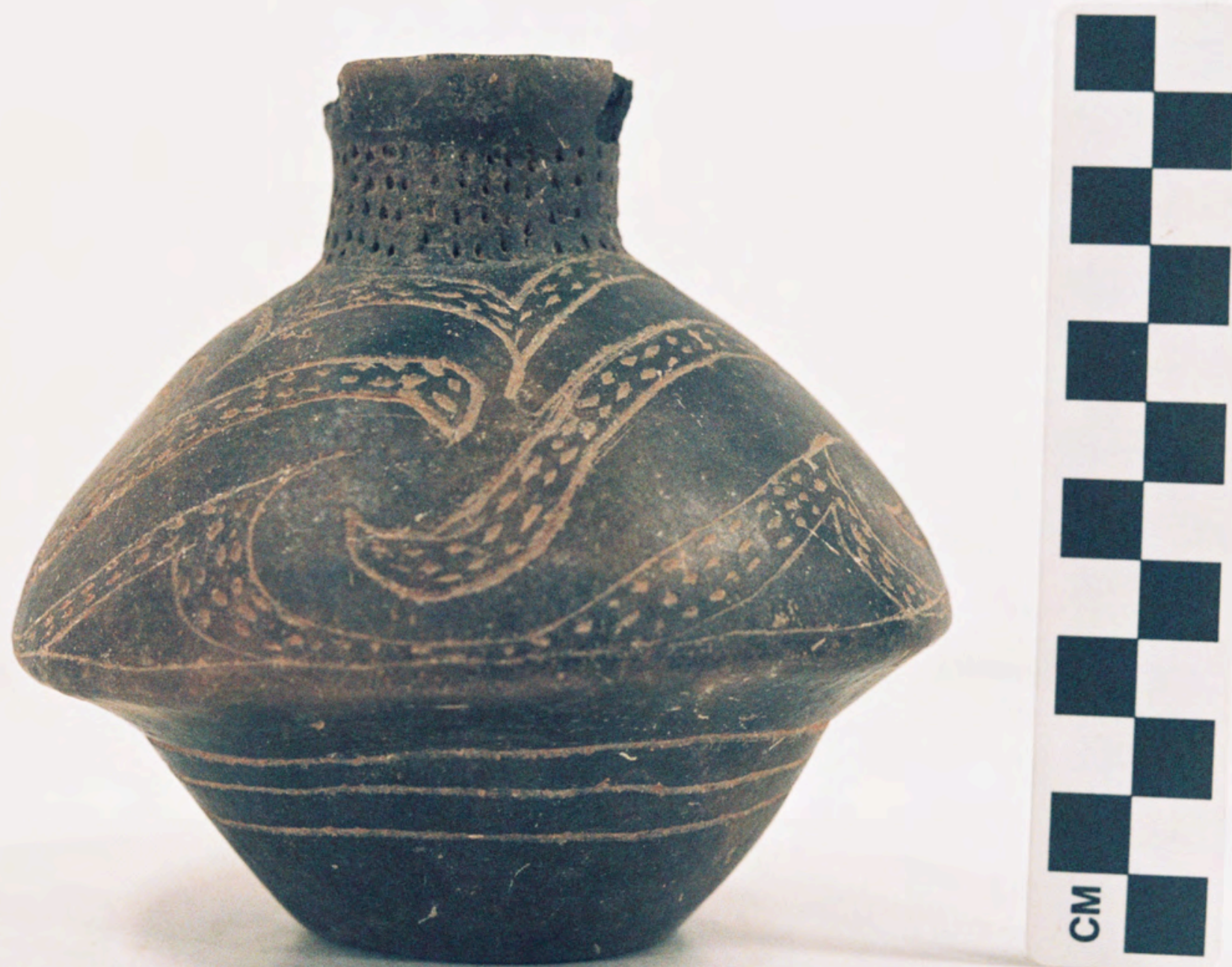

Figure A3-40a 


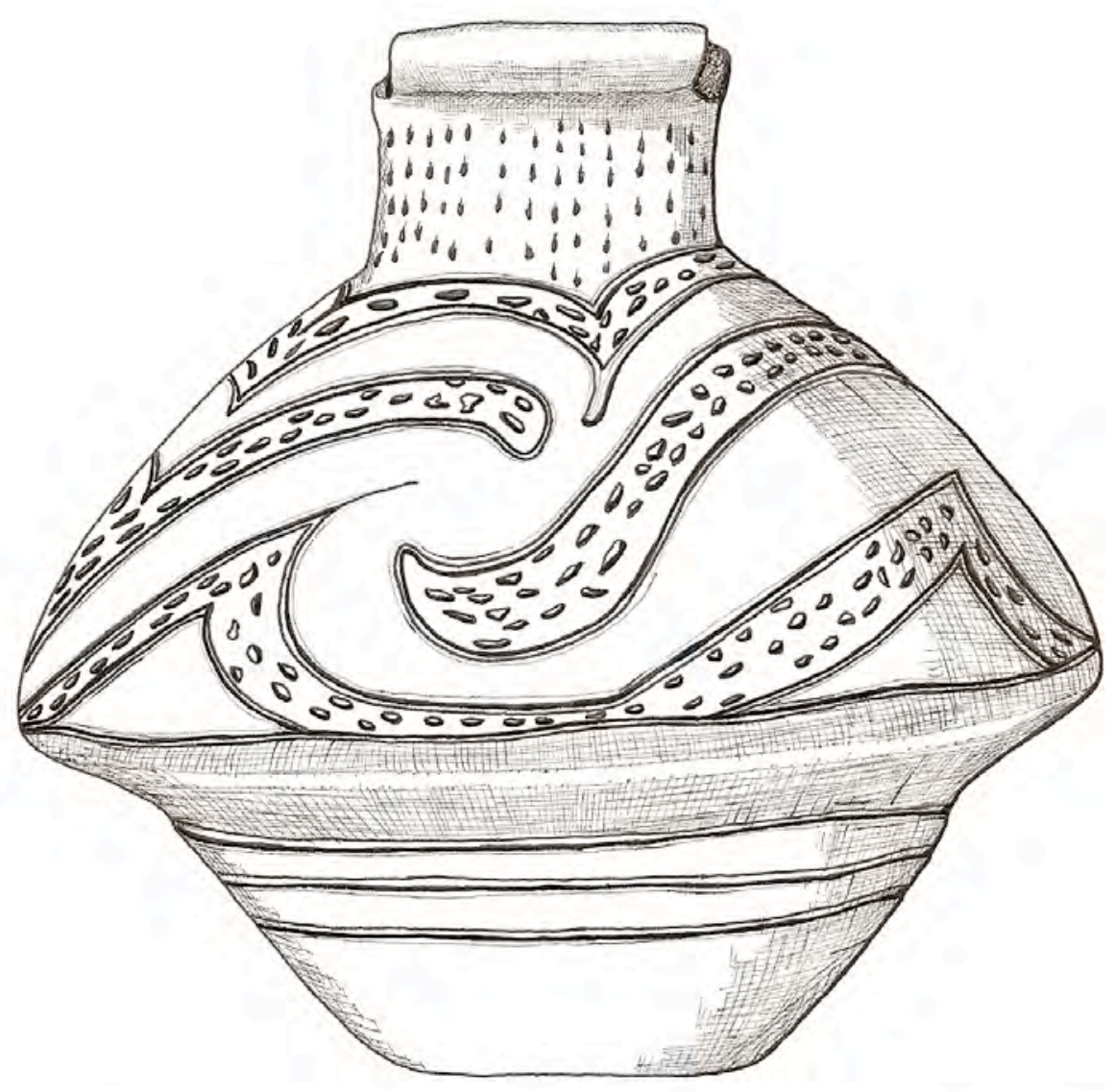

Figure A 3-40. Engraved and punctated bottle (5425-965) b, drawing by Bobby Gonzalez.

Figure A3-40b 


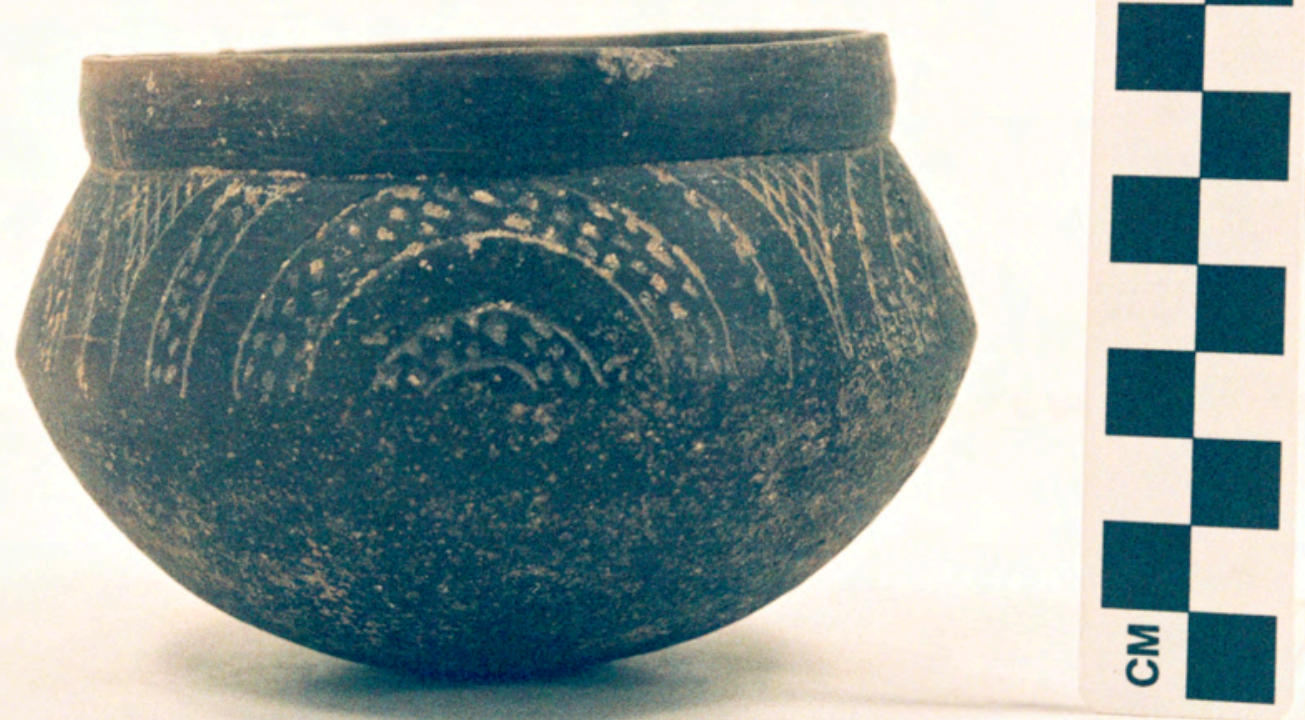

Figure A3-41 


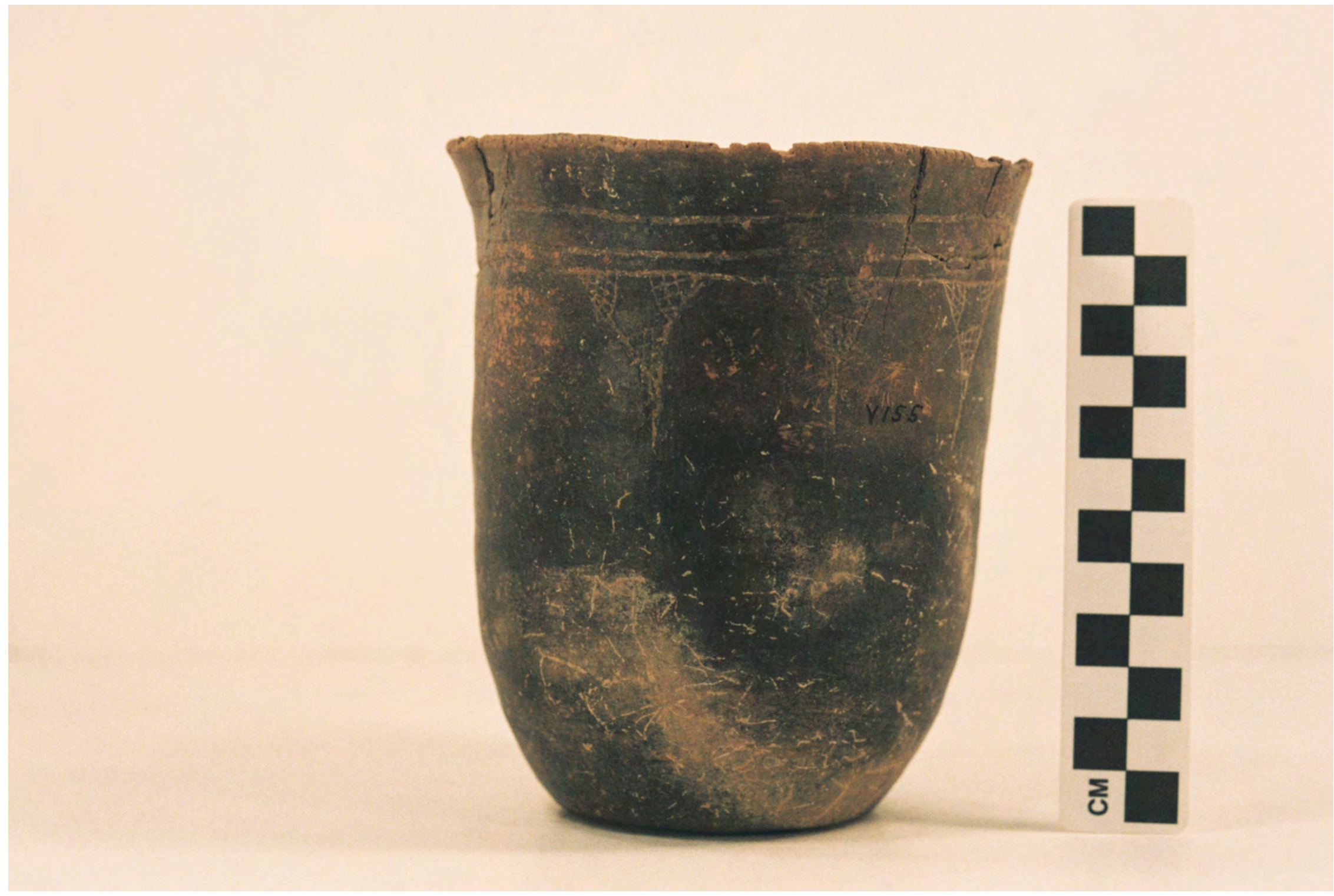

Figure A3-42 


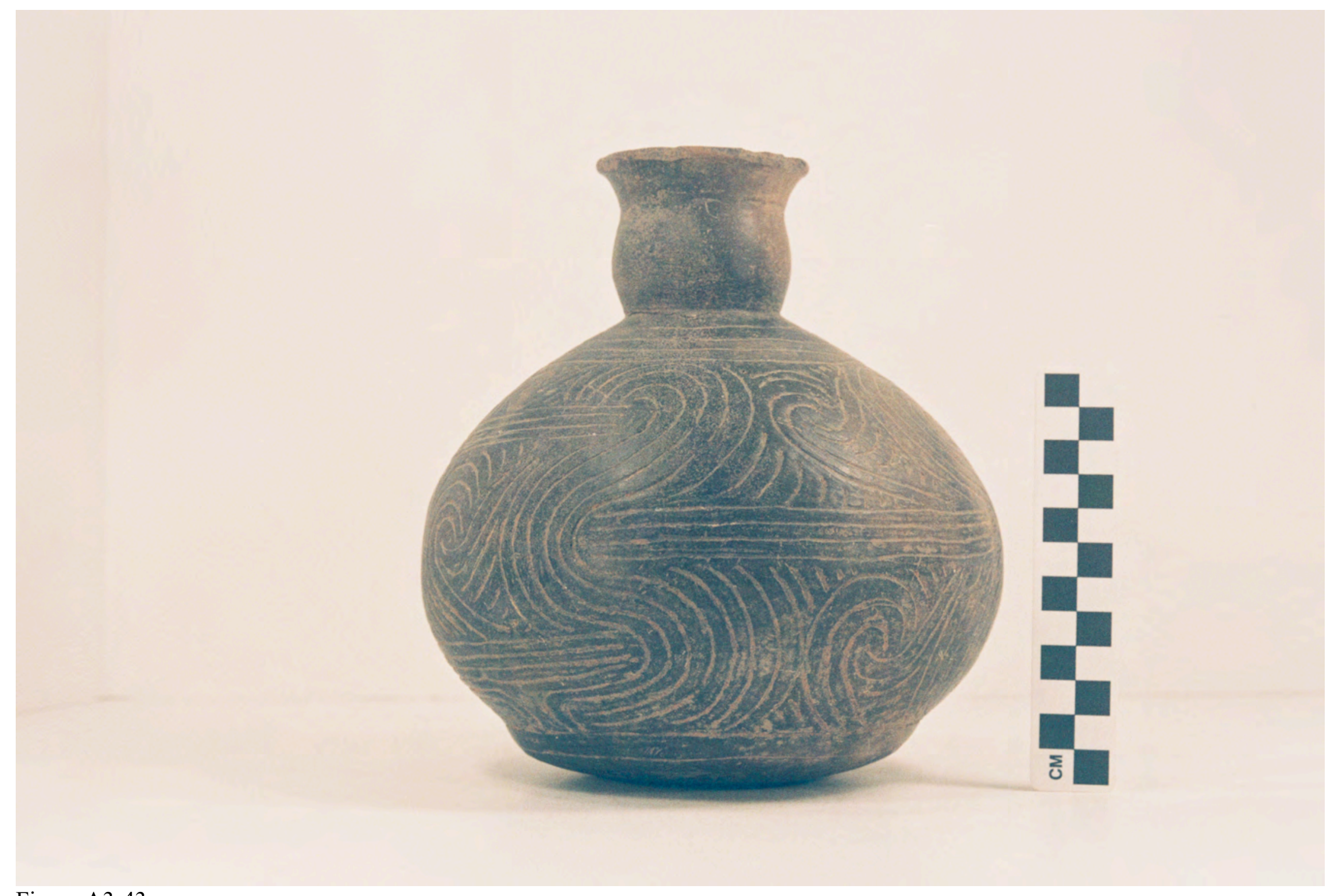

Figure A3-43 


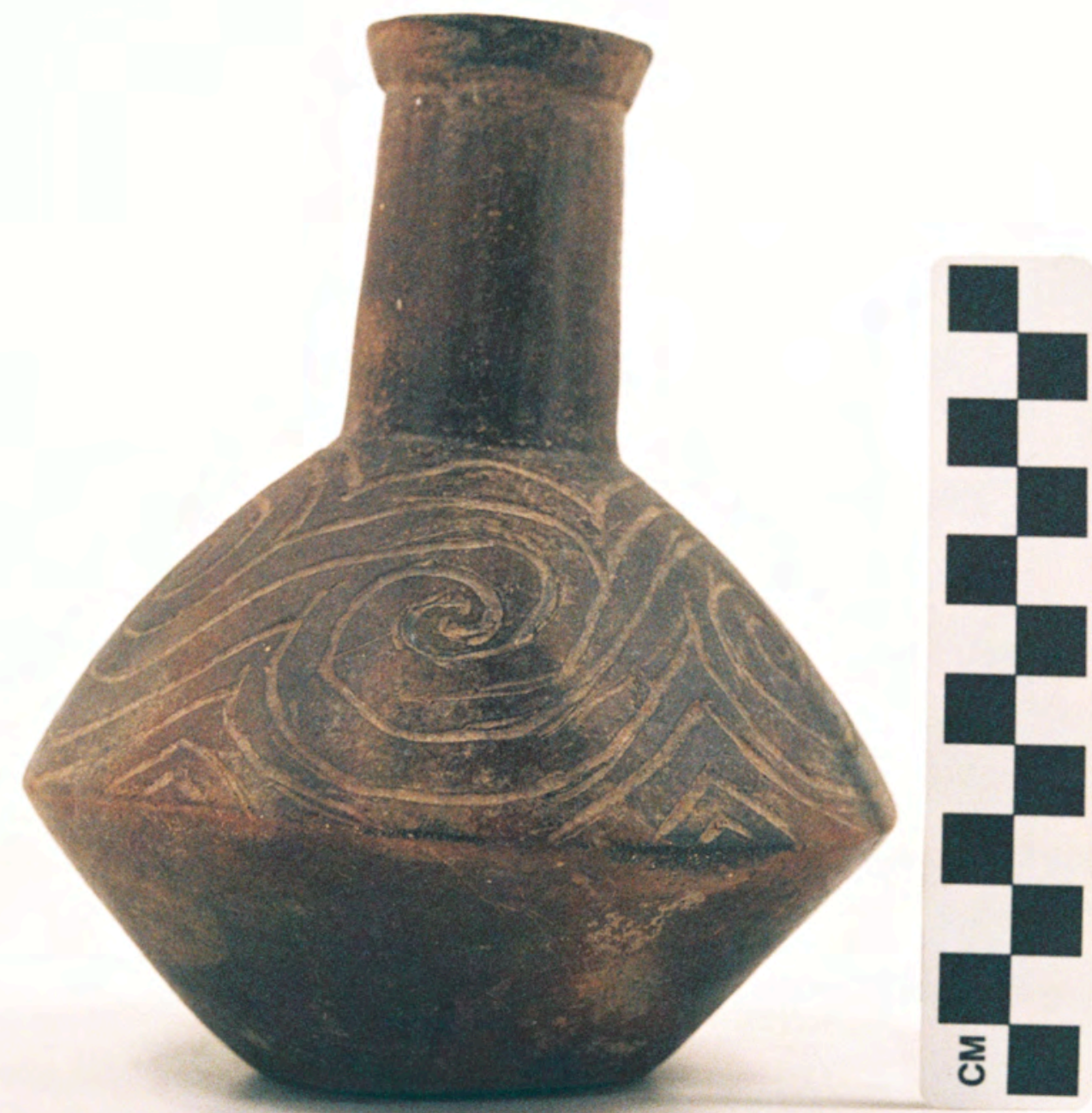

Figure A3-44 


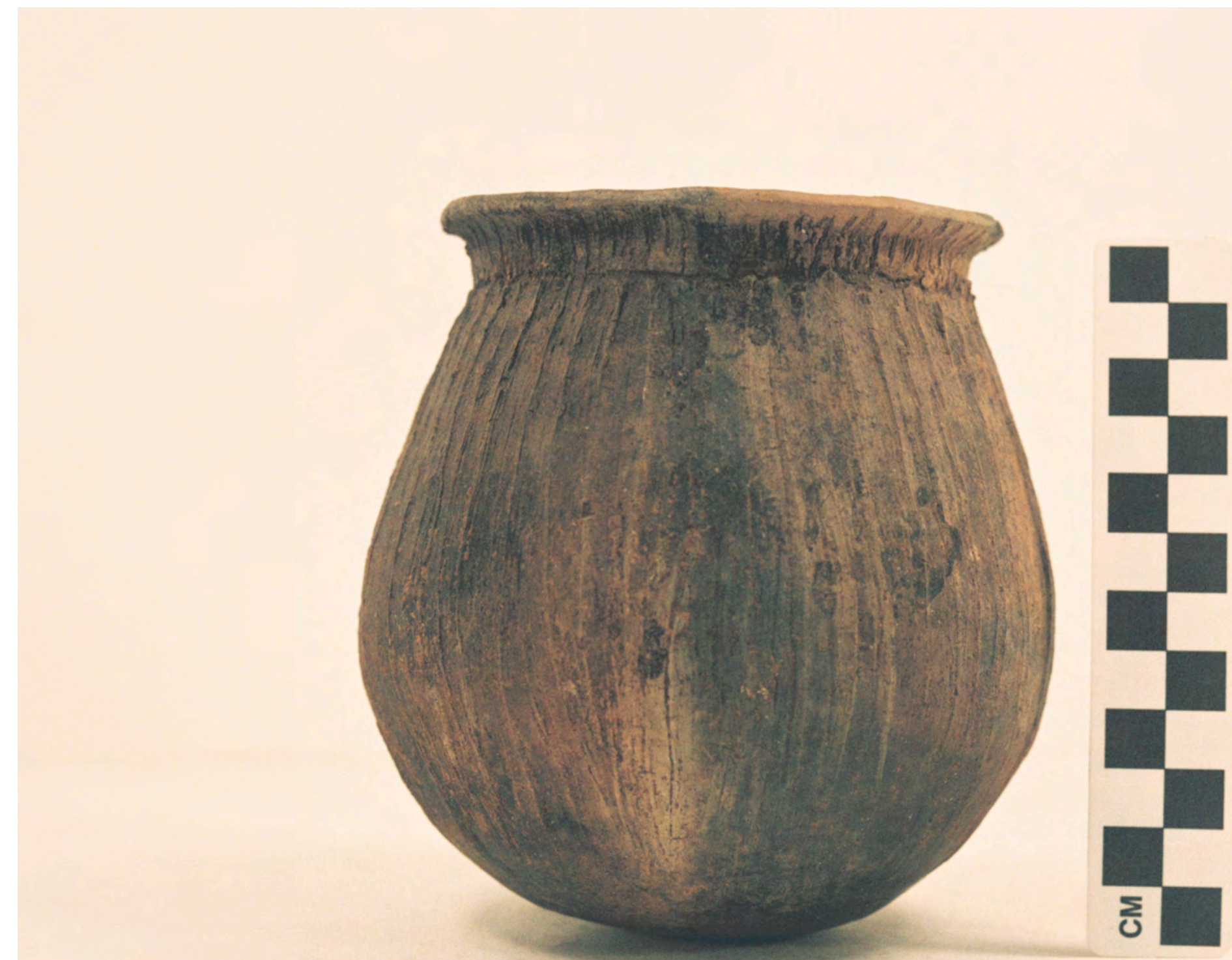

Figure A3-45 


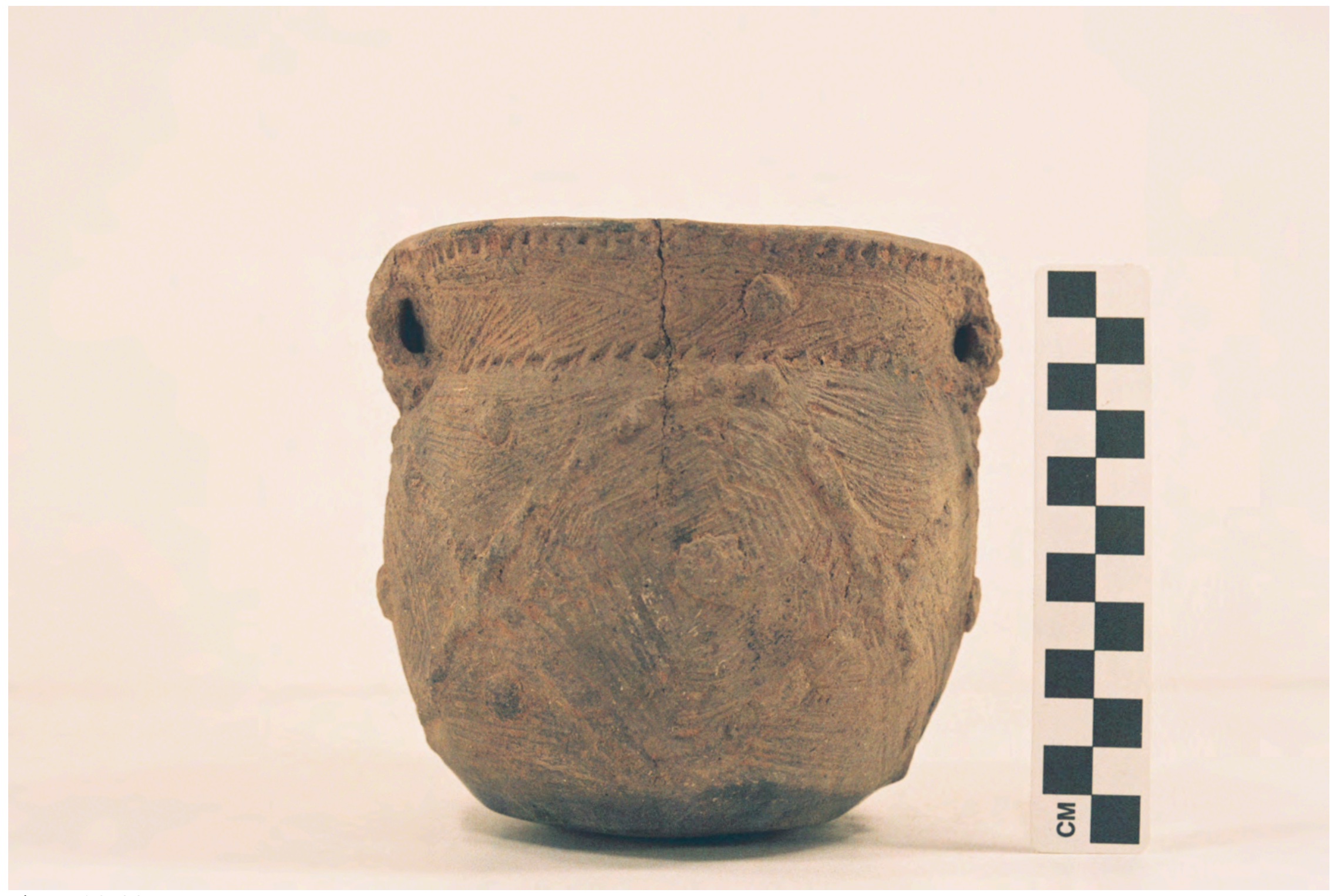

Figure A3-46 


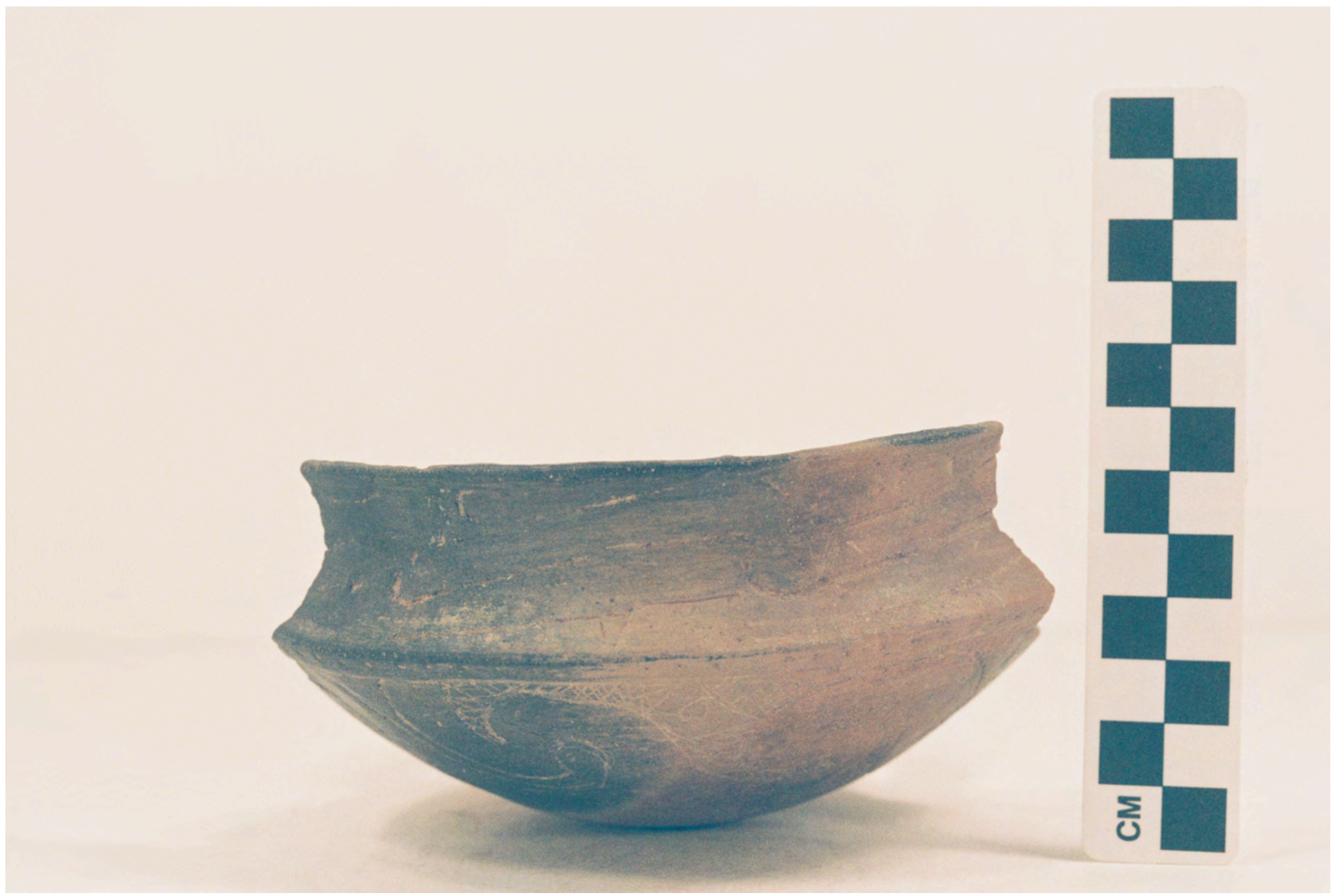

Figure A3-47 


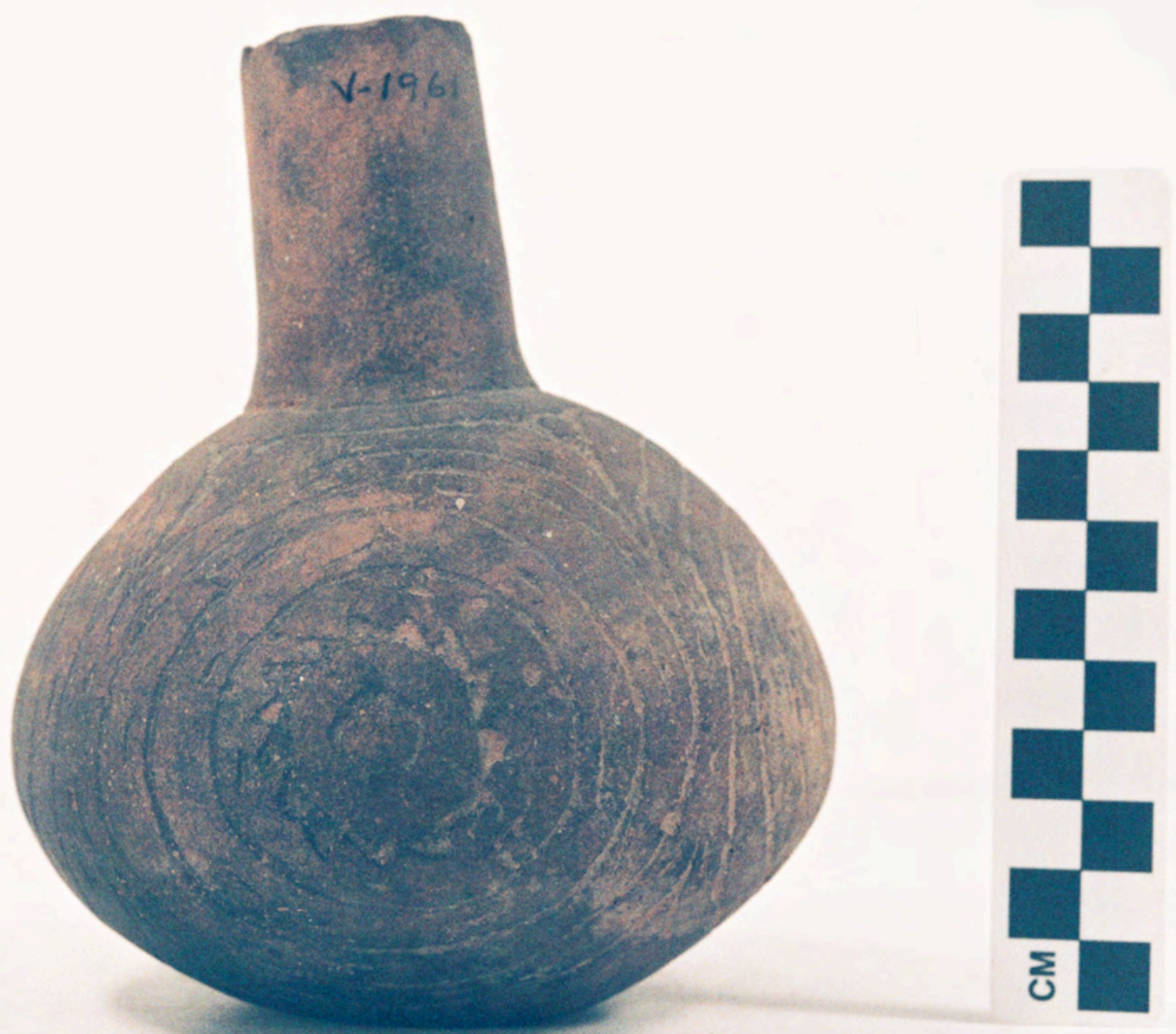

Figure A4-1 


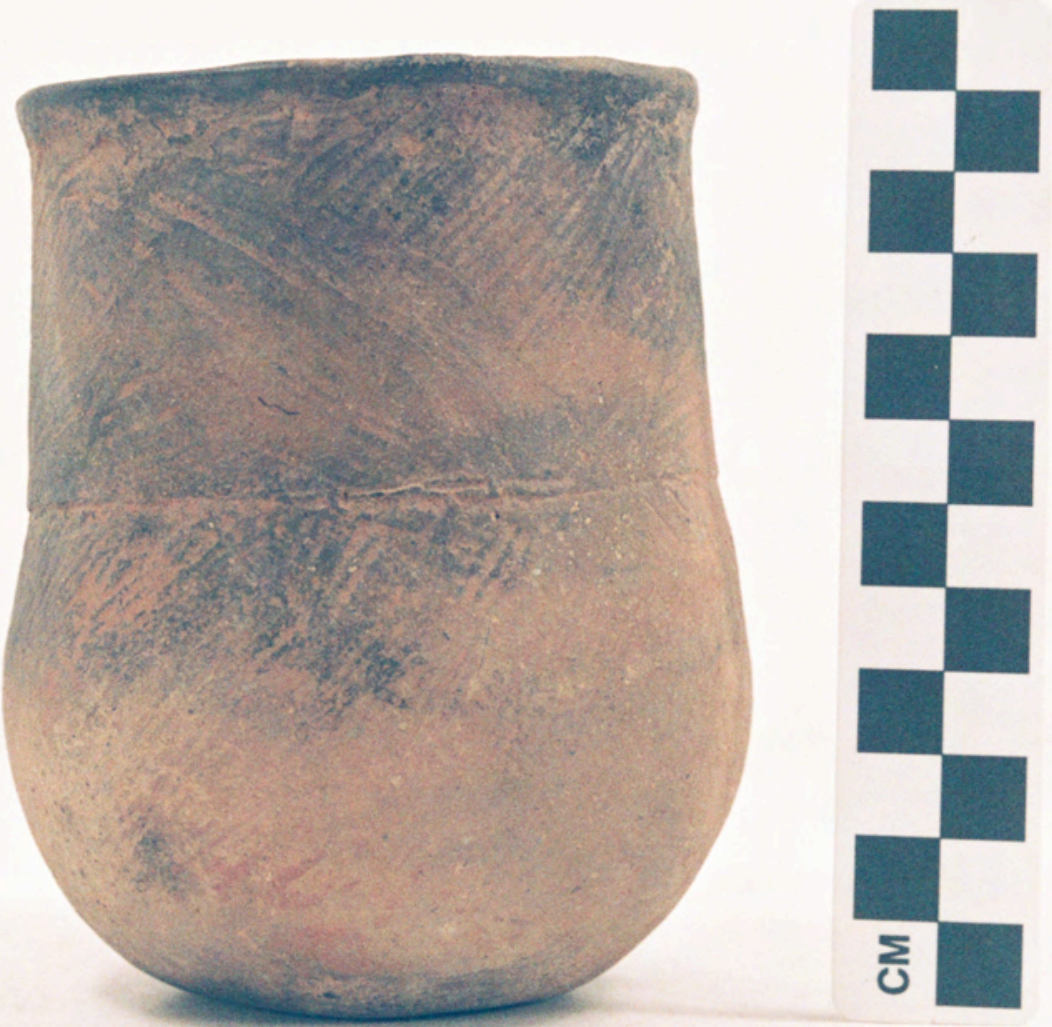

Figure A4-2 


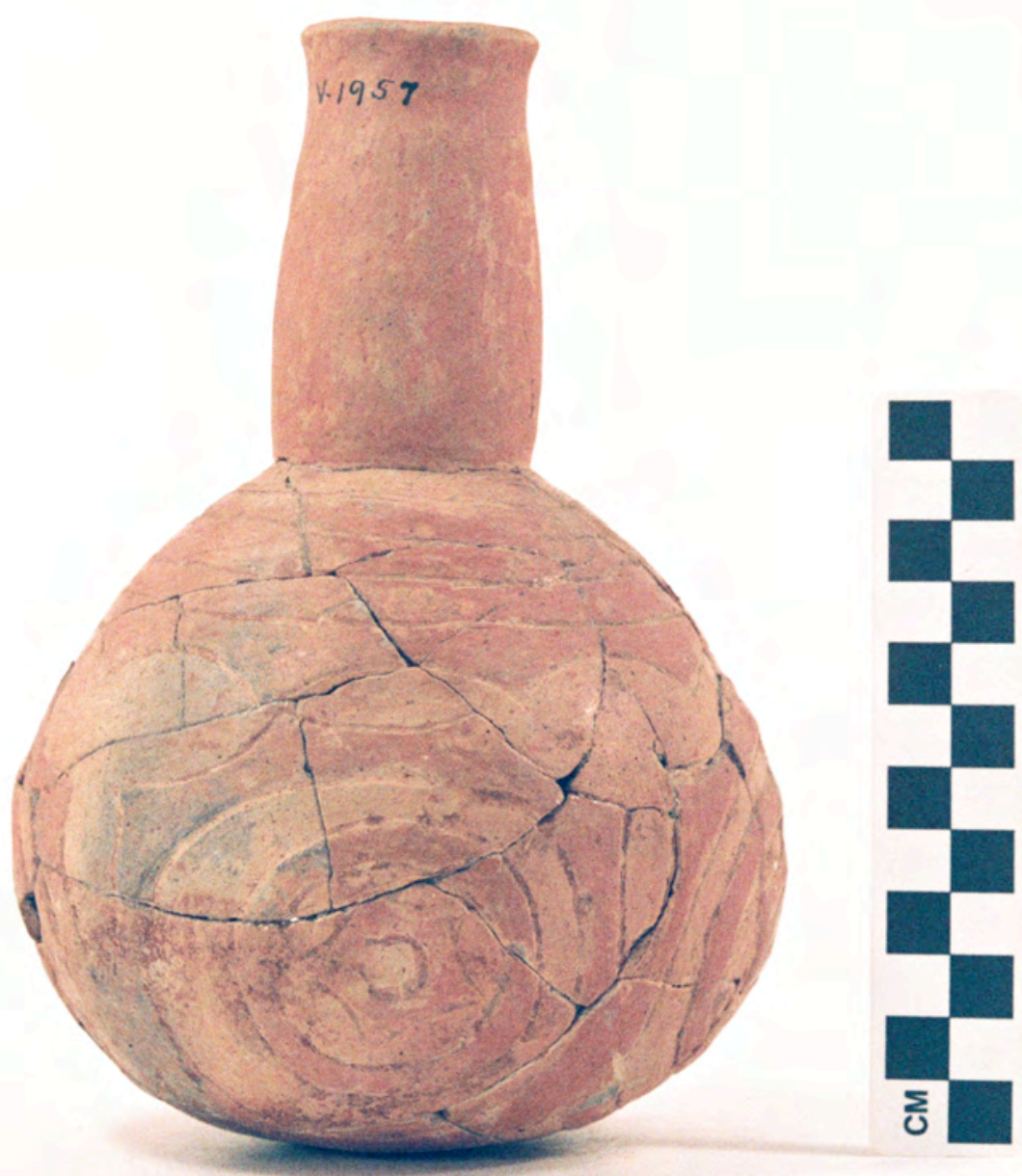

Figure A4-3 


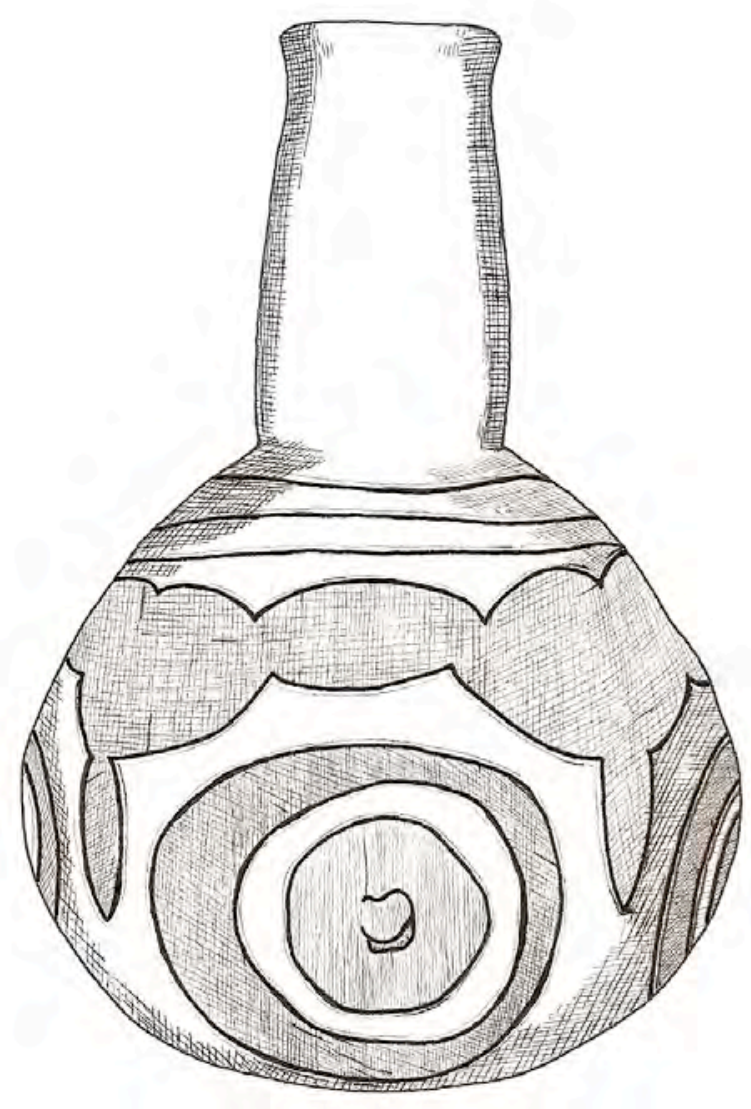

Figure A-4-4. Hatina Engraved bottle from the Foster Place (5425-2136). Drawing by Bobby Gonzalez.

Figure A4-4 


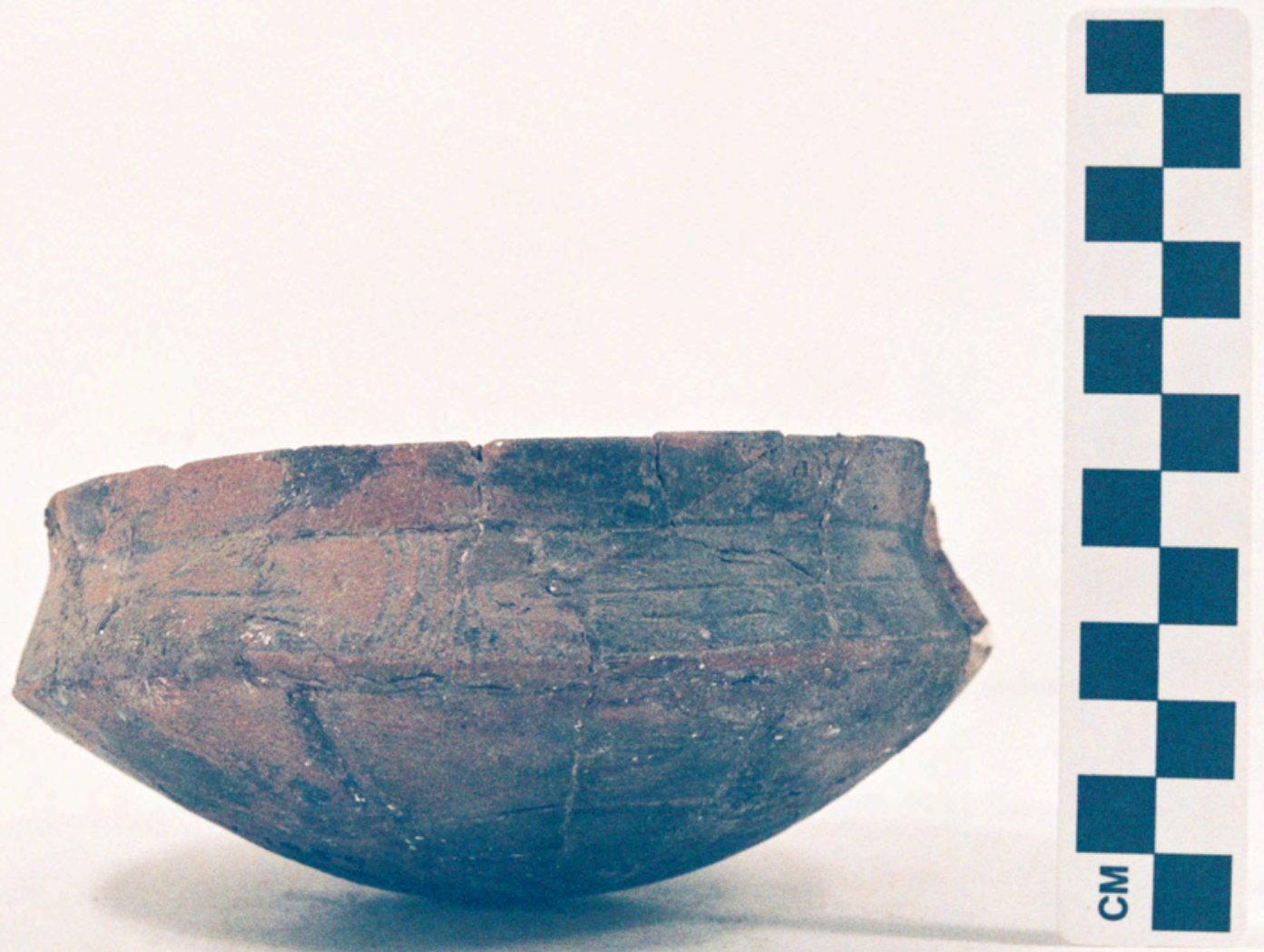

Figure A4-5 


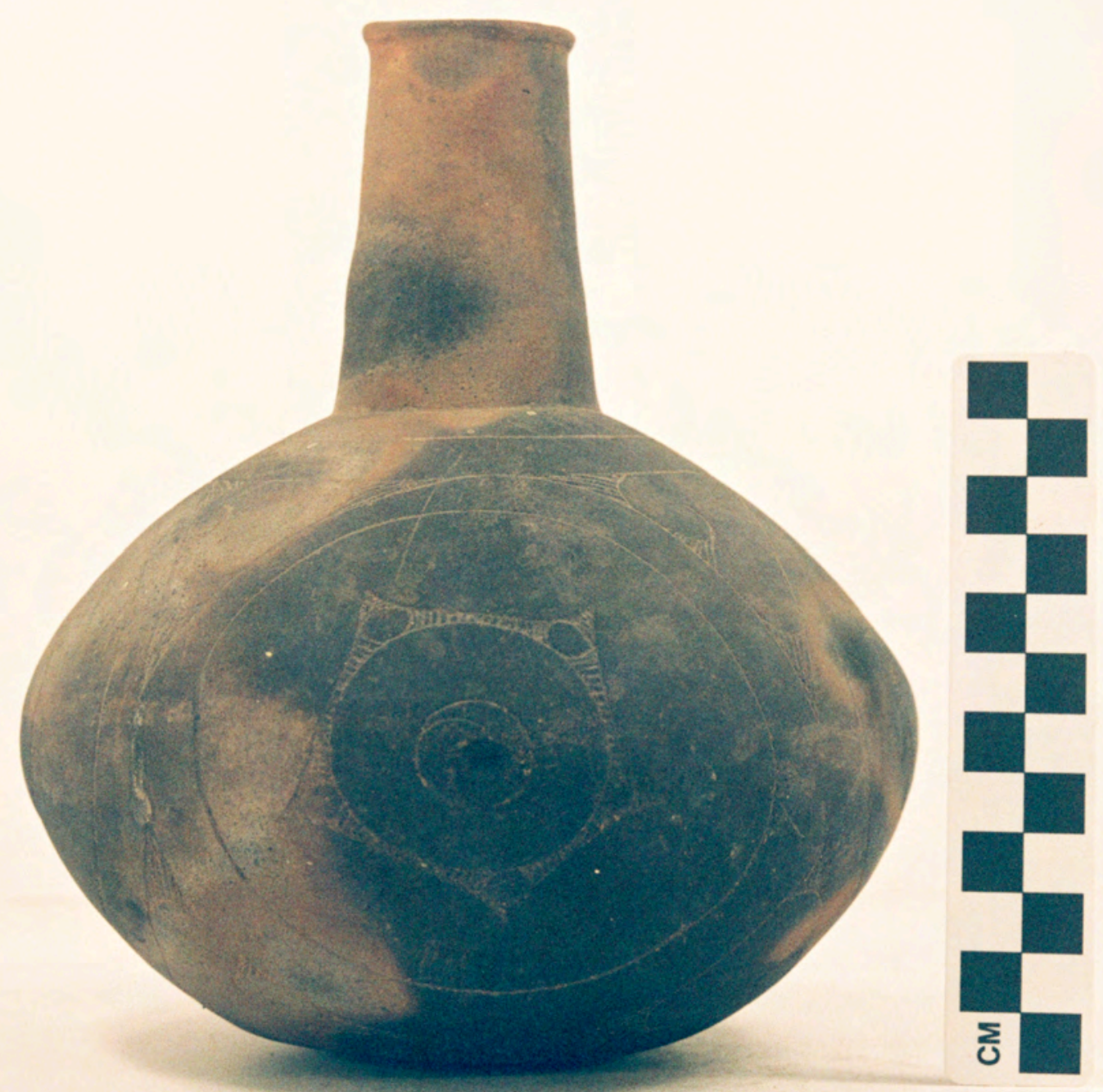

Figure A4-6 


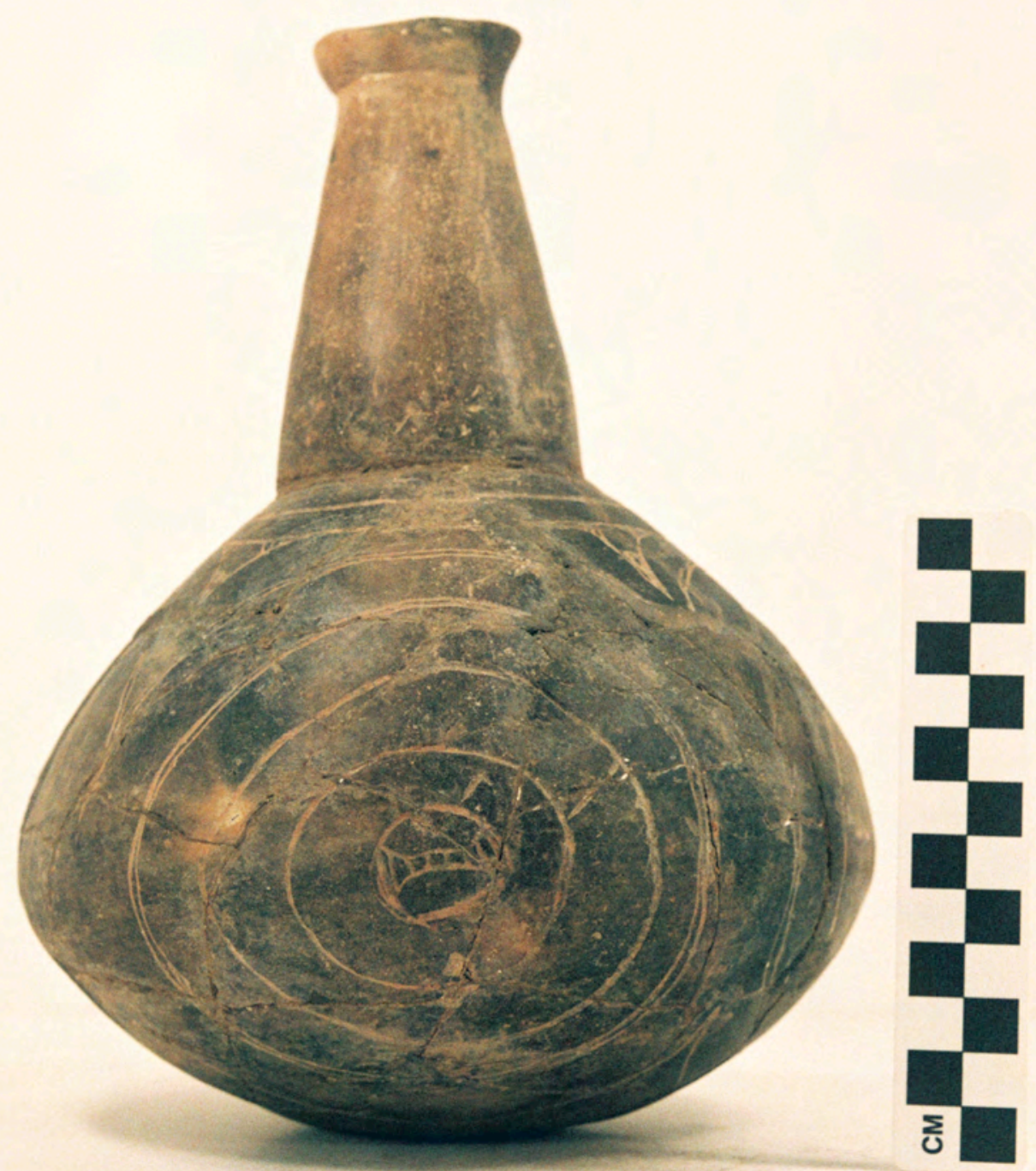

Figure A4-7 


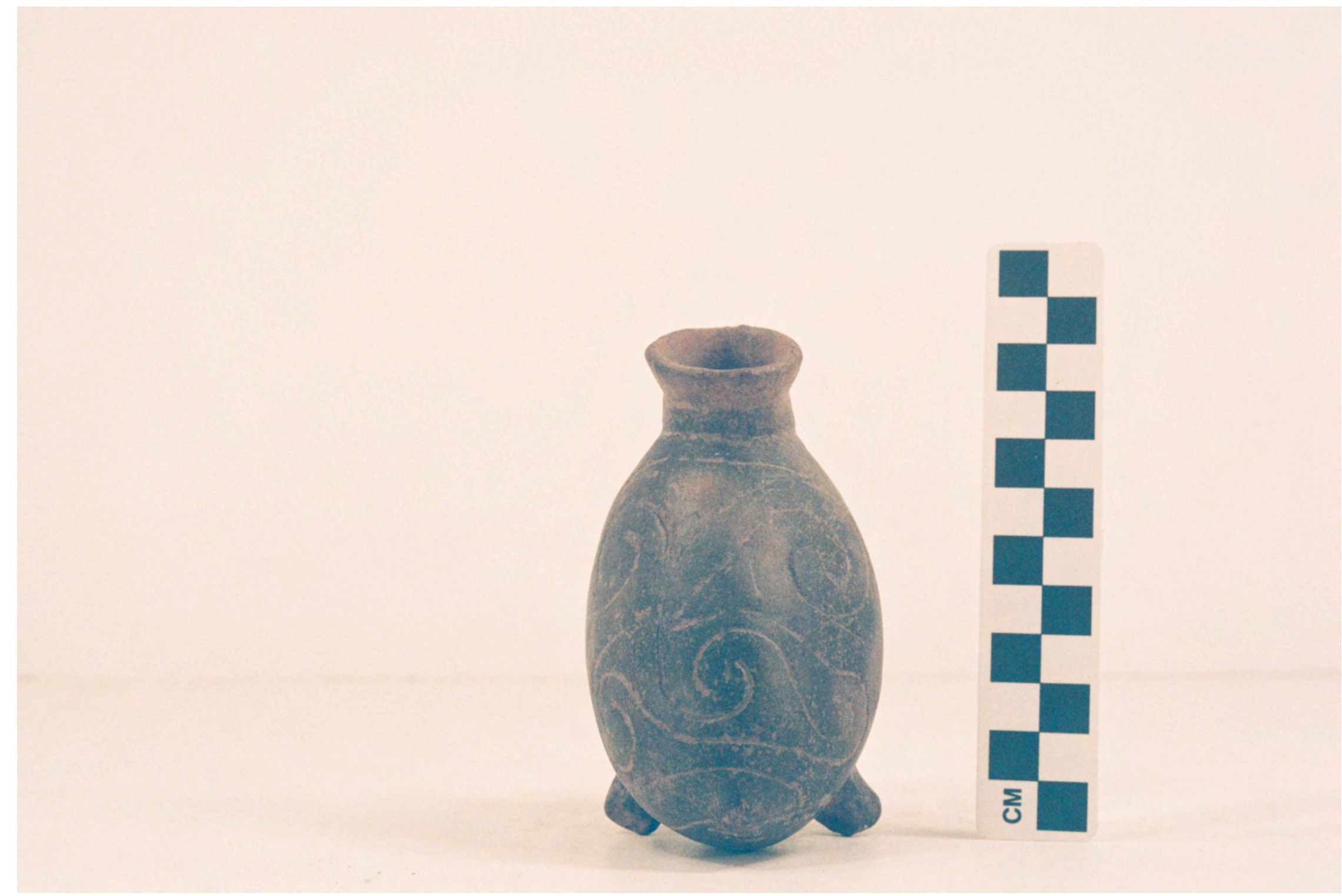

Figure A5-1a 


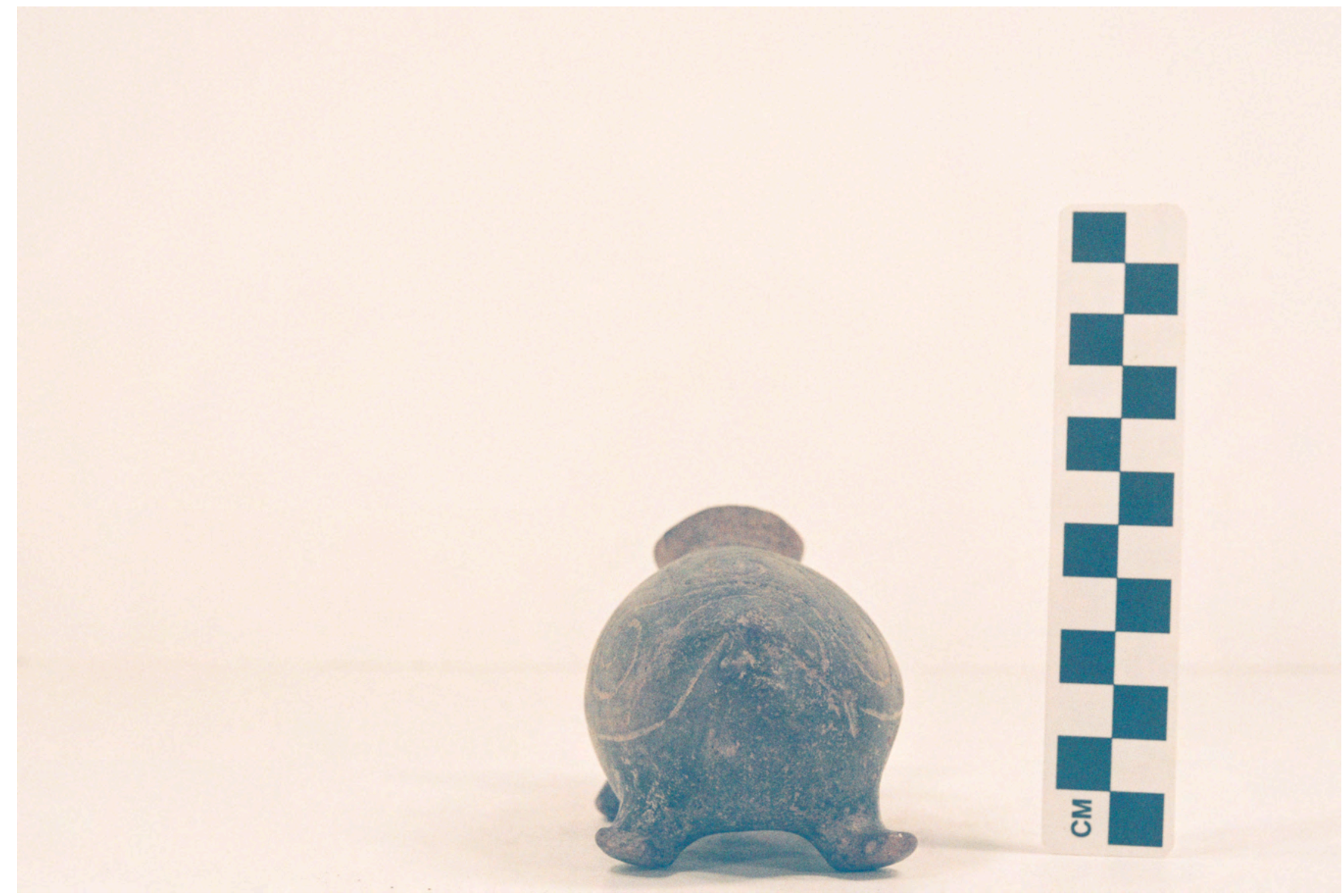

Figure A5-1b 


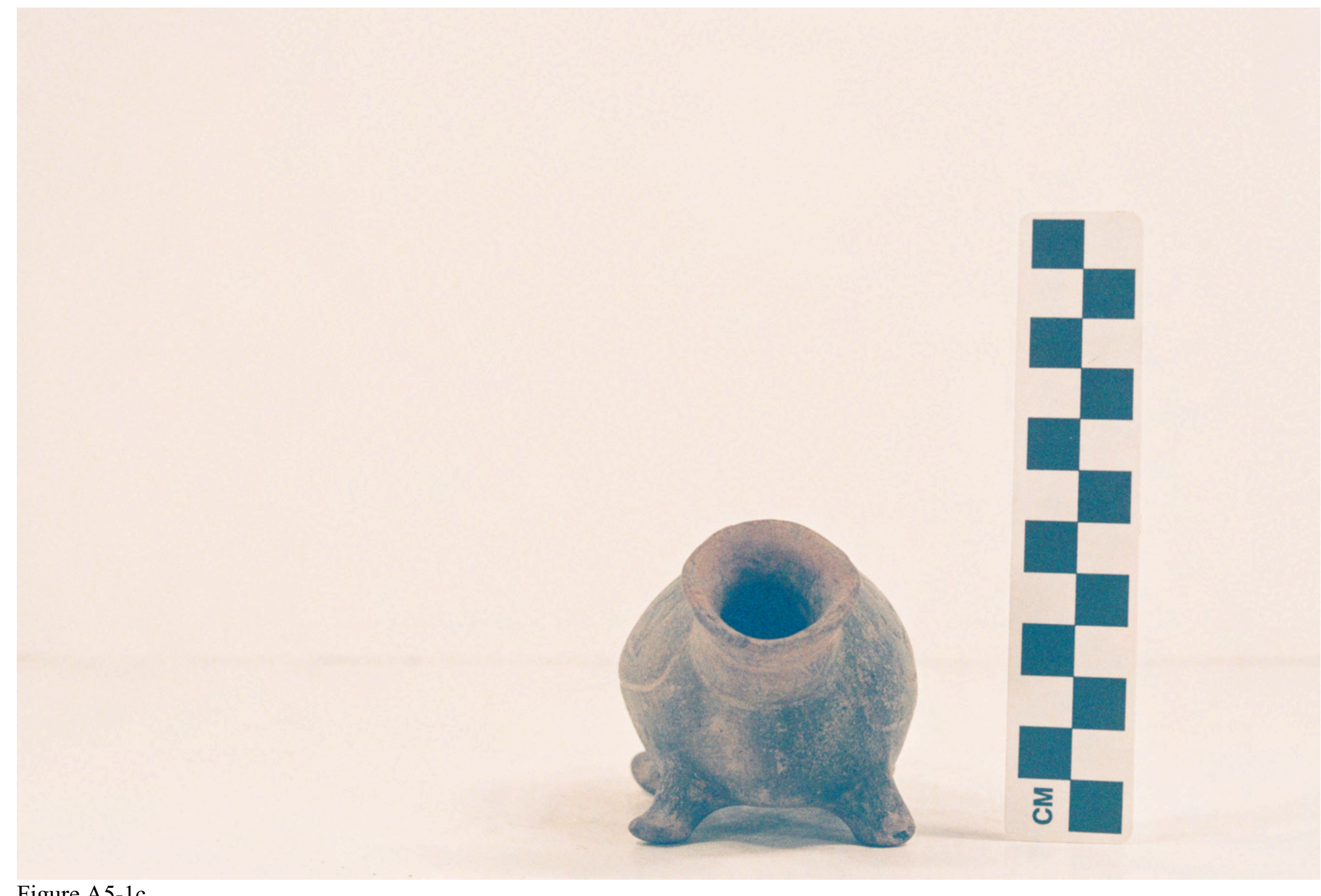

Figure A5-1c 


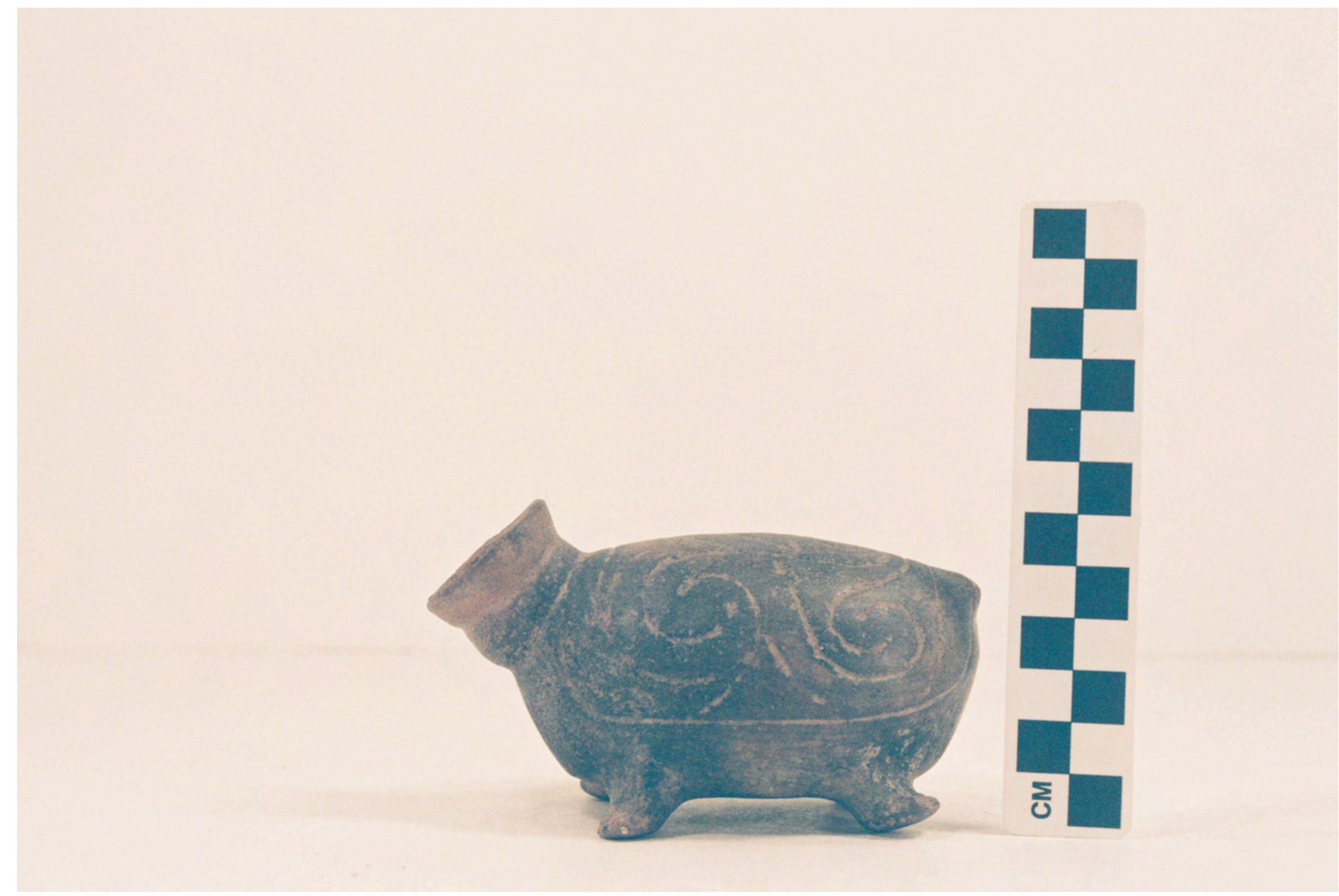

Figure A5-1d 


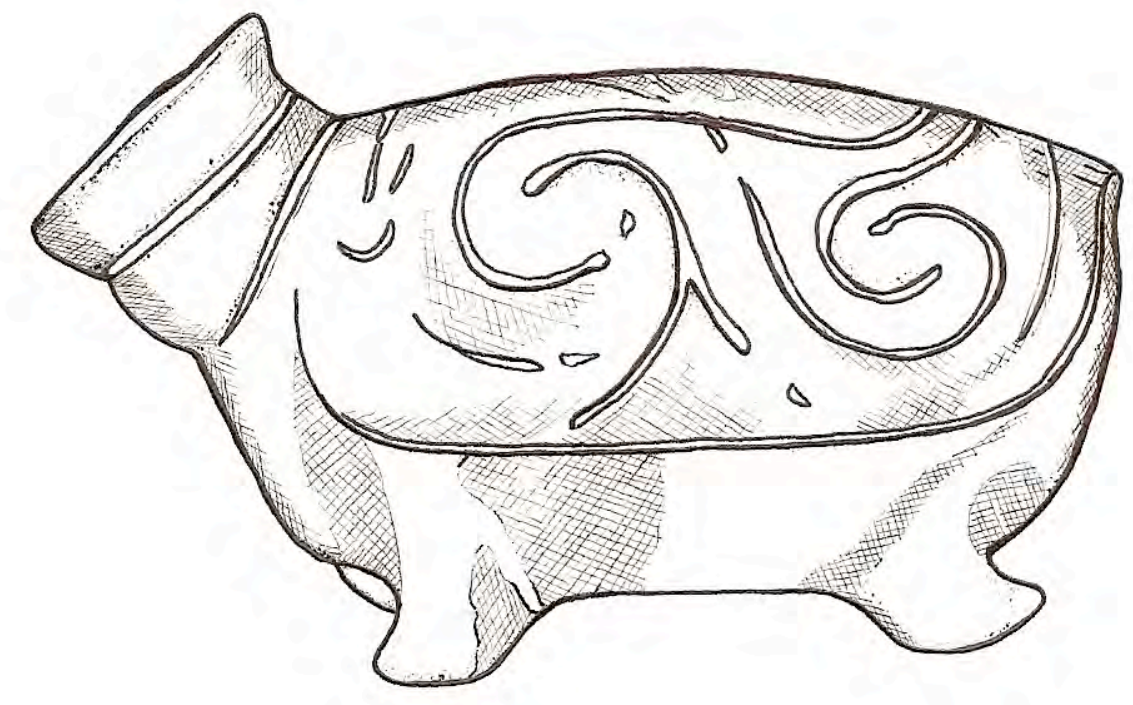

Figure A5-1. Engraved effigy vessel from the George Sentell Place (5425-420): e, drawing by Bobby Gonzalez.

Figure A5-1e 


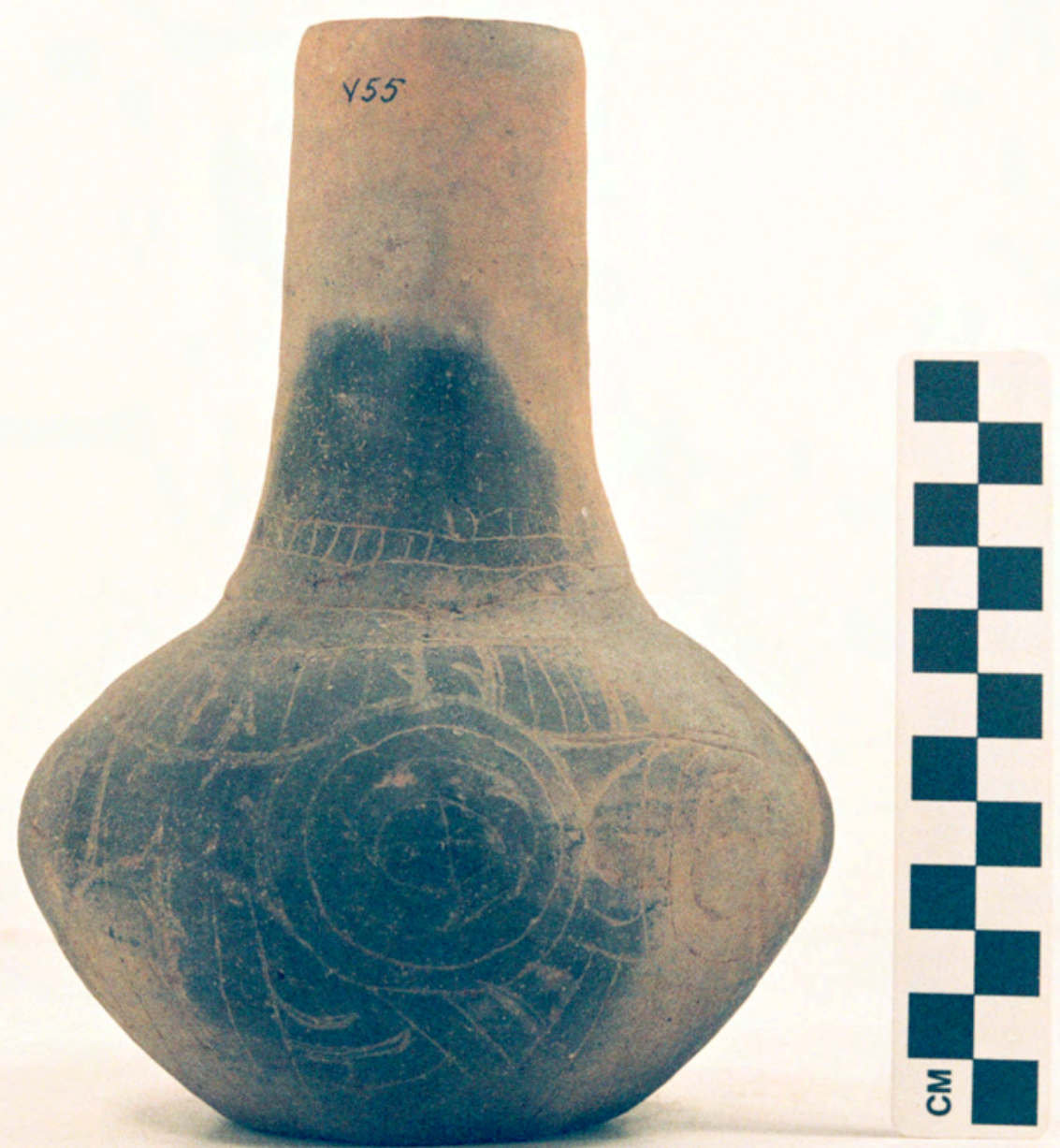

Figure A5-2 


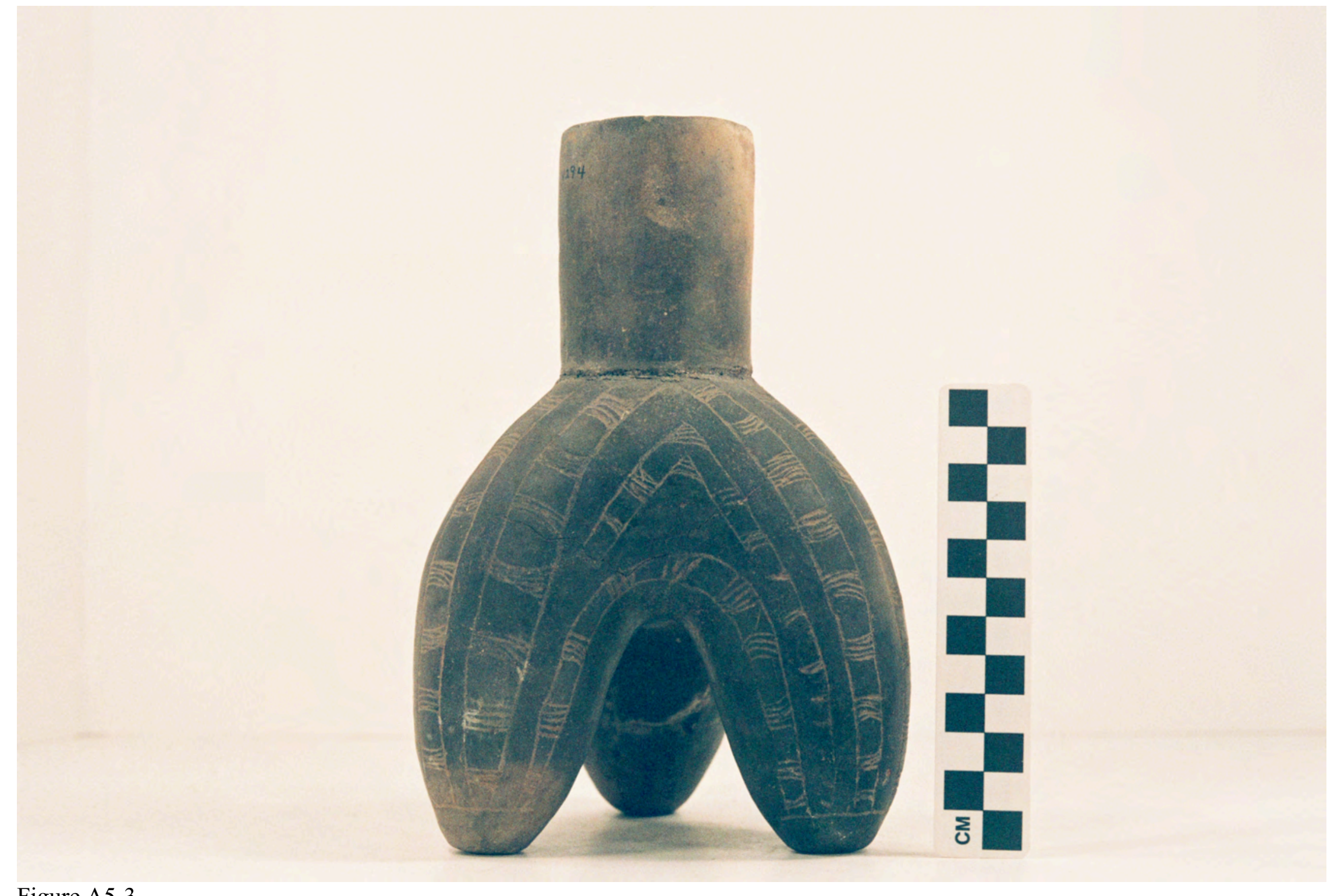

Figure A5-3 


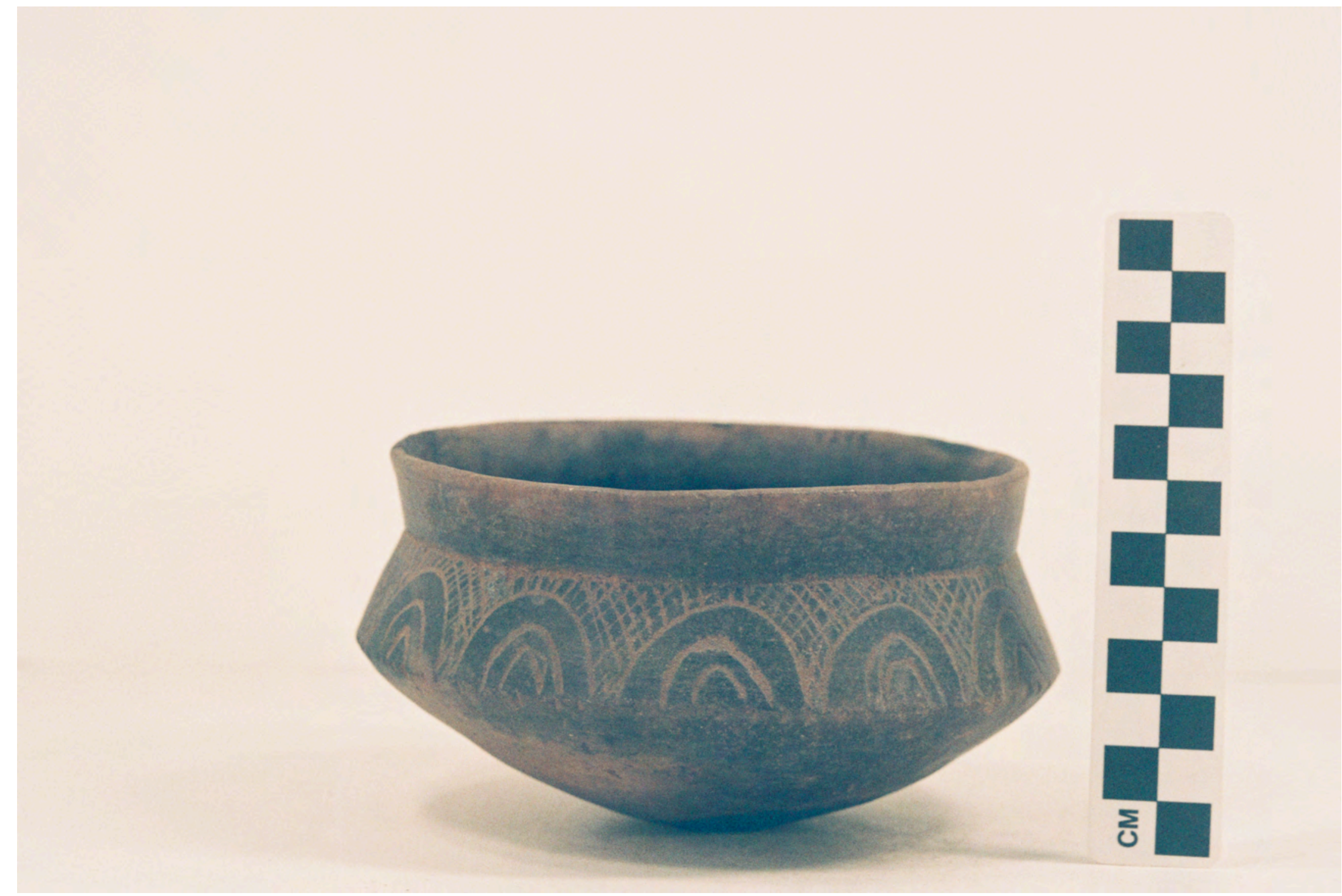

Figure A5-4 


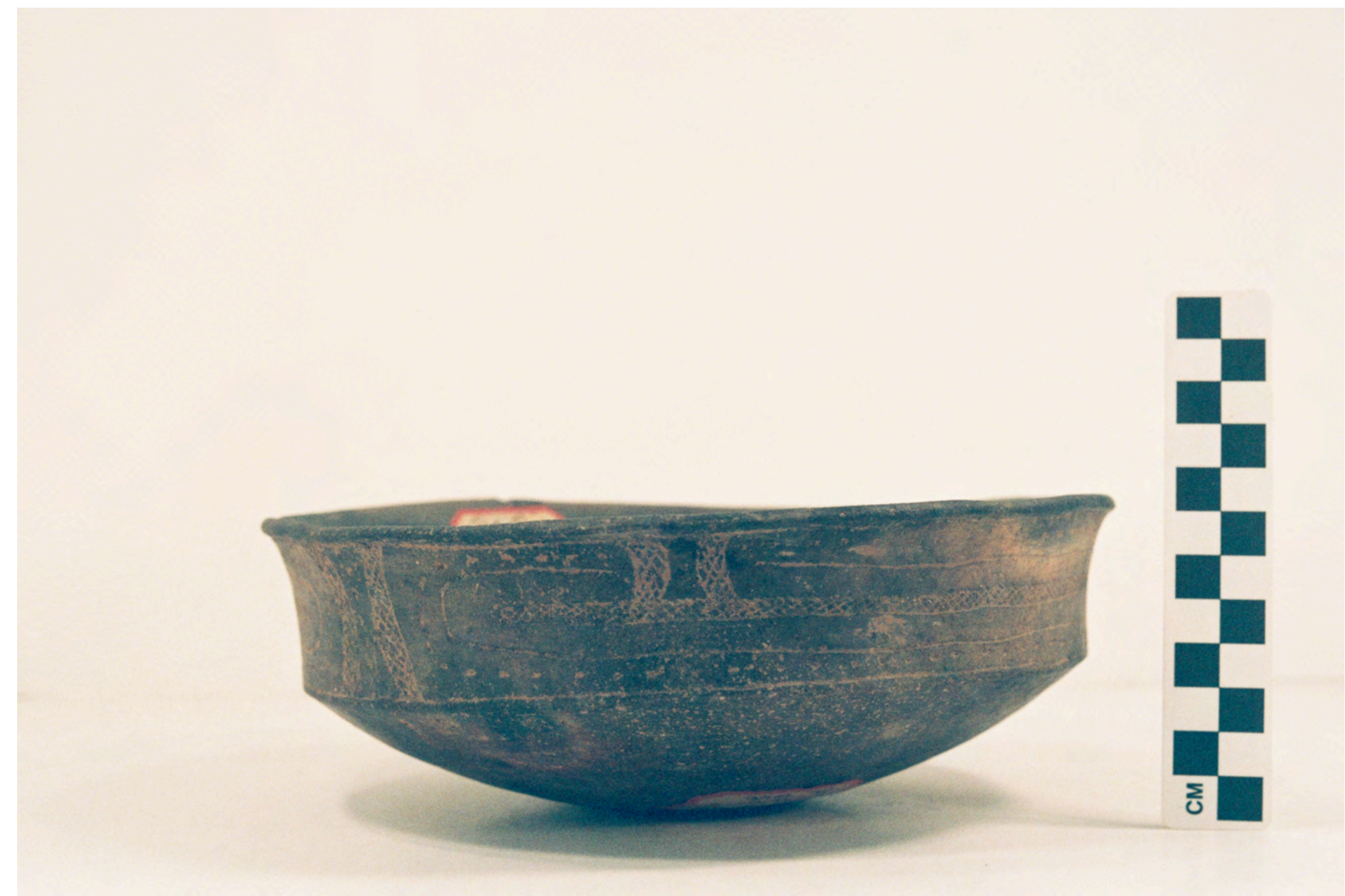

Figure A5-5 


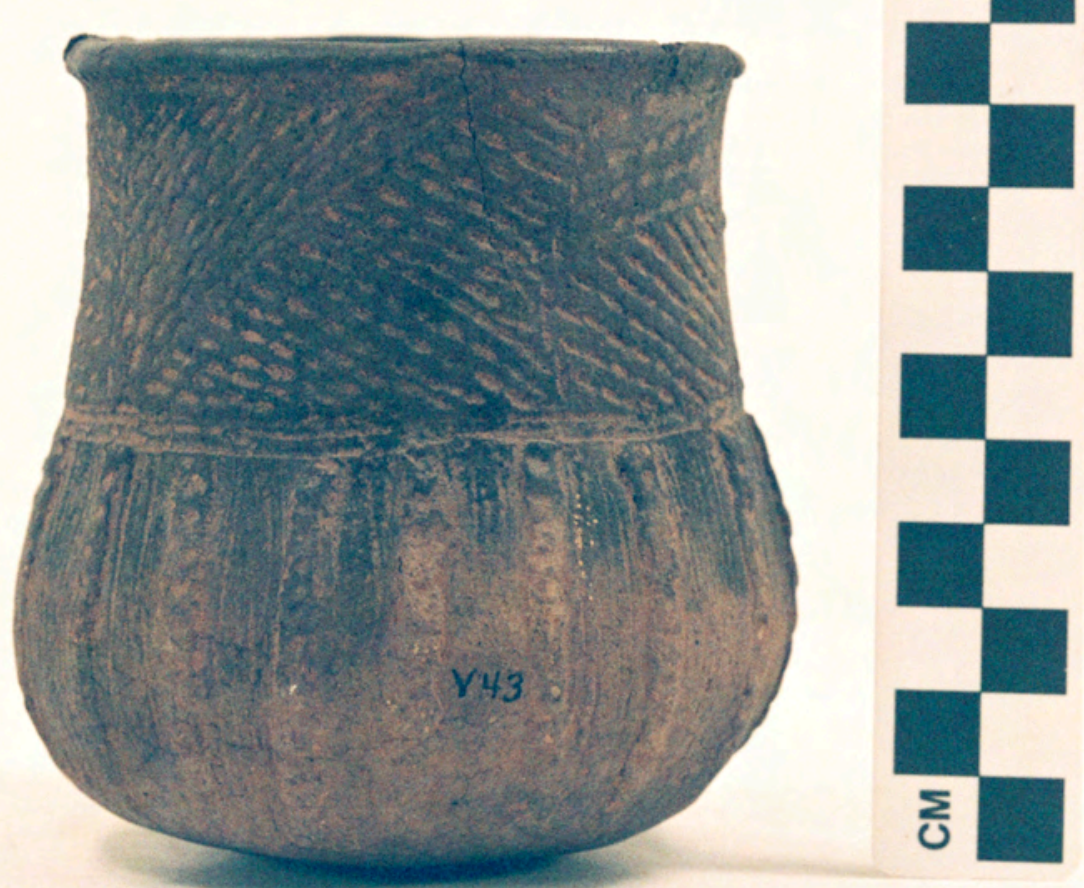

Figure A5-6 


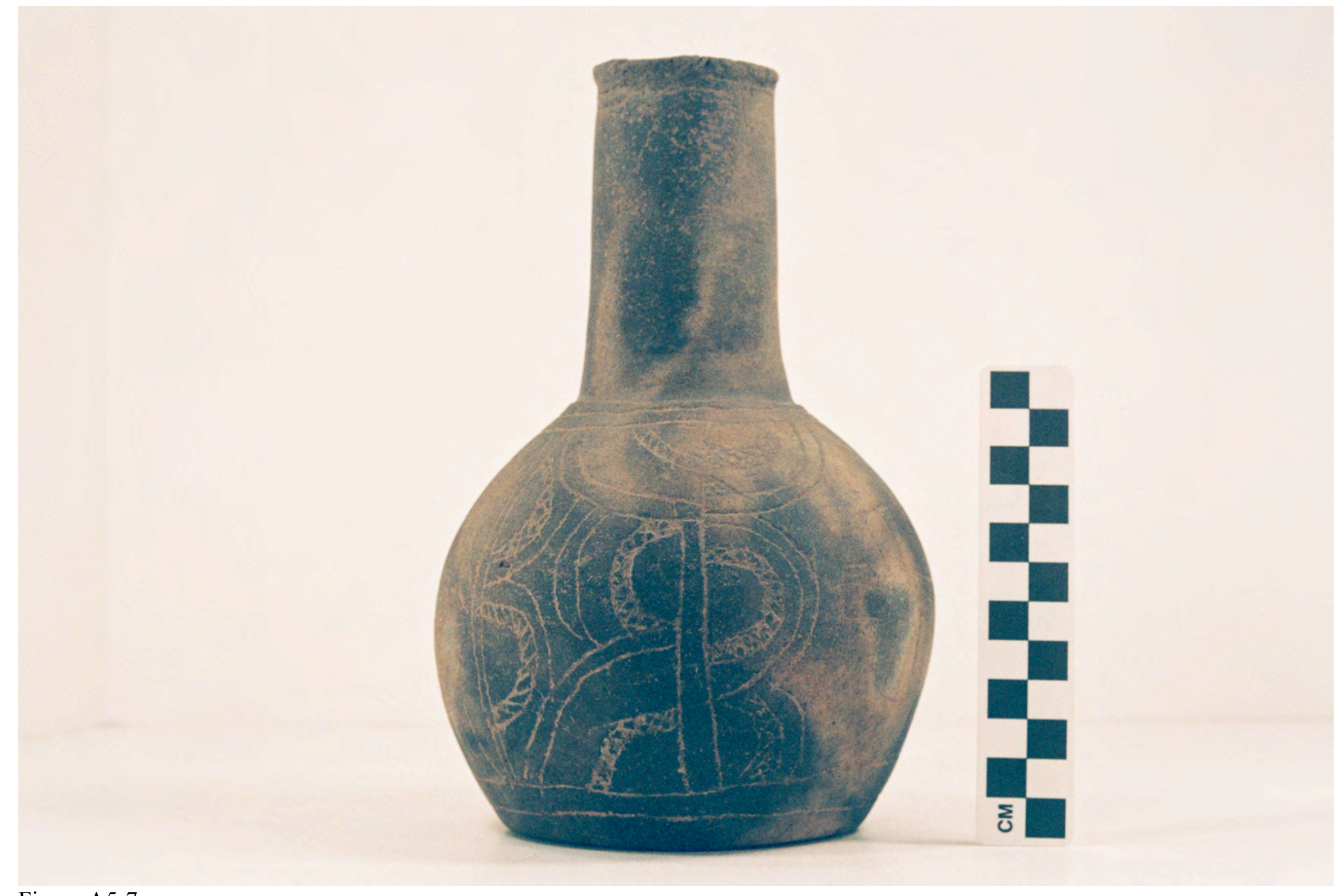

Figure A5-7 


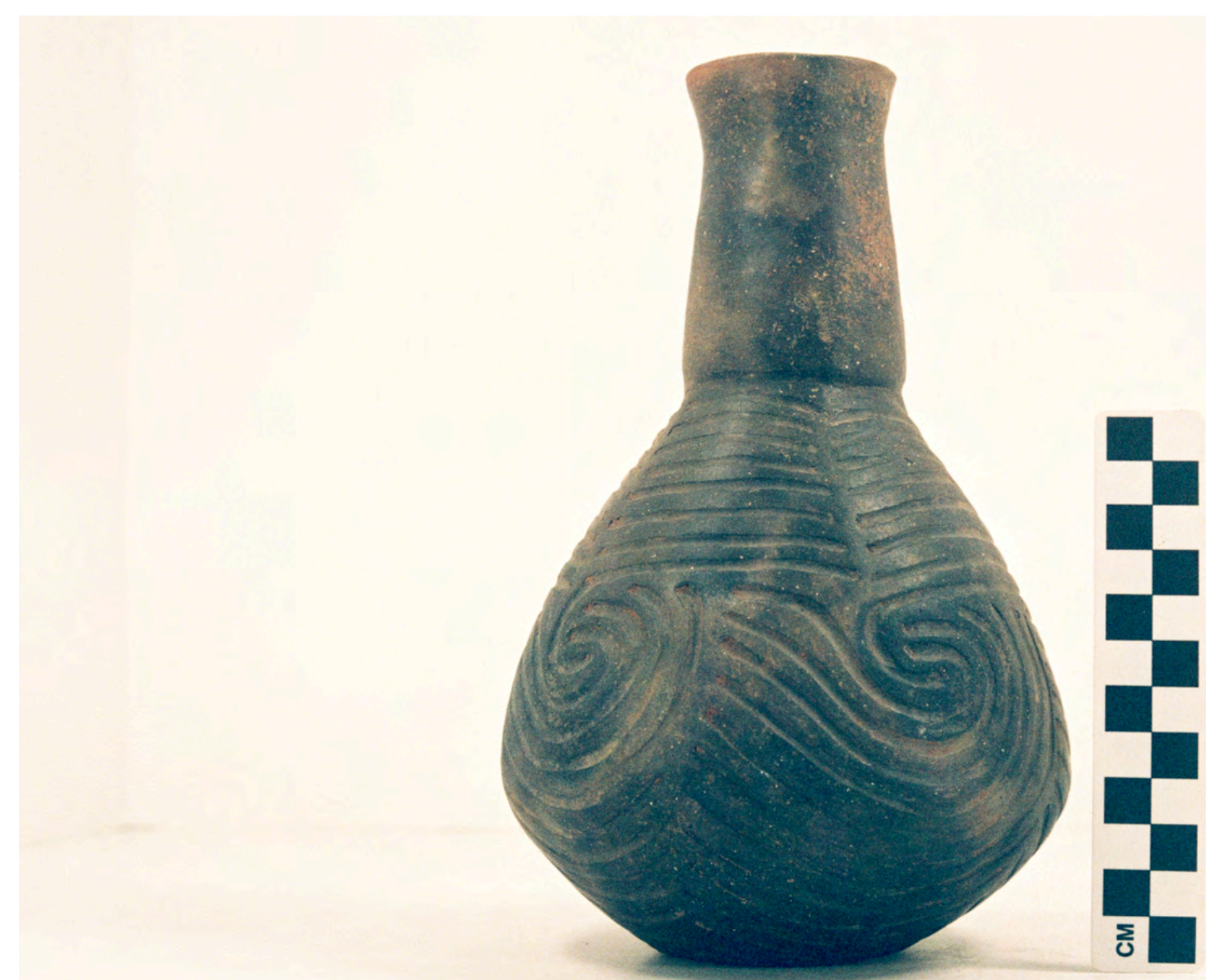

Figure A5-8 


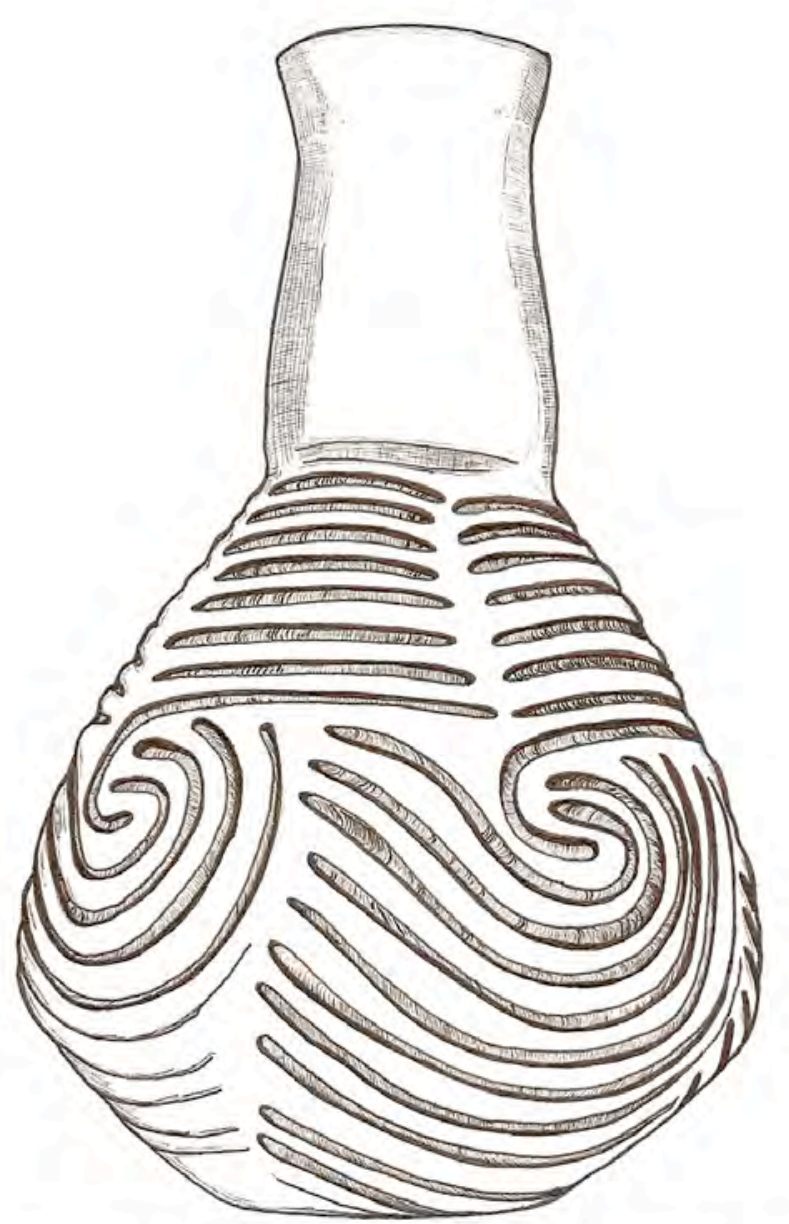

Figure A5-9. Keno Trailed, var. McClendon bottle from the George Sentall Place (5425-3627).

Drawing by Bobby Gonzalez

Figure A5-9 


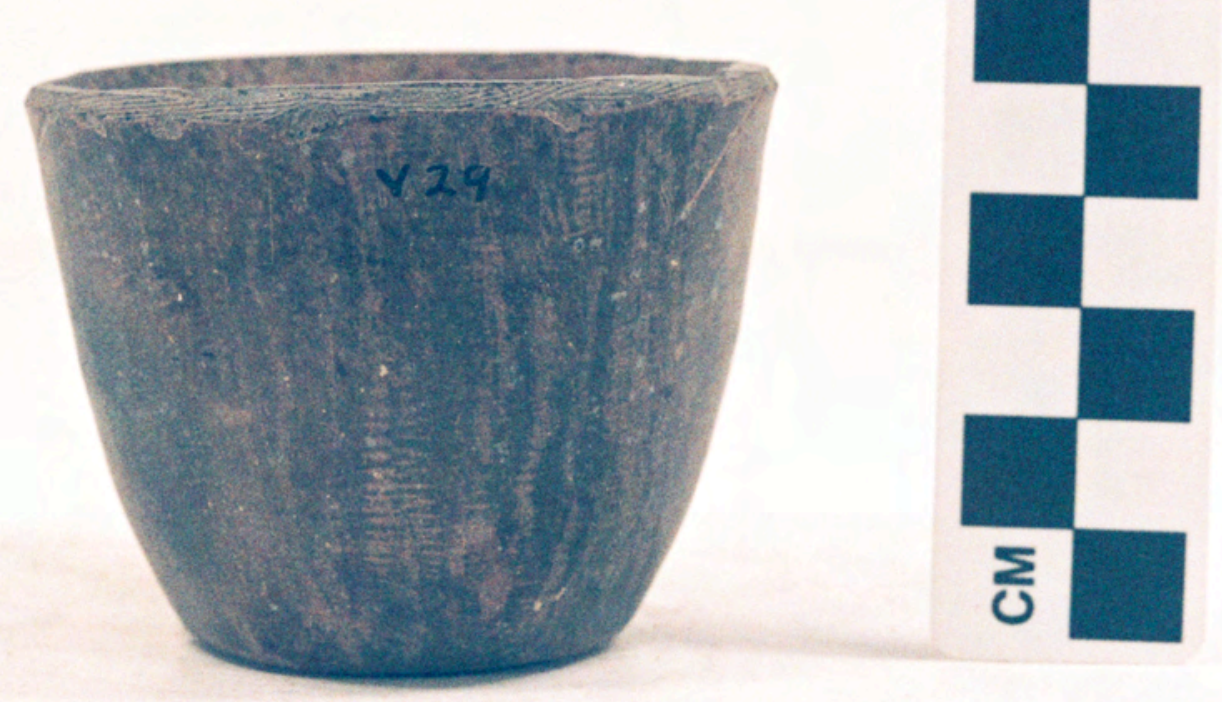

Figure A6-1 


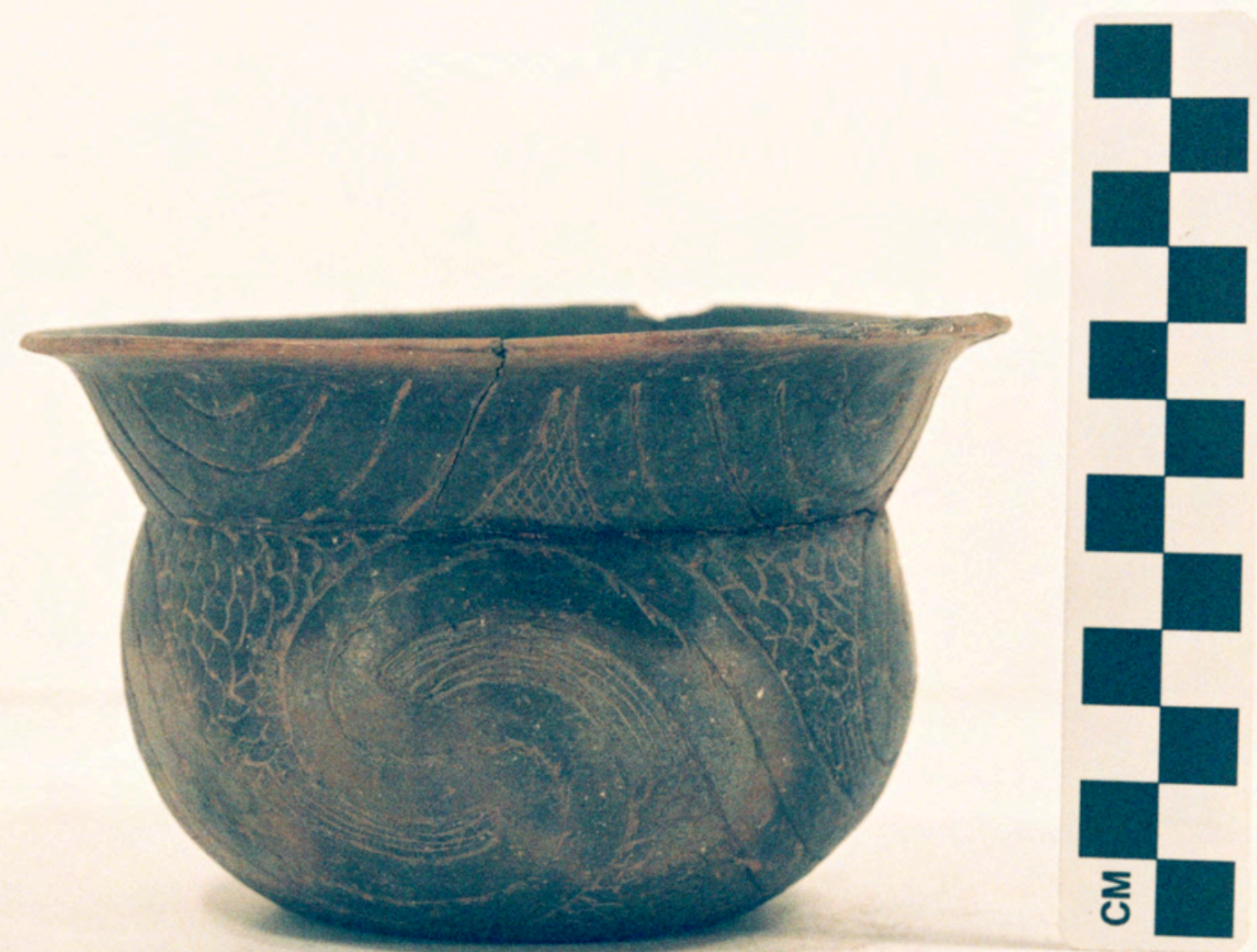

Figure A6-2 


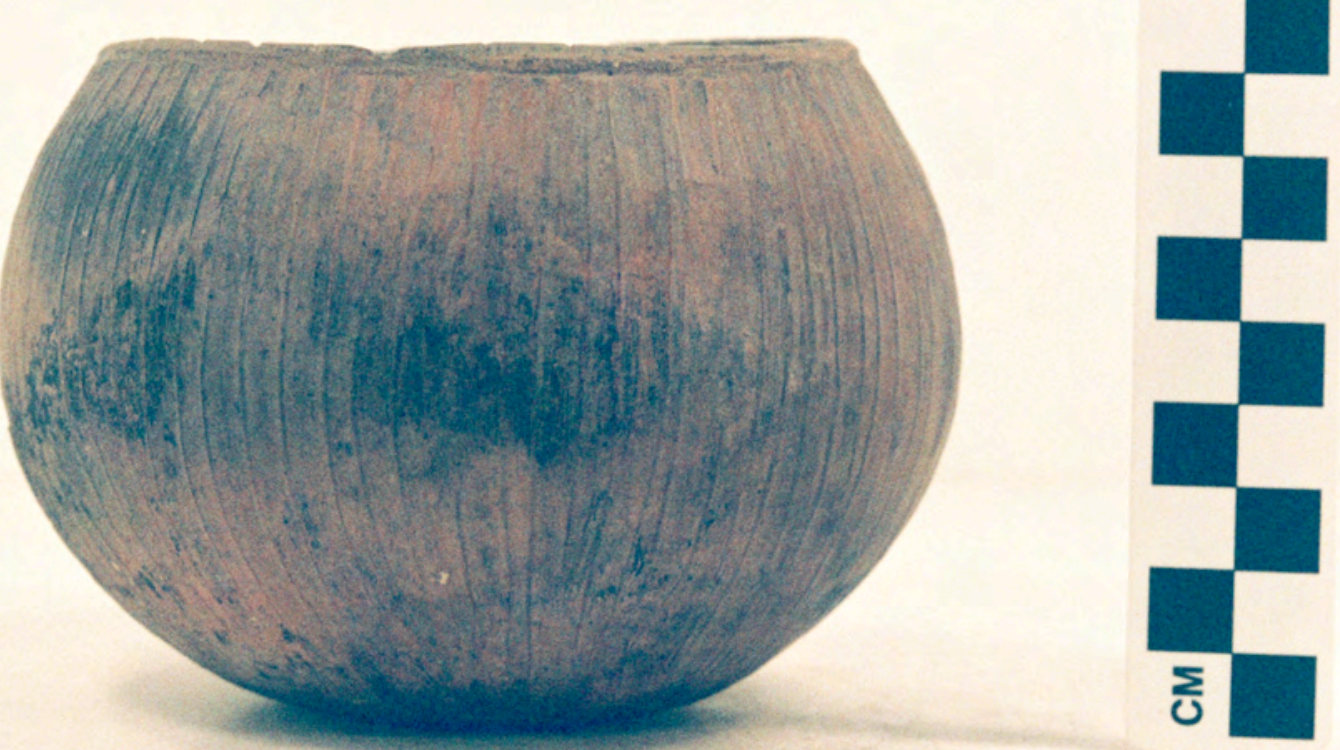

Figure A6-3 


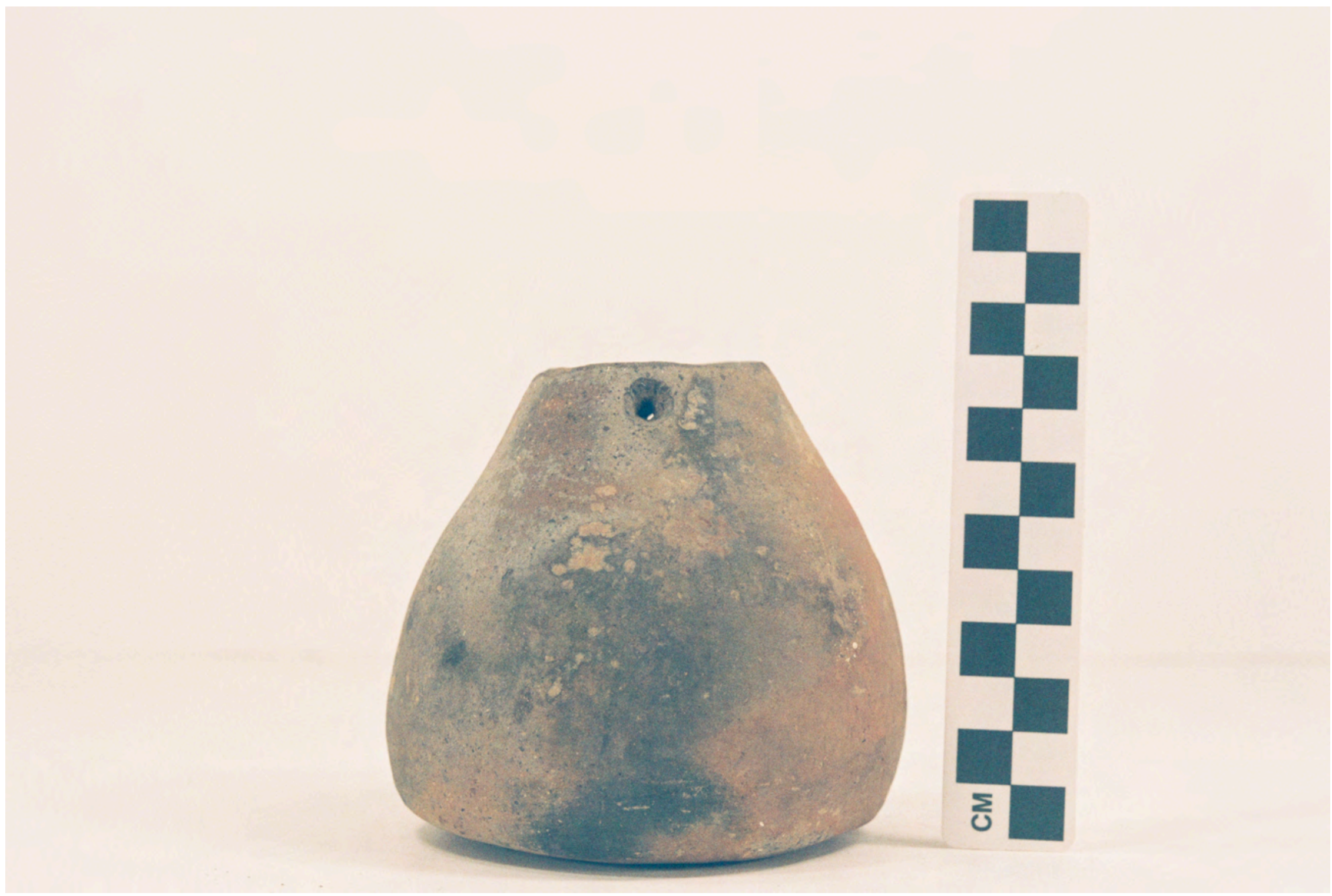

Figure A6-4a 


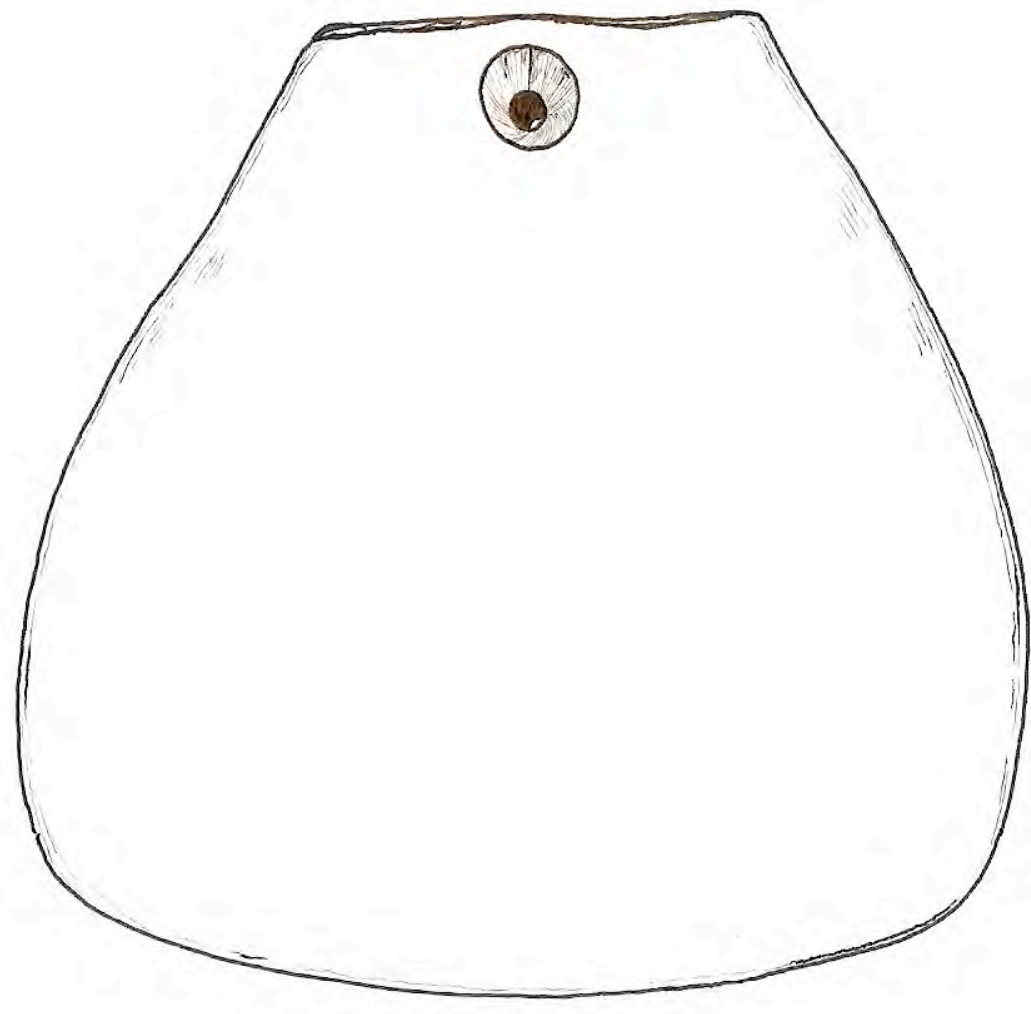

Figure A6-4. Plain seed jar from the Cabaness Place (5425-225) b, drawing by Bobby Gonzalez.

Figure A6-4b 


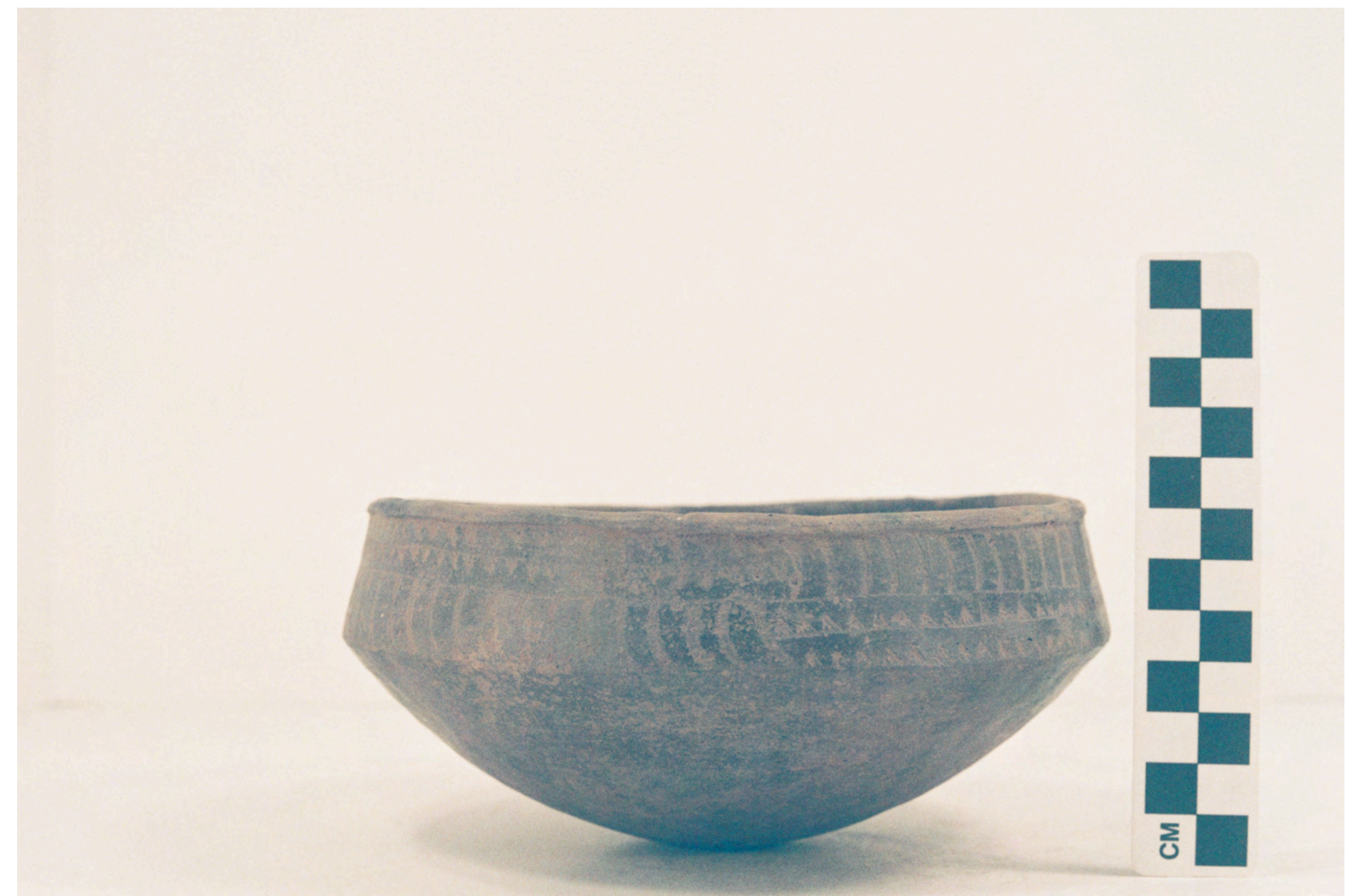

Figure A6-5 


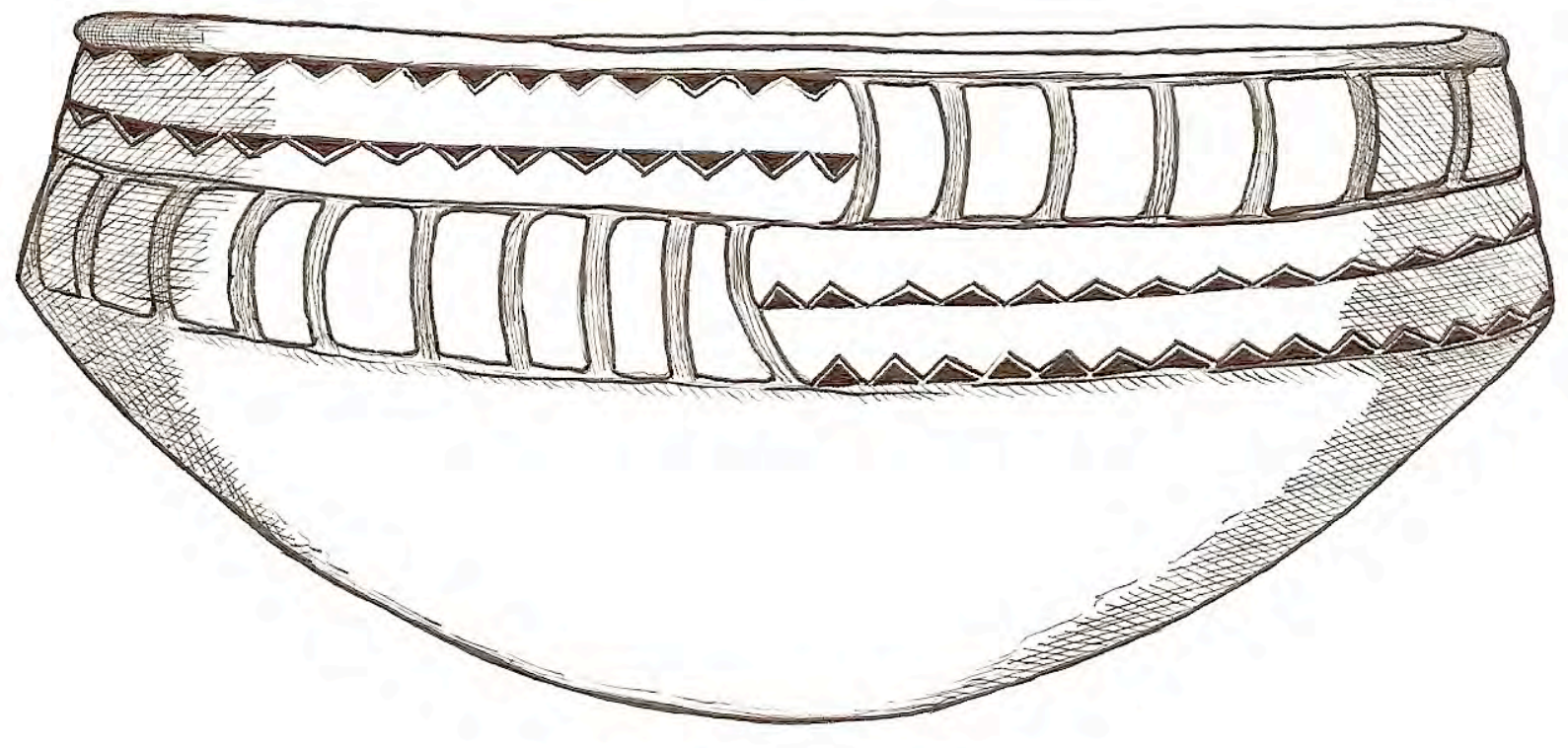

Figure A6-6. Glassell Engraved carinated bowl from the Cabaness Place (5425-226). Drawing by Bobby Gonzalez.

Figure A6-6 